\title{
Klimats un ilgtspējīga attīstība
}





\section{Klimats un \\ ilgtspējīga attīstība}

Māra Klavinina un Jāṇa Zalıokšṇa redakciijā 
Klimats un ilgtspējīga attīstība. Māra Kḷaviṇa un Jāṇa Zaḷokšṇa redakcijā. Rīga: LU Akadēmiskais apgāds, 2016, 384 lpp.

Grāmatas autori: Dagnija Blumberga (8. nodal̦a), Agrita Briede (4. nodal̦a), Jānis Brizga (14. nodal̦a), Džineta Dimante (10. nodal̦a), Gunta Kalvāne (9. nodal̦a), Māris Kḷaviṇš (1., 2., 3., 5., 13. nodalı), Viesturs Melecis (6. nodal̦a), Ilze Prūse (11. nodal̦a, autores redakcijā), Zane Vincēviča-Gaile (7. nodaļa), Jānis Zaḷoksnis (12., 15. nodal̦a), GRID-Arendal* darbinieki (16. nodaḷa).

Grāmata "Klimats un ilgtspējīga attīstība" izstrādāta un izdota Eiropas Ekonomikas zonas finanšu instrumenta 2009.-2014. gada perioda programmas "Nacionālā klimata politika" neliela apjoma grantu shēmas atklāta konkursa "Kapacitātes celšana pētījumiem un pasākumiem sabiedrības zināšanu uzlabošanai par klimata pārmaiṇām un to radītajām sekām” projekta "Klimata pārmaiṇu izglītība visiem" ietvaros.
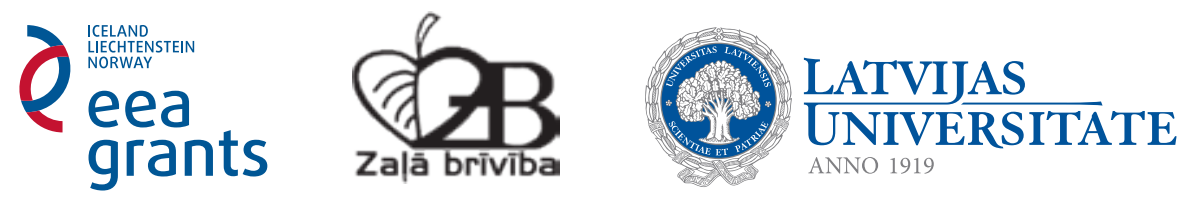

Grāmatas autori izsaka pateicību GRID-Arendal* un īpaši tā darbiniekiem John Crump, Kaya Asdal, Levi Westerveld, Marie Loe Halvorsen.

Liels paldies Ievai Ručevskai par nozīmīgo ieguldījumu klimata izglītības sekmēšanā Latvijā un projekta rezultātu sasniegšanā.

Kolektīvā monogrāfija apstiprināta izdošanai saskaṇā ar

LU Zinātnes padomes lēmumu Nr. 2 (11.04.2016.).

Recenzenti: Dr. biol. Gunta Springge, Dr. geogr. Inese Silamiksele

Zinātniskie redaktori: Māris Kḷaviṇš un Jānis Zaḷoksnis

Literārā redaktore: Anna Šmite

Grāmatas maketu, attēlu un vāka noformējumu sagatavojusi Ieva Tiltiṇa

Vāka noformējumam izmantotas fotogrāfijas ar Creative Commons licenci Nodaļu titullapu noformējumam izmantotas Māra Kḷaviṇa fotogrāfijas

(C) Dagnija Blumberga, Agrita Briede, Jānis Brizga, Džineta Dimante, Gunta Kalvāne, Māris Kḷaviņš, Viesturs Melecis, Ilze Prūse, Zane Vincēviča-Gaile, Jānis Zalıoksnis, GRID-Arendal, 2016

(C) Latvijas Universitāte, 2016

ISBN 978-9934-18-136-8

\footnotetext{
* GRID-Arendal ir Norvēǵijas 1989. gada nodibinājums, kura direktoru padomi ieceḷ Norvēǵijas Klimata un vides ministrija, un tas strādā ciešā sadarbībā ar ANO Vides programmu.
} 


\section{Saturs}

Grāmatas autori . . . . . . . . . . . . . . . . . . . . . . . . . . 10

1. levada vietā: vai cilvēks spēj ietekmēt dabu? . . . . . . . . . . . . . . . . . . . 13

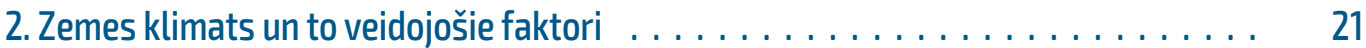

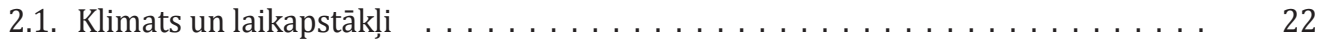

2.2. Zemes atmosfēra un tās uzbūves ietekme uz klimatu . . . . . . . . . . . 23

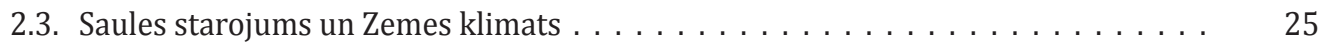

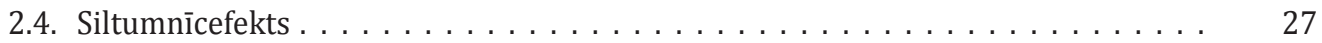

3. Klimata mainība un klimata pārmainas . . . . . . . . . . . . . . . . . . . . 31

3.1. Zemes klimats un tā veidošanos ietekmējošie faktori $\ldots \ldots \ldots \ldots \ldots \ldots . \quad 32$

3.2. Saules starojuma un kosmiskā starojuma mainības ietekme uz Zemes klimatu . . . 36

3.3. Zemes orbitālās un rotācijas kustības rakstura izmainas $\ldots \ldots \ldots \ldots \ldots \ldots . \ldots 37$

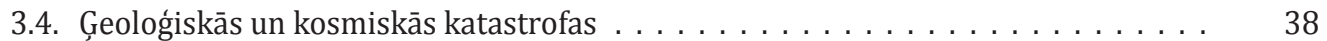

3.5. Okeānu ūdeñu plūsmu mainība $\ldots \ldots \ldots \ldots \ldots \ldots \ldots \ldots \ldots \ldots \ldots \ldots \ldots$

3.6. Jūru un okeānu ūdennu un atmosfēras mijiedarbība . . . . . . . . . . . . . 42

3.7. Klimata mainības raksturs un cilvēka ietekme uz to $\ldots \ldots \ldots \ldots \ldots$. . . . . 45

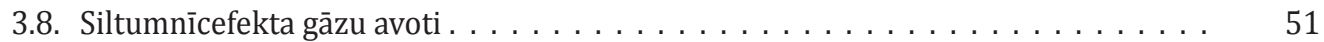

4. Latvijas klimats un tā mainības raksturs . . . . . . . . . . . . . . 55

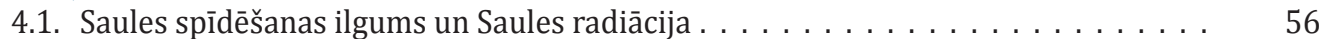

4.2. Gaisa temperatūra un tās mainības raksturs $\ldots \ldots \ldots \ldots \ldots \ldots \ldots \ldots$

4.3. Nokrišñi un to daudzuma mainība $\ldots \ldots \ldots \ldots \ldots \ldots \ldots \ldots \ldots \ldots \ldots \ldots \ldots$

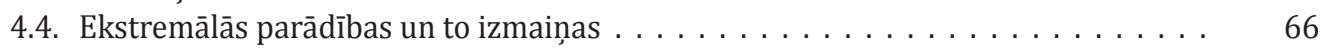

4.5. Sniega segas raksturs un tā mainība $\ldots \ldots \ldots \ldots \ldots \ldots \ldots \ldots \ldots \ldots \ldots \ldots$

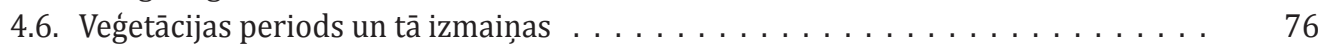

4.7. Vējšs un tā raksturojošo lielumu ilglaicīgās izmainas $\ldots \ldots \ldots \ldots \ldots \ldots \ldots$

4.8. Atmosfēras cirkulācijas procesu mainība $\ldots \ldots \ldots \ldots \ldots \ldots \ldots \ldots \ldots . \ldots \ldots$

4.9. Klimata pārmainu ietekme uz Latvijas upju hidroloǵisko režìmu . . . . . . . . 82

4.10.Iespējamās klimata pārmaiṇas Latvijā 21. gadsimta laikā $\ldots \ldots \ldots \ldots \ldots .90$

5. Globālā sasilšana un tās sekas $\ldots \ldots \ldots \ldots$. . . . . . . . . . . . . . . . . . . 97

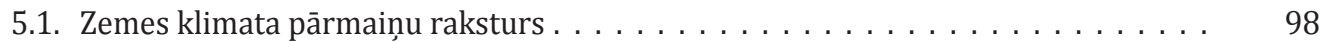

5.2. Zemes klimata modelēšana un klimata mainības scenāriji $\ldots \ldots \ldots \ldots \ldots$

5.3. Globālās sasilšanas iespējamās sekas . . . . . . . . . . . . . . . . . . . . . 109 
6. Klimatisko faktoru ietekme uz dzivajiem organismiem . . . . . . . . . . . . . . . 115

6.1. Vides faktoru ietekme uz dzīvajiem organismiem: Šelforda likums . . . . . . . . 116

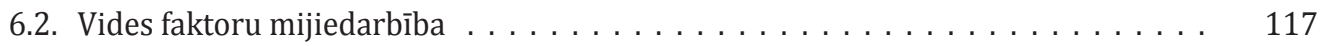

6.3. Temperatūras ietekme uz dzīvajiem organismiem . . . . . . . . . . . . . . 119

6.4. Mitruma ietekme uz dzīvajiem organismiem . . . . . . . . . . . . . . 119

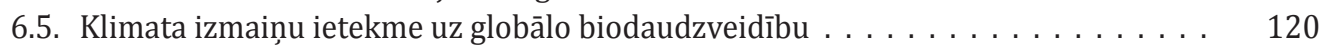

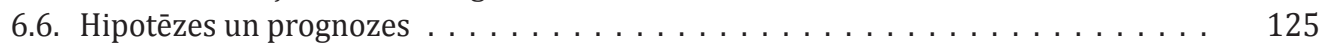

6.7. Draudi pasaules lauksaimniecībai un mežsaimniecībai $\ldots \ldots \ldots \ldots \ldots \ldots . \quad 128$

6.8. Klimata izmainu ietekme uz Latvijas ekosistēmām un to bioloǵisko daudzveidību . 133

6.8.1. Klimatisko un antropogēno faktoru mijiedarbības ietekme . . . . . . . . 133

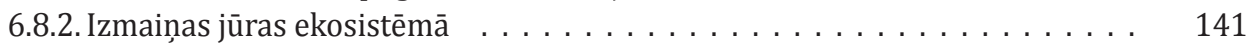

6.8.3. Saldūdens ekosistēmu izmainas $\ldots \ldots \ldots \ldots \ldots \ldots \ldots \ldots \ldots \ldots$

6.8.4. Ietekme uz lauksaimniecību un mežsaimniecību $\ldots \ldots \ldots \ldots \ldots \ldots \ldots$.

7. Klimata pārmainu ietekme uz cilvēka veselību . . . . . . . . . . . . . . . . . . . . 149

7.1. Klimata pārmainu ietekme uz veselību - veidi un intensitāte . . . . . . . . . . 150

7.2. Pret klimata pārmaiṇām jutīgās iedzīvotāju grupas . . . . . . . . . . . . . . . 153

7.3. Ārkārtas vides apstākḷ ietekme uz veselību . . . . . . . . . . . . . . . . 158

7.4. Pārtikas un ūdens pieejamības izmainas klimata pārmainu ietekmē . . . . . . . . . . . 162

7.5. Klimata pārmainu veicinātas slimības . . . . . . . . . . . . . . . . . . . . 164

8. Klimats un energèetika . . . . . . . . . . . . . . . . . . . . . . . 175

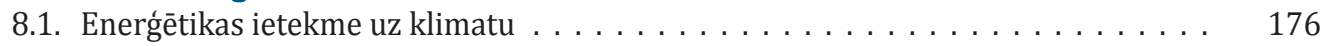

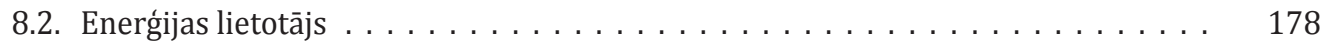

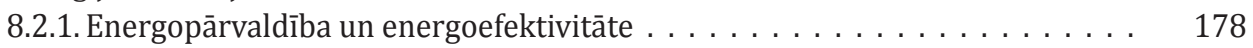

8.2.2. Enerǵijas patērētāju klimata tehnoloǵijas $\ldots \ldots \ldots \ldots \ldots \ldots \ldots \ldots \quad 178$

8.2.2.1. Ēkas . . . . . . . . . . . . . . . . . . . . . . . . 179

8.2.2.2. Ražošanas procesi . . . . . . . . . . . . . . . . . . . . . . . . 180

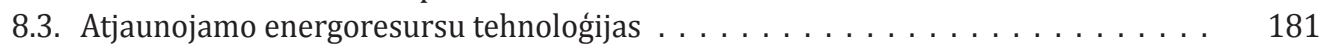

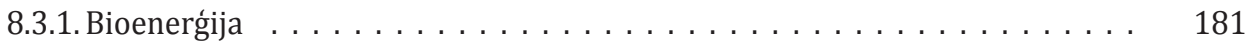

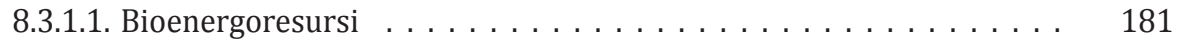

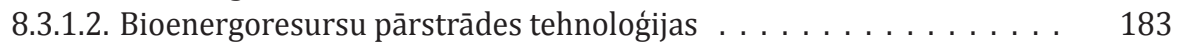

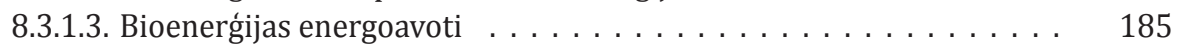

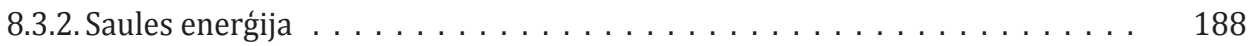

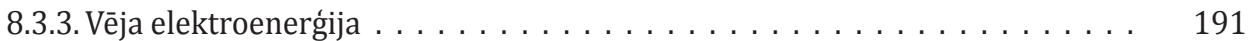

8.3.4. Hidroenerǵija . . . . . . . . . . . . . . . . . . . 192

8.3.5. Geotermālās un citas atjaunojamās enerǵijas tehnolog̣ijas . . . . . . . . . 192

8.3.6. Atjaunojamās elektroenerǵijas avotu darbības režìmi . . . . . . . . . . 193

8.4. $\mathrm{CO}_{2}$ uzglabǎšanas iespējas $\ldots \ldots \ldots \ldots \ldots \ldots \ldots \ldots \ldots \ldots \ldots \ldots \ldots \ldots \ldots$

9. Augšanas sezonas izmainas un tās ietekme uz mežsaimniecību un lauksaimniecību 199

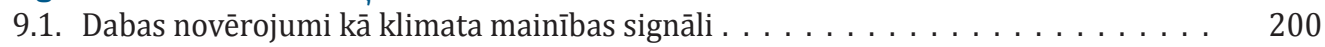

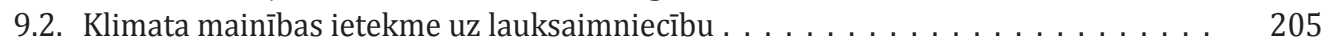

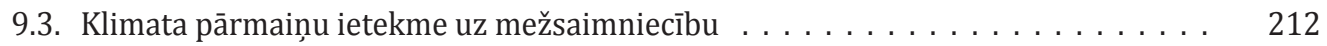

10. Klimata pārmainas un ekonomika . . . . . . . . . . . . . . . . . . . . 215

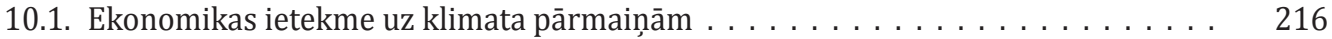

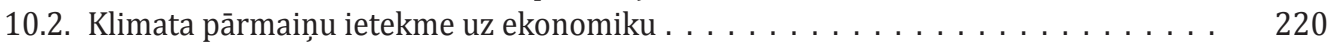

10.3. Adaptācijas pasākumi dažādās uzṇēmējdarbības jomās . . . . . . . . . . . . . 224 
10.4. Klimata pārmaiṇu mazināšanas ekonomiskie paṇēmieni ～. . . . . . . . . . . 226

10.5. Klimata pārmaiṇu mazināšanas pasākumi uzṇēmējdarbībā . . . . . . . . . . . . . . 229

11. Klimata politika . . . . . . . . . . . . . . . . . . . . . . 233

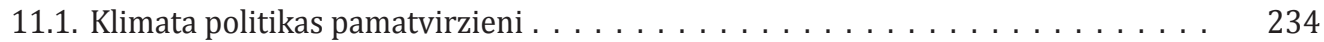

11.1.1. Klimata pārmaiņu novēršana . . . . . . . . . . . . . . . . 234

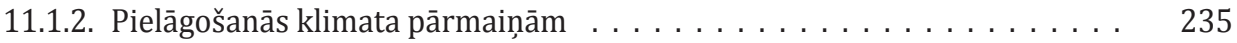

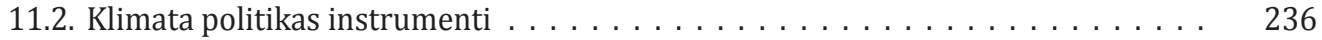

11.3. Starptautiskā klimata politika . . . . . . . . . . . . . . . . . . . . . 238

11.3.1. Starptautisko klimata sarunu dinamika . . . . . . . . . . . . 240

11.3.2. Kioto protokola elastīgie mehānismi . . . . . . . . . . . . . . . . . . . . . . . . 242

11.4. Eiropas Savienības klimata politika . . . . . . . . . . . . . . . . . . 243

11.4.1. Eiropas Savienības virzība uz oglekḷa mazietilpīgu attīstību . . . . . . . . 243

11.4.2. Eiropas Savienības Emisijas kvotu tirdzniecības sistēma . . . . . . . . . 245

11.4.3. Eiropas Savienības pielāgošanās klimata pārmaiṇām . . . . . . . . . . . 249

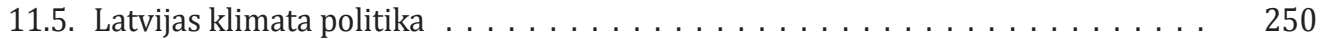

11.5.1. Latvijas mērḳi siltumnīcefekta gāzu ierobežošanai . . . . . . . . . . . . 250

11.5.2. Latvijas progress siltumnīcefekta gāzu ierobežošanā . . . . . . . . . . . . . 251

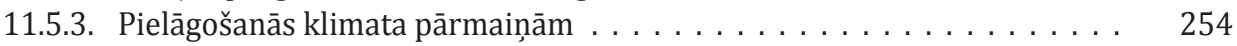

11.6. Nevalstiskā sektora loma klimata politikas veidošanā un īstenošanā . . . . . . . . . . 255

12. Ilgtspējīgas attīstības pamati . . . . . . . . . . . . . . . . . . . 259

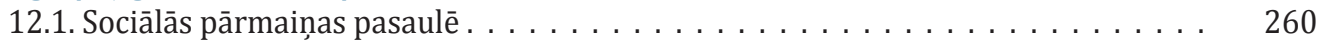

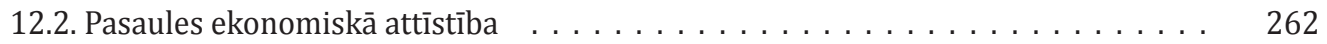

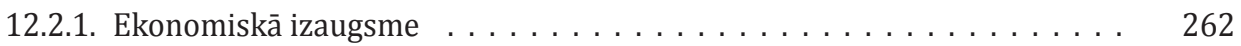

12.2.2. Ekonomikas izaugsmes pirmsākumi . . . . . . . . . . . . . . 263

12.2.3. Enerǵētikas un tehnoloǵiju revolūcija un tās sekas . . . . . . . . . . . 264

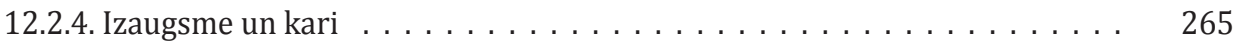

12.2.5. "Izaugsme kā parasti" . . . . . . . . . . . . . . . . . . 266

12.2.6. Globālās diskusijas par izaugsmi . . . . . . . . . . . . . . . . . . . . . . . . . . . . . . . . . . . . . . . .

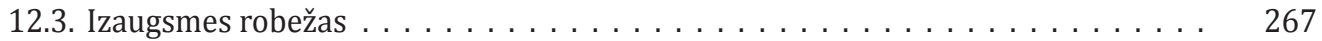

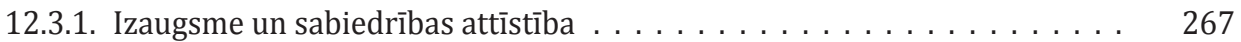

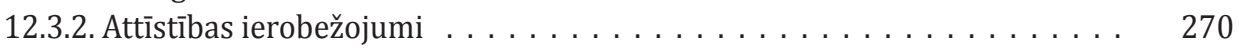

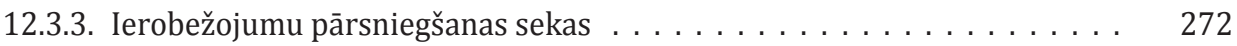

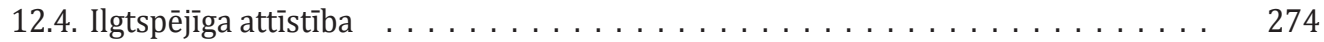

12.4.1. Ilgtspējīgas attīstības koncepcija . . . . . . . . . . . . . . . . 274

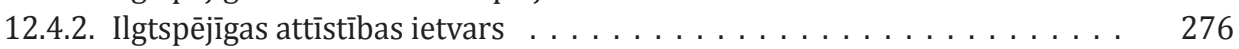

12.4.3. Ilgtspējīgas attīstības pamatprincipi . . . . . . . . . . . . 279

13. Adaptācija klimata pārmainām . . . . . . . . . . . . . . . . . . . . . . . . 283

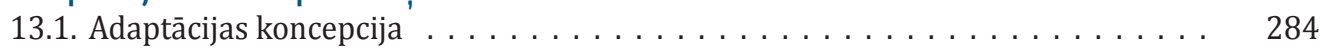

13.2. Adaptācijas politika . . . . . . . . . . . . . . . . . . . . 287

13.3. Ieteikumi adaptācijas risinājumiem . . . . . . . . . . . . . . . . . . . . . . . . 292

13.3.1. Klimata pārmaiṇu adaptācijas risinājumi valsts līmenī . . . . . . . . . . . . 293

13.3.2. Izglītība un zinātne adaptācijas izstrādei un ieviešanai . . . . . . . . . . . 294

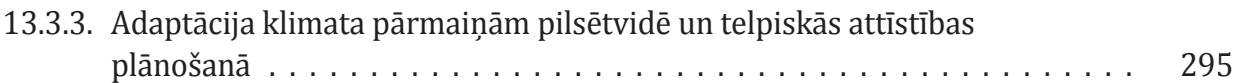

13.3.4. Adaptācija klimata pārmaiṇām lauksaimniecībā, mežsaimniecībā . . . . . 298

13.3.5. Adaptācija klimata pārmaiṇām un ūdens resursu apsaimniekošana . . . . 299 
14. Klimata pārmainas, dzīvesveids un patērin̦š, oglekḷa mazietilpīga attīstība . . . . . 301

14.1. Siltumnīcefekta gāzu emisiju novērtēšanas metodes - "oglekḷa pēda" . . . . . . . 302

14.2. Oglekḷa mazietilpīga attīstība $\ldots \ldots \ldots \ldots \ldots \ldots \ldots \ldots \ldots \ldots \ldots . \ldots \ldots$

15. Ilgtspèjīgas attīstības īstenošana . . . . . . . . . . . . . . . . . . . . . . . . 315

15.1. Starptautiskā sadarbība ilgtspējīgas attīstības îstenošanai . . . . . . . . . . . . . . 316

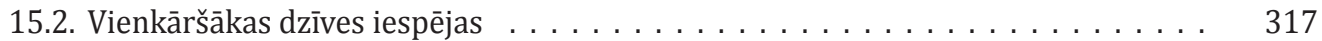

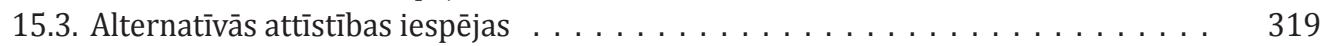

15.3.1. Ekonomiskās izaugsmes vēsturiskais pamats . . . . . . . . . . . . . 319

15.3.2. "Jaunā ekonomika" . . . . . . . . . . . . . . . . . . 320

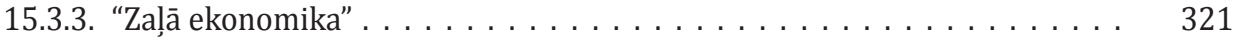

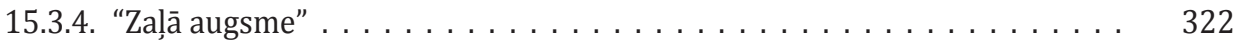

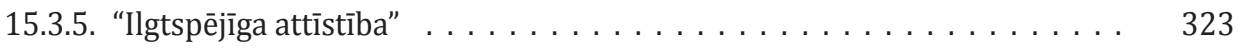

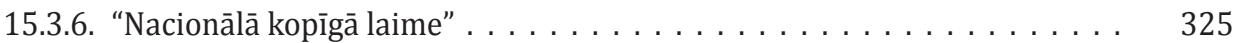

15.3.7. "Ne-augsme" . . . . . . . . . . . . . . . . . . . . . . . 327

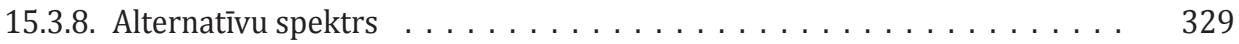

15.3.9. Dzīve bez augsmes? . . . . . . . . . . . . . . . . . . . . . . . 329

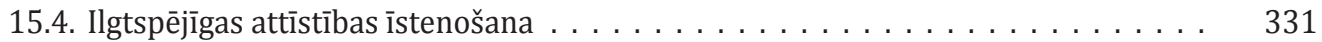

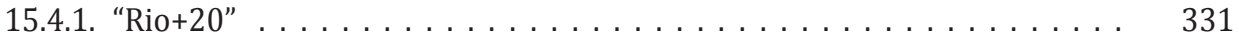

15.4.2. ANO Tūkstošgades attīstības mērksi $\ldots \ldots \ldots \ldots \ldots \ldots \ldots \ldots \ldots \quad 332$

15.4.3. Latvijas ilgtspējīga attīstība $\ldots \ldots \ldots \ldots \ldots \ldots \ldots \ldots \ldots . \quad 336$

15.4.4. Latvijas ilgtspējìgas attīstības stratēǵija $\ldots \ldots \ldots \ldots \ldots \ldots \ldots . \quad 338$

15.5. Pašvaldības un ilgtspējīga attīstība $\ldots \ldots \ldots \ldots \ldots \ldots \ldots \ldots \ldots \ldots \ldots \ldots \ldots$

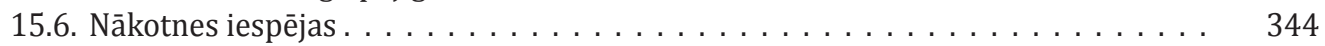

16. Piemērošanās klimata pārmainām Eiropā . . . . . . . . . . . . . . . . . . . . . . . . . . . 349

16.1. Norvēǵijas Klimata līgums . . . . . . . . . . . . . . . . . . 350

16.2. Maksa par oglekḷa savienojumu emisijām Norvēǵijā . . . . . . . . . . . 351

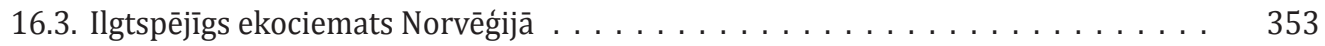

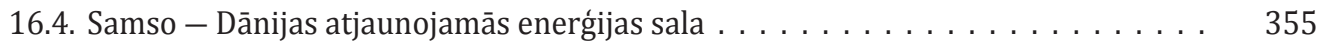

16.5. Dānijas "zaḷā" sala Bornholma . . . . . . . . . . . . . . . . . . . . . . . . 357

16.6. Biroju ēkas apsildīšana ar k̦ermeṇa siltumu Zviedrijā . . . . . . . . . . . . . 359

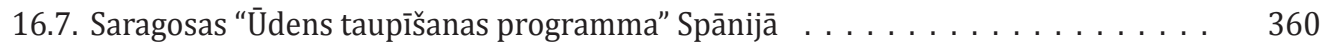

16.8. Freiburga - Vācijas Saules enerǵijas galvaspilsēta . . . . . . . . . . . . . 362

16.9. Ietekmes uz klimatu novēertēšana Londonā un pielāgošanās

16.10. Pielāgošanās klimata pārmaināām Nīderlandes lauksaimniecības nozarē ... . . 367

16.11. Piekrastes plānošana Horvātijāa . . . . . . . . . . . . . . . . . . . . . . . . 369

16.12. "Klimata bēgli" . . . . . . . . . . . . . . . . . . . . . . . . 370

16.13. Klimata pārmaingu radītie riski Latvijai un ieteikumi to novēršanai $\ldots \ldots \ldots .376$

Climate and Sustainable Development . . . . . . . . . . . . . . . . . . . . . . . . . 383 


\section{Cienijamo lasītāj!}

Šajā grāmatā Tu izlasīsi, ka klimata pārmaiñas ir realitāte, kuru mēs nedrīkstam ignorēt.

Pazīstu daudzus cilvēkus, kuri bieži dodas uz Kurzemes jūrmalu, apsēžas stāvajā jūras krastā un vēro saulrietu. Ir bijis tā, ka iecienītajā vietā vairs nav iespējams atrast tik pazīstamo pauguru, solinu vai priedi.

Ja atceramies, 21. gadsimta pirmā dekāde bija siltākā mūsu zemes meteoroloǵisko novērojumu vēsturē. Tas nozīmē ne tikai augstāku gaisa temperatūru, bet arī stiprākas vētras, sausumu un plūdus.

Īpaši jūtamas šìs pārmaiṇas ir Latvijas jūras piekrastē, kura erozijas ietekmē pastāvīgi samazinās. Ja nerīkosimies, turpmāk riskējam ik gadu zaudēt pat līdz sešiem metriem mūsu skaisto pludmalu.

Tomēr klimata pārmainas nav tikai vides aizsardzības problēma. Tas ir arī starptautiskā miera un drošības jautājums! Klimata pārmaiṇu dēl daudzas auglīgas zemes Tuvajos Austrumos pārvēršas par tuksnešiem, teritorijas applūst. Rezultātā iedzīvotāji spiesti meklēt citu dzìvesvietu, kas savukārt rada nekontrolējamu migrāciju, starptautiskus konfliktus, palielina terorisma risku.

Šo jautājumu risināšana ir mūsu pastāvīgs uzdevums un atbildība. Gan valsts, gan pašvaldības, gan ikviena cilvēka rīcības līmenī.
2015. gads ir bijis l,oti nozìmīgs pasaules ceḷā uz ilgtspējīgu attīstību. Septembrī Apvienoto Nāciju Organizācijas G̣enerālā Asambleja pieñēma Ilgtspējīgas attīstības mērksus laika posmam pēc 2015. gada. Decembrī Klimata pārmaiṇu konferencē Parīzē tika pien,emts vēsturisks nolīgums klimata pārmaiṇu ierobežošanai.

Šie lēmumi ilgtermin̄ā ietekmēs Latvijas un citu pasaules valstu politiku. Mums jāattīsta oglekḷa mazietilpīgu ekonomiku un noturību pret klimata pārmaiṇām. Nepietiekama rīcība klimata pārmaiṇu mazināšanai būtiski apgrūtinās un sadārdzinās pielāgošanos klimata pārmaiñām.

Grāmata "Klimats un ilgtspējīga attīstība" palīdzēs pieñemt izsvērtus un pamatotus lēmumus un atrast īsto cel̦u.

Esmu pārliecināts, ka mums izdosies!

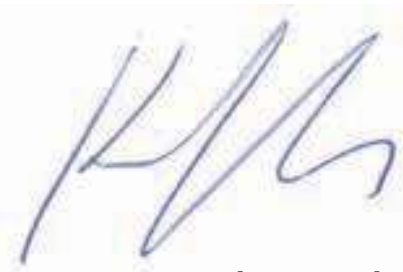

Vides aizsardzības un reǵionālās attīstības ministrs Kaspars Gerhards 


\section{Grāmatas autori}

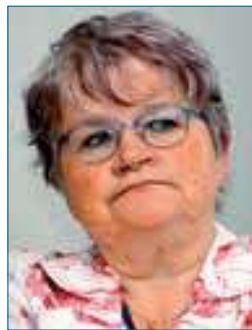

Rīgas Tehniskās universitātes profesore Dr. habil. sc. ing. Dagnija Blumberga ir pārliecināta, ka Latvijas universitāšu vides zinātṇu studiju programmās studē īpaši atvērti un radoši studenti, kuri spēj izzināt un saprast procesus vidē un kuri ir gatavi darìt visu iespējamo, lai mazinātu cilvēku ietekmi uz klimata pārmaiṇām. Dagnijai Blumbergai dzīves garumā ir bijuši dažādi valıasprieki: no sēn,ošanas skrajā priežu mežā ar mīkstām sūnām līdz politikas vērošanai. Tomēr to gandarījumu un prieku, ko sagādā laba grāmata, nespēj aizstāt ne kino, ne internets.

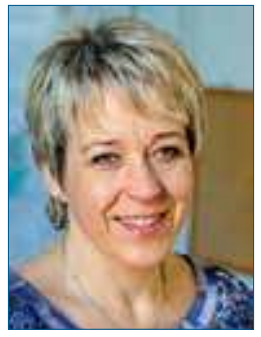

Latvijas Universitātes profesore Dr. geogr. Agrita Briede ir Gueogrāfijas un Zemes zinātṇu fakultātes G̦eogrāfijas nodaḷas vadītāja. Ir vadījusi Latvijas Zinātnes padomes finansētus projektus, kā arī piedalījusies vairāku starptautisku projektu realizācijā (ES 5. ietvara programmas projekts, INTERREG projekts ASTRA, Baltijas jūras reǵiona projekts BaltCICA, projekts Baltadapt u.c.). Zinātniskās intereses ir saistìtas ar pētījumiem par Latvijas klimatu un tā mainību, klimata ekstrēmiem, kā arī klimata mainības ietekmi uz virszemes ūdeniem.

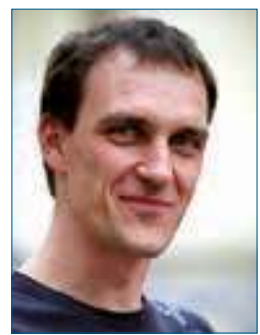

Dr. geogr. Jānis Brizga doktora grādu vides zinātnes apakšnozarē ieguvis 2012. gadā, aizstāvot promocijas darbu "Ilgtspējīga patēriṇa pārvaldība: politikas instrumenti, tīkli un indikatori". Jānis Brizga ir biedrības "Zal̦ā brīvība" valdes priekšsēdētājs. Pirms tam darbojies par starptautiska NVO sadarbības tīkla ANPED (The Northern Alliance for Sustainability) valdes priekšsēdētāju, Vides politikas programmas direktoru Pasaules dabas fondā un izpilddirektoru Koalīcijas par tīru Baltiju Latvijas birojā. Viṇš risina jautājumus, kas saistìti ar ilgtspējīgu attīstību, ilgtspējīga patēriņa pārvaldību un videi draudzīgu dzīvesveidu.

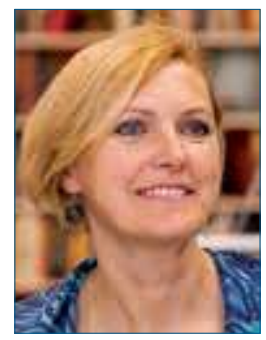

Latvijas Universitātes asociētā profesore Dr. econ. Džineta Dimante doktora grādu ekonomikā ir ieguvusi 2007. gadā. Viṇa ir studējusi arī Kembridžas universitātē (Lielbritānijā), kur ieguvusi diplomu ekonomikā. Viṇas docētie studiju kursi ir saistīti ar vides un dabas resursu ekonomiku, līdzsvarotas attīstības vadīšanu un optimizācijas teoriju. Galvenās pētniecības tēmas saistītas ar ilgtspējīgu attīstību, vides ekonomisko vērtēšanu, zaļo ekonomiku. Džineta 
Dimante ir Latvijas Universitātes Ekonomikas un vadības fakultātes zinātṇu prodekāne, kā arī Zaḷās Ekonomikas Institūta (Oksforda, Lielbritānija), KSA Latvija un Latvijas Ekonometristu asociācijas biedre. Ārpus darba Džinetu interesē cel̦ošana, aktīva atpūta dabā, grāmatu lasīšana, kultūras pasākumu apmeklēšana.

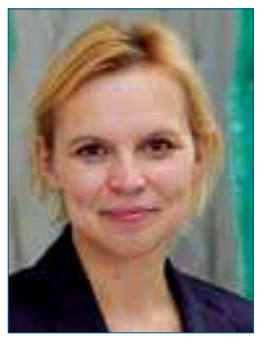

Latvijas Universitātes docente Dr. geogr. Gunta Kalvāne ieguvusi doktora grādu dabas ǵeogrāfijā 2011. gadā, aizstāvot promocijas darbu "Fenologiskās izmaiñas un to ietekmējošie klimatiskie faktori". Zinātniskās intereses saistās ar bioklimatoloǵijas un sezonalitātes pētījumiem cilvēka dzīvē un dabā, arī ar klimata mainības ietekmi uz sezonālajām parādībām. Gunta Kalvāne kā Latvijas Universitātes G̣eogrāfijas un Zemes zinātnuu fakultātes G̦eogrāfijas didaktikas centra vadītāja ir iesaistīta jauno geogrāfijas skolotāju sagatavošanā un zinātnes komunikācijas aktivitātēs.

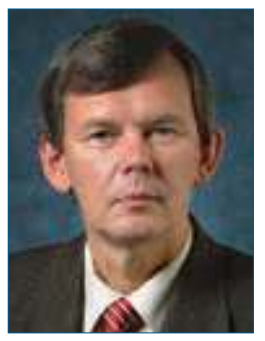

Latvijas Universitātes profesors Dr. habil. chem. Māris Kḷaviṇš ir Latvijas Zinātṇu akadēmijas akadēmikis, daudzu vides izglītības jautājumiem veltītu grāmatu autors un redaktors. Lai nodrošinātu sabiedrības izpratni par vides jautājumiem, problēmām un to risinājumiem, svarīgi ir sagatavot augstas kvalitātes materiālus un spēt atsijāt "pelavas" no "graudiem", respektīvi, izmantot tikai kvalitatīvus un ticamus informācijas avotus, spējot orientēties milzīgajā informācijas plūsmā, kā arī uzrunāt sabiedrību tai saprotamā veidā. Zinātniekam uzrunājot studentus, sabiedrību, ir svarīgi savu viedokli pamatot ne tikai ar autoritatīviem literatūras avotiem, bet arī ar paša veiktiem pētījumiem.

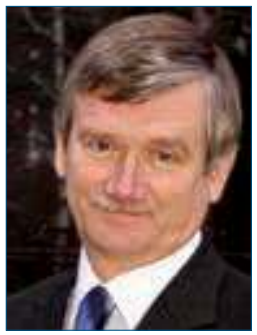

Latvijas Universitātes profesors Dr. biol. Viesturs Melecis ir Geogrāfijas un Zemes zinātṇu fakultātes Dabas aizsardzības katedras vadītājs, kā arī Latvijas Universitātes Biologijas institūta direktors un vadošais pētnieks, Latvijas Zinātṇu akadēmijas korespondētājloceklis. Viṇa pētījumi saistīti ar cilvēka ietekmes novērtēšanu uz ekosistēmām un biodaudzveidību. Viṇš ir Latvijas Nacionālā ilgtermiṇa ekoloǵisko pētījumu tīkla dibinātājs un pārstāv valsti Starptautiskajā un Eiropas ilgtermiņa ekoloǵisko pētījumu tīklā (ILTER network). Tā viens no galvenajiem uzdevumiem ir pētìt klimata izmaiṇu ietekmi uz planētas biodaudzveidību.

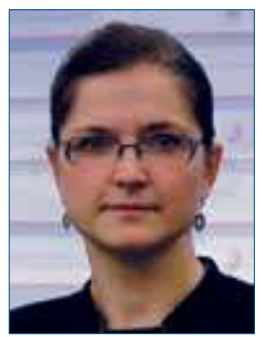

Dr. oec. Ilze Prūse ir Vides aizsardzības un reǵionālās attīstības ministrijas Klimata pārmaiṇu departamenta direktore. Piedalïjusies daudzu projektu attīstīšanā un īstenošanā. Pārstāvējusi Latvijas valsti emisijas vienību tirdzniecībā un bijusi viena no Klimata pārmain,u finanšu instrumenta attīstītājiem, ir Latvijas sarunu vedējs starptautiskajās sarunās par klimatu. Latvijas Prezidentūras Eiropas Savienības (ES) Padomē ietvaros vadījusi ES Padomes darba grupu un pārstāvējusi ES starptautiskajās klimata sarunās ar pārējām pasaules valstīm, t.sk. piedalījusies Parīzes vienošanās sagatavošanā. Paralēli Latvijas interešu starptautiskajai aizstāvībai tiecas attīstīt vispusīgu un ilgtspējīgu nacionālo klimata politiku. 


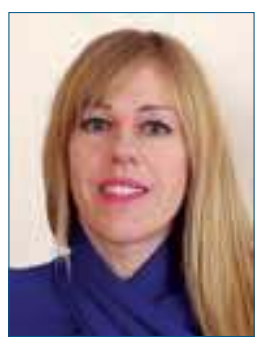

Dr. chem. Zane VincēvičaGaile 2002. gadā Latvijas Medicīnas akadēmijā ieguvusi farmaceita grādu, bet 2014. gadā Latvijas Universitātē, aizstāvot promocijas darbu "Vides apstākḷu ietekme uz mikro- un makroelementu saturu pārtikas produktos Latvijā", ieguvusi doktora grādu kīmijā, vides zinātnes nozarē. Pašlaik Latvijas Universitātes G̣eogrāfijas un Zemes zinātṇu fakultātes Vides zinātnes nodaḷā nodarbojas ar starpdisciplināriem pētījumiem, kas saistīti ar vides un veselības, ekotoksikologiijas jautājumu izzināšanu, ir Starptautiskās Medicīniskās G̣eoloǵijas asociācijas dalībniece. Starp dažādajām ārpusdarba interesēm nozīmīgākās ir veselīgs dzīvesveids un svešvalodas.

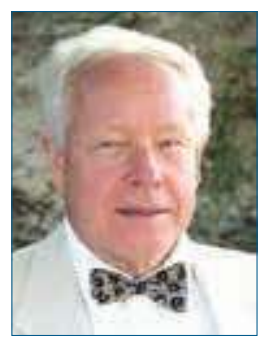

Dr. chem. docents Jānis Zalıoksnis sāka pasniegt kursu "Dabas aizsardzība" Latvijas Valsts Universitātes Ķìmijas fakultātē jau pagājušajā gadsimtā. Pēc Latvijas neatkarības atjaunošanas sadarbībā ar Upsalas Universitāti sagatavoja studiju kursu "Baltijas regiona ilgtspēja", kas tika izmantots arī Rīgas Tehniskajā universitātē, Latvijas Lauksaimniecības universitātē, Daugavpils Universitātē, Latvijas Kultūras akadēmijā un citās augstskolās. Papildinājis zināšanas Kolumbijas Universitātē, Oksfordas Universitātē, Kembridžas Universitātē, Maskavas Valsts universitātē, Lineburgas Universitātē (Vācija) un Islandes Tehnoloǵiju universitātē. Latvijas Universitātē pasniedz studiju kursu "Vide un ilgtspèjīga attīstība". 
1.

vai cilvēks spēj

ietekmēt dabu? 
Pirmais jautājums, kas rodas, diskutējot par klimata pārmaiñām, ir tas, vai cilvēks vispār var ietekmēt klimatu un dabu. Tas ir pilnīgi dabisks jautājums, ja mēs izdzirdam ziṇas par virpulviesuḷiem, zemestrīcēm un apjaušam šo dabas parādību spēku un cilvēka spējas to ietekmēt. Dabas spēku darbības spilgtākais piemērs ir uz Saules notiekošie procesi, kas ir galvenais energijas avots uz Zemes. Tektoniskie procesi nosaka kalnu veidošanos, un jebkādi cilvēka pūliṇi škiet nenozīmīgi šo spēku priekšā. Līdz ar to vēlreiz rodas jautājums: vai cilvēks vispār spēj ietekmēt kādu dabas procesu uz Zemes? Katrs no mums ir atkarīgs no dabas norisēm, bet mēs varam tikai nojaust, kādu ietekmi katrs no mums var atstāt uz tām.

Cilvēka kā indivīda iespējas ietekmēt dabu ir niecīgas, un primitīvās sabiedrības, kuras eksistēja saskaņā ar dabas likumiem, to neietekmēja. Taču cilvēces attīstību pēdējo gadsimtu laikā raksturo iedzīvotāju skaita, ražošanas un patēringa eksponenciāls pieaugums un vairāku procesu globalizācija. Daudzas cilvēku darbības, sākot no minerālmēslu izmantošanas līdz pilsētu attīstīšanai, ir eksponenciāli augošas,
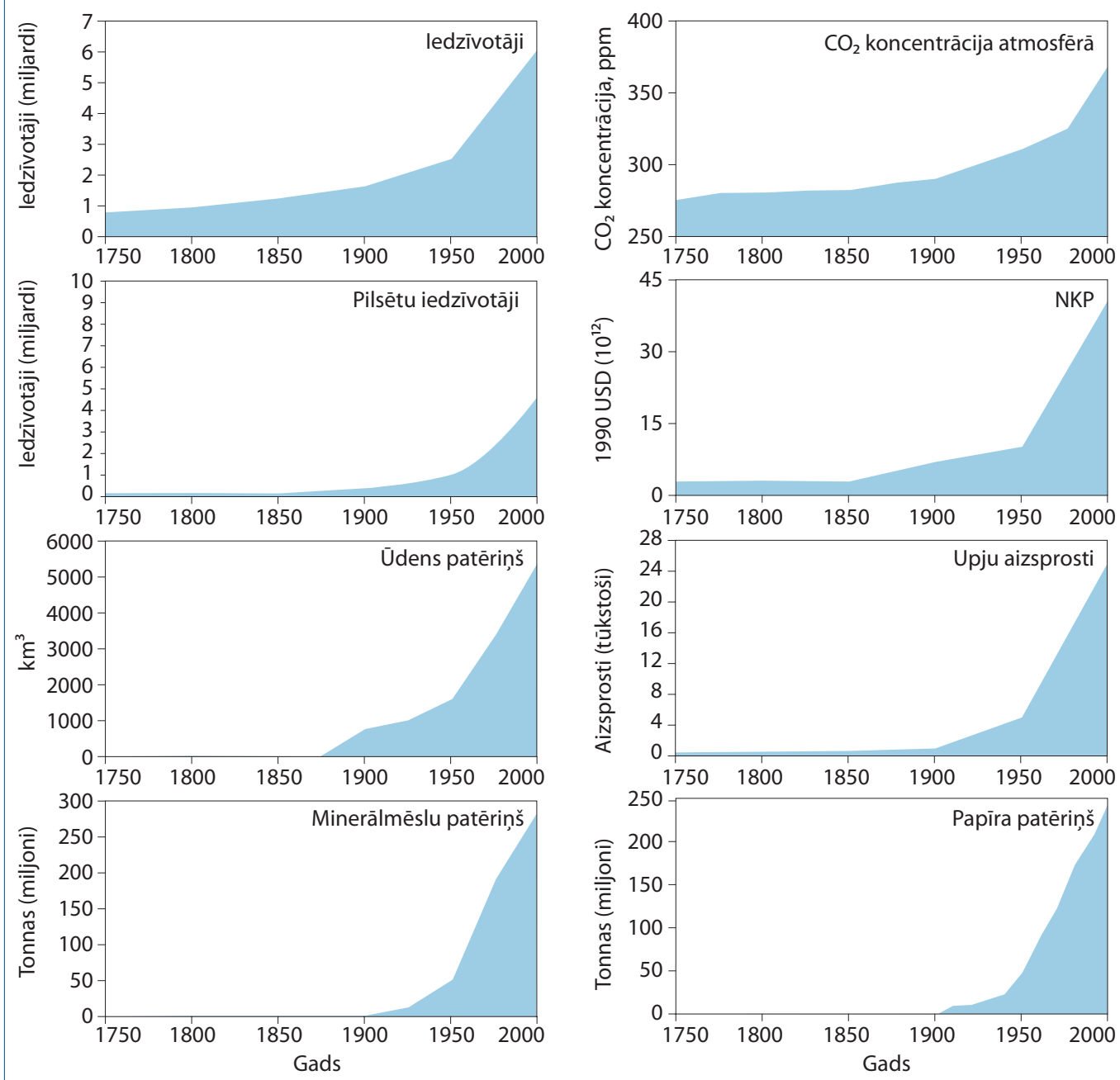

1.1. att. Cilvēces attīstībai raksturīgo rādītāju mainība pēdējās simtgadēs. 
un tās var aprakstīt ar atbilstošām līknēm (sk. 1.1. att.). Tajās redzams, ka pārmainu ātrumi ir atškirīgi, bet kopējā tendence - palielinājums (turklāt eksponenciāls palielinājums) - turpinās. Eksponenciālais pieaugums var izraisīt pārsteidzošus rezultātus, ja mēǵinām izprast, ko tas nozīmē sadzìvē. To labi ilustrē persiešu leǵenda par gudro galminieku, kas dāvināja valdniekam brīnišksīgu šaha galdiṇu un, jautāts par atlīdzību, lūdza dot rīsu graudus, liekot tos dubultā skaitā uz katra nākamā kvadrāta. Uz pirmā kvadrāta viens grauds, uz otrā divi, bet uz desmitā kvadrāta vajadzēja uzlikt 512 graudus, uz piecpadsmitā 16384 , bet uz divdesmit pirmā jau vairāk nekā miljonu rīsa graudu. Un, protams, valdnieka rīsa krājumu tam nepietika.

Cilvēces izaugsmes apjoms ir pārsteidzošs: laikā no 1900. līdz 2015. gadam pasaules iedzīvotāju skaits pieauga vairāk nekā četrkārt, turklāt katrs cilvēks mūsdienās vidēji izmanto četrreiz vairāk resursu nekā 20. gadsimta sākumā. Tādējādi resursu izmantošana šajā laika periodā ir pieaugusi gandrīz sešpadsmit reizes, un to labi raksturo cilvēces izaugsmes raksturs:

- pasaules iedzìvotāju skaits pieaudzis vairāk nekā 4 reizes - no 1,5 līdz 7,4 miljardiem,

- pasaules ekonomiskais apgrozījums palielinājies 14 reizes,

- ražošanas apjoms pieaudzis 40 reizes,

- enerǵijas izmantošana palielinājusies 16 reizes (gandrīz pilnībā uz fosilā kurināmā rēksina),

- oglekḷa dioksīda izmešu apjoms pieaudzis 17 reizes,

- sēra dioksīda izmešu apjoms pieaudzis 13 reizes,

- okeāna nozvejas apjoms pieaudzis 35 reizes,

- cūku skaits pieaudzis 9 reizes.

Eksponenciālā izaugsme ir virzošais spēks, kas izraisa sabiedrības ekonomikas tuvošanos planētas iespēju fizikālajām robežām. Pasaules iedzīvotāju skaits ir sācis palielināties eksponenciāli pēc 2. pasaules kara. Pasaules rūpniecības produkcijas daudzums parāda eksponenciālās izaugsmes tendences. Arī piesārn,ojošo vielu emisijas apjomi pieaug. Cilvēces izaugsmei nav precedenta ne mūsu sabiedrības, ne visas Zemes vēsturē. Ja mēs uzmanīgāk pasekojam attīstībai laika gaitā, redzams, ka izaugsmes ātrums aizvien pieaug. Protams, tas nevar turpināties bezgalīgi. Izaugsmei ir ierobežojumi - tos nosaka mūsu planēta.

Planētas resursu ierobežojums kā robeža cilvēces attīstībai vislabāk ir saprotams, aplūkojot derīgo izrakteṇu krājumu izsmelšanas robežas. Ir skaidrs, ka noteiktam resursu veidam ir krājumi, kurus, protams, var precizēt, bet to apjoms ir ierobežots. Šos krājumus, respektīvi, katru konkrētu elementu (piemēram, zelta) vai savienojumu (piemēram, naftas) krājumus, kas ir izveidojušies, vai nu veidojoties planētai Zemei, vai uzkrājušies miljoniem gadu laikā, cilvēce var izsmelt. Nafta, akmen,ogles ir resursi, no kuriem ir atkarīga mūsdienu cilvēces labklājība, jo tie ir ķīmiskās ražošanas galvenās izejvielas. Piemēram, nafta tiek izmantota transportā kā galvenais enerǵijas resurss. Vienlaikus naftas krājumus iespējams novērtēt visai precīzi, un to izmantošanas apjoms jau ir sasniedzis savu maksimumu (1.2. att.). Tiek vērtēts, ka naftas patēriña maksimums tika sasniegts 2008. gadā.

Cilvēces pastāvēšana ir atkarīga no resursiem, kuru avots ir Zeme. Resursu izmantošana rada piesārn,ojumu un atkritumus, un līdz ar to izaugsmi ierobežo ne tikai resursu izsīkšana, bet arī piesārṇojuma uzkrāšanās un planētas ierobežotā spēja absorbēt atkritumus un piesārṇojumu.

Cilvēces attīstība ir atkarīga ne tikai no resursu izmantošanas, bet arī tās dzīvesveida izmaiṇas. Aizvien lielākas dabiskās teritorijas tiek izmantotas cilvēka vajadzībām. Liela daḷa no zemes ir pārvērsta par aramzemi, daudzi Zemes apvidi (piemēram, Eiropa), no kosmosa skatoties, naktīs ir gaiši, tropiskie lietusmeži tiek izcirsti un pārvērsti par kultūraugu plantācijām. Augsne, virszemes un pazemes ūdeñi, pārmitrās teritorijas, daba un vide ir sākusi degradēties. Pat vietās, kur atjaunojamie resursi šksiet stabili (piemēram, Ziemel̦amerikas meži vai Eiropas augsnes), resursu kvalitāte, daudzveidība un izdzīvošanas spējas var tikt apšaubītas. 


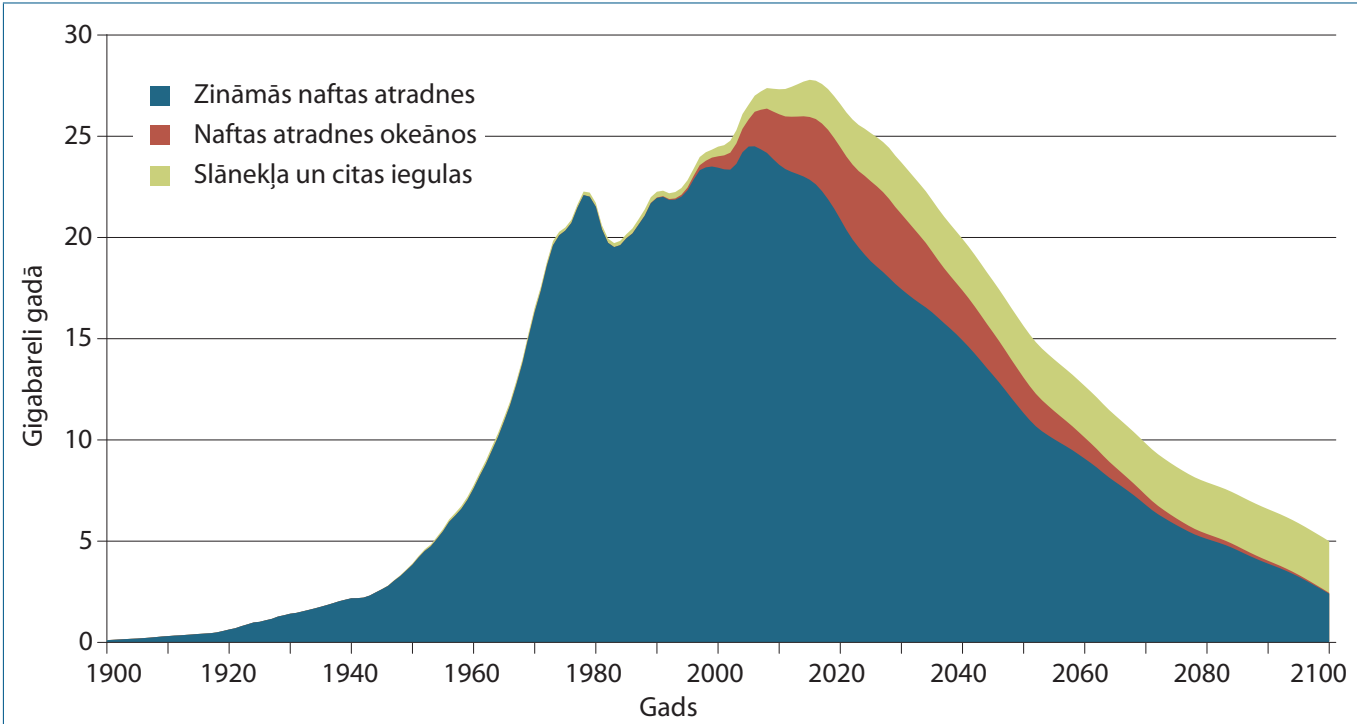

1.2. att. Naftas un naftas ogḷūdeņražu ieguves apjoms un izmantojamo resursu novērtējums nākotnē.

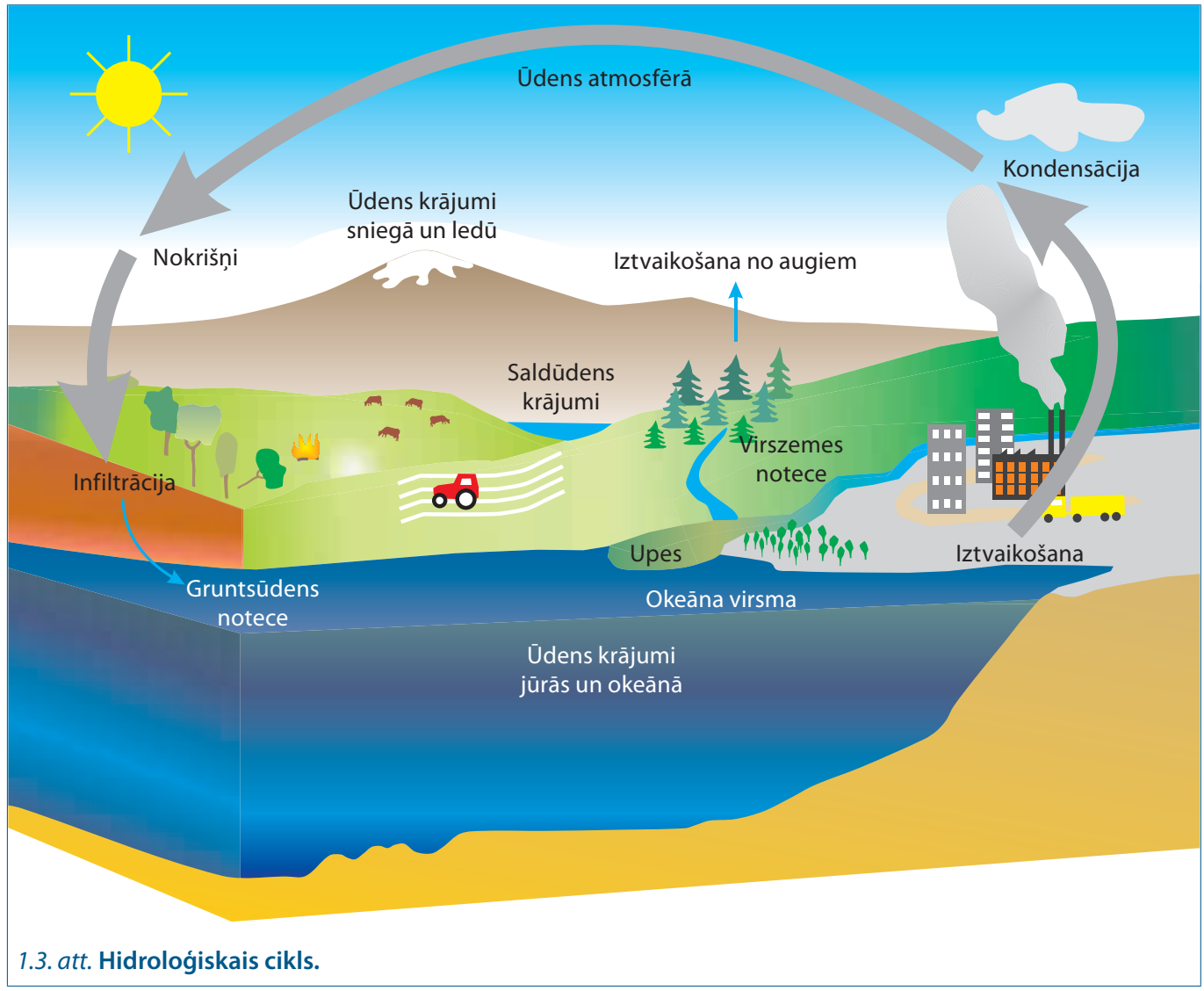


Cilvēces darbība spēj ietekmēt vielu un savienojumu plūsmas vidē, piemēram, ūdens aprites ciklu - hidrologisko ciklu (sk. 1.3. att.). Ūdens ir dabas resurss, kas atjaunojas un uztur dzīvību uz Zemes. Tas ir mūsu un visu pārējo sugu svarīgākais eksistences pamats.

Hidrologiskais cikls parāda saistību starp galvenajiem ūdens avotiem un atspoguḷo iztvaikošanas un arī atmosfēras nokrišnu veidošanās procesu lielo nozìmi ūdens bilancē. Galvenais enerǵijas avots, kas nosaka ūdens iesaistī̌̌anos globālās aprites ciklā, ir Saule.

Ūdens ir viena no cilvēka visvairāk patērētajām vielām - milzīgi ūdens daudzumi tiek izmantoti gan sadzìves vajadzībām, gan arī ražošanā, bet visvairāk ūdens tiek lietots lauksaimniecībā (sk. 1.4. att.):

- lauksaimniecībā (69\%),

- rūpniecībā (23\%),

- mājsaimniecībās un pakalpojumu sniegšanā (aptuveni 8\%).

Kaut arī hidrologiskajā ciklā iesaistītās ūdens masas ir milzīgas, tomēr cilvēka darbība ietekmē ūden,u plūsmas. Pašlaik cilvēces ūdens

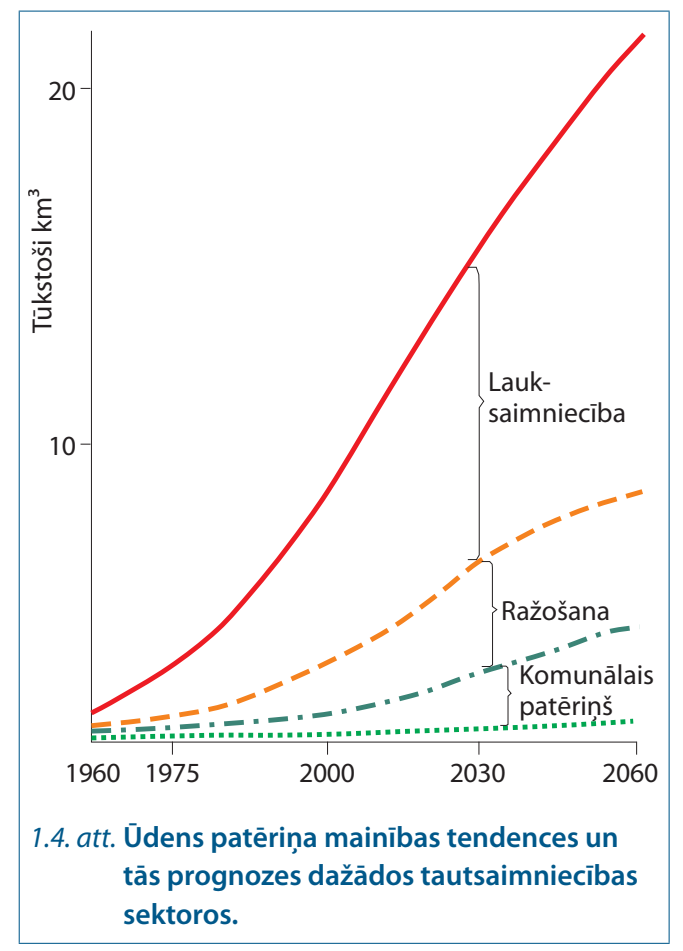

patēriņš ir salīdzināms ar būtisku daḷu no pasaules upju noteces. Jau tuvā nākotnē cilvēka ūdens patēriņš varētu pārsniegt dabisko ūdeṇu plūsmu iespējas.

Cilvēka negatīvo ietekmi uz ūdens aprites procesiem ilustrē Arāla jūras izsīkšana, ko izraisīja tajā ieplūstošo upju ūden,u intensīva izmantošana lauku apūden,ošanai (galvenokārt, audzējot kokvilnu). 1960. gadā Arāla jūras platība bija 67000 kvadrātkilometri, bet 2014. gadā tās platība jau bija sarukusi līdz 13000 kvadrātkilometriem, un tiek prognozēts, ka pārredzamā nākotnē tā var izzust pilnībā, atstājot savā vietā sāls tuksnesi.

Uz Zemes notiek nemitīga elementu, vielu un energijas aprite, kuru apraksta vielu aprites cikli. Vielu aprites ciklus sauc par bioǵeoksīmiskiem cikliem, jo tie ietver daudzas k,īmiskās pārvērtības, geologiskos procesus, un to veidošanā aktīvi piedalās dzīvie organismi - biotiskā vide. Vielu (piemēram, ūdens) un elementu (piemēram, skābekḷa, sēra, oglekḷa) avots ir litosfēra, no kuras vielas var nokḷūt atmosfērā un hidrosfērā vulkānu izvirdumos vai iežiem dēdējot. Vielas un elementi no hidrosfēras noklūust atmosfērā, turklāt nozīmīgi ir procesi, kas saistās ar ūdens apriti dabā. Dzīvie organismi biosfērā asimilē vielas no litosfēras, hidrosfēras un atmosfēras, bet pēc to bojāejas vielas atgriežas ar biosfēru saistītajās vidēs.

Cilvēka darbība var ietekmēt arī vielu plūsmas, piemēram, ietekmēt galveno atmosfēru veidojošo vielu - slāpekli. Slāpeklis veido $76 \%$ no atmosfēras masas, ietilpst olbaltumvielu un DNS sastāvā un tāpēc ir viens no dzīvo organismu pastāvēšanai nepieciešamajiem elementiem. Tajā pašā laikā litosfērā un hidrosfērā slāpekla savienojumu koncentrācija ir ievērojami zemāka, turklāt slāpeklis ir inerts, un tiešā veidā lielākā daļa dzīvo organismu nespēj to izmantot. Līdz ar to slāpekḷa aprites ciklā noris dažādi procesi, kas nodrošina atmosfēras slāpekḷa $\left(\mathrm{N}_{2}\right)$ saistǐšanu tādu savienojumu veidā, kas ir pieejami dzīvajiem organismiem. Slāpekl̦a savienojumi ir savstarpēji saistīti, un tie var pārvērsties cits citā. Tāpat kā citu elementu apriti, arī slāpekḷa apriti ilustrē tā biogeoḳīmiskās aprites cikls (sk. 1.5. att.). 

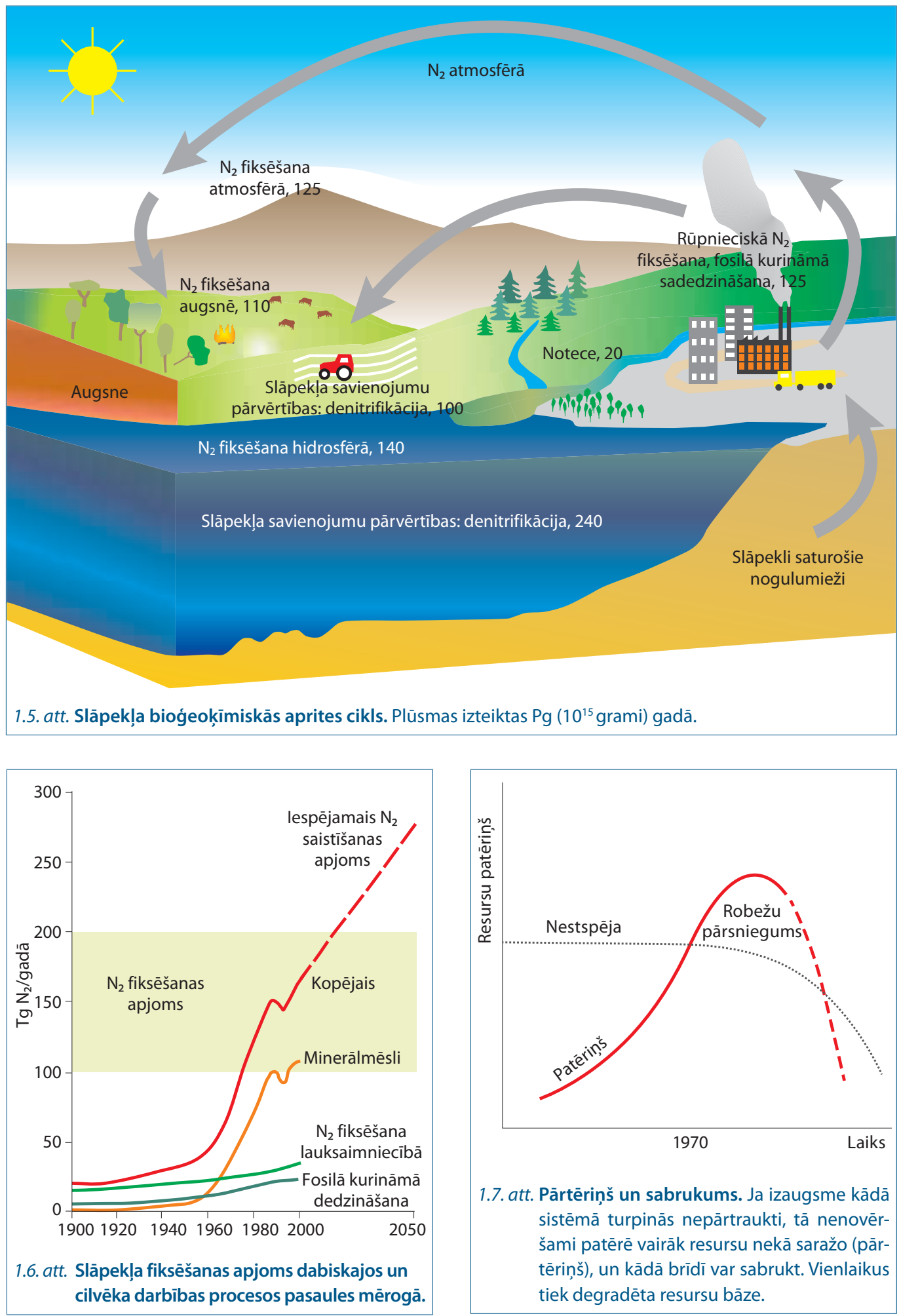

1.7. att. Pārtērinš un sabrukums. Ja izaugsme kādā sistēmā turpinās nepārtraukti, tā nenovēršami patērē vairāk resursu nekā saražo (pārtērinšs), un kādā brīdī var sabrukt. Vienlaikus tiek degradēta resursu bāze. 
1914. gadā vācu ķīmiķi Fricis Hābers un Ulrihs Bošs izstrādāja rūpniecisku metodi gaisa slāpekḷa izmantošanai amonjaka ražošanā - tā radīja pamatu liela mēroga minerālmēslu rūpniecības attīstībai. Mūsdienās minerālmēslu ražošanas kopapjoms ir apmēram 100 miljoni tonnu gadā, kas aptuveni atbilst tam slāpekḷa apjomam, kas tiek fiksēts mikroorganismu darbības rezultātā (100-200 miljoni tonnu gadā; sk. 1.6. att.). Tātad cilvēka darbība jau pašlaik pēc apjoma ir salīdzināma ar dabiskajiem slāpekḷa bioǵeoḳimiskās aprites cikla procesiem, bet paredzams, ka tuvākā nākotnē tos pārsniegs.

N̦emot vērā slāpekḷa savienojumu ražošanas ievērojamos apjomus, tie var negatīvi ietekmēt gan vidē norisošos procesus, gan arī cilvēku un dzīvnieku veselību.

Visai acīmredzamie ierobežojumi gan fosilās enerǵijas, gan citu neatjaunojamo resursu izmantošanai ir likuši sāpīgi apzināties mūsu sabiedrības un ekonomikas izaugsmes robežas. "Izaugsmes robežas"1 ir pasaulē plaši pazīstama grāmata, kas publicēta 1972. gadā. Tās pamatā ir pētījums par to, kas notiks ar mūsu pasauli, ja izaugsme turpināsies atbilstoši tā saucamajam attīstības modelim "viss kā parasti", kas neizbēgami noved pie resursu pārtēriṇa, maksimumpunkta sasniegšanas un sabrukuma (sk. 1.7. att.).

Cilvēces attīstības rakstura modelēšana (sk. 1.7. att.) parāda, ka, turpinoties līdzšinējai attīstībai, pat pastāvot tehnologiskajam progresam un paplašinoties izejvielu un resursu pieejamībai, jau šì gadsimta laikā iespējama izaugsmes robežu pārsniegšana un labklājības rādītāju katastrofāla samazināšanās. Tā sekas var būt rūpnieciskās ražošanas un pārtikas pieejamības, kā arī iedzīvotāju skaita samazināšanās.

Nesen veiktā pētījumā mēǵināts noteikt robežas tādiem procesiem uz Zemes, no kuriem ir atkarīga cilvēces pastāvēšana, tās nosaucot par planētas robežām. Planētas robežas novērtētas deviniem dažādiem procesiem un

${ }^{1}$ Meadows D. H., Meadows D. L., Randers J. (1972) The Limits to Growth. New York: Universe Books. resursiem (sk. 1.8. att.). Trīs no šīm robežām jau ir pārkāptas:

- siltumnīcefekta gāzu koncentrācija atmosfērā,

- ātrums, ar kādu samazinās biologiiskā daudzveidība,

- slāpekḷa un fosfora savienojumu daudzums biosfērā.

Tomēr arī planētas iespēju pārējās robežas ir tuvu pārsniegšanai, piemēram, cilvēka ietekme uz ūdens apriti. Dažos gadījumos tās ir grūti precīzi novērtēt (piemēram, attiecībā uz vides piesārn,ojumu), tomēr cilvēka radītās ietekmes neapšaubāmi ir būtiskas.

Cilvēka ietekme uz dabas vidi ir salīdzināma ar dabas spēku ietekmēm. Mūsdienu civilizācijas attīstība ir notikusi relatīvi stabilos vides apstākḷos, ko raksturo atmosfēras sastāva stabilitāte, vielu biogeoksimisko procesu raksturs. Šo laika posmu kopš ledus laikmeta beigām geologijā sauc par holocēnu. Cilvēce mūsdienās ir kḷuvusi par ievērojamu spēku un līdz ar to pēdējo gadsimtu laikā mainījusi Zemes vidi. Zemes evolūcija ir pārgājusi jaunā attīstības fāzē - antropocēnā, kuru raksturo cilvēku aktīva ietekme uz visiem norisošajiem procesiem.

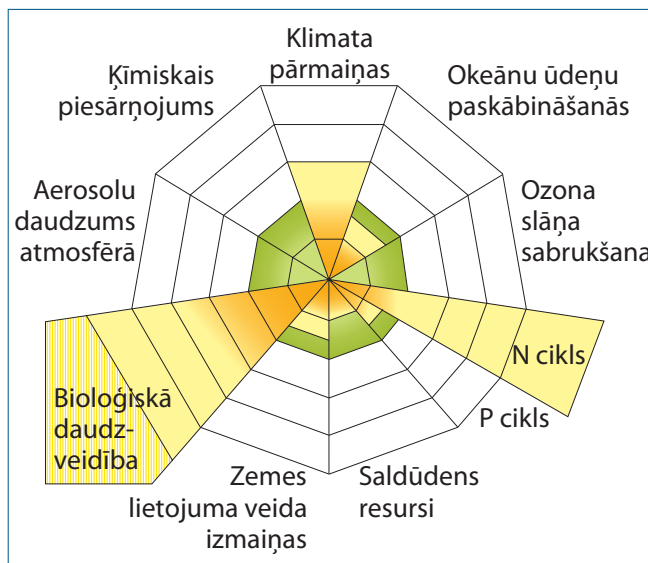

1.8. att. Planētas iespēju robežu koncepcija. Zal̦ie sektori raksturo cilvēka darbības jomas, kurās cilvēka ietekmes ir minimālas, dzeltenie sektori - jomas, kurās cilvēka ietekme ir salīdzināma ar dabisko procesu intensitāti vai pārsniedz dabiski norisošo procesu intensitāti un apjomu. 
Avoti tālākām studijām

Biogeochemical Cycles. Pieejams: http://www.enviroliteracy.org/subcategory.php/198.html

Leopold Education Project. Pieejams: http://www.lep.org

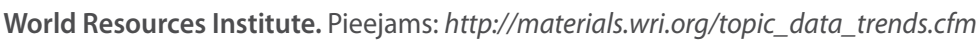

Anthropocene Info. Pieejams: $h$ ttp://www.anthropocene.info/en/home

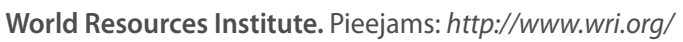

Anthropocene. Pieejams: http://www.eoearth.org/view/article/150125

\section{Literatūra}

Berner E. K., Berner A. B. (1996) Global Environment. Water, Air and Geochemical Cycles. N.Y.: Prentice Hall.

Botkin D., Keller E. (2000) Environmental Science: Earth as a Living Planet. N.Y.: J. Wiley.

Cunningham W. P., Saigo B. W. (2001) Environmental Science: a Global Concern. N.Y.: McGraw-Hill.

Enger E. D., Smith B. F. (2006) Environmental Science: A Study of Interrelationships. $10^{\text {th }}$ ed. Boston: McGraw Hill.

Environmental Science (Ed. L. Ryden) (2003) Uppsala: Baltic University Press.

Lovelock J. (2007) The Revenge of Gaia. London: Penguin Books Ltd.

Montgomery C. W. (1997) Environmental Geology. $5^{\text {th }}$ ed. Boca Raton: McGraw-Hill.

Commoner B. (1971) The Closing Circle: Nature, Man, and Technology. Random House.

Goudie A. (2006) The Human Impact on the Natural Environment: Past, Present, and Future. Wiley-Blackwell.

Huesemann M. H., Huesemann J. A. (2011) Technofix: Why Technology Won't Save Us or the Environment. New Society Publishers.

The Garden of Our Neglect: How Humans Shape the Evolution of Other Species. July 5, 2012 Scientific American.

Izmantotie attēli

1.1. Sagatavošanai izmantoto datu avoti: World Population Data Sheet (Washington DC: Population reference Bureau) www.prb.org; United Nations Statistical Year Book N.Y.: UN, 2008; C. D. Keeling, T. P. Whorf (2001) Atmospheric $\mathrm{CO}_{2}$ concentrations derived from in situ air samples collected at Mauna Loa observatory, Hawaii. In: Trends: a compendium of data on global change. http://cdiac.esd.ornl.gov/trends; UN Food and Agriculture Organization FAOSTAT on-line database http://apps.fao.org; International Energy Outlook 1998 (Washigton DC: Energy information Administration, US Dept. Of Energy, 1998) http://eia.doe.gov/oiaf/ieo

1.2. Avots $h$ ttp://crudeoilpeak.info/global-peak

1.4. Sagatavots, izmantojot Millenium Ecosystem Assesment, 2005.

1.6. Sagatavots, izmantojot Millenium Ecosystem Assesment, 2005.

1.7. Izveidots ar ațauju - Dennis Meadows, 2004 no Meadows D. H., Randers J., Meadows D. L. (2008) Limits to Growth: The 30-Year Update. Earthscan: London.

1.8. Sagatavots, izmantojot http://www.stockholmresilience.org/21/research/research-programmes/planetaryboundaries.html 
Zemes klimats un

to veidojošie faktori 


\subsection{Klimats un laikapstākḷi}

Ja gaisa temperatūra vienas dienas laikā samazinās no $+25^{\circ} \mathrm{C}$ līdz $+18^{\circ} \mathrm{C}$, vai tas ir saistāms ar klimata pārmaiṇām? Ko šāda piemēra kontekstā nozīmē ierobežot klimata pārmaingas, lai globālās vidējās temperatūras pieaugums nepārsniegtu $2{ }^{\circ} \mathrm{C}$ ? Lai izprastu to, kas ir klimata pārmaiñas, vispirms nepieciešams skaidri nošksirt jēdzienu "klimats" un "laiks" vai "laikapstākḷı" saturu. Laiks (ārlaiks, laikapstākḷii) ir atmosfēras stāvoklis kādā noteiktā laika sprīdī. Laiku raksturo gaisa temperatūra, atmosfēras spiediens, mitrums, nokrišn,u daudzums, kā arī veids, un, mainoties kaut vienam no šiem lielumiem, mainās laikapstākḷi. Tātad laikapstākḷi ir l̦oti mainīgi. Klimats ir ilggadējs laikapstākḷu režīms, kas veidojas Saules radiācijas, Zemes virsmas veida un atmosfēras cirkulācijas procesu rezultātā. Klimatu raksturo vidējotas un ilglaicīgas atmosfēras fizikālo rādītāju vērtības, kas piemīt Zemei kopumā (globālais klimats) vai noteiktai teritorijai (valstij vai regionam). Konkrētās teritorijas klimats ir daudz pastāvīgāks nekā laikapstākḷi, un tās klimatu nosaka Saules starojuma intensitāte (enerǵijas daudzums) un sadalījums gada laikā, atmosfēras cirkulācijas un Zemes virsmas veids.

Zemes klimats ir l̦oti sarežǵìta sistēma, un galvenais to veidojošais faktors ir energija, kuru Zeme sañem no Saules. Klimats veidojas, Saules enerǵijai izkliedējoties un mijiedarbojoties ar Zemi, līdz ar to klimata sistēmu veido atmosfēra, hidrosfēra, kriosfēra (Zemes ledāji, sniega sega un mūžīgais sasalums), litosfēra un biosfēra (sk. 2.1. att.).

Atmosfēra, kuru veido gāzes, ūdens tvaiki, kā arī putekḷi un aerosoli, ir klimata sistēmas nestabilākā daḷa, kas mainās visstraujāk.

Hidrosfēru veido sauszemes un pazemes ūdeṇi, jūru un okeānu ūden,i, kuri klāj $\approx 70 \%$ Zemes virsmas. Jūru un okeānu ūdeṇi uzglabā

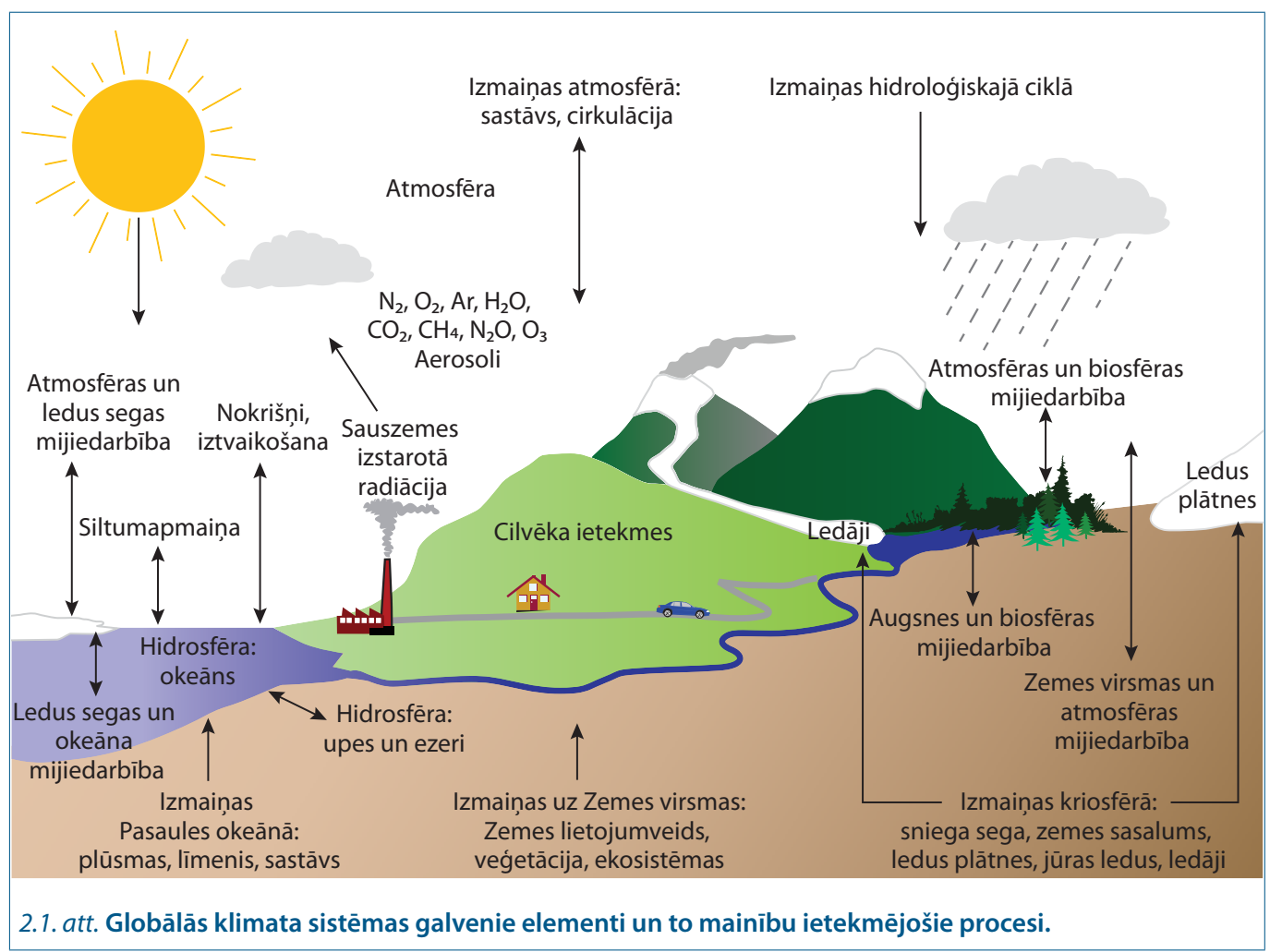


milzīgus enerǵijas, kā arī izšķīdušās og̣̣skābās gāzes un citu gāzu daudzumus, kas tiek pārnesti ar straumju kustību. Jūru un okeānu ūdeṇu cirkulāciju rada Zemes rotācija, vēja darbība, ūden,u uzsilšana, iztvaikošana, saldūden,u ieplūde, atmosfēras nokrišnu rezultātā radies atškirīgais sāḷ saturs ūdenī un līdz ar to ūdens blīvums (termohalīnā cirkulācija - to rada temperatūras un sāḷu koncentrācijas atšķirības). Tajā pašā laikā jūru un okeānu ūdeṇu apritei salīdzinājumā ar lıti kustīgo atmosfēru, ir raksturīga ievērojami lielāka inerce. Jūru un okeānu plūsmu termiskā inerce (lēni uzkrāj, bet arī lēni atbrīvo enerǵiju) regulē Zemes klimatu un ir viens no galvenajiem klimata mainības cēloṇiem.

Kriosfēra ietver Arktikas, Antarktīdas un Grenlandes ledājus, kontinentu ledājus, jūras ledu un grunts mūžīgo sasalumu (pazemes apledojumu). Kriosfēru raksturo tas, ka ledāja virsma spēj atstarot Saules starojumu. Tam ir liela nozīme hidrosfērā norisošajos procesos. Ledāju segā ir uzkrājies liels daudzums ūdens, un tiek uzskatīts, ka, tiem izkūstot, jūru un okeānu līmenis varētu ievērojami pacelties.

Veǵetācija, kas sedz Zemes virsmu, ietekmē Saules starojuma asimilāciju, bet iztvaikošana gan no hidrosfēras, gan sauszemes ir ūdens tvaiku un nokrišn,u avots. Ūdenu un sauszemes biosfēra, saistot ogḷskābo gāzi un atbrīvojot skābekli un ūdens tvaikus, ietekmē atmosfēras sastāvu. Biosfēra ir noteicošā oglekḷa aprites ciklā.

Visi aplūkotie klimata sistēmas elementi mijiedarbojas, turklāt mijiedarbības raksturs ir mainīgs gan laikā, gan telpā. Katru klimata sistēmas elementu atšksirīgi ietekmē Saules starojums. Klimata sistēma, protams, ir pakḷauta arī kosmiskās telpas ietekmei, piemēram, Saules starojuma un kosmiskā starojuma mainībai. Zemes klimatu ḷoti būtiski var ietekmēt arī geologiskas katastrofas (lieli vulkānu izvirdumi, kontinentu pārvietošanās), kosmiskas katastrofas (piemēram, meteorītu triecieni) vai arī cilvēka darbība (jaudīgu atomieroču izmantošana, upju noteces kontinentāla mēroga pārdale).

Kaut arī klimata sistēmas elementus raksturo atškirīgs ķīmiskais sastāvs, fizikālās īpašîbas un ietekme uz Zemes klimata veidošanos, starp tiem notiek vielu un energijas apmaiña. Jebkuras izmaiṇas klimata sistēmā neatkarīgi no tā, vai tās nosaka procesi, kas noris dabiski, vai arī cilvēka iedarbība, var ietekmēt citus sistēmas elementus un radīt klimata izmainnas.

\subsection{Zemes atmosfēra un tās uzbūves ietekme uz klimatu}

Zemes atmosfēras uzbūve un sastāvs ietekmē Saules starojuma pārvērtības un līdz ar to Zemes klimatu.

Zemes atmosfēra nav viendabīga, tai ir izteikti slān,aina uzbūve. Atmosfēru veido dažāda biezuma zonas - troposfēra, stratosfēra, mezosfēra, termosfēra un eksosfēra, kurām ir atšksirīgas fizikālḳīmiskās īpašības (sk. 2.2. att.). Starp šīm zonām atrodas pārejas zonas - tropopauze, stratopauze un mezopauze.

Troposfēra ir atmosfēras apakšējais slānis, kas saskaras ar litosfēru, hidrosfēru, biosfēru un ir vitāli svarīgs dzīvības nodrošināšanai uz Zemes. To visvairāk ietekmē Zemes virsma. Temperatūra troposfērā pazeminās līdz ar attālināšanos no Zemes virsmas. Būtiskākās troposfēras iezīmes: augstums no 0 līdz $\approx 16 \mathrm{~km}$, raksturīga temperatūras pazemināšanās līdz ar augstumu $\approx 6,5^{\circ} \mathrm{C} / \mathrm{km}$, dominē spēcīga gaisa vertikālā sajaukšanās un horizontālā pārnese. Troposfēra satur $\approx 80 \%$ atmosfēras masas un gandrīz visu atmosfēras ūdeni.

Tropopauze ir pirmais aukstais slieksnis, kas veido robežu starp troposfēru un stratosfēru, un tajā sākas temperatūras inversija (parādība, kad siltāks gaiss atrodas virs vēsāka gaisa).

Stratosfēra atrodas 10-50 km attālumā no Zemes virsmas, bet tās temperatūras režìmu raksturo tas, ka $\approx 20 \mathrm{~km}$ augstumā gaisa temperatūra sāk paaugstināties (sk. 2.2. att.).

Temperatūras inversijas cēlonis stratosfērā ir fotokīmiskas reakcijas ultravioletā starojuma iedarbībā, kas sekmē ozona $\left(\mathrm{O}_{3}\right)$ veidošanos. Fotokjīmiskajās reakcijās tiek saistīta daḷa 


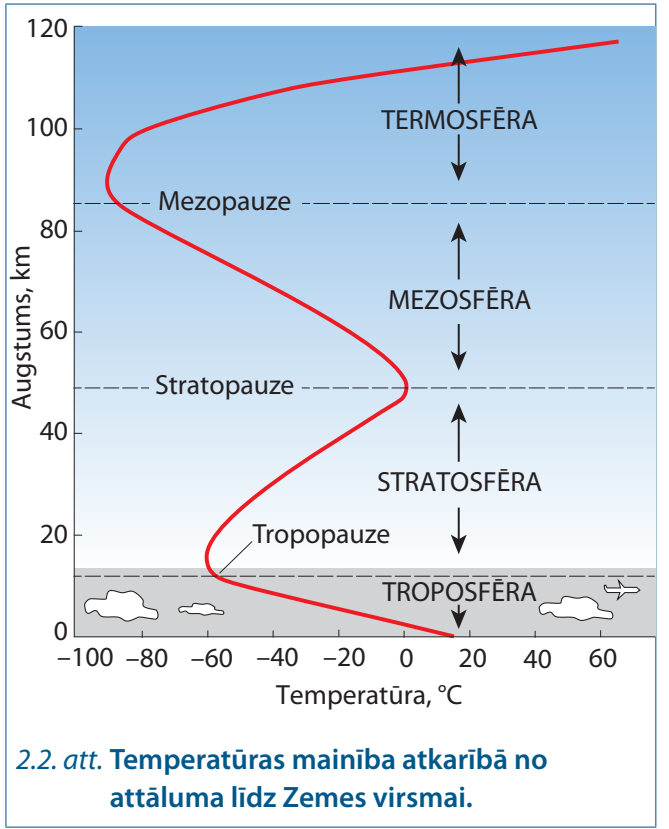

gaismas starojuma enerǵijas. Maksimālā ozona koncentrācija novērojama $\approx 25 \mathrm{~km}$ augstumā, bet maksimālā temperatūra - apmēram 50 km augstumā. Šādu temperatūras sadalījumu ietekmē gaisa retinājums. Liela dạla energíjas tiek absorbēta augšējos stratosfēras slāṇos un nesasniedz maksimālās ozona koncentrācijas zonu, taču, tā kā gaisa blīvums ir zems, siltuma enerğijas pārnese no augšējiem stratosfēras slān,iem ir lēna.

Slānis, kas atrodas tuvu $50 \mathrm{~km}$ augstumam, veido stratopauzi, kas ir temperatūras inversijas augšējā robeža. Gaisa spiediens stratopauzē ir zems ( $\approx 1$ milibārs, mb), un tas nozīmē, ka tikai 1/1000 daḷa no visām atmosfērā esošajām molekulām atrodas virs šì līmeņa. Mezosfēra atrodas virs stratosfēras (apmēram 50-90 km), tajā temperatūras pazemināšanās notiek līdz ar augstuma palielināšanos. Mezosfēras augšējā daḷa ir aukstākā atmosfēras daḷa. Kaut arī gaisa blīvums mezosfērā ir ḷoti zems, atmosfēras sastāvs tajā ir tāds pats kā piezemes slānī.

Termosfēra ir atmosfēras slānis virs $\approx 90 \mathrm{~km}$ augstuma, kuram nav noteiktas augšējās robežas. Termosfērā atmosfēru veidojošo gāzu molekulas absorbē kosmisko starojumu, Saules gamma $(\gamma)$ starojumu, rentgenstarojumu un nozīmīgu daļu ultravioletā starojuma, tādēl atmosfēru veidojošo gāzu molekulu kustības ātrums pieaug. Šo gāzu molekulas, mijiedarbojoties ar augstas enerǵijas elektromagnētisko starojumu, var zaudēt elektronus, un tāpēc atmosfēras augšējos slānos tās pastāv brīvu atomu vai jonu veidā. Tā kā Saules energija ir būtiski atkarīga no Saules aktivitātes, temperatūra šajā slānī ir mainīga. Virs termosfēras $\approx 500 \mathrm{~km}$ augstumā atmosfēru veidojošo gāzu molekulas var veikt $\approx 10 \mathrm{~km}$ distanci, pirms tās saduras cita ar citu. Raksturīgi, ka šajā apgabalā molekulas kustoties var iziet no Zemes gravitācijas ietekmes kosmosā. Šo regionu, kur atomi un molekulas nonāk kosmiskajā telpā, sauc arī par eksosfēru.

Atmosfēras procesus būtiski ietekmē elektromagnētiskā starojuma mijiedarbība ar atmosfēru veidojošām gāzēm. Atmosfēru pamatā veido slāpeklis (78\%) un skābeklis (21\%), bet arī ūdens tvaikiem un og̣̦skābajai gāzei ${ }^{1}$ ir būtiska nozīme klimata veidošanā.

\footnotetext{
${ }^{1}$ Mitrā gaisā pie Zemes virsmas ir vidēji no 0,2\% (polārie platumi) līdz 2,5\% (ekvators), bet dažos gadījumos pat līdz $4 \%$ ūdens tvaiku, bet oglskābā gāze $\left(\mathrm{CO}_{2}\right)$ veido $0,035 \%$ atmosfēras tilpuma.
}

\section{1. tabula. Galveno atmosfēras zonu raksturojošie parametri}

\begin{tabular}{|l|c|c|c|c|c|}
\hline \multirow{2}{*}{ Atmosfēras zonas } & \multicolumn{2}{|c|}{ Temperatūra, $^{\circ} \mathrm{C}$} & $\begin{array}{c}\text { Temperatūras } \\
\text { gradients, }{ }^{\circ} \mathrm{C} / \mathbf{k m}\end{array}$ & $\begin{array}{c}\text { Augšējā un apakšējā } \\
\text { robeža, km }\end{array}$ & $\begin{array}{c}\text { Raksturīgās } \\
\text { vielas }\end{array}$ \\
\hline Troposfēra & 15 & -56 & $-6,45$ & no 0-6 līdz 16 & $\mathrm{N}_{2}, \mathrm{O}_{2}, \mathrm{CO}_{2}$ \\
\hline Stratosfēra & -56 & -2 & $+1,38$ & $10-50$ & $\mathrm{O}_{3}$ \\
\hline Mezosfēra robeža & Augšēā robeža & $-2,56$ & $50-85$ & $\mathrm{O}_{2}^{+}, \mathrm{NO}^{+}$ \\
\hline Termosfēra & -2 & +120 & $+3,11$ & $85-500$ & $\mathrm{O}^{+}, \mathrm{NO}^{+}$ \\
\hline
\end{tabular}




\subsection{Saules starojums un Zemes klimats}

Galvenie faktori, kas nosaka Saules enerǵijas daudzumu, ir

- starojuma veiktais attālums;

- leṇkis, kādā Saules starojums sasniedz Zemi;

- atmosfēras sastāvs, Saules un kosmiskās telpas starojuma mijiedarbība ar Zemes atmosfēru veidojošām gāzēm.

Iemesls Saules staru krišanas leņksa un dienas garuma izmain̄ām ir nepārtrauktās Zemes stāvokḷa izmaiṇas attiecībā pret Sauli un Zemes griešanās ass slīpuma ilglaicīgās svārstības. Zemes griešanās ass ir par 23,5 grādiem novirzīta no vertikāles pret Zemes orbītas plakni. Zemei riṇķojot ap Sauli, tās ass stāvoklis būtiski nemainās. Dažādos orbītas posmos pret Sauli vairāk tiek pavērstas dažādas Zemes puslodes, tādēḷ mainās gadalaiki. Ar Zemes griešanās ass slīpuma lenkiki ir cieši saistīts klimats. Ja Zemes rotācijas ass būtu perpendikulāra orbītas plaknei, tad visu gadu Saule apgaismotu Zemi vienādi, gadalaiki nemainītos, un, piemēram, ekvatoriālajos platuma grādos vienmēr būtu loti karsts, bet polārajos - loti auksts. Ja Zemes griešanās ass slīpuma leṇkis būtu lielāks nekā pašlaik, gadalaiku izmainas būtu krasākas (ziemā aukstāks, vasarā karstāks), bet atškirīības starp klimatiskajām zonām nebūtu tik izteiktas.

Zemi sasniedz gan pilna spektra Saules elektromagnētiskais starojums, gan jonizētu dalıiņu plūsma (piemēram, ūden,raža vai hēlija atomu kodoli), kā arī elementārdalılinas un kosmiskās telpas dalıinu un starojuma plūsma (kosmiskais starojums). Zemes klimatu galvenokārt ietekmē elektromagnētiskā starojuma plūsma. Zemes atmosfēras ārējos slānuus sasniedz starojums, kura spektrālais sastāvs atbilst melna kermeña starojumam, kura temperatūra ir $\approx 6000 \mathrm{~K}$ (sk. 2.3. att.). Saules elektromagnētiskā starojuma spektru veido ultravioletie stari, rentgenstarojums, $\gamma$ stari, kā arī redzamā gaisma, radioviḷni un infrasarkanais starojums (sk. 2.4. att.). Elektromagnētiskā starojuma enerǵija samazinās, palielinoties viḷnu garumam, un lielākajai daḷai starojuma, kas sasniedz Zemi, ir augsta enerǵija un relatīvi îss vilınu garums.

Redzamās gaismas vilṇu garums ir aptuveni no 0,40 līdz $0,75 \mu$. Redzamā gaisma nodrošina enerǵiju, kas ir vajadzīga zalı augu fotosintēzei, bet dzīvniekiem tā regulē reprodukcijas laiku, migrāciju un daudzas citas dzīvības norises.

Infrasarkanajam starojumam (siltumstarojumam) ir ievērojami mazāka enerǵija, tomēr šis starojums ir nozīmīgs Zemes klimata izveidē, jo nodrošina atmosfēras apakšējo slāṇu un Zemes virsmas uzsilšanu.

Dažas mikroviḷnu frekvences tiek lietotas radiosakaros, mikroviḷnu krāsnīs, arī laikapstākḷu noteikšanai ar radariem.

Radiovil̦ni ir zemas enerǵijas vilıni pie elektromagnētiskā starojuma spektra augšējās

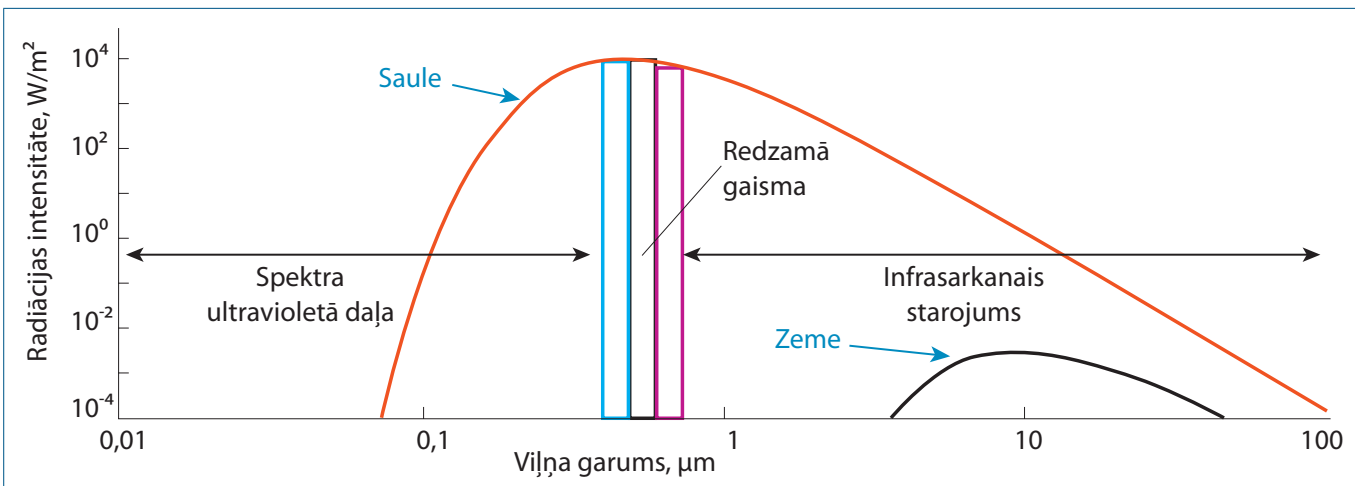

2.3. att. Saules un Zemes starojuma intensitāte un spektrs. 
jūras līmeṇa augstumā tiešais starojums vidēji ir $1045 \mathrm{~W} / \mathrm{m}^{2}$, bet kalnos (4-5 km augstumā) $\approx 1184 \mathrm{~W} / \mathrm{m}^{2}$.

Saules starojuma enerǵija ir gandrīz līdzsvarā ar Zemes virsmas atstarotās enerǵijas daudzumu (sk. 2.5. att.). Enerǵijas plūsma, kas sasniedz Zemes atmosfēras augšējos slānuus, ir $\approx 1370 \mathrm{~W} / \mathrm{m}^{2}$. Lielākā dal̦a no šīs enerǵijas tiek atstarota kosmiskajā telpā vai arī tiek absorbēta, mijiedarbojoties ar Zemes atmosfēru veidojošām gāzēm. Enerǵijas plūsma, kas sasniedz troposfēru, ir vairs tikai $342 \mathrm{~W} / \mathrm{m}^{2}$.

Aptuveni 30\% Saules starojuma tiek atstaroti Visumā, turklāt dalı šīs enerǵijas atstaro mākoṇu sega un sīkās dạlinas, kas atrodas atmosfērā, proti, aerosoli. Gaišākie Zemes virsmas apgabali - sniegs, ledus un tuksneši atstaro $1 / 3$ Saules starojuma. Zemes virsma absorbē 51\% Saules starojuma, un šī enerǵija tiek izlietota iztvaikošanas procesos (23\%), konvekcijas un advekcijas (no lat. advection gaisa masu horizontāla pārvietošanās, kas no rajona uz rajonu pārnes siltumu, mitrumu, puteklus u.tml.) procesos (7\%) un Zemes virsmas infrasarkanā starojuma veidā ( $\approx 21 \%$ ).

Lielas izmainas klimata sistēmā var izraisīt vulkānu izmestais materiāls - aerosoli, kas paceḷas lielā augstumā. Katastrofiski vulkānu izvirdumi var pazemināt globālo virsmas temperatūru uz vairākiem mēnešiem vai pat gadiem. Arī cilvēka veidotie aerosoli var ietekmēt Saules gaismas atstarošanu.

Zemes klimatu ietekmē Zemes virsmas spēja atstarot starojumu. Radiācijas dalı, kas tiek atstarota no Zemes virsmas, raksturo virsmas albedo (virsmas albedo ir virsmas atstarotās elektromagnētiskā starojuma plūsmas attiecība

\section{2. tabula. Dažādu virsmu albedo vērtības}

\begin{tabular}{|l|c|}
\hline \multicolumn{1}{|c|}{ Virsma } & Albedo, \% \\
\hline Svaigi uzkritis sniegs & $75-95$ \\
\hline Blīvi mākoṇi & $60-90$ \\
\hline Ledus & $30-40$ \\
\hline Smiltis & $15-45$ \\
\hline Zeme un atmosfēra - planetārais albedo & 31 \\
\hline Okeāns (diennakts vidējais) & 8 \\
\hline Mežs & $1-18$ \\
\hline
\end{tabular}

pret plūsmu, kas krīt uz šo virsmu). Parasti to attiecina uz redzamo gaismu (sk. 2.2. tabulu).

$$
\text { albedo }=\frac{R_{a}}{R_{s}} \times 100 \%
$$

kur $R_{a}-$ atstarotā radiācija,

$R_{S}$ - summārā radiācija.

Saules enerǵija sasilda troposfēru un Zemes virsmu. Kad gāzes (gaiss) sasilst, tās izplešas. Sasilušais gaiss ir mazāk blīvs un tāpēc ceḷas augšup, un tā vietā ieplūst aukstāks gaiss. Šāda veida atmosfēras cirkulācija - siltuma enerǵijas izkliede atmosfērā - ir galvenais mehānisms, kas nosaka klimatiskos apstākḷus. Klimatu l,oti lielā mērā ietekmē arī okeānu straumes, un īpaši liela nozīme ir tā sauktajai termohalīnajai cirkulācijai. Saules gaismas enerǵija visvairāk tiek saṇemta tropu platuma grādos, kas tālāk tiek transportēta uz lielākiem platuma grādiem ar atmosfēras un okeāna cirkulācijas sistēmas starpniecību. Enerğija arī tiek patērēta iztvaikošanā un pārvēršas latentā enerǵijā (veido mākoṇus). Šìs abas cirkulācijas sistēmas mijiedarbojas.

\subsection{Siltumnīcefekts}

Koncepcijai, ka Zemes atmosfēras sastāvs var ietekmēt Zemes klimatu un no Saules saṇemto enerǵijas daudzumu, ir vairāk nekā 100 gadu. Pirmie atmosfēras gāzu sastāva ietekmi uz Zemes klimatu pētīja ang̣̦u fiziķis Džons Tindals un zviedru k̦imiksis Svante Areniuss.
No Saules starojuma Zemes virsma uzsilst, un līdz ar to Zeme izstaro siltumu kosmiskajā telpā. Tomēr Zemes virsmas temperatūra ir ievērojami zemāka nekā Saules virsmas temperatūra, tādēl starojuma enerǵija, ko Zeme izstaro, ir ievērojami zemāka un starojuma viḷnu 


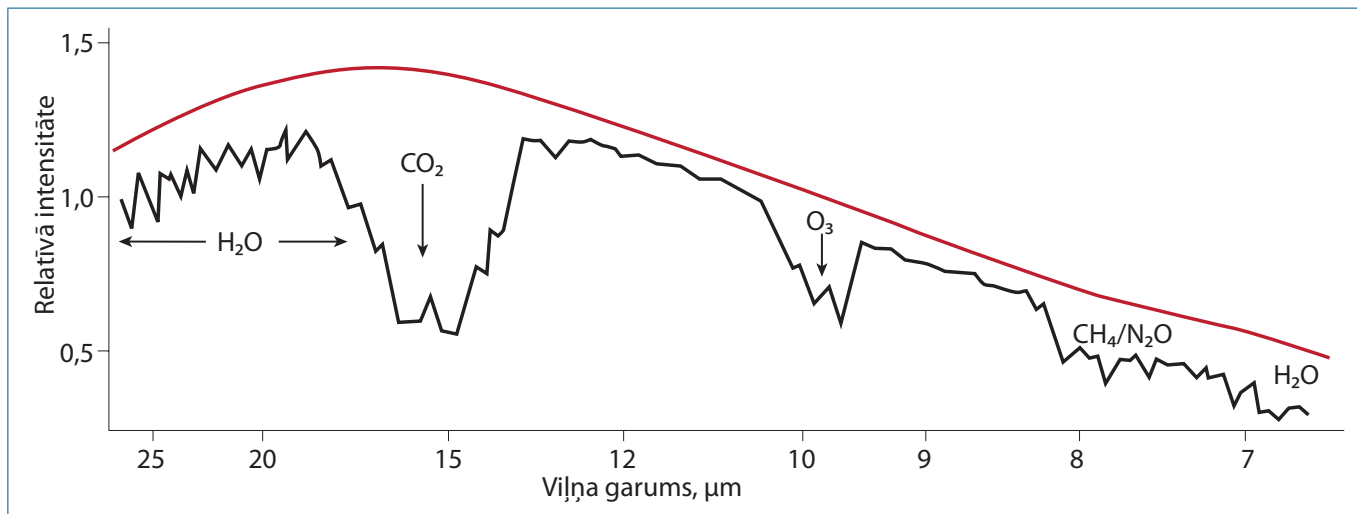

2.6. att. No Zemes virsmas izstarotā starojuma spektrs un mijiedarbība ar atmosfēru veidojošām gāzēm.

garums - ievērojami lielāks nekā starojumam, kas nāk no Saules (sk. 2.3. att.). Zemes virsma galvenokārt izstaro infrasarkano jeb siltuma starojumu. Arī no Zemes virsmas atstarotais infrasarkanais starojums spēj mijiedarboties ar atmosfēru veidojošām gāzēm (sk. 2.6. att.).

Vairākas atmosfēru veidojošās gāzes spēj intensīvi absorbēt infrasarkano starojumu. Šādas gāzes ir og̣̦skābā gāze $\mathrm{CO}_{2}$, metāns $\mathrm{CH}_{4}$, ozons $\mathrm{O}_{3}$ un ūdens tvaiki, kā arī slāpekḷa(I) oksīds $\mathrm{N}_{2} \mathrm{O}$ un cilvēka darbības rezultātā atmosfērā nokḷuvušās gāzes - hlorfluorogḷūdeṇraži (freoni) un sēra heksafluorīds $\mathrm{SF}_{6}$.

Tādas gāzes kā og̣̣skābā gāze, metāns un arī ūdens tvaiki atmosfērā darbojas līdzīgi kā stikls siltumnīcā (sk. 2.7. att.). Tās ir caurlaidīgas ienākošajam starojumam, bet aiztur no Zemes virsmas atstaroto infrasarkano (siltuma) starojumu. N,emot vērā iedarbības efektu, šīs gāzes sauc par siltumnīcefekta gāzēm. Jo augstāka ir siltumnīcefekta gāzu koncentrācija atmosfērā, jo vairāk infrasarkanā starojuma (siltuma) tiek aizturēts Zemes atmosfērā un līdz ar to pieaug Zemes virsmas temperatūra. Ja Zemes atmosfēru veidotu tikai slāpeklis un skābeklis - gāzes, kas neietekmē siltumstarojumu, kas tiek izstarots no Zemes virsmas, - Zemes vidējā temperatūra būtu tikai $6^{\circ} \mathrm{C}$ (faktiski tā ir aptuveni $+15^{\circ} \mathrm{C}$ ).

Hipotēzi par siltumnīcefektu veidojošo gāzu un, vispirms, par $\mathrm{CO}_{2}$ nozìmi Zemes klimata veidošanā Svante Areniuss izteica jau 1896. gadā. Viṇa aprēksini, ka $\mathrm{CO}_{2}$ koncentrācijas dubultošanās atmosfērā var izraisīt Zemes vidējās temperatūras pieaugumu par $5-6^{\circ} \mathrm{C}$, mūsdienās pilnībā apstiprinās.

Pat nelielas siltumnīcefekta gāzu daudzuma izmaiñas atmosfērā pavada temperatūras izmaiṇas uz Zemes, līdz ar to mainās ledāju platība, okeāna līmenis, straumju režīms, biotopu izplatība un klimats.

Katru no siltumnīcefekta gāzēm (sk. 2.3. tabulu) raksturo atšksirīga spēja saistīt un atgriezt uz Zemi Saules starojumu. Radiācijas daudzums, ko izsaka vatos uz kvadrātmetru $\left(\mathrm{W} / \mathrm{m}^{2}\right)$, parāda, kā attiecīgā gāze ietekmē enerǵijas daudzumu, kas sasniedz Zemes virsmu, un līdz ar to parāda, cik lielā mērā tā spēj ietekmēt klimata mainības veidu. Ja radiācijas

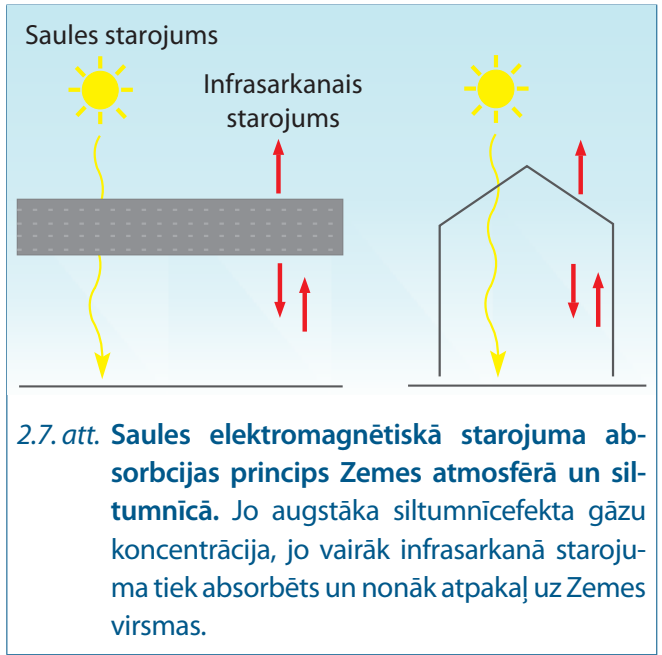


2.3. tabula. Siltumnīcefektu veidojošo gāzu koncentrācijas mainība atmosfērā un ietekme uz Zemes enerǵētisko bilanci

\begin{tabular}{|c|c|c|c|c|c|}
\hline \multirow{2}{*}{ Siltumnīcefekta gāze } & \multicolumn{2}{|c|}{ Gāzes koncentrācija atmosfērā* } & \multirow{2}{*}{$\begin{array}{c}\text { Emisijas } \\
\text { apjoms, gadā }\end{array}$} & \multirow{2}{*}{$\begin{array}{l}\text { Mūža ilgums } \\
\text { atmosfērā, gadi }\end{array}$} & \multirow{2}{*}{$\begin{array}{c}\text { Radiācijas } \\
\text { daudzums** } \\
\text { (RD), W/m² }\end{array}$} \\
\hline & 2012 & 1750 & & & \\
\hline Og̣ıskābā gāze $\mathrm{CO}_{2}^{* * *}$ & 385 & 278 & $26,4 \mathrm{Gt}^{* * * * *}$ & & 1,46 \\
\hline Metāns $\mathrm{CH}_{4}^{* * * *}$ & 1745 & 700 & $600 \mathrm{Tg}^{* * * * * * *}$ & 8,4 & 0,48 \\
\hline Slāpekl’a(I) oksīds $\mathrm{N}_{2} \mathrm{O}^{* * * * *}$ & 314 & 270 & $16,4 \operatorname{Tg} N$ & 120 & 0,15 \\
\hline Perfluoretāns $\mathrm{C}_{2} \mathrm{~F}_{6}^{* * * * *}$ & 3 & 0 & $\approx 2 \mathrm{Gg}$ & 10000 & 0,001 \\
\hline Sēra(VI) fluorīds $\mathrm{SF}_{6}^{* * * *}$ & 4,2 & 0 & $\approx 6 \mathrm{Gg}$ & 3200 & 0,002 \\
\hline Freons $11 \mathrm{CFCl}_{3}^{* * * *}$ & 268 & 0 & - & 45 & 0,07 \\
\hline Freons $12 \mathrm{CF}_{2} \mathrm{Cl}_{2}^{* * * *}$ & 533 & 0 & - & 100 & 0,17 \\
\hline Freons $23 \mathrm{CHF}_{3}^{* * * *}$ & 14 & 0 & $\approx 7 \mathrm{Gg}$ & 260 & 0,002 \\
\hline
\end{tabular}

* Šeit un turpmāk siltumnīcefektu izraisošo gāzu koncentrācijas izteiktas kā tilpuma un skaita daḷas (attiecīgi: miljonās daḷas (angḷu val. parts per million) - ppm; mlrd.d. - miljardās daḷas; t.d. - triljonās daḷas). Šis koncentrācijas apzīmējums norāda uz vielas daudzumu kopējā gaisa daudzumā, 300 ppm nozīmē to, ka miljons gaisu veidojošo gāzu molekulu satur 300 molekulu attiecīgās siltumnīcefekta gāzes, piemēram, miljons $\mathrm{cm}^{3}$ gaisa satur $300 \mathrm{~cm}^{3}$ attiecīgās gāzes.

** Radiācijas daudzuma (RD) lielums parāda atstarotās enerǵijas izmaiṇas pie troposfēras augšējās robežas, kuras notiktu, ja attiecīgais komponents tiktu pilnīgi izṇemts no atmosfēras.

*** Koncentrācija izteikta kā miljonā daḷa.

***** Koncentrācija izteikta kā miljardā daḷa.

***** Gigatonna (Gt) $-10^{9}$ tonnas.

****** Teragrams $(\mathrm{Tg})-10^{12}$ grami.

daudzuma vērtība ir ar pozitīvu zīmi, tad gāze sekmē Zemes temperatūras paaugstināšanos, bet, ja ar negatīvu zīmi, - temperatūras pazemināšanos. Radiācijas daudzuma jēdziena izmantošana l̦auj to sasaistīt ar atmosfēras kīimiskā sastāva un Zemes vidējās temperatūras izmaiṇām un klimata mainības jutīguma parametru $\lambda$, izsakot to kā attiecību starp globālās gada vidējās temperatūras izmainu $\Delta \mathrm{T}_{\mathrm{s}}$ un radiācijas daudzuma izmainu $\triangle \mathrm{RD}$ :

$$
\lambda=\Delta \mathrm{T}_{\mathrm{s}} / \Delta \mathrm{RD}
$$

Siltumnīcefekta pastāvēšana nodrošina to, ka mūsdienās temperatūra uz Zemes atbilst dzīvības pastāvēšanas priekšnoteikumiem. Siltumnīcefekts pastāv ne tikai uz Zemes. Tiek uzskatīts, ka tas nosaka klimatu arī uz Venēras, un siltumnīcefekta dēl temperatūra uz šīs planētas sasniedz pat $450^{\circ} \mathrm{C}$.

Daudzām siltumnīcefektu veidojošām gāzēm raksturīgs augsts noturīgums, kuru var novērtēt kā laiku, kas paiet, kamēr tās tiek saistītas vai izvadītas no atmosfēras (sk. 2.3. tabulu). Ūdens tvaiki relatīvi ātri tiek izvadīti no atmosfēras nokrišnu veidā, bet metāns fotoḳimiski oksidējas par $\mathrm{CO}_{2}$. Ogl̦skābā gāze tiek saistīta, tai izšksīstot ūdenī, bet siltumnīcefekta gāzei slāpekḷa(I) oksīdam $\mathrm{N}_{2} \mathrm{O}$ raksturīgs loti augsts noturīgums un stabilitāte. Îpaši noturīgas ir daudzas cilvēka darbības rezultātā atmosfērā nokḷuvušās vielas, piemēram, freoni, kas spēj ietekmēt atmosfērā norisošos procesus vēl ilgu laiku.

Dažādās siltumnīcefektu veidojošās gāzes var atšksirīgi ietekmēt Zemes klimatu, gan n,emot vērā to spēju atstarot atpakal infrasarkano starojumu, gan arī to koncentrāciju atmosfērā. Ja $\mathrm{CO}_{2}$ potenciālo ietekmi uz Zemes klimatu pien,em par 1 , tad citu siltumnīcefektu izraisošo vielu relatīvais potenciāls ietekmēt Zemes siltuma bilanci var būt ievērojami lielāks: metānam tas ir 11 ilgtermin̄ā, $\mathrm{N}_{2} \mathrm{O}-270$, bet freonam $\mathrm{CF}_{3} \mathrm{Cl}-3400$. Zinot siltumnīcefekta gāzu radiācijas daudzumu, var novērtēt, kādas izmaiṇas radīs to koncentrācijas pieaugums atmosfērā un kāda būs šì pieauguma ietekme (sk. 2.8. att., 2.3. tabulu). 

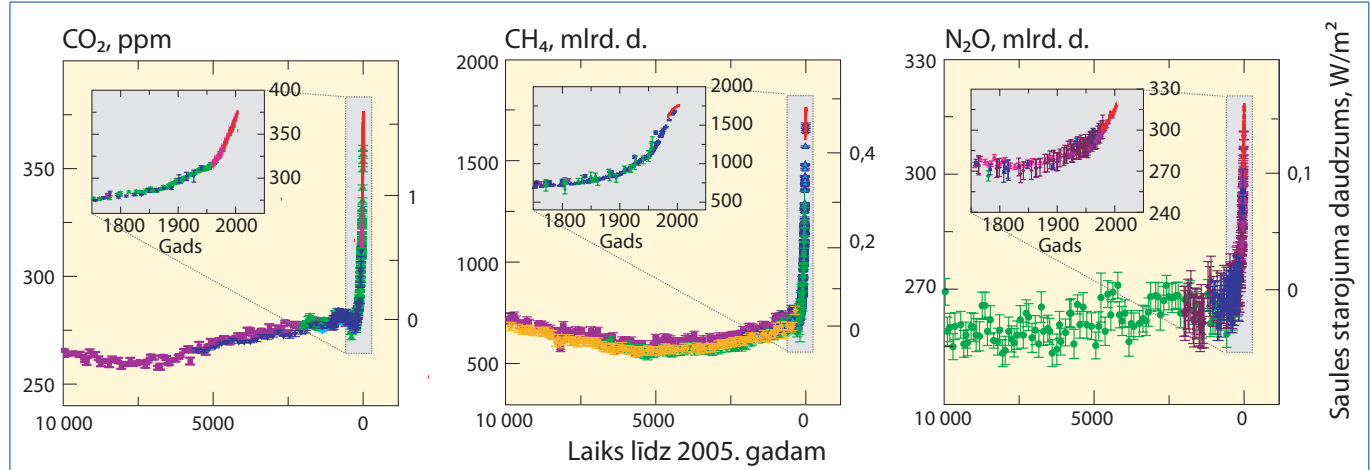

2.8. att. Siltumnīcefektu veidojošo gāzu koncentrāciju izmaiṇas un to ietekme uz saṇemtā Saules starojuma daudzumu pēdējo 10000 gadu laikā.

Pēdējo 10000 gadu laikā, bet it īpaši pēdējā gadsimta laikā, trīs nozīmīgāko siltumnīcefekta gāzu $\left(\mathrm{CO}_{2}, \mathrm{CH}_{4}, \mathrm{~N}_{2} \mathrm{O}\right)$ koncentrācija Zemes atmosfērā ir ievērojami pieaugusi, un līdz ar to palielinājies Saules starojuma daudzums, kas tiek atgriezts atpakal, uz Zemes virsmas (sk. 2.8. att.).

\section{Avoti tālākām studijām}

What's the difference between weather and climate: http://www.nasa.gov/mission_pages/noaa-n/climate/climate_ weather.html

\section{Basic information on climate change $h t t p: / / w w w . c r u u e a . a c . u k / c r u / i n f o$}

Greenhouse gases and climate change $h t t p: / / w w w . i e a g r e e n . o r g . u k$

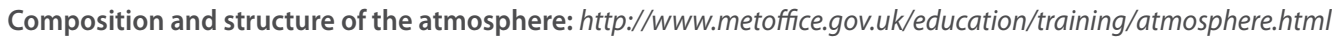

Sunspots and climate: $h$ ttp://earthobservatory.nasa.gov/Library/SORCE/

Ocean currents and climate change: $h t t p: / / p i k$-potsdam.de/ stefan/Lectures/ocean_currents.htmI

Climate of the Earth: http://www.windows2universe.org/earth/climate/cli_define.html

Climate: $h$ ttps://www.climate.gov/

World climate: $h$ ttp://www.climate-charts.com/index.html

\section{Literatūra}

O'Hare G., Sweeney J., Wilby R. (2005) Weather, Climate and Cimate Change. Human Perspective. Prentice Hall: Edinghburgh (UK).

Drake F. (2000) Global Warming: the Science of Climate Change. Arnold: London.

Burroughs W. J. (2001) Climate Change: a Multidisciplinary Approach. Cambridge University Press: Cambridge.

Henson R. (2013) A Rough Guide to Climate Change. Peguin Books: London.

Aguado E., Burt J. (1999) Understanding Weather and Climate. Prentice Hall: New Jersey.

Izmantotie attēli

2.1. Aț̦auja pēc "Climate Change 2007: The Physical Science Basis", IPCC.

2.3. Modificēts pēc Jacobson, 2002.

2.5. Aț̣auja pēc "Climate Change 2007: The Physical Science Basis", IPCC.

2.6. Modificēts pēc Jacobson, 2002.

2.7. Aț̣uja pēc "Climate Change 2007: The Physical Science Basis", IPCC.

2.8. Ațauja pēc "Climate Change 2007: The Physical Science Basis", IPCC. 


\section{Klimata mainïba un klimata pārmaiṇas}




\subsection{Zemes klimats un tā veidošanos ietekmējošie faktori}

Kaut arī Zemes, dažādu reǵionu un geogrāfisku vietu klimats ir būtisks ne tikai ikdienas labsajūtai, bet tieši ietekmē arī lauksaimniecību, enerǵétiku, tūrismu un citas nozares, klimats ir visai maz pētīts. Attīstītajās valstīs klimata novērošanas staciju ir pietiekami daudz, bet Pasaules okeānā, kur lielā mērā veidojas Zemes klimats, ir veikts maz novērojumu.

Ikdienas laikapstāklı,u, ciklonu un anticiklonu un Zemes mākoṇu segas neviendabīgums un mainība labi saskatāma Zemes satelītuzṇēmumos (sk. 3.1. att.).

Klimata veidošanos ietekmē daudzi faktori (sk. 3.2. att.).

Jāatceras, ka Zemes klimata elementi - atmosfēra, hidrosfēra, litosfēra un biosfēra - ir savstarpēji cieši saistīti un mijiedarbojas. Izmaiṇas vienā sfērā var radīt izmaiṇas kādā citā. Piemēram, zemestrīce var pacelt un paplašināt piekrastes zonu, izmainot piekrastes jūras vidi. Spēcīgs vulkāna izvirdums var izmest ievērojamu daudzumu lavas un aizškēersot upes, izmainot to noteces sistēmu, kā arī radīt aerosolu koncentrācijas pieaugumu atmosfērā, kas savukārt var mainīt globālo temperatūru pat vairāku gadu garumā. Temperatūras izmaiṇas var

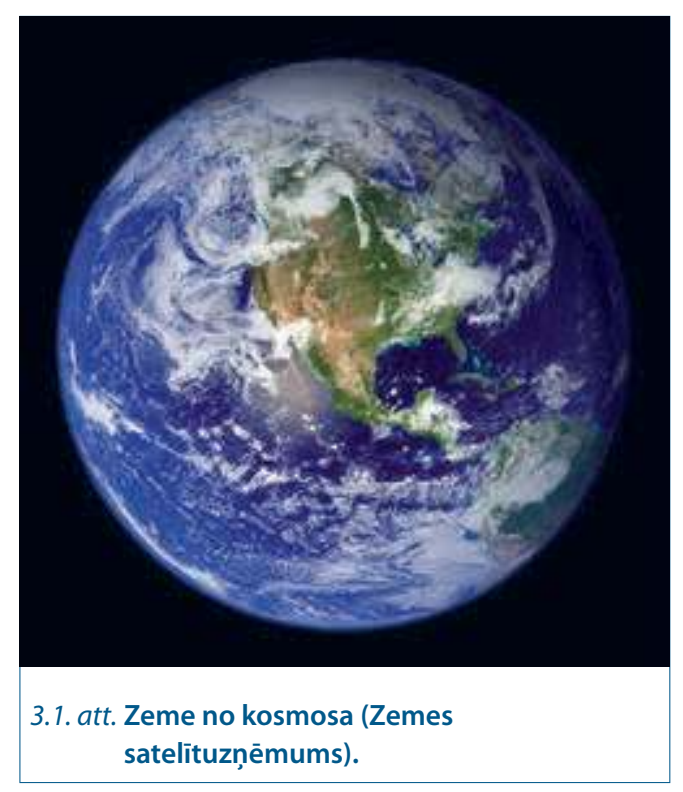

pamanīt, pētot geologiskos nogulumus, koku gadskārtu gredzenus, korallı u augšanas ātrumu, ledāju dinamiku un skābekḷa stabilo izotopu ${ }^{16} \mathrm{O}$ un ${ }^{18} \mathrm{O}$ attiecību ledāju dziḷurbumos ${ }^{1}$. Temperatūras svārstības pēdējā tūkstošgadē ir bijušas visai ievērojamas, bet, pamatojoties uz prognozēm, šìs simtgades laikā temperatūra var pieaugt vēl straujāk (sk. 3.3. att.).

Uzskats, ka Zeme ir dinamiska sistēma un vienmēr bijusi mainīga, ir akceptēts salīdzinoši nesen. Ikvienam redzams, ka laikapstākḷi mainās ḷoti strauji, bet izmaiṇas, kas ietekmē dabas līdzsvaru Zemes sistēmā, t.i., Zemes garozas tektonisko plātṇu pārvietošanās un klimata pārmaiṇas, parasti notiek l̦oti lēni un nav izmērāmas pat ar vairākiem cilvēka mūžiem. Tomēr gadās arī neparedzami izṇēmumi. Spēcīgi vulkānu izvirdumi izraisa tik lielu gāzu un puteklıu piemaisījumu stratosfērā, ka Saules radiācija tiek atstarota kosmosā, tādējādi sekmējot atmosfēras atdzišanu pat vairāku gadu garumā. 1883. gada augustā notika katastrofāls Krakatau izvirdums jūras šaurumā starp Javas un Sumatras salu, kas radīja ap $40 \mathrm{~m}$ augstu cunami vilni, nopostija 165 piekrastes ciematus un aiznesa vairāk nekā 36 tūkstošus cilvēku dzīvību. Krakatau izvirduma laikā atmosfērā līdz 50 km augstumam tika izmesti ap $20 \mathrm{~km}^{3}$ vulkānisko pelnu. Stratosfērā nonākušie putekḷi 13 dienu laikā aplieca zemeslodi un 1884. gadā izraisīja vidējās gaisa temperatūras pazemināšanos par $0,5^{\circ} \mathrm{C}$.

Klimata sistēma ir sarežgìita, bet klimata mainības izpēte un klimata veidošanās procesu izpēte joprojām ir tikai sākuma stadijā. Šì zinātnes nozare nodarbojas ne tikai ar meteorologisko prognožu izstrādi, bet veic arī

\footnotetext{
${ }^{1}$ Temperatūras rekonstrukcija pēc skābekḷa izotopu attiecības balstīta uz pieñēmumu, ka vieglākās ūdens molekulas iztvaiko ātrāk, bet kondensējas vēlāk, salīdzinot ar smagākajām. Izotopu attiecības novirze pētāmajā ūdens paraugā no to attiecības mūsdienu standarta okeāna ūdenī tiek izteikta ar rādītāju $\Delta^{18} 0$. Atrasta empīriska sakarība starp $\Delta^{18} 0$ sniega ūdenī no dažādiem Grenlandes rajoniem un gaisa temperatūru. Šĩ sakarība tiek lietota, rekonstruējot paleoklimatu pēc $\Delta^{18} 0$ no ledāju dzil̦urbumiem.
} 


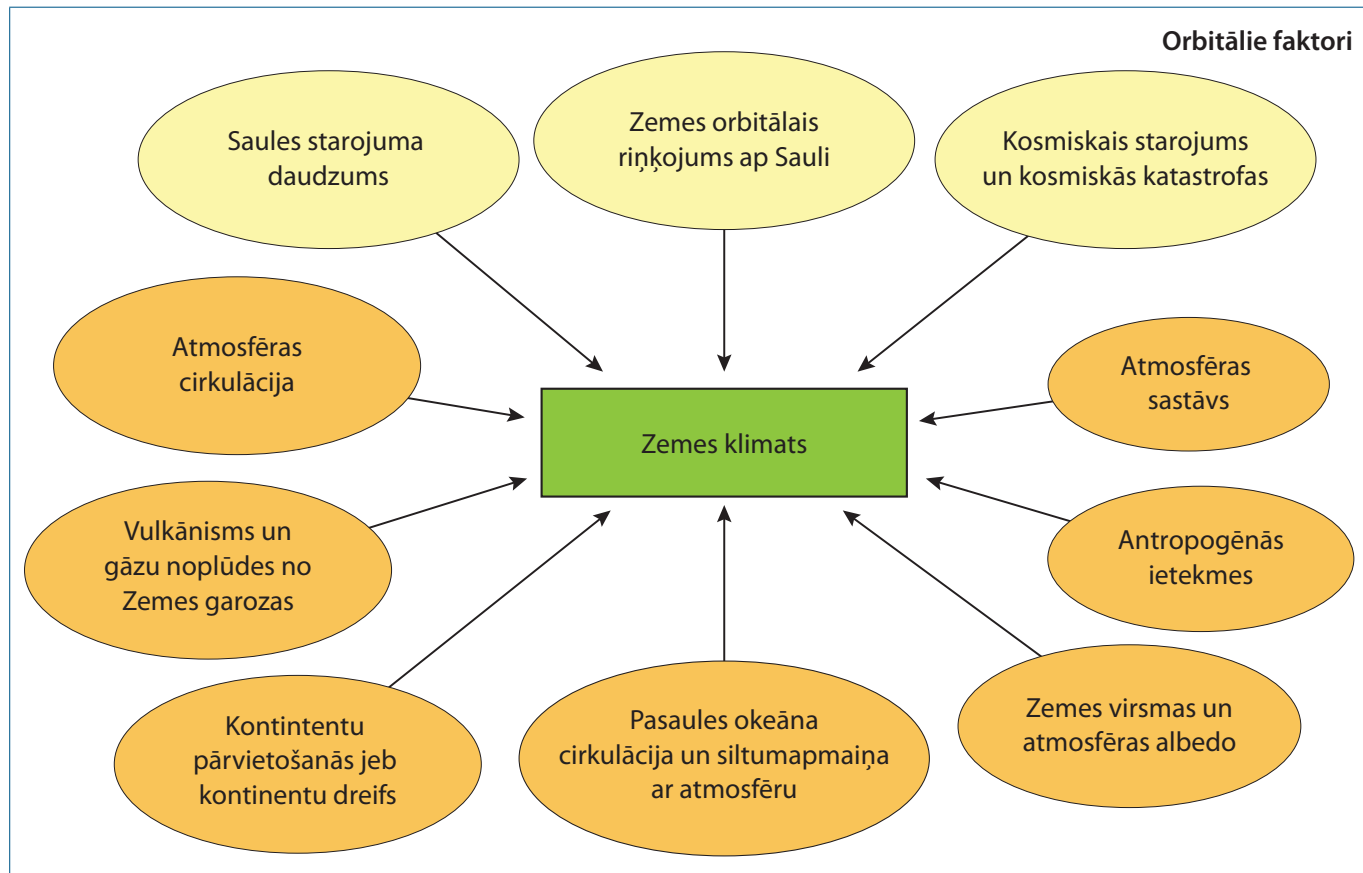

Okeāna, atmosfēras un sauszemes faktori

3.2. att. Zemes klimatu ietekmējošie faktori.

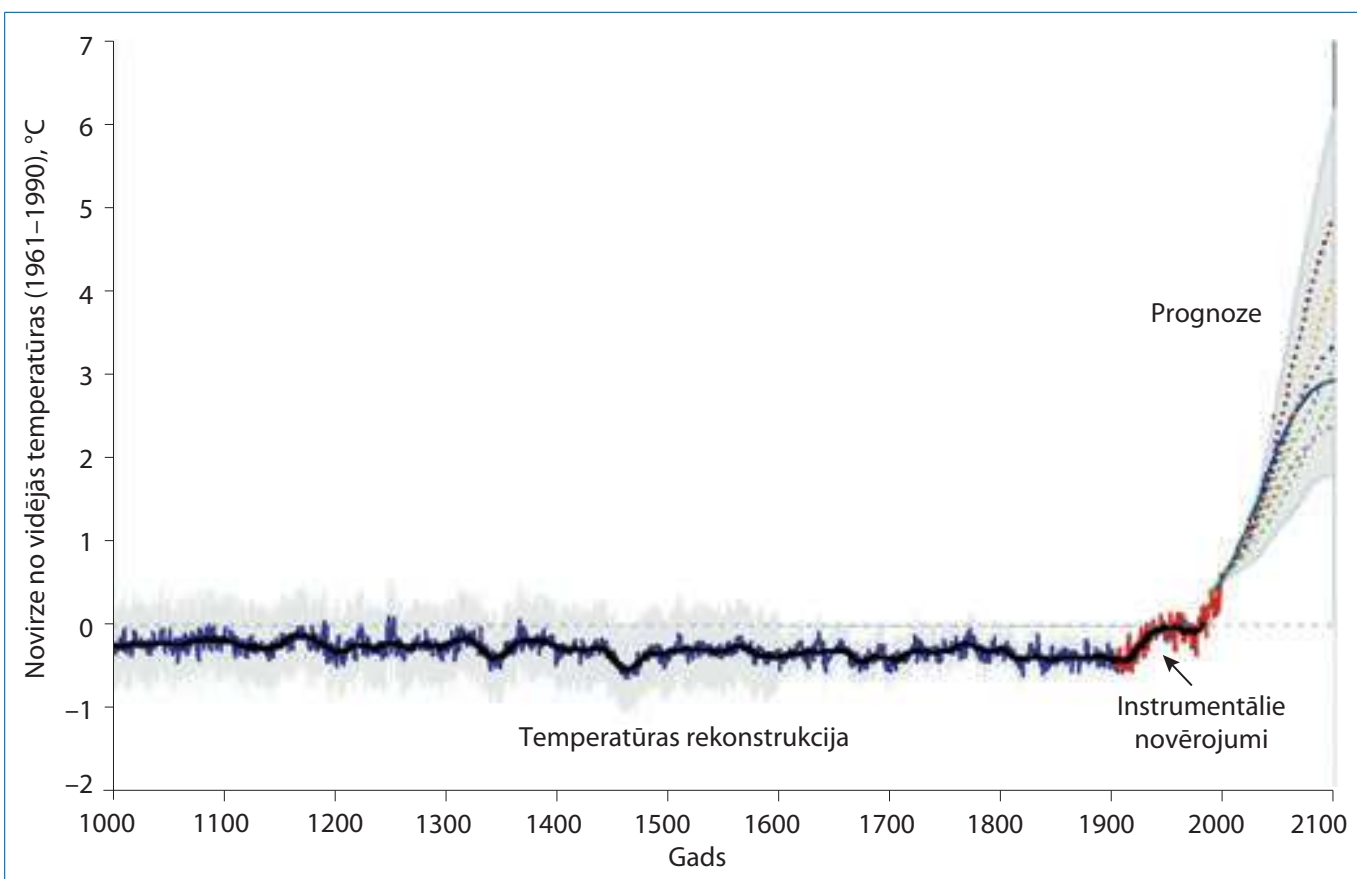

3.3. att. Temperatūras mainība ziemeḷu puslodē pēdējo 1000 gadu laikā un iespējamo izmaiṇu prognozes. 
ievērojamus pētījumus vidē, procesu modelıu izstrādi un analīzi. Acīmredzams, ka pašreizējās zināšanas ir pretrunīgas un piel̦auj vienu un to pašu faktu atšķirīgu interpretāciju. Tātad tikai izpētes turpināšana l̦aus izprast cilvēka ietekmes apmērus un dabisko procesu ietekmes, kuras vispirms raksturo noteikts cikliskums.

Klimata rakstura un tā mainības izpētei izmantojami tiešie gaisa temperatūras un citu atmosfēras īpašību novērojumi, kas Eiropā l̦auj spriest par klimata parādībām pēdējo gadsimtu laikā. Tiešos temperatūras mērījumus var salīdzināt ar hidrometeorologisko parādību novērojumiem: ledus iešanas sākumu upēs, ezeru ūden,u aizsalšanas laikiem, lieliem plūdiem u.c. Tiešo novērojumu datus iespējams papildināt, izmantojot dažādas klimata rekonstrukcijas metodes, piemēram, koku augšanas ātruma analīzi. Šîs metodes pamatā ir fakti, ka labvēlīgos apstākḷlos koksnes pieaugums ir ātrāks un gadskārtējās koksnes gredzens platāks. Līdzīgi klimata rekonstrukcijai izmantojama korallı pieauguma ātruma izpēte tropiskajos ūdenos.

Klimatu raksturo ievērojama dabiskā mainība, nosacīti klimata optimuma periodi (piemēram, Ziemel̦eiropā ap 1000. gadu) mijas ar vēsākiem periodiem (piemēram, tā sauktais "mazais ledus laikmets" Ziemel̦eiropā aptuveni no 1400. līdz 1850. gadam), kuru laikā vasaras bija ievērojami īsākas, ar zemāku temperatūru, ziemas aukstākas, bet ūdenstilpju aizsalums ilgāks.

Garākos laika posmos iespējams analizēt klimata mainību, izmantojot ledāju sastāva analīzi. Ledāju ledus (kalnos, Grenlandē, Antarktīdā) veidojas, sablīvējoties sniega masai, un tā vecums var sasniegt vairākus simtus tūkstošu vai pat pārsniegt miljonu gadu. Turklāt, veidojoties ledus masai, tajā tiek iekḷautas gaisā esošās putekḷu dalı̣nas, kā arī atmosfēru veidojošās gāzes. Veicot ledus gāzu sastāva analīzi, iespējams rekonstruēt atmosfēras kīmisko sastāvu un arī klimatiskos apstākḷus, kādi pastāvējuši ledāju veidošanās laikā. Klimata rekonstrukcija pēdējā miljona gadu laikā liecina par ievērojamu klimata mainību dabā norisošo procesu ietekmē (sk. 3.4. att.).
Klimata mainības raksturs norāda laika posmus, kad Zemes gada vidējā temperatūra ir bijusi ievērojami zemāka nekā pašlaik (ledus laikmetus), bet arī laikmetus, kad ir bijis siltāks nekā pašlaik, ko acīmredzami noteikusi klimata dabiskā mainība. N̦emot vērā izmaiñas fiziskajās un biologiskajās sistēmās, kas notikušas bez cilvēka līdzdalības dažādos Zemes attīstības posmos, ir iespējams raksturot, kāda bijusi sistēmas reakcija uz dabiskām izmaiñām vidē. Īpašu interesi izraisa tieši straujas un krasas klimata izmainnas, tādas, kas notikušas gadsimta laikā vai pat īsākā laika posmā, jo šīs analoǵijas var tikt izmantotas nākotnes klimata izmainu prognozēm. Agrajā holocēnā pirms 10 000-6000 gadu vidējā gaisa temperatūra bija par $0,5-1,0^{\circ} \mathrm{C}$ augstāka nekā pašlaik. Tāpat par $1-2{ }^{\circ} \mathrm{C}$ augstāka temperatūra ir bijusi pēdējā starpledus laikmetā pirms $\approx 137-115$ tūkstošiem gadu. Arī pirms $\approx 4,5-3$ miljoniem gadu viduspliocēnā Zemes klimats ir bijis par $3-4{ }^{\circ} \mathrm{C}$ siltāks nekā mūsdienās. Tomēr jāṇem vērā, ka senākajās klimata izmainās nevar meklēt analogijas ar mūsdienu klimata pārmaiṇām, jo Saules starojuma enerǵija, kas sasniedza Zemes virsmu, bija atšksirīga. Okeāna nogulumu paraugu izotopu analīze rāda, ka viduspliocēnā okeāna virsmas ziemas temperatūra ir bijusi par $3^{\circ} \mathrm{C}$ augstāka nekā pašreiz.

Savukārt ar kontinentu dreifa teoriju, ko izstrādāijis vācu ǵeofizik̦is A. Vēgeners 1912. gadā, var izskaidrot $\approx 200$ miljonus gadus vecus ledāju nogulumus Sahāras tuksnesī, kā arī fosilos tropiskos augus Grenlandē. Šādi atklājumi palīdz izprast klimatiskos apstākḷus, kādi valdījuši pirms miljoniem gadu, kad kontinenti atradās citos platuma grādos un sauszemes un okeānu izvietojums uz Zemes bija citāds nekā mūsdienās.

Ja salīdzina klimatiskos apstākḷus, kādi ir dominējuši lielākajā daḷā ǵeoloǵiskā laika, jāsecina, ka vidējā temperatūra ir bijusi par $10^{\circ} \mathrm{C}$ augstāka nekā pēdējos 2 miljonus gadu. Temperatūras pazemināšanās tendences sākās pirms apmēram 40 miljoniem gadu un kulmināciju sasniedza pleistocēna ledus laikmetu laikā.

Zemes klimata mainības raksturs apliecina dabiski norisošo procesu lielo ietekmi uz Zemes klimatu. 


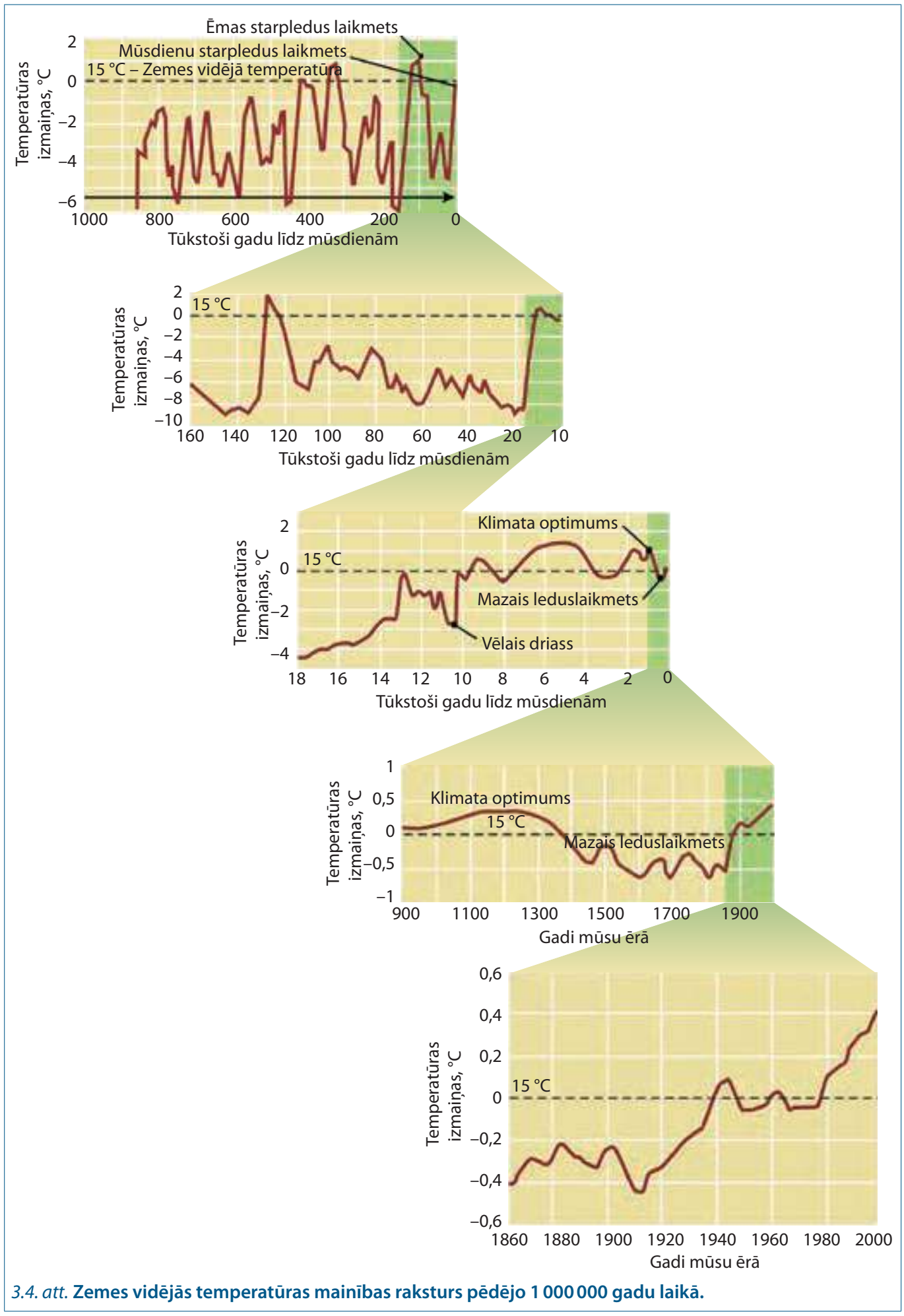




\subsection{Saules starojuma un kosmiskā starojuma mainības ietekme uz Zemes klimatu}

Dabiski norisošo procesu ietekmju piemērs ir Saules starojuma un tā mainības ietekme. Saule ir galvenais faktors, kas nosaka Zemes energeētisko bilanci. Arī atmosfēras gaisa masu kustību, kas ir galvenais laikapstākḷus veidojošais faktors, ietekmē Saules starojuma sadalījums. Klimats ir laikapstākḷu integrāls apzīmējums noteiktam laika periodam un tādēl tas ir atkarīgs no Saules aktivitātes. Jāpiebilst, ka Saules aktivitāte ir lielā mērā mainīga un ka šīs ietekmes ne vismazākajā mērā nav atkarīgas no cilvēka darbības. Plašāk pazīstamais Saules aktivitātes mainību raksturojošo procesu kopums ir "Saules plankumi" - tumšu plankumu veidošanās uz Saules, kurus raksturo 11, 36, 180 gadu atkārtošanās cikls (sk. 3.5. att.). Saules plankumi ir apgabali uz Saules, kuru temperatūra ir zemāka (4000-5000 K) salīdzinājumā ar Saules virsmas temperatūru $(\approx 6000 \mathrm{~K})$, un līdz ar to uz Saules virsmas tos var novērot kā tumšus plankumus. Saules plankumu diametrs mainās no $10^{3} \mathrm{~km}$ līdz $2 \cdot 10^{5} \mathrm{~km}$, bet to pastāvēšanas laiks - no dažām stundām līdz mēnešiem (Hathaway and Wilson, 2004). Pieaugot Saules plankumu skaitam, Zeme saṇem vairāk elektromagnētiskā starojuma un jonizētu dalıiņu plūsmas.

Pirmais Saules plankumus atklāja Galileo Galilejs, bet regulāri novērojumi sākās ar
1849. gadu. Saules plankumu skaitu nosaka, vispirms saskaitot to grupas un pēc tam atsevišksus plankumus. Jaudīgā teleskopā uz Saules var saskatìt vismaz 10-20 plankumu, bet to raksturošanai izmanto Saules plankumu skaitu, ko aprēḳina pēc Rūdolfa Volfa formulas:

$$
R=k(10 g-S) \text {, }
$$

kur $R$ - Saules plankumu skaits,

$g$ - Saules plankumu grupu skaits Saules diskā,

$k-$ mainīgais faktors (parasti $<1$ ), kas tiek aprēksināts pēc Saules novērojumiem un teleskopa tipa (binokulāri, kosmosa teleskopi u.c.). Zinātnieki apvieno dažādās observatorijās iegūtos datus - katrai observatorijai ir savs $k$ faktors,

$S$ - kopējais atsevišķo Saules plankumu skaits.

Laikā, kad samazinājās Saules aktivitāte (plankumu skaits), no 1400. līdz 1850. gadam, uz Zemes iestājās tā saucamais Mazais ledus laikmets. Ziemel̦amerikā, Eiropā un pārējās zemeslodes dalās klimats kḷuva vēsāks (sk. 3.5. att.).

Par pierādītu uzskatāms apgalvojums, ka Saules plankumu veidošanās laikā ievērojami mainās enerǵijas daudzums, kuru saṇem atmosfēra un Zemes virsma. Tā enerǵija, kuru

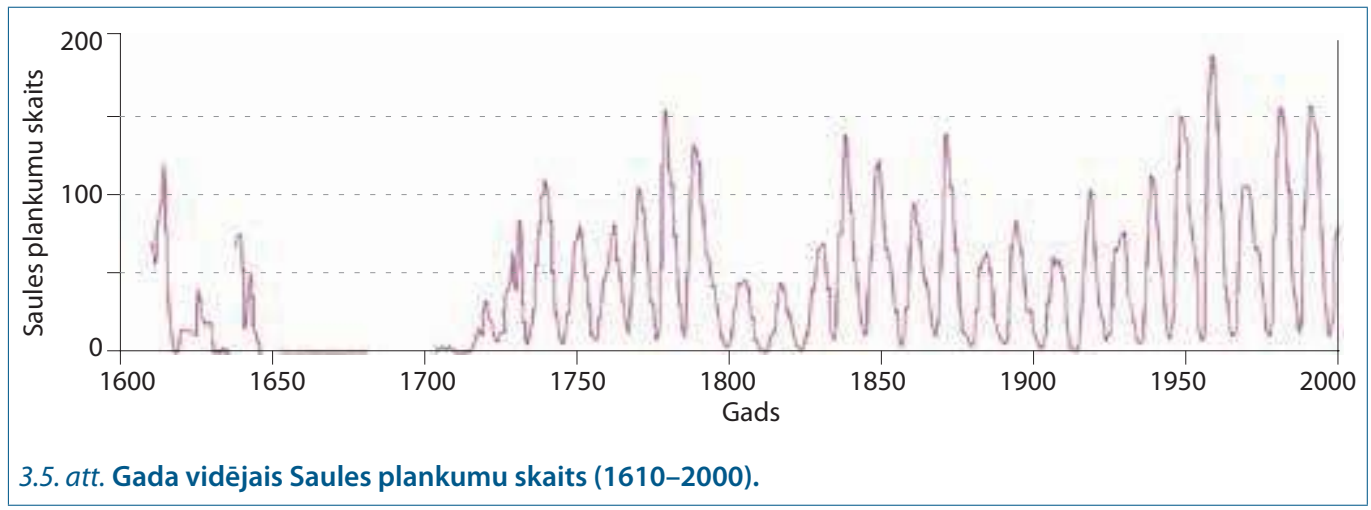


sañem Zemes virsma, protams, var mainīties ilgākā laika posmā. Ir pierādītas arī pašas Saules aktivitātes būtiskas izmaiṇas, kuras raksturo ievērojama enerǵijas daudzuma mainība, ko saṇem Zemes virsma. Izpratne par to, kā tieši Saules aktivitāte ietekmē Zemes klimatu, vēl joprojām tikai attīstās. Paaugstinoties Saules aktivitātei, vispirms pieaug augstas enerǵijas dalıinu plūsmas. Viens no iespējamiem ietekmju veidiem ir ietekme uz mākon,u segas veidošanos (sk. turpmāk), jo jonizētās dalıiṇas noder par ūdens tvaiku kondensācijas centriem. Vairāki pētījumi ir pierādījuši, ka Saules starojuma mainība tieši korelē ar Zemes klimata mainību. Šie pētījumi ir l̦āvuši izvirzìt hipotēzi (Scaffetta and West, 2005), ka Saules aktivitātes mainība nevis $\mathrm{CO}_{2}$ emisijas pieaugums ir nozīmīgs, bet, iespējams, pat galvenais faktors, kas nosaka klimata mainību.

Klimatu būtiski var ietekmēt arī kosmiskā starojuma mainība. Kosmiskajam starojumam ir zināma ietekme uz aerosolu un mākonu segas veidošanos atmosfēras augšējos slān,os. Dānijas Kosmosa centra klimata pētnieki apgalvo, ka viens no galvenajiem globālās sasilšanas cēloṇiem ir kosmiskā starojuma intensitātes mainība kombinācijā ar Saules aktivitātes un dabiskām Zemes magnētiskā lauka izmaiñām. Saskaṇā ar izvirzìtajām hipotēzēm pastāv nepārprotama sakritība starp Saules un kosmiskā starojuma un lādētu daḷiṇu plūsmām un Zemes magnētiskā lauka mainību, un temperatūras svārstībām uz Zemes. Tiek uzskatīts, ka kosmiskajam starojumam ir liela ietekme uz to, cik daudz mākoṇu veidojas atmosfērā. Tā kā mākoṇu sega atstaro lielu dậ Saules starojuma izplatījumā, tad mākoṇu daudzums lielā mērā nosaka to, cik silts ir uz Zemes. Mākoṇi veidojas, ūdens tvaikiem atmosfērā kondensējoties, turklāt par kondensācijas centriem var kalpot jonizētas dalinnas, kuru avots var būt gan Saule, gan kosmiskais starojums. Savukārt Zemes magnētiskā lauka intensitāte ietekmē to, cik daudz no Saules nākošo jonizēto dal̦inu un kosmiskā starojuma sasniedz Zemes atmosfēru. Gan Saules aktivitāte, gan kosmiskā starojuma daudzums mainās. Tiek uzskatīts, ka pēdējo 700 gadu laikā Saules aktivitāte ir pieaugusi līdz augstākajam līmenim. Šajā periodā ir piedzīvota globāla temperatūras paaugstināšanās. Pēc Henrika Svensmarka domām, šie faktori ir savstarpēji saistīti. Pēdējo reizi Saules aktivitāte mūsdienu līmenī bija viduslaikos aptuveni no 1000. līdz 1300. gadam. Tolaik bija tik silts, ka vikingi nodarbojās ar lauksaimniecību Grenlandē. Nosakot ogleklı izotopa ${ }^{14} \mathrm{C}$ daudzumu koku gadskārtu gredzenos, noskaidrota arī kosmiskā starojuma intensitāte attiecīgajā laika posmā. Ogleklis ${ }^{14} \mathrm{C}$ veidojas, kosmiskā starojuma augstas enerǵijas dalıiņām atmosfērā saduroties ar atomu kodoliem. Jo vairāk ogleklıa ${ }^{14} \mathrm{C}$ ir gadskārtu gredzenos, jo vairāk kosmiskā starojuma attiecīgajā gadā nonācis Zemes atmosfērā.

Neapšaubāmi Saules starojuma un kosmiskās telpas ietekme uz Zemes klimatu ir viens no saistošākajiem klimata mainības pētījumu virzieniem, kuros iegūtās atziṇas ir būtiskas izpratnei par Zemes klimata veidošanos.

\subsection{Zemes orbitālās un rotācijas kustības rakstura izmaiṇas}

Zemes orbītas izmaiņas nosaka Saules starojuma un tā daudzuma sadalījumu uz zemeslodes. Līdz ar to periodiski norisoša klimata mainība saistāma ar Saules radiācijas intensitātes izmaiņām, kuras nosaka ne tik daudz starojuma daudzuma izmainas, kuras Zeme saṇem no Saules, kā Zemes kustības orbītas izmainas ap Sauli. Zemes kustību ap
Sauli raksturo trīs mainības veidi (sk. 3.6. att.). Pirmkārt, mainībai ir pakḷauts Zemes orbītas veids - elipses ekscentricitāte, proti, izmaiṇas attālumā līdz Saulei. Šì mainības perioda ilgums ir ap 100000 gadu. Mainībai ir paklıuts arī Zemes rotācijas aksiālais slīpums - Zemes rotācijas ass novietojums attiecībā pret kustības plakni ap Sauli, kas var mainīties no 21,6 
līdz 24,5 grādiem (pašlaik tas ir 23,5 grādi). Zemes rotācijas aksiālais slīpuma izmaiñas periods ir 41000 gadu. Trešais Zemes kustības ap Sauli rakstura mainības veids saistīts ar tā gadalaika nomaiṇu, kurā Zeme ir vistuvāk Saulei (Zemes perihēlijs). Šì perioda ilgums ir ap 23000 gadu (pašlaik Zeme ir vistuvāk Saulei janvārī). Klimata mainībai desmitu un simtu gadu tūkstošu laikā (ledus laikmetu veidošanās un klimata optimuma periodi) pirmo reizi uzmanību pievērsa britu zinātnieks Džeimss Krolls, bet šīs idejas tālāk attīstīja serbu klimatologs Milutins Milankovičs, saistot klimata mainību ar Zemes ass novietojuma mainību attiecībā pret Sauli. Pēc Milankoviča teorijas, Zemes kustības orbītas ap Sauli periodiskā mainība un Zemes rotācijas ass mainība ir bijuši vieni no svarīgākajiem virzītājspēkiem, kas veicinājuši ledus laikmetu iestāšanos. Orbitālās izmaiṇas notiek gadu tūkstošiem ilgi. Klimata sistēmas atbildes reakcija uz šīm izmainām arī var norisināties tūkstošiem gadu. Pamatvilcienos aprēkninātās Zemes orbītas kustības rakstura izmainas un ledus laikmeta periodi sakrìt, līdz ar to apstiprinot Zemes kustības ap Sauli rakstura nozīmību Zemes klimata sistēmas izveidē.

Mainoties Zemes kustības ap Sauli raksturam un tās ass novietojumam, būtiski mainās Saules starojuma sadalījums uz Zemes un tā izmaiṇas gada laikā. Šĩs izmain, inas īpaši skar Zemes polāros reǵionus. Tajā pašā laikā tikai

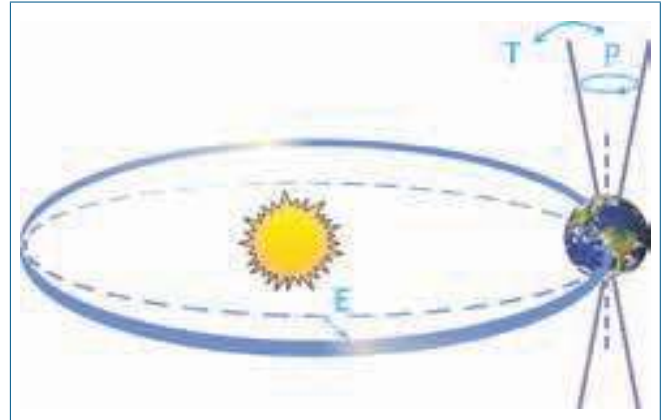

3.6. att. Zemes kustības ap Sauli orbitāles $(E)$ un Zemes rotācijas ap savu asi un tās novietojuma $(T, P)$ mainības raksturs.

izmaiņas enerǵijas daudzumā, kuru Zeme san,em, mainoties Zemes kustības orbītai ap Sauli un Zemes rotācijai ap savu asi un tās novietojumam, nel̦auj pilnībā izskaidrot temperatūras pazemināšanos ledus laikmetu laikā. Ledus laikmetu iestāšanās un to nomaiṇa korelē ar attiecīgām izmaiṇām atmosfēras ogḷskābās gāzes koncentrācijā. Siltumnīcefekta gāzu koncentrācija atmosfērā, to atbrīvošanās un atgriezeniskā saite starp Zemes orbitālajiem faktoriem un atmosfēras sastāvu ir principiāli nozīmīgs klimatu veidojošs faktors. Milankoviča teorija l̦auj prognozēt, kad Zemes kustības rakstura izmainnas izraisīs būtisku temperatūras pazemināšanos uz Zemes - nākamo ledus laikmetu. Saskaṇā ar aprēksiniem tas var iestāties pēc $\approx 50000$ gadu.

\section{4. Ģeoloğiskās un kosmiskās katastrofas}

Dažāda veida katastrofas var būtiski ietekmēt Zemes klimatu, kaut arī šķiet, ka tās notiek reti. Jau Bendžamins Franklins norādīja, ka vulkānu izvirdumi var ietekmēt klimatu, un uzskatīja, ka auksto ziemu Eiropā 1783./1784. gadā radīja Laki vulkāna izvirdums Islandē 1783. gada jūlijā. Vulkānu izvirdumu laikā atmosfērā nonāk un sasniedz stratosfēru (pat 15-50 km augstumu) puteklı dalıiņas, kā arī sēra savienojumi, galvenokārt sēra dioksīds. Atmosfēras augšējos slān,os putekḷu dalịnas var saglabāties ilgu lai$\mathrm{ku}$ (vairākus gadus vai gadu desmitus), turklāt var izkliedēties visā Zemes atmosfērā. Puteklu un aerosolu klātbūtne atmosfērā nosaka to, ka liela dalı Saules starojuma tiek atstarota kosmiskajā telpā, un līdz ar to mazāks siltuma daudzums sasniedz Zemes virsmu. Turklāt putekḷu un aerosolu daļinas noder par ūdens tvaiku kondensācijas centriem, sekmējot mākon,u segas izveidošanos, kas vēl vairāk samazina starojuma daudzumu, kurš sasniedz 
Zemes virsmu. Mākoṇu segas izveidošanos īpaši sekmē sulfātjonus saturoši putekḷ un aerosoli, kā arī sēra dioksīds.

Krakatau vulkāna (Indonēzija) izvirdums 1883. gadā tika minēts jau iepriekš, tomēr vislabāk ir izpētītas pēdējo 50 gadu laikā notikušo vulkānu izvirdumu sekas. Piemēram, Pinatubo vulkāna (Filipīnas) izvirduma laikā 1991. gadā atmosfērā tika izmesti 20000000 tonnu putekḷu un ievērojams daudzums sēra savienojumu. Tiek lēsts, ka vulkāna izvirdums samazināja enerǵijas daudzumu, kas no Saules sasniedza Zemi, par 3-4 W/m². Tas savukārt radīja Zemes temperatūras pazemināšanos, turklāt vulkāna izvirduma sekas ietekmēja Zemes temperatūru divus līdz trīs gadus pēc šìs katastrofas. Līdzīgi arī Elčičona vulkāna izvirdums Meksikā spēja ietekmēt globālo klimatu, galvenokārt augstā sēra satura dēḷ gāzu un putekḷu masā, kas tika izmesta no vulkāna. Tomēr ne Zemes, ne arī cilvēces vēsturē šie vulkānu izvirdumi nepavisam nav apjomīgākie. Tiek vērtēts, ka Tambora vulkāna izvirdumā (Indonēzijā) 1815. gadā atmosfērā nokḷuva desmitiem reižu lielāks puteklı un aerosolu daudzums nekā Pinatubo vulkāna izvirdumā, un tādēl 1816. gadu apraksta kā "gadu bez vasaras", kad vēlas salnas iznīcināja graudaugu ražu, bet vasara lielā dal̦ā Eiropas bija neparasti ìsa un auksta. Tiek piel̦auts, ka vēl spēcīgāki izvirdumi (piemēram, pirms 73000 gadu) spēja izraisīt ledus laikmetu.

Mūsdienās veiktā klimata mainības modelēšana ir pierādījusi, ka arī kodolkarš, kura laikā atmosfērā nokḷūtu liels apjoms radioaktìvu putekḷu, radītu līdzīgu efektu - tā saukto kodolziemu.

Arī kosmiskas katastrofas spēj būtiski ietekmēt Zemes klimatu. Tas attiecas gan uz meteoru un komētu nokrišanas sekām, gan arī uz kosmisko putekḷu ietekmēm.

\subsection{Okeānu ūdeṇu plūsmu mainība}

Protams, pastāv arī citas ietekmes, kas kopumā nosaka esošos laikapstākḷus un klimatu. No tiem vispirms var minēt okeānu kustības raksturu un tā mainību. Ūdens lielās siltumietilpības un sajaukšanās dēl okeānu un jūru virskārta sasilst un atdziest daudz lēnāk nekā sauszeme. Tādēḷ piejūras apgabalu klimatam raksturīgas mazākas sezonālās un diennakts gaisa temperatūras svārstības salīdzinājumā ar iekšzemes apgabaliem, kuros valda kontinentāls klimats. Pasaules okeāna tilpums ir gandrīz $1349 \cdot 10^{6} \mathrm{~km}^{3}$, bet virsējā 1000 m slān,a tilpums - ap $160 \cdot 10^{6} \mathrm{~km}^{3}$ (aprēḳināts kā 11,915\% no Pasaules okeāna kopējā tilpuma). Lai uzsildītu 1 litru ūdens par $1^{\circ} \mathrm{C}$, jāpatērē $1 \mathrm{kcal}$ jeb aptuveni 4,186·10 ${ }^{3} \mathrm{~J}$ enerǵijas. Primārā Saules starojuma plūsma, kas sasniedz Zemes virsmu, ir $168 \mathrm{~W} / \mathrm{m}^{2}$ jeb $5,298 \cdot 10^{9} \mathrm{~J} / \mathrm{m}^{2}$ gadā. Var aprēksināt, ka gada laikā saṇemtā energijas daudzuma pietiek, lai uzsildītu okeāna virsējo, $1000 \mathrm{~m}$ biezo sajauktā ūdens slāni tikai par aptuveni $1,26^{\circ} \mathrm{C}$. Okeāna siltumietilpība ir tik milzīga, ka pat niecīgas ūdens temperatūras izmainas liecina par nozīmīgām siltuma bilances izmaiṇām. ASV Nacionālā okeanogrāfisko datu centra zinātnieki aprēksinājuši, ka laikposmā kopš 20. gs. 50. gadu vidus okeāna vidējā temperatūra pieaugusi par $0,06^{\circ} \mathrm{C}$. Tam nepieciešami aptuveni $2 \cdot 10^{23} \mathrm{~J}$. Vērtējot Pasaules okeāna izlīdzinošo ietekmi uz Zemes klimatu, jāṇem vērā arī siltuma daudzums, kas tiek saistìts un atbrīvots, mainoties ūdens agregātstāvoklim, - ūdens iztvaikošanas un ledus kušanas siltums (tā sauktais latentais siltums). Ikvienam pazīstamas parādības, kas saistītas ar iztvaikošanas siltumu - kermeña "atvēsināšanās", iztvaikojot sviedriem, salnas augsnes virskārtā, kad ūdens iztvaikošana no augiem un augsnes pazemina temperatūru pat zem $0{ }^{\circ} \mathrm{C}$. No Pasaules okeāna virsmas gadā vidēji iztvaiko 420 tūkstoši $\mathrm{km}^{3}$ ūdens, kas atbilst apmēram 1,25 m biezam ūdens slānim. Iztvaicējot šādu ūdens daudzumu, tvaika latentajā siltumā tiek saistīts $2,840 \cdot 10^{9} \mathrm{~J} / \mathrm{m}^{2}$ gadā, tātad vairāk nekā puse no Saules starojuma enerǵijas, kas sasniedz okeāna virsmu. Jāṇem 
vērā, ka ūdens tvaikos saistītais latentais siltums atbrīvojas atmosfērā, kad, veidojoties mākon,iem, tvaiks kondensējas ūdens pilieniņos. Šādi latentā siltuma plūsma pārnes siltumu no okeāna virsmas atmosfērā. Ir aprēksināts ja šīs parādības nebūtu, sauszemes temperatūra sasniegtu $65^{\circ} \mathrm{C}$ un tad iestātos starojuma līdzsvars starp Zemes virsmas sanemto Saules starojumu un izstaroto enerǵiju. Ūdens iztvaikošanas siltums ir $2272 \mathrm{~J} / \mathrm{g}$, bet sasalšanas siltums ir $334 \mathrm{~J} / \mathrm{g}$. Pien,emot, ka Zemes ledāju un sniega masa ir ap 29,7 miljoni $\mathrm{km}^{3}$, var aprēķināt siltuma daudzumu, kas tiktu saistìts latentajā siltumā, ja viss ledus un sniegs izkustu.

Pasaules okeāns izlīdzina ne tikai temperatūras izmaiṇas laikā, bet arī mazina klimata kontrastus starp dažādām zonām un regioniem. Straumes okeāna virskārtā rodas vēja un Zemes griešanās spēka (t.s. Koriolisa spēka) mijiedarbībā. Līdz ar ūdeni siltās virsūdens straumes pārvieto milzīgu siltuma enerǵijas daudzumu no Pasaules okeāna tropiskajiem rajoniem uz mērenā un aukstā klimata joslām, tādējādi padarot daudz maigāku klimatu plašos sauszemes apgabalos. Savukārt aukstās straumes "atdzesē" tropiskos apgabalus.

Plašāk pazīstama (un arī caurplūduma ziṇā iespaidīgākā) ir siltā Golfa straume un tās turpinājums: Ziemel̦atlantijas straume Atlantijas okeānā un Kurosio straume Klusajā okeānā. Golfa straume, kuras plūdums aizsākas Meksikas līcī, nereti tiek tēlaini dēvēta par pasaules lielāko upi, jo parasti tā ir $80-150 \mathrm{~km}$ plata un 800-1200 m dziḷa. Lielākais straumes ātrums ir okeāna virskārtā - ap 2,5 m/s. Izplūstot no Meksikas līča, Golfa straumes caurplūdums ir ap 30 miljonu kubikmetru sekundē, bet, sasniedzot Haterasa ragu, tas pieaug līdz pat 80 miljoniem kubikmetru sekundē. Pakāpeniski atdodot savu siltumu atmosfērai, Golfa straume plūst gar Ziemel̦amerikas krastu, bet tās turpinājumi - Ziemel̦atlantijas straume un Norvēgoijas straume - apskalo Ziemeleiropas krastus.

Golfa straumes analogs Klusajā okeānā ir siltā Kurosio straume, kura aizsākas pie Taivānas un plūst ziemeḷaustrumu virzienā gar Japānas arhipelāga austrumu malu. Tiek uzskatīts, ka Kurosio straumes dēl Japānas salu klimats ir krietni maigāks, nekā tam vajadzētu būt atbilstoši ǵeogrāfiskajam novietojumam. Kurosio straume būtiski ietekmē jūras biologisko produktivitāti, nodrošinot bagātīgus zivju lomus, un tādēl var pastāvēt pasaulē vistālāk uz ziemel̦iem sastopamie korall lu rifi.

Izplatīts ir uzskats, ka Golfa straume ir galvenais iemesls, kāpēc Ziemel̦eiropā klimats ir daudz maigāks salīdzinājumā ar Ziemel̦amerikas austrumu piekrastes apgabaliem tajos pašos platuma grādos. Tomēr šo hipotēzi, kura izvirzīta 19. gs. vidū, mūsdienu klimata model̦i neapstiprina. Sasniedzot Eiropu, Ziemel̦atlantijas straumes ūdeñi jau atdevuši tik daudz siltuma, ka to ietekme uz gaisa temperatūru nepārsniedz dažus grādus. Pēc vairāku zinātnieku domām, daudz lielāka nozīme ir atmosfēras gaisa masām, kas pārsvarā pārvietojas no Atlantijas okeāna Eiropas virzienā. Protams, nevar noliegt, ka par šo gaisa masu "sasildīšanu" jāpateicas Golfa straumei. Tiek uzskatìts, ka, pastāvot Mazajam ledus laikmetam, Golfa straumes plūdums pavājinājies apmēram par 10\% salīdzinājumā ar mūsdienām. Tomēr model̦aprēķini neapstiprina saziņas līdzeklos plaši atspoguḷotos minējumus par Golfa straumes pavājināšanās katastrofālo efektu uz klimatu Ziemel̦amerikā un Eiropā. Golfa straumes "apstāšanās" varētu izraisìt temperatūras pazemināšanos tikai par dažiem grādiem.

Okeāna virsūdens straumes ietekmē klimatu galvenokārt piekrastes rajonos, kamēr okeāna termohalīnā cirkulācija lielā mērā nosaka klimatu visas Zemes mērogā. Okeānu ūden,u globālo plūsmu raksturu veido mazāka blīvuma virsūdens plūsmas, kurās notiek pirmprodukcija (līdz ar to intensīvi asimilējot biogēnos elementus - slāpeklı, fosfora un silīcija savienojumus), un zemūdens plūsmas. Virsūdens plūsmas ūdeṇi ir siltāki, piesātināti ar skābekli, bet ar ievērojami zemāku sāḷu koncentrāciju (to nosaka atmosfēras nokrišņi un virszemes notece) nekā zemūdens plūsmas. Zemūdens plūsmu sālums ir ievērojami augstāks, bet, dzīvajai organiskajai vielai nogrimstot, tās ir bagātinājušās ar biogēnajiem elementiem. Reǵionālās okeānu ūdeṇu sāḷuma izmaiṇas (piemēram, Atlantijas okeāna centrālajā daḷā ieplūstot 
Vidusjūras ūden,iem) ievērojami maina ūdeṇu plūsmu raksturu. Iztvaikošanas dēl Atlantijas okeāna silto straumju nestais ūdens atdziest, bet tā sālums ievērojami palielinās, tādējādi padarot ūdeni blīvāku. Sasniedzot okeāna ziemelı robežu, no dienvidiem plūstošais virsmas ùdens ir jau tik blīvs, ka tas "nogrimst" zem sastaptā Ziemel̦u Ledus okeāna ūdens. Jūras šaurumos abpus Grenlandei (Dāṇu šaurumā starp Grenlandi un Islandi un Deivisa šaurumā starp Bafina zemi un Grenlandi) novērojama spēcīgākā virsūdens grimšana visā Pasaules okeānā. Dziḷākajos slān,os nonākušais ūdens plūst atpakal uz dienvidiem līdz pat Antarktīdas šelfam, kur tas papildinās ar aukstu ūdeni no Dienvidu cirkumpolārās straumes. Okeāna virskārtā nogrimušais ūdens nonāk, kad tas sasniedzis Indijas un Klusā okeāna ziemel̦u šelfa nogāzes. Izmaiṇas okeānu ūdeṇu plūsmas raksturā Klusajā okeānā rada būtisku ietekmi uz ḷoti plašu reǵionu klimatu (El Niño un La Niña). Grandiozais "okeāna konveijers" (sk. 3.7. att.) virzās lēni, tā aprites cikls ir 1400-1600 gadu, taču tā nozīme, regulējot globālo klimatu, pēc zinātnieku vairākuma domām, ir milzīga.

Pretēji vairāku klimata modelētāju apgalvojumam, ka okeāna straumju ietekme uz sauszemes klimatiskajiem apstākḷiem ir pārspīlēta, ǵeologiskie pētījumi liecina, ka laikposmos, kad virsūdens grimšana Atlantijas okeāna ziemelıs bijusi traucēta, bet okeāna termohalīnā cirkulācija pavājinājusies vai pat pagriezusies pretējā virzienā, Eiropas klimats kḷuvis ievērojami skarbāks. Apmēram pirms 12 90011500 gadu ledāju ledussegas atkāpšanos pārtrauca īslaicīgs aukstuma periods - Vēlais driass. Ziemel̦eiropā taigas mežus no jauna aizstāja tundra, bet kalnu apvidos ledāju kušanu nomainīja jauna uzsaluma veidošanās. Neñemot vērā dažas pretrunas, vairums zinātnieku uzskata, ka Vēlā driasa pēkšñā uzsākšanās saistāma ar traucējumiem okeāna termohalīnajā cirkulācijā. Ziemel̦amerikas ledāju kušanas ūdens izveidoja milzīgu saldūdens baseinu kontinenta vidienē, mūsdienu ASV un Kanādas teritorijā, tā saukto Agasī ezeru. Kad aptuveni pirms 13000 gadu Agasī ezera ūdens pārrāva ūdensšksirtni, kas to norobežoja no Atlantijas okeāna, saldūdens ieplūda okeānā, strauji samazinot okeāna virskārtas ūdens sāḷmu un blīvumu. Bija jāpaiet vairāk nekā 1000 gadiem, lai Atlantijas okeāna virsūdens blīvums atgūtu tādu pakāpi, ka varētu atjaunoties ūdens grimšana un līdz ar to arī termohalīnā cirkulācija.

Pašreiz notiekošās globālās sasilšanas kontekstā jāpiemin, ka ap 55 miljoniem gadu atpakal paleocēna/eocēna temperatūras maksimuma laikā, līdzīgi kā mūsdienās, notika globāla sasilšana, kuru izraisīja siltumnīcefekta gāzu koncentrācijas pieaugums atmosfērā. Okeāna ūdens strauji sasila vidēji par 7-8 grādiem, un dažu tūkstošu gadu laikā okeāna termohalīnā cirkulācija pavērsās pretējā virzienā. Zīmīgi, ka termohalīnās cirkulācijas apgrieztais plūdums

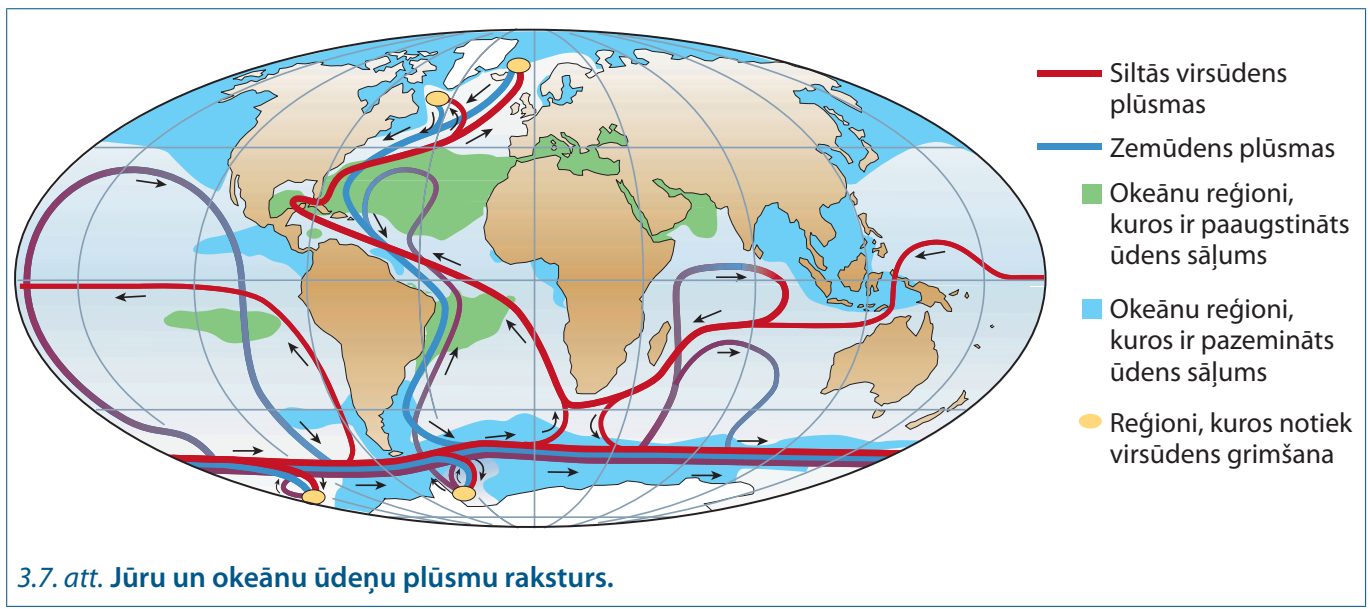


turpinājās vismaz 100000 gadu. Līdzīgi vēlā driasa laikā termohalīnās cirkulācijas izbeigšanos izraisīja ūdens grimšanas pavājināšanās Ziemel̦atlantijā.

Termohalīnā cirkulācija darbojas ne tikai kā temperatūru izlīdzinošs mehānisms, bet arī palīdz noglabāt okeāna dzilākajos slān,os ūdenī izšķīdušo atmosfēras $\mathrm{CO}_{2}$. Nesen veiktie aprēķini rāda, ka pēdējo 200 gadu laikā Pasaules okeāns spējis absorbēt apmēram 1/3 (118 \pm 19 Pg C) no visa cilvēka darbības rezultātā emitētā ogḷskābās gāzes daudzuma (244 \pm 20 Pg C). "Okeāna konveijera” lēnās kustības dēl lielākā dal̦a okeāna dziḷāko slānu ūdens šajā laikā vēl ne reizes nav bijusi saskarē ar atmosfēru. Tādējādi pašlaik tiek izmantota apmēram $1 / 3$ no Pasaules okeāna ūdens spējas absorbēt atmosfēras $\mathrm{CO}_{2}$. Šì spēja var pilnībā realizēties tikai tad, ja okeāna termohalīnā cirkulācija darbojas normālā režīmā.

\subsection{Jūru un okeānu ūdeṇu un atmosfēras mijiedarbība}

Klimatu katrā konkrētajā vietā ietekmē ne tikai Saules starojuma intensitāte, bet arī atmosfēras gaisa masu plūsmas un to mijiedarbības raksturs gan ar sauszemes virsmu, gan ar jūru un okeānu ūden,iem. Tā kā jūras un okeāni aizn,em lielāko dal̦u no Zemes virsmas, bet tie ir kustīgi un straumes spēj pārnest uzsilušas vai atdzisušas ūdens masas lielos attālumos, tad atmosfēras gaisa plūsmu un ùdeṇu plūsmu mijiedarbība ir nozīmīgs klimatu veidojošs faktors.

Par gaisa masām sauc plašas zemākās atmosfēras (troposfēras) daḷas ar viendabīgām fizikālām īpašībām, kuru iekšienē gaisa temperatūras un citu meteorologisko rādītāju vērtību mainība ir relatīvi zema. Gaisa masas pārvietojas ar atmosfēras cirkulācijas plūsmām. Tās spēj absorbēt ūdens tvaikus, kas iztvaiko no sauszemes vai jūru un okeānu virsmas, bet pēc tam atbrīvojas no tiem nokrišņu veidā. Gaisa masas var aiznnemt tūkstošiem kvadrātkilometru plašus apgabalus, bet to izmēri vertikālā virzienā var būt no dažiem kilometriem līdz pat $10 \mathrm{~km}$ augstumam. No vietas, kur gaisa masas ir veidojušās un kas tiek saukta par gaisa masu cilmvietu, tās paṇem līdzi konkrētās virsmas iezīmes. Gaisa masas pārvietojas ar atmosfēras cirkulācijas plūsmām kā vienots veselums. Parasti tās atrodas cita citai blakus vai slīpā plaknē cita aiz citas. Gaisa masas šksir šauras pārejas joslas jeb atmosfēras frontes. Gaisa masas atškiriras pēc to cilmvietas, temperatūras, mitruma un sadul,ķojuma (putekḷi, ūdens tvaiki un citas dalinas). Gaisa masu plūsmas ietekmē laikapstākḷus, jo tās nosaka

1) gaisa mitrumu un temperatūru. Ja gaisa mitrums ir zems, raksturīgs neliels mākonu daudzums, bet, ja sauszemes teritoriju ir sasniegušas gaisa masas, kuras izveidojušās virs okeāniem, to mitrums ir augsts, un var veidoties mākon,i, migla vai nokrišn,i;

2) gaisa masu stabilitāti.

Latvijā ieplūst dažādas izcelsmes gaisa masas, kas ir veidojušās dažādos platuma grādos gan virs Atlantijas okeāna, gan kontinentiem un tāpēc ir l̦oti atškirīgas pēc temperatūras, mitruma, vēja stipruma un citām īpašībām. Gaisa masas pamatā var iedalīt okeāniskās un kontinentālās atkarībā no to mitruma jeb ūdens tvaiku satura gaisā. Okeāniskās gaisa masas veidojas virs okeāniem, un tās satur daudz mitruma. Kontinentālo gaisa masu cilmvietas ir sauszemes apgabali, tāpēc tās parasti satur maz mitruma. Kontinentālās gaisa masas no okeāniskajām gaisa masām atškkiras ar putekḷu un aerosolu daudzumu, kā arī cilvēku radītā piesārn,ojuma klātbūtni. Kontinentālās gaisa masas, kas veidojas arktiskajos apgabalos, var būt aukstas un ar zemu mitruma saturu, kā arī zemu putekḷu un aerosolu saturu. Gaisa masu plūsmu raksturs gada laikā būtiski mainās atkarībā no Saules radiācijas intensitātes, kā arī katram gadalaikam tipiskā gaisa plūsmu režīma. Ja ziemā izveidojas noturīgs anticiklons un ilgstoši pastāv zema temperatūra, tā cēlonis ir no ziemel̦iem ieplūdušās arktiskās gaisa masas, bet vasarā ilgstoši 

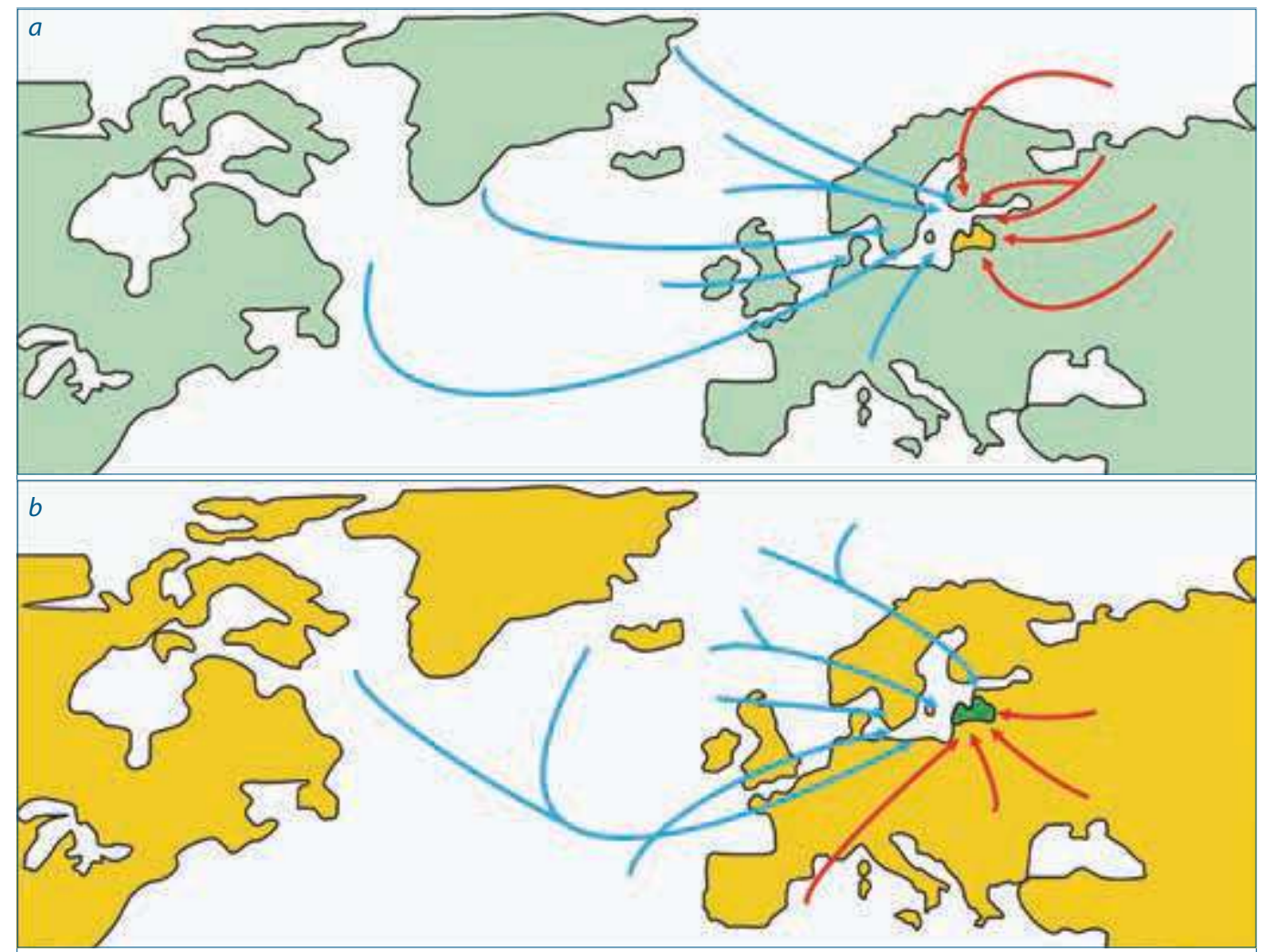

3.8. att. Latvijā ieplūstošo gaisa masu veidošanās un transformēšanās apgabali un tipiskas gaisa masu trajektorijas ziemā (a) un vasarā (b). Zilās līnijas - okeānisko, sarkanās līnijas - kontinentālo gaisa masu plūsmu virzieni.

siltu laiku nosaka gaisa masas, kuras Latvijas teritorijā ir pārnestas no Āfrikas kontinenta vai no Eiropas dienvidu dalsas (sk. 3.8. att.).

Globālā atmosfēras cirkulācija ir sistēma, kas pēc apjoma līdzinās kontinentu vai okeānu izmēriem. Šì gaisa kustība kopā ar okeāna cirkulāciju nosaka siltuma sadalījumu uz visas Zemes. Tā, piemēram, ja nenotiktu atmosfēras cirkulācija, vidējā ziemas temperatūra polu rajonos būtu ap $-100^{\circ} \mathrm{C}$ tagadējo $-30{ }^{\circ} \mathrm{C}$ vietā. Liela mēroga gaisu masu pārnese nosaka Latvijai raksturīgos mainīgos laikapstākl̦us. Atlantijas okeāna ūdeṇu cirkulācijas raksturs būtiski ietekmē klimatu Latvijā un bieži ir galvenais faktors, kas nosaka laikapstākḷus, ietekmējot to lielo mainību. Laikapstākḷus Latvijā nosaka tas, ka atmosfēras gaisa masu liela mēroga cirkulācija veidojas virs Atlantijas okeāna ziemel̦daļas.

Liela mēroga atmosfēras gaisa masu veidošanās un cirkulācijas procesus ietekmē pazeminātais atmosfēras spiediens Atlantijas okeāna ziemeḷdaḷā (pastāv zema spiediena sistēma), kamēr ekvatora tuvumā izveidojas augsta spiediena apgabals (sk. 3.10. att.). Šīs sistēmas raksturošanai izmanto gaisa spiediena atškirību Islandes un Azoru salu meteorologiskajās stacijās izdarītajos mērījumos. Islandes un Azoru atmosfēras spiediena sistēmas un spiediena starpība starp tām periodiski mainās, tās apraksta kā Ziemal̦atlantijas oscilāciju (ZAO, anglu valodā North Atlantic Oscillation - NAO), bet mainības skaitliskai izteikšanai izmanto ZAO indeksu (sk. 3.10. att.). 


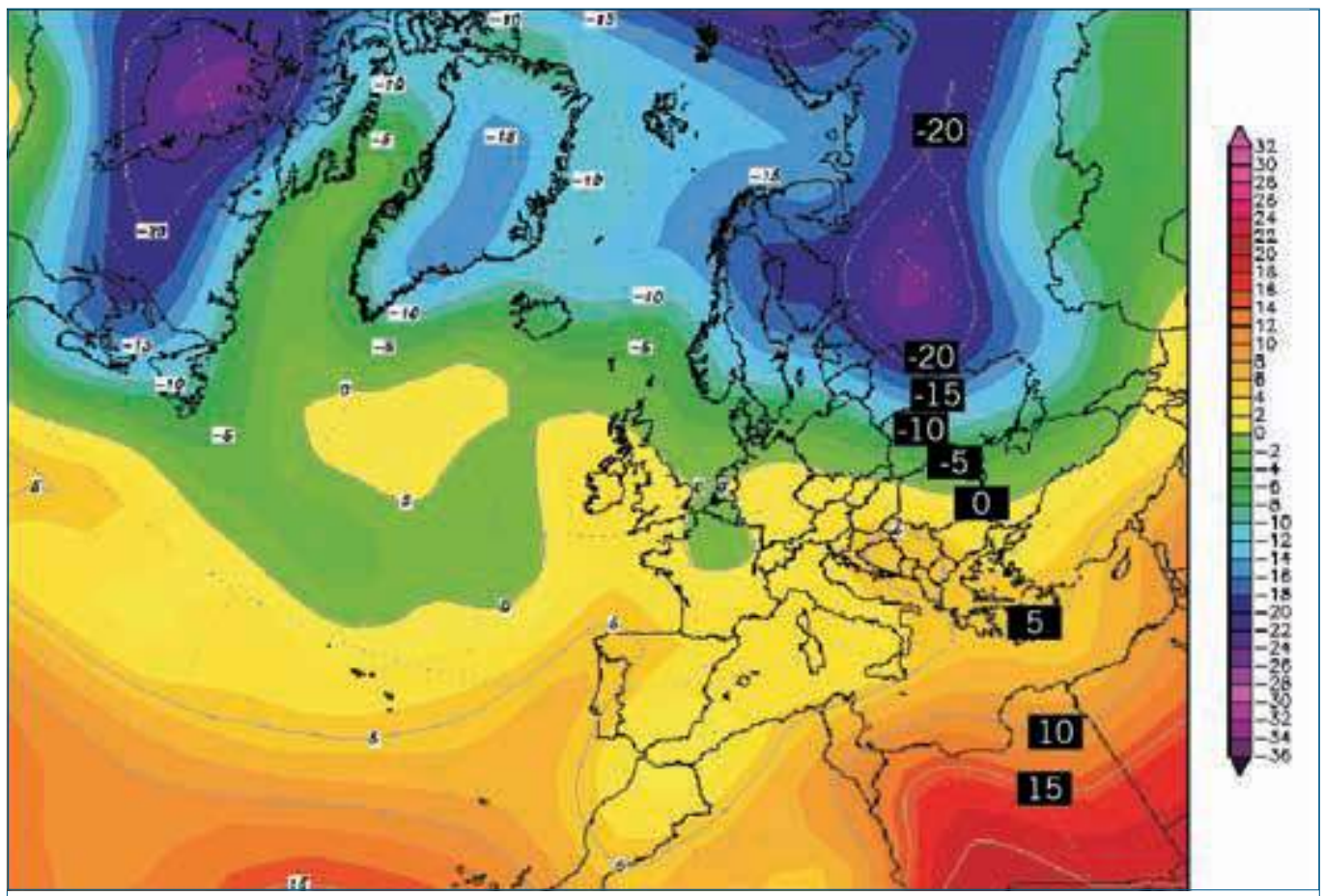

3.9. att. Gaisa temperatūras sadalïjums, ${ }^{\circ} \mathrm{C}, 850 \mathrm{hPa}$ lïmenī virs Eiropas (2007. gada 22. februāris). Izotermu izvietojums parāda auksta gaisa $\left(<-20^{\circ} \mathrm{C}\right)$ ieplūšanu Latvijā no ziemeḷaustrumiem. Tās ir kontinentālas arktiskas gaisa masas.
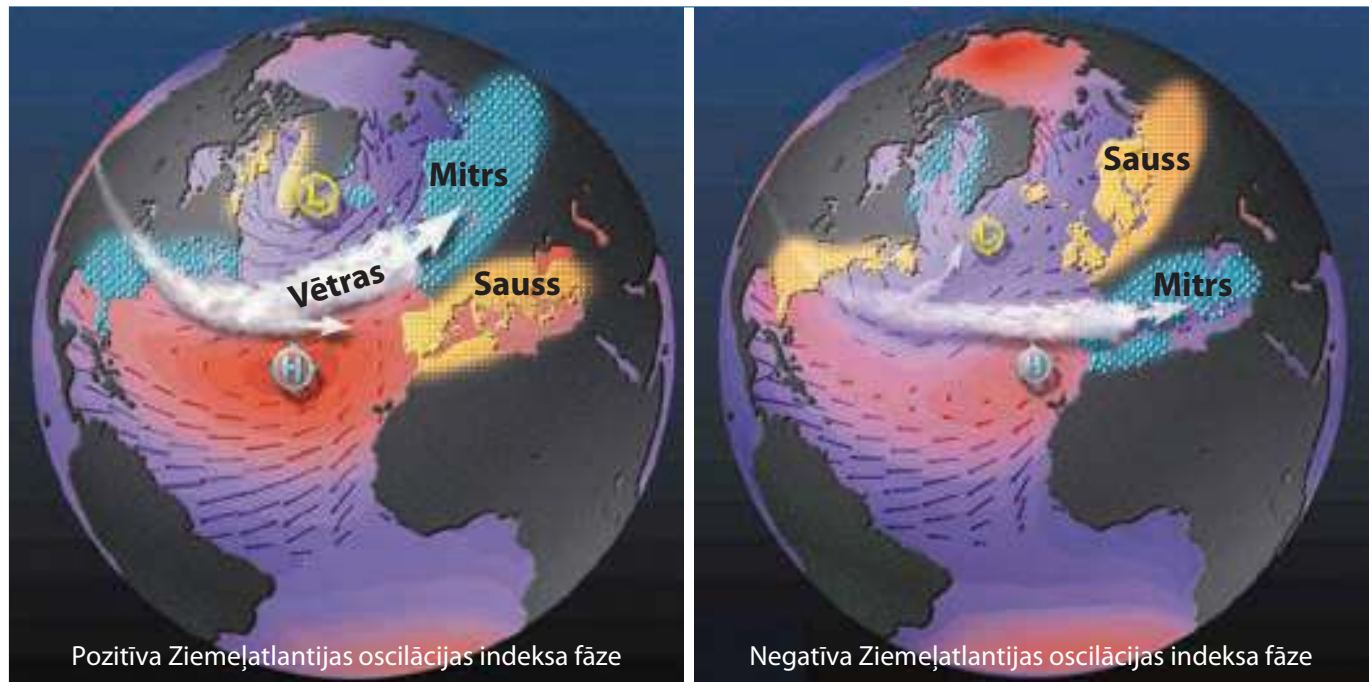

3.10. att. Ziemeḷatlantijas oscilācijas fāzes ietekme uz laikapstākḷu veidošanos Eiropā.

$\mathrm{L}$ - zema spiediena apgabals, $\mathrm{H}$ - augsta spiediena apgabals. 


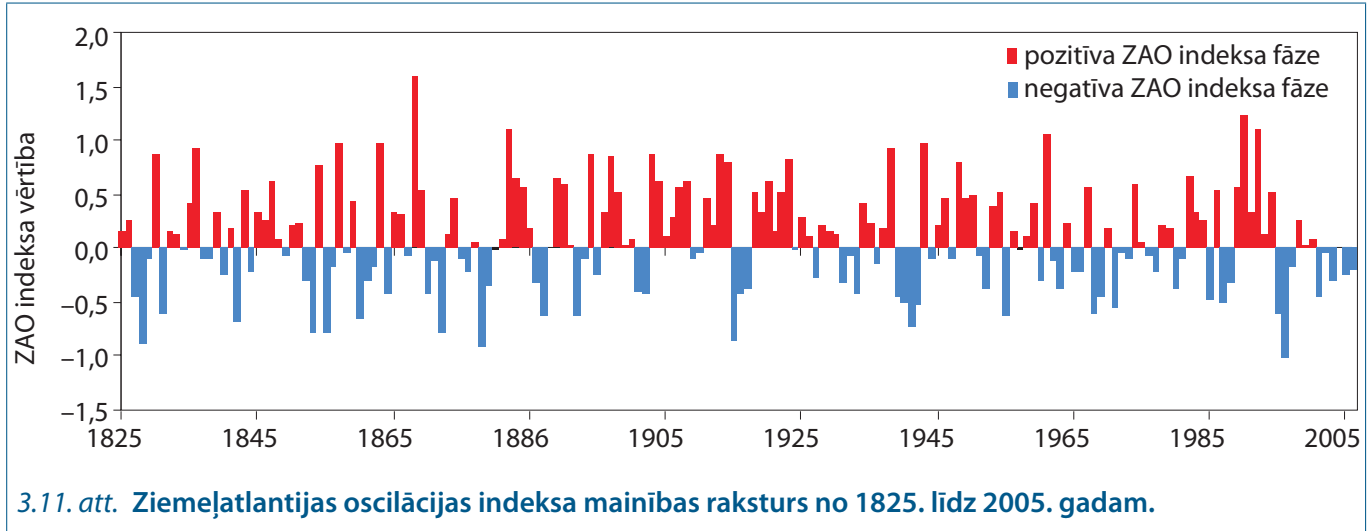

Ja Ziemel̦atlantijas klimata sistēmā izveidojas izteikti augsta spiediena apgabals virs Azoru salām (pozitīva ZAO indeksa fāze), bet pazemināta spiediena centrs virs Islandes, tad spēcīgas gaisa masu plūsmas no rietumiem sekmē ar ūdeni piesātinātu gaisa masu pārnesi no Ziemel̦atlantijas uz Eiropas ziemel̦dal̦u un Krieviju, vienlaikus sekmējot auksta gaisa plūsmas Rietumgrenlandes virzienā (sk. 3.10. att.). Šĩs noturīgās gaisa plūsmas bloḳē cel̦u virs Āfrikas uzsilušajām gaisa masām, un līdz ar to Vidusjūras reǵionā veidojas karsts un sauss laiks.
Negatīvas Ziemeḷatlantijas oscilācijas indeksa fāzes gadījumā Ziemel̦atlantiju šḳērso mazāk ciklonu, un tie novirzās vairāk Vidusjūras apgabala virzienā, bet Eiropas ziemel̦dal̦ā valda sauss un kontinentāls klimats (sk. 3.11. att.).

Jūru un okeānu ūdeṇu plūsmu un atmosfēras cirkulācijas mijiedarbība uzskatāma par nozīmīgu faktoru, kas nosaka augsto klimata mainību, tomēr klimata sistēmas izmainas (to skaitā arī globālā sasilšana) var mainīt šĩs mijiedarbības raksturu, sekmēt ekstremālu parādību biežuma palielināšanos.

\subsection{Klimata mainības raksturs un cilvēka ietekme uz to}

Klimatu pēdējo simts gadu laikā raksturo ievērojamas pārmainas, kas ir l,oti straujas salīdzinājumā ar izmaiṇu raksturu pēdējo tūkstošu gadu laikā, kā arī garākā laika posmā (sk. 3.12. att.). Tiek vērtēts, ka laika posmā no 1861. līdz 2005. gadam Zemes gada vidējā temperatūra ir paaugstinājusies par $0,6 \pm 0,2^{\circ} \mathrm{C}$, turklāt temperatūras paaugstinājums ir noticis galvenokārt laika posmā no 1910. līdz 1945. gadam un no 1976. gada līdz mūsdienām. Desmit gadi ar augstāko gada vidējo temperatūru meteorologisko novērojumu vēsturē bijuši pēc 1980. gada, bet septiṇi - pēc 1990. gada. Novērojumi apstiprina, ka pēdējās simtgades laikā mainījies arī temperatūras diennakts sadalījums, kā arī paaugstinājusies temperatūra virs jūru un okeānu virsmas.

Klimata pārmaiṇu raksturs saistāms ne tikai ar temperatūras paaugstināšanos, bet arī ar izmain̄ām nokrišnu daudzumā, klimata kā sistēmas stabilitātē, ekstremālo klimatisko parādību biežuma mainībā un citu klimatu raksturojošo parametru būtiskajās izmain̄ās.

Liela dalı pētījumu klimata mainību saista ar cilvēka darbības rezultātā veidoto gāzu emisijas pieaugumu pēdējā gadsimta laikā. Ir pierādīts, ka pēdējo 100 gadu laikā ir ievērojami palielinājusies lielākā daḷa siltumnīcefekta gāzu 


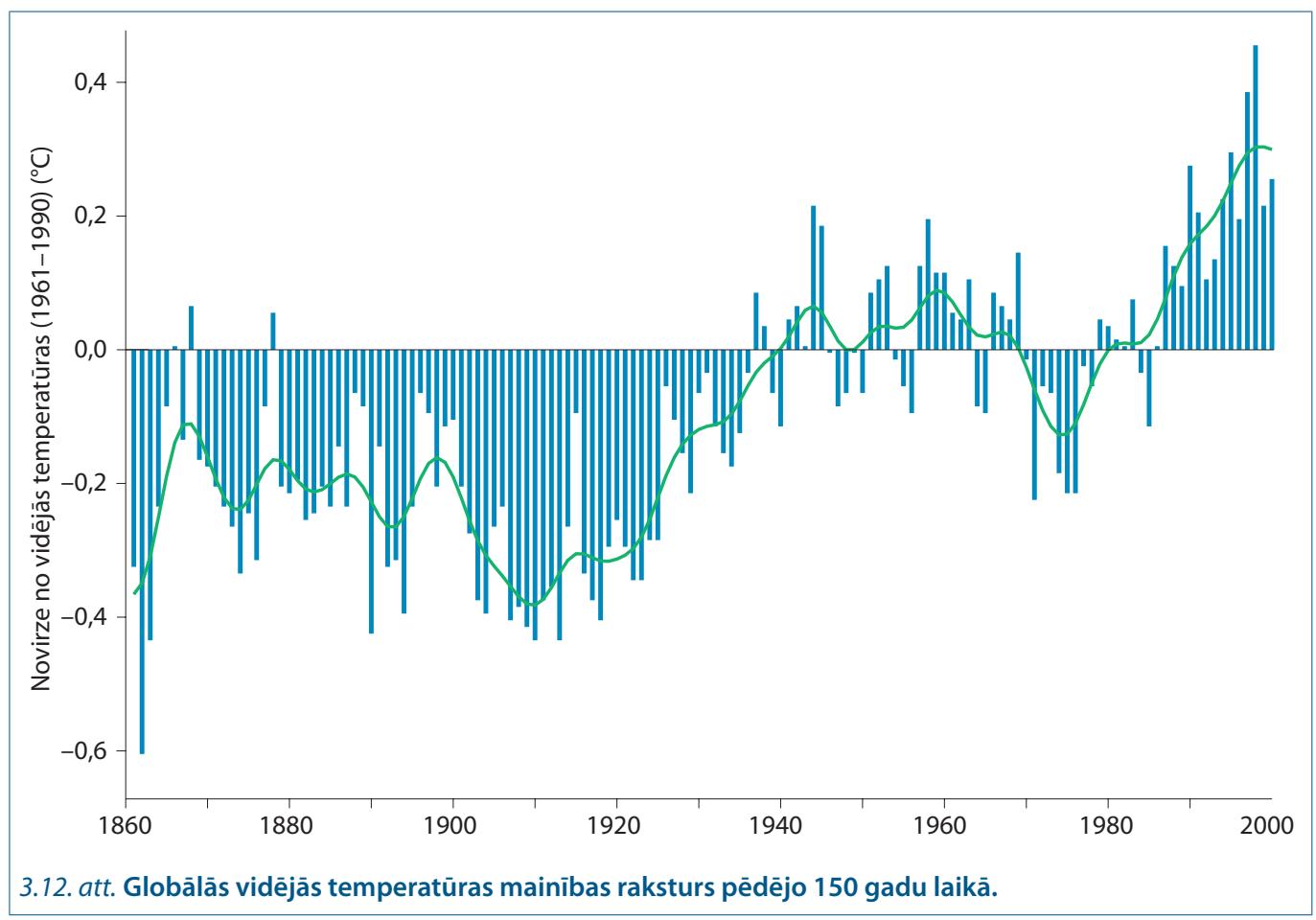

koncentrācija gaisā. To vislabāk pierāda $\mathrm{CO}_{2}$ koncentrācijas pieauguma tendences Maunaloa observatorijā (Havaju salas, ASV).

Novērojumi, kas veikti Maunaloa observatorijā, sākot no 1958. gada, parādỉja, ka og̣̣skābās gāzes koncentrācija novērojumu punktā, kas atrodas tālu no tieša piesārṇojuma avotiem, vidēji pieaug par 0,46\% gadā (sk. 3.13. att.). Og!̣ skābās gāzes koncentrācija gaisā ievērojami mainās atkarībā no sezonas. Tas saistìts ar fotosintēzes procesu intensitātes izmaiṇu sezonālo raksturu. Līdzīgi rezultāti konstatēti arī citās pētījumu stacijās Eiropā un Āzijā.

Og̣sskābās gāzes un vairāku citu siltumnīcefekta gāzu koncentrācija atmosfērā tieši korelē ar cilvēka darbības rezultātā emitēto vielu apjomu (sk. 3.14. att.). Galvenais $\mathrm{CO}_{2}$ emisijas avots ir fosilā kurināmā (naftas pārstrādes produkti, ogles, kūdra, degslāneklis) sadedzināšana, nozīmīgs metāna avots ir lauksaimnieciskā ražošana un naftas pārstāde. Tajā pašā laikā mūsdienu sabiedrība ir lielā mērā atkarīga no enerǵijas avotiem, kas nodrošina lielāko dal̦u ražotṇu, transportu un katra cilvēka labklājību.
Ņemot vērā $\mathrm{CO}_{2}$ emisijas apjomu pieaugumu, tiek vērtēts, ka līdz gadsimta vidum oglekḷa dioksīda koncentrācija atmosfērā salīdzinājumā ar mūsdienām dubultosies, kas var izraisīt Zemes gada vidējās temperatūras paaugstināšanos par $1,5-4,5^{\circ} \mathrm{C}$.

Analizējot vēsturiski novēroto klimata mainības raksturu, piemēram, ledus masā ieslēgto gāzu sastāvu, un rekonstruējot temperatūras mainības gaitu pēdējo 500000 gadu laikā, redzams, ka rekonstruētās temperatūras vērtības cieši korelē ar siltumnīcefekta gāzu, vispirms $\mathrm{CO}_{2}$, koncentrācijas vērtībām (sk. 3.14. att.), kas apstiprina pieñēmumu, ka siltumnīcefekta gāzu nozīme Zemes klimata veidošanā ir ievērojama un globālā sasilšana saistāma ar šo gāzu koncentrācijas izmaiṇām.

Og̣̣lskābā gāze ir viena no būtiskākajām siltumnīcefekta gāzēm, jo tās koncentrācija atmosfērā salīdzinājumā ar citām siltumnīcefektu veicinošām gāzēm ir vislielākā. Taču ogḷskābā gāze ir viens no oglekḷa aprites elementiem. Oglekḷa apritē (biogeoḳīmiskās aprites cikls) vieni oglekla savienojumi pārvēršas 


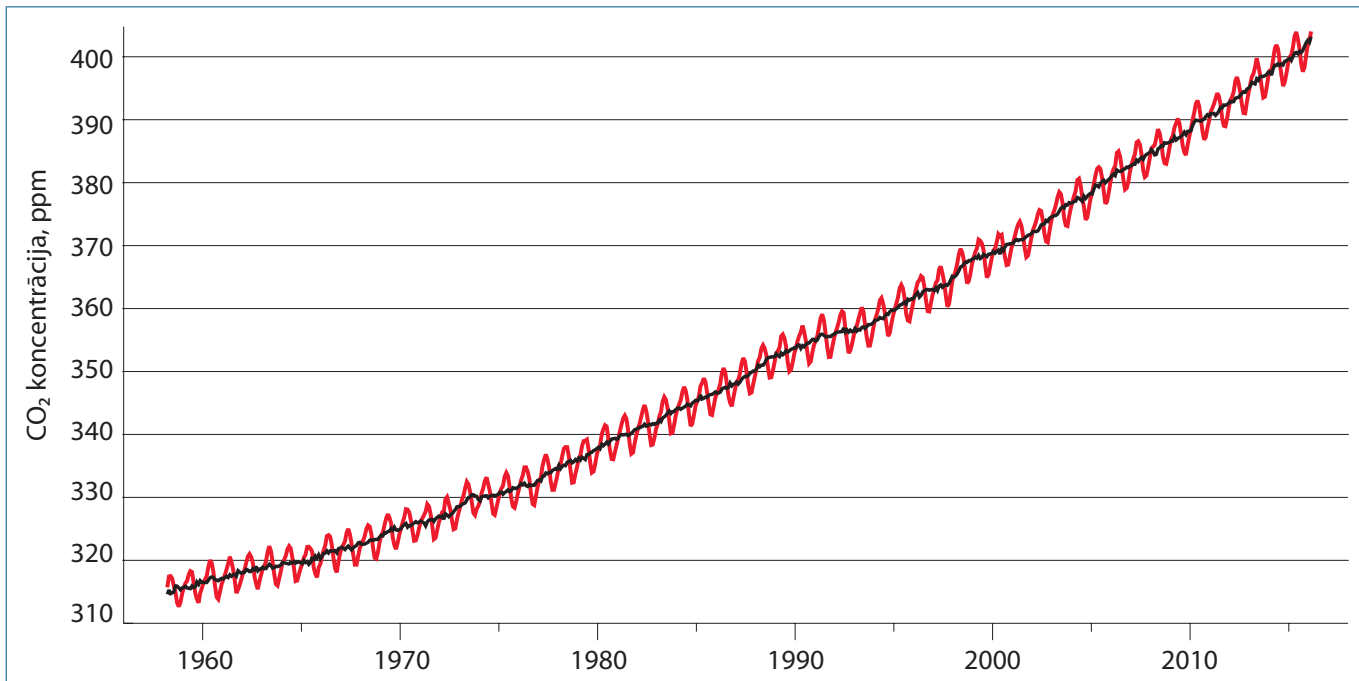

3.13. att. Og!̣skābās gāzes koncentrācijas izmaiṇas atmosfērā Maunaloa observatorijā (Havaju salas).

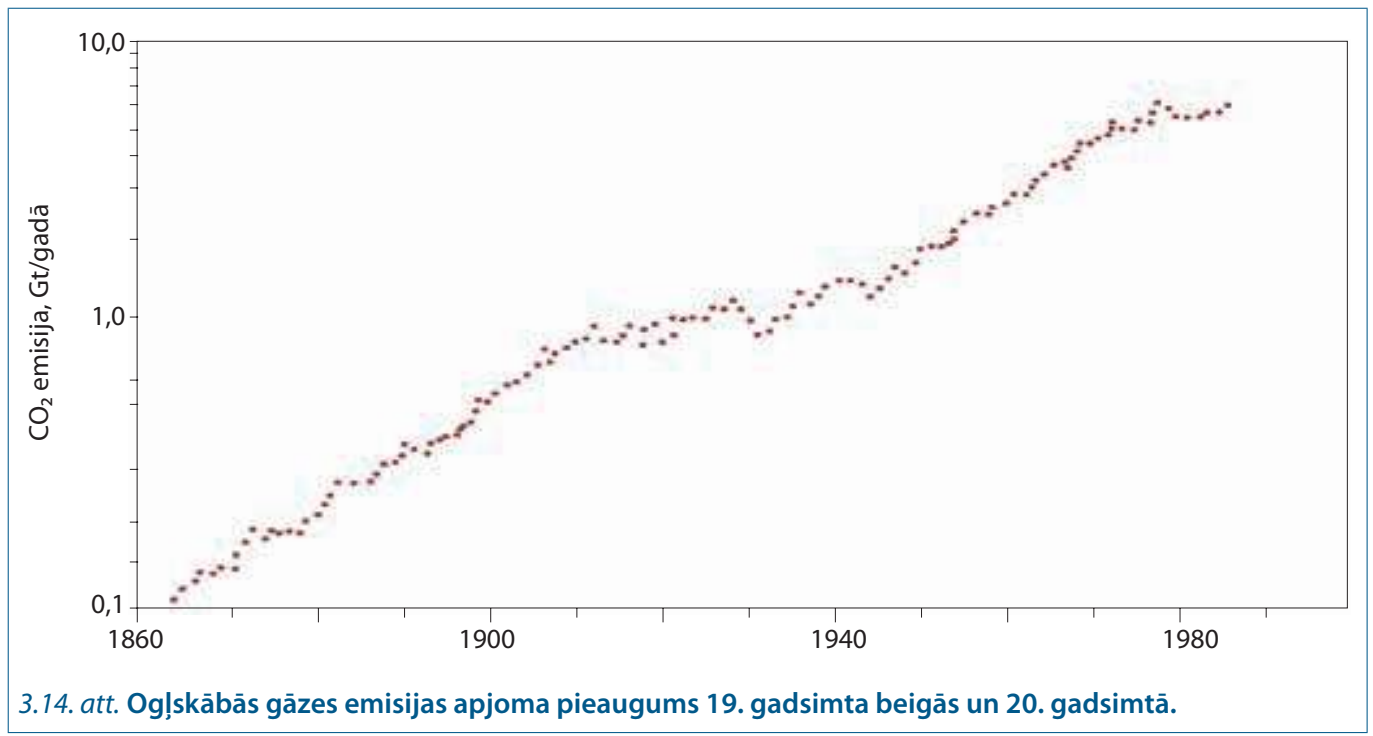

citos, un tas var notikt atmosfērā, hidrosfērā un biosfērā. Kā kīmisks elements ogleklis ir nozīmīgs visām dzīvības formām. Ogleklis ir sastopams piecās "krātuvēs":

1) atmosfērā oglekḷa dioksīda formā;

2) organiskos savienojumos biosfērā;

3) hidrosfērā izšksīduša oglekḷa dioksīda un karbonātjonu, kā arī izšksīdušo oglekḷa organisko savienojumu formā;
4) kalcija karbonāta veidā kalı̣kakmeņos un organiskajos nogulumiežos;

5) humusa veidā augsnes sastāvā.

Katra no šìm "krātuvēm" ir iesaistīta oglekl̦a aprites ciklā (sk. 3.16. att.).

Oglekḷa ciklā nozīmīgākā ir biosfēra un jūru un okeānu dzīvie organismi, kas fotosintēzes procesā nepārtraukti no atmosfēras saista $\mathrm{CO}_{2}$ un veido organiskus savienojumus. 
$\mathrm{CO}_{2}$ pilnīgs aprites cikls atmosfērā ir ātrs un notiek $\approx 4,5$ gados.

Ne visi mirušie organismi un augi sadalās uzreiz. Neliela dalı tiek pārvietoti uz iekšzemes ūdenstilpju, jūru un okeānu dzilıākajām daļām un uzkrājas nogulumu veidā. Organiskais materiāls, kas lēni sadalās, iekḷaujas iežu veidošanas procesā un var atkal dabiskā cel̦ā pāriet atmosfērā (piemēram, erozijas procesā).

Atmosfērā esošais oglekḷa dioksīds izšḳist hidrosfēras ūden,os, kur to izmanto alǵges tādā pašā veidā, kā to saista sauszemes augi. Papildus tam daži ūdenī dzīvojošie dzīvnieki no ūdens ekstrahē kalciju un oglekḷa dioksīdu, veidojot kalcija karbonāta čaulas. Organismiem atmirstot, tās nogulsnējas jūras dibenā un, iespējams, tālākā gaitā veido kal̦ķakmeni. Šādā veidā dalı oglekḷa pievienojas iežu ciklam. Pastāv varbūtība, ka iežu cikls "uznesīs" kaḷkakmeni atpakal Zemes virspusē, kur erozijas process un dēdēšana kalı kukmeni sadalīs un tādējādi ogleklis izškīidušā veidā atgriezīsies atpakal okeānā un iekḷūs atmosfērā kā $\mathrm{CO}_{2}$.

Cilvēka saimnieciskā darbība maina visas minētās oglekḷa krātuves un sekmē litosfērā uzkrāto oglekḷa savienojumu nokḷūšanu atmosfērā. Fosilā kurināmā izmantošana un mežu izciršana veicina $\mathrm{CO}_{2}$ pāreju no litosfēras un biosfēras uz atmosfēru daudz ātrākā tempā nekā dabiskā ceḷā. Tajā pašā laikā $\mathrm{CO}_{2}$ atgriešana no

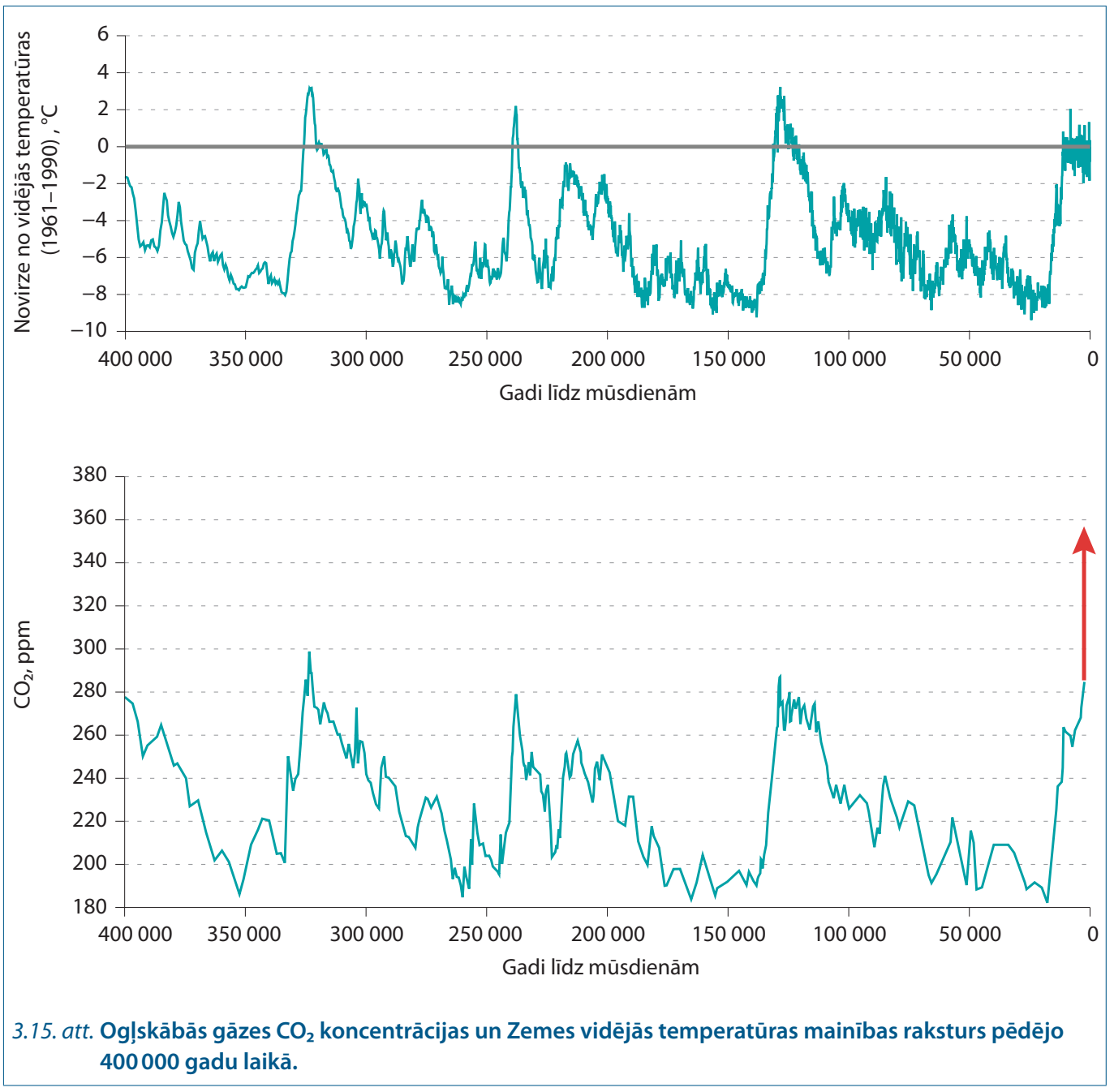


atmosfēras dabiskā cel̦ā norisinās daudz lēnāk nekā cilvēku saimnieciskā darbība to papildina, tādēl $\mathrm{CO}_{2}$ daudzums atmosfērā palielinās.

Metāns absorbē infrasarkano starojumu daudz efektīvāk nekā $\mathrm{CO}_{2}$, tādēl metāna nozīme siltumnīcefekta palielināšanā ir lıti nozīmīga, kaut arī metāna koncentrācija atmosfērā ir salīdzinoši zemāka.

Kopš 20. gs. 60. gadiem, kad uzsākti metāna koncentrāciju mērījumi atmosfērā, tā daudzums kopumā ir pieaudzis aptuveni par 1\% gadā. Daḷa metāna rodas rīsu audzēšanā, kā arī mājlopu, īpaši liellopu, audzēšanā. Vēsturiski metāna koncentrācijas izmainas, tāpat kā $\mathrm{CO}_{2}$ koncentrācijas izmainnas ir saistītas ar klimata izmaiṇām ledus laikmetu un starpledus laikmetu laikā. Tomēr pēdējā laikā veiktie pētījumi liecina, ka geoloǵiskie procesi var būt nozīmīgs metāna avots un, piemēram, tādas dabas parādības kā dubḷu vulkāni, var būt uzskatāmi par izcelsmes avotu gandrīz 10\% atmosfērā nonākušā metāna.

Ogḷskābās gāzes koncentrācija atmosfērā ir pieaugusi no 280 miljonām daḷām (ppm) pirmsindustriālajā laikmetā līdz 403 ppm 2015. gadā. Pētot kontinentālo ledāju un ledū ieslēgtā gaisa sastāvu, pierādīts, ka mūsdienās $\mathrm{CO}_{2}$ koncentrācija ir ievērojami augstāka, nekā tā bijusi pēdējo 650000 gadu laikā (180-300 ppm). Galvenais faktors, kas nosaka $\mathrm{CO}_{2}$ koncentrācijas paaugstināšanos, ir cilvēka darbība. 20. gadsimta laikā og̣̦skābās gāzes emisija ir ievērojami pieaugusi, bet laika posmā no 2000. līdz 2005. gadam tā jau bija vi-

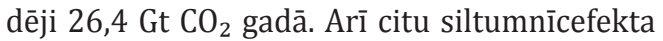
gāzu (piemēram, metāna $\mathrm{CH}_{4}$, slāpekḷa(I) oksīda $\mathrm{N}_{2} \mathrm{O}$, freona) koncentrācija ir ievērojami pieaugusi.

Troposfēras ozona un slāpekḷa oksīda koncentrācija atmosfērā pieaug ik gadu par

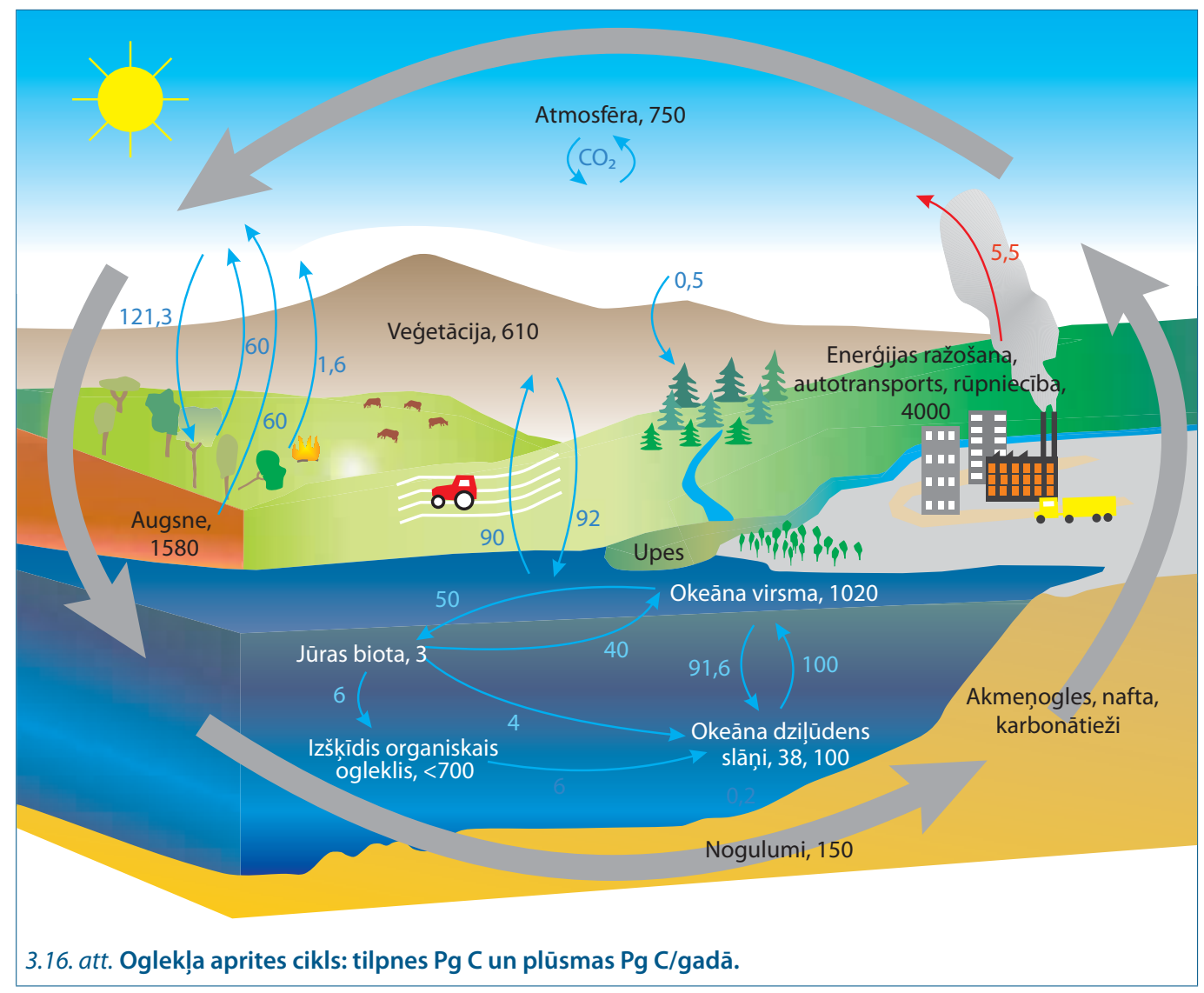




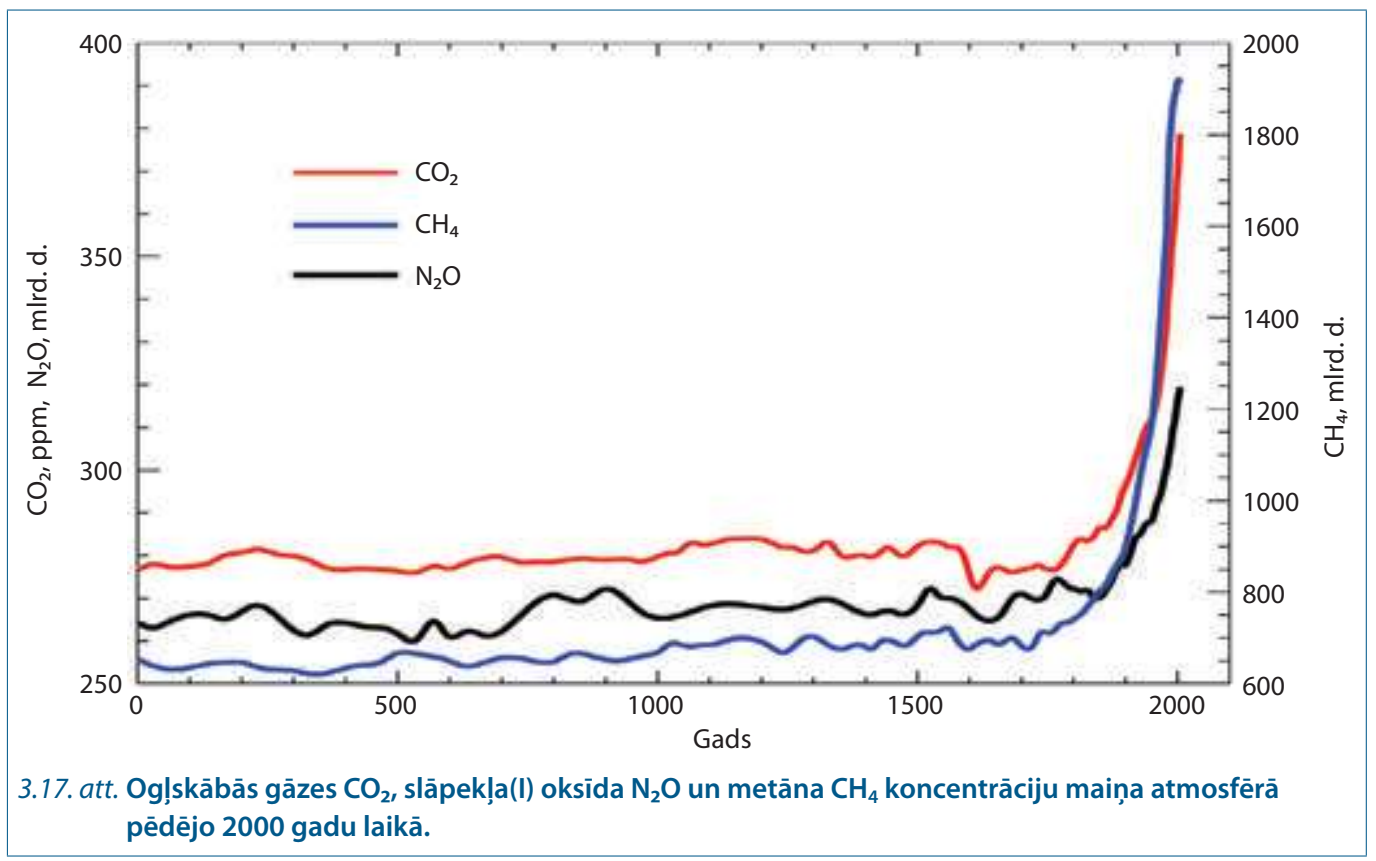

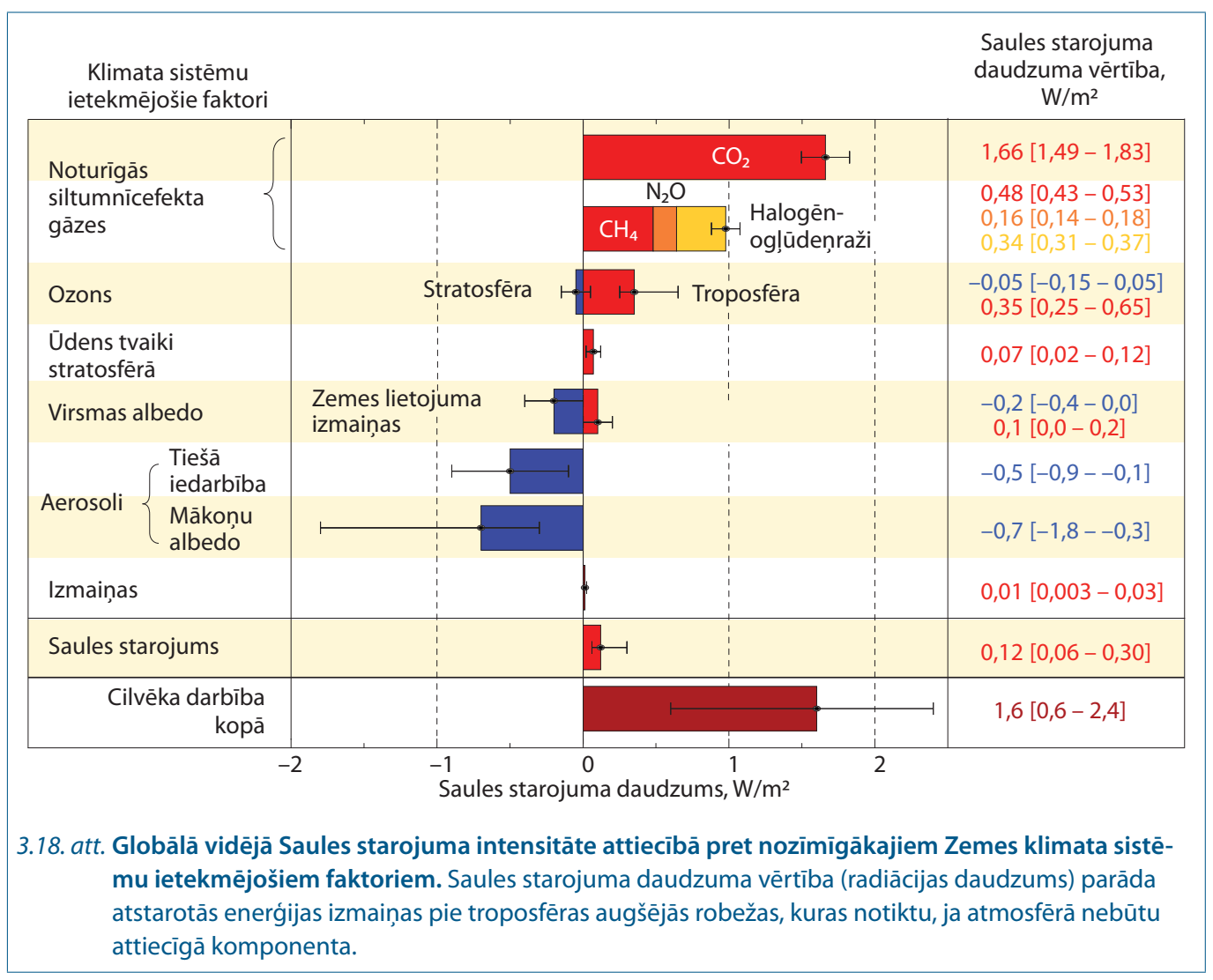


$0,5-2 \%\left(\mathrm{O}_{3}\right)$ un $3 \%\left(\mathrm{~N}_{2} \mathrm{O}\right)$, kopumā veidojot $\approx 13 \%$ no siltumnīcefekta gāzu radītā efekta.

Tropiskie meži ir svarīgs oglekḷa aprites cikla elements, jo fotosintēzes gaitā tiek patērēts daudz og̣̣skābās gāzes. Daḷa biomasā asimilētā oglekḷa uzkrājas humusvielu veidā, un tādējādi $\mathrm{CO}_{2}$ koncentrācija atmosfērā samazinās. Mežu izciršanas samazināšana varētu būtiski palielināt vides spēju saistìt og̣̦skābo gāzi nākotnē. Slāpekḷa(I) oksīdam, kas atbrīvojas augsnē mikroorganismu darbības rezultātā un rodas, sadedzinot koksni un fosilo kurināmo, ir daudz ilgāks dzīves laiks atmosfērā salīdzinājumā ar og̣̣skābo gāzi un metānu, tādēl slāpekḷa(I) oksīda koncentrācijas stabilizācija var notikt vēl ilgi pēc tā emisijas samazināšanās.

Katra siltumnīcefekta gāze citādi spēj ietekmēt infrasarkanā starojuma atgriešanu uz Zemes, un katrai no tām raksturīga konkrēta starojuma intensitātes vērtība. Novērtējot siltumnīcefekta gāzu daudzumu pirmsindustriālājā laikmetā (1750. gads) un salīdzinot to ar attiecīgo gāzu koncentrāciju mūsdienās, var novērtēt kopējās radiācijas daudzuma izmaiñas, šo izmaiṇu ietekmi uz mūsdienu klimatu, kā arī prognozēt klimata mainības raksturu apstākḷıs, kad siltumnīcefekta gāzu koncentrācijas atmosfērā turpina pieaugt (sk. 3.18. att.). Tiek uzskatīts, ka siltumnīcefekta gāzu koncentrācijas pieaugums atmosfērā kopš 1750. gada līdz mūsdienām ir palielinājis uz Zemes atgrieztās enerǵijas daudzumu par $2,43 \mathrm{~W} / \mathrm{m}^{2}$. Nozīmīgākais siltumnīcefekta gāzu devums: $\mathrm{CO}_{2}-1,46 \mathrm{~W} / \mathrm{m}^{2}, \mathrm{CH}_{4}-$ $0,48 \mathrm{~W} / \mathrm{m}^{2}, \mathrm{~N}_{2} \mathrm{O}-0,15 \mathrm{~W} / \mathrm{m}^{2}$ un halogēnogḷūden,raži $-0,34 \mathrm{~W} / \mathrm{m}^{2}$. Ozons stratosfērā ietekmē Zemes klimata sistēmu pretēji siltumnīcefekta gāzēm, tādēḷ ozona daudzuma samazināšanās stratosfērā izraisījusi starojuma daudzuma palielināšanos par $\approx 0,15 \mathrm{~W} / \mathrm{m}^{2}$. Tajā pašā laikā troposfērā ozona daudzums ir palielinājies, galvenokārt metāna $\mathrm{CH}_{4}$, tvana gāzes $\mathrm{CO}$, slāpekḷa oksīdu $\mathrm{N}_{\mathrm{x}} \mathrm{O}_{\mathrm{y}}$ un ogḷūden,ražu pieaugošā daudzuma dēḷ. Ozona koncentrācijas pieaugums troposfērā parāda, ka starojuma daudzums ir pieaudzis par $0,35 \mathrm{~W} / \mathrm{m}^{2}$. Starojuma daudzuma izmainas ietekmē arī dabiskā mainība, piemēram, Saules starojuma intensitātes mainība. Tomēr starojuma daudzuma pieaugums Saules aktivitātes mainības rezultātā, kaut arī tas ir neapšaubāmi nozīmīgs Zemes klimatu veidojošs faktors, laika posmā kopš 1750. gada veido tikai $+0,3 \pm 0,2 \mathrm{~W} / \mathrm{m}^{2}$. Protams, garākos laika posmos Saules starojuma intensitātes, Zemes kustības ap Sauli un kosmiskā starojuma intensitātes mainība var izrādīties būtiski vai pat izšksiroši klimatu ietekmējoši faktori.

\subsection{Siltumnīcefekta gāzu avoti}

Cilvēka darbības rezultātā veidojas milzīgi daudzumi siltumnīcefekta gāzu un to emisijas ir pieaugušas kopš rūpnieciskās revolūcijas sākuma. Siltumnīcefekta gāzu koncentrācijas atmosfērā ir sasniegušas nebijušas vērtības salīdzinājumā ar situāciju pēdējo 800000 gadu laikā. Galvenie faktori, kas nosaka siltumnīcefekta gāzu emisijas apjomus, ir ekonomiskā izaugsme un cilvēku skaita pieaugums.

Kopējais cilvēka radīto siltumnīcefekta gāzu emisijas apjoms laika posmā starp 1750. un 2011. gadu sasniedz $2040 \pm 310 \mathrm{Gt} \mathrm{CO}_{2}$. Apmēram 40\% no šì emisiju apjoma joprojām saglabājas atmosfērā ( $\left.880 \pm 35 \mathrm{Gt} \mathrm{CO}_{2}\right)$, bet atlikušos daudzumus ir saistījuši augi un augsne, bet okeānu ūden,os ir izšksīduši ap 30\% no cilvēka darbības rezultātā veidotās $\mathrm{CO}_{2}$, tādā veidā veicinot jūru un okeānu ūden,u paskābināšanos. Lielākā dalı no SEG emisijām ir veidojušās pēdējo 40 gadu laikā (sk. 3.19. att.).

Kopējās antropogēno siltumnīcefekta gāzu emisiju pieaugums ir turpinājies arī pēdējās desmitgadēs, bet īpaši kopš 2000. gada. $\mathrm{CO}_{2}$ emisijas, kas radušās fosilā kurināmā sadedzināšanas rezultātā un cita veida saimnieciskās darbības rezultātā, veido $\approx 78 \%$ no kopējā emisiju apjoma, turklāt ir iedalāmas tiešajās emisijās un netiešajās emisijās (sk. 3.20. att.). 

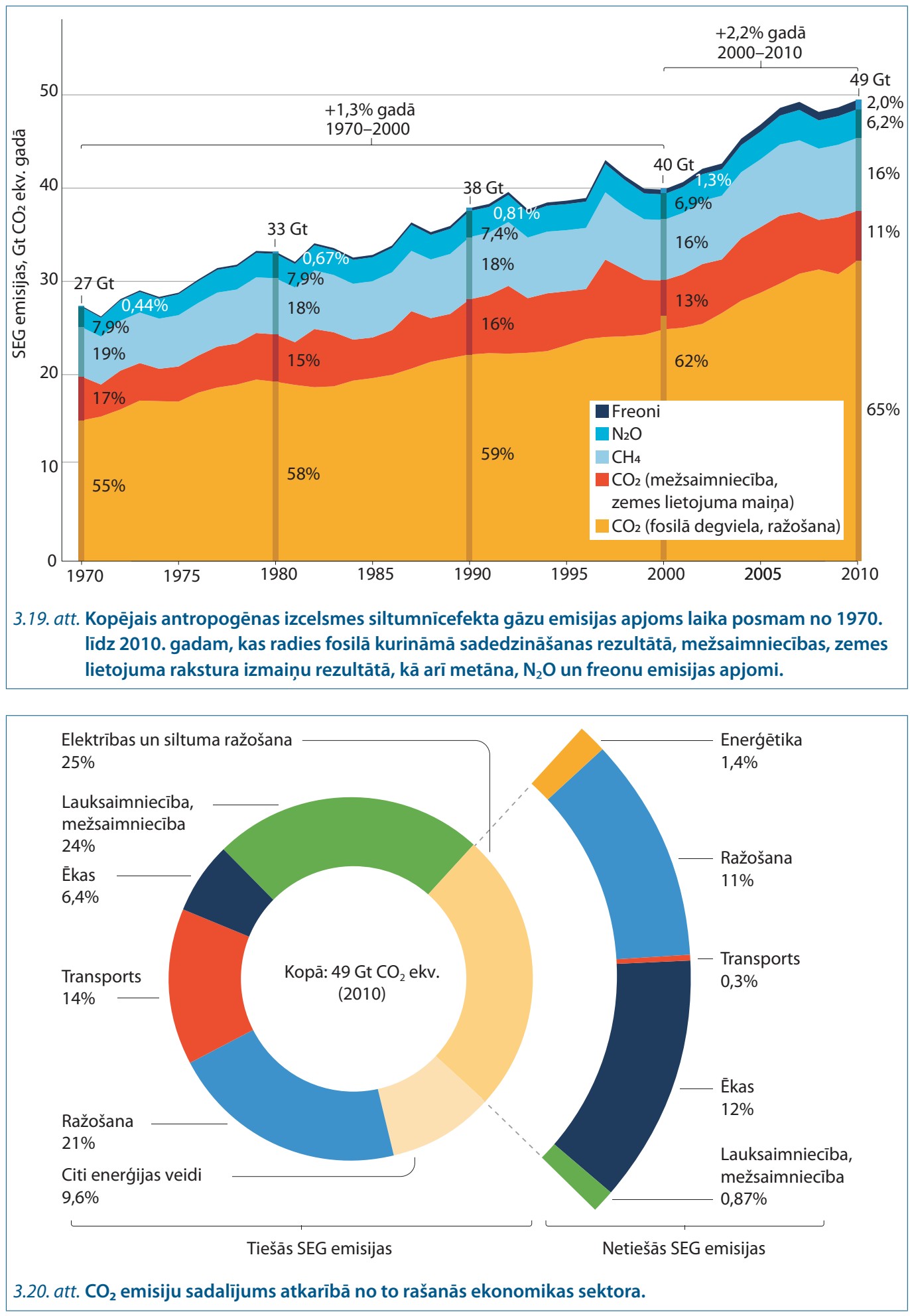
Kaut arī pasaules attīstītās valstis sekmē energoefektīvas ražošanas augšupeju un cenšas samazināt enerǵijas patēriṇu, tomēr industriālo SEG emisiju apjoms kopš 1990. gada ir samazinājies tikai par dažiem procentiem. Enerǵijas ekonomijas un SEG emisiju apjoma samazinājumu pozitīvo ietekmi uz SEG samazinājumu industriāli attīstītajās valstīs līdzsvaro ražošanas apjoma pieaugums trešās pasaules valstīs un attīstības valstīs (Brazìlija, Krievija, Kīna, Indija, Dienvidāfrika), vispirms jau Ķ̄nā un Indijā. Tomēr emisiju pieaugums no rūpnieciskās ražošanas palielinās mazāk $(<1 \%)$ nekā kopējās emisijas (> 2\%). Citi nozīmīgi SEG emisiju avoti ir emisijas no dzīvojamām ēkām un transporta.

SEG emisiju apjoms ir ievērojami atšksirīgs dažādās valstīs. Valstu ieguldījums ir atkarīgs gan no tās industrijas apjoma, gan iedzīvotāju skaita. Kaut arī, rēḳinot uz vienu iedzīvotāju (per capita), SEG emisiju apjomi Kīnā ir zemi, tomēr, n,emot vērā iedzīvotāju lielo skaitu, kopējais emisiju apjoms ir milzīgs. SEG emisiju apjomu ietekmē arī zemes lietojuma veida izmainsas, un šajā sakarībā būtiski negatīva ietekme ir tādām valstīm kā Brazīlija, Indonēzija, kurās notiek apjomīgi mežu izciršanas darbi.

\section{Avoti tālākām studijām}

Climate prediction: $h t t p: / / w w w . c l i m a t e p r e d i c t i o n . n e t$

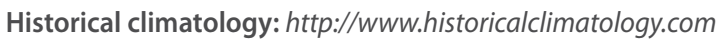

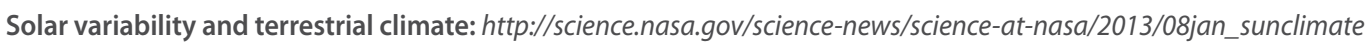
Basic information on climate change: $h t t p: / / w w w . c r u u e a . a c . u k / c r u / i n f o$

Sunspots: $h t t p: / / s o h o w w w . n a s c o m . n a s a . g o v / s u n s p o t s$

Space weather: $h t t p: / / w w w . s p a c e w e a t h e r . c o m$

Greenhouse gases and climate change: $h t t p: / / w w w . i e a g r e e n . o r g . u k$

Composition and structure of the atmosphere: http://www.met-office.gov.uk/education/training/atmospghere.html

Sunspots and climate: $h t t p: / / e a r t h o b s e r v a t o r y . n a s a . g o v / L i b r a r y / S O R C E$

Ocean currents and climate change: $h$ ttp://pik-potsdam.de/ stefan/Lectures/ocean_currents.htm/

Greenhouses gases: http://www.esrl.noaa.gov/gmd/aggi

\section{Literatūra}

O'Hare G., Sweeney J., Wilby R. (2005) Weather, Climate and Climate Change. Human Perspective. Prentice Hall: Edinghburgh (UK).

Drake F. (2000) Global Warming: the Science of Climate Change. Arnold: London.

Burroughs W. J. (2001) Climate Change: a Multidisciplinary Approach. Cambridge University Press: Cambridge.

Henson R. (2013) A Rough Guide to Climate Change. Peguin Books: London.

Aguado E., Burt J. (1999) Understanding Weather and Climate. Prentice Hall: New Jersey.

Al Gore (2008) An Inconvenient Truth. Rodale: N.Y.

Āboltiņš O. (2010) No leduslaikmeta līdz globālajai sasilšanai. Rīga: LU Akadēmiskais apgāds.

Climate Change in Latvia (2007) Ed. M. Kḷaviņš. Rīga: LU Akadēmiskais apgāds.

Eberhards G., Lapinskis J. (2009) Baltijas jūras Latvijas krasta procesi. Rīga: LU Akadēmiskais apgāds.

Eberhards G. (2003) Latvijas jūras krasti. Rīga: LU Akadēmiskais apgāds.

Universities and Climate Change (2012) Ed. W. L. Filho, Springer: Berlin.

\section{Izmantotie attēli}

3.1. Pēc http://www.solarviews.com/cap/earth/bluemarblewest.htm

3.3. Modificēts pèc IPCC, 2001.

3.4. Modificēts pēc Botkin and Keller, 2005.

3.5. Pēc http://spaceweather.com/glossary/sunspotnumber.htm/ 
3.6. Ar ațauju, pēc "Climate Change 2007: The Physical Science Basis", IPCC.

3.7. Pēc http://www.grida.no/climate

3.8. Pèc Dravenieces, 2006.

3.9. Pēc $h t t p: / / w w w . w e t t e r z e n t r a l e . d e$

3.10. Pēc http://www.ldeo.columbia.edu/NAO/

3.11. Izmantoti dati no http://www.cru.uea.ac.uk

3.12. Modificēts pēc IPCC 2001.

3.13. Pēchttp://cdiac.esd.ornl.gov/trends/co2/sio-mlo.htm

3.14. Pēc Jacobson, 2002.

3.15. Pēchttp://ncdc.noaa.gov/paleo/icecore/antarctica/vostok

3.16. Pēc http://earthobservatory.nasa.gov/Library/CarbonCycle

3.17. Ar ațauju no "Climate Change 2007: The Physical Science Basis", IPCC.

3.18. Ar ațauju no "Climate Change 2007: The Physical Science Basis", IPCC.

3.19. Ar ațauju no "Climate Change 2015: The Physical Science Basis", IPCC.

3.20. Ar ațauju no "Climate Change 2015: The Physical Science Basis", IPCC. 


\section{4.}

Latvijas klimats un

tā mainības raksturs 
Klimatiskos apstākḷus Latvijā ietekmē teritorijas novietojums Eirāzijas kontinenta ziemel̦rietumos, kas nosaka kontinentālā klimata ietekmi. Savukārt, gaisa masu pārnese ar atmosfēras cirkulāciju no Atlantijas okeāna nosaka jūras klimata ietekmi. Biežā laikapstākḷu mainība ir saistīta ar aktīvu ciklonu darbību Latvijas teritorijā. Pēc V. Kepena klimata klasifikācijas Latvijas teritorija atrodas mitrajā klimata zonā ar siltu vasaru un sniega nokrišņiem ziemā.

\subsection{Saules spīdēšanas ilgums un Saules radiācija}

Latvijas teritorijā dienas garums un līdz ar to Saules spīdēšanas ilgums ir mainīgs gada laikā. Vasaras saulgriežu laikā Latvijas teritorijas dienvidu dal̦ā Saules staru krišanas lenkis pārsniedz 57 grādus, bet ziemel̦u dal̦ā ir nedaudz lielāks par 55 grādiem. Garākā diena ir 22. jūnijā (17 stundas un 52 minūtes), un īsākā - 22. decembrī ( 6 stundas un 43 minūtes). Ziemas saulgriežos Saules augstums virs horizonta ir tikai 8-9 grādi Latvijas ziemel̦u daḷā un 10-11 grādi dienvidu dal̦ā. Kopumā vidēji Saule spīd 1790 stundas gadā (vidējais lielums aprēksināts laika periodam no 1950. līdz
2010. gadam pēc 12 meteorologisko staciju novērojumu rindām), variējot Latvijas teritorijā no 1600 līdz 1970 stundām (sk. 4.1. att.). Vislielākais Saules spīdēšanas ilgums gadā novērojams Baltijas jūras piekrastē (Kolka, Ventspils, Liepāja): 1840-1940 stundu gadā. Apmēram 1850 stundu gadā Saule spīd arī Zemgalē. Austrumu rajonos Saules spīdēšanas ilgums ir mazāks: 1670-1720 stundu gadā, bet Vidzemes augstienes rajonā - tikai 1580 stundu gadā. Kopumā vasarās piekrastes rajonos ir lielāks skaidro dienu skaits un mazāk nokrišn,u nekā apvidos, kas atrodas tālāk no jūras. Saules

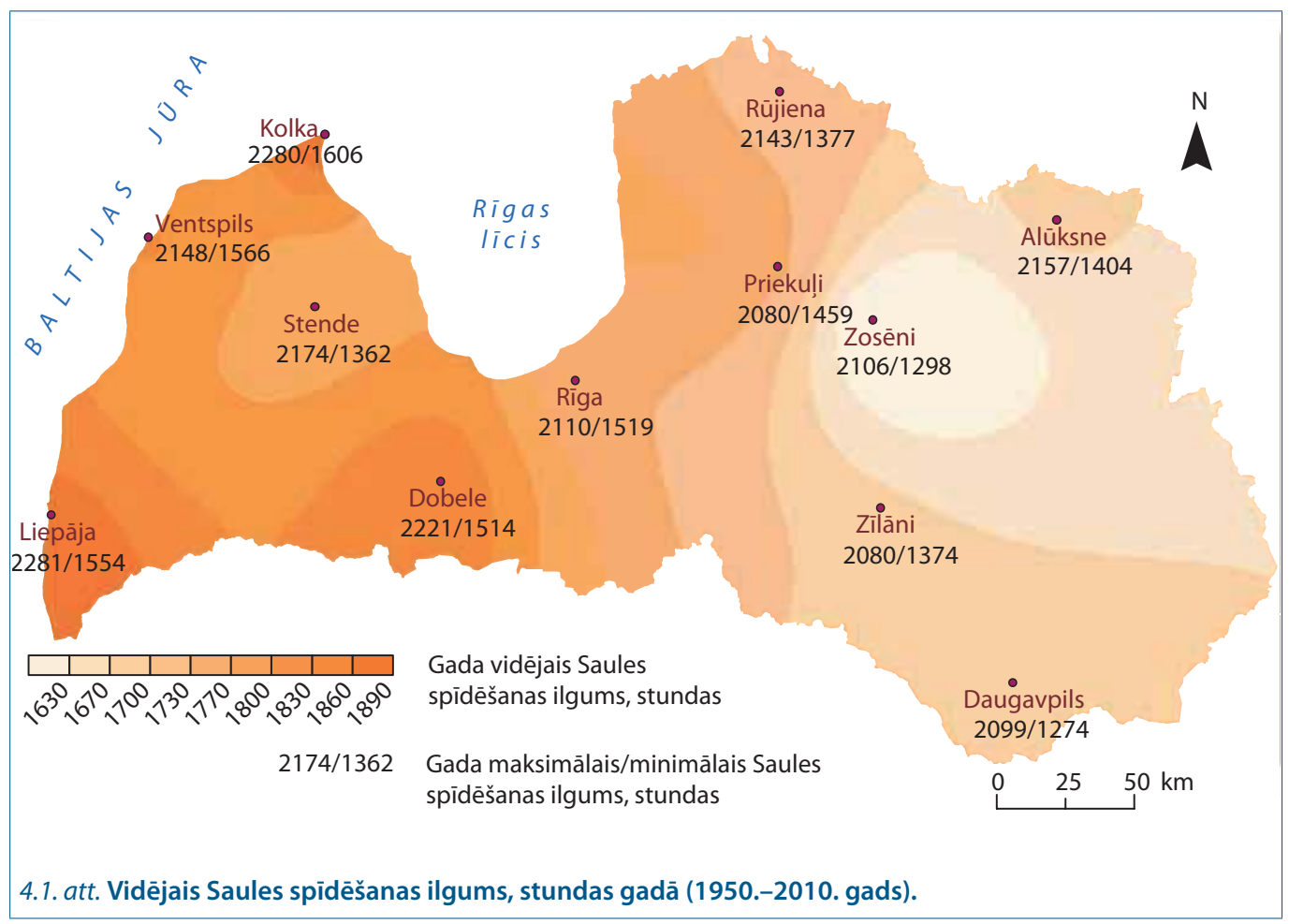


parādīšanās ilgumu bez astronomiskajiem faktoriem lielā mērā nosaka arī mākoṇu daudzums. Lielās mākoṇainības ietekmē Latvijas teritorijā kopumā Saule redzama nedaudz mazāk kā pusi no iespējamā Saules spīdēšanas ilguma. Ziemas mēnešos Latvijas teritorijā Saule parādās tikai 10-25\% no iespējamā spīdēšanas laika. Pat vasaras mēnešos kopumā vidēji Latvijā Saule redzama tikai 50-60\% no iespējamā Saules spīdēšanas ilguma. Latvijas teritorijā vidēji gada laikā ir 90-110 dienas, Vidzemes un Latgales augstien,u rajonos 110-120 dienas bez Saules. Ziemas mēnešos vidēji vairāk nekā pusi no mēneša dienām Saule neparādās. Vasaras mēnešos (jūnijs, jūlijs) visā Latvijas teritorijā ir tikai 1-2 dienas bez Saules.

Gada vidējais kopējās Saules radiācijas daudzums ir 3500-4000 MJ/m², no kuriem 600$650 \mathrm{MJ} / \mathrm{m}^{2}$ Zemes virsma sañem jūnijā un apmēram $30 \mathrm{MJ} / \mathrm{m}^{2}$ decembrī (sk. 4.1. tabulu). Vidēji gadā tiešā Saules starojuma un izkliedētā starojuma attiecība ir 1,1: 1. Tas norāda, ka Zemes virsma gadā Saules enerǵiju tiešās enerǵijas veidā saṇem nedaudz vairāk nekā izkliedētās enerǵijas veidā. Rudenī un ziemā izkliedētā Saules starojuma veidā Zemes virsma sañem ievērojami vairāk enerǵijas nekā tiešā starojuma veidā. Laikā no maija līdz augustam tiešā starojuma ir vairāk. Tiešā un izkliedētā Saules starojuma sadalījumu ietekmē mākoṇu daudzums, kas ir galvenais starojuma izkliedētājs atmosfērā.

Absorbējot Saules starojumu, Zemes virsma vienlaikus to zaudē garo viḷnu izstarošanas veidā, ko sauc par efektīvo izstarojumu. Starojuma bilanci veido starpība starp Zemes virsmas saṇemto un zaudēto Saules energijas daudzumu. Pēc Zīlānu novērojumu stacijas datiem, starojuma bilance ir apmēram $1500 \mathrm{MJ} / \mathrm{m}^{2}$ gadā. Novembrī, decembrī un janvārī radiācijas bilance ir negatìva, bet gada pārējos mēnešos - pozitīva.

Atstarotās radiācijas daudzums ir atkarīgs no Zemes virsmas rakstura. Procentos izteikto atstarotās radiācijas daudzumu sauc par albedo. Kopumā gada laikā vidējais albedo ir $27 \%$. Ziemā albedo vērtības ir lielākas (vidēji 65$70 \%$ ). Tas izskaidrojams ar sniega segas lielajām atstarošanas spējām. Vasarā vidējais albedo (vidēji 22\%) kopumā atbilst zaḷas zāles atstarošanas īpašībām.

Absorbētā radiācija iegūta, no summārās radiācijas atņemot atstaroto radiāciju. Albedo lielums iegūts aprēksinu cel̦ā kā procentos izteikta atstarotās radiācijas dalı no summārās radiācijas.

4.1. tabula. Vidējā mēneša un gada Saules radiācija, $\mathrm{MJ} / \mathrm{m}^{2}$, un vidējais albedo,\%

\begin{tabular}{|l|c|c|c|c|c|c|c|c|c|c|c|c|c|}
\hline & I & II & III & IV & V & VI & VII & VIII & IX & X & XI & XII & Gads \\
\hline $\begin{array}{l}\text { Tiešā radiācija } \\
\text { virsmu horizontālu }\end{array}$ & 7,7 & 29,2 & 120,8 & 188,2 & 330,3 & 319,5 & 327,7 & 256,5 & 140,4 & 55,5 & 13,5 & 6,5 & 1795,7 \\
\hline $\begin{array}{l}\text { Izkliedētā } \\
\text { radiācija }\end{array}$ & 32,8 & 69,6 & 129,7 & 138,8 & 229,3 & 252,5 & 240,6 & 201,5 & 133,1 & 73,4 & 30,9 & 22,8 & 1600 \\
\hline $\begin{array}{l}\text { Summārā } \\
\text { radiācija }\end{array}$ & 40,5 & 98,6 & 250,2 & 372 & 559,6 & 572 & 568,3 & 458 & 273,5 & 128,9 & 44,4 & 29,4 & 3395,9 \\
\hline $\begin{array}{l}\text { Atstarotā } \\
\text { radiācija }\end{array}$ & 28,3 & 68,3 & 117,5 & 79,6 & 123,3 & 124,3 & 125,9 & 98,3 & 65 & 33,6 & 21,6 & 18,9 & 904,6 \\
\hline $\begin{array}{l}\text { Absorbētā } \\
\text { radiācija }\end{array}$ & 12,3 & 30,5 & 133 & 292,4 & 436,4 & 447,7 & 442,4 & 359,7 & 208,5 & 95,3 & 22,8 & 10,5 & 2491,3 \\
\hline $\begin{array}{l}\text { Radiācijas } \\
\text { bilance }\end{array}$ & $-12,6$ & 5,5 & 58,7 & 173,9 & 294,9 & 310,1 & 322,6 & 242,8 & 105,1 & 30 & $-6,3$ & -14 & 1510,5 \\
\hline Albedo & 70 & 69 & 47 & 21 & 22 & 22 & 22 & 21 & 24 & 26 & 49 & 64 & 27 \\
\hline
\end{tabular}

Saules radiācijas vērtības iegūtas pēc Zīlānu novērojumu stacijas datiem laika periodam no 1991. līdz 2005. gadam. 


\subsection{Gaisa temperatūra un tās mainības raksturs}

Gaisa temperatūras režīmu un sadalījumu Latvijas teritorijā nosaka sañemtais Saules starojums, atmosfēras cirkulācijas īpatnības, kā arī Baltijas jūras, Rīgas līča un reljefa ietekme.

Relatīvi līdzenais reljefs ir cēlonis tam, ka virs Atlantijas okeāna izveidojušās siltās un mitrās jūras gaisa masas planetāro plūsmu ietekmē virzās no rietumiem uz austrumiem un iespiežas tālu Eiropas kontinentā. Tādēl Latvijā gada vidējā temperatūra par $4-6^{\circ} \mathrm{C}$, bet ziemā pat par $9{ }^{\circ} \mathrm{C}$ pārsniedz mūsu platuma grādu vidējo temperatūru. Piekrastes rajonos ir mazākas temperatūras svārstības. Tā kā jūras ūdens ir vasarā uzkrājis lielu siltuma daudzumu, ziemas un rudeṇi te ir siltāki nekā dziḷāk sauszemē. Savukārt pavasari un vasaras piekrastē ir vēsākas, jo jūrā ūdens sasilst lēnāk nekā sauszeme.

Vidējā gada gaisa temperatūra Latvijas teritorijā pēc ilglaicīgiem novērojumiem no 1950. līdz 2010. gadam ir bijusi $6,0^{\circ} \mathrm{C}$, bet pēdējo 30 gadu periodā (1981.-2010. gads) tā ir pieaugusi līdz $6,4^{\circ} \mathrm{C}$. Augstākā gada vidējā gaisa temperatūra ir Baltijas jūras piekrastē, zemākā - Vidzemes un Latgales augstienes teritorijā. Kopumā vidējā gaisa temperatūra (1951.2010. gads) Latvijas teritorijā ir mainījusies no $4,8^{\circ} \mathrm{C}$ (Zosēnos, Alūksnē) līdz 7,0 ${ }^{\circ} \mathrm{C}$ (Liepājā). Vidējās gada gaisa temperatūras teritoriālajā sadalījumā atspoguḷojas Baltijas jūras un Rīgas līča ietekme, t.i., gaisa temperatūras pazemināšanās meridionālā virzienā, attālinoties no jūras. Tikai pašos dienvidaustrumos gaisa temperatūras sadalījumā izpaužas pazemināšanās dienvidu-ziemel̦u virzienā. Gaisa temperatūras sadalïjumu ietekmē reljefs - zemāka temperatūra ir Kurzemes augstien,u, Vidzemes augstienes un Latgales augstienes teritorijā (sk. 4.2. att.).

Siltākais mēnesis (vidēji) Latvijas teritorijā ir jūlijs. Jūlija vidējā gaisa temperatūra Latvijas teritorijā ir $16,9^{\circ} \mathrm{C}$ (1950.-2010. gadā) bet, aprēķinot to pēdējo 30 gadu periodam (1981.2010. gadam) tā ir pieaugusi līdz $17,4^{\circ} \mathrm{C}$. Jùlija vidējā gaisa temperatūra mainās robežās no $+18,2^{\circ} \mathrm{C}$ (Rīgā) līdz $+16,3^{\circ} \mathrm{C}$ (Zosēnos) un $16,4^{\circ} \mathrm{C}$ (Pāvilostā, Stendē). Jūlijā gaisa

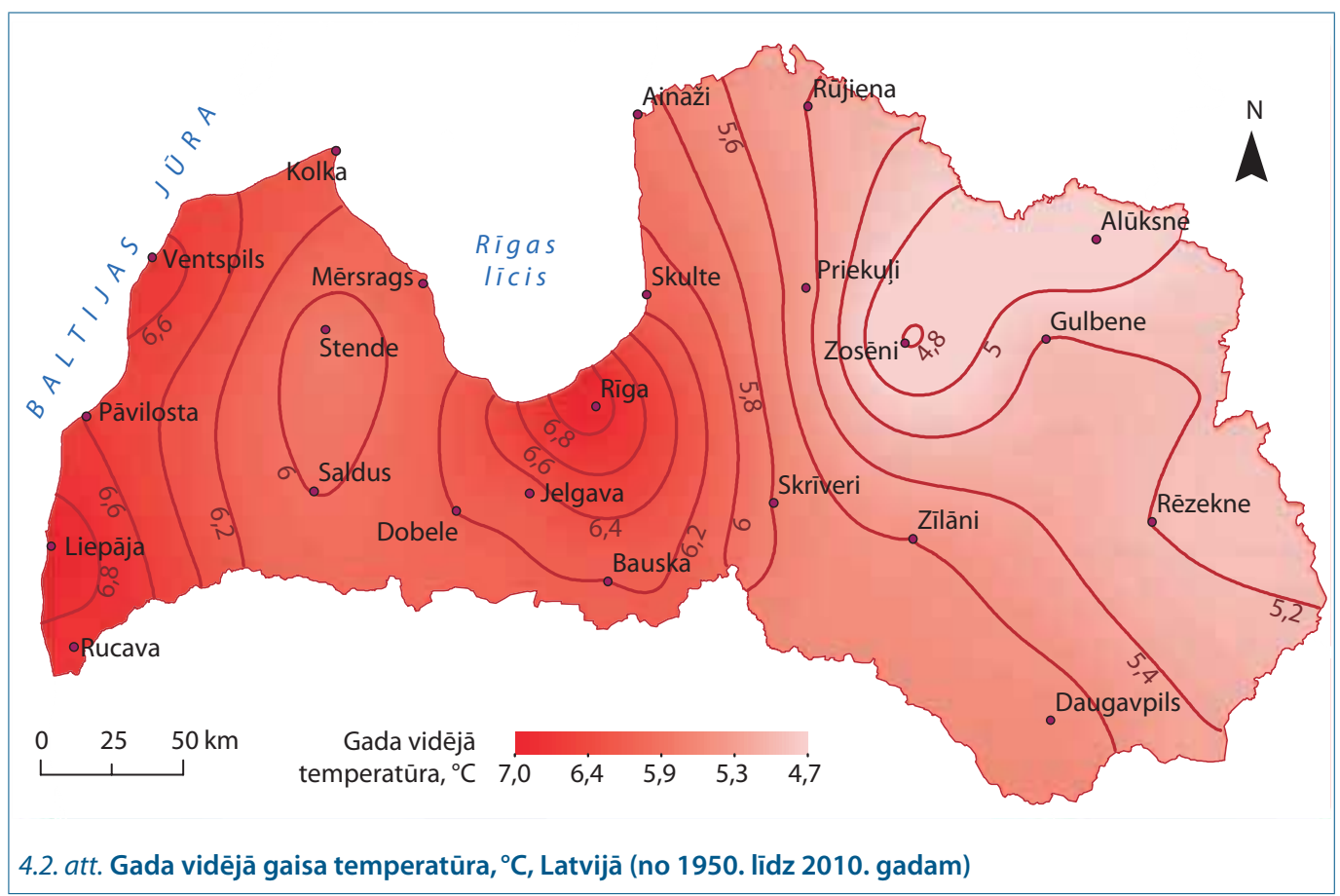


temperatūra Latvijas rietumu dalāā pazeminās virzienā no Baltijas jūras uz valsts centrālo dalı (sk. 4.3. att.). Īpaši izcel̦as Rīgas paaugstinātā gaisa temperatūra, kas ir spilgts pilsētvides ietekmes un gaisa temperatūras sadalījuma piemērs. Savukārt teritorijas kontinentālākajā austrumu dalāa gaisa temperatūra nedaudz pazeminās dienvidu-ziemel̦u virzienā. Jūlija mēneša zemākās vidējās temperatūras ir novērotas Vidzemes augstienes teritorijā.

Pēdējās desmitgadēs (1981.-2010. gadā) zemākā vidējā gaisa temperatūra Latvijas teritorijā visās novērojumu stacijās kopumā ir februārī: $-3,6^{\circ} \mathrm{C}$. Savukārt ilglaicīgā periodā (1950.-2010. gadā) tikai Latvijas kontinentālākajā dalıā (Zīlāni, Gulbene, Rēzekne un Daugavpils, Alūksne) februāra vidējā gaisa temperatūra bija par $0,1-0,2^{\circ} \mathrm{C}$ augstāka par janvāra vidējo gaisa temperatūru. Aukstākā mēneša gaisa temperatūru atškirīibas Latvijas teritorijā ir lielākas nekā tās ir jūlija mēnesī. Februārī tās ir robežās no $-2,5^{\circ} \mathrm{C}$ (Ventspils) līdz $-6,5^{\circ} \mathrm{C}$ (Alūksne). Februāra mēneša gaisa temperatūru sadalījumā labi iezīmējas Baltijas jūras un Rīgas līča ietekme (sk. 4.4. att.).
Absolūtais temperatūras maksimums $+37,8^{\circ} \mathrm{C}$ tika fiksēts 2014. gada 8 . augustā Ventspilī. Savukārt absolūtais temperatūras minimums $-43,2^{\circ} \mathrm{C}$ Latvijas teritorijā novērots dienvidaustrumu dạ̦ā, Daugavpilī 1956. gada 8. februārī. Tādējādi ekstremālo gaisa temperatūru amplitūda veido $81,0^{\circ} \mathrm{C}$. Mazākā gaisa temperatūras maksimālā amplitūda bijusi Baltijas jūras piekrastē (Kolkā), kur absolūtās maksimālās un absolūtās minimālās gaisa temperatūras starpība ir $63,5^{\circ} \mathrm{C}$.

Gaisa temperatūrai Latvijas teritorijā ir raksturīga izteikta diennakts gaita ar lielākajām diennakts gaisa temperatūras svārstībām laikā no maija līdz jūlijam $\left(9-12^{\circ} \mathrm{C}\right)$, mazākas diennakts gaisa temperatūras amplitūdas ir no novembra līdz janvārim $\left(4-5^{\circ} \mathrm{C}\right)$.

21. gs. pirmā desmitgade (2001.-2010. gads) ar vidējo gaisa temperatūru $+6,7^{\circ} \mathrm{C}$ ir bijusi siltākā visā regulāru meteorologisko novērojumu vēsturē Latvijas teritorijā. Jāatzīmē arī, ka tā bijusi tikai par $0,1^{\circ} \mathrm{C}$ augstāka nekā 20. gs. pēdējā desmitgadē (1991.-2000. gads).

Nepieciešams uzsvērt, ka temperatūras pieaugums nav novērojams vienmērīgi visa gada

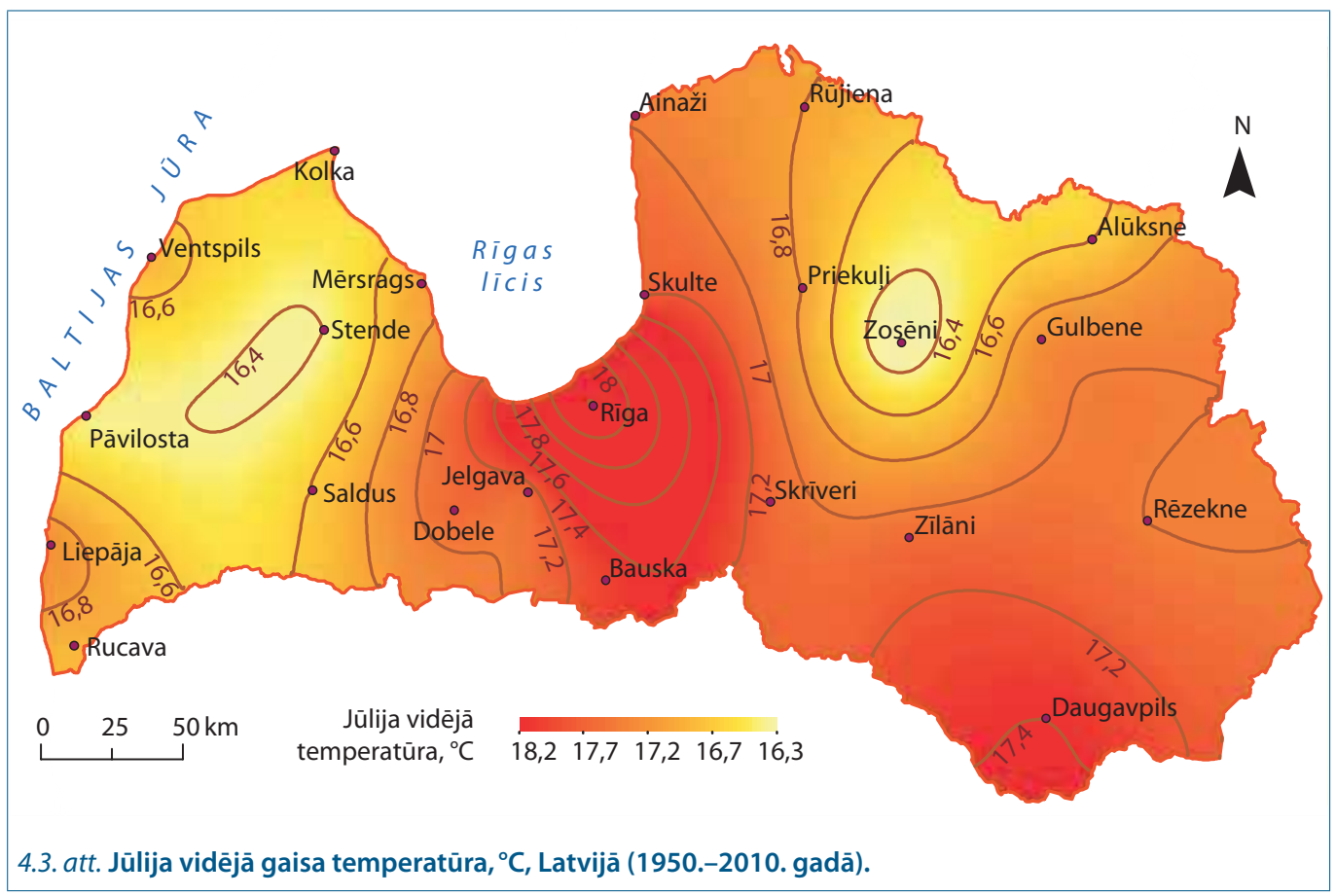




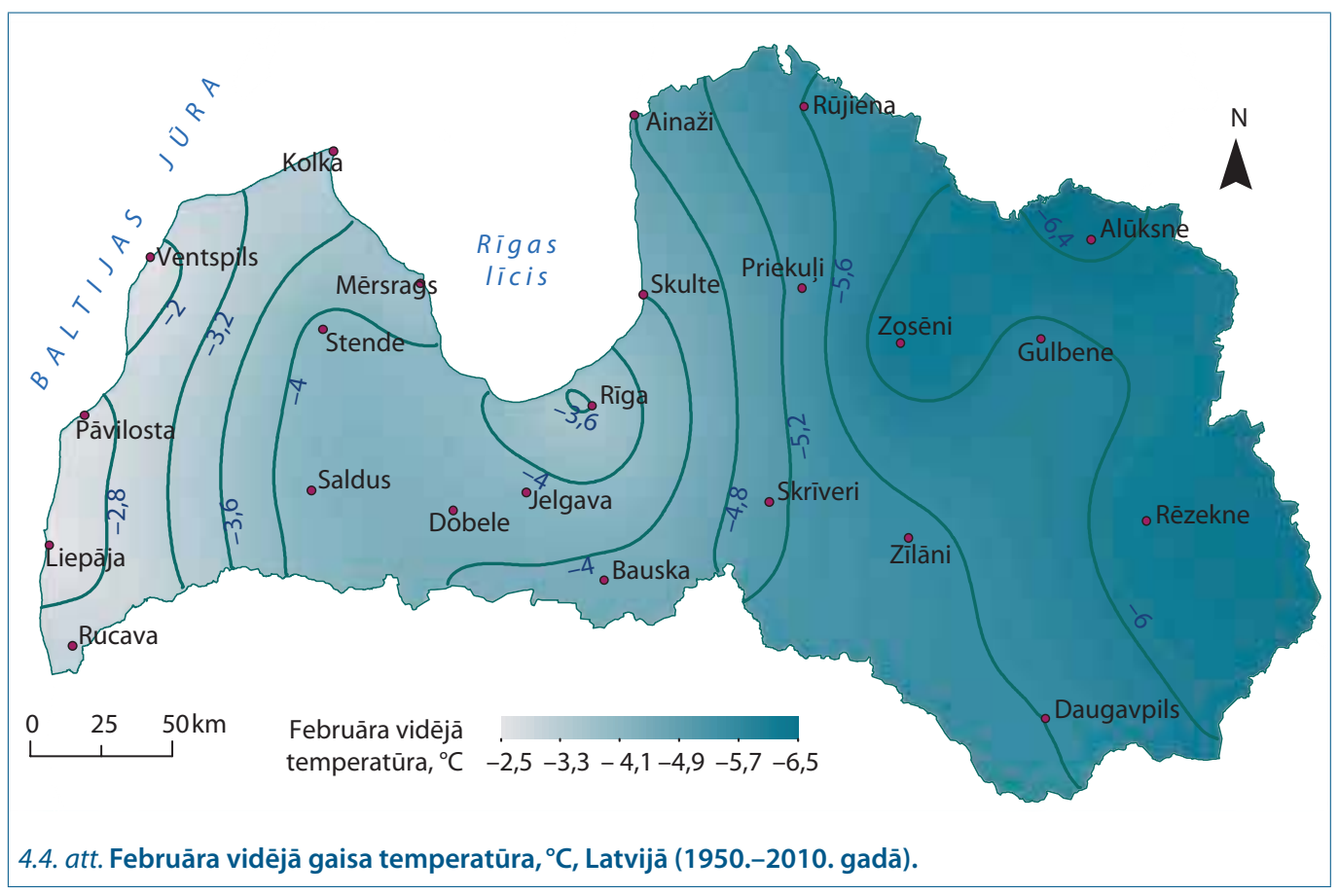

garumā, bet tam raksturīgas izteiktas sezonāla rakstura izmaiṇas. Ilglaicīgā periodā no 1950.2010. gadam statistiski nozīmīgākais gaisa temperatūras pieaugums ir novērots gada vidējām temperatūrām (sk. 4.2. tabulu). Aprēḳinātā vidējā skaitliskā pieauguma vērtība gada vidējām temperatūrām ir $0,26^{\circ} \mathrm{C} / 10$ gados. Lielākā vērtība $-0,31^{\circ} \mathrm{C} / 10$ gados ir iegūta Priekulı u novērojumu stacijā. Mēnešu griezumā statistiski nozīmīgākais pieaugums tika iegūts marta, aprīla, augusta mēnešu vidējām gaisa temperatūrām. Statistiski nozīmīgas temperatūras izmaiṇas periodā no 1950. līdz 2010. gadam nav konstatētas jūnijā, oktobrī un decembrī. Svarīgi ir vēlreiz atgādināt par būtiskajām atšksirībām starp klimata rādītājiem - vidējotām vērtībām noteiktā reǵionā, tās izsakot kā gada vai mēneša vidējo temperatūru un laikapstākḷliem (lai$\mathrm{ku}$ ), kurus noteiktos posmos var raksturot neparasti augstas vai zemas temperatūras, līdz ar to l̦aužu atmiṇā saglabājot kādu vasaru kā "karstu" vai "aukstu un lietainu". Tomēr klimatiskie rādītāji neapšaubāmi parāda klimata mainības raksturu un l̦auj izvērtēt mainības tendences jeb trendus.
Tā kā klimatu, īpaši gaisa temperatūru, kā arī atmosfēras nokrišņus raksturo augsta mainība un noteiktu laikapstākḷu veidu periodiska atkārtošanās (diennakts temperatūras mainības cikls, temperatūras mainības raksturs gada laikā), ir īpaši svarīgi, lai temperatūras un citu klimatu raksturojošo parametru mainības raksturs būtu izvērtēts, izmantojot matemātiskās statistikas metodes. Visus procesus dabā ietekmē l’oti daudz dažādu faktoru, no kuriem pētnieki parasti vēlas noskaidrot tos, kuru ietekme uz pētāmo parādību ir visbūtiskākā. Mērījumu dati satur gan informāciju par pētniekus interesējošiem faktoriem, gan arī nejaušās svārstības jeb "troksni", ko rada visi pārējie faktori. Matemātiskās statistikas metodes l̦auj izdalīt un novērtēt pētniekus interesējošo faktoru ietekmi uz šī "trokšna" fona. Ja faktora vai faktoru ietekmes vērtējums pacel̦as virs "trokšna" līmeņa, t.i., pārsniedz noteikta statistiskā kritērija vērtību, tad faktora ietekme ar noteiktu varbūtību tiek uzskatīta par ticamu, turpretī, ja šis vērtējums neatšksiras no "trokšn,a" jeb nesasniedz kritērija vērtību, šādu secinājumu izdarìt nevar. 
4.2. tabula. Manna-Kendala testa un izmaiņu intensitātes vērtības, kas noteiktas pēc Sena metodes. Šie lielumi raksturo, par cik ${ }^{\circ} \mathrm{C}$ katros 10 gados palielinājusies (pozitīvas vērtības) vai samazinājusies (negatīvas vērtības) gaisa temperatūra).

\begin{tabular}{|c|c|c|c|c|c|c|c|c|c|c|c|c|c|}
\hline Novērojuma stacija & I & II & III & IV & V & VI & VII & VIII & IX & $\mathrm{X}$ & XI & XII & $\begin{array}{c}\text { Gada } \\
\text { vidējāā }\end{array}$ \\
\hline Ainaži & 2,08 & 1,47 & 2,57 & 2,11 & 2,01 & 0,05 & 2,37 & 2,72 & 0,60 & 0,18 & 0,89 & 0,47 & 3,32 \\
\hline Alūksne & 2,54 & 1,49 & 2,84 & 2,88 & 1,92 & 0,03 & 2,20 & 2,09 & 1,16 & 0,45 & 1,20 & 0,55 & 4,07 \\
\hline Bauska & 2,33 & 1,69 & 2,81 & 2,77 & 2,12 & $-0,27$ & 2,52 & 2,70 & 1,32 & 0,19 & 1,18 & 0,61 & 3,75 \\
\hline Daugavpils & 2,32 & 1,33 & 2,85 & 2,60 & 0,99 & $-1,18$ & 0,92 & 1,17 & 0,57 & $-0,06$ & 0,85 & 0,36 & 3,07 \\
\hline Dobele & 2,48 & 1,66 & 2,61 & 2,33 & 2,54 & 0,22 & 2,81 & 2,96 & 1,44 & $-0,31$ & 1,49 & 0,78 & 4,00 \\
\hline Gulbene & 2,32 & 1,51 & 2,90 & 3,18 & 1,80 & $-0,35$ & 2,41 & 2,70 & 1,71 & 0,85 & 1,49 & 0,37 & 3,93 \\
\hline Jelgava & 2,30 & 1,61 & 2,50 & 2,12 & 1,69 & $-1,03$ & 2,19 & 1,91 & 0,74 & $-0,11$ & 1,01 & 0,55 & 3,37 \\
\hline Kolka & 2,30 & 1,61 & 2,50 & 2,12 & 1,69 & $-1,03$ & 2,19 & 1,91 & 0,74 & $-0,11$ & 1,01 & 0,55 & 3,37 \\
\hline Liepāja & 1,90 & 1,73 & 2,38 & 2,73 & 3,28 & 0,72 & 2,30 & 2,70 & 0,47 & $-0,43$ & 0,72 & 0,58 & 3,44 \\
\hline Mērsrags & 2,34 & 1,84 & 2,26 & 2,42 & 2,60 & $-0,30$ & 1,91 & 2,42 & 0,97 & $-0,36$ & 1,01 & 0,39 & 3,25 \\
\hline Pāvilosta & 2,09 & 1,90 & 2,66 & 2,67 & 2,95 & 0,74 & 2,39 & 3,25 & 1,12 & 0,22 & 1,06 & 0,78 & 3,95 \\
\hline Priekuḷi & 2,50 & 1,64 & 2,86 & 2,66 & 2,38 & 0,25 & 2,85 & 2,81 & 1,58 & 0,59 & 1,31 & 0,68 & 4,21 \\
\hline Rēzekne & 2,54 & 1,59 & 2,87 & 2,96 & 1,68 & $-0,37$ & 2,07 & 2,07 & 1,17 & 0,52 & 1,24 & 0,47 & 3,81 \\
\hline Rīga - LU & 2,18 & 1,62 & 2,61 & 2,28 & 1,82 & $-0,11$ & 2,91 & 2,46 & 1,31 & $-0,21$ & 1,25 & 0,39 & 3,62 \\
\hline Rucava & 2,00 & 1,59 & 2,33 & 2,24 & 2,63 & 0,30 & 2,32 & 2,43 & 0,89 & $-0,40$ & 0,72 & 0,41 & 3,30 \\
\hline Rūjiena & 2,43 & 1,44 & 2,68 & 2,60 & 2,43 & 0,35 & 3,06 & 2,88 & 1,59 & 0,21 & 0,92 & 0,46 & 4,03 \\
\hline Saldus & 2,23 & 1,82 & 2,48 & 2,28 & 2,28 & $-0,32$ & 2,43 & 2,42 & 0,93 & $-0,18$ & 1,08 & 0,57 & 3,70 \\
\hline Skulte & 2,20 & 1,55 & 2,98 & 1,92 & 1,94 & 0,19 & 2,40 & 2,81 & 0,91 & 0,34 & 1,17 & 0,57 & 3,65 \\
\hline Skrīveri & 2,41 & 1,61 & 2,67 & 2,34 & 1,64 & $-0,54$ & 2,21 & 2,15 & 1,25 & 0,40 & 1,10 & 0,54 & 3,64 \\
\hline Stende & 2,25 & 1,55 & 1,87 & 2,02 & 2,10 & $-0,50$ & 2,15 & 2,35 & 0,92 & $-0,10$ & 0,77 & 0,46 & 3,16 \\
\hline Zosēni & 2,38 & 1,40 & 2,68 & 2,05 & 1,91 & 0,22 & 2,34 & 2,37 & 1,04 & 0,25 & 1,19 & 0,55 & 3,83 \\
\hline Zīlāni & 2,60 & 1,72 & 2,55 & 2,71 & 1,87 & 0,00 & 2,54 & 2,52 & 1,11 & 0,45 & 1,49 & 0,57 & 3,88 \\
\hline Ventspils & 2,19 & 1,89 & 2,90 & 2,73 & 3,23 & 1,66 & 2,77 & 3,85 & 1,43 & 0,42 & 1,43 & 0,93 & 4,08 \\
\hline $\begin{array}{l}\text { Vidējais mēneša } \\
\text { un gada tempera- } \\
\text { tūras pieaugums } \\
\text { vai samazinā- } \\
\text { jums, }{ }^{\circ} \mathrm{C} / 10 \text { gados }\end{array}$ & 0,61 & 0,48 & 0,56 & 0,35 & 0,25 & $-0,01$ & 0,29 & 0,26 & 0,13 & 0,02 & 0,13 & 0,12 & 0,26 \\
\hline $\begin{array}{l}\text { Maksimālā mēneša } \\
\text { un gada temperatū- } \\
\text { ra, }{ }^{\circ} \mathrm{C} / 10 \text { gados }\end{array}$ & 0,77 & 0,57 & 0,67 & 0,46 & 0,36 & 0,16 & 0,38 & 0,36 & 0,21 & 0,11 & 0,22 & 0,19 & 0,31 \\
\hline $\begin{array}{l}\text { Minimālais mēneša } \\
\text { un gada tempe- } \\
\text { ratūras pieau- } \\
\text { gums/samazinā- } \\
\text { jums, }{ }^{\circ} \mathrm{C} / 10 \text { gados }\end{array}$ & 0,47 & 0,41 & 0,42 & 0,27 & 0,14 & $-0,14$ & 0,13 & 0,12 & 0,04 & $-0,05$ & 0,08 & 0,07 & 0,20 \\
\hline
\end{tabular}

trends nozīmīgs, ja $a=0,001$ trends nozīmīgs, ja $a=0,01$ trends nozīmīgs, ja $\alpha=0,05$ trends ticams, ja $a=0,1$ 
Klimata mainības izpētē mainības tendenču izvērtēšanai izmanto Manna-Kendala testu, kas ir īpaši izstrādāts klimatisko parametru mainības tendenču (trendu) izpētei. Manna-Kendala tests l̦auj analizēt datu rindas pat tad, ja tajās ir iztrūkstošas vērtības (meteorologisko parametru novērojumi, piemēram, ir tikuši pārtraukti 1. un 2. pasaules kara laikā), kā arī datu rindas ar netipiskām (loti augstām vai zemām) vērtībām. Manna-Kendala testa pamatā ir tā sauktais rangu jeb pāru princips, pēc kura salīdzina divas novērojumu vērtības. Manna-Kendala testu var izmantot datu rindām, kam ir sezonāls vai sērijveida mainības raksturs, jo tas lıuj aprēḳināt testa vērtības katram mēnesim atsevišksi. Pētāmā parametra mainības tendences ir statistiski būtiskas $(0,01)$, ja testa vērtība ir lielāka par 2 vai mazāka par -2 .

Gaisa temperatūra ir klimata mainības indikators, kas visbiežāk tiek izmantots, lai raksturotu globālās sasilšanas procesus. Gaisa temperatūras mainība viegli un saprotami parāda, ka notiek gaisa temperatūras paaugstināšanās pēdējās desmitgadēs.

Gaisa temperatūras mainības raksturs Rīgā divu gadsimtu laikā parādīts 4.5. attēlā.

Gada vidējais temperatūras pieaugums Rīgā laika posmā no 1795. gada līdz 2010. gadam ir $1,3{ }^{\circ} \mathrm{C}$, bet augstākais tas ir pavasara mēnešos (maijā, aprīlī, martā), kā arī ziemas sākumā (decembrī).

Gaisa temperatūru Rīgā raksturo ievērojama mainības amplitūda - mēneša minimālā vidējā temperatūra $\left(-17,1^{\circ} \mathrm{C}\right)$ novērota
1803. gada janvārī, bet maksimālā $\left(+22,8^{\circ} \mathrm{C}\right)-$ 1914. gada jūlijā. Temperatūras ilgtermiṇa mainību raksturo izteiktas gada vidējo temperatūru fluktuācijas (svārstības), tomēr, analizējot līknes, ir acīmredzams, ka temperatūras mainību kopš 20. gadsimta vidus raksturo izteikta tās paaugstināšanās tendence. 2002., 2010. un 2011. gada vasaras sezonas ir bijušas vienas no siltākajām meteorologisko novērojumu vēsturē Latvijas teritorijā (sk. 4.3. tabulu), kad vidējā gaisa temperatūra bija robežās no $19,2^{\circ} \mathrm{C}$ līdz $19,9^{\circ} \mathrm{C}$. Desmit aukstākās vasaras ar vidējo gaisa temperatūru no $13,6^{\circ} \mathrm{C}$ līdz $15,2^{\circ} \mathrm{C}$ pēc Rìga Universitāte novērojumiem raksturīgas 19. gs., kā arī līdz 20. gs. vidum. Novērojama arī iezīme, ka vidējās minimālās gaisa temperatūras paaugstinās vairāk nekā vidējās maksimālās gaisa temperatūras, kas ir galvenais temperatūras amplitūdas samazināšanās iemesls.

Gaisa temperatūras mainības raksturs Rīgā attēlo visai lielā reǵionā norisošo klimata veidošanās procesu raksturu, kā tas redzams, salīdzinot gaisa temperatūras mainības raksturu Rīgā un Upsalā (sk. 4.6. att.), kas atrodas Zviedrijā (520 km attālumā no Rīgas). Kaut arī Upsala atrodas ievērojami tālāk uz ziemeliem nekā Rīga un klimats šajā Zviedrijas pilsētā ir ievērojami aukstāks, tomēr gada vidējo temperatūru mainības raksturs ir līdzīgs (sinhrons). Tātad Rīgā 20. gadsimta otrajā pusē veiktie klimata pasiltināšanās procesa novērojumi l̦auj analizēt norises un to raksturu Baltijas jūras reǵionā.

\subsection{Nokrišṇi un to daudzuma mainība}

Nokrišn,u daudzumu Latvijā nosaka atmosfēras liela mēroga cirkulācija (Rietumu planetārā plūsma, kas vidējos platuma grādos novērojama troposfērā un stratosfērā), kas nosaka mitro gaisa masu pārnesi no Atlantijas okeāna pāri Baltijas jūrai galvenokārt cikloniskās darbības dēl̦. Tāpēc Latvijas teritorijai ir pietiekami liels nokrišņu daudzums - vidēji $685 \mathrm{~mm}$ (sk. 4.7. att.). Kaut arī Latvijas augstienes nav pārāk augstas, tās tomēr ietekmē temperatūras un nokrišņu sadalījumu vietējā mērogā.

Gada vidējo nokrišnu daudzuma sadalījumā dominē kopējas likumsakarības - lielākais vidējais gada nokrišņu daudzums (760$870 \mathrm{~mm}$ ) ir raksturīgs Vidzemes augstienes, Rietumkursas augstienes un Latgales augstienes rietumu uzvēja nogāzēm (sk. 4.8. att.). Vismazākais nokrišnu daudzums (580 mm) tiek 
4.3. tabula. Desmit siltākās un aukstākās vasaras pēc Rīga Universitāte novērojumu rindām (1795.-2012. gads)

\begin{tabular}{|c|c|c|c|}
\hline Siltākās vasaras, gads & $\begin{array}{c}\text { Vidējā temperatūra } \\
\text { siltākajās vasarās, }{ }^{\circ} \mathbf{C}\end{array}$ & Aukstākās vasaras, gads & $\begin{array}{c}\text { Vidējā temperatūra } \\
\text { aukstäkajäs vasaräs, }{ }^{\circ} \mathbf{C}\end{array}$ \\
\hline 1826 & 21,1 & 1874 & 13,6 \\
\hline 2010 & 19,9 & 1873 & 14 \\
\hline 1798 & 19,8 & 1928 & 14,1 \\
\hline 2002 & 19,7 & 1962 & 14,1 \\
\hline 1939 & 19,7 & 1821 & 14,4 \\
\hline 1972 & 19,6 & 1902 & 14,5 \\
\hline 1834 & 19,3 & 1904 & 14,5 \\
\hline 1868 & 19,2 & 1844 & 14,6 \\
\hline 2011 & 19,2 & 1830 & 14,8 \\
\hline 1973 & 19,1 & 1849 & 15,2 \\
\hline
\end{tabular}
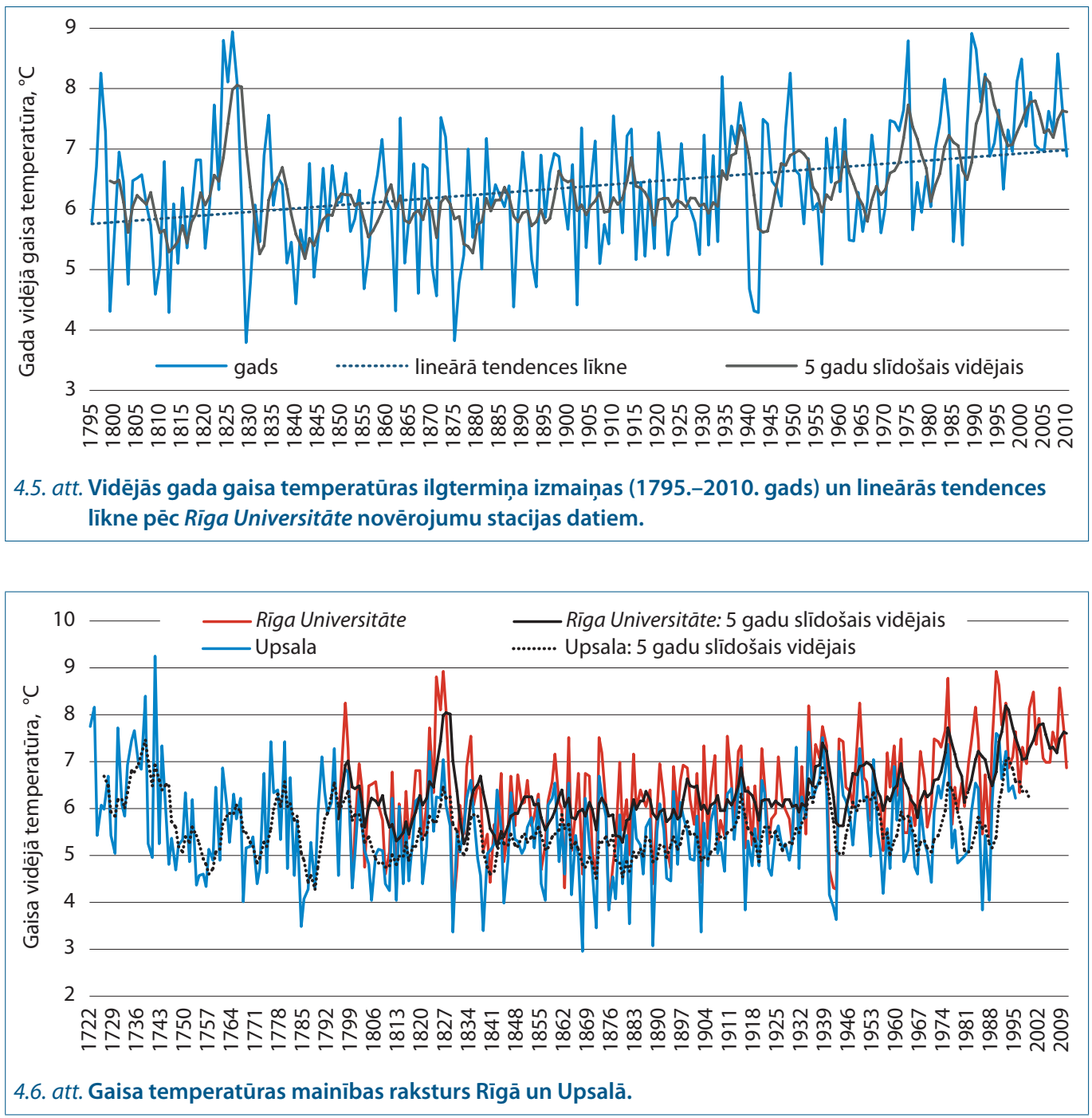
novērots Zemgales līdzenumā, kā arī ieplakās, kas atrodas augstien,u aizvēja nogāzēs. Lielākie mēnešu nokrišņu daudzumi (> 80 mm mēnesī) tiek novēroti vasaras periodā. Aukstajā gadalaikā parasti nokrišņu daudzums ir ievērojami mazāks (apmēram 20 mm mēnesī).
Vidējais nokrišņu daudzums 853 mm Latvijas teritorijā ir reǵistrēts 2010. gadā, un tas bija nokrišniem bagātākais gads ne tikai laika periodā no 1950. līdz 2010. gadam, bet arī 89 gadu meteorologisko novērojumu vēsturē (sk. 4.8. att.). Taču ir reǵistrēti vairāki gadi,
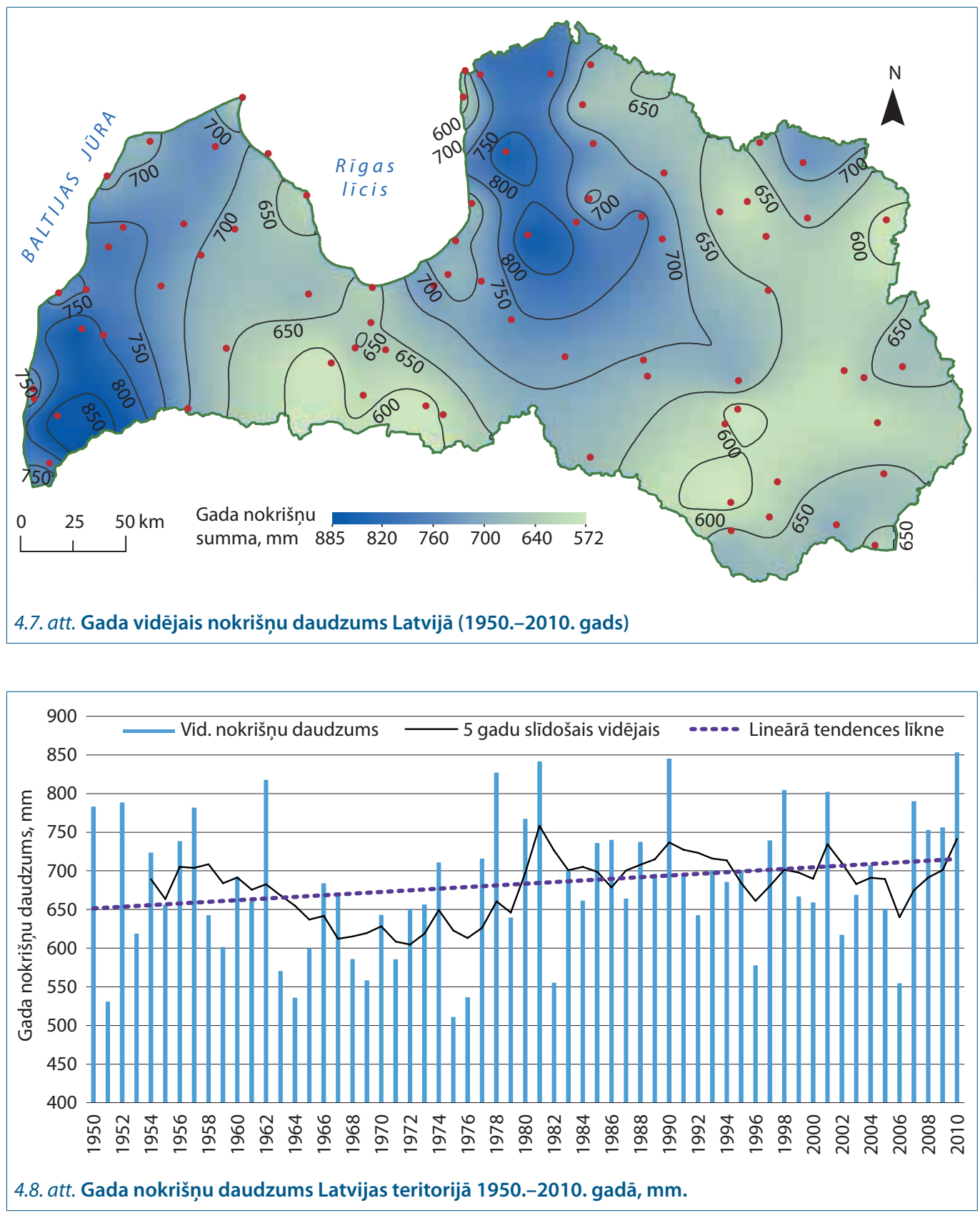
piemēram, 1951. un 1963. gads, kad vidējais nokrišn,u daudzums Latvijas teritorijā ir attiecīgi bijis 531 un 536 mm. Intensīvi un loti intensīvi nokrišn, galvenokārt raksturīgi siltajai sezonai (aprīlis-septembris). Vislielākais registrētais diennakts nokrišņu daudzums Latvijas teritorijā ir $160 \mathrm{~mm}$ (novērots Ventspilī 1973. gadā). Viens no intensīvākajiem nokrišņu apjomiem pēdējo gadu laikā registrēts 2014. gada 29. jūlijā Siguldā, kad vienā stundā izkrita 83,9 mm nokrišnu, bet 6 stundās - 122,8 mm, kas ievērojami pārsniedza jūlija mēneša normu $(99,9$ mm). Vidējais dienu skaits ar diennakts nokrišniem $>10 \mathrm{~mm}$ un $>20 \mathrm{~mm}$ Latvijas teritorijā ir attiecīgi 1221 dienu un 2-4 dienas. Kopumā diennakts nokrišn,i $>50 \mathrm{~mm}$ tiek novēroti reti.

Intensīvo nokrišnu izmaiņu analīze tika veikta pēc dienu skaita, kurās diennakts nokrišn,u summa >10 mm un >20 mm. Līdzīgi kā gada nokrišn,u ilgtermiña gaitai, arī atmosfēras nokrišn,u ekstrēmuma rādītājiem raksturīgas cikliskas svārstības, kas visbiežāk ir spilgtāk izteiktas kā lineārās pārmainas. Tomēr statistiskā testa rezultāti parādīja, ka gan dienu skaitam ar intensīviem nokrišñiem, gan dienu skaitam ar loti intensīviem nokrišniem ir tendence palielināties un ka daudzos gadījumos izmainas ir statistiski nozīmīgas.
Atmosfēras nokrišñu daudzums un tā mainības raksturs ietekmē ekosistēmas, cilvēka dzīves vidi un daudzas saimnieciskās darbības jomas, piemēram, lauksaimniecību un enerǵētiku. Būtisks ir ne tikai kopējais nokrišnu daudzums noteiktā laika posmā (gads, mēnesis), bet arī tā sadalījums gada laikā (sezonālā mainība) un intensitāte. Piemēram, nokrišn,u pieejamība un to izkrišanas raksturs būtiski ietekmē lauksaimniecības kultūru attīstību.

Kopumā nokrišnu daudzums uz mūsu planētas kopš 20. gadsimta sākuma ir pieaudzis aptuveni par 2\%, kaut arī nokrišnu daudzuma pieauguma sadalïjums uz Zemes nav vienmērīgs. Tiek vērtēts, ka gada nokrišņu daudzums Ziemel̦eiropā 20. gadsimta laikā ir palielinājies par 10-40\%, kamēr vairākos Dienvideiropas rajonos nokrišnu daudzums ir samazinājies par $\approx 20 \%$.

Latvijā, tāpat kā citās Ziemel̦eiropas valstīs, pēdējā gadsimta laikā kopumā ir novērojams gan temperatūras, gan nokrišņu daudzuma pieaugums (sk. 4.9. att.).

Arī nākotnes klimata prognožu model̦i paredz, ka līdz ar siltāku klimatu palielināsies ūdens piesātinājuma kapacitāte atmosfērā. Tas nozīmē, ka palielināsies arī ekstremālo nokrišnu daudzums.

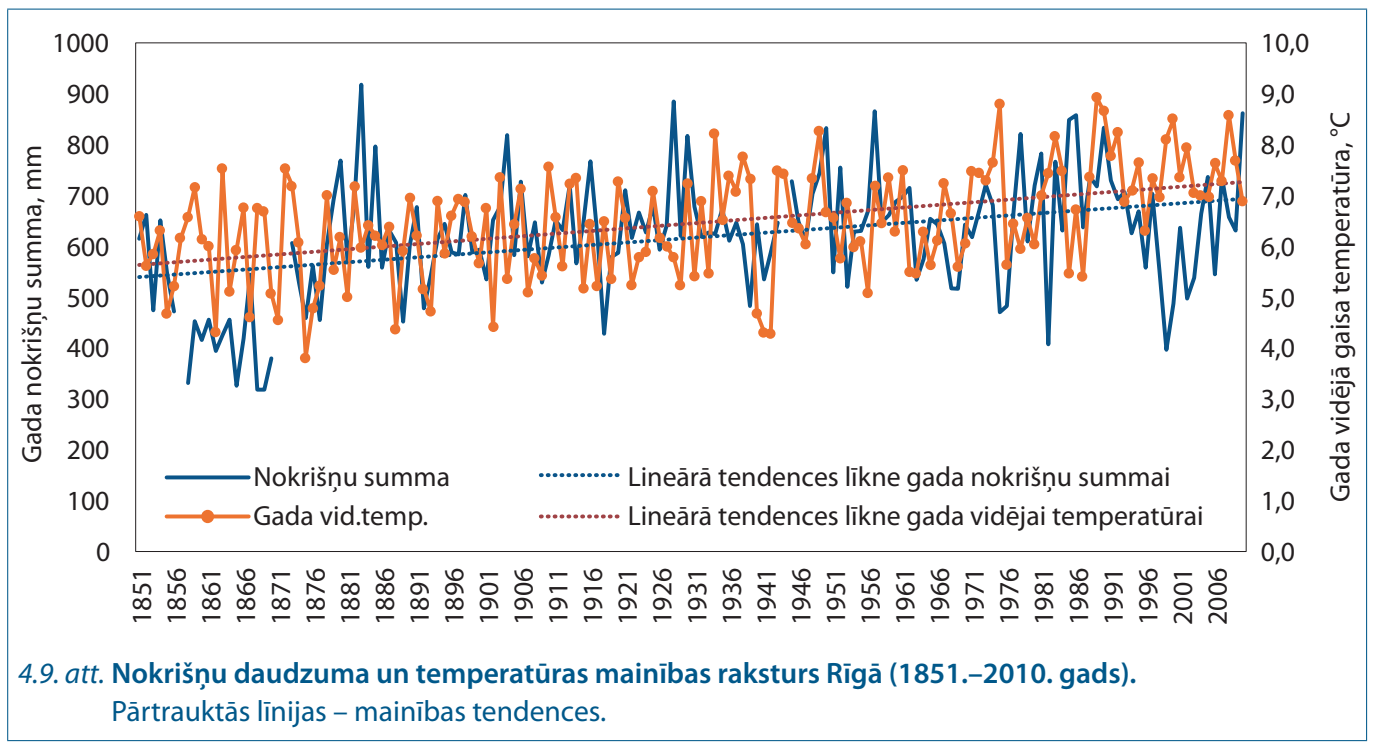




\subsection{Ekstremālās parādības un to izmaiṇas}

Ekstremālas parādības jeb ekstremālie laikapstākḷi raksturo laikapstākḷu notikumus, kas ir ekstrēmi vēsturiskā griezumā, īpaši netipiski, bargi vai sezonai neraksturīgi. Tādējādi var teikt, ka ekstrēmi laikapstākḷi ir ne tik bieži sastopami meteorologiskie notikumi, kuriem ir būtiska ietekme uz sabiedrību vai ekosistēmu. Ekstrēmi laikapstākḷi to izpausmes veida un ietekmes dēl visbiežāk tiek definēti lokāli, jo tie ir specifiski un atšksirīgi katrai vietai. Ekstrēmi laikapstākḷi pēc norises veida var būt pēkšn,i (intensīva lietusgāze, vētra) vai ilglaicīgi (karstuma vilnni, sausumi). Katrs ekstrēms notikums ir unikāls pēc mēroga, laika, norises, atrašanās vietas un iedarbības uz cilvēku dzīves vidi. Ekstrēmi laikapstāklıli ietekmē sektorus, kuri ir cieši saistīti ar klimatu, piemēram, lauksaimniecība, mežsaimniecība, cilvēku veselība, tūrisms u.c.

Izmaiñas mūsdienu klimatā palielina un nākotnē palielinās ekstrēmo laikapstākḷu biežumu un to intensitāti. Pat, ja nav novērotas izmainnas vidējās vērtībās, ekstrēmiem laikapstākḷu notikumiem var būt novērotas būtiskas tendences. Ekstrēmie laikapstākḷu notikumi klimata pārmaiṇu un klimata dabiskas variabilitātes dēl arvien vairāk tiek apzināti kā apdraudējums cilvēku veselībai, lauksaimniecībai, mežsaimniecībai u.c.

Ekstremāli laikapstākḷi nav meteorologiska situācija, kas sastopama tikai mūsdienās.

\section{Guntis Eberhards}

Vēsturiskos avotos aprakstītie dabas apstākḷi Baltijā un Latvijā vairāk nekā 900 gadu garumā sniedz ieskatu par neparastām ziemām, pavasariem, vasarām un rudeniem, par katastrofāliem plūdiem Daugavā un citās upēs, par lielu karstumu un neiedomājamu sausumu, kad izžūst upes un akas, deg meži un purvi, kad lietus nepārtraukti līst mēnešiem ilgi. Ziemā snieg un puteño nepārtraukti 1-2 mēnešus. Visi sējumi izsalst pavasarī vai vasaras sākumā ap Jānu dienu vai arī noslīkst vasaras un rudens lietavās. Iestājas ilgstošs bads bez maizes visā Baltijā. Katrā gadsimtā sevišḳi bargās ziemās vairākas reizes aizsalst Baltijas jūra (nemaz nerunājot par Rīgas līci) un cilvēki no Dānijas, Vācijas un Polijas kājām vai ar ragavām ceḷo uz Zviedriju un Somiju, arī uz Baltiju un atpakal, jo pa ledu ir vieglāk pārvietoties nekā pa aizputinātiem laukiem un mežiem.

Lai iegūtu priekšstatu par to, kas ir bijis un ko varam varbūt arī sagaidīt tuvākā vai tālākā nākotnē, ieskatīsimies tālās pagātnes notikumos, to aprakstos, kas atrodami dažādos vēstures avotos - hronikās, gada grāmatās, avīzēs un monogrāfiskajos apkopojumos.

1172. gadā, kā rakstīts arhīvu materiālos, ziema Daugavas baseinā bijusi tik silta, ka kokiem izplaukušas lapas, bet putni vijuši ligzdas. Savukārt 1214. un 1216. gadā ziemas atkal bijušas tik bargas, ka Rīgas līci klājis tik biezs ledus, ka pa to brīvi pārvietojies liels rīdzinieku karaspēks karagājienā pret Vidzemes lībiešiem un latgalıliem. Arī 1219. gadā, kad satiksme no Rīgas uz Igauniju notikusi pa līča ledu, kḷuvis tik auksts, ka cel̦otāji masveidā guvuši sejas, kāju, roku apsaldējumus un bijuši spiesti atgriezties atpakal, "Livonijas hronikā" rakstīts, ka Bīskaps Alberts ar savu karaspēku no Rīgas uz Sāremā pāri Rīgas līcim karagājienā devies 1225. un 1227. gadā, kad bijušas bargas ziemas un līcis aizsalis. Kustībā esošā karaspēka radītais troksnis esot līdzinājies pērkonam: šķindējuši ieroči, sadūrušās ragavas, klieguši l̦audis, uz slidenā ledus krituši un atkal cēlušies cilvēki un zirgi. Līdzīgi karagājieni un ceḷojumi pa aizsalušo Rīgas līci no Livonijas uz Igauniju notikuši arī 1228. gadā, no 1260. līdz 1261. un no 1269. līdz 1270. gadam.

1617. gadā Baltijā bijusi l̦oti silta un lietaina ziema bez sniega. Visu janvāri pūtis dienvidaustrumu vējš un lijis, augusi zāle un izplaukuši ziedi, ziedējuši k̦irši. Arī pēc 7 gadiem 1624. gadā atkal iestājusies tāda pati l̦oti silta ziema. 1624. gada 18. martā sākas Daugavas pali, bet aprīlī jau tik silts kā ap Jān,iem. 15. aprīlī ziedējuši ķirši . Tā rakstījis J. Broce. 
1835. gadā ziema Latvijā bija ar neiedomājami biezu sniega segu, kas sasniegusi 1,8-2,1 m. Snigšana sākusies no jaunā gada, bet sevišşi daudz sasnidzis martā. Aprīlī Saule un lietus to strauji nokausējis un sākušies lieli plūdi. Ledus segas biezums upēs sasniedzis pieauguša vīrieša garumu.

1431. gada vasarā valdīja liels sausums. Par to rakstīts: "Zeme un purvi dega, dūmaka stāvēja 6 nedēl̦as, Sauli neredzēja, zivis ūdenī nobeidzās un putni krita zemē, neredzēja tos lidojam".

L̉oti neparasti notikumi 1795. gada vasarā novēroti Rīgā. 10. jūnijā pāri pilsētai brāzusies viesulvētra 2 km platā joslā un 160 km garumā ar stipru krusu. Krusas graudu lielums bijis vistas olas lielumā. Viesulis nodarījis l̦oti lielus postījumus. 1826. gads bijis ar sevišksi karstu un sausu vasaru. Deguši meži, kūdrāji un virsāji, kas bija l̦oti izkaltuši. Valdījis drausmīgs sausums, bez ūdens pārstājušas darboties ūdensdzirnavas. Vidējā gaisa temperatūra jūnijā bijusi $+18,9$, jūlijā $+22,5$, bet augustā $+20,7$ grādi pēc Celsija.

L̦oti neparasts gads un seviškki vasara 1827. gadā bija Kurzemē. Pēc Kurzemes draudžu hroniku datiem vasara sākusies ḷoti ātri: jau jūnija beigās pḷāvuši rudzus (t.i., vairāk nekā mēnesi agrāk nekā tagad - ap augusta pirmo pusi). Arī rudens bijis silts un sauss.

Par drausmīgu vasaru 1844. gadā rakstīts "Rīgas avīzēs" un citos izdevumos: "Pie mums lietus un plūdi. 12 nedēḷ garumā tikai 15 dienas nelija, pat divas dienas pēc kārtas bez lietus neredzējām, bet piln̄̄gi skaidru dienu nebija vispār. Jūlijs bija vēl lietaināks. Ūdens appludinājis ne vien plavas un zemos laukus vairāk nekā pavasarī. Applūduši cel̦i un tilti. Vairāk nekā divus mēnešus lietus lijis bez apstājas, visi grāvji pārvērtušies upēs, upes - lielās ūdens straumēs, plavas - ezeros. Tilti, dambji un arī vairākas ūdensdzirnavas sagrautas, bet ceḷi kḷuvuši neizbraucami".

Apkopojot vēsturiskos datus, P. Ludvigs rakstīja, ka visbriesmīgākie Rīgai tomēr bijuši 1709. gada plūdi. Kopējo situāciju autors apraksta šādi: "Plūdi sākušies jau iepriekšējā gada rudenī. Novembrī tad plosījusies ārkārtīgi stipra vētra, kas daudziem Rīgas namiem, daḷēji arī Doma baznīcai, noārdījusi jumtu. Vētras sadzītais ūdens vietām appludinājis Daugavas krastus un salas, aizskalojot mājas, lopus un cilvēkus. Sadauzīti un izmesti krastā arī daži kuǵi. Vētrai sekojis bargs sals, kas gandrīz nepārtraukti pieturējies visu ziemu. Daugavā ledus sasalis 1,5 m biezumā tā, ka upe vietām bija aizsalusi līdz dibenam. Ledū iesaluši 22 kuǵi. Tanī ziemā Latvijā izsaluši gandrīz visi aug̣̣u koki. Sākoties pavasara atkusnim, straume nesusi Daugavas augšgala ledu uz leju, bet lejasgala ledus nav salūzis - tas palicis turpat, kur bijis. Tā upes lejasgalā radies l̦oti liels ledus sastrēgums. Ūdens tad lauzis sev divus jaunus cel̦us uz jūru un appludinājis Daugavas salas un Pārdaugavu. Ledū iesalušos kuǵus nav bijis iespējams vairs glābt. Ledum sakustoties, tie saspiesti, saārdīti un aiznesti jūrā. Jūrā aizrauti arī lieli kokmateriālu daudzumi un vairākas mājas ar visiem iedzīvotājiem. Viena pati Zaksusala zaudējusi 52 mājas. Vēl sliktāk gājis pašā Rīgā. Ledus masas un plūdu ūden,i ielauzuši pilsētas vārtus, ieplūduši pilsētā, pārpludinot tur ielas, ēkas un pagrabus. Doma baznīcā ūdens kāpis līdz altārim. Juku jukām tur peldējuši soli, zārki un izskalotie līksi".

1855. gadā pēc sniegotas ziemas bez atkušniem 11. aprīlī Daugavā sākusies ledus lūšana un virzīšanās uz jūru. Pie Baltās baznīcas, kas Vecmīlgrāvī atrodas pie upes, ledus apstājies, jo pati upes grīva vēl bijusi ar stingru ledus segu. Pie Podraga tikuši sastumti lieli ledus kalni. Lìmenim strauji cel̦oties, 12. aprīlī ūdens plūdis pāri aizsargdambjiem un applūdusi visa zemā Daugavas paliene kreisajā krastā, labajā krastā Ganību dambja rajons, liela daḷa Maskavas forštates un Daugavas salas. Mājas uz salām bijušas līdz jumtiem ūdenī. Apejot ledus sastrēgumu, Daugavas ūdeṇi un ledus izrāvuši jaunu ceḷu pāri Spilves plavām, aiznesot līdzi 2 mājas un citas būves. 14. aprīlī līmenis sācis kristies. Pēc vērtējuma maksimālais palu līmenis Rīgā bijis par 8,24 m augstāks nekā vasaras laikā.

Kopumā vērtējot, turpat 600 gadu garumā no 14. gadsimta līdz 20. gadsimta sākumam Rīga un tās iedzīvotāji piedzīvojuši vairāk nekā 20 ledus sastrēgumu izraisīto katastrofālo plūdu postījumus. Tādi bijuši 1358., 1363.,1587., 1589., 1597., 1615., 1618., 1643., 1709., 1727., 1744., 1770., 1771., 1783., 1795., 1807., 1814., 1829., 1837., 1912., 1917., 1924. un 1929. gadā. 
Mūsdienās veikto pētījumu rezultāti liecina, ka ilggadīgā laika periodā Latvijā novērotas būtiskas ekstremālo klimatisko parādību izmaiñas - biežākas ir kḷuvušas ekstremāli karstas dienas un naktis, kā arī dienas ar stipriem nokrišniem, savukārt ekstremāli aukstas dienas tiek novērotas aizvien retāk. Šie rezultāti ir saskaṇā ar līdzīgu klimata pārmaiṇu novērtējuma un analīzes pētījumu rezultātiem gan kaimiṇvalstīs un Ziemel̦eiropā, gan arī Eiropas un pasaules mērogā. Kā redzams 4.10. attēlā, Eiropā ir vērojama būtiska sala dienu samazināšanās (vidēji no 2-6 dienām dekādē) un tikai atsevišķās novērojumu stacijās (zaḷas krāsas aplīši) šĩs izmainnas nav nozīmīgas.

Laika posmā no 1951. līdz 2014. gadam lielākajā dal̦ā Eiropas vasaras dienu skaits ir palielinājies vidēji par 4 dienām 10 gados, tomēr
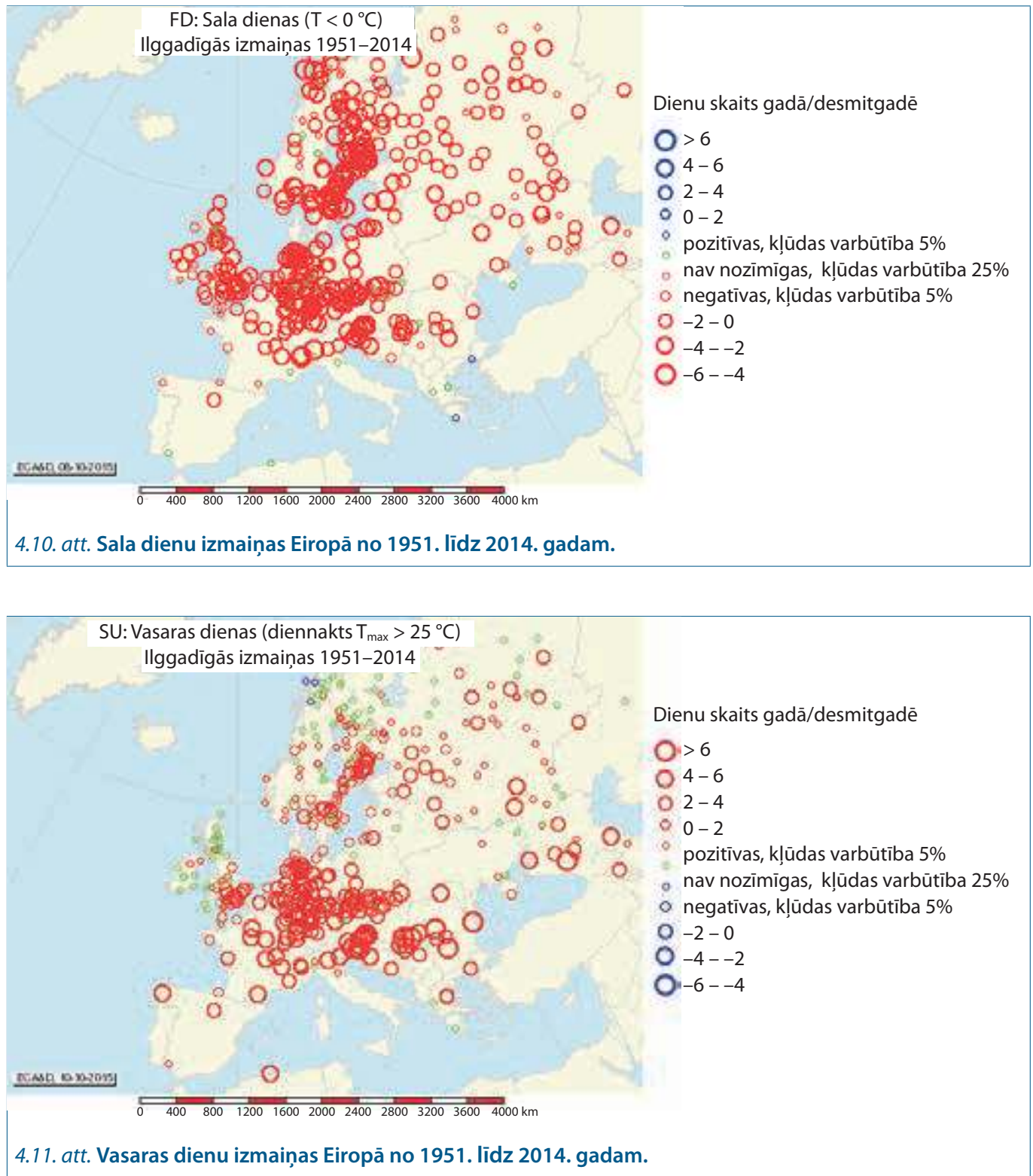
būtiski ir tas, ka lielāks to pieaugums ir bijis tieši vairāk dienvidu rajonos, kur vasaras dienu skaits palielinājies aptuveni par 4-6 dienām 10 gados, bet Eiropas centrālajos rajonos dominējis palielinājums par 2-4 dienām desmit gados (sk. 4.11. att.).

Dienu skaita izmaiñas ar stipriem nokrišñiem parāda atškkirīgas iezīmes Eiropas ziemel̦dal̦ā, vidusdalıā un dienviddal̦ā (sk. 4.12. att.). Raksturīgi, ka Ziemel̦eiropā dienu skaits ar stipriem nokrišñiem kopumā ir palielinājies no 1 līdz 3 dienām desmit gados. Eiropas vidusdal̦ā izteikti parādās zalıā krāsa. Tas nozīmē, ka nav vērojamas izmainnas stipru nokrišnu dienu skaita ziṇā laika periodā no 1951. līdz 2014. gadam. Mazākie zilie aplīši norāda izmaiñas no 0 -1 vai 1-2 dienām desmit gados. Savukārt visbūtiskākā stipro nokrišn,u dienu skaita samazināšanās novērota Eiropas dienviddal̦ā no 1 līdz pat 3 un vairāk dienām desmit gados.

Novērojumu datu analīze Latvijā liecina, ka līdz ar vidējo gaisa temperatūru paaugstināšanos mainās arī ekstremālās gaisa temperatūras. Lielākajā daḷā teritorijas ir samazinājies sala dienu skaits (sk. 4.4. tabulu). Baltijas jūras piekrastes teritorijās kḷuvuši ievērojami īsāki sala periodi. Vairākas ekstremālo lielumu izmaiṇu izteiktas tendences ir konstatētas Rīgas pilsētā. Īpaši tas attiecas uz vasaras dienu skaita palielināšanos (tās ir dienas, kad diennakts maksimālā gaisa temperatūra ir augstāka par $25^{\circ} \mathrm{C}$ ). Palielinās arī tropisko nakšu skaits, kad gaisa temperatūra ir augstāka par $20^{\circ} \mathrm{C}$. Iespējams, ka tas ir saistīts ar pilsētas kā siltuma salas intensitātes palielināšanos un specifisko pilsētas klimata efektu.

Pētījuma rezultāti par ekstremālo rādītāju izmaiṇām 10 novērojumu stacijās laika periodā no 1923. līdz 2012. gadam atspogulıtoti 4.4. tabulā. Pētījumā tika lietoti ekstremālo klimatisko parādību indeksi, ar kuru palīdzību var raksturot klimata pārmainu procesus un izvērtēt iespējamās klimata pārmainu ietekmes uz dažādiem sociālajiem un ekonomiskajiem rādītājiem. Indeksu vērtības tika aprēḳinātas gada griezumā. Ekstremālo rādītāju izmainu tendences izvērtētas ar neparametriskā Manna-Kendala testa palīdzību, par statistiski būtiskām pien,emot testa vērtības, kas $>1,96$ vai $<-1,96$, ja būtiskuma līmenis $\leq 0,05$. Līdzīgi līdzšinējo pētījumu rezultātiem, ekstremālo klimatisko parādību ilggadīgo izmainu tendenču analīze (sk. 4.4. tabulu) norāda uz būtiskām ekstremālu gaisa temperatūru un atmosfēras nokrišnu izmaiñām: ilggadīgā laika periodā būtiski paaugstinājusies temperatūra, kas izraisījis arī ekstremāli

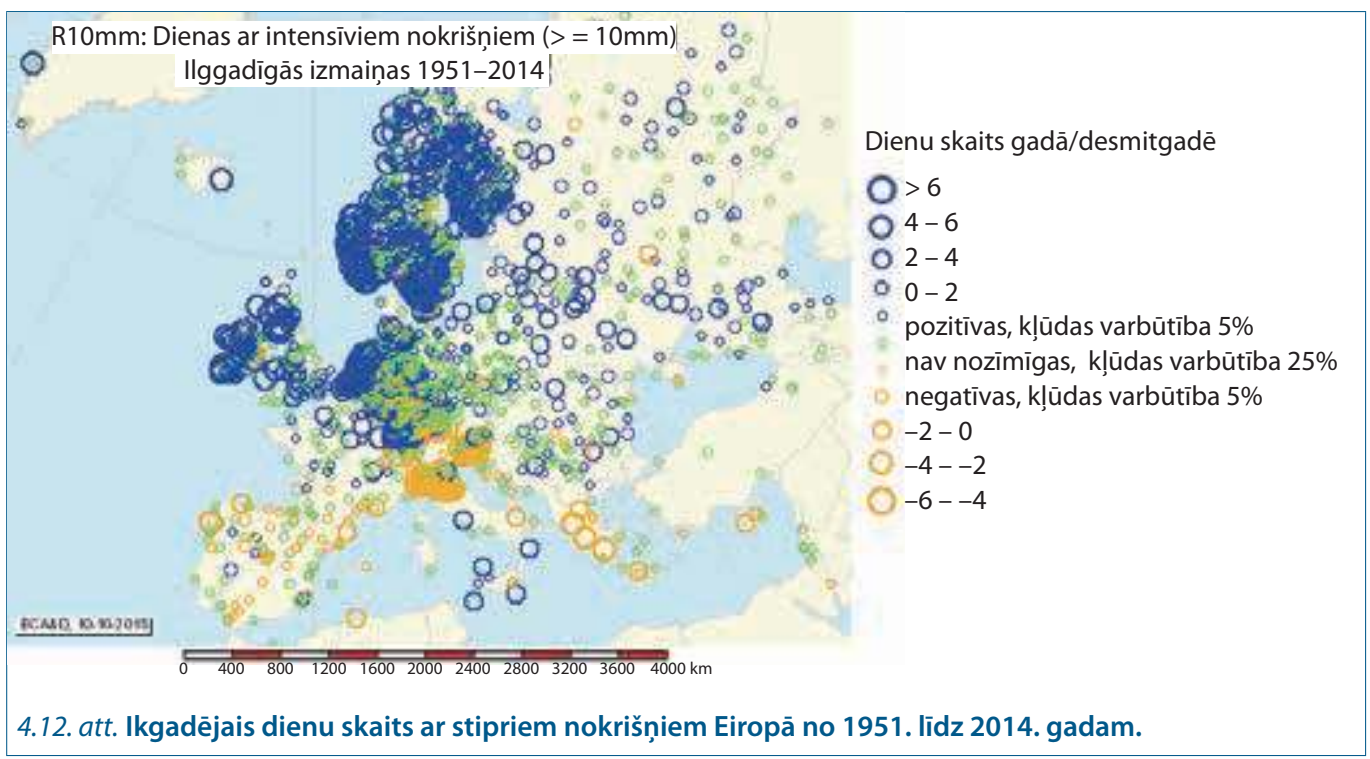


4.4. tabula. Ekstremālo klimatisko parādību indeksu izmainu tendences (Manna-Kendala testa vērtības) Latvijā 1923.-2012. gadā

\begin{tabular}{|c|c|c|c|c|c|c|c|c|c|c|}
\hline Ekstr & 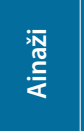 & 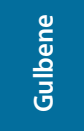 & 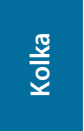 & 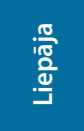 & 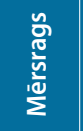 & 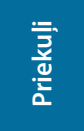 & 疍 & 丞 & 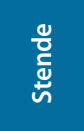 & $\frac{n}{\frac{n}{0}}$ \\
\hline 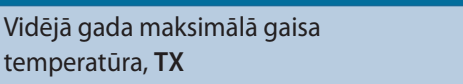 & 3,48 & 3,91 & 4,05 & 4,22 & 4,06 & 4,87 & 4,50 & 3,71 & 3,54 & \\
\hline $\begin{array}{l}\text { Vidējā gada minimālā gaisa temperatūra, } \\
\text { TN }\end{array}$ & 1,98 & 3,29 & 2,96 & 1,68 & 1,43 & 3,92 & 4,97 & 3,83 & 2,12 & \\
\hline $\begin{array}{l}\text { Vidējā diennakts temperatūras } \\
\text { amplitūda, DTR }\end{array}$ & 2,29 & 1,08 & 2,67 & 5,37 & 5,18 & 0,84 & $-3,08$ & 0,08 & 2,67 & -5, \\
\hline Augšanas sezonas garums, GSL & 1,05 & 2,87 & 3,09 & 2,47 & 1,99 & 2,38 & 3,34 & 3,24 & 1,67 & \\
\hline $\begin{array}{l}\text { Vasaras dienas (ikgadējais dienu skaits, } \\
\left.\operatorname{kad} \mathrm{TX}>+25^{\circ} \mathrm{C}\right) \text {, SU }\end{array}$ & 0,80 & 2,32 & 1,82 & 2,58 & 4,15 & 2,90 & 2,53 & 1,77 & 1,51 & \\
\hline Karstuma viḷna ilguma indikators, WSDI & 2,56 & 2,55 & 3,30 & 2,61 & 2,29 & 3,33 & 3,72 & 2,54 & 2,68 & \\
\hline $\begin{array}{l}\text { Sala dienas (ikgadējais dienu skaits, } \\
\text { kad TN }<0^{\circ} \mathrm{C} \text { ), FD }\end{array}$ & $-1,99$ & $-3,19$ & $-3,43$ & $-1,89$ & $-1,74$ & $-3,61$ & $-4,52$ & $-3,03$ & $-2,39$ & -4 , \\
\hline $\begin{array}{l}\text { Dienas bez atkušña (ikgadējais dienu } \\
\text { skaits, kad } \mathrm{TX}<0^{\circ} \mathrm{C} \text { ), ID }\end{array}$ & $-2,51$ & $-2,48$ & $-1,96$ & $-1,98$ & $-1,32$ & $-3,08$ & $-1,89$ & $-2,19$ & $-2,03$ & -2, \\
\hline Aukstuma viḷna ilguma indikators, CSDI & $-0,01$ & 0,33 & $-1,93$ & $-0,99$ & $-0,13$ & $-1,41$ & $-2,30$ & $-0,88$ & 0,26 & -2 \\
\hline $\begin{array}{l}\text { Ikgadējā kopējāā nokrišnu daudzuma } \\
\text { summa dienās ar nokrišniem, PTOT }\end{array}$ & 2,12 & 4,10 & 3,12 & 3,01 & 5,50 & 3,08 & 2,92 & 1,49 & 4,93 & \\
\hline $\begin{array}{l}\text { Ikgadējais dienu skaits ar } \\
\text { stipriem nokrišņiem, R10 }\end{array}$ & 2,28 & 1,61 & 1,77 & 2,11 & 4,14 & 1,61 & 2,85 & 1,54 & 3,82 & \\
\hline $\begin{array}{l}\text { Ikgadējais dienu skaits ar loti } \\
\text { stipriem nokrišñiem, R20 }\end{array}$ & $-0,06$ & 0,12 & 1,79 & 2,59 & 2,45 & $-0,64$ & 2,13 & $-1,91$ & 1,62 & \\
\hline
\end{tabular}

aukstu dienu skaita samazināšanos un ekstremāli karstu dienu skaita palielināšanos.

Laika periodā no 1923. līdz 2012. gadam Latvijā bijušas arī sezonas ar ekstremālām izmaiñām temperatūras un nokrišnu ziņā (sk. 4.5. tabulu): ievērojami samazinājies ekstremāli aukstu vasaru un pavasaru skaits un palielinājies ekstremāli siltu sezonu skaits. Pēc nokrišn,u sadalījuma ekstremālu sezonu izmaiṇas būtiski ietekmējušas tikai ziemas sezonu, kad mitru sezonu skaits būtiski palielinājies līdz ar būtisku sausu sezonu skaita samazināšanos, t.i., ekstremāli sausas ziemas ir kḷuvušas retākas un ievērojami palielinājies ekstremāli mitru un nokrišñiem bagātu ziemu skaits.

Šie rezultāti ir saskaṇā ar līdzīgu klimata pārmaiṇu novērtējuma un analīzes pētījumu rezultātiem gan kaimiṇvalstīs un Ziemel̦eiropā, gan arī Eiropas un pasaules mērogā. Izmaiṇas identificējamas arī ekstremālajiem atmosfēras
4.5. tabula. Ekstremālo sezonu ilggadīgo izmainu tendences (Manna-Kendala testa vērtības) Latvijā 1923.-2012. gadā

\begin{tabular}{|c|c|c|c|c|}
\hline & \multicolumn{4}{|c|}{ Minimālā gaisa temperatūra } \\
\hline & Vasara & Rudens & Ziema & Pavasaris \\
\hline $\begin{array}{l}\text { Aukstas } \\
\text { sezonas }\end{array}$ & $-2,06$ & 0,01 & $-1,59$ & $-2,3$ \\
\hline \multirow[t]{3}{*}{$\begin{array}{c}\text { Siltas } \\
\text { sezonas }\end{array}$} & 2,21 & $-0,26$ & 0,97 & 2,69 \\
\hline & \multicolumn{4}{|c|}{ Maksimālā gaisa temperatūra } \\
\hline & Vasara & Rudens & Ziema & Pavasaris \\
\hline $\begin{array}{l}\text { Aukstas } \\
\text { sezonas }\end{array}$ & $-1,82$ & $-0,6$ & $-1,48$ & $-3,1$ \\
\hline \multirow[t]{3}{*}{$\begin{array}{c}\text { Siltas } \\
\text { sezonas }\end{array}$} & 2,49 & 0,77 & 1,05 & 1,86 \\
\hline & \multicolumn{4}{|c|}{ Atmosfēras nokrišņi } \\
\hline & Vasara & Rudens & Ziema & Pavasaris \\
\hline $\begin{array}{c}\text { Mitras } \\
\text { sezonas }\end{array}$ & 1,31 & 0,18 & 4,03 & $-0,17$ \\
\hline $\begin{array}{l}\text { Sausas } \\
\text { sezonas }\end{array}$ & $-0,14$ & $-1,5$ & $-3,08$ & $-1,66$ \\
\hline
\end{tabular}


nokrišniem, to biežums un intensitāte pārsvarā ir palielinājusies, tomēr nevienmērīgā telpiskā nokrišnu sadalījuma dēl arī izmainnu tendences ir teritoriāli atšksirīgas, kas no novērojumu datiem katrai meteorologiskajai stacijai aprēksināti gada griezumā.

Arī nesen Latvijā ir pieredzēti ekstremālu laikapstāklı notikumi.

- Spēcīgā 2005. gada ziemas vētra. 2005. gada 8.-9. janvārī Latvija pieredzēja lıoti spēcīgu vētru. Situāciju Latvijā ietekmēja virs Botnijas lǐča valdošā ciklona dienvidu mala, kas noteica Latvijas atrašanos maksimālā vēja ātruma zonā. Maksimālais novērotais vēja ātrums brāzmās bija $40 \mathrm{~m} / \mathrm{s}$ Ventspilī, 36 m/s Liepājas ostā, 30 m/s Rīgā. Rìgas ostā ūdens līmenis cēlās līdz $213 \mathrm{~cm}$ virs novērojumu stacijas nullpunkta atzīmes. Ūdens līmeña celšanās rezultātā tika appludinātas lielas platības Mangaḷsalā, Kundziņsalā, Vecāḳos, Bullıুos, Juglas ezera apkārtnē, Jūrmalas gatvē, kā arī Daugavgrīvā, Dubultos, Bulduros, Dzintaros. Spēcīgā vēja dēḷ daudzās vietās tika pārtraukta elektrības piegāde un sakari, tika sagāzti un izrauti koki, norauti jumti, kā arī nodarīti milzīgi zaudējumi daudziem zemes īpašumiem, lauksamniecībai.

- 2005. gada septembris. Pretēja hidrometeoroloǵiskā situācija - augstas ūdens temperatūras un zems ūdens līmenis. Sliktā ūdens kvalitāte veicināja ekologisko katastrofu - zivju masveida noslāpšanu Lielupē.

- 2006. gada vasara. Ekstrēmi augstas gaisa temperatūras un nepārtrauktais sausuma periods radijja augstu meža ugunsgrēku risku - tas bija viens no garākajiem un postošākajiem šāda veida periodiem Latvijas vēsturē. 3790,6 ha mežu tika iznīcināti ugunsgrēkos, lielas ganību platības izkalta (Valsts meža dienesta dati), karstais un sausais laiks radīja lielus zaudējumus lauksamniecībai (nokaltuši zālāji, pavasara graudaugi, dārzeñi). Dažos reǵionos Latvijā tika pasludināti ārkārtas apstākḷi.

- 2010. gada temperatūras ekstrēmi. Neparedzēts karstums iestājās 2010. gadā, kad maksimālā temperatūra gandrīz visā Latvijas teritorijā pārsniedza $+30^{\circ} \mathrm{C}$ un karstums turpinājās ilgu laika periodu. 4.13. attēlā ir redzamas vasaras periodā novērotās maksimālās temperatūras, kas skaidri atspoguḷo

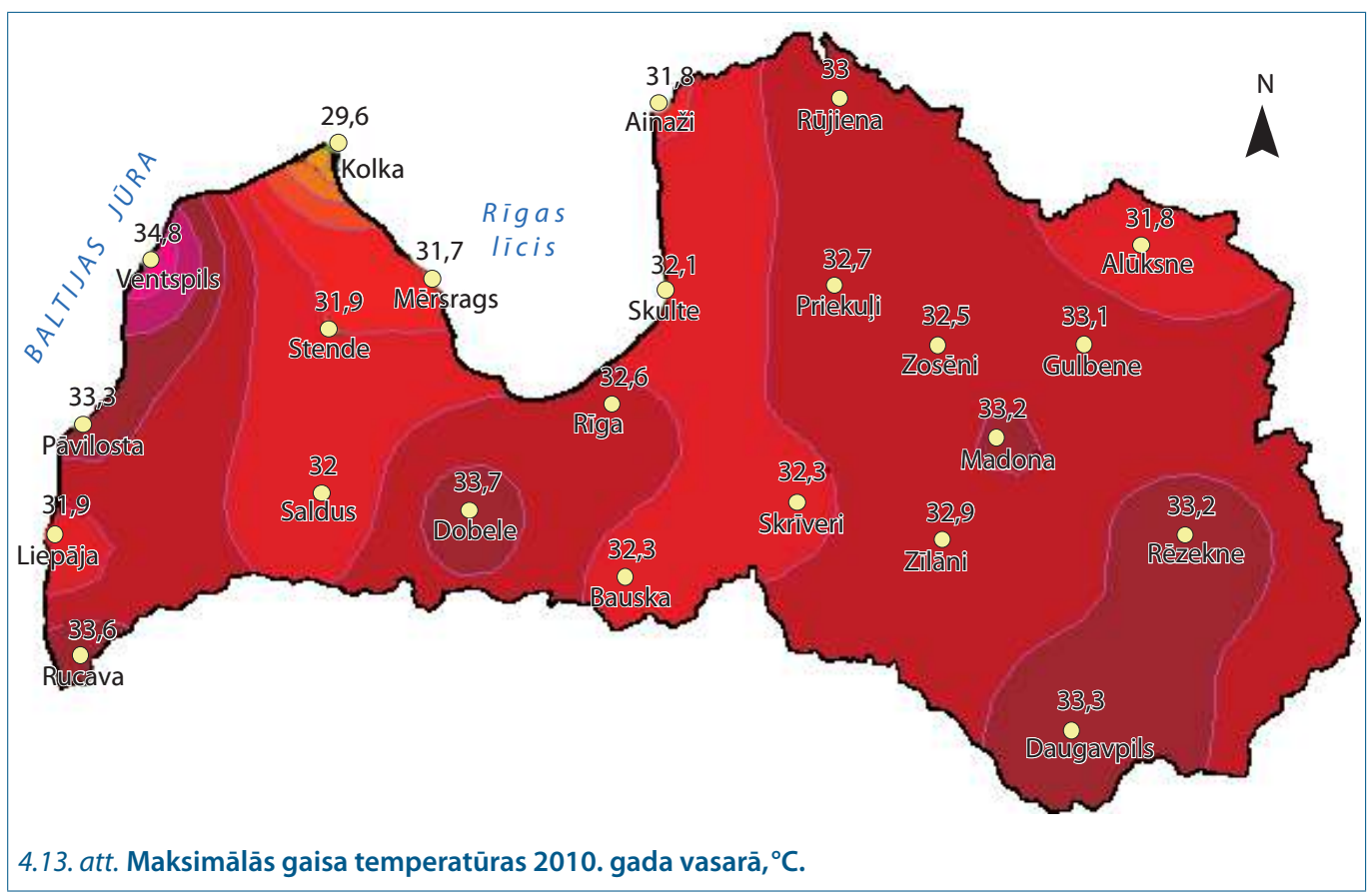



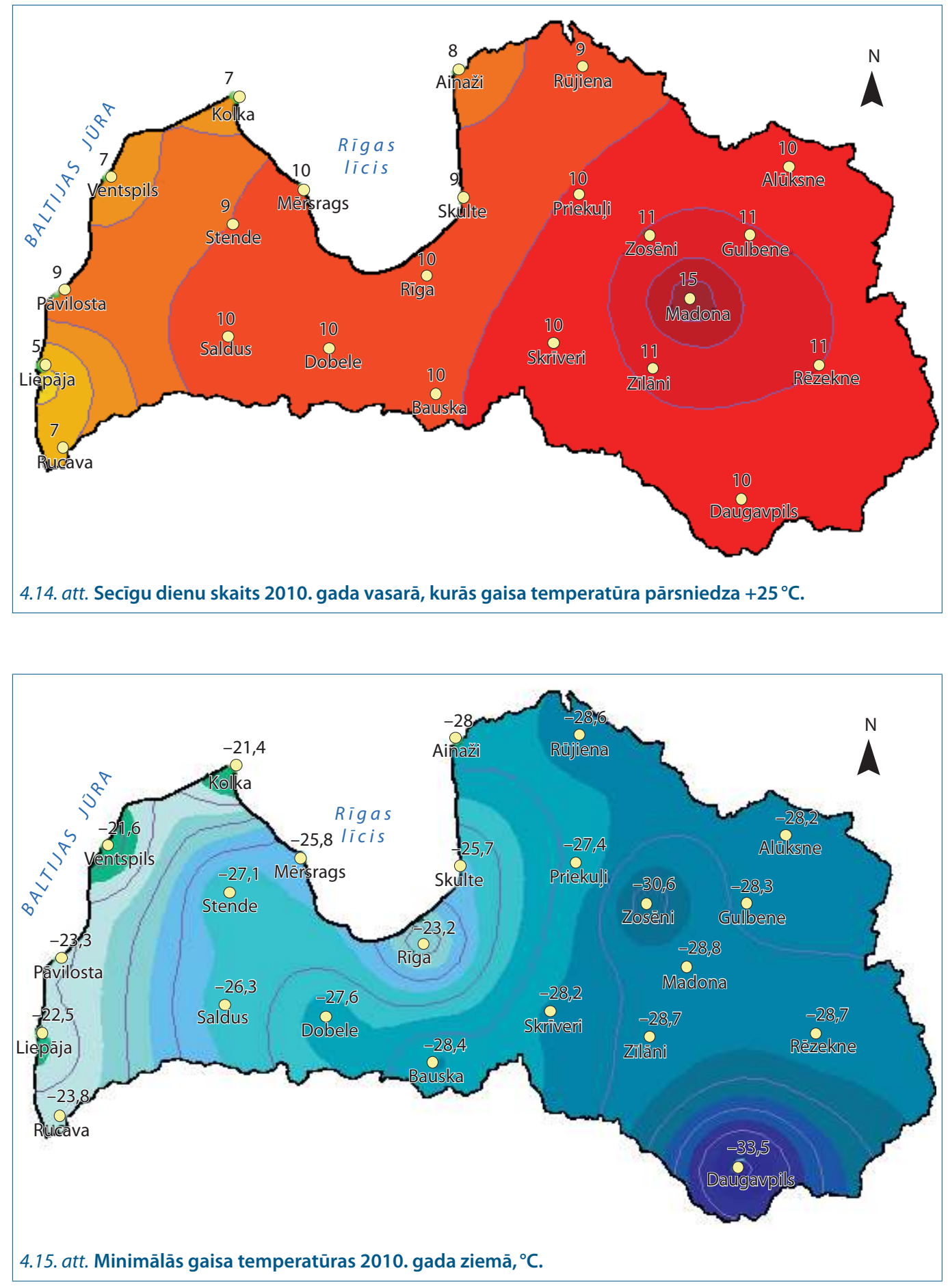
arī lokālos faktorus maksimālās temperatūras telpiskajā sadalījumā. Šajā gadījumā dominējošo austrumvēju ietekmē maksimālās un rekordaugstas temperatūras tika novērotas Baltijas jūras piekrastes rajonos, to skaitā Ventspils apkārtnē. Turklāt karstums bija stabils un Latvijas austrumdalas reǵionos secīgu vasaras dienu skaits pārsniedza pat 15 (sk. 4.14. att.).

Neskatoties uz novēroto temperatūras pieaugumu, pēdējā laikā Latvijā ir novērotas arī loti aukstas ziemas ar ḷoti zemām temperatūrām. Temperatūras 2010. gada ziemas sezonā bija ekstremāli zemas, visā Latvijas teritorijā tās bija zemākas par $-20^{\circ} \mathrm{C}$, un minimums tika sasniegts Daugavpilī: $-33,5^{\circ} \mathrm{C}$ (sk. 4.15 . att.).

- Ekstremāls apledojums un sniegs 2010./2011. gada ziemas sezonas laikā radīja nopietnus bojājumus elektropārvades līnijām, kā arī lielai daḷai Latvijas mežu.

- Sniega segas ekstremāls biezums 2013. gada pavasarī un plūdi. 2013. gada pavasarī sniega sega saglabājās līdz pat aprịla otrajai dekādei, kas ir vidēji par mēnesi ilgāk nekā ilggadīgie vidējie datumi.
2013. gada martā Austrumlatvijas augstieñu rajonos sniega segas biezums līdz pat 2,5 reizēm pārsniedza normu, atsevišskās dienās sasniedzot pieaugumu par 50-60 cm. Aprịla pirmajā dekādē Austrumlatvijā vidējais sniega segas biezums bija $40 \mathrm{~cm}$, kas 10 reizes pārsniedza normu. Alūksnē 9. aprīlī sniega sega sasniedza vislielāko biezumu $-70 \mathrm{~cm}$. Straujā sniega un ledus kušana aprīla otrajā pusē izraisīja apjomīgus plūdus. Vislielākā ūdens līmen,a celšanās tika novērota Ogres upē Ogres pilsētas tuvumā. Aprēkuini liecina, ka tur sasniegts tāds ūdens līmenis, kas var atkārtoties tikai reizi 200 gados.

- Loti stipras pērkona lietusgāzes Siguldā 2014. gada 29. jūlijā. Jūlija beigās pēc ilgstoša karstuma viḷna Latviju skāra ḷoti spēcīgas pērkona lietusgāzes. Nokrišņu daudzums Siguldā sešās stundās sasniedza 123 mm. Pēc klimatiskajiem datiem šis nokrišñu daudzums Siguldā bijis lielākais jebkad novērotais, savukārt kopumā Latvijā sestais lielākais. Tālajā 1973. gada 9. jūlijā visstiprāk lija Ventspilī, kad nokrišn,u daudzums 12 stundās sasniedza $160 \mathrm{~mm}$.

\subsection{Sniega segas raksturs un tā mainība}

Klimata sistēmā nozīmīgi ir laikapstākl̦i ziemā un sniega segas izveidošanās. Aukstajā sezonā liela dalı nokrišnu izkrīt sniega veidā. Sezonālā sniega sega var saturēt lielu ūdens daudzumu, kas izkūstot ievērojami ietekmē gan virszemes, gan pazemes ūdeņu hidroloǵisko režīmu. Ūdens saturs sniega segā lielā mērā ietekmē arī hidroenergoresursus, kā arī ir nozīmīgs raksturlielums plūdu riska paredzēšanai. Lìdz ar to sniega sega ir būtiska ne tikai klimata mainības aspektā, bet arī no tautsaimniecības viedokḷa. Sniega segas biezums, tās pastāvēšanas ilgums ir nozīmīgs daudzu augu, it īpaši lauksaimniecībā izmantojamo kultūru, izdzīvošanai un augšanai. Sniega segas pastāvēšana ir nozīmīga arī rekreācijai un ziemas sporta veidu attīstībai, cel̦u uzturēšanai.

Sniega sega uzskatāma par jutīgu klimata izmaiṇu rādītāju, jo ir tieši atkarīga no gaisa temperatūras un nokrišnu daudzuma. Kopumā sniega segu Latvijā raksturo relativi liela dažādība. Tas attiecas gan uz dienu skaitu, kad izveidojas un pastāv pastāvīga sniega sega, gan arī uz sniega segas biezumu. Sniega sega ir raksturīga Latvijai gada aukstajā periodā, kad gaisa temperatūra pārsvarā ir zemāka par nulli, bet tās ikgadējais pastāvēšanas ilgums ir mainīgs. Reǵionālo mainību nosaka gaisa temperatūru sadalījums. Jo tālāk no Baltijas jūras un Rīgas līča piekrastes, jo sniega segas pastāvēšanas 
ilgums un tās biezums ir lielāks, īpaši rajonos, kur zemes virsmas augstums virs jūras līmeña un novietojums pret valdošajiem vējiem sekmē gaisa masu augšupejošu kustību. Ir pierādīts, ka Baltijas jūras ietekme skaidri izpaužas 30-100 km platā piekrastes joslā.

Pirmā sniega sega parādās laikā no 1. līdz 23. novembrim: Baltijas jūras piekrastē parasti tā pirmoreiz izveidojas tikai novembra 3. dekādē, bet 2. dekādē - Rīgas līča piekrastē un Zemgales līdzenumā, kā arī Kurzemes augstienēs. Visagrāk, jau novembra 1. dekādē, sniega sega izveidojas Vidzemes augstienē un rajonos uz ziemel̦iem no tās, Austrumlatvijas zemienē un Latgales augstienē. Pēc ilggadējiem rādītājiem, Alūksnē sniega sega parasti izveidojas 1. novembrī, bet Dagdā un Zosēnos - 5. novembrī. Noturīga jeb stabila sniega sega Latvijā izveidojas vidēji 30-45 dienas pēc pirmās sniega segas parādīšanās, t.i., laikā no 6. decembra līdz 6. janvārim (Alūksnē un Ventspilī), bet lielākajā teritorijas daḷā - decembra 2. un 3. dekādē. Vidējais dienu skaits ar sniega segu ir tieši atkarīgs no novērojumu stacijas izvietojuma (vietas augstuma virs jūras līmeṇa). Tas palielinās virzienā no rietumiem uz teritorijas austrumu daḷu - no 62 dienām Rucavā, Baltijas jūras piekrastē līdz 133 dienām Alūksnes augstienē (sk. 4.16. att.), un dienu skaits ar stabilu sniega segu attiecīgi ir no 50 līdz 110 dienām. Gadu no gada sniega segas raksturlielumos ir iespējamas ievērojamas svārstības. Ziemā bieža parādība ir atkušņi. Tiem parasti raksturīga maza intensitāte, kā arī īslaicīgums (vidēji 5-6 dienas). Tādēl samērā plašā Latvijas teritorijas daḷā noturīga sniega sega dažkārt vispār neizveidojas, bet valsts austrumu rajonos, savukārt, loti retas ir ziemas ar nenoturīgu sniega segu.

Vietas geogrāfiskais novietojums ietekmē ne tikai sniega segas pastāvēšanas ilgumu, bet arī sniega segas biezumu (gan sezonas vidējo, gan arī dekādes maksimālo). Biezums ir uzskatāms par vienu no būtiskākajiem sniega segas rādītājiem. Vidējā sniega segas biezuma izmaiṇas ziemas sezonā Latvijā ir atspogulotas 4.17. attēlā. Izvēlētajām stacijām Latvijas teritorijā raksturīgi atšksirīgi fizioǵeogrāfiskie apstākḷi (augstums virs jūras līmeña un attālums no Baltijas jūras vai Rīgas līča). Visās stacijās sniega sega maksimālo biezumu sasniedz

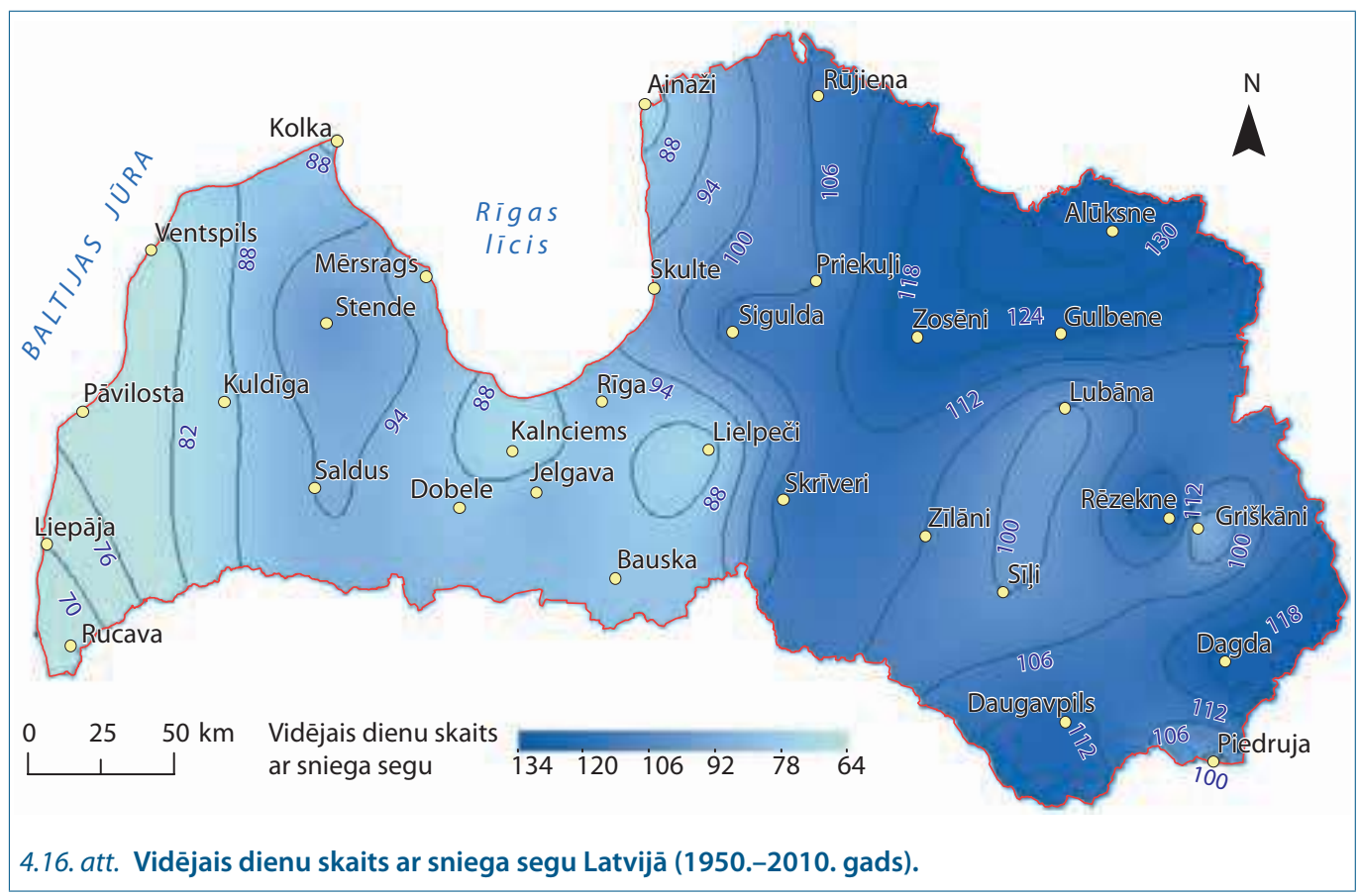


februāra 3. dekādē. Sniega segas biezuma mainīšanās stacijās ir līdzīga - uzkrāšanās periods maksimumu sasniedz februārī un pēc sniega uzkrišanas ir pakāpenisks un vienmērīgs, turpretim sniega kušanas periods pēc maksimuma sasniegšanas notiek straujāk.
Vidēji visbiezākā sniega sega ziemas sezonā izveidojas februāra mēneša 3. dekādē (no $7 \mathrm{~cm}$ teritorijas rietumu daḷā līdz pat $42 \mathrm{~cm}$ centrālajā daḷā, sk. 4.18. att.). Visbiezākā novērojumu stacijās reǵistrētā sniega sega ir bijusi $130 \mathrm{~cm}$. Tā regiistrēta Vidzemes augstienē.
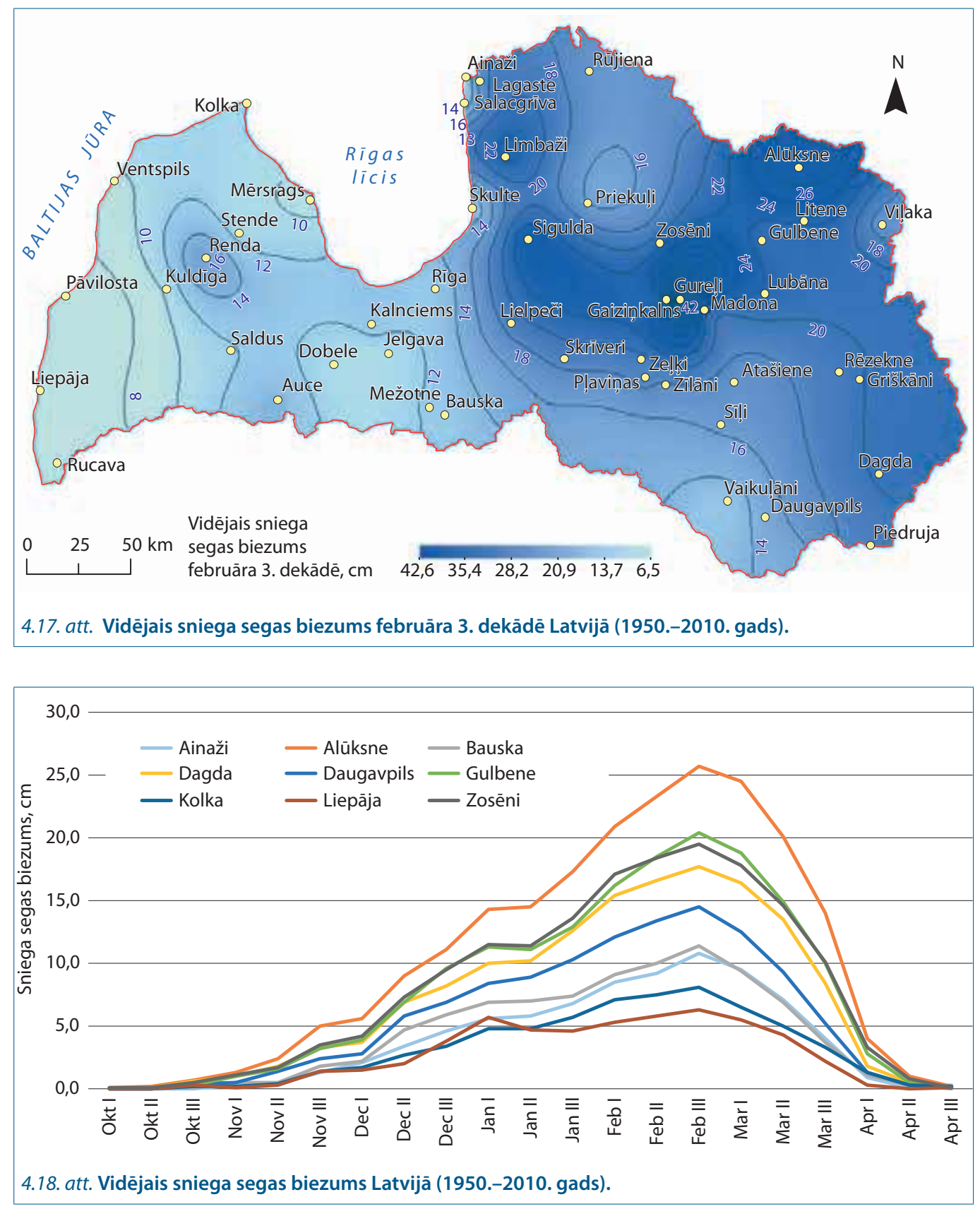


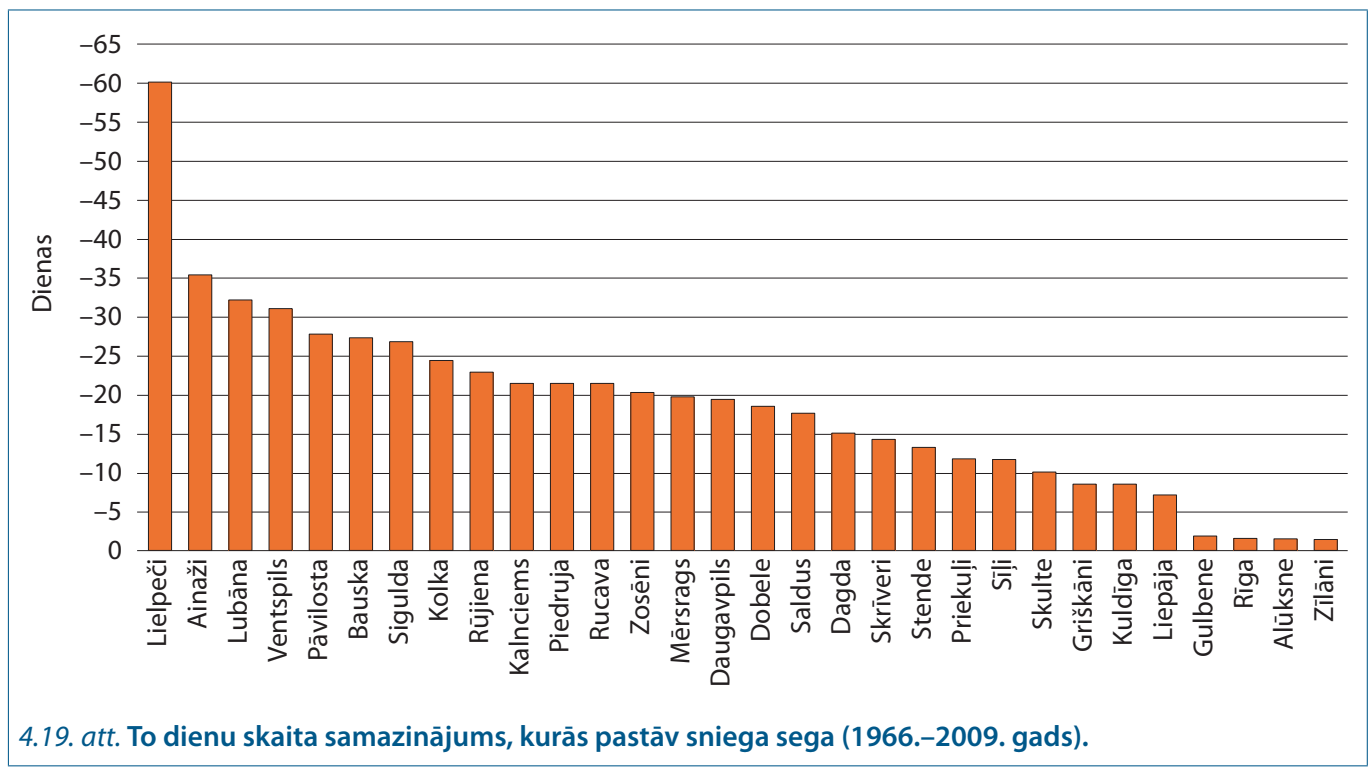

Laika posmā no 1966. līdz 2009. gadam sniega segas pastāvēšanas ilgums Latvijā ir samazinājies no 1-2 dienām (Zīlānos, Alūksnē, Rīgā un Gulbenē) līdz 30-35 dienām (Ainažos, Lubānā un Ventspilī) un Lielpečos pat līdz 60 dienām (sk. 4.19. att.). Manna-Kendala tests apliecina, ka statistiski būtiskas izmaiņas dienu skaitā ar sniega segu ir bijušas tikai Lielpečos. Turpretim izteiktas samazinājuma tendences parādās arī Ainažos, Lubānā un Ventspilī.

Ņemot vērā Manna-Kendala testa rezultātus un dienu skaitu ar sniega segu, var secināt, ka sniega segas režīmam ir raksturīga liela mainība ikgadējā griezumā, kā arī zināms periodiskums, kuru raksturo laika posmi ar ievērojami biezāku sniega segu, kā arī posmi, kuros dienu skaits ar sniegu segu ir mazāks un sniega sega ir plāna.

Noturīga sniega sega atsevišķās Baltijas jūras piekrastē esošās novērojumu stacijās var pat vispār neizveidoties. Pašreizējam sniega segas pastāvēšanas un biezuma mainības periodam raksturīga sniega segas noturīguma samazināšanās tendence.

\subsection{Vegetācijas periods un tā izmaiṇas}

Gaisa temperatūras režīms var būt izmantojams kā viens no rādītajiem, lai raksturotu veǵetācijas jeb augšanas sezonu. Visbiežāk Latvijā par veǵetācijas perioda sākšanos pieṇem laiku, kad vidējā diennakts temperatūra pārsniedz $5^{\circ} \mathrm{C}$ vismaz 5 dienas pēc kārtas. Pasaulē eksistē un lieto dažādas veǵetācijas perioda definīcijas. Piemēram, veǵetācijas periods tiek definēts arī kā gada periods, kurā augšanas apstākḷi gan vietējiem, gan kultivētajiem augiem ir izdevīgākie:

1) vidējā temperatūra ir virs temperatūras sliekšn,a, kad kultūra izdīgst un turpina augšanu (šì temperatūra ir atkarīga no attiecīgās kultūras),

2) veǵetācijas periods ir bezsala dienu skaits jeb dienu skaits starp pēdējo pavasara salnu un pirmo rudens vai ziemas salnu. 
Eiropas mērogā veiktie pētījumi norāda, ka izmaiṇas vidējā veǵetācijas perioda sākumā Eiropā kopš 1989. gada labi korelē ar vidējās gaisa temperatūras izmaiṇām no februāra līdz aprīlim. No 1969. līdz 1988. un no 1989. līdz 1998. gadam vidējā pavasara temperatūra Eiropā pieauga par $0,8^{\circ} \mathrm{C}$, vidējais veǵetācijas perioda sākums iestājās par 8 dienām ātrāk. Atšksirība starp vidējo gaisa temperatūru un vegetācijas perioda sākumu ir nozīmīgi, ja būtiskuma limenis $<0,05$.

Labi veǵetācijas perioda izmaiṇas raksturo augšanai labvēlīgo temperatūru dienas, t.i., dienas, kad vidējā diennakts gaisa temperatūra ir augstāka par $4^{\circ} \mathrm{C}$. Veiktie pētījumi, izmantojot Rĭga Universitāte meteostacijas novērojumus, apliecināja, ka kopumā visā 211 gadu novērojumu periodā (1795.-2006. gads) ievērojami pieaugusi augšanai labvēlīgo temperatūru dienu grādu summa. Pētījumā tika konstatēts, ka pastāv cieša korelācija starp augšanas grādu dienām un vidējo gaisa temperatūru aprīlī-oktobrī. Tas liecina, ka nākotnē, paaugstinoties vidējai gaisa temperatūrai, ir paredzams arī augšanas grādu dienu pieaugums. Pēc Rìga
Universitāte novērojumiem ir konstatēts, ka straujākās augšanas sezonu izmaiñas notikušas 20. gs. laikā, kad augšanas sezona pakāpeniski iestājusies agrāk un beigusies vēlāk. Augšanas sezonas garums 20. gs. laikā ir palielinājies par 25,9 dienām.

Latvijā kopumā vidējais veǵetācijas perioda dienu skaits variē vairāk nekā trīs nedēlı amplitūdā, ko ietekmē ne tikai attiecīgās vieta reǵionālā mērogā, bet arī augstums virs jūras līmeṇa un reljefs. Baltijas jūras piekrastē novērojams vidēji garākais veǵetācijas periods. Arī Rīgas pilsētā pēc Rīga Universitāte ilglaicīgajām novērojumu rindām ir viens no garākajiem veǵetācijas periodiem, ko nosaka ne tikai tās geogrāfiskais novietojums, bet arī pilsētas centra "siltuma sala”. Noteicošais faktors, kas ietekmē augstāku gaisa temperatūru Rīgas pilsētā salīdzinājumā ar ārpus pilsētas teritorijām, ir aktīvo virsmu absorbēšanas spējas. Arī Bauskā un Dobelē ir salīdzinoši garāks veǵetācijas periods, kas saistāms ar to atrašanos Zemgales līdzenumā, kur ir viens no lielākajiem Saules spīdēšanas ilgumiem Latvijā. Mazākais veǵetācijas periods ir Latvijas A un ZA dalāās, īpaši augstienēs (sk. 4.20. att.).

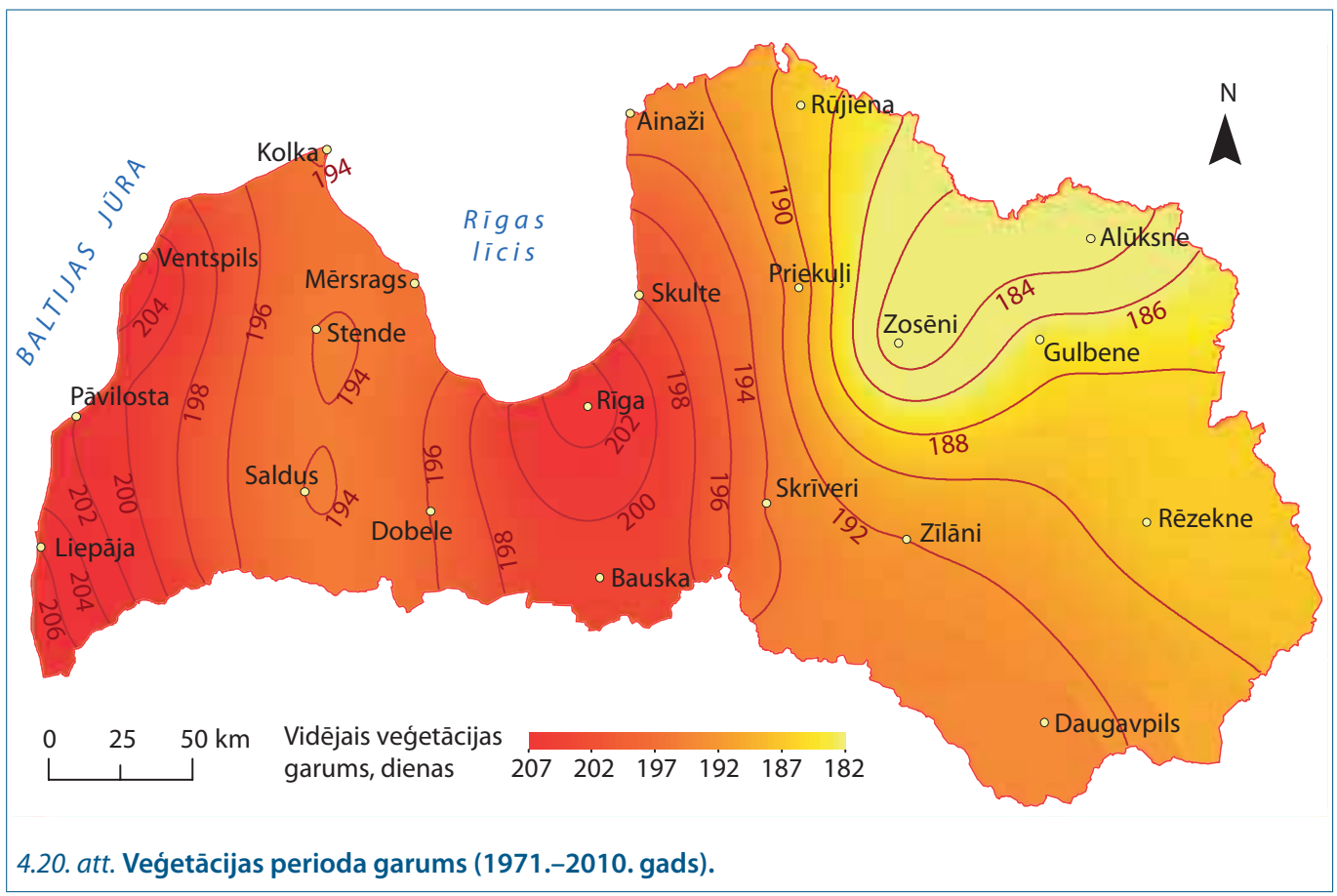


Statistiski nozīmīgas izmaiņas veǵetācijas perioda garumā tika iegūtas Latvijas A un ZA daḷās esošajās novērojumu stacijās.

Laika posmā no 1981.-2010. gadam vidēji visagrākā veǵetācijas perioda iestāšanās fiksēta Rīgā, vidēji 8. aprīlī, kas ir par 6 dienām agrāk nekā vidēji šajā periodā Latvijā. Agra veǵetācijas perioda iestāšanās vērtības konstatētas arī Bauskas, Skrīveru un Zīlānu novērojumu stacijās - vidēji 10. aprīlī. Visvēlākā iestāšanās datēta Kolkā - vidēji 24. aprīlī. Vegetācijas perioda iestāšanās amplitūda Latvijā starp stacijām ar agrāko un vēlāko datumu ir aptuveni 2 nedēlas (sk. 4.21. att.).

Statistiski nozīmīgas veǵetācijas perioda iestāšanās laika izmaiṇas visā pētāmajā periodā tika konstatētas 9 no 21 novērojumu stacijas (Stendē, Rēzeknē, Alūksnē, Ventspilī, Pāvilostā, Ainažos, Kolkā, Mērsragā un Saldū). Visās šajās stacijās tendences vērtība ir negatīva, kas norāda uz arvien agrāku veǵetācijas perioda iestāšanos.

Laika periodā no 1971. līdz 2010. gadam vidējais veǵetācijas perioda iestāšanās laiks Latvijā ir 13. aprīlis, kaut arī atsevišksos gados tas izteikti variē. Piemēram, 1990. gadā vidēji visās novērojumu stacijās veǵetācijas periods iestājās jau 6. martā, kas ir par 39 dienām agrāk nekā vidēji. Savukārt, ja aplūko katru novērojumu staciju atsevišksi, tad ir redzams, ka veǵetācijas periods Kolkas, Liepājas, Ventspils, Mērsraga un Stendes stacijās 1990. gadā ir iestājies jau 20. februārī. 1990. gada februāris ne tikai Latvijā, bet arī visā Eiropā iezīmējas ar neparasti agro pavasara sākumu. Turpretim visvēlākais veǵetācijas perioda iestāšanās laiks Latvijā datēts 1981. un 1985. gadā, kad vidēji tas ir iestājies 3. maijā, kas, savukārt, ir par 19 dienām vēlāk par normas perioda vidējo vērtību. Absolūti visvēlākais veǵetācijas periods laika posmā no 1971. līdz 2010. gadam iestājies 1979. gada 12. maijā (Liepājas novērojumu stacijas dati).

Attiecībā uz veǵetācijas perioda beigām Latvijas teritorijā izteikti iezīmējas regionālās atškirības - Latvijas R daḷa ar vēlāku veǵetācijas perioda beigu datumu un kontinentālā Latvijas centrālā un ZA daḷa, îpaši augstien,u teritorijas, kur veǵetācijas periods beidzas visagrāk (sk. 4.22. att.). No visām novērojumu stacijām Zosēnos un Alūksnē veǵetācijas periods noslēdzas visagrāk - oktobra otrajā dekādē (15.-16. oktobris). Visvēlāk veǵetācijas periods beidzas piekrastes teritorijās, īpaši Baltijas jūras, kā arī Rīgas līča piekrastē, ko nosaka jūrā uzkrātais siltuma daudzums siltajā gada laikā un tā atdošana rudens sezonas laikā. Kolkā, Liepājā, Pāvilostā un Ventspilī veǵetācijas periods pēc vidējiem ilggadīgajiem datiem beidzas novembra pirmās dekādes sākumā. Manna-Kendala iegūtās testa vērtības nav statistiski būtiskas, norādot, ka ilgākā laika periodā (1971.-2010. gads) nav notikušas nozīmīgas izmaiṇas veǵetācijas perioda beigu datumos.

\subsection{Vējš un tā raksturojošo lielumu ilglaicīgās izmaiṇas}

Atmosfēras spiediena sadalījums, kas nosaka arī vēja raksturu, Latvijas teritorijā ir cieši saistīts ar atmosfēras cirkulācijas īpatnībām. Reǵionālās atmosfēras spiediena un vēja virziena atšksirības Latvijas teritorijā neizpaužas tik spilgti kā vēja ātruma sadalījums.

Atmosfēras spiediena gada gaita ir atkarīga no valdošajām bāriskajām sistēmām dažādās sezonās un aktīvās virsmas sasilšanu un atdzišanu radiācijas bilances izmaiṇu rezultātā. Visā Latvijas teritorijā atmosfēras spiediena gada sadalījumā spilgti izpaužas maksimumi februārī, maijā un oktobrī un minimumi aprīlī, jūlijā un decembrī. Teritorijas kontinentālākajā dal̦ā galvenais maksimums ir februāra mēnesī, bet Baltijas jūras un Rīgas līča piekrastē - maija mēnesī. Visā Latvijas teritorijā gada vidējā atmosfēras spiediena amplitūda ir salīdzinoši neliela, 4-5 mb. Atsevišksos gados atkarībā no dažādu bārisko veidojumu intensitātes ir iespējamas lielas atmosfēras spiediena novirzes no ilggadīgā vidējā rādītāja. 

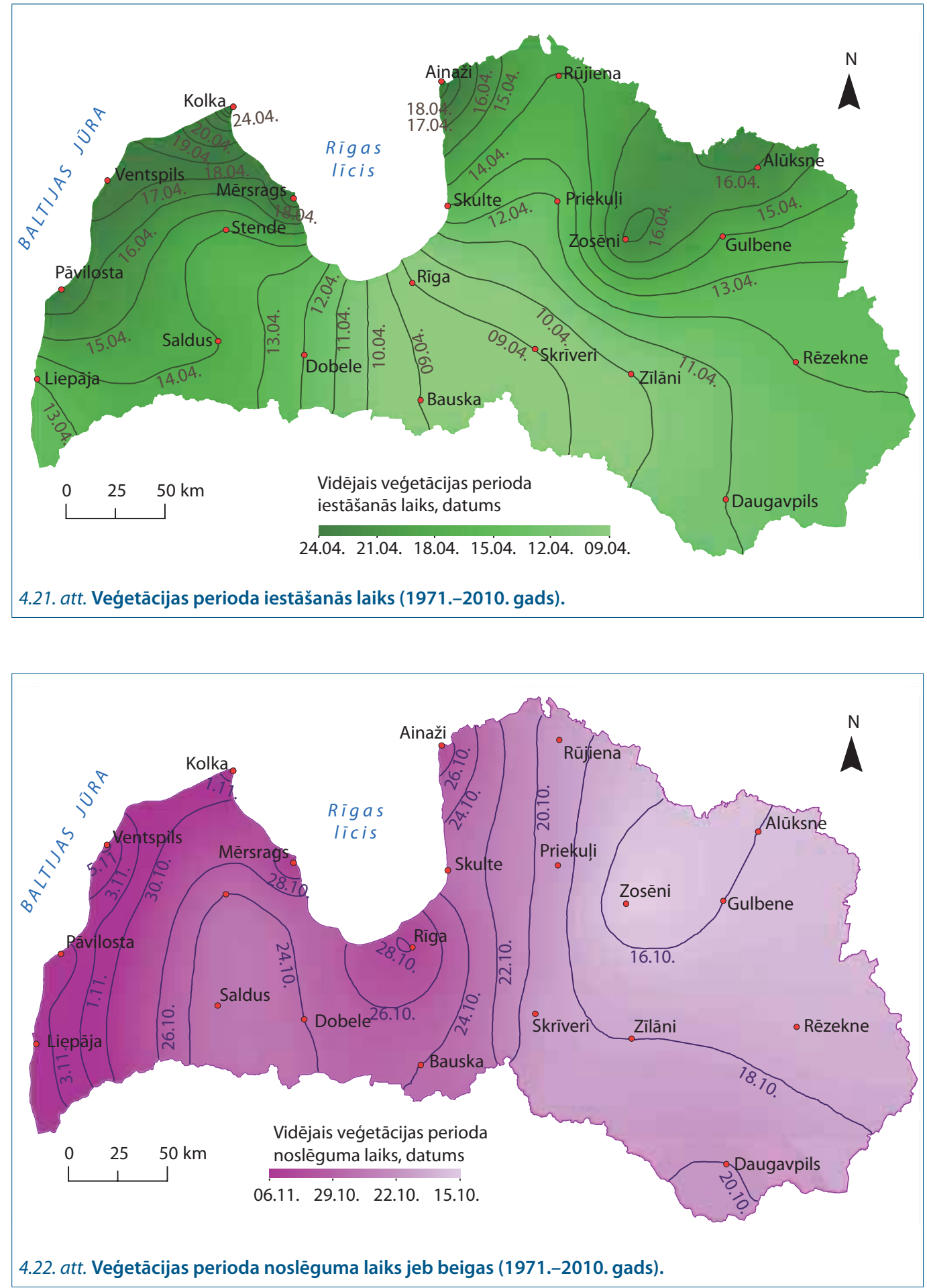
Kopumā gada griezumā Latvijā valdošie ir dienvidrietumu, rietumu un dienvidu virzienu vēji (sk. 4.23. att.). Latvijas lielākajā dal̦ā vējš gada laikā biežāk pūš no dienvidrietumiem. Rīgas līča dienvidu un austrumu dal̦ā ir izteiktāks dienvidu virziena vēju īpatsvars, bet teritorijas austrumos (Daugavpils, Rēzekne, Alūksne) rietumu virziena vēji.

Aukstajā gadalaikā galvenie bāriskie veidojumi, kas ietekmē Latvijas klimatiskos apstāklus, ir plašs stacionārs anticiklons virs Āzijas (Āzijas maksimums) un zema spiediena apgabals Atlantijas okeāna ziemel̦u dal̦ā (Islandes minimums). Ziemas periodā, padzilinoties Islandes depresijai un Āzijas maksimuma rietumu atzaram, izobāras ir vērstas virzienā no dienvidrietumiem uz ziemel̦austrumiem, un tām ir raksturīgi lieli horizontālie bāriskie gradienti. Līdz ar to valdošie vēju virzieni aukstajā gada laikā ir dienvidu un dienvidrietumu vēji, kas pūš ar mērenu vai stipru spēku. Vasaras periodā sakarā Āzijas anticiklona transformāciju un depresijas izveidošanos, Islandes minimuma pavājināšanos un plaša augsta spiediena apgabala aktivizēšanos Atlantijas okeānā virs Azoru salam, bāriskie gradienti virs teritorijas pavājinās. Ar to saistīta vēja ātruma samazināšanās, kā arī rietumu un ziemel̦u virziena vēju īpatsvara palielināšanās (sk. 4.24. att.).

Gada vidējais vēja ātrums variē no apmēram $5 \mathrm{~m} / \mathrm{s}$ Baltijas jūras piekrastes teritorijās, bet kontinentālajā dalāa - ap 3-4 m/s. Lielākie

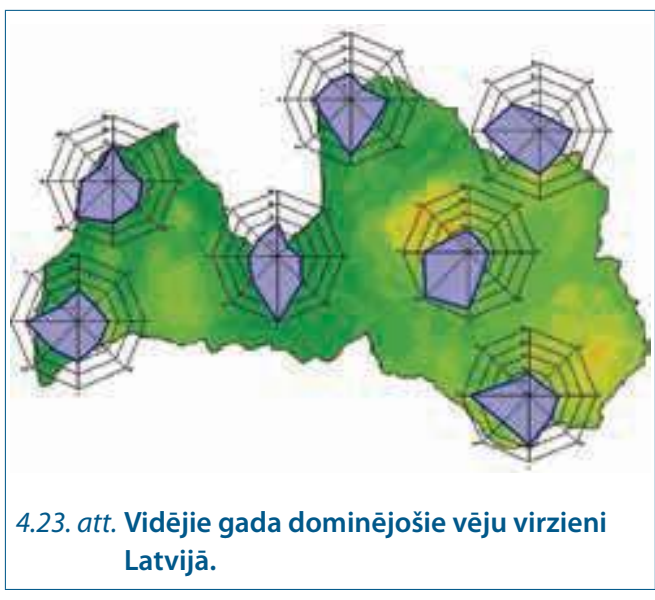

vidējie vēja ātrumi tiek registrēti novembrī un janvārī (piekrastes teritorijās 4-6 m/s, bet iekšzemē $3 \mathrm{~m} / \mathrm{s}$ ). Mazākie vēja ātrumi tiek novēroti jūlijā un augustā (piekrastē $4 \mathrm{~m} / \mathrm{s}$, iekšzemē $2 \mathrm{~m} / \mathrm{s}$ ). Latvijas teritorijā reǵistrētās lielākās vēja brāzmas sasniegušas ātrumu 48 m/s. Spēcīgas vētras teritorijā neatkārtojas katru gadu. Parasti vētras ilgst vienu dienu, tomēr dažkārt to ilgums sasniedz 2-3 dienas. Vēja ātrums brāzmās, kas sasniedz vētras spēku 20 m/s, Latvijas teritorijā ir iespējams visās vietās un visās sezonās. Novembra mēnesī Baltijas jūras piekrastē vētru atkārtošanās biežums ir reizi 10-15 gados. Tomēr l,oti spēcīgi vēji ar ātrumu brāzmās līdz $30 \mathrm{~m} / \mathrm{s}$ ir iespējami arī vasaras sezonā Latvijas iekšzemes teritorijās. Vasarās virpulviesuḷi var veidoties visā teritorijā. Bezvēja apstākḷi ir samērā reti. Periodā no septembra līdz martam bezvēja apstākḷi Latvijas teritorijā tiek reǵistrēti vidēji 1-15\% no novērojumiem, periodā no aprīla līdz augustam $-2-24 \%$.

Lai izvērtētu vēja izmaingu raksturu, tika analizētas piekrastes novērojumu staciju ilggadīgās novērojumu rindas. Iegūtie rezultāti apstiprināja, ka laika periodā no 1966. līdz 2011. gadam Liepājā, Pāvilostā, Mērsragā, Skultē, Ainažos novērojama būtiska vidējā un maksimālā vēja ātruma samazināšanās visu virzienu vējiem, ko apstiprina Manna-Kendala testa rezultāti (sk. 4.6. tabulu) un parāda 4.25. attēls Liepājas piemērā.

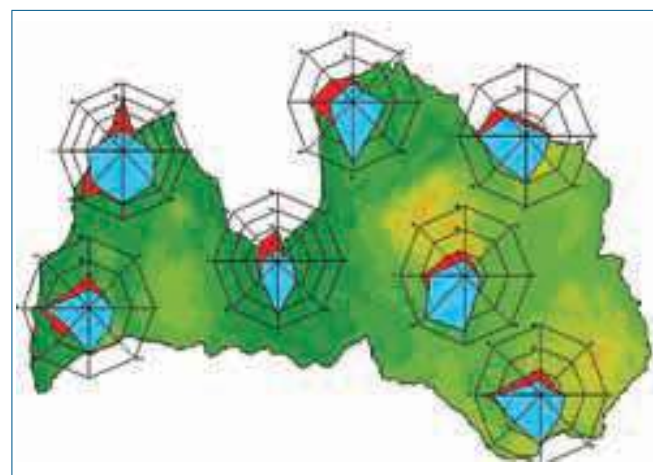

4.24. att. Valdošie vēju virzieni Latvijā vasarā (sarkanā krāsā) un ziemā (zilā krāsā). 
4.6. tabula. Manna-Kendala testa rezultāti gada vidējā un maksimālā vēja ātruma izmaiṇām (1966.-2011. gads)

\begin{tabular}{|l|c|c|c|}
\multicolumn{1}{c|}{$\begin{array}{c}\text { Meteoroloǵisko } \\
\text { novērojumu stacija }\end{array}$} & $\begin{array}{c}\text { MK testa vērtïba vidējam } \\
\text { vëja ätrumam }\end{array}$ & $\begin{array}{c}\text { MK testa vērtïba } \\
\text { maksimälam vēja ātrumam }\end{array}$ & $p$ vērtïba \\
\hline Liepāja & $-7,43$ & $-7,11$ & 0,00 \\
\hline Pāvilosta & $-7,89$ & $-6,13$ & 0,00 \\
\hline Ventspils & $-1,07$ & $-0,54$ & 0,59 \\
\hline Kolka & $-1,56$ & $-0,96$ & 0,34 \\
\hline Mērsrags & $-6,05$ & $-4,76$ & 0,00 \\
\hline Skulte & $-6,30$ & $-4,10$ & 0,00 \\
\hline Ainaži & $-5,31$ & $-4,23$ & 0 \\
\hline
\end{tabular}

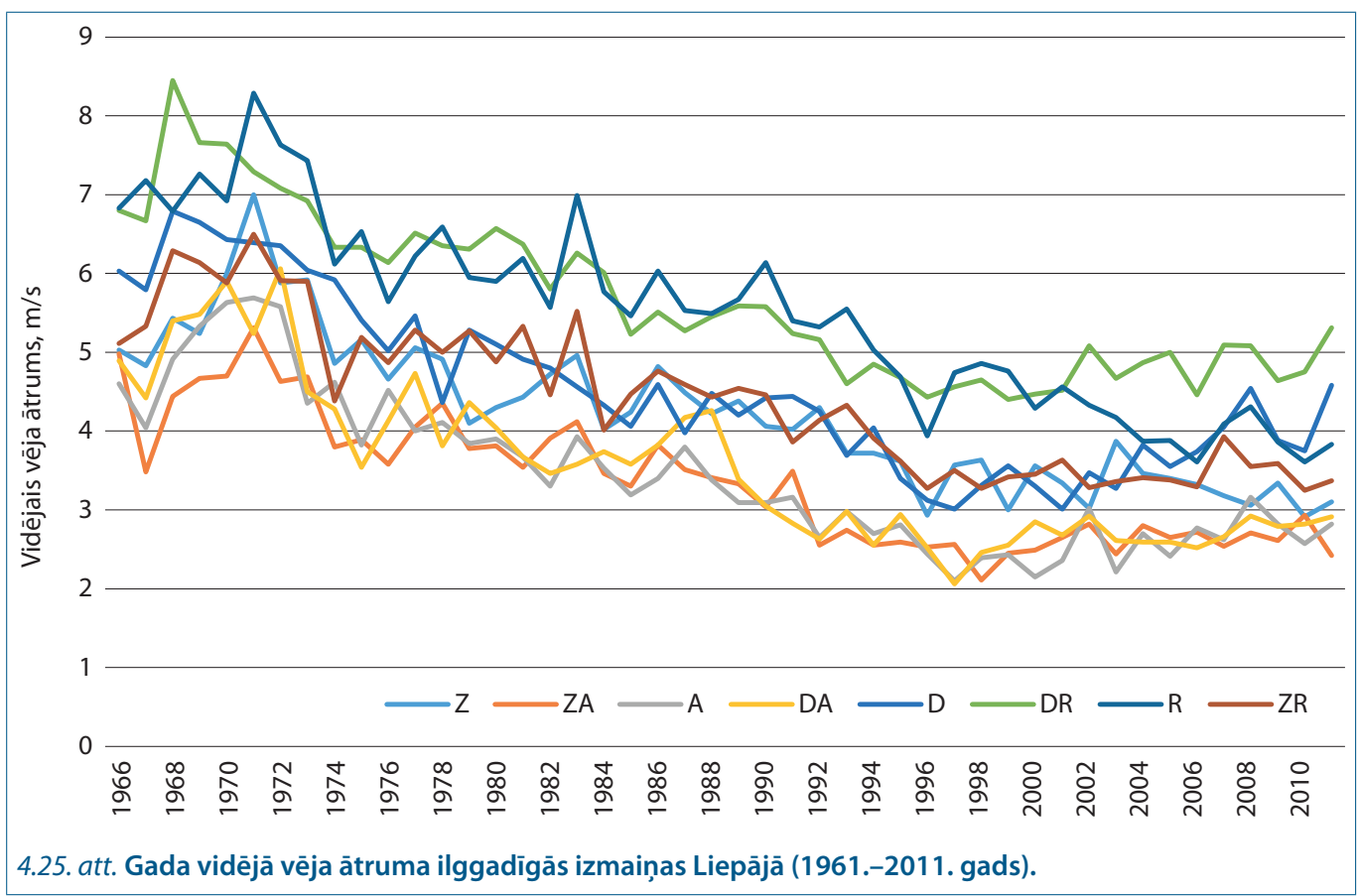

\subsection{Atmosfēras cirkulācijas procesu mainība}

Gan klimatu, gan laikapstākḷus ietekmē atmosfēras gaisa masu cirkulācijas un pārneses process. Tomēr gaisa masu pārneses procesi var mainīties ne tikai nedēḷas un mēneša ietvaros, bet arī ilgākā laika posmā, mainoties dominējošam gaisa masu pārneses veidam. Latvijā ieplūst dažādas izcelsmes okeāniskas un sauszemes gaisa masas, kas veidojušās dažādos platuma grādos un tāpēc ir l,oti atšksirīgas pēc siltuma satura, mitruma satura, vēja stipruma un citām īpašībām. Gada laikā, mainoties Saules radiācijas pieplūdumam pa geogrāfiskā platuma grādiem, mainās gaisa masu pārvietošanās intensitāte starp dažādiem ǵeogrāfiskiem 


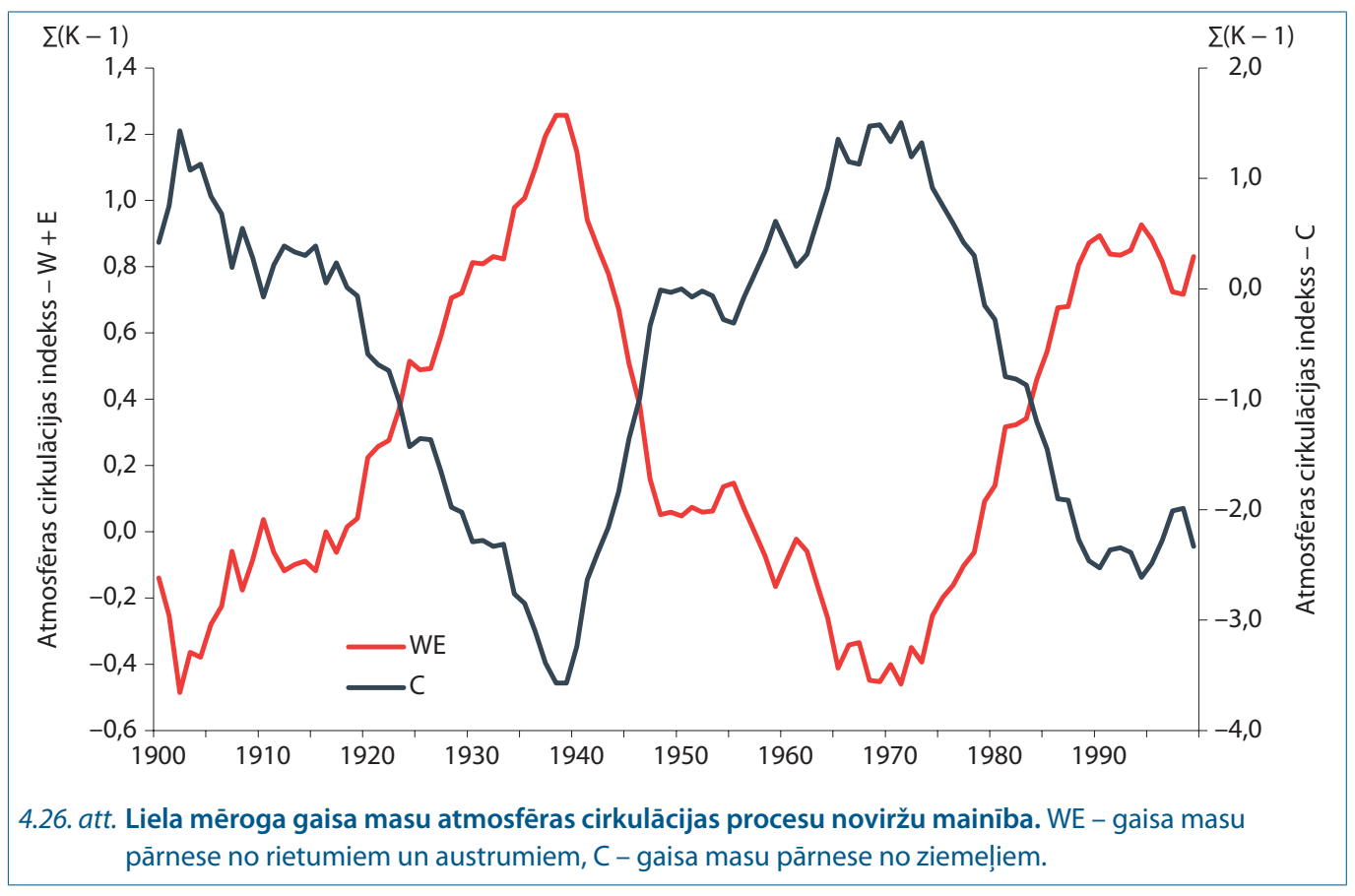

platumiem, starp Atlantijas okeānu un sauszemi un līdz ar to cikloniskās rietumu plūsmas izpausmes. Atkarībā no gadalaika, bāriskās sistēmas, diennakts laika un citiem faktoriem katrs gaisa masas tips var veidot atškirīgus laikapstāklus.

Šāda mainība var ietekmēt ne tikai laikapstākḷus, bet arī klimatu ilgākā laika periodā. Dominējošie liela mēroga atmosfēras gaisa masu cirkulācijas procesi - gaisa masu zonālā pārnese, galvenokārt no rietumiem (W) un austrumiem (E) vai arī gaisa masu meridionālā pārnese, galvenokārt no ziemel̦iem (C), ko apraksta atmosfēras cirkulācijas indekss (sk. 4.26. att.). Atmosfēras cirkulācijas indeksi, kas atspoguḷo gaisu masu pārneses variabilitāti, virs Latvijas pēdējā gadsimta laikā ir izteikti mainījušies, tādējādi ietekmējot laikapstākḷus. Piemēram, arktisko gaisu masu pārneses dominēšana noteica aukstās ziemas 20. gs. 40. gados. Gaisa masu pārneses izmaiṇas būtiski ietekmē klimatu, piemēram, tieši nokrišn,u daudzumu un upju noteci. Atmosfēras gaisa masu cirkulāciju lıti lielā mērā ietekmē arī dabiski norisoši procesi, tomēr ir pierādīts, ka arī cilvēka darbība var mainīt tās raksturu.

\subsection{Klimata pārmaiṇu ietekme uz Latvijas upju hidroloǵisko režīmu}

Klimata mainības rakstura novērtēšanai ir svarīgi analizēt klimata mainības rādītājus dažādos telpiskos un laika mērogos, jo tikai tā var iegūt izpratni par mainības raksturu. Izpratne par klimata mainību ir būtiska, lai izprastu globāli norisošo procesu raksturu un precizētu globālos klimata model̦us, kā arī lai tālāk attīstītu dabas vidē norisošo procesu pētījumus. Klimata mainības pētījumi Latvijas apstākḷos var sniegt nozīmīgu informāciju, jo novērojumi dabā daudzos gadījumos veikti jau ilgu laiku, bet galveno klimata raksturojošo rādītāju regulāri novērojumi (monitorings) visā Latvijā notiek kopš 20. gadsimta 20. gadiem. 
Atsevišksi parametri, piemēram, ledus iešanas sākums Daugavā, atzīmēts jau kopš 1536. gada, bet neparastu dabas parādību apraksti atrodami jau vissenākajās hronikās par Latviju. Vēsturiskos avotos aprakstītie dabas apstākḷi Baltijā un Latvijā vairāk nekā 900 gadu garumā sniedz ieskatu par neparastām ziemām, pavasariem, vasarām un rudeñiem, par katastrofāliem plūdiem Daugavā un citās upēs, par lielu karstumu un neiedomājamu sausumu, kad izžūst upes un akas, deg meži un purvi, kad lietus nepārtraukti līst mēnešiem ilgi, vai arī ziemā snieg un puteño 1-2 mēnešus, kad visi sējumi izsalst pavasarī vai vasaras sākumā ap Jāṇu dienu, vai arī noslīkst vasaras un rudens lietavās un iestājas ilgstošs bads bez maizes visā Baltijā, kad katrā gadsimtā sevišksi bargās ziemās vairākas reizes aizsalst Baltijas jūra un cilvēki no Dānijas, Vācijas un Polijas kājām vai ar ragavām ceḷo uz Zviedriju un Somiju, arī uz Baltiju un atpakal, jo pa ledu ir vieglāk pārvietoties nekā pa aizputinātiem laukiem un mežiem.

Klimata pārmaiṇas būtiski ietekmē virszemes un pazemes ūdeñu hidroloǵisko režìmu. Pieaugot nokrišn,u daudzumam, palielinās upju notece. Ar vārdu "notece" tiek apzīmēts ūdens daudzums, kas plūst pa zemes virsmu, kā arī pa augsni un iežu slānniem. Notece ir ūdens aprites sauszemes posms dabā. Atbilstoši tam izdala virszemes noteci, augsnes noteci un pazemes noteci, kas kopumā veido upju noteci. Noteci var raksturot ar caurplūdumu $\mathrm{m}^{3} / \mathrm{s}$ vai mazās

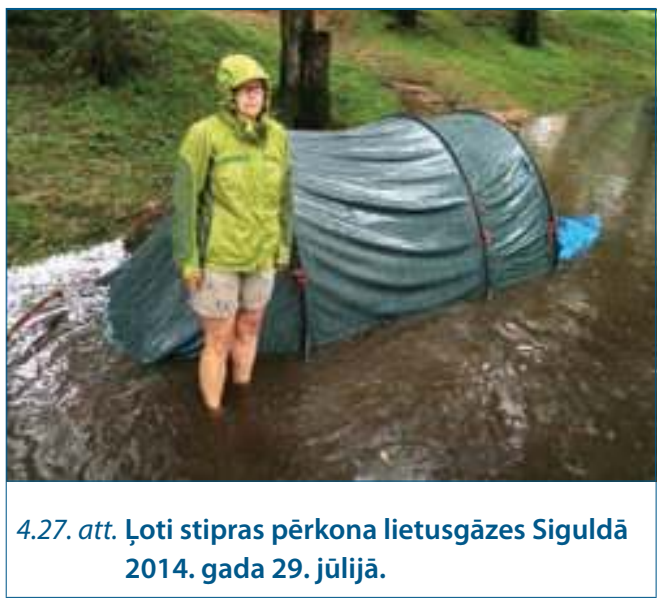

upēs arī L/s, ar noteces apjomu $\mathrm{m}^{3}$, noteces slāni $\mathrm{mm}$, noteces moduli un noteces koeficientu.

Temperatūras pieaugums ietekmē iztvaikošanas procesus un līdz ar to sekmē upju noteces samazināšanos vai arī ezeru ūdens līmeña pazemināšanos. Tāpat gaisa temperatūra ir viens no galvenajiem faktoriem, kas ietekmē upju un ezeru ledus režīmu. Klimata pārmaiñas var būtiski ietekmēt arī ekstremālās dabas parādības, piemēram, plūdus, kuru cēlonis var būt strauja sniega segas kušana pavasarī, kā arī intensīvas lietavas vasaras vai rudens periodā (sk. 4.27. att.).

Ne mazāk nozīmīgas var būt ilgstoša sausuma radītās ietekmes. Gan ūden,u režìma, gan arī ekstremālo parādību ietekmes var būtiski iespaidot iedzīvotājus, tautsaimniecību, lauksaimniecisko ražošanu un hidroenerǵētiku (sk. 4.28. att.).

Klimata pārmaingu ietekmi uz ūdeñiem var analizēt, izmantojot upju caurplūdumu un ezeru līmeṇu ilglaicīgās izmaiñas un to savstarpējo saistību ar gaisa temperatūras un nokrišņu mainības raksturu.

Gaisa masu pārnesei no Atlantijas okeāna ir liela nozīme nokrišṇu daudzuma sadalījumā un līdz ar to arī upju noteces režīmā ar periodiski mainīgu raksturu (sk. 4.29. att.).

Upju caurplūduma mainību nosaka gan ilgtermiṇa mainības raksturs, gan arī sezonāli norisošu procesu ievērojamās atškirības (sk. 4.30. att.). Piemēram, upes caurplūduma

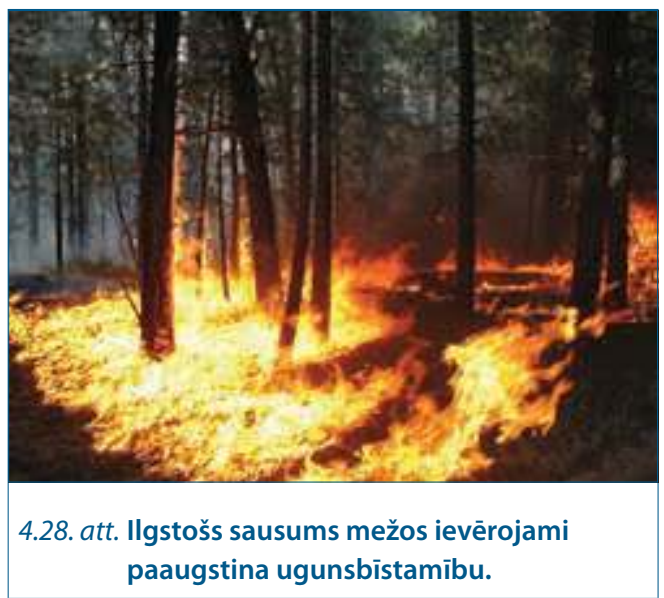


atkarība no sezonāli norisošiem procesiem, plūdu un mazūdens periodu ietekmes apgrūtina mainības tendences izvērtēšanu. Lai analizētu upju režìma mainības raksturu, parasti var izmantot gada vidējo upju caurplūduma vērtību, datus statistiski apstrādājot.
Izmantojot datu apstrādes metodes, redzams, ka upju caurplūdumu (gan Latvijas lielākajām upēm, gan arī pēc noteces apjoma vidējām upēm) raksturo ne tikai augsta caurplūduma sezonālā mainība, bet arī izteikta mazūdens jeb zema ūdens periodu nomainga ar laika

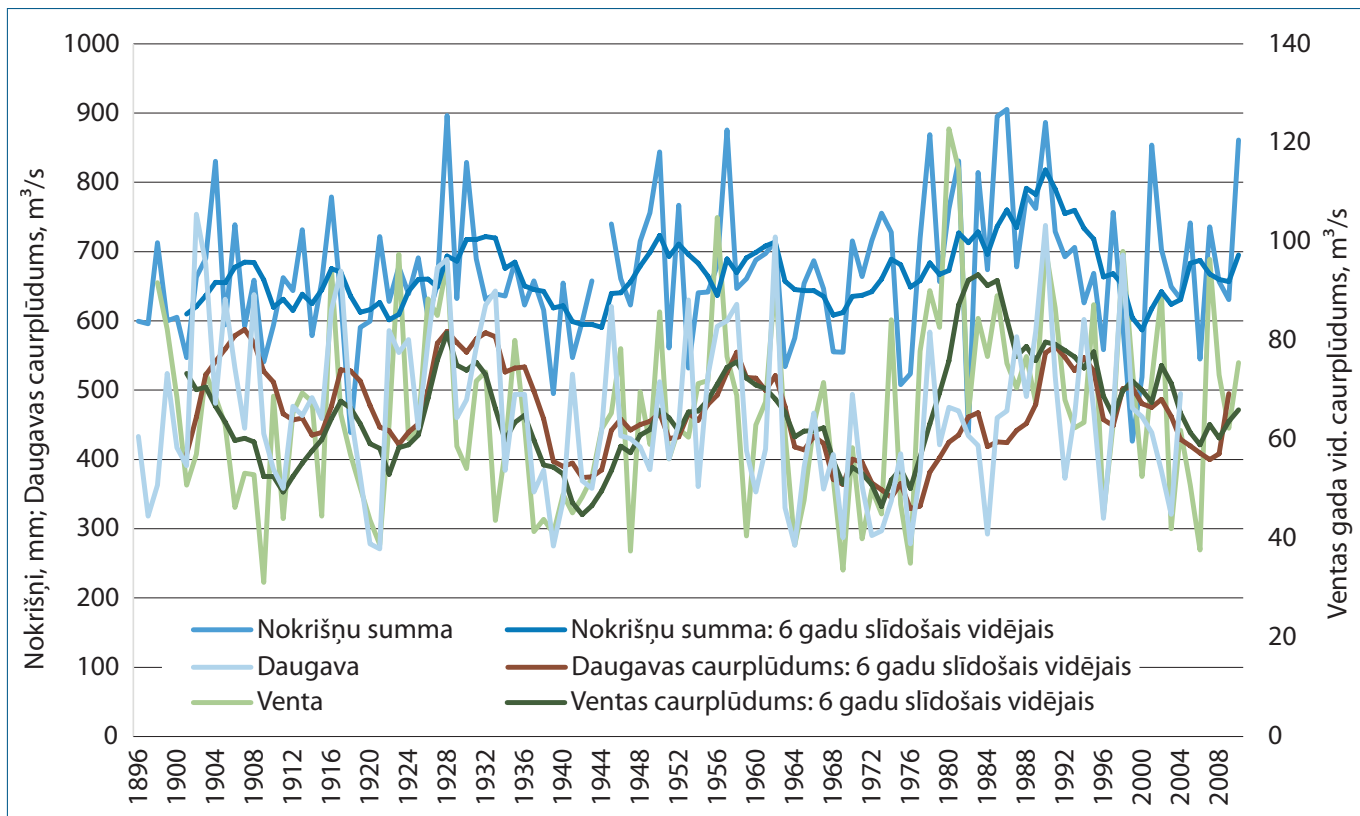

4.29. att. Kopsakarības starp nokrišņu daudzumu un Ventas un Daugavas gada vidējo mēneša caurplūdumu.

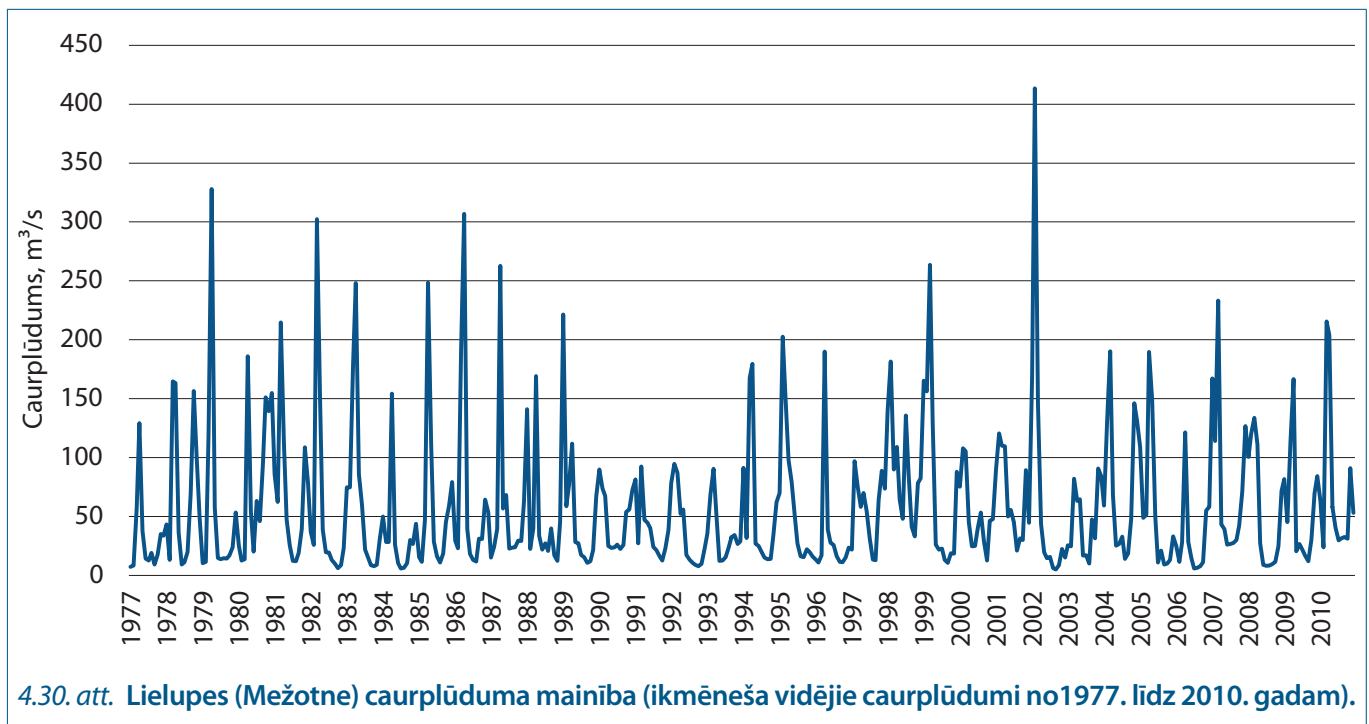


posmiem, kuros upju caurplūdums ir izteikti lielāks (sk. 4.31. att.). Augstūdens un mazūdens periodu mainības raksturs ir izteikts visām Latvijas upēm sezonālā un ilggadīgā skatījumā, bet gadījumos, kad to sateces baseinā novērojamas būtiskas upes hidroloǵiskā režìma izmainas (hidrotehniskās būves, zemes lietojuma rakstura izmainnas, piemēram, Lielupes baseinā), caurplūdumi var ievērojami atškkirties. Šāds mainības raksturs parāda upju caurplūdumu izmaiṇu vispārējās tendences un laika periodu, kurā vidējie caurplūdumi ir relatīvi augsti vai zemi.

Latvijas lielāko upju gada noteces izmaiņas visā novērojuma periodā ir apkopotas
4.7. tabulā un 4.31. attēlā. Noteces līknes indicē ne tikai iekšgada svārstības, bet arī noteces veidošanās īpatnības noteiktos hidrologiskajos reǵionos, kā arī to saistību ar klimatisko situāciju 130 gadu ilgā laika posmā. Upju ūdens noteces integrālās līknes l̦auj saskatīt ilglaicīgākus ciklus svārstībām nekā datu lineārā analīze, izmantojot vidējos slīdošos lielumus periodu identificēšanai.

Latvijas upēs atšksirības starp caurplūdumiem augstūdens un mazūdens periodos var veidot pat līdz 15-20\% no vidējām caurplūdumu vērtībām, bet periodu ilgums jeb cikliskums, kurā viens tipiskais upes režìms

4.7. tabula. Mazūdens un augstas noteces periodu mainība Latvijas lielākajām upēm

\begin{tabular}{|c|c|c|c|c|c|c|c|}
\hline $\begin{array}{c}\text { Zemas noteces } \\
\text { periodi }\end{array}$ & $\begin{array}{l}\text { Ilgums, } \\
\text { gadi }\end{array}$ & $\mathrm{Q}_{\mathrm{vid}, l} \mathrm{~m}^{3} / \mathrm{s}$ & $\mathbf{K}^{*}$ & $\begin{array}{c}\text { Augstas noteces } \\
\text { periodi }\end{array}$ & $\begin{array}{l}\text { Ilgums, } \\
\text { gadi }\end{array}$ & $\mathbf{Q}_{\text {vid, }} \mathrm{m}^{3} / \mathrm{s}$ & K \\
\hline \multicolumn{8}{|c|}{ Daugava (1881-2010) } \\
\hline 1881-1901 & 21 & 401 & 0,88 & 1902-1908 & 7 & 595 & 1,31 \\
\hline 1909-1921 & 13 & 442 & 0,97 & $1922-1936$ & 15 & 549 & 1,21 \\
\hline 1937-1952 & 16 & 419 & 0,92 & $1953-1958$ & 6 & 555 & 1,22 \\
\hline 1959-1985 & 27 & 401 & 0,88 & 1986-2010 & 25 & 490 & 1,08 \\
\hline \multicolumn{8}{|c|}{ Venta (1897-2010) } \\
\hline 1900-1923 & 24 & 60,2 & 0,92 & 1924-1930 & 7 & 72,1 & 1,10 \\
\hline 1931-1949 & 19 & 57,0 & 0,87 & 1950-1959 & 10 & 69,9 & 1,07 \\
\hline 1960-1977 & 18 & 57,1 & 0,88 & 1978-2002 & 25 & 79,1 & 1,21 \\
\hline $2003-2010$ & 8 & 60,6 & 0,93 & & & & \\
\hline \multicolumn{8}{|c|}{ Salaca (1927-2010) } \\
\hline $1933-1952$ & 20 & 25,6 & 0,82 & 1927-1932 & 6 & 44,9 & 1,44 \\
\hline 1963-1976 & 14 & 22,4 & 0,72 & 1953-1962 & 10 & 34,6 & 1,14 \\
\hline & & & & 1977-2010 & 34 & 34,9 & 1,12 \\
\hline \multicolumn{8}{|c|}{ Gauja (1940-2010) } \\
\hline 1940-1952 & 13 & 62,5 & 0,88 & 1953-1962 & 10 & 84,5 & 1,21 \\
\hline 1963-1977 & 15 & 55,8 & 0,79 & 1978-1999 & 27 & 77,4 & 1,10 \\
\hline 2000-2007 & 8 & 64,4 & 0,91 & $2008-2010$ & 3 & 86,2 & 1,22 \\
\hline \multicolumn{8}{|c|}{ Lielupe (1921-2010) } \\
\hline 1933-1942 & 10 & 49,4 & 0,89 & 1921-1932 & 12 & 71,9 & 1,27 \\
\hline 1963-1977 & 15 & 39,8 & 0,71 & 1943-1962 & 20 & 61,8 & 1,10 \\
\hline \multirow[t]{2}{*}{ 1984-1997 } & 14 & 48,9 & 0,87 & 1978-1983 & 6 & 66,3 & 1,18 \\
\hline & & & & 1998-2010 & 13 & 63,0 & 1,12 \\
\hline
\end{tabular}

* K (noteces modulis) - vidējā caurplūduma visā novērojuma periodā attiecība pret vidējo caurplūdumu konkrētajā gadā. 


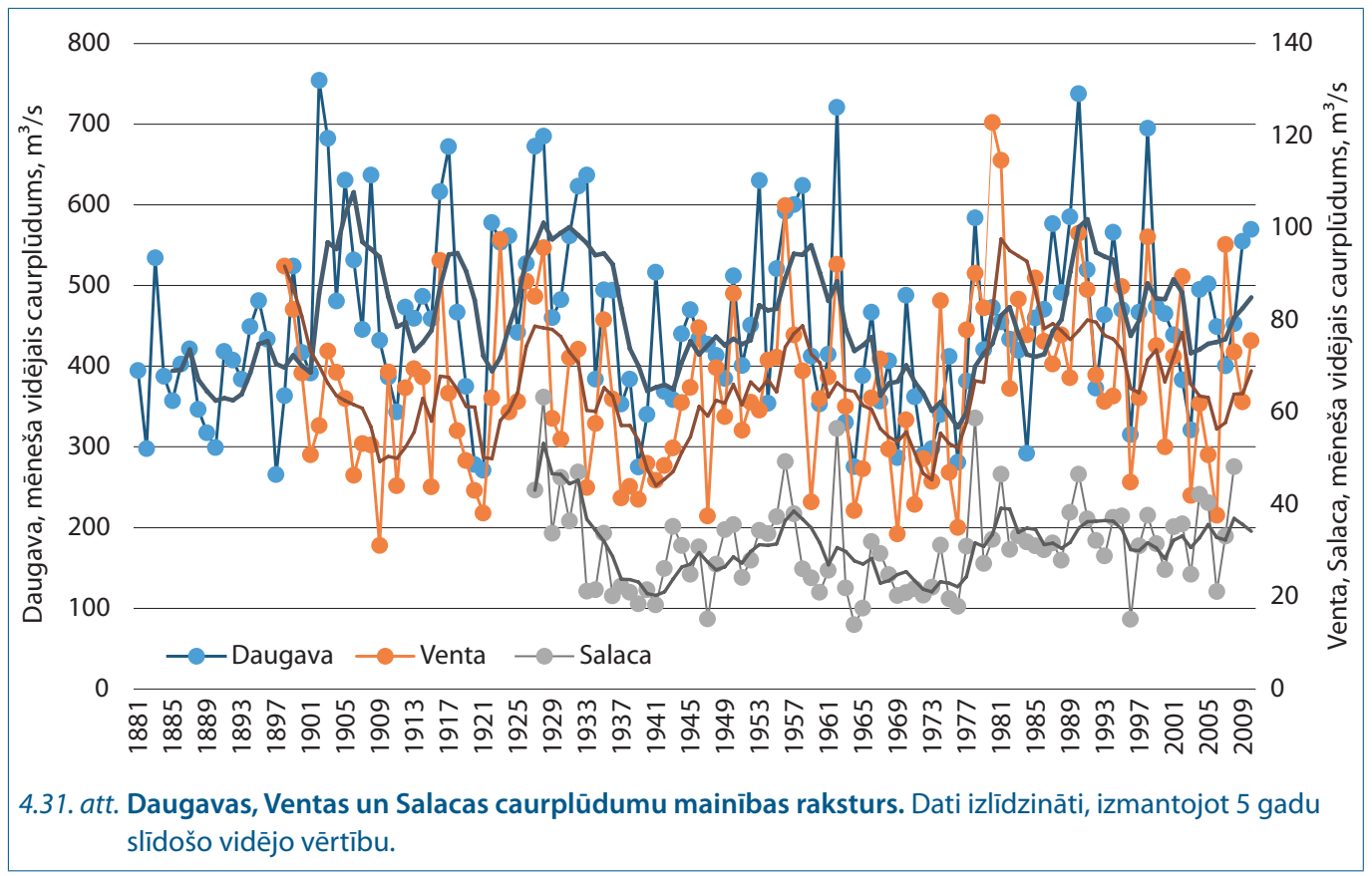

nomaina citu, ir no 6 līdz 34 gadiem (sk. 4.7. tabulu). Ja no 20. gs. pirmās puses un līdz 20. gs. vidum šie cikli vairāk vai mazāk sakrita visām upēm, tad, sākot no 20. gs. septingdesmitiem gadiem, perioda ilgums un sinhronitāte visu upju cikliem vairs nesakrīt. Piemēram, Gaujai, Ventai un Salacai no 1976. līdz 1977. gadam un Daugavai no 1986. gada iezīmējās augstas noteces periods ar ilgumu 25-34 gadi, savukārt, Lielupei augstas noteces periods ilga tikai no 1978. līdz 1983. gadam ( 6 gadi) un to nomainīja 14 gadu ilgs zemas noteces periods (1998.-2010. gads). Šo minēto ciklu iekšienē iezīmējas arī mazi (līdz 3 gadiem) periodi, kuriem raksturīga noteces samazināšanās vai pieaugums. Iespējams, ka to nosaka klimatiskā un hidrologiiskā ziṇā anomāli gadi, kuru biežums pēdējās četrās desmitgadēs ir ievērojami pieaudzis.

Tāpat kā citu meteorologisko parametru gadījumā, arī upju hidrologisko režīmu būtiski ietekmē sezonāli norisošie procesi. Caurplūdumu mainība ir būtiski atkarīga no gada sezonas: caurplūdumu pieaugums ir būtisks un statistiski ticams kopumā visām piecām upēm ziemas mēnešos - februārī, janvārī (izṇemot Daugavu, kur redzama izteikta pieauguma tendence, bet tā nav statistiski nozīmīga), kā arī Gaujai un Lielupei decembrī. Savukārt pavasara sezonā pieaugums attiecas tikai uz marta mēnesi (iznemot Ventu, kur redzama izteikta pieauguma tendence, bet tā nav statistiski nozīmīga). Savukārt, aprīlī visām upēm (izṇemot Salacu), un maijā tikai Daugavai caurplūdumu samazinājums ir būtisks un statistiski ticams (sk. 4.32. att.). Šāds upju noteces mainības raksturs sakrīt ar temperatūras, atmosfēras nokrišnu un ledus segas mainības sezonālo raksturu. Proti - rudens, ziemas, pavasara sezonā paaugstinās gaisa temperatūra, pieaug nokrišnu daudzums, īpaši Latvijas rietumu dal̦ā esošajām upēm, vēlāk notiek ledus segas veidošanās un ātrāk sākas ledus iešana. Pavasara, vasaras sezonā caurplūdumi palielinās Ventā un Lielupē, bet pārējos reǵionos upju noteces procesi būtiski nemainās. Arī Daugavā caurplūdumi ziemā pieaug ievērojami straujāk nekā vasarā, kad caurplūdumi novērojumu laikā nav mainījušies. Ziemas caurplūdumi īpaši būtiski ir palielinājušies pēdējo gadu desmitu laikā. 


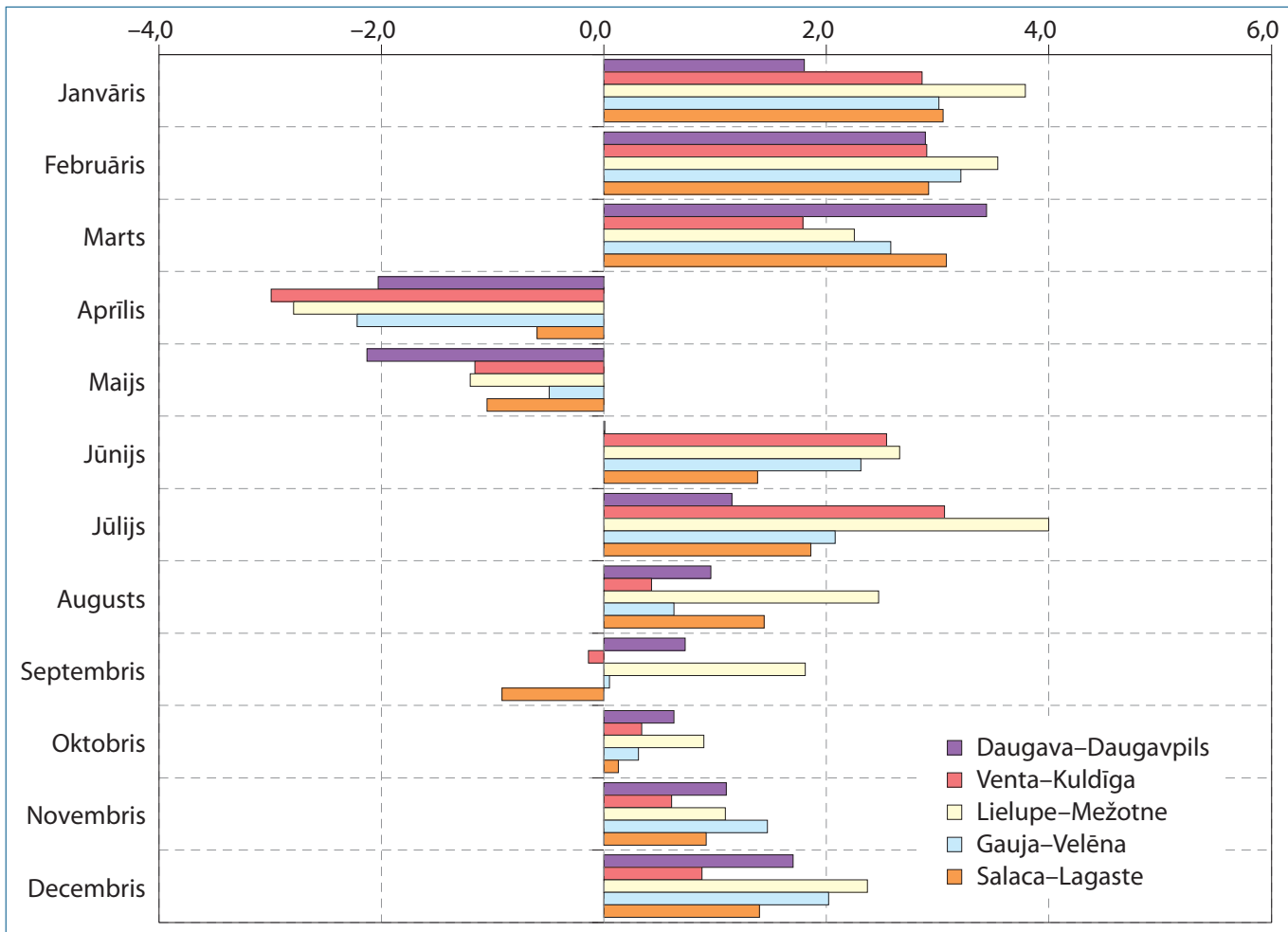

4.32. att. Mēneša vidējo caurplūdumu mainības tendences Latvijas upēm (1951.-2010. gads) pēc Manna-Kendala testa vērtībām.

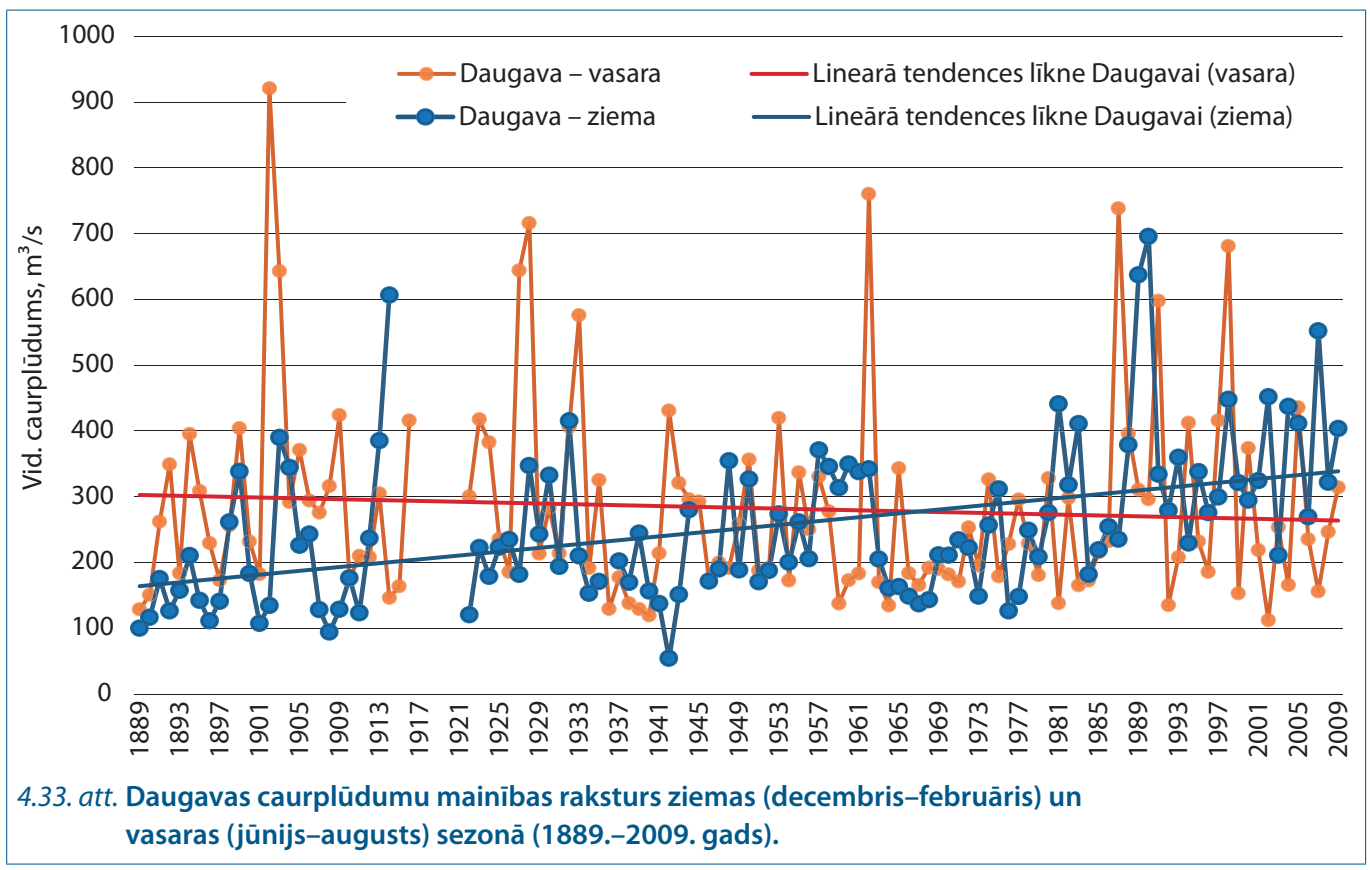


Kopumā var uzskatīt, ka upju noteces mainības raksturu nosaka galvenokārt dabiski norisoši procesi, tomēr upju noteces režīma izmaiṇas neapšaubāmi ir saistītas ar klimata mainību, kā tas redzams, analizējot gada noteces mainību (sk. 4.7. tabulu, 4.31. att.). Līdz ar to var teikt, ka klimata pārmaiṇas Latvijā ietekmē ne tikai noteces ilgterminna mainības procesu, bet arī sezonālās noteces rakstura izmaiñas, kas ir saistāmas ar izteiktu noteces pieaugumu ziemā (sk. 4.33. att.), tādējādi, iespējams, ietekmējot arī augstūdens/mazūdens periodu cikliskumu.

Cits būtisks klimata mainības rādītājs ir ekstremālu klimatisku parādību biežums. Upju gadījumā īpaši nozīmīgi ir plūdi, vispirms jau ñemot vērā to radītos materiālos zaudējumus. Ja Daugavā vidējais caurplūdums ir $450 \mathrm{~m}^{3} / \mathrm{s}$, tad plūdu apstākḷıs tas var sasniegt vairāk nekā $6000 \mathrm{~m}^{3} / \mathrm{s}$ (sk. 4.34. att.). Pēdējā laikā augsti caurplūdumi ir kḷuvuši ievērojami retāki. Līdzīga tendence raksturīga arī citām Latvijas upēm, arī to minimālie caurplūdumi ir pieauguši, bet maksimālie - samazinājušies.

Pètījumā par klimata pārmaiṇu ietekmi uz Latvijas upju hidroloǵisko režīmu ir apstiprinājies pierādījums, ka globālās klimata pārmainas pēdējos gadu desmitus ir noteikušas arī ilgtermiṇa un sezonālās izmaiṇas Latvijas upju notecē, novērojot būtiskas izmaiña upju hidrogrāfos tieši ziemas un pavasara sezonās. Pētījuma periodā no 1951. līdz 1987. gadam (sk. 4.35. att.), kas ir uzskatāms kā periods bez būtiskām klimata pārmainu iezīmēm, upēs no gada kopējās noteces lielākais apjoms veidojās pavasara sezonās (37-52\%) ar lielāko caurplūdumu līdz 30\% tieši aprīḷa mēnesī, pēc tam ziemas notece (17-30\%), rudens notece $(17-25 \%)$ un vasaras notece (9-14\%) Zemākais caurplūdums bijis jūlijā un augustā (24\%). Savukārt pēdējās desmitgades iezīmējās ar sezonālām izmaiṇām upes kopējā notecē. Vidējos platuma grādos, kur hidrologisko režīmu galvenokārt nosaka sniega uzkrāšanās un kušana, tiek novērotas būtiskas izmaiñas noteces režīmā tieši ziemas un pavasara sezonās. Lai arī pētījuma rezultāti periodam no 1988. līdz 2009. gadam rāda, ka no kopējās noteces lielākais noteces apjoms joprojām veidojas pavasara sezonā, tomēr ir konstatēta izteikta tendence notecei palielināties janvārī un februārī un samazināties aprīlī un maijā (sk. 4.36. att.).

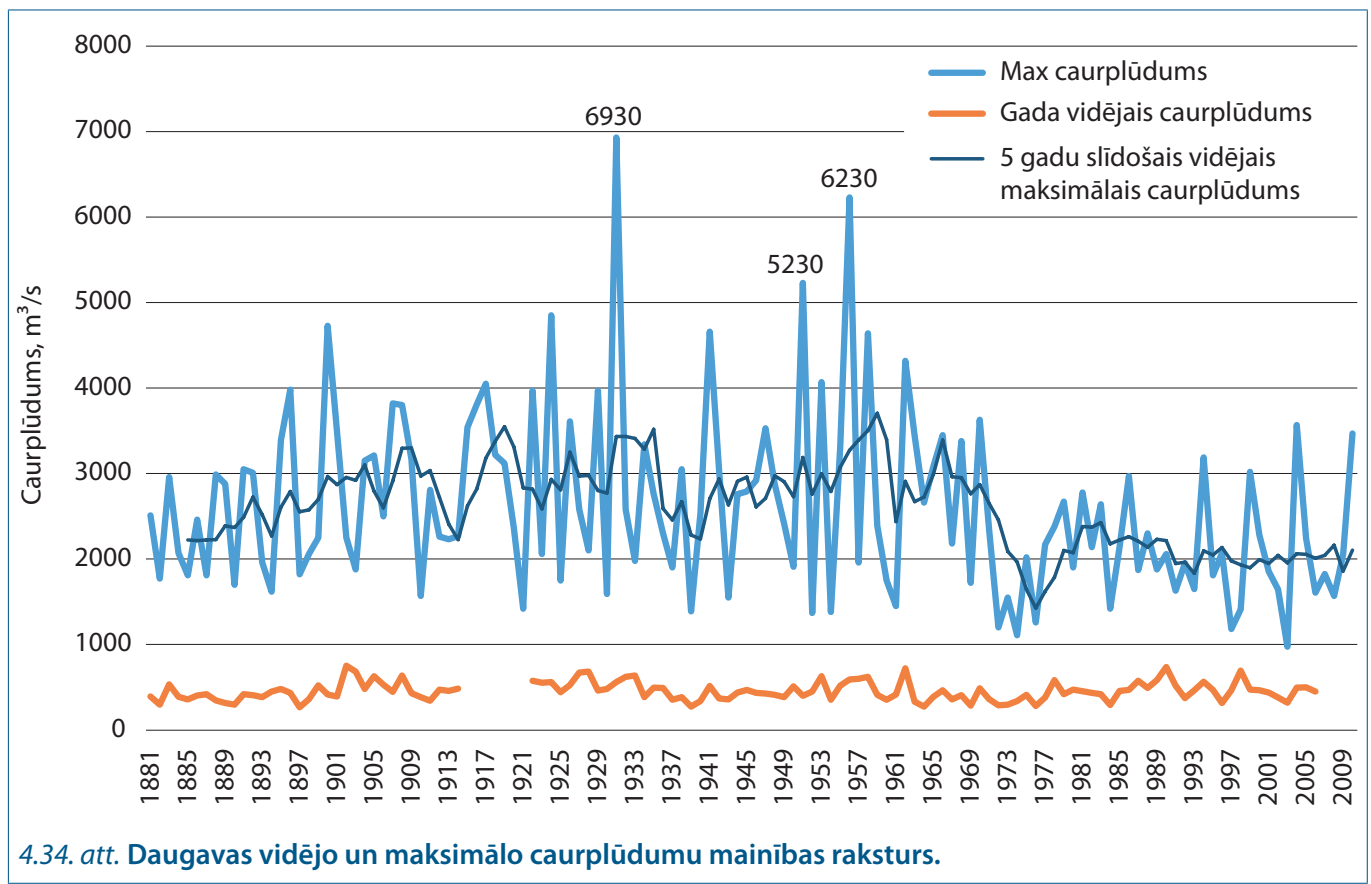


Lai vērtētu klimata mainību un vidē norisošos procesus, kā arī to likumsakarības, nepieciešams analizēt dažāda veida aspektus. Dati par upju ledus sasalšanu un atkušanu, kā arī izmaiñām ledus segas biezumā l̦auj novērtēt ilgtermiṇa un sezonālo klimata mainīgumu, jo tieši gaisa temperatūra ir viens no galvenajiem faktoriem, kas būtiski ietekmē ledus režīma izmaiñas. Ir pētījumi, kas pierādījuši, ka gaisa temperatūras pieaugums ziemas sezonā statistiski nozīmīgi izskaidro $60-70 \%$ gadījumu izmainas ledus režīmā.
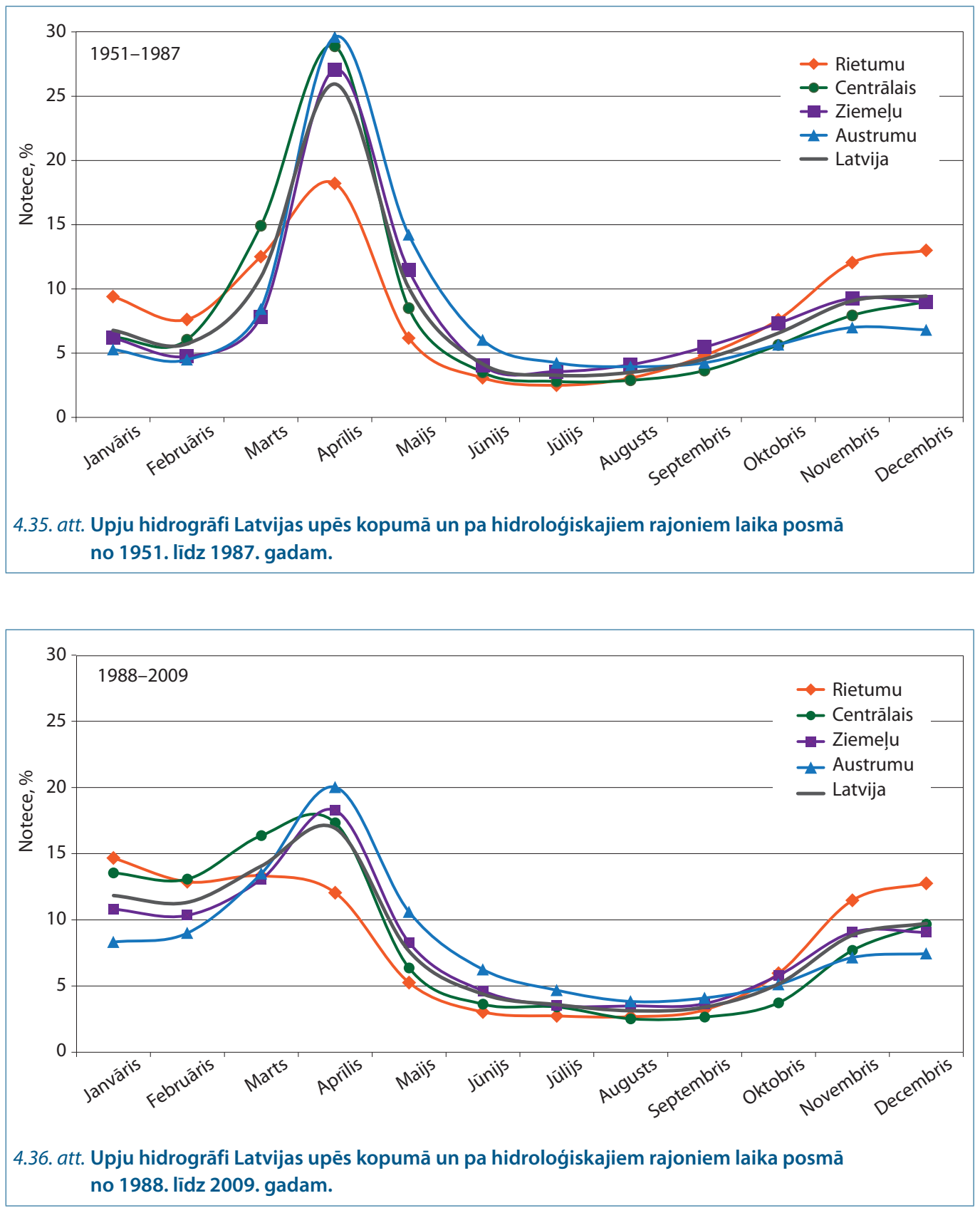
Ledus režīma pētījumi ir svarīgi triju iemeslu dēl̦:

- jau pirms instrumentālo novērojumu veikšanas Latvijā ir reǵistrēti daudzu upju un arī atseviš̌su ezeru aizsalšanas un atkušanas datumi, kas netieši l̦auj spriest par konkrētās ziemas bargumu. Tādējādi šie klimatu raksturojošie dati ir pieejami ilgāku laika periodu nekā dati par meteorologiskajiem parametriem pēc instrumentālajiem mērījumiem;

- ledus režīms ietekmē hidrologisko režīmu akumulēto atmosfēras nokrišnu maksimālās noteces laikā;

- ledus režīms ir izmantojams kā precīzs un objektîvs klimata mainības indikators.

Ledus segas izveidošanās vai ledus iešanas sākšanās ir viens no rādītājiem, kas ir vissenāk dokumentēts. Arī Rīgas saimnieciskā dzīve kā ostas pilsētai un tirdzniecības centram bija atkarīga no tā, vai Daugavas ūden,i bija izmantojami kuǵošanai. Tāpēc ledus iešanas sākumu Daugavā sākts atzīmēt jau vairāk nekā pirms piecsimt gadiem. Ledus iešanas sākuma laikam Daugavā raksturīga liela mainība (sk. 4.37. att.). Izteikta tendence agrākam ledus iešanas sākumam Daugavā ir novērota kopš 19. gs. 60. gadiem, pirms šī perioda tendences izmaiñas ir nenozīmīgas.

Par būtiskiem faktoriem, kas ietekmē ledus režīmu iekšzemes ūden,os, var uzskatīt gaisa temperatūru, nokrišņu daudzumu un vēja ātrumu (īpaši stiprās vētras). Pastāv tieša saikne starp temperatūru un ledus režìmu upēs. Lai notiku ledus segas izveidošanās, viens no galvenajiem priekšnosacījumiem ir negatīvas gaisa temperatūras, taču, ja negatīvās gaisa temperatūras ziemas laikā samazinās, tad būtiski tiek ietekmēts ledus režīms un ledstāves ilgums upēs (sk. 4.38. att.) samazinās un atseviškos gados ledus var neizveidoties nemaz. Ledus iešanas sākuma laika datumiem upēs ir tendence kḷūt agrākiem, tāpēc ātrāk sākas arī pali, kas izskaidro ziemas sezonas ūdens noteces palielināšanos Latvijas upēs.

Ledstāves ilgums Latvijas lielākajās upēs laika periodā no 20. gs. 20. gadiem līdz 2000. gadam ir samazinājies par 2,8-5,1 dienām 10 gados un par 6-15 dienām 10 gados laika periodā no 1945. līdz 2012. gadam. Sākot ar 20. gs. 70. gadiem arvien vairāk ir sastopami gadỉjumi, kad ledus sega uz upēm vispār neizveidojas (tieši Latvijas rietumdal̦ā).

\subsection{0. lespējamās klimata pārmaiṇas Latvijā 21. gadsimta laikā}

Klimats visos laika periodos ir bijis mainīgs, un viens no iemesliem, kas to nosaka, ir klimatisko parametru cikliskums. Jāuzsver, ka atškkirīga ir bijusi klimatisko rādītāju izmain,u amplitūda. Mūsdienās satraukumu rada fakts, ka klimata pārmaiṇas ir intensificējušās, ko visticamāk nosaka cilvēka saimnieciskā darbība. Piemēram, globālā mērogā deviṇi no desmit siltākajiem gadiem kopš 1880 . gada ir novēroti 21. gadsimtā. Globālā vidējā temperatūra šajā periodā ir pieaugusi par $0,8^{\circ} \mathrm{C}$. Tāpēc mūsdienās īpaši aktuāli ir jautājumi par to, kāds klimats Latvijā būs tuvā un tālā nākotnē. Atbildi uz šo jautājumu, kaut arī ar zināmu nenoteiktību, var sniegt klimata nākotnes model̦i.
Klimata modelēšana paver iespējas prognozēt klimata mainības raksturu nākotnē. Par pamatu klimata mainības modelēšanai tiek izmantoti globālie atmosfēras cirkulācijas model̦i, kuri savukārt izveidoti saskaṇā ar iespējamiem siltumnīcefekta gāzu emisijas izmaiṇu scenārijiem. Baltijas jūras reǵionā reǵionālie klimata mainības scenāriji izstrādāti Zviedrijā (Zviedrijas Meteoroloǵijas un hidroloǵijas institūts) projekta SWECLIM ietvaros, Vācijā (Potsdamas Klimata mainības institūts) un Somijā (Somijas Vides institūts). Reǵionālajos klimata mainības modelıos ir iekḷauta arī Latvijas teritorija. Tie l̦auj novērtēt mainību tādiem klimata rādītājiem kā gaisa vidējā temperatūra, diennakts maksimālā 

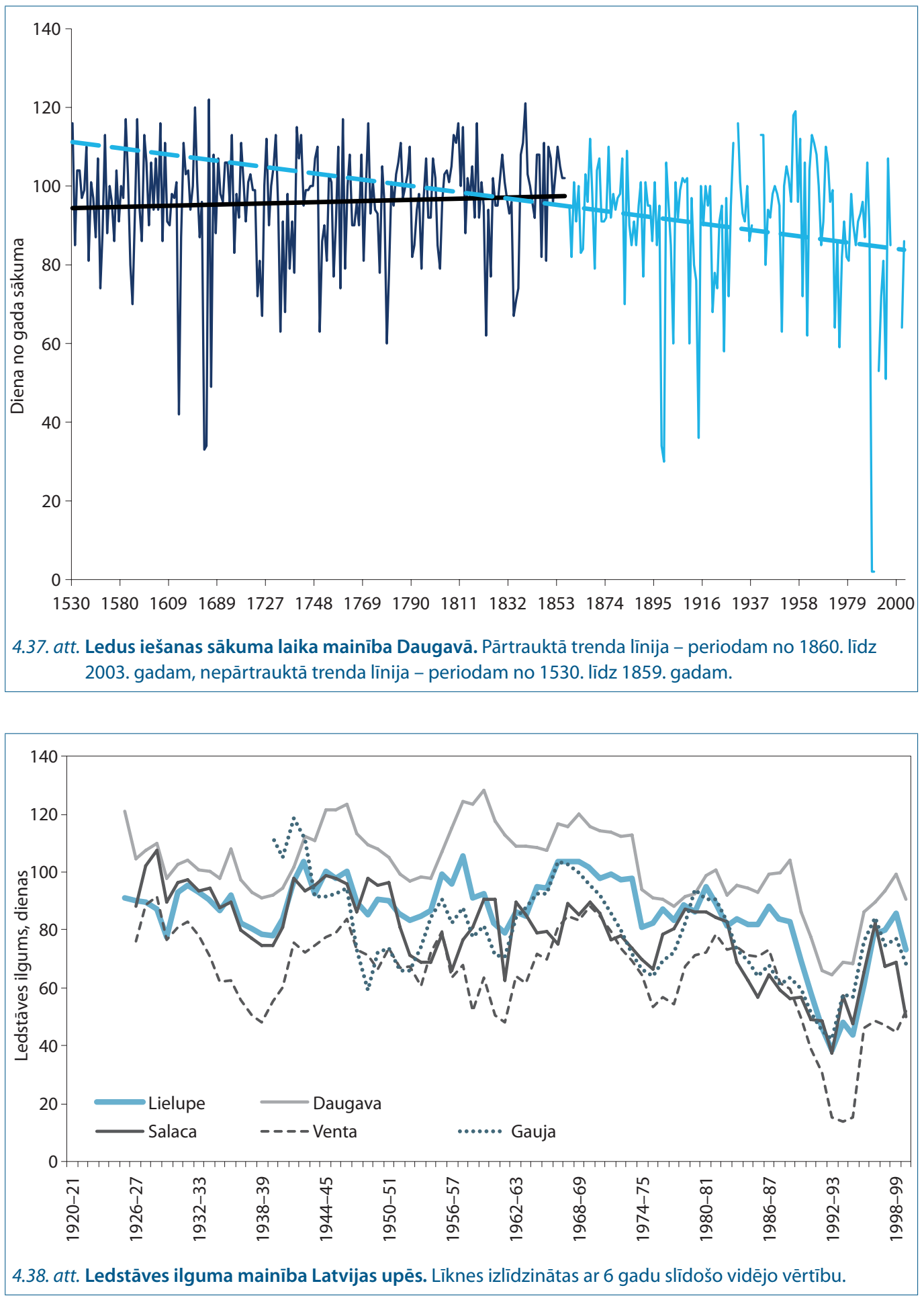
temperatūra, nokrišņu daudzums, Saules spīdēšanas ilgums, notece un citi. Izstrādātie klimata mainības model̦i l̦auj novērtēt ne tikai klimata mainības vidējotās vērtības, bet arī ekstremālo dabas parādību varbūtību un to mainību pētītajā laika posmā, kas parasti ir līdz 2100. gadam. Tā kā Baltijas reǵiona klimata mainības modelii izstrādāti, izmantojot globālos atmosfēras cirkulācijas modeḷus, uz to pamata izdarītie secinājumi par globālās sasilšanas raksturu nav pretrunā ar modeliem, kas raksturo globāli norisošos procesus. Ja globālajos model̦os Latvijas teritorija aptver tikai vienu vai dažas zemes virsmas platības vienības (šūnas), tad reǵionālajos modelıos jau iespējams izsekot klimata mainības raksturam visā Latvijas teritorijā.

Reǵionālie klimata mainības model̦i aprobēti, pārbaudot to sniegto klimata raksturojumu salīdzinājumā ar novērotajiem datiem, un līdz ar to tie ievērojami precīzāk atspoguḷo Latvijas teritorijā norisošos procesus. Nepieciešams uzsvērt, ka Zviedrijā, Somijā un arī Vācijā izstrādāto klimata mainības model̦u mērksis ir analizēt klimata mainības iespējamo raksturu šajās valstīs un viens no Latvijas zinātnieku būtiskiem uzdevumiem ir izveidot klimata mainības modeli, kas l̦autu novērtēt iespējamās klimata pārmainas Latvijas teritorijā nākotnē. Tomēr arī esošie klimata mainības model̦i l̦auj iegūt priekšstatu par klimata mainības raksturu un pamatot darbības, lai samazinātu siltumnīcefekta gāzu emisiju pieauguma radītās sekas, kā arī izstrādātu risinājumus, lai piemērotos klimata pārmain̄ām.

Zviedrijā izstrādātais klimata mainības modelis SWECLIM l̦auj novērtēt ikmēneša vidējās temperatūras mainības raksturu laika posmā līdz 2100. gadam. Kā redzams 4.39. attēlā, janvāra vidējā temperatūra līdz 2100. gadam būtiski mainīsies - Skandināvijas ziemeḷos tā var pieaugt par $\approx 10^{\circ} \mathrm{C}$, bet Latvijas teritorijā janvāra vidējā temperatūra, sākot no 2040. gada, var būt $0-5^{\circ} \mathrm{C}$, kas ir ievērojami augstāka nekā pašlaik. Tāpat būtiskas klimata izmain,as var raksturot gaisa temperatūru vasaras mēnešos (jūlijs, augusts).

Līdzīgu klimata mainības raksturu parāda arī Vācijā (Potsdamas Klimata mainības
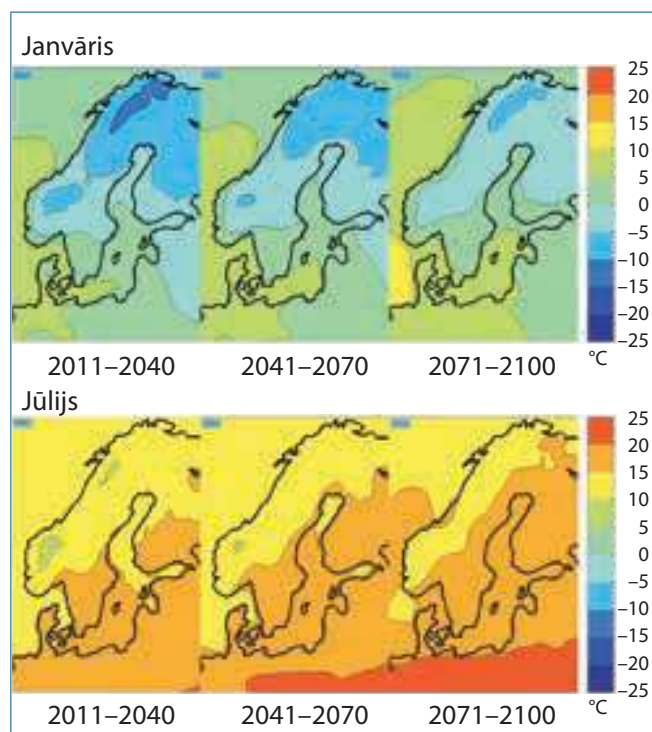

Augusts

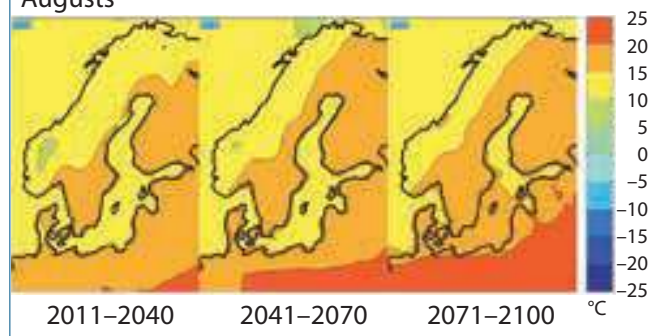

4.39. att. Mēneša vidējās temperatūras mainības raksturs Baltijas jūras reǵionā laikā līdz 2100. gadam, pēc klimata pārmainu scenārija A1B.

institūtā) izstrādātais klimata mainības modelis (sk. 4.40., 4.41. att.), kas izveidots atbilstoši klimata mainības scenārijam A2. Pēc šā model̦a laika posmā līdz 2100. gadam gada vidējā temperatūra salīdzinājumā ar gada vidējo temperatūru 2000 . gadā pieaugs par $5-7^{\circ} \mathrm{C}$.

Klimata mainības model̦i l̦auj novērtēt arī mēneša maksimālās temperatūras paaugstināšanos, un atbilstoši SWECLIM mainības modelim mēneša maksimālā temperatūra var paaugstināties par $6^{\circ} \mathrm{C}$, īpaši vasaras mēnešos var ievērojami palielināties maksimālo temperatūru biežums. Taču atbilstoši Potsdamas Klimata mainības institūta modelim gada maksimālā temperatūra var pieaugt pat par $+8^{\circ} \mathrm{C}$. 

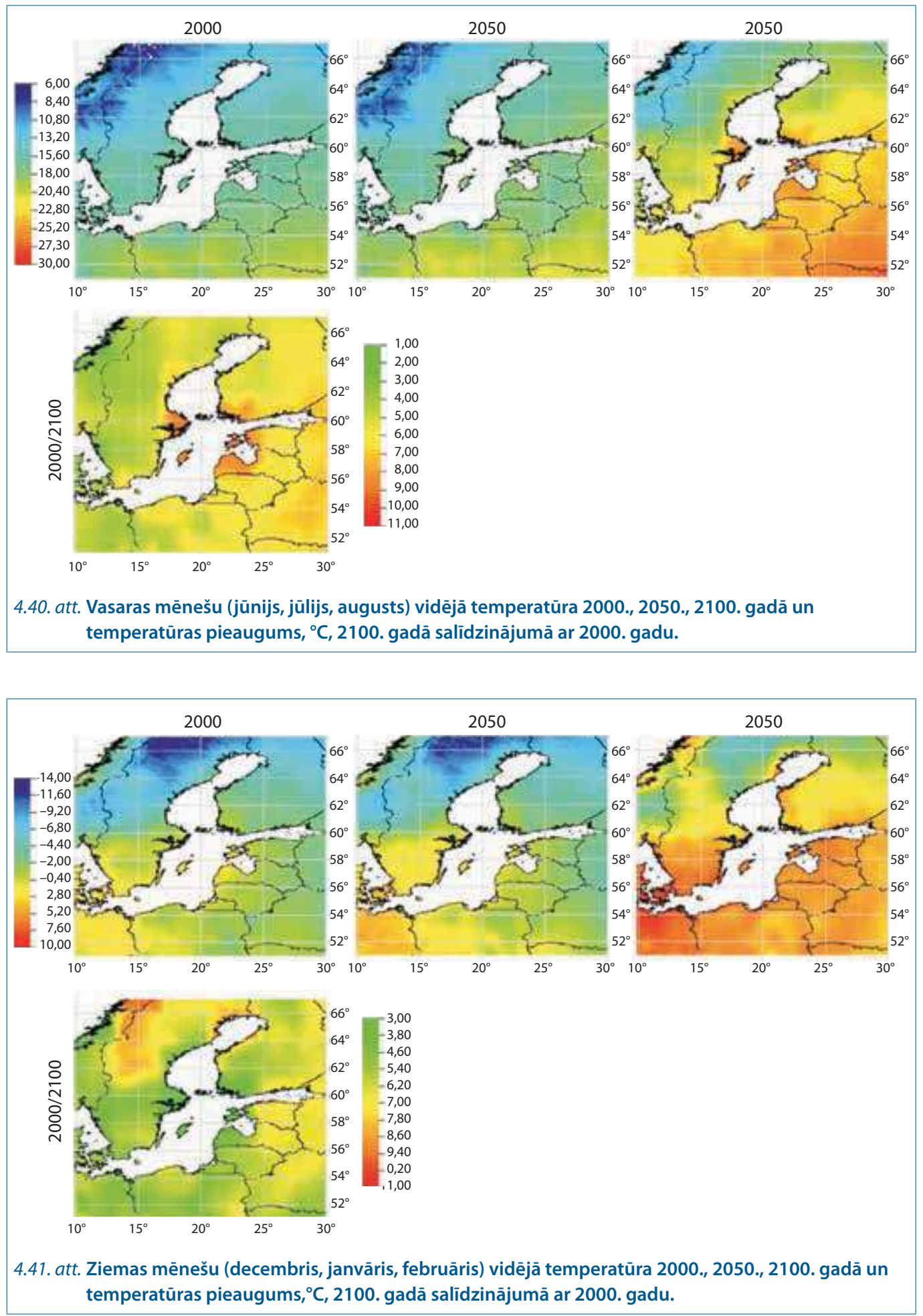
Respektīvi, biežāk var parādīties tā saucamie karstuma vilıni.

Citu klimata mainības parametru izmainnas atbilstoši izstrādātajiem model̦iem nav tik būtiskas. Piemēram, Saules spīdēšanas ilgums vasaras mēnešos, pēc SWECLIM model̦a, praktiski nemainīsies, bet pavasarī (piemēram, martā) tas var nedaudz samazināties (sk. 4.42. att.).

Izstrādātie klimata mainības model̦i paredz to, ka visai būtiski var mainīties klimats ziemas sezonā. Pēc SWECLIM klimata mainības modela, sniega segas biezums laikā līdz 2100. gadam būtiski samazināsies Skandināvijas valstīs un Somijā, bet Latvijā tipiskas var kḷūt bezsniega ziemas (sk. 4.43. att.). Arī ledus segas izveidošanās iekšējos ūden,os var nenotikt (4.44. att.). Šis klimata izmaiṇu veids var izrādīties īpaši būtisks Skandināvijas pussalas centrālajos rajonos un Somijā.

Modelēšanas rezultātā iegūtie dati par Latvijas upju noteces izmainām nākotnē pēc A2 un B2 scenārija paredz, ka gada griezumā maksimālās noteces apjoms būs vērojams no janvāra līdz martam, augstāko vērtību sasniedzot februārī A2 scenārija gadījumā (sk. 4.45. att.). Līdz ar to būtiskas izmaiṇas salīdzinājumā ar situāciju mūsdienās būs raksturīgas aprīla un maija mēnešos. Pēc abiem nākotnes klimata scenārijiem arī gada otrajā pusē prognozēta noteces apjoma samazināšanās ar izteiktām izmaiñām tieši septembra un oktobra mēnešos.

Citu būtisku klimata pārmaiṇu ietekmju nozīmība atbilstoši Potsdamas Klimata mainības institūta pētījumu rezultātiem saistās ar jūras līmeņa izmain̄ām, kurš līdz šì gadsimta beigām var pieaugt par 0,8 m, līdz ar to ietekmējot zemāk izvietotu teritoriju applūšanas risku, kā arī pastiprinātu piekrastes eroziju.

Meteorologisko parametru mainības un globālās sasilšanas iespējamās ietekmes saistāmas ne tik daudz ar noteiktu meteorologisko parametru izmaiṇām jau visai pārredzamā nākotnē, bet ar to, ka šīs pārmain,as var ietekmēt daudzas ikvienam cilvēkam nozīmīgas dzīves jomas. Globālās sasilšanas sekas var skart lauksaimniecību, mežsaimniecību, zvejniecību, rekreācijas un tūrisma nozari, enerǵētiku, īpaši hidroenergétiku, pārtikas rūpniecību,
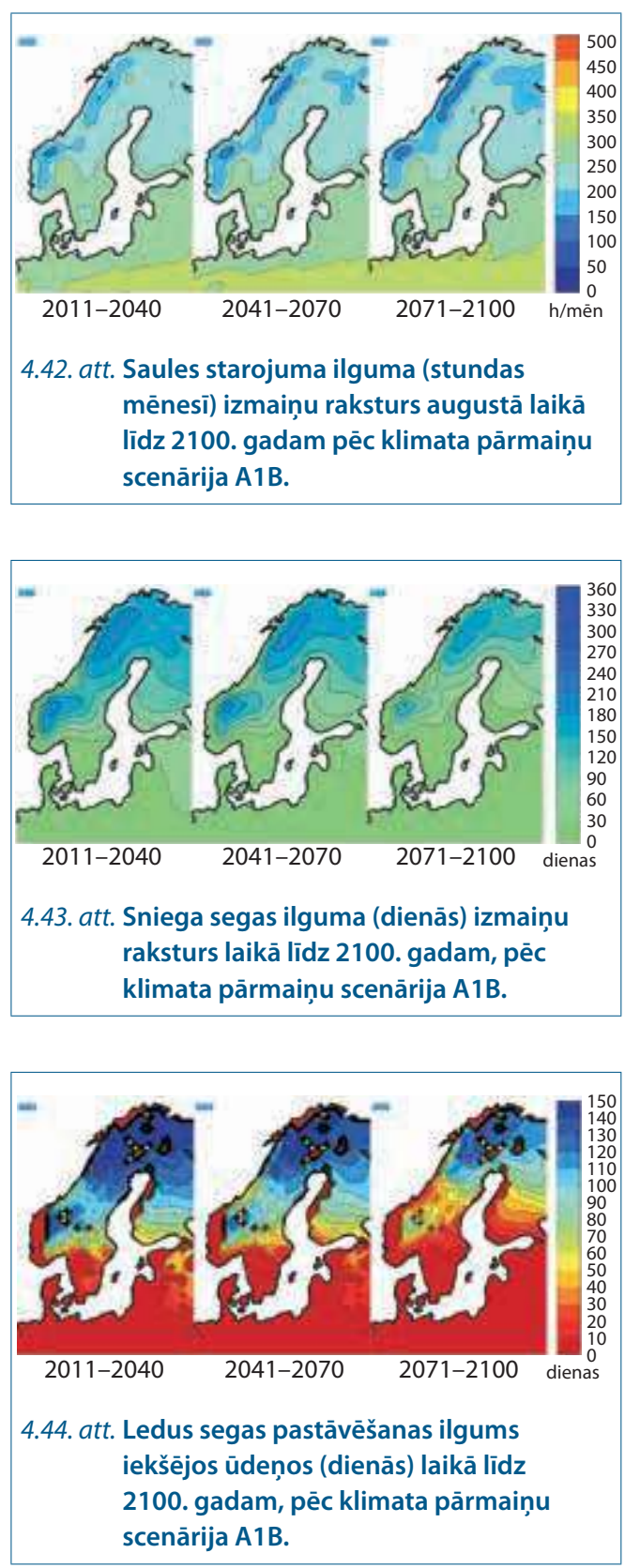

medicīnisko aprūpi un daudzas citas jomas. Dabas katastrofu varbūtības pieaugums, kurš saistāms ar klimata mainību, var ietekmēt ikvienu. Tāpēc ir nozīmīgi turpināt pētīt klimata pārmaiṇu raksturu un izstrādāt risinājumus, lai mazinātu šo pārmaiṇu nelabvēlīgās sekas. 


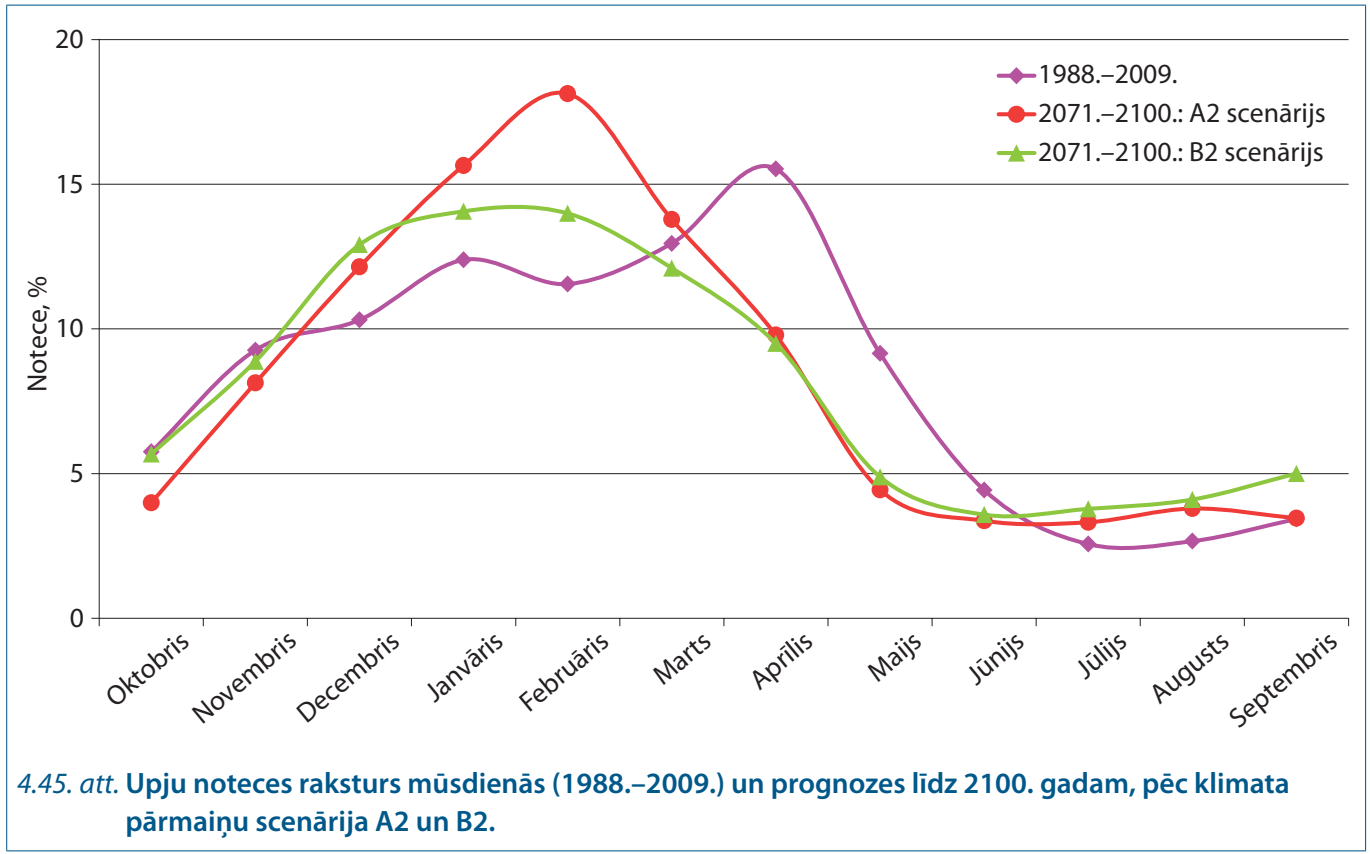

Avoti tālākām studijām

Website of the European Climate Assessment \& Dataset project http://eca.knmi.nl https://www.meteo.Iv/lapas/laiks/fakti-un-noderiga-informacija/fakti-un-noderiga-informacija?id=1717\&nid=573 http://www.varam.gov.IV/lat/darbibas_veidi/Klimata_parmainas

\section{Literatūra}

Apsīte E., Bakute A., Elferts D., Kurpniece L., Pallo I. (2011) Climate Change Impacts on River Runoff in Latvia. Clim Res 48. pp. 57-71.

Apsīte E., Elferts D., Zubaničs A., Latkovska I. (2014) Long-term Changes in Hydrological Regime of the Lakes in Latvia. Hydrology Research, 45 (3), pp. 308-321 doi: 10.2166/nh.2013.435/ scopus.

Apsite E., Rudlapa I., Latkovska I., Elferts D. (2013) Changes in Latvian River Discharge Regime at the Turn of the Century. Hydrology Research, 44 (3), 554-569 IWA Publishing 2013 doi:10.2166/nh.2012.007, (upju noteces un Salaca), http://www.editorialmanager.com/hydrology/ scopus.

Avotniece Z., Rodinov V., Lizuma L., Briede A., Kḷaviņš M. (2010) Trends in the Frequency of Extreme Climate Events in Latvia. Baltica 23, pp. 135-148.

Beḳere A. (2015) Veǵetācijas periods un tā izmaiṇas Latvijā. Bakalaura darbs, 48 Ipp.

Chmielewski F. M., Rotzer T. (2002) Annual and Spatial Variability of the Beginning of Growing Season in Europe in Relation to Air Temperature Changes. Climate Research. 19(1), pp. 257-264.

Eberhards G. Unusual Weather Conditions in Latvia (900-1860). In: Climate Change in Latvia and Adaptation to It. Editors: Māris Kḷaviņš and Agrita Briede. Rīga, University of Latvia Press, 2012, p. 188.

Klavins M., Rodinov V. (2010) Influence of Large-Scale Atmospheric Circulation on Climate in Latvia. Boreal Env Res 15, pp. 533-543.

Klimata mainība un globālā sasilšana (2008) Kḷavinš̌ M., Briede A. (red.). Rīga, LU Akadēmiskais apgāds, 174 lpp.

Latkovska I. (2015) Latvijas upju hidroloǵiskā režìma ilgtermiṇa un sezonālās izmaiṇas. Rĩga, LU, 123 lpp.

Latkovska I., Apsīte E., Elferts D., Kurpniece L. (2012) Forecasted Changes in the Climate and the River Runoff Regime in Latvian River Basins. Baltica, 25(2), pp. 143-152. Vilnius. ISSN 0067-3064. 
Latvia's sixth National Communication and First Biennial Report under the United Nations Framework Convention on Climate Change, MEPRD, December 2013, pp. 139.

Lizuma L. (2008) Klimata pārmaiṇas Rĩgā: gaisa temperatūra un atmosfēras nokrišñi. Promocijas darbs, LU, 240 lpp. Lizuma L., K!̣aviņš M., Briede A., Rodinovs V. (2007) Long-term Changes of Air Temperature in Latvia. In: Kḷaviņš M. (ed.) Climate change in Latvia, pp. 11-20.

Pāps K. (2014) Sniega segas raksturs un tā izvērtējums Latvijā. Bakalaura darbs, 52 lpp.

Second Assessment of Climate Change for the Baltic Sea Basin (2015) The BACC II Author Team, Heidelberg, Springer.

\section{Izmantotie attēli}

4.10. European Climate Assessment \& Dataset.

4.11. European Climate Assessment \& Dataset.

4.12. European Climate Assessment \& Dataset.

4.27. $h$ ttp://www.meteo.lv

4.28. http://www.tvnet.IV

4.39. Ar aț̣auju pēc Zviedrijas Meteoroloǵijas un hidroloǵijas institūta (SMHI) kartogrāfiskā materiāla.

4.40. Ar aț̣auju pēc Potsdamas Klimata mainības institūta kartogrāfiskā materiāla.

4.41. Ar aț̣auju pēc Potsdamas Klimata mainības institūta kartogrāfiskā materiāla.

4.42. Ar ațlauju pēc Zviedrijas Meteoroloǵijas un hidroloǵijas institūta (SMHI) kartogrāfiskā materiāla.

4.43. Ar ațlauju pēc Zviedrijas Meteoroloǵijas un hidroloǵijas institūta (SMHI) kartogrāfiskā materiāla.

4.44. Ar aț̣auju pēc Zviedrijas Meteoroloǵijas un hidroloǵijas institūta (SMHI) kartogrāfiskā materiāla. 


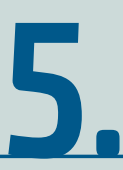

Globālā sasilšana un

tās sekas 


\subsection{Zemes klimata pārmaiṇu raksturs}

Zemes klimata mainības tendenču analīze sniedz pārliecinoši daudz pierādījumu tam, ka pēdējā gadsimta laikā Zemes klimats ir būtiski mainījies. Pārmaiṇas skar gan klimata kopējos rādītājus, piemēram, Zemes temperatūra, nokrišnu daudzums, sniega segas stabilitāte Zemes ziemel̦u reǵionos un kalnos, gan arī izmaiñas Zemes biofizikālajās sistēmās (piemēram, vielu apritē, plūsmā).

Ir pamats uzskatīt, ka siltumnīcefekta gāzu emisijas apjoms un koncentrācijas pieaugums atmosfērā uzskatāms par galveno faktoru, kas nosaka Zemes klimata būtiskās izmainas - globālo sasilšanu.

Katra no pēdējām trim desmitgadēm ir bijusi ar augstāku temperatūru nekā jebkura desmitgade kopš 1850. gada. Laika posms no 1983. līdz 2012. gadam ir bijis siltākais laika periods pēdējo 1400 gadu laikā Ziemel̦u puslodē, kur šādu klimata rekonstrukciju ir iespējams veikt. Globālā gada vidējā temperatūra virs sauszemes un okeāniem uzrāda lineāru pieauguma tendenci laika posmam no 1880 . līdz 2012. gadam, ko apliecina daudzi neatkarīgi veikti novērojumi un aprēkini.

Globālā sasilšana pēdējos 150 gados ir noteikusi ne tikai temperatūras paaugstināšanos, bet ietekmējusi jūras līmeña celšanos un ziemelı puslodes sniega segas platības samazināšanos (sk. 5.1. un 5.2. att.). Būtiskākās sasilšanas ietekmes apkopotas 5.1. tabulā.

Tomēr temperatūras paaugstināšanās uz Zemes nav bijusi vienmērīga. Visstraujāk temperatūra ir paaugstinājusies Zemes polu regionos - Arktikā un Antarktīdā. Ir pierādīta ne tikai piezemes temperatūras, bet arī troposfēras temperatūras paaugstināšanās (izmantojot satelītu novērojumus un meteorologískās zondes), turklāt temperatūras paaugstināšanās ātrums pētītajā atmosfēras masā ir līdzīgs. Palielinājies arī ūdens tvaiku daudzums atmosfērā, ko savukārt nosaka temperatūras paaugstināšanās. Ūdens tvaiku koncentrācijas pieaugums atmosfērā var pastiprināt siltumnīcefektu nākotnē, jo ūdens ir viena no siltumnīcefektu veicinošām vielām. Kopš 1960. gada veiktie

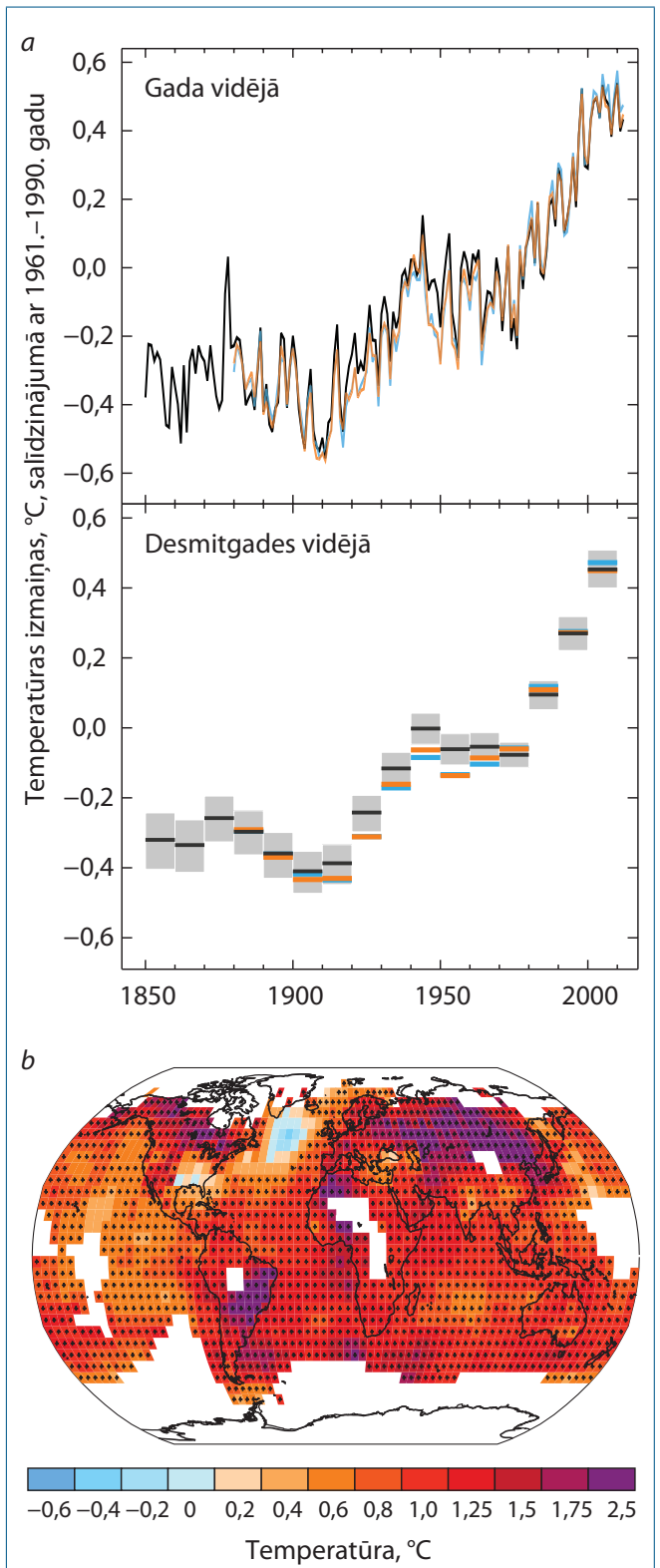

5.1. att. Globālās gada vidējās gaisa temperatūras (virs sauszemes un okeāniem), desmitgades vidējās gaisa temperatūras novirzes (salīdzinājumā ar vidējo temperatūru 1961.-1990. gadā) laika posmam no 1850. lĩdz 2012. gadam (a) un novērotās temperatūras izmainas laikā no 1901. līdz 2012. gadam (b). 


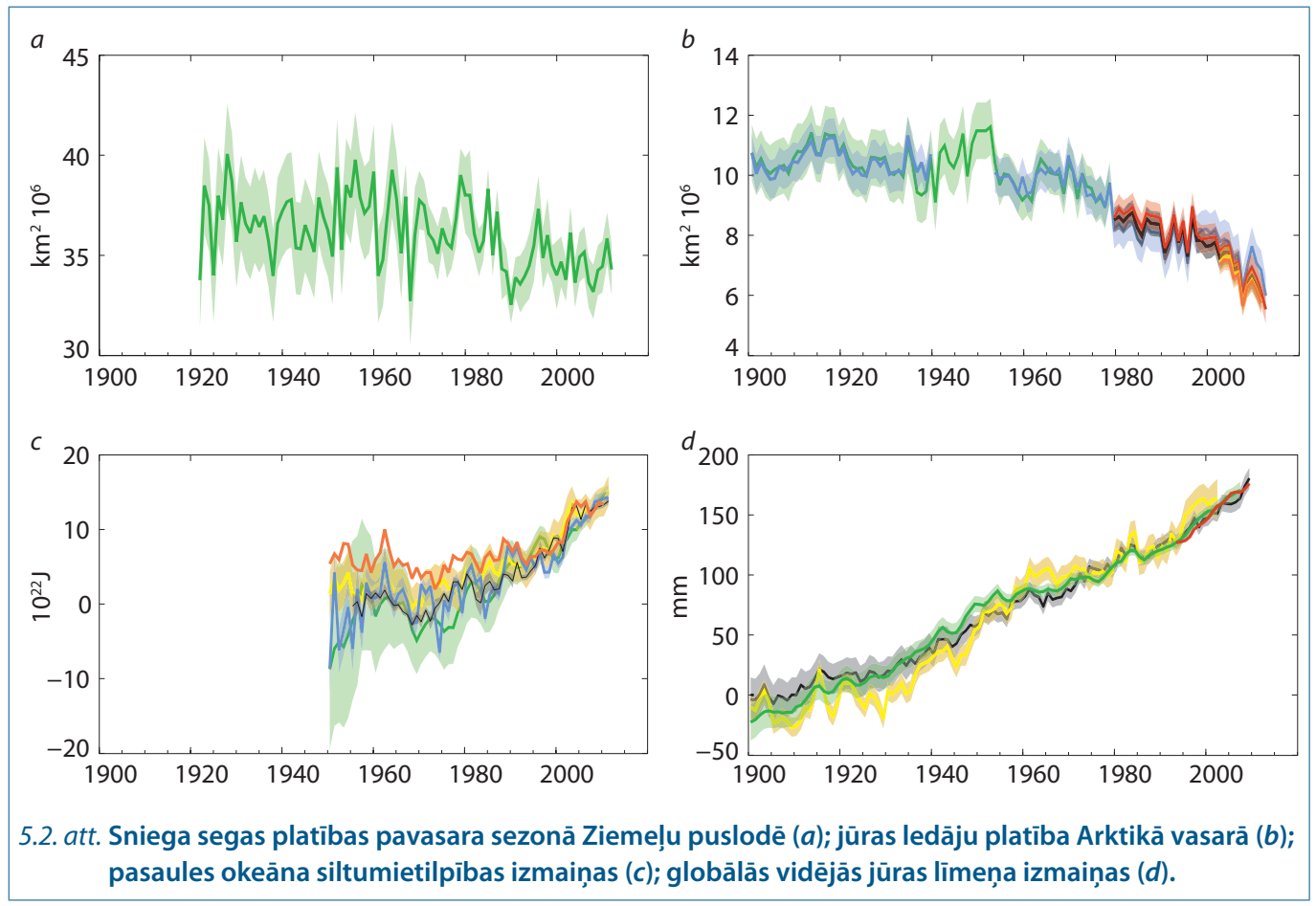

mērījumi pierāda, ka paaugstinājusies okeānu ūdeṇu temperatūra (līdz pat 3000 m dzil̦umam), jo ūdens absorbē lielāko daḷu pieplūstošā siltuma daudzuma. Okeānu ūdeñu temperatūras paaugstināšanās var sekmēt ūdens tilpuma palielināšanos un jūras līmeña celšanos, kā arī ietekmēt ūdeṇu plūsmu raksturu.

Pēdējā gadsimta laikā ir samazinājusies ne tikai sniega segas platība ziemel̦u puslodē, bet arī kalnu un kontinentālo ledāju aizṇemtā platība, kā arī mūžīgā sasaluma aizṇemtās platības, kuras uzskatāmas par nozīmīgu faktoru, kas sekmē jūras līmeña celšanos. Īpaši būtiski tiek ietekmēti Antarktīdas un Grenlandes ledāji (sk. 5.3. att.). Reǵionālo pētījumu rezultāti parāda, ka kalnāju ledāji kḷūst arvien īsāki un plānāki. Piemēram, Vidusāzijā un Dienvidsibīrijas kalnājos daudzi šlūunoṇi pēdējo 200 gadu laikā ir kḷuvuši īsāki par 4 km. Alpu kalnu ledāju platība samazinājusies par 30 līdz 40\% salīdzinājumā ar platību, kādu tie aizṇēma Mazajā ledus laikmetā. Eiropā šlūdoṇu straujā samazināšanās ir tieši saistīta ar Alpu reǵiona klimata pasiltināšanos 20. gadsimta laikā. Samazinās arī Zemes sasaluma platība mūžīgā sasaluma apgabalos.

Tā kā temperatūras paaugstināšana īpaši ietekmē Zemes polāros reǵionus, ir samazinājusies arī ledus aizṇemtā platība jūrās. Jūras līmeña mainība ir ievērojami ietekmējusi krasta erozijas procesus un sekmējusi piekrastes teritoriju degradāciju.

Novērojumi pierāda, ka nokrišn,u daudzums, lai arī nevienmērīgi, bet vidēji uz Zemes ir palielinājies par 2\% kopš 20. gadsimta sākuma, kā arī ievērojami ir pieaudzis ekstremālu nokrišņu biežums (sk. 5.4. att.). Nokrišņu daudzums ir palielinājies Ziemel̦amerikā un Dienvidamerikā, Ziemel̦eiropā, Ziemel̦āzijā un Centrālāzijā. Taču nokrišņu daudzums samazinājies Sāhela reǵionā, Vidusjūras reǵiona valstīs un Dienvidāfrikā.

Globālā sasilšana tiek saistīta arī ar klimata sistēmas stabilitātes ietekmēšanu un ekstremālu klimatisko parādību biežuma pieaugumu. Tas attiecas gan uz tropisko ciklonu un 

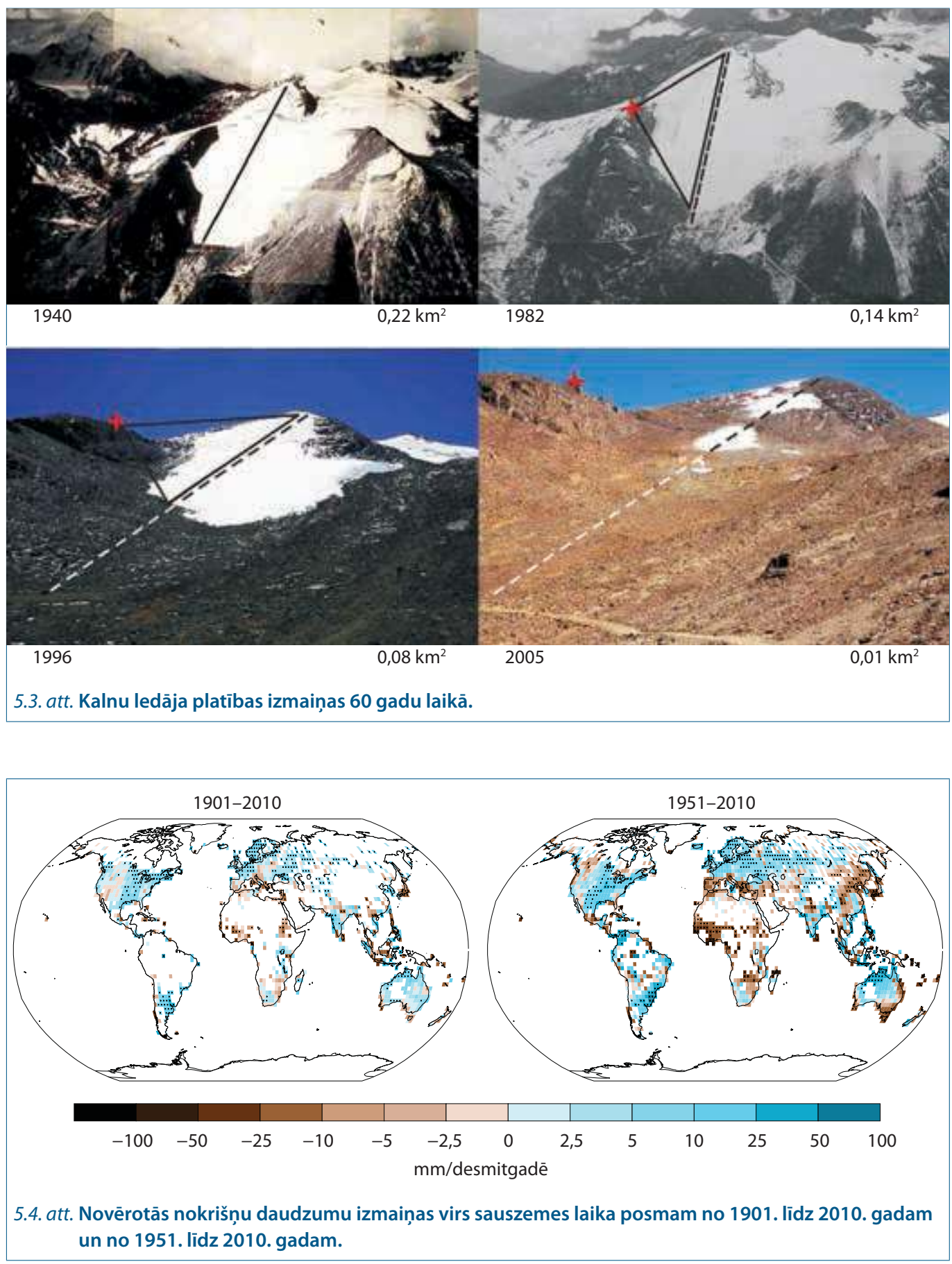
viesulvētru biežuma un intensitātes mainību Karību jūras regionā, gan arī uz musonu lietavām Āzijā.

Klimata mainība tieši ietekmē ne tikai dabas vidi, bet arī cilvēkvidi. Vasaras globālās sasilšanas ietekmē daudzos reǵionos ir kḷuvušas siltākas, kā arī biežāki ir kḷuvuši laika posmi, kad novērojami ekstremāli augstas temperatūras "karstuma vilıni", kas ietekmē cilvēku veselību. Negatīvo ietekmi lıtoti karstās vasarās pastiprina pieaugošais gaisa mitrums. Konstatēts, ka mērenā klimata reǵionos l̦oti karstos laika apstākḷos nāves gadījumu skaits dienā palielinās. Karstuma viḷni ASV pilsētās, Francijā 2003. gadā un Grieksijā 2007. gada vasarā prasīja vairāku simtu cilvēku dzīvības. Piemēram, karstuma viḷni Londonā palielināja mirstību par 15\%. Ar klimata mainību tiek saistīta arī konkrētajam reǵionam netipisku sugu invāzija.

Og̣̦skābās gāzes koncentrācijas pieaugums atmosfērā ietekmē ne tikai Zemes klimatu. Og̣̦skābajai gāzei izšksīstot ūdenī, palielinās izšksīdušās $\mathrm{CO}_{2}$ koncentrācija un pazeminās okeānu ūdeṇu pH (sk. 5.5. att.), t.i., tie kḷūst skābāki.

\section{1. tabula. Novērotās izmaiṇas Zemes atmosfērā}

\begin{tabular}{|c|c|}
\hline Indikators & Novērotās izmaiņas \\
\hline \multicolumn{2}{|l|}{ Koncentrācijas indikatori } \\
\hline $\mathrm{CO}_{2}$ koncentrācija atmosfērā & $\begin{array}{l}\text { No 1000. līdz 1750. gadam } \mathrm{CO}_{2} \text { koncentrācija atmosfērā bijusi } 280 \text { ppm, 2016. gadā - } \\
400 \text { ppm ( } 40 \pm 4 \% \text { pieaugums) }\end{array}$ \\
\hline $\begin{array}{l}\mathrm{CO}_{2} \text { saistīšanās spēja Zemes } \\
\text { biosfērā }\end{array}$ & $\begin{array}{l}\text { No 1800. līdz 2012. gadam piesaistītā oglekl̦a dioksīda daudzums bijis aptuveni } 30 \text { Gt C; } \\
\text { 20. gs. } 90 \text {. gados tas samazinājies par } 14 \pm 7 \text { Gt C }\end{array}$ \\
\hline $\mathrm{CH}_{4}$ koncentrācija atmosfērā & $\begin{array}{l}\text { No 1000. līdz 1750. gadam - } 700 \text { mlrd.d., 2016. gadā - } 1834 \text { mlrd.d. (262 } \pm 25 \% \text { pieau- } \\
\text { gums) }\end{array}$ \\
\hline $\mathrm{N}_{2} \mathrm{O}$ koncentrācija atmosfērā & No 1000. līdz 1750. gadam - 270 mlrd.d., 2016. gadā - 328 mlrd.d. (22 $\pm 2 \%$ pieaugums) \\
\hline $\mathrm{O}_{3}$ koncentrācija troposfērā & No 1750. līdz 2016. gadam pieaugusi līdz 337 mlrd.d. (30 $\pm 3 \%$ pieaugums) \\
\hline $\mathrm{O}_{3}$ koncentrācija stratosfērā & $\begin{array}{l}\text { Samazinājusies no 1970. līdz 2016. gadam, variē atkarībā no augstuma virs jūras līme- } \\
\text { ņa un ǵeogrāfiskā platuma grādiem }\end{array}$ \\
\hline Citas siltumnīcefekta gāzes & Vispārējs pieaugums pēdējos piecdesmit gados \\
\hline \multicolumn{2}{|l|}{ Laika apstāklu indikatori } \\
\hline Zemes virsmas temperatūra & $\begin{array}{l}\text { 20. gadsimta laikā paaugstinājusies par } 0,84 \pm 0,2 \% \text {, turklāt vairāk uz sauszemes nekā } \\
\text { okeānā }\end{array}$ \\
\hline Temperatūra ziemel̦ puslodē & $\begin{array}{l}\text { Salīdzinājumā ar citiem laika posmiem pēdējos } 1000 \text { gados temperatūra 20. gadsimtā } \\
\text { paaugstinājusies visvairāk; } 20 . \text { gs. } 90 \text {. gadi ir tūkstošgades siltākā desmitgade }\end{array}$ \\
\hline $\begin{array}{l}\text { Diennakts temperatūras } \\
\text { amplitūda }\end{array}$ & $\begin{array}{l}\text { No 1950. līdz 2016. gadam sauszemes teritorijā samazinājusies. Temperatūras mini- } \\
\text { mums naktī pieaudzis divas reizes salīdzinājumā ar dienas maksimālo temperatūru }\end{array}$ \\
\hline Karstās dienas/karstuma indekss & Pieaudzis \\
\hline $\begin{array}{l}\text { Aukstums/sals (dienas ar } \\
\text { temperatūru zem } 0^{\circ} \mathrm{C} \text { ) }\end{array}$ & Samazinājies sauszemē 20. gadsimtā \\
\hline Nokrišņi (kontinentāli) & $\begin{array}{l}\text { 20. gadsimtā ziemel̦u puslodē pieauguši par 5-10\%, tomēr dažos reǵionos - Āfrikas } \\
\text { rietumos un ziemel̦os, Vidusjūras reǵionos - samazinājušies }\end{array}$ \\
\hline $\begin{array}{l}\text { Dabas kataklizmas ar palielinātu } \\
\text { nokrišn,u daudzumu }\end{array}$ & Pieaug vidējos un augstākajos ziemel̦u platuma grādos \\
\hline $\begin{array}{l}\text { Sausuma periodu biežums un } \\
\text { intensitāte }\end{array}$ & $\begin{array}{l}\text { Sausuma pieaugums vasaras mēnešos saistīts ar sausuma perioda biežuma palielinā- } \\
\text { šanos dažos apgabalos - teritorijās Āfrikā un Âzijā sausuma periodu intensitātes un } \\
\text { biežuma pieaugums novērots pēdējā desmitgadē }\end{array}$ \\
\hline
\end{tabular}


5.2. tabula. Novērotās izmaiṇas Zemes biofizikālajās sistēmās

\begin{tabular}{|c|c|}
\hline Indikators & Novērotās izmaiņas \\
\hline \multicolumn{2}{|l|}{ Biologiskie un fizikālie indikatori } \\
\hline Jūras līmenis & 20. gadsimtā paaugstinājies vidēji par 1-2 mm gadā \\
\hline $\begin{array}{l}\text { Ledus segas pastāvēšanas } \\
\text { perioda ilgums upēs un ezeros }\end{array}$ & $\begin{array}{l}\text { 20. gadsimtā samazinājies aptuveni par } 2 \text { nedēḷām vidējos un augstākajos platuma } \\
\text { grādos ziemeḷu puslodē }\end{array}$ \\
\hline $\begin{array}{l}\text { Ledus segas biezums un } \\
\text { platība Ziemeḷu Ledus okeānā }\end{array}$ & $\begin{array}{l}\text { Vasaras beigās un agros rudeṇos pēdējā desmitgadē ledus segas biezums samazinājies } \\
\text { par } 40 \% \text {. Kopš 1950. gada pavasara un vasaras par 10-15\% samazinājusies ar ledu klātā } \\
\text { teritorija }\end{array}$ \\
\hline Ledāji & Izplatīta ledāju atkāpšanās 20. gadsimtā \\
\hline Sniega sega & No 20. gs. 60 . gadiem, kad novērojumiem sāka izmantot satelītus, samazinājusies par $10 \%$ \\
\hline Mūžīgais sasalums & Sācis atkust un sarukt polārajos, subpolārajos un kalnu reǵionos \\
\hline El Niño parādība & $\begin{array}{l}\text { Pēdējos 20-30 gados salīdzinājumā ar iepriekšējo simts gadu periodu kḷuvusi biežāka, } \\
\text { pastāvīga un spēcīga }\end{array}$ \\
\hline Veǵetācijas sezona & $\begin{array}{l}\text { Pēdējo } 40 \text { gadu laikā pagarinājusies par 1-4 dienām desmitgadē ziemeḷu puslodē, } \\
\text { it īpaši augstākajos platuma grādos }\end{array}$ \\
\hline Augu un dzīvnieku izplatība & $\begin{array}{l}\text { Augu, kukaiṇu, putnu un zivju izplatības areāls paplašinājies uz ziemeḷiem un } \\
\text { augstkalnu rajoniem }\end{array}$ \\
\hline $\begin{array}{l}\text { Ziedēšanas, vairošanās un } \\
\text { migrācijas sezona }\end{array}$ & $\begin{array}{l}\text { Agrāka augu ziedēšana un putnu atcel̦ošana, agrāka vairošanās sezona, kā arī kukaiṇu } \\
\text { strauja savairošanās Ziemeḷu puslodē }\end{array}$ \\
\hline Koraḷ]u rifu izbalošana & Palielinās, īpaši El Niño efekta ietekmē \\
\hline
\end{tabular}

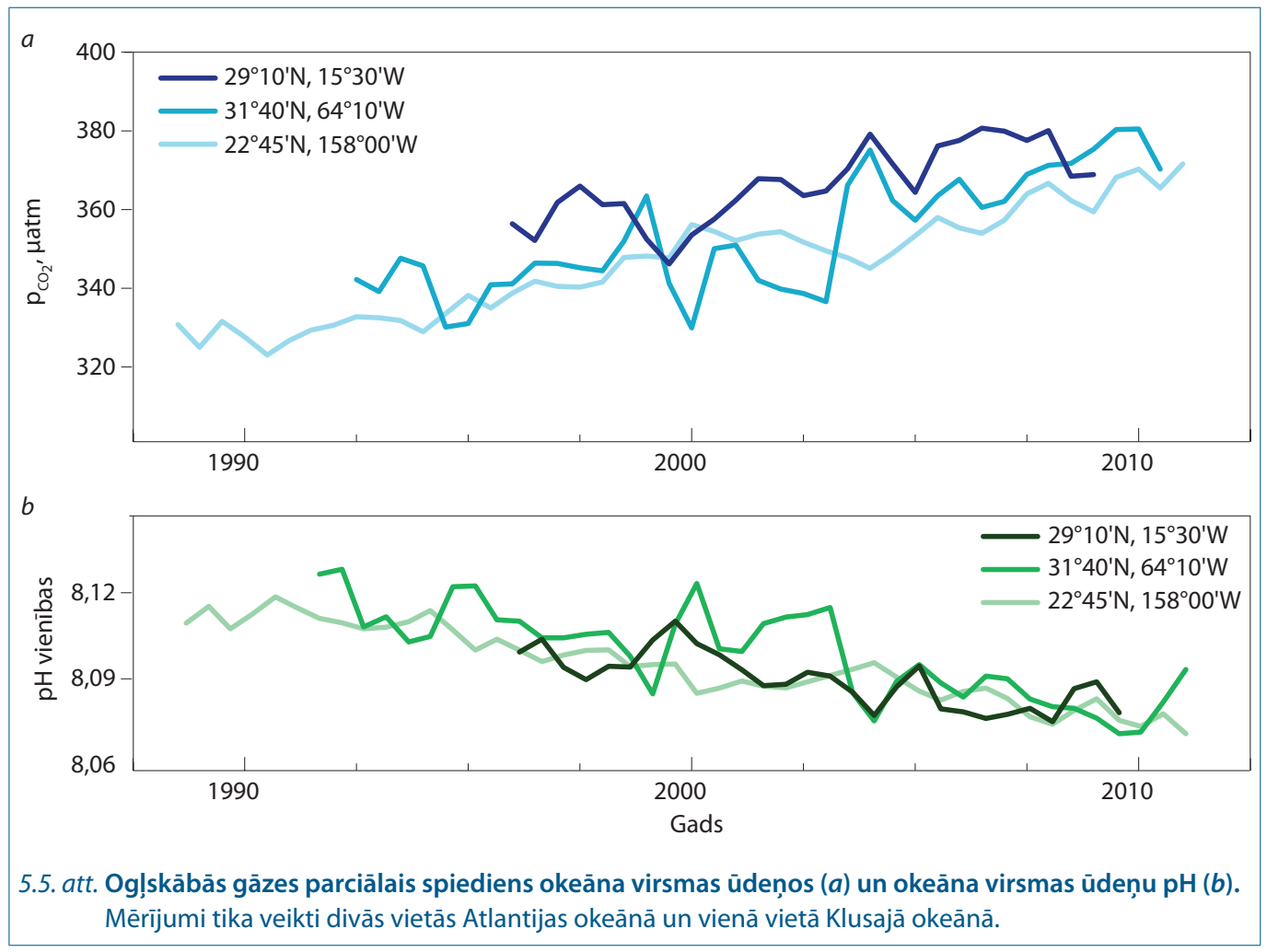


Pašas par sevi šādas ietekmes izsaka visai maz ko, bet pH līdzsvars ir būtisks visu jūru un okeānu dzīvo organismu sekmīgai attīstībai. Šādu izmaiṇu tiešās sekas var būt jutīgu sugu iznīkšana un nozvejas samazināšanās, bet netiešās izmaiṇas var būt visu dzìvo kopienu izmainas.

Klimata mainība vispirms ietekmē sociāli neaizsargātos iedzīvotājus, kā arī nabadzīgākās valstis, tādējādi padzilıinot sociāli ekonomisko krīzi un sekmējot nabadzības pieaugumu.

Neapšaubāmi, ka klimata mainība un klimata veidošanos ietekmējošie procesi un to mijiedarbības raksturs ir sarežgìita un maz izpētīta parādība un šo jautājumu risināšana ir tagadnes un nākotnes uzdevums, kura pamatā ir klimatologiskie pētījumi un klimata mainības prognozēšana.

\subsection{Zemes klimata modelēšana un klimata mainības scenāriji}

Klimata sistēmas mainību un procesus var pētīt un prognozēt, izmantojot klimata modelēšanu. Modelis ir procesu, sistēmu vai darbības aprakstīšana vai attēlošana ar matemātisku vienādojumu palīdzību. Izzin,as metodi, kur pētāmo objektu aizstāj ar modeli, lieto gadījumos, kad objekti tiešai izpētei grūti pieejami.

Klimata modelēšana pamatojas uz klimatu ietekmējošo elementu sakarību un kādā konkrētā laika periodā novērotu to vērtību kopumu, kuru tālākās pārmaiņas (modelēšanu) veic ar l̦oti jaudīgiem datoriem, lai iegūtu ieskatu šìs sistēmas izmaiñās, kādas tās varētu būt nākotnē un ir notikušas pagātnē.

Ideālam klimata modelim jāatbilst šādām prasībām:

1) pilnīga izpratne par visu klimata veidošanā iesaistīto faktoru savstarpējo mijiedarbību niansēm, šo sakarību matemātisks formulējums, kas ietvertu

- atmosfēras cirkulāciju,

- Zemes reljefu,

- okeānu cirkulāciju,

- Saules enerǵijas pieplūduma īpatnības,

- geologiska rakstura ietekmes (vulkāni, augsnes atbrīvotās siltumnīcefekta gāzes),

- ārējo kosmisko apstākḷu ietekmes (magnētiskās vētras, meteorīti u.tml.),

- antropogēnās ietekmes,

- atmosfēras - biosfēras mijiedarbības raksturu;

2) precīzi dati par šīm vērtībām konkrētos laika periodos visā pētāmajā teritorijā;
3) skaiţ̦ošanas jaudas, kuras l̦auj matemātiski apstrādāt izmantojamo informāciju (klimata modelēšana ir viena no vadošajām superdatoru izmantošanas jomām pasaulē). Datiem ir nepieciešama arī augsta izšksirtspēja, lai spētu iekḷaut visas izmainas modelēšanai dažādos telpiskos mērogos.

Kaut arī klimata sistēma ir loti sarežǵīta un ir gūti neapšaubāmi sasniegumi klimata un tā mainības modelēšanā, klimata pētniecība joprojām ir aktīvas izpētes stadijā. Klimata modelēšanā tiek izmantoti vairāki modelu veidi, kas tiek savstarpēji savienoti. Parasti ar laikapstākḷu vai klimata modeḷiem tiek saprasti vispārējās atmosfēras cirkulācijas model̦i (anglu val. GCM - General Circulation Models) jeb globālie klimata model̦i. Vienkāršie vispārējās cirkulācijas model̦i sastāv no pamatvienādojumiem, kas apraksta enerǵijas plūsmas sistēmā un enerǵijas izkliedēšanas mehānisma algoritmu. Ar šiem model̦iem var modelēt vietēja mēroga procesus atmosfērā. Atmosfēriskie vispārējās cirkulācijas modeḷi parasti aptver atmosfēras un Zemes virsmas mijiedarbības procesu raksturu. Okeāna model̦i apraksta atmosfēras un jūru un okeānu virsmas mijiedarbību, enerǵijas apmaiṇu, iztvaikošanas un kondensācijas procesus, kā arī mijiedarbību, n,emot vērā ledus segas ietekmi uz gaisa masu plūsmām. Kompleksie jeb saistītie model̦i ietver iepriekšèjos elementus un vēl citus faktorus.

Klimata modelēšanā jāsastopas ar daudzām un dažādām problēmām. Dabā ir l,oti 
daudz faktoru, kas savstarpēji ir cieši saistīti un ko grūti objektīvi atspoguḷot modelī. Tāpat ir vērojamas problēmas ar cilvēka darbības ietekmes neprognozējamo faktoru, kas saistāms ar ekonomiskās izaugsmes ātrumu un attīstību (piemēram, kādu attīstības scenāriju izvēlēties modelējot).

Laika prognozēm izmanto īstermiņa modelıus, kurus papildina ar jaunākajiem novērojumiem no satelītiem un meteorologiskajām stacijām, lai iegūtu pēc iespējas precīzāku iespējamo laika prognozi. Dažādām saimniecības nozarēm ir nepieciešamas l,oti precīzas laikapstākḷu prognozes, un šie model̦i ir l̦oti noderīgi.
Dažādu klimata sistēmas komponentu model̦i tiek savstarpēji sasaistīti, kas nodrošina kompleksās sistēmas iespējami precīzāku aprakstu. Izstrādājot modeḷus, vispirms tiek pārbaudìts, cik precīzi izmantotais matemātiskais aparāts l̦auj aprakstīt situāciju, par kuru ir pieejami dati meteorologisko novērojumu periodā vai arī pagātnē. Nākotnes klimata izmainu modelēšana dod ieskatu iespējamās klimata izmaiṇās atbilstoši noteiktām izmain,ām model̦a darbībai izmantojamos datos, n,emot vērā faktorus, kuri var izraisīt klimata mainību. Būtiska vieta klimata mainības modelēšanā ir antropogēno faktoru novērtēšanai un dabisko klimata
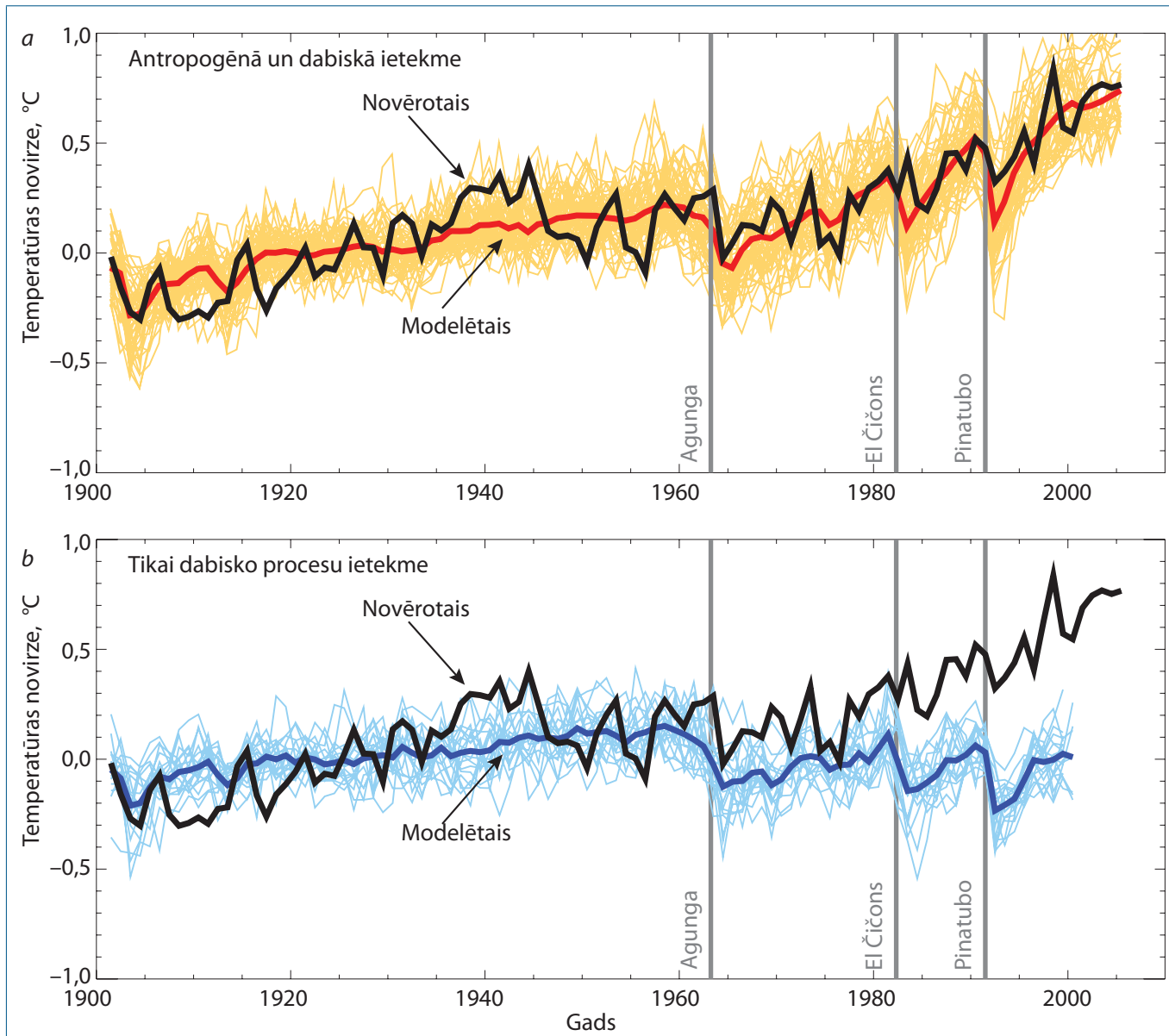

5.6. att. Novērotās vidējās gada Zemes temperatūras novirzes no normas (1901.-1951. gads) un modelējot noteiktais temperatūras mainības raksturs, ṇemot vērā: (a) dabiskās un antropogēnās ietekmes; (b) tikai dabiskās ietekmes. 
mainību ietekmējošo faktoru analīzei. Kaut arī pašlaik izmantotie model̦i, neapšaubāmi, neaptver visus klimata mainību ietekmējošos procesus, tomēr tie l̦auj pietiekami precīzi aprakstīt izmain,as, kuras notiek pašlaik, un novērtēt antropogēno ietekmju nozīmi kā būtisku klimata mainības cēloni.

Kā redzams, klimata mainības model̦i l̦auj novērtēt vulkānu izvirdumu ietekmes uz klimatu, un tie pierāda, ka klimata mainību nav iespējams izskaidrot tikai ar dabiskiem faktoriem un antropogēnās ietekmes uzskatāmas par galveno klimata mainību ietekmējošo faktoru kopš 20. gadsimta sākuma.

Atkarībā no siltumnīcefekta gāzu emisijas apjoma un cita veida antropogēnās slodzes izmaiñām 21. gadsimtā var ievērojami mainīties temperatūras paaugstināšanās raksturs (sk. 5.7. att.). Līdz ar to klimata izpētē būtiska ir izpratne par to, kā var attīstīties pasaules valstis un sabiedrība kopumā. Apvienoto Nāciju Organizācijas Starpvaldību klimata pārmainu komisijas eksperti izškরir vairākus iespējamos sabiedrības attīstības un klimata mainības scenārijus:

1. A1 scenārijs. Saglabājoties 2000. gada SEG koncentrācijai un nepalielinoties iedzīvotāju skaitam un ekonomiskajai izaugsmei, temperatūras izmainu raksturu noteiks klimata sistēmas inerce. Kaut arī temperatūras paaugstināšanās šādā gadījumā ir vismazākā, protams, šāds attīstības raksturs nevar apmierināt lielāko dạlu Zemes iedzīvotāju.

2. B1 scenārijs (ilgtspējīgas attīstības scenārijs) paredz to, ka pasaules iedzīvotāju skaits pieaugs līdz 21. gadsimta vidum, bet pēc tam sāksies tā samazināšanās. Ekonomiskā izaugsme notiek, palielinoties pakalpojumu apjomam un attīstoties informācijas tehnoloǵijām. Samazinoties materiālietilpīgām tehnoloǵijām, kā arī izstrādājot un ieviešot tīrās un resursus saudzējošās tehnologijas, tiek nodrošināta valstu un sabiedrību attīstība, kas sekmē nevienlīdzības samazināšanos un globālus risinājumus vides aizsardzības, ekonomiskās izaugsmes un sociālās labklājības jomās.

3. A2 scenārijs ("rīcība kā līdz šim") apraksta visai neviendabīgu pasauli, kurā galvenā tēma ir palıaušanās uz pašu spēkiem un resursiem. Pasaules iedzīvotāju skaits turpina pieaugt, līdz ar to nosakot aizvien lielāku resursu un enerǵijas patēriṇu. Ekonomiskā attīstība un tehnologiskais progress pamatā notiek atsevišķos regionos.

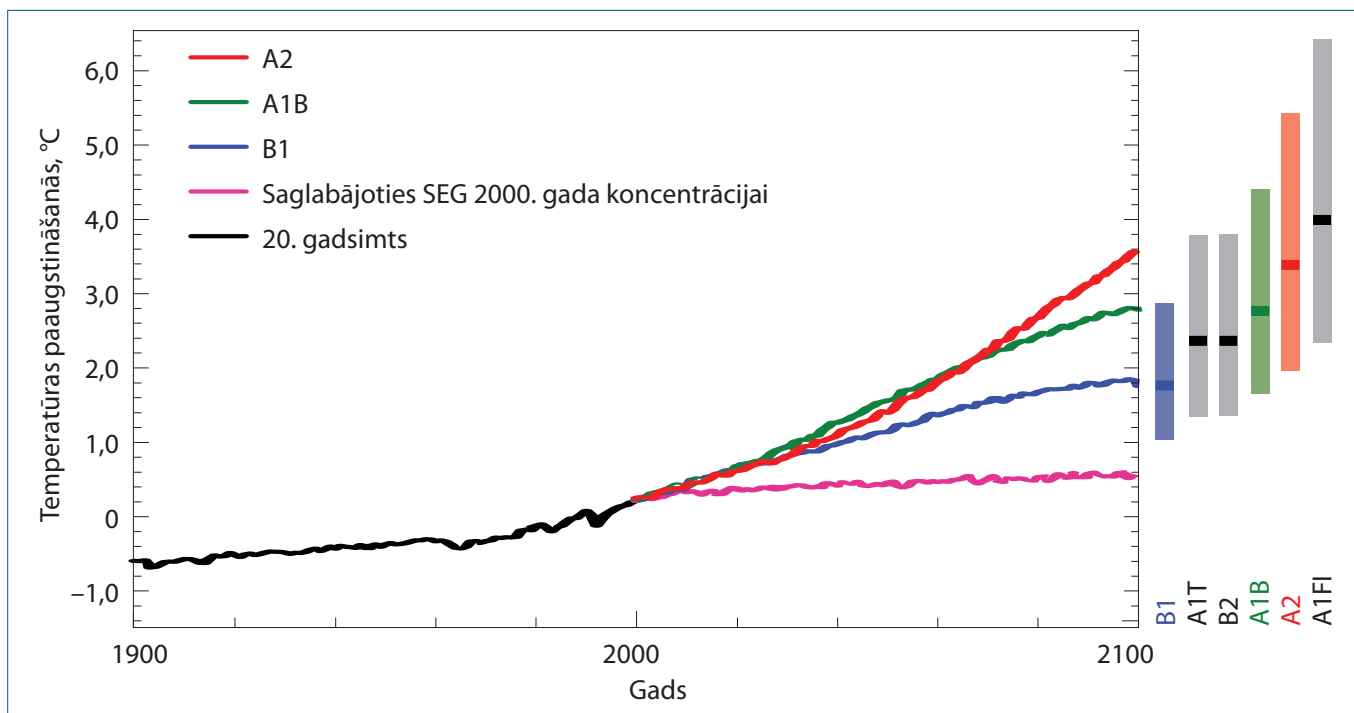

5.7. att. Zemes vidējās temperatūras paaugstināšanās raksturs atkarībā no siltumnīcefekta gāzu izmešu pieauguma un sabiedrības attīstības scenārijiem. 
4. A1B scenārijs apraksta nākotnes pasauli, kuru raksturo, no vienas puses, strauja ekonomiskā izaugsme un iedzīvotāju skaita pieaugums, bet, no otras puses, tehnoloǵiskais progress (īpaši enerǵijas ieguves jomās), kas gadsimta otrajā pusē l̦auj samazināt materiālu un resursu patēriṇa pieaugumu. Sabiedrības attīstību raksturo nevienlīdzības samazināšanās starp reǵioniem un dažādu kultūru mijiedarbība.

Nākotnes klimata izmaiņu scenāriji paredz, ka globālā vidējā temperatūra paaugstināsies par $1,4-5,8^{\circ} \mathrm{C}$ un paredzamais sasilšanas temps būs daudz straujāks, nekā tas bija novērots 20. gadsimtā un pēdējo 10000 gadu laikā. Atkarībā no prognozētā siltumnīcefekta gāzu koncentrācijas pieauguma scenārijā ievērojami atšksiras ne tikai Zemes gada vidējās temperatūras paaugstināšanās prognozes, bet arī temperatūras paaugstināšanās sadalījums uz Zemes laika posmā līdz 21. gadsimta beigām (sk. 5.10. att.). Saistībā ar siltumnīcefekta gāzu emisiju apjomu Zemes temperatūra var ievērojami paaugstināties, turklāt temperatūras celšanās ir izteikti nevienmērīga un maksimāli var paaugstināties Arktikā un ekvatoriālajos apgabalos.

Globālā sasilšana neizbēgami ietekmēs nokrišnu daudzumu, un klimata mainības modelıi paredz, ka 21. gadsimta laikā pieaugs globālā vidējā ūdens tvaiku koncentrācija atmosfērā un nokrišnu daudzums. Turklāt ir paredzama

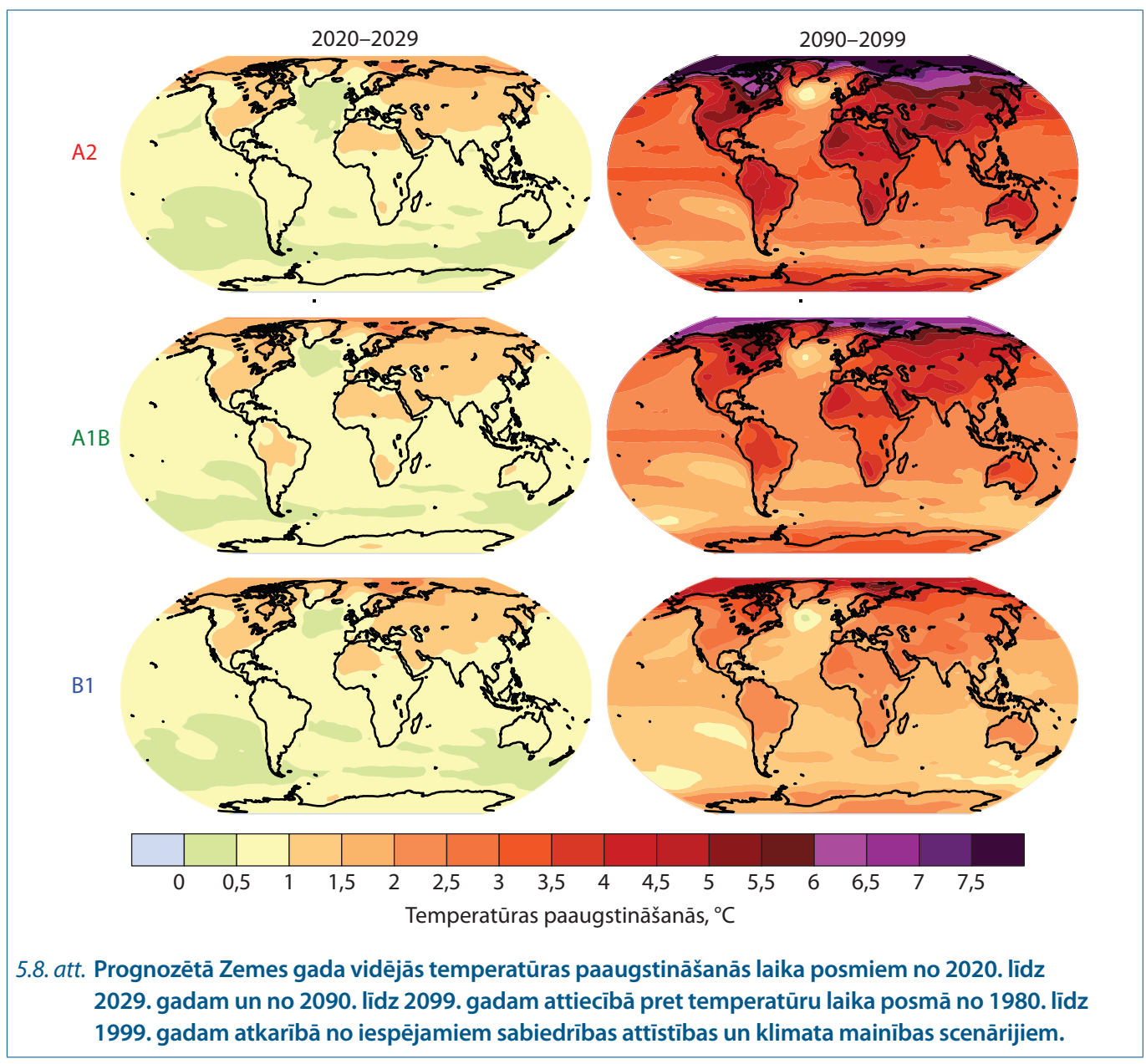



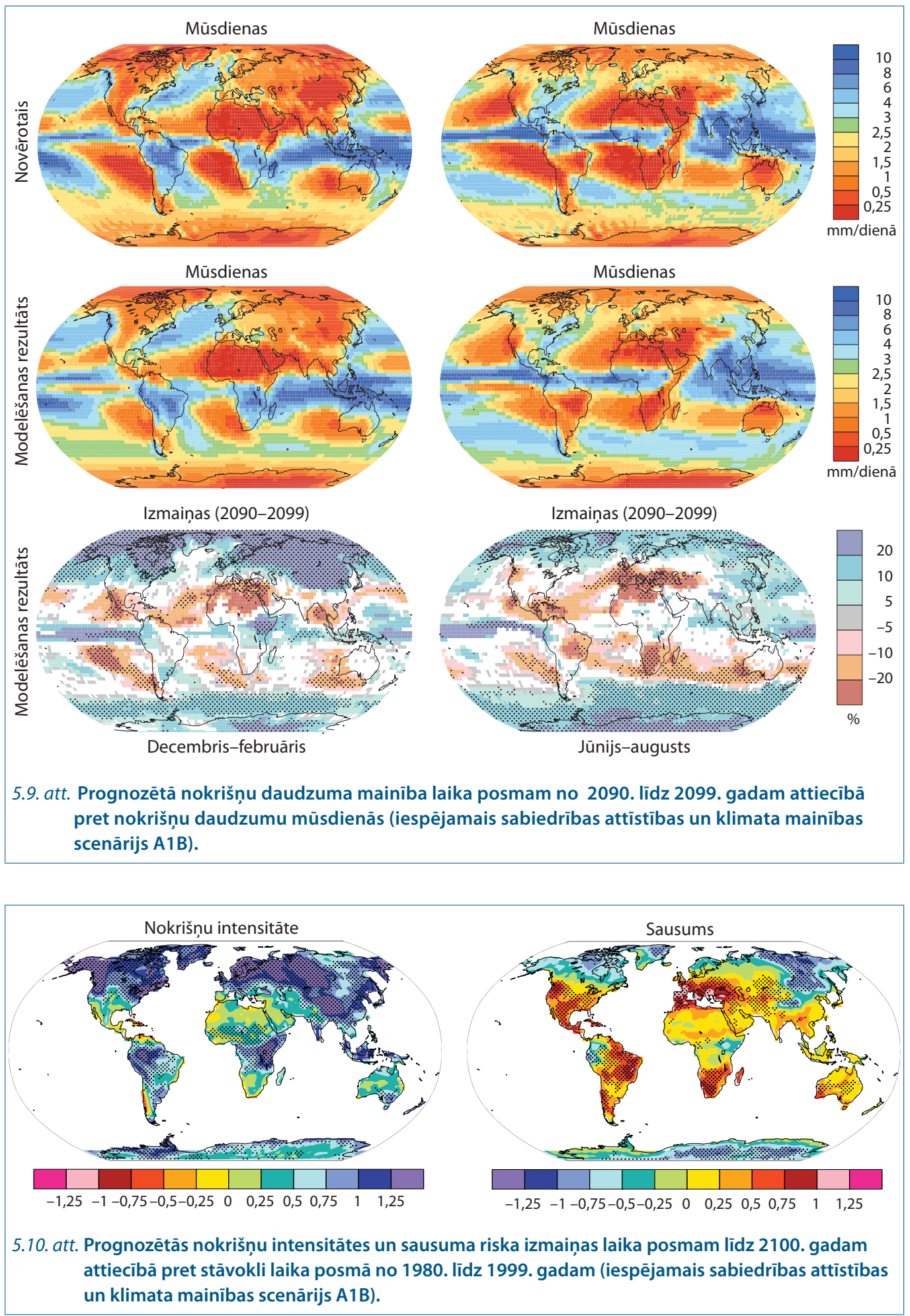
lielāka nokrišnu daudzuma mainība no gada uz gadu reǵionos ar pieaugošu prognozēto nokrišnu daudzumu.

Izmaiņas musonu klimatā saistītas ar pasiltināšanos un pieaugošu nokrišņu daudzumu vasaras musonu laikā Āzijā. Āfrikā, kā arī Vidusjūras reǵionā paredzama nokrišnu daudzuma samazināšanās. Šie modelētie rezultāti sakrīt ar jau 20. gadsimtā novērotajām nokrišn,u daudzuma mainības tendencēm, kas apliecina izstrādāto klimata mainības modeḷu spēju prognozēt klimatu nākotnē.

Kopējā nokrišnu daudzuma mainība ir saistīta gan ar nokrišnu intensitātes pieaugumu, gan arī ar sausuma periodu risku (sk. 5.10. att.). Šajā gadījumā ietekmes ir izteikti reǵionālas, bet visvairāk ietekmētajos regionos izmaiñas var būt l̦oti nozīmīgas. Piemēram, nokrišnu daudzuma pieaugums polārajos reǵionos var ietekmēt ledāju stabilitāti un līdz ar to arī okeānu ūdeṇu straumju raksturu, bet Vidusjūras reǵionā un Āfrikas dienvidu daḷā nokrišnu daudzuma samazināšanās var veicināt pārtuksnešošanās procesus.

Klimata mainības model̦i paredz, ka iespējama jūru un okeānu līmeṇu celšanās no 0,09 līdz 0,88 m laika posmā līdz 2100. gadam (sk. 5.11. att.). Globālā vidējā jūru un okeānu ūdeṇu virsmas temperatūra paaugstināsies un jūras līmena celšanās no okeāna siltuma ekspansijas turpināsies pat simtiem gadu pēc siltumnīcefekta gāzu stabilizēšanās perioda (pat ja saglabāsies tagadējais SEG koncentrācijas līmenis). Taču pašreizējie model̦i neparedz pilnīgu termohalīnās cirkulācijas izbeigšanos līdz 2100. gadam, kas varētu izraisīt straujas klimata izmaingas.

Izvērtējot klimata mainības prognozēšanas iespējas, jāpiebilst, ka klimata sistēma uzskatāma par nelineāru (nelielas ietekmes var radīt būtiskas sekas). Līdz ar to, tāpat kā laikapstākḷu prognozēšana, arī klimata mainības modelēšana nenodrošina $100 \%$ precīzus rezultātus, tādēl jāizmanto jēdzieni "varbūtīgs", "iespējams" un "l,oti iespējams". To, ka klimata mainība var būt strauja, pierāda sugu bojāeja, kas vēsturiski ir notikusi vairākas reizes, kā arī straujas klimata izmaiṇas pēdējā ledus laikmeta laikā. Straujas klimata izmain,as var saistīties, piemēram, ar okeānu cirkulācijas rakstura izmaināam, putekḷu un aerosolu nokḷūšanu atmosfērā vulkānu darbības vai kodolkara gadījumā. Lai apzinātu un izprastu šādas ietekmes, nepieciešams turpināt pētīt klimata mainības raksturu un pilnveidot modelēšanas metodes.

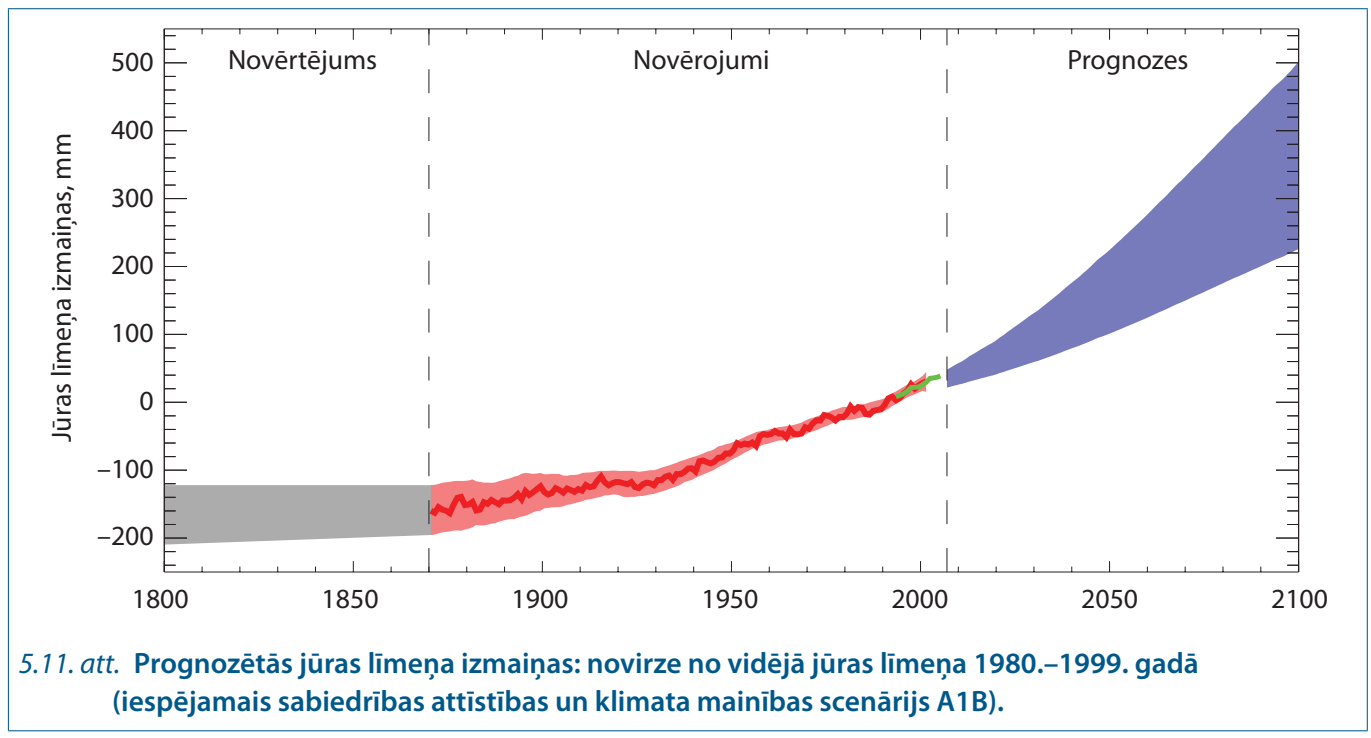




\subsection{Globālās sasilšanas iespējamās sekas}

Pastāvošo klimata mainību raksturo strauja temperatūras paaugstināšanās, kas jau pašlaik var radīt ievērojamas izmain,as mūsu dzīves vidē. Kā iespējamās negatīvās sekas tiek minētas ievērojamas laikapstākḷu izmainnas. Būtiski, ka globālā sasilšana nozīmē ne tikai temperatūras paaugstināšanos, bet tās sekas saistāmas ar klimata sistēmas stabilitātes ietekmēšanu. Piemēram, noteiktās teritorijās var būt novērojama arī reǵionāla temperatūras pazemināšanās un nokrišnu daudzuma ievērojama mainība. Globālās sasilšanas sekas var būt jūru un okeānu līmeṇu paaugstināšanās, krasta joslas erozijas pastiprināšanās un mitrzemju pārplūšana (sk. 5.12. att.), veǵetācijas mainība, upju un ezeru līmenu un noteces mainība. Šìs ietekmes savukārt var skart ne tikai cilvēka veselību, sabiedrībā norisošos procesus un ražošanu, lauksaimniecību, zivsaimniecību, mežsaimniecību, bet arī ietekmēt, piemēram, ostu sektoru (sk. 5.12. att.). Îpaši dramatiska klimata mainības ietekme var būt zemien,u reǵionos (pie kuriem pieskaitāma arī Latvija) un Zemes tropiskajos regionos, kuros tuksneša zonas ievērojams pieaugums var būtiski ietekmēt cilvēku izdzīvošanas iespējas. Protams, ka šādas ietekmes ir satraucošas. Arī
Baltijas jūras regiionā veikta klimata mainības un tās iespējamo seku izpēte un modelēšana, izstrādāti iespējamie klimata mainības model̦i, ar kuru palīdzību, n,emot vērā gaisa masu cirkulācijas raksturu un atmosfēras sastāva mainību, var prognozēt klimatu šajā reǵionā.

Būtiskas ietekmes saistāmas ar temperatūras izmain̄ām un to ietekmi uz biosfēru (sk. 5.13. att.). Temperatūras paaugstināšanās vispirms ietekmēs salnu varbūtības samazināšanos un izraisīs būtisku augšanas sezonas ilguma palielināšanos, kas ietekmēs lauksaimnieciskās ražošanas iespējas Ziemel̦amerikā un Eirāzijas ziemel̦u dal̦ā. Var pieaugt "karstuma viḷnu" varbūtība, bet ekstremāli karsti laikapstākḷi var kḷūt tipiski teritorijās, kurās līdz šim tie nav bijuši raksturīgi.

Klimatisko rādītāju izmaiṇas savukārt var nozīmīgi ietekmēt lauksaimniecisko ražošanu un svarīgāko lauksaimniecisko kultūru ražību (sk. 5.14. att.). Tiek prognozēts, ka, piemēram, ievērojami var pieaugt graudaugu ražỉba ziemelsu puslodē, vienlaikus tai ievērojami samazinoties Āfrikā un Āzijas dienviddal̦ā. Klimata mainība var sekmēt invazīvo sugu izplatību un lauksaimniecības kultūru kaitēkḷu migrāciju.

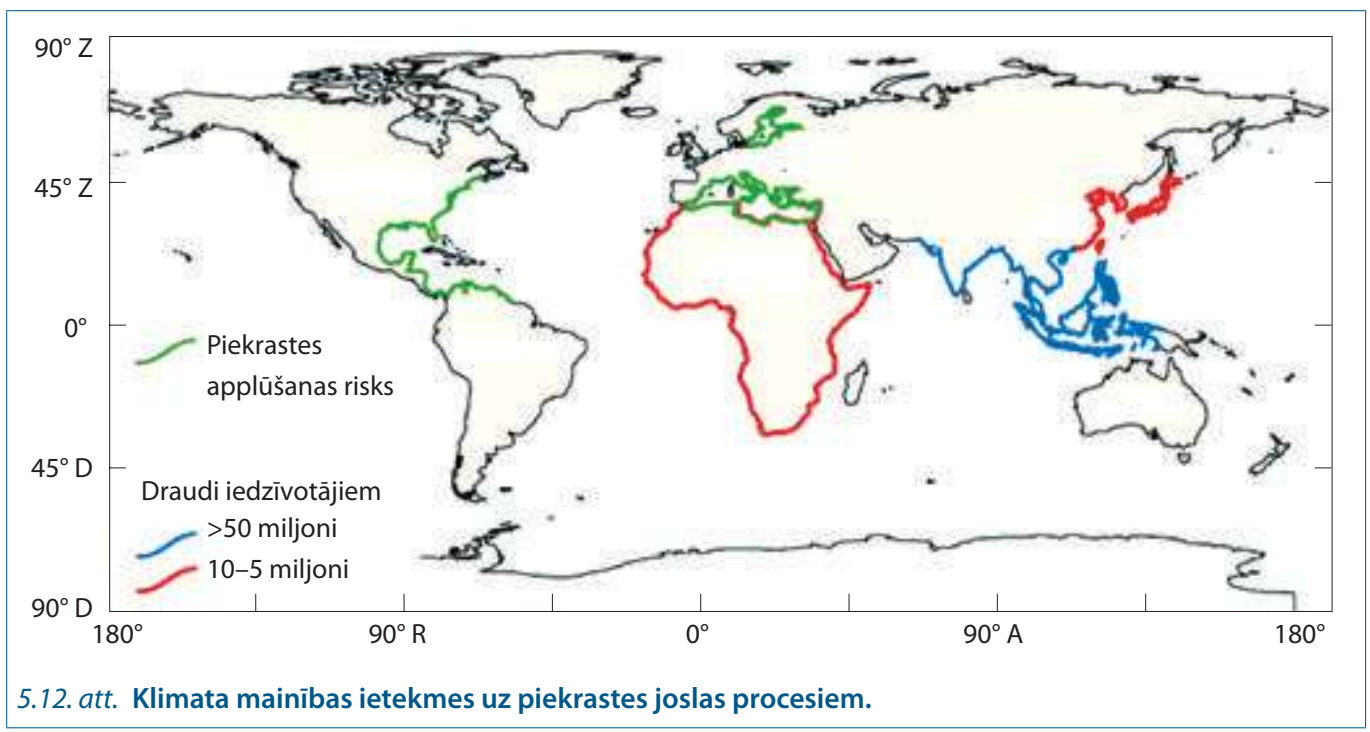




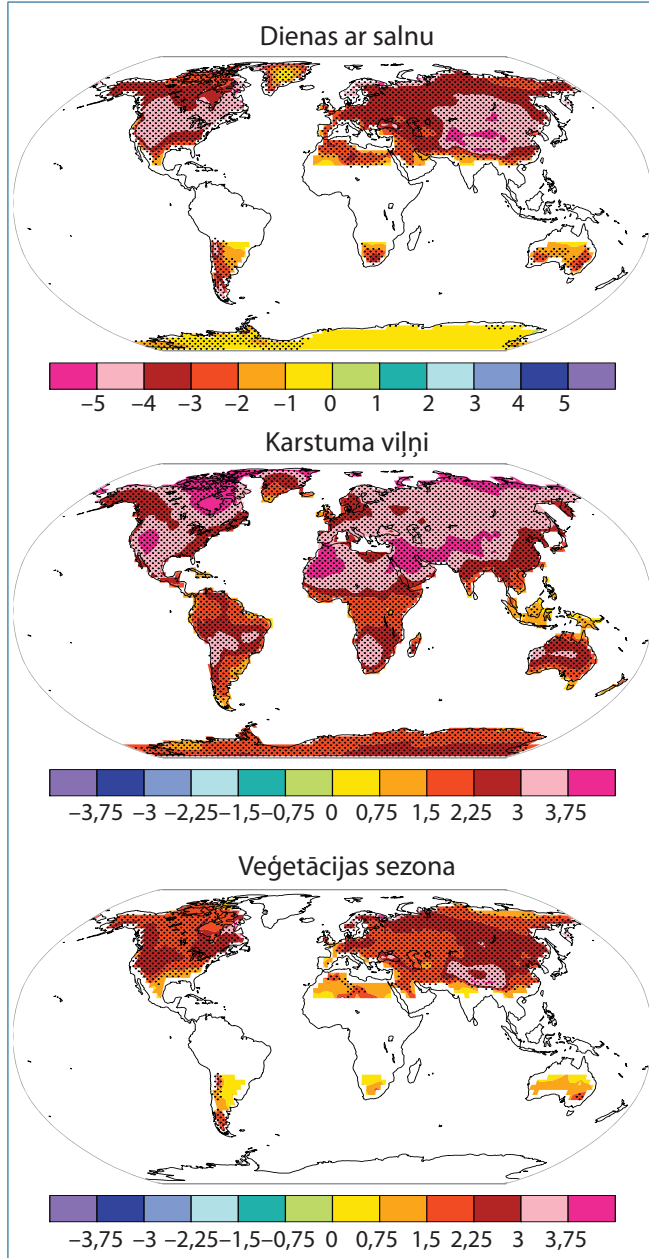

5.13. att. Dienu skaita ar salnām, karstuma viḷnu un veǵetācijas sezonas ilguma prognozētās izmainas 2100. gadā salīdzinājumā ar situāciju laika posmā no 1980. lídz 1999. gadam (iespējamais sabiedrības attīstības un klimata mainības scenārijs A1B).

Augstākas vasaras temperatūras var veicināt ablācijas procesu, tādēl var ievērojami samazināties kalnu ledāju platības zemos un vidēji augstos kalnājos. Polārajam jūras ledum raksturīgs augsts albedo, samazinoties ledus platībai, samazināsies īsviḷnu Saules starojuma atstarošana kosmosā, tādējādi palielinot siltuma daudzumu, ko absorbē okeāns.
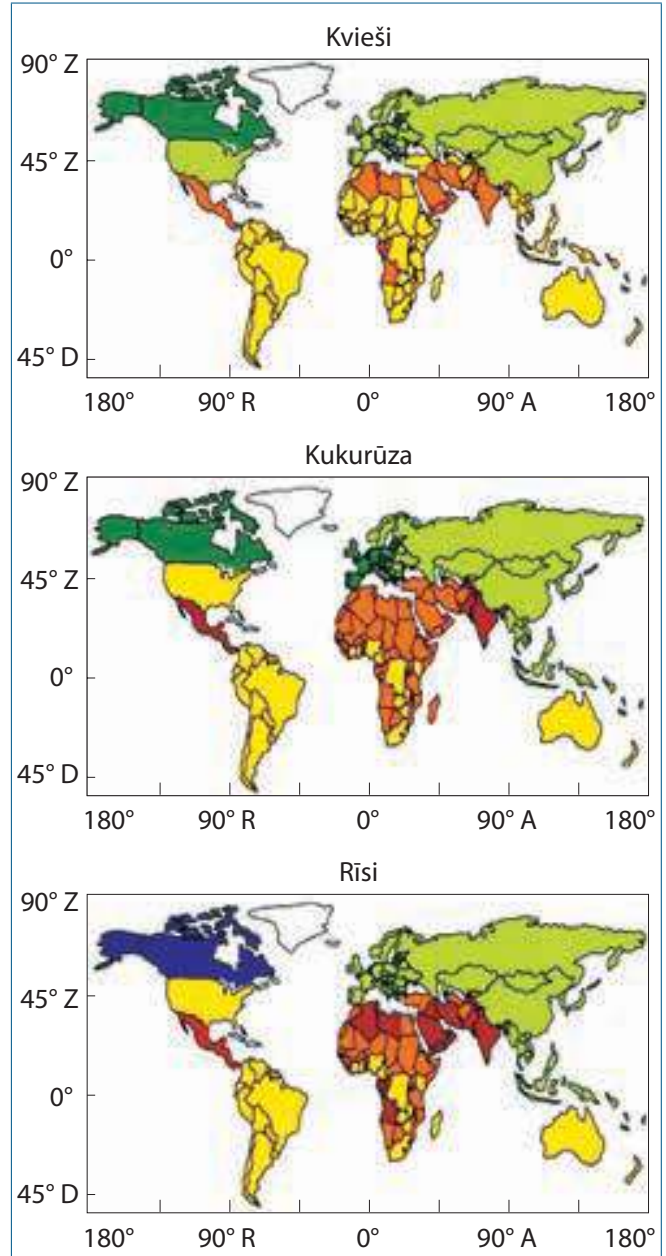

Graudaugu ražu izmaiṇas 2050. gadā, \%

\begin{tabular}{lllllllll}
\hline-40 & -30 & -20 & -10 & 0 & 10 & 20 & 30 & 40
\end{tabular}

5.14. att. Klimata mainības iespējamās ietekmes uz lauksaimniecības kultūru ražību.

Globālās sasilšanas ietekme uz biologisko daudzveidību kopumā ir maz pētīta. Ir pamats apgalvot, ka, klimatam strauji mainoties un kḷūstot siltākam, lielas izmaiṇas ir sagaidāmas mitrājos, kas aizṇem 4-6\% sauszemes. Mitrājos mainīsies hidrologiiskais režīms, dabas norišu sezonalitāte un tiks ietekmētas mitrāju bioloǵiskās, bioḳimiskās un hidroloǵiskās 
funkcijas. Iespējams, ka notiks izteikta dabas zonu pārvirze polu virzienā un vertikālā joslojuma izmaiņas kalnājos.

Globālā sasilšana var būtiski ietekmēt visdažādākās cilvēka dzīves un darbības jomas, un līdz ar to jau konstatētās ietekmes var izpausties visai negaidītos veidos. Klimata mainība ir kḷuvusi par vienu no svarīgākajām globālajām vides aizsardzības problēmām, kas ietekmē cilvēku veselību un sekmē dažādu slimību izplatību uz Zemes.

Cilvēka veselība ir atkarīga no l̦oti daudziem faktoriem: sociālajiem, politiskajiem, ekonomiskajiem, ekologiskajiem faktoriem, tehnologiju attīstības, apdzīvotības, zinātnes attīstības, iedzimtības u.c. Atbilstoši prognozēm dažas no paredzamajām klimata izmain,ām var būt cilvēku veselībai labvēlīgas. Piemēram, pateicoties maigākam klimatam ziemas mēnešos, mērenā platuma grādos samazināsies cilvēku mirstība no aukstuma. Karstajos pasaules reǵionos, paaugstinoties temperatūrai, atsevišk̦ās vietās samazināsies infekcijas slimību pārnēsātāju (piemēram, moskītu) izplatība. Tomēr vairumā gadījumu klimata radītās izmaiṇas būs nelabvēlīgas cilvēku veselībai un veicinās dažādu slimību izplatību. Spēcīgāk tas izpaudīsies nabadzīgās valstīs. Valstīs ar labvēlīgiem vides, sociāli ekonomiskiem apstākḷiem, stabilu veselības aprūpes sistēmu un tehnoloǵijām būs iespējams vieglāk pielāgoties klimata mainībai.

Klimata mainības ietekmi uz cilvēka veselību var iedalīt trīs galvenajās grupās:

- tieša ietekme uz cilvēku veselību, ko parasti izraisa dabas kataklizmas (ievainojumi, nāve),

- ietekmes, kas saistītas ar izmainām apkārtējā vidē, vides stāvoklī,

- dažādas veselības problēmas, slimības, kas saistītas ar klimata pārmaiṇu izraisītām kritiskām situācijām, piemēram, cilvēku evakuāciju, ietekmēm uz ekonomisko situāciju.

Lai izvērtētu klimata ietekmes un ar tām saistītos riskus kopumā, ir izstrādāts Globālais klimata risku indekss ${ }^{1}$, kas raksturo valstu jutību un pakḷautību ekstremālām klimatiskām parādībām, lauj novērtēt to atkārtojamību (biežumu) un līdz ar to iespējamos riskus nākotnē.

\footnotetext{
${ }^{1}$ Global Climate Risk Index

https://germanwatch.org/en/cri
}

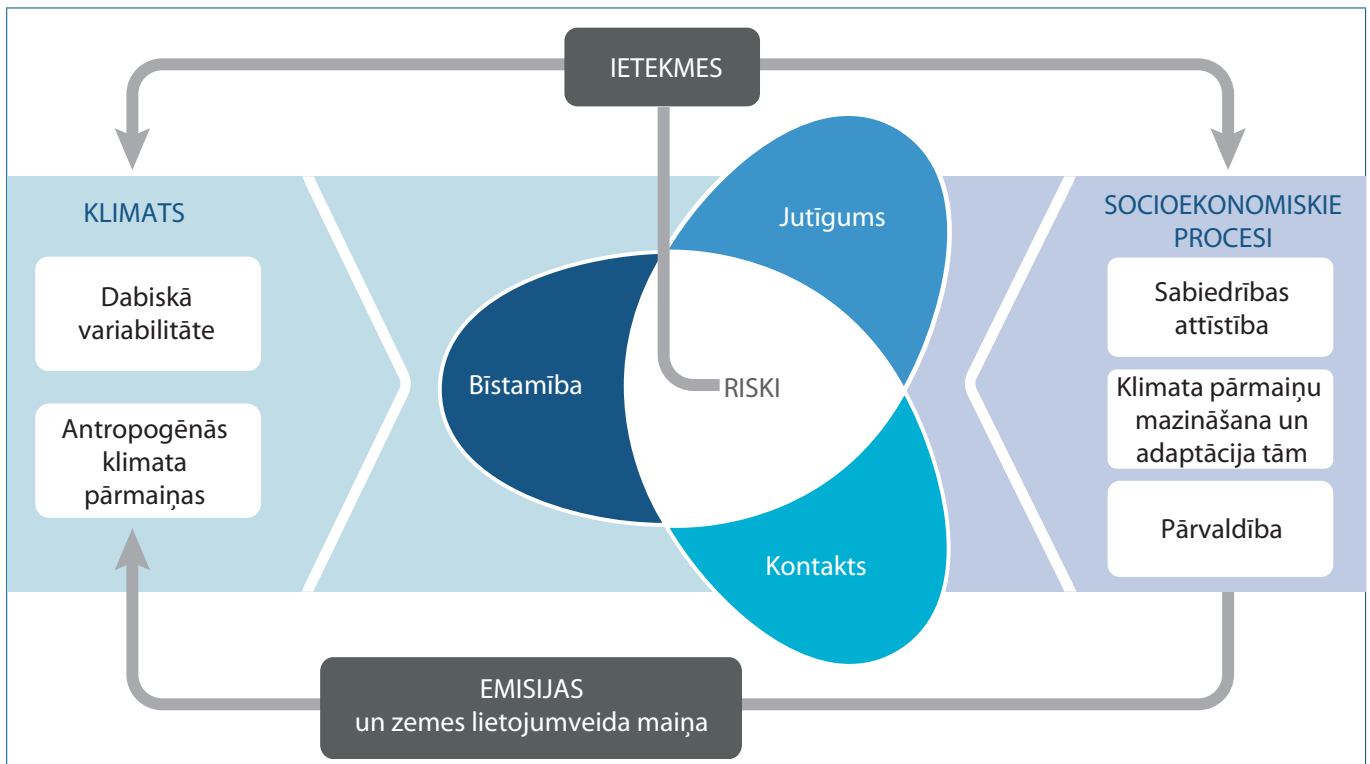

5.15. att. Klimata pārmaiṇu ietekmes uz sabiedrību un nepieciešamās darbības šo ietekmju mazināšanai. 
Klimata risku noteikšanas pamatā ir ekstremālo klimatisko parādību skaitliski izmērāmas ietekmes: gan attiecībā uz nāves gadījumiem, gan materiāliem zaudējumiem. Saskaṇā ar Globālo klimata risku indeksu laikā no 1994. līdz 2013. gadam vairāk nekā 530000 cilvēku miruši apmēram 15000 ekstremālu klimata gadījumu rezultātā, bet materiālie zaudējumi par šo periodu ir $\approx 2,2$ triljoni ASV dolāru. Protams, augstākais klimata risks raksturīgs jaunattīstības valstīm, piemēram, Hondurasai, Mjanmai, Haiti, Filipīnām, Bangladešai. Lielāko nāves gadījumu skaitu rada gan plūdi, gan bads, kuru izraisa ilgstošs sausums. Taču lielākos materiālos zaudējumus veido ekstremāli klimata gadījumi tieši attīstītajās valstīs, piemēram, plūdi 2002. gadā Vācijā un citās Centrāleiropas valstīs radīja zaudējumus 14,6 miljardu ASV dolāru apjomā. Arī attīstītās valstīs klimata ekstrēmi prasa cilvēku upurus, piemēram. 2003. gada karstuma vilṇa dēl Eiropā bija $\approx 70000$ nāves gadījumu, bet 2010. gada karstuma vilnis Krievijas federācijā bija cēlonis 55000 nāves gadījumu.

Svarīgs cilvēka veselības riska faktors ir paaugstinātas temperatūras ietekme. Karstajā laikā riskam ir pakḷauti cilvēki gados, it īpaši vecāki par 75 gadiem, cilvēki ar hroniskiem veselības traucējumiem, elpcel̦u vai sirds un asinsvadu slimnieki, zīdaiņi un mazi bērni. Karstums var būt iemesls karstuma dūrienam un Saules dūrienam, kas atsevišksos gadījumos var izraisìt pat nāvi. Arī jauni un veseli cilvēki nav pasargāti no karstuma radītā vājuma. Pilsētu un apdzìvotu vietu iedzīvotāji ir vairāk paḳlauti karstuma negatīvajai ietekmei nekā laukos dzīvojoši cilvēki. Gaisa piesārn,ojums, kas parasti ir augstāks apdzīvotās vietās, vēl vairāk

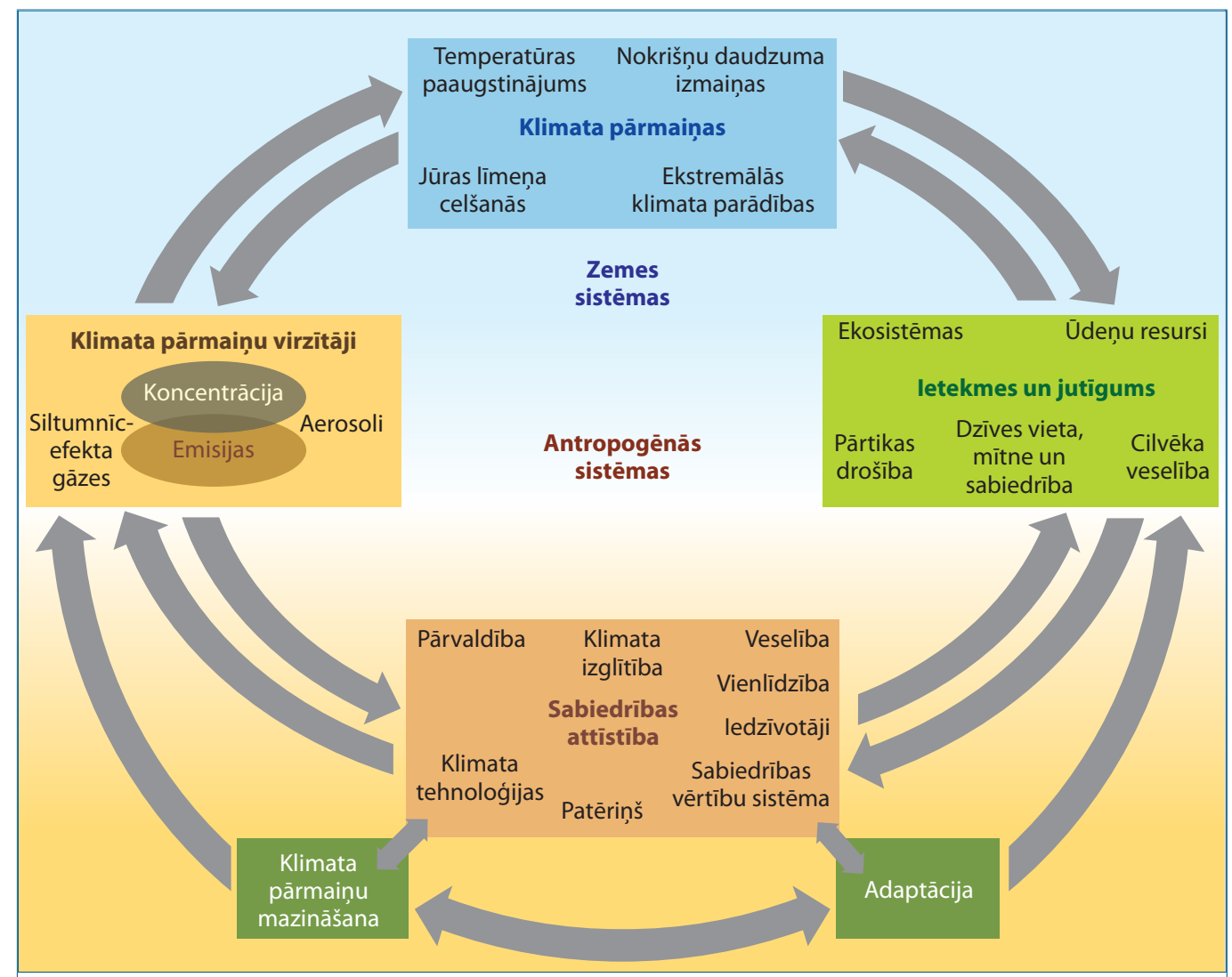

5.16. att. Klimata pārmaiṇu ietekmju, iespējamo seku un nepieciešamo rīcību kopsakarības. 
pastiprina karstuma ietekmes negativo efektu. Postošāk karstums var ietekmēt nabadzīgākos reǵionos un jaunattīstības valstīs, kur ir vājāk attīstīta veselības aprūpes sistēma, trūkst resursu un līdzekḷu, lai varētu pielāgoties temperatūras izmain̄ām, kā arī ir ierobežotas iespējas izmantot gaisa kondicionētājus.

Globālā sasilšana var ietekmēt arī dabas kataklizmu biežumu un intensitāti. Dal̦a šo klimata anomāliju tiek saistītas ar El Niño fenomenu: neparasti stipras lietavas, viesulvētras un plūdi. Arī šo dabas parādību sekas postošāk izpaudīsies nabadzīgajās un jaunattīstības valstīs, jo glābšanas dienestu gatavība kritiskām situācijām un medicīnas infrastruktūra industriāli attīstītās valstīs ir samazinājusi bojā gājušo cilvēku skaitu.

Globālā sasilšana var sekmēt straujāku tādu infekcijas slimību izplatīšanos kā malārija, Denges drudzis, dzeltenais drudzis. Malārija ir daudzos tropu un subtropu regionos izplatīta un cilvēku dzīvībai bīstama slimība. Slimības ierosinātāju pārnēsā malārijodu sugas. Apmēram $40 \%$ pasaules iedzīvotāju mīt teritorijās, kur pastāv iespēja inficēties ar malāriju. Pasaulē katru gadu no šīs slimības mirst aptuveni 1 miljons cilvēku, pārsvarā bērni. Zinātnieki prognozē, ka, temperatūrai paaugstinoties par $2-3{ }^{\circ} \mathrm{C}$ (par 3-5\%), palielināsies to indivīdu skaits (t.i., par vairākiem simtiem miljonu cilvēku), kas dzīvos malārijas riska teritorijās.

Arī Denges vīrusa infekcija, ko pārnēsā moskīti, ir izplatīta Centrālamerikas un Dienvidamerikas tropu un subtropu rajonos, Dienvidāzijā un Dienvidaustrumāzijā, kā arī Āfrikā. Vairāk nekā puse pasaules iedzìvotāju mìt teritorijā, kurā pastāv risks ar to saslimt. Tā ir slimība, kas novērota tropu rajonos visu gadu, bet izplatības maksimumu sasniedz mitros un lietainos mēnešos. Globālās sasilšanas dēḷ var ievērojami pieaugt Denges vīrusa izplatības areāls. Klimata mainība ietekmē arī laimas slimības baktēriju un encefalìta vīrusa izplatību. Laimas slimības izplatības areāls maigo un silto ziemu dēl var paplašināties uz ziemeliem.

Lielu dabas kataklizmu laikā, paaugstinoties gaisa temperatūrai, pasliktinoties ūdens kvalitātei un ūdenim sajaucoties ar lietus un zemes dal̦ām, var attīstīties patogēni mikroorganismi, kas izraisa dažādas slimības un pat to epidēmijas (dizentēriju, holeru, tīfu, A hepatītu u.c.). Zemes rajonos, kur ir problēmas ar dzeramo ūdeni, ar diareju saistīto slimību iespējamība klimata mainības ietekmē līdz 2030. gadam palielināsies par desmit procentiem.

Arī antropogēnais gaisa piesārṇojums un putekḷi nopietni ietekmē un apdraud cilvēku veselību. Gaisa piesārn,ojuma problēma ir aktuāla pilsētās, kuras strauji aug un attīstās. Dažādi gaisa piesārṇotāji var izraisīt elpošanas cel̦u slimību saasināšanos un pat nāvi. Nopietnas problēmas cilvēku veselībai rada alergēni (piemēram, ziedputekšni). Vējā ziedputekšñi pārvietojas l̦oti tālu. Augu ziedēšanas laiks un ziedputekšn,u izplatība ir atkarīga no laikapstākḷiem. Zinātnieki prognozē, ka, iestājoties agrākam pavasarim un vēlākam rudenim, būs ilgāka alerǵiju izraisošo augu ziedēšanas sezona. Bērzu ziedputekšnu daudzums (galvenais sezonālo alerǵiju izraisītājs Ziemel̦eiropā) palielinās, paaugstinoties sezonālajai temperatūrai. Radona koncentrācijas pieaugums zemākajos atmosfēras slān,os, pasiltinoties klimatam, palielina risku saslimt ar plaušu vēzi. Sausuma periodos pieaugs postošu ugunsgrēku (īpaši meža ugunsgrēku) skaits, kas piesārn,o gaisu un izraisa elpošanas cel̦u slimības un acu iekaisumus.

\section{Avoti tālākām studijām}

Intergovernmental panel on climate change: $h t t p: / / w w w . i p c c . c h /$

Climate change and global warming: http://climate.nasa.gov/

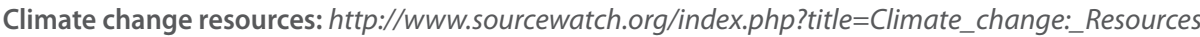

Basic information on climate change $h t t p: / / w w w . c r u u e a . a c . u k / c r u / i n f o$

Greenhouse gases and climate change $h t t p: / / w w w . i e a g r e e n . o r g . u k$ 


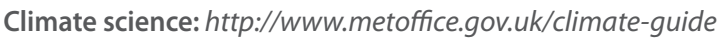

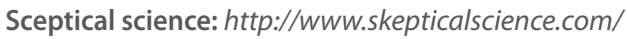

State of the climate: $h t t p: / / w w w . n c d c . n o a a . g o v / s o t c /$

\section{Literatūra}

Aguado E., Burt J. (1999) Understanding Weather and Climate. Prentice Hall: New Jersey.

Burroughs W. J. (2001) Climate Change: a Multidisciplinary Approach. Cambridge University Press: Cambridge.

Drake F. (2000) Global Warming: the Science of Climate Change. Arnold: London.

Henson R. (2013) A Rough Guide to Climate Change. Peguin Books: London.

IPCC 2013 Climate change (2013) The Physical Science Basis. Contribution of Working Group I to the Fifth Assesment Report of the Intergovernmental Panel on Climate Change. Cambridge University Press: Cambridge UK.

O'Hare G., Sweeney J., Wilby R. (2005) Weather, Climate and Climate Change. Human Perspective. Prentice Hall: Edinghburgh (UK).

Izmantotie attēli

5.1. Ar ațauju no IPCC 2015.

5.2. Ar ațauju no IPCC 2015.

5.3. Ar atlauju no IPCC 2015.

5.4. Ar ațlauju no IPCC 2015.

5.5. Ar ațauju no IPCC 2015.

5.6. Ar ațauju no IPCC 2013.

5.7. Ar ațauju no IPCC 2015.

5.8. Ar ațlauju no IPCC 2015.

5.9. Ar ațlauju no IPCC 2013.

5.10. Ar ațauju no IPCC 2013.

5.11. Ar ațauju no IPCC 2013.

5.12. Modificēts pēc IPCC 2001.

5.13. Ar ațauju no IPCC 2013.

5.14. Modificēts pēc IPCC 2001.

5.15. Modificēts pēc IPCC 2015.

5.16. Modificēts pēc IPCC 2015.

Izmantotās tabulas

5.1. Pēc IPCC 2015.

5.2. Pēc IPCC 2015. 


\section{6.}

:

Klimatisko faktoru ietekme

uz dzivajiem organismiem 


\subsection{Vides faktoru ietekme uz dzivajiem organismiem: Šelforda likums}

Klimatu veido vides faktoru komplekss temperatūra, nokrišn,u daudzums, Saules energija, atmosfēras cirkulācija. Šie faktori, savukārt, ir atkarīgi no konkrētās geogrāfiskās vietas, geogrāfiskā platuma, reljefa, okeāna straumju un gaisa masu cirkulācijas īpatnībām. Vides faktori iedarbojas uz dzīvajiem organismiem, nosaka to sadalījumu telpā, skaitu un sugu sastāvu konkrētajā vietā.

Dzivvo organismu reakciju uz katru atseviško vides faktoru apraksta Šelforda diagrammas teorētiskais modelis - viena maksimuma līkne (6.1. att.). Kā organisma reakcijas skaitliskās vērtības var izmantot dažādas organismu dzīvības procesus raksturojošas īpašības, piemēram, kustīgumu, organismu skaitu, vairošanās vai vielmainas intensitāti, u.tml., bet kā faktora iedarbību raksturojošās vērtības - faktora intensitāti. Šelforda diagrammā līknes maksimums atbilst tādām faktora intensitātes vērtībām, pie kurām organisms jūtas vislabāk, tāpēc šo faktora vērtību apgabalu dēvē par faktora optimuma zonu (6.1. att.). Pa labi un pa kreisi no optimuma zonas atrodas nepietiekamības

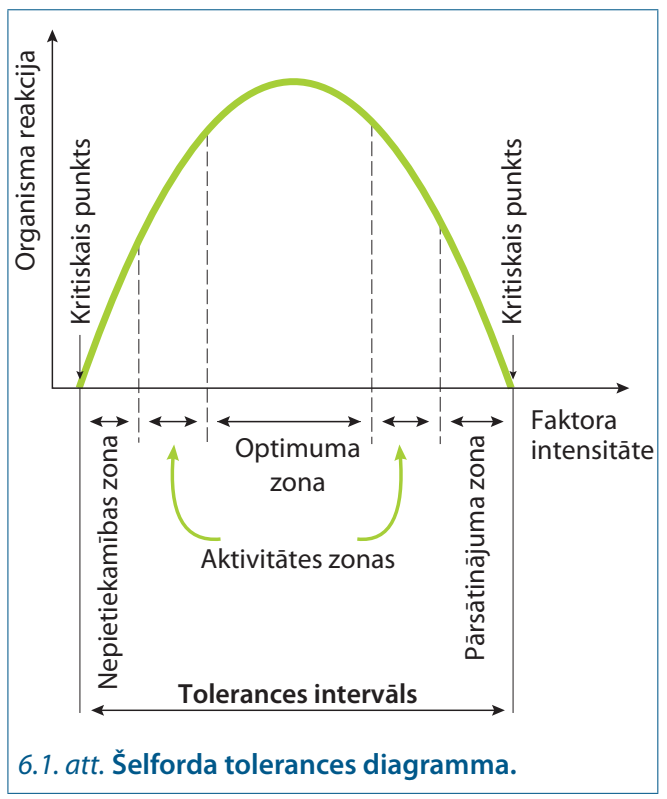

un pārsātinājuma zonas - faktora intensitātes vērtību apgabali, kuros organisma stāvoklis vērtējams kā tuvs kritiskam. Nokḷūstot šādos apstākḷlos, organisms parasti cenšas veikt darbības, lai atgrieztos optimuma zonā. Šĩs darbības sauc par izvairīšanās reakcijām.

Izvairīšanās reakcijas var būt, piemēram, organisma bēgšana no nelabvēlīgās vides, diennakts un sezonālās migrācijas, snaudošo stadiju (cistu, sporu, sēklu) veidošana, ziemas vai vasaras guḷ. Katram organismam attiecībā uz konkrētu vides faktoru pastāv noteiktas izturības robežas. Faktora intensitātes apgabalu starp minimālo un maksimālo kritisko punktu sauc par organisma tolerances intervālu. Ja faktora intensitāte atrodas ārpus tolerances intervāla, organismi iet bojā.

Organisma tolerances intervālus sīkākiem organismiem, piemēram, kukainiem, nosaka laboratorijā, izmantojot īpašus stendus vai kameras, kurās var regulēt pētāmā faktora intensitāti, turpretī lielākiem organismiem jāveic pētījumi dabā, uzskaitot organismus vietās ar atškkirīgu pētāmā faktora intensitāti. Jāatzīmē, ka šādos pētījumos iegūtās Šelforda līknes ne vienmēr ir simetriskas (sk. 6.2., 6.3. att.) tāpēc, ka pētījumos ir grūti pilnībā izslēgt citu faktoru ietekmi.

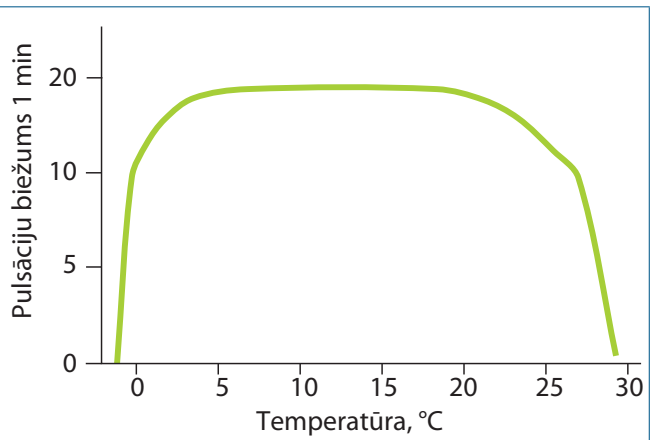

6.2. att. Laboratorijas apstākḷ os noteikta medūzas Aurelia aurita tolerances līkne, kas rāda medūzas ḳermeṇa saraušanās pulsācijas biežumu dažādās ūdens temperatūrās. 


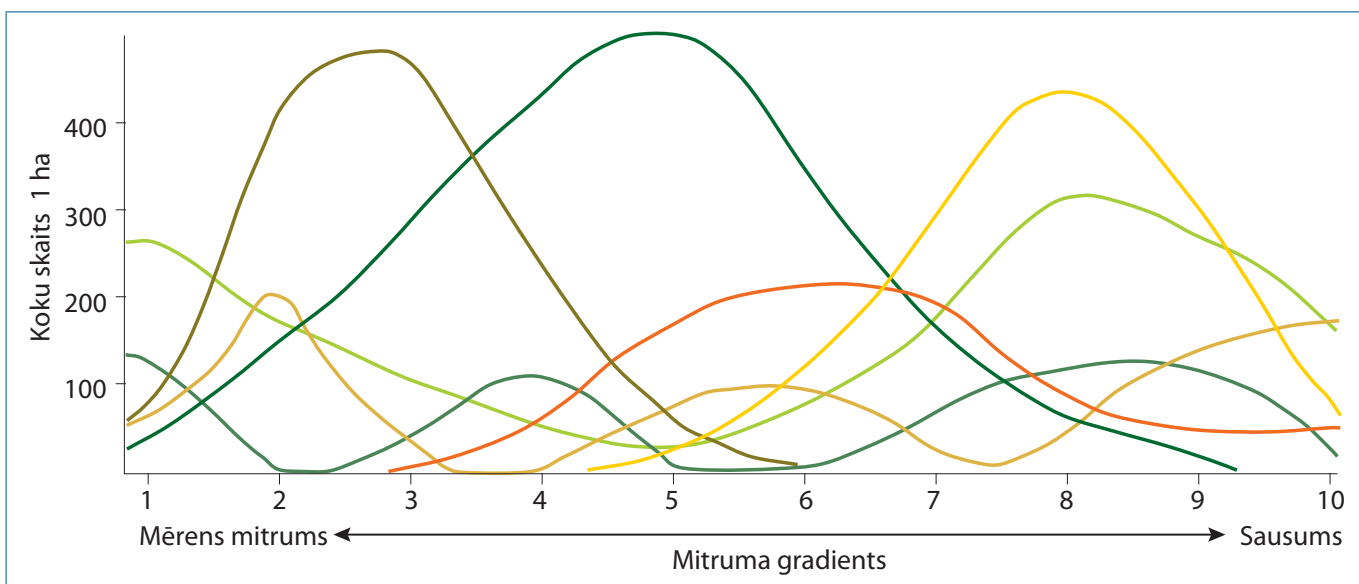

6.3. att. Dažādu sugu koku skaita izmaiṇas parauglaukumos, kas iekārtoti uz augsnes mitruma izmaiṇu gradienta kalnu nogāzē Viskosinas štatā ASV. Katra līkne atbilst vienai koku sugai.

\subsection{Vides faktoru mijiedarbība}

Uz dzīvajiem organismiem dabā vienlaikus iedarbojas l̦oti daudz dažādu vides faktoru. Tādēl, analizējot organismu reakciju uz šiem faktoriem, bieži vien jārunā ne tik daudz par katra atsevišksa faktora ietekmi, kā par vairāku faktoru mijiedarbības ietekmi. Faktoru mijiedarbība izpaužas tādējādi, ka, pastāvot viena faktora vienām un tām pašām intensitātes vērtībām, organisma reakcija ir atšksirīga atkarībā no citu faktoru iedarbības intensitātes. Piemēram, augu izturība pret sausumu ir atkarīga ne vien no mitruma daudzuma, bet arī no organisko vielu satura augsnē. Ja organisko vielu saturs ir lielāks, auga izturība pret vienu un to pašu pazeminātā mitruma līmeni augsnē ir lielāka. Tādējādi organiskās vielas saturs darbojas kā kompensējošs faktors sausuma ietekmei. Tomēr, ja kāda organismam vitāli svarīga faktora iedarbības intensitāte pārsniedz tolerances intervāla robežas, nekāda citu faktoru kompensējošā iedarbība nespēj to glābt no bojāejas. To izsaka Šelforda tolerances likums:

neatkarīgi no pārējo vides faktoru nodrošinātības, organisma darbību limitē tas faktors, kas atrodas tuvāk minimālajam vai maksimālajam kritiskajam punktam.
Mūsdienās papildus dabiskajiem vides faktoriem dzìvos organismus ietekmē arī dažādi antropogēnie faktori - vides piesārn,ojums, zemes apsaimniekošana, būvniecība un transports, invazīvo sugu parādī̌̌anās apgabalos, kur tās agrāk nav bijušas sastopamas, resursu pārekspluatācija (6.4. att.). Turpat 83\% no planētas sauszemes atrodas tiešā cilvēka ietekmē un 36\% sauszemes cilvēka darbība dominē pār dabas procesiem. Gandrīz 60\% planētas ekosistēmu mūsdienās ir uzskatāmas par degradētām. Cilvēks izmanto pusi no planētas saldūdens resursiem. Saimnieciskā darbība mūsdienās kontrolē daudz lielākus slāpekḷa aprites apjomus nekā slāpekḷa dabiskā aprite. Antropogēno faktoru mijiedarbība ar dabiskajiem vides faktoriem, to skaitā klimatiskajiem faktoriem, var būt l̦oti sarežǵìta. Pat tādā gadījumā, ja visi dabiskie vides faktori, arī temperatūra un mitrums ir optimāls, suga var aiziet bojā no vides piesārṇojuma vai tās dzīvotnes izmainu dēl, ja cilvēks ar savu saimniecisko darbību ir padarījis ekologiskos apstākḷus sugas eksistencei nepiemērotus. Un otrādi, ja cilvēks ar savu saimniecisko darbību ir mainījis temperatūras vai mitruma režīmu un barības 


\begin{tabular}{|c|c|c|c|c|c|c|c|}
\hline \multirow[b]{2}{*}{ Ekosistēmas } & & \multirow{3}{*}{$\begin{array}{c}\text { Dzīvotñu } \\
\text { izmain,as } \\
\nearrow\end{array}$} & \multirow{3}{*}{$\begin{array}{c}\text { Klimata } \\
\text { izmainas }\end{array}$} & \multicolumn{3}{|c|}{ Faktori } & \multirow{2}{*}{$\begin{array}{l}\text { Piesārnojums } \\
\text { (slāpeklis, } \\
\text { fosfors) }\end{array}$} \\
\hline & sistēmas & & & $\begin{array}{l}\text { Invazivās } \\
\text { sugas }\end{array}$ & eksp & tācija & \\
\hline \multirow{3}{*}{ Mežu } & Boreālo & & & $\pi$ & & & $\uparrow$ \\
\hline & Mērenās joslas & $y$ & $\uparrow$ & $\uparrow$ & & & $\uparrow$ \\
\hline & Tropisko & $\uparrow$ & $\uparrow$ & $\uparrow$ & & & $\uparrow$ \\
\hline \multirow{4}{*}{ Sauszemes } & Mērenās joslas zālāju & $\pi$ & $\uparrow$ & $\rightarrow$ & & & $\uparrow$ \\
\hline & Vidusjūras & $\pi$ & $\uparrow$ & $\uparrow$ & & & $\uparrow$ \\
\hline & $\begin{array}{l}\text { Tropisko zālāju un } \\
\text { savannas }\end{array}$ & $\pi$ & $\uparrow$ & $\uparrow$ & & & $\uparrow$ \\
\hline & Tuksnešu & $\rightarrow$ & $\uparrow$ & $\rightarrow$ & & & $\uparrow$ \\
\hline \multicolumn{2}{|c|}{ lekšzemes ūden̦u } & $\uparrow$ & $\uparrow$ & $\uparrow$ & & & $\uparrow$ \\
\hline \multicolumn{2}{|c|}{ Piekrastes } & $\pi$ & $\uparrow$ & $\pi$ & & & $\uparrow$ \\
\hline \multicolumn{2}{|l|}{ Jūras } & $\uparrow$ & $\uparrow$ & $\rightarrow$ & & & $\uparrow$ \\
\hline \multicolumn{2}{|l|}{ Salu } & $\rightarrow$ & $\uparrow$ & $\rightarrow$ & & & $\uparrow$ \\
\hline \multicolumn{2}{|l|}{ Kalnu } & $\rightarrow$ & $\uparrow$ & $\rightarrow$ & & & $\uparrow$ \\
\hline \multicolumn{2}{|c|}{ Polārās } & $\pi$ & $\uparrow$ & $\rightarrow$ & & & $\uparrow$ \\
\hline & & \multicolumn{2}{|c|}{$\begin{array}{l}\text { Dažu galveno faktoru ietekme } \\
\text { uz biodaudzveidību pēdējā gadsimta laikā }\end{array}$} & \multicolumn{4}{|c|}{$\begin{array}{l}\text { Dažu galveno faktoru ietekmes } \\
\text { pašreizējo izmainu tendences }\end{array}$} \\
\hline & & \multicolumn{2}{|l|}{ Maza } & \multicolumn{2}{|c|}{ Samazināšanās } & $y$ & \\
\hline & & Mērena & & \multicolumn{2}{|c|}{ Bez izmaiṇām } & $\rightarrow$ & \\
\hline & & Liela & & \multirow{2}{*}{\multicolumn{2}{|c|}{$\begin{array}{l}\text { Palielināšanās } \\
\text { Loti strauja } \\
\text { palielināšanās }\end{array}$}} & $\pi$ & \\
\hline & & Loti liela & & & & $\uparrow$ & \\
\hline \multicolumn{8}{|c|}{$\begin{array}{l}\text { 6.4. att. Dažādu faktoru salīdzinošā ietekme uz planētas ekosistēmām 20. gs. laikā, un šo faktoru ietekmes } \\
\text { pašreizējās izmainu tendences. }\end{array}$} \\
\hline
\end{tabular}

vielu koncentrāciju konkrētā vietā, tā var kḷūt piemērota kādas sugas attīstībai un tad tā pārmērīgi savairojas.

Piemēram, ir aprēḳināts, ka 42\% Dienvidaustrumāzijas sugu līdz 2100. gadam var izzust mežu izciršanas un ainavu fragmentācijas dēḷ. Visu šo faktoru sarežgiìtās mijiedarbības dēḷ sugu izmiršanas process uz planētas notiek simtiem un tūkstošiem reižu ātrāk nekā visā Zemes ǵeoloǵiskās vēstures laikā.

Vērtējot klimata izmainu ietekmi uz sugām, parasti tiek apskatīta divu visiem dzīvajiem organismiem vitāli svarīgu vides faktoru - temperatūras un mitruma ietekme. Apskatīsim sīkāk tieši šo faktoru ietekmi uz dzivvajiem organismiem. 


\subsection{Temperatūras ietekme uz dzivajiem organismiem}

Vides temperatūra ir viens no svarīgākajiem organismus ietekmējošiem klimatiskajiem faktoriem. Ja vides temperatūra ir mazāka vai pārsniedz noteiktu kritisko robežlielumu, organisms nespēj nodrošināt dzīvības procesus un iet bojā, vai nu nosalstot vai pārkarstot. Dažādu sugu organismu tolerances intervāli attiecībā uz temperatūru l̦oti atšksiras. Primitīviem organismiem, tādiem kā baktērijas un sēnes, tolerances intervāli parasti ir ievērojami plašāki nekā augstāk attīstītajiem. Sēṇu sporas saglabā dzīvotspēju pat temperatūrās, kas tuvas absolūtajai nullei $\left(-273^{\circ} \mathrm{C}\right)$ vai ievērojami pārsniedz ūdens viršanas temperatūru $\left(+100^{\circ} \mathrm{C}\right)$. Augstāk attīstītajiem organismiem tolerance pret temperatūru ir daudz mazāka un svārstās robežās no $0{ }^{\circ} \mathrm{C}$ līdz $+50^{\circ} \mathrm{C}$.

Minētie adaptācijas mehānismi vides temperatūras izmainām ir izveidojušies ilgstošā sugu evolūcijas procesā, pielāgojoties konkrēta klimatiskā apgabala temperatūras režīmam. Gadījumos, ja notiek krasas izmaiṇas šajā režīmā, sugas masveidā iet bojā. Konkrētas sugas eksistencei ir svarīgas šādas temperatūras: minimālās temperatūras ziemā, maksimālās temperatūras vasarā un pozitīvo temperatūru summas. Pēdējās iegūstamas, ja saskaita visas mēneša vai sezonas diennakts temperatūras, kuras nav mazākas par noteiktu normu, teiksim $+4^{\circ} \mathrm{C}$ (tiek izmantotas arī citas vērtības, piemēram $+5^{\circ} \mathrm{C}$ vai $+6^{\circ} \mathrm{C}$ ). Pozitīvo temperatūru summai kā rādītājam ir loti liela biologiska jēga; organisma fiziologiskie procesi - augšana, dzimumšūnu nobriešana un vairošanās nevar notikt temperatūrā, kas zemāka par attiecīgo normu. Respektīvi, ja laika periods ar temperatūrām, kas augstākas par konkrēto normu, nav pietiekami ilgs, organisms nepagūst izaugt, nobriest vai savairoties. Līdz ar to pilnvērtīga sugas eksistence tādos apstāklıos nav iespējama. Tāpēc daudzi dienvidu augi mērenajā zonā var gan uzziedēt, bet dod auglus tikai apsildāmas oranžērijas apstākḷos. Ja klimata pasiltināšanās rezultātā palielinās temperatūru summa, veǵetācijas sezona kḷūst garāka un attiecīgais reǵions kḷūst piemērotāks dienvidu sugu attīstībai. Taču lıti būtiskas sugas eksistencei ir arī gada maksimālās un minimālās temperatūras. Pietiek, ja sezonas laikā kaut uz dažām stundām temperatūra pazeminās vai pārsniedz attiecīgās sugas kritisko punktu, lai tās eksistence konkrētajā regionā nebūtu iespējama. Tas notiek, neraugoties uz to, ka pārējā laikā temperatūras svārstības ir sugai pien,emamas.

Jebkurai dzìvo organismu sugai piemīt ekspansijas tieksmes. Suga savā izplatības areālā ir sastopama lielāku vai mazāku indivīdu grupu - populāciju veidā. Temperatūra ir viens no sugas ekspansiju ierobežojošiem faktoriem, kas nosaka tās izplatības areāla robežas. Siltākos gados dienvidu sugu populācijas izlaužas uz ziemel̦iem, gluži tāpat vēsākos gados ziemel̦u populācijas paplašina savus areālus uz dienvidiem. Tādējādi sugu areālu robežas ir izplūdušas, un atšksirībā no valstu robežām nemitīgi mainās. Klimata pasiltināšanās ir viens no būtiskiem iemesliem dienvidu sugu ekspansijai ziemel̦u regíonos un vēsāku klimatu mīlošu sugu izzušanai dienvidu reǵionos.

\subsection{Mitruma ietekme uz dzivajiem organismiem}

Mitrums ir otrs svarīgākais vides faktors, kas ietekmē sugu izplatību gan regionālā, gan lokālā mērogā sauszemes ekosistēmās. Mitrums ir cieši saistīts, no vienas puses, ar nokrišnu daudzumu, konkrētajai vietai pieplūstošajiem gruntsūden,iem vai pazemes ūden,iem un, no otras puses, ar iztvaikošanu. Ja iztvaikošanas intensitāte ievērojami pārsniedz pieplūstošā ūdens daudzumu, iestājas sausums. Tajos dienvidu reǵionos, kur valda ilgstošs sausums, veidojas stepes, pustuksneši un tuksneši. Ja nokrišn,u un pieplūstošā ūdens daudzums pārsniedz iztvaikošanu, veidojas pārmitri apstākḷi. Mērenās joslas un ziemel̦u 
regiionos, kur nokrišņi dominē pār iztvaikošanu, zemākās reljefa vietās veidojas purvi.

Sauszemes ekosistēmās galvenais mitruma rezervuārs ir augsne. Augsnē ieplūstošais ūdens veido augsnes mitrumu. Atmosfēras gaisa mitrumu veido iztvaikojušais ūdens.

Ūdenim ir vitāli svarīga nozīme sauszemes organismu dzīvē. Ūdens ir svarīga jebkura organisma ķīmiskā sastāvdalı. Bez ūdens nevar notikt bioksimiskās reakcijas organismu šūnās. Visu sauszemes organismu dzimumšūnu saplūšanai un embriju attīstībai nepieciešama ūdens vide.

Atmosfēras gaisa mitrums nodrošina dzīvnieku elpošanas orgānu mitrināšanu. Pastiprināta iztvaikošana veicina dzīvnieku un augu organismu atdzišanu, tādējādi kompensējot Saules siltuma starojuma ietekmi. Taču pārāk intensīva iztvaikošana ir arī kaitīga, piemēram, abiniekiem, gliemjiem, sēnēm tā var būt nāvējoša.

Augsnes mitrums ir limitējošs faktors daudziem augsnes organismiem, piemēram, baktērijām, vienšūṇiem, augsnes nematodēm, sliekām, kas spēj eksistēt tikai mitrā vidē, ūdens plēvītēs vai starp augsnes daļinām ieslēgtos pilienos.

Tā kā mitrums sauszemes organismiem bieži vien ir limitējošs faktors, tie evolūcijas procesā ir izstrādājuši dažādus pielāgojumus, lai izdzīvotu nepietiekama vai pārmērīga mitruma apstākḷıs. Pēc spējas regulēt ūdens daudzumu šūnās, atkarībā no tā daudzuma vidē, organismus iedala poikilohidros un homohidros organismos. Poikilohidriem organismiem ūdens saturs organismā mainās atkarībā no ūdens pieejamības vidē. Ja ūdens nav, šie organismi sažūst, bet, mitrumam atjaunojoties, atkal spēj uzṇemt ūdeni šūnās un nodrošināt dzīvības procesus. Tipiski poikilohidrie organismi ir alǵges un sēnes. Homohidrie organismi turpretī cenšas saglabāt organismā noteiktu ūdens daudzumu un, ja tas samazinās, organisms iet bojā.

Dzīvie organismi ūdeni nemitīgi zaudē transpirējot (augi) vai elpojot un izvadot ar vielmainas atkritumproduktiem - urīnu, ekskrementiem, sviedriem (dzīvnieki). Tādēḷ visiem dzīvajiem organismiem jārūpējas vai nu par zaudētā ūdens atjaunošanu, vai taupīšanu. Dzīvnieki trūkstošo ūdens daudzumu kompensē, dzerot vai ēdot sulīgu barību. Augi pārsvarā uzṇem ūdeni ar saknēm no augsnes. Ūdens saknēs nokḷūst osmozes ceḷā. Tas ir fizikāls process: ūdens molekulas no augsnes, kur šķīduma koncentrācija ir mazāka, pārvietojas saknes šūnās, kur šksīduma koncentrācija ir augstāka. Augi aptuveni 90-95\% ūdens zaudē, transpirējot caur atvārsnītēm - īpašām mikroskopiskām atverēm lapu virsmā. Ar transpirāciju augi nodrošina nemitīgu augsnes ūdenī izšk̦īdušo barības elementu pārvietošanos no saknēm uz auga virszemes dal̦ām. Ja augsnē ūdens pietrūkst vai arī tajā izš̌kīdušo vielu koncentrācija kḷūst lielāka nekā auga sulā, ūdens plūsma apstājas un augs novīst.

\subsection{Klimata izmainu ietekme uz globālo biodaudzveidību}

Jaunā gadu tūkstoša sākumā meteorologisko datu analīze nepārprotami liecināja, ka klimata pasiltināšanās ir neapstrīdams fakts. Zinot dzīvo organismu atkarību no temperatūras, radās jautājums, vai nav vērojamas arī izmaiṇas dabā. Literatūrā bija uzkrājies ne mazums datu par dažādu sugu populāciju skaita un dzīves ritma jeb fenoloǵijas izmainām temperatūras izmaiṇu ietekmē. Taču kritiski noskaņotiem zinātniekiem šie dati nešķita pietiekami pārliecinoši, lai varētu apgalvot, ka novērotās izmain,as tik tiešām ir skaidrojamas ar klimata pasiltināšanos, nevis ar kaut kādu lokālu faktoru, piemēram, zemes lietojumveida mainu, vides piesārn,ojuma līmeña izmainnu, dabiskās sugu nomaiṇas ekosistēmu attīstības procesu jeb ekologisko sukcesiju u.tml. Skeptiḳi norādīja uz nepietiekami ilgiem novērojumiem un kḷūdām datu statistiskajā analīzē, līdz ar to noliedzot, ka būtu novērojama jebkāda klimata pasiltināšanās ietekme uz biodaudzveidību. 
Lūzumu šajā problemātiskajā situācijā radīja divi raksti, kas 2003. gadā tika publicēti vienā no pasaules respektablākajiem zinātniskajiem žurnāliem Nature. To autori, galvenokārt, ASV pētnieki, bija veikuši pēdējos 50 gados vairāk nekā tūkstoš izdotu literatūras avotu un dokumentu analīzi, izmantojot jaunas pieejas datu statistiskajā apstrādē. Analīzē bija iekḷautas vairāk nekā 1700 sugas no visdažādākajām dzīvo organismu grupām, to skaitā kokaugiem, zālaugiem, kuērpjiem, putniem, abiniekiem, rāpuḷiem, kukaiṇiem, zivīm un zīdītājiem. Turklāt tika analizēti tikai tie dati, kas bija iegūti vismaz 10 gadu ilgā laika posmā. Galvenokārt tās bija izmaiṇas sugu fenologijā un izplatībā uz temperatūras izmaiṇu fona. Nepārprotama reakcija uz klimata pasiltināšanos tika pierādīta 279 sugām.

Vēlāk vairāki pētnieki pauda viedokli, ka par biodaudzveidības izmaiṇām nevajadzētu ipaši uztraukties, jo galu galā paleontologisko atradumu analīze liecina, ka masveida sugu izmiršana uz mūsu planētas ir notikusi jau vairākkārt, pirms vēl zemi sāka apdzīvot cilvēks, un arvien dzīvība ir atradusi jaunas eksistences formas - jaunu dzīvnieku un augu sugu veidolā. Arī klimata izmaiṇas uz Zemes ir notikušas vairākkārt un nekas neliecinot, ka arī šoreiz tās varētu būt planētas biodaudzveidībai kritiskas.

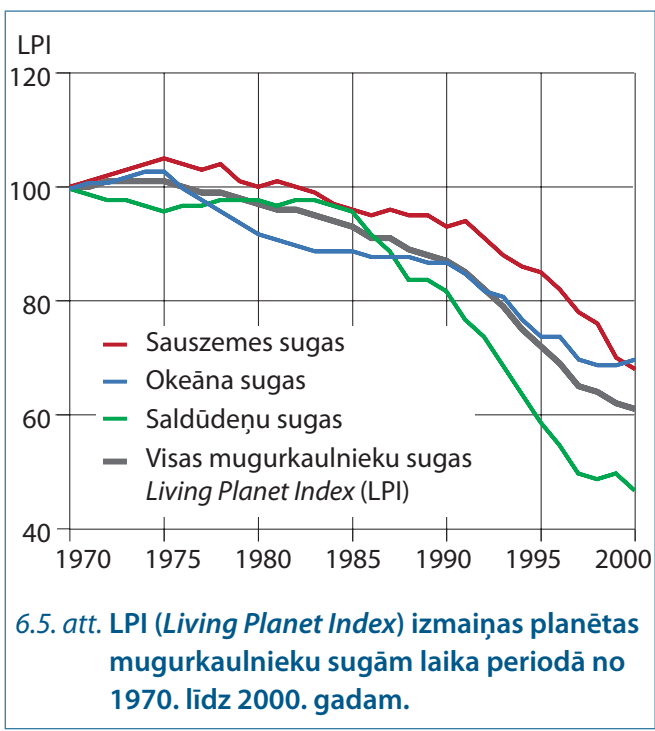

Kādi argumenti tad tomēr liek bažīties par planētas ekosistēmu stāvokli šobrīd notiekošo biodaudzveidības izmaiṇu kontekstā?

Pirmkārt, tie ir ḷoti straujie tempi, kādos tās notiek. Biodaudzveidības samazināšanās tempu raksturošanai WWF (World Wide Fund for Nature) sadarbībā ar UNEP WCMC (The United Nations Environment Programme's World Conservation Monitoring Centre) izstrādāts LPI indekss (Living Planet Index), kas tiek aprēksināts kā 1145 planētas mugurkaulnieku sugu populācijas sarukums procentos kopš 1970. gada (6.5. att.). Starplaikā līdz 2000. gadam tas samazinājies par $40 \%$, to skaitā sauszemes sugām par $30 \%$, saldūdens sugām par $50 \%$, bet okeāna sugām par $30 \%$.

Ja klimata izmaiṇu gaitā, kādas bija novērojamas pirms 7-15 tūkstoš gadiem, temperatūra mainījās tikai aptuveni par $0,005^{\circ} \mathrm{C}$ desmit gados, tad šobrīd sasilšanas temps ir $0,2-0,6^{\circ} \mathrm{C}$ desmitgadē un turpmāk draud paātrināties. Pēc optimistiskām prognozēm temperatūra uz Zemes 21. gs. pieaugs vidēji par $2^{\circ} \mathrm{C}$. Tā ir temperatūra, kāda uz planētas nav pieredzēta kopš vidējā Pliocēna pirms 3 milj. gadu. Ja Zemes atmosfēras vidējās temperatūras paaugstinājums pārsniegs $4{ }^{\circ} \mathrm{C}$, mēs piedzīvosim no ledus brīvu pasauli, kāda tā bija pirms 35 milj. gadu. Aprēksināts, ka sugas "dzīves ilgums" ir caurmērā 3 miljoni gadu. Tas nozīmē, ka viena gadsimta laikā iestāsies tādi apstākḷi, kādus savā evolūcijā nav piedzìvojusi neviena no šodien sastopamajām dzīvo organismu sugām.

Otrkārt, ir svarīgi saprast, ka 21. gs. ekosistēmām būs jāsāk pārstrukturēties, pastāvot l̦oti nestabilai bāzei, jo cilvēks ar savu saimniecisko darbību un vides piesārṇojumu ir tās daḷēji vai jau pilnīgi degradējis. Šādā situācijā šo sistēmu adaptācija sasilšanai, okeāna paskābināšanās procesam, piemērotu dzīvotṇu izzušanai, kīmiskā piesārn,ojuma un invazīvo sugu ietekmei izraisīs sugu izmiršanas kaskādes efektu. Tādējādi mijiedarbībā ar antropogēnajiem faktoriem klimata pasiltināšanās ietekme uz biodaudzveidību būs vēl izteiktāka.

Treškārt, sugu adaptācija klimata izmaiñām planētas pagātnē notika, lielākoties pārbīdoties to izplatības robežām uz augstākiem vai 
zemākiem ǵeogrāfiskiem platumiem, vai augšup un lejup pa kalnu nogāzēm, atkarībā no tā, vai klimats kḷuva siltāks vai aukstāks. Līdz ar to sugu populācijām, lai izdzīvotu, bija nepieciešams kḷūt genētiski daudzveidīgākām. Taču uz mūsdienu klimata pasiltināšanās fona tas vairs nebūs iespējams, jo sugām vienkārši nebūs kur paslēpties.

Izmirstot augstāk attīstīto organismu sugām, protams, dzīvība uz planētas saglabāsies termofilu zemāko dzīvības formu veidā, taču lieki atzīmēt, ka cilvēka populācijas eksistence, neraugoties uz iespējamiem tehnologiskajiem sasniegumiem, šādos apstākḷos kḷūs problemātiska.

Sistemātiski vāktu ilgtermiṇa datu trūkums par biodaudzveidības izmainām bija viens no galvenajiem iemesliem, kāpēc 1993. gadā pēc ASV pētnieku iniciatīvas tika izveidots starptautiskais ilgterminga ekoloǵisko pētījumu tīkls ILTER (International Long Term Ecological Research), kura uzdevums bija veikt ilgtermina pētījumus dažādās ekosistēmās, dažādās klimatiskajās zonās, lai iegūtu ticamus datus par ekosistēmu izmaiñām dabisko un antropogēno faktoru ietekmē. Šobrīd ILTER tīkls apvieno 40 pasaules valstis, to skaitā arī Latviju. Par vienu no centrālajiem uzdevumiem ILTER tīkls pasludināja pētījumus par biodaudzveidības izmaiṇām klimata pasiltināšanās ietekmē.

Klimata izmainu ietekme uz biodaudzveidību var būt tieša un netieša. Klimats ietekmēe gan sugu gan tām nepieciešamo eksistences resursu, pirmām kārtām barības, izplatību telpā un laikā. Klimata izmaiṇu ietekmi uz globālo biodaudzveidību galvenokārt saista ar temperatūras paaugstināšanos, taču kā nozīmīgs blakus faktors tiek minēts arī nokrišn,u daudzums. İstenībā dzīvajiem organismiem nozīmīga ir abu šo faktoru mijiedarbība. Ja tiek runāts par kādas sugas skaita izmaiṇām temperatūras paaugstināšanās ietekmē, būtībā tiek pieñemts, ka mitruma režīms saglabājas nemainīgs.

Netiešas ietekmes gadījumā būtiska nozīme ir barības attiecībām un invazīvajām sugām. Ja plēsēja tolerance pret temperatūras vai mitruma izmain̄ām ir pietiekami liela, bet upuris plēsēja barības objekts, ir jutīgāks pret šīm izmaiṇām, klimata izmaiṇu ietekme uz plēsēju būs netieša. Jaunu sugu ieviešanās reǵionos, kur tās līdz šim nav bijušas sastopamas, var būtiski ietekmēt šo reǵionu ekosistēmas. Tā kā jaunienācējām sugām bieži vien šajās ekosistēmās nav dabisko ienaidnieku, kas regulētu to populāciju skaitu, tās nereti savairojas milzīgā daudzumā un nomāc vai pilnīgi izkonkurē vietējās sugas. Sugu invāzija notiek gan tîšas, gan netīšas cilvēka darbības rezultātā, kā arī pašām sugām veicot migrāciju uz apgabaliem, kuri klimata pasiltināšanās dēl kḷuvuši to eksistencei piemērotāki. Tīša svešu sugu ieviešana saistīta ar lauksaimniecisko darbību, krāšn,umaugu introdukciju un medību faunas papildināšanu, bet netǐša ieviešana notiek ar transporta līdzekḷiem, to skaitā ar kuǵu balasta ūden,iem, dzelzcel̦a vagoniem un preču konteineriem.

Kopumā pasaulē pētnieku rīcībā esošie dati par sugu daudzveidības izmaiñām uz klimata pasiltināšanās fona joprojām ir nepilnīgi. Visvairāk novērojumu datu ir par lielām, viegli pamanāmām vai ekonomiski svarīgām sugām, kā arī par tādām sugām, kurām pieškirts īpašs aizsardzības statuss. Pētniekiem lielākoties neredzamas ir palikušas norises mikropasaulē, it īpaši augsnē. Un tikai reizi pa reizei tās par sevi atgādina negaidītu, konkrētajam reǵionam neraksturīgu augu, dzīvnieku vai cilvēka slimību uzplaiksnījumos.

Par vispārliecinošāko pierādījumu temperatūras paaugstināšanās ietekmei uz dzìvajiem organismiem tiek uzskatīti fenologisko novērojumu dati - augu ziedēšanas un lapu plaukšanas sākums pavasarī, lapu dzeltēšanas sākums rudenī, dažādu sugu gājputnu atlidošana vai aizlidošana un citas sezonālās dabas parādības.

Ziemel̦u puslodē veǵetācijas sezona pēdējo 40 gadu laikā ir pagarinājusies par 1-4 dienām, it īpaši augstākajos platuma grādos. Daudzi novērojumi liecina par būtiskām nobīdēm fenologiskās parādībās 20. gs. laikā. Piemēram, Eiropā lapu plaukšana sākas vidēji par 6,3 dienām agrāk, bet lapu dzeltēšana aizkavējās par 4,5 dienām. Kopumā veǵetācijas perioda ilgums no 60. gadu sākuma caurmērā ir palielinājies par 10,8 dienām. Rietumkanādā apses Populus tremuloides sāk ziedēt par 26 dienām 
agrāk. Igaunijā pēdējos 80 gados pavasara atnākšana notiek caurmērā par 8 dienām agrāk, turklāt visstraujākās izmaiñas novērotas tieši pēdējos 40 gados. Lietuvā fenologiskais pavasaris 20. gs. beigās sākās 8-16 dienas agrāk nekā 70. gados. Vācijā laukaugu un dekoratīvo augu fenologiskie procesi, arī uzziedēšana un nobriešana laikā no 1951.-2004. gadam ir paàtrinājušies vidēji par 6-7 dienām.

Jāatzīmē tas, ka rudens fenoloǵiskās parādības atškkirībā no pavasara parādībām ir daudz mazāk nobīdītas laikā, tādēḷ kopumā vegetācijas periodam ir tendence pagarināties, kas sekmē pozitīvo temperatūru summu pieaugumu un līdz ar to nodrošina mērenās joslas un ziemel̦u reǵionos ienākušo dienvidu sugu izdzīvošanu un savairošanos.

Mainoties dažādu sugu fenologijai, atzīmēta dzīvības procesu sinhronitātes izjaukšana starp ekologiskās barības kuēes posmiem, piemēram, putnu mazuḷu izšk̦ilšanās laiks vairs nesakrīt ar vinu barības objektu - kukainu masveida izlidošanas laiku. Eiropā un Ziemel̦amerikā 45 ligzdojošo putnu sugām konstatēts agrāks ligzdošanas sākums, taču nesakritība ar kukaiṇu masveida izlidošanu samazina mazul̦u izdzīvošanu.

Lielbritānijā parastajai vardei Rana temporaria pārošanās, nārsts un kurkuḷu šksilšanās sākas agrāk un norisinās ilgāk. Registrēts, ka 2004. gadā pēc 2003. gada karstuma vilı̣na varžu auglība samazinājās.

Ja mērenās joslas un ziemeḷu reǵionos kā galvenais faktors tiek minēta temperatūra, tad dienvidu rajonos pirmajā vietā izvirzās nokrišņi un mitruma režìms. Īpašas bažas rada augstkalnu ledāju pakāpeniskā izkušana, kas samazina no kalniem plūstošo upju ūdens resursus. Piemēram, Himalaju ledāji ir svarīgs ūdens resurss liela Dienvidāzijas reǵiona ekosistēmām un būtībā nodrošina šo reǵionu lauksaimniecību.

Tā kā globālās sasilšanas dēl strauji kūst arktiskie ledāji, pamazām cel̦as pasaules okeāna ūdens līmenis. Applūšanas riskam tiek pakḷautas lielas kontinentu piekrastes un salu teritorijas, piemēram, Nīlas delta un Maldivu salas. Tam būs negativva ietekme uz piekrastes mitrājiem - mangrovēm, kuras veido koku sugas, kas sakṇojas jūras piekrastes dibenā un kuru lapotnes atrodas virs ūdens. Tiek prognozēts, ka $20 \%$ no tām izzudīs. Tas savukārt pastiprinās krastu eroziju vētru laikā, jo mangrovu audzes darbojas kā savdabīgs viḷnu slāpētājs. To izzušana vēl vairāk veicinās jūru ūdeṇu ieplūšanu dziḷāk iekšzemē, un līdz ar to notiks radikālas izmaiṇas applūstošo teritoriju ekosistēmās praktiski tiks iznīcināta lauksaimniecība plašās piekrastes teritorijās.

Joprojām zinātnieku rīcībā ir maz reālu datu par augu un dzìnnieku sugu izplatības un skaita izmain̄ām. Kopumā tiek uzsvērts, ka augu, kukain,u, putnu un zivju izplatības areāli ir paplašinājušies uz ziemel̦iem un augstkalnu rajoniem.

Kritiska situācija veidojas arktisko regionu iemītniekiem. Izpētīts, ka pēdējos gadu desmitos leduslāču izplatības areāls atvirzījies tālāk uz ziemel̦iem - vietām, kur jūru visu gadu klāj ledus. Izmantojot genētiskās analīzes metodes, ASV pētnieki ir kartējuši leduslāču migrācijas cel̦us (6.6. att.). Agrāk lāči dzīvojuši četros dažādos apgabalos plašā teritorijā, taču kopš pagājušā gadsimta beigām biežāk uzturas vienā daudz mazākā reǵionā Kanādas ziemel̦rietumos.

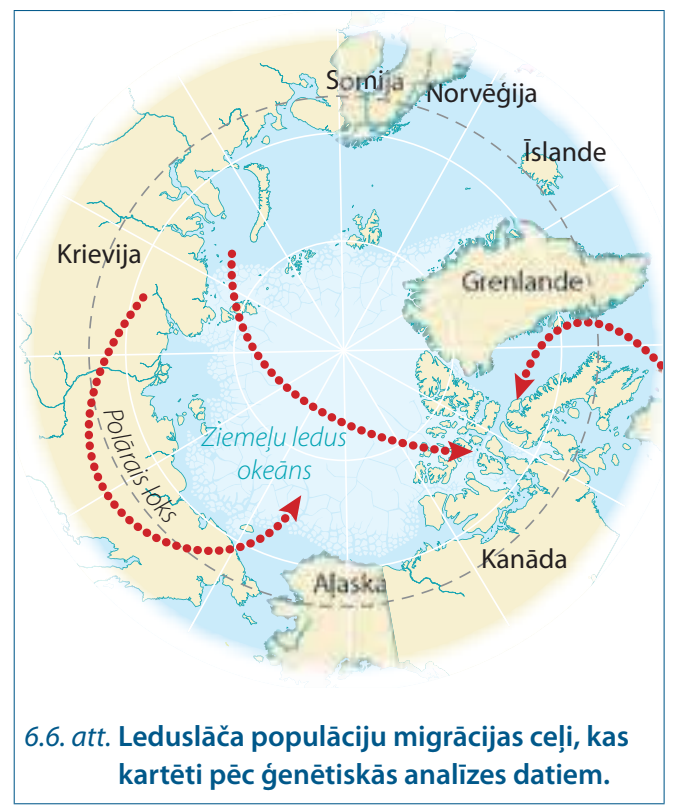


No bezmugurkaulniekiem sauszemes ekosistēmās vispilnīgākie dati ir par tauriṇu sugu skaita un izplatības areālu izmaiñām Lielbritānijā. Temperatūrai paaugstinoties, daudzu tauriṇu sugu izplatības areāli ir pavirzījušies uz ziemel̦iem un līdz ar to ziemel̦u reǵionos sugu daudzveidība ir pieaugusi. Tomēr kopumā tā ir pieaugusi uz eiribiontu rēksina (tās ir sugas ar plašiem tolerances diapazoniem pret vitāli svarīgiem vides faktoriem), kamēr daudzas stenobiontas sugas ar šauriem tolerances diapazoniem to nespēj, jo tām šajās teritorijās vienkārši nav piemērotu dzīvotņu. Tādējādi Lielbritānijas tauriṇu sugu biokopās sāk dominēt eiribiontās sugas un šo sabiedrību struktūra kḷust teritoriāli viendabīga. Spānijā tauriṇu sugu daudzveidība ir samazinājusies, izṇēmums ir augstkalnu rajoni. Dažas sugas ir paplašinājušas izplatību kalnos. Taču kopumā tauriṇu sugu daudzveidība Spānijas dienvidos ir samazinājusies.

Konstatētas ar klimata pasiltināšanos saistītas ūdens bezmugurkaulnieku struktūras izmaiñas Ronas upē: termofilie ūdens dzīvnieki ir aizstājuši auksto ūdeṇu iemītniekus. Pēdējos gados ilgstošo sausuma periodu laikā Dienvideiropas upes bieži vien cieta no ūdens trūkuma. Vidusjūras reǵionā upēs dominēja bezmugurkaulnieku sugas, kurām raksturīga augsta izplatīšanās spēja un kuras noteiktos apstākḷıs varētu ātri kolonizēt arī mērenās joslas upes gadījumā, ja turpmāko klimata izmainu dēḷ izzustu tām raksturīgie ūdens dzīvnieki.

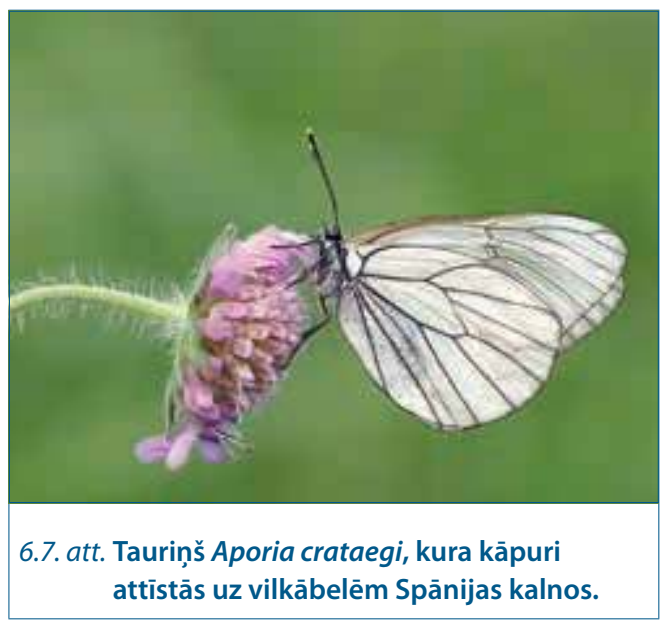

Līdz šim ir loti maz datu par netiešo klimata izmainu ietekmi uz dzīvajiem organismiem. Piemēram, konstatēts, ka taurinu suga Aporia crataegi (6.7. att.) nespēj pārvarēt savu augšējo izplatības robežu Spānijas kalnos, jo tās barības augs vilkābele neaug augstāk par 1800 m virs jūras līmeṇa. Mainoties sugas izplatības areālam, dažkārt var novērot īslaicīgu tās savairošanos jaunajās vietās, kamēr šeit vēl nav nokḷuvuši tās dabiskie ienaidnieki, kas cenšas sekot savam barības objektam pa pēdām. Taču šāda rakstura parādības ir visai grūti pierādīt, jo attiecībā uz bezmugurkaulniekiem, arī daudzām kukaiṇu sugām, viṇu dabiskie ienaidnieki zinātniekiem vēl nav zināmi.

Konstatēts, ka spāres ir pagarinājušas savu aktīvās lidošanas periodu, pavasarī izlidojot agrāk un vasaras beigās turpinot lidot ilgāk. Līdzīgs aktīvās sezonas "pagarinājums" novērots daudziem kukaiṇiem, to skaitā tauriṇiem, siseñiem, sienāžiem un lapsenēm.

Klimata pasiltināšanās ir nopietni skārusi okeāna ekosistēmas, it īpaši korallı lu rifus. Korallı u rifi ir viena no sugu ziṇā bagātākajām planētas ekosistēmām. Rifos dzīvo aptuveni ceturtā dalı visu okeānos sastopamo sugu, to skaitā 5000 zivju un 1000 korallı sugu. Korallı lu attīstībai nepieciešami dzidri, Saules gaismas caurausti ūden,i, kas bagāti ar kalcija savienojumiem. Korallıi ir stenotermi dzivnieki, kuru temperatūras optimuma zona ir no $+25^{\circ} \mathrm{C}$ līdz $+29^{\circ} \mathrm{C}$. Temperatūrai paaugstinoties, iet bojā

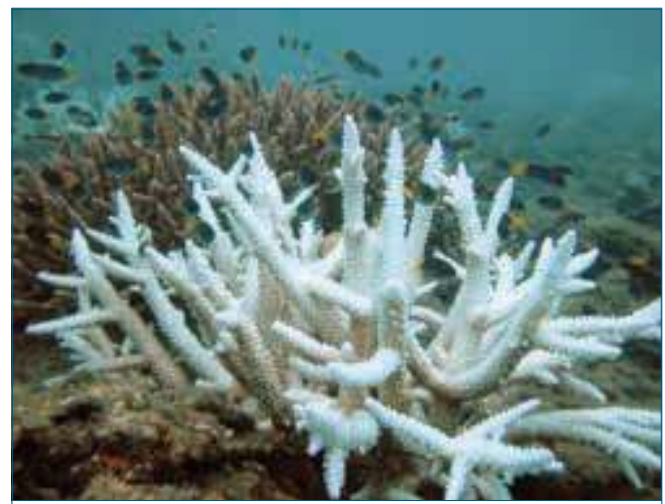

6.8. att. Koralı̣u izbalēšana okeāna temperatūras paaugstināšanās ietekmē. 
alğes, kas ir simbiozē ar korallıliem. Drīz pēc tam iet bojā arī paši korallıli. Dzīvniekiem atmirstot, paliek to veidotie baltie kalı,ka skeleti, tādēl korallı u masveida atmiršanas parādību dēvē par korallı izbalēšanu (6.8. att.). 1998. gadā, kas reǵistrēts kā līdz šim karstākais gads, okeānos aizgāja bojā aptuveni 16\% korallı lu rifu. Jāatzīmē, ka korallıi, veidojot savu kal,ksa skeletu, piesaista ievērojamu daudzumu okeāna ūdenī izšḳīdušā $\mathrm{CO}_{2}$, tādējādi mazinot siltumnīcefektu.
Tādēl korallı nozīme oglekḷa piesaistīšanā pasaules okeānā ir salīdzināma ar mežu nozīmi uz sauszemes.

Jūras ūdens temperatūras paaugstināšanās var ietekmēt ūdens dzīvniekus arī netieši, veicinot slimību un parazītu izplatības pieaugumu. Vidusjūrā tika novērota jūras dibena iemìtnieku, to skaitā sūkḷu un gorgoniju masveida bojāeja kādas patogēnās baktērijas ietekmē, kas savairojās, pasiltinoties ūdenim.

\subsection{Hipotēzes un prognozes}

Saprotot to, ka klimata izmainu dēl biosfērā jau parādījušās izmain,as, ko šobrīd vairs nevar noliegt pat skeptiki, cilvēku sabiedrība arvien uzstājīgāk uzdod jautājumus pētniekiem par nākotnē sagaidāmajām prognozēm arī attiecībā uz biodaudzveidības transformāciju. Prognožu izstrādāšanas pamatā ir ekspertu vērtējumi un matemātiskie model̦i. Attiecībā uz biodaudzveidības izmaiṇām l̦oti noderīgi būtu tādi modeḷi, kas dotu iespēju prognozēt sugu areālu izmaiṇas, norādot uz draudiem lauksaimniecībai, mežsaimniecībai, veselības aizsardzībai un dabas aizsardzībai konkrētā reǵionā. Matemātiskā modeḷa vērtība ir precizitātē, ar kādu tas apraksta modelējamo parādību. Tādējādi, lai izveidotu šādu modeli,

1) ir nepieciešams veikt padziḷinātus pētījumus par modelējamo parādību,

2) ievākt pietiekami daudz datu, lai veiktu model̦a pārbaudi.

Līdz ar to modelēšana kā instruments prognožu izstrādāšanai par sugu areālu izmain̄ām klimata pasiltināšanās ietekmē būtībā ir iespējama tikai par labi izpētītām sugām. Tādas sugas ir starp kokaugiem, tauriņiem, abiniekiem, rāpuḷiem un putniem.

Koku sugu izplatīšanās spēja ir atkarīga no vairākiem faktoriem. Kā viens no nozīmīgiem faktoriem ir minamas sēklu īpašības. Kokiem ar mazām sēklām, kuras izplata vējš, raksturīga augsta izplatīšanās spēja, turpretī sugas ar smagām sēklām, ko pārvieto dzīnnieki vai ūdeņi, izplatās relatīvi lēni. Apšu un kārklu sīkās sēklas ar gaisa masām var izplatīties pat simtiem kilometru tālu. Arī kḷavu sēklas var pārvietoties vairākus kilometrus. N̦emot vērā kokiem raksturīgo lielo sēklu skaitu, arī sugas ar smagākām sēklām, kuras pārnes putni un zīdītāji, spēj migrēt ievērojamā attālumā. Tomēr, vērtējot sugu migrāciju vēsturi, šksiet, ka galvenais faktors koku sugu pārvietošanā ir cilvēks.

Lai prognozētu mežu kokaugu sastāva izmaiṇas, Eiropā ir izveidoti vairāki matemātiskie modelsi. Vairums no tiem paredz, ka tuvāko 60 gadu laikā nemorālo sugu izplatības areāli paplašināsies uz ziemel̦iem, izspiežot ziemel̦u sugas, arī parasto priedi. Šīs prognozes balstītas uz klimata izmaiṇu scenārijiem, kas paredz temperatūras paaugstināšanos Ziemel̦eiropā un ilgākus sausuma periodus Centrāleiropā. Tādējādi sagaidāms, ka tuvākajās desmitgadēs notiks koku sugu nomaiṇa. Eiropas dienvidu dal̦ā izplatīsies Vidusjūras reǵionam raksturīgas koku sugas.

Eiropas tauriniiem izstrādāts klimata riska atlants. Tas prognozē 294 taurinu sugu izplatību pēc trim klimata pasiltināšanās scenārijiem. Pieñemot, ka līdz 2080. gadam vidējā temperatūra pieaugs par $2,4^{\circ} \mathrm{C}, 140$ sugām paredzama izplatības areālu samazināšanās vairāk nekā par $50 \%$, bet 9 sugām vairāk nekā par $95 \%$. Ja temperatūras pieaugums būs $4,1^{\circ} \mathrm{C}$, sagaidāmais iznākums ir vēl skarbāks - 229 sugām izplatības areāli saruks par $50 \%$, bet 70 sugām par 95\%, kas praktiski nozīmē to, ka tās atrastos uz izmiršanas robežas. Model̦a autori 
papildus mēǵinājuši prognozēt izplatību 15 no 23 ar Bernes konvenciju aizsargātām taurinu sugām. Šìs konvencijas mērksis ir aizsargāt savval̦as floru un faunu un to dabiskās dzīvotnes, īpaši tās sugas un dzīvotnes, kuru aizsardzībai nepieciešama vairāku valstu sadarbība. Deviñām no tām klimata izmainu radītais risks ir augsts vai l,oti augsts. Jāatzīmē, ka precīzākus rezultātus modelēšana var dot par izplatītākām tauringu sugām. Stenobiontiem, kam raksturīga mozaīkveida izplatība, to prognozēt tikai pēc temperatūras izmain̄ām nav iespējams. Šajā gadījumā to izdzìvošana ir atkarīga no piemērotu dzīvotṇu vai barības augu sastopamības, uz kuriem attīstās šo sugu kāpuri. Taču, ja attālumi starp teritorijām ar sugām piemērotiem dzīves apstākḷiem pārsniedz 10-50 km, sugu pārcelšanās uz tām kḷūst neiespējama. Astonām no atlikušajām Bernes konvencijā minētajām sugām modelēšana netika veikta vispār, jo tās ir endēmas, proti, sastopamas nelielās teritorijās uz salām vai kalnu nogāzēm. Līdz ar to tām nav kur atkāpties, ja klimata izmainas kḷūst turpmākai eksistencei nelabvēlīgas.

Tiek prognozēts, ka klimata izmainas apdraud arī vairākas citas Bernes konvencijas sarakstā ietilpstošās kukaiṇu sugas. Pie tām pieder, piemēram, lielais ozolu koksngrauzis, Cerambix cerdo (6.9. att.), kura kāpuru attīstībai nepieciešami lieli izretināti augoši koki, kādi dažviet veido Eiropas retmežu ganību ainavu, lapkoku praulgrauzis Osmoderma barnabita (6.10. att.), kas sastopams tikai vecu ozolu audzēs un kurš nespēj veikt tālas migrācijas. Abas minētās sugas ir īpaši aizsargājamas un ietvertas arī Latvijas Sarkanajā Grāmatā.

Tauriņu izplatības modelēšanā nav iespējams ñemt vērā visus vides faktorus, piemēram, vides piesārn,ojumu, kas sugu izplatību var būtiski mainīt. Tā, piemēram, slāpekḷa piesārn,ojuma telpiskais sadalījums Ziemeḷeiropā korelē ar to taurinu sugu populāciju samazināšanos, kuru kāpuru attīstība notiek pavasarī. Tika izteikta hipotēze, ka slāpekḷa piesārṇojums saistībā ar ilgāku veǵetācijas periodu ir radījis izmain,as augu sugu savstarpējā konkurencē. Dažu augu pastiprināta augšana izraisīja siltu, nenoēnotu dzīvotṇu sarukumu, kas pasliktināja šo sugu kāpuru attīstības apstākl̦us. To, cik liela ir vides piesārn,ojuma kā papildu faktora nozimme klimata ietekmes pastiprināšanā vai pavājināšanā, liecināja pētījumi par upju bezmugurkaulniekiem Lielbritānijā. Analīze parādīja, ka šie organismi varētu vieglāk pārciest klimata izmaiņas, ja vien tiktu novērsts ūdens piesārṇojums.

Lìdzīgs atlants ir izveidots par Eiropas ligzdojošo putnu klimatisko nišu izmain̄ām. Modelis pārbaudīts uz esošajiem ligzdojošo putnu atlanta datiem, tādēl lielākajai dal̦ai sugu

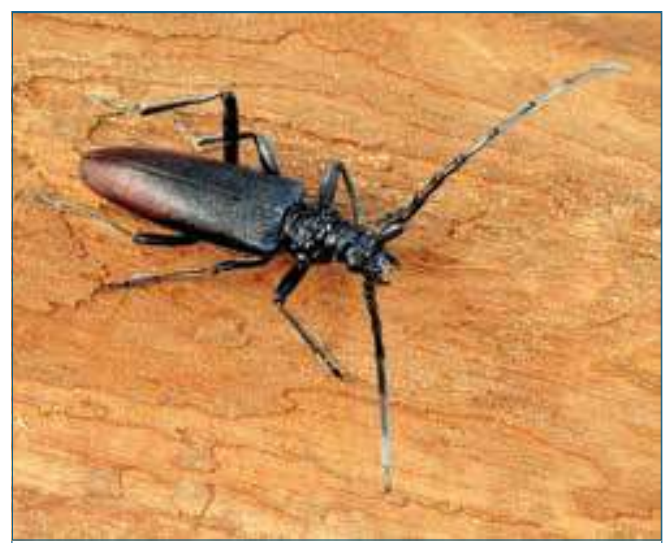

6.9. att. Lielais ozolu koksngrauzis Cerambix cerdo.

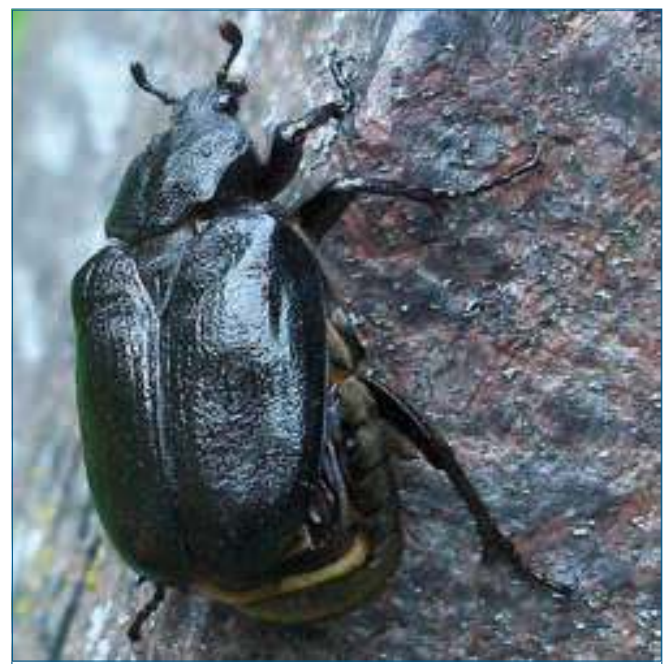

6.10. att. Lapkoku praulgrauzis Osmoderma barnabita. 
konstatēta l̦oti laba atbilstība starp modelēto un reālo sugas izplatību. Veikta sugu klimatisko nišu prognozēšana, iegūstot kartes, kas rāda to iespējamo izplatību 21. gs. beigās. Modelis izstrādāts trim scenārijiem - vidējai, pesimistiskai un optimistiskai prognozei. Pēc vidējās prognozes Eiropas putnu izplatības areāli pārvietosies uz ziemel̦austrumiem vidēji par $550 \mathrm{~km}$, turklāt tie samazināsies caurmērā par $20 \%$. Pēc vidējā scenārija tagadējās un prognozētās klimatiskās nišas ǵeogrāfiski nepārklāsies 21 sugai, bet 10 sugām tās nepārklāsies nevienā no scenārijiem. Tas nozīmē, ka šo sugu izzušanas varbūtība ir ḷoti liela. Diemžēl model̦i, līdzīgi kā tauriṇu gadījumā, var nodrošināt prognozes, balstoties vienīgi uz temperatūras un nokrišn,u/iztvaikošanas attiecību datiem, bet neñem vērā sugu prasības pēc citiem ekoloǵiskajiem faktoriem, piemēram, sugas izplatǐšanās spēju, stāvokli sugu ziemošanas vietās un uz migrācijas trasēm.

Abinieku un rāpuḷu izplatības modelēšana veikta vairākos pētniecības projektos gan globālā, gan reǵionālā mērogā. Atšksirībā no putniem un kukaiņiem (daudzi no tiem spēj veikt pārlidojumus ievērojamos attālumos, tādējādi kaut dal̦ēji izmantojot spēju migrēt, lai izvairītos no nelabvēlīgām klimata izmainām savās dzīves vietās) abinieku un rāpulu migrācijas iespējas ir l̦oti ierobežotas. Tādēl šajā gadījumā vairāk jārunā nevis par izplatības robežu pārbīdīšanos, bet gan par to sašaurināšanos un sugu izmiršanu. Starptautiska pētnieku grupa veica abinieku globālās izplatības modelēšanu. Pavisam tika izmantoti dati par 5527 sugām. Vienlaikus ar klimata izmain̄ām abinieku populācijas visā pasaulē īpaši ietekmē dzìvotṇu degradācija lauksaimniecības un mežsaimniecības pasākumu dēḷ, vides piesārn,ojums un hitridiomikoze - abinieku slimība, ko izraisa parazītiska sēne Batrachochytrium dendrobatidis, kas izraisa abinieku masveida bojāeju bez jebkādiem ārēji redzamiem simptomiem. Daudzos planētas reǵionos šie faktori mijiedarbojas. Tādēl modelı autori apskata visu šo trīs faktoru iedarbību uz pasaules abinieku populācijām. Tika konstatēts, ka vislielākās negatīvās izmain,as notiks Āfrikā, Dienvidamerikas ziemel̦u dal̦ā un Andu piekalnēs. Tie ir reǵioni ar visbagātāko abinieku faunu, un tur arī tiek prognozēti vislielākie zaudējumi. Tiek prognozēts, ka līdz 2080. gadam izmirs 73\% no visām zināmajām abinieku sugām. Hitridiomikozes izplatības sakarā model̦a autori īpaši norāda uz mērenā klimata joslas zemēm.

Spāṇu autoru grupa veikusi vairāku modelıu salīdzinošo analìzi attiecībā uz abinieku un rāpuḷu izplatību Eiropā. Lai gan pētnieki atzīst abinieku ierobežotās migrācijas iespējas, viṇi tomēr uzskata, ka klimata pasiltināšanās, pien,emot, ka nesamazinās pieejamā ūdens daudzums, varētu veicināt abinieku izplatības robežu pārbīdīšanos ziemel̦u virzienā. Gan abinieki, gan rāpuḷi ir poikilotermi (aukstasiṇu) organismi, kuru attīstībai būtisks ir siltums. Pēc spāṇu pētnieku veiktās analīzes rezultātiem, nelabvēlīgākie vides apstākḷ klimata pasiltināšanās gadījumā veidosies Dienvidrietumeiropā, bet labākie - Dienvidaustrumeiropā.

Angḷu pētnieki veikuši abinieku un rāpulu izplatības analīzi Lielbritānijas teritorijai pēc abu minēto model̦u rezultātiem. Projicējot globālā model̦a rezultātus uz Lielbritānijas teritoriju, viṇi secinājuši, ka krupju un varžu sugu skaits šajā zemē līdz 2080. gadam varētu samazināties par 30-70\%, bet salamandru un tritonu sugu skaits par 60-80\%. Tai pašā laikā spānu pētnieku prognozes Lielbritānijai izrādījušās optimistiskākas: $26 \%$ abinieku un $44 \%$ rāpuḷu sugu izplatība varētu pat palielināties, un tikai 5\% abinieku un 5\% rāpuḷu sugām tā varētu samazināties. Tik radikāli atšksirīgas prognozes lika anglu pētniekiem izstrādāt savu abinieku un rāpuḷu izplatības reǵionālos model̦us tieši Lielbritānijas teritorijai. Kā papildus faktors, veidojot šos modelıus, tika nemts vērā vides piesārṇojuma līmenis: pirmais scenārijs, pastāvot zemam, bet otrs - augstam piesārn,ojuma līmenim. Modelēšanas rezultāti izrādījās līdzīgāki spāṇu variantam. Pastāvot zemam vides piesārṇojuma līmenim, 9 no 13 modelētajām abinieku un rāpuḷu sugām varētu saglabāt vai pat paplašināt savu izplatības areālu. Tikai 4 sugas varētu saglabāt vai paplašināt savu izplatību, pastāvot abiem scenārijiem. Taču, pastāvot augstam piesārṇojuma 
līmenim, vairumam sugu izplatība ievērojami samazinātos. Papildus atzīmēts, ka, izstrādājot prognozes, jān,em vērā arī starpsugu attiecības, to skaitā plēsēja - upura attiecības, kas pastāv starp daudzu rāpuḷu un abinieku sugu populācijām. Turklāt pastiprināta uzmanība jāpievērš tām sugām, kas dažādu iemeslu dēḷ (pārsvarā cilvēku ievestām un ievazātām sugām), mainoties klimatam, ir ienākušas un jau naturalizējušās Lielbritānijas faunā. Tādas ir divas varžu un viena krupju suga, kā arī pa vienai tritonu, kirzaku un čūsku sugai.

Pēc ekspertu vērtējuma tiek prognozēts, ka 2-30\% no pašreiz zinātnei pazīstamajām augu un dzīvnieku sugām nespēs pielāgoties vidējās temperatūras pieaugumam un tās izraisītajām pārmaiñām to dabiskajās dzīvotnēs. Šìs pārmain, vis visvairāk skars polāros zīdītājus - leduslāčus, roṇus, valzirgus un putnus, it īpaši pingvīnus, kuriem ir ierobežotas migrācijas iespējas. Nākamo 50 gadu laikā leduslāču populācija varētu samazināties par divām trešdal̦ām. Apdraudēti ir arī okeānu iemītnieki. Ūdens sasilšana okeānā ir sasniegusi $700 \mathrm{~m}$ dziḷumu. Daudzi jūras zīdītāji optimāli jūtas vēsākos ūdeños, tādēl tie tiks atspiesti uz okeāna ziemel̦u rajoniem. Aizejot bojā korallı lu rifiem, izmirs arī tie organismi, kas ir saistīti ar tiem barības kēēdē - dažādi bezmugurkaulnieki un zivis. Pēdējo skaita samazināšanās katastrofāli ietekmēs okeāna piekrastes un salu zvejniecību.

Mainoties temperatūrai, mainās augsnes mikroorganismu sugu sastāvs un skaitliskās attiecības - siltākos laika apstākḷos mikroorganismi var aktīvi darboties ilgāk. Tādēl gaisa temperatūras paaugstināšanās palielina augsnes organisko vielu noārdīšanas intensitāti un arī $\mathrm{CO}_{2}$ izdalīšanos. Kūdrai žūstot, tās sadalīšanās process notiek straujāk un $\mathrm{CO}_{2}$ izdalī̌̌anās intensitāte pieaug. Šajā procesā producētais siltumnīcefekta gāzu daudzums varētu būt samērojams ar rūpniecības un transporta emitēto gāzu daudzumu. Īpaši liels drauds šajā ziṇā ir mūžīgā sasaluma atkušana simtiem tūkstošu kvadrātkilometru lielās teritorijās Sibīrijā un Aḷaskā, kur kopš pēdējā ledus laikmeta uzkrāti 70 miljardi tonnu ogleklı (savienojumu veidā), kas sāks izdalīties atmosfērā, sasalumam atkūstot.

Kopumā tiek prognozēts, ka klimata pasiltināšanās radītās izmaiṇas pamatā sekmīgāk pārdzīvos sugas, kurām raksturīgi augsti vairošanās tempi un kosmopolītiska izplatība.

\subsection{Draudi pasaules lauksaimniecībai un mežsaimniecībai}

Saskaṇā ar ANO Klimata pārmaiṇu starpvaldību padomes (Intergovernmental Panel on Climate Change, IPCC) 5. novērtējuma ziṇojumu klimata pārmaiṇas pēdējos 30 gados ir samazinājušas pasaules lauksaimniecības produkciju par 3-15\%. Nesen veiktie pētījumi rāda, ka, globālajai temperatūrai pieaugot tikai par $2^{\circ} \mathrm{C}$, sagaidāma katastrofāla lauksaimniecības produkcijas samazināšanās, it īpaši tropu reǵionos.

Klimata izmainu ietekmē notiek mājdzīvnieku un kultūraugu slimību ierosinātāju un parazītu migrācija pāri ǵeogrāfiskajām un valstu robežām, apdraudot pārtikas ražošanu un drošību. Lai ierobežotu tādu slimību kā putnu gripas, mutes un nagu sērgas izplatīšanos, valstīm jātērē ievērojami līdzekḷi. Angḷu zinātnieki, analizējot augu kaitēkḷu un slimību izplatību, konstatējuši, ka vairumam no tiem kopš 1960. gada izplatības robežas intensīvi pārbīdās no ekvatora zemeslodes polu virzienā ar vidējo ātrumu 3,2 km gadā. Vienlaikus tiek atzīmēta strauja jaunu formu veidošanās vienas sugas robežās. Tā, piemēram, rīsu puves ierosinātāja sēne Magnaporthe grisea, kas izplatīta daudzās dienvidu valstīs, ir pielāgojusies dz̄̄vei arī uz kviešiem un tādējādi Brazīlijā kḷuvusi par nopietnu lauksaimniecības problēmu. Ja graudaugu kaitēkḷu uzvaras gājiens turpināsies, tas radīs nopietnus draudus pasaules pārtikas drošībai, īpaši tāpēc, ka Zemes iedzīvotāju skaits palielinās. Pastāv liela varbūtība, ka kāda 


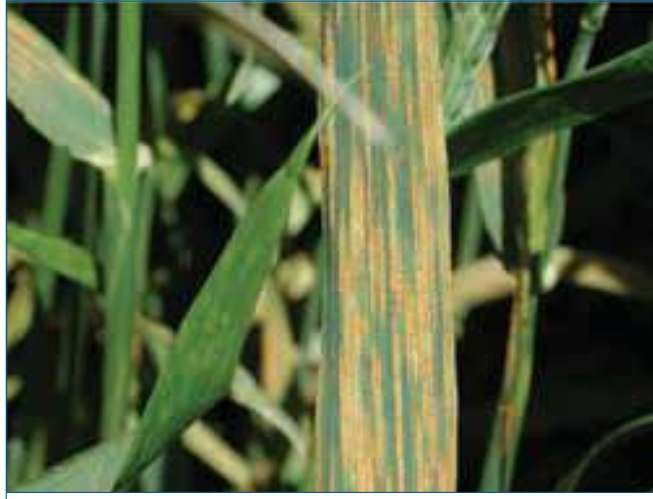

6.11. att. Kviešu dzeltenā rūsa Puccinia striiformis.

jauna vai ievazāta augu slimība varētu pilnībā iznīcināt vienu no trim svarīgākajām pasaules graudaugu kultūrām - rīsus, kviešus vai kukurūzu. Jau ir konstatējami šādas iespējas pirmie signāli - kviešu dzeltenā rūsa Puccinia striiformis (6.11. att.), kas iznīcina šīs kultūras sējumus Āfrikā, jau ir paguvusi iespiesties gandrīz visās kviešu audzētājās zemēs.

Eiropā līdz šim jau uzskaitītas 11 kukainu sugas - lauksaimniecības augu kaitēkḷi, kuru izplatību ir veicinājusi galvenokārt klimata pasiltināšanās. Piemēram, Helicoverpa armige$r a$ - taurinsš, kura kāpuri agrāk bija pazīstami vairāk kā kokvilnas kaitēkḷi zemēs, kur šo kultūru audzē, šobrīd ir izplatījies vairākās Eiropas valstīs, arī Lielbritānijā, Austrijā un Vācijā, kur uzbrūk 120 dažādām kultūraugu sugām, to skaitā tomātiem, pupām, kartupel̦iem, lucernai, kukurūzai, tabakai u.c. Līdzīgs izplatības pieaugums ir divām bruṇutu sugām: Icerya purchasi (6.12. att.), kas šobrīd konstatēta uz 50 dažādām augu sugām, un Chloropulvinaria floccifer, kas agrāk bija pazīstama kā dažādu kultūraugu kaitēklis Vidusjūras reǵiona valstīs, bet pašlaik ir palielinājusi izplatības areālu Eiropā uz ziemel̦iem un sastopama uz 34 dažādu dzimtu augiem. Piemēram, Zviedrijā šì suga līdz šim bija konstatēta kā siltumnīcu kaitēklis, bet šobrīd ir jau sastopama āra apstāklılos.

2015. gada jūnijā Londonas centrā parādījās ozolu kaitēkḷa - kodes Thaumetopoea processionea kāpuru sakopojumi, kuri nekavējoties

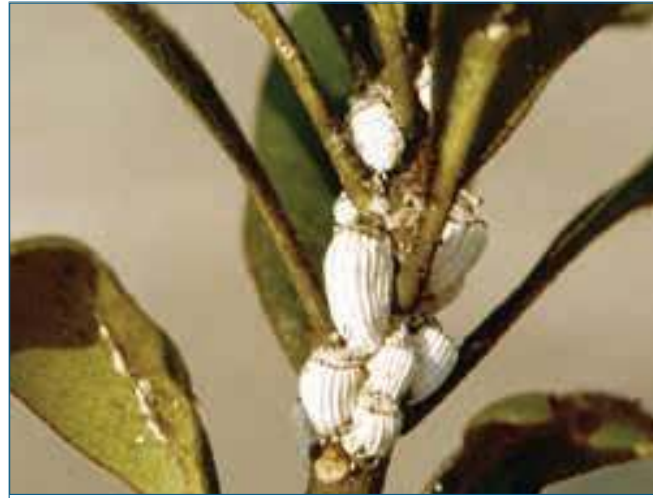

6.12. att. Bruṇutu Icerya purchasi kolonija.

tika savākti un iznīcināti. Cilvēki tika brīdināti, ka kāpuru ķermen,a viegli lūstošie sariņi ieduras ādā un rada nopietnus iekaisumus, tādēl jābūt īpaši uzmanīgiem, tiem pieskaroties. Līdz šim šī suga bija sastopama Dienvideiropā un Centrālajā Eiropā, bet pēdējos gados registrēta Lielbritānijā, Zviedrijā, Nīderlandē, Beḷgijā un Dānijā. Kodes savairošanās ziemel̦u reǵionos ir notikusi tāpēc, ka sinhronizējies olu izškilš̌nās laiks ar vēlo pavasara salnu iestāšanās laika pārbīdi.

Vaboles - dzeltenās priedes lūksngrauža Dendroctonus ponderosae savairošanās Ziemel̦amerikas ziemel̦rietumu reǵionos tiek skaidrota ar siltākām ziemām, kas veicina kukain,u izdzīvošanu zem koku mizas, kā arī ar ilgstošiem sausuma periodiem vasarās, kas novājina kokus un līdz ar to pakḷauj tos kaitēkḷu uzbrukumiem. Vabole ir paplašinājusi izplatības robežas ne tikai uz ziemel̦iem, bet arī augstkalnu zonā, vietās, kur tā nekad agrāk nebija sastopama.

Japāṇu zinātnieki ziṇo par 40 tauriṇu sugu izplatības robežu pavirzišsanos uz Japānas ziemel̦iem. Šajā procesā bija novērojamas specifiskas starpsugu konkurences izpausmes. Kāds tropu un subtropu augu kaitēklis - tauriņš Nezara viridula, pamazām virzoties uz Japānas ziemeliem, izkonkurējis tur mērenā klimata reǵioniem raksturīgo radniecīgo sugu Nazara antennata.

Klimata izmaiñas ir uzskatāmas par vienu no galvenajiem faktoriem augu kaitēkḷu un mājdzīvnieku slimību, kā arī invazìvo ūdens organismu pārrobežu izplatībā pasaulē. Tomēr 
nevar noliegt, ka šajā procesā l,oti būtisks faktors ir arī starptautiskā tirdzniecība un transports. Augu un dzīvnieku sugas uz planētas ir nevienmērīgi izplatītas, to migrāciju ierobežo dažādas ǵeogrāfiskās barjeras, piemēram, kalnu grēdas, jūras un tuksneši. Cilvēku ceḷošanas aktivitātes straujais pieaugums, kā arī augu stādāmā materiāla un mājdzīvnieku pārvietošana starp valstīm un kontinentiem, neraugoties uz daudzās valstīs piennemtajiem stingrajiem ievedamo nedzìvo un dzīvo kravu kontroles un karantīnas noteikumiem, šīs ǵeogrāfiskās barjeras praktiski ir nojaukusi. Līdz ar to, dzīvajiem organismiem nonākot teritorijās, kur tie līdz šim nav bijuši, to iedzīvošanās ir atkarīga no spējām izdzivvot un uzsākt vairošanos. Daudzos gadijumos tas tiem ir lieliski izdevies, radot lielus finansiālus zaudējumus valstīm, kur tas ir noticis. Pietiek minēt, piemēram, mutes un nagu sērgu Ziemeḷeiropā un Dienvidamerikā, cūku mēri Eiropā, Rifta ielejas drudzi Āfrikā, kafijas krūmu lapu rūsu Hemileia vastatrix (6.13. att.), kas izplatījusies visās pasaules kafijas audzētājās zemēs, sojas rūsu Phakopsora pachyrhizi Amerikā un citrusu tristeza (spāṇu val. skumjas) vīrusslimību, kas pieder Closterovirus ǵintij, Dienvidamerikā un Vidusjūras regionā.

Turklāt mūsdienās visai bieža kḷūst jaunu slimību formu parādīšanās. Tas saistīts ar jaunu pārnēsātāju ieslēgšanos slimību cirkulācijas ciklos, jaunu ǵenētisku rekombināciju veidošanos uz jaunu saimniekaugu vai dzīvnieku šksirṇu bāzes, kā arī tad, kad kaitēkḷi un to pārnēsātāji nonāk teritorijās, kur tiem nav dabisko ienaidnieku, kas varētu bremzēt to savairošanos.

Sagaidāms, ka klimata izmaiṇas īpaši ietekmēs to vīrusslimību izplatību, kuras mājdzīvnieku populācijās pārnēsā kukaiṇi. Ir iegūti pārliecinoši pierādījumi, ka klimata pasiltināšanās ir izraisījusi, piemēram, tādas slimības izplatību vairākās mērenā klimata zemēs kā "zilā mēle" atgremotājdzīvniekiem. Šo slimību pārnēsā asinssūcēji divspārṇi - miǵeles. Arī Rifta ielejas drudža izraisītājus pārnēsā dzēlējodi un, mainoties ekologiskajai situācijai, nav izslēgta šīs slimības "pārcelšanās" uz mērenās joslas zemēm. Nevar izslēgt jaunu slimību pārnēsātāju, kā arī jaunu saimnieku ieslēgšanos

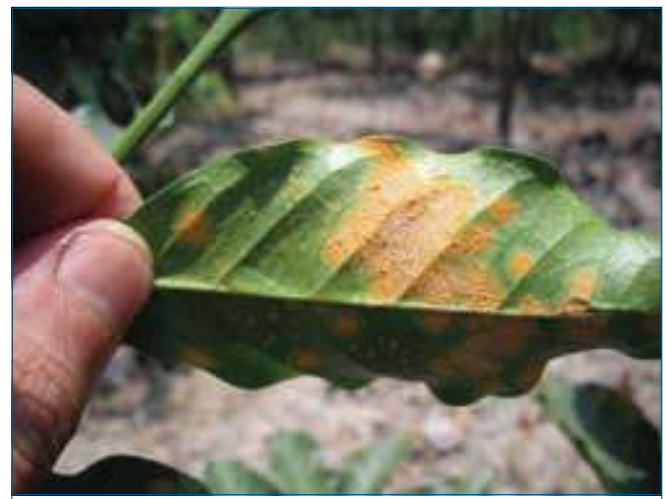

6.13. att. Kafijas krūmu lapu rūsa Hemileia vastatrix.

slimību ierosinātāju cirkulācijas ciklos. Netiešo ietekmju komplekss, ko radījusi klimata pasiltināšanās uz mājlopu slimību attīstību, var būt visai sarežgiits. Šobrīd aktuālais Āfrikas cūku mēris cirkulē starp mājas un meža cūku populācijām. Taču nesen šis vīruss ir atklāts ziloṇroñu populācijā, kas mājo Kalifornijas piekrastē. Šie dzīvnieki gan neslimo, bet ir vīrusa nēsātāji, un pētniekiem nav skaidrs, kāds ir šīs invāzijas mehānisms.

Ḷoti sarežğìta situācija attiecībā uz lauksaimniecības dzīnnieku slimībām un jaunu to formu parādīšanās varbūtību, protams, ir jaunattīstības valstīs. Tomēr, klimatam pasiltinoties, tieši mērenā klimata zonas valstis izjutīs pastiprinātu kukaiṇu pārnēsāto slimību un parazītu invāzijas izplatîšanos. Îpaši bīstama ir tā saukto arbovīrusu parādīšanās mūsu platuma grādos. Šo vīrusu pārnēsātāji ir galvenokārt kukaiṇi, to skaitā dzēlējodi, miǵeles, asinssūcējas ērces, blusas u.c. Kamēr tie cirkulē dabiskajās ekosistēmās, savvaḷas dzīvniekiem tie parasti problēmas nerada, jo ilgstošā evolūcijas procesā dzīvniekiem ir izstrādājusies imunitāte. Tropiskās joslas zemēs šo vīrusu dabiskais rezervuārs ir sikspārṇi, putni, grauzēji, kā arī citi dzīvnieki. Taču ar minētajiem asinssūcējiem šie vīrusi visai viegli nokḷūst arī cilvēka organismā, kur parādās to graujošā iedarbība - hemorāgiskie drudži, encefalīts un citas izpausmes, kuru sekas bieži vien ir letālas. Arbovīrusu 
daudzveidība un augstā pielāgošanās spēja dažādiem saimniekiem uz klimata pasiltināšanās fona būs 21. gadsimta globālā problēma gan lopkopībā, gan veselības aizsardzībā.

Paplašinoties teritorijām, kurās ir dzēlējodiem, knišliem un citiem asinssūcējiem divspārṇiem, kā arī asinssūcējām ērcēm labvēlīgi klimatiskie apstākḷi, izplatīsies arī šo kukaiṇu pārnēsātās slimības, piemēram, malārija, leišmanioze, Denges drudzis un citas slimības. Daži aprēksini liecina, ka 2080. gadā Denges drudzis apdraudēs jau 5-6 miljardus cilvēku. Latvijā līdz šim reǵistrēti vairāki ievesti Denges drudža gadijjumi (slimnieks ar to inficējies tropiskajās valstīs).

Izmainnas mājlopu infekcijas slimību izplatībā uz klimata pasiltināšanās fona ir atkarīgas no dažādu blakus faktoru tiešas un netiešas ietekmes. Blakus faktori var būt slimību pārnesēju kukainnu populāciju skaits un telpiskais sadalījums, pārnesēju kukainu dabisko ienaidnieku un konkurentu populāciju stāvoklis, saimniekorganismu - gan mājlopu, gan savval̦as sugu populāciju skaits un izplatība, sausums un citi faktori. Tā, piemēram, Austrumāfrikas ganību platībās ilgstoša sausuma apstākḷıs samazinās dzīvniekiem pieejamo dzeramā ūdens vietu skaits. Līdz ar to palielinās mājlopu koncentrācija atsevišksās vietās, un tie nonāk ciešākā saskarē ar savvaḷas zālēdājiem.

Attiecībā uz augu kaitēkḷiem līdzās temperatūras paaugstinājumam un nokrišnu daudzuma izmaiñām liela nozīme ir $\mathrm{CO}_{2}$ koncentrācijai gaisā, jo šo gāzi augi uzṇem kā barības vielu. Ne mazāka ietekme ir ekstrēmiem laikapstākḷiem - vētrām un orkāniem, pašu kaitēklıu populāciju stāvoklim, to skaitā diapauzes jeb snaudošās stadijas ilgumam, paaudžu skaitam veǵetācijas sezonā un citiem faktoriem.

Piemēram, kukurūzas kā lauksaimniecības kultūras izplatība mērenajā klimata zonā uz klimata pasiltināšanās fona izraisa arī sakñu kaitēkḷa - vaboles Diabrotica virgifera virgifera savairošanos un izplatību. Vaboles kāpuri ieurbjas un nograuž kukurūzas saknes. Arī dažādas raibspārnmušu (dz. Tephritidae) sugas, kuru kāpuri ir ne tikai augu atlieku noārdītāji, bet bojā arī dažādus kultūraugus, klimatam

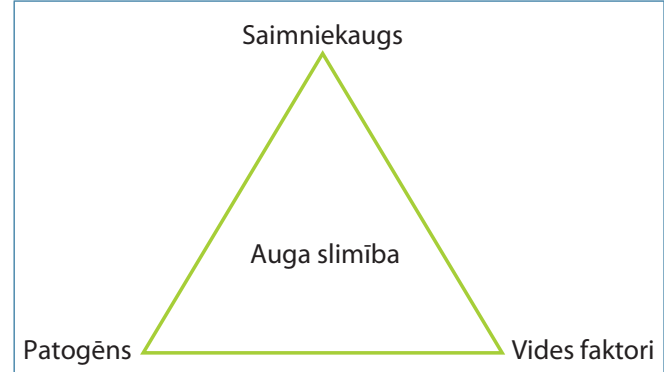

6.14. att. Auga slimības attīstība ir atkarīga no triju faktoru - patogēna, paša saimniekauga un vides faktoru, to skaitā temperatūras un mitruma mijiedarbības.

pasiltinoties, izplatīsies uz ziemel̦iem, it īpaši, ja netiks ievēroti fitosanitārijas un starptautiskās tirdzniecības noteikumi.

Temperatūras paaugstināšanās, protams, ir uzskatāma par būtisku priekšnoteikumu kaitēkḷu un slimību izplatībā, taču l,oti svarīga ir arī kaitīgā organisma un saimniekauga savstarpējā mijiedarbība uz vides faktoru fona. ASV pētnieki iesaka augu slimību apskatīt kā triju faktoru - patogēna, saimniekauga un vides faktoru mijiedarbības rezultātu (6.14. att.).

Pietiek izmainīties kaut vienam no minētajiem trim faktoriem, lai būtiski mainītos saslimstība. Vides faktori - temperatūra, mitrums un $\mathrm{CO}_{2}$ ietekmē augu slimību attīstību dažādos veidos, tāpēc klimata izmaiṇu ietekmi uz augu slimībām ir visai sarežǵîti prognozēt. Pētījumi rāda, ka kultūraugu kviešu un auzu jutība pret mikroskopisko sēṇu izraisītiem rūsu uzbrukumiem augstākās temperatūrās palielinās, bet dažām lopbarības zālaugu sugām, gluži otrādi, samazinās. Kopumā augu slimības izraisošām sēnēm optimālas ir mērenas temperatūras. Tādēḷ tieši mērenā klimata zona, kurai raksturīgas relatīvi zemas vidējās gada temperatūras, klimatam pasiltinoties, klūs piemērotāka patogēno mikroorganismu attīstībai. Piemēram, model̦i, kas prognozē kartupel̦u un tomātu lakstu puvi, ko izraisa Phytophthora infestans, rāda, ka šīs sēnes attīstības temperatūras optimums ir no $+7,2 \mathrm{līdz}+26,8^{\circ} \mathrm{C}$. Ātrāka silta laika iestāšanās pavasarī varētu izraisīt 
augu agrāku saslimšanu un straujāku epidēmiju izplatību.

Mitrumam ir daudzveidīga ietekme gan uz saimniekaugu, gan patogēnu. Dažu sugu patogēnie organismi, piemēram, ābel̦u kraupis, kartupel̦u lakstu puve un daži sakṇaugu patogēni, aktivizējas, palielinoties nokrišņu un mitruma daudzumam. Turpretī daži citi patogēni, piemēram, miltrasas, straujāk izplatās un vairojas, pastāvot mazākam vides mitrumam. Daži klimata prognožu model̦i paredz biežākus ekstremālu nokrišn,u periodus, kas varētu radīt labvēlīgākus apstākḷus dažu augu patogēnu attīstībai. Savukārt, saimniekaugu sugas, kas parasti cieš no sausuma, šādos apstāklı os veidos bagātīgāku lapojumu, kas veicinās mitruma saglabāšanos piezemes atmosfēras slānī un līdz ar to nodrošinās labvēlīgākus apstākḷus mitrumu mīlošo patogēnu attīstībai. Ja vienlaikus paaugstināsies temperatūra un atmosfēras mitrums, uzvaras gājienā mērenajā klimata joslā dosies daudzas dienvidu augu patogēnu sugas.

Arī $\mathrm{CO}_{2}$ koncentrācijas palielināšanās atmosfērā var dažādos veidos ietekmēt gan patogēno organismu sugu, gan saimniekaugu attīstību. Eksperimenti ir parādījuši, ka, pastāvot augstākai $\mathrm{CO}_{2}$ koncentrācijai, veidojas bagātīgāks un blīvāks augu lapojums, kas nodrošina mitrāku mikroklimatu un līdz ar to labākus apstākḷus patogēno organismu attīstībai. Augstākas $\mathrm{CO}_{2}$ koncentrācijas palēninās augu atlieku sadalīšanās ātrumu, tās ilgāk uzglabāsies augsnē un nodrošinās labākus patogēnu dīgḷu pārziemošanas apstākḷus un ātrāku to parādīšanos pavasarī. Augstākas $\mathrm{CO}_{2}$ koncentrācijas veicina arī patogēno sēṇu sporu intensīvāku producēšanu. Taču nav izslēgti arī gadījumi, kad og̣̣skābā gāze izraisa tādas fiziologiskās izmainas saimniekaugā, kas palielina tā rezistenci pret patogēnu uzbrukumiem.

Klimata izmaiñas var radīt būtiskas problēmas mežsaimniecībā. Temperatūras paaugstināšanās mijiedarbībā ar tādiem vides faktoriem kā nokrišnu daudzums, vētras, plūdi, kā arī pašu koku jutības un konkurētspējas izmaiñas var kḷut par jaunu, postošu kokaugu slimību izplatības cēloni mērenajā un ziemel̦u joslā. Daudzām patogēnajām sēnēm šìs izmaiṇas veidos īpaši labvēlīgu vidi sporu producēšanai un izplatībai kokaudzēs. Šādos apstākḷos patogēni var izvēlēties kā izplatītājas jaunas kukaiñu sugas un pārceḷot uz jauniem saimniekaugiem. Atsevišķu sugu koku novājināšanās un bojāeja radīs strukturālas izmainas augu sabiedrībās un kokaugu sugu daudzveidības izmainas.

Vairākas patogēnās sēnes, kuru izplatību ietekmē siltāks laiks, jau atrastas Viduseiropas un Ziemel̦eiropas valstīs. Piemēram, Mycosphaerella pini izraisa skuju sarkansvītraino plankumainību priedēm un palēnina to augšanu. Tā izplatās ar vēju un pārsvarā inficē priedes, bet ir konstatēta arī uz duglāzijām, lapeglēm un eglēm. Nereti vainaga bojājumi izraisa koka bojāeju. Sēnes izplatību ietekmē triju faktoru - mitruma, temperatūras un gaismas intensitātes mijiedarbība. Priežu rezistence pret sēnes izraisīto slimību ir atkarīga no priežu sugas un vecuma. Agrāk tika uzskatīts, ka šì slimība ir izplatīta tikai dienvidos un uz eksotiskām priežu sugām. Nesen tā konstatēta arī Latvijā.

Nepilnīgi pazīstamā sēne Sphaeropsis sapinea ir pazīstama kā izplatītākais skujkoku patogēns, kas rada nopietnus ekonomiskos zaudējumus eksotisko priežu sugu plantācijās Jaunzēlandē, Austrālijā un Dienvidāfrikā. Slimība ir sastopama arī Ziemel̦amerikas centrālajā daḷā un dienviddalāā ne tikai uz introducētām, bet arī uz vietējām skuju koku sugām. Nesen tā atrasta arī Igaunijā. Šìs sēnes izplatību veicina divu vides faktoru - sausuma un minerālvielu

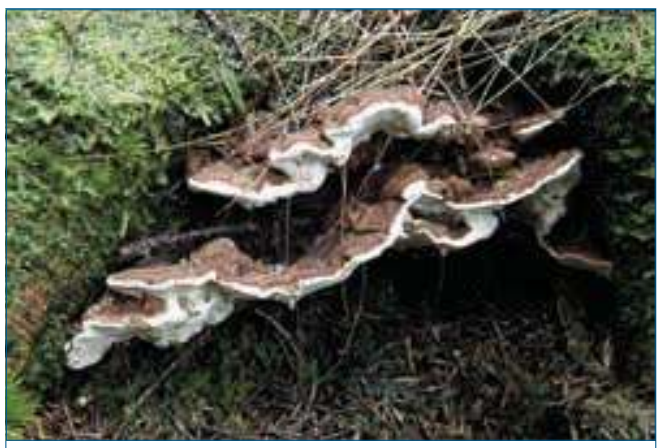

6.15. att. Saknu piepe Heterobasidion annosum. 
deficīta mijiedarbības radītais stress un straujāka koku augšana paaugstinātas temperatūras apstākḷıs.

Klimata pasiltināšanās radīs labākus apstākḷus sakṇu piepes Heterobasidion annosum s.l. (6.15. att.) attīstībai, jo to sporu produkcija palielinās temperatūrās virs $+5^{\circ} \mathrm{C}$. Pagarināsies sporu veidošanās periods un līdz ar to koku inficēšanās iespējas, radot koksnes zaudējumus. Pēdējos gados aktivizējusies šĩs piepes forma, kas spēj inficēt ne tikai skuju kokus, bet arī lapu kokus. Sagaidāms, ka intensificēsies arī vairākas agrāk par maznozīmīgiem patogēniem uzskatītas celmeñu Armillaria spp. sugas, kas varētu inficēt karstuma stresa novājinātus kokus. Gan melnalkšn,us, gan baltalkšnus apdraud patogēns Phytophthora alni, kas šobrīd intensīvi izplatās visā Eiropā. Šì patogēna izplatību lielā mērā veicina plūdi un ūdens vidējās temperatūras paaugstināšanās vasarā.

Kā papildu faktors kokaugu patogēno sēṇu attīstībai jāmin koku kaitēkḷi, kas ar savu darbību novājina kokus un paver cel̦u infekcijai. Augstākas gaisa temperatūras labvēlīgi ietekmē daudzu kaitēkḷu attīstību, to skaitā priežu koksnes nematožu un mizgraužu attīstību. Sagaidāma egles un priedes dendrofāgo kukaiṇu populāciju masveida savairošanās, jo tās ir pamatā siltummīlošas, tolerantas pret karstumu. Ja notiks ievērojama temperatūras paaugstināšanās (vidēji par $5^{\circ} \mathrm{C}$ ), sāksies strauja invazìvo kokaugu kaitēkḷu sugu ienākšana mērenās un ziemeḷu joslas zemēs. Šādu sugu aklimatizācijai sekotu to masveida savairošanās dabisko ienaidnieku trūkuma dēḷ. Īpaši ciestu ekonomiski nozīmīgi lapu koki, piemēram, ozoli, bērzi, apses, oši un alkšn,i, jo tikai uz šiem kokiem dzivojošas lapgraužu sugas īpaši strauji attīstās temperatūrās, kas pārsniedz $+25^{\circ} \mathrm{C}$.

N,emot vērā klimata izmainu prognozes, kopumā 21. gs. visvairāk slimību un kaitēkḷu apdraudēti mērenajā joslā būs skuju koki, bet vēlākajā laika periodā, ja klimata pasiltināšanās turpināsies, arī lapu koki.

\subsection{Klimata izmainu ietekme uz Latvijas ekosistēmām un to biologisko daudzveidību}

\subsubsection{Klimatisko un antropogēno faktoru mijiedarbības ietekme}

Tāpat kā citur pasaulē, arī Latvijā sistemātisku ilgtermiņa pētijumu datu, kas nepārprotami liecinātu par klimata izmaiņu ietekmi uz ekosistēmām un to biologisko daudzveidību, ir loti maz.

Arī Latvijā par pārliecinošāko pierādījumu temperatūras paaugstināšanās ietekmei uz dzīvajiem organismiem tiek uzskatīti fenoloǵiskie novērojumi, kas aptverti garum garās datu rindās par dzīvo organismu stāvokla izmaiṇām. Dažu fenologisko parādību dati ir uzkrāti pat kopš 19. gs. beigām, pateicoties entuziastu - dabas pētnieku novērojumiem. Analizējot 9 augu sugu (baltalkšña Alnus incana, apses Populus tremula, sarkano jān,ogu Ribes rubrum, kḷavas Acer platanoides, dziedniecības pienenes Taraxacum officinale, oša Fraxinus excelsior, pīlādža Sorbus aucuparia, ceriṇu Syringa vulgaris) fenologisko fāžu iestāšanās datumus, konstatēts, ka pēdējo 30 gadu laikā tām ir tendence iestāties arvien agrāk. Laika periodā no 1971. līdz 2000. gadam pavasara un vasaras sākums, vērtējot pēc minēto augu fenofāzēm, iestājās caurmērā par 4 dienām agrāk. Taču dažādām sugām tas ievērojami atšksiras. Piemēram, baltalksnim ziedēšanas fāze minētā perioda beigās salīdzinājumā ar sākumu iestājās par 33 dienām agrāk. Turpretī lapu dzeltēšanas fāze rudenī ir nobīdīta l̦oti nedaudz - tikai par 1-2 dienām. Līdz ar to pagarinājās arī veǵetācijas sezona. Bērzam tā bija 157, bet kḷavai 155 dienas. Caurmērā veǵetācijas periods bērzam un kḷavai sākās 1. maijā un beidzās attiecīgi 5. un 2. oktobrī. Bērzam un kḷavai tas pagarinājās caurmērā par 


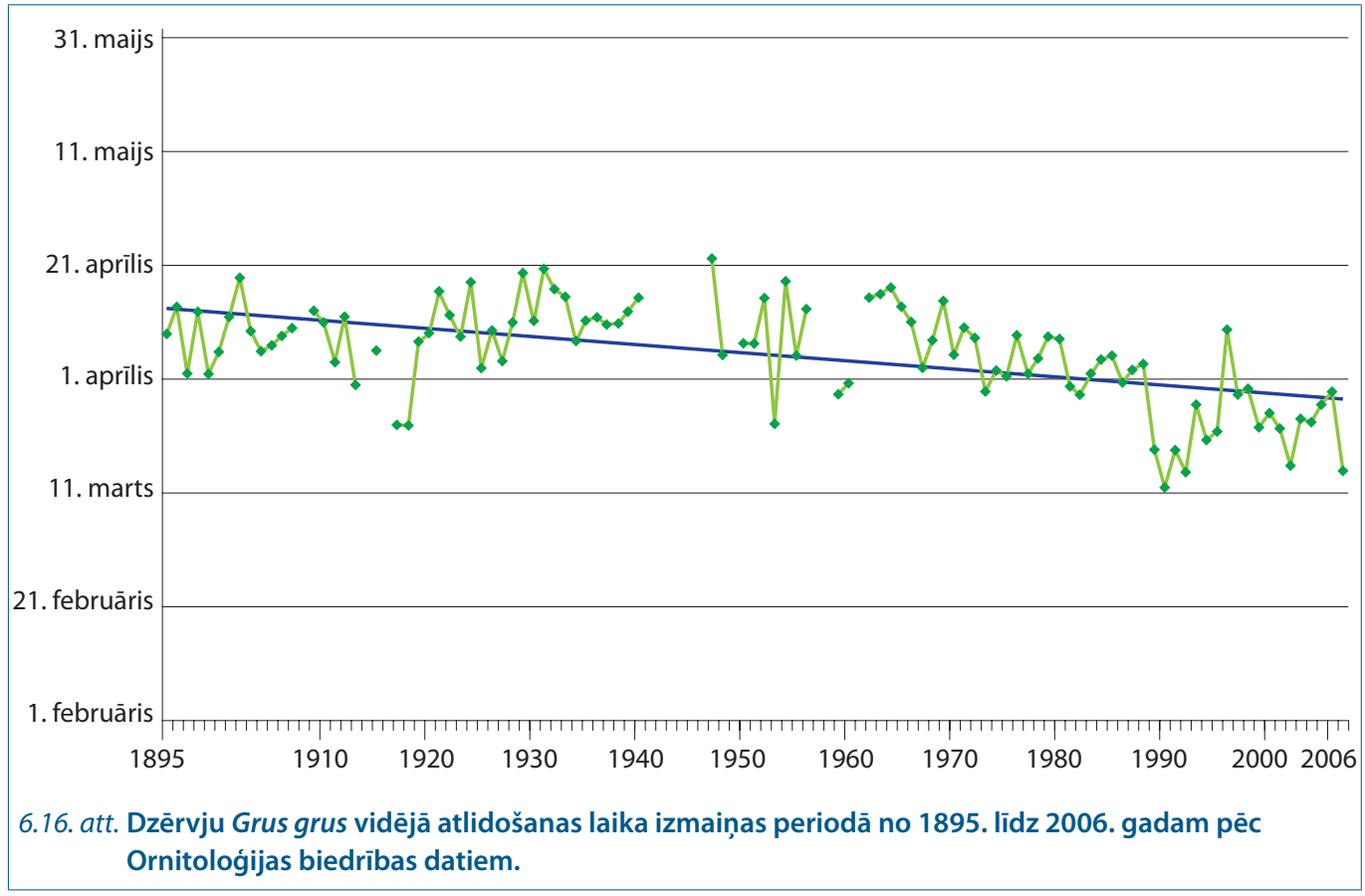

14 dienām. Analizējot nokrišnu daudzuma ietekmi uz fenoloǵiskajām parādībām, būtiska ietekme netika konstatēta.

Daudzām gājputnu sugām, kas atgriežas Latvijā līdz ar sniega nokušanu, kopš 20. gs. 70. un 80. gadiem ir tendence atlidot aizvien ātrāk (6.16. att.). Šì tendence ir kḷuvusi īpaši izteikta kopš 20. gs. 70.-80. gadiem.

Ar klimata pasiltināšanos Latvijā tiek skaidrota baltā zaḳa Lepus timidus skaita svārstības un aḷna Alces alces skaita samazināšanās. Pēdējos gadu desmitos, biežākām kḷūstot ziemām ar niecīgu sniega segu, zaksa baltais kažoks vairs nekalpo kā maskēšanās krāsa un zaksis biežāk kḷūst par upuri plēsējiem. Savukārt aḷna populācijas samazināšanos skaidro ar nobīdēm barības augu kvalitātē saskañā ar šì dzīvnieka barošanās ciklu. Aḷna populācijas skaita samazināšanās novērojama visā ziemel̦u puslodē, arī Ziemel̦amerikā, kur tas tiek skaidrots ar dažu no dienvidu rajoniem ienākušu zālēdāju parazītu savairošanos.

2013. gadā Latvijā pirmoreiz tika nomedīts zeltainais šakālis Canis aureus (6.17. att.), kas pamatā apdzīvo Eiropas Vidusjūras reǵiona austrumus, Tuvos Austrumus un Dienvidāziju. Konstatēts, ka Eiropā zeltainie šakālsi pēdējās desmitgadēs izplatās uz ziemel̦iem. Tie ir sastopami Balkānos, Ungārijā, Rumānijā, Ukrainā, Austrijā, Slovākijā, Slovēnijā un Itālijā. Šo dzīvnieku populācijā Baltijas valstis ir tālākā vieta uz ziemel̦iem, kur tie līdz šim sastapti un, domājams, liela nozīme šakāḷa izplatības procesā ir klimata izmaiñām. Spriežot pēc barošanās īpatnībām, tas varētu kḷūt par nopietnu

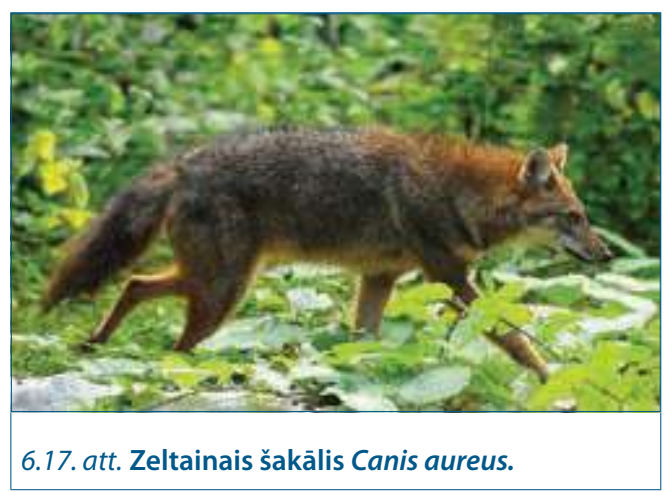


konkurentu gan rudajai lapsai, gan agrāk Latvijā introducētajam jenotsunim.

Attiecībā uz augiem ir visai grūti nosaukt sugu, kuras ieviešanās Latvijas florā būtu saistāma tikai un vienīgi ar klimata pasiltināšanos. Jāatzīmē, ka 2/3 mūsdienu Latvijas floras sugu gadsimtu gaitā ir tîši vai netī̌si ievazāti svešzemju augi. Pētniekiem nav pierādījumu, ka pagājušā gadsimtā Latvijā ienākušo svešzemju augu sugu, piemēram, Kanādas zeltslotinnas Solidago canadensis, puksu spriganes Impatiens glandulifera, parastās sērmūkšspirejas Sorbaria sorbifolia, Japānas un Sahalīnas dižsūrenes Reynoutria japonica un $R$. Sachalinensis masveida savairošanās varētu būt skaidrojama ar klimata pasiltināšanos, jo tās kā krāšn,umaugi nākušas no teritorijām ar visai līdzīgu temperatūras režīmu. Atzīmēts tikai, ka sūreṇu izplatību līdz šim ierobežojušas vēlās pavasara salnas. Vienīgā līdz šim zināmā augu suga, kuru varētu uzskatīt par klimata pasiltināšanās indikatoru, ir pusparazītiskā suga baltais āmulis Viscum album, kurš parazitē lapu koku lapotnēs un kuram caur Latviju iet izplatības ziemel̦u robeža. Šì suga 19. gs. bija konstatēta tikai Kurzemes un Latgales dienvidu rajonos. Sākot ar pagājušā gs. 90. gadiem, tās atrašanās vietu skaits Latvijā ir strauji pieaudzis.

Tomēr prognozes liecina, ka, paaugstinoties temperatūrai, daudzu Eiropas augu sugu potenciālais areāls varētu pārvietoties vairākus simtus kilometru uz ziemel̦iem un ziemel̦austrumiem. Šāda tendence sagaidāma arī attiecībā uz koku sugām. Rezultātā Baltijas jūras regiona mežos iespējama platlapu koku dižskābarža Fagus sylvatica, klinšu ozola Quercus petraea izplatīšanās un parastās liepas Tilia cordata un parastās kḷavas Acer platanoides īpatsvara palielināšanās. Protams, tas ietekmēs arī citu, ar šìm koku sugām saistītu augu

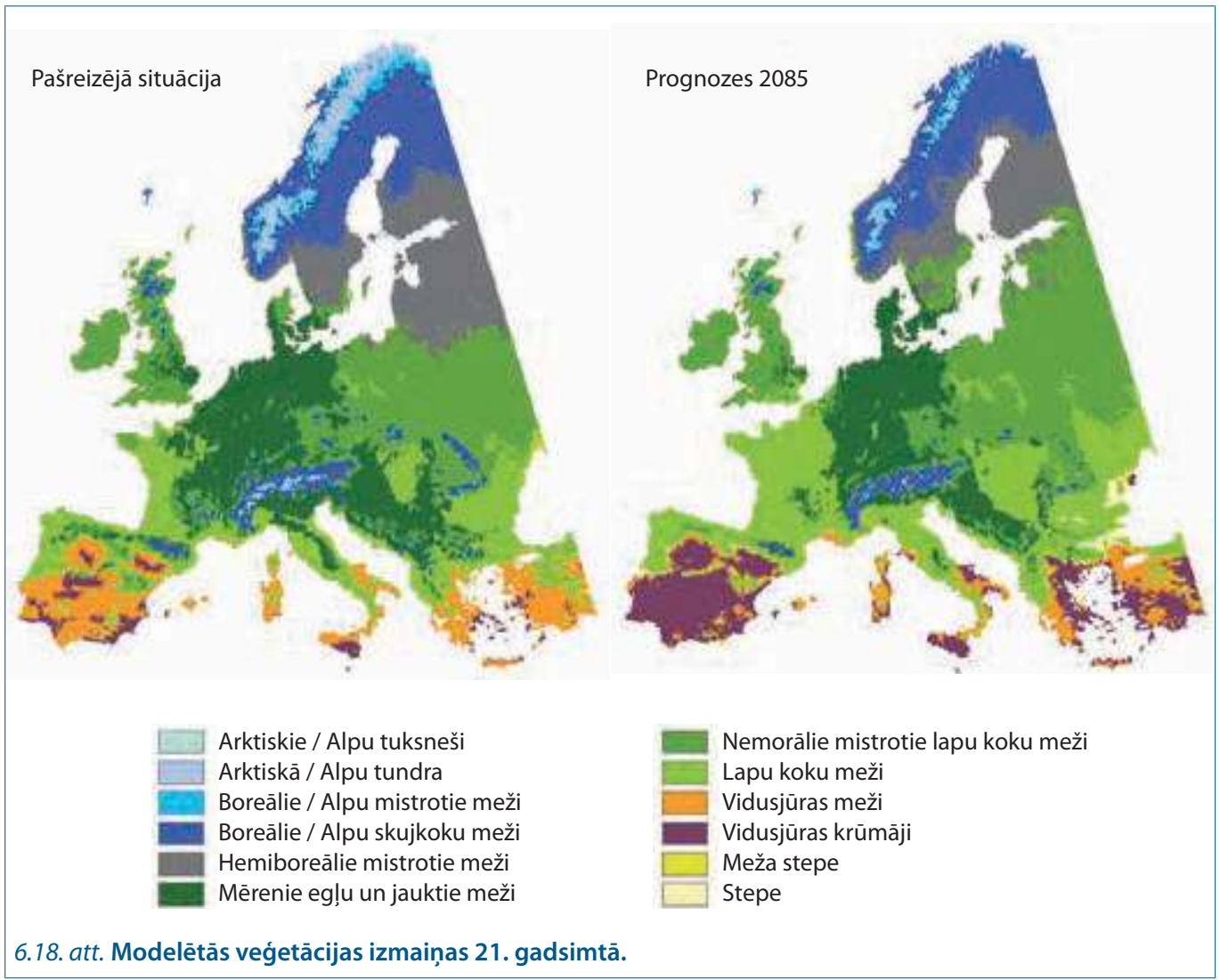


un dzīvnieku sugu izplatības areālus. Skuju koki, kam Latvijā var prognozēt piemērotu klimatisko apstākḷu iestāšanos 21. gs., ir lapegles Larix spp. To augšanai nepieciešama pakāpeniska temperatūru samazināšanās rudenī un ziemas sākumā, lai koks iegūtu salcietību. Līdz ar to nākamajā gadsimtā Latvijas teritorijā līdzšinējo hemiboreālo mistroto mežu vietā varētu dominēt nemorālie mistrotie lapu koku meži (6.18. att.) ar iepriekš minētājām koku sugām.

Vienīgie sistemātiskie ilgtermiña dati, kas reǵistrē atsevišku putnu sugu izplatības areālu izmaiṇas un to populāciju skaita izmaiṇas, apkopoti un iegūti LU Bioloǵijas institūtā Latvijas Nacionālā ilgtermiṇa ekologisko pētỉjumu tīkla pētījumu programmas ietvaros. Latvija ir Starptautiskā ilgtermiņa ekologisko pētījumu tīkla (International Long-Term Ecological Research network, ILTER) dalībvalsts. Veikt pētījumus par globālā klimata izmaiṇu ietekmi uz biologisko daudzveidību ir viens no ILTER tīkla uzdevumiem. Zināmu ieskatu par putnu sugu sastāva izmainām kopš pagājušā gadsimta beigām Latvijā sniedz arī divu ligzdojošo putnu atlantu salīdzinājums, no kuriem pirmais tapis 1980.-1984. gadā, bet otrais 2000.-2004. gadā kopā ar Latvijas ornitologu biedrību.

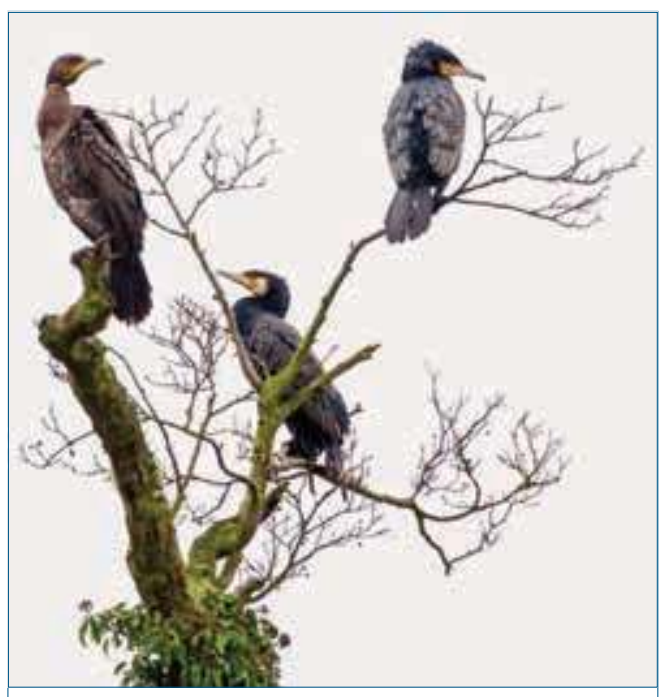

6.19. att. Jūras kraukḷi jeb kormorāni Phalacrocorax carbo.
Bioloǵijas institūta Ornitoloǵijas laboratorijā uzkrāti dati par putnu faunas un populāciju skaita izmaiñām kopš 20. gs. 50. gadiem vienā no Latvijas LTER pētījumu vietām Engures ekoreǵionā - Engures ezerā un tā sateces baseinā. Šajā laika periodā konstatēta vairāku dienvidu sugu ienākšana reǵionā, kā arī vairāku ziemel̦u sugu aiziešana no tā.

Engures ekoreǵionā pastāvīgi sākusi ligzdot meža zoss Anser anser, pelēkā pīle Anas strepe$r a$, gredzenūbele Streptopelia decaocto, vidējais dzenis Dendrocopus medius, bārdzīlīte Panurus biarmicus, Seivi k,aukjis Locustella luscinioides. Neregulāri sācis ligzdot baltacis Aythya nyroca un lielgalvis Netta rufina. Vienlaikus atzīmēts, ka regionā vairs neligzdo garknābja gaura Mergus serrator, lauku lija Circus cyaneus, parastais šnibītis Calidris alpina, gugatnis Philomachus pugnax, un purva tilbīte Tringa glareola, no pastāvīgi par epizodiski ligzdojošu sugu kḷvis garkaklis Anas acuta.

Pēc ligzdojošo putnu atlantu salīdzināšanas redzams, ka no regulārajām ligzdotājām izzudušas arī tādas putnu sugas kā brūnkakla gārgale Gavia stellata, baltirbe Lagopus lagopus un vistilbe Lymnocryptes minimus. Pēc ornitologu domām šo sugu izplatības areālu dienvidu robežas pārbīdīšanās uz ziemel̦iem vai ziemel̦austrumiem 20. gs. gaitā galvenais iemesls varētu būt klimata pārmainas. Toties Latvijā sākušas ligzdot četras jaunas putnu sugas, kas ienākušas no dienvidiem - bišu dzenis Merops apiaster, baltkakla muškēēājs Ficedula albicollis, baltais gārnis Ardea alba un tumšā čakstīte Saxicola rubicola. Latvijā pamanīts arī tuksneša k,auksis Sylvia nana un tuksneša čakstīte Oenanthe deserti.

Pēdējos gados l̦oti strauji palielinājusies jūras kraukla jeb kormorana Phalacrocorax carbo (6.19. att.) populācija Latvijā. Nav īsti skaidrs, vai šīs sugas ekspansija Eiropā varētu būt saistīta ar klimata pasiltināšanos. Taču šo putnu ekoloǵija, ligzdošana lielās kolonijās un lielā zivju daudzuma patērēšana radījusi nopietnas problēmas dīkssaimniecībā un ezeru apkārtnē, kā arī uz salām esošajās mežaudzēs, kur putni apmetušies. Kolonija īsā laikā spēj pilnībā degradēt kokaudzi, piesātinot augsni ar saviem ekskrementiem. 
Klimata pārmaiṇas varētu jūtami ietekmēt arī putnu migrāciju. Dažas putnu sugas, kuru sezonālās migrācijas notiek nelielos attālumos, piemēram, baltā cielava Motacilla alba, dažkārt novērota pārziemojam Latvijā. Tāpat no sezonālajām migrācijām varētu atteikties daži vārnveidīgie putni, svilpis Pyrrhula pyrrhula un zīdaste Bombycilla garrulus. Turpretī sugas ar ligzdošanas areālu ziemel̦os, piemēram, žubīšu dzimtas sugas, varētu Latvijas teritorijā pat izzust. Putni, kuru migrācija ir starpkontinentāla, jādomā, savas ziemošanas vietas saglabās, tomēr šo sugu izdzivošanu varētu apdraudēt klimata pasiltināšanās dēḷ notikušās izmainas to migrācijas ceḷos. Daudzu Latvijā ligzdojošo putnu sugu migrācijas cel̦i ved pāri Sahāras tuksnesim. Šajā pārlidojumā putniem jāveic aptuveni 2000 km bez atpūtas. Ja klimata pasiltināšanās turpināsies, notiks pārtuksnešošanās process Sahāras tuksneša perifērijā. Tādēl, tuksnesim izplešoties, putniem pārlidojamais attālums var ievērojami palielināties un kḷūt tiem nepārvarams.

Tomēr maldīgi būtu domāt, ka izmaiñas ligzdojošo sugu sastāvā ir atkarīgas tikai un vienīgi no temperatūras. Ilgtermiṇa pētījumi par dažu citu putnu sugu populāciju skaita izmaiñām un to noteicošajiem faktoriem Engures ekoreǵionā parādīja, ka šīs izmaiṇas ir radušās sarežgìtas antropogēnā faktora un klimatisko faktoru mijiedarbības rezultātā. Analizētas lauča Fulica atra, vairāku bridējputnu, pīlu, dūkuru un kaijveidīgo sugu populāciju, kā arī jūras kraukḷa Phalacrocorax carbo populāciju ilgtermiña izmaiñas laikā no 1948. līdz 2012. gadam. Kopš 19. gs. sākuma, kad zemes platību palielināšanas nolūkā 1842. gadā tika izrakts Mērsraga kanāls un pazemināts ezera ūdens līmenis, izveidojās plašas lopu ganīšanai un siena ieguvei piemērotas piekrastes pḷavu teritorijas. Pḷavu izveidošanās un vēlākā kḷūdainā to izmantošanas aizlieguma dēḷ, 1975. gadā izveidojot dabas liegumu, neapšaubāmi tika veicināta tārtinnveidīgo putnu, to skaitā kīìites Vanellus vanellus, plavu tilbītes Tringa totanus, melnās puskuitalas Limosa limosa ligzdošana un attiecīgs šo putnu populāciju pieaugums. Siena ieguvei tika izmantotas pat zemo purvu slīkšn,as, kuru augāju izplāàva ar izkaptīm un sienu žāvēja un glabāja uz speciāli šim nolūkam ierīkotām virs ūdens līmeña paceltām kaudžu vietām. Ziemā šis siens pa ledu tika nogādāts lopu novietnēs. Taču, ziemām kḷūstot siltākām, siena kaudzes nebija iespējams transportēt un tās palika ezerā, veidojot salinu tīklu, kas izrādījās l, loti piemērots pīlu, arī prīkškses Anas querquedula ligzdošanai un veicināja to populācijas pieaugumu. Tādējādi pīlu populāciju palielināšanās ir cilvēka saimnieciskās darbības un klimatisko faktoru mijiedarbības rezultāts. 50. gadu beigās pēc lieguma režīma ieviešanas un it īpaši 90. gadu sākumā, kad ekonomisko izmaiṇu dēl plavas un ganības masveidā tika pamestas un aizauga ar krūmiem, plavās ligzdojošo putnu dzīves apstāklıli krasi pasliktinājās. Līdz ar to samazinājās arī to populācijas.

Būtisku ietekmi uz ūdensputnu ligzdošanas sekmēm atstāj ezera ūdens līmeṇa svārstības, kas lielā mērā atkarīgas no nokrišnu daudzuma un gaisa temperatūras vasarā. Augsts ūdens līmenis un ezera vēlā aizsalšana uz klimata pasiltināšanās fona samazina ūdensputniem piemērotu virsūdens augāja slīkšṇu platību. Pētījumi rāda, ka kaijveidīgo un pīḷu ligzdošanai piemērotākā ir nelielu niedru un citu purva augu slīkšn,u mozaīka, nevis lieli niedru masīvi. Ja ūdens līmenis ir augsts, mazās slīkšn,as salinas tiek atrautas no ezera dibena un spēcīgo rudens vētru laikā izpūstas krastā. Savukārt augu barības vielu ieneses pastiprināšanās ar ezerā ieplūstošajām upēm no sateces baseina intensīvās lauksaimniecības teritorijām veicina ezera aizaugšanu. Visu šo procesu gaitā notiek ūdensputnu ligzdošanai labvēlīgo slīkšņu mozaīkveida struktūras homogenizācija. To īpaši veicina veǵetācijas perioda pagarināšanās. Savukārt, slīkšn,u saplūšana un milzīgu masīvu veidošanās ar niedru audzēm un krūmājiem nodrošina labus apstākḷus divu invazivo plēsēju - Usūrijas jenotsuña Nyctereutes procyonoides un Amerikas ūdeles Mustela vison dzivei, kuri šeit nereti veido midzenus un bez grūtībām piekḷūst masīvu perifērijā ligzdojošiem ūdensputniem un masveidā tos iznīcina. Tādējādi ūdensputnu populāciju stāvokli Engures ezerā kopumā ietekmē sarežgíta klimatisko un antropogēno faktoru mijiedarbība. 
Kukaiṇi un ērces ir tās organismu grupas, ko klimata izmainnas potenciāli var ietekmēt visvairāk, n,emot vērā to straujo vairošanos, īsos attīstības periodus un lielo jutību pret temperatūras un mitruma izmainām.

Siltākās ziemās labāk pārziemo parazītiskās asinssūcējas ērces, kas pārnēsā nopietnu slimību - encefalīta un boreliozes jeb laimas slimības izraisītājus. Klimatam kḷūstot siltākam, ērces kḷūst aktīvas jau martā un saglabā augstu aktivitāti līdz pat vēlam rudenim, tā palielinot cilvēku inficēšanās varbūtību.

Sugu daudzveidības ziṇā kukaiṇi neapšaubāmi ir dominējošā organismu grupa. Lielā sugu daudzveidība un indivīdu skaits, kā arī daudzveidīgā sugu ekologija nosaka kukaiñu kā ekosistēmu komponenta milzīgo nozīmi. Bažas par klimata izmaiṇu ietekmi uz cilvēkam labi pamanāmām sugām, tādām kā putni un zīdītāji, pārsvarā ir saistītas ar šo sugu aizsardzību. Taču attiecībā uz kukaiṇiem, kuru izmēri lielākoties sasniedz tikai dažus milimetrus un kuru ekoloǵiskā nozīne to lielā skaita un straujās vairošanās dēḷ nereti ir daudz lielāka, bažas rada pašu ekosistēmu funkcionēšanas izmaiñas un to sniegto pakalpojumu samazināšanās. Tādēḷ kukaiṇi tika iekḷauti kā viens no ilgtermiṇa ekoloǵisko pētījumu objektiem Latvijas ilgtermiña ekoloǵisko pētījumu programmā. Šìs programmas ietvaros Engures ekoreǵionā pētītas zāles stāvu apdzīvojošo kukaiṇu sugu daudzveidības izmaiṇas 12 dažādos biotopos, sākot ar sausu priežu silu un mēreni mitriem mežiem un plavām un beidzot ar mitrām plavām un zemo purvu. Laika posmā no 1995. līdz 2012. gadam ar entomoloǵisko tīkliṇu veikti regulāri kukaiṇu vākumi šajos biotopos. Viena no dominējošām kukain,u grupām bija mušveidīgie divspārṇi, kuru skaits ievāktajā materiālā nereti sasniedza 70-80\%. Kopumā līdz šim konstatētas 411 sugas, kuru lielākais vairums pēc kermeṇa izmēriem nepārsniedz pāris milimetru, respektīvi, parastam novērotājam nav pat pamanāmas. Visā pētījumu perioda laikā tika konstatēts pakāpenisks sugu skaita pieaugums no 70-100 sugām dažādos biotopos perioda sākumā līdz 120-160 sugām perioda beigās. Sugu skaita palielināšanās sakrita ar pozitīvo temperatūru summu pieaugumu reǵionā, tādēl pirmais izskaidrojums bija, ka tās notikušas klimata pasiltināšanās ietekmē. Tā kā sugu skaits pētītajos biotopos bija palielinājies uz "iekšējo resursu rēḳina”, respektīvi, netika konstatēta nevienas dienvidu sugas ienākšana, radās jautājums, vai šajā procesā ir vainojama tikai un vienīgi temperatūras paaugstināšanās. Analizējot sugu skaita izmaiñas pa atseviškiem biotopiem, tika konstatēts, ka statistiski ticams sugu skaita pieaugums pētījumu periodā novērojams tikai sausajos un mēreni mitrajos biotopos, bet slapjajos biotopos tas uzrāda vienīgi nenoteiktas svārstības pa gadiem. Izteiktākie sugu skaita palielināšanās trendi bija novērojami zoofāgu jeb plēsīgo sugu grupā, nevis saprofāgu jeb atmirušo organisko atlieku noārdītāju un fitofāgu jeb augēdāju sugu grupās. Tā kā plēsēju skaita palielināšanās parasti notiek uz upuru skaita palielināšanās fona, bija pamats domāt, ka palielinājies augsnes saprofāgu populācijas skaits. Gandrīz visām no pētījumos konstatētajām plēsīgo divspārṇu sugām kāpuri attīstās augsnē un trūdošos substrātos, kur tie arī uzmeklē savus upurus - citu divspārṇu kāpurus un dažādus sīkus augsnes bezmugurkaulniekus (tārpus un posmkājus). Taču ar ko varētu būt saistīta šo bezmugurkaulnieku savairošanās tieši sausos un mēreni mitros biotopos, kur to attīstībai nebūt nav optimāli apstākḷi? Cēlonis varētu būt vai nu ilggadīgās izmaiṇas augājā (ekologiiskās sukcesijas) vai arī augšnuu eitrofikācija - piesārṇojums ar slāpekḷa savienojumiem. Tā kā attiecīgajos biotopos izteikta augāja sukcesija netika novērota, kā vienīgais izskaidrojums atlika slāpekḷa piesārn,ojuma ietekme. Kā papildu apstiprinājums pēdējam pieñēmumam bija līdzīgas sugu skaita izmain,as divos plavu parauglaukumos, kuros zālāju biotopu apsaimniekošanas programmas ietvaros bija ieviesti lielie zālēdāji - savval̦as govis. Šo biotopu teritorijā bija daudz zālēdāju ekskrementu - ar slāpekḷa savienojumiem bagāta vide, kas ir ḷoti piemērota divspārṇu kāpuru un citu augsnes bezmugurkaulnieku attīstībai. Arī šajos parauglaukumos tika novērota līdzīga zoofāgo divspārṇu sugu skaita palielināšanās. 
Sausajos, ar augu barības vielām nabadzīgajos biotopos dabiski augsnē ir vērojams slāpekḷa trūkums. Barības vielu pienesumu šeit var nodrošināt atmosfēras nokrišni, kas slāpekli satur piesārn,ojuma veidā. Un izrādās, tas pēdējos gadu desmitos patiešām bija ievērojams - pētījumi liecina, ka Baltijas kāpu ekosistēmas, kurām pieder arī Engures ekoreǵiona sausie un mēreni mitrie parauglaukumi, laika posmā pēc 2000. gada ar atmosfēras nokrišñiem ir saṇēmušas 3-8 kg/ha slāpekḷa gadā. Tas ir ievērojams daudzums, lai izraisītu būtiskas izmaiṇas dabiski ar slāpekli nabadzīgajās kāpu augsnēs. Tā kā zoofāgo divspārņu sugu skaita palielināšanās būtiski korelē arī ar pozitīvo temperatūru summām, var izvirzīt hipotēzi par vesela vides faktoru kompleksa ietekmi uz minētajām izmaiņām, kur viens no galvenajiem faktoriem tomēr ir klimata pasiltināšanās (6.20. att.).

Četri vides faktori ir tieši vai netieši iesaistīti šajās izmaināa: temperatūra, nokrišn,i, $\mathrm{CO}_{2}$ satura palielināšanās atmosfērā un slāpekl̦a piesārṇojums. Divi pēdējie faktori uz klimata pasiltināšanās un veǵetācijas perioda pagarināšanās fona veicina augu biomasas un nobiru daudzuma palielināšanos. Temperatūras paaugstināšanās paātrina nobiru noārdīšanos, aktivizējot augsnes mikroorganismus un augsnes faunu. Šādos apstākḷos svarīgs ir mērens augsnes mitruma režìms, ko nodrošina pietiekams nokrišnu daudzums. Tādējādi zoofāgo mušu sugu skaita palielināšanās varētu būt uzskatāma par lielisku minēto ekologisko procesu indikatoru, kas parāda, ka sugu daudzveidības izmaiṇās svarīga ir ne vien temperatūra (klimata pasiltināšanās), bet arī citi vides faktori, to skaitā vides piesārṇojums, un sugu daudzveidības izmaiṇas ir sarežǵìts šo faktoru mijiedarbības galarezultāts.

Latvijas ilgtermiṇa ekologisko pētījumu programmas ietvaros pētītas arī augsnes faunas sugu daudzveidības izmaiņas priežu mežos uz klimata pasiltināšanās fona. Augsnes fauna sugu daudzveidības ziṇā pārspēj visas mērenās joslas virszemes un ūdens ekosistēmas. Sugu skaita ziṇā ar to var mēroties vienīgi tropu lietusmeži un korallı rifi. Augsnē mājo simtiem dažādu sugu bezmugurkaulnieku, kuru

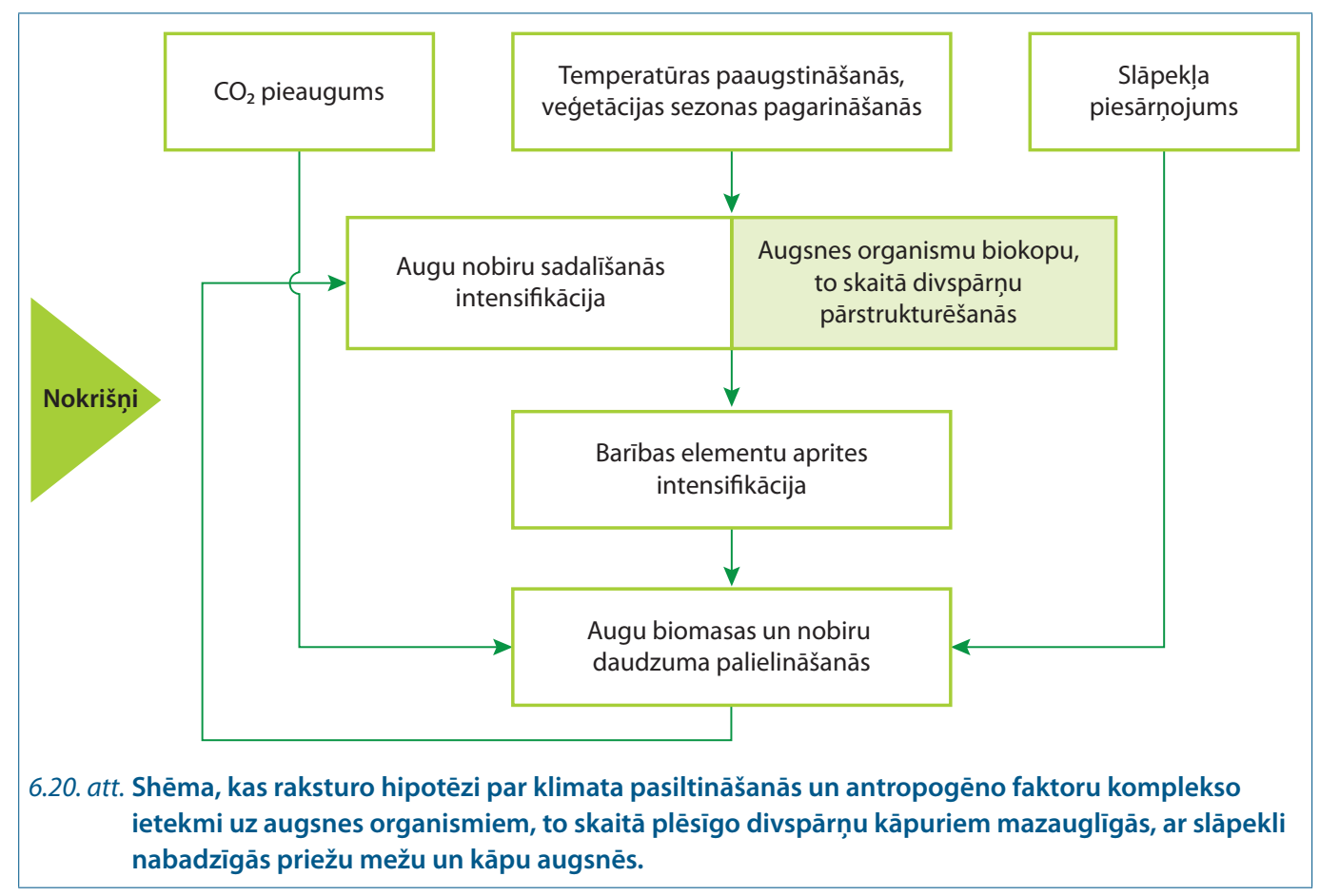


izmēri nepārsniedz 1-2 mm. Toties šo dzīvnieku skaits augsnē ir no dažiem tūkstošiem līdz miljonam uz vienu kvadrātmetru. Šiem organismiem ir milzīga nozīme augsnes veidošanā, augu un dzīvnieku organisko atlieku un ekskrementu noārdīšanā, augu barības vielu atbrīvošanā un to recirkulācijā ekosistēmā.

Pētījumu rezultātā konstatētas būtiskas dažu augsnes bezmugurkaulnieku sugu skaita izmaiṇas laika periodā kopš 1992. gada, kad pētījumi tika uzsākti. Viena no šādām augsnes organismu grupām ir kolembolas jeb lēcastes, kas savu nosaukumu ieguvušas no īpatnējā veidojuma - lēcdakšas vēdera galā, ar kuras palīdzību lēcaste var veikt tālus lēcienus, izvairoties no plēsēju uzbrukumiem (sk. 6.21. att).

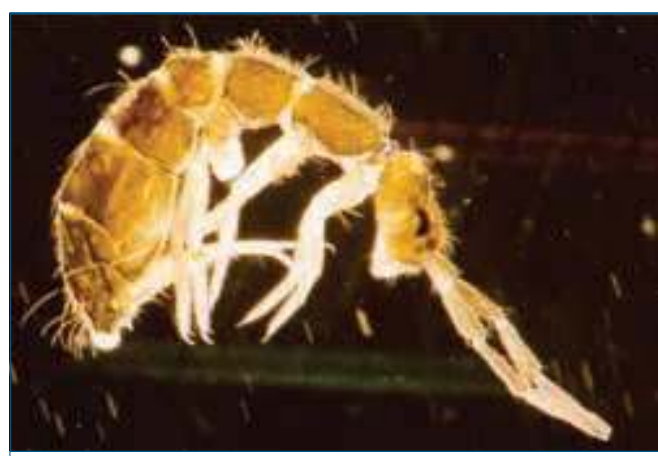

6.21. att. Kolembola jeb lēcaste.
Priežu mežu augsnē, sūnās un nobirās šie sīkie 0,5-4 mm garie kukaiṇi ir viena no dominējošām augsnes faunas grupām, sasniedz augstu apdzīvotības blīvumu - vairāki simti tūkstoši uz kvadrātmetru, ievērojamu sugu skaitu - vidēji 25-30 sugas. Lēcastes pamatā barojas ar augu atliekām un mikroskopiskām sēnēm. Barošanās procesā lēcastes producē lielu daudzumu sīku, mikronos mērāmu ekskrementu dalıinu, kuras ir ķīmiski noturīgas un, tāpat kā slieku ekskrementi ir biohumuss, kas uztur meža augsnes mikrostruktūru un auglību. Saskaṇā ar pētnieku aprēksiniem, kolembolu populācija, kuras blīvums sasniedz 10000 ind./m², gada laikā producē 183 g ekskrementu, kas atbilst 0,2 mm biezam humusa slānim. Laika periodā no 1992. līdz. 2002. gadam lēcastu sugu skaits priežu meža augsnē pakāpeniski samazinājās (sk. 6.22. att.). Tā kā šìs izmaiñas bija novērojamas dažāda vecuma mežaudzēs, tās nevar izskaidrot ar ekoloǵisko sukcesiju, toties sugu skaita izmainas negatīvi korelēja ar pozitīvo temperatūru summām. Analizējot sugu struktūras izmainas pētījumu periodā, tika konstatēts, ka tās pamatā nosaka divi faktori - pozitīvo temperatūru summas un augsnes mitrums, kas savukārt ir atkarīgs no nokrišnu daudzuma. Temperatūras izmainnas nosaka kolembolu sugu struktūras izmaiṇu trajektoriju laikā, bet nokrišṇu

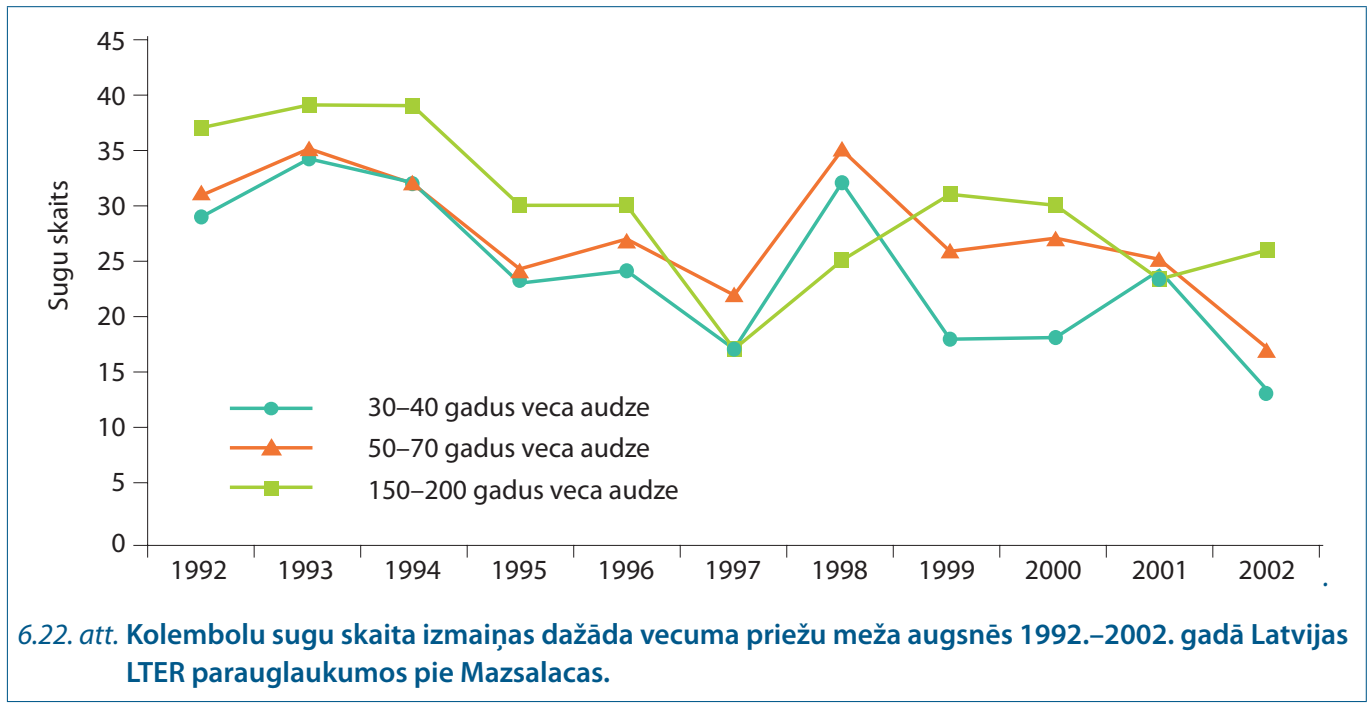




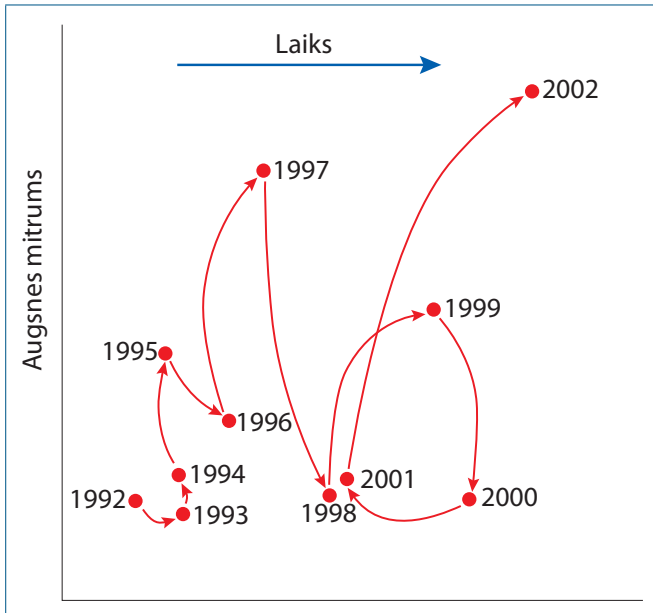

Pozitīvo temperatūru summa

6.23. att. Kolembolu biokopas struktūras izmainu trajektorijas galvenajās šo struktūru noteicošajās asīs, kas identificējas ar pozitīvo temperatūru summām un augsnes mitrumu.

izmainas pa gadiem veido šajā trajektorijā savdabīgas cilpas (sk. 6.23. att.). Tādējādi arī šajā gadījumā sugu daudzveidības izmaiņas ir uzskatāmas par vairāku faktoru mijiedarbības rezultātu.

Sugu skaita samazināšanās ekosistēmā jebkurā gadỉjumā uzskatāma par negatīvu procesu, kas samazina ekosistēmas stabilitāti un pretošanās spējas dažādām ārējām nelabvēlīgām ietekmēm. Konkrētajā gadījumā, n,emot vērā kolembolu ekoloǵiju, tās var uzskatīt par indikatīvu signālu traucējumiem meža augsnes veidošanās procesā.

\subsubsection{Izmaiṇas jūras ekosistēmā}

Baltijas jūras ekosistēmu ietekmē pieci galvenie faktori to mijiedarbībā - ūdens temperatūra, sālums, ūdens pH, skābekḷa saturs un cilvēka darbības rezultātā radītā eitrofikācija - piesārṇojums ar augu barības vielām. Klimata izmaiñas skar visu šo faktoru kompleksu. Baltijas jūra ir gandrīz pilnībā noslēgta; ūdens apmaiṇa ar pasaules okeānu notiek caur šaurumiem Ėresundu, Lielo un Mazo Beltu. Jūrai ir raksturīga izteikta ūdens slān,u stratifikācija. Virsējā siltākā slāṇa ūdeṇi pa minētajiem šaurumiem plūst ārā no Baltijas jūras, bet tajā ieplūst sāl,ie, aukstie, ar skābekli bagātie ūdeñi no Ziemeḷjūras. Šie ūdens slāṇi praktiski nesajaucas un saglabā atšksirīgu temperatūru un sāḷumu. Svaigo, ar skābekli bagāto ūdeṇu ieplūšana caur šaurumiem no Ziemeljjūras tomēr notiek reti un neregulāri. Pēdējo reiz šāds notikums novērots 1993. gadā. Toties Baltijas jūrā pastāvīgi ieplūst liels daudzums saldūdeñu no Baltijas jūras baseina upēm, kas nes sev līdzi gan duḷ,kes gan augu barības vielas. Tāpēc veidojas izteikts sāluma izmainu gradients no gandrīz saldūdens apstākḷiem lielo upju grīvu tuvumā līdz dziḷākā slān,a sāḷajiem ūdeṇiem 70-100 m dziḷumā jūras centrālajā dal̦ā. Šis slānis ir gandrīz nekustīgs, tas nesatur skābekli, tādēḷ tur nav dzīvo organismu, kam skābeklis ir nepieciešams elpošanai. Tā kā Rīgas līča dzilıms nepārsniedz 60 m, atšksirībā no daudzām citām Baltijas jūras daḷām, tā ūdeṇi tiek regulāri samaisīti visā ūdens dziḷumā. Rīgas līcī ir novērojams sāluma samazinājums. Pēdējo trīsdesmit gadu laikā ūdens sālums samazinājies vidēji par vienu promili. Turpmākajos gados Baltijas jūras reǵionā tiek prognozēts nokrišñu daudzuma pieaugums, tāpēc attiecīgi palielināsies arī upju noteces apjoms. Ziemeḷjūras ūden,u ieplūšanas gadījumi kḷūs vēl retāki, samazināsies ūdens virsējā slāṇa temperatūra, sāḷums samazināsies par 7-49\%, bet dzilākajos slānosos saglabāsies stagnantie apstākḷi. Tas būtiski ietekmēs Baltijas jūrā dzìvojošo sugu struktūru, ekoloǵiskās barības kjēdes un organismu dzives ciklus.

Sarežǵītas mijiedarbības starp atmosfēru, sateces baseinu un jūru rada grūtības atšksirt antropogēnā faktora radītās izmainnas, to skaitā jūras eitrofikāciju, no izmaināàm, ko radījušas pārmaiṇas klimatā. Klimata ietekme uz jūras ekosistēmu var būt tieša un netieša. Tiešā ietekme izpaužas kā ūdens slāṇu temperatūras, ķīmiskā sastāva, sāluma un citu īpašību ietekme uz dzīvo organismu vielmainu, augšanu un attīstību, izdzīvotību un vairošanās spējām. Netiešā ietekme izpaužas caur biokopu struktūras 
izmaiņām, kad vienas sugas indivīdu skaita izmain, as, kas notikušas, mainoties ūdens temperatūrai, ietekmē kādu citu sugu, kura ir trofiski saistīta ar pirmo.

Organisko vielu ienese ar upju ūdeniem un sāluma samazināšanās rada specifiskas izmainas mikroskopisko ūdens alǵgu - fitoplanktona sugu struktūrā. Palielinoties ūdens duḷkainībai, pasliktinās apgaismojums, un alǵēm ir traucēta fotosintēze. Šādos apstākḷıos fitoplanktonā virsroku gūst ciānbaktērijas, kas savairojoties izraisa ūdens "ziedēšanu" un atbrīvo citiem dzìvajiem organismiem toksiskus savienojumus. Sāḷuma samazināšanās un fitoplanktona struktūras izmainas negatīvi ietekmē zooplanktonu - sīkus vēžveidīgos, kas barības kēēē ir viens no galvenajiem fitoplanktona biomasas patērētājiem. Baltijas jūrā sastopamo ekonomiski nozīmīgāko zivju sugu, to skaitā mencu, brētliṇu un renggu, reakcija uz šìm izmaiņām ir atšksirīga. Organisko vielu un augu barības vielu, arī fosfora ienese ar saldūdeniem, intensificē bakterioplanktona attīstību, kas piedalās šo organisko vielu noārdīšanā. Taču šajā procesā tiek patērēts daudz skābekḷa un tā koncentrācija ūdenī samazinās. Mencām, kuru ikru attīstībai nepieciešams sāḷāks ūdens ar augstu skābekḷa saturu, veidojas attīstībai nepiemēroti apstākḷi. Tādēl to skaits samazinās. Ja šādos apstākḷlos tiek palielināta mencu nozveja, to populācija samazinās līdz kritiskam līmenim. Brētliṇu ikru attīstībai, gluži otrādi, siltums ir labvēlīgs. Cita citai sekojošās siltās ziemas un mencu skaita samazināšanās, kurām brētlinas ir viens no barības objektiem, izraisīja vairākkārtēju brētliṇu populācijas skaita pieaugumu.

Renggu sekmīgam nārstam svarīgas ir brūnalǵg - fikusu audzes, kas daudzviet Rīgas līča piekrastes ūden,os veido plašas zemūdens pḷavas. Prognozēts, ka renggu populācija, paaugstinoties ūdens temperatūrai maijā, kad notiek šo zivju nārsts, palielināsies. Gan brētliṇu gan renggu galvenā barība ir zooplanktona vēžveidīgie, kuru skaita samazināšanās uzskatāma par negatīvu faktoru šo zivju populāciju attīstībā. Taču, kā rāda pētījumi, mencu skaita samazināšanās šajā gadījumā darbojas kā kompensējošs faktors brētliṇu un renggu populācijas skaitliskajās izmaiṇās.

Baltijas jūru neapšaubāmi skars arī Pasaules okeānā novērojamā ūdens paskābināšanās problēma. Pēc viena no modelu scenārijiem līdz 2100. gadam šis process Baltijas jūrā palielinās ūdens skābumu par 0,2-0,4 pH vienībām. Analizējot šo izmaiṇu potenciālo ietekmi uz jūras ekosistēmu, jānnem vērā Baltijas jūras kā daḷeji noslēgtas un saldūdeṇu ienešu ietekmētas ūdenstilpes īpatnības. Piemēram, Kategata centrālajā dal̦ā laika periodā no 1992. līdz 2007. gadam registrētās pH svārstības bija 8,06-8,42, savukārt Baltijas jūras centrālajā daḷā 8,02-8,70, kamēr saldūdeṇu ietekmētajā Botnijas līcī pH svārstījās 7,408,37 robežās. Ūdens skābuma izmaināan Baltijas jūrā raksturīgas arī sezonālas izmaiṇas pat par $0,7 \mathrm{pH}$ vienībām un diennakts fluktuācijas $\pm 0,15$ pH vienību robežās. Kaut arī līdz šim trūkst tiešu pētījumu par Baltijas jūrā mītošo organismu reakciju uz pH izmaiñām, pieejamie dati l̦auj secināt, ka vairumam no jūras ekoloǵisko barības ķēdi veidojošām fitoplanktona, zooplanktona, makrozoobentosa, kā arī zivju sugu - mencu un brētliṇu - tolerances diapazoni attiecībā uz ūdens pH izmaiñām ir samērā plaši. Vienlaikus tomēr būtu jāṇem vērā iespējamā $\mathrm{pH}$ izmaiṇu mijiedarbība ar citiem vides faktoriem, kas praktiski līdz šim nav pētīta.

Dažādas ar jūru saistītas dzīvnieku sugas klimata izmainas ietekmē atškirīgi. Piemēram, pogaino roṇu populāciju negatīvi ietekmē ledus trūkums ziemā, jo roṇu mātītes mazul,us dzemdē uz ledus. Klimatam pasiltinoties, ūdens temperatūra salīdzinājumā ar 20. gs. sākumu jūrā cēlusies par $0,5^{\circ} \mathrm{C}$. 1942. gadā viss Rīgas līcis un lielākā dalı Baltijas jūras bijusi klāta ar ledu. Pēdējos gadu desmitos ledus sega nav izveidojusies, tikai dažās ziemās ledus pārklāja Rīgas līci.

Klimata izmainu radītās problēmas ir arī ūdens līmeña paaugstināšanās Baltijas jūrā. Tas katru gadu pieaug vidēji par diviem milimetriem. 


\subsubsection{Saldūdens ekosistēmu} izmaiñas

Dati par ilgtermiṇa izmaiṇām Latvijas upēs un ezeros līdz šim nav nepārprotami liecinājuši par klimata pasiltināšanās ietekmi. Lielā mērā to varētu skaidrot ar cilvēka saimniecisko darbību, kas veicina piesārnojumu, slāpekḷa un fosfora ienesi no sateces baseina. Ciānbaktēriju jeb zilalıgu masveida savairošanās gadījumi nekorelē ar temperatūras paaugstināšanos, drīzāk ar saimnieciskās darbības intensitātes izmaiñām ūdenstilpju krastos. Daudzos gadījumos šis izmaiñas varētu maskēt klimata pasiltināšanās rezultātā radušās pārmainas. Piemēram, cilvēka relatīvi maz ietekmētās Salacas upes ilgtermiṇa pētījumi liek pien,emt, ka klimata pasiltināšanās varētu būt cēlonis pastiprinātai upes aizaugšanai ar augstākajiem ūdensaugiem.

Ūdensaugu masveida savairošanās un atmiršanas dēl Latvijas upēs veidojas biezs dūṇu slānis. Tas negatīvi ietekmē tādu retu īpaši aizsargājamo sugu kā ziemel̦u upespērlenes Margaritifera margaritifera un zaḷās upjuspāres Ophiogomphus cecilia eksistences apstāklus. Upespērlenes kāpuri parazitē tikai lašveidīgajās zivīs, kuru trūkums praktiski nozīmē pērl’ gliemenes populācijas iznīkšanu. Ja kāpuram laimējies sastapt lašveidīgo zivi, tad pēc parazītiskās stadijas tas ierokas dzilı upes gultnē, bet, ja upes dibenu sedz dūnu slānis, tad kāpuram nepiekḷūst skābeklis. Arī zal̦ā upjuspāre apdzīvo tikai upes ar tīru, neaizaugušu gultni. Ja upes aizaugšanu var uzskatīt par klimata pasiltināšanās sekām, tad minēto sugu izzušana nākotnē arī būs uzskatāma kā klimata izmainu sekas.

Klimata izmainas mijiedarbībā ar vides piesārn,ojumu būtiski ietekmē arī Latvijas ezerus. Ūdens dzidrībai samazinoties, pirmie cieš ūdensaugi, kuru augšanai nepieciešams labs apgaismojums. Ūdens dzidrības samazināšanās dēl daudzos ezeros ir izzudusi reta, īpaši aizsargājamā suga Dortmaṇa lobēlija Lobelia dortmanna.

Klimata pasiltināšanās dēl var izzust tās zivju sugas, kuru temperatūras optimuma zona ir zemāka, piemēram, lašveidīgās zivis. To vietā ienāks jaunas siltummīlošās sugas. Visvairāk apdraudētas ir zivis, kurām nepieciešams vēsāks, ar skābekli bagāts ūdens. Tādas sugas ir foreles Salmo trutta ssp., sīgas Coregonus sp., alatas Thymallus thymallus, vēdzeles Lota lota, platgalves Cottus sp. u. c. Vasarās, ùdenim sasilstot virs $+20^{\circ} \mathrm{C}$, šīs zivis paslēpjas vēsākās ūdenstilpes vietās un pārstāj baroties. Vasarām kḷūstot siltākām un garākām, šo zivju eksistence ir apdraudēta. Tās var aizstāt pret skābeklı samazināšanos izturīgas sugas ar plašāku toleranci pret ūdens temperatūras izmaiñām, piemēram, karpas Cyprinus carpio, karūsas Carassius sp., linni Tinca tinca, rudul, Scardinius erythrophthalmus un sami Silurus glanis. Jāatzīmē gan, ka šīs zivis ir neaktīvas un nebarojas ūdens temperatūrās, kas zemākas par $+12-+15^{\circ} \mathrm{C}$, kādas mēdz būt pavasara periodā. Klimatam kḷūstot siltākam, to barošanās periods varētu pagarināties. Līdz ar to tās augtu ātrāk un sasniegtu lielākus izmērus, izkonkurējot tādas sugas kā raudas Rutilus rutilus, asarus Perca fluviatilis u.c. Atzīmēts, ka klimata pasiltināšanās ir jau izraisījusi tādu Dienvideiropai un Viduseiropai raksturīgu zivju kā barbes Barbus sp. un apakšmutes Chondrostoma spp. izplatības robežu paplašināšanos Eiropā. Ievērojami palielinās risks savvaḷā aklimatizēties tur nejauši nokluvuušām vai tīši vietējās ūdenstilpēs ielaistām dienvidu sugām, piemēram, tilāpijām Thylapia sp.

Klimata pasiltināšanās Latvijā, saglabājoties mērenam mitruma režīmam, varētu labvēlīgi ietekmēt dažu abinieku - ugunssalamandras Salamandra salamandra, dzeltenvēdera ugunskrupja Bombina variegata, kā arī rāpuḷu zal̦ās kirzakas Lacerta viridis - izplatību. Latvijā varētu uzlaboties dzīves apstākḷi kokvardei Hyla arborea, kas pagājušā gadsimta beigās tika reintroducēta Latvijas rietumdaḷā, un Eiropas purva brunurupucim Emys orbicularis, kuram caur Latviju iet izplatības ziemel̦u robeža un kurš līdz šim ḷoti reti novērots dabā. Ienākot vairākām dienvidu sugām, abinieku un rāpuḷu skaits Latvijā varētu palielināties.

Klimata izmainas var ietekmēt ne vien upju ūdens organismus, bet arī tos dzìnniekus, kas 
mìt upju krastos un barojas ar ūdens organismiem. Viena no tādām sugām ir zivju dzenītis Alcedo atthis, kurš ligzdo stāvos upju krastos izraktās alās un pārtiek no upē nomedītām zivīm. Šì putna eksistencei kritiski kḷuvuši neregulārie plūdi, kas pat vasaras vidū izskalo upes krastus un tādējādi iznīcina zivju dzenīša ligzdas. Plūdu laikā upes ūdens kḷūst duļ̣,kains un putns vairs nespēj sekmīgi medīt zivis. Tāpēc zivju dzenīši pamet savas ligzdošanas vietas vai arī, nesan,emot pietiekami daudz barības, iet bojā to mazuḷi.

\subsection{4. letekme uz lauksaimniecību un mežsaimniecību}

Klimata pasiltināšanās radītās izmainas sauszemes ekosistēmās ietekmēs lauksaimniecības un mežsaimniecības nozares Latvijā. No vienas puses, veǵetācijas perioda prognozētā pagarināšanās līdz gadsimta beigām par 3040 dienām no marta beigām līdz pat novembra

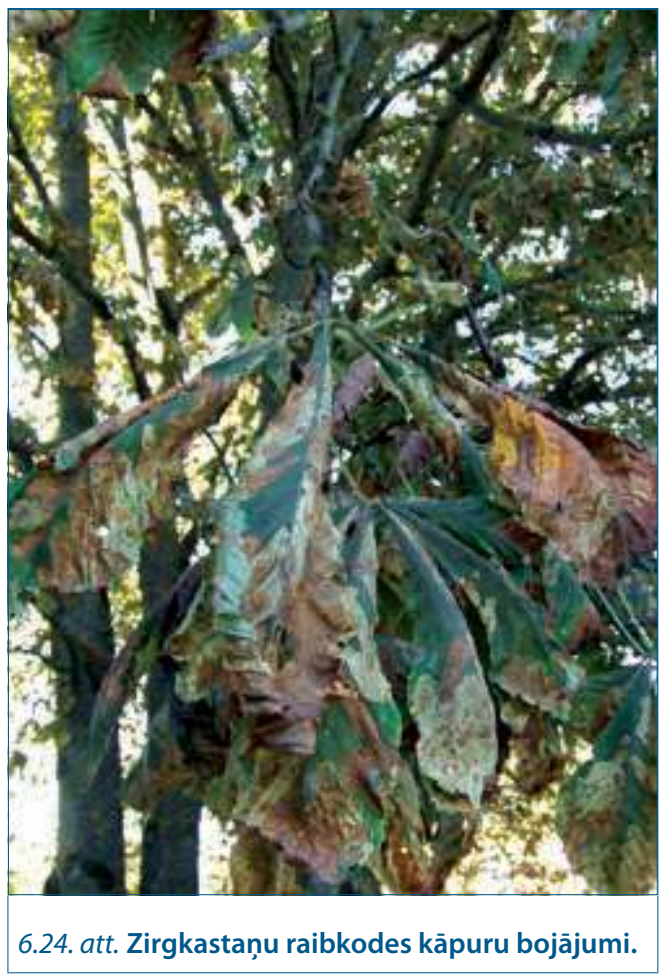

sākumam un pozitīvo temperatūru summas pieaugums varētu palielināt daudzu lauksaimniecības kultūru ražību, dodot iespējas ar labām sekmēm audzēt Latvijā vairākas līdz šim dienvidu rajoniem raksturīgus kultūraugus. Paaugstināta $\mathrm{CO}_{2}$ koncentrācija atmosfērā veicinās fotosintēzi un augu produktivitāti. Tāpēc var prognozēt, ka ražība pieaugs pat par 34-54\%. Garāks veǵtācijas periods veicinās zālaugu un lopbarības tauringziežu ražības pieaugumu. Ilgāks siltuma periods samazinās lauksaimniecības dzīvnieku uzturēšanas un audzēšanas izmaksas. No otras puses, siltāks klimats atnesīs sev līdzi jaunu, Latvijas apstākliem līdz šim neraksturīgu kultūraugu kaitēkḷu un slimību, kā arī invazìvo sugu ieviešanos, tādēḷ būs jālieto vairāk pesticīdu augiem un veterināro preparātu lauksaimniecības dzīvnieku slimību ārstēšanai.

Jau šobrīd Latvijā ir parādījušies tādi augu kaitēkḷi kā k̦iršu muša Rhagoletis cerasi, zirgkastanu raibkode Cameraria ohridella, kas ir izteikti dienvidnieki.

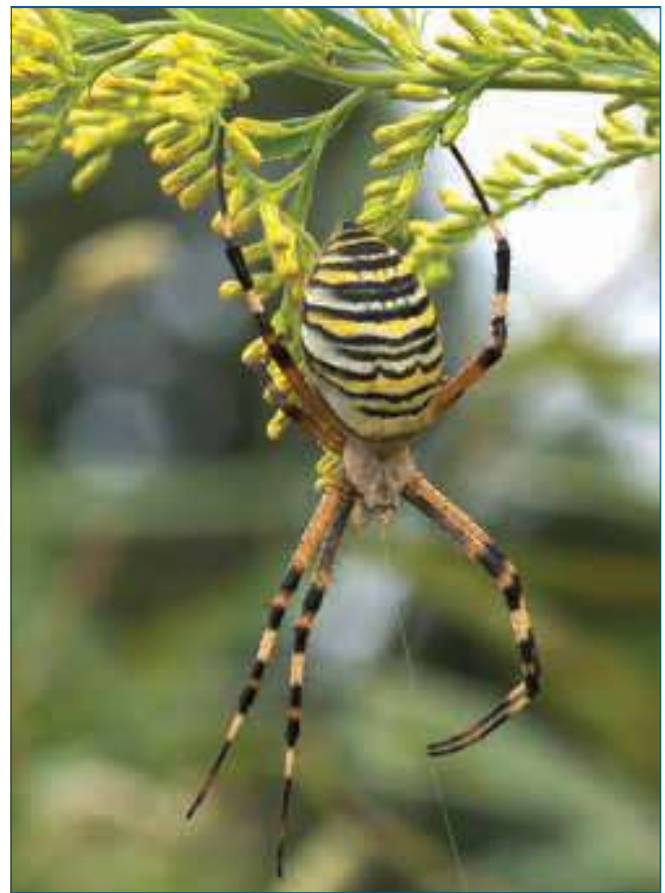

6.25. att. Lapsenveida zirneklis Argiope bruennichi. 
Pēdējos gados regulāri konstatēts arī klejotājsisenis Locusta migratoria no Viduseiropas. Jaunu augu kaitēkḷu parādīšanās parasti ir labāk pamanāma, it īpaši, ja to ierašanās saistīta ar liela apjoma augu bojājumiem. Daudz mazāk pamanāmas ir plēsīgās sugas. Daudzas no tām ir kaitēkḷu dabiskie ienaidnieki. Izṇēmums ir lielas vai uzkrītoši krāsotas sugas. Tā, piemēram, Latvijā Liepājas rajonā Papē 2004. gadā pirmoreiz tika pamanìts lapsenveida zirneklis Argiope bruennichi (sk. 6.25. att.), kas ir tipiska dienvidu suga un kopš gadsimta sākuma strauji izplatās uz ziemel̦iem. Šobrīd tas jau ir sastopams lielākajā dậā Latvijas teritorijas.

Siltāks un mitrāks klimats veicinās mikotoksīnus izdalošo mikroskopisko sēnu izplatību, un palielināsies to nokḷū̌sanas varbūtība pārtikas produktos.

Klimatam kḷūstot siltākam, sagaidāmas ievērojamas izmaiṇas augsnē, kas ir lauksaimniecības produkcijas ražošanas pamats. Ziemām kḷūstot maigākām un īsākām, augsnes virskārta vai nu nesasals vispār, vai arī būs novērojami bieži atkušṇi. Tādējādi augsne ilgāk saglabās bioloǵisko aktivitāti, intensīvāki būs atmirušo organisko vielu noārdīšanās un mineralizācijas procesi. Ja klimata izmainu rezultātā palielināsies nokrišnu daudzums, pastiprināsies augu barības elementu izskalošanās no sakṇu zonas, kā arī augsnes erozija. Jāatzīmē, ka klimata pasiltināšanās ierosinātā augsnes biologiskās aktivitātes pastiprināšanās nenovēršami radīs siltumnīcefekta gāzu - $\mathrm{CO}_{2}, \mathrm{~N}_{2} \mathrm{O}$ un $\mathrm{CH}_{4}$ papildu emisiju no augsnes un kūtsmēsliem to sadalīšanās procesā.

Ja temperatūras paaugstināšanās vidēji par $2{ }^{\circ} \mathrm{C}$ Ziemel̦eiropas lauksaimniecībai varētu būt labvēlīga, veicināt ražas pieaugumu, tad, pārsniedzot šo līmeni, stāvoklis saskaṇā ar prognozi pasliktinātos.

Klimata izmainu ietekmē vietējās izcelsmes kokiem rodas atšksirīgi augšanas apstākḷi salīdzinājumā ar iepriekšējiem gadsimtiem. Gadskārtu pieauguma analīze priedēm gan Latvijā gan Baltijas regiionā kopumā liecināja par koku pieauguma palielināšanos gados ar siltākām ziemām un pavasariem, jo šādos apstāklos augsnes sasalšanas dzilıums ir mazāks un kokiem ātrāk iestājas aktīvās augšanas sezona. Savukārt, sausums vasarā var negatīvi ietekmēt koku augšanu. Dabiskās izlases procesā vairāku simtu paaudžu laikā katrā konkrētā geogrāfiskā vietā ir saglabājušies koku genotipi, kas maksimāli izmanto augšanai labvēlīgos pieejamos resursus, veidojot lielākus pieaugumus un izkonkurējot citus. Bojā iet gan koki, kas nepilnīgi izmanto veǵtācijas periodu, gan arī tie koki, kuriem ir tendence veǵetācijas periodu "pagarināt", tādējādi ciešot no pavasara vai rudens salnām. Klimatam strauji mainoties, koki nespēj tūlītēji izmantot visus papildu resursus, un tiem būs nepieciešami vairāki simti paaudžu, lai dabiskās selekcijas gaitā notiktu pielāgošanās izmainītā klimata apstākḷiem. To varētu paātrināt, veicot mērkstiecīgi virzītu selekciju. Kā liecina pētījumi par Zviedrijas priežu stādījumu Latvijā, pat klimatam strauji mainoties, sagaidāms, ka sēklu plantāciju pēcnācēju krāja būs lielāka nekā mežaudžu pēcnācējiem, tāpēc meža atjaunošanā lietderīgāka būs stādīšana, nevis paḷaušanās uz dabisko atjaunošanos.

Tiek prognozēts, ka, klimatam kḷūstot siltākam, turpmākajos gados notiks skuju un lapu grauzēju kaitēkḷu, piemēram, priežu rūsganās zāǵlapsenes Neodiprion sertifer masveida savairošanās. Būtiskāk cietīs lapu koki, to skaitā bērzi, apses, alkšņi, uz kuriem dzīvojošās augēdāju kukaiṇu sugas ir prasīgākas pret augstākām temperatūrām. Klimata pasiltināšanās

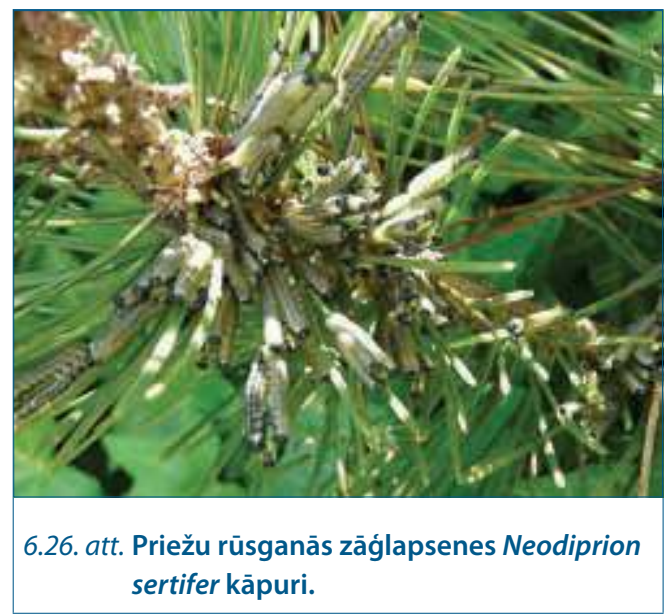


varētu būt labvēlīga sakṇu trupes Heterobasidion annosum s.l. attīstībai. Klimata izmainas nes sev līdz biežākas ekstrēmās meteorologiskās parādības - vētras, ilgstošus sausuma periodus. Tas veicinās lielāka daudzuma mizgraužu attīstībai piemērotu gāztu vai vides stresa novājinātu koku parādīšanos mežaudzēs.

Jau tagad ir konstatēts, ka, paaugstinoties gada vidējai temperatūrai, palielinās kukaiñu paaudžu skaits gada laikā (piemēram, egl̦u astonzzobu mizgrauzim Ips typographus). Siltas ziemas veicinājušas dažu dienvidu sugu ienākšanu Latvijā. Piemēram, ozolu mūḳenes $L y$ mantria dispar masveida savairošanās pirmo reizi konstatēta 2008. gadā Liepājas rajonā un ietekmējusi mežaudzes apmēram 40 ha platībā. Agresīvas kḷūst sugas, kas agrāk tika uzskatītas par nenozīmīgiem kaitēkḷiem, piemēram, galotṇu sešzobu mizgrauzis Ips accuminatus, kas apdzīvoja tikai novājinātus kokus, kopš 2007. gada spējis iznīcināt priežu audzes vairāku hektāru platībā. Šì kukaiṇa agresivitāte ir saistīta ar otrās paaudzes sekmīgu attīstību, kam priekšnosacījums ir garas un siltas vasaras.

Mežam kā ekosistēmai ir l̦oti liela nozīme $\mathrm{CO}_{2}$ piesaistīšanā no atmosfēras. Parasti dabiskās mežaudzēs ogleklis uzkrājas vairāk nekā intensīvi apsaimniekotās, jo tur koki sasniedz savu biologisko vecumu. Taču apsaimniekotos mežos ogleklis saglabājas iegūtajos celtniecības materiālos un mēbelēs un, dalı koksnes izmantojot kā kurināmo, tiek aiztaupīta fosilā kurināmā izmantošana un līdz ar to izslēgtas papildus $\mathrm{CO}_{2}$ emisijas. Dabiskajās mežaudzēs turpretī atmirusī koksne tiek noārdīta, tādējādi atbrīvojot atmosfērā $\mathrm{CO}_{2}$, kas gan dậ̄ji tiek piesaistīts atpakal nākamajā meža paaudzē.

\section{Avoti tālākām studijām}

Vai augi un dzīvnieki var pielāgoties klimata izmaiṇām: http://www.scepticalscience.com/Can-animals-and-plantsadapt-to-global-warming.htm

Klimata izmainas un Latvijas daba: http://kalme.daba.IV/failiNPP_informativie_materiali/VPP/Atskaites_2008/Publ_ prezentacija_28.11.2008./

Klimata izmaiṇas un Latvijas lauksaimniecïba: https://www.zm.gov.Iv/lauksaimnieciba/statiskas-lapas/klimataparmainas-un-lauksaimnieciba?nid=1129\#jump

Klimata izmaiṇas un mežsaimnieciba Latvijā: http://www.silava.Iv/23/section.aspx/View/139

Klimata izmainas un pasaules lauksaimniecïba: $h t t p: / / d o c u m e n t s . w o r l d b a n k . o r g / c u r a t e d / e n / 2013 / 06 / 17911216 /$

climate-change-agriculture-review-impacts-adaptations

Klimata izmainas un jūras ekosistēmas:

http://wwf.panda.org/about_our_earth/blue_planet/problems/inadequate_protection/

https://cgspace.cgiar.org/handle/10568/66472 (Climate change and agriculture of Africa)

http://www.fao.org/3/a-ai785e.pdf

\section{Literatūra}

Auniņš A. (2008) Klimata pārmaiṇu ietekme uz Latvijas savvaḷas dabas bioloǵisko daudzveidību. Grām.: Stratēǵiskās analīzes komisija 2008. Klimata pārmaiṇas: izaicinājumi Latvijai starptautiskajā vidē. Rīga, 54.-77. Ipp.

Chapin F. S., Zavaleta E. S., Eviner V. T., Naylor R. L., Vitousek P. M., Reynolds H. L., Hooper D. U., Lavorel S., Sala O. E., Hoddie S. E., Mack M. C., Diaz S. (2000) Consequences of Changing Biodiversity. Nature 405, $234-242$ Ipp. Chris D. T., Alison C., Rhys E. G., Michel B., Linda, J. B., Yvonne, C. C., Barend F. N. E., Marinez F. S., Alan G., Lee H., Lesley H., Brian H., van Jaarsveld A. S., Guy F. M., Lera M., Ortega-Huerta M. A., Peterson A. T., Oliver L. P., Stephen E. W. (2004) Extinction Risk from Climate Change. Nature 427, 145-148 Ipp.

Climate-related Transboundary Pests and Diseases, Technical Background Document from the Expert Consultation held on 25 to 27 February 2008, FAO, Rome. www.fao.org/foodclimate/expert/em3/en 
Dunford R. W., Berry P. M. (2012) Climate Change Modelling of English Amphibians and Reptiles: Report to Amphibian and Reptile Conservation Trust (ARC-Trust). Final Report: May 2012, Environmental Change Institute, University of Oxford Centre for the Environment, South Parks Road, Oxford, OX13QY.

The BACC II Author Team (2015) Second Assessment of Climate Change for the Baltic Sea Basin, Regional Climate Studies, Springer Cham Heidelberg New York Dordrecht London, DOI 10.1007/978-3-319-16006-1_20.

K!̣aviņš M. (ed.) (2007) Climate Change in Latvia. LU Akadēmiskais apgāds: Rīga.

K!̣aviņ̌ M., Blumberga D., Bruṇiniece I., Briede A., Grišule G., Andrušaitis A., Āboliṇa K. (2008) Klimata mainība un globālā sasilšana. LU Akadēmiskais apgāds: Rīga.

Wilson R. (2009) Impacts of Climate Change on European Invertebrates, with reference to the vulnerability of Bern Convention Species, Draft Version. Centre for Ecology and Conservation, University of Exeter UK. Strasbourgh, 16 June 2009. www.fao.org/foodclimate/expert/em3/en

\section{Izmantotie attēli}

6.2. Odum E. P. 1971. Fundamentals of Ecology W.B. Saunders Company, Philadelphia-London-Toronto.

6.3. Whittaker R. H. 1975. Communities and Ecosystems. Macmillan Publishing Co., Inc. New York.

6.4. Millenium Ecosystem Assessment, 2005.

6.5. Pēc WWF UNEP-WCMC.

6.6. Pēc Peacock E., Sonsthagen S.A., Obbard M.E., Boltunov A., Regehr E.V., et al. (2015) Implications of the Circumpolar Genetic Structure of Polar Bears for Their Conservation in a Rapidly Warming Arctic. PLoS ONE 10(1): e112021. doi:10.1371/journal.pone.0112021 http://127.0.0.1:8081/plosone/article?id=info:doi/10.1371/ journal.pone.0112021c

6.7. https://www.flickr.com/photos/gnilenkov/9052248188_46c42afea3_o.jpg Saskaņā ar Creative Commons licenci.

6.8. https://upload.wikimedia.org/wikipedia/en/9/90/Keppelbleaching.jpg

6.9. https://commons.wikimedia.org/wiki/Category:Cerambyx_cerdo\#/media/File:Cerambyxcerdo_fg03.jpg

6.10. https://commons.wikimedia.org/wiki/File:Osmoderma_eremita_no.jpg

6.11. https://en.wikipedia.org/wiki/Wheat_yellow_rust\#/media/File:Stripe_rust.jpg

6.12. https://en.wikipedia.org/wiki/lcerya_purchasi\#/media/File:Icerya_purchasi_1435060.jpg

6.13. https://en.wikipedia.org/wiki/Hemileia_vastatrix\#/media/File:Hemileia_vastatrix_-_coffee_leaf_rust.jpg

6.14. Francl, L. J. 2001. The Disease Triangle: A plant pathological paradigm revisited. The Plant Health Instructor. DOI: 10.1094/PHI-T-2001-0517-01

6.15. "Heterobasidion annosum - Lindsey" by James Lindsey at Ecology of Commanster. Licensed under CC BY-SA 3.0 via Commons - https://commons.wikimedia.org/wiki/File:Heterobasidion_annosum_-_Lindsey.jpg\#/media/ File:Heterobasidion_annosum_-_Lindsey.jpg

6.16. Auniņš A., 2008. Klimata pārmaiṇu ietekme uz Latvijas savvaḷas dabas bioloǵisko daudzveidību. Grām.: Stratēǵiskās analizzes komisija 2008. Klimata pārmainas: izaicinājumi Latvijai starptautiskajā vidē. Rīga, 54-77.

6.17. https://lv.wikipedia.org/wiki/Zeltainais_\%C5\%A1ak\%C4\%81lis\#/media/File:Canis_aureus_Kaeng_Krachan_ national_park.jpg

6.18. Hickler et al., 2012. Projecting the future distribution of European potential natural vegetation zones with a generalized, tree species-based dynamic vegetation model. Global Ecol. Biogeogr., 21, 50-63

6.19. https://commons.wikimedia.org/wiki/File:3_cormorants_on_a_tree.jpg\#/media/File:3_cormorants_on_a_tree.jpg

6.20. Melecis,V., Karpa, A., Vilks, K. 2014. Increase in abundance and species richness of flies (Diptera, Brachycera) in the Lake Engure Nature Park, Latvia: effects of climate warming? Proc. Latvian Acad. Sci. Section B, 68, 1/2 (688/689), 46-67.

6.21. https://upload.wikimedia.org/wikipedia/commons/b/ba/Isotoma_Habitus.jpg

6.23. Juceviča E., Melecis V., 2006. Global warming affect Collembola community: A long-term study. Pedobiologia, 50, 2: 177-184.

6.24. I. Meleces foto.

6.25. https://en.wikipedia.org/wiki/Argiope_bruennichi\#/media/File:Argiope_bruennichi_08Oct10.jpg

6.26. https://en.wikipedia.org/wiki/Neodiprion_sertifer\#/media/File:Neodiprion_sertifer_chenilles_\%281\%29.JPG 



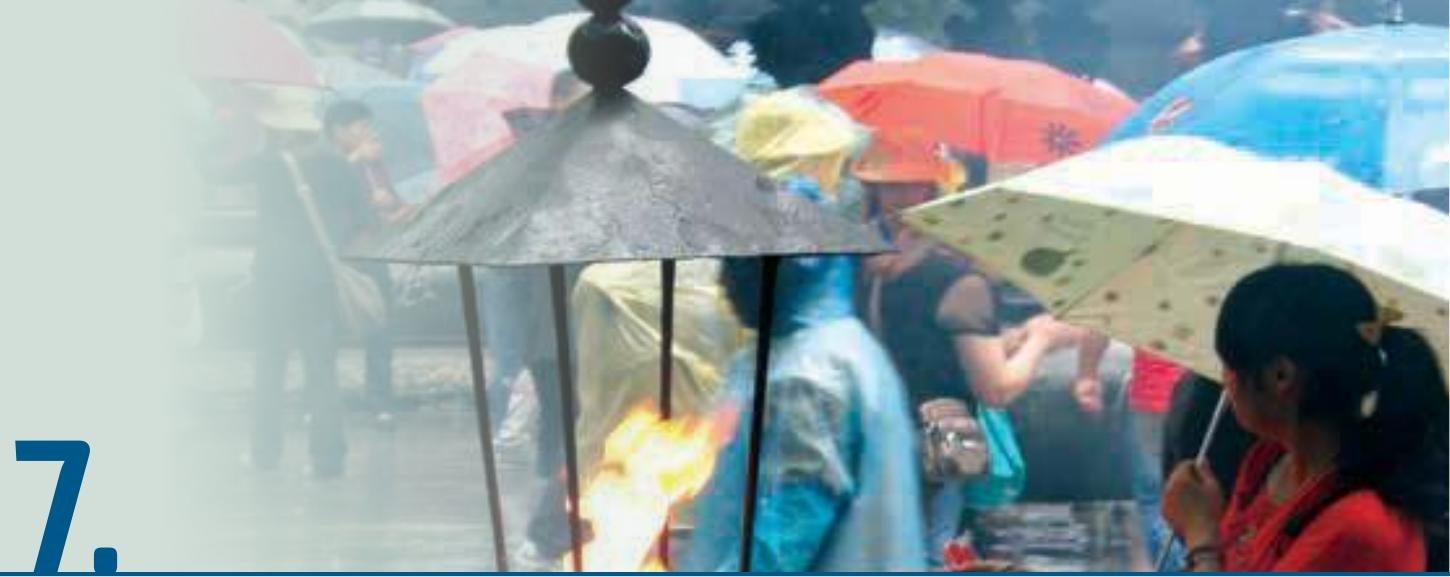

Klimata pārmaiṇu ietekme uz cilvēka veselību 


\subsection{Klimata pārmaiṇu ietekme uz veselību - veidi un intensitāte}

Cilvēks ir jutīgs pret ārkārtas vides un klimata izmaiñām, un tās var izraisīt vispārēju veselības stāvokḷa un labsajūtas pasliktināšanos, piemēram, radot stresu, traumas, slimības, psihiskus un sociālus traucējumus, darbspēju samazināšanos un citas sekas, kā arī nāvi.

Tieša un netieša ietekme. Globālas klimata pārmaingas tiešā un netiešā veidā veicina slimību izplatību un mirstību. Tiešā veidā cilvēku var ietekmēt intensīvas un biežas temperatūras un nokrišnu izmain,as (karstuma un sausuma periodi, viesulvēetras un plūdi, dabas ugunsgrēki), kas var radīt funkcionālus un fiziologiskus organisma darbības traucējumus. Savukārt netiešas ietekmes ir saistītas ar klimata pārmaiṇu izraisītām vides un ekoloǵiskām izmaiṇām un to sekām (7.1. att.). Netieši cilvēka veselību un labklājību var ietekmēt ražas un pārtikas kvalitātes un pieejamības samazināšanās, dzeramā ūdens trūkums, slimību pārnēsātāju invāzija, kā arī klimata pārmaiṇu provocētas sociāli ekonomiskās atbildes reakcijas sabiedrībā iedzīvotāju migrācija ilgstošu sausuma periodu vai plūdu dēl, bezdarbs, mājvietas zaudēšana, sociālā vardarbība. Trīs galvenās faktoru grupas - fizikālie, bioloǵiskie un ekonomiskie faktori - ietekmē cilvēka labklājību, veselību un izdzīvošanas spējas jebkuros apstākḷ,os, bet klimata pārmaiṇu rezultātā ietekmes intensitāte saasinās, turklāt, cilvēka biologiskā un sociālā adaptācija jaunos apstākḷos ir daudz sarežgìtāka nekā stabilā vidē.

Paredzams, ka klimata pārmaiņas ietekmēs daudzu slimību epidemioloǵiju (infekcijas slimību izcelšanos, izplatǐšanās likumsakarības un apkarošanas iespējas), kā arī sabiedrības un indivīda fiziskās un psihiskās veselības un higiēnas nosacījumus. Ietekmes veids un intensitāte var būt atškirīga, n,emot vērā gan klimatiskos, reǵionālos un ǵeogrāfiskos apstākḷus, gan veselības aprūpes sistēmas kvalitāti, adaptācijas pasākumus, iedzīvotāju informētību un

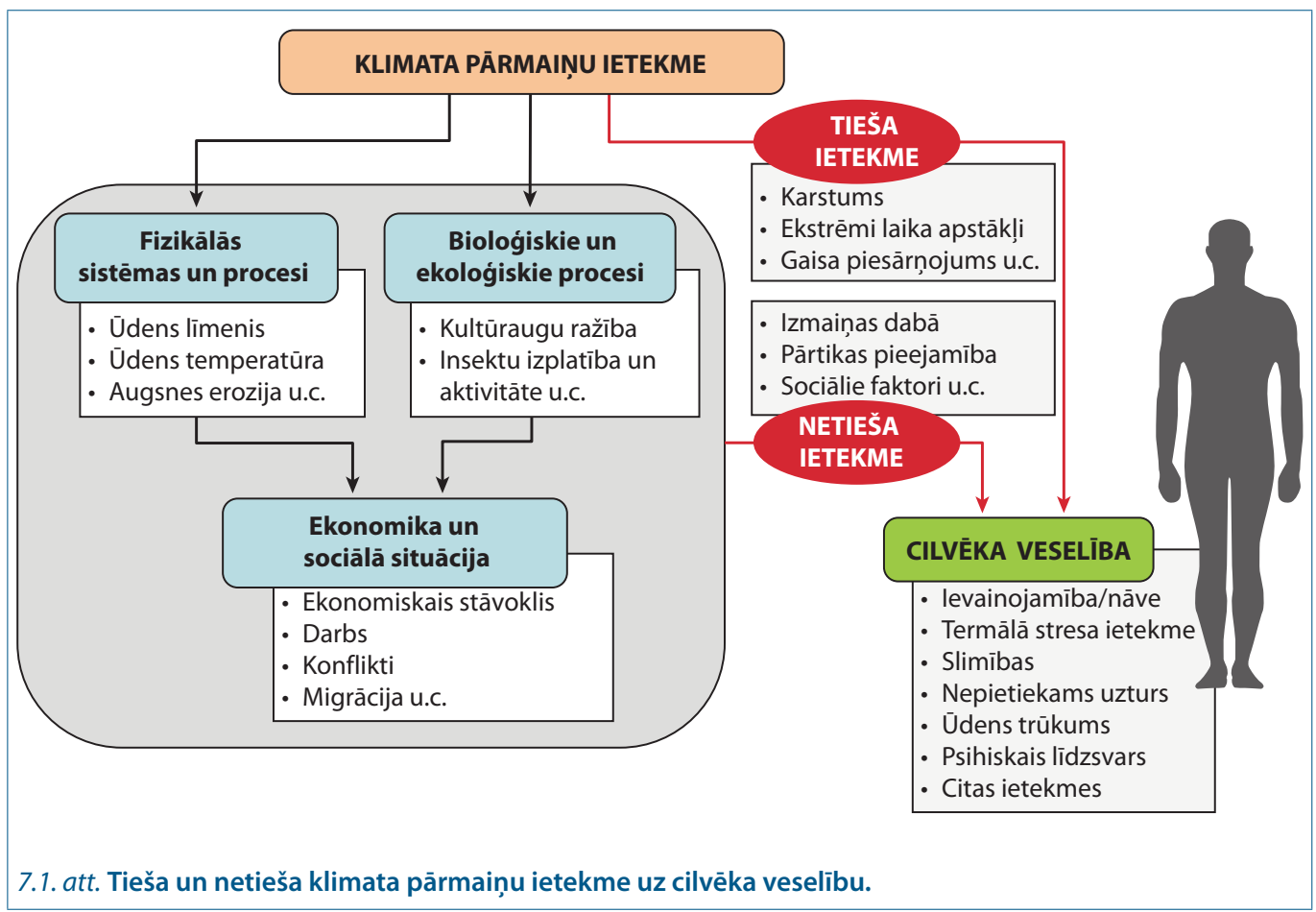


pieklıves nodrošinājumu profilakses un ārstniecības pakalpojumiem, kā arī sagatavotību un rīcības spējas ārkārtas gadījumos. Pieredze rāda, ka parasti valstu veselības aizsardzības sistēmas nespēj darboties ārkārtas klimatisko pārmainuu apstākḷlos. Piemēram, 2003. gada vasara Eiropā tiek vērtēta kā karstākā vasara kopš 1540. gada. Karstums, sausums un ražas samazinājums īpaši smagi skāra Franciju un citas valstis Dienvideiropā. Francijā temperatūra 7 dienas pārsniedza $40^{\circ} \mathrm{C}$. Nacionālās veselības aǵentūras ziṇoja, ka karstuma ietekmes radītu veselības problēmu dēl Francijā bojā gājuši vairāk nekā 14 800, Portugālē ap 2000, Nīderlandē ap 1500 cilvēki, bet kopumā Eiropā - vairāk nekā 70000 cilvēki.

Ja klimata pārmaiṇas turpināsies tā, kā tiek prognozēts, tad cilvēka veselības apdraudējums būs statistiski iespējams ar vidēju līdz ḷoti augstu ticamības pakāpi (7.1. tab.).

Taču ne visas ar klimatu saistītās pārmaiñas ietekmē cilvēku veselību nelabvēlīgi. Mērenā klimata joslā iespējamas siltākas ziemas, kas mazinās ar nosalšanu saistītu nāves gadījumu skaitu, kā arī būs vienkāršāk uzturēt komfortablus iekštelpu mikroklimata apstākḷus, ārpus telpām nodarbinātie mazāk saskarsies ar aukstuma izraisītiem negadījumiem ziemas periodā, kas savukārt uzlabos darba produktivitāti. Ilgāka siltuma sezona un augu vegetācijas periods, ja vien to negatīvi neietekmēs ārkārtas karstuma un sausuma periodi, sekmēs lauksaimniecību un pārtikas ražošanu, arī privāto dārzkopību un ārpustelpu aktivitātes. Tomēr ar augstu ticamības pakāpi var apgalvot, ka pozitīvās ietekmes no klimata pārmaiṇām, piemēram, ar aukstumu saistītas mirstības samazinājums, ir krasi pārvērtētas salīdzinājumā ar negativvo klimata pārmaingu ietekmes pieaugumu, apmēru un seku smagumu.

Lai arī ilgtermiṇa vidējie pasaules klimata rādītāji līdz šim ir bijuši samērā stabili, pēdējo 50 gadu dati liecina, ka izmainnas paātrinās, piemēram, globālā vidējā temperatūra ir paaugstinājusies par $0,7^{\circ} \mathrm{C}$, un līdz 2100 . gadam tiek paredzēts temperatūras pieaugums par $1,5-4,0^{\circ} \mathrm{C}$, kas var nopietni aktivizèt klimata pārmaiṇu ietekmes intensitāti uz cilvēka veselību (7.2. att.).

Primāra, sekundāra un terciāra ietekme. Klimata pārmaiṇu ietekmes uz cilvēku var iedalīt primārās, sekundārās un terciārās. Primāra ietekme ir tāda ietekme, kas rodas, ja regionālas iedzīvotāju grupas vai arī atsevišķu profesiju pārstāvji (7.3. att.) ir tieši paklauti nelabvēlīgiem vides apstākḷiem: karstuma, lietus un plūdu, krusas, sniega vētru, vēja un dabas ugunsgrēku ietekmei. Rezultātā var iestāties dehidratācija (organisma atūden,ošanās), karstuma dūriens, traumu risks, infekcijas un pat nāve. Primāra klimata pārmaiṇu ietekme ir samērā tieša ietekme (jo seko tūlīt pēc notikuma) uz cilvēka fizisko stāvokli un psihisko veselību, darbspēju, sadzīvi, kā arī sabiedrības morāli un citiem ar cilvēka labklājību saistītiem aspektiem.

\section{1. tabula. Prognozētie veselības riski klimata pārmaiņu ietekmē un prognožu ticamība.}

\begin{tabular}{|c|c|}
\hline Prognozētie veselïbas riski klimata pärmainu ietekmē & Prognozes ticamïbas pakāpe \\
\hline $\begin{array}{l}\text { - Traumu, slimību un nāves gadijumu risks intensīvu karstuma periodu un dabas } \\
\text { ugunsgrēku dēl. } \\
\text { - Risks saslimt ar pārtikas un ūdens izraisītām slimībām. }\end{array}$ & $\begin{array}{l}++++ \\
\text { L̦oti augsta }\end{array}$ \\
\hline $\begin{array}{l}\text { - Nepietiekams uzturs un dzeramā ūdens apgāde. } \\
\text { - Veselības problēmu sekas - samazinātas darbspējas un darba ražīguma kritums } \\
\text { neaizsargātās iedzīvotāju grupās. }\end{array}$ & $\begin{array}{l}+++ \\
\text { Augsta }\end{array}$ \\
\hline $\begin{array}{l}\text { - Pārnēsātāju izraisītas slimības (malārija, Denges drudzis u.c.). } \\
\text { - G Geogrāfiskās vietas pārmaiñas pārtikas produktu ražošanā. } \\
\text { - Samazināta slimību pārnēsātāju kapacitāte pārsniegtu temperatūras sliekšnu dēl. }\end{array}$ & $\begin{array}{c}++ \\
\text { Vidēja }\end{array}$ \\
\hline $\begin{array}{l}\text { - Mērens ar aukstumu saistītu saslimšanu un mirstības samazinājums dažos reǵionos, } \\
\text { jo saīsināsies aukstuma periodu iespējamība un ilgums. }\end{array}$ & $\begin{array}{c}+ \\
\text { Zema }\end{array}$ \\
\hline
\end{tabular}



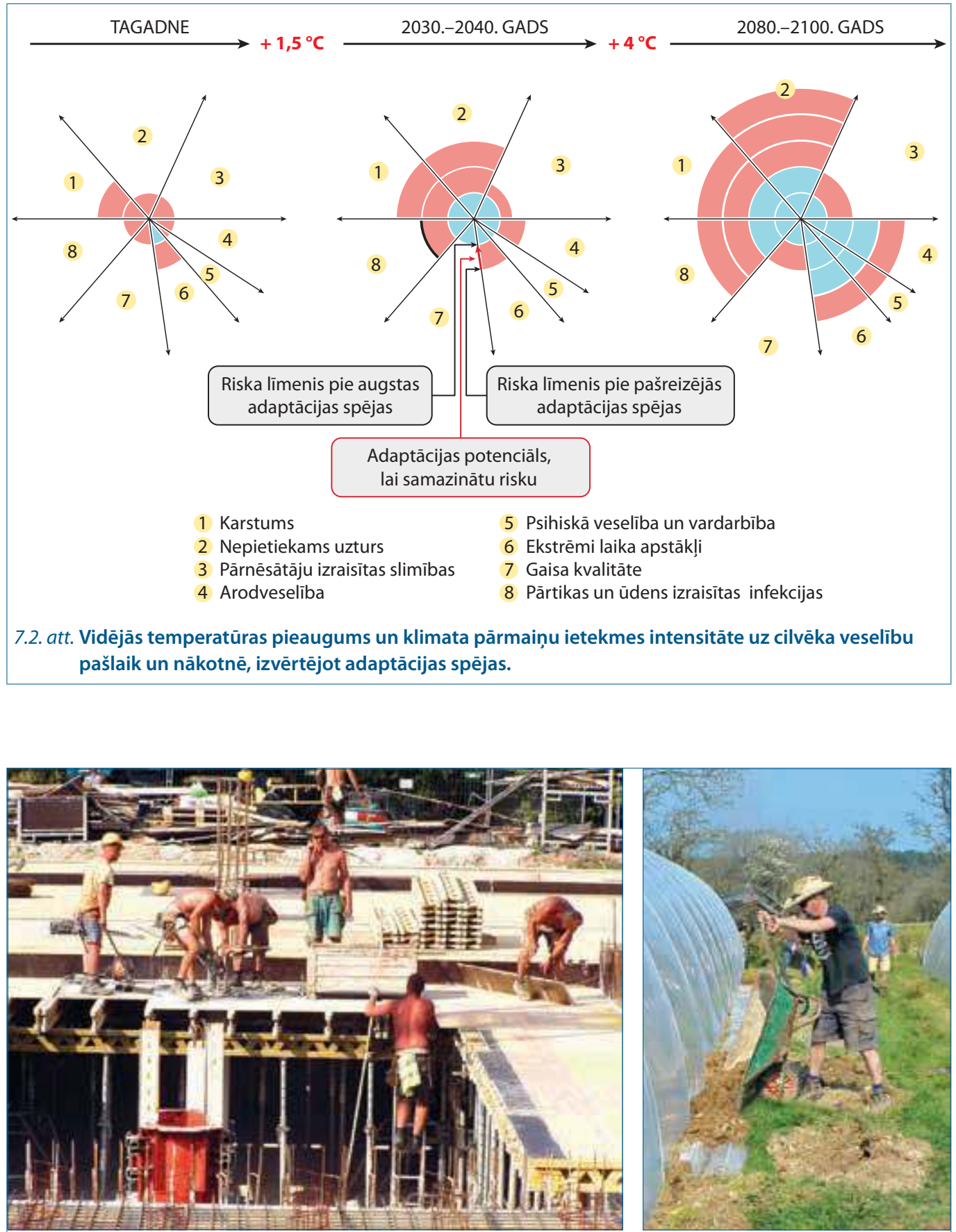

7.3. att. Atsevišḳu profesiju pārstāvji, kuri strādā ārpus telpām, piemēram, būvstrādnieki, lauksaimnieki, var tikt paḳ̣auti lielākam klimata pārmaiṇu ietekmes riskam uz veselïbu. 
Sekundārā klimata pārmaiṇu ietekme izpaužas kā mediators starp vidi un cilvēku. Sekundārā ietekme ietver infekcijas slimību izplatības diapazona, intensitātes un sezonalitātes izmain,as, kā arī lauksaimniecības ražìbas samazināšanos. Tā ietekmē arī cilvēka uztura un dzeramā ūdens nodrošinājumu, higiēnas apstākḷus. Ekoloǵisko mediatoru ierosināta ietekme uz veselību ietver arī aeroalergēnu (putekšn,u, sporu, putekḷu) izplatības pastiprināšanos, paaugstinot astmas, siena drudža un citu alerǵisku reakciju risku. Globālas klimata izmaiñas, piemēram, kalnu ledāju sarukums un reǵionālu nokrišnu samazinājums, var samazināt saldūdens plūsmas, tādējādi apdraudot iedzīvotāju higiēnu, dzeramā ūdens kvalitāti un pieejamību, vietēji iegūstamās pārtikas apjomu. Plūdi, kas pēc prognozēm jo vairāk iespējami tieši klimata pārmaiṇu dēl, arī var apdraudēt ūdens kvalitāti, bojājot kanalizācijas sistēmu infrastruktūru. Pie klimata pārmaiṇu sekundārās ietekmes var pieskaitīt arī jūras līmeña celšanās izraisītu piekrastes gruntsūdeņu un līdz ar to dzeramā ūdens sāḷuma pieaugumu. Epidemiologiskie pētijumi Bangladešā, kur raksturīgas zemas piekrastes, ir atklājuši, ka ievērojami palielinās piekrastes iedzīvotāju uzṇemtā ikdienas sāls deva. Tas ir lıti iespējams iemesls pieaugošajai hipertensijas (paaugstināta asinsspiediena) izplatībai piekrastes lauku kopienās, kur dzeramajā ūdenī konstatēta paaugstināta sāls koncentrācija. Dzeramā ūdens paaugstinātais sāḷums tiek saistīts arī ar augstāku veselības apdraudējuma risku grūtniecības vēlīnā stadijā.

Klimata pārmainu terciārā ietekme uz cilvēka veselību rodas no netiešas, daudz sarežğītākas un ilgstošas cēloṇu kēēdes. Sekas parādās lēnāk, ietekmē fundamentālos sociālo attiecību balstus un institūcijas, kā arī cilvēku veselību, labklājību un izdzīvošanas spējas. Terciāro ietekmi ir sarežgíti pētìt un izvērtēt, jo tā parasti izpaužas kā vairāku faktoru iedarbības seku kopums; piemēram,

- psihologiskā spriedze, emocionāls nemiers un uzvedības traucējumi bērniem un pieaugušajiem, satraukums par nākotni;

- ietekme uz sabiedrības veselību (gan negatīva, gan pozitīva) un iedzìvotāju grupu piespiedu migrācija, kas var rasties populācijas pieauguma un ārkārtas vides apstākḷu vai vides katastrofu rezultātā;

- sociālo saspīlējumu un konfliktu draudi, kas saistīti ar dabas resursu pieejamības samazināšanos attiecībā uz aramzemes platībām, saldūdens krājumiem, apmetn,u un dzìvesvietas pieejamību u.c.

\subsection{Pret klimata pārmaiṇām jutīgās iedzìvotāju grupas}

Klimata pārmaiṇas globālā mērogā ietekmē visas sabiedrības veselību un labklājību, taču dažas iedzīvotāju grupas ir vairāk pakḷautas ietekmes riskam. Tādi faktori kā vecums, dzimums, veselības stāvoklis, etniskā piederība, sociālais stāvoklis un ekonomiskais nodrošinājums rada atškirīgas iedzīvotāju riska grupas (7.4. att.).

Pie īpaši mazaizsargātām iedzīvotāju grupām var pieskaitīt:

- bērnus, vecāka gadagājuma cilvēkus, grūtnieces un cilvēkus ar hroniskām slimībām (īpaši ar sirds un asinsvadu sistēmas un elpošanas orgānu slimībām), kuri nespēj par sevi parūpēties ārkārtas situācijās un kuru slimības saistībā ar klimata pārmaiṇu ietekmi var paasināties;

- lauku teritoriju vai no centriem attālu reǵionu iedzìvotāju kopienas, kuras pakḷautas ilgstošiem sausuma vai arī lietus un plūdu periodiem un kuras nespēj nodrošināties ar pārtikas un ūdens krājumiem, kā arī ir apdraudētas sakarā ar reǵionālu, tradicionālu pārtikas augu un dzīvnieku sugu iznīkšanu;

- piekrastes vai salu kopienas, kas saskaras ar vētrām, plūdiem un pastiprinātu ciklonu ietekmi; 


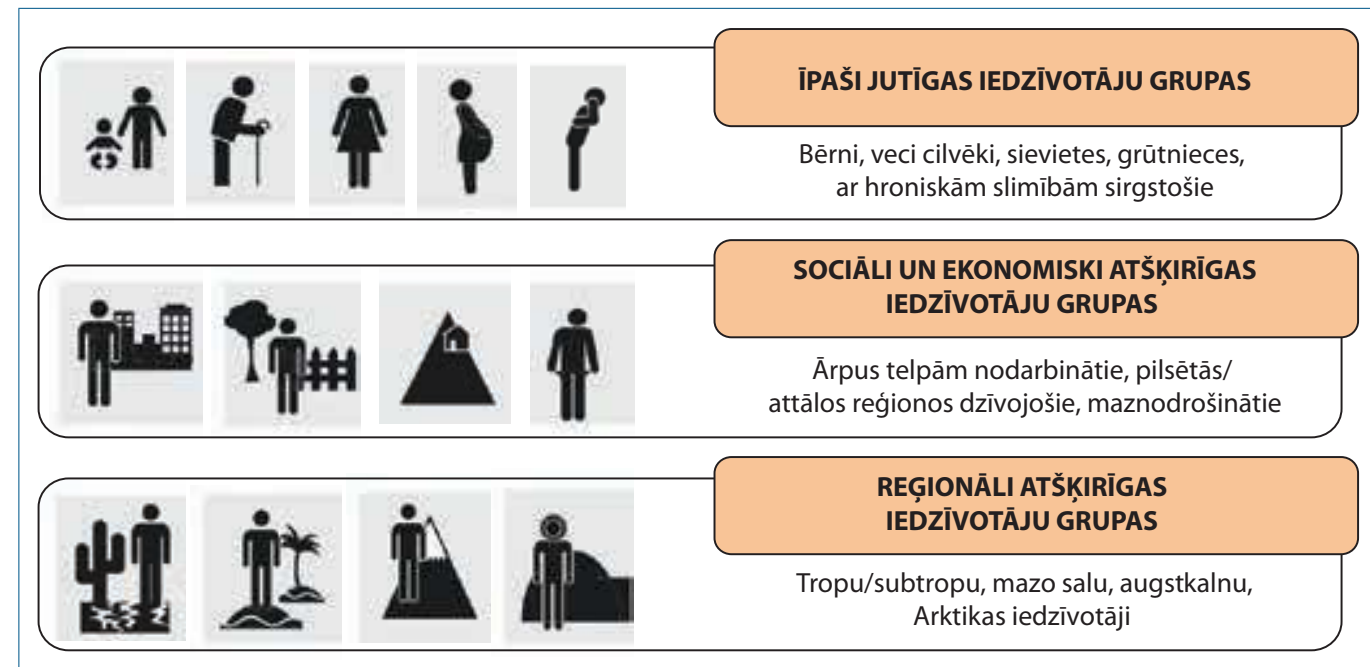

7.4. att. Pret klimata pārmaiṇām īpaši jutīgās iedzīvotāju riska grupas.

- iedzīvotāji, kas mīt reǵionos ar noteiktiem apstākḷiem, piemēram, ar paaugstinātu mitruma līmeni. Tur klimata jutīgas infekcijas slimības var izplatīties straujāk - iespējama, piemēram, reǵionam netipisku slimību - malārijas, Denges drudža un citu slimību izplatība ārpus to endēmiskā areāla.

Zinātnieki norāda, ka dažādos veidos mūsdienās sabiedrības indivīds ir biologiski jutīgāks pret veselības apdraudējumiem, kas saistīti ar klimata pārmaiñām, nekā pagātnē. Piemēram, iedzīvotāju veselības ievainojamības risku paaugstina:

- sabiedrības novecošanās - garāks mūža ilgums, kas rada augstāku organisma uzñēmību pret karstumu un citiem ārkārtas vides notikumiem, infekcijas slimībām;

- ievērojamais neinfekcijas slimību, piemēram, sirds un asinsvadu, elpošanas sistēmas slimību, vielmaiñas traucēju$\mathrm{mu}$, izplatības pieaugums, kas paaugstina organisma uznēmību pret karstumu un citām slodzēm, palielinot insulta, sirdslēkmju, elpošanas mazspējas risku;

- augsta temperatūra gan ārpus telpām, gan telpās (dzīvesvietā vai darbavietā), kas palielina karstuma uzñēmības, dehidratācijas un nieru bojājumu risku;
- pilsētas "siltuma salas" efekts: paaugstināta karstuma iedarbība un samazinātas organisma aizsargspējas;

- augstāka uzñēmība pret alerǵijām, ko nereti izraisa pārspīlēta bērnu higiēna (tiek kroplotota imūnsistēmas nobriešana) - paaugstināts siena drudža un astmas risks sakarā ar aeroalergēnu koncentrācijas palielināšanos;

- paaugstināts infekcijas slimību risks sakarā ar biežāku un plašāku patogēno mikroorganismu izplatību un ietekmi uz vispārējo populācijas imūnsistēmas novājinātību;

- iedzīvotāju nodarbinātība rūpniecībā, lauksaimniecībā vai citās nozarēs, kur darba laikā netiek nodrošināta atbilstoša ventilācija un gaisa kondicionēšana, kā arī nav iespējama regulāra piekḷuve dzeramajam ūdenim.

Vecums. Bērni un gados vecāki cilvēki ir visvieglāk ievainojamās iedzīvotāju grupas vētru, plūdu, karstuma viḷnu un citu ārkārtas vides notikumu ietekmē, jo bieži vien nespēj patstāvīgi par sevi parūpēties, izvairīties no bīstamām situācijām un traumām (7.5. att.). Gados vecāki cilvēki biežāk cieš no veselības traucējumiem, kas ierobežo organisma spēju reaǵēt uz negatīvo vides faktoru, piemēram, karstuma un gaisa 
piesārn,ojuma ietekmi, kā arī hroniskas slimības var saasināt organisma atbildes reakciju. Savukārt bērni ir vairāk paklıauti karstuma izraisīto slimību riskam, n,emot vērā nelielo k, kermeña masas un virsmas laukuma attiecību. Bērnu veselība lielā mērā ir atkarīga no pārtikas un dzeramā ūdens kvalitātes un pieejamības. Kvalitatīvu uzturvielu un dzeramā ūdens trūkums var izraisìt vairākas veselības problēmas, piemēram, organisma novājināšanos un samazinātu kermeña masu, paaugstinātu uzṇēmību pret slimībām, fiziskās un psihiskās attīstības traucējumus. Tādas slimības kā malārija un akūtas zarnu infekcijas ir cieši saistìtas ar pārtikas un ūdens kvalitāti un apdraud bērnus paaugstinātās organisma fiziologiskās uzṇēmības dēl̦.

Pašlaik prognozētās globālās klimata pārmaiñas notiek kopsolī ar augsto pasaules iedzīvotāju skaita pieauguma tempu, nevienmērīgo iedzivotāju blīvuma sadalījumu pasaulē un pieaugošo demogrāfisko novecošanos. Paredzamais iedzīvotāju skaita pieaugums visnopietnāk skar pilsētu aglomerācijas, it īpaši valstīs tropu un subtropu klimata joslās, kur liela daḷa nodarbināto strādā ārpus telpām un nav nodrošināta ar pietiekamu aizsardzību pret karstuma ietekmi. Tādējādi paredzams, ka nākotnē to iedzīvotāju skaits, kas būs pakḷauti augstākam vides apstāklı apdraudējuma riskam, pieaugs. 2002. gadā (pirmais gads, par kuru ir pieejami visu ES-28 dalībvalstu dati) tika paredzēts, ka 2013. gadā vidējais dzīves ilgums būs 80,6 gadi, sasniedzot 83,3 gadus sievietēm un 77,8 gadus

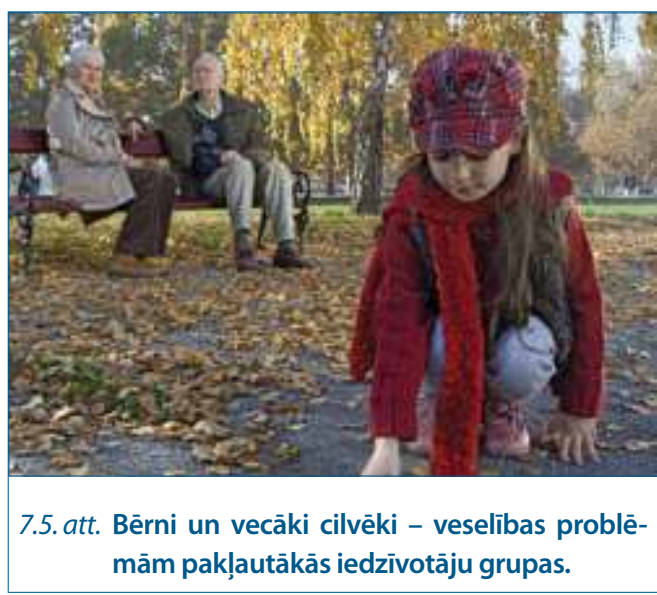

vīriešiem. Tātad paredzēts, ka desmit gadu laikā dzīves ilgums ES-28 palielināsies vidēji par 2,9 gadiem, no 77,7 līdz 80,6 gadiem; pieaugums sievietēm 2,4 gadi un 3,3 gadi vīriešiem.

Pēc EUROSTAT datiem Latvijā 2013. gadā dzīves ilgums sievietēm bija 78,9 gadi, bet vīriešiem 69,3 gadi.

Daudzos pasaules reǵionos, tostarp Eiropā, liela daḷa sabiedrības būs gados vecāki cilvēki, kas ir vairāk apdraudēti un mazāk spējīgi pielāgoties klimata pārmaiṇām.

Dzimums. Izvērtējot dzimumu atškirības, sievietes ir pakḷautas augstākam klimata pārmaiṇu ietekmes riskam, īpaši grūtniecības periodā, kad samazinās sievietes organisma aizsargspējas pret plašu vides apdraudējumu klāstu, tostarp piesārṇojumu, pārmērīgu karstumu un infekcijas slimībām.

Esošās veselības problēmas. Līdz 21. gadsimta vidum klimata pārmaiṇu sekas izpaudīsies, galvenokārt saasinot jau pastāvošās iedzīvotāju veselības problēmas, veicinot arī hronisku slimību attīstību (7.6. att.). Hroniskas slimības, piemēram, diabēts, sirds un asinsvadu slimības, aptaukošanās un liekais svars palielinās klimata pārmainu izraisītu smagu slimību skaitu vai mirstības risku. Sirds un asinsvadu slimības pašlaik ir nozīmīgākais iedzīvotāju mirstības cēlonis pasaulē, jo tas izraisa 31\% no visiem nāves gadījumiem (pēc 2012. gada datiem). Savukārt no liekā svara un aptaukošanās cietušo iedzìvotāju īpatsvars pasaulē kopš 1980. gada ir dubultojies un 2014. gadā skāris 39\% pasaules iedzīvotāju. Iedzīvotāji, kas cieš no šìm slimībām, ir īpaši jutīgi pret ārkārtas karstuma periodiem.

Klimata pārmaiṇu ietekmē var rasties jauni apstākḷi, un ar augstu ticamību var apgalvot, ka esošās slimības (piemēram, pārtikas un ūdens izraisītas infekcijas, pārnēsātāju izraisītas saslimšanas) var paplašināt savu diapazonu uz apgabaliem, kuri līdz šim nav bijuši skarti. Lielākam riskam tiks pakḷauti to reǵionu iedzīvotāji, kurus jau šobrīd visvairāk ietekmē ar klimatu saistītas veselības problēmas. Paredzams, ka veselības zaudējumi sakarā ar klimata pārmain,u izraisītu uztura nepietiekamību īpaši negatīvi ietekmēs regionus, kur ir pārapdzīvotība, militārie konflikti, zems ekonomiskais 


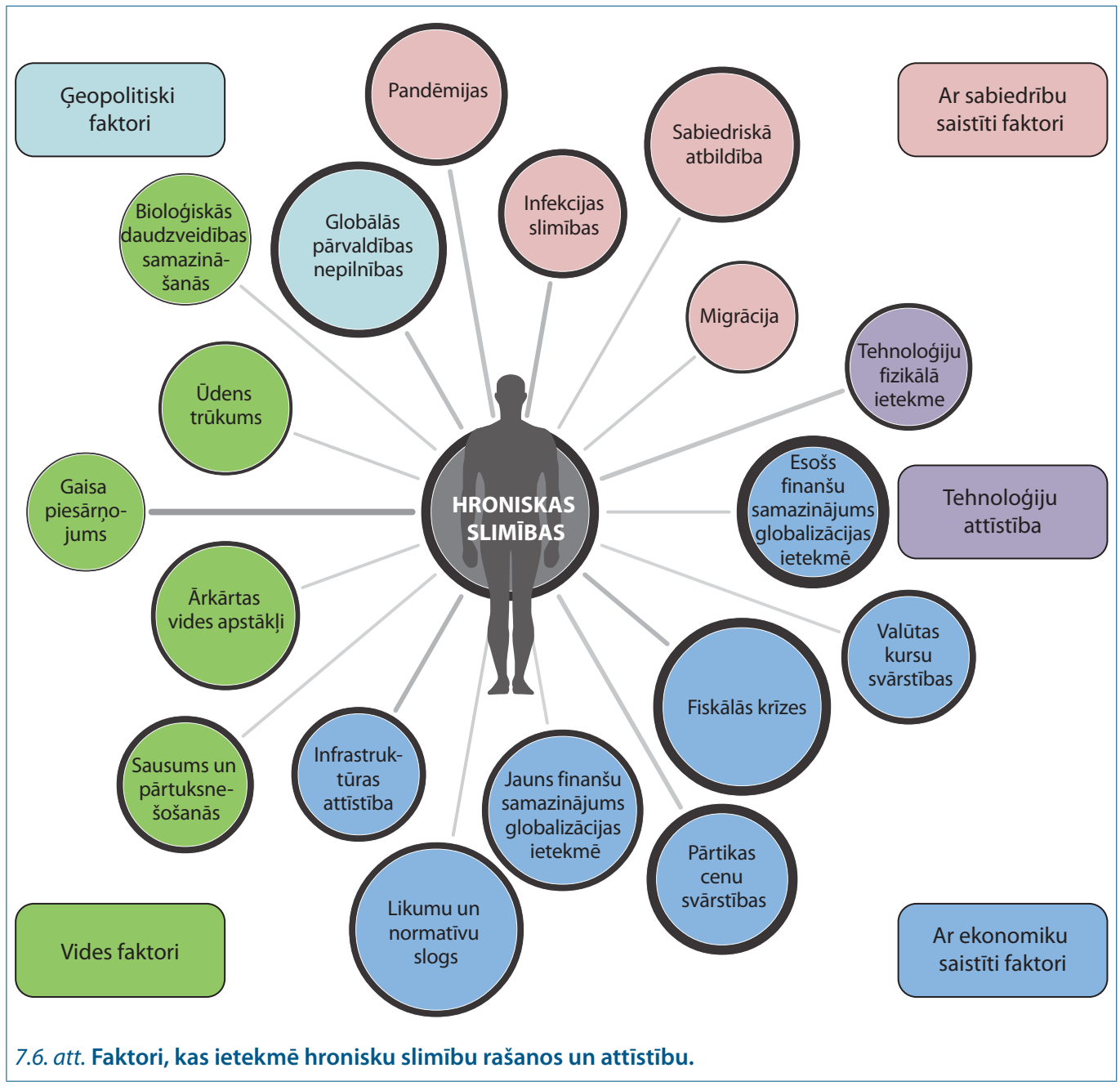

nodrošinājums un jau pašlaik ir pārtikas un dzeramā ūdens trūkums.

Sociāli ekonomiskie faktori. Cilvēka veselība un labklājība ir cieši saistīta ne tikai ar vides ietekmi, bet arī ar tādiem sociāli ekonomiskiem faktoriem kā nodarbinātība, ienākumu līmenis, ikdienas sadzīves un mājokḷa nodrošinājums, dzīvesveids, izglīiība, dzimumu līdztiesība, etniskā piederība, religiskie uzskati. Klimata pārmaiṇas var palielināt nevienlīdzību starp atškirīgām sabiedrības sociāli ekonomiskām grupām, piemēram, nenodrošinot vienlīdzīgu veselības aprūpi cilvēkiem ar zemākiem ienākumiem un mazaizsargātām iedzīvotāju grupām. Jau pašlaik karstuma izraisīta iedzīvotāju mirstība tiek cieši saistīta ar sociāli ekonomisko ietekmi. Ar augstu ticamību var apgalvot, ka klimata pārmaiṇu ietekme uz veselību būs mazāk izteikta, bet netiks pilnībā novērsta sabiedrības grupās, kas gūs labumu no straujas sociālās un ekonomiskās attīstības, bet būs īpaši izteikta nabadzīgākajās un slimību skartajās iedzīvotāju grupās (7.7. att.). Klimata pārmain,as ir šksērslis noturīgiem veselības uzlabojumiem daudzos pasaules regionos. Ja valstu ekonomiskā izaugsme neuzlabos iedzīvotāju ekonomisko stāvokli, tad klimata pārmainu ietekme vēl vairāk pasliktinās cilvēku veselību.

Lai gan jaunattīstības valstis un nabadzīgākie reǵioni ir uzṇēmīgāki pret kaitējumu, ko 

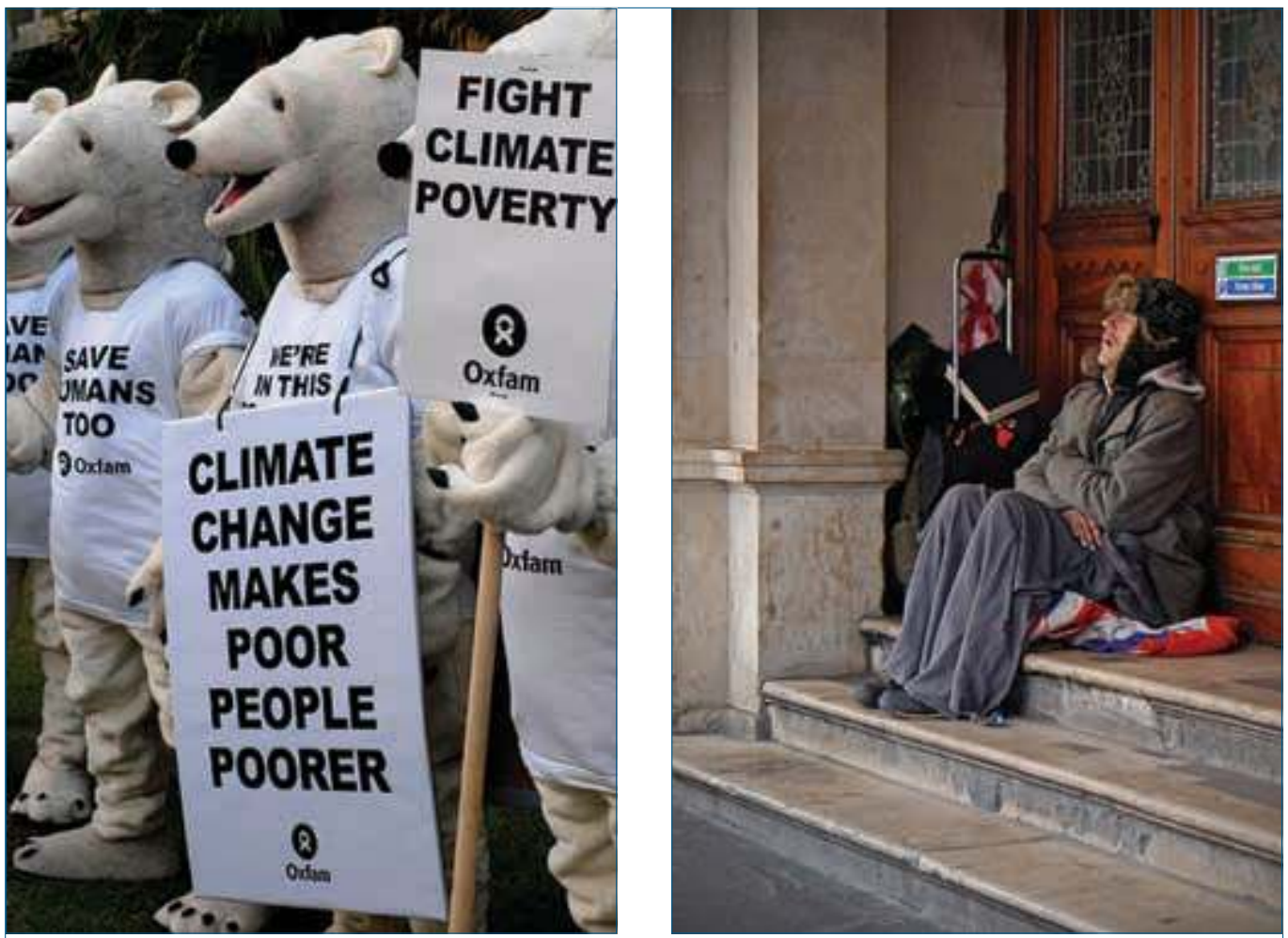

7.7. att. Klimata pārmaiṇas var veicināt nevienlīdzību starp atšḳirīgām sabiedrības sociāli ekonomiskām grupām.

izraisa ārkārtēji vides apstākḷi. Arī attīstītās valstis nav pilnībā pasargātas no zaudējumiem. Piemēram, ārkārtas karstuma periodi izraisa pastiprinātu sausumu un dabas ugunsgrēku risku. Par "melno sestdienu" nodēvētajos dabas ugunsgrēkos Austrālijā 2009. gadā tika ievainoti vismaz 400 cilvēki, bet gāja bojā vairāk nekā 170 cilvēki; nodega vairāk nekā 3500 ēkas, un kopumā uguns izpostīja teritorijas apmēram 450000 hektāru lielā platībā. Amerikas Savienotajās Valstīs pēc karstuma perioda Čikāgā 1995. gadā un viesulvēetras "Katrīna" N,ūorleānā 2005. gadā atškirības starp cietušo ievainojumu smagumu, citiem veselības traucējumiem un nāvi ievērojami variēja starp dažādām etniskām un sociāli ekonomiskām grupām. ANO Tūkstošgades attīstības mērksi paredz centienus samazināt atšksirības starp nodrošinātām un tām sabiedrības grupām, ko ietekmē nabadzība, nepietiekams uzturs, bads, māšu mirstība, tādas slimības kā pārtikas un ūdens izraisītas infekcijas (piemēram, akūtas zarnu infekcijas), malārija, HIV/AIDS, tuberkuloze. Tomēr negatīvā klimata pārmaiṇu ietekme un citas izaugsmes ierobežojuma izpausmes attiecībā uz vidi, nabadzības līmeni un veselības riskiem var traucēt sasniegt nospraustos mērksus un kopumā palielināt nevienlīdzību iedzīvotāju vidū attiecībā uz veselību. Tāpēc kopienas un sabiedrības grupas daudzās valstīs ar zemiem ienākumiem, jo sevišksi pārapdzīvotos reǵionos, ir īpaši apdraudēto iedzīvotāju riska grupas. Turklāt, iedzīvotāji, kuriem nav piekḷuves kvalitatīvai veselības aprūpei un būtiskiem sabiedrības veselības pakalpojumiem, visticamāk, tiks vairāk ietekmēti no klimata pārmaiṇām.

Reǵionālās atškirības. Pašlaik tiek vērtēts, ka klimata pārmaiṇu ietekme uz cilvēka veselību ir neliela, tomēr paredzams, ka ar laiku tā palielināsies visos pasaules regionos. 
G̦eogrāfiskajai atrašanās vietai ir nozīmīga loma klimata pārmaiṇu ietekmju intensitātē un apjomā. Tādējādi daži reǵioni un to iedzivotāji ir vairāk pakḷauti klimata pārmaiņu ietekmei uz veselību nekā citi, piemēram:

- reǵioni un tiem blakus esošie robežregioni, kuros ir augsta endēmisku pret klimata izmaiñām jutīgu slimību (piemēram, malārijas) izplatība;

- reǵioni, kuros novērota saikne starp epidēmiskām slimībām un ārkārtas vides apstāklıliem (piemēram, El Ninjo vai La Ninja piesaistītas epidēmijas - holēras uzliesmojums);

- reǵioni, ko apdraud kombinēti klimata iedarbības faktori, kas saistīti ar veselību (piemēram, stress par pārtikas un ūdens sagādi);

- riska reǵioni ar savstarpēji konkurējošu vides vai sociāli ekonomiska stresa apdraudējumu un ar nelielu spēju pielāgoties.

\section{3. Ārkārtas vides apstākḷu ietekme uz veselību}

Ārkārtas vides apstākḷi - karstuma un sausuma periodi, vētras, plūdi un zemes nogruvumi, dabas ugunsgrēki, gaisa piesārṇojums var pastiprināties klimata pārmainu ietekmē, būtiski ietekmēt cilvēka veselību un veicināt pāragru mirstību (7.8. att.).

Ir pietiekami daudz pierādījumu par vides apstākḷ un klimata ietekmi uz cilvēka veselību, un paredzams, ka klimata pārmaiṇu ietekmē negatīvās sekas var saasināties, pastiprinot cita citu. Tā kā klimata pārmainnas ir ilgstošs process, kas parasti vērtēts desmitgadēs, tad tikai ilgtermiña pētijumi var atklāt klimata pārmaiņu ietekmi uz veselību. Kā piemēru var minēt attiecības izmainu starp nāves gadījumu skaitu vasarā un ziemā. No 1968. gada līdz 2010. gadam Austrālijā ši attiecība ir palielinājusies vienlaikus ar gada vidējās temperatūras paaugstināšanos. Savukārt Amerikas Savienotajās Valstīs pārmērīga karstuma periodi izraisa vairāk nāves gadījumu katru gadu nekā visi citi ārkārtas vides apstākli kopā. Tāda temperatūras paaugstināšanās, kas kādreiz tika novērota vienu reizi 20 gados, tagad atkārtojas ik pēc 2 lìdz 4 gadiem.

Pētijumos svarīgi ir iegūt ne tikai ilgtermiña datu sērijas par klimata un cilvēka veselības izmaiņu attiecībām un saiknēm, bet arī papildu informāciju par jebkādiem iespējamiem konstatētiem vai potenciāliem cēloṇiem, lai ar statistiskās analīzes metodēm būtu iespējams meklēt korelāciju starp veselības izmainām un dažādiem faktoriem. Tomēr saikne starp vides apstākḷu ietekmi un veselību bieži vien nav pietiekami tieša, lai l̦autu iegūt fundamentālus secinājumus par cēloṇu un seku sakarībām.

Karstums. Galvenais ar klimata pārmain̄ām saistītais iemesls bažām par iedzīvotāju veselību Eiropā ir karstuma radītu veselības traucējumu un mirstības palielināšanās. Paredzams,

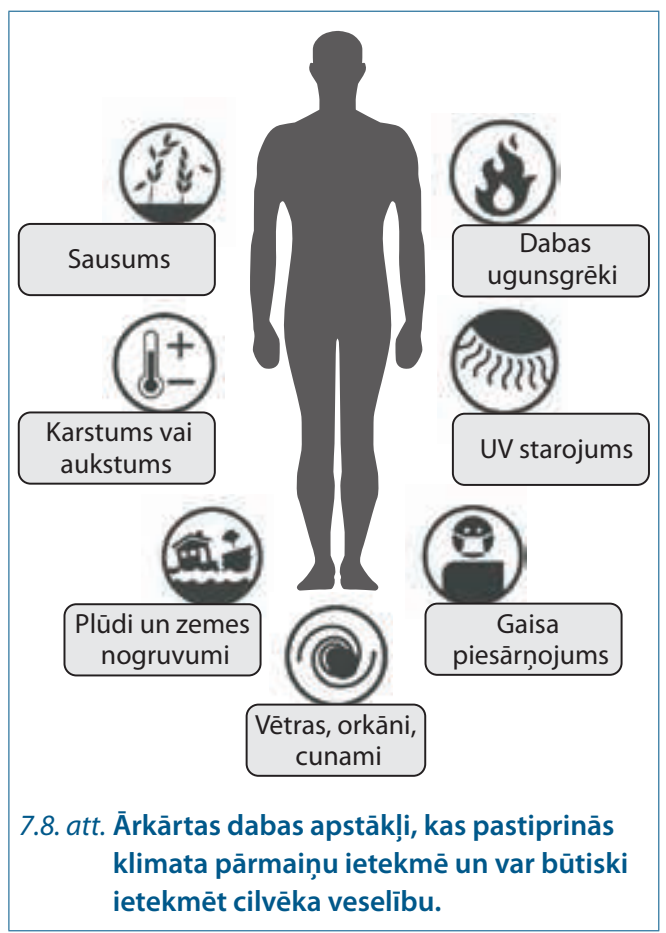


ka, paaugstinoties gada vidējai temperatūrai par 1 grādu un biežāku ārkārtas karstuma periodu dēl, mirstība palielināsies par 1-4\%, t.i., līdz 2080. gadam būtu 50 000-110 000 nāves gadījumi gadā. Karstuma izraisīto slimību saasinājumu izraisītu nāves gadījumu risks īpaši skar bērnus un vecus cilvēkus, kuru organisms nespēj strauji pielāgoties un regulēt ķermeņa temperatūru. Lai gan nāves gadījumu skaits ir cieši saistīts ar iedzīvotāju skaitu, mirstības rādītāju būtiskākās izmaiṇas varētu būt vērojamas reǵionos, kuros ir lielāka klimata pasiltināšanās tendence. Līdz ar to Eiropā karstuma periodu ietekme uz iedzīvotāju veselību būs reǵionāli nevienmērīga - vairāk tiks skartas Dienvideiropas un Viduseiropas valstis.

Daudzi pētījumi ir balstīti uz slimnīcu pacientu uzṇemšanas vai pirmās palīdzības sniegšanas datiem un liecina par sirds un asinsvadu, elpošanas sistēmas, nieru slimību un vielmaiñas traucējumu saasināšanos atkarībā no karstuma ietekmes ilguma un intensitātes. Veselības riski ārkārtas karstuma periodu laikā ir augstāki cilvēkiem ar hroniskām slimībām un tiem, kuri ir fiziski aktīvi (piemēram, veic fizisku darbu vai nodarbojas ar sportu). Lìdz ar to karstuma ietekmei ir būtiska nozīme uz arodveselību un darba produktivitāti.

Cilvēka termoregulācijas procesi ir sen izpētīti. Ja kurmeña temperatūra pārsniedz $38^{\circ} \mathrm{C}$, var iestāties karstuma stress - cilvēks kḷūst apātisks, noguris, letarǵisks, parādās tādi simptomi kā reibonis, galvassāpes, viegla aizkaitināmība, apjukums, slikta dūša, vemšana, caureja, arī tā dēvētie karstuma izsitumi, fiziskās un kognitīvās funkcijas pavājinās. Kermeña temperatūrai paaugstinoties virs $40,6^{\circ} \mathrm{C}$ iestājas karstuma dūriens - tas var izraisīt iekšējo orgānu bojājumu risku, saman,as zudumu, un nāves iestāšanās risks strauji pieaug, it īpaši iedzīvotāju riska grupās. Augsta vides temperatūra veicina pastiprinātu asins pieplūdi k̦ermeña virsmai, kas var izraisīt asinsrites kolapsu jeb piepešu sirds un asinsvadu vājumu.

Ārkārtas karstuma periodi rada arī iekštelpu mikroklimata apstākḷu pasliktināšanos, ja netiek nodrošināta ventilācija, optimāls mitruma līmenis un gaisa kondicionēšana. Tādējādi tiek pētīta arī klimata pārmaiṇu ietekme uz iekštelpu apstākḷiem (7.2. tab.).

Gan ar temperatūras paaugstināšanos, gan pazemināšanos saistīti ārkārtas vides apstākḷi rada augstu saslimšanas un mirstības risku salīdzinājumā ar uzturēšanos stabilā vai cilvēka organismam komfortablā temperatūras diapazonā. Saikni starp temperatūru un saslimšanu un mirstību raksturo J-formas līkne ar straujāku kāpumu augstākā temperatūrā. Tomēr joprojām pastāv neskaidrības par iedzīvotāju fiziologiisko, sociālo un tehnoloǵisko pielāgošanās spēju ilglaicīgos karstuma periodos.

Dabas ugunsgrēki. Sausuma un karstuma ietekmē pieaug dabas ugunsgrēku risks. Laika posmā starp 1970.-1986. gadu un 1987.2003. gadu dabas ugunsgrēku biežums ASV rietumos ir palielinājies 4 reizes. Lai gan liela dal̦a dabas ugunsgrēku izcel̦as cilvēka neuzmanīgas vai l̦aunprātīgas rīcības dēḷ, to izcelšanās

\section{2. tabula. Ārkārtas vides apstākḷu ietekme uz iekštelpu mikroklimatu un cilvēka veselību.}

\begin{tabular}{|c|c|c|}
\hline $\begin{array}{c}\text { Vides apstākḷu izmaiṇas klimata } \\
\text { pārmaiņu ietekmē }\end{array}$ & lekštelpu mikroklimata izmainas & $\begin{array}{l}\text { letekme uz cilvēka veselību un } \\
\text { labsajūtu }\end{array}$ \\
\hline Ārkārtas karstuma periodi & Paaugstināta temperatūra & $\begin{array}{l}\text { Diskomforts, karstuma stress, slimību } \\
\text { saasinājumi, hospitalizācija, nāve }\end{array}$ \\
\hline $\begin{array}{l}\text { Intensīvi un ilgi nokrišn,i, viesuḷvētras, } \\
\text { plūdi }\end{array}$ & Mitrums un pelējums & Elpošanas sistēmas slimības \\
\hline Dabas ugunsgrēki, gaisa piesārṇojums & Augsta putekḷu koncentrācija & $\begin{array}{l}\text { Elpošanas sistēmas, sirds un asinsvadu } \\
\text { slimības, hospitalizācija, nāve }\end{array}$ \\
\hline $\begin{array}{l}\text { Ozona slān,a noārdīšanās, UV } \\
\text { starojuma palielināšanās }\end{array}$ & Augsts ozona līmenis & $\begin{array}{l}\text { Elpošanas sistēmas slimības, } \\
\text { hospitalizācija, nāve }\end{array}$ \\
\hline Putekšn,i & Paaugstināta alergēnu koncentrācija & Alerǵijas, astma \\
\hline
\end{tabular}


iespēju un izplatības ātrumu veicina meteoroloǵiskie apstākl̦i - karstums, sausums un vējš. Latvijā izplatītākie dabas ugunsgrēki ir mežu un purvu ugunsgrēki, kā arī tie, kas rodas pērnās zāles dedzināšanas dēḷ, galvenokārt, sausās pavasara un vasaras sezonās (7.9. att.). Nereti paaugstināta ugunsbīstamība veidojas Latvijas austrumu novados, kad deg Krievijas pierobežas meži. Ugunsgrēki var ietekmēt gan tiešā to norises vietā esošos iedzivvotājus, gan tālākā apkārtnē dzīvojošos. Dabas ugunsgrēku radītie dūmi, karstums un liesmas var būtiski apdraudēt cilvēka veselību, labklājību un dzīvību - paaugstinās risks gūt apdegumus, ievainojumus, saindēties ar dūmiem, kā arī zaudēt mājvietu. Dūmu ietekme uz veselību var izpausties kā acu kairinājums (dedzināšana acīs, asarošana), kakla un rīkles kairinājums, klepus, elpas trūkums, sāpes krūtīs, galvassāpes, iesnas. Noteiktām iedzīvotāju grupām - cilvēkiem, kas cieš no hroniskām sirds un asinsvadu vai elpošanas sistēmas slimībām, bērniem, grūtniecēm, gados vecākiem cilvēkiem, smēkēēājiem - dūmu kaitīgā iedarbība uz organismu ir intensīvāka, izraisot nopietnus akūtus un hroniskus veselības traucējumus.

Ultravioletais starojums. Klimata pārmaiṇu ietekmē, pieaugot maksimālajai dienas temperatūrai vasaras sezonā, palielinās arī ultravioletā (UV) starojuma ietekme, kas var izraisīt ādas vēzi un acu slimības (piemēram, kataraktu, mākulas deǵenerāciju) (7.10. att.). Pētījumi liecina, ka, paaugstinoties dienas

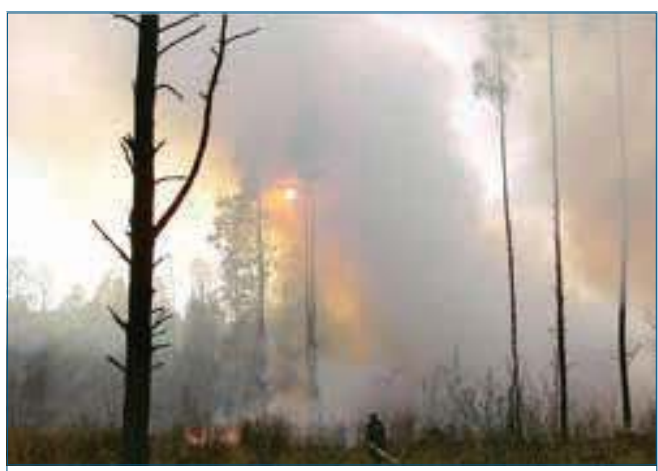

7.9. att. Meža ugunsgrēks Rīgas apkārtnē. vidējai temperatūrai par $1^{\circ} \mathrm{C}$, karcinomas gadījumu skaits var palielināties par 2-6\%. Tomēr Saules iedarbībai ir labvēlīga ietekme uz D vitamīna sintēzi cilvēka organismā, kas pozitīvi ietekmē veselību. Tādējādi UV starojuma limeña ietekmes pieauguma ieguvumu un zaudējumu bilance atšķiras atkarībā no reǵiona, starojuma iedarbības intensitātes un ilguma, kā arī no citiem faktoriem, piemēram, uztura īpatnībām, kas ietekmē D vitamīna līmeni organismā. Pētījumi par stratosfēras ozona atjaunošanos un klimata pārmaiṇām liecina, ka UV starojuma līmenim pie Zemes virsmas ir tendence samazināties, un līdz 21. gadsimta vidum dažviet tas sasniegs tādu līmeni, kāds tas bija pirms 1980. gada. Lai gan ir neskaidrības ar mērījumu precizitāti, paredzams, ka UV starojuma līmenis līdz 2100. gadam turpinās samazināties. Mērenā klimata joslā, paaugstinoties dienas vidējai temperatūrai un saulaino dienu skaitam, cilvēki vairāk laika pavada ārpus telpām, kas var izraisīt UV starojuma ietekmes paaugstināšanos, īpaši uz cilvēkiem ar gaišu un jutīgu ādu.

Aukstums. Klimata pārmaiņu ietekmē paredzamais minimālās temperatūras paaugstinājums tiek saistīts ar aukstuma izraisītu nāves gadījumu samazināšanos. Tā kā mirstības pieaugums, kas saistīts ar vasaras sezonas temperatūras paaugstināšanos, ir konsekventi

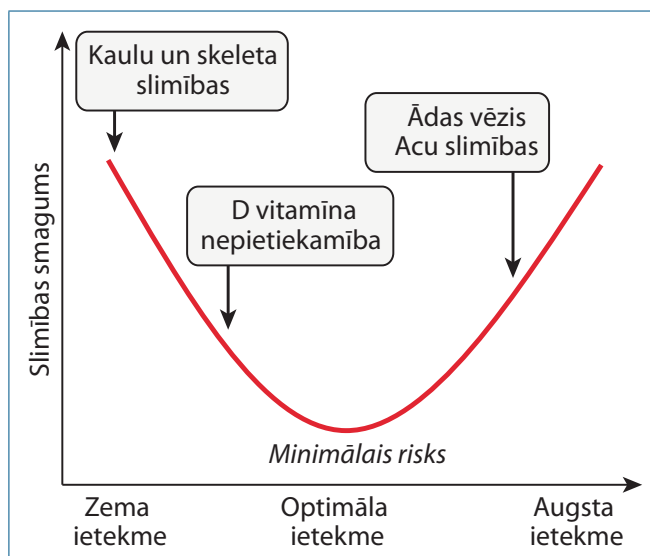

7.10. att. Ultravioletā starojuma ietekme uz cilvēka veselību. 
prognozēts pētijumos par klimata pārmaiṇām, tad tas vismaz dalēeji tiek kompensēts ar aukstuma izraisītas mirstības samazināšanos ziemas sezonā. Tomēr maz ticamas, ka salīdzinoši maigākas ziemas, ko veicina klimata pārmainas, kompensēs karstuma izraisīto ietekmi uz veselību, jo negatīvā ietekme uz veselību saistībā ar biežākiem ārkārtas karstuma periodiem lielā mērā prevalē pār ieguvumiem no samazinātā auksto dienu skaita. Nākotnes vasaras un ziemas klimata scenāriju modelēšana liecina, ka kopumā klimata pārmainu ietekme saistīsies ar ikgadēju kopējā nāves gadījumu skaita pieaugumu.

Nokrišņi, plūdi un vētras. Vairums klimata pārmaiṇu scenāriju paredz būtisku nokrišn,u biežuma un intensitātes un/vai apjoma pieaugumu. Globāli tiek prognozēts, ka teritorijas, ko skar musonu ietekme, 21. gadsimtā palielināsies, un musonu nokrišņi pastiprināsies. Savukārt intensīvi nokrišñi izraisīs vai pastiprinās plūdu iespējamību. Jau pašlaik plūdi ir kḷuvuši par ārkārtas vides apstākḷiem, kas visbiežāk ietekmē daudzu pasaules reǵionu iedzivotāju veselību un labklājību. 2011. gadā pasaulē sešas no desmit lielākajām dabas katastrofām bija plūdi gan pēc cietušo iedzīvotāju skaita (skāra 112 miljonus cilvēku), gan pēc nāves gadījumu skaita (bojā gāja vairāk nekā 3100 cilvēku). Laika periodā no 1980. gada līdz 2009. gadam plūdi skāruši apmēram 2,8 miljardus pasaules iedzīvotāju, izraisot 500000 nāves gadījumu.

Klimata pārmaiñu ietekmē pasaulē īpaši pieaug upju plūdu biežums, bet paredzama arī jūras līmeña celšanās, kas radīs ekonomiskos zaudējumus, gan ietekmējot iedzivotāju veselību, gan nopostot īpašumus un infrastruktūru applūstošajās teritorijās. Plūdi rada paaugstinātu risku noslīkt, gūt ievainojumus, ciest no hipotermijas, infekcijas slimībām (piemēram, caurejas, leptospirozes, holēras), kā arī izraisa piespiedu migrāciju vai iedzīvotāju evakuācijas nepieciešamību. Plūdi ilgtermiṇā būtiski ietekmē iedzīvotāju psihisko veselību. Psihisko traucējumu simptomu (psihologiskas ciešanas, trauksme un depresija) izplatība ir 2-5 reizes lielāka indivīdiem, kuri saskārušies ar plūdu ietekmi, salīdzinājumā ar plūdu neskartiem iedzīvotājiem.
Latvijā nopietnākos draudus upēs rada pavasara pali, ko ietekmē ledus un vižñu sastrēgumi, taču arī lietus uzplūdi un vējuzplūdi reizumis izraisa teritoriju applūdumus. Plūdi var skart plašas Lielupes, Daugavas un Gaujas upju baseinu teritorijas (7.11. att.).

Arī vētras rada paaugstinātu risku noslīkt, gūt ievainojumus, ciest no hipotermijas un rada piespiedu migrāciju vai iedzīvotāju evakuācijas nepieciešamību. Kopumā mirstība no plūdu un vētru ietekmes samazinās, bet tas atkarīgs no reǵiona ekonomiskā nodrošinājuma un spējas laikus palīdzēt cietušajiem.

Plūdu un vētru ietekmē pieaug piekrastes erozijas draudi zemos piekrastes rajonos. Tas var apdraudēt lielu skaitu pasaules iedzīvotāju, turklāt 14 no 19 pasaules lielākajām pilsētām (ar apdzīvotību virs 10 miljoniem iedzīvotāju) atrodas jūras līmeņa augstumā. Jūras līmeña celšanās var izraisīt iedzìvotāju piespiedu migrāciju, zaudējot iztikas līdzekḷus un dzīvesvietu, ciešanas no piekrastes vētrām un plūdiem.

Plūdu, vētru un spēcīgu nokrišnu ietekme ir saistāma arī ar vairākiem ūdens izraisītu slimību uzliesmojumiem patogēnu mobilizācijas (pasīvas pārneses no viena saimnieka uz otru) vai ārkārtēja piesārn,ojuma dēl, ko izraisa notekūdeṇu cauruḷvadu un/vai attīrīšanas iekārtu pārplūšana. Samazinoties ūdenstecēm vasarā, var palielināties bakteriāla un kīmiska piesārñojuma risks. Paaugstināta ūdens temperatūra veicina toksisku alggu izplatību. Fekālā piesārn,ojuma risks apdraud gan dzeramā ūdens

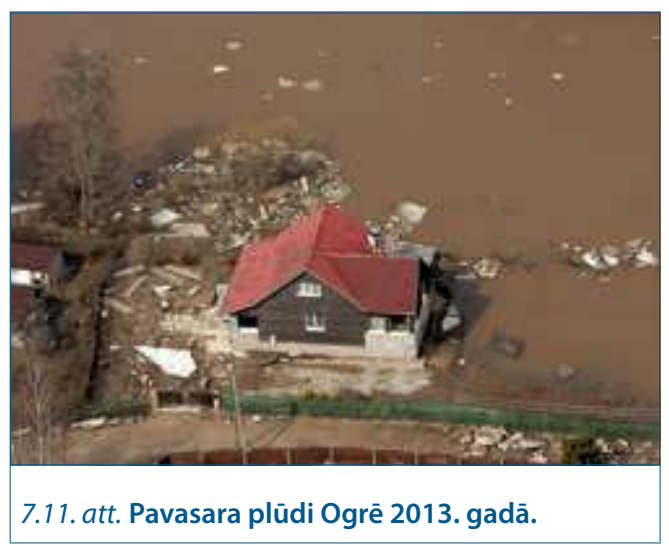


ieguves vietas, gan teritorijas, kurās ūdens tiek izmantots rekreācijai un lauksaimniecībai.

Viesulvēētras, plūdi, tropiskie cikloni, dabas ugunsgrēki, vētras, zemes nogruvumi un sausums pēdējo desmitgažu laikā ir negatīvi ietekmējuši dzīvi vairākiem miljoniem cilvēku, radot plašus īpašuma bojājumus, veselības problēmas un līdzcilvēku nāvi. No 1970. gada līdz 2012. gadam pasaulē notikušas vairāk nekā 8300 dabas katastrofas, kuras tieši saistītas ar meteoroloǵiskiem un hidroloǵiskā režīma apstākḷiem un kuru ietekmē bojā gājuši 1,94 miljoni iedzīvotāju. Mazāk attīstītajos reǵionos katastrofas var izraisīt liela mēroga iedzivvotāju piespiedu migrāciju vai evakuāciju, bieži uz vietām, kas slikti sagatavotas uzṇemt un rūpēties par cietušajiem un ko apdraud uztura nepietiekamība un infekcijas slimības. Pārvietoto cilvēku grupas parasti arī ir pakḷautas vardarbības riskam, seksuālai izmantošanai un psihiskām slimībām. Kopumā mirstības rādītāji šādās pārvietotās populācijās var pieaugt 30 reizes salīdzinājumā ar nāves gadījumu skaitu mītnes zemē. İpaši augsta mirstība ir bērniem, kas jaunāki par 5 gadiem.

Gaisa piesārnojums. 20. gadsimta 50.60. gados piesārņojuma problēma tika uzskatīta par galveno vides apdraudējumu cilvēka veselībai. Arī pašlaik šì ir nozīmīga problēma (7.12. att.). Klimata pārmainas var īpaši veicināt gaisa piesārn,ojumu. Katru gadu no gaisa

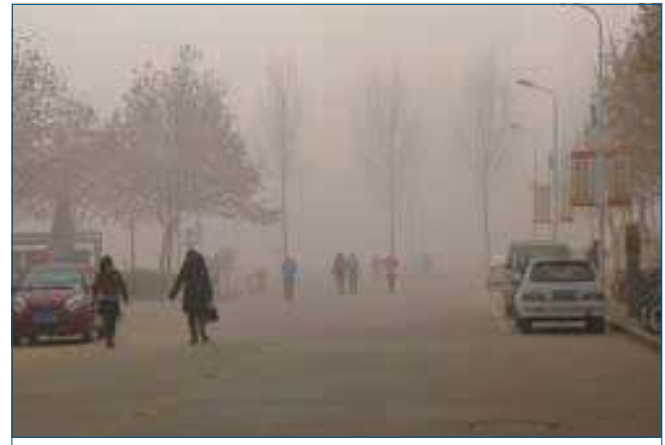

7.12. att. Smogs pilsētā - intensīvs gaisa piesārṇojums, kas apdraud cilvēka veselību.

piesārṇojuma, ko rada fosilā kurināmā sadegšanas produkti, iet bojā 7 miljoni cilvēku. Lai gan gaisa piesārn,ojums Eiropā ir krasi samazinājies pēdējās desmitgadēs, gaisa piesārṇojuma apdraudējums veselībai aizvien ir nozīmìgs, galvenokārt palielinātas cieto dalịnu un ozona koncentrācijas dēḷ, kas ietekmē elpošanas sistēmas slimību izplatību un ar tām saistīto mirstību. Klimata pārmaiṇu ietekme, iespējams, ir saistìta arī ar ozonu kā vienu no piesārṇotājiem daudzviet Eiropā. Vēl nav izstrādātas detalizētas prognozes klimata pārmaiṇu turpmākai ietekmei uz gaisa piesārn,ojumu Eiropā, un pat jaunākie pētījumi par gaisa piesārņojumu precīzi neizskaidro to, kā klimata pārmaiṇas ietekmēs gaisa kvalitāti nākotnē.

\subsection{Pārtikas un ūdens pieejamības izmaiṇas klimata pārmaiṇu ietekmē}

Galvenās nozares, kas visciešāk saistītas ar iespējamo cilvēka veselības apdraudējumu klimata pārmainu ietekmē, ir

- lauksaimniecība - saistībā ar pārtikas krājumu kvalitātes un pieejamības apdraudējuma risku un ietekmi uz iedzīvotāju nodrošinājumu ar pārtiku sekas var būt nepilnvērtīgs, piesārņots un nepietiekams uzturs, bads;
- ùdenssaimniecība - saistībā ar riskiem, kas skar iedzīvotāju nodrošinājumu ar dzeramo ūdeni un personīgajai higiēnai nepieciešamo ūdeni, kā arī ar ūdens un pārtikas izraisītu slimību izplatību.

Klimata pārmaiṇas var būtiski ietekmēt pārtikas kultūraugu un lopkopības, kā arī zvejniecības nozares produkcijas ražošanas apjomus un kvalitāti. Dažas ietekmes būs pozitīvas, 
citas - negatīvas; kopējā klimata pārmaiṇu ietekme uz pārtikas ražošanu atšksirsies reǵionāli. Izmaiṇas pārtikas ražošanā var ietekmēt vairāki vides faktori, piemēram:

- temperatūra - ražas samazināšanās karstuma un sausuma ietekmē, kā arī lauksaimniecības zemju platību samazināšanās pārtuksnešošanās dēḷ;

- nokrišñu apjoms un intensitāte - ražas kvalitātes pazemināšanās paaugstināta mitruma ietekmē, izraisot, piemēram, labības pūšanu, pelēšanu;

- $\mathrm{N}_{2} \mathrm{O}$ līmenis - saistībā ar mēslojumu lauksaimniecības zemēs;

- ārkārtas vides apstākḷu periodi - postījumi gan lauksaimniecības, gan pārtikas rūpniecības nozarēs, tehnikas bojājumi, infrastruktūras, elektroapgādes, komunikācijas un transporta traucējumi;

- jūras līmeña celšanās - lauksaimniecībā izmantojamo augšnu sasāḷošanās un erozija, zemes nogruvumi un noslīdējumi, kas izraisīs lauksaimniecības zemju platību samazināšanos.

Nepietiekams uzturs ir pamatcēlonis nāves gadījumiem pusei no 10,5 miljoniem bērnu (līdz 5 gadu vecumam) pasaulē katru gadu. Apmēram puse no mātēm un bērniem pasaulē cieš no samazinātas ķermeña masas, kas ir nepietiekama uztura sekas. Kvalitatīva ūdens nepieejamība un trūkums rada paaugstinātu infekcijas slimību, īpaši akūtu zarnu infekciju, uzliesmojumu risku, kas veicina mirstības pieaugumu. Dzeramā ūdens un pārtikas nepietiekamība, kā arī nekvalitatīva uztura un ūdens izraisītās akūtas zarnu infekcijas veido būtisku dalı no pašreizējā globālā slimību sloga, jo īpaši attiecībā uz bērniem un sievietēm, un tiek prognozēts, ka situācija pasliktināsies, klimata pārmaiṇu ietekmei pastiprinoties. Reǵionos ar zemu ekonomisko nodrošinājumu, kur pārtikas krājumi jau pašlaik ir ierobežoti, piemēram, Subsahāras Āfrikā un Dienvidāzijā, nākotnē klimata pārmaiṇu ietekmē paredzams lielākais pārtikas un dzeramā ūdens apgādes samazinājuma risks. Piemēram, 2015. gadā Zimbabvē kukurūzas ražas samazinājums par apmēram 50\% lika ciest badu 1,5 miljoniem iedzīvotāju. Pasaules Veselības organizācija pārtikas apjoma un kvalitātes samazināšanās risku vērtē kā būtiskāko klimata pārmaiṇu izraisīto ietekmi uz cilvēka veselību. 2010. gada dati liecina par iespējamu 225000 bada izraisītu nāves gadījumu skaitu pasaulē, bet līdz 2030. gadam mirstība pieaugs līdz 380000 nāves gadījumiem gadā.

Klimata pārmaiṇas var ietekmēt arī mazdārziṇos un savval̦ā augošu pārtikas augu ražu iepriekš neparedzētu slimību, kaitēkḷu vai invazīvu sugu izplatības dēl̦. Piemēram, Latvijā kopš 2007. gada auglu kokus apdraud bakteriālā iedega - slimība, kuras ierosinātāja baktērijas Erwinia amylovora vairošanos un izplatību veicina mitri un silti klimatiskie apstākḷi augu ziedēšanas laikā. Slimības ietekmē iet bojā vai arī jāiznīcina augḷ koki un krūmi ābeles, bumbieres, vilkābeles, pīlādži, klintenes, cidonijas, krūmcidonijas, korintes u.c. (7.13. att.).

Pasaulē aptuveni 150 miljoni cilvēku pašlaik dzīvo pilsētās, kuras ietekmē hronisks ūdens trūkums, un līdz 2050. gadam ūdens trūkuma skarto pilsētu iedzīvotāju skaits pieaugs līdz vienam miljardam, ja netiks rasti ātri un efektīvi pilsētvides uzlabojuma risinājumi. Pašlaik aptuveni 1,7 miljardi pasaules iedzìvotāju dzīvo reǵionos ar paaugstinātu ūdens trūkuma risku, un šis skaitlis palielināsies līdz 5 miljardiem 2025. gadā.

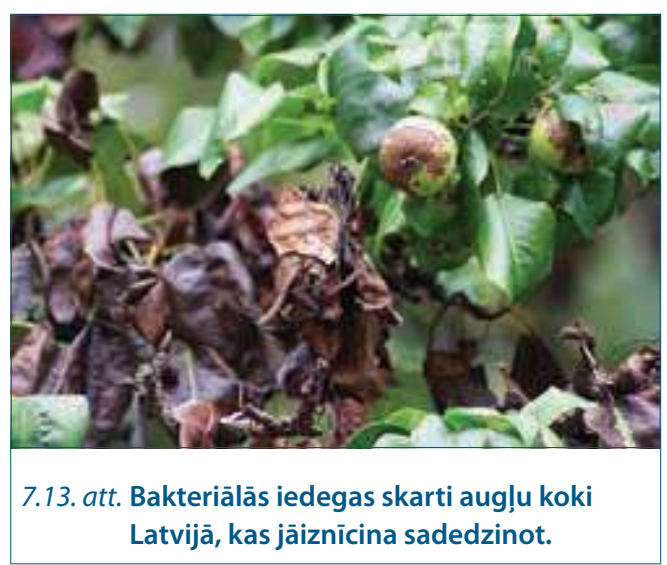




\subsection{Klimata pārmainu veicinātas slimības}

Pārtikas un ūdens izraisìtas slimības. Klimata pārmaingu ietekmē paaugstinās pret temperatūras svārstībām jutīgu, tostarp arī pārtikas un ūdens izraisītu, infekcijas slimību izplatības risks. Eiropā līdz 2030. gadam saslimstība ar šāda veida slimībām palielināsies par 20000 gadījumiem gadā, bet līdz 2080. gadam - par 25 000-40 000 gadījumiem gadā.

Pārtikas un ūdens izraisītas slimības, parasti kunǵa un zarnu trakta infekcijas, kuru simptoms ir caureja, joprojām ir globāla veselības problēma, kas it īpaši skar bērnus regionos ar zemu ekonomiskās attīstības līmeni. Higiēnas normu ievērošana un pastāvīgs nodrošinājums piekḷuvei sanitāriem mezgliem, kā arī droša dzeramā ūdens apgāde ir pamats pārtikas izraisītu saslimšanu profilaksei. Klimata pārmainnu ietekme, piemēram, ārkārtas sausuma periodi, plūdi vai intensīvas lietusgāzes parasti samazina pieejamību drošai ūdens apgādei. Pētījumi liecina, ka saslimšana ar akūtām zarnu infekcijas slimībām palielinās reizē ar vides temperatūras paaugstināšanos, proti, temperatūrai paaugstinoties par $1^{\circ} \mathrm{C}$, saslimšanas gadījumu skaits pieaug par 3-11\%.

Ar pārtikas un ūdens izraisītām slimībām cilvēks var saslimt, uzn,emot patogēnus ar piesārnotu dzeramo ūdeni, inficētu vai termiski neapstrādātu pārtiku, nejauši norijot ūdeni peldoties vai ūdenim nonākot tiešā kontaktā ar acīm, ausīm, glotādu vai vaḷējām brūcēm. Patogēni ūdenī var būt zoonozes, kas koncentrētas, piemēram, divvāku gliemjos (austerēs u.c.), kā arī tiek deponēti, apūden,ojot pārtikas kultūraugus. Patogēni, kas rada infekciju risku, ir cilvēku un dzīvnieku zarnās mītoši mikroorganismi, kas tiek pārnēsāti fekāli orālā cel̦ā, kā arī baktērijas un vienšūṇi, kas dabiski attīstās ūdens vidē (7.14. att.). Klimata faktori var tieši ietekmēt patogēnu attīstību, izdzīvošanas spējas, noturību vidē, pārnešanu un virulenci (patogenitātes pakāpi). Netieša klimata faktoru ietekme ietver infekciju uzliesmojumus vietējās ekosistēmās vai sugu dzīvotnēs, kas darbojas kā zoonozes krātuves. Piemēram, temperatūras paaugstināšanās ir tieši saistīta ar akūtu zarnu infekcijas slimību izplatības risku Arktikas kopienās, jo mūžīgā sasaluma izkušana pastiprina notekūden,u plūsmas uz gruntsūdeniem, dzeramā ūdens avotiem vai citiem virszemes ūdeñiem. Siltos apstākḷlos patogēni var savairoties uz pārtikas kultūraugiem (piemēram, salātu lapām). Arī nokrišnu apjoms un intensitāte tiek saistīta ar akūtu zarnu infekciju izplatības riska izmaiṇām - augstāka akūtu zarnu infekciju izraisītāju, piemēram, enterovīrusu, koncentrācija biežāk tiek konstatēta dzeramajā ūdenī un peldūden,os pēc stiprām lietusgāzēm.

Visbiežāk pasaulē pārtikas un ūdens izraisītās akūtās zarnu infekcijas ir kampilobakterioze un salmoneloze, kuru uzliesmojumi var atškirties reǵionāli sezonalitātes un gaisa temperatūras mainības ietekmē. Kampilobakteriozi izraisa Campylobacter ǵints baktērijas, un tā ir iemesls 5-14\% caurejas gadījumu visā pasaulē visās vecuma grupās, bet augstāka saslimstība registrēta bērniem līdz 5 gadu vecumam un jauniem cilvēkiem (19-25 g. v.).

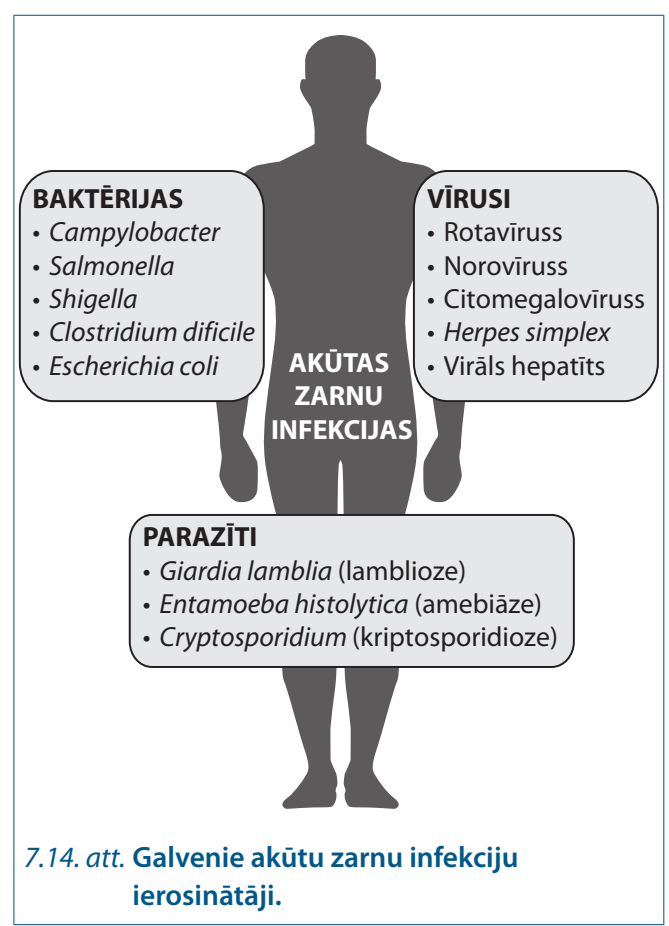


Mērenā klimata joslā saslimšanas gadījumu skaits pieaug gada siltajos mēnešos. Salmonelozi izraisa Salmonella gints baktērijas (visizplatītākās - S. enteritidis un S. typhimurium). Salmonellas dzīvo un vairojas zarnu traktā, un izplatās apkārtējā vidē ar fekālo piesārṇojumu. Eiropā salmonelozes un kampilobakteriozes simptomi ir līdzīgi - slikta dūša, vemšana, krampji, caureja, drudzis, galvassāpes. Bīstama salmonelozes komplikācija ir baktēriju ieklūšana asinīs no zarnu trakta, kas var radīt iekšējo orgānu inficēšanos (abscesu, artrītu, meningītu u.c.), pat izraisīt nāvi. Akūtu zarnu infekciju izraisīta caureja ir iemesls gandrīz 2 miljoniem bērnu bojāejai katru gadu.

Arī rotavīrusa un norovīrusa izraisītas infekcijas izplatās fekāli orālā ceḷā un ar piesārn,otu ūdeni vai pārtiku. 2008. gadā rotavīrusa infekcija izraisīja apmēram 450000 nāves gadījumus to bērnu vidū, kas jaunāki par 5 gadiem. Sezonalitāte ietekmē rotavīrusa infekciju uzliesmojumu mērenās klimata joslas un subtropu reǵionos, kā arī konstatēta reǵionāla saslimšanas mainība un saikne starp jaundzimušo skaitu un sezonalitāti. Lai gan gaidāms, ka vakcinācija pret rotavīrusu samazinās kopējo slimības slogu, sezonalitātes izmainas saslimstības risku palielinās.

Klimata pārmainu ietekmē var mainīties enterovīrusu izplatība. Tā mainās arī atkarībā no sezonas un temperatūras. Amerikas Savienotajās Valstīs enterovīrusu infekciju uzliesmojums sasniedz maksimumu vasaras un rudens mēnešos. Enterovīrusi veido lielu vīrusu grupu (poliovīrusi, Koksaki vīrusi A un B un ECHO vīrusi), kuriem dabiskā dzīves vieta ir cilvēka zarnu trakts. Enterovīrusi izraisa apmēram $90 \%$ no serozā meningīta saslimšanas gadījumiem; turklāt, tie var izraisīt vairākas citas slimības: encefalìtu, paralīzi, miokardītu, perikardītu, elpcel̦u infekcijas, konjunktivītu u.c. Enterovīrusi viegli izplatās, ja netiek ievērotas higiēnas normas. Piesārṇota ūdens vai pārtikas produktu lietošana uzturā var izraisīt enterovīrusu izraisītu slimību uzliesmojumus ar lielu saslimušo skaitu.

Ar pārtiku un dzeramo ūdeni izplatās arī holēra, ko izraisa Vibrio gints baktērijas
(V. cholerae, V. parahaemolyticus, V. vulnificus, $V$. alginolyticus). Holēra ir akūta zarnu infekcijas slimība, kam piemīt spēja izplatīties pandēmiski. Holēras klīniskās izpausmes ir drudzis, vemšana, muskul̦u krampji, caureja. Inficēšanās risku ietekmē gaisa temperatūra, nokrišnu daudzums un intensitāte, organisko vielu koncentrācijas pieaugums ūdenstilpēs, kā arī sāl̦uma un pH izmaiņas ūdenstilpēs. Āfrikā, Āzijā un Dienvidamerikā ik gadu tiek registrēti desmitiem tūkstoši holēras slimnieku, atsevišķi gadījumi ir arī Eiropā. Holēras uzliesmojumi tropu un subtropu reǵionos bieži saistīti ar spēcīgu lietusgāžu radītiem plūdiem. Valstīs, kur holēra ir endēmiska slimība, konstatēta stabila attiecība starp vides temperatūras izmaiṇām un slimības izplatību. Līdz 19. gadsimta sākumam holēra bija Dienvidaustrumāzijas valstu endēmiskā slimība. 2010. gada oktobrī Haiti izcēlās holēras uzliesmojums, un kopējais saslimšanas gadījumu skaits pārsniedza (līdz 2013. gada augusta vidum) 671 000; vairāk nekā 8200 saslimušie nomira.

Klimata pārmaiṇu izraisītā siltās sezonas pagarināšanās var veicināt alğu savairošanos saldūdens un sālsūdens ūdenstilpēs, ko arī var saistīt ar ūdens izraisītu slimību risku. Potenciāli bīstamas aḷges, piemēram, dinoflagelāti (Dinoflagellata), zilalı́ges (Cyanobacteria), kramalges (Diatomea), paaugstinoties temperatūrai, var savairoties lielā apjomā un izdalīt toksīnus, kas kaitīgi cilvēka veselībai. Zilalı̣gu ziedēšanas laikā izdalās toksīni, kas var izraisìt nervu sistēmas, gremošanas orgānu, aknu un ādas bojājumus, bet kramalǵges izdala domoīnskābi, kas ir spēcīgs neirotoksīns un var bioakumulēties zivīs. Zilalğg ziedēšana Latvijā tiek bieži novērota siltās vasarās gan Baltijas jūras piekrastē un Rīgas līcī, gan upēs, ezeros un dīķos (7.15. att.). Saindēšanos ar zilalǵgèm var izraisīt piesārn,ota ūdens iedzeršana, kā arī saskare ar glıtōādu (piemēram, acu glotādu), vaḷējām brūcēm. Zilaḷgu toksīni var izraisīt vairākas dažādas veselības problēmas, piemēram, ādas un glotādas kairinājumu, alerǵiskas reakcijas, krampjus, sliktu dūšu, vemšanu, caureju, drudzi, galvassāpes, muskuḷu un locītavu sāpes, aknu bojājumus. 


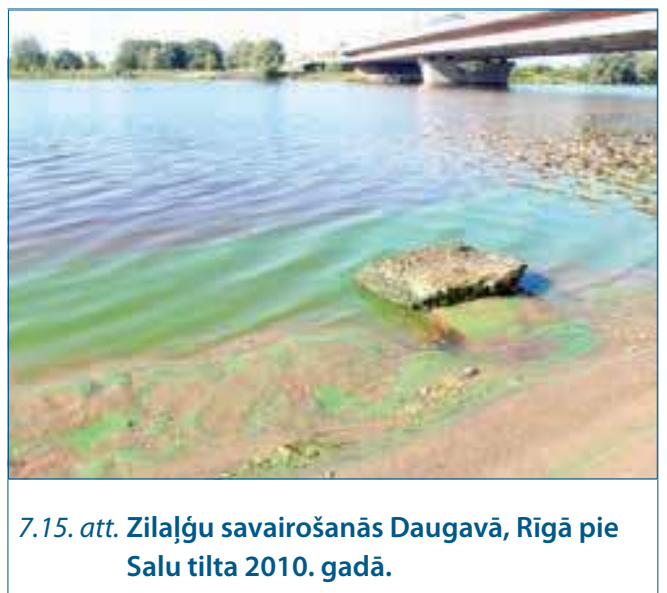

Pārtikas un ūdens kvalitātes un pieejamības izmaiṇas nākotnē var ietekmēt arī parazìtu (cērmju, lenteñu u.c.) dzīvesciklu un pārnesi uz saimniekorganismu.

Pārnēsātāju izraisītas slimības. Klimata pārmaiṇas var būtiski ietekmēt pārnēsātāju izraisītu slimību izplatību. Paredzams, ka mainīsies tādu infekcijas slimību ǵeogrāfiskās izplatības areāls, kas izplatās ar odu, mušu, ērču vai citu pārnēsātāju (parasti asinssūcēju kukainuu) starpniecību, un līdz ar to globāli pieaugs saslimšanas gadījumu skaits. Pārnēsātāju izraisītu slimību riska pieaugums visvairāk tiek saistīts ar klimata pārmaiṇu ietekmi, jo šādu slimību izplatība ir īpaši pētīta. Slimību pārnēsātāji un paši patogēni ir jutīgi pret tādiem vides faktoriem kā temperatūra, ūdens augšējo slān,u īpatnības, gaisa un augsnes mitrums, nokrišn,i, vējš, veǵetācijas īpatnības, sezonalitāte. Paaugstināts mitrums un siltums ir galvenie vides faktori, kas stimulē pārnēsātāju izraisītu slimību izplatību. Tropu reǵionos pārnēsātāju izraisītas slimības ir cēlonis lielākajai daḷai saslimšanu un nāves gadījumiem. Reǵionāli pārnēsātāju izraisītu slimību izplatību var samazināt, vakcinējot iedzīvotājus, kā arī izmantojot pesticīdus pārnēsātāju iznīdēšanai. Tomēr pastāv paaugstināts pret pesticīdu iedarbību noturīgu jeb rezistentu pārnēsātāju sugu un patogēnu attīstības risks.

Būtiskākā pārnēsātāju izraisītā slimība pasaulē ir malārija - tās izplatības intensitāte klimata pārmaiṇu ietekmē dažos pasaules regionos ir īpaši augsta (7.3. tab.). Citu pārnēsātāju izraisītu slimību izplatības risks ir zemāks un arī atkarīgs no reǵionālām klimata īpatnībām. Dažādu sugu dzēlējodi izplata Denges drudža, limfātiskās filariozes, dzeltenā drudža ierosinātājus, dažādu sugu mušas - onhocerkozi, šistosomiāzi Āfrikas tripanosomiāzi, leišmaniozi, bet Triatominae sugas blaktis - Amerikas tripanosomiāzi jeb Čagasa slimību.

Katru gadu pasaulē tiek reǵistrēti aptuveni 300-500 miljoni malārijas saslimšanas gadījumu un vairāk nekā viens miljons nāves gadījumu, no kuriem 75\% skar Âfrikas valstīs dzīvojošus bērnus, kas jaunāki par 5 gadiem. Subsahāras Āfrikā malārija ir visizplatītākā parazitārā slimība un ir galvenais iemesls bērnu un grūtnieču saslimšanai un mirstībai. Āfrikas valstīs konstatē $80 \%$ no visiem malārijas saslimšanas gadijumiem un $90 \%$ no visiem nāves gadījumiem pasaulē. Lai arī malārija ir visnozīmīgākā pārnēsātāju izraisītā slimība pasaulē, tā ir slimība, kuras izplatību var ierobežot un novērst.

Malāriju ierosina sarkanajos asinsķermenīšos parazitējoši vienšūṇi - malārijas plazmodiji. Tie var parazitēt cilvēka organismā. Malārijas ierosinātājus pārnēsā vairākas Anopheles gints malārijodu sugas, kas ir aktīvas galvenokārt nakts laikā. Malārija ir akūta slimība, kuras simptomi atkarīgi no ierosinātāja, bet parasti ir drudzis, drebul̦i, galvassāpes, muskuḷu sāpes un vājums, iespējama vemšana, klepus, caureja un sāpes vēderā (7.16. att.). Ceḷotājiem risks saslimt ar malāriju ir augstāks, jo viṇi nav imūni pret to. Drudzis, kas parādās trīs mēnešu laikā pēc atgriešanās no ceḷojuma uz malārijas endēmiskiem reǵioniem, var būt malārijas simptoms, tomēr bieži vien var tikt uzstādīta vēlīna vai nepareiza diagnoze.

Prognozes liecina, ka klimata pārmain,as, galvenokārt, temperatūras un nokrišnu pieaugums, ietekmē tādu teritoriju geogrāfisko paplašināšanos, kas piemērotas stabilai $P$. falciparum malārijas izplatībai, mainoties pārnēsātāja (Anopheles) un patogēnu (Plasmodium) izdzīvošanai labvēlīgiem apstākḷiem endēmiskajos reǵionos. Dati par malārijas izplatību norāda 


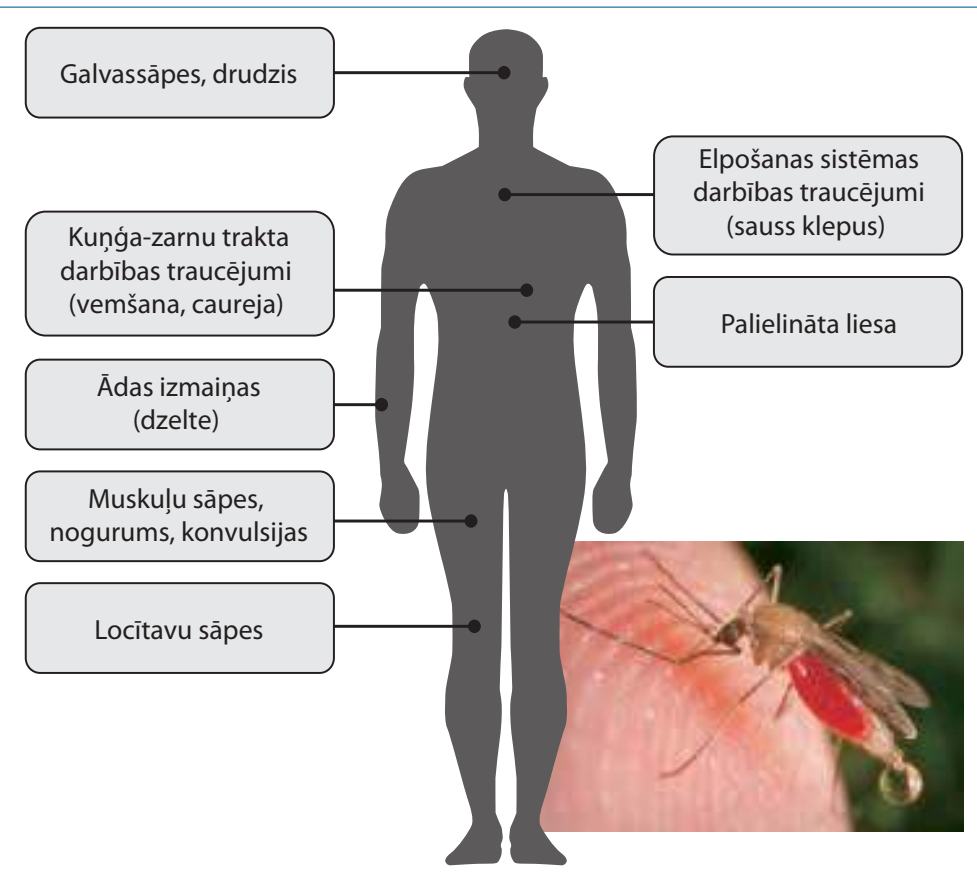

7.16. att. Malārijas simptomi un ierosinātāju pārnēsātājs Anopheles ǵints ods.

\section{3. tabula. Pārnēsātāju izraisītas slimības un to iespējamā izplatības intensitāte}

\begin{tabular}{|c|c|c|c|c|c|}
\hline Slimība & lerosinātājs & Pārnēsātājs & $\begin{array}{c}\text { Riskam pakl̦auto } \\
\text { iedzīvotāju skaits } \\
\text { pasaulē }\end{array}$ & $\begin{array}{c}\text { Pašreizējās } \\
\text { izplatības areāls }\end{array}$ & $\begin{array}{l}\text { lespējamā } \\
\text { izplatības } \\
\text { intensitāte }\end{array}$ \\
\hline Malārija & Plasmodium & $\begin{array}{l}\text { Malārijodi } \\
\text { (Anopheles) }\end{array}$ & 2400 miljoni & Tropi un subtropi & $\begin{array}{c}+++ \\
\text { Īpaši iespējama }\end{array}$ \\
\hline Šistosomiāze & Schistosoma & $\begin{array}{l}\text { Moluski, ūdens } \\
\text { gliemeži }\end{array}$ & 600 miljoni & Tropi un subtropi & \multirow{3}{*}{$\begin{array}{c}++ \\
\text { L̦oti iespējama }\end{array}$} \\
\hline $\begin{array}{l}\text { Onhocerkoze jeb } \\
\text { upes aklums }\end{array}$ & $\begin{array}{l}\text { Onchocerca } \\
\text { volvulus }\end{array}$ & $\begin{array}{l}\text { Melnās mušas } \\
\text { (Simulium) }\end{array}$ & 123 miljoni & $\begin{array}{l}\text { Āfrika, } \\
\text { Latīṇamerika }\end{array}$ & \\
\hline $\begin{array}{l}\text { Tropu drudzis jeb } \\
\text { Denges drudzis }\end{array}$ & Denges vĩruss & $\begin{array}{l}\text { Dzēlējodi } \\
\text { (Aedes aegypti) }\end{array}$ & 1800 miljoni & Tropi & \\
\hline Limfātiskā filarioze & Filariodidea & $\begin{array}{l}\text { Dzēlējodi } \\
\text { (Culex, Aedes) }\end{array}$ & 1094 miljoni & Tropi un subtropi & \\
\hline $\begin{array}{l}\text { Āfrikas } \\
\text { tripanosomiāze } \\
\text { jeb miega slimība }\end{array}$ & Trypanosoma & $\begin{array}{l}\text { Cece mušas } \\
\text { (Glossina) }\end{array}$ & 55 miljoni & Tropiskā Āfrika & \\
\hline Leišmanioze & Leishmania & $\begin{array}{l}\text { Smilšu mušas } \\
\text { (Phlebotominae) }\end{array}$ & 350 miljoni & $\begin{array}{l}\text { Āzija, } \\
\text { Dienvideiropa, } \\
\text { Āfrika, Amerika }\end{array}$ & $\begin{array}{c}+ \\
\text { lespējama }\end{array}$ \\
\hline $\begin{array}{l}\text { Amerikas } \\
\text { tripanosomiāze } \\
\text { jeb Čagasa slimība }\end{array}$ & Trypanosoma cruzi & $\begin{array}{l}\text { Blaktis } \\
\text { (Triatominae) }\end{array}$ & 100 miljoni & $\begin{array}{l}\text { Centrālamerika, } \\
\text { Dienvidamerika }\end{array}$ & \\
\hline Dzeltenais drudzis & Flavivirus & $\begin{array}{l}\text { Dzēlējodi (Aedes, } \\
\text { Haemogogus) }\end{array}$ & 450 miljoni & $\begin{array}{l}\text { Tropiskā Dienvid- } \\
\text { amerika, Āfrika }\end{array}$ & \\
\hline
\end{tabular}


uz to, ka, koncentrējoties tikai uz pašreizējo veselības aizsardzības stiprināšanu, ir maz ticami sasniegt pietiekamu efektu šīs slimības izplatības samazināšanā un apturēšanā, jo klimata pārmaiṇas var pasliktināt agrīnās brīdināšanas sistēmas shēmu. Lai gan patlaban ir sarežgìiti precīzi prognozēt, tomēr kopumā malārijas izplatīšanās risks, kas saistīts ar vietējas nozīmes klimata pārmaiṇām, nav augsts, jo īpaši reǵionos, kur pieejama atbilstoša veselības aprūpe un laba insektu kontroles pārvaldība.

Pārnēsātāju izraisītu slimību izplatības areāla maiña var būt saistìta ne tikai ar klimata pārmaiñām, bet arī ar sociāli ekonomiskiem faktoriem, piemēram, cilvēku pārvietošanos un preču transportu, kā arī ar klimata ietekmētām izmaiṇām vides resursu un zemes platību izmantošanā. Šie faktori var sekmēt zināmo pārnēsātāju un patogēnu izplatību, kā arī jaunu patogēnu rašanos un izplatību. 2007. gadā Eiropā (Itālijā un Francijā) tika konstatēti regionam netipisku dzēlējodu sugu (Aedes albopictus un Aedes aegypti) pārnēsātas slimības - Čikunguñjas drudža - vietējas izcelsmes gadījumi. Piemērota patogēna pārnēsātāja ilgstoša klātbūtne regionā var būt labvēlīga turpmākam slimības gadījumu skaita pieaugumam. Lai arī ar zemu varbūtības risku, tomēr iespējami arī tropu jeb Denges drudža uzliesmojumi. 2010. gadā Latvijā tika registrēti septiṇi, bet 2012. gadā 12 ievesti Denges drudža gadījumi, savukārt Francijā - divi vietējas izcelsmes Denges drudža saslimšanas gadijjumi. Tāpēc tika veikti plaši insektu kontroles pasākumi. Denges drudzis ir vīrusu infekcijas slimība, kura ir endēmiska tropu un subtropu klimatiskās joslas valstīs Āfrikā, Amerikā un Āzijā. Dabā endēmiskajās teritorijās Denges drudzis cirkulē pērtiķu, vāveru un lemuru populācijās, bet uz cilvēku vīruss tiek pārnests ar Aedes gints odu starpniecību. Denges drudža gadījumi Eiropā liecina par lokālas infekcijas risku valstīs, kurās ir odu sugas, kas spēj pārnest šīs infekcijas ierosinātājus.

Klimata pārmaiñas, iespējams, ietekmē arī ērču izplatību - ērču populācijai Eiropā ir tendences paplašināties virzienā uz ziemel̦iem un uz augstkalnu reǵioniem. Klimata pārmaiṇu izraisītu siltāku ziemu dēḷ ērču populācija var palielināties un tādējādi lielākā mērā nekā līdz šim apdraudēt cilvēkus ar laimas slimību un ērču encefalītu. Mainās arī smilšu mušu ǵeogrāfiskā izplatība, kuras ir infekcijas slimības leišmaniozes ierosinātāju pārnēsātājas.. Precīzus datus par slimību pārnēsātāju izplatību var iegūt tikai ilgtermiṇa pētījumos, kas sarežgì savlaicīgu profilakses pasākumu ieviešanu.

Ixodes gints ērces ("cietās ērces"), kas sastopamas arī Latvijā, var pārnēsāt ērču encefalìta un laimas slimības ierosinātājus. No Latvijas mežos un krūmājos sastopamajām ērču sugām divas ir epidemiologiski nozīmīgas sugas - suñu ērce (Ixodes ricinus) un taigas ērce (Ixodes persulcatus). Sunu ērce ir Latvijas teritorijā dominējošā ērču suga, savukārt taigas ērce vairāk izplatīta Latvijas austrumu daḷā. Suṇu un taigas ērce ir galvenie ērču encefalìta vīrusa pārnēsātāji Latvijā. Ērču encefalīta un citu vīrusu infekcijas slimību ierosinātājus var pārnēsāt arī citas Ixodes ǵints ērces, kā arī Dermacentor gints ērces. Arī citi bezmugurkaulnieki (piemēram, citu grupu parazītiskās ērces, blusas vai utis) var kḷūt par īslaicīgiem encefalīta vīrusa pārnēsātājiem, ja tie sūkuši ar vīrusu inficēta dzīvnieka vai cilvēka asinis.

Laimas slimība ir sistēmiska akūta infekcijas slimība, ko izraisa spirohetu baktērijas Borrelia burgdorferi, kas tiek pārnestas uz cilvēku ar inficētas ērces kodienu. Katru gadu Latvijā registrē vairākus simtus saslimšanas gadījumu. Laimas slimība agrīnā lokālā stadijā izpaužas ar tādām ādas pārmaiñām kā eritēma jeb koši sarkani vai zilgansarkani plankumi uz ādas (7.17. att.). Ja slimību agrīni nediagnosticē un neārstē, tad pēc dažām nedēḷām vai mēnešiem var parādīties centrālās nervu sistēmas bojājumi (aseptisks meningīts, neirīti), locītavu sāpes, artrīts, kardīts. Retāk pēc vairākiem mēnešiem vai gadiem laimas slimība var pāriet vēlīnā persistējošas infekcijas stadijā, kas izpaužas kā hronisks artrīts, encefalopātija, encefalomielīts, var attīstīties demence.

Ērču encefalītu izraisa encefalīta vīruss, un tā ir endēmiska slimība mērenās klimata joslas valstīs Eiropā, Ziemel̦amerikā un Āzijā. Ērču encefalìta izplatība konstatēta no Atlantijas 
okeāna līdz Klusajam okeānam, tomēr pēdējās desmitgadēs encefalīta vīrusa izplatības areālam ir tendence paplašināties, ko veicina mežu izciršana, izcirtumu un lauksaimniecības zemju aizaugšana. Ērču encefalīta simptomi var būt līdzīgi gripas simptomiem, tomēr iespējamas komplikācijas, piemēram, smadzeñu apvalka iekaisums - tad saslimšana var beigties ar invaliditāti vai pat nāvi. Pētījumi liecina par saistību starp klimata pārmain̄ām un ērču izplatības areāla paplašināšanos. Piemēram, Ziemel̦amerikā laika periodā no 1996. gada līdz 2004. gadam ir novērota ērču Ixodes scapularis izplatības areāla paplašinās ziemel̦u virzienā. Tomēr nav datu par saslimšanas gadījumu skaita pieaugumu no ērču pārnēsātām slimībām šajā reǵionā.

Alerǵijas. Alerǵija ir paaugstināta jutība pret organismā vai vidē esošām specifiskām vielām - alergēniem. Klimata pārmaiṇas veicina gaisā sastopamu alergēnu (aeroalergēnu) koncentrāciju un izplatību vidē, paaugstinoties $\mathrm{CO}_{2}$ lìmenim un mainoties silto un auksto sezonu ilguma attiecībai, kas savukārt var labvēlīgi ietekmēt augu veǵetācijas periodu, paildzinot ziedēšanas laiku, kā arī regionam netipisku augu sugu izplatību. Sausums un spēcīgs vējš var radīt putekḷus un citu atmosfēras materiālu, kas satur ziedputekšn,us un sporas, un gaisa masas var pārnest šos alergēnus uz iepriekš neskartiem regioniem. Klimata pārmain,u ietekmē gaisa kvalitāte mainās gan ārpus telpām, gan iekštelpās, palielinoties gaisa piesārn,ojumam un aeroalergēnu, piemēram, ziedputekšn,nu, putekļu vai pelējuma sēṇu sporu, veidam, koncentrācijai un ekspozīcijas ilgumam. Sezonāli agrāka un noturīgāka aeroalergēnu klātbūtne gaisā rada paaugstinātu risku saslimt ar elpošanas sistēmas un alerğiskām slimībām, piemēram, alerǵisku rinītu, siena drudzi, konjunktivītu vai dermatītu. Paaugstinātais alerǵiju risks pazemina cilvēka darbspējas un paaugstina izmaksas par medicīnisko aprūpi un zālēm, kā arī veicina smagu slimību attīstību. Īpaši apdraudēti ir iedzīvotāji, kas cieš no hroniskām elpošanas sistēmas slimībām, piemēram, astmas vai hroniskas obstruktīvas plaušu slimības. Jau pašlaik hroniska obstruktīva plaušu slimība izraisa ceturto augstāko mirstības rādītāju to pasaules iedzīvotāju vidū, kas vecāki par 45 gadiem, un mirstība joprojām turpina pieaugt. Putekšn,u koncentrācijas pieaugums paaugstina organisma jutību pret alergēniem un veicina smagāku alerǵisko reakciju izpausmes, par ko liecina pieaugošais no astmas, alerǵiska rinīta un citām alerǵiskām slimībām cietušo hospitalizāciju skaits. Pētījumi liecina par pozitīvu korelāciju starp gaisa mitrumu un ekzēmas gadījumu skaitu bērniem un par negativu korelāciju starp gaisa temperatūru un saulaino stundu skaitu attiecībā pret ekzēmas gadījumu skaitu bērniem. Pēc Pasaules Veselības organizācijas datiem apmēram 15\% Eiropas iedzīvotāju ir jutīgi pret putekšņiem.
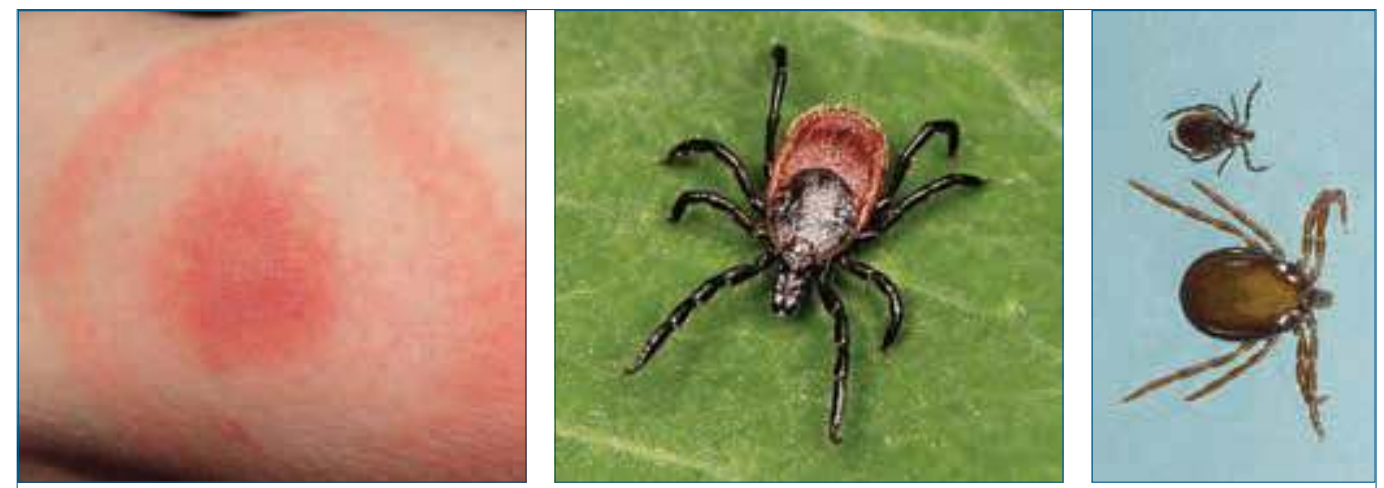

7.17. att. Laimas slimībai raksturīga eritēma (pa kreisi) un lxodes ǵints ērces (pa labi). 
Sakarā ar pieaugošo ziedputekšņu izraisītas alerǵijas izplatību, Latvijā kopš 2003. gada tiek veikts aerobiologiskais monitorings. Latvijā alerǵijas visvairāk izraisa:

- koku un krūmu ziedputekšñi - bērzs, alksnis, lazda, ozols, kḷava, papele, osis, goba u.c.;

- graudzāl,u ziedputekšñi - timotinšs, auzene, skarene, kvieši, rudzi, griksi u.c.;

- savval̦as lakstaugu ziedputekšnni - vībotne, pienene, kan,epe, nātre, vērmele, gundega, cel̦teka u.c.

Ziemel̦eiropā bērza putekšn,i tiek vērtēti kā agresīvākie alergisko simptomu izraisītāji (7.18. att.), bet Centrāleiropas Vidusjūras regionā - olīvu putekšñi. Dienvideiropā vairāku sugu ambroziju (Ambrosia spp.) putekšn,i atzīti par agresīviem alergēniem, turklāt, ambrozijas ir augi, kuru izplatības areāls strauji palielinās globālās klimata sasilšanas ietekmē. Trīs ambroziju sugas - vērmellapu ambrozija (A. artemisiifolia), trīsdaivu ambrozija (A. trifida) un kailvārpu ambrozija (A. psilostachya) ir iekḷautas karantīnas augu sarakstā Latvijā. Vērmeḷlapu ambrozija ir visbīstamākā no šīm invazìvajām sugām, jo augs izplata īpaši alergiskus ziedputekšn,us, kas jutīgiem cilvēkiem izraisa smagas alerǵiskas reakcijas. Alerǵiskas reakcijas pret vērmel̦lapu ambrozijas putekšniem rodas vienam no 5 eiropiešiem, kuri cieš no regulārām alerǵiskām izpausmēm, kā arī vienam no 7 eiropiešiem, kuri cieš no rinīta, un vienam no 11 astmas slimniekiem. Saskaṇā ar augu ziedēšanas laiku izdala trīs alergísko slimību saasināšanās periodus: pirmais - pavasarī koku ziedēšanas laikā, otrais - vasarā graudaugu ziedēšanas laikā, trešais - rudenī vairāku savvalıas lakstaugu (nezāļu) ziedēšanas laikā.

Arī pelējuma sēnnu sporas var būt nopietns alergēns. Piemēram, alternārijas (Alternaria) pelējuma sēnuu sporas ir ne tikai viens no spēcīgākajiem aeroalergēniem pasaulē, bet arī patogēns augu slimību ierosinātājs. Alternārijas sporu koncentrācija un izplatība ir atkarīga no gaisa temperatūras. Biologiskais piesārņojums ar alternārijas sporām dažviet Centrāleiropā un Austrumeiropā tiek vērtēts kā augsts un tiek saistīts ar nopietnu veselības risku jutīgiem cilvēkiem, ja sporu koncentrācija ilgāku laiku pārsniedz 300 sporas vienā kubikmetrā gaisa. Biežāk sastopamās iekštelpu pelējuma sēṇu gintis ir Alternaria, Aspergillus, Cladosporium un Penicillium. Pelējuma sēṇu sporas var izraisīt ietekmi uz veselību, sākot ar vājām alerǵiskām reakcijām - šķaudīšanu, deguna, acu, kakla vai plaušu kairinājumu līdz astmatiskām lēkmēm.
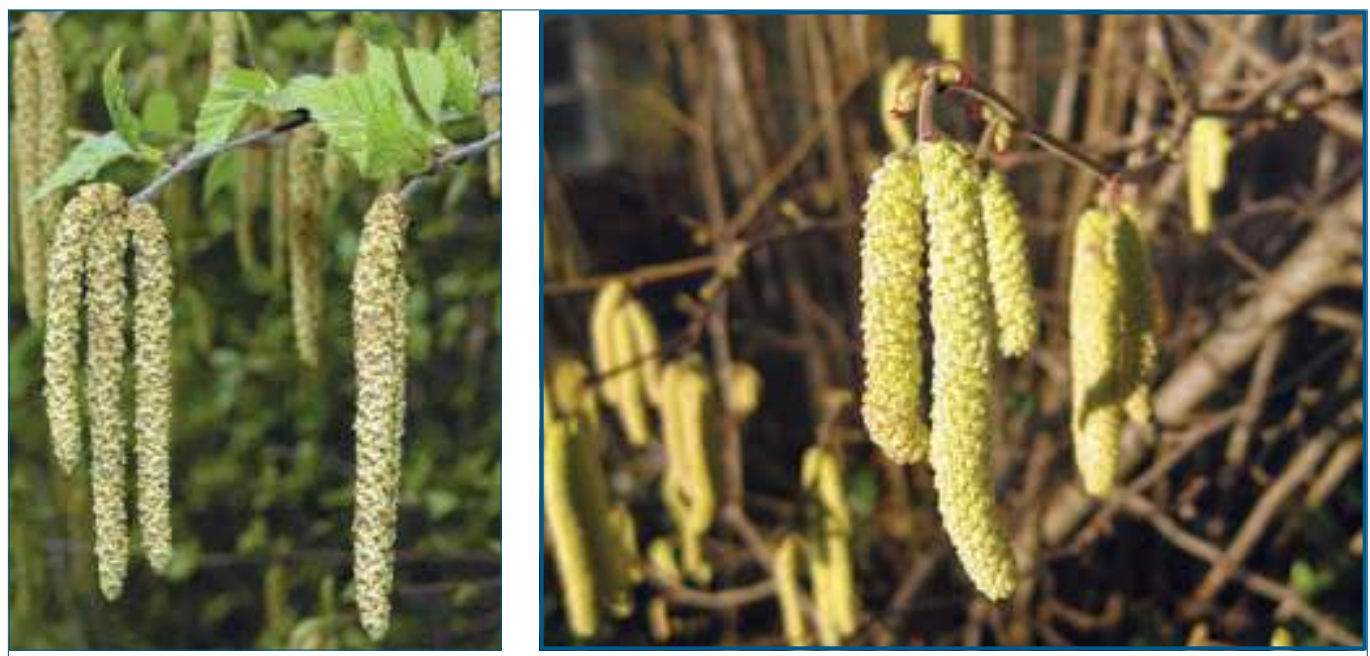

7.18. att. Nozīmīgākie aeroalergēnu putekšņu avoti - bērza spurdzes (pa kreisi) un lazdas sievišḳie ziedi pumpurveida ziedkopā un spurdzes jeb vīrišḳie ziedi (pa labi). 
Iekštelpu gaisā esošie aeroalergēni ir putekḷi, kas sastāv no pelējuma sēnu sporām, augu škiedrām, pārtikas dalı̣n̄ām, insektu ekskrementiem, mājdzīvnieku spalvām, cilvēku un dzīvnieku ādas (epidermas) dalıinām. Putekḷos var iemājot putekḷu ērcìtes, kas var pastiprināt alerǵisko reakciju izpausmes. Ilgstošs sausums var paaugstināt putekḷu koncentrāciju gaisā.

Alerǵiju izplatība ir cieši saistīta ar vides piesārṇojumu. Intensīvs gaisa piesārṇojums var izraisìt elpošanas traucējumus, klepu, bronhiālās astmas lēkmes. Automašīnu izplūdes gāzes kairina acu un elpceḷu glotādu. Tādējādi alerǵisku slimību izplatība vērtējama kā gaisa piesārn,ojuma indikators.

Citas saslimšanas. Veselība ir fiziska, emocionāla un sociāla labsajūta. Klimata pārmaiṇu ietekmi uz cilvēka veselību var saistīt ar dažādu slimību izplatību (bez iepriekš minētajām), piemēram, veicinot psihisko traucējumu rašanos, kā arī vēža un citu slimību attīstību noteiktu faktoru ietekmē. Dabas katastrofas vai ārkārtas vides apstākḷi un to radītā piespiedu migrācija var ietekmēt cilvēka funkcionēšanu kognitīvā, emocionālā un uzvedības līmenī, mainot daudzu cilvēku, īpaši bērnu, psihisko stāvokli, radot stresu, bailu un panikas lēkmes, depresiju u.c. Gan sociālie apstākḷi, gan apkārtējā vide ietekmē cilvēka emocionālo stāvokli un psihisko līdzsvaru. Sociālā atbalsta tīkli, sociālā stabilitāte, vides drošība, nodrošinājums ar palīdzību nepieciešamības gadījumā veicina cilvēka psihiskās veselības stabilitāti. Savukārt vides maina, izolācija, zema sociālā loma, vardarbība un karš, vides piesārn,ojums un mainība, dabas katastrofas un tamlīdzīgi faktori rada riskus psihisku traucējumu attīstībai.

Pastāv arī citas slimības, kuru izplatības pieaugumu var saistīt ar klimata pārmaiṇu ietekmi, piemēram, vēzis, kas var attīstīties paaugstināta UV starojuma un citu faktoru ietekmē; sirds un asinsvadu slimības, kuru rašanos veicina paaugstināta vides temperatūra; elpošanas sistēmas slimības, kuras var provocēt izmaiṇas hidroloǵiskajā režīmā; jaunas un nezināmas slimības, kuru izraisītājiem rodas labvēlīgi apstāklıi attīstībai un izplatībai vidē.

Klimata pārmainu ietekmes seku uz cilvēka veselību samazināšanā vai novēršanā liela nozìme ir atbalstam iedzīvotājiem, ko var nodrošināt valsts attieksme pret sabiedrību, piemēram, stiprinot sociālā atbalsta tīklus, uzlabojot vides drošību un veselības aprūpes pieejamību, paaugstinot sabiedrības informētību par riskiem un rīcību ārkārtas situācijās, mazinot ekonomisko nestabilitāti.

\section{Literatūras avoti patstāvīgām studijām}

Baltic Climate (2011) Klimata pārmainu ietekme uz cilvēku veselību Baltijas jūras reǵionā. Pieejams: http://toolkit. balticclimate.org/

DARA (2012) Climate Vulnerability Monitor. A Guide to the Cold Calculus of a Hot Planet. (2 ${ }^{\text {nd }}$ ed.) Madrid: Fundacion DARA Internacional, $340 \mathrm{p}$.

EEA, European Environmental Agency (2015) Climate Change and Human Health. Pieejams: http://www.eea. europa.eu/signals/signals-2015/interviews/climate-change-and-human-health

EKK, Eiropas Kopienu Komisija (2009) Klimata pārmainu ietekme uz cilvēku, dzīvnieku un augu veselību. Komisijas dienestu darba dokuments. Brisele: EKK, 18 lpp.

Franchini M., Mannucci P. M. (2015) Impact on Human Health of Climate Changes. European Journal of Internal Medicine, 26, 1-5.

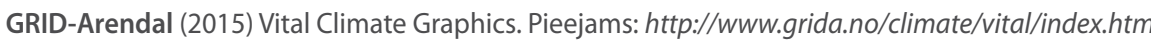

NIH, National Institute of Environmental Health Sciences (2015) Pieejams: http://www.niehs.nih.gov/research/ programs/geh/climatechange/

Patz J. A., Grabow M. L., Limaye V. S. (2014) When it Rains, it Pours: Future Climate Extremes and Health. Annals of Global Health, 80, 332-344.

Smith K. R., Woodward A., Campbell-Lendrum D., Chadee D. D., Honda Y., Liu Q., Olwoch J. M., Revich B., Sauerborn R. (2014) Human Health: Impacts, Adaptation, and Co-benefits. In: Climate Change 2014: 
Impacts, Adaptation, and Vulnerability. Part A: Global and Sectoral Aspects. Contribution of Working Group II to the $5^{\text {th }}$ Assessment Report of the Intergovernmental Panel on Climate Change (Field C. B., Barros V. R., Dokken D. J., Mach K. J., Mastrandrea M. D., Bilir T. E., Chatterjee M., Ebi K. L., Estrada Y. O., Genova R. C., Girma B., Kissel E. S., Levy A. N., MacCracken S., Mastrandrea P. R., White L. L. (eds.)). Cambridge: Cambridge University Press, 709-754.

Thomas F., Sabel C. E., Morton K., Hiscock R., Depledge M. H. (2014) Extended Impacts of Climate Change on Health and Wellbeing. Environmental Science and Policy, 44, 271-278.

US EPA, United States Environmental Protection Agency (2015) Climate Impacts on Human Health. Pieejams: http://www.epa.gov/climatechange/impacts-adaptation/health.html

WHO, World Health Organisation (2015) Climate Change and Hhuman Health. Pieejams: http://www.who.int/ globalchange/en/

Woodward A., Smith K. R., Campbell-Lendrum D., Chadee D. D., Honda Y., Liu Q., Olwoch J., Revich B., Sauerborn R., Chafe Z., Confalonieri U., Haines A. (2014) Climate Change and Health: On the Latest IPCC Report. The Lancet, 383(9924), 1185-1189.

\section{Izmantotie literatūras avoti}

Baltic Climate (2011) Klimata pārmainu ietekme uz cilvēku veselïbu Baltijas jūras reǵionā. Pieejams: http://toolkit. balticclimate.org/

Barrett B., Charles J. W., Temte J. L. (2015) Climate Change, Human Health, and Epidemiological Transition. Preventive Medicine, 70, 69-75.

Bowen K.J., Ebi K.L. (2015) Governing the Health Risks of Climate Change: Towards Multi-sector Responses. Current Opinion in Environmental Sustainability, 12, 80-85.

Cohen G. (2015) Warning: Climate Change is Dangerous to Your Health (in case you were not sure). Health and the Environment, 11(1), 72-73.

DARA (2012) Climate Vulnerability Monitor. A Guide to the Cold Calculus of a Hot Planet. ( $2^{\text {nd }}$ ed.) Madrid: Fundacion DARA Internacional, $340 \mathrm{p}$.

Ebi K. L. (2009) Managing the Changing Health Risks of Climate Change. Current Opinion in Environmental Sustainability, 1, 107-110.

EKK, Eiropas Kopienu Komisija (2009) Klimata pārmainu ietekme uz cilvēku, dzīvnieku un augu veselïbu. Komisijas dienestu darba dokuments. Brisele: EKK, 18 lpp.

Fisk W. J. (2015) Review of Some Effects of Climate Change on Indoor Environmental Quality and Health and Associated No-regrets Mitigation Measures. Building and Environment, 86, 70-80.

Franchini M., Mannucci P. M. (2015) Impact on Human Health of Climate Changes. European Journal of Internal Medicine, 26, 1-5.

WEF, World Economic Forum (2010) Global Risks 2010. Pieejams: http://www.weforum.org/pdf/globalrisk/ globalrisks2010v1/default.htm

GRID-Arendal (2015) Vital climate graphics. Pieejams: http://www.grida.no/climate/vital/index.htm

Jacobs J., Moore S. K., Kunkel K. E., Sun L. (2015) A Framework for Examining Climate-driven Changes to the Seasonality and Geographical Range of Coastal Pathogens and Harmful Algae. Climate Risk Management, 8, 16-27.

McMichael A. J., Butler C. D., Dixon J. (2015) Climate Change, Food Systems and Population Health Risks in their Eco-social Context. Public Health, DOI: 10.1016/j.puhe.2014.11.013, 1-8.

Monaghan A. J., Moore S. M., Sampson K. M., Beard C. B., Eisen R. J. (2015) Climate Change Influences on the Annual Onset of Lyme Disease in the United States. Ticks and Tick-borne Diseases, 6(5), 615-622.

NMPD, Neatliekamās medicīniskās palīdzības dienests (2015) Padomi. Pieejams: http://www.nmpd.gov.lv/nmpd/ padomi/

Patz J. A., Grabow M. L., Limaye V. S. (2014) When it Rains, it Pours: Future Climate Extremes and Health. Annals of Global Health, 80, 332-344.

Perry K. A. (2014) Typhoid Fever, Infectious Diarrhea, Diphtheria, and Pertussis. Pieejams: http://www.slideshare.net/ openmichigan/gemc-nursing2012perryid-typhoidfeverinfectiousdiarrheaoer

Smith K. R., Woodward A., Campbell-Lendrum D., Chadee D. D., Honda Y., Liu Q., Olwoch J. M., Revich B., Sauerborn R. (2014) Human Health: Impacts, Adaptation, and Co-benefits. In: Climate Change 2014: Impacts, Adaptation, and Vulnerability. Part A: Global and Sectoral Aspects. Contribution of Working Group II 
to the $5^{\text {th }}$ Assessment Report of the Intergovernmental Panel on Climate Change (Field C. B., Barros V. R., Dokken D. J., Mach K. J., Mastrandrea M. D., Bilir T. E., Chatterjee M., Ebi K. L., Estrada Y. O., Genova R. C., Girma B., Kissel E. S., Levy A. N., MacCracken S., Mastrandrea P. R., White L. L. (eds.)). Cambridge: Cambridge University Press, 709-754.

SPKC, Slimību profilakses un kontroles centrs (2015) Infekcijas slimïbas. Pieejams: http://www.spkc.gov.lv/

Thomas F., Sabel C. E., Morton K., Hiscock R., Depledge M. H. (2014) Extended Impacts of Climate Change on Health and Wellbeing. Environmental Science and Policy, 44, 271-278.

US EPA, United States Environmental Protection Agency (2015) Climate Impacts on Human Health. Pieejams: http://www.epa.gov/climatechange/impacts-adaptation/health.htm/

Utaaker K. S., Robertson L. J. (2015) Climate Change and Foodborne Transmission of Parasites: A consideration of possible interactions and impacts for selected parasites. Food Research International, 68, 16-23.

Vineis P., Chan Q., Khan A. (2011) Climate Change Impacts on Water Salinity and Health. Journal of Epidemiology and Global Health, 1, 5-10.

WHO, World Health Organisation (2015a) Fact Sheets. Pieejams: http://www.who.int/mediacentre/factsheets/en/

WHO, World Health Organisation (2015b) Ultraviolet Radiation and the INTERSUN Programme. Pieejams: http:// www.who.int/uv/health/en/

Woodward A., Smith K. R., Campbell-Lendrum D., Chadee D. D., Honda Y., Liu Q., Olwoch J., Revich B., Sauerborn R., Chafe Z., Confalonieri U., Haines A. (2014) Climate Change and Health: On the latest IPCC report. The Lancet, 383(9924), 1185-1189.

Izmantotie attēli un tabulas

7.1.Pēc McMichael et al., 2015.

7.2. Pēc Woodward et al., 2014.

7.3. Foto: Jaroslav A. Polák, www.flickr.com/photos/kojotisko/9354308870/;

Ashley Basil, www.flickr.com/photos/28438417@N08/17209912446/.

7.4. Pēc DARA, 2012.

7.5. Foto: I. Djokovic (World Bank), www.flickr.com/photos/worldbank/6839467416/.

7.6. Pēc WEF, 2010.

7.7. Foto: Oxfam International, www.flickr.com/photos/oxfam/2090815555/,

Adrian Snood, www.flickr.com/photos/adriansnood/13509492555/.

7.8. Pēc DARA, 2012; Patz et al., 2014.

7.9. Foto: J. Vazdikis, www.rigasmezi.Iv/lv/mezi/par_meziem fakti_/mezu_apsardziba/?doc=1311.

7.10. Pēc WHO, 2015b.

7.11. Foto: Gatis Diezinš (RJC), www.flickr.com/photos/latvijas_armija/8662034221/.

7.12. Foto: V.T. Polywoda, www.flickr.com/photos/vtpoly/12380443483/.

7.13. Foto: VAAD, www.vaad.gov.Iv/11/section.aspx/3686.

7.14. Pēc Perry, 2014.

7.15. Foto: Hidrotox, hidrotox.daba.Iv/notikumi/vasara_2010.shtml.

7.16.Pēc WHO, 2015; foto: James Gathany (CDC), www.map.ox.ac.uk/explore/mosquito-malaria-vectors/bionomics/ anopheles-freeborni/.

7.17. Foto: CLDN, www.childrenslymenetwork.org/children-lyme/lyme-disease-diagnosis/; Kaldari, www.inaturalist.org/photos/592905; AFPMB, www.flickr.com/photos/49089395@N04/8677331149/.

7.18. Foto:Trees Planet, treesplanet.blogspot.com/2013/05/betula-pendula-silver-birch-warty-birch.html; Eggert, www.eggert-baumschulen.de/products/sv/Laubgehoelze/botanisch-deutsch/C/Corylus-avellana.html.

7.1. tabula: pēc Smith et al., 2014; Woodward et al., 2014.

7.2. tabula: pēc Fisk, 2015.

7.3. tabula: pēc GRID-Arendal, 2015; WHO, 2015. 

8.

Klimats un energeètika 
Enerǵétikas problēmas ir kā daudzdurvju brīnumskapis, kurā glabājas zināšanas par inovatīvu klimata tehnologiju risinājumiem. Svarīgi, lai katrs no mums pareizajā laikā ielūkojas tajā un pasmel no šīs krātuves konkrētajā brīdī nepieciešamo. Enerǵijas patērētājs lieto triju veidu enerǵiju - energoresursus, siltumenerǵiju un elektroenerǵiju, kas atšksirīgi ietekmē klimata pārmaiñas. Par klimata tehnologijām sauc tādu procesu, metožu un paṇēmienu kopumu, kuru izmantošana mazina ietekmi uz klimata pārmaiṇām.

\subsection{Energ̉ētikas ietekme uz klimatu}

Enerǵētika ir viena no svarīgākajām tautsaimniecības nozarēm, bez kuras nav iespējama citu nozaru attīstība. Enerǵētikas sektors ietver dažādus energoresursu izmantošanas posmus:

- energoresursu ieguvi un piegādi energoresursu lietotājam,

- energoresursu enerǵijas pārveidi enerǵijas patērētājam piemērotā enerǵijas veidā - siltumenerǵijā vai elektroenerǵijā,

- siltumenerǵijas un elektroenerǵijas piegādi patērētājiem.

Enerǵijas ražošanai izmanto dažādus energoresursus, kas atšksirīgi ietekmē klimata pārmainas:

- neatjaunojamos fosilos energoresursus - naftas produktus, dabasgāzi, kūdru un ogles, kuru izmantošanas rezultātā atmosfērā nonāk siltumnīcefekta gāzes (SEG), kas būtiski ietekmē klimata pārmainas;

- atjaunojamos energoresursus - hidroenerǵiju, bioenerǵiju, ǵeotermālo, Saules un vēja enerǵiju, vilı̣nu, paisuma-bēguma enerǵiju, un šie energoresursi tiek uzskatīti par klimatam neitrāliem resursiem;

- kodolenerǵiju, kuras izmantošana neietekmē globālās klimata pārmaiṇas.

Globālā līmenī siltumenerǵijas un elektroenerǵijas ražošanai ir liels īpatsvars kopējā siltumnīcefekta gāzu emisiju veidošanās apjomā. Enerǵētika veido ceturto daļu no kopējām SEG emisijām pasaulē (sk. 8.1. att.).

Energotehnoloǵijas enerǵijas ražošanai un iegūtās enerǵijas pārvadei un patēringam veicina tādu tehnoloǵisku risinājumu ieviešanu, kas mazina siltumnīcefekta gāzu koncentrāciju gaisā. Ar energotehnologijām saistītās tiešās SEG ir og̣̦skābā gāze (oglekḷa dioksīds) $\mathrm{CO}_{2}$, metāns $\mathrm{CH}_{4}$ un slāpekḷa(I) oksīds $\mathrm{N}_{2} \mathrm{O}$, kā arī netiešās SEG - tvana gāze CO un sēra dioksīds $\mathrm{SO}_{2}$. Šo gāzu emisijas veidojas galvenokārt fosilo energoresursu degšanas procesā. Kurināmā gaistošo frakciju emisija atmosfērā, kas nav saistīta ar degšanas procesu, piemēram, ir

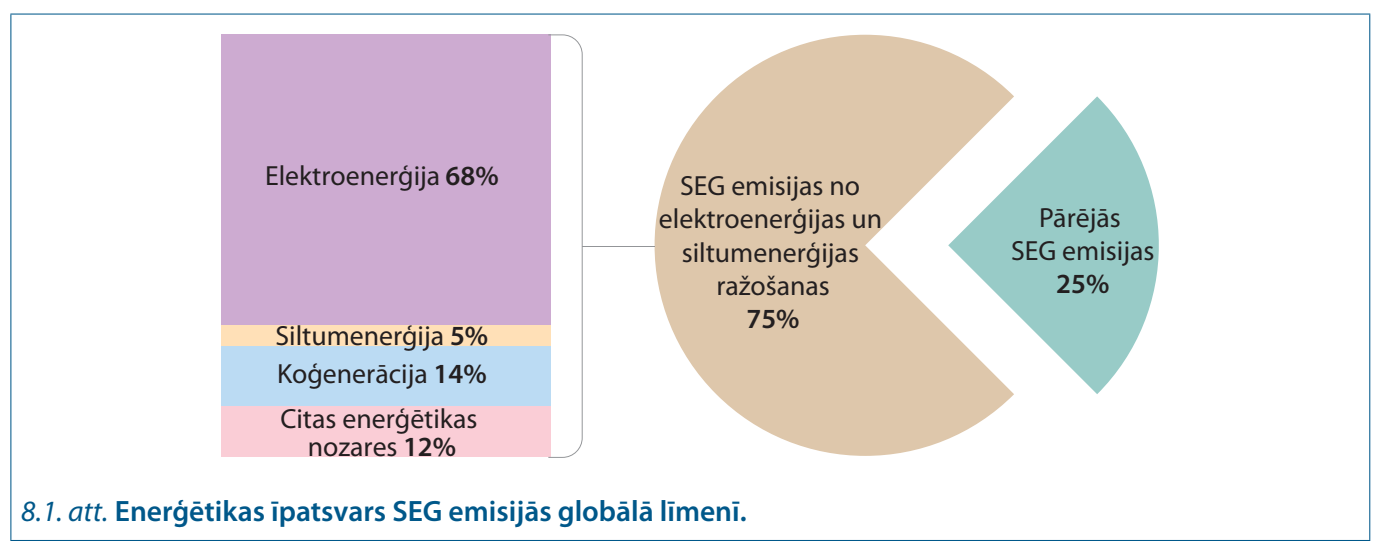


$\mathrm{CH}_{4}$ noplūde no dabasgāzes cauruḷvadu sistēmām vai krātuvēm.

Pastāv trīs reālas iespējas, kā samazināt energotehnoloǵiju izmantošanas rezultātā radušās $\mathrm{CO}_{2}$ emisijas atmosfērā:

- paaugstinot esošo tehnoloǵiju energoefektivitāti vai uzstādot inovatìvas un energoefektīvas iekārtas esošo vietā,

- veicinot atjaunojamo energoresursu izmantošanu, nomainot esošās fosilo energoresursu iekārtas ar alternatīvām energotehnologiijām, kurās rodas mazākas $\mathrm{CO}_{2}$ emisijas,

- uzglabājot $\mathrm{CO}_{2}$ pazemes krātuvēs.

N̦emot vērā straujo inovatīvo tehnologiju ienākšanu ikdienā, jāprognozē arī jaunu, ilgtspējīgu klimata tehnoloǵiju radīšana un izveide. Tās pārsteigs ne tikai speciālistus, bet arī visu sabiedrību, uz kuru gulstas atbildība par klimata pārmaiṇām. Viens no tādiem virzieniem ir $\mathrm{CO}_{2}$ izmantošana kīmisku reakciju un biologisku procesu realizēšanā. Rezultātā $\mathrm{CO}_{2}$ nevis nonāk atmosfērā, bet ir izejviela tautsaimniecībā nepieciešamu produktu ražošanai.

Visus energoefektivitātes paaugstināšanas pasākumus neatkarīgi no tā, kurā enerǵētikas posmā (ražošanā, pārvadē vai patērin,ā) tie tiek īstenoti, uzskata par klimata tehnologiju ieviešanas pasākumiem.

Visprecīzāk klimata tehnologiju ideju ilustrē atjaunojamo energoresursu ieviešanas projekti, kuru īstenošanas laikā fosilos energoresursus nomaina atjaunojamie energoresursi.

Klimata pārmaingas kḷūst par mūsu planētas izdzìvošanas problēmu, tāpēc klimata tehnoloǵiju attīstība notiek strauji un grūti ir prognozēt, kādas inovatīvas tehnoloǵijas un pārsteigumi mūs gaida tuvākajā un tālākajā nākotnē.

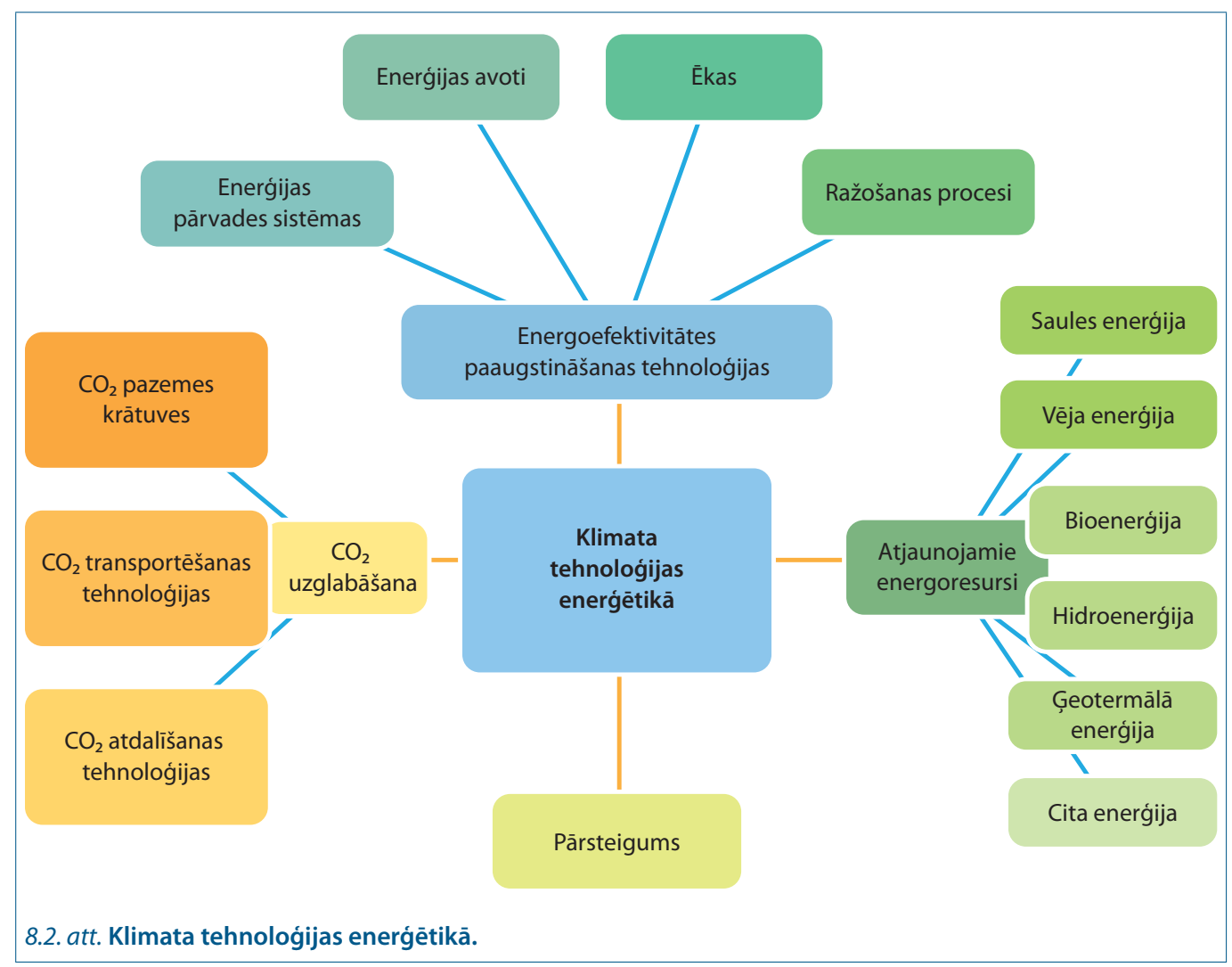




\subsection{Enerğijas lietotājs}

Enerǵijas lietotājs ir tas, kurš nosaka, kāda enerǵija tam ir nepieciešama noteiktā vietā un noteiktā laikā. Tāpēc enerǵijas pieprasījumam ir ne tikai jaudas un kvalitātes, bet arī teritorijas un laika dimensija. Enerǵijas patērētāja pieprasîjums un tā izmaiñas būtiski ietekmē ne tikai energétikas attīstību, bet arī siltumnīcefekta gāzu emisiju apjomus, kas katru stundu, mēnesi, gadu nonāk apkārtējā vidē.

Enerǵijas patērētāja pieprasījumu pēc kvalitātes un jaudas novērtē gan ar enerǵijas patēriṇu un tā parametriem, gan arī ar lietotāju raksturojumu un tehnologiskajiem risinājumiem. Energopatērētāji atrodas vismaz piecos tautsaimniecības sektoros:

- mājsaimniecībās enerǵija galvenokārt tiek patērēta siltuma nodrošināšanai ēkās;

- rūpniecībā - galvenokārt tehnologisko iekārtu darbināšanai, kā arī siltuma nodrošināšanai ēkās;

- pakalpojumu sniegšanā enerǵija galvenokārt tiek patērēta siltuma nodrošināšanai ēkās, ka arī biroja un sadzìves iekārtu darbībai;

- lauksaimniecībā - galvenokārt siltuma nodrošināšanai ēkās un tehnoloǵisko iekārtu darbībai;

- transportā energoresursu patērētāji ir transporta līdzekḷi.

Energeētikas ietekmi uz klimata pārmain̄ām, galvenokārt, nosaka enerǵijas patērētājs, kuram vienmēr ir iespēja veikt energoefektivitātes paaugstināšanas pasākumus, lai ietaupītu enerǵiju un naudas līdzekḷus, kā arī samazinātu ietekmi uz klimata pārmaiṇām.

\subsubsection{Energopārvaldība un energoefektivitāte}

Energopārvaldība ir energiijas patērētāja darbība ar mērksi mazināt enerǵijas patērinu, nepasliktinot darbības parametrus un komfortu. Energoefektivitātes paaugstināšanas pasākumi ir dažādi: vienus ir iespējams realizēt ar mazām investīcijām, bet citiem ir nepieciešamas lielas investīcijas. Tas attiecas uz katru enerǵijas patērētāju, kuram ir iespējams izvēlēties prioritāros pasākumus. Enerǵētikas speciālisti dod priekšroku pasākumiem bez lielām sākotnējām investīcijām, kuru îstenošana ir saistīta ar energopārvaldības ieviešanu.

Îstenojot energopārvaldības idejas, ir iespējams iegūt salīdzinoši lielus ietaupījumus. Energopārvaldības ieviešana Latvijā ir devusi iespēju pārliecināties par lieliskiem energoietaupijjuma rezultātiem, kas vienlaikus rāda, ka varam kḷūt videi un klimatam draudzīgi. Labo piemēru ir daudz, bet viss ir atkarīgs no katra cilvēka uzvedības paradumiem un domāšanas.

Zinātnieki ir veikuši pētījumus, lai noskaidrotu cilvēku paradumus energoresursu lietošanā. Enerǵijas lietotāju kopu var iedalīt trijās grupās.

- Pirmā cilvēku grupa energoefektivitāti saista ar pavisam vienkāršu rīcību veikšu konkrētas darbības un ietaupīšu līdzekḷus. Tas risina problēmu tikai daḷēji, jo ir arī cilvēki, kuriem tas vispār nav svarīgi, vai arī kuri uzskata, ka ietaupījums ir salīdzinoši neliels.

- Otru grupu aptaujāto var dēvēt par hedonistiem, kuri vienmēr skatās, kā rīkojas kaimiņi vai pazingas. Un līdz ar to viniem nepieciešams sevi apliecināt, pārspējot kaiminu. Tas veicina konkurenci un sacensību, mudinot cilvēkus būt vēl energoefektīvākiem savā ikdienā nekā kaiminsš.

- Trešā grupa ir cilvēki, kuriem ir būtisks "zalıis" dzīvesveids. Viṇiem ir svarīga vides aizsardzība, jo viṇi ir daudz interesējušies par šo tēmu un zina, kā energoefektīvs dzīvesveids mazina vides piesārṇošanu un klimata pārmaiṇu negatīvo ietekmi.

\subsubsection{Enerǵijas patērētāju klimata tehnoloğijas}

Enerǵijas lietotāju klimata tehnoloǵijas ir visas iekārtas, ierīces un materiāli, kas tiek izmantoti, lai samazinātu enerǵijas patēriṇu. 


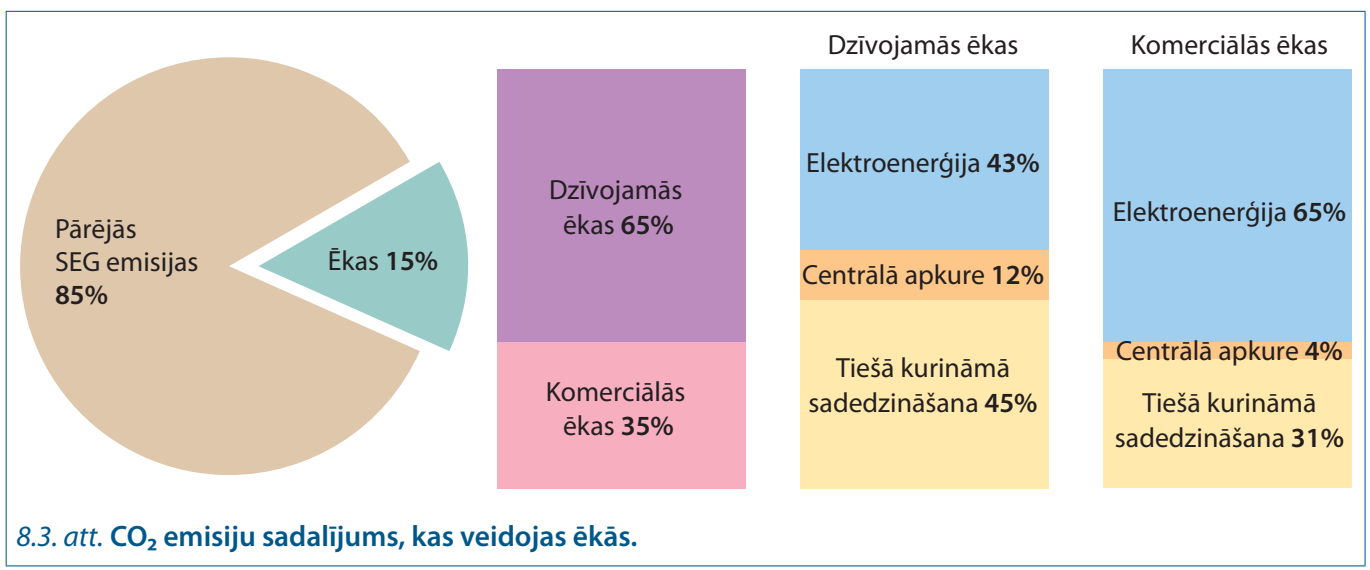

\subsubsection{1. Ëkas}

Ēkas kā enerğijas patērētājs ietekmē klimata pārmaiñas. Ēkas veido septīto dalı no kopējām SEG emisijām pasaulē. Šobrīd ne tikai Eiropā, bet arī Latvijā viens no lielākajiem enerǵijas patērētājiem ir mājsaimniecības, kas veido $65 \%$ no kopējā enerǵijas patēriṇa.

\section{Siltumenerğijas lietotāji èkās}

Ēkas siltumenerǵijas patērinš ir atkarīgs no dažādiem faktoriem: klimata, ēkas atrašanās vietas un novietojuma, mājokḷa fizikālajām īpašỉbām, iekārtu un sistēmu efektivitātes, īpašnieka un iedzīvotāju rīcības. Ēku enerǵijas patēriņu un ietekmi uz vidi nosaka ēkas tehniskie raksturlielumi (ēkas forma un apjoms, izmantotie materiāli, konstruktīvais risinājums, ēkas gaisa caurlaidība) un ēkas funkcijas (uzturētais mikroklimats telpās, ēkas izmantošanas ilgums, lietotās iekārtas un ēkā veiktās darbības).

Ēku klimata tehnoloǵiju lietojums pēdējā laikā ir izvērties ne tikai par ēku energoefektivitātes pasākumu īstenošanas vietu, bet arī par teritorijas labiekārtošanas un vides ainavas sakārtošanas jautājumu.

Siltinot ēkas, tajās ne tikai samazinās siltumenerǵijas patērinnš, bet tās iegūst arī jaunu veidolu, pieaug nekustamā īpašuma vērtība un vienlaikus èku iedzīvotājiem ir iespēja dzīvot sakārtotā vidē.

Ar ēku siltumenerğijas patērina indikatora palīdzību, kas parasti ir īpatnējais ikgadējais siltumenerǵijas patēriņš uz vienu kvadrātmetru apsildāmās platības $\left(\mathrm{kWh} / \mathrm{m}^{2}\right.$ gadā), ir iespējams ēkas sagrupēt četrās lielās grupās:

- ēkas ar zemu energoefektivitāti, kas patēerē vairāk par $85 \mathrm{kWh} / \mathrm{m}^{2}$ gadā;

- būvnormatīviem LBN 0902-01 atbilstošas ēkas, kas patērē $85 \mathrm{kWh} / \mathrm{m}^{2}$ gadā un mazāk;

- zema enerǵijas patēriṇa ēkas, kas patērē $45 \mathrm{kWh} / \mathrm{m}^{2}$ gadā un mazāk;

- pasīvās ēkas, kas patērē $15 \mathrm{kWh} / \mathrm{m}^{2}$ gadā un mazāk.

Vidējais siltumenerǵijas patērinš̌ ēkās Latvijā parāda, ka zema enerǵijas patēriṇa ēku ietekme uz klimata pārmain̄ām ir četras reizes mazāka nekā vidēja siltumenerǵijas patērina ēkām.

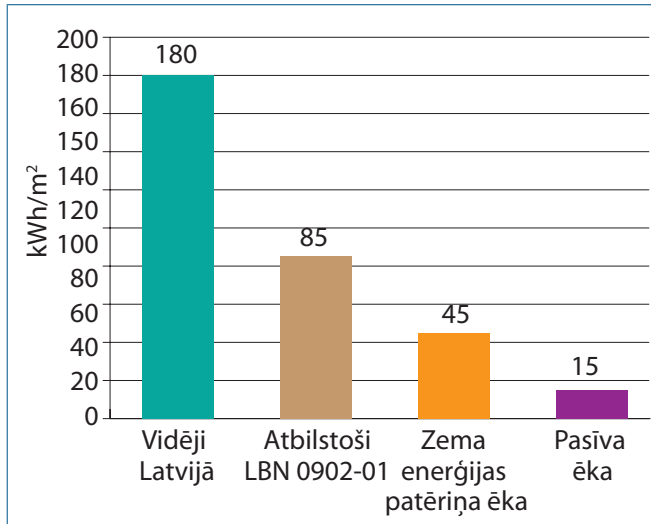

8.4. att. Siltumenerǵijas patēriṇa salīdzinājums. 


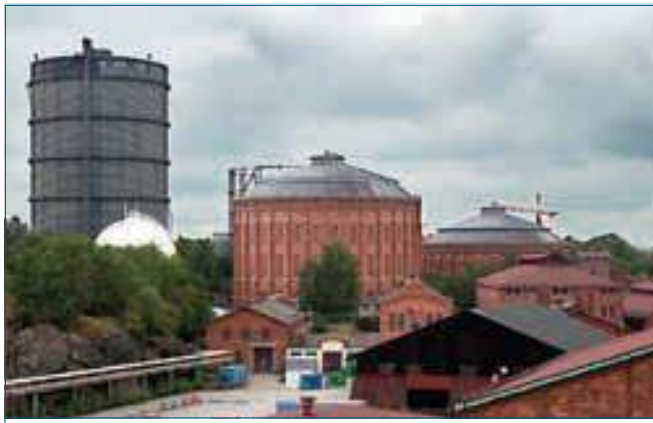

8.5. att. Ėku lietojuma maiṇa Stokholmā Gasworks teritorijā.

Cits risinājums ir vecu rūpniecisko ēku "iedzīvināšana”, tās sakārtojot jaunu darbību veikšanai. Piemēram, Eiropas pilsētās gāzes glabātuves pamazām tiek pārvērstas par koncertzālēm, ekskluzīvu dzīvokḷu mājām, viesnīcām un citām daudzfunkcionālām ēkām. Parasti ēkas lietojuma maiña tiek plānota un projektēta tā, lai vienlaikus nodrošinātu arī enerǵijas patēriṇa samazinājumu.

Prakse liecina, ka Latvijā esošo rūpnīcu ēku ippatnējais siltumenerǵijas patēriņš ir liels, jo bieži ražošanas tehnologijas ir izvietotas vecajās ražotnēs, kuras pielāgotas jaunu produktu ražošanai, un šo ēku platība ir lielāka nekā nepieciešams. Šajos gadījumos klimata tehnoloǵijas ir saistītas ne tikai ar siltināšanas materiālu izvēli un inženiertehnisko komunikāciju rekonstrukciju, bet arī ar telpu racionālu izmēru nodrošināšanu, piemēram, starpsienu izveidi un ventilācijas sistēmas uzstādīšanu lielas rūpnīcas ēkā.

\section{Elektroenerğijas lietotāji ēkās}

Plašs ir arī ēku elektroenerǵijas lietotāju klimata tehnologiiju klāsts visās elektroierīču lietojuma grupās.

- Apgaismes tehnologijas: pēdējo desmit gadu laikā gaismas diodes jeb LED spuldzes ne tikai kardināli samazina enerǵijas patēriṇu apgaismojuma nodrošināšanai, bet arī maina izpratni par iespējām būtiski mazināt ietekmi uz klimata pārmaiñām katrā mājā, birojā, veikalā, rūpniecības uzṇēmumā un ielās.
- Sadzīves elektroierīces: kaut arī augstākās energoefektivitātes A klases vel̦as un trauku mazgāšanas mašīnas, ledusskapji, saldētavas, mūzikas centri, indukcijas elektroplītis un citas energoefektīvas iekārtas ir kḷuvušas ikdieniškas, katru gadu zinātniski pamatotas inovācijas sniedz jaunus klimata tehnoloǵiju risinājumus, piemēram, ledusskapjiem ir jau sakrājušies trīs plusi pie A klases marḳējuma, kas liecina, ka gada elektroenerǵijas patēriņš ir samazinājies no $500 \mathrm{kWh} /$ gadā $(\mathrm{A}+)$ līdz 170 kWh/gadā (A+++).

- Biroju elektroiekārtas: arī datori, monitori, kopēšanas iekārtas, serveri un citas elektroiekārtas būtiski mainās gadu gaitā elektroenerǵijas patēriṇa samazinājuma virzienā, piemēram, pēdējos gados ražota LED ekrāna izmantošana samazina enerǵijas patērinuu par $80 \%$.

- Elektrodzinējos, kas uzstādīti sūkṇu, ventilatoru un citu iekārtu piedziņai, visnoderīgākā iekārta siltumnīcefekta gāzu emisiju samazināšanai ir frekvenču pārveidotājs, kas samazina elektroenerǵijas patēriṇu, samazinoties slodzei.

- Siltuma sūkṇi: no siltumnīcefekta gāzu emisiju samazināšanas viedokḷa to nākotne saistās ar laiku, kad fosilo elektroenergíju aizvietos atjaunojamo resursu enerǵija (bioenerǵija, Saules un vēja enerǵija.

\subsubsection{Ražošanas procesi}

Rūpniecības uzñēmumu ražošanas procesos klimata tehnologijas ir sastopamas trīs veidu iekārtās: kurināmā sadedzināšanas iekārtās, siltumenerǵijas ieguves iekārtās un elektroenerǵijas izmantošanas iekārtās.

Lielākais siltumnīcefekta gāzu emisiju daudzums gaisā nonāk no kurināmā sadedzināšanas iekārtām: katlu agregātiem, krāsnīm, kurtuvēm un citām iekārtām. SEG samazinājums ir iespējams, gan nomainot fosilo kurināmo ar bioenergoresursiem, gan arī paaugstinot iekārtu darbības efektivitāti.

SEG emisiju samazinājums siltumenerǵijas izmantošanas iekārtās: siltummaiṇos, autoklāvos, vannās, karstā ūdens un ventilācijas 
sistēmās un citās tehnologiiskās iekārtās un sistēmās ir sasniedzams, ieviešot jaunas modernākas un energoefektīvākas tehnologijas.

SEG samazinājums elektroenerǵijas izmantošanas iekārtās: elektrosildītājos, krāsnīs, saldēšanas iekārtās, dzirnavās, sūkṇos, transporta iekārtās un citās specifiskās tehnologiskās iekārtās vairāk ir orientēts uz katras ražošanas nozares labāko pieejamo tehnoloǵisko risinājumu ieviešanu.

\subsection{Atjaunojamo energoresursu tehnologiijas}

Visas atjaunojamo energoresursu tehnologijas ir klimata tehnologijas, jo to izmantošana neietekmē klimata pārmaiñas. Tiek piennemts, ka SEG emisijas šīm tehnologijām, arī biomasas degšanas tehnoloǵijām, ir vienādas ar nulli.

\subsubsection{Bioenerǵija}

Jēdziens bioenerǵija ir saistīts ar plašu bioenergoresursu diapazonu:

- biomasa dažāda veida atkritumos, piemēram, bioloǵiski noārdāmā frakcija;

- rūpniecības, sadzives un lauksaimniecības atkritumi (ieskaitot augu un dzìnnieku izcelsmes vielas);

- mežsaimniecības un līdzīgu nozaru ražošanas atlikumi;

- atkritumu poligonu un notekūdenu attīrīšanas iekārtu gāzes un biogāze.

\subsubsection{Bioenergoresursi}

Bioenerǵiju iegūst no bioloǵiskas izcelsmes avota - gan augu valsts produktiem, piemēram, kokiem, krūmiem, graudaugiem, niedrēm, algéēm, gan dzīvnieku valsts produktiem, piemēram, taukiem, atkritumiem. Bioenerǵija kā atjaunojamais enegoresurss nodrošina aptuveni $10-15 \%$ no pasaules primārā enerǵijas pieprasījuma.

Biomasa ir viela, kuru veido galvenokārt ogleklis, ūdeņradis, skābeklis un slāpeklis. Augu biomasa sastāv no trim galvenajiem komponentiem (celulozes, hemicelulozes un lignīna), kam jāpievērš uzmanība, analizējot dažādu tipu augu biomasu. Celuloze un hemiceluloze ir biomasas struktūru stiprinošās šksiedras, bet lignīns šìs šksiedras satur kopā. Biomasa var būt arī blakusprodukts, piemēram, lauksaimniecības kultūrām, mežu izejmateriāliem, cietajiem sadzīves atkritumiem, mēslojumam, dūṇām.

Bioenergoresursus klasificē, izmantojot dažādus kritērijus: pēc to izcelsmes, sastāva, izmantošanas iespējām utt. Atkarībā no katra bioenergoresursu komponenta (lignīna, celulozes, hemicelulozes) sastāva izškirami dažādi biomasas veidi.

Terminu "lignocelulozes biomasa" bieži izmanto, aprakstot šķiedrainus materiālus, kas galvenokārt sastāv no celulozes un lignīna, kuri ir savstarpēji saistīti vienotā struktūrā. Šì biomasas tipa sastāvā esošajiem proteīniem, sāliem, skābēm un minerāliem ir zema koncentrācija. Tāpēc lauksaimnieciskas izcelsmes izejvielas pārtikas ražotāji dažreiz neizmanto kā rūpniecisku izejvielu.

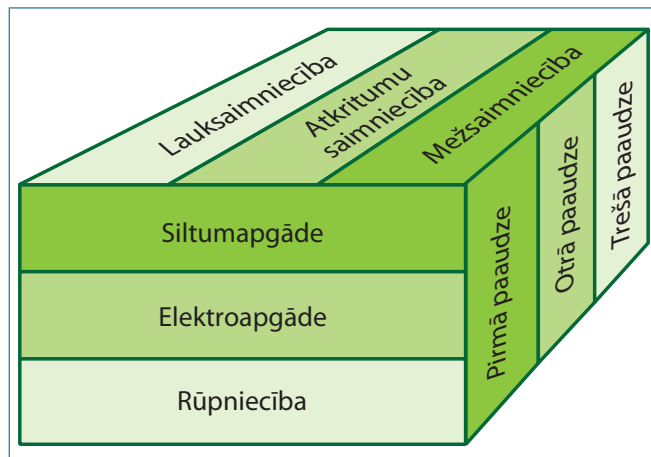

8.6. att. Bioenerǵijas ieguves un izmantošanas puduris. Bioenerǵijas ieguves un izmantošanas puduris aptver bioresursu avotus (augšējā skaldne), bioresursu pārstrādes tehnoloǵijas (sānu skaldne) un enerǵijas patērētāja avotus (priekšējā skaldne). 
Lignocelulozes biomasas izmantošanā jārēkinās ar sešām lignocelulozes biomasas sastāvdalıām:

- celulozi,

- hemicelulozēm,

- lignīnu,

- pelniem,

- ekstraǵentiem,

- ūdeni.

Celuloze ir galvenā augu šūnu sastāvdal̦a. Tās molekulas veidotas no $\beta$-D-glikopiranozes atlikumiem. Tā arī ir biomasas pamatsastāvdaḷa.

Hemicelulozes sastāv no dažādiem monosaharīdiem un hidrolizējas vieglāk nekā celuloze.

Lignīns ir augu valsts otrs izplatītākais biopolimērs pēc celulozes. Lignīns ir termiski izturīgāks nekā celuloze un hemicelulozes. Dažādu biomasas veidu sastāvā ir atškkirīgi lignīnu tipi, kuru struktūra un uzbūve atšksiras. Piemēram, mīkstkoka, cietkoka, salmu un zāles sastāvā esošajam lignīnam ir dažāds sastāvs.

Pelni ir ciets atlikums, kas rodas biomasas degšanas rezultātā. Pilnīgi sadegušu pelnu saturā nav oglekḷa un ūdeñraža. Pelnos ir nedaudz slāpekḷa, sēra vai skābekḷa savienojumu, bet ir galvenokārt biomasas sastāvā esošās minerālvielas - dažādi alumīnija, magnija, nātrija vai kālija savienojumi.

Galvenās lignocelulozes biomasas izejvielas:

- lauksaimniecības izejvielas,

- mežsaimniecības izejvielas,

- "energétisko augu" kultūras,

- organiskie atkritumi.

Bioenergoresursu veidi atšksiras pēc to izmantošanas. Tos izlieto tiešajai siltumenerǵijas

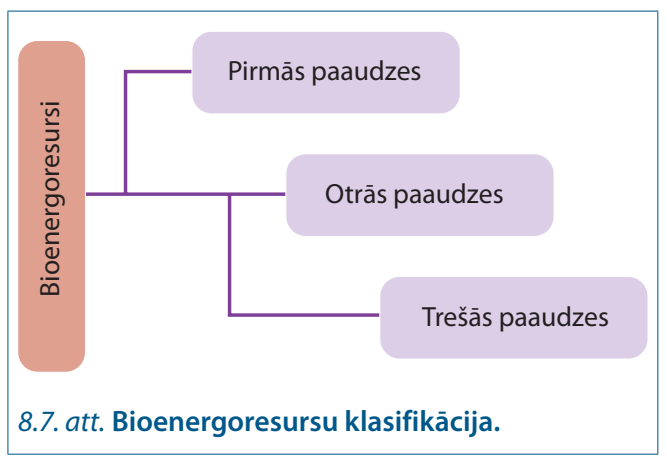

un elektroenerǵijas ražošanai, dedzinot katlu kurtuvēs, vai arī starpproduktu ražošanai, kas paver plašākas bioenergoresursu izmantošanas iespējas. Tādā gadījumā notiek bioenergoresursu pārveide biodegvielā, kuru tālāk izmanto enerǵētikā, rūpniecībā, lauksaimniecībā, mājsaimniecībā un transportā.

Pirmās paaudzes bioenergoresurss ir biomasa, kas iegūta no lauksaimniecības kultūrām, ko tradicionāli audzē cilvēku pārtikai un dzīvnieku barībai. Parasti no šīs biomasas iegūst škidru un gāzveida biodegvielu. Galvenie produkti, kas pašlaik pieejami pasaules tirgū, ir bioetanols, biobutanols, biodīzel̦degviela un biometāns.

Otrās paaudzes bioenergoresursi tiek ražoti no izejvielām, kuras nevar tieši lietot pārtikas ražošanā. Šìs biomasas izejvielas sauc par lignocelulozes biomasu, kas ietver, piemēram, enerǵētisko koksni, ātraudzīgos krūmus, lapas, zāli, salmus. Lignocelulozes biomasas tipa izmantošana otrās paaudzes biodegvielas ražošanā minimāli ietekmē pārtikas un šksiedru nozari, un tas praktiski izslēdz savstarpējo degvielas un pārtikas sektora konkurenci. Otrās paaudzes biokurināmā ražošanā ir vairākas priekšrocības salīdzinājumā ar fosilo kurināmo un pirmās paaudzes biodegvielu. Būtiskākā otrās paaudzes biodegvielas priekšrocība ir tā, ka tiek novērsta konkurence starp biodegvielas un pārtikas ražošanu. Otrās paaudzes biodegvielas ražošana un izmantošana veicina siltumnīcefekta gāzu (SEG) samazinājumu atmosfērā. Salīdzinājumā ar pirmās paaudzes biodegvielām biomasas audzēšanai ir nepieciešamas mazākas zemes platības, turklāt pieeja šiem resursiem tiek nodrošināta visa gada garumā, ja nav augu veǵetācijai nepiemērotas sezonas.

Trešās paaudzes biodegvielu var ražot no tādiem biomasas veidiem, kuri nekonkurē ar pārtikas un šksiedru sektoru. Par avotu trešās paaudzes biodegvielas ražošanā uzskatāmas algges. Svarīgākais ir alğu augstais eḷlas saturs un plašā sugu daudzveidība, kas padara alǵges par plaši pieejamu un viegli kultivējamu biomasas veidu. Alǵēm piemīt ātra masas pieauguma spēja, to audzēšanai nav vajadzīgas 
iekoptas platības un augsta ūdens kvalitāte. To ieguvei nepieciešami tikai trīs avoti:

- Saules gaisma - fotosintēzes procesa nodrošinājumam, kas ir alı́gu augšanas pamatā,

- $\mathrm{CO}_{2}$ - oglekḷa avota nodrošināšanai augšanas procesa laikā,

- barības vielas - slāpekḷa un fosfora savienojumi.

Ir vērojama strauja trešās paaudzes bioenergoresursu attīstība, un var secināt, ka otrās paaudzes biodegviela nav vienīgais avots, ar ko aizstāt fosilo degvielu un novērst konkurenci ar pārtikas ražošanu.

\subsubsection{Bioenergoresursu pārstrādes tehnoloǵijas}

Bioenergoresursu pārstrādes rezultātā tiek ražoti produkti, kuri tiek izmantoti dažādos tautsaimniecības sektoros: energètikā, transportā, mājsaimniecībās, pakalpojumu sniegšanā, rūpniecībā un lauksaimniecībā.

Bioenergoresursu pārstrādes tehnologískos produktus var iedalīt pēc dažādām pazìmēm: gan pēc agregātstāvokḷa un produktu fizikālajām vai k̦īmiskajām īpašībām, gan produktu avota, gan arī pēc to izmantošanas iespējām. Visprecīzāk bionergoresursu produktu klasifikāciju atspoguḷo iedalījums trīs grupās.

- Cietā biomasa tehnologisko produktu ražošanai, kuru izmanto, piemēram, kalı,ku apdedzināšanas procesā:

- koksnes šķelda, briketes un granulas, malka,

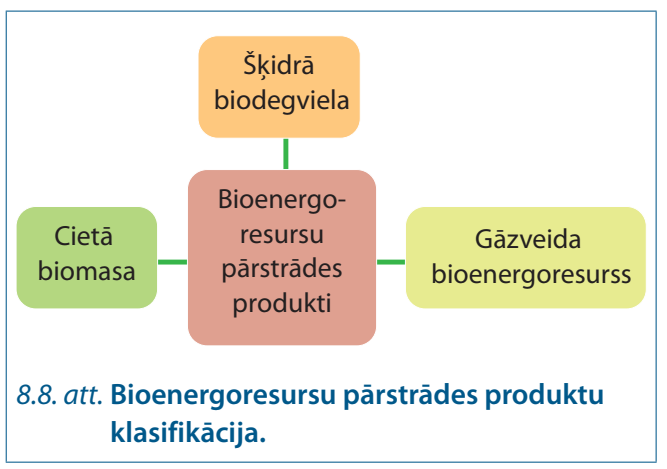

- salmi, salmu granulas,

- atkritumi, piemēram, lietotas riepas, no atkritumiem atvasināts kurināmais (NAIK),

- kokogles.

- Gāzveida energoresurss elektroenerǵijas un siltumenerǵijas ražošanai koǵenerācijas stacijās, elektrostacijās un katlu mājās, transporta līdzeklıs:

- biogāze,

- sintēzes gãze.

- Šksidrā degviela transporta līdzekḷiem, elektroenerǵijas un siltumenerǵijas ražošanai elektrostacijās un koǵenerācijas stacijās:

- biodīzel̦degviela,

- bioetanols,

- biobutanols.

Visu triju veidu bioenergoresursus iespējams izmantot energosektorā elektroenerǵijas, siltuma un aukstuma ražošanai, patērētāju vajadzību nodrošināšanai visās tautsaimniecības nozarēs.

\section{Cietais biokurināmais}

Visbiežāk lietotais bioenergoresursu pārstrādes produkts ir cietais biokurināmais. Siltumenerǵijas ražošanai mājsaimniecībās krāšnu, katlu un kamīnu kurtuvju degšanas procesos vēl joprojām izmanto malku. Tomēr aizvien biežāk tiek izmantoti koksnes škeldas, granulu, brikešu un citu bioenergoresursu pārstrādes produkti,

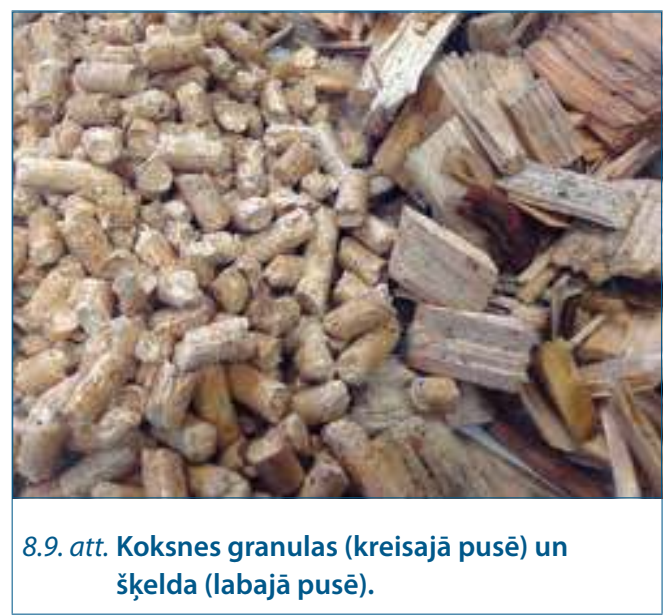


kurus iegūst, koksni žāvējot un mehāniski apstrādājot. Cits biomasas pārstrādes produkts ir kokogles, kuras iegūst pirolīzes procesā.

\section{Škidrā biodegviela}

Bioetanolu izmanto kā aizstājēju tradicionālajam benzīnam iekšdedzes dzinējos. Tas tiek ražots no graudaugu kultūrām un cukuru saturošiem augiem. $80 \%$ no pasaules bioetanola tiek saražoti no kukurūzas un cukurniedrēm. Pašlaik bioetanols ir dominējošais pirmās paaudzes biodegvielas veids. Tomēr pamazām bioetanola ražotnes pārkārtojas uz otrās paaudzes tehnologijām ar nepārtikas bioresursu izmantošanu. Pienemts, ka bioetanola izmantošana iekšdedzes dzinējos samazina siltumnīcefekta gāzu emisijas par 33-46\%.

Biodīzel̦degviela ir dīzel̦degvielai līdzīgas kvalitātes šksidrā degviela, ko iegūst no biomasas vai izmantotajām pārtikas ellıām. Arī biodīzel̦degvielas ražotnes aizvien vairāk pārkārtojas, lai aizvietotu saulespuķu un rapšu sēklas un citas pārtikā lietojamas izejvielas ar nepārtikas bioresursiem. Tādējādi notiek lēna pāreja no pirmās paaudzes uz otrās paaudzes bionergoresursu ražotnēm. Biodīzel̦degvielas priekšrocības salīdzinājumā ar cieto biomasu ir to transportēšanas un uzglabāšanas atvieglotas iespējas (līdzīgi kā naftas produktiem), kā arī iespēja to izmantot tvaika katlos, gāzes turbīnās un mazas un vidējas jaudas dīzelıdzinējos ar augstāku energoefektivitāti, ražojot elektroenerǵiju un siltumenerǵiju. Biodīzel̦degvielas galvenās priekšrocības ir šādas:

- degšanas procesā neveidojas sēra oksīdu emisijas. Ja arī $\mathrm{SO}_{\mathrm{x}}$ emisijas rodas (atkarībā no biodīzeḷdegvielas kvalitātes, kas savukārt ir atkarīga no biomasas izejvielas kvalitātes), to lielumi nepārsniedz $\mathrm{SO}_{\mathrm{x}}$ emisiju normatīvos un standartos noteiktās robežvērtības,

- degšanas procesā veidojas relatīvi zemas $\mathrm{NO}_{\mathrm{x}}$ emisijas. Pieñemts, ka biodīzel̦degviela rada par $\approx 50 \%$ zemākas $\mathrm{NO}_{\mathrm{x}}$ emisijas salīdzinājumā ar fosilajām degvielām, kas tiek izmantotas gāzu turbīnu darbināšanai, kā arī salīdzinājumā ar dīzel̦degvielu, kas tiek izmantota stacionārajos dīzel̦motoros,

- biodīzel̦degvielu uzskata par SEG neitrālu degvielu, kam siltumnīcefekta gāzu emisijas ir vienādas ar nulli. Ir pieñemts, ka biomasa un no tās iegūtās degvielas ir SEG neitrālas. SEG netiek iekḷautas arī $\mathrm{CO}_{2}$ emisijas, kas rodas pašas biomasas un pēc tam arī iegūtās biodīzel̦degvielas izmantošanas un transportēšanas laikā.

- biodīzel̦degviela ir atjaunojama un vietēji ražota degviela. Valstī, kur ir pieejami lieli biomasas vai organisko atkritumu daudzumi, biodīzel̦degvielas ražošana pirolīzes procesā var samazināt valsts atkarību no fosilās degvielas importa. Salīdzinājumā ar citām no biomasas iegūtām degvielām, biodīzel̦degvielu var uzglabāt un transportēt līdzīgi kā naftas produktus. Tas kopumā palīdz izlīdzināt energíjas pieprasījumu un energíjas sadali. Viena no galvenajām biodīzel̦degvielas priekšrocībām ir tā, ka to var izmantot jebkurā laikā un vietā, kur līdz šim lietoja gāzveida vai šksidro kurināmo.

\section{Biogāze}

Biogāze ir atjaunojams energoresurss. Biogāze ir degoša gāze, kas sastāv galvenokārt no metāna $\mathrm{CH}_{4}$ un oglekḷa dioksīda $\mathrm{CO}_{2}$. Tā tiek iegūta anaerobās fermentācijas procesā. Anaerobā fermentācija ir bioḳimisks process, kura laikā dažādi organiskie substrāti (piemēram, augu biomasa, kūtsmēsli un virca, organiskie atkritumi) baktēriju ietekmē anaerobā (bezskābekḷa) vidē sadalās, veidojot biogāzi un pārstrādātu substrātu jeb digestātu. Biogāzes ražošanu ietekmē gan anaerobās fermentācijas procesa parametri, gan biogāzes stacijas darbināšanas parametri.

Anaerobā fermentācija ir sarežgiīts mikrobiologisks process, kas noris bez skābekḷa klātbūtnes. Pamatā procesu veic baktērijas, bet procesā piedalās arī augstākas trofiskās grupas, piemēram, protozoji (vienšūn,i) un anaerobās sēnes. Mikrobu populācija satur dažādu tipu nepieciešamās anaerobās baktērijas un 


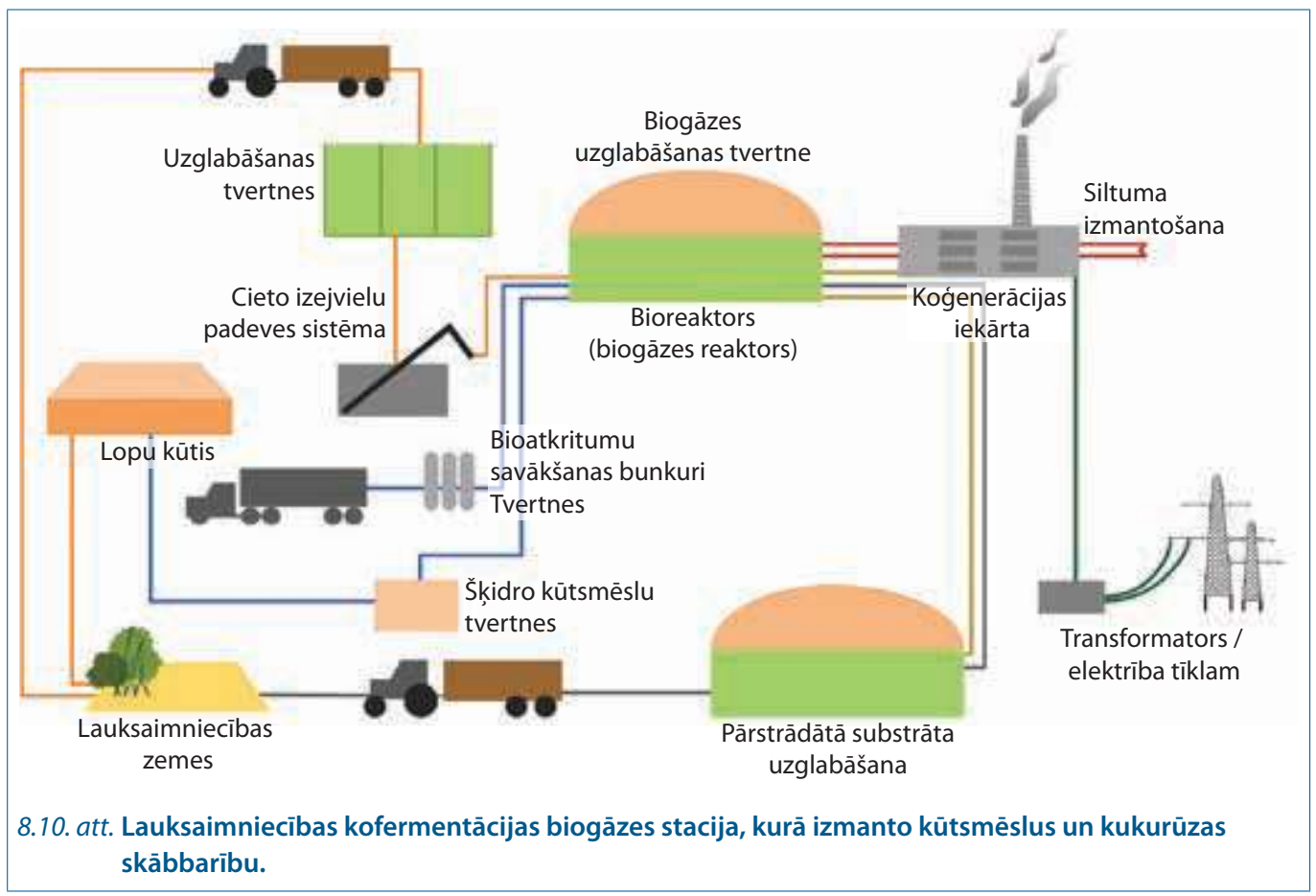

fakultatīvās (tādas, kas spēj dzīvot gan aerobos, gan anaerobos apstākḷos) baktērijas.

Procesa laikā organiskās izejvielas tiek pārveidotas digestātā un biogāzē. Biogāzes galvenās sastāvdaḷas ir divas: $\mathrm{CH}_{4}(50-70 \%)$ un $\mathrm{CO}_{2}$ (30-50\%). Biogāzes sastāvā sastopams arī sērūdeñradis $\left(\mathrm{H}_{2} \mathrm{~S}\right)$, un tā koncentrācija ir atkarīga no izejvielu sastāva. No kūtsmēsliem iegūtā biogāzē $\mathrm{H}_{2} \mathrm{~S}$ saturs ir augstāks nekā biogāzē, kas iegūta no augu biomasas.

Biogāzes ražošanas tehnologisko iekārtu kopums ir vienota sistēma, kura ietver dažādus izejvielu avotus (kūtsmēslus, organiskos atkritumus un dažreiz arī zal̦o biomasu, piemēram, kukurūzu), biogāzes reaktorus, biogāzes rezervuārus, digestāta bloku un biogāzes izmantošanas iekārtas enerǵijas ražošanai.

Biogāzes ražošanas blakusprodukts ir digestāts jeb pārstrādātais substrāts, ko izmanto kā augsnes mēslojumu. Anaerobās fermentācijas procesā rodas maz siltuma atšksirībā no aerobās (skābekḷa klātbūtnē notiekošās) sadalīšanās, piemēram, kompostēšanas.

\subsubsection{Bioenerǵijas energoavoti}

Lai nodrošinātu siltumenerǵijas un elektroenerǵijas patērētājam nepieciešamo enerǵiju, energoavotos uzstāda energotehnoloǵiju iekārtas, kurās energoresursu kūmiskā enerǵija pārvēršas siltumenerǵijā, un tās ir izveidotas tā, lai šì pārveide notiktu ar minimāliem enerǵijas zudumiem. Tiek pien,emts, ka bioenergijas energoavoti atšksiras no fosilajiem energoavotiem ar to, ka par kurināmo izmanto bioenergoresursus, tādējādi samazinot SEG emisijas līdz nullei.

Bioenerǵijas energoavotos uzstādītās energotehnologíjas iekārtas atšksiras gan konstruktīvi, gan ar uzstādītajām jaudām un energonesējiem, gan arī ar darbināšanas parametriem. Bioenergotehnologiju iekārtu galvenā sastāvdal̦a ir kurtuve (degkamera), kurā notiek degšanas process. To izmanto dažādu konstrukciju iekārtās:

1) krāsnīs, kuras ir atseviškss neliels siltumavots, un tās izmanto ēkās siltuma nodrošināšanai telpās, turklāt tās lieto arī rūpnieciskās ražotnēs, piemēram, maizes ceptuvēs; 
2) kamīni arī ir atsevišķi nelieli siltuma avoti, kurus lieto telpu apsildei, vienlaikus iegūstot arī estētisku baudījumu;

3) katli var būt gan atseviš̌si, gan lielu sistēmu siltuma avoti, kuru kurtuvēs dedzina biokurināmo, lai sasildītu ūdeni vai kādu citu siltumnesēju, no kuriem siltumenerǵija tiek nodota tās lietotājam;

4) dzinēji var būt gan atsevišksi, gan lielu sistēmu energoavoti, kuru kurtuvēs dedzina biodegvielu vai biogāzi, ražojot elektroenerǵiju un siltumenerǵiju;

5) gāzes turbīnas parasti ir lielu energosistēmu energoavoti, kuru degkamerās dedzina biogāzi, lai ražotu elektroenerǵiju un siltumenerǵiju.

Kurināmā degšanas procesa k̦īmiskās reakcijas nodrošina divas vielas - kurināmais un gaisa skābeklis. Kurināmā īpašỉbas, agregātstāvokḷi, daḷinu izmēri un formas atšksiras. Tas nozīmē, ka jānodrošina skābekḷa piekḷūšana degošajiem elementiem nepieciešamās proporcijās, lai notiktu jebkura kurināmā pilnīga sadegšana. Svarīgi ir panākt, ka dūmgāzēs ir tikai biokurināmā pilnīgas sadegšanas produkti (no cietā un šksidrā kurināmā), t.i., og̣̣skābā gāze $\mathrm{CO}_{2}$ un ūdens tvaiki $\mathrm{H}_{2} \mathrm{O}$.

Degšanas procesā vienlaikus norisinās aptuveni 250 ķīmiskas reakcijas, un tāpēc degšanas produkti veido arī videi kaitīgas emisijas:

- slāpekla oksīdus $\mathrm{NO}_{x}$;

- sēra oksīdus $\mathrm{SO}_{2}, \mathrm{SO}_{3}$;

- degšanas starpproduktus, kuri veidojas nepilnīgas degšanas gadījumā $\left(\mathrm{CO}, \mathrm{C}_{\mathrm{m}} \mathrm{H}_{\mathrm{n}}, \mathrm{C}\right.$, aldehīdi u.c.).

Kurtuve (degkamera) ir tikai viens elements energotehnologiju iekārtu sistēmā, kas izveidota un uzstādīta energoavotos. Tajos ir uzstādītas kurināmā, ūdens sagatavošanas ierīces, galvenie agregāti, ar kuru palīdzību ražo siltumenerǵiju un elektroenerǵiju, un palīgiekārtas. Atkarībā no avotā saražotā un patērētājiem nodotā enerǵijas veida energoapgādes sistēmu bioenerǵijas avotus iedala divās lielās grupās:

1. Katlu mājas ir energoavots siltumenerǵijas ražošanai. Tajās ir iespējams izmantot dažāda veida bioenergoresursus,
2. Koǵenerācijas stacijas ir energoavots vienlaicīgai elektroenerǵijas un siltumenerǵijas ražošanai. Tajās galvenokārt izmanto divu veidu bioenergoresursus: cieto biomasu un biogāzi.

\section{Katlu mājas}

Katlu mājas ir visizplatītākais siltumenergijas ražošanas avots Latvijā. Katlu māju tehnologiskie risinājumi aptver dažādu iekārtu kopumu, kas saistītas ar degšanas procesa organizāciju, siltuma un masas apmain,as procesu īstenošanu. Katlu mājās uzstādīto iekārtu kopas ir atšksirīgas un, meklējot līdzības ar dzīviem organismiem, tās iespējams iedalīt trīs grupās:

- degšanas tehnoloǵijas (kurtuves ar kurināmā piegādes un pelnu aizvadīšanas iekārtām) ir energoavota sirds;

- katlu sildvirsmas (starošanas, konvektīvās un kondensācijas virsmas) pilda asinsvadu sistēmas funkcijas, kas piegādā organismam nepieciešamo enerǵiju;

- palīgiekārtas (sūkṇi, ventilatori, dūmsūcēji, biokurināmā saimniecības, ūdens sagatavošanas un dūmgāzu attīīǐsanas

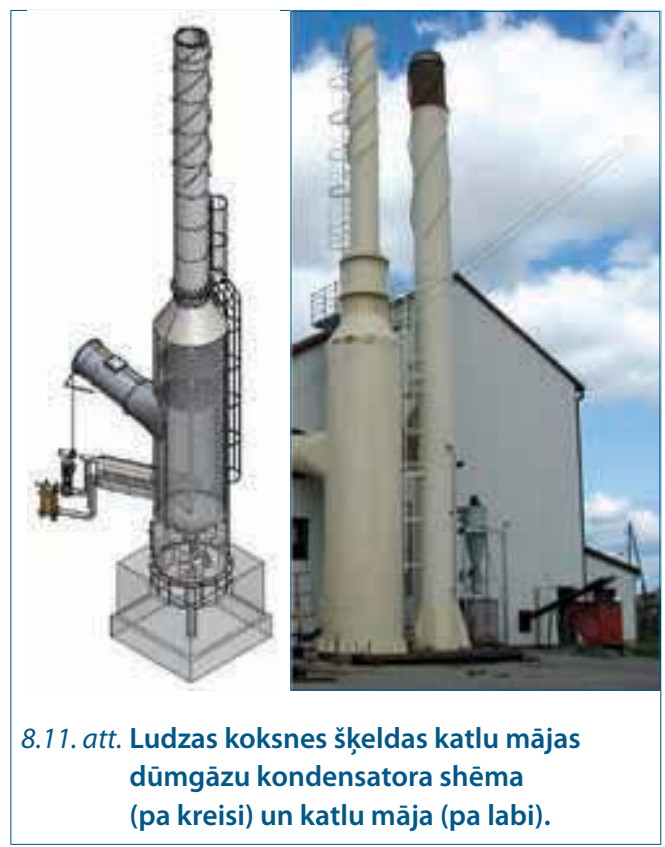


iekārtas) ir organisma sastāvdal̦as, bez kurām organisms nav spējīgs pilnvērtīgi eksistēt.

Latvijā ir uzbūvētas vairāk nekā 50 energoefektīvas biomasas katlu mājas, kurās ir uzstādīti koksnes šķeldas katli, un tās ražo siltumenerǵiju Balvos, Cēsīs, Ludzā, Tukumā, Ventspilī, Salaspilī, Rīgā un citās pilsētās, novados.

Zinātnisko inovāciju ieviešana koksnes škseldas katlu mājās l̦āvusi paaugstināt energoavota energoefektivitāti. Piemēram, Ludzas un Tukuma katlu mājās uzstādīti dūmgāzu kondensatori, kuri izveidoti, pateicoties sadarbībai starp Rīgas Tehniskās universitātes Vides aizsardzības un siltuma sistēmu institūta zinātniekiem, metālapstrādes rūpnīcas "Komforts" darbiniekiem un siltumapgādes uzṇēmumiem Ludzā un Tukumā. Dūmgāzu kondensatoru uzstādīšana l̦āvusi paaugstināt energoavota lietderības koeficientu par 15-20\%.

\section{Kog̉enerācijas stacijas}

Koǵenerācija ir būtisks enerǵijas izstrādes un energoefektivitātes paaugstināšanas līdzeklis. Ar kompleksu tehnologiju lietojumu tiek nodrošinātas enerǵijas patērētāja vajadzības pēc siltuma, aukstuma, elektriskās vai mehāniskās enerǵijas. Izmantojot biokurināmā k̦īmisko enerǵiju, tiek ražota siltumenerǵija, kuru parasti pārveido elektroenerǵijā. Retāk siltuma energiju lieto absorbcijas iekārtās, radot aukstumu. Koǵenerācijas kā enerǵijas ražošanas veida priekšrocības vērtē, salīdzinot to ar tradicionālo enerǵijas veidu atsevišķu ražošanu:

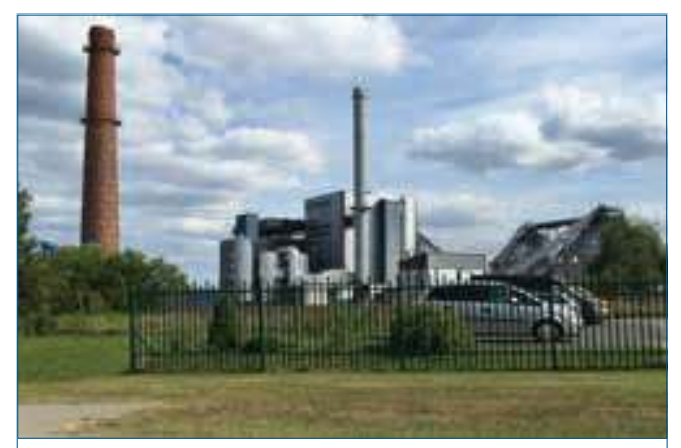

8.12. att. Biomasas koǵenerācijas stacija Jelgavā. siltumenerǵiju - katlu mājā, bet elektroenergiju - elektrostacijā. Tehnoloǵiski ir iespējams, ka enerǵiju koǵenerācijā saražo ar mazāku kurināmā patēriṇu, un tas nozīmē arī augstāku energoefektivitāti.

Klimata tehnoloǵijas koǵenerācijas staciju gadījumā ir "augstas efektivitātes kogenerācija”, saprotot to, ka tā nevar būt vienkārši elektrostacija, kurā ražo tikai elektroenerǵiju. Šajā gadījumā koǵenerācijas stacijai ir jānodrošina šādi nosacījumi:

- primārās enerǵijas ietaupījums ir vismaz 10\% apmērā salīdzinājumā ar siltumenergijas un elektroenerǵijas atsevišķu ražošanu;

- primārās enerǵijas ietaupījums mazas jaudas un mikrokoǵenerācijas gadījumā salīdzinājumā ar siltumenerǵijas un elektroenerǵijas atsevišķu ražošanu.

Koǵenerācijas efektivitātes aprēksināšanai Eiropas valstīs noteikti efektivitātes rādītāji atsevišksai elektrības un siltuma ražošanai, kuri ir atkarīgi no gada, kad iekārta izgatavota un nodota ekspluatācijā, tehnologijas, kurināmā veida u.c.

Lielākā biomasas koǵenerācijas stacija Latvijā darbojas Jelgavā. Stacija atrodas pilsētas vidē un siltumenerǵijas patērētāju tuvumā.

Koǵenerācijas stacijas galvenā iekārta ir tvaika katla kurtuve ar "verdošā" (pseidošḳidrā) slān,a koksnes šķeldas sadedzināšanu. Katla kurtuvē un gāzu ejās ir izvietotas sildvirsmas. Kondensāts (ūdens) plūst caur tām, pakāpeniski uzsilstot un iztvaikojot. Piesātināts tvaiks pārkarsētājā saṇem papildu siltumu no dūmgāzēm. Tādējādi no katla uz turbīnu aizplūst pārkarsēts tvaiks ar augstu entalpijas (siltumsatura) vērtību.

Pārkarsētais tvaiks griež turbīnu un ražo elektroenerǵiju. Turbīnā pārpalikušo zemākas temperatūras tvaiku izmanto siltumapgādes sistēmas ūdens sildīšanai. Ūdens un tvaiks cirkulē pa noslēgtu kontūru. Atdzesētais kondensāts atgriežas katlā. Tā zudumi ir niecīgi, tāpēc ir nepieciešams tikai neliels ūdens papildinājums kontūrā. Koǵenerācijas stacijai ir vēl divi svarīgi bloki: koksnes škseldas glabātuves un dūmgāzu attīrīšana iekārtas. 


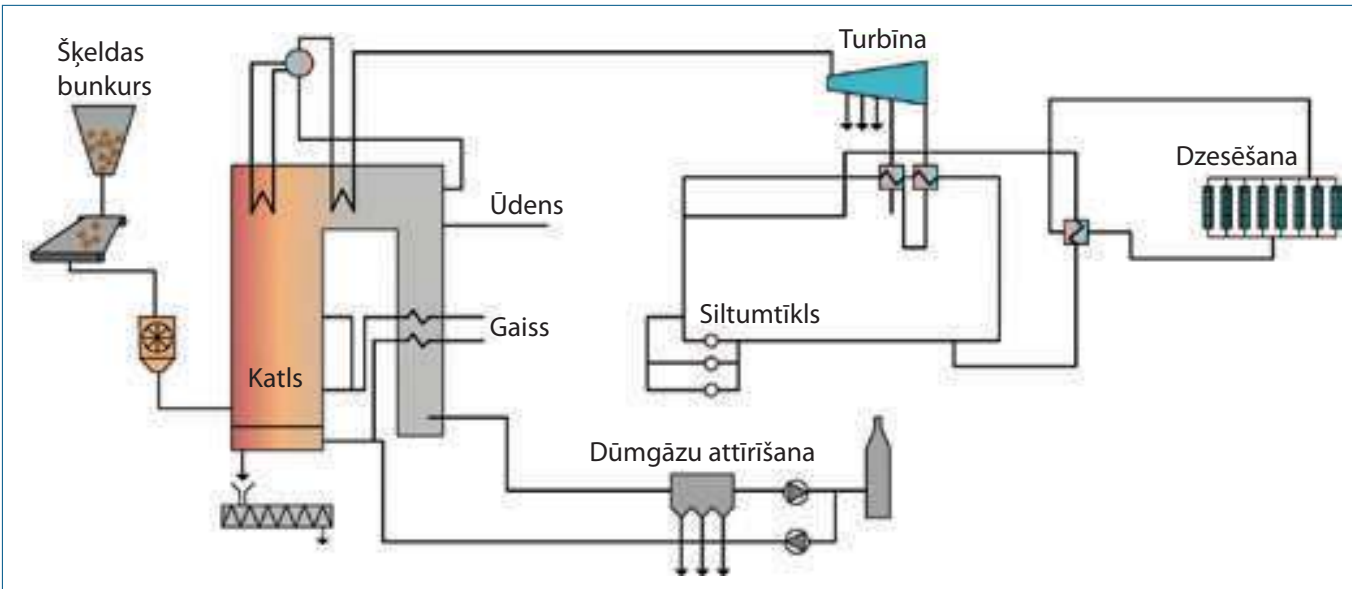

8.13. att. Jelgavas biomasas koǵenerācijas stacijas tehnoloǵiskā shēma.

Elektroenerǵijas un siltumenerǵijas ražošana biomasas koǵenerācijas stacijā ar augstu energoefektivitāti ir uzskatāma par mūsdienu modernāko, videi draudzīgāko un efektīvāko klimata tehnoloǵiju bioenerǵētikā.

\subsubsection{Saules enerǵija}

Saules enerğijas izmantošanas tehnologiju straujā attīstība Eiropā un pasaulē ir saistīta ar problēmas risinājumu par siltumnīcefekta gāzu emisiju pieaugumu gaisā.

Visas Saules izmantošanas tehnoloǵijas ir klimata tehnologijas, ja ar tām saražotā energija aizvieto fosilā energoresursa tehnologijas. Tās ir SEG neitrālas enerǵijas tehnoloǵijas.

Ilggadīgs Eiropas ekspertu monitorings un datu apstrāde liecina, ka Latvijā izmantojamā ikgadējā Saules radiācija ir $1100 \mathrm{kWh} / \mathrm{m}^{2}$. Nedaudz zemāks radiācijas līmenis ir Ziemelvvalstīs. Tomēr Saules enerǵijas izmantošanā Skandināvijas valstis ir mūs apsteigušas, ne tikai uzstādot individuāli pāris kvadrātmetru nelielus Saules enerǵijas kolektorus, bet arī uzbūvējot lielus Saules kolektoru vai Saules fotoelementu laukus.

Saules enerǵijas tehnoloǵijas atškjiras pēc saražotās enerǵijas veida. Saules tehnoloǵijas izmanto abu enerǵijas veidu ražošanai:
- elektroenerǵijas ražošanai izmanto Saules panel̦us (fotoelementus jeb Saules baterijas);

- siltumenerǵijas ražošanai izmanto Saules enerǵijas kolektorus;

- kombinētās sistēmās - Saules baterijas izmanto kombinācijā ar Saules enerǵijas kolektoriem. Saules baterijas tiek izmantotas, lai darbinātu Saules enerǵijas kolektora cirkulācijas sūkni.

No Saules enerǵijas iegūtās elektroenerǵijas lietderīga izmantošana ir saistīta ar šīs energijas uzglabāšanu. L̦oti bieži tas kḷūst par vienu no svarīgākajiem elementiem Saules energíjas tehnologískajās sistēmās.

\section{Saules kolektori}

Saules enerǵijas kolektoru izmantošanas pirmsākumi meklējami jau pirms tūkstots gadiem, kad cilvēki Saules enerǵiju izmantoja, sildot ūdeni mucās vai citos traukos. Cilvēki gribēja izmantot pēc iespējas vairāk enerǵijas, tāpēc palēnām sākās fizikas atziṇu izmantošana, piemēram, mucas tika nokrāsotas melnā krāsā.

Šobrīd lieto četrus Saules enerǵijas kolektoru veidus ar atšksirīgām Saules enerǵijas absorbcijas virsmu konstrukcijām:

- tilpuma kolektorus - tvertnes ar Saules enerǵijas absorbēšanas virsmu; 


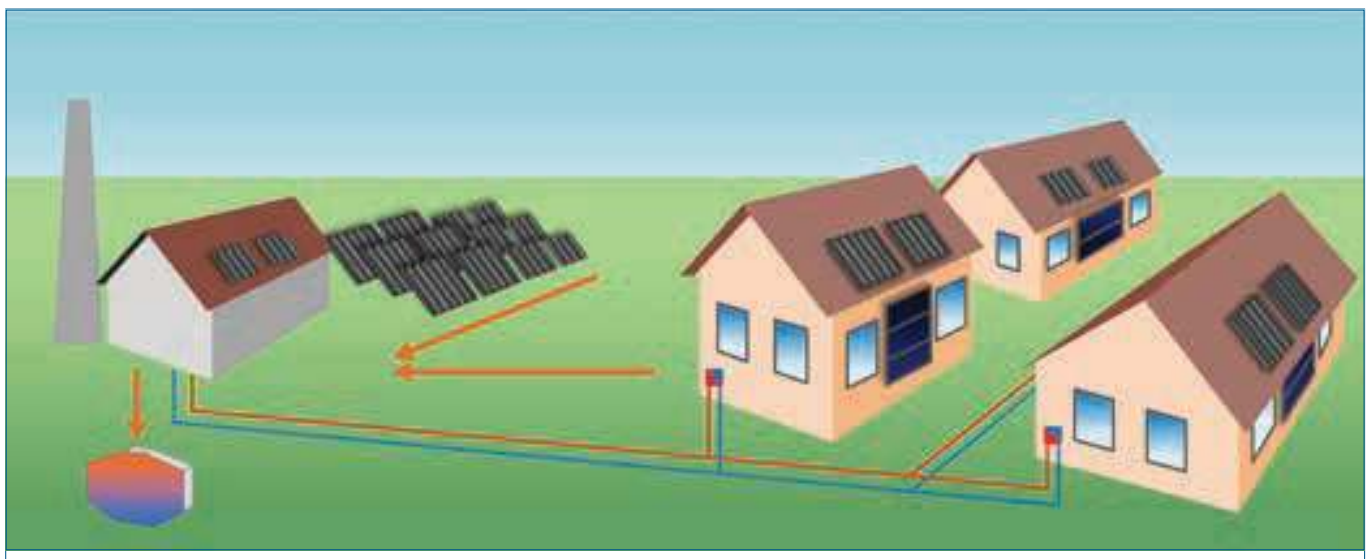

8.14. att. Saules kolektoru sistēmas integrācija centralizētās siltumapgādes sistēmā.

- plakanos kolektorus - absorbēšanas virsmas tajos ir plāksnes, kas izveidotas no dažādiem materiāliem un pārklājumiem,

- caurulī̌ru kolektorus - absorbcijas virsmas izveidotas no stikla vai cita materiāla caurulītēm ar dažādiem pārklājumiem;

- koncentrēšanas kolektorus - Saules enerǵijas uztveršanai tie veidoti no augstas temperatūras izturīgiem materiāliem vai to pārklājumiem.

Zinātniskā izpēte šajā jomā attīstās Saules kolektoru energoefektivitātes paaugstināšanas virzienā, meklējot efektīvākus Saules enerǵijas absorbcijas virsmu materiālus vai pārklājumus.

Saules kolektorus uzstāda ne tikai individuāli uz èku jumtiem vai pie sienām, bet arī ippaši izveidotos laukos (vairāki desmiti tūkstošu kvadrātmetru Saules kolektoru). Saules kolektoru lauki kḷūst arvien plašāk veidoti Eiropā, jo Saules enerǵijas nozīme centralizētās siltumapgādes sistēmās strauji pieaug. Atkarībā no izraudzītā Saules kolektoru novietojuma pilsētā vai novadā ir jāizvēlas arī Saules kolektoru pieslēguma veids centralizētās siltumapgādes sistēmai. Centralizētas siltumapgādes sistēmas saṇem siltumenerǵiju no Saules kolektoriem, kas izvietoti uz ēku jumtiem un Saules kolektoru lauka. Uz ēku sienām izvietoti Saules panel̦i, kuros saražoto elektroenerǵiju izmanto katlu māju ūdens sasildīšanai un padevei siltuma tīklos.

No Saules kolektoriem pienākošo siltumenerǵiju novirza gan uz akumulācijas tvertni, gan siltumenerǵijas patērētājiem. Citas šì slēguma alternatīvas ir gadījumā, kad katlu māja atrodas tālu no Saules kolektoru lauka. Tad Saules kolektori ir pievienoti siltumenerǵijas akumulācijas tvertnei, savukārt tvertne ir savienota ar pilsētas vai pašvaldības centralizētās siltumapgādes tīklu.

Saules siltumenerǵijas sezonālās uzglabāšanas metodes izmanto divus atšķirīgus veidus: zem zemes izveidotas krātuves vai pazemes rezervuārus. Izplatītais veids, kā uzglabāt Saules siltumenerǵiju, ir zemē ierakti rezervuāri.

Bedres tipa akumulācijas tilpums (8.15. att. b) tiek izveidots, izklājot ar necaurlaidīgu materiālu izraktās krātuves sienas. Pārklājumam ir pludinna tipa vāks, kas hermētiski noslēdz bedres augšējo dal̦u.

Līdzīgi veidotas arī akumulācijas betona tvertnes, kas novietotas zem zemes. Zemākās izmaksas ir virszemes akumulācijas tvertnēm. Tādas tvertnes būvē, ja tās labi iederas ainavā.

Pareizi izveidota siltumenerǵijas akumulācijas tvertne nodrošina arī labākus akumulētās siltumenerǵijas blīvuma rādītājus uz $1 \mathrm{~m}^{3}$. 


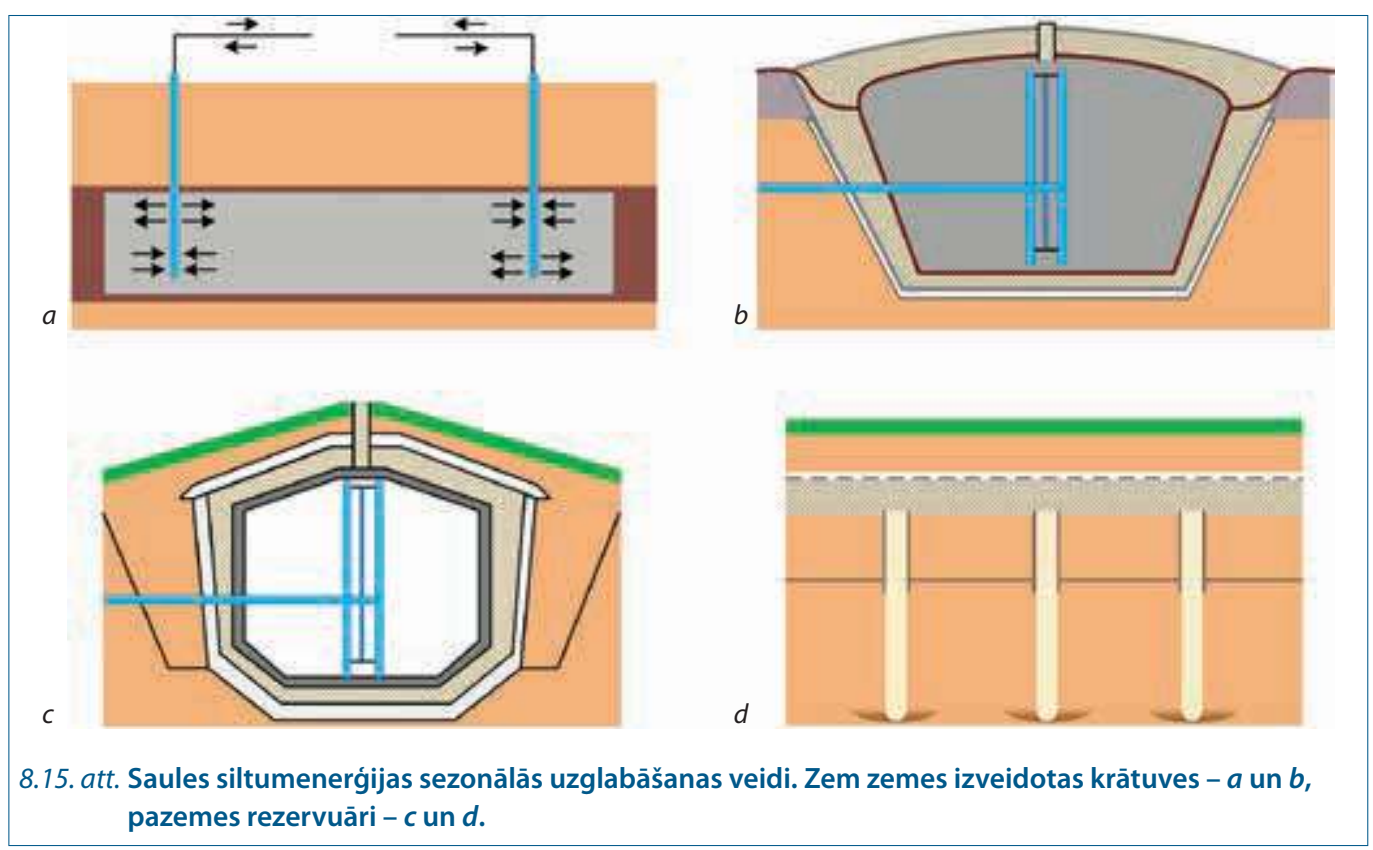

Akumulētās siltumenerǵijas blīvuma rādītājs pazemes rezervuāros ir $60-80 \mathrm{kWh} / \mathrm{m}^{3}$.

Citi siltumenergijas uzglabāšanas tehnologiskie risinājumi ir saistīti ar pazemes ūdeṇu slān,a izmantošanu (8.15. att. $a$ ) ar zemāku akumulētās siltumenerǵijas blīvumu 30-60 $\mathrm{kWh} / \mathrm{m}^{3}$ vai speciālu urbumu izveidi (8.15. att. $d$ ) ar zemu akumulētās siltumenergijas blīvumu $15-30 \mathrm{kWh} / \mathrm{m}^{3}$. Tādā gadījumā siltumenerǵijas akumulācijai ir nepieciešami lielāki tilpumi.

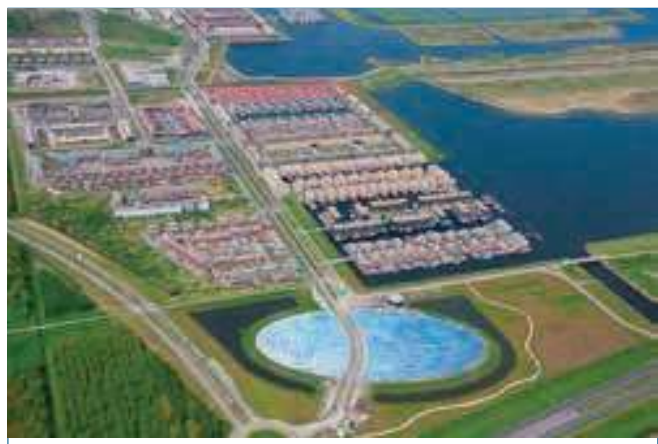

8.16. att. "Saules sala" Almerē, Nīderlandē.
Saules kolektoru lauka integrācija centralizētās siltumapgādes tīklos vizuāli ilustrēta 8.16. attēlā. Nīderlandē Almeres pilsētā izveidota "Saules sala", kas ietver pilsētas tuvumā novietotu saules kolektoru lauku ar lielu akumulācijas tvertni. "Sala" nozīmē, ka apkārt ir izveidota virszemes ūdens tilpne. Visbiežāk apkārt kolektoru laukam ir apjozts žogs un par mauriṇa uzkopšanu rūpējas teritorijā ielaistie truši vai aitas.

\section{Saules panel̦i}

Saules panel̦us veido no fotoelementiem elektriskās sistēmas ierīcēm, kas Saules enerǵiju pārvērš elektroenerǵijā. Fotoelementi elektroenerǵiju var nodot elektrotīklam, pievadìt elektroenerǵijas patērētājam vai akumulatoru baterijām. Fotoelementi apkopoti panelī, kas iekapsulēts stiklā un plastikātā. Panelis parasti ir ievietots alumīnija ietvarā. Panelī generētās enerǵijas daudzums atkarīgs no tā virsmas lieluma, radiācijas līmeņa, fotoelementu efektivitātes un novietojuma pret Sauli. Panelıi visbiežāk ir zilā vai melnā krāsā, pārklāti ar neatstarojošu materiālu, kas uzlabo gaismas absorbēšanu. 


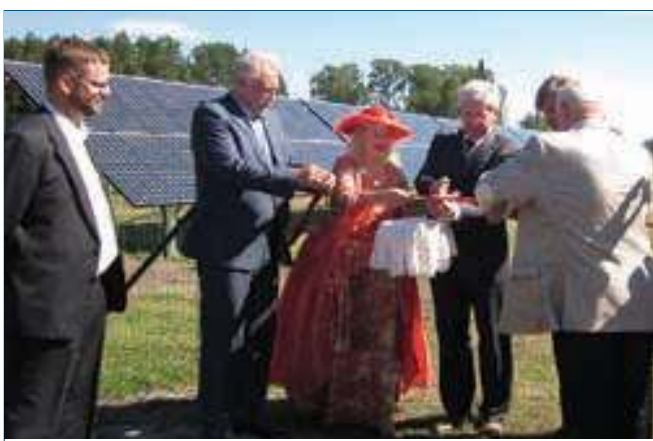

8.17. att. Saules fotoelementu lauka atklāšana Minhauzena muzejā Duntē.

Saules panel̦u energoefektivitāte vēl joprojām ir zema. Vismodernākie panel̦i spēj nodrošināt 25\% energoefektivitāti, bet masveidā ražoti - 16-18\%. Parasti no $1 \mathrm{~m}^{2}$ var iegūt vidēji 80-85 W, bet iekārtās ar augstāku efektivitāti - līdz pat $130 \mathrm{~W}$. Fotoelementi ražo līdzstrāvu, ko pēc tam nepieciešams pārvērst maiṇstrāvā.

Viens no svarīgākajiem jautājumiem energoefektīvu saules panel̦u izveidē ir fotoelementu materiāls. Šobrīd galvenokārt lieto uz silīcija bāzes veidotas sistēmas. Uz organiskiem materiāliem balstītu fotoelementu izveide ir perspektīvs un inovatīvs novirziens.

Latvijā Saules panel̦u ieviešana ir attīstības sākuma stadijā. Daži individuālo māju īpašnieki ir uzstādījuši Saules panel̦us dažu kvadrātmetru platībā. Pirmais lielākais Saules fotoelementu lauks ir izveidots Minhauzena muzejā Duntē.

\subsubsection{Vēja elektroenerǵija}

Vēja enerǵija ir Latvijas nākotnes elektroenerǵija, jo ar to saistās ne tikai $\mathrm{CO}_{2}$ emisiju neitrālas energétikas attīstība, bet arī fosilās enerǵijas aizvietošana ar atjaunojamo enerǵiju. Eiropas Savienības eksperti ir konstatējuši, ka Latvijai ir augsts vēja elektrostaciju (VES) tehnoloǵiju uzstādītās jaudas potenciāls: ir noteikts, ka nākotnē valstī varētu būt ekonomiski izdevīgi uzstādīt VES ar 1500 MW $_{\mathrm{e}}$. Nemot vērā mūsdienu vēja enerǵijas tehnoloǵijas, jūrā uzstādītie vēja generatori varētu būt ar jaudu $1000 \mathrm{MW}_{\mathrm{e}}$, bet uz sauszemes - ar jaudu $500 \mathrm{MW}_{\mathrm{e}}$. Šobrīd uz sauszemes ir uzstādīti vēja generatori, kuru jauda ir mazāka par $50 \mathrm{MW}_{\mathrm{e}}$.

Vēja enerǵijas tehnologiju pirmsākumi meklējami vēja dzirnavās. Vēja geneneratori atškiras ar jaudu, novietojuma augstumu, ass veidu un konstruktīviem parametriem.

1. Šobrīd ir divu veidu vēja generatori, kas atšksiras ar ass veidu:

- vēja turbīnas ar vertikālu rotācijas asi,

- vēja turbīnas ar horizontālu rotācijas asi.

2. Pašlaik ir divu veidu elektroǵeneratori:

- asinhronais generators,

- sinhronais generators.

3. Vēja generatoru orientācija pret vēju ir divējāda:

- vēja elektrogeneratori, kas paredzēti darbam pret vēju (lielākā daḷa VES),

- vēja elektroǵeneratori, kas darbojas pa vējam (atrodas aiz torña).

4. Vēja generatori atškiras ar griešanās veidu:

- astes spārnu vēja generatori - lieto mazas jaudas stacijās,

- vējrozes ǵeneratori ar griešanās vārpstu, kas ir perpendikulāra VES galvenajai vārpstai - lieto vidējas jaudas stacijās,

- servodzinēji (lieto lielas vai vidējas jaudas stacijās).

5. VES klasifikācija pēc to jaudas ir nosacīta, jo nav iespējams noteikt precīzu jaudas robežu:

- mikrostacijas - jauda 2-3 $\mathrm{kW}_{\mathrm{e}}$;

- mazās vēja elektrostacijas - jauda 3-30 $\mathrm{kW}_{\mathrm{e}}$;

- vidēja lieluma vēja elektrostacijas - jauda 30-500 kW ;

- lielās vēja elektrostacijas - jauda lielāka par 0,5 $\mathrm{MW}_{\mathrm{e}}$.

6. Arī vēja generatoru augstums ir atšksirīgs:

- 10-15 m augstumā virs zemes līmeña vēja generatorus uzstāda uz stabiem, pie māju korēm;

- 50 m augstumā virs zemes līmeña vienkāršas konstrukcijas stabi;

- 100 m augstumā no zemes līmeña - modernāki stabi lielākiem ǵeneratoriem; 


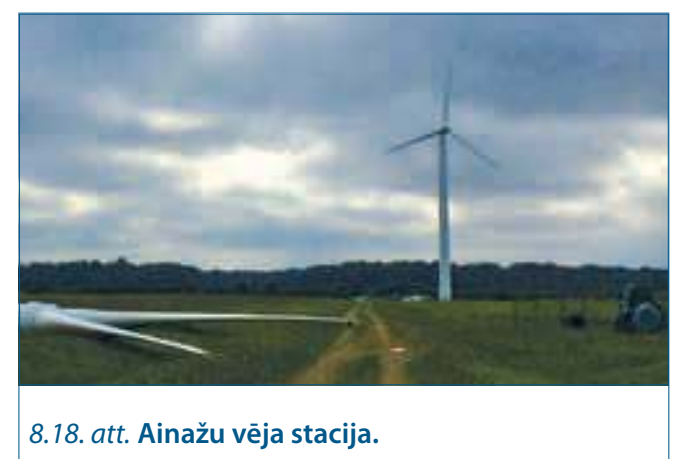

- 100-300 m augstumā no zemes līmeña - Kanādā uzsākti izmēǵinājumi ar dirižabḷiem, palaižot tos lielā augstumā.

Svarīgākais parametrs vēja enerǵijas izmantošanai ir vēja ātrums. To mēra 10, 50 un 100 metru augstumā. Varētu šķist, ka ir svarīgi, lai ātrums būtu pēc iespējas lielāks. Tas neatbilst patiesībai, jo dažreiz, pastāvot lielam vēja ātrumam, vēja stacijas apstādina. Izmantojamie vēja ātrumi ir atkarīgi no vēja ǵeneratora konstrukcijas. Piemēram, Vācijā iespējams iegādāties vēja ǵeneratorus, kuri sāk ražot lietderīgo enerǵiju, ja vēja ātrums ir tikai 2,5-3 m/s. Ir generatori, kuri darbojas, pastāvot vēja ātrumam 3-4 m/s. Tomēr visbiežāk VES sāk darboties, ja vēja ātrums ir > 4,5 m/s.

Pirmie vēja generatori Latvijā pēc neatkarības atgūšanas bija saistīti ar pirmo emisiju tirdzniecības kopīstenošanas projektu. To īstenoja Latvijas un Vācijas inženieri un klimata pārmaiṇu speciālisti. Projekta mērksis bija veikt vēja stacijā saražotās elektroenerǵijas un SEG emisiju samazinājuma monitoringu. Galvenais uzdevums bija praktiski sagatavot klimata tehnologiiju speciālistus, kas vēlāk realizētu Kioto protokolā paredzēto elastīgo mehānismu īstenošanu Eiropā un pasaulē.

\subsubsection{Hidroenerǵija}

Pasaulē hidroelektrostacijas (HES) galvenokārt būvē uz kalnu upēm. Latvijas pieredzi šajā jomā var uzskatīt par izṇēmumu, jo lieli HES ir uzbūvēti uz līdzenuma upes Daugavas.
Cita situācija Latvijā veidojās sakarā ar mazo HES būvniecību. Šobrīd skaita ziṇā hidroelektrostacijām ar ūdens krātuvēm ir sasniegts maksimums: Latvijā darbojas apmēram 150 mazās HES. Tās ir atjaunotas pie dzirnavu ezeriem un būvētas no jauna, izveidojot ūdenstilpes uz mazajām līdzenuma upēm. Jaudu iespējams palielināt, tikai uzstādot energoefektīvākas iekārtas.

Vieni vides speciālisti Eiropā un Latvijā atbalsta hidroelektrostaciju būvēšanu uz līdzenuma upēm, bet citi to vērtē kā videi kaitīgu pasākumu. Pirmie savu pamatojumu balsta uz iespēju aizvietot fosilo kurināmo ar atjaunojamiem resursiem, turklāt to var darīt brīžos, kad nav pieejama Saules un vēja enerǵija, tādējādi sabalansējot neregulāros atjaunojamos energoavotus. Otrie protestē par pārpurvotajām teritorijām, kas veidojas lielo krātuvju ūdens līmeṇa pacelšanās gadījumā, par ūdens baseina piesārṇojuma izmaiñām HES baseinos. Piemēram, HES ūdenstilpnēs tiek novērota zilalğgu augšana, ietekme uz zivju celiem un to nārstošanas vietām. Tāpēc ir nepieciešami speciāli pasākumi, lai hidroturbīnas nekḷūtu par škēersli zivīm ceḷā uz nārstošanas vietām.

Tomēr arī šajā jomā ir vērojama zinātnes sasniegumu izmantošana. Mazo HES inovatīvie tehnoloǵiskie risinājumi ir saistīti ar straumes enerǵijas izmantošanu, hidroturbīnas uzstādot upes vidū, galvenajā ūdens plūsmā.

\subsubsection{Gieotermālās un citas atjaunojamās enerǵijas tehnologijas}

Ir arī citi atjaunojamās siltumenerǵijas un elektroenerǵijas energoavoti. To izmantošanas tehnologiskajiem risinājumiem ir dažādas attīstības pakāpes un lietojums. Šobrīd pasaulē jau izmanto geotermālo enerǵiju, viḷnu enerǵiju, paisuma un bēguma enerǵiju. Zinātnes sasniegumi var nest arī pārsteigumus, un agrākā vai vēlākā nākotnē var parādīsies jauni atjaunojamās energíijas veidi. 
G̣eotermālās enerǵijas izmantošanas lielisks piemērs ir Islandes vulkāniskās aktivitātes zonas, kur karstie pazemes ūden, tiek izmantoti siltumapgādē, rūpniecībā un ārstniecībā. Eiropā geotermālās enerǵijas izmantošanas iekārtas pārsvarā ir sastopamas mājsaimniecībās - siltumenerǵijas ieguvei privātmāju apkures un karstā ūdens apgādes sistēmās.

Eiropā ir īstenoti daži ǵeotermālās enerǵijas izmantošanas projekti rūpniecības vajadzībām gan siltuma, gan aukstuma ieguvei. Pēdējo desmit gadu laikā Klaipēdas pilsēta izmanto geotermālo enerǵiju siltumapgādes sistēmā. Kaut gan šie piemēri ir interesanti, šobrīd tiem nav lielas nozīmes enerǵētikas attīstībā. G̦eotermālās enerǵijas izmantošanas attīstība varētu būt saistīta ar atjaunojamās elektroenerǵijas īpatsvara palielināšanu, piemēram, izmantojot siltuma sūkṇus.

\subsubsection{Atjaunojamās elektroenerğijas avotu darbības režīmi}

Atjaunojamās enerǵijas avotu darbības režìmu raksturo to pieejamība laikā, tāpēc svarīgi ir izzināt ne tikai katra avota potenciālu, bet arī tā iespējamo darbību. N̦emot vērā šo aspektu, ir izšķirami trīs veidu elektroenerǵijas ieguves avoti.

Pirmo grupu pārstāv biomasas (arī biogāzes) koǵenerācijas stacijas, kuras elektrosistēmā var darboties nepārtraukti. Šajā grupā ietilpst arī geotermālās elektrostacijas.

Otro grupu pārstāv Saules un vēja energijas avoti, kā arī viḷnu, paisuma un bēguma elektrostacijas. Tomēr šie energoavoti nespēj nodrošināt elektrosistēmā nepieciešamo elektroenerǵijas apjomu. Periodiskas darbības elektroenerǵijas avoti ir atkarīgi no resursa pieejamības diennakts, nedēl̦as, mēneša un gada griezumā.

Trešo grupu pārstāv elektroenerǵijas avoti, kurus ir iespējams ātri ieslēgt un izslēgt brīžos, kad patērētājam ir nepieciešama papildu elektroenerǵija, lai nosegtu elektrosistēmā trūkstošo elektroenerǵiju. Šîs grupas elektroenerǵijas avoti ir HES, kas labi papildina elektroapgādes sistēmas darbības stabilitāti un drošumu, maksimāli integrējot otrās grupas energoavotu saražoto elektroenerǵiju.

Ceturtais tehnologiskais risinājums atjaunojamo energoresursu integrēšanai valsts vai reǵiona energobilancē ir otrās grupas neregulāro energoavotu pārpalikuma elektroenerǵijas uzkrāšana. Tas ir īpaši svarīgi, lai palielinātu vēja un Saules elektroenerǵijas izmantošanu, kas nenoliedzami ir apkārtējai videi draudzīgs enerǵijas avots, jo samazina ietekmi uz klimata pārmaiñām.

Tāpēc, lai pilnvērtīgi un lietderīgi izmantotu Saules un vēja energíjas potenciālu, ir jāattīsta iegūtās vēja un Saules elektroenerǵijas akumulācijas tehnoloǵijas. Elektroenerğijas uzkrāšanas sistēma ir klimata tehnologija, kas l,auj palielināt atjaunojamo energoresursu īpatsvaru. Nepastāvīgās atjaunojamās enerǵijas uzglabāšana padara elektroenerǵijas patērētāju mazāk atkarīgu no laika apstākḷiem, l̦auj pārdot elektroenerǵiju par izdevīgāku cenu, kā arī palīdz optimizēt ierobežoto tīklu jaudu. Tādējādi palielinās iespēja integrēt vēja un Saules elektroenergiju iekšējā tirgū pašu valstī un eksportēt to.

Tehnoloǵijas, kas nodrošina saražotās elektroenerǵijas akumulāciju, ir atškirīgas. Plašāk izmantotās akumulācijas iekārtas ir dažādu veidu akumulatori, taču tie nav domāti lielu energiijas daudzumu uzkrāšanai. Šìs tehnologijas vairāk domātas izmantošanai nelielās mājsaimniecībās, nevis lielās elektrostacijās. Lielu enerǵijas daudzuma akumulācijai izmanto saspiestā gaisa tehnologijas, ūdeñraža sistēmas un citas enerǵijas uzkrāšanas tehnoloǵijas.

Rīgas Tehniskās universitātes Vides aizsardzības un siltuma sistēmu institūta darbinieku zinātniskā izpēte un inovācijas ir vērstas vienā no neregulāru atjaunojamo energoresursu elektroenerǵijas avotu ūden,raža akumulācijas virzieniem. Izstrādāta un modelēta shēma ūdeṇraža izmantošanai biometāna ražošanas akumulācijas sistēmas izveidei. Vēja un Saules elektroenerǵijas ūdennraža-biometāna akumulācijas principiālā shēma ilustrēta 8.19. attēlā. 

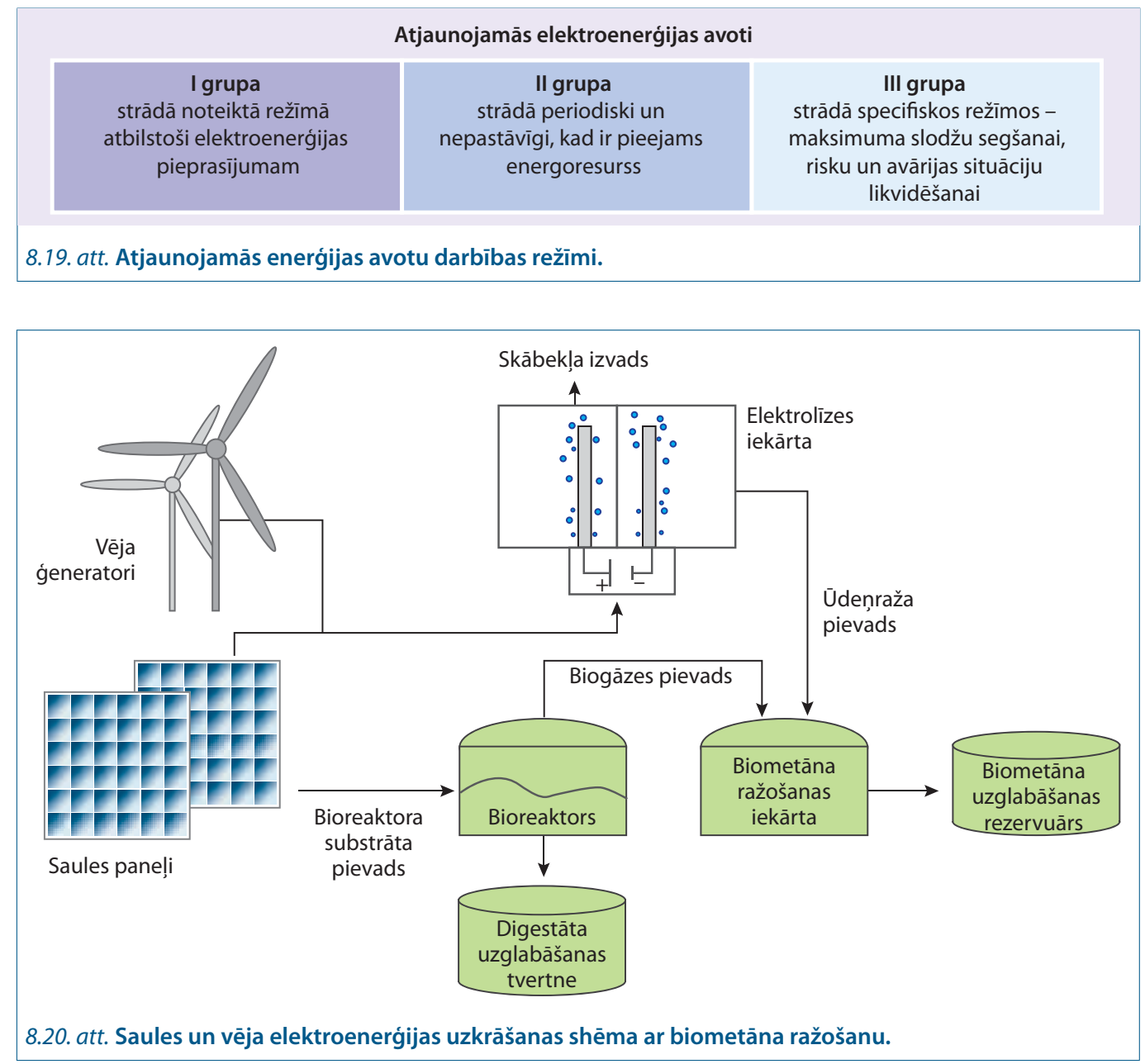

Neregulāras elektroenerǵijas ūden,ražabiometāna akumulācijas sistēmas sastāvā ietilpst vairāki elementi.

1. Saules panel̦i, kas ir neregulārs elektroenergíijas avots.

2. Vēja geneneratori, kas arī ir neregulārs elektroenergijas avots.

3. Elektrolīzes iekārta ūdeñraža ražošanai, izmantojot elektroenerǵiju.

4. Bioreaktora substrāta pievads - substrāts biogāzes ražošanas procesā var būt lauksaimniecības atkritumi, kūtsmēsli, alğges vai kāda cita biomasa.

5. Bioreaktors - biogāzes ražošana notiek anaerobos apstākḷos, kur tiek nodrošināta konstanta temperatūra, un biogāzes ražošanas gala produkti ir metāns un $\mathrm{CO}_{2}$.

6. Digestāta uzglabāšanas tvertne.

7. Biometāna ražošanas iekārtas biogāzes (metāns un $\mathrm{CO}_{2}$ ) pievads;

8. Biometāna iekārta - biogāzi pēc bioreaktora ievada biometāna iekārtā, kurā ievada arī ūdeñradi, lai palielinātu metāna koncentrāciju biogāzē un samazinātu $\mathrm{CO}_{2}$ koncentrāciju.

9. Biometāna iekārtas ūden̦raža pievads.

10. Biometāna uzglabāšanas rezervuārs.

11. Skābekḷa izvads no elektrolīzes iekārtas.

Periodiskas atjaunojamo energoresursu elektroenerǵijas ūdeṇraža-biometāna akumulācijas shēmā ieslēgtās biogāzes stacijās biogāzi 
ražo, izmantojot dažādus bioresursus. No substrāta sastāva un procesa bioreaktorā ir atkarīga biogāzes sastāvā esošā metāna koncentrācija. $\mathrm{CH}_{4}$ koncentrācija ir plašā diapazonā no 50 līdz 70\%. Biogāzes stacijās ražotās biogāzes kvalitātes uzlabošanai izmanto ūden,radi, ko iegūst ar Saules vai vēja elektroenerǵiju. Biogāzes staciju šajā gadījumā papildina ar elektrolīzes iekārtu un biometāna reaktoru. Sabalansētu un sistēmas elementos īstenotu procesu rezultātā ir iespējams no oglekḷa dioksīda un ūdeņraža iegūt metānu, tādējādi paaugstinot $\mathrm{CH}_{4}$ koncentrāciju biogāzē.

$$
\mathrm{CO}_{2}+2 \mathrm{H}_{2} \rightarrow \mathrm{CH}_{4}+\mathrm{O}_{2}
$$

Šì it kā vienkāršā kūmiskā reakcija vienlaikus ir jāvērtē kā nākotnes klimata tehnologiju reakcija, jo tā demonstrē siltumnīcefekta gāzu emisiju lietojuma iespējas.

\section{4. $\mathrm{CO}_{2}$ uzglabāšanas iespējas}

Viens no klimata tehnoloǵiju attīstības virzieniem ir saistīts ar $\mathrm{CO}_{2}$ uzglabāšanu, kas l̦auj nodrošināt enerǵijas ražošanu bez $\mathrm{CO}_{2}$ emisijām atmosfērā. Enerǵijas ražošana un rūpnieciskie procesi, kuros izmanto fosilo kurināmo, ir galvenie objekti, kuru izdalīto oglekḷa dioksīdu ir iespējams tehnologiski uzglabāt speciālās krātuvēs. Pēc būtības $\mathrm{CO}_{2}$ uzglabāšana ir $\mathrm{CO}_{2}$ izmantošana kīmisku reakciju un biologisku procesu realizēšanā. $\mathrm{CO}_{2}$ uzglabāšanas tehnologijas nosacīti var iedalīt 5 posmos (sk. 8.21. att.).

Koǵenerācijas stacijas ir efektīvs energoavots, kurā vienlaikus ražo siltumenerǵiju un elektroenerǵiju. Kurināmā degšanas procesā radīto $\mathrm{CO}_{2}$ daudzumu iespējams samazināt atškirīgos veidos. Viens no svarīgākajiem nosacījumiem šĩs siltumnīcefekta gāzes uzglabāšanai ir nodrošināt, lai $\mathrm{CO}_{2}$ būtu bez piemaisījumiem. Tas nozīmē, ka lielajās koǵenerācijas stacijās tiek uzstādītas iekārtas $\mathrm{CO}_{2}$ atdalīšanai. Klimata tehnologiju risinājumi ir dažādi: gan tehnologiski mazinot piemaisījumu veidošanos kurtuvē, gan attīrot $\mathrm{CO}_{2}$ no citām dūmgāzēs esošām gāzēm, piemēram, slāpekḷa un slāpekḷa oksīdiem, gan arī, izmantojot kombinētu piemaisījumu atdalǐšanu.

Tīrai og̣̣skābajai gāzei kompresoru stacijās tiek paaugstināts spiediens, lai nebūtu jābūvē milzīga izmēra cauruḷvadi šīs gāzes transportēšanai pa caurulvadiem uz glabātuvi.

Šobrīd tiek izmantoti dažādi $\mathrm{CO}_{2}$ uzglabāšanas veidi, kuriem ir gan priekšrocības, gan trūkumi. Visvairāk pētītās iespējas ir par $\mathrm{CO}_{2}$ uzglabāšanu dažādās krātuvēs: okeānos un jūrās, gāzes rezervuāros, oglu šahtās, dabiskos pazemes tukšumos. Plānota arī $\mathrm{CO}_{2}$ mineralizācija un rūpnieciska izmantošana.

Oglekḷa uzglabāšanas metožu attīstība un plašais spektrs nākotnē l̦aus izdarīt izvēli par piemērotāko tehnologiisko risinājumu, izvērtējot dažādus aspektus:

- likumdošanas sakārtotību - valsts iespējas un enerǵētikas attīstības stratēǵijas un politikas;

- geogrāfiskos apsvērumus - pazemes krātuvju pieejamību un izvietojumu dabā;

- inženiertehniskos pañēmienus - tehnoloǵisko risinājumu pieejamību un iespējamās inovācijas,

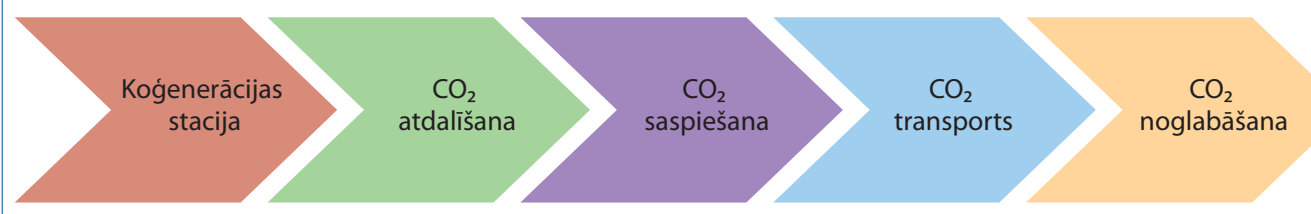

8.21. att. $\mathrm{CO}_{2}$ uzglabāšanas posmi. 
- krātuvju pieejamību - $\mathrm{CO}_{2}$ uzglabāšanas ietilpību vai uzglabāšanas ilgumu;

- ekonomiskos apsvērumus - nepieciešamās investīcijas, apkalpošanas un uzturēšanas izmaksas;

- vides prasības - ietekmes uz vidi izvērtēšanas rezultātus;

- izturētspējas līmeni - krātuves izmantošanas drošību.
Oglekḷa dioksīda uzkrāšanā labas izredzes ir mineralizācijas procesa ieviešanai, kura rezultātā $\mathrm{CO}_{2}$ pārveido par cietu vielu, piemēram, kalcija karbonātu vai hidrogēnkarbonātu. Mineralizācijas procesa gala produktu ir vienkāršāk transportēt, uzglabāt virs zemes, izmantot kā izejvielu ražotnēs ar iespēju paaugstināt pievienoto vērtību, piemēram, ražojot celtniecības materiālus.

\section{1. tabula. $\mathrm{CO}_{2}$ uzglabāšanas iespējas un iespējamā uzglabāšanas ietilpība}

\begin{tabular}{|l|l|}
\hline \multicolumn{1}{|c|}{ Uzglabāšanas metode } & \multicolumn{1}{c|}{ lespējamais uzglabāšanas potenciāls } \\
\hline $\mathrm{CO}_{2}$ mineralizācija & $\begin{array}{l}\text { Vislielākais - lielāks nekā kopējā pieejamā fosilā kurināmā oglekḷa } \\
\text { daudzums pasaulē }\end{array}$ \\
\hline $\mathrm{CO}_{2}$ rūpnieciska izmantošana & Šobrīd niecīgs, bet ar lielu potenciālu \\
\hline $\mathrm{CO}_{2}$ uzglabāšana okeānos & Otrs lielākais no uzglabāšanas ietilpības viedokla \\
\hline $\mathrm{CO}_{2}$ uzglabāšana dabas pazemes krātuvēs & $3-5 \%$ no kopējā pieejamā fosilā kurināmā daudzuma pasaulē \\
\hline $\mathrm{CO}_{2}$ uzglabāšana gāzes krātuvēs & $3-5 \%$ no kopējā pieejamā fosilā kurināmā daudzuma pasaulē \\
\hline Mežsaimniecības attīstība & $2-3 \%$ no kopējā pieejamā fosilā kurināmā daudzuma pasaulē \\
\hline Bioloǵiski piesaistot $\mathrm{CO}_{2}$ & Neliels \\
\hline
\end{tabular}

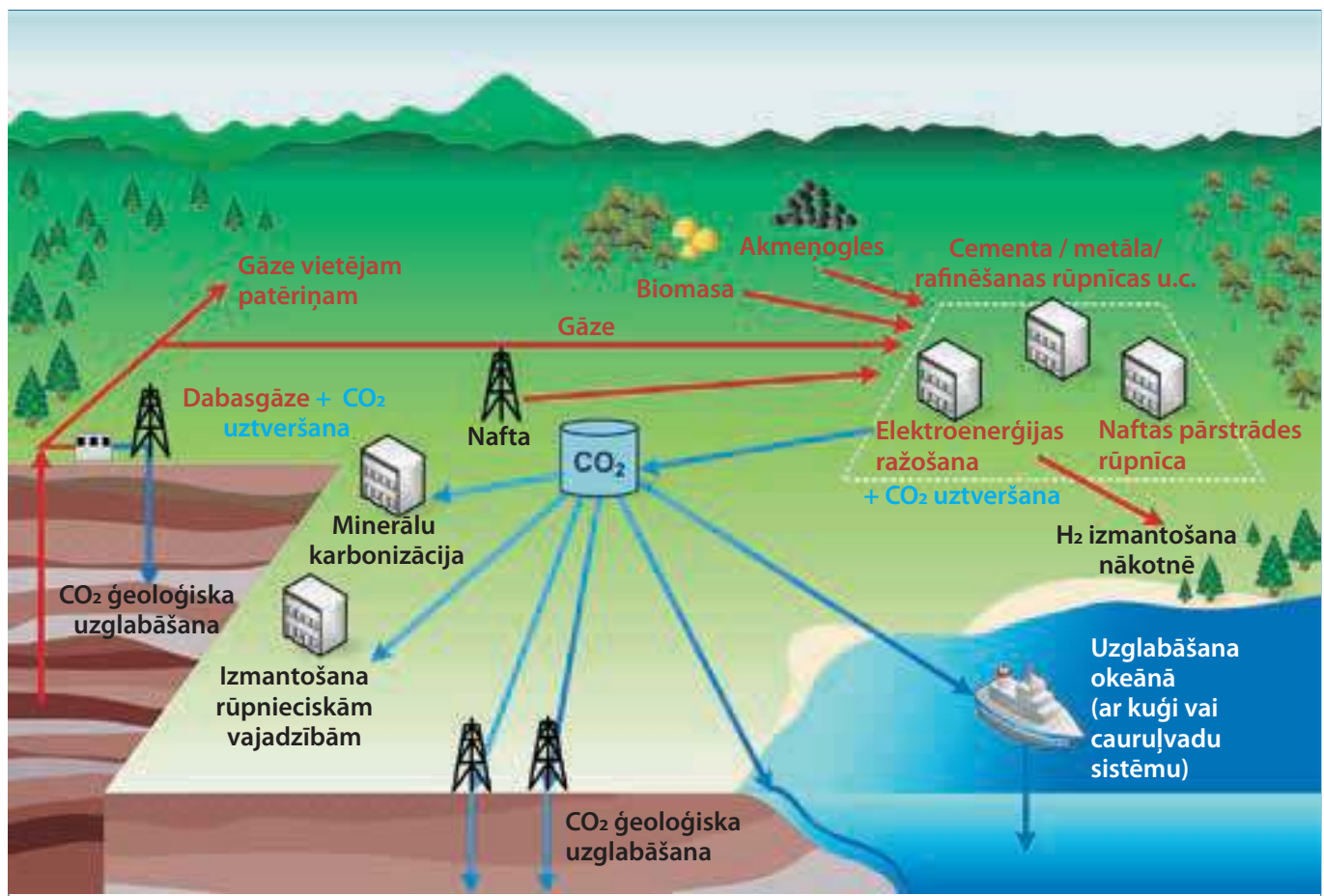

8.22. att. Oglekḷa dioksīda uzglabāšanas un izmantošanas iespējas. 
$\mathrm{CO}_{2}$ uzglabāšanas metodes, iespējas un ietilpības potenciāls apkopots 8.1. tabulā. Tajā atspoguḷots arī ekspertu kvalitatīvas uzglabāšanas metožu vērtējums. Patiesie uzglabāšanas ietilpības apjomi nav skaidri zināmi vairāku iemeslu dēl, jo $\mathrm{CO}_{2}$ uzglabāšanas inovācijas attīstās un tas ietekmē metožu pieejamību un izvēli.

$\mathrm{CO}_{2}$ uzglabāšanai okeānos pēc ietilpības ir nākamais lielākais potenciāls pēc mineralizācijas. $\mathrm{CO}_{2}$ uzglabāšana dabas pazemes krātuvēs un gāzes rezervuāros spēj nodrošināt 8 līdz 10 reizes mazāku ietilpību nekā uzglabāšana okeānos. Pārējās uzglabāšanas iespējas šobrīd ir ar mazāku potenciālu, kaut arī dažas no metodēm ir sasniegušas ekonomiski izdevīgas ieviešanas līmeni.

$\mathrm{CO}_{2}$ uzglabāšanas ilgums ir otrs svarīgākais aspekts, izvēloties, kurai metodei dot priekšroku, jo norāda, pēc cik ilga laika $\mathrm{CO}_{2}$ var izplūst atmosfērā.

Tāpēc dabiskie procesi, piemēram, $\mathrm{CO}_{2}$ iesaistǐšanās fotosintēzes procesos augos, netiek uzskatīti par nozīmīgu $\mathrm{CO}_{2}$ uzglabāšanas metodi, jo šāds uzglabāšanās ilgums ir mazs (līdz 100 gadiem) salīdzinājumā ar uzglabāšanu okeānos. Īpaši svarīgs uzglabāšanas ilgums ir tāpēc, ka tiek ieguldīta enerǵija, finanšu un materiālie līdzekḷi un tērēts laiks $\mathrm{CO}_{2}$ uztveršanai rūpnīcās, elektrostacijās un citur, kur izmanto fosilo kurināmo. Ātra un lielu apjomu $\mathrm{CO}_{2}$ atgriešanās vidē no $\mathrm{CO}_{2}$ glabātuvēm nav ekonomiski izdevīga un rada draudus videi un cilvēkiem. Vides aizsardzības jautājumus var dažādi interpretēt un norādīt uz uzglabāšanas metožu trūkumiem, tomēr $\mathrm{CO}_{2}$ uzglabāšana ir problēmas risinājums.

\section{Literatūra}

Blumberga A., Blumberga D., Bažbauers G., Davidsen P., Moxnes E., Dzene I., Barisa A., Žogla G., Dāce E., Bērziña A. (2011) System Dynamics for Environmental Engineering Students. Rīga: Rīgas Tehniskās universitātes Vides aizsardzības un siltuma sistēmu institūts, 351 lpp.

Blumberga D., Veidenbergs I., Romagnoli F., Rochas C., Žandeckis A. (2011) Bioenerǵijas tehnoloǵijas. - Rīga, Latvija : RTU Vides aizsardzības un siltuma sistēmu institūts, 272 Ipp.

Adamovičs A., Blumberga D., Lazdina D., Lazdinš A., Plūme I., Rochas C., Romagnoli F., Rošā M. (2011) Biomass : Study Course for Students. Rēzekne: Rēzeknes Augstskola, 176 Ipp.

Vide un ilgtspējīga attīstība (M. Kḷaviṇa un J. Zal̦okšṇa red.) Rīga: LU Akadēmiskais apgāds, 334 Ipp.

Environment and Sustainable Development (2010) Edited by M. Kḷavinšs, W. L. Filho and J. Zaḷoksnis. Riga: Academic Press of University of Latvia, 300 Ipp.

Blumberga D. (2010) Ilgtspējīga enerǵētika Latvijā. Rīga: RTU tipogrāfija, 38 Ipp.

Rošā M., Blumberga D., Bērziṇa A., Rochas C., Žandeckis A. (2010) Kompakts saules un granulu modulis siltumapgādes sistēma daudzdzīvokḷu ēkai. Rīga: Rīgas Tehniskās universitātes Vides aizsardzības un siltuma sistēmu institūts, $20 \mathrm{lpp}$.

Blumberga A., Blumberga D., Bažbauers G., Davidsen P., Moxnes E., Dzene I., Barisa A., Žogla G., Dāce E., Bērziṇa A. (2010) Sistēmdinamika vides inženierzinātṇu studentiem. Madona: Madonas Poligrāfists, 318 lpp.

Blumberga D., Klavinš M. (2010) Climate Change Education in Curricula of Technical and Classical Universities. No: Universities and Climate Change. New York: Springer, pp. 99-107 ISBN 9783642107504.

Blumberga D., Rošã M., Blumberga A., Rochas C., Dzene I., Kamenders A. (2012) Energoefektivitāte pašvaldībās. Rīga: Mēness upe, 36 Ipp.

Blumberga A., Blumberga D., Kḷavinšs M., Rošā M., Valtere S. (2010) Vides tehnoloǵijas. Rīga: Latvijas Universitāte, 212 lpp.

Blumberga A., Blumberga D., Bažbauers G., Dāce E., Bērziṇa A., Žogla G., Moxnes E., Davidsen P. (2010) Sistēmiskas domāšanas integrēšana vides politikā. Rīga: Rīgas Tehniskās universitātes Siltuma sistēmu un vides aizsardzības institūts, $225 \mathrm{lpp}$.

Blumberga D., Dzene I., Al Sedi T., Rucs D., Prasls H., Ketners M., Finstervalders T., Folka S., Jansens R. (2009) Biogāze: rokasgrāmata. Rīga : SIA Ekodoma, 155 Ipp. 
Dzene I., Rochas C., Blumberga A., Blumberga D., Rošā M. (2009) Ilgtspējīga energoplānošana. Rīga: SIA Ekodoma, $72 \mathrm{lpp}$.

Dzene I., Bulgakova J., Rochas C., Blumberga D. (2009) Publisko iepirkumu vadlinijas energoefektivitātes un atjaunojamo energoresursu izmantošanas veicināšanai. Rīga: SIA Ekodoma, 8 lpp.

Blumberga D., Ozoliṇa L., Rošā M., Gaj H., Zuwala J., Lechawacka M., Kallaste T., Laur A., Perednis E., Jakubes J., Tantareanu C., Pchelka F., Weber R., Brinker S. (2009) Lìdzsadedzināšana - no izpētes līdz reālam pielietojumam. Rīga: SIA Ekodoma, 72 Ipp.

Blumberga D. (2008) Siltuma sūkṇi. Rīga: RTU, 140.

Blumberga D., Veidenbergs I. (2008) Kliedētas energosistēmas. Mazas koǵenerācijas stacijas. Rīga: RTU, 240 Ipp.

Āboliṇa K., Andrušaitis A., Blumberga D., Briede A., Bruṇiniece I., Grišule G., Kḷaviņš M. (2008) Klimata mainība un globālā sasilšana. Rīga: LU Akadēmiskais apgāds, 174 lpp.

Blumberga D., Blumberga A., Žogla G. (2008) Rokasgrāmata ēku energoefektivitātes pasākumu ieviešanai. Rīga: Ekodoma, 97 lpp.

Blumberga D., Rošā M. (2004) Energoserviss. 1. gr.: Energoefektivitāte. Rīga, 127 lpp.

Blumberga A., Blumberga D. (2004) Energoserviss. 2. gr.: Energoservisa pakalpojumi. Rīga, 126 lpp.

Blumberga D. (1996) Energoefektivitāte. Rīga: Pētergailis, 320 lpp.

Valtere S., Kalniṇš S. N., Blumberga D. (2014 ) Vides vadība un energopārvaldība. Rīga: RTU Izdevniecība, 288 Ipp.

Izmantotie attēli un tabulas

8.1. World Resources Institute.

8.4. World Resources Institute

8.15. Solar District Heating Guidelines

8.21. IPCC Intergovernmental panel on Climate change. SRCCS Figure TS-1 
Augšanas sezonas izmaiṇas un tās ietekme uz mežsaimniecību un lauksaimniecibu 
Klimata ekstremālās parādības (karstuma viln,ni, intensīvie nokrišn,i) un augšanas sezonas pagarināšanās klimata pārmaiṇu ietekmē ir divi no būtiskākajiem faktoriem, kam būs jāpielāgojas lauksaimniekiem un mežsaimniekiem tuvā un tālā nākotnē.
20.-21. gs. augu attīstības fāžu iestāšanās laiks, piemēram, lapu plaukšanas sākums, pirmā raža, arī augšanas sezonas sākums un beigas, kā arī augšanas sezonas ilgums ir būtiski mainījies, ko apliecina pētījumi gan Eiropā, gan visā pasaulē.

\subsection{Dabas novērojumi kā klimata mainības signāli}

Augi un dzīvnieki jutīgi reaǵē uz apkārtējās vides izmaiṇām, tāpēc arvien biežāk bioklimatiskie dati (lapu plaukšana, krāsošanās, auglu nogatavošanās, putnu migrācija u.c.) tiek izmantoti kā klimata pārmaiṇu bioindikatori. Dabas novērojumu analīze iespējams ir vienkāršākais un lētākais veids, kā pierādīt un pamatot klimata pārmaiṇas un var palīdzēt klimata pārmaiṇu prognozēšanā nākotnē un pielāgošanās scenāriju izveidē.

Klimatu, kas ir augu attīstību noteicošais faktors, ietekmē gan globālas parādības, piemēram, atmosfēras cirkulācija, okeāna straumes, gan mikroklimatiskie apstākḷi. Pētījumi bioklimatologijā jeb dabas ritmu pētījumi notiek vairākos līmenos.

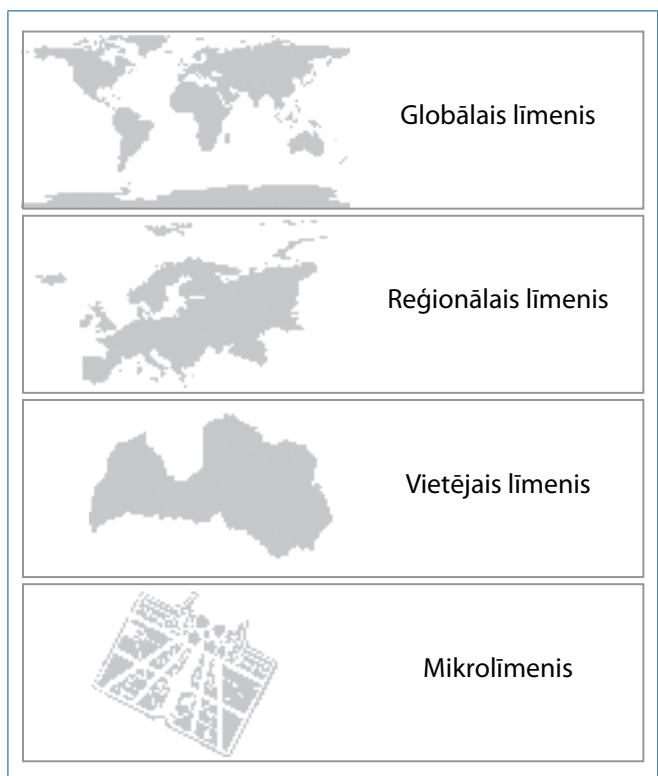

9.1. att. Dabas novērojumu pētijjumu lïmeṇi.
Nereti tieši mikroklimatiskajiem apstākliem ir būtiskākā nozīme augu attīstībā, jo, piemēram, ievas ziedēšanas sākums upes malā var būtiski atškkirties no ievas ziedēšanas sākuma mežmalā.

Katram pētījumu līmenim ir savi veicamie uzdevumi un metodes, piemēram, lai analizētu kokaudzes produktivitāti, $\mathrm{CO}_{2}$ aprites ciklus, veiktu nākotnes prognozes, svarīgi ir globāla mēroga pētījumi, kurus mūsdienās veic, analizējot satelītattēlus. Savukārt, lai kalibrētu satelītattēlus, nepieciešami lauka pētījumi, ko veic brīvprātīgie novērotāji. Aizvien biežāk pētījumos tiek izmantotas tīmekḷa kameras vai digitālo attēlu kameras ar automātisko režīmu.

Dabas novērojumi tiek veikti jau sen. Pasaulē pirmais bioklimatologs ir bijis cilvēks, kura ikdiena bija nesaraujami saistīta ar dabas

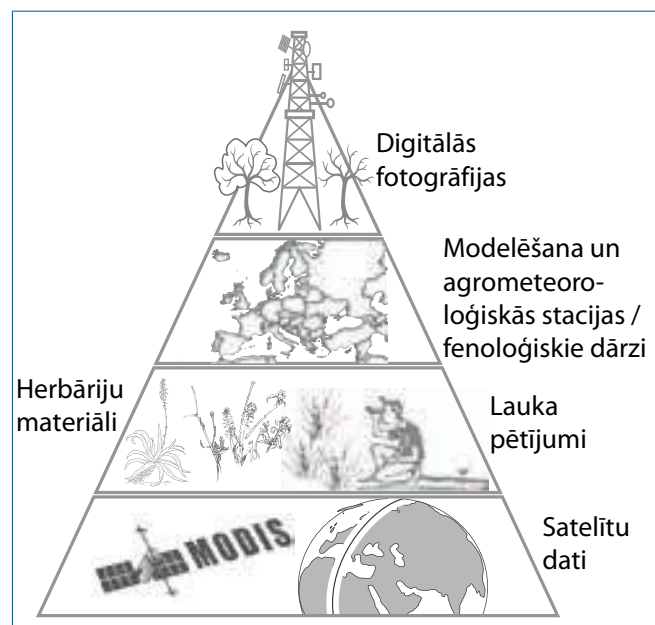

9.2. att. Dabas novērojumu veikšanas metodes. 
ritmiem, pārmain̄ām tajos. Daudzu tautu kalendāri balstīti uz dabas novērojumiem. Piemēram, senajiem latviešiem aprīlis ir bijis sulu mēnesis, maijs - lapu (pieneñu) mēnesis u.tml.

Senākie pierakstītie sistemātiski veiktie novērojumu dati ir atrasti Japānā, kur imperatora pils arhīvos ir saglabājušās ziṇas, sākot no 705. gada, par ķiršu Prunus subhirtella ziedēšanu kā pavasara atnākšanas laiku.

Eiropā rekonstruēti dati par Pinot Noir vīnogu nogatavošanās laiku Francijā kopš 1370. gada. Savukārt Latvijā pirmie rakstiskie novērojumi datēti ar 1822. gadu, taču sistemātiski novērojumi ir veikti, sākot ar 1927. gadu. Ik gadu (ar pārtraukumiem 2. pasaules kara laikā) dabas novērojumi tiek publicēti gada grāmatās un kalendāros ("Daba un vēsture" līdz 2013. gadam; no 2014. gada "Latvijas avīzes gadagrāmatā").

Ikviens ir pamanījis, ka katru gadu lapu plaukšana vai ziedēšana, pirmās zemenes parādās dažādos laikos, t.i., fenologisko fāžu iestāšanās laiks gadu no gada variē. Tāpēc īpaši svarīgi ir veikt datu ievākšanu ilgtermiṇā un analizēt vismaz 30 gadu griezumā jeb normas periodā (piemēram, 1981.-2010. gads).

Ilgtermiña datu analīze l̦auj veikt bioklimatisko parametru izmainu pētījumus, kurus tālāk var praktiski izmantot mežsaimniecības, lauksaimniecības un citu nozaru pētniecībā.
Izanalizējot vairāk nekā 100000 fenologisko datu rindu Eiropā (iekḷauti arī Latvijas dati), secināts, ka gan lapu plaukšana (78\% gadīju$\mathrm{mu}$ ), gan ziedēšana (31\% gadījumu) augiem iestājusies agrāk. Savukārt rudenī 48\% datu rindu uzrādīja pozitīvu tendenci, t.i., iestājas vēlāk un 52\% - negativvu tendenci (lapu krišana iestājas vēlāk). Augḷ nogatavošanās normas periodā tika novērota agrāk (galvenokārt tas attiecas uz lauksaimniecības kultūrām nevis uz savvalıas augiem).

Kopumā fenologiskais pavasaris un vasara Eiropas teritorijā normas periodā (1971.2000. gads) iestājies par 2,5 dienām agrāk desmitgadē. Pētījumi pierāda, ka gaisa temperatūras izmaiṇas ir galvenais ietekmējošais faktors. Paaugstinoties gaisa temperatūrai par $1{ }^{\circ} \mathrm{C}$, pavasara-vasaras fāzes iestājas 2,5 dienas agrāk, savukārt rudens fāzes - 1 dienu vēlāk. Turklāt agrās pavasara fāzēs augi ir jutīgāki pret temperatūras izmainām. Starp lapu dzeltēšanu, lapu krišanu un gaisa temperatūru netika atrasta būtiska sakarība. Tas nozīmē, ka rudens fāzēm ir citi limitējošie faktori, kuri, kā atzīst zinātnieki, vēl nav līdz galam izpētīti.

Pētījumi pasaules vai Eiropas līmenī palīdz izprast dabas ritmu likumsakarības un ietekmējošos faktorus, bet svarīgi veikt un analizēt vietējos novērojumus, kā arī salīdzināt dažādas sugas, jo kultūraugu izmain,as nenotiek tik

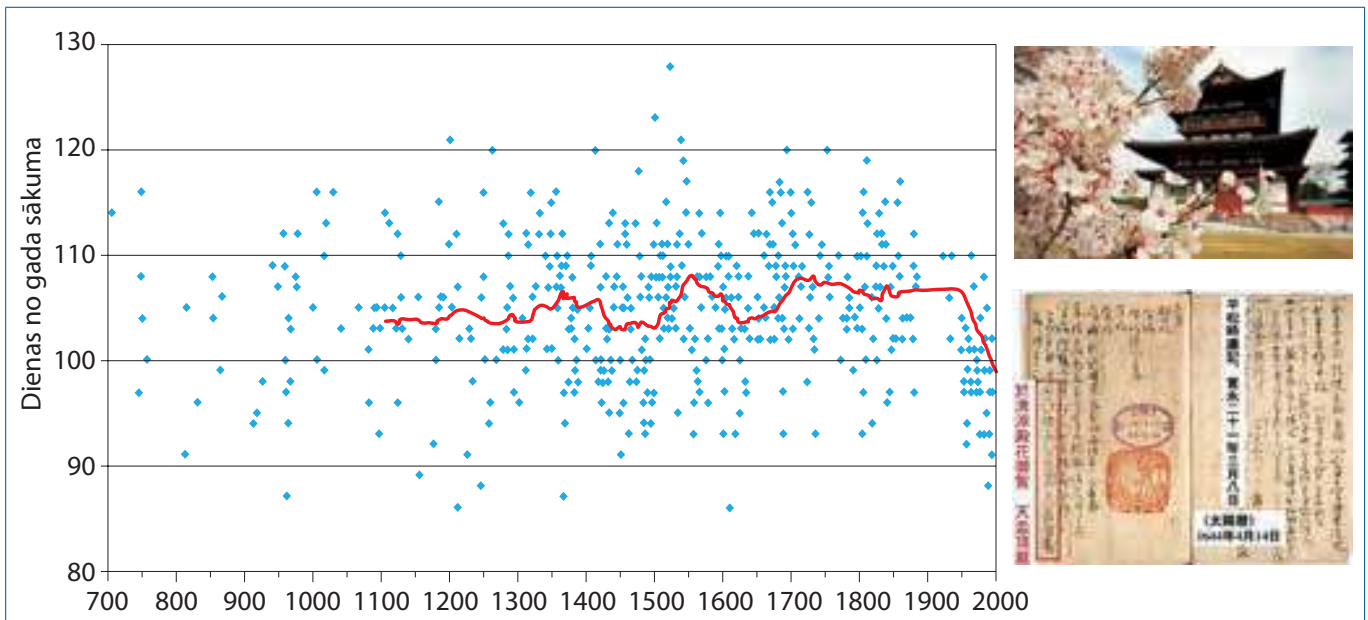

9.3. att. Kiršu ziedēšanas sākuma iestāšanas laiks Kioto, Japānā, sākot no 705. gada. 
strauji kā savval̦as augiem, tāpat pastāv lielas teritoriālas atškirības. Piemēram, augšanas sezonas sākums augḷ kokiem Vācijas teritorijā ir mainījies - tas sākas vidēji 2,3 dienas agrāk desmitgades laikā (kjiršu ziedēšana 2 dienas, ābel̦u ziedēšana 2,2 dienas agrāk) .

Francijā aprikožu un persiku ziedēšanas laiks pēdējos 30 gados mainījies par vienu līdz trijām nedēḷām. Mainījies arī sēšanas vai stādīšanas laiks gan graudaugiem, gan citām kultūrām. Piemēram, kartupel̦i Somijā tiek stādīti vidēji 5 dienas agrāk, kukurūza un cukurbietes Vācijā - 10 dienas agrāk, Francijā kukurūzas sēšana notiek pat līdz 20 dienām agrāk.

Lai arī Latvijā novērojumu skaits un novērojumu vietas gadu no gada mainās, kas apgrūtina datu analīzi, tomēr kopumā bioklimatiskās

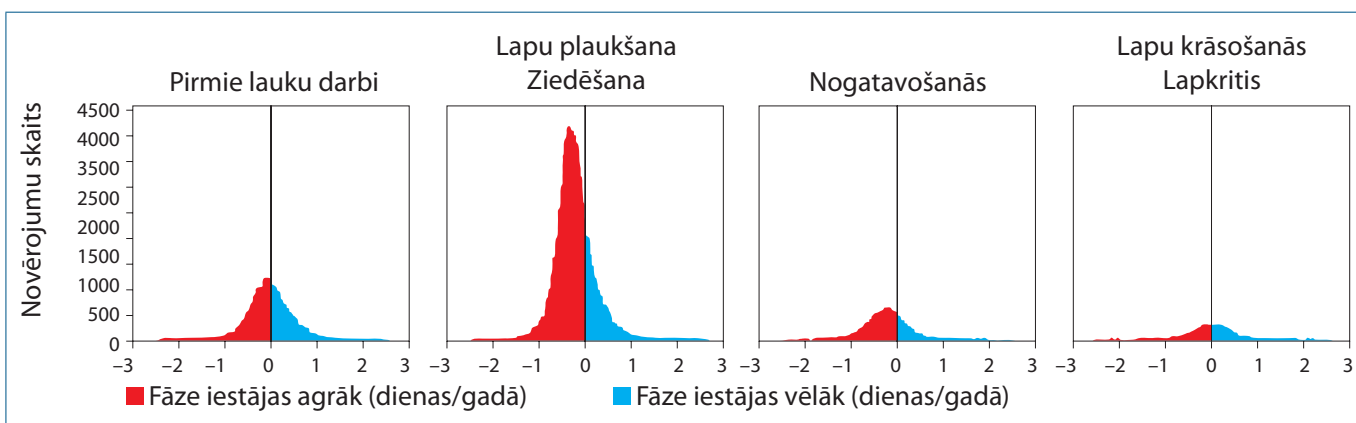

9.4. att. Fenoloǵisko fāžu iestāšanās laika izmaiṇas (dienas/gads) laika periodā no 1971. līdz 2000. gadam Eiropā (analizēti 21 valsts dati, vairāk nekā 542 augu sugas).

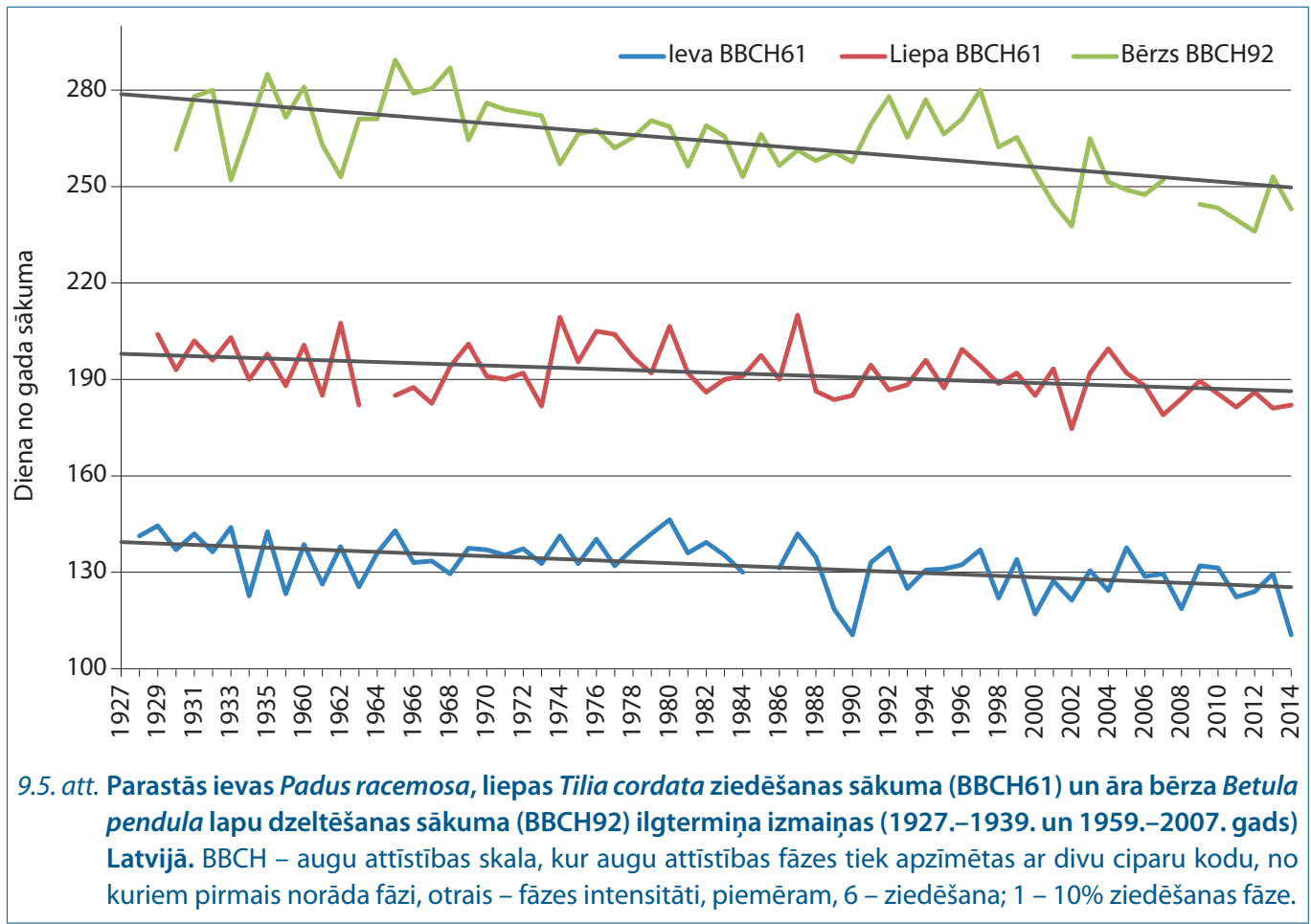


tendences Latvijā sakrīt ar Eiropā un citur pasaulē novēroto: fenologiskajam pavasarim un vasarai ir tendence sākties agrāk. Pretstatā Eiropā novērotajām tendencēm arī fenologískais rudens Latvijas, kā arī Lietuvas teritorijā atsevišksās novērojumu vietās iestājās agrāk (lapas dzeltē un krīt agrāk) vai arī izmaiṇu tendence ir neitrāla.

Lai kvalitatīvāk un vieglāk uztverami raksturotu dabas ritmus, izmaiṇas kalendārā gada griezumā, tiek izdalītas fenologiskās sezonas, par sezonas robežu pien,emot raksturīgu, viegli nosakāmu augu vai dzīvnieku attīstības fāzi, piemēram, liepas ziedēšanu vasarā.

Dažādās valstīs indikatorsugas, kā arī sezonu skaits atšksiras, piemēram, Vācijā tiek izdalìtas 10 sezonas, Latvijā izdala pat 12 sezonas.

Visbiežāk par fenologiskā pavasara indikatoru tiek pien,emts lazdas ziedēšanas sākums, kas vidēji Latvijā iestājas 24. martā. Savukārt meža avenuu ziedēšana, kas ir fenoloǵiskās vasaras indikators, vidēji iestājas 11. jūnijā. 18. septembris ir vidējais fenologiskā rudens sākums, ko iezīmē bērza lapu dzeltēšana. Pirmais sniegs ir fenologiskās ziemas sākums. Kā redzams 9.6. attēlā, normas periodā (1971.2000. gads) ir būtiski mainījies gan sezonas sākums, gan ilgums.

Lauksaimniecības un mežsaimniecības vajadzībām svarīgi ir definēt un analizēt augšanas sezonu, ko zinātniskajā literatūrā izsaka trīs veidos:

1) periods jeb dienu skaits starp pēdējo salnu pavasarī un pirmo salnu rudenī (izmanto galvenokārt Ziemel̦amerikā);

2) klimatiskā augšanas sezona (veǵetācijas periods);

3) fenoloǵiskā augšanas sezona kā periods starp lapu plaukšanu lapu kokiem un lapu dzeltēšanu vai arī citos avotos starp pumpurošanos un lapu krišanu vai starp lapu plaukšanu un lapu krišanu.

Latvijā augšanas sezonas sākums ir diena, kad vidējā diennakts temperatūra ir augstāka par $+5^{\circ} \mathrm{C}$ vismaz 5 dienas pēc kārtas, savukārt augšanas sezonas beigas iestājas tad, kad vidējā diennakts temperatūra 5 dienas ir bijusi zemāka par $+5^{\circ} \mathrm{C}$.

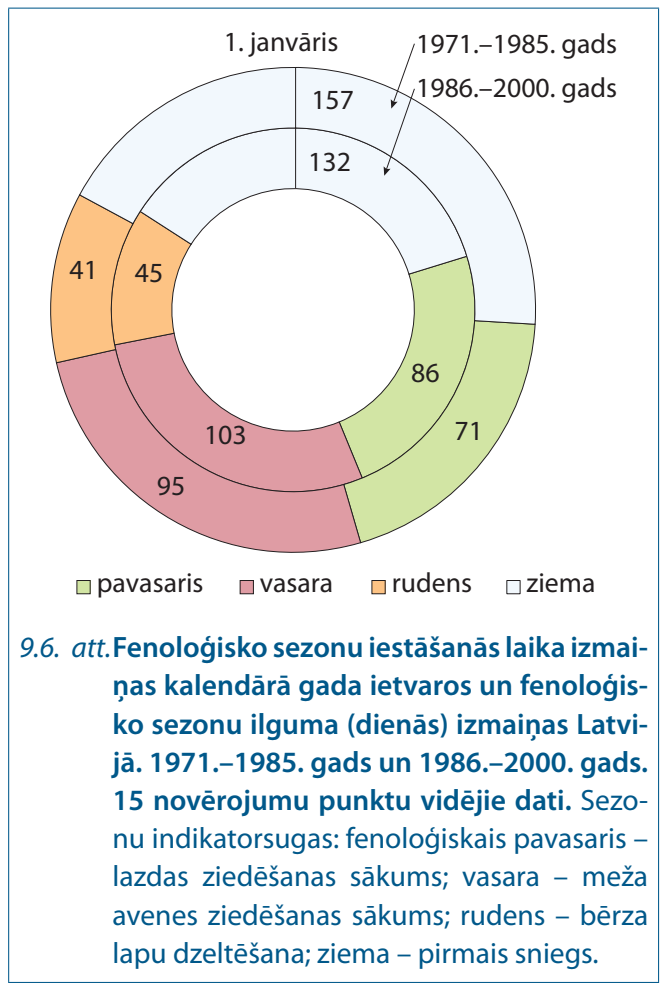

20. un 21. gs. fenologiisko fāžu iestāšanās laiks, tostarp fenologiiskās augšanas sezonas sākums, beigas un ilgums ir būtiski mainījies. Pasaulē vidēji fenologiskais pavasaris iestājas 8 dienas agrāk, bet augšanas sezona ir pagarinājusies līdz pat 12 dienām. Atšḳirības variē atkarībā no novērojumu vietām, piemēram, analizējot Eiropas fenologiskos dārzu datus, konstatēts, ka kopumā augšanas sezonas ilgums vidēji pagarinājies par 10,5 dienām, t.i., par 3,5 dienām desmitgadē. Vislielākās izmaiñas konstatētas Centrāleiropā, mazāk Skandināvijas ziemelıos un Dienvidaustrumeiropā. Ir aprēķināts, ka fenologískā augšanas sezona Eiropā virzās ar ātrumu $44 \mathrm{~km}$ diennaktī no dienvidiem uz ziemel̦iem un $200 \mathrm{~km}$ diennaktī no rietumiem uz austrumiem.

Satelītattēlu datu analīze liecina, ka Ziemel̦eiropas lielākajā dal̦ā fenologiskais pavasaris iestājies līdz divām nedēlām agrāk (atsevišksās vietās pat vairāk nekā 2 nedēḷas agrāk), savukārt fenoloǵiskais rudens iestājies 2 līdz 
4 nedēl̦as vēlāk, augšanas sezonas ilgumam pagarinoties no 2 līdz pat vairāk nekā 4 nedēlām.

Augšanas sezonas vidējais ilgums kā periods starp lapu plaukšanu un lapu dzeltēšanu āra bērzam periodā vidēji mainījies 7 dienu intervālā, galvenokārt uz pavasara fāzes agrāku iestāšanos.
Augšanas sezonas iestāšanās laiks galvenokārt ir atkarīgs no gaisa temperatūras izmaiñām, savukārt augšanas sezonas beigu iestāšanos ietekmē citi faktori vai faktoru kopums (apgaismojuma ilgums (fotoperiods), mitruma apstākḷi, ekstremālās gaisa temperatūras, jūras ietekme u.c.), kas precīzi nav noskaidroti.
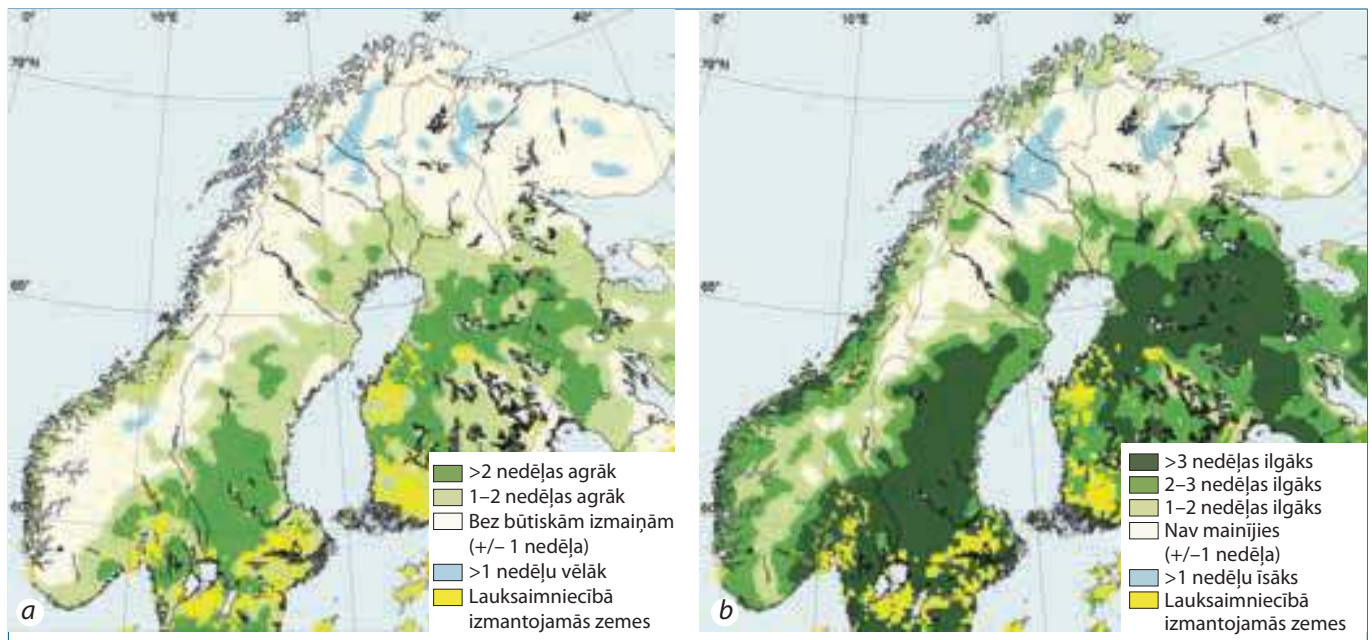

9.7. att. Augšanas sezonas sākuma (a) un ilguma (b) izmaiṇas periodā no 1982. lĩdz 2006. gadam Ziemeḷeiropā.
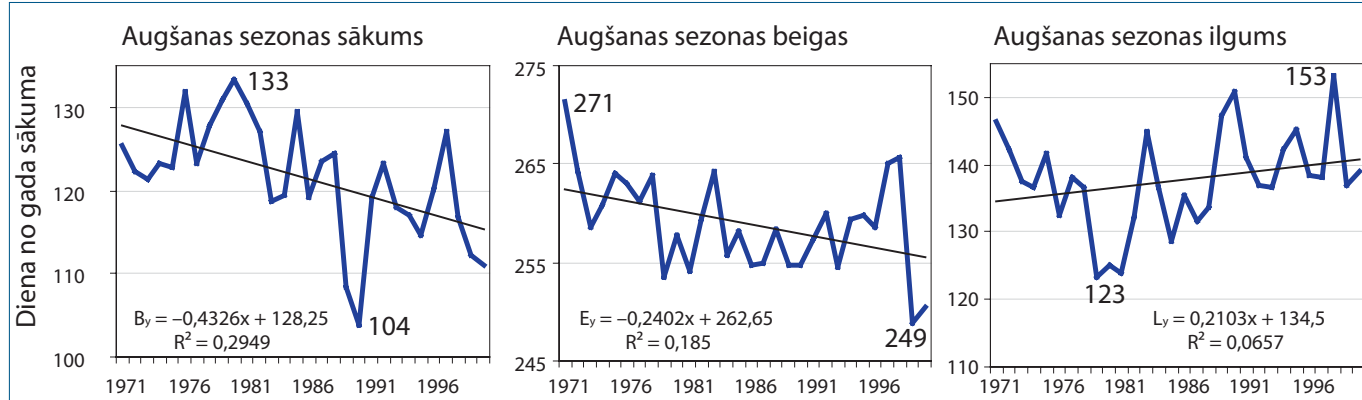

9.8. att. Augšanas sezonas sākuma, beigu un ilguma izmainas āra bērzam Betula pendula (1971.-2000. gads) Latvijā un Lietuvā. 


\subsection{Klimata mainības ietekme uz lauksaimniecību}

Klasiski dabas novērojumi ir izmantoti lauksaimniecībā un mežsaimniecībā, tāpēc bioklimatiskos pētījumus, kas ir īpaši svarīgi šajās nozarēs, un modelētās prognozes var izmantot nākotnes risku, iespēju un adaptācijas piemēru analīzei.

Tomēr dabas novērojumu nozīme ir daudz plašāka - tie palīdz izskaidrot komplekso ekologisko dinamiku (ietekmējošos faktorus un ekologiskās sekas), kā arī tiek izmantoti globālajos klimata mainības un biogeokīmisko ciklu $\left(\mathrm{CO}_{2}\right.$ aprite, barības vielu aprites cikli, hidrologiskie cikli) pētījumos (ekosistēmu produktivitāte, sugu un populāciju savstarpējā dinamika).

Klimata mainības ietekmi nevar vērtēt ne kā sliktu, ne kā labu, jo tā nes gan ieguvumus, gan zaudējumus. Lauksaimniecības un mežsaimniecības gadījumā uz pārmaiṇām jāskatās kompleksi, kritiski izvērtējot ietekmējošos faktorus, jo pēdējos 100 gados ir būtiski mainījušās mežu izmantošanas un lauku apstrādes tehnoloǵijas, valsts politika, zemes lietojums u.c.

Augšanas sezonas pagarināšanās būtiskākās sekas gan lauksaimiecībā, gan mežsaimniecībā ir $\mathrm{CO}_{2}$ koncentrācijas palielināšanās gaisā, kas rada izmaingas primārajā produkcijā. Globālā primārā produkcija (neto) laika periodā no 1982.-1999. gadam, balstoties uz satelītdatu analīzi, ir pieaugusi par 6\%. Lielāks pieaugums bijis tropu ekosistēmās, bet Eirāzijā - pat par 12\% 1981.-1999. gada periodā.

Lauksaimniecība ir viena no visjutīgākajām tautsaimniecības nozarēm attiecībā uz klimata mainību, jo uzreiz reaǵē uz laika apstākḷu un vides apstākḷu maiṇu, taču ir visgrūtāk prognozējama. Tāpēc nākotnes prognozes lauksaimniecībai tiek veiktas l,oti piesardzīgi, jo lauksaimniecību kā nozari ietekmē sarežgíts ietekmējošo faktoru kopums.

Daudzas no kultūraugu sugām uz klimata mainību reaǵē diametrāli pretēji: kādai no sugām $\mathrm{CO}_{2}$ un gaisa temperatūras pieaugums kḷūst par pozitīvu faktoru agrākai, àtrākai un produktīvākai augšanai, kādai citai tā ir iznīcinoša kombinācija.
Pētījumi liecina, ka sugas, kuras apputeksnē kukaiṇi, zied agrāk nekā vēja apputeksnētie augi.

Klimata mainība savval̦as augus ietekmē vairāk nekā kultūraugus, piemēram, Vācijā veiktajā pētījumā secināts, ka laika periodā no 1951. līdz 2004. gadam savvalıas augu attīstības fāzes iestājušās 4,4 līdz pat 7,1 dienas agrāk desmitgadē. Kultūraugiem attīstības fāzes iestāšanās laiks nav tik izteikts (2,1 diena desmitgadē).

Latvijā veikto agrometeorologisko staciju datu analīze apstiprina, ka lielākajai dal̦ai pētījumā analizēto kultūraugu (graudaugi, kartupeḷi, jāṇogas un ābeles) fenoloǵiskās fāzes iestājas agrāk, tomēr izmainas nav tik būtiskas kā savvalıs augiem.

Ābeles Malus domestica vidēji pēc agrometeorologisko staciju datiem pumpurojas no 6. līdz 18. aprīlim (atkarībā no šksirnes). Ilggadīgie novērojumu dati liecina, ka tendence ir neitrāla (pumpurošanās sākums būtiski nemainās) vai ir negatìva (Dobele, Dagda), savukārt lapu plaukšanas un ziedēšanas tendence ir negatīva vairumā vietu (izṇemot Dagdu). Kopumā ābeḷu ziedēšana iestājas 1 līdz 3 dienas agrāk desmitgadē. Lielākoties pavasara fāžu agrākie laiki konstatēti 20. gs. 90. gados, bet vēlākie - 70. un 80. gados. Vidēji no pumpurošanās līdz ābolu nogatavošanās fāzei paiet 138 dienas "Baltajam dzidrajam" un vidēji 160 dienas "Antonovkai" un "Rudens svìtrainajam". Faktiski āboli nogatavojas agrāk.

Lapu dzeltēšana novērota no 6. līdz 14. oktobrim. Lapu dzeltēšanas tendence Dobelē un Priekuḷos ir neitrāla (fāze nav mainījusies), Dagdā - pozitīva, savukārt Stendē - negatīva. Augšanas ilgums āboliem vidēji ir 150 dienas, ar tendenci pagarināties, kas īpaši izteikts ir "Antonovkas" šksirnei.

Klimata mainības ietekme uz lauksaimniecību nākotnē izpaudīsies atšksirīgi dažādos pasaules reǵionos. Pasaules mērogā graudaugu (kvieši, kukurūza, mieži) raža temperatūras paaugstināšanās dēl ir samazinājusies. 
Dienvideiropas valstīs ražas apjomi ir sākuši samazināties, bet Ziemel̦eiropā atsevišku graudaugu raža ir pat palielinājusies.

Latvijas gadījumā vislielākās grūtības lauksaimniekiem sagādās prognozētie sausuma periodi un intensīvie nokrišñi.

Visbiežāk kā pozitīvas klimata mainības sekas lauksaimniecībā tiek minēta augšanas sezonas pagarināšanās, fotosintēzes intensitātes paaugstināšanās, jaunu kultūraugu augšanas iespējas un produktivitātes pieaugums Ziemel̦eiropā.

Tomēr klimata mainība nesīs sev līdz daudz risku: atsevišksos reǵionos būs nepietiekams ūdens daudzums, samazināsies augsnes mitrums, notiks kultūraugu postījumi, palielināsies pesticīdu lietojums, var pat samazināties augkopības iespējas.

Papildu siltums un mitrums radīs labvēlīgu vidi sēnuu, dažādu patogēno mikroorganismu attīstībai, kas nelabvēlīgi ietekmēs augu attīstību un pastarpināti arī cilvēku veselību, jo lauksaimniekiem būs jāizmanto vairāk augu aizsardzības līdzeklu.

Būtisks risks lauksaimniekiem ir vēlās pavasara salnas. Lai arī bezsala periods kopumā pagarinās, lielākoties tas notiek uz rudens salnu vēlākas iestāšanās rēksina. Eiropā 1992.-2008. gada periodā bezsala perioda beigu laiks ir +8,2 dienas desmitgadē, bet sākums - agrāks par 3,2 dienām desmitgadē. Pēdējās pavasara salnas beidzas agrāk, bet arī augu attīstība pavasarī sākas agrāk, līdz ar to pastāv būtisks augu postījumu risks, kā tas notika 2003. gadā Eiropā.

Nepastāvīgo, netipisko un grūti prognozējamo laika apstākḷu rezultātā lauksaimnieki nevarēs prognozēt ikgadējās kultūraugu ražas. Tas ir liels risks lauksaimniecības nozares attīstības plānošanai.

No vienas puses, pagarinoties augšanas sezonai, palielinās kultūraugu produktivitāte, jo ilgāks augu attīstības cikls l̦auj maksimāli izmantot pieejamo Saules siltuma daudzumu, ūdens un barības vielas, kas palielinās kultūraugu ražu. No otras puses, negatīvā ietekme ir tāda, ka gaisa temperatūras un mitruma režīma ietekmē var samazināties laiks starp augu attīstības cikliem, piemēram, laiks starp stiebrošanos un vārpošanos graudaugiem, kas var samazināt iegūstamo ražu.

Eiropas Vides aǵentūra, kā arī Eiropas Komisijas pētniecības centri regulāri veic nākotnes prognozes par lauksaimniecībai svarīgo sugu izmaiṇām attīstības fāzēs.

Tiek prognozēts, ka ziemas kviešu ziedēšanas laiks Eiropā var mainīties līdz pat mēnesim (ziedēšana iestāsies agrāk), tomēr lielākajā daḷā teritorijas izmaiņas tiek prognozētas 2 nedēlas agrāk attiecībā pret 1975.-1994. gada

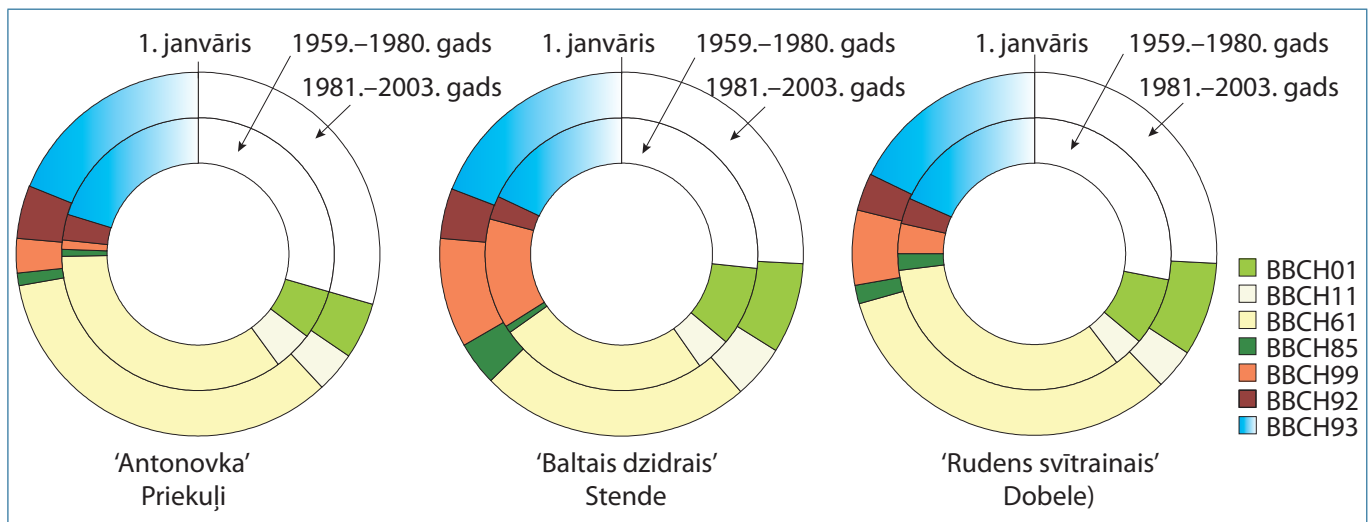

9.9. att. Fenoloǵisko fāžu izmaiṇas ābelēm. $\mathrm{BBCH} 11$ - pumpurošanās sākums; $\mathrm{BBCH} 11$ - plaukšanas sākums; BBCH61 - ziedēšanas sākums; BBCH85 - augḷ nogatavošanās; BBCH92 - lapu dzeltēšana; BBCH93 lapu krišanas sākums; BBCH99 - augḷ novākšanas laiks. 
periodu. Kā redzams 9.10. attēlā, ziedēšanas lielākas izmaiṇas tiek prognozētas piekrastes teritorijās. Ziemas kviešu nogatavošanās fāzes iestāšanās laiks mainīsies vairāk nekā ziedēšanas laiks, t.i., tiek prognozēts, ka ziemas kvieši gatavību sasniegs 20-25 dienas agrāk salīdzinājumā ar 1975.-1994. gada periodu.

Pētījumā arī minēts, ka vasaras kviešu sēšanas laiks, ziedēšanas un gatavības iestāšanās laiks kḷūs agrāks par 1-3 nedēḷām atkarībā no regiona. Ziemel̦eiropas teritorijā lielākās izmaiṇas tiek prognozētas kukurūzai, mazākas - ziemas kviešiem. Taču, kā norāda arī pētījuma autori, modelētie rezultāti atšksiras atkarībā no lietotā modelıa, reǵiona. Tas nozīmē, ka prognozēt lauksaimniecības kultūru izmaiñas ir sarežǵīti.

Eiropas dienvidu dal̦ā lielākoties tiek prognozēts ražas apjoma samazinājums, pretstatā Ziemel̦eiropas teritorijai, kur prognozēts, ka 2080. gadā labības ražu palielinājums būs pat līdz 30\%. Attiecībā uz Latviju model̦a dati rāda nelielu graudaugu ražas pieaugumu līdz 10\%.

Gaisa temperatūras un $\mathrm{CO}_{2}$ lìmeña paaugstināšanās būtiski mainīs gan kultūraugu
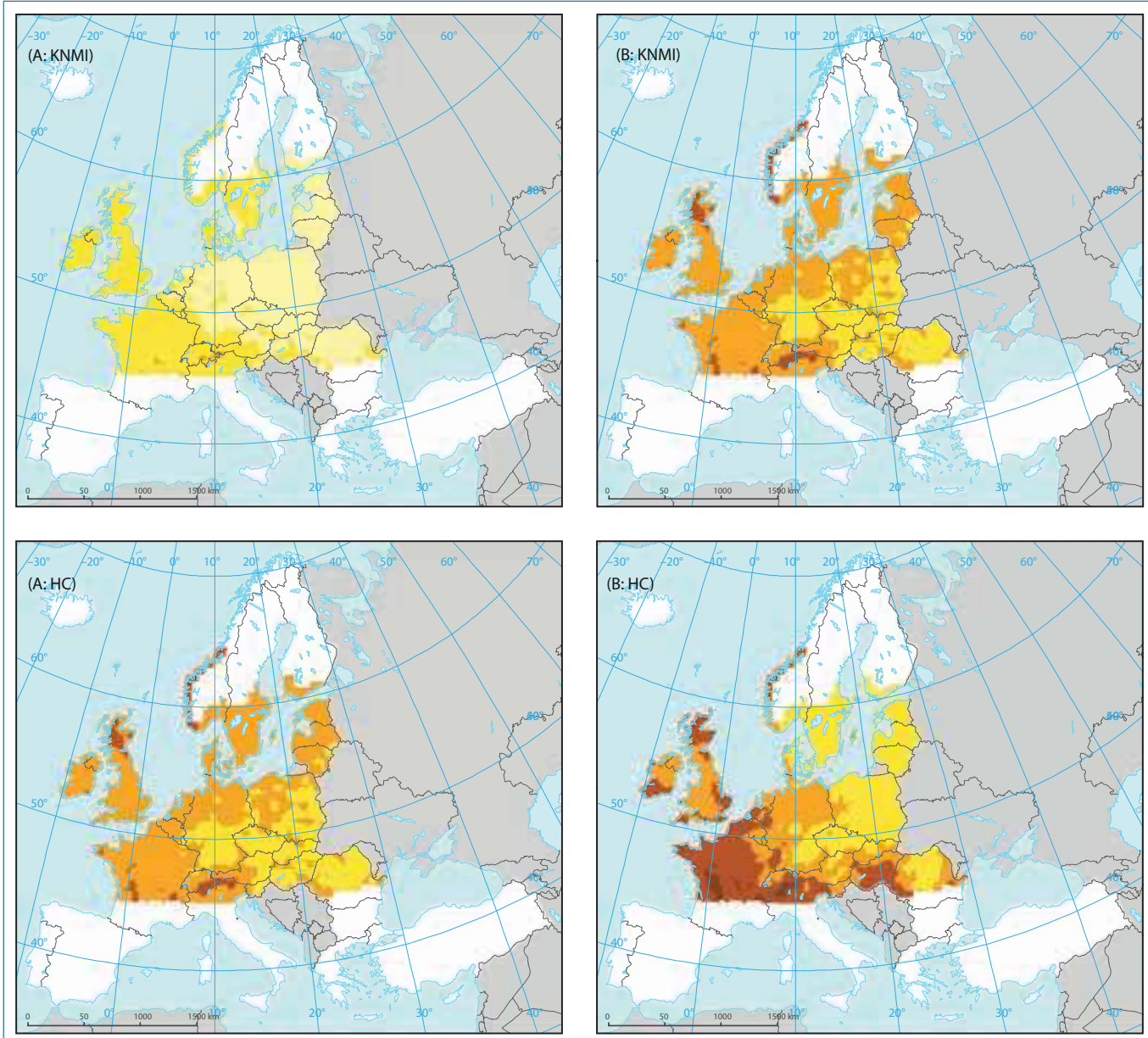

Dienas $-25 \quad-20 \quad-15 \quad-10 \quad-5 \quad 0 \quad 5 \quad$ Nav datu

9.10. att. Prognozētās izmainas (dienās) ziemas kviešu attīstības fāzēm: ziedēšanas sākumam (A) un gatavības fāzei (B) periodam 2031.-2050. gads, pastāvot klimata scenārijam A1B. 


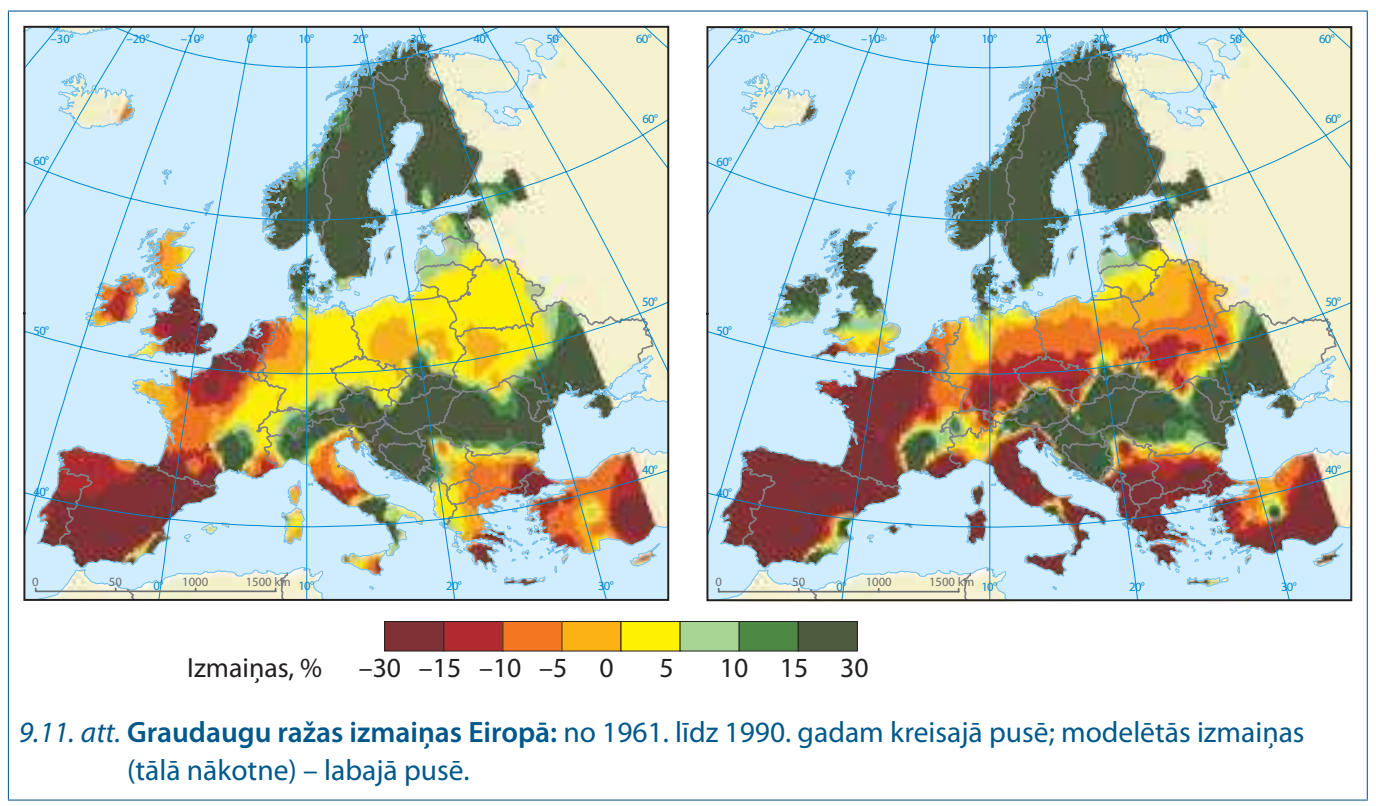

sastāvu, gan to kvalitāti, kā arī ietekmēs lopkopības nozari.

Prognozētie karstuma vilı̣i vasarās apdraudēs ne tikai cilvēkus, bet arī ietekmēs lopkopības nozares produktivitāti. Tāpat karstums ietekmē piena izslaukumu, mājlopu reproduktīvās funkcijas, kā arī organisma spēju pretoties slimībām. Lopkopību nākotnē īpaši ietekmēs zālāju daudzums un kvalitāte. Netipiski augstās gaisa temperatūras vasarā, kas tiek prognozētas Eiropas (arī Latvijas) teritorijai, galvenokārt sausuma dēl negatīvi ietekmēs zālāju augšanu. Sausums samazina augu dabisko spēju pretoties gan kaitēkḷiem, gan samazina augšanas spēju. Tas nozīmē, ka zālāju vērtība pazemināsies un būs jāiegulda papildu līdzekḷi mājlopu uztura nodrošināšanai.

Lai aizsargātu sausuma novājinātos augus no kaitēkḷliem, būtiski būs jāpalielina augu aizsardzības pasākumi, kas savukārt paaugstinās kopējās izmaksas.

Dabas ritmu pētijumos nākotnes prognozes tiek izteiktas, veicot bioklimatisko modelēšanu, izstrādājot gan globāla mēroga model̦us, gan arī vietēja mēroga model̦us, kuri ietver ietekmējošos faktorus (vietas reljefs, hidrologiskais tīkls, dominējošie vēji, jūras ietekme).
Latvijas teritorijai, arī abām kaimiṇvalstīm, ir izstrādāts parastās ievas Padus racemosa fenologisko fāžu iestāšanās laika prognozes modelis un zemeṇu ziedēšanas un ražas prognozes nākotnē.

2014. gadā tika veikts mēginājums prognozēt savvalıas augu fenologiskās fāzes Baltijas jūras valstīs. Pētījums balstījās uz brīvprātīgo novērotāju datiem, kā arī tika veikti lauka maršruta pētījumi, fotografējot parastās ievas Padus racemosa fāzes ik pa $30 \mathrm{~km}$. Datu analīzē tika izmantoti vairāk nekā 200 punktu novērojumu. Fotogrāfijas tika apstrādātas, aprakstot ievas attīstības fāzes.

Modelis balstās uz agrometeorologijā daudz izmantoto pieeju par grādu dienām. Grādu dienu augšanas modelis ir vienkāršākais no fenoloǵisko model̦u veidiem. Tajā tiek pien,emts, ka augu attīstība notiek, ja gaisa temperatūra pārsniedz noteiktu bāzes vērtību, t.i., jo ir siltāks, jo augi attīstās ātrāk. Temperatūru, kas pārsniedz bāzes temperatūru, sauc par aktīvo temperatūru. Tiek pieñemts, ka noteiktu attīstības fāžu sasniegšanai ir nepieciešama noteikta aktīvo temperatūru summa. Aktīvo temperatūru summa tiek iegūta, saskaitot kopā katras dienas vidējās 


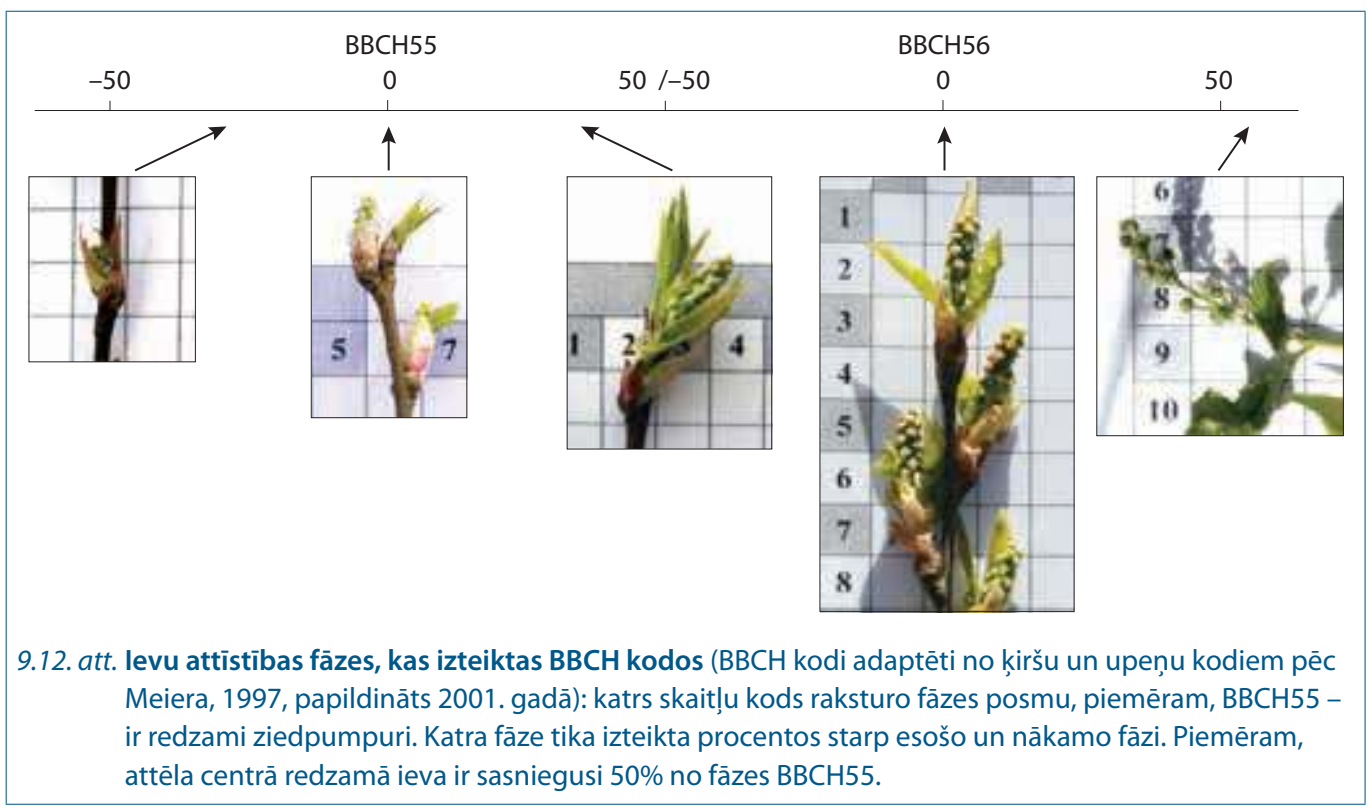

temperatūras, ${ }^{\circ} \mathrm{C}$, kas pārsniedz bāzes temperatūru.

Izmantojot ilgtermina fenologiskos un meteoroloǵiskos novērojumus, ir iespējams aprēķināt katrai augu sugai raksturīgo bāzes temperatūru un grādu dienu summu, kas ir nepieciešama noteiktu attīstības stadiju sasniegšanai.

Model̦a rezultāti rāda, ka Lietuvas dienvidu teritorijās tiek prognozēta fāze BBCH69, kas ir ziedēšanas beigu fāze, kamēr Igaunijas ziemel̦austrumos, Peipusa ezera tuvumā tikai pumpurošanās fāze.

Fenologiskais modelis kā izejas datus izmanto laikapstākḷu prognozi, kas iegūta no regionālajiem atmosfēras pētījumu model̦iem.

2014. gada aprēķinu gadījumā model̦a dati atpalika no reāli dabā novērotās attīstības, kas, iespējams, ir saistīts ar neparasti silto 2013./2014. gada ziemu.

Latvijas Universitātes Vides un tehnologisko procesu matemātiskās modelēšanas laboratorijas (VTPMML) pētījumi apliecina, ka pastāv iespējas aprēkeināt augu attīstību, izmantojot model̦us un veicot šo model̦u uzlabojumus.

VTPMML pētījumā tika modelēts arī dārza zemeṇu ziedēšanas un ražas laiks trīs

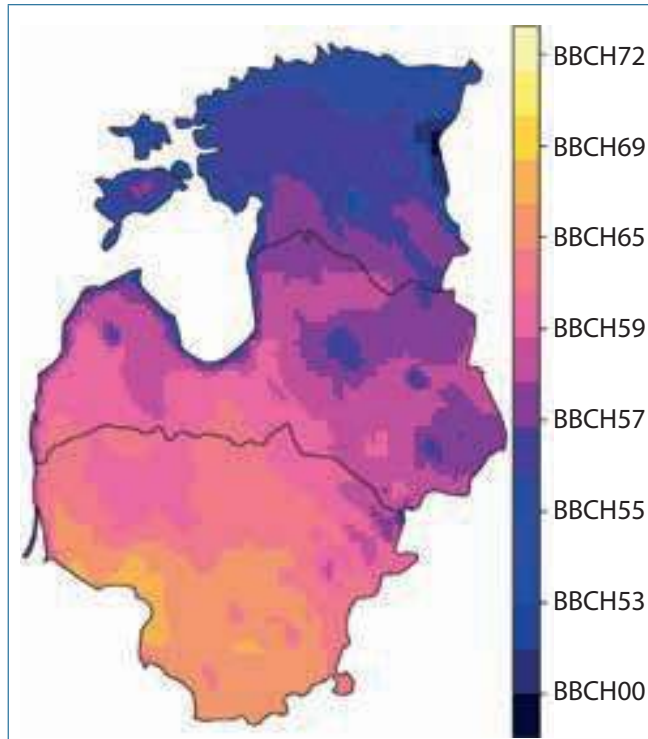

9.13. att. Parastās ievas Padus racemosa attīstības fãzes 2014. gada 30. aprīī: modela rezultāti. Krāsu skala iezīmē ievas attīstības progresu jeb fāzes: $\mathrm{BBCH} 00$ - snaudoši pumpuri; $\mathrm{BBCH} 10$ lapu plaukšanas sākuma fāze; $\mathrm{BBCH} 5 \mathrm{X}$ dažādas lapu attīstības fãzes; BBCH60-69 ziedēšanas fāzes. 
periodiem: pagātnei (1951.-1980. gads), tagadnei un tuvākai nākotnei (2001.-2030. gads), kā arī tālākai nākotnei (2070.-2099. gads) Baltijas valstīs.

Mūsdienās zemeņu ziedēšana vidēji iestājas no maija vidus līdz jūnijam (gada 20.24. nedēḷā). Visagrāk zemeṇu ziedēšana iestājas
Lietuvas dienvidos un pakāpeniski virzās uz ziemel̦iem ar ātrumu 200-300 km/nedēl̦ā.

Pētījuma dati liecina, ka 1951.-1980. gadā zemeñu ziedēšana iestājusies nedēl̦ vai pat 2 nedēḷas vēlāk salīdzinājumā ar iespējamo periodu līdz 2030. gadam. Savukārt tālākā nākotnē sagaidāms, ka zemenes sāks ziedēt jau
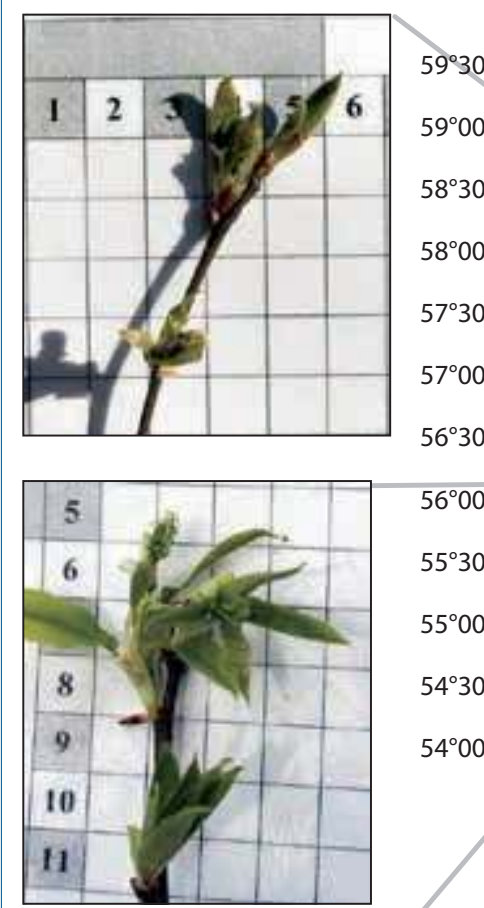

$56^{\circ} 30^{\prime} \mathrm{N}$
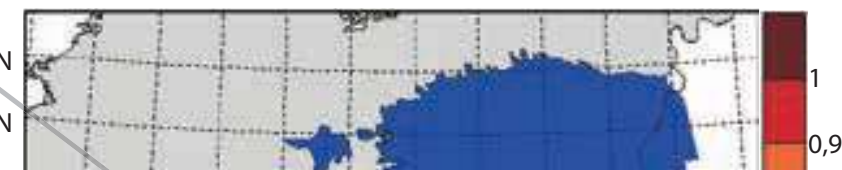

$56^{\circ} 00^{\prime} \mathrm{N}$

$55^{\circ} 30^{\prime} \mathrm{N}$
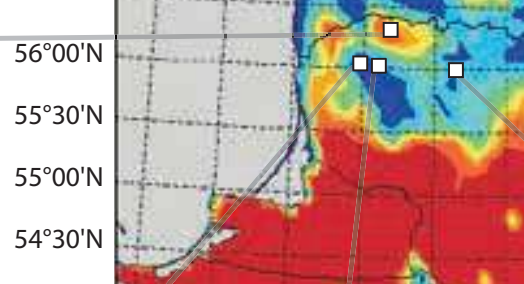

$54^{\circ} 00^{\prime} \mathrm{N}$
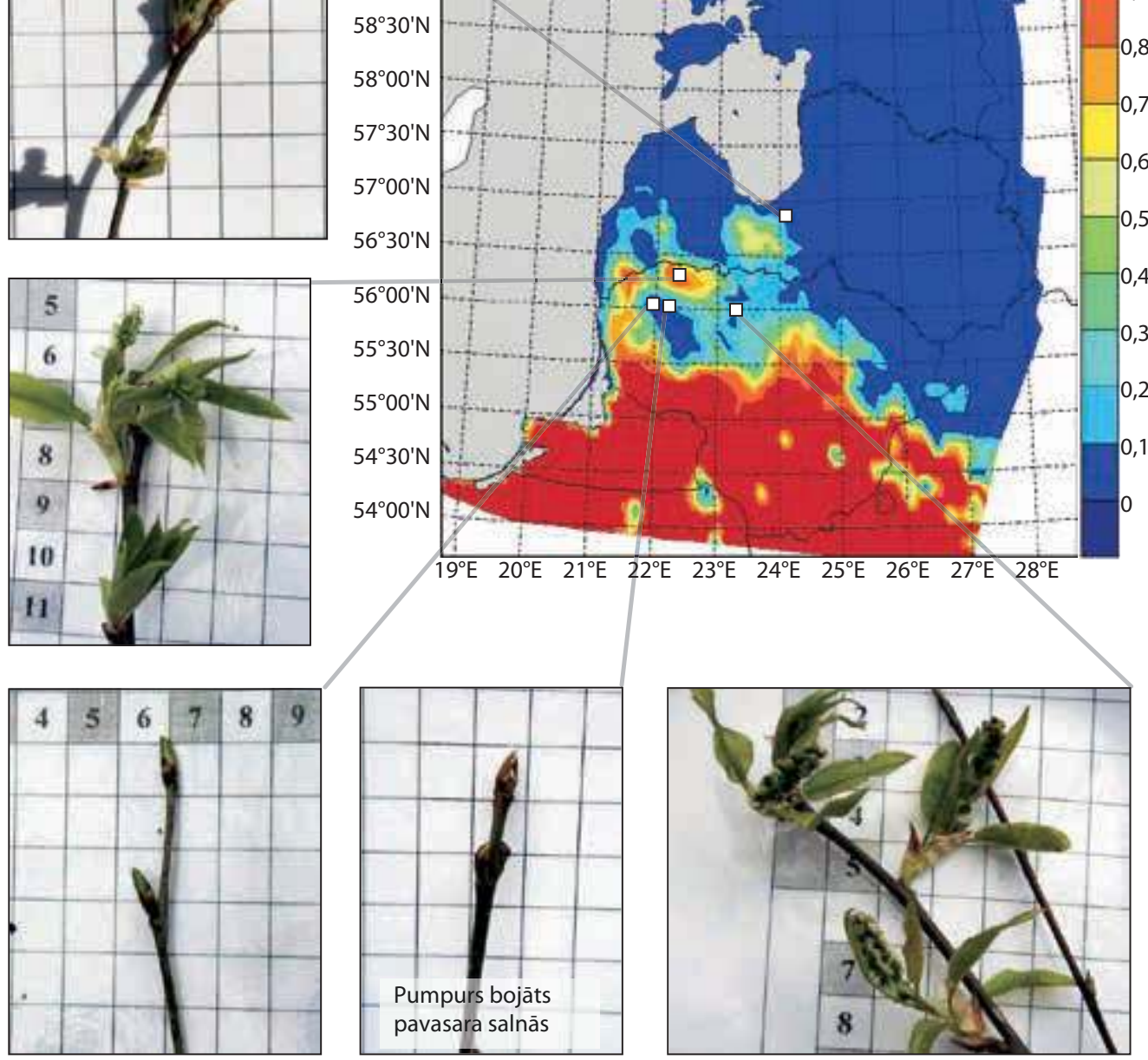

9.14. att. Modeḷa un reālo lauka novērojumu salīdzinājums Baltijas valstīs 2014. gada pavasarī parastās ievas Padus racemosa lapu plaukšanas fāzei.

Ar krāsu skalu parādīta fāzes sasniegšanas iespējamība: ja krāsas skala ir 1, t.i., sarkana tiek prognozēts, ka atbilstošajā teritorijā ir vērojams ievas lapu plaukšanas sākums. Kartē - modelētie novērojumi jeb prognozētā ievas attīstības fāze; attēlos - reālās uz lauka novērotās ievas attīstības fāzes. 

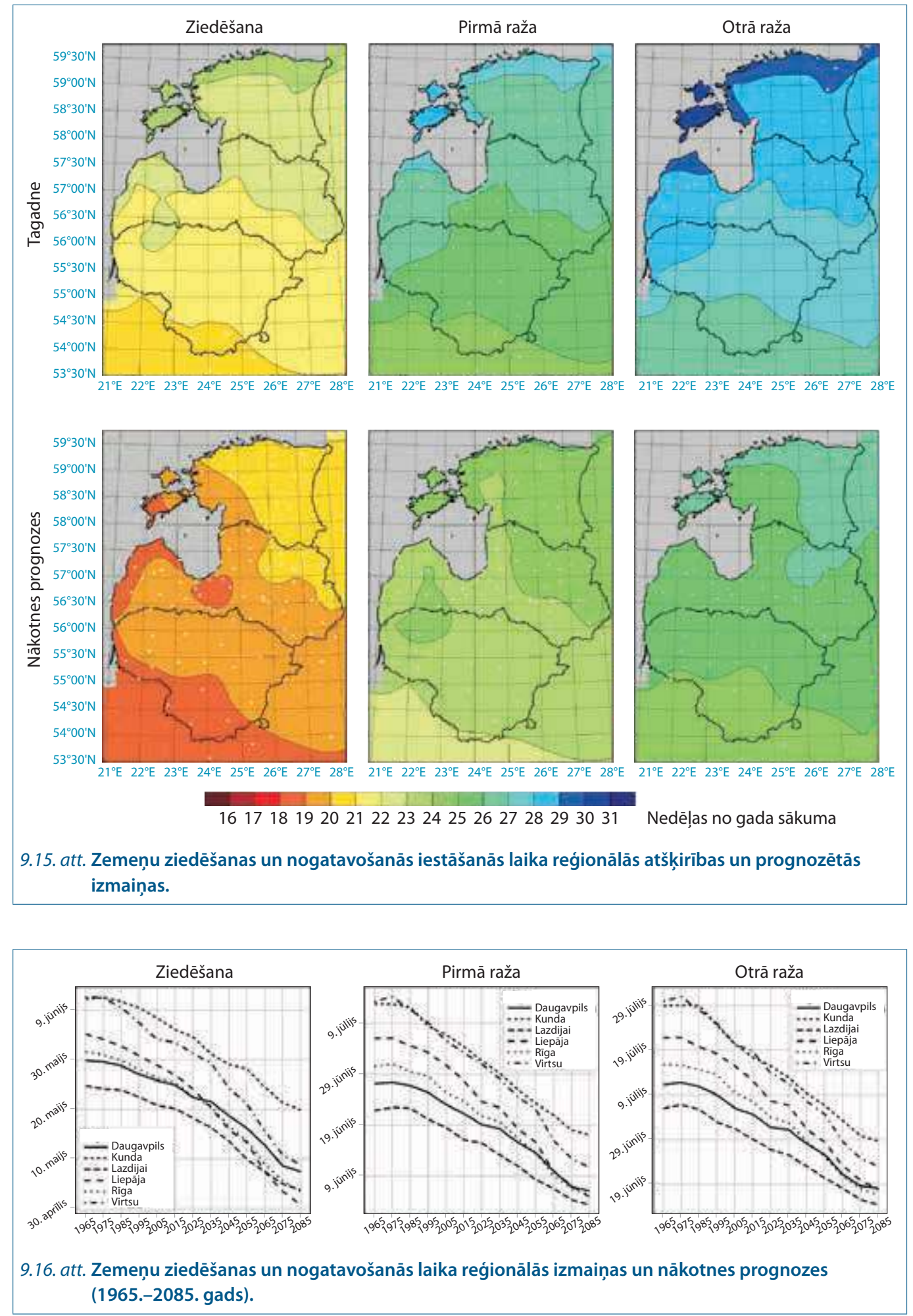
aprīla beigās (18.-22. gada nedēl̦ā). Savukārt pirmā raža varētu būt 2 nedēḷas agrāk (22.26. gada nedēlāā) salīdzinājumā ar pašreizējo laiku, kad zemenes nogatavojas jūnijā-jūlijā (24.-29. gada nedēlıā).

Modelētās izmaiṇas atšksiras atkarībā no pētỉjuma vietas novietojuma attiecībā pret reljefu (augstienēs vēlāk), bet, jo īpaši, attiecībā pret attālumu no Baltijas jūras vai Rīgas līča.

Tiek prognozēts, ka jūras piekrastes teritorijās izmainnas būs lielākas un, iespējams, ka attiecībā uz zemenēm fāzes, kas mūsdienās iestājas agrāk kontinentālajā daḷā, nākotnē pirmās būs vērojamas piekrastē, taču šie rezultāti jāinterpretē piesardzīgi, jo jān,em vērā, ka klimata model̦i varētu būt "pārvērtējuši" Baltijas jūras sasilšanas tendences.

Nākotnes prognozes modeḷu veidā, kā arī zināšanas par klimata pārmaiṇu radītajām sekām, kā arī laikus veiktie pasākumi l,aus lauksaimniekiem un mežsaimniekiem izmantot klimata pārmaiṇas izdevīgākā veidā.

\subsection{Klimata pārmaiṇu ietekme uz mežsaimniecību}

Pētījumi rāda, ka, pastāvot optimālam mitruma un temperatūras režìmam, $\mathrm{CO}_{2}$ koncentrācijas pieaugums gaisā meža augšanu ietekmēs pozitīvi - palielināsies koku caurmēra pieaugums, turklāt skuju koku mežos izmaiṇas būs lielākas nekā lapu koku mežos. Zinātnieki aprēḳinājuši, ka Somijas ziemel̦u dal̦ā koksnes produktivitāte varētu pieaugt pat par 70\%. Taču teritorijās ar nepietiekamu mitruma režīmu prognozētais $\mathrm{CO}_{2}$ pieaugums var radīt papildu risku meža audzēm.

Arī gaisa temperatūras izmainām var būt gan pozitīvas, gan negatīvas sekas - siltummīlošās sugas palielinās izplatības areālus, migrējot vairāk uz ziemel̦iem vai kalnu rajoniem, savukārt kalnos daudzas sugas aizies bojā, nespējot pielāgoties.

Gaisa temperatūras paaugstināšanās pozitīvi ietekmēs skuju koku (priedes, egles) augšanu
Eiropas ziemel̦u teritorijās. Bērzi, kas ir dominējošā koku suga Baltijas jūras reǵionā, eksperimentālajos pētījumos uzrāda pozitīvas izmain,as - augs labāk.

Jaukto koku mežos gaisa temperatūras paaugstināšanās var drīzāk veicināt koku augšanas riskus, piemēram, dižskābārdim šādā gadījumā novēro samazinātu pieaugumu. Jau tagad pētījumi apliecina, ka Somijas ziemel̦u dal̦ā ir vērojams meža koksnes pieaugums, bet priedei Somijas dienvidu dal̦ā - samazinājums, ko galvenokārt ietekmējusi ūdens bilance.

Gaisa temperatūras izmain,as radīs sniega segas izmaiṇas, kas savukārt ietekmēs sezonālo ūdens daudzumu mežos. Ūdens bilances izmaiñas izraisīs nokrišn,u sadalījuma un daudzuma izmaingas, un tas var būt viens no galvenajiem mežsaimniecības riskiem nākotnē, jo optimāls mitruma režīms ir ḷoti svarīgs mežu augšanai.

9.1. tabula. Klimata mainības ietekme Baltijas reǵiona valstīs

\begin{tabular}{|l|c|c|c|c|c|c|c|}
\multicolumn{1}{c|}{ letekme } & Zviedrija & Somija & Igaunija & Latvija & Lietuva & Krievija & Vācija \\
\hline Meža platības & $\uparrow \uparrow$ & $\uparrow \uparrow$ & 0 & 0 & $\circ$ & - & $\uparrow \uparrow$ \\
\hline Meža ugunsgrēku risks & $\uparrow$ & $\uparrow$ & $\uparrow$ & $\uparrow$ & $\uparrow$ & $\uparrow$ & $\uparrow \uparrow$ \\
\hline $\begin{array}{l}\text { Salnas iespējamība pēc } \\
\text { pumpurošanās fāzes }\end{array}$ & $\uparrow$ & $\circ$ & $\uparrow \uparrow$ & $\uparrow \uparrow$ & $\uparrow \uparrow$ & $\uparrow \uparrow$ & $\downarrow \downarrow$ \\
\hline $\begin{array}{l}\text { Ekosistēmas primārā } \\
\text { neto produkcija }\end{array}$ & $\uparrow \uparrow$ & $\uparrow \uparrow$ & $\uparrow$ & $\uparrow$ & $\uparrow$ & $\uparrow$ & $\downarrow$ \\
\hline
\end{tabular}

$\uparrow \uparrow$ - ievērojams pieaugums, $\uparrow$ - neliels pieaugums, $\downarrow \downarrow$ - ievērojams samazinājums, $\downarrow$ - neliels samazinājums, o - izmainu nav vai tās nav būtiskas, - nav datu. 
Sausuma periodi, kas Latvijas teritorijā tiek prognozēti ilgāki un noturīgāki, augiem un kokiem var radīt augšanas stresu. Sausums negatīvi ietekmē augu aizsardzības mehānismus, gan noturību pret kaitēkḷiem (kukaiñiem), gan arī pret slimības izraisošiem mikroorganismiem.

Sausums paaugstinās ugunsbīstamības risku, un tiek prognozēts, ka palielināsies mežu ugunsgrēku skaits. Jān,em vērā, ka ugunsgrēkos rodas l, loti daudz $\mathrm{CO}_{2}$, kas nonāk atmosfērā un vēl vairāk paaugstina SEG līmeni.

Prognozētie "karstuma vilı̣i”" ietekmēs mežsaimniecību, jo, piemēram, 2003. gada "karstuma vilṇi" būtiski samazināja meža augšanas produktivitāti dal̦ā Eiropas.
Klimata pārmaiṇu sekas mežos var būt ilgtermiṇa (sugu migrācija) vai arī īstermiṇa (kaitēkḷu invāzija, meža ugunsgrēki, vētras un spēcīgi vēji), kas nākotnē tiek prognozētas biežākas un intensīvākas. Arī īstermiṇa traucējumi var radīt lielu risku un neatgriezeniskus bojājumus mežaudzēm.

Tomēr kopumā tiek prognozēts, ka klimata pārmaiṇu ietekme uz mežsaimniecību Eiropas ziemel̦u dal̦ā lielākoties būs pozitīva, tomēr veiksmīgai mežsaimniecības darbībai svarīgi ir ievērot meža pielāgošanās apsaimniekošanu, kas ietver praksi audzēt klimatam atbilstošas sugas, mainīt retināšanas un ciršanas laikus. Pareiza meža apsaimniekošana produktivitāti ietekmēs daudz vairāk nekā klimata pārmaiṇas.

\section{Literatūra}

BAAC Author Team (2008) Assessment of Climate Change for the Baltic Sea Basin. Springer-Verlag Berlin Heidelberg. Bethere L., Sile T., Sennikovs J., Bethers U. (2016) Impact of climate change on the timing of strawberry phenological processes in the Baltic States. Estonian Journal of Earth Sciences. 65, 1, 48-58.

Chmielewski F. M., Rötzer T. (2001) Responses of Tree Phenology to Climatic Changes Across Europe. Agricultural and Forest Meteorology.108, 101-112.

Chuine I., Pascal Y., Viovy N., Seguin B., Daux V., Ladurie E. (2004) Historical Phenology; Grape Ripening as a Past Climate Indicator. Nature. 432, 289.

EEA (2008) Impacts of Europe's Changing Climate-2008 Indicator-based Assessment. EEA-JRC-WHO, 2008 report. Office for Official Publications of the European Communities, Luxemburg.

EEA (2012) Climate Change, Impacts and Vulnerability in Europe 2012. EEA, Copenhagen

IPCC (2007) Climate Change 2007: Synthesis Report. Contribution of Working Groups I, II and III to the Fourth Assessment Report of the Intergovernmental Panel on Climate Change [Core Writing Team, Pachauri R. K. and Reisinger A. (eds.)]. IPCC, Geneva, Switzerland.

Kalvāne G. (2011) Fenoloǵiskās izmainas un to ietekmējošie klimatiskie faktori. Rīga, LU Akadēmiskais apgāds.

Kalvāne G., Romanovska D., Briede A., Bakšiene E. (2009) Influence of the Climate Change to the Phenological Changes in Latvia and Lithuania, Climate Research. Vol 39., 209-219.

Kalvāns A., Bitāne M., Kalvāne G. (2015). Forecasting Plant Phenology: Evaluating the Phenological Models for Betula pendula and Padus racemosa Spring Phases, Latvia. International Journal of Biometeorology. 2,59, 165-179.

Karlsen S. R., Tolvanen A., Kubin E., Poikolainen J., Høgda K. A., Johansen B., Danks F. S., Aspholm P., Wielgolaski F. E., Makarova O. (2008) MODIS NDVlbased Mapping of the Length of the Growing Season in Northern Fennoscandia. International Journal of Applied Earth Observation and Geoinformation. 10, 253-266.

Lieth H. (1974) Purpose of a Phenology Book. In: Phenology and Seasonality Modeling. Lieth H. (ed). Springer-Verlag, New York, 3-15.

Linderholm H. W. (2006) Growing Season Changes in the Last Century. Agricultural and Forest Meteorology. 137, 1-14. Meier U. (1997) Growth Stages of Mono- and Dicotyledonous Plants. BBCH Monograph. (ed) Federal Biologische Research Centre for Agriculture and Forestry. Blackwell Wissenschafts-Verlag, Berlin - Wien.

Menzel A, Sparks T. H., Estrella N., Koch E. and others (2006) European Phenological Response to Climate Change Matches the Warming Pattern. Global Change Biology. 12, 1969-1976.

Roetzer T., Wittenzeller M., Haeckel H., Nekovar J. (2000) Phenology in Central Europe - Differences and Trends of Spring Phenophases in Urban and Rural Areas. International Journal of Biometeorology. 44-2, 60-66. 
Interneta resursi

EPA a[bez datējuma]. ASV Vides aizsardzïbas aǵentūra. Climate impact on forests. Pieejams: http://www3.epa.gov/ climatechange/impacts/forests.html. Skat. 20.09.2015.

EPA b[bez datējuma]. ASV Vides aizsardzības aǵentūra. Climate impact on agriculture. Pieejams: http://www3.epa. gov/climatechange/impacts/agriculture.html. Skat. 20.09.2015.

EEA, 2009. Projected crop yield changes between the 2080s and the reference period 1961-1990 by two different models. Pieejams: http://www.eea.europa.eu/data-and-maps/figures/projected-crop-yield-changes-between-the2080s-and-the-reference-period-1961-1990-by-two-different-models. Skat. 14.10.2015.

Baltic Climate [bez datējuma] Mežsaimniecība. Pieejams: $h t t p: / / w w w . t o o l k i t . b a l t i c c l i m a t e . o r g / l v / k l i m a t a-p a r m a i n u-$ ietekme/klimata-parmainu-scenariji/mezsaimnieciba. Skat. 14.10.2015.

Koch E., Bruns E., Chmielewski F. M., Defila C., Lipa W., Menzel A. (2006) Guidelines for plant phenological observations. COST 725 materiāls. Sk. 12.09.2015. Pieejams: http://topshare.wur.nl/publicfiles/73471_1_guidelinesges-fin_2.pdf.

\section{Izmantotie attēli un tabulas}

9.2. Pēchttp://wwwpaztcn.wr.usgs.gov/rsch_highlight/articles/200610.html

9.3. Koch, et al., 2006 pēc Menzel and Fabian, 2002 un Rushing, et al., 2012

9.4. Adaptēts pēc IPCC, 2007.

9.7. Adaptēts pēc Karlsen et al., 2009

9.10. Adaptēts no EEA, 2012.

9.11. EEA, 2009

9.13. Kalvans, et al., 2015.

9.15. Bethere et al., 2016.

9.16. Bethere et al., 2016.

9.1. tabula. Adaptēts no Baltic Climate, bez datējuma. 


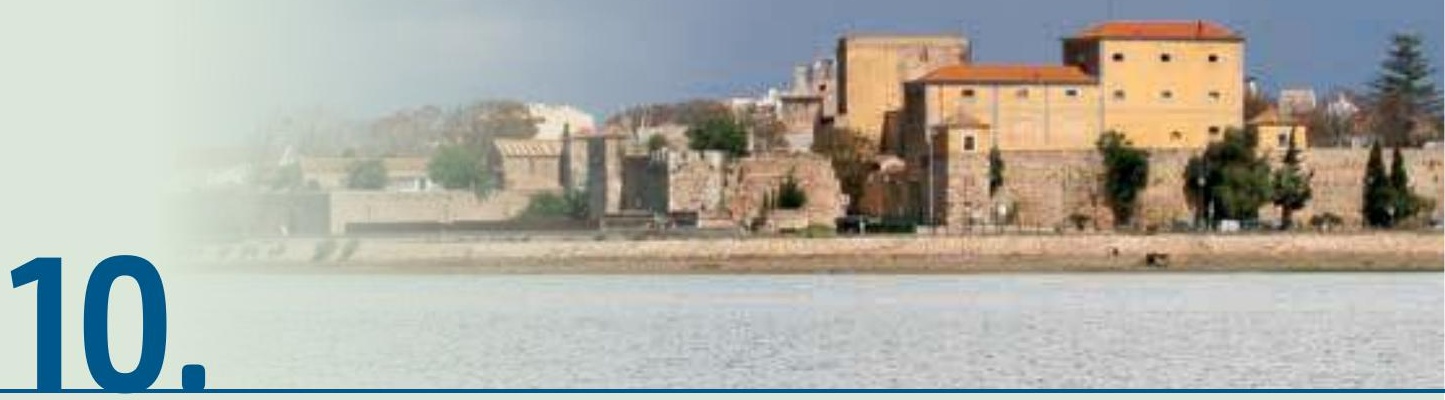

Klimata pārmaiṇas un

ekonomika 


\subsection{Ekonomikas ietekme uz klimata pārmaiṇām}

Klimata pārmaiṇu antropogēnās (cilvēka radītās) ietekmes ir pierādītas daudzos zinātniskos pētījumos - gan atsevišķu zinātnie$\mathrm{ku}$, gan starptautisku pētnieku grupu un vides aǵentūru darbos. Cilvēka radītās ietekmes galvenokārt ir saistītas ar fosilā kurināmā (ogles, dabasgāze, nafta) izmantošanu, lai ražotu energiju - elektrisko enerǵiju vai siltumenerǵiju. Un energija ir viens no l,oti svarīgiem ekonomiskās attīstības priekšnoteikumiem, jo tā nodrošina ražošanas un pakalpojumu sniegšanas iespējamību.

Nākamo reizi, kad šaubīsieties, vai sasniegt galamērksi ar personīgo automašīnu, sabiedrisko transportu vai kājām, vai ar velosipēdu, iedomājieties arī par sava lēmuma ietekmi uz klimata pārmain,ām. Viena atsevišksa cilvēka lēmuma sekas, patiešām, var būt relatīvi nelielas, taču daudziem cilvēkiem kopā ir iespēja ietekmi ievērojami palielināt. Piemēram, ja tikai daži cilvēki izvēlas izmantot velosipēdu automašīnas vietā, ielas nekḷūs daudz brīvākas, bet, ja pilsētas iedzīvotāji masveidā sāktu izmantot velosipēdus, autosatiksme tiktu būtiski atslogota, samazinātos degvielas patērinšs un automašīnu sastrēgumi, uzlabotos gaisa kvalitāte un arī iedzīvotāju veselība. Spilgti piemēri attīstītai veloceliṇu infrastruktūrai un ievērojami mazākai automašīnu plūsmai ir redzami Amsterdamā un Kopenhāgenā. Arī citas Eiropas pilsētas aizvien lielāku uzmanību pievērš

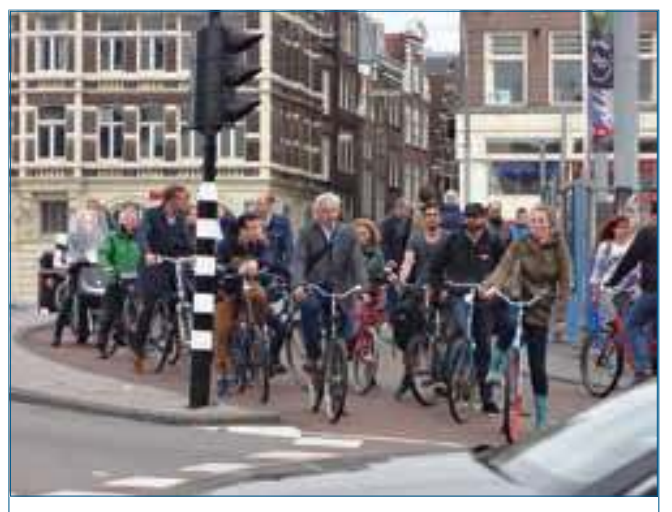

10.1. att. Riteņbraucēji Amsterdamas ielās. videi un cilvēkam draudzīgākām pārvietošanās iespējām pilsētās - veido veloceliṇus, attīsta infrastruktūru elektroautomobiliem, pilnveido sabiedriskā transporta infrastruktūru u.tml. Parīzē 2015. gada 27. septembris tika pasludināts par dienu bez automašīnām. Tajā dienā Parīzes ielās bija aț̣auta vienīgi neatliekamo avārijas dienestu automašīnu kustība.

Cilvēkiem kā atbildīgiem patērētājiem arī ir iespēja ietekmēt, kāda veida preces tiek pieprasītas. Tā kā pircēji aizvien vairāk uzmanības pievērš dažādiem ekomarķejumiem, piemēram, ES "Ekopukītei", kas apzīmē produktu ar samazinātu ietekmi uz vidi (zemāks ūdens patēriņš, noteiktu vielu neizmantošana utt.), ražotāji ir spiesti ñemt vērā šīs pircēju prasības, lai varētu savu produkciju realizēt. Tādējādi arī katrs cilvēks ar saviem patēriṇa paradumiem ietekmē kopējo tautsaimniecības ietekmi uz vidi.

Klimata pārmainām ir globālas sekas, tāpēc to risināšanai ir nepieciešama gan vietējo cilvēku iesaiste un rīcība, gan starptautiska sadarbība. Kā būtiskākie ar ekonomiku saistītie klimata pārmainu cēloṇi ir iedzīvotāju skaita eksponenciālais pieaugums, rūpniecības straujā attīstība, kuras nodrošināšanai nepieciešams aizvien vairāk enerǵijas, un globalizācija, kas prasa aizvien lielāku degvielas patēriṇu sakarā ar izejvielu un gatavo produktu transportēšanu lielos attālumos. Dažādas tautsaimniecības nozares palielina siltumnīcefektu, galvenokārt, patērējot enerǵiju, taču tas notiek arī citos tehnologiskajos procesos, emitējot siltumnīcefektu izraisošas gāzes (SEG).

Vislielākā nozīme siltumnīcefekta veicināšanai ir oglekḷa dioksīda emisijām, kas veido apmēram trīs ceturtdaḷas no kopējā SEG emisiju apjoma, un to galvenais avots ir fosilā kurināmā sadedzināšana, kas ir nepieciešama elektroenerǵijas un siltumenerǵijas ražošanā, transportēšanā un visās citās tautsaimniecības nozarēs, kurās tiek izmantota enerǵija.

Arī vairākos ražošanas procesos, kas nav saistīti ar kurināmā sadedzināšanu, rodas oglekḷa dioksīda emisijas ḳimisko reakciju 
rezultātā, piemēram, cementa, metālu un tērauda ražošanā. Būtiska nozīme oglekḷa dioksīda emisiju samazināšanai ir energoefektivitātes uzlabošanai un atjaunojamo energoresursu (AER) - biomasas, hidroenerǵijas, Saules, vēja un ǵeotermālās enerǵijas izmantošanai. Taču arī AER izmantošana nav brīva no SEG emisijām. Tās rodas, lai, piemēram, saražotu un transportētu vēja generatorus vai Saules baterijas un kolektorus, uzbūvētu dambjus hidroelektrostaciju vajadzībām u.tml. Lai novērstu oglekḷa dioksīda emisiju nonākšanu atmosfērā, tiek strādāts pie tehnologijām, kas lauutu piesaistìt un droši uzglabāt oglekḷa dioksīdu pazemes izsmeltās naftas un gāzes atradnēs vai dziḷos sālsūdens nesējslān,os.

Metāna izmešu galvenie avoti ir lauksaimniecība un atkritumu saimniecība. Metāns rodas dažādu organisko vielu trūdēšanas procesā, tātad visās jomās, kur šāda trūdēšana notiek - lauksaimniecībā (it īpaši, lopkopībā un rīsu audzēšanā), mežsaimniecībā, atkritumu saimniecībā u.tml.

Metāns rodas daudzos dabiskos procesos, piemēram, purvos, pārveidojoties organiskajām vielām. Metāna aprites cikls ir ievērojami īsāks nekā oglekḷa dioksīdam, taču tā ietekme uz siltumnīcefektu ir 23 reizes lielāka (100 gadu periodā). Tas nozīmē, ka 1 tonna metāna atbilst siltumnīcefektam, ko rada 23 tonnas ogleklıa dioksīda. Tā kā metāns ir galvenā dabasgāzes sastāvdal̦a, tad arī dažādas citas nozares rada metāna emisijas, ko izraisa noplūdes gāzes un naftas ieguves, pārstrādes, glabāšanas un transportēšanas procesā. Tomēr arī atjaunajamo energoresursu izmantošana rada metāna emisijas. Tās rodas dambju dēl, kas veidoti hidroelektrostaciju (HES) vajadzībām. Uzpludinot ūdeni dambī, milzìgs augu un koku daudzums tiek paklıuts trūdēšanas procesam un metāns uzkrājas dublılos. Pēc ūdens līmeña pazemināšanas, kad dubḷus vairs nesedz ūdens, metāns lielos daudzumos nonāk atmosfērā. Pētījumos par metāna emisiju apjomu no HES dambjiem iegūti ḷoti atšksirīgi rezultāti. Lielākās emisijas ir novērotas dambjos, kas atrodas tropu joslā - tie emitē apmēram 1300-3000 g CO $\mathrm{CO}_{\text {ekv. }} / \mathrm{kWh}$, bet tikai 160- $250 \mathrm{~g} \mathrm{CO}_{2 \mathrm{ekv}} / \mathrm{kWh}$ jaukto mežu joslā.
Salīdzinājumam: termoelektrostacijās, ko darbina ar gāzi, emisijas ir 400- $500 \mathrm{~g} \mathrm{CO}_{2 \mathrm{ekv}} / \mathrm{kWh}$, ar naftu - 700-900 $\mathrm{g} \mathrm{CO}_{2 \mathrm{ekv}} / \mathrm{kWh}$ un oglēm 900-1200 g CO $_{2 \text { ekv. }} / \mathrm{kWh}$. Arī dabiskos procesos radušās metāna emisijas ir iespējams samazināt, izmantojot tehnoloǵijas, kas l̦auj savākt un pārstrādāt trūdošos materiālus atkritumu izgāztuvēs, izmantojot lopu barošanas ieteikumus, kas l̦auj samazināt dabisko metāna rašanos gremošanas procesā, uzlabojot naftas un gāzes ieguves, pārstrādes un transportēšanas tehnoloǵijas un iekārtu kvalitāti.

Slāpekḷa(I) oksīds $\mathrm{N}_{2} \mathrm{O}$ arī ir daudzu dabisku procesu produkts, un tā ietekme uz siltumnīcefektu ir 296 reizes lielāka nekā oglekla dioksīdam. Galvenās ekonomiskās darbības, kas rada $\mathrm{N}_{2} \mathrm{O}$ ir lauksaimniecība, fosilā kurināmā sadedzināšana, notekūdenu apsaimniekošana un rūpnieciskie procesi. Lauksaimniecībā $\mathrm{N}_{2} \mathrm{O}$ emisijas izraisa augsnes bagātināšana ar slāpekḷa minerālmēsliem un kūtsmēsliem. Slāpekḷa(I) oksīds rodas arī transporta nozarē, sadedzinot degvielu, kā arī dažu sintētisko materiālu ražošanas procesā. Slāpekla(I) oksīda emisijas var samazināt, efektīvāk izmantojot minerālmēslus un kūtsmēslus, samazinot degvielas patērinu transporta līdzeklos un uzlabojot tehnologijas.

Fluoru saturošām gāzēm nav dabisko avotu, un tās veidojas tikai cilvēku saimnieciskās darbības rezultātā. Tās tiek emitētas dažādos rūpnieciskajos procesos, piemēram, alumīnija un pusvadītāju ražošanā. Daudzām fluoru saturošām gāzēm ir ḷoti augsts siltuma absorbcijas potenciāls, t.i., 22000 reižu lielāks nekā oglekla dioksīdam. Tāpēc pat to mazai koncentrācijai atmosfērā var būt liela ietekme uz siltumnīcefektu. Turklāt dažām no šīm vielām aprites ilgums atmosfērā ir mērāms tūkstošos gadu. Fluorogḷūden,raži tiek izmantoti kā dzesējošās vielas, aerosolu propelenti (izsmidzinātāji), šksīdinātāji un antipirēni (aizsargvielas pret degšanu). Šĩs kīmiskās vielas tika izstrādātas, lai aizstātu tādas ozona slāni noārdošās vielas kā hlorfluorog]̣ūden,ražus un hidrohlorfluorog!̣ūden,ražus, kas tiek pakāpeniski aizliegtas atbilstoši Monreālas protokolam par vielām, kas grauj ozona slāni (tas stājās spēkā 1989. gadā). 
Fluoru saturošo gāzu emisijas ir iespējams samazināt, pilnveidojot tehnoloǵijas, aizstājot fluoru saturošās gāzes ar gāzēm, kurām ir mazāks siltumnīcefekta potenciāls, kā arī attīstot šo gāzu atkārtotu izmantošanu. Klimata pārmaiñu starpvaldību padomes 5. novērtējuma ziṇojumā, kas publicēts 2014. gadā, secināts, ka apmēram trīs ceturtdalıas no SEG emisijām ir oglekḷa dioksīda emisijas gan no fosilā kurināmā izmantošanas, gan no mežsaimniecības un zemes izmantošanas. Savukārt fluoru saturošās gāzes veido tikai aptuveni $2 \%$ no emisijām. Emisiju sadalījumā pa nozarēm pasaulē starp tiešajām emisijām vislielākais īpatsvars - 24\% tiek radīts lauksaimniecībā, mežsaimniecībā un cita veida zemes izmantošanā, $21 \%$ rada ražošana, bet $14 \%$ - transports.

Vidējais SEG emisiju gada pieaugums laika periodā no 2000. līdz 2010. gadam ir palielinājies līdz 2,2\% gadā salīdzinājumā ar 1,3\% vidējo pieaugumu laikā no 1970. līdz 2000. gadam. Tas ir noticis apstākḷıs, kad ir zinātniski apstiprinājies, ka SEG emisijas ir cēlonis globālās temperatūras paaugstinājumam, kad ir notikušas neskaitāmas klimata pārmaiṇu izraisītas katastrofas un attīstītās valstis ir noteikušas konkrētus SEG emisiju samazināšanas mērksus Kioto protokola ietvaros. Tas ir skaidrojams ar l,oti straujo attīstības valstu ekonomisko izaugsmi, kas izraisījusi lielu energijas patēriṇa un SEG emisiju pieaugumu. Kopējais iedzīvotāju skaits attīstības valstīs laikā no 1990. līdz 2009. gadam pieauga par apmēram $33 \%$, savukārt kopējās $\mathrm{CO}_{2}$ emisijas no kurināmā sadedzināšanas ir palielinājušās par apmēram $139 \%$.

Būtiskāko $\mathrm{CO}_{2}$ emisiju pieaugumu, ko radījusi fosilā kurināmā sadedzināšana, ir izraisījis globālā kopprodukta pieaugums, nedaudz mazāka ietekme ir iedzīvotāju skaita pieaugumam. Pateicoties IKP iegūšanā ieguldītajam enerğijas samazinājumam, emisijas ir pieaugušas lēnāk nekā pieaudzis IKP, kas 10.2. attēlā redzamas kā negatīvas izmaiṇas.

IKP enerǵijas intensitāti ietekmē gan izmantoto tehnoloǵiju enerǵētiskā efektivitāte, gan tautsaimniecības struktūra: rūpniecības, pakalpojumu un lauksaimniecības proporcijas.

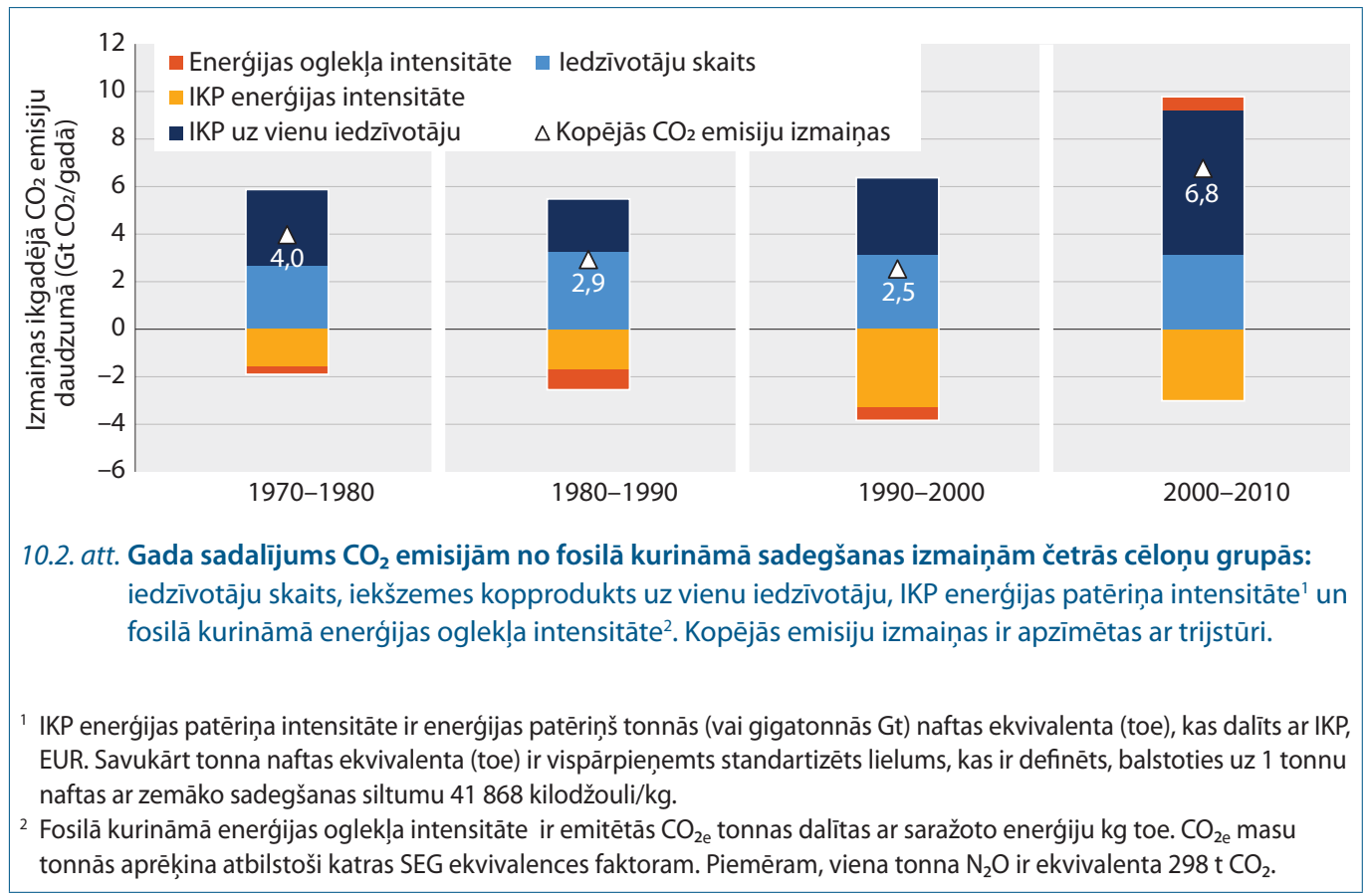


Savukārt enerǵijas oglekḷa intensitāte rāda, cik daudz oglekḷa emisiju tiek radìts, izmantojot enerǵiju vienas tonnas naftas ekvivalenta apjomā. To, galvenokārt, ietekmē izmantotie energoresursi. Piemēram, enerǵija, kas saražota HES, nerada $\mathrm{CO}_{2}$ tiešās emisijas, bet akmeñogles rada ievērojami lielākas emisijas nekā dabasgāze.

Pēdējās desmitgadēs ir veikta virkne uzlabojumu tehnologijās, kas samazina patērētās energíjas daudzumu, ir attīstīti dažādi alternatīvie energoresursi, tomēr emisijas turpina palielināties, jo ekonomiskās aktivitātes pieaugums ir straujāks nekā panāktie energoefektivitātes uzlabojumi. To vides ekonomikā sauc par "atsitiena" efektu. Tas nozīmē, ka tehnologiskie uzlabojumi izraisa lielāku pieprasījumu pēc uzlabotajiem produktiem un kopējais patērinšs pat palielinās.

Klimata pārmainu starpvaldības padomes 5. zinojumā (2014. gadā) ir izstrādāti vairāki scenāriji, kas parāda iespējamās globālās temperatūras izmaiņas. Lai ierobežotu globālo sasilšanu līdz $<2{ }^{\circ} \mathrm{C}$ (salīdzinājumā ar pirmsindustriālā laikmeta (18. gs. vidus) temperatūru), ir nepieciešams stabilizēt oglekḷa dioksīda koncentrāciju atmosfērā līdz 375 ppm.
Tas savukārt prasa, lai pasaules $\mathrm{CO}_{2}$ emisijas līdz 2050. gadam tiek samazinātas par 4070 procentiem salīdzinājumā ar 2010. gada emisiju līmeni, bet līdz 2100. gadam jāpanāk nulles vai negatīvs emisiju līmenis (to panāk, noglabājot $\mathrm{CO}_{2}$ ). Tas prasīs būtiskas izmaiñas daudzās tautsaimniecības nozarēs.

Vēl pie cilvēku izraisītām SEG emisijām jāmin ugunsgrēki. Pētījumi liecina, ka mežu ugunsgrēki, piemēram, ASV un Aḷaskā rada aptuveni 290 miljonus $\mathrm{CO}_{2}$ tonnu gadā. Tas ir apmēram 4-6\% no kopējām SEG emisijām, ko ASV emitē, sadedzinot fosilo kurināmo. SEG un dažādu veselībai kaitīgu vielu emisijas rodas arī, izmantojot ieročus, ugunsgrēku laikā, kā arī izšaujot svētku salūtus. Piemēram, pētījumu rezultāti rāda, ka Cīrihē nacionālo svētku laikā, kas parasti tiek atzīmēti ar salūtu visā Šveicē, vairāku kaitīgu gāzu koncentrācijas līmeṇi ir desmit reizes augstāki par fona koncentrāciju vienu nedēḷu pirms un divas nedēḷas pēc svētkiem.

Paralēli SEG koncentrācijas palielināšanai atmosfērā, kas izraisa globālo sasilšanu, tautsaimniecībā radītais gaisa piesārn,ojums rada arī pretēju efektu, kas nel̦auj Saules gaismai izkḷūt caur atmosfēru. "Aptumšošanu" izraisa

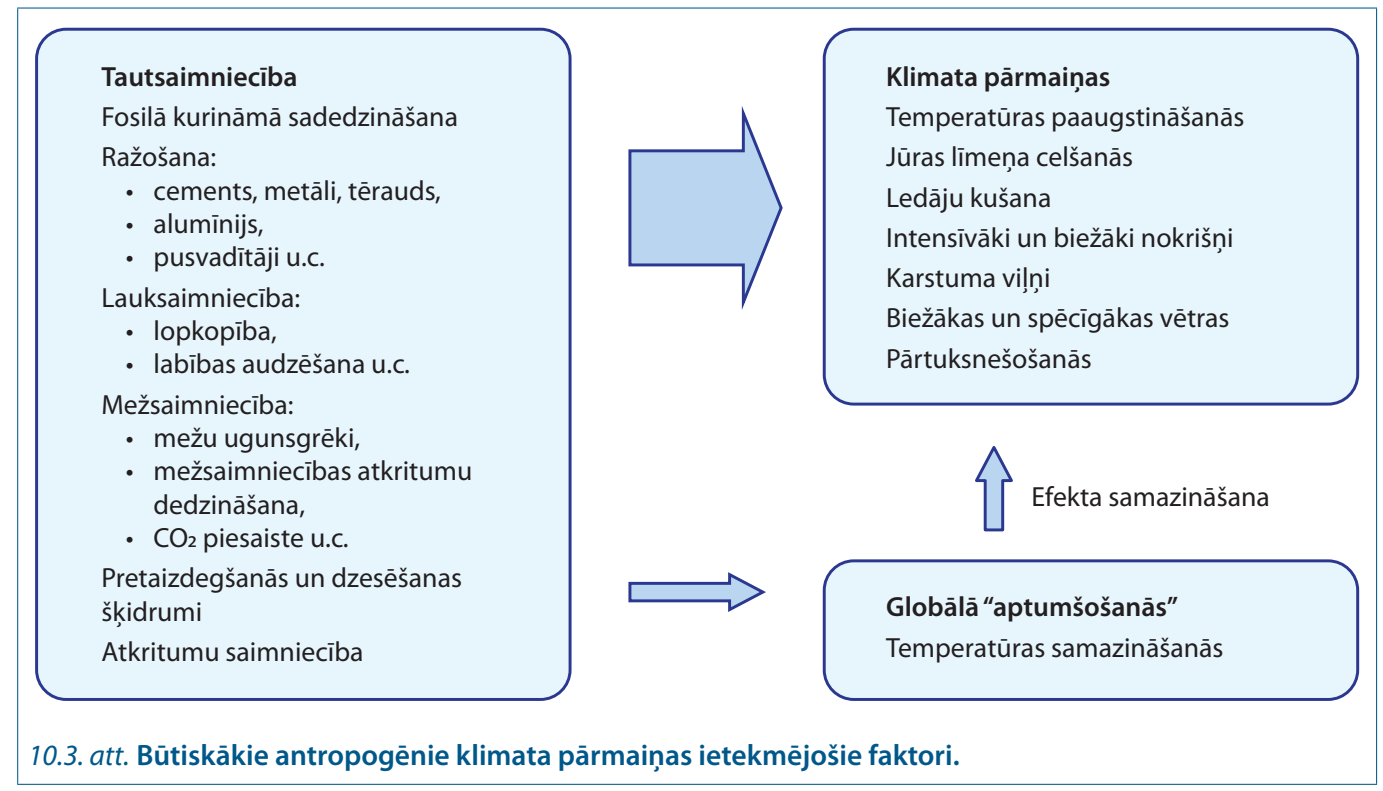


sīko dalı̣nu (putekḷu, pelnu, kvēpu) nonākšana un izkliede atmosfērā. Šìs dalinnas rodas dažādos degšanas procesos, un šo procesu efekts ir gluži pretējs - atdzišana. Taču, rūpējoties par cilvēku un citu dzīvo būtņu veselību, tiek pievērsta liela uzmanība sīko dạliņu emisiju samazināšanai, kas samazinās arī "aptumšošanas" efektu un nākotnē var vēl vairāk paātrināt globālo sasilšanu.

Cīnu par klimata pārmaiṇu ātruma samazināšanu ievērojami apgrūtina dažādi pretējie efekti, kas rodas, cenšoties uzlabot cilvēku veselību un dzīves kvalitāti. Piemēram, lai samazinātu $\mathrm{CO}_{2}$ emisijas, mēs izmantojam HES, bet tropu joslā tas palielina metāna emisiju. Audzējot enerǵētiskās kultūras, lai pārietu uz atjaunojamiem energoresursiem, mēs apdraudam biologisko daudzveidību un aiznnemam zemi, kas būtu nepieciešama pārtikas audzēšanai. Uzlabojam gaisa kvalitāti, attīrot to no sīkajām dalıinām, taču vienlaikus samazinām "aptumšošanas" efektu. Tāpēc, risinot klimata pārmaiṇu un tās adaptācijas jautājumus, īpaša uzmanība jāpievērš sistēmiskajai domāšanai, kurā tiek analizēti cēloṇi, sekas un atgriezeniskās saites pēc iespējas plašākā sistēmā, lai, risinot vienu problēmu, nenodarām vēl lielāku kaitējumu citā jomā.

\subsection{Klimata pārmaiṇu ietekme uz ekonomiku}

Neviens nevar prognozēt klimata pārmaiñu sekas ar pilnu pārliecību, bet ir zināms pietiekami daudz, lai saprastu to radītos riskus. Galvenie riski un potenciālie zaudējumi ir saistīti ar plūdiem, spēcīgām vētrām, karstuma viḷniem, ūdens un pārtikas trūkumu. Piemēram, 2013. gadā bija vairāk nekā 600 dabas katastrofu, no kurām 37 bija nepieciešama no 100000 līdz 4,5 miljonu cilvēku pārvietošana.

Ja klimata pārmaiṇu mazināšanas pasākumi netiek veikti šobrīd, tas var radīt l̦oti lielas izmaksas nākamajās desmitgadēs dažādu klimata izraisīto katastrofu dēḷ. Dažas no tām ir izmērāmas naudas izteiksmē, piemēram, plūdu nodarītie kaitējumi nekustamajiem īpašumiem un infrastruktūrai, lauksaimniecības ražas zudumi ekstrēmu laika apstākḷu dēḷ u.tml. Taču daudzas klimata pārmainu radītās sekas ir neiespējami novērtēt naudas izteiksmē - zaudētās cilvēku dzīvības vai veselība, zaudēti vēstures un dabas pieminekḷi, kas var iet bojā plūdu un vētru rezultātā. Klimata pārmainu mazināšana, veicot stingrus pasākumus, lai samazinātu SEG emisijas, ir jāuzskata nevis par lieliem izdevumiem, bet gan par investīcijām nākotnē. Ja šie ieguldījumi tiek veikti pārdomāti, paveras plašas iespējas vietējās ekonomikas izaugsmei un attīstībai, kā arī nodarbinātības palielināšanai.
Viens no nozīmīgākajiem ziṇojumiem, kas sagatavots par klimata pārmainu ekonomiskajām ietekmēm, ir 2006. gadā publicētais Nikolā Šterna apjomīgais (vairāk nekā 600 lappušu) ziṇojums "Klimata pārmainu ekonomika". Tajā tiek uzsvērts, ka klimata pārmaiṇu ignorēšana būtiski var kaitēt ekonomikas izaugsmei un apdraudēt sociālās darbības. Šādas izmaiṇas būs grūti vai pat neiespējami novērst. Jo agrāk tiks uzsākti efektīvi pasākumi klimata pārmaiņu mazināšanai, jo lētāki tie būs. Ziṇojumā tiek brīdināts, ka klimata pārmaiṇu sekas var samazināt globālo IKP pat par 20\% katru gadu līdz gadsimta beigām un pasaulē būtu jātērē apmēram $1 \%$ no pasaules IKP gadā, lai šos riskus samazinātu. 2008. gadā N. Šterns koriǵēja šo viedokli un uzskatīja, ka investīciju apjomam būtu jābūt 2 \% no pasaules IKP katru gadu. Galvenās klimata pārmaiṇu negatīvās ietekmes izpaudīsies ūdens pieejamībā, pārtikas ražošanā, veselībā un vides kvalitātē. Planētai sasilstot, simtiem miljonu cilvēku varētu ciest badu, ūdens trūkumu un zaudēt mājokḷus piekrastes applūšanas dēḷ. Ziṇojumā norādīts, ka ietekmētas tiks visas valstis, taču visneaizsargātākās ir nabadzīgākās valstis, un cilvēki būs tie, kuri cietīs agrāk un vairāk, pat ja tie ir vismazāk veicinājuši negatīvās klimata pārmain,as. Tādas salu valstis kā Maldivu Republika, Filipīnu Republika, 
Fidži Republika, Kiribati Republika, Nauru Republika, Zālamana salas un daudzas citas var pilnīgi zaudēt savas teritorijas jūras līmeña celšanās dēḷ. Klimata pārmaiṇas tādēl ir arī ètiska un morāla problēma, jo lielākus zaudējumus cieš tās valstis un cilvēki, kuru ietekme klimata pārmaiṇu izraisīšanā ir bijusi relatīvi maza. Taču izmaksas, kas saistītas ar ekstremāliem laika apstākḷiem, tostarp plūdiem, sausumu un vētrām, lielus zaudējumus rada arī bagātajām valstīm, piemēram, ASV, Japānai, Nīderlandei, Lielbritānijai u.c.

2015. gada vasara pasaulē iezīmējās ar daudzām dabas radītām problēmām, piemēram, rekordlieliem "karstuma vil̦niem" Pakistānā un Indijā, kur katrā no tiem gāja bojā vairāk nekā tūkstoš cilvēku. ASV Vašingtonas štatā pirmo reizi aizdegās Olimpijas Nacionālā parka (Olympic National Park) meži, Londona piedzīvoja jūlija augstākās temperatūras rekordu Apvienotajā Karalistē $-36,7^{\circ}$ C. 2015 . gadā Kalifornija jau ceturto gadu cieta no ievērojama sausuma, mežu ugunsgrēkiem, ūdens lietošanas ierobežojumiem. Puertoriko piedzīvoja visstingrāko ūdens normēšanu, simtiem tūkstošu iedzīvotāji ūdeni no ūdensvada saṇēma tikai katru trešo dienu, ūdens trūkuma dēl tika saīsinātas mācības skolā.

Arī Austrumeiropu skāra karstuma vilnis, kas Polijā radīja nopietnus elektroenergíjas apgādes traucējumus un sausumu. Latvijā vairākās upēs tika fiksēti ūdens līmen,a pazemināšanās rekordi.

Tieši vai netieši klimata pārmainas ietekmē visas tautsaimniecības nozares. Būtiskākās tiešās ietekmes jau notiek un sagaidāma to pastiprināšanās lauksaimniecībā, mežsaimniecībā, zivsaimniecībā, energoapgādē, ūdensapgādē, transportā, būvniecībā, veselības aprūpē, tūrisma un viesmīlības pakalpojumu sniegšanā.

Lauksaimniecībā un mežsaimniecībā klimata pārmainu dēl rodas nepieciešamība ieviest jaunas kultūraugu šksirnes, kas būtu piemērotākas krasām temperatūras un mitruma režīma izmaināam, kā arī ir noturīgas pret jauniem kaitēkḷiem. Ir aprēksināts, ka sugu pārvietošanās polu virzienā notiek vidēji ar ātrumu 17,6 km desmitgadē un augstāk kalnos - ar àtrumu 12,2 metri desmitgadē, kas maina sugu sastāvu katrā konkrētā apvidū. Tā kā ir būtiskas atšķirības starp dažādu sugu pārvietošanās ātrumiem, ir iespējams, ka atseviš̌si kaitēkḷi parādās ievērojami agrāk nekā to dabiskie ienaidnieki. Tāpēc ir nepieciešami savlaicīgi pētījumi par to ietekmēm uz kultūraugiem. Arī zivsaimniecībā jārēḳinās ar sugu migrāciju, kas ietekmē gan zivju pieejamību, izvietojumu un klāstu.

Lai samazinātu SEG emisijas un tādējādi mazinātu klimata pārmaiṇas, ir nepieciešama pāreja uz enerǵijas resursiem, kuru radītās oglekḷa dioksīda emisijas ir ievērojami mazākas. Tāpēc būtiskas pārmaiṇas ir sagaidāmas resursu, it īpaši energoresursu ieguvē. Ir aprēksināts: lai paliktu salīdzinoši drošajās 2 grādu globālās sasilšanas robežās, piel̦aujamās oglekḷa dioksīda emisijas ir 900 Gt. N̦emot vērā iespējamo oglekḷa savienojumu savākšanas un noglabāšanas tehnologiju attīstību, piel̦aujamais oglekḷa savienojumu apjoms līdz 2050. gadam var palielināties par 125 Gt. Tas tiktu emitēts, ja tikai aptuveni $20-40 \%$ no pašreiz jau zināmajām fosilā kurināmā rezervēm tiktu sadedzinātas. Tas rada milzīgu risku investoriem, kam jāapzinās, ka $60-80 \%$ no jau atklātajām fosilā kurināmā rezervēm nemaz nevar tikt sadedzinātas, lai nepārsniegtu globālās temperatūras paaugstināšanos par $2^{\circ} \mathrm{C}$ salīdzinājumā ar pirmsindustriālo laikmetu. Tā kā fosilā kurināmā ieguves projekti parasti izmaksā loti dārgi, tajos tiek investēti lieli sabiedrības līdzekḷi, kas kḷūst par izniekotu kapitālu, jo fosilā kurināmā ieguvē ieguldītie aktīvi nespēs sniegt ekonomisko atdevi, jo nebūs piel̦aujama iegūtā kurināmā sadedzināšana.

Investīciju pārtraukšana fosilo kurināmo ieguves kompānijās radīs lielākas iespējas investīcijām alternatīvo energoresursu ražotājiem. Jānem vērā, ka cilvēku apziṇas maiṇa ir ilgs process un joprojām ir pietiekami daudz ieguldītāju, kas turpina atbalstīt fosilā kurināmā atradņu meklēšanu un ieguvi. Enerǵijas ieguves uzṇēmumiem jāṇem vērā, ka aizvien vairāk tiks izmantoti ekonomiskie līdzekḷi, kas sadārdzinās to energoresursu izmantošanu, kas veido SEG emisijas. 
Latvijā kā viena no būtiskām fosilās enerǵijas alternatīvām tiek izmantota ūdens enerǵija elektrības ražošanā. Klimata pārmaiņas būtiski ietekmēs arī šo enerǵijas ieguves veidu. Tā kā augstākas gaisa temperatūras paātrina ūdens iztvaikošanu un tā hidrologisko apriti, būtiski tiks ietekmēta upju noteces sezonalitāte un apjoms. Līdz ar to HES enerǵijas ražošanas jaudas var kḷūt apdraudētas un ekonomiski neizdevīgas. Tāpēc būtiska vērība jāvelta tehnoloǵiju attīstībai, kas l̦auj maksimāli efektīvi izmantot pat nelielas ūdens plūsmas enerǵiju. Jārēksinās ar lielāku pieprasījumu pēc elektroenerǵijas karstajos vasaras periodos, lai nodrošinātu telpu dzesēšanu. Savukārt, ziemā varētu samazināties pieprasījums pēc siltuma enerǵijas telpu apsildǐ̌̌anai.

Būtiskas izmaiñas tiek prognozētas tūrisma nozarē, jo pašlaik populārajiem Vidusjūras reǵiona kūrortiem gaidāms atpūtnieku pieplūdums pavasarī un rudenī, bet vasarā lielā karstuma un sausuma dēl šis regions tūristiem vairs nebūs pievilcīgs. Tad lielāku tūristu plūsmu var sagaidīt Baltijas jūras reǵiona kūrorti, kam savlaicīgi ir jāsagatavojas, lai samazinātu tūrisma nozares ietekmi uz vidi.
Jāsagatavojas arī lielākam zilaḷgu savairošanās un ilgākas "ziedēšanas" riskam. Dabiskās ūdenskrātuves var kḷūt nepiemērotas drošai peldēšanai.

Lielus zaudējumus tautsaimniecībā var radīt klimata pārmainu seku ietekme uz infrastruktūru - energíjas un ūdens apgādi, transporta sistēmu. Savukārt infrastruktūras, piemēram, ūdensapgādes sistēmu bojājums ietekmē visas nozares, kas izmanto šos pakalpojumus. Īpaši bīstama ir dzeramā ūdens kvalitātes zaudēšana. Zaudējumi radīsies arī jūras piekrastes teritorijās jūras līmen,a celšanās dēḷ.

Tā kā visvairāk klimata pārmaiṇām ir pakḷauti tieši nabadzīgākie iedzìvotāji, kuri nespēj veikt atbilstošus adaptācijas pasākumus, jārēḳinās arī ar lielākiem izdevumiem šo cilvēku uzturēšanai. Turklāt ir jārēksinās ar milzīgām bēĝ̣lu plūsmām no reǵioniem, kas vai nu applūšanas vai pārtuksnešošanās dēḷ vairs nav dzīvošanai piemēroti. Klimata bēgḷ skaits tiek prognozēts apmēram 200 miljonu cilvēku apmērā līdz 2050. gadam.

Resursu, it īpaši ūdens trūkums ir cēlonis arī geopolitiskiem konfliktiem, kas var vēl

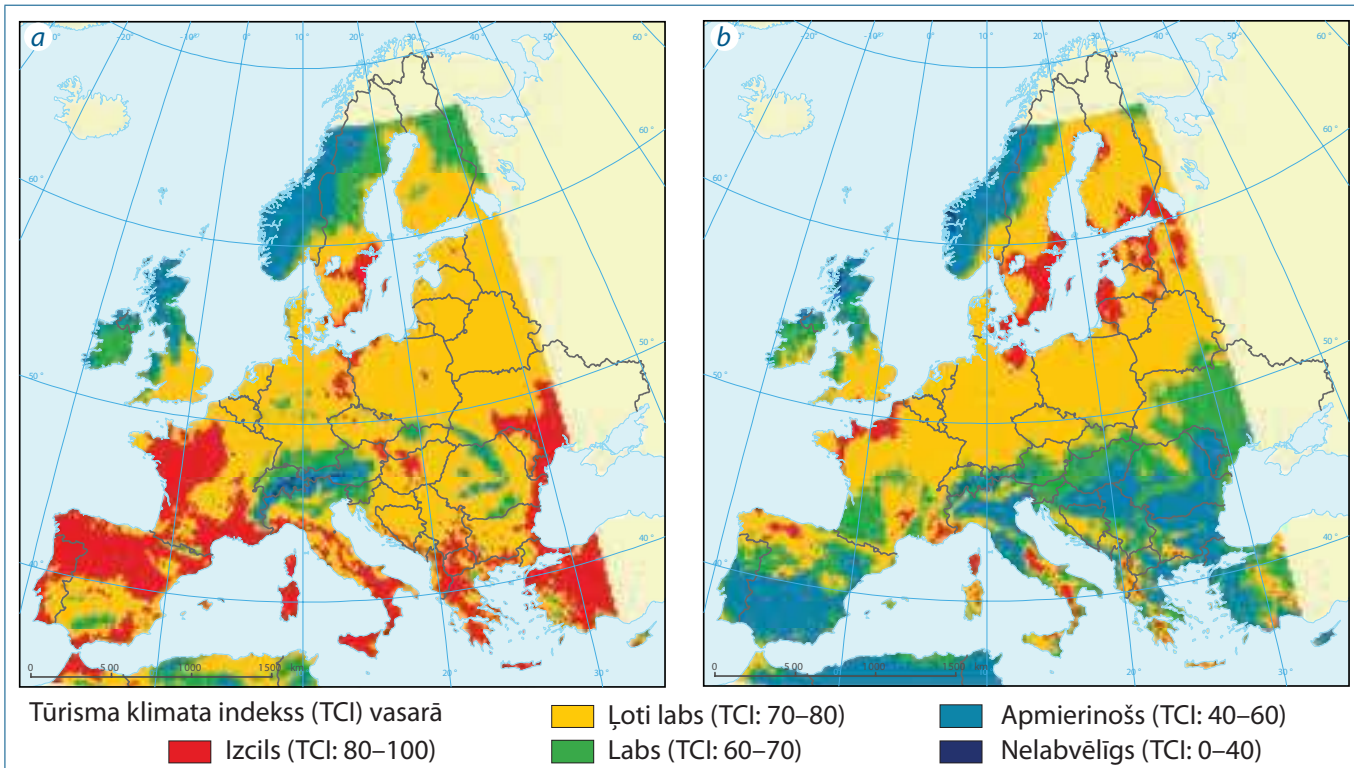

10.4. att. Tūrisma klimata indeksa salīizinājums 20. gadsimta beigās (a) un 21. gadsimta beigās (b). 
vairāk palielināt bēg̣̣u daudzumu. Mūsdienās ir grūti izšksirt bēgḷ migrācijas cēloṇus, jo gan klimatiskie, politiskie, reliǵiskie, drošības un ekonomiskie faktori ir savstarpēji cieši saistīti. Šāda masveidīga migrācija noteikti ietekmēs daudzas tautsaimniecības nozares, it īpaši izglītību, veselību, drošỉbu un sociālo aprūpi. Latvijai kā valstij ar salīdzinoši mazapdzīvotu teritoriju viens no lielākajiem klimata pārmaiṇu riskiem varētu būt bēgḷu uzṇemšana. Aizvien pieaugot bēglu skaitam un samazinoties teritorijām ar cilvēka dzīvošanai labvēlīgiem klimatiskajiem apstākḷiem, neizbēgami mazapdzīvotās teritorijas kḷūs par l,oti pievilcīgu galamērksi, pat tās teritorijas, kurās ir vāji attīstīta sociālās palīdzības sistēma. Arī tam ir laikus jāsagatavojas, lai pēc iespējas veiksmīgāk integrētu dažādu kultūru, religiju, rasu un dzīvesveida cilvēkus.

2015. gadā Latvijā ir notikušas karstas diskusijas un piketi gan par Latvijas iedzīvotāju atbildību uzn,emt bēglus, gan kategoriski noliedzot šādu iespēju. Līdzīgas sabiedrības pretrunas būs jārisina arī klimata bēg̣̣u jautājumā.

Tā kā ietekmju nozīmīgums un iespējamie riski dažādās tautsaimniecības nozarēs ir atšķirīgi, katram uzṇēmējam un organizācijai būtu rūpīgi jāizvērtē, kādas ietekmes var radīt klimata pārmaiṇas viṇu darbībā un tām atbilstoši gatavoties.

\section{Mežsaimniecība \\ Lielāks lapu koku īpatsvars \\ Lielāka kaitēkḷu savairošanās iespējamība \\ Jaunu kaitēklu parādīšanās \\ Augstāka ugunsbīstamība \\ sausajos periodos \\ Enerǵētika \\ Dārgāki energoresursi \\ Upju noteces samazināšanās sakarā ar elektrības ražošanu HES \\ Lielāks enerǵijas pieprasijums vasarās dzesēšanai un mazāks ziemā apkurei}

\section{Transports}

Augstākas prasības transporta līdzeklu energoefektivitātei un piel̦aujamām emisijām

Lielāka nepieciešamība pēc sabiedriskā transporta

pakalpojumiem

\section{Infrastruktūras nodrošināšana}

Augstākas prasības infrastruktūras objektiem pret vētrām un plūdiem

Alternatīvu pakalpojumu nodrošināšana dabas katastrofu situācijās

\section{Lauksaimniecība}

Jaunu kultūraugu ieviešana, kas izturīgāki pret apjomīgiem nokrišn,iem

Garāks veǵetācijas periods, atseviškiem kultūraugiem iespējamas vairākas ražas gadā Lielāka nepieciešamība pēc lauku meliorācijas

KLIMATA PĀRMAIṆAS

Temperatūras paaugstināšanās Izmainas nokrišnu intensitātē Jūras līmeṇa celšanās

\section{Tūrisms}

Lielāks tūristu pieplūdums

Lielāka nepieciešamība pēc mākslīgi izveidotām peldvietām dabīgo ūdenstilpju piesārn,ojuma dē| Bezsniega ziemu lielāka iespējamība

\section{Zivsaimniecība}

Intensīvāka zilalǵgu ziedēšana un toksisko vielu nonākšana zivju organismos

Izmaiṇas zivju sugās augstāku ūdens temperatūru dēl

\section{Ūdensapgāde}

Lielāks nokrišn,u daudzums un intensitāte

Lielāks plūdu risks

Ūdens pieprasijums no sausuma skartajos reǵionos

Ūdens kvalitātes pasliktināšanās

\section{Veselības aprūpe}

levainojumi un nāves gadijumi dabas katastrofu rezultātā Infekciju slimību pieaugums Elpošanas ceḷu infekciju pieaugums Nepietiekama uztura izraisītas slimïbas

\section{Būvniecība}

Augstākas prasības ēku siltumizolācijai Augstākas prasības ēku un būvju izturībai pret vētrām un plūdiem Lielāka nepieciešamība pēc aizsprostiem un jūras piekrasti nostiprinošām būvēm 


\subsection{Adaptācijas pasākumi dažādās uzṇēmējdarbības jomās}

Klimata pārmain̄ām ir liela inerce - pat ja 2000. gadā būtu pārtrauktas SEG emisijas, klimata pārmaiṇas turpinātos un globālā temperatūra paaugstinātos par aptuveni $0,5^{\circ} \mathrm{C}$ līdz gadsimta beigām. Tā kā tas nav noticis, ir l̦oti svarīgi veikt pasākumus, kas veidotu noturību pret dažādām sagaidāmajām klimata katastrofām un samazinātu iespējamos zaudējumus. Tos sauc par adaptācijas jeb pielāgošanās pasākumiem.

Svarīgākie adaptācijas pasākumi: savlaicīgas un precīzākas informācijas sniegšana, uzlabota plānošana, klimata pārmain,ām noturīgu augu kultūru veidošana, kā arī infrastruktūras uzlabošana. Nozīmīga loma adaptācijai klimata pārmainām ir pašvaldībām, kam savos teritoriālajos plānos ir jān,em vērā klimata pārmaiṇu ietekmes un savlaicīgi jāpielāgojas tām.

Pašvaldībām būtu jāizstrādā savas stratēǵijas un rīcības plāni adaptācijai klimata pārmainām. Īpaši sarežgìiti ir veikt adaptācijas pasākumus attīstības valstīs, kam trūkst resursu, lai realizētu šos miljardus vērtos projektus. Šajā jomā loti nozīmīga ir starptautiskā sadarbība un attīstīto valstu investīcijas klimata pārmaiñu adaptācijas projektos. Šie pasākumi var arī ievērojami uzlabot vietējās tautsaimniecības, jo rada jaunas darbavietas, uzlabo cilvēku labklājību un veicina inovācijas.

Uzṇēmumu līmenī gan nozarēs, kuras klimata pārmaiñas ietekmē tieši, gan tās, kurās ietekme ir netieša, ir l̦oti svarīgi būt sagatavotiem dažādajiem ar klimata pārmaiṇām saistītajiem riskiem. Ir jāvērtē potenciālās ietekmes, to kaitējumu apmērs un jāizvērtē, kā šos riskus novērst un kā rīkoties to iestāšanās gadījumā.

Līdzšinējie pētījumi ir parādījuši, ka kopumā salīdzinoši maz uzṇēmumu ir veikuši pietiekamus riska novērtējuma pasākumus Tikai 55\% no 300 Eiropas lielākajām kompānijām ir ilgtermiṇa mērḳi klimata pārmaiṇu vadīšanā. Līdzšinējie novērojumi liecina, ka arī liela dalıa Latvijas uzṇēmēju konkrētus adaptācijas pasākumus vēl neveic. Bažīgi ir tie uzñēmēji, kuru bizness ir atkarīgs no sniega un ledus esamības ziemā, kā arī ziemas nestabilajām temperatūrām.
Tiem uzṇēmumiem, kurus klimata pārmain,as ietekmē netieši, būtiska uzmanība jāvērš uz to, kā viṇu rentabilitāti var ietekmēt pieaugošās oglekḷa un tā savienojumu izmaksas salīdzinājumā ar konkurentiem. Pētījumi rāda, ka apmēram 80\% emisiju tiek radīti piegādes kuēdēs, tas nozīmē, ka liela dalıa izmaksas par $\mathrm{CO}_{2}$ emisijām tiks iekḷautas piegādāto produktu cenā. Nozares, kuras visvairāk ietekmēs $\mathrm{CO}_{2}$ emisiju izmaksu iekḷaušana cenā, ir k̦īmiskā rūpniecība, pārtikas un dzērienu ražošana, kā arī rūpniecības preču ražošana.

Lauksaimniecībā un mežsaimniecībā būtiska uzmanība jāpievērš jaunu kultūraugu sugu un šķirņu ieviešanai. Tā kā klimata pārmaiṇu prognožu model̦i Baltijas jūras reǵionam paredz garākus veǵetācijas periodus ar lielāku nokrišnu daudzumu, atsevišksiem, garākiem nekā līdz šim, "karstuma viln,niem", tad lauksaimniecībā ir jāpārorientējas uz sugām, kam šādi laika apstākḷi nekaitē. Sausuma un karstuma vilņi, visticamāk, prasīs ierobežot mežizstrādes darbus vasarā un pastiprināt ugunsdrošības prasības. Uzmanība jāpievērš dažādu kaitēkḷu un insektu, kā arī jaunu invazīvo sugu savairošanās lielākai iespējamībai.

Piemēram, Latvijā ir parādījušies Vidusjūras reǵionam raksturīgie Spānijas kailgliemeži, kas ir invazīva un agresīva suga, kurai Latvijā nav dabisko ienaidnieku. Ja šie kailgliemeži savairojas, tie var nodarīt būtiskus zaudējumus lauksaimniecības ražām un var samazināties īpašumu vērtība. Lauksaimniekiem būs jāmeklē jauni augu aizsardzības līdzekḷi pret mūsu

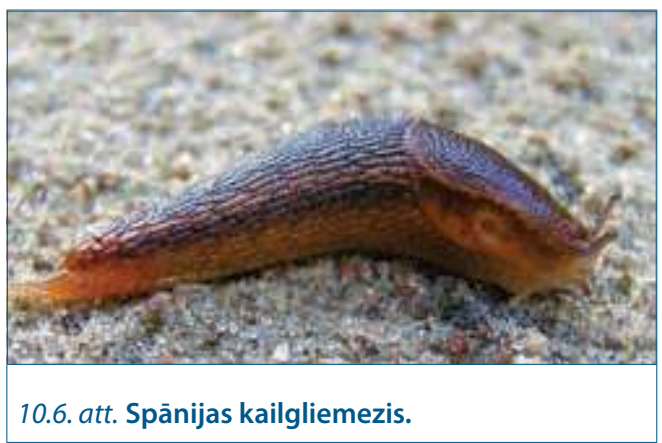


reǵionam neierastām agresīvām sugām. Garāks veǵetācijas periods, iespējams, l̦aus iegūt vairākas ražas gadā.

Zivsaimniecībā jārēḳinās ar augstākām vidējām ūdens temperatūrām. To ietekmē ievērojami paātrinās alıgu vairošanās process, ūdenstilpēs ieviešas neraksturīgas sugas, kas izjauc barības k,ēdi, ilgāk un intensīvāk "zied" zilalǵges, kas palielina risku toksisko vielu nokḷūšanai zivju organismos un tālāk to nonākšanai cilvēku organismos. Jāattīsta paṇēmieni, kā savairojušās alı́ges savākt un izmantot, piemēram, biogāzes ieguvei.

Veselības aprūpes organizācijām jau laikus ir jāsagatavojas lielākām alerǵisko reakciju sekām sakarā ar ilgstošāku ziedēšanas periodu, kā arī to pacientu daudzuma pieaugumam, kas cietuši no "karstuma viḷniem". Iespējams, ka insektu migrācija polu virzienā var atnest jaunas slimības - pat malāriju. Ir jābūt gataviem uzñemt slimnīcās lielāku cietušo skaitu dažādu klimata izraisīto katastrofu rezultātā. Taču var samazināties apsaldējumus guvušo skaits ziemā. Pastiprinātā bēgḷu migrācija var līdzi atnest dažādu, līdz šim neiepazītu, slimību risku.

Infrastruktūras objektiem, ko izmanto energoapgādē, ūdensapgādē un transportā, ir jābūt izturīgiem pret lielākām vētrām, plūdiem, lielām temperatūras svārstībām. Līdz ar to būvniecībā ir jāveido atbilstoši standarti, kas nodrošina būvju un ēku izturību pret ekstremāliem laika apstākḷiem. Tā kā gaisa dzesēšana prasa vēl lielāku enerǵijas patēriṇu nekā apsildīšana, ēku siltumizolācijai ir jāpievērš l̦oti liela uzmanība pat tad, ja ziemas kḷūst siltākas. Transporta sektorā jāizmanto telekomunikāciju tehnologiju piedāvātās iespējas, lai līdz minimumam samazinātu lieku attālumu veikšanu sastrēgumu vai brīvas stāvvietas meklējumu dēḷ, pilsētās jāveido viedās transporta plūsmas regulēšanas gaismas signālu sistēmas, lai samazinātu nepieciešamību katrā krustojumā bremzēt un uzsākt braukšanu. Tas nozīmē, ka laikā ar lielu transporta kustību gaismas signāli mainās biežāk, bet, kad intensitāte samazinās, retāk. Turklāt gaismas signālu nomaiṇa ielas garumā tiek sinhronizēta tā, lai automašīnām pēc iespējas retāk jāapstājas pie gaismas signāliem. Šādas sistēmas jau darbojas vairākās pilsētās ASV un Kopenhāgenā. Tas tiek izmēgināts arī citviet pasaulē.

Tūrisma un viesmīlības pakalpojumu jomā Baltijas jūras reǵionam tiek prognozētas labākas iespējas, jo vasaras būs agrākas, siltākas, arī ūdens temperatūra paaugstināsies. Taču ir jāṇem vērā riski, jo augstākas ūdens temperatūras rada ūdens toksiskuma riskus pastiprinātas aḷgu vairošanās un ūdens "ziedēšanas" dēḷ. Baltijas jūrā, upēs un ezeros pastiprināsies eitrofikācija. Lai biznesu sekmīgi attīstītu, jāveido alternatīvas atpūtas iespējas, ja zilaḷgu "ziedēšanas" laikā atpūta ūdenstilpnēs kḷūst bīstama cilvēka veselībai.

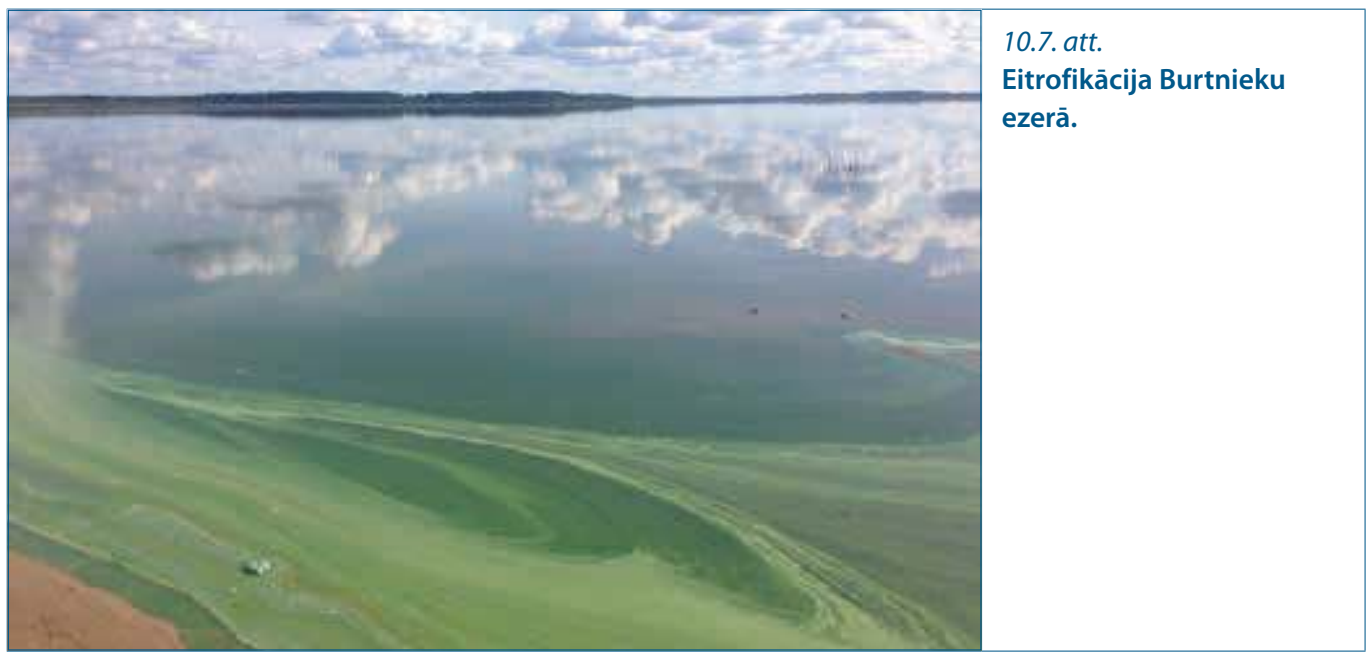




\subsection{Klimata pārmaiṇu mazināšanas ekonomiskie paṇēmieni}

Klimata pārmaiñas tiek uzskatītas par lielāko tirgus fiasko pasaules vēsturē. Tirgus fiasko ir tirgus stāvoklis, kad tas nav spējīgs nodrošināt nepieciešamo pieprasījuma un piedāvājuma attiecību, lai efektīvi tiktu izmantoti sabiedrībai pieejamie resursi. To izraisa ārējie efekti - izmaksas, kas rodas visā pasaulē un radīsies nākamajām paaudzēm klimata pārmainu dēḷ. Šìs izmaksas diemžēl nesedz tie, kas šīs klimata pārmaiṇas izraisa - SEG emitētāji. Līdz ar to emitētājiem nav ekonomiskās ieinteresētības šìs emisijas samazināt. Turklāt klimats ir sabiedrisks labums - nav iespējams ierobežot tā izmantošanu tiem, kas nemaksā par tā saglabāšanu cilvēkiem piemērotā stāvoklī. Tāpat kā citu tirgus fiasko gadījumā, tos var novērst, izmantojot valsts iejaukšanos tirgu darbībā.

Lai uzṇēmēji, kuru saimnieciskās darbības blakusprodukts ir SEG, būtu ieinteresēti samazināt SEG emisijas, valdības var izmantot dažādus ekonomiskos līdzekḷus: noteiktu vielu izmantošanas vai emisiju ierobežojumus, aizliegumus vai ekonomiskās ieinteresētības mehānismus. Šādi līdzekḷi nodrošina to, lai rīcībai, kas samazina SEG emisijas un citādi ir videi draudzīgāki, arī ekonomiski ir izdevīgāki. To panāk ar dažādu nodokḷu, maksu un emisijas tirdzniecības sistēmu palīdzību. Taču, ja šādi mehānismi tiek izmantoti tikai atsevišksās

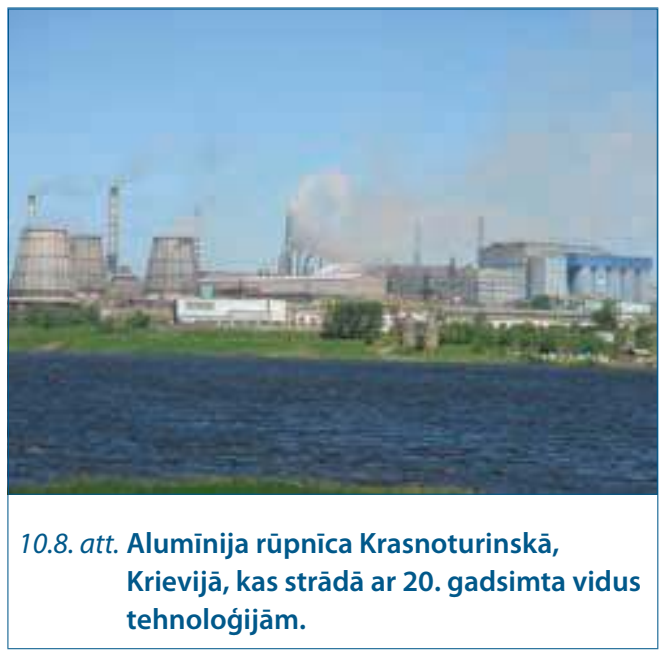

valstīs, tas samazina uznēmumu konkurētspēju, jo palielinās ražošanas izmaksas.

Jāṇem vērā, ka klimata pārmaiṇu ārējie efekti ir globāli gan cēloṇu, gan seku ziṇā. Atšksirībā no, piemēram, gaisa vai cita veida piesārņojuma, viena tonna SEG emisiju rada vienādu ietekmi uz klimata pārmaiṇām neatkarīgi no tā, kurā pasaules valstī tā ir emitēta, jo SEG atmosfērā izkliedējas un vietējās klimata izmaiñas ir atkarīgas no globālās klimata sistēmas. Tāpēc, lai globālo klimata pārmaiṇu problēmu risinātu, ir nepieciešama dziḷāka starptautiskā sadarbība daudzās jomās. Piemēram, jāizveido cenu signāli, kas veicina zemāku $\mathrm{CO}_{2}$ emisiju ekonomisko izdevīgumu, jāizveido oglekḷa emisiju tirgus, jāstimulē tehnologíju izpēte, attīstība un ieviešana, jāveicina pielāgošanās klimata pārmaiṇām. Līdzīgi kā ilgtspējīgas attīstības jomā, arī klimata pārmaiṇu dēḷ ekonomiskai analīzei ir jābūt globālai un jānem vērā loti ilgi laika posmi, būtisku uzmanību pievēršot risku un nenoteiktības analīzei.

Kā viens no efektīvākajiem klimata pārmaiņu mazināšanas ekonomiskajiem līdzekḷiem vairākos starptautiskos un individuālos pētījumos tiek uzskatīta cenas noteikšana ogleklı savienojumu emisijām. Tā var notikt vai nu emisiju tirdzniecības sistēmas veidā, vai oglekḷa savienojumu emisiju nodokḷu veidā. Mērḳis ir produktu cenā ietvert tās izmaksas, kas rodas sabiedrībai $\mathrm{CO}_{2}$ emisiju dēl, piemēram, samazināta labības ražība, veselības aprūpes izmaksas karstuma un sausuma periodu dēl vai kaitējums īpašumiem plūdu un jūras līmeña celšanās dēḷ. Šîs ārējās izmaksas būtu iespējams sasaistīt ar to cēlon,iem, izmantojot oglekḷa savienojumu cenu. Aprēksini liecina, ka, piemēram, elektrības ražošanā oglekḷa savienojumu emisiju izraisītās ārējās izmaksas ir no 1,6-5,8 eirocenti/kWh atkarībā no energoresursa, kur zemākā robeža saistīta ar elektrības ražošanu no gāzes un augšējā, izmantojot oglu tehnoloǵijas.

Cena par SEG emisijām palīdz novirzīt slogu par zaudējumiem uz tiem, kas par to ir atbildīgi un kam ir iespējas tās samazināt. Tā vietā, lai noteiktu kam un par cik vajadzētu samazināt 
emisijas, maksājumi par $\mathrm{CO}_{2}$ emisijām dod ekonomisku signālu un piesārn,otāji var paši izlemt, vai pārtraukt piesārn,ojošu darbību, samazināt emisijas, vai arī turpināt piesārn,ošanu un samaksāt par to. Tādējādi mērksis tiek sasniegts pēc iespējas elastīgi un ar mazākajām kopējām izmaksām sabiedrībai. Oglekḷa savienojumu cena stimulē arī tīrāku tehnoloǵiju ieviešanu un tirgus inovācijas, kā arī veicina jaunu, zemas oglekḷa savienojumu emisijas ekonomikas nozaru izaugsmi. Nozīmīga problēma ir tā, ka ir neiespējami noteikt oglekḷa emisiju radītās precīzās ārējās izmaksas, līdz ar to tiek izmantotas dažādas metodes, kas dod tikai aptuvenu rezultātu. Viena no šīm metodēm - oglekḷa savienojumu cenu nosaka emisiju ațauju tirgus pieprasījuma un piedāvājuma attiecība.

Izmantojot $\mathrm{CO}_{2}$ nodokli, tiek noteikta konkrēta cena par oglekḷa savienojumu emisijām vai, biežāk, par fosilo kurināmo, kas satur oglekli. Taču pasaulē vēl daudzviet fosilajam kurināmajam netiek uzlikti nodokḷli, bet gluži pretēji - tiek maksātas subsīdijas.

Pasaules Bankas pētījums par globālo sasilšanu uzsver, ka pašlaik pasaulē apmēram triljons EUR tiek izmaksāts subsīdijās par fosilās degvielas sadedzināšanu. Šì nauda būtu jāiegulda atjaunojamo un zemas oglekḷa savienojumu emisijas energoresursos.

Viens no svarīgiem veidiem, kā atbilstoši ieguldījumi var palīdzēt cīñā ar klimata pārmaiñām, ir investīcijas infrastruktūrā. Ir lıti svarīgi, lai veidojot un rekonstruējot infrastruktūras objektus, tiktu mazināta to ietekme uz klimata pārmaiṇām. Turklāt šīm infrastruktūrām ir jābūt noturīgām pret ekstremālām laikapstākḷu ietekmēm. Savukārt, veidojot infrastruktūras objektus atbilstoši iepriekšējai biznesa praksei, kas ir izraisījusi klimata pārmaiṇas, mēs pakḷaujam vidi negatīvai ietekmei daudzu gadu desmitu garumā. Piemēram, pien,emot lēmumus par jaunu energiijas ražotņu vai cel̦u infrastruktūras būvniecību, jāapzinās, ka pat tad, ja pasaulē tiek atklātas jaunas naftas atradnes un apgūtas jaunas ieguves tehnoloǵijas, SEG emisijas, ko radīs šīs degvielas sadedzināšana, pasaule vairs nevarēs ațlauties, lai nepārsniegtu kritisko globālās temperatūras paaugstināšanos.
Kopumā pāreja no fosilā kurināmā uz atjaunojamiem energoresursiem ir ļoti sarežǵīta. Tas prasa izmaiṇas visā enerǵétikas sistēmā no ražošanas un uzglabāšanas līdz izplatīšanai un gala patēriņam. Piemēram, elektrībai, ko ražo, izmantojot Saules paneḷus vai vēja generatorus, ir jābūt pieejamai izmantošanai vajadzīgajā laika posmā un vietā. To var panākt tad, ja ir izveidoti labi savienoti viedie elektrotīkli. Arī transporta sistēmai ir nepieciešamas radikālas pārmaiṇas: elektrisko transporta līdzeklu daudz plašāka izmantošana, radot un pilnveidojot sabiedriskā transporta tīklu, kas var risināt pieprasījumu pēc mobilitātes, piedāvājot alternatīvas braukšanai privātajās automašīnās. Ieguldījumi, kas nepieciešami, lai šīs izmain, as realizētu, varētu būt l̦oti apjomīgi.

Saskaṇā ar Eiropas Komisijas aplēsēm, lai ES energétikas un transporta sistēmu padarītu par zemas ogleklı savienojumu emisijas sistēmu, būs nepieciešami aptuveni 270 miljardi EUR papildu valsts un privātiem ieguldījumiem katru gadu nākamo 40 gadu laikā. Šì papildu summa atbilst aptuveni 1,5\% no ES IKP. Investoriem būtu jārīkojas jau tagad, lai mazinātu nākotnes klimata pārmainu ietekmes.

Investīcijas gan transporta, gan ūdens un enerǵijas pārvades sistēmās notiek visu laiku, tāpēc tās mērkstiecīgi būtu jāiegulda ilgtspējīgākiem risinājumiem. Valsts izdevumu pārorientēšana no fosilā kurināmā uz atjaunojamiem energoresursiem dod skaidru signālu par vēlamajiem attīstības virzieniem gan enerǵijas ražotājiem, gan pētniekiem un tehnoloǵiju izstrādātājiem, gan enerǵijas lietotājiem.

Ir 10 galvenie virzieni, kuros jāstrādā, lai nodrošinātu zemas oglekl̦a dioksīda emisijas un pret klimata pārmaiṇām noturīgu ekonomisko izaugsmi un attīstību:

1. Paātrināt oglekḷa savienojumu izmantošanas mazietilpīgu attīstību pasaules pilsētās.

2. Atjaunot un aizsargāt lauku vides un mežu ainavas, palielināt lauksaimniecības ražīgumu.

3. Ieguldīt vismaz 1 triljonu EUR gadā no SEG brīvas enerǵijas ražošanā un energoefektivitātes uzlabošanā.

4. Palielināt enerǵijas efektivitātes standartus līdz pasaules augstākajam līmenim. 
5. Ieviest efektīvu cenu par SEG emisiju un pakāpeniski atteikties no fosilo kurināmo subsidēšanas.

6. Nodrošināt jaunu, klimatu saudzējošu infrastruktūru.

7. Veicināt inovācijas, kas saistītas ar zemām SEG emisijām.

8. Vadīt ekonomisko izaugsmi uzñēmumiem ar zemām oglekḷa dioksīda emisijām, izmantojot uzñēmējdarbības un ieguldītāju rīcību.

9. Izvirzīt mērḳus, lai samazinātu starptautiskās aviācijas un jūras transporta SEG emisijas.

10. Pakāpeniski samazināt halogēnoglūūeṇražu izmantošanu.

Dažādu ekonomisko instrumentu izmantošana ir nepieciešama ne tikai tāpēc, lai mazinātu klimata pārmaiñas vispār, bet arī lai sasniegtu Eiropas Savienības izvirzītos mērksus klimata jomā līdz 2020. gadam:

- samazināt SEG emisijas par 20\% (vai 30\%, ja par to notiks vienošanās visā pasaulē),

- par 20\% palielināt energoefektivitāti,

- iegūt $20 \%$ enerǵijas no atjaunojamiem enerǵijas avotiem.
Kā vēl vienu ekonomisko mehānismu, kas būtiski var ietekmēt pāreju uz tīrām tehnologijām un tādējādi samazināt ietekmi uz klimata pārmaiṇām, var minēt izmaiṇas intelektuālā īpašuma aizsardzībā. Samazinot patentu darbības laiku vai atvieglojot licenču ieguves iespējas, tehnologiskie uzlabojumi izplatītos ātrāk. Ir jādomā, cik ētiski un racionāli ir sargāt patentus, kas paredz energijas ieguvi no atjaunojamiem enerǵijas resursiem, ja klimata pārmaiṇu dēl tiek apdraudēta cilvēku dzīvotspēja uz Zemes.

Protams, ka intelektuālā ìpašuma aizsardzība ir nepieciešama, lai stimulētu izgudrojumu attīstību, bet tā ir jāsabalansē ar nepieciešamību šos izgudrojumus realizēt dzivē pēc iespējas ātrāk un plašāk. Valdības varētu zināmu finansējuma dalı novirzìt licenču iegādei un likumdošanā stingrāk ievērot, ka ar patentiem aizsargātie izgudrojumi ir jāizmanto obligāti.

Vēl viena nozīmīga iespēja, ar kuru var samazināt SEG emisijas, ir informēšana un apziñas veidošana vides jomā. Tas varētu nodrošināt patērētāju uzvedības maiṇu - patērētāji ar saviem macin,iem "balsotu" par zemāku oglekla savienojumu emisiju produktiem, izvēlētos

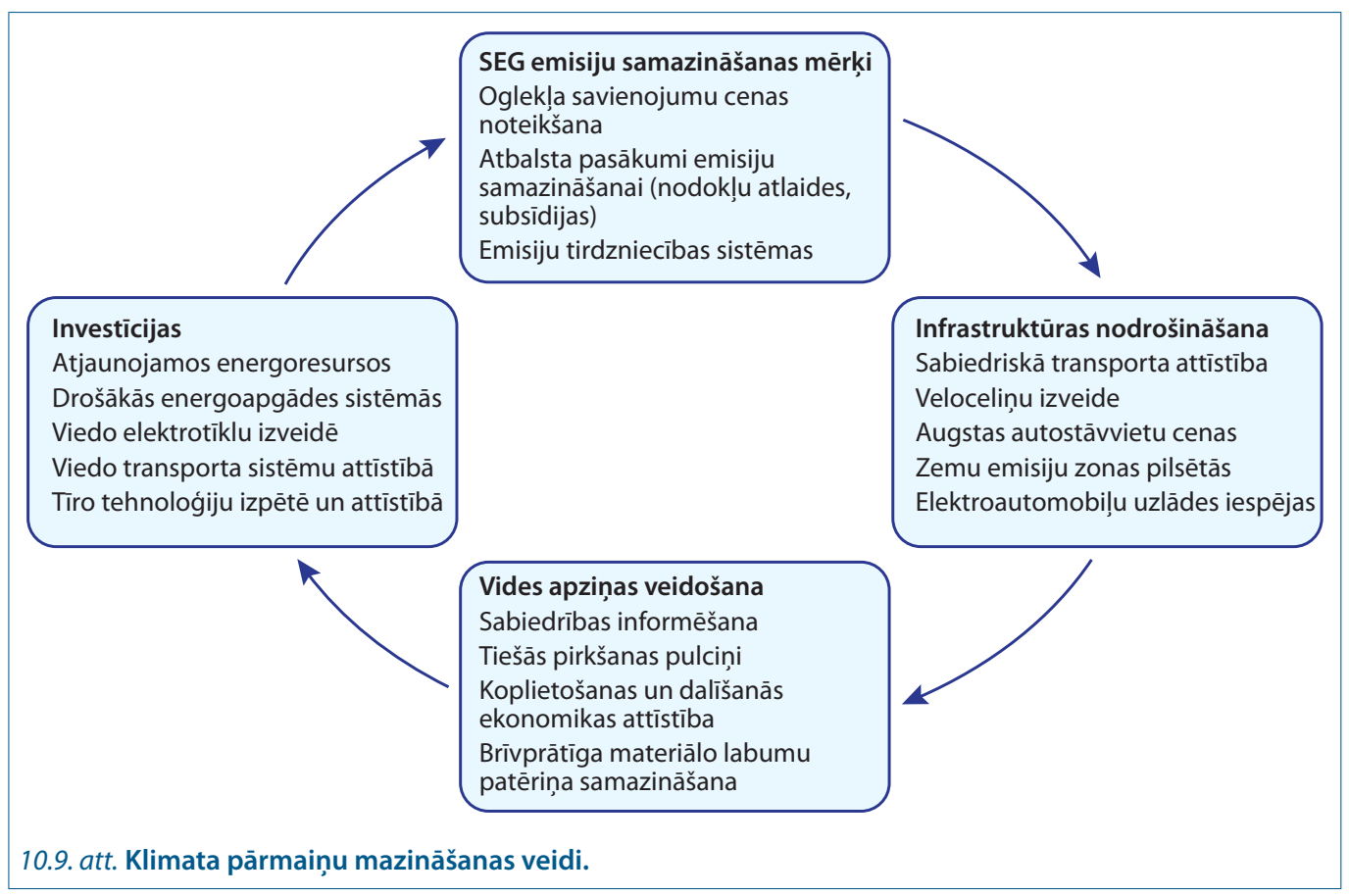


klimatam draudzīgākus pārvietošanās veidus, piedalītos klimata adaptācijas pasākumos, investētu klimatam draudzīgos uzñēmumos utt. Te lielu ieguldījumu var sniegt nevalstiskās organizācijas, formālās un neformālās izglītības institūcijas.

Šajā procesā ir iesaistījušās arī augstākās religískās institūcijas. Piemēram, 2015. gadā izdota pāvesta Franciska Enciklika "Esi slavēts!", kurā centrālais jautājums ir: "Kādu pasauli mēs gribam nodot tālāk tiem, kuri dzīvos pēc mums - bērniem, kuri aug?" Dokuments ir veltîts rūpēm par "kopējām mājām" - mūsu planētu. Pāvests uzsver, ka cilvēku egoisms kḷuvis par vienu no galvenajiem iemesliem, kāpēc notiek globālā sasilšana. Klimats ir kopējais labums, kas pieder visiem un domāts visiem, tāpēc cilvēcei ir jāatzīst nepieciešamība pēc izmaiñām dzivesveidā, ražošanā un patēriṇā. Liela nozīme ir pievērsta arī klimata pārmainu ietekmei uz nevienlīdzības pastiprināšanos. Jāizprot, ka tiešām pastāv "ekologisks parāds" starp pasaules attīstītajiem ziemel̦iem un attīstības valstu dienvidiem, kuri visvairāk cieš no klimata pārmaiṇām.

N̦emot vērā klimata pārmainuu sarežǵìtos cēloṇus un sekas, skaidrs, ka tikai kāda atsevišksa pan̄ēmiena izmantošana to neatrisinās. Ir nepieciešama daudzu ekonomisko metožu nodrošināšana. Tā ir nodoḳlu, emisiju tirdzniecības sistēmu izveidošana un attīstǐšana, tehnologiju attīstība, informācijas izplatīšana, patēriṇa paradumu maiṇas sinerǵija, tās ir investīcijas cilvēkam drošā un labvēlīgā infrastruktūrā.

\subsection{Klimata pārmaiṇu mazināšanas pasākumi uzṇēmējdarbībā}

Uzṇēmējiem ir jārēķinās ar iepriekšējā apakšnodaḷā aprakstīto iespēju izmantošanu jau tuvākajā nākotnē, t.i.., jāzina, ka pieaugs izmaksas izejvielām un starpproduktiem, kas saistītas ar lielām SEG emisijām. Jāvērtē sava konkurētspēja attiecībā pret konkurentu produktu SEG ietilpību, kas atspogulıosies arī ražošanas izmaksās. Lai samazinātu savu galaproduktu kopējās SEG emisijas, ir svarīga sadarbība visā piegādes kēēdē - sākot ar izejvielu ražotājiem un beidzot ar patērētājiem, kam aprites cikla beigās būs jāatbrīvojas no produkta atkritumiem. Lai samazinātu ietekmi uz klimata pārmaiṇām, uzṇēmējdarbībā ir jātaupa visi resursi un jāizstrādā atbilstošas stratēgijas.

Daudzi Latvijas uzṇēmumi piegādā atsevišksas produktu sastāvdaḷas vai gatavos produktus ārvalstu ražotājiem. Tāpēc ir jārēḳinās, ka pasūtītāji uzstādīs augstākas prasības saistībā ar ražošanas procesā radītajām emisijām, ūdens patēriṇu un piesārn,ojumu, energoefektivitāti u.tml. gan tāpēc, lai izpildītu savu gala patērētāju prasības, gan tāpēc, ka piesārṇojošo tehnologiju izmaksas nākotnē palielināsies.

Viens no kompleksiem risinājumiem, kā samazināt ietekmes uz klimata pārmaiṇām un vidi kopumā ir t.s. aprites ekonomika. Aprites ekonomikas galvenais princips ir imitēt dabā esošās barības ķēdes, kurās atkritumu nav viss ir barība nākamajam barības k,ēdes posmam. Tāpat arī aprites ekonomikā mērkuis ir visus ražošanas un patēriṇa atlikumus izmantot kā izejvielas.

Pieci galvenie biznesa model̦i ko izmanto aprites ekonomikā ir šādi.

1. Noslēgta piegādes ķēde, kurā ražotāji izmanto pilnībā atjaunojamas, atkārtoti pārstrādājamas vai bioloğiskas izejvielas, kas ir pamatā aprites ražošanas un patēriṇa sistēmām. Šāda noslēgta sistēma nodrošina visu ražošanas un patēringa atlikumu izmantošanu citu produktu ražošanā, samazina neefektīvus risinājumus. Piemēram, Dānijā industriālajā zonā Kalundborgas pilsētā ir izveidots ekoindustriālais parks. Tas ir laika gaitā attīstījies, sākot no vienas spēkstacijas, iekḷaujot savā klāsterī aizvien jaunus uzñēmumus, kas paḷaujas cits uz cita materiālajiem ieguldījumiem. Uzṇēmumu grupā par galvenajiem dalībniekiem uzskata

- Asnae oglu elektrostaciju (lielāko Dānijā),

- naftas pārstrādes rūpnīcu, kas pieder Statoil, 
- farmācijas rūpnīcu, kas pieder Novo Nordisk,

- Gyproc, Skandināvijas lielāko gípškartona ražotāju,

- Kalundborgas pašvaldību, kas piegādā ùdeni, elektroenerǵiju un nodrošina centralizēto siltumapgādi aptuveni 20000 cilvēku.

Sadarbojoties kopējā materiālu un energíjas izlietošanā, kas uzṇēmumiem rodas kā blakusprodukti, ik gadu izdodas ietaupīt ievērojamas summas (1972.-1994. gada periodā apmēram 10 miljonus EUR gadā). Piemēram, attīrītie notekūdeñi no Statoil pārstrādes rūpnīcas tiek izmantoti kā dzesēšanas ūdens Asnae elektrostacijā. Statoil un Novo Nordisk iegādājas tvaiku, kas ir blakusprodukts Asnae spēkstacijā, lai varētu darbināt savas ierīces. Atlikušo siltumu no spēkstacijas izmanto apkārtējo māju sildīšanai un arī vietējās zivjaudzētavās. Savukārt, spēkstacijā no sēra dioksīda iegūst izejmateriālu ǵipša materiālu ražošanai. Barības vielām bagātās dūn,as no Novo Nordisk tiek piegādātas vietējiem zemniekiem mēslojumam utt.

2. Resursu atgūšana, kurā, izmantojot tehnologískos risinājums, ir iespējams produktu atkritumus ne tikai pārstrādāt par zemākas vērtības produktiem, bet pārstrādē iegūt tikpat vērtīgus vai vēl vērtīgākus produktus, piemēram, uzñēmuma ietvaros attīrìt un atkārtoti izmantot notekūdenus, ar videi nekaitīgu tinti drukātus laikrakstus izmantot komposta veidošanai, no izlietotām PET pudelēm ražot Saules baterijas. Šajā procesā būtiska nozīme jāpievērš produktu dizainam un sastāvam. Jau projektējot produktu, jāparedz, kam tiks izmantotas tā sastāvdaḷas aprites cikla beigās un cik viegli tās būs atgūt un saškirirot.

\section{Produktu izmantošanas paildzināša-}

na, kas dod iespēju augstas kvalitātes un ilgstošas lietojamības preces izmantot ilgu laiku, nomainot tikai bojātās sastāvdaḷas, un netērēt resursus un enerǵiju jaunu produktu ražošanai. Tādas preces kā veḷas mazgājamās mašīnas, ledusskapji un cita ilgstošas lietošanas sadzīves tehnika pēc nepieciešamās atjaunošanas var atrast atkal jaunus saimniekus starp zemāku ienākumu līmeṇa cilvēkiem. Jānodrošina iespējas preces nodot, atjaunot un atjaunotas atkal pārdot vai ziedot.

4. Dalī̌sanās (koplietošanas) ekonomika, kas jau produkta dizainā paredz, ka tos lietos daudzi savstarpēji neatkarīgi lietotāji (koplietošanas produkti, noma, nodošana vai pārdošana no viena lietotāja nākamajam u.tml.), kas ievērojami samazina pieprasījumu pēc jauniem produktiem un līdz ar to samazina vides ietekmes.

\section{Produkta aizstāšana ar pakalpojumu,} kas motivē uzñēmumus ražot ilgākas lietojamības un energoefektīvākus produktus, kā arī nodrošina atkritumu izmantošanu produkta aprites cikla beigās. Piemēram, ASV kompānija Interface iznomā grīdas segumu pakalpojumu, nevis pārdod grīdas segumus. Šì kompānija ir pazīstama ar savu ambiciozo plānu līdz 2020. gadam panākt nulles atkritumu līmeni. Pašlaik Interface ir miljardu dolāru vērta korporācija, kas darbojas 110 valstīs, un žurnāls Fortune to ir nosaucis par vienu no "apbrīnotākajiem uzṇēmumiem Amerikā" un "100 labākajiem uzñēmumiem, kur strādāt."

Saglabājot īpašuma tiesības uz grīdas segumiem, Interface spēj atgūt ievērojamu dal̦u materiālu, ko izmantot jaunu segumu ražošanā. Līdzīgs biznesa modelis ir Nīderlandes kompānijai Bundles, kas iznomā vel̦as mazgāšanas iespēju, nevis pārdod vel̦as mazgājamās mašīnas un tādējādi nodrošina pārraudzību, uzturēšanu un mūža apsaimniekošanu ieguldītajiem materiāliem. Klientiem, kuru mājās atrodas vel̦as mazgājamās mašīnas, ir jāmaksā tikai par izmantotajām mazgāšanas ciklu reizēm un to uzskaite tiek nodrošināta, izmantojot interneta tehnologijas. Bundles savā biznesā izmanto Miele ražotās veḷas mazgājamās mašĩnas, jo tās mūsdienās ir vienīgās, kas joprojām izmanto 100\% pārstrādājamus vai atkārtoti izmantojamus materiālus. Taču nākotnē arī vel̦as mazgājamo mašīnu ražotājam būtu jāṇem vērā šāds biznesa modelis un jāpielāgo mašīnas funkcionalitāte tam.

Tā kā liels īpatsvars SEG emisijās ir transporta sektoram, uzṇēmējdarbībā liela nozīme jāpiešķir loǵistikas uzlabošanai. Ja ar ekonomisko metožu palīdzību oglekḷa dioksīda emisiju radītās izmaksas būs jākompensē, tad tas 
būs arī ekonomiski izdevīgi. Pašlaik uzṇēmējiem nereti ir izdevīgāk lētākus produktus vai izejvielas iepirkt no Kinnas, Indijas vai citām attālām vietām ar salīdzinoši lētu darbaspēku, jo par transportēšanas izraisītajām ietekmēm pašiem tieši nav jāmaksā. Ja par $\mathrm{CO}_{2}$ emisijām būs jāmaksā, tad transportēšanas k,ēdes būs izdevīgi ievērojami saīsināt. Tā kā ūdens transports un dzelzcel̦š ir transports ar zemākajām oglekla savienojumu emisijām, kur iespējams, jāpārorientējas uz tiem.

Arī pašiem transporta līdzekḷiem jākḷūst daudz efektīvākiem un "tīrākiem". Ievērojamus ietaupījumus transportēšanā var panākt arī ar iepakojuma daudzuma un dizaina izmain,ām. Pasaulē pazīstamajam zviedru mēbel̦u un sadzīves priekšmetu ražotājam IKEA izdodas uzturēt zemas cenas, lielā mērā pateicoties tam, ka viṇi nepārvadā gaisu, piemēram, mēbeles tiek pārdotas plakanos iepakojumos, nevis saliktā veidā, sīkākiem priekšmetiem pēc iespējas tiek taupīti iepakojuma materiāli un izvietojums tajos veidots tā, lai tie aizñem mazāk vietas. Piemēram, nomainot tējas svecīšu iepakojumu no brīva iepakojuma maisingos uz blīvo iepakojumu regulāros četrstūra formas iepakojumos, IKEA ir izdevies ietaupīt apstrādes laiku par 3045 minūtēm dienā, vietu - par 108 iepakojumiem vairāk uz katras paletes, kā arī 400 kravas

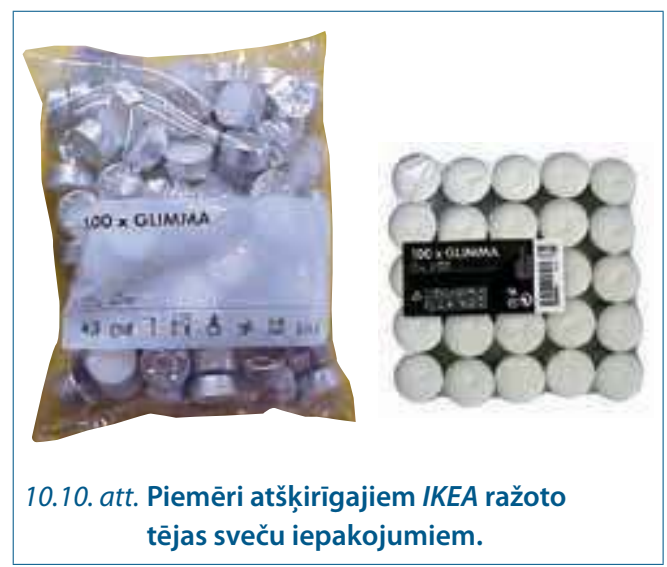

automašīnu reisus. Rezultātā uzñēmums varēja samazināt pārdošanas cenu par $10 \%$.

Uzṇēmējdarbībā ir svarīgi, lai videi un klimatam labvēlīgi risinājumi radītu arī adekvātu ienākumu plūsmu. Maz ticams, ka uzñēmēji izmantos iepriekš minētos biznesa model̦us filantropisku mērksu vadīti. Tiem ir jābūt arī ekonomiski izdevīgiem. Pareizi izmantojot ekonomiskās metodes un audzinot gala patērētājus, kas ir daudz prasīgāki attiecībā uz ietekmēm pret vidi, šie biznesa model̦i nenoliedzami būs arī lielāku peḷnu nesoši nekā tradicionālais bizness.

\section{Literatūra}

Chichilnisky G., Sheeran K. (2009) Saving Kyoto: An Insider's Guide to the Kyoto Protocol. New Holland Publishers, p. 198.

China Carbon Emissions Decline as 2014 Global $\mathrm{CO}_{2}$ Stays Flat. Pieejams http://www.bloomberg.com/news/ articles/2015-03-13/china-s-carbon-emissions-drop-for-the-first-time-since-2001

Chen I.-C., Hill J. K., Ohlemüller R., Roy D. B., Thomas C. D. Rapid Range Shifts of Species Associated with High Levels of Climate Warming. Science, Vol. 333, 2011, pp. 1024-1026.

Energy, Climate Change and Environment: Executive Summary. International Energy Agency, 2014.

ExternE-Pol, Externalities of Energy: Extension of Accounting Framework and Policy Applications. Final Technical Report, August 2005.

Fearnside P. M. Emissions from Tropical Hydropower and the IPCC, Environmental Science \& Policy, Volume 50, June 2015, pp. 225-239.

Gemenne F. Climate-induced Population Displacements in a $4^{\circ} \mathrm{C}+$ world (2011) Philosophical Transactions of the Royal Society A: Mathematical, Physical and Engineering Sciences, 369 (1934), pp. 182-195.

IPCC, 2014: Climate Change 2014: Synthesis Report. Contribution of Working Groups I, II and III to the Fifth Assessment Report of the Intergovernmental Panel on Climate Change [Core Writing Team, R. K. Pachauri and L. A. Meyer (eds.)]. IPCC, Geneva, Switzerland. p. 151. 
Iglesias A., Garrote L. Adaptation Strategies for Agricultural Water Management Under Climate Change in Europe, Agricultural Water Management, Volume 155, June 2015, pp. 113-124.

Stern N. (2006) The Economics of Climate Change: The Stern Review. Cambridge University Press, p. 692

The CSR International Research Compenduium. Volume 2 - Environment. Eds. Visser W., Megureanu I., Yadav K. Kaleidoscope Futures, 2015, p. 611

Interneta resursi

Eiropas Vides Aǵentūras ziṇojums par jauno klimata ekonomiku http://2015.newclimateeconomy.report/ Bezpe!̣nas organizācijas Carbon Tracker mājas lapa http://www.carbontracker.org/

ASV Vides Aizsardzības aǵentūras mājas lapas sadạ̣a par klimata pārmaiṇām http://epa.gov/climatechange/

Klimata pārmaiṇu visapdraudētākās vietas pasaulē $h$ ttp://www.climatehotmap.org/

Pasaules Bankas mājas lapas sadaḷ par klimata pārmaiṇām http://www.worldbank.org/en/programs/pricing-carbon Klimata pārmainu starpvaldību padomes 5. ziṇojums http://www.ipcc.ch/report/ar5/syr/

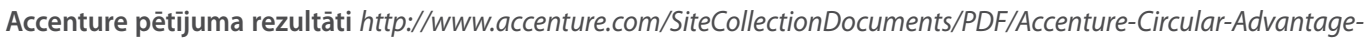
Innovative-Business-Models-Technologies-Value-Growth.pdf

Ellenas Makartūras fonda mājas lapa http://www.ellenmacarthurfoundation.org/

Īss skaidrojums par to, kas ir aprites ekonomika https://www.youtube.com/watch?v=zCRKvDyyHml

Interface kompānijas mājas lapas sadaḷa par ilgtspējas programmu http://www.interfaceglobal.com/Sustainability.aspx

Izmantotie attēli

10.2. "Climate Change 2015: The Physical Science Basis", IPCC

10.4. Eiropas Komisijas Kopīgās pētniecības centra pētijums PESETA II, pieejams http://peseta.jrc.ec.europa.eu/peseta1_Tourism.html

10.6. Valsts Augu Aizsardzïbas Dienesta mājas lapa http://www.vaad.gov.lv/11/section.aspx/293

10.7. Foto: R. Indrāns 


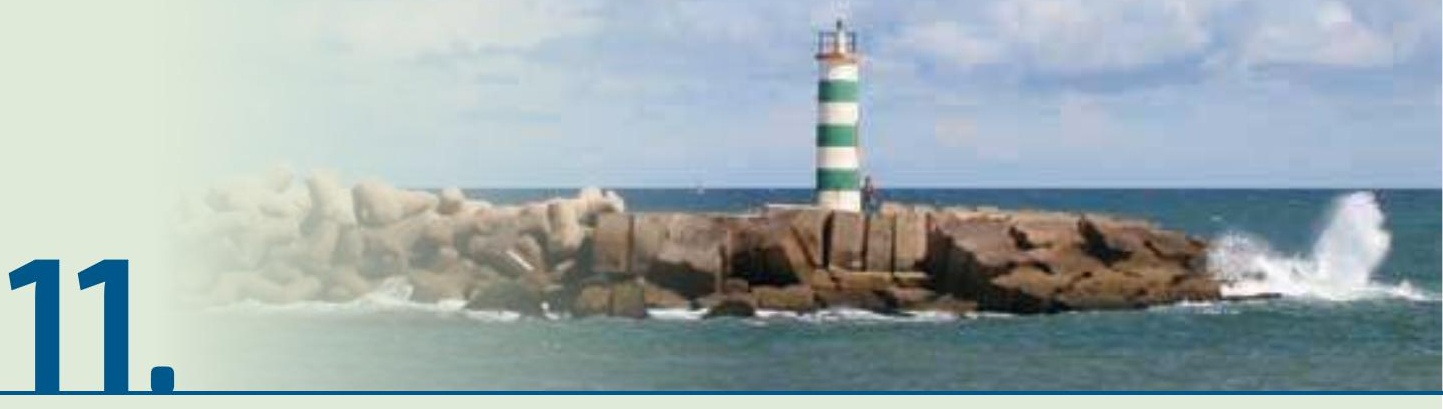

Klimata politika 


\subsection{Klimata politikas pamatvirzieni*}

Klimata politikas (climate policy) veidošanās un attīstība ir saistīta ar mūsdienās novērojamo klimata pārmaiṇu parādīšanos un pastiprināšanos. Klimata politikā šobrīd izdalāmi divi pamatvirzieni:

- klimata pārmaiṇu novēršana (climate change mitigation);

- pielāgošanās klimata pārmaiṇām (adaptation to climate change).

Senākais ir klimata pārmaiṇu novēršanas virziens - tas izveidojās līdz ar prognozēm par klimata pārmaiṇu iespējamību un apziṇu par nepieciešamību tās novērst. Turpretim pielāgošanās (adaptācijas) klimata pārmaiṇām virziens radās salīdzinoši nesen - tad, kad tika konstatēts, ka pilnībā novērst klimata pārmaiñas neizdosies, un tāpēc ir nepieciešams mazināt to radītos riskus un pielāgoties.

Klimata politikas mērksis ir virzība uz oglekla mazietilpīgu attīstību, OMA (low carbon development) un pret klimata pārmaiñām noturīgu sabiedrību. Klimata politikas veidošana un ieviešana iespējama gan nacionālā, gan regionālā mērogā, un lielā mērā klimata politikas pasākumi aktuāli arī komersantiem, mājsaimniecībām un ikvienam sabiedrības loceklim.

\subsubsection{Klimata pārmaiṇu novēršana}

Klimata pārmainu novēršanas politikas mērksis ir novērst antropogēni (cilvēka darbības rezultātā) izraisītās klimata pārmaiṇas un panākt klimata sistēmas stabilizēšanos. Klimata pārmaiṇu novēršanu teorētiski iespējams sasniegt divējādi:

- klimata geoinženierijas (climate geoengineering) rezultātā;

- nodrošinot siltumnīcefekta gāzu, SEG (greenhouse gas, GHG) apjoma ierobežošanu atmosfērā.

Klimata ǵeoinženierija paredz tiešu iejaukšanos atmosfēras dabiskajos procesos, lai samazinātu oglekḷa dioksīda un citu SEG apjomu vai samazinātu Saules starojuma absorbēšanos Zemes atmosfērā. Lai gan dalıa zinātnieku klimata ǵeoinženieriju uzskata par perspektīvu jomu, vairums ir vienisprātis, ka tā tomēr nevar aizstāt SEG apjoma ierobežošanu. Pētījumi klimata ǵeoinženierijas jomā vēl aizvien ir pārsvarā teorētiski, un praktisko eksperimentu rezultāti ir neviennozīmīgi. Praksē klimata pārmaiņu novēršanas politika, tātad, nozīmē klimata pārmainu cēloṇu novēršanu, proti, SEG apjoma ierobežošanu, un to iespējams panākt, samazinot SEG emisijas, nodrošinot un palielinot ogleklı dioksīda piesaisti, kā arī uztverot un noglabājot oglekḷa dioksīdu zemes struktūrās (carbon capture and storage, CCS) vai atkārtoti izmantojot (carbon capture and utilisation, $C C U$ ).

SEG emisiju samazināšana saistīta ar SEG emisiju avotiem. Klimata politikas kontekstā SEG grupā ietilpst 4 vielas un 3 vielu grupas:

- oglekḷa dioksīds $\left(\mathrm{CO}_{2}\right)$ - rodas visos degšanas procesos;

- metāns $\left(\mathrm{CH}_{4}\right)$ - rodas galvenokārt dažādos organisko vielu pārvērtības procesos, t.sk. zarnu fermentācijā;

- slāpekla (I) oksīds $\left(\mathrm{N}_{2} \mathrm{O}\right)$ - rodas galvenokārt degšanas procesos, slāpekḷa mēslojuma izmantošanas rezultātā un arī organisko augšn,u izmantošanā;

- slāpekla trifluorīds $\left(\mathrm{NF}_{3}\right)$ - pārsvarā izmanto elektronikas nozarē LCD displejos, siltuma pārneses šķidrumos;

- fluoroglūdeñraži (HFCs), perfluoroglūden,raži (PFCs) un sēra heksafluorīds $\left(\mathrm{SF}_{6}\right)$ - izmanto dažādās rūpnieciskās iekārtās, piemēram, aukstuma iekārtās.

N̦emot vērā SEG emisiju avotu dažādību, SEG emisiju ierobežošanas nolūkā uzmanība jāpievērš visām tautsaimniecības nozarēm (seviški enerǵētikai, transportam un lauksaimniecībai), kā arī iedzìvotāju dzīvesveidam un patēringam.

$\mathrm{CO}_{2}$ piesaistes (saistǐšanas) nodrošināšana un palielināšana galvenokārt ir saistīta ar mežsaimniecību. $\mathrm{CO}_{2}$ piesaisti nodrošina

* 11. nodaḷa "Klimata politika" publicēta autores Ilzes Prūses redakcijā. 
fotosintēzes process, kas notiek visās augu zalajās daḷās. Fotosintēzes laikā pēc $\mathrm{CO}_{2}$ piesaistīšanas tiek atbrīvots skābeklis $\left(\mathrm{O}_{2}\right)$ un augā paturēts ogleklis (C).

$\mathrm{CO}_{2}$ noglabāšana zemes struktūrās nozīmē $\mathrm{CO}_{2}$ iesūknēšanu un uzglabāšanu pazemē līdzīgi kā tas tiek darīts ar dabasgāzi. Lai tas būtu iespējams, nepieciešama ne vien atbilstoša zemes struktūra un tehnologijas, kas ir ievērojami sarežgiītākas nekā dabasgāzes gadījumā, bet arī tuvumā esošs liels stacionārs $\mathrm{CO}_{2}$ emisiju avots. Savukārt $\mathrm{CO}_{2}$ atkārtotā izmantošana iespējama tiešã veidā vai pārveidojot $\mathrm{CO}_{2}$ citās formās, piemēram, pārveidojot karbonātos, pārveidojot šksidrajos kurināmajos, polimēros u.tml.

SEG apjoma ierobežošanas vīzija ir OMA. OMA nozīmē pakāpenisku pāreju uz ogleklı mazietilpīgu ekonomiku - ekonomiku, kas rada minimālas SEG emisijas, sevišksi $\mathrm{CO}_{2}$ (sk. 11.1. att.). Viens no nozīmīgākajiem brīžiem OMA ieviešanā ir iekšzemes kopprodukta (IKP) atsaiste no SEG, proti, situācija, kad, palielinoties IKP, SEG emisijas proporcionāli nepalielinās vai pat samazinās.

OMA ietver klimata politikas un ilgtspējīgas attīstības politikas mērķus. Lai gan ilgtspējīga attīstība ir plašāks koncepts, n,emot vērā to, ka OMA savukārt ir daudz konkrētāks jēdziens, mūsdienās aizvien biežāk ilgtspējīgas attīstības kontekstā runā tieši par OMA. OMA koncepts atbilst visām trim ilgtspējīgas attīstības dimensijām (vide, ekonomika un sociālie aspekti). OMA nodrošina ne vien SEG emisiju apjoma ierobežošanu, bet arī jaunu darba vietu radīšanu un dzīvesvides drošības un kvalitātes uzlabošanos, ekonomikas konkurētspējas paaugstināšanu u.c.

\subsubsection{Pielāgošanās klimata pārmaiṇām}

Pielāgošanās klimata pārmaiṇām politikas mērksis ir samazināt klimata pārmaiṇu negatìvās ietekmes un izmantot klimata pārmainu

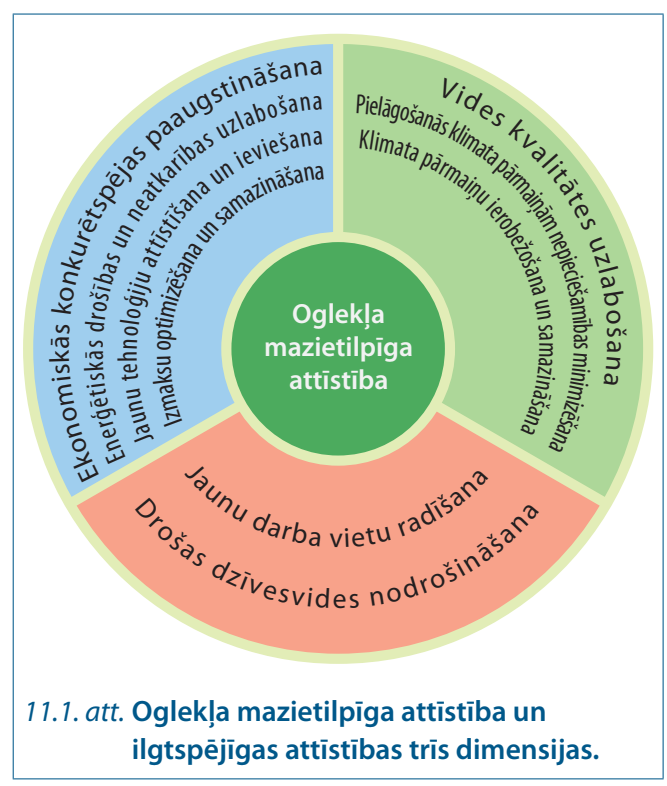

radītās iespējas. Nepieciešamība pielāgoties klimata pārmaiṇām tiešā veidā saistīta ar klimata pārmaiṇu novēršanu - jo ātrāk novērš klimata pārmaiñas, jo mazāka ir vajadzība pēc pielāgošanās klimata pārmaiṇām.

Pielāgošanās klimata pārmaiṇām pasākumi ir vērsti uz cilvēku, ēku, infrastruktūras, komercdarbības un ekosistēmu aizsardzību. Pielāgošanās klimata pārmaiṇām ietvaros jāpievērš uzmanība gan tautsaimniecības nozaru pielāgošanai un infrastruktūras aizsardzībai, gan arī katastrofu riska mazināšanai, piekrastes teritoriju aizsardzībai, veselības aizsardzībai, bioloǵiskās daudzveidības saglabāšanai u.c. (sk. 11.2. att.).

Pielāgošanās klimata pārmaiṇām plānošanā jāṇem vērā visas klimata pārmaiṇu ietekmes, t.sk. temperatūras paaugstināšanas, jūras ūdens līmeņa celšanās, nokrišņu (gan lietus, gan sniega) režīma maiṇas, biežākas un spēcīgākas vētras, biežāki un plašāki plūdi, sausuma periodi u.tml. Pielāgošanās klimata pārmaiṇām nozīmē klimata pārmaiṇu radīto risku pārvaldību. 


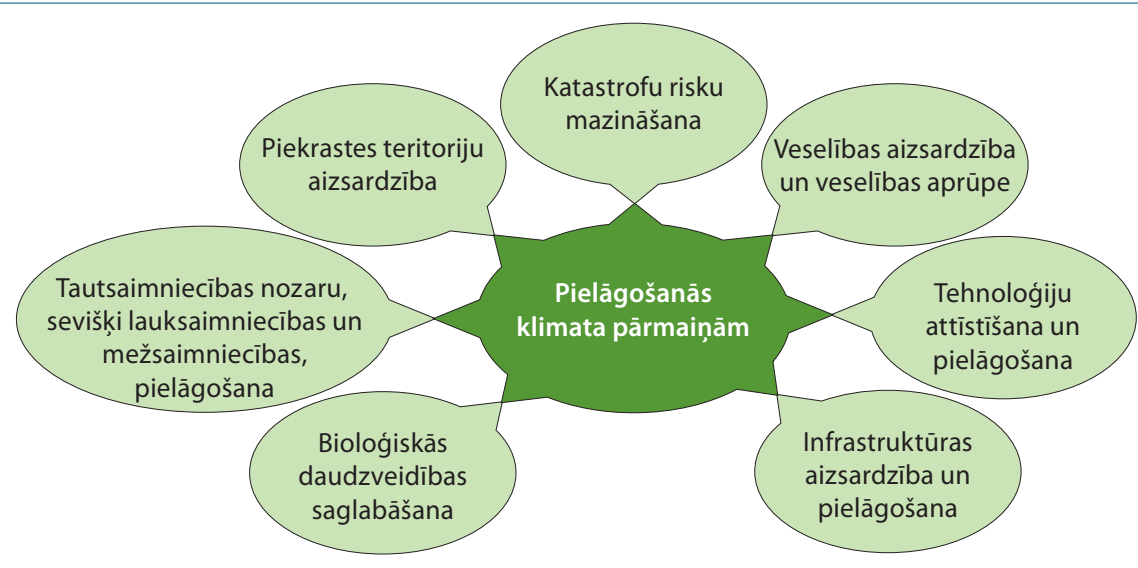

11.2. att. Pielāgošanās klimata pārmaiṇām galvenie virzieni.

\subsection{Klimata politikas instrumenti}

Klimata politikas mērḳu sasniegšanai galvenokārt izmanto tos pašus instrumentus, ko vides aizsardzības mērḳu sasniegšanai, proti, ekonomiskos, fiskālos un finanšu instrumentus. Tomēr klimata politikai raksturīgs tas, ka vairums instrumentu ir citu nozaru pārzin̄ā, un klimata politikas mērksu sasniegšanai tie nevis tiek radīti no jauna, bet gan pielāgoti klimata politikas vajadzībām. Klimata politikas veiksmīgai īstenošanai tādējādi sevišksi svarīga ir dažādu nozaru politiku saskan,otība.

Klimata politikas īstenošana ir balstīta uz zinātni un pētniecību, SEG inventarizāciju (SEG apjomu pagātnē precīzu aprēksināšanu un uzskaiti) un prognozēšanu, kā arī dažādu klimata politikas pasākumu uzraudzību un kontroli. Būtiskākos klimata politikas pasākumus var iedalīt četrās grupās - izglītošana un informēšana, likumdošanas nosacījumi, oglekḷa cenas iekḷaušanas instrumenti (oglekḷa cenošana) un finansiālā atbalsta nodrošināšanas instrumenti (sk. 11.3. att.).

N,emot vērā to, ka klimata politikas mērku sasniegšana ir saistīta ar sabiedrības ieradumu maiṇu, nepieciešams izglītot un regulāri informēt gan atsevišksas mērksauditorijas, gan sabiedrību kopumā. Tāpat būtiski klimata politikas interesēs izmantot iespēju likumdošanā noteikt īpašus nosacījumus, piemēram, noteiktus standartus un prasības, tiesības vai aizliegumus, specifiskus nodokḷu un nodevu nosacījumus. Pozitīvu ietekmi rada "zaļais" publiskais iepirkums (green public procurement), vides pārvaldības sistēmu ieviešana u.tml. Neatñemama klimata politikas sastāvdalı ir arī finansiāāā atbalsta nodrošināšana noteiktu pasākumu ieviešanas veicināšanai, t.sk. dotācijas (granti), subsīdijas un aizdevumi. Tomēr populārākie instrumenti klimata politikas mērksa sasniegšanai ir tie, kas nodrošina SEG emisiju izmaksu n,emšanu vērā jeb oglekḷa cenas iekḷaušanu (carbon pricing) produktu un pakalpojumu cenās, proti, ațauju tirdzniecības sistēmas, kā arī nodokḷi atkarībā no radītā SEG emisiju apjoma.

Nodoklis ir tradicionāls politikas instruments daudzuma ierobežošanai vai resursu pārdalei. Tas ir ar likumu noteikts obligāts maksājums valsts vai pašvaldību budžetā. Mūsdienās nereti piemēro nodokḷus, kuru bāze ir SEG emisiju apjoms, proti, jo vairāk SEG emisiju, jo lielāks nodokḷa maksājums. Taču klimata politikas mērksu sasniegšanas nodrošināšanai var pielāgot arī esošos nodokḷus - diferencējot nodokḷu likmes un apliekamos objektus vai arī mainot nodokḷu struktūru, piemēram, palielinot patēriņa nodoklu īpatsvaru vai palielinot vides vai klimata nodokḷu ippatsvaru. 
Aț̣auju tirdzniecības mērksis ir sasniegt atbilstību stingriem vides standartiem, tajā pašā laikā nodrošinot atbilstības sasniegšanas izmaksu samazināšanos un veicinot daudz stingrāku standartu pieñemšanu. Atḷauju tirdzniecības instrumenta būtiskākie elementi ir tirgojamas atlıaujas, ațlauju tirgus dalībnieki un ațauju reǵistri. Savukārt no šo trīs elementu mijiedarbības veidojas atl̦auju tirdzniecības instrumenta pamats - tirgus. Trīs galvenie ațauju tirdzniecības sistēmu veidi ir kredītu tirdzniecība, viduvējotā tirdzniecība un "ierobežojumu un tirgus" jeb "cepures un tirgus" (cap and trade) sistēma, kas ir visplašāk pazīstamā un visvairāk izmantotā aț̣auju tirdzniecības sistēma. "Ierobežojumu un tirgus" sistēma paredz ierobežojumu jeb "cepures" noteikšanu, kā arī tirdzniecību "cepures" ietvaros (sk. 11.4. att.).

Būtiskākā "ierobežojumu un tirgus" sistēmas atškirība no tādiem tradicionāliem daudzuma

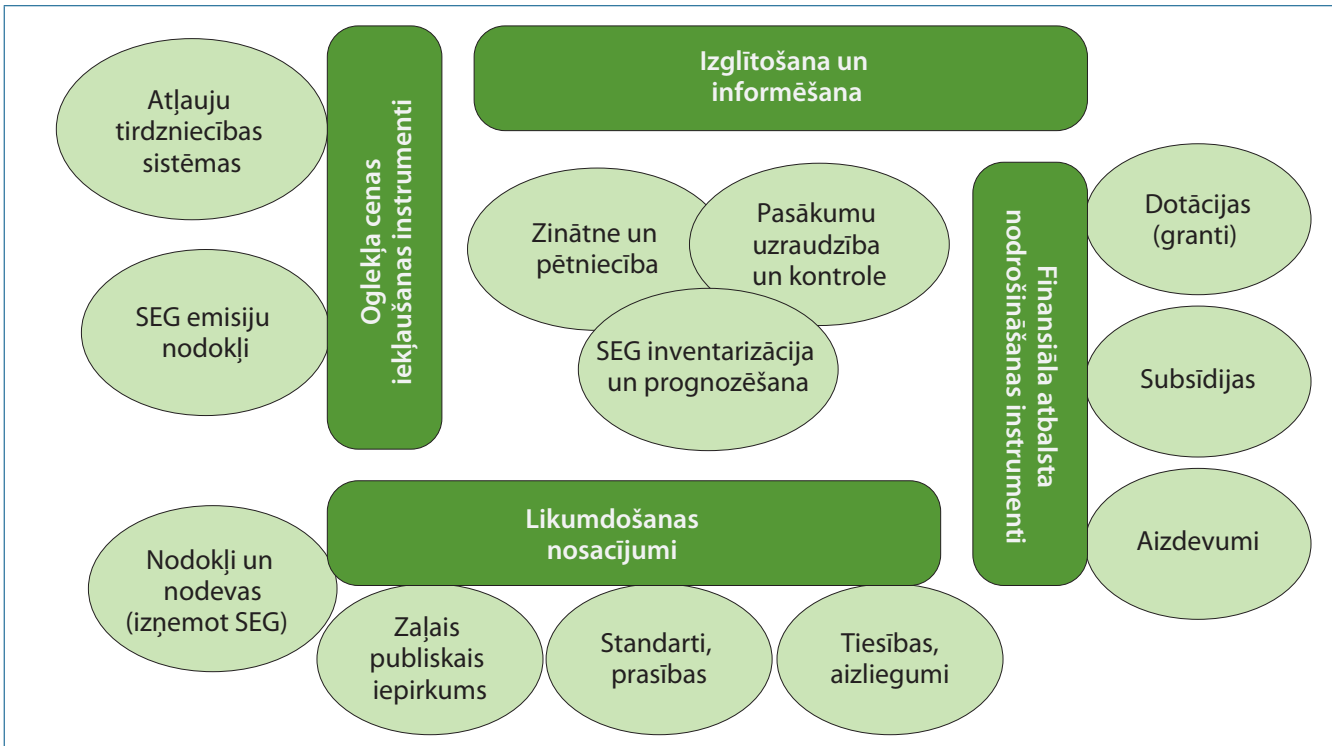

11.3. att. Klimata politikas būtiskākie instrumenti.

1. situācija (tirdzniecības perioda ietvaros)

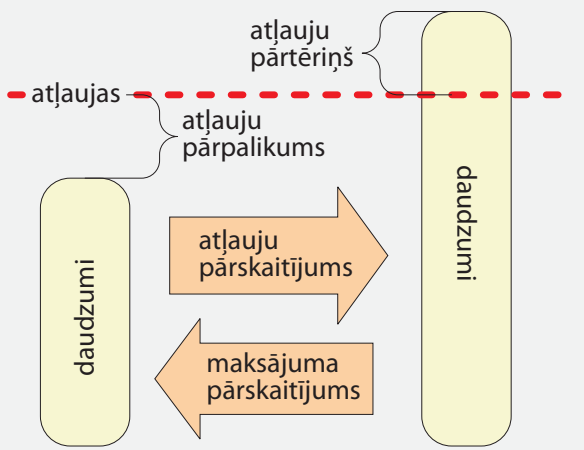

Aț̣auju pārdevējs
Atḷauju pircējs
2. situācija (tirdzniecības perioda beigās)

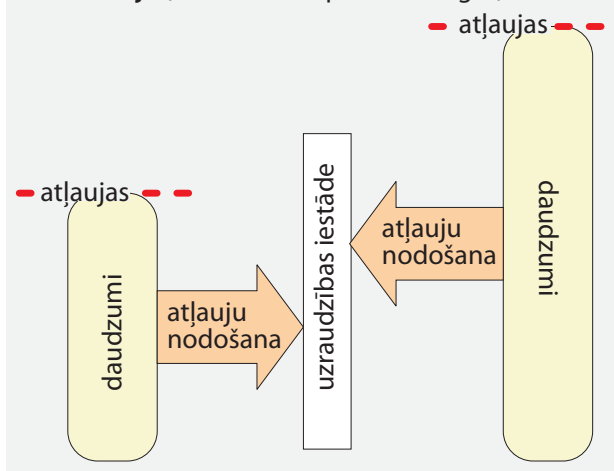

Aț̣auju pārdevējs

11.4. att. Aț̣auju tirgus darbības mehānisms "ierobežojumu un tirgus" sistēmas gadījumā. 
racionalizēšanas instrumentiem kā, piemēram, nodoklı̣, ir tā, ka "ierobežojumu un tirgus" sistēma paredz ne tikai kategoriskus ierobežojumus, bet arī instrumentu, lai tajos iekḷautos, un rada iespējas gūt papildu labumu.

Atl̦auju tirdzniecības sistēmas darbības galvenie posmi:

1) aț̦auju tirgus darbības nosacījumu izraudzī̌sana un apstiprināšana;

2) atḷauju sākotnējā sadalǐšana starp aț̣auju tirgus tiešajiem dalībniekiem;

3) atlıuju tirgus darbība;

4) atḷauju tirgus darbības periodiska pārskatīšana.

Atḷauju sākotnējo sadalīšanu starp atḷauju tirgus tiešajiem dalībniekiem var īstenot divējādi: atlıaujas var piešksirt bez maksas vai arī pārdot vairāksolīšanā (izsolīšana). Atḷauju tirdzniecības sistēmas var izveidot gan starptautiskā, gan starpvalstu, gan nacionālā un pat reǵionālā mērogā. Būtiskākie nosacījumi aț̣auju tirdzniecības sistēmas efektivitātes nodrošināšanai ir šādi:

- optimāls aț̦auju kopējais daudzums,

- tirgum piemērots un iespējami taisnīgs aț̣auju sākotnējās sadales mehānisms,
- atl̦auju pārskaitījumu iespējami zemas izmaksas,

- optimāls terminšs atl̦auju derīgumam,

- ieñēmumu no ațiauju pārdošanas atstāšana tirgus dalībniekiem,

- atl̦auju tirgus dalībnieku kompetence un "pareiza" motivācija,

- atlıaju tirgus vispusīga un progresīva uzraudzība, kontrole.

SEG emisiju aț̣auju tirdzniecības sistēmu attīstīšana aizsākās 20. gadsimta beigās, redzot veiksmīgo pieredzi ațauju tirdzniecības sistēmu izmantošanā citās jomās - seviškci gaisu piesārṇojošo vielu emisiju ierobežošanā. Pirmā SEG emisiju aț̣auju tirdzniecības sistēma darbību sāka 2000. gadā - tā bija Dānijas $\mathrm{CO}_{2}$ emisiju tirdzniecības sistēma, kas darbību pārtrauca 2004. gadā. Savukārt šobrīd aktīvākās un lielākās šajā jomā ir Eiropas Savienības Emisijas kvotu tirdzniecības sistēma, Reǵionālā Siltumnīcefekta Gāzu Iniciatīva un Starptautiskā emisiju tirdzniecība. SEG emisiju aț̣auju tirdzniecības sistēmu galvenā kopīgā iezīme ir fakts, ka tajās visās 1 atḷauja apzīmē 1 tonnu SEG emisijas, kas izteiktas oglekḷa dioksīda ekvivalentos $\left(\mathrm{CO}_{2 \mathrm{e}}\right)$.

\subsection{Starptautiskā klimata politika}

Klimata pārmaiṇu jautājums ievērību ieguva līdz ar Pasaules Meteoroloǵijas organizācijas (World Meteorological Organisation, WMO) un Apvienoto Nāciju Organizācijas (ANO) Vides programmas (United Nations Environment Programme, UNEP) darbības sākumu. 1979. gadā Pasaules Meteorologijas organizācija organizēja pirmo pasaules klimata konferenci. Tajā secināja, ka pieaugošā $\mathrm{CO}_{2}$ koncentrācija atmosfērā, iespējams, veicina globālo sasilšanu. 1988. gadā, lai turpmāk apkopotu un izvērtētu visas ar klimata pārmain̄ām saistītās liecības, Pasaules Meteorologijas organizācija ar ANO Vides programmas atbalstu izveidoja Klimata pārmaiṇu starpvaldību komisiju (Intergovernmental Panel on Climate Change, IPCC). 1990. gadā pirmajā šīs komisijas ziņojumā tika secināts, ka 20. gs. laikā gada globālā vidējā atmosfēras temperatūra ir paaugstinājusies par $0,3-0,6^{\circ} \mathrm{C}$ un ka cilvēku rīcība ir pastiprinājusi dabisko siltumnīcefektu.

1992. gadā Riodežaneiro ANO konferencē "Vide un attīstība" vienojās par ANO Vispārējo konvenciju par klimata pārmain̄ām (United Nations Framework Convention on Climate Change, UNFCCC) (turpmāk - Konvencija). Šì Konvencija ir pirmais starptautiskais līgums cīṇai pret klimata pārmaiṇām. Tā stājās spēkā 1994. gada 21. martā, un līdz šim to ir ratificējušas 196 Puses $^{1}$, t.sk. Eiropas Savienība (ES)

\footnotetext{
1 "Puse" apzīmē valstis un reǵionālās organizācijas, kas ir parakstījušas konkrēto dokumentu, piemēram, Konvenciju.
} 
un visas tās dalībvalstis, Amerikas Savienotās Valstis un Kanāda.

Konvencijas mērķis ir SEG koncentrācijas stabilizācija atmosfērā tādā līmenī, kas novērš bīstamu antropogēnu iejaukšanos klimata sistēmā. Konvencija nosaka, ka attīstītajām valstīm (I pielikums) ir jāvada SEG samazināšanas process un ka tām ir ne vien jāsamazina SEG emisijas, bet arī jānodrošina finansējums un tehnoloǵiju pārnese uz attīstības valstīm. Konvencija nosaka pamatprasības SEG uzskaitei. Konvencijā noteikti starptautiskās klimata politikas principi.

- Taisnīguma (equity) un vienotas, bet dažādotas atbildības (common but differentiated responsibilities, $C B D R$ ) princips - atspogul̦o SEG emisiju un resursu atšksirīgo sadalījumu starp valstīm pagātnē un tagadnē. Dažādošanas jeb diferenciācijas (differentiation) tiešs apliecinājums ir Konvencijas I pielikums. I pielikumā noteiktas valstis, kurām ir pienākumi (t.s. I pielikuma valstis), bet pārējām valstīm (t.s. ne-I pielikuma valstis) būtisku pienākumu nav. Valstu bināro dalījumu neformāli sauc par robežmūri (firewall). Dažādošana ir pamats arī Konvencijas II pielikuma esamībai, kurā iekḷautas visas I pielikuma valstis, iznemot valstis ar pārejas ekonomiku. II pielikuma valstīm, atškkirībā no I pielikuma valstīm, nav pienākuma nodrošināt finansējumu un tehnologiju pārnesi ne-I pielikuma valstīm. Papildus, dažādošana vērojama arī ne-I pielikuma valstu vidū - dal̦a valstu atpazīstamas kā vismazāk attīstītās valstis (least developed countries, $L D C s$ ), atseviški izdalītas pret klimata pārmaiṇām visjutīgākās valstis (most vulnerable countries) u.tml. Pret katru no valstu grupām izturēšanās ir nedaudz atšksirīga.

- Piesardzīguma princips (precautionary principle) - līdzīgi, kā tas noteikts vides aizsardzības starptautiskajos un nacionālajos tiesību aktos, arī klimata politikā, ja pastāv nopietna un neatgriezeniska kaitējuma draudi, pierādījumu trūkums nav attaisnojums draudu novēršanai.

- Izmaksu efektivitātes (cost-effectiveness) princips - Konvencijas mērķu sasniegšana nedrīkst radīt nevajadzīgu slogu ekonomikai. Viens no izmaksu samazināšanas veidiem ir pasākumu kopīga ieviešana.

1997. gadā Konvencija tika papildināta ar Kioto protokolu (turpmāk - Kioto protokols), jo tika konstatēts, ka Konvencijas nosacījumi nav pietiekami. Kioto protokols stājās spēkā 2005. gadā. Tajā noteikti starptautiski saistoši pienākumi 39 valstīm (t.s. B pielikuma valstis) no 2008. līdz 2012. gadam (Kioto protokola 1. periods) noteiktā apmērā samazināt SEG emisijas. Kioto protokolu ir ratificējušas $192 \mathrm{Pu}$ ses, taču Amerikas Savienotās Valstis un Kanāda, kurām Kioto protokolā ir noteiktas saistības, tomēr nav tā Puses (Amerikas Savienotās Valstis Kioto protokolu neratificēja, bet Kanāda izstājās no tā). Nuemot vērā to, ka Kopenhāgenā 2009. gadā valstīm neizdevās vienoties par Kioto protokola aizstājēju, 2012. gadā Dohā valstis vienojās par Kioto protokola grozījumu (t.s. Dohas grozijjums) un pagarināja Kioto protokola darbību ar 2. periodu - no 2013. līdz 2020. gadam. Dohas grozījumu līdz 2015. gada 18. novembrim bija ratificējušas tikai 50 Puses, un kamēr to nebūs ratificējušas vismaz 144 Puses, tas nestāsies spēkā.

Kioto protokola 2. periodā saistības SEG emisiju samazināšanai paredzētas tikai ES dalībvalstīm, Austrālijai, Baltkrievijai, Kazahstānai, Monako, Norvēǵijai, Šveicei un Ukrainai. Kioto protokola 2. periods nosedz vien $14 \%$ no globālajām SEG emisijām. Kioto protokola 2. perioda galvenais uzdevums faktiski ir nodrošināt Kioto protokola nepārtrauktību līdz mirklim, kad spēkā stāsies vienošanās par visaptverošu rīcību Konvencijas mērķu sasniegšanai.

N̦emot vērā to, ka Kioto protokols nebija spējīgs nodrošināt Konvencijas mērḳa sasniegšanu (nepietiekams dalībnieku skaits un nepietiekams saistību apmērs), 2015. gada 12. decembrī visas pasaules valstis vienojās par Kioto protokola aizstājēju laikam pēc 2020. gada tika apstiprināts Parīzes nolīgums (Paris Agreement). Parīzes nolīguma mērksis ir stiprināt globālo rīcību klimata pārmaiṇu novēršanai un:

- noturēt globālās vidējās temperatūras paaugstinājumu būtiski zem $2{ }^{\circ} \mathrm{C}$ robežām salīdzinājumā ar pirmsindustriālo 
līmeni, un censties ierobežot temperatūras paaugstinājumu $1,5^{\circ} \mathrm{C}$ robežās salīdzinājumā ar pirmsindustriālo līmeni, jo tas būtiski samazinās klimata pārmain,u izraisītos riskus un ietekmes;

- uzlabot spējas pielāgoties klimata pārmainu negatīvajām ietekmēm un sekmēt noturīgumu pret klimata pārmaiṇām un oglekḷa mazietilpīgu attīstību tā, lai neapdraudētu pārtikas ražošanu;

- sekmēt investīciju novirzī̌šnu oglekl̦a mazietilpīgai un pret klimata pārmaiñām noturīgai attīstībai.

Parīzes nolīgums prasa visām valstīm regulāri uzn,emties un starptautiski iesniegt ambiciozas apṇemšanās Parīzes nolīguma mērksa sasniegšanai. Attīstītajām valstīm jāturpina rādīt priekšzīme, uzṇemoties SEG emisiju samazināšanas mērķus, taču pasākumi jāīsteno ne vien attīstītajām, bet arī attīstības valstīm. Parīzes nolīgumā arī iekḷauta prasība pēc iespējas ātrāk sasniegt un pārvarēt SEG emisiju maksimumu un 21. gadsimta otrajā pusē nodrošināt līdzsvaru starp SEG emisijām un $\mathrm{CO}_{2}$ piesaisti.

Pirmās nacionāli noteiktās apṇemšanās (nationally determined contribution, NDC) valstīm jāiesniedz ne vēlāk kā līdz Parīzes nolīguma ratifikācijai. Līdz 2016. gada 1. martam iecerētās nacionāli noteiktās apṇemšanās (intended nationally determined contribution, INDC) bija iesniegušas 188 valstis (t.sk. ES un tās 28 dalībvalstis), un tās aptvēra vairāk nekā 98\% no pasaules SEG emisijām. Ja vien šīs valstis nelems savādāk, to iecerētās nacionāli noteiktās apṇemšanās būs arī to pirmās faktiski īstenojamās nacionāli noteiktās apṇemšanās. Savukārt turpmāk nacionāli noteikto apṇemšanos aktualizēšana būs jāveic katrus 5 gadus, un katrai nākamajai nacionāli noteiktajai apñemšanās, saskaṇā ar Parīzes nolīgumu, būs jābūt ambiciozākai nekā iepriekšējai. Apn,emšanos izpildi kontrolēs ar vienotas SEG emisiju inventarizācijas sistēmas palīdzību un starptautisku atbilstības mehānismu.

Parīzes nolīgums nosaka arī globālo mērķi pielāgošanās un noturīguma pret klimata pārmaiṇām jomā. Tiek atzīts, ka pielāgošanās ir globāls izaicinājums, ar ko sastopas visi un kam ir vietējas, regionālas, nacionālas, starpvalstu un starptautiska mēroga dimensijas. Visām valstīm tiek prasīts iesaistīties pielāgošanās pasākumu plānošanā un ieviešanā. Katrai valstij regulāri starptautiski jāziṇo par paveikto un plānoto.

Parīzes nolīgums stāsies spēkā pēc tam, kad to būs ratificējušas vismaz 55 valstis un šo valstu kopējās SEG emisijas būs vismaz 55\% no pasaules kopējām SEG emisijām. Parīzes nolīgums ietver visu nepieciešamo, lai panāktu globālu pāreju uz oglekḷa mazietilpīgu un pret klimata pārmaiṇām noturīgu attīstību un sasniegtu visus klimata politikas mērķus.

\subsubsection{Starptautisko klimata sarunu dinamika}

Starptautiskās klimata sarunas notiek vairākās sarunu plūsmās un formātos. Lēmumus pieñem ikgadējās Klimata pārmain,u konferencēs, kurās tiekas Konvencijas Puses (COP), Kioto protokola Puses (CMP), un turpmāk tiksies arī Parīzes nolīguma Puses (CMA). Savukārt lēmumu sagatavošana notiek Paklıutajā izpildinstitūcijā (SBI), Zinātnes un tehnologiiju konsultatīvajā padomē (SBSTA), kā arī citās īpašiem mērksiem izveidotās plūsmās, piemēram, Īpašās darba grupas par Durbanas Paplašināto rīcības platformu $(A D P)$ uzdevums bija sagatavot Parīzes nolīguma teksta projektu.

Lēmumu pieṇemšana Klimata pārmaiṇu konferencēs notiek ar vienprātību, kas, n,emot vērā lielo Pušu skaitu (COP 196 un CMP 192), ir lıti sarežǵītu un niansētu sarunu (pārsvarā daudzu gadu) rezultāts. N,emot vērā ANO tradīcijas, visas valstis iedalītas 5 reǵionālās grupās (Āfrikas valstis, Āzijas valstis, Austrumeiropas valsis, Latīnamerikas un Karību valstis (GRULAC), Rietumeiropas un pārējās valstis (WEOG)). Taču sarunās vislielākā nozīme ir valstu grupām, kas izveidojušās, n,emot vērā valstu līdzīgās intereses.

- G77 - attīstības valstu grupa, kurā ietilpst 134 valstis, t.sk. daudzu citu attīstības valstu grupu dalībnieki (arī Ķīna, Indija, Dienvidāfrika). Grupai sarunās ir l̦oti liela 
ietekme, taču nereti dalībnieku atšksirīgo viedokḷu tā dēḷ nespēj vienoties par vienotu nostāju. Īpaši aizstāv "robežmūra" uzturēšanu, pieprasa attīstīto valstu līderību un aktīvu rīcību.

- Vismazāk attīstītās valstis (Least developed countries, LDC) - attīstības valstu grupa, kurā ietilpst 50 valstis (vairums no Āfrikas), kas ANO atzītas par visnabadzīgākajām. Vēlas, lai tiktu n,emtas vērā to īpašās vajadzības un ierobežotās iespējas. L̦oti interesējas par pielāgošanos klimata pārmaiṇām.

- Līdzīgi domājošās attīstības valstis (Like minded developing countries, LMDC) - attīstības valstu grupa, kurā ietilpst aptuveni 30 sevišksi aktīvas attīstības valstis (t.sk. Ķīna, Indija, Saūda Arābija). Ĺoti asi aizstāv "robežmūra" saglabāšanu un stiprināšanu.

- Mazo salu valstu alianse (Alliance of Small Island States, AOSIS) - attīstības valstu grupa, kurā ietilpst 43 nelielas un virs jūras līmen,a zemu izvietotas salu valstis. Vēlas globālās temperatūras iespējami ātru stabilizāciju (paaugstināšanās nevis $<2{ }^{\circ} \mathrm{C}$, bet gan $<1,5^{\circ} \mathrm{C}$ ) un uzstāj, ka pielāgošanās klimata pārmaiñām jābūt prioritāram virzienam.

- Āfrikas grupa (African group, AG) - attīstības valstu grupa, kurā ietilpst 54 Āfrikas valstis. Uzstājīgi prasa attīstīto valstu rīcību SEG samazināšanā un atbalsta sniegšanā attīstības valstīm.

- Amerikas cilvēku Bolivārā alianse (Bolivarian Alliance for the Peoples of Our America, ALBA) - attīstības valstu grupa, kurā ietilpst 9 sevišksi kategoriskas valstis (t.sk. Venecuēla, Bolīvija, Kuba un Ekvadora), kas nepiekāpīgi aizstāv savas, kā attīstības valstu, intereses.

- BASIC - grupa, kurā ietilpst 4 lielas attīstības valstis ar vidējām vai augstām SEG/iedz., t.i. Brazīlija, Dienvidāfrika, Indija un Kīna. Aizstāv to, ka galvenā atbildība ir attīstītajām valstīm.

- Naftas eksportētājvalstu grupa (Organisation of Petroleum Exporting Communities, OPEC) - attīstības valstu grupa, kurā ietilpst 12 naftas eksportētājvalstis. Iespēju robežās cenšas bloḳēt SEG emisiju samazināšanas iniciatīvas.
- Centrālāzijas un Kaukāza, Albānijas un Moldovas grupa (CACAM) - attīstības valstu grupa, kurā ietilpst 7 valstis no Centrālāzijas un Kaukāza regiona, kā arī Albānija un Moldova.

- Lietusmežu valstu alianse (Coalition of $R a$ inforest Nations, (fRN) - attīstības valstu grupa, kurā ietilpst valstis ar plašām lietusmežu teritorijām. Vēlas panākt kompensācijas par mežu saglabāšanu un atjaunošanu.

- Centrālamerikas integrācijas sistēma (Central American Integration System, SICA) attīstības valstu grupa, kurā ietilpst 8 valstis. Vēlas panākt pret klimata pārmaiṇām visjutīgāko valstu plašāku atzīšanu.

- Latīnamerikas un Karību alianse (Alliance of Latin America and the Caribbean, AILAC) attīstības valstu grupa, kurā ietilpst 7 progresīvas Latīnamerikas un Karību reǵiona valstis, t.sk. Čìle, Gvatemala, Kolumbija, Kostarika, Panama, Paragvaja un Peru. Saredz nepieciešamību pēc attīstības valstu lomas maiṇas un attīstīto valstu iesaistī̌̌anās klimata pārmainu problēmas risināšanā.

- Eiropas Savienība, ES (European Union, EU) - attīstīto valstu grupa, kurā ietilpst visas 28 ES dalībvalstis, kā arī pati ES, ko pārstāv ES Padomes prezidējošā valsts un Eiropas Komisija. Vēlas panākt klimata pārmaiṇu novēršanu, nodrošinot visu valstu iesaisti. Cenšas būt kompromisu veidotāji domstarpību gadijjumos.

- "Lietussarga" grupa (Umbrella Group, UG) attīstīto valstu un pārejas ekonomikas valstu grupa, kurā ietilpst Austrālija, Kanāda, Islande, Japāna, Jaunzēlande, Norvēǵija, Krievija, Ukraina un ASV. Iestājas par to, ka turpmāk nevar pastāvēt strikts dalījums starp I pielikuma un ne-I pielikuma valstīm.

- Vides integritātes grupa (Environmental Integrity Group, EIG) - attīstīto valstu grupa, kurā ietilpst Meksika, Korejas Republika un Šveice. Loti aktīva un dzirdama grupa, kuras intereses līdzīgas kā ES un "Lietussarga" grupai.

N̦emot vērā attīstības valstu skaitlisko pārsvaru pār attīstītām valstīm, vairums sarunu grupu ir attīstības valstu grupas. ES līdzīgi domājošas ir "Lietussarga" grupa un Vides 
integritātes grupa. Daudzos jautājumos ES kopīgi strādā arī ar Latīnamerikas un Karību aliansi, Mazo salu valstu aliansi un Vismazāk attīstītajām valstīm, tomēr jāatceras, ka vienošanās panākšanai nepieciešama 195 valstu vienprātība, un tādējādi ES sadarbojas ar pilnīgi visām valstu grupām un valstīm.

\subsubsection{Kioto protokola elastīgie mehānismi}

Lai Kioto protokolā noteiktos SEG emisiju samazināšanas mērksus sasniegtu izmaksu efektīvā veidā, Kioto protokolā noteikti trīs elastīgie mehānismi (flexible mechanisms):

- Tīras attīstības mehānisms (Clean Development Mechanism, CDM);

- Kopīgās īstenošanas mehānisms Uoint Implementation, JI);

- Starptautiskā emisiju tirdzniecība (International Emissions Trading, IET).

Tīras attīstības mehānisms ir SEG emisijas samazinošu projektu īstenošana valstīs, kas nav ieklıutas Kioto protokola B pielikumā, proti, projektu īstenošana attīstības valstīs. Tìras attīstības mehānisma projektu rezultātā par katru samazināto SEG emisiju tonnu piešksir sertificētu emisiju samazināšanas vienību (certified emission reduction, CER). Valstīm, kurās īsteno šos projektus, ieguvums ir investīcijas un tehnologijas, bet investoru ieguvums ir Starptautiskajā emisiju tirdzniecībā un citās SEG emisiju aț̣auju tirdzniecības sistēmās izmantojams aktīvs - sertificētas emisiju samazināšanas vienības.

Kopīgās īstenošanas mehānisms ir SEG emisijas samazinošu projektu īstenošana valstīs, kas ir ieklautas Kioto protokola B pielikumā, proti, projektu īstenošana attīstītajās valstīs, kuras ir izpildījušas visus Kioto protokola nosacījumus. Kopīgās īstenošanas mehānisma projektu rezultātā par katru samazināto SEG emisiju tonnu piešksir emisijas samazināšanas vienību (emission reduction unit, ERU). Valstīm, kurās īsteno šos projektus, kā arī investoriem ieguvumi ir līdzīgi kā tīras attīstības mehānisma gadījumā.
Starptautiskā emisiju tirdzniecība ir starptautiska "ierobežojumu un tirgus" veida atl̦auju tirdzniecības sistēma, kuras mērksis ir veicināt Kioto protokolā noteikto SEG emisijas samazināšanas mērḳu izpildi. Starptautiskās emisiju tirdzniecības darbība ir strukturēta atbilstoši Kioto protokola periodiem (1. periods bija 2008.-2012. gads, 2. periods ir 2013.2020. gads). Papildus, pēc katra Kioto protokola perioda beigām ir vēl aptuveni 2 gadus ilgs kopējo emisiju aprēksināšanas un emisijas vienību nodošanas periods, t.s. "True-up period".

Starptautiskās emisiju tirdzniecības ietvaros galvenā tirgojamā ațauja ir noteiktā daudzuma vienība, NDV (assigned amount unit, AAU). Kopējais NDV daudzums atbilst Kioto protokola B pielikuma valstu kopējam SEG emisiju daudzumam, nemot vērā Kioto protokolā tām noteiktās SEG emisiju samazināšanas saistības. $1 \mathrm{NDV}$ atbilst 1 tonnai $\mathrm{CO}_{2 \mathrm{e}}$. Taču, lai gan šādu dalījumu neparedz nedz Kioto protokols, nedz kāds cits tiesību akts, praksē tiek izdalīti divi NDV pamatveidi:

- "zalıumota" NDV (greened AAU), t.sk. "tieši zalumota" NDV (hard-greened $A A U$ ) un "netieši zalımota" NDV (soft-greened $A A U$ );

- "nezalımota" NDV (non-greened $A A U$ jeb hot air).

Jēdziens "zalımota" NDV apzīmē vienību, kuras pārdošanā iegūtais finansējums izmantots tādu projektu finansēšanai, kas nodrošina SEG emisiju samazināšanu. "Tieši zal̦umotas" NDV pamatā ir projekti, kas nodrošina SEG emisiju samazināšanu tiešā veidā, piemēram, atjaunojamo energoresursu izmantošanas veicināšana vai arī energoefektivitātes pasākumu īstenošana. "Netieši zal̦umotas" NDV pamatā ir projekti, kas nodrošina SEG emisiju samazināšanu netiešā veidā, piemēram, SEG emisijas samazinošu tehnoloğiju attīstǐšana (pētniecība), sabiedrības izglītošana par klimata pārmainu novēršanas iespējām u.tml. Savukārt jēdziens "nezalıumota" NDV apzīmē vienību, kuras pārdošanā iegūtais finansējums izmantots jebkuriem citiem mērķiem, izn,emot SEG emisiju samazināšanu. "Zalıumošanas" nolūkā valstis veido t.s. "zal̦ās investēšanas sistēmas" (green investment scheme, GIS). 
Starptautiskās emisiju tirdzniecības ietvaros, papildus NDV, var izmantot vēl trīs citus vienību veidus - iepriekš pieminētās sertificētās emisijas samazināšanas vienības un emisijas samazināšanas vienības, kā arī piesaistes vienības (removal unit, RMU), ko saskañā ar Kioto protokolu piešksir par SEG emisijas piesaisti. Katra no šīm vienībām, tāpat kā NDV, atbilst 1 tonnai $\mathrm{CO}_{2 \mathrm{e}}$ un līdz ar to pēc būtības ir aizstājama.

Starptautiskās emisiju tirdzniecības primārie dalībnieki ir Kioto protokola B pielikuma valstu valdības, kas ir ratificējušas Kioto protokolu un ir izpildījušas Kioto protokolā noteiktos atbilstības nosacìjumus.

Starptautiskās emisiju tirdzniecības darbības nodrošināšanai izmanto emisijas vienību registru sistēmu, kurus savstarpēji sasaista Starptautiskais Darījumu Žurnāls (International Transaction Log, ITL). Tas reālajā laikā pārbauda katras vienības pārskaitījuma atbilstību Konvencijas un Kioto protokola nosacījumiem. Savukārt ES ietvaros izmanto arī Kopienas Neatkarīgo Darījumu Žurnālu (Community Independent Transaction Log, CITL), kura funkcijas 2012. gada vidū pārṇēma Eiropas Savienības Darījumu Žurnāls (European Union Transaction Log, EUTL). Sertificētās emisijas samazinājuma vienības izdod Tīras attīstības mehānisma registra (CDM registry) ietvaros.

N,emot vērā faktu, ka divas no potenciāli būtiskākajām Starptautiskās emisiju tirdzniecības dalībniecēm - Amerikas Savienotas Valstis un Kanāda - tajā nav iesaistījusies, NDV tirgū pastāv nesabalansēts pieprasījums un piedāvājums. NDV ir l̦oti nelikvīdas, un Starptautiskās emisiju tirdzniecības darbība neatbilst "ierobežojumu un tirgus" sistēmas efektīvas funkcionēšanas pamatnosacījumiem. Starptautiskās emisiju tirdzniecības tirgū nosacījumus diktē NDV pircēji. Pirmie darījumi NDV tirgū notika 2008. gada otrajā pusē. Savukārt kopš 2014. gada darījumi ar NDV nav konstatēti.

NDV cenu darījumu partneri publiski neatklāj, taču neoficiālā informācija (Point Carbon ziñas un Pasaules Bankas apsekojumu dati) liecina, ka 2008.-2009. gadā NDV cena bijusi vidēji 10 EUR līmenī. 2010. gadā, pieaugot NDV piedāvājumam, NDV cena samazinājusies līdz 5-7 EUR. Savukārt 2011.-2012. gadā, padzilinoties ES valstu ekonomiskajām un finanšu problēmām un samazinoties ražošanas apjomiem, kā rezultātā samazinājās SEG emisijas, NDV cena nokritusies līdz 1-3 EUR un vēlāk pat līdz 0 EUR.

\subsection{Eiropas Savienības klimata politika}

ES ir pasaules līderis klimata politikas veidošanā un ieviešanā. ES emisiju pieaugums ir atsaistīts no ES iekšzemes kopprodukta (IKP) pieauguma. 1990-2014. gadā IKP palielinājās par $46 \%$, bet SEG emisiju intensitāte samazinājās par apmēram pusi. 2012. gadā ES radīja vien 9\% no pasaules kopējām SEG emisijām, turklāt ES emisiju īpatsvars pasaulē turpina samazināties.

ES ir ratificējusi Kioto protokolu kā reǵionāla organizācija (papildus tam, ka Kioto protokolu ir ratificējušas ES dalībvalstis). ES ir noteikti SEG emisiju samazināšanas mērksi - 1 . periodā $8 \%$ samazinājums un 2. periodā $20 \%$ samazinājums salīdzinājumā ar 1990. gadu. ES ir izpildījusi 1. perioda mērksi un visticamāk izpildīs arī 2. perioda mērḳi (2015. gadā aktuālās prognozes liecināja, ka 2020. gadā ES būs sasniegusi $24 \%$ samazinājumu). Lai nodrošinātu SEG emisiju samazināšanas mērk̦a izpildi, ES ievieš mērkstiecīgu klimata politiku. Tā vērsta uz oglekḷa mazietilpīgu un pret klimata pārmaiñām noturīgu attīstību, un tās galvenais instruments ir SEG emisiju ațauju tirdzniecība.

\subsubsection{Eiropas Savienības virzïba uz ogleklı mazietilpigu attīstību}

ES klimata politika ir balstīta uz 2008. gadā apstiprināto Eiropas Klimata un energétikas pakotni 2020. gadam (turpmāk - KEP2020) un 2014. gadā apstiprināto 
Eiropas Klimata un energètikas politikas satvaru 2030. gadam (turpmāk - KEPS2030). Savukārt ES ilgtermiṇa vīzija (nesaistoša) ir noteikta 2011. gadā pien,emtajā Celvvedī virzībai uz konkurētspējīgu ekonomiku ar zemu oglekḷa dioksīda emisiju līmeni 2050. gadā, ko papildina 2011. gadā pieñemtā Baltā grāmata "Celvedis uz Eiropas vienoto transporta telpu - virzība uz konkurētspējīgu un resursefektīvu transporta sistēmu".

Celvedis virzībai uz konkurētspējīgu ekonomiku ar zemu oglekḷa dioksīda emisiju līmeni 2050. gadā paredz, ka ES līdz 2050. gadam SEG emisijas jāsamazina par vismaz 80\% salīdzinājumā ar 1990. gadu. Celvedī noteiktie indikatīvie starpmērķi, proti, 20\% samazinājums līdz 2020. gadam un 40\% samazinājums līdz 2030. gadam ir jau pārn,emti ES likumdošanā un kḷuvuši juridiski saistoši, bet $60 \%$ samazinājuma sasniegšana periodā līdz 2040. gadam pagaidām ir tikai indikatīvs mērkis (sk. 11.5. att.). Cel̦vedis uzsver, ka SEG emisiju samazināšana ir iespējama un ilgtermiṇā ir izmaksu ziṇā efektīva, turklāt samazinājumi iespējami visās nozarēs (sk. 11.1. tabulu).
Saskaṇā ar Eiropas Komisijas novērtējumu, vislielākais emisiju samazināšanas potenciāls ir enerǵētikā, energointensīvajā rūpniecībā un mājokḷu sektorā. Galvenie oglekḷa mazietilpīgas attīstības (OMA) elementi:

- iespējami plaša elektroenerǵijas izmantošana,

- iespējami plaša atjaunojamo energoresursu izmantošana,

- energoresursu izmantošanas efektivitātes paaugstināšana,

- elektroenerǵijas izmantošanas efektivitātes paaugstināšana,

- siltumenerǵijas izmantošanas efektivitātes paaugstināšana,

- zemes ilgtspējīga izmantošana.

Eiropas Komisija ir aprēḳinājusi, ka ES pārejai uz OMA 2010.-2050. gadā ir jāinvestē papildus 270 miljardi EUR (vidēji 1,5\% no ES IKP), taču SEG emisiju samazināšanas mērķa sasniegšana nodrošinās daudz vairāk nekā tikai pozitīvu ietekmi uz klimatu. OMA stimulēs ES tautsaimniecību, n,emot vērā nepieciešamību pēc tīrākām tehnoloǵijām un oglekḷa mazietilpīgiem enerǵijas ieguves un izmantošanas

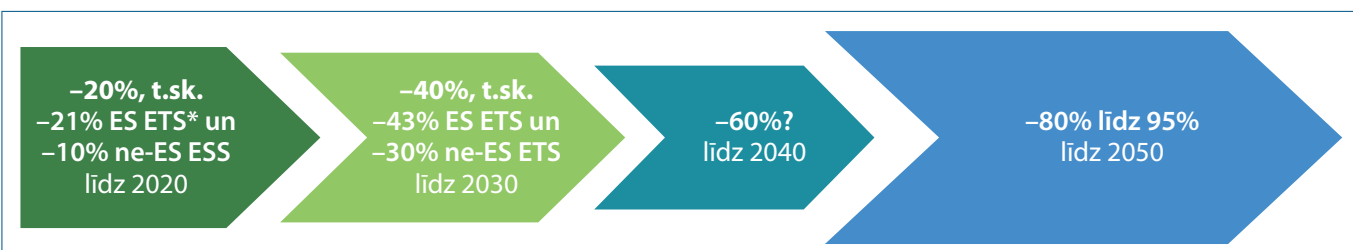

11.5. att. Eiropas Savienības virzība uz oglek!̣a mazietilpīgu attīstību - ikgadējie mērḳi un to sadalījums, ṇemot vērā ilgtermiṇa vīziju (ES ETS - emisijas kvotu tirdzniecības sistēma).

11.1. tabula. Nozaru potenciāls siltumnīcefekta gāzu emisiju samazināšanā Eiropas Savienībā līdz 2050. gadam salīdzinājumā ar 1990. gadu

\begin{tabular}{|c|c|c|c|}
\hline Emisiju avots & 2005. & 2030. & 2050. \\
\hline Enerǵētika $\left(\mathrm{CO}_{2}\right)$ & $-7 \%$ & -54 lídz $-68 \%$ & -93 līdz $-99 \%$ \\
\hline Rūpniecība $\left(\mathrm{CO}_{2}\right)$ & $-20 \%$ & -34 lídz $-40 \%$ & -83 lìdz $-87 \%$ \\
\hline Transports (t.sk. aviācijas $\mathrm{CO}_{2}$ emisijas; izṇemot jūras transportu) & $+30 \%$ & +20 lĩdz -9\% & -54 līdz $-67 \%$ \\
\hline Mājokḷi un pakalpojumi $\left(\mathrm{CO}_{2}\right)$ & $-12 \%$ & -37 lídz $-53 \%$ & -88 līdz $-91 \%$ \\
\hline Lauksaimnieciiba (iznemot $\mathrm{CO}_{2}$ ) & $-20 \%$ & -36 lídz $-37 \%$ & -42 līdz $-49 \%$ \\
\hline Citas emisijas (iznemot $\mathrm{CO}_{2}$ ) & $-30 \%$ & -72 lídz $-73 \%$ & -70 lìdz $-78 \%$ \\
\hline
\end{tabular}


veidiem, un radīs jaunas darba vietas un veicinās izaugsmi. OMA palīdzēs samazināt ES resursu patērin,u, t.sk. izejvielu, zemes, ūdens un energíjas patēriṇu, kā arī samazinās ES atkarību no naftas un dabasgāzes importa. OMA radīs arī priekšnoteikumus veselības uzlabošanai, jo līdz ar SEG emisiju samazināšanu iespējams samazināt arī gaisa piesārṇojumu.

KEP2020 nosaka pienākumu līdz 2020. gadam samazināt ES kopējās SEG emisijas par 20\% salīdzinājumā ar 1990. gadu, kā arī nodrošināt atjaunojamo energoresursu īpatsvaru $20 \%$ apmērā un energoefektivitātes uzlabojumu par 20\% (nereti 2020. gadam noteikto mērksi sauc par "20-20-20"). Par galveno instrumentu SEG emisiju samazināšanai ES izvēlējusies ES emisijas kvotu tirdzniecības sistēmu (ETS), kas sāka darboties 2005. gadā. Tādējādi SEG emisiju mērksim ir divi apakšmērksi - 21\% samazinājums salīdzinājumā ar 2005. gadu ES ETS aptvertajām SEG emisijām (turpmāk - ETS mērḳis) un 10\% samazinājums salīdzinājumā ar 2005. gadu ES ETS neaptvertajām SEG emisijām (turpmāk - ne-ETS mērḳis). ETS mērḳa sasniegšana ir atkarīga no ES ETS darbības, un atbildība par tā sasniegšanu iedalīta ES ETS dalībniekiem. Savukārt ne-ETS mērksis ir pārdalīts starp visām ES dalībvalstīm, un katra dalībvalsts ir atbildīga par sev iedalītās mērḳa dal̦as izpildi. Dalībvalstu mērksi ir sadalīti ikgadējos mērksos. Katra ikgadējā mērksa (un arī kopējā mērķa) izpilde ir juridiski un finansiāli saistoša. Lai pierādītu mērḳa izpildi, dalībvalstīm ik gadu ir jānodod mērksim ekvivalents emisijas vienību skaits. Gadījumā, ja faktiskās emisijas pārsniedz ikgadējā mērķa apjomu, trūkstošās emisijas vienības var aizṇemties no nākamā gada (limits 5\%) vai iegādāties. Savukārt, ja faktiskās emisijas nepārsniedz mērksa apjomu, pāri palikušās emisijas vienības var uzkrāt nākamajiem gadiem vai pārdot. Visa nepieciešamā ES likumdošana gan ETS mērķa, gan ne-ETS mērksa izpildes nodrošināšanai ir apstiprināta un ir sākta tās ieviešana. Mērķu izpildi kontrolē Eiropas Komisija.

KEPS2030 nosaka pienākumu līdz 2030. gadam samazināt ES kopējās SEG emisijas par vismaz 40\% salīdzinājumā ar 1990. gadu. Papildus, KEPS2030 noteikti arī ES līmenī saistoši mērksi līdz 2030. gadam nodrošināt atjaunojamo energoresursu ipatsvaru vismaz $27 \%$ apmērā un energoefektivitātes uzlabojumu vismaz par 27\%. Līdzīgi kā KEP2020 gadījumā, arī KEPS2030 ietvaros SEG emisiju samazināšanas mērksis sadalīts divos apakšmērķos, proti, vismaz 43\% samazinājums, salīdzinot ar 2005. gadu, ES ETS aptvertajām SEG emisijām un vismaz 30\% samazinājums salīdzinājumā ar 2005. gadu ES ETS neaptvertajām SEG emisijām. Atbildību sadalījums par mērḳu sasniegšanu būs tāds pats kā KEP2020 gadījumā - ES ETS dalībnieki būs atbildīgi par mērḳa izpildi attiecībā uz ES ETS aptvertajām emisijām, bet ES dalībvalstis būs atbildīgas par samazinājumu ES ETS neaptvertajās SEG emisijās. Dalībvalstu mērḳi attiecībā uz ES ETS neaptvertajām SEG emisijām būs 0 līdz 40\% samazinājums salīdzinājumā ar 2005. gadu. KEPS2030 ieviešanai nepieciešamās ES likumdošanas izstrāde tika uzsākta 2015. gadā.

\subsubsection{Eiropas Savienības Emisijas kvotu tirdzniecības sistēma}

ES Emisijas kvotu tirdzniecības sistēma (ETS) ir galvenais ES klimata politikas instruments. ES ETS mērķis ir īstermiñā un ilgtermiñā veicināt SEG emisiju samazināšanu rentablā un ekonomiski efektīvā veidā, tādējādi sekmējot SEG emisiju samazināšanas mērḳu izpildi.

ES ETS ir starptautiski reǵionāla "ierobežojumu un tirgus" veida SEG emisiju ațauju tirdzniecības sistēma, kas izveidota, ievērojot subsidiaritātes un proporcionalitātes principus. ES ETS šobrīd aptver 31 valsti, t.sk. 28 ES dalībvalstis un kopš 2012. gada arī Islandi, Norvēǵiju un Lihtenšteinu. ES ETS aptver aptuveni 45\% no visām ES dalībvalstu SEG emisijām. Saskaṇā ar ES sniegto informāciju, ieviešot ES ETS, Kioto protokolā noteikto mērksu izpilde ES izmaksās 2,9 līdz 3,7 miljardus EUR/gadā (mazāk nekā 0,1\% no ES IKP). Turpretim bez ES ETS šĩs ikgadējās izmaksas varētu sasniegt 6,8 miljardus EUR. ES ETS ir atvērta savienojumiem arī ar citām SEG emisiju aț̣auju tirdzniecības sistēmām. 
Nepieciešamību samazināt SEG emisijas primāri nosaka nepieciešamība novērst klimata pārmaiṇas, kā arī nepieciešamība pielāgoties klimata pārmain̄ām (sk. 11.6. att.). Taču ES ETS tiecas arī veicināt efektivitātes uzlabošanu (šī jēdziena visplašākajā nozīmē). N̦emot vērā SEG emisiju ciešo saistību ar ražošanas procesiem, ES ETS ir veidota tā, lai tautsaimniecībā stimulētu SEG emisiju aktīvu samazināšanu, optimizējot energoresursu (sevišksi fosilo energoresursu, jo to izmantošana rada visvairāk SEG emisiju) patēriņu, elektroenerǵijas un siltumenerǵijas patēriṇu. Savukārt, nosakot ambiciozus SEG emisiju samazināšanas mērksus, ES ETS motivē dažādu inovāciju attīstǐšanu un ieviešanu, kas veicina efektivitātes uzlabošanas iespēju un klimata pārmaiṇu novēršanas iespēju palielināšanos. ES ETS ne vien orientē uz investīciju ieguldīšanu, bet arī veicina investīciju piesaisti. Tādējādi ES ETS ne vien veicina SEG emisiju samazināšanu un klimata pārmaiṇu novēršanu, bet arī rada jaunas darba vietas un nodrošina ES tautsaimniecības konkurētspējas uzlabošanu un pāreju uz oglekḷa mazietilpīgu ekonomiku. Papildus, ES ETS sniedz arī atbalstu attīstības valstīm, jo klimata pārmaiṇu novēršanā ir svarīga visu pasaules valstu iesaiste. ES ETS atbalsts attīstības valstīm izpaužas galvenokārt caur tās aț̣auju ES ETS ietvaros kā kompensējošās vienības izmantot sertificētās emisijas samazināšanas vienības un emisijas samazināšanas vienības.

ES ETS sāka darboties 2005. gada 1. janvārī. ES ETS darbība ir strukturēta tirdzniecības periodos. 1. periods bija no 2005. līdz 2007. gadam, 2. periods - no 2008. līdz 2012. gadam, 3. periods - no 2013. līdz 2020. gadam. Sākot no ES ETS 3. perioda (lai nodrošinātu pēc iespējas garāku investīciju atmaksāšanās laiku) katra nākamā tirdzniecības perioda ilgums būs 8 gadi. Katra perioda nosacījumi ir nedaudz atškirīgi. ES ETS 1. perioda darbība nebija sasaistīta ar nākamajiem posmiem, taču ES ETS 2. perioda un turpmāko periodu darbība ir savstarpēji saistīta.

ES ETS ietvaros galvenā tirgojamā atḷauja ir Eiropas Savienības emisijas kvota (European Union Allowance, EUA). 1 EUA apzīmē ațauju emitēt 1 tonnu $\mathrm{CO}_{2 \mathrm{e}}$. Kopējo tirdzniecības perioda ietvaros tirgū izvietojamo EUA daudzumu aprēksina, balstoties uz Kioto protokolā noteiktajām saistībām. Katrā nākamajā periodā

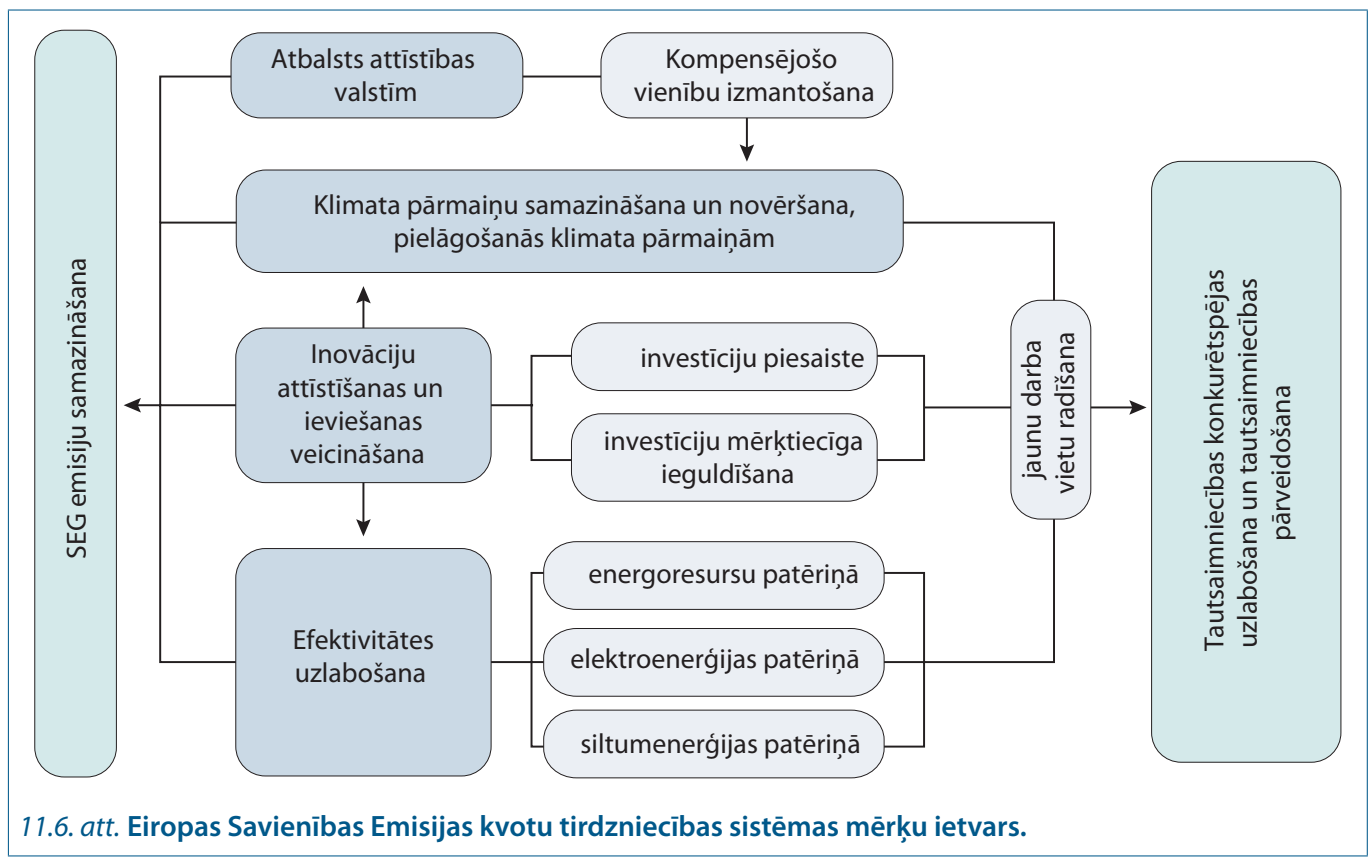


attiecībā pret iepriekšējo periodu tirgū izvietojamo EUA daudzumu samazina. EUA pagaidām izmantojamas vienīgi ES ETS ietvaros.

ES ETS tiešie primārie dalībnieki ir to iekārtu operatori (komersanti, kas ekspluatē iekārtu), uz kurām attiecas SEG emisiju samazināšanas saistības. Taču juridiski ES ETS primārie dalībnieki ir attiecīgās iekārtas, jo visas ES ETS prasības SEG emisiju samazināšanai ir piesaistītas konkrētām iekārtām. ES ETS kopumā piedalās aptuveni 11000 iekārtu. Noteiktām iekārtām dalība ES ETS ir obligāta, bet pārējās tajā var iesaistīties (un vēlāk arī izstāties) brīvprātīgi. Tādējādi ES ETS tiešie primārie dalībnieki iedalāmi obligātajos un brīvprātīgajos dalībniekos. ES ETS obligāti ir jāpiedalās iekārtām, kas veic kādu no šādām darbībām:

- kurināmā sadedzināšana iekārtās ar kopējo nominālo ievadīto siltumspēju, kas pārsniedz 20 MW (izñemot bīstamo atkritumu vai sadzīves atkritumu sadedzināšanas iekārtas); minerāleḷıu rafinēšana; koksa ražošana;

- metāla rūdu (t.sk. sēra rūdas) apdedzināšana vai saķepināšana, t.sk. granulēšana; čuguna vai tērauda ražošana, t.sk. izmantojot nepārtraukto liešanu, kuras kopējā jauda pārsniedz 2,5 t/h; melno metālu (t.sk. ferosakausējumu) ražošana vai pārstrāde, kurā tiek izmantotas sadedzināšanas vienības, kuru kopējā nominālā siltumspēja ir lielāka par $20 \mathrm{MW}$ (pārstrādē tiek izmantoti velmēšanas stāvi, tvaika pārkarsētāji, atlaidināšanas krāsnis, kaltuvju, lietuvju, pārklājumu un kodināšanas iekārtas); primārā alumīnija ražošana; sekundārā alumīnija ražošana, kurā tiek izmantotas sadedzināšanas vienības, kuru kopējā nominālā siltumspēja ir lielāka par 20 MW; krāsaino metālu ražošana vai pārstrāde, t.sk. sakausējumu ražošana, rafinēšana, liešana u.c., kurā izmantojamo sadedzināšanas vienību kopējā nominālā siltumspēja (t.sk. kurināmo siltumspēja, kurus izmanto kā reducējošus aǵentus) ir lielāka par $20 \mathrm{MW}$;
- cementa klinkera ražošana rotācijas krāsnīs ar ražošanas jaudu, kura lielāka par 500 t/dienā, vai cita veida krāsnīs, kuru jauda ir lielāka par 50 t/dienā; kal̦ku ražošana, kā arī dolomīta vai magnezīta apdedzināšana rotācijas krāsnīs vai cita veida krāsnīs, kuru jauda ir lielāka par 50 t/dienā; stikla, t.sk. stikla šķiedras, ražošana iekārtās ar kausēšanas jaudu, kas pārsniedz 20 t/dienā; apdedzinātu keramikas izstrādājumu ražošana, īpaši kārniṇu, kiegeḷu, ugunsizturīgo ķieǵelıu, flīžu, keramikas vai porcelāna ražošana ar jaudu lielāku par 75 t/dienā; minerālvates izolācijas materiālu ražošana, izmantojot stiklu, akmeni vai izdedžus, ar kausēšanas jaudu virs 20 t/dienā; ǵipša žāvēšana vai apdedzināšana vai ǵipškartona sausā apmetuma plātṇu un citu ǵipša izstrādājumu ražošana, kur izmantojamo sadedzināšanas vienību kopējā nominālā siltumspēja ir lielāka par $20 \mathrm{MW}$;

- celulozes ražošana no koksnes vai citiem škiedrainiem materiāliem; papīra vai kartona ražošana, ražošanas jaudai pārsniedzot 20 t/dienā u.c.

Iekārtas, kurām obligāti jāpiedalās ES ETS, var būt no jebkuras tautsaimniecības nozares, taču visvairāk šādu iekārtu ir enerǵētikas un rūpniecības nozarēs. Kopš 2012. gada ES ETS prasības attiecas arī uz lidojumiem uz lidlauku vai no lidlauka, kas atrodas ES ETS dalībvalstu teritorijās vai ES valstu attālajās un aizjūras teritorijās.

Lai minimizētu jebkādus potenciālos ar ES ETS darbību saistītos riskus ES tautsaimniecības konkurētspējas saglabāšanai un uzlabošanai, ES ETS paredz arī vairākus izṇēmumus. ES ETS neieklauj iekārtas, ko izmanto pētnieciskos nolūkos, un iekārtas, kurās izmanto tikai biomasu. ES ETS paredzēti īpaši nosacījumi nozarēm, kas ir pakḷautas emisiju pārvirzes riskam, un iekārtām, kurās plānota plaša mēroga modernizācija. ES ETS paredzēti īpaši nosacījumi mazo iekārtu izslēgšanas iespējai no dalības sistēmā, un jaunām (tikko uzstādītām) iekārtām. ES ETS arī sākot ar 2013. gadu un līdz 
2016. gadam noteikts periodisks izṇēmums lidojumiem "uz" un "no" trešo valstu lidostām, t.i. ES ETS aptver tikai tos lidojumus, kas ir uzsākti un pabeigti Eiropas Ekonomiskās Zonas valstīs.

ES ETS tiešie papildu dalībnieki ir juridiskās vai fiziskās personas, kas ES ETS iesaistījušās spekulatīvos nolūkos (nevis ar mērksi samazināt SEG emisijas). Uz šiem dalībniekiem neattiecas SEG emisiju samazināšanas saistības, taču tiem ir tiesības piedalīties EUA tirgus darbībā - pirkt un pārdot EUA.

ES ETS darbību koordinē Eiropas Komisija. Galvenie Eiropas Komisijas kompetencē esošie uzdevumi ir ES ETS likumdošanas bāzes uzturēšana, priekšlikumu sagatavošana un izskatī̌sana par tirgū izvietojamo EUA apjomu, iekārtām bez maksas piešksiramo EUA apjomu izvērtēšana, atl̦auju tirgus darbības vispārīgā uzraudzība, priekšlikumu izstrāde ES ETS darbības pilnveidošanai, ES ETS sadarbības attīstīšana ar citām ETS, kā arī vienību reǵistra darbības uzturēšana.

Būtiskākie dalībvalstu kompetento iestāžu pārziñā esošie uzdevumi ir ES ETS darbības nodrošināšanai nepieciešamās nacionālās likumdošanas ieviešana, t.sk. direktīvu prasību transponēšana, priekšlikumu sagatavošana par bezmaksas EUA pārdali un piešksiršanu, bezmaksas EUA pieškiršana, ES ETS operatoru darbības uzraudzība, sankciju piemērošana par ar ES ETS darbību saistītās likumdošanas pārkāpumiem, līdzdarbošanās ES ETS darbības pilnveidošanā u.c. Papildus, lai nodrošinātu EUA pareizu uzskaiti, katrā valstī jābūt arī verificētājiem - atbilstības novērtēšanas institūcijas, kas verificē pārskatus par iekārtu ikgadējām SEG emisijām. Ar ES ETS darbību cieši saistīti arī emisiju pārvaldīšanas konsultanti, emisiju auditori, emisijas vienību tirdzniecības konsultāciju firmas, emisijas vienību tirdzniecības brokeri, biržas u.c.

EUA izvietošanu tirgū veic divējādi - EUA pieškirot bez maksas un izsolot. ES ETS 1. periodā bez maksas tika piešksirtas vismaz 95\% EUA, bet ES ETS 2. periodā bez maksas tika pieškirtas vismaz 90\% EUA (dažādās valstīs bez maksas piešķirto EUA apjoms atšksiras). EUA piešksiršana bez maksas ES ETS 1. un 2. periodā bija balstīta uz iekārtu vēsturiskajām SEG emisijām un prognozētajiem ražošanas apmēriem katra atsevišksa gada un perioda ietvaros. EUA varēja tikt piešķirtas gan esošām iekārtām, gan jaunām iekārtām - tām iekārtām, kuras perioda sākumā vēl nedarbojās. Bez maksas piešksiramo EUA sadalījums atsevišșām iekārtām ES ETS 1. un 2. periodā katras valsts mērogā bija noteikts valstu izstrādātajos un Eiropas Komisijas apstiprinātajos nacionālajos emisijas kvotu sadales plānos, bet izsolāmais EUA daudzums - ES tiesību aktos.

Lai no ES ETS viedokḷa nodrošinātu EUA iespējami labāku sadali, sākot no ES ETS 3. perioda, aptuveni puse no EUA tirgū tiek izvietota izsolot. Elektroenerǵiju ražojošajām iekārtām, sākot ar 2013. gadu, bez maksas nepieškirir nevienu EUA un visas nepieciešamās EUA izsola, ja vien konkrētā valsts nav pieṇēmusi lēmumu par izṇēmuma piemērošanu. Rūpniecības nozares un siltumenerǵiju ražojošām iekārtām nepieciešamo EUA daudzumu izsolī̌sanu uzsāk pakāpeniski. Bez maksas piešksiramo EUA sadali veic, izmantojot līmeñatzīmes metodi (benchmarking) un nuemot vērā oglekḷa pārvirzes (carbon leakage) risku. Iekārtām nozarēs, kas pakḷautas būtiskam oglekḷa pārvirzes riskam, ES ETS 3. periodā visas EUA pieškir bez maksas. Savukārt iekārtām nozarēs, kas nav pakḷautas būtiskam oglekḷa pārvirzes riskam, 2013. gadā bez maksas pieškīira 80\% no EUA, bet 2020. gadā bez maksas pieškirs 30\% no EUA.

ES ETS tirdzniecības periodu ietvaros katra gada sākumā ES ETS primārajam dalībniekam, kuram ir paredzēts bez maksas piešksirt EUA, uz viņa atvērto EUA kontu emisijas vienību registrā pārskaita viṇam konkrētajā gadā bez maksas pieškkirto EUA daudzumu (nākamajiem gadiem bez maksas piešksirto EUA daudzumu pārskaitīta katra nākamā gada sākumā), bet izsolāmās EUA iepriekš noteiktos laikos valstu valdības izsola. Katra nākamā gada sākumā līdz 31. martam ES ETS primārajam dalībniekam ir jāpaziṇo iepriekšējā gadā radītais verificētais SEG emisiju daudzums un līdz 30. aprīlim uz speciālu emisijas vienību registra kontu ir jāpārskaita (jānodod) tāds daudzums EUA vai arī 
emisijas samazināšanas vienību vai sertificētu emisijas samazināšanas vienību (kompensējošās vienības), kas ekvivalents tā rīcībā esošās iekārtas radītajām verificētajām SEG emisijām (surrendering). Vienīgi, n,emot vērā to, ka kompensējošo vienību izmantošana neveicina SEG emisiju samazināšanu ES ETS ietvaros, to izmantojamais apjoms un avotu veidi ES ETS ir ierobežoti. Ja kāda gada beigās ES ETS primārais dalībnieks nenodod pietiekami daudz EUA vai kompensējošās vienības, lai "nosegtu" attiecīgā gada verificētās SEG emisijas, tam piemēro soda sankcijas.

Tirdzniecību ar EUA var veikt vai nu ārpusbiržas darïjumos (over-the-Counter, OTC), vai arī izmantojot biržu (exchange) pakalpojumus. Iespējami gan tagadnes darījumi (spot), gan nākotnes darījumi (forward), kā arī iespēju līgumu (options) un fjūčeru (futures) tirdzniecība. Populārākās specializētās biržas ir EEX (European Energy Exchange) un ICE (ICE Futures Europe).

ES ETS 1. periodā EUA cenas kopš 2005. gada sākuma strauji pieauga līdz pat 2006. gada aprīlim un salīdzinoši stabili turējās 20-30 EUR/EUA robežās. Augstākā EUA cena ES ETS 1. perioda ietvaros bija 32,15 EUR/EUA. Taču 2006. gada maijā tika publicēti dati par ES ETS iekārtu pirmā gada (2005. gads) kopējo SEG emisiju apjomu, un tā kā bija vērojams mazāks SEG emisiju apjoms nekā plānots, radās liels bez maksas pieškiirto EUA pārpalikums. EUA pieprasījuma un piedāvājuma līdzsvars tika izjaukts. EUA cena "sabruka", un 2007. gadā bija vairs tikai dažu eirocentu līmenī. EUA viszemākā cena ES ETS 1. periodā bija 0,03 EUR/EUA. Lai novērstu EUA tirgus neefektivitāti, visas ES ETS 1. periodā neizmantotās EUA tika anulētas, un ES ETS 2. periods tika sākts pavisam no jauna.

ES ETS 2. perioda EUA tirdzniecības pirmie gadījumi fiksēti 2005. gadā, kad tika uzsākta 2008. gadā izpildāmo nākotnes darījumu tirdzniecība. Gandrīz visu 2008. gadu EUA cenas stabili turējās virs 20 EUR/EUA, taču no 2008. gada beigām līdz 2009. gada sākumam EUA cenas būtiski pazeminājās fosilo energoresursu cenu krituma dēl un dēl prognozēm par salīdzinoši mazākām sagaidāmajām
SEG emisijām globālās krīzes laikā. Lai gan 2009. gada otrajā ceturksnī EUA cenas stabilizējās vidēji 13 EUR/EUA, 2012. gadā, pasliktinoties prognozēm par ES valstu ekonomiku atlabšanu, EUA cena atkal strauji samazinājās.

EUA tirgū bija liels neizmantoto EUA pārpalikums, tāpēc 2014. gada sākumā, lai atjaunotu tirgus līdzsvaru, ES pieñēma lēmumu par ārkārtas pasākumu, proti, 2014.-2016. gadā izsolāmo EUA daudzuma samazināšanu par 900 miljoniem EUA. Savukārt, lai nodrošinātu ilgtermiṇa risinājumu situācijām, kad neprognozētu ekonomisko apstākḷu dēl būtiski samazinās pieprasījums pēc EUA un tiek apdraudēta ES ETS darbība, 2015. gadā tika pieñemts lēmums par tirgus stabilitātes rezerves (market stability reserve) izveidi. Tā sāks darboties no 2019. gada, un tā automātiski koriǵēs ik gadu izsolāmo EUA apjomu gadījumos, kad kopējais apritē esošais EUA daudzums būs ārpus diapazona 400-833 milj. EUA.

\subsubsection{Eiropas Savienības pielāgošanās klimata pārmaiṇām}

2007. gadā Eiropas Komisija publicēja Zaḷo grāmatu "Adaptācija klimata pārmaiṇām Eiropā. ES rīcības varianti”. Savukārt 2009. gadā Eiropas Komisija publicēja Balto grāmatu "Adaptācija klimata pārmaiñām - iedibinot Eiropas rīcības pamatprincipus". Tajā uzsvērts, ka pielāgošanās politikas un instrumenti jāmeklē jau esošajā klāstā, t.sk. attīstot krīzes situāciju un risku pārvaldību, veicinot pielāgošanās klimata pārmaiñām pasākumus visos līmen,os (gan nacionālajā, gan reǵionālajā, gan vietējā), integrējot politiku un tās īstenošanas instrumentus galvenajos tautsaimniecības sektoros.

2013. gadā Eiropas Komisija apstiprināja ES Stratēǵiju par pielāgošanos klimata pārmaiñām. Tās mērksis ir uzlabot ES noturīgumu pret klimata pārmainām, samazinot sektoru, sistēmu, cilvēku un aktīvu jutīgumu. Šĩ stratēǵija papildina ES dalībvalstu aktivitātes, uzlabo koordināciju un informācijas apmaiṇu. 


\subsection{Latvijas klimata politika}

Latvijas klimata politikas pirmsākumi saistīti ar Konvencijas ratifikāciju un pirmā Nacionālā ziṇojuma par Latvijas SEG emisijām sagatavošanu 1995. gadā. Latvija līdzdarbojās arī Kioto protokola pien,emšanā 1997. gadā, kuru ratificēja 2002. gadā. Kioto protokola 1. perioda ietvaros Latvijai bija noteikts mērksis līdz 2012. gadam samazināt SEG emisijas par 8\% salīdzinājumā ar 1990. gadu, savukārt Kioto protokola 2. periodā Latvija piedalās kopējā ES mērksa izpildē, jo Latvijai vairs nav noteikts atseviškss mērksis. Klimata politikas izstrādi un ieviešanas koordinēšanu Latvijā nodrošina Vides aizsardzības un reǵionālās attīstības ministrija sadarbībā ar nozaru ministrijām.

Pirmo politikas plānošanas dokumentu klimata politikas jomā Latvija apstiprināja 2005. gadā. Tā bija Klimata pārmaiṇu samazināšanas programma 2005.-2010. gadam. 2009. gadā klimata politikas mērķi un darbības virzieni tika ieklauti Vides politikas pamatnostādnēs 2009.-2015. gadam un 2014. gadā Vides politikas pamatnostādnēs 2014.2020. gadam (turpmāk - VPP2020). Sākotnēji Latvijas klimata politika bija vērsta tikai uz klimata pārmaiṇu novēršanu. Pielāgošanos klimata pārmaiṇām, kā atseviškরu darbības virzienu, noteica 2014. gadā.

Latvija ir aktīvi izmantojusi starptautiskās klimata politikas ietvaros izveidotos elastīgos mehānismus. 2002. gadā Latvija uzsāka pasaulē pirmā kopīgi īstenojamā projekta ieviešanu. Sākot no 2005. gada Latvijā darbību uzsāka ES Emisijas kvotu tirdzniecības sistēma (ETS), un kopš 2012. gada ES ETS ietvaros Latvija veic arī ES emisijas kvotu (EUA) izsoles, ieñēmumus novirzot Emisijas kvotu izsolīšanas instrumentam (EKII). Savukārt 2006. gadā Latvija pieñēma lēmumu par iesaistī̌̌anos Starptautiskajā emisiju tirdzniecības sistēmā. Pirmos darījumus Starptautiskajā emisiju tirdzniecībā Latvija veica 2008. gadā. Lai nodrošinātu pārdoto noteiktā daudzuma vienību (NDV) "zal̦umošanu", Latvija pasaulē pirmā izveidoja "zaḷās investēšanas sistēmu" un nosauca to par Klimata pārmaiṇu finanšu instrumentu (KPFI).
Būtiskākās Latvijas īpatnības klimata politikas kontekstā:

- salīdzinoši neliela ekonomika, kurai nepieciešams vēl būtiski attīstīties un kuras pieprasījums pēc enerǵijas nākotnē noteikti pieaugs;

- salīdzinoši neliels SEG emisiju kopapjoms un jebkādu nozīmīgu ekonomikas attīstības projektu būtiska ietekme uz SEG emisiju dinamiku;

- salīdzinoši neliels ES ETS nosegto emisiju īpatsvars un daudz t.s. ne-ETS emisiju, t.sk. liels transporta un lauksaimniecības emisiju ipatsvars;

- salīdzinoši liela emisiju intensitāte enerǵijas patēriṇā.

\subsubsection{Latvijas mērki siltumnīcefekta gāzu ierobežošanai}

Latvijas mērḳi SEG ierobežošanai līdz 2020. gadam ir noteikti starptautiskajos un ES tiesību aktos un pārṇemti Latvijas likumdošanā (sk. 11.2. tabulu). ES ETS ietverto SEG emisiju samazināšanai Latvijai piemēro ES kopējo mērksi par 21\% samazinājumu salīdzinājumā ar 2005. gadu (n,emot vērā mērksa sadalījumu ES ETS iekḷautajām iekārtām). Savukārt Latvijas mērḳis ne-ETS emisiju ierobežošanai ir $+17 \%$ salīdzinājumā ar 2005. gadu, t.i., Latvijai jāierobežo ne-ETS emisiju pieaugums tā, lai līdz 2020. gadam to pieaugums salīdzinājumā ar 2005. gadu nebūtu lielāks kā 17\%. Ne-ETS mērksis ir sadalīts ikgadējos mērksos. Papildus, Latvijai noteikts arī mērksis $\mathrm{CO}_{2}$ piesaistei - ik gadu izpildāms $\mathrm{CO}_{2}$ piesaistes līmenis.

Ņemot vērā KEP2020 noteiktos mērķus atjaunojamo energoresursu ipatsvaram un energoefektivitātes uzlabošanai, klimata politikas mērķu līdz 2020. gadam sasniegšanas kontekstā Latvijai būtiskākie citi mērksi:

- gala patēriña ietaupījums 2013.-2020. gadā 9896 GWh;

- 5,4 Mtoe (toe - tonne of oil equivalent) kopējais patēriṇa samazinājums; 
- $3 \%$ valstij piederošo ēku platības renovācija ik gadu;

- atjaunojamo energoresursu ipatsvars līdz 40\% (pret 2005.), t.sk. 10\% transportā.

Nozīmīgākie saistītie politikas plānošanas dokumenti:

- Latvijas Ilgtspējīgas attīstības stratēǵija līdz 2030. gadam (apstiprināta 2010. gadā);

- Nacionālais attīstības plāns 2014.2020. gadam (2012.);

- Latvijas nacionālā reformu programma ES2020 stratēgijas īstenošanai (2011.);

- Transporta attīstības pamatnostādnes 2014.-2020. gadam (2013.);

- Latvijas Lauku attīstības programma 2014.-2020. gadam (2015.);

- Meža un saistīto nozaru attīstības pamatnostādnes 2015.-2020. gadam (2015.);

- Atkritumu apsaimniekošanas valsts plāns 2013.-2020. gadam (2013.);

- Zal̦ā iepirkuma veicināšanas plāns 2015.-2017. gadam (2015.);

- Energétikas attīstības pamatnostādnes 2015.-2020. gadam (2016.);

Latvijas Ilgtspējīgas attīstības stratēǵijā līdz 2030. gadam ("Latvija2030") viens no trim Latvijas mērkiem ir "Latvija - mūsu mājas - zaḷa un sakopta, radoša un ērti sasniedzama vieta pasaules telpā, par kuras ilgtspējīgu attīstību mēs esam atbildīgi nākamo paaudžu priekšā". Netiešā veidā klimata politikas aspekti skarti arī “Latvija2030" prioritātēs - trešā prioritāte ir "Inovatīva un ekoefektīva ekonomika", un tai izvirzīti divi attīstības virzieni - "Masveida jaunrade un inovācija" un "Atjaunojama un droša enerǵija". Savukārt ceturtā prioritāte ir "Daba kā nākotnes kapitāls" un tās ietvaros izvirzìts attīstības virziens "Dabas vērtību un pakalpojumu ilgtspējīga apsaimniekošana”. Līdzīgā veidā mērksi, prioritātes un pasākumi ietverti arī citos politikas plānošanas dokumentos. Tomēr dažos no tiem plānotais nepietiekami n,em vērā vai pat ir pretrunā ar klimata politikas mērksiem.

2016. gadā Vides aizsardzības un reǵionālās attīstības ministrija plāno izstrādāt Latvijas oglekḷa mazietilpīgas attīstības stratēgiju 2050. gadam.

\subsubsection{Latvijas progress siltumnīcefekta gāzu ierobežošanā}

SEG ierobežošanu nodrošina ar nozaru politiku pasākumiem - energoefektivitātes uzlabošanu, pāreju no fosilajiem uz atjaunojamajiem energoresursiem, elektromobilitātes attīstīšanu utt. VPP2020 noteiktie rīcības virzieni:

- ES ETS darbības nodrošināšana,

- biomasas ilgtspējīga izmantošana,

- $\mathrm{CO}_{2}$ piesaistes nodrošināšana meža zemēs un oglekḷa saistīšana koksnes produktos ar ilgu kalpošanas laiku,

11.2. tabula. Latvijas mērḳi siltumnīcefekta gāzu ierobežošanai 2015.-2020. gadā

\begin{tabular}{|c|c|c|c|c|c|c|c|}
\hline \multirow{2}{*}{ Politikas rezultāts } & \multirow{2}{*}{ Rezultatīvais rādītājs } & \multicolumn{6}{|c|}{ Sasniegšanas rādītāji pa gadiem } \\
\hline & & 2015 & 2016 & 2017 & 2018 & 2019 & 2020 \\
\hline $\begin{array}{l}\text { lerobežotas vai stabilizētas valsts } \\
\text { kopējās SEG emisijas }\end{array}$ & Kopējās SEG emisijas $\mathrm{Mt} \mathrm{CO}_{2 \mathrm{e}}$ & 12,02 & 12,06 & 12,10 & 12,13 & 12,15 & 12,16 \\
\hline $\begin{array}{l}\text { lerobežotas SEG emisijas } \\
\text { nozarēs, kas nav iekḷautas ETS }\end{array}$ & Ikgadējās SEG emisijas $\mathrm{Mt} \mathrm{CO}_{2 \mathrm{e}}$ & 9,44 & 9,53 & 9,62 & 9,72 & 9,801 & 9,90 \\
\hline $\begin{array}{l}\text { Samazinātas SEG emisijas ETS } \\
\text { nozarēs }\end{array}$ & Kopējās SEG emisijas $\mathrm{Mt} \mathrm{CO}_{2 \mathrm{e}}$ & - & - & - & - & - & 2,26 \\
\hline $\begin{array}{l}\text { Tautsaimniecības SEG emisiju } \\
\text { intensitāte }\end{array}$ & $\mathrm{tCO}_{2 \mathrm{e}} / 1000 \mathrm{LVL}$ no IKP & - & - & 1,30 & - & - & 1,13 \\
\hline $\begin{array}{l}\text { Nodrošināta } \mathrm{CO}_{2} \text { piesaiste } \\
\text { mežsaimniecības sektorā }\end{array}$ & $\mathrm{Mt} \mathrm{CO} 2 \mathrm{e}$ & \multicolumn{6}{|c|}{16,30} \\
\hline
\end{tabular}


- ēku energoefektivitātes uzlabošana,

- apgaismojuma infrastruktūras energoefektivitātes uzlabošana,

- videi draudzìgas transporta infrastruktūras attīstīšana un atjaunojamo energoresursu izmantošana transportā,

- ilgtspējīgas saimniekošanas prakses ieviešana lauksaimniecībā,

- atjaunojamo energoresursu izmantošana enerǵijas ražošanā,

- "zal̦ā" publiskā iepirkuma veicināšana,

- ogleklı mazietilpīgu tehnologiju attīstīšana un ieviešana,

- SEG samazināšanas un $\mathrm{CO}_{2}$ piesaistes jautājumu integrēšana dažādu nozaru politikās un pašvaldību darbībā, t.sk. reǵionālu stratēǵiju un plānu izstrāde.

VPP2020 nosaka arī vairākus rīcības virzienus SEG emisiju uzskaitei un prognozēšanai (SEG ikgadējās inventarizācijas sistēmas pilnveidošana, nacionālās sistēmas izveide SEG emisiju un piesaistes prognozēšanai, Latvijas starptautisko ziṇošanas saistību izpilde), kā arī nepieciešamību īstenot pētījumus, informēt un izglītot sabiedrību.

Klimata politikas ieviešana balstīta galvenokārt uz likumu "Par piesārn,ojumu" (2001.) un likumu "Par Latvijas Republikas dalību Kioto protokola elastīgajos mehānismos" (2007.) un saskañā ar tiem izdotajiem Ministru kabineta noteikumiem, rīkojumiem un instrukcijām.
Sankcijas par prasību neizpildi ir noteiktas Latvijas Administratīvo pārkāpumu kodeksā (1984.), savukārt likumā "Dabas resursu nodokḷa likums" (2005.) noteikti pamatnosacījumi nodokḷa aprēksināšanai par $\mathrm{CO}_{2}$ emisijām no stacionārajām tehnologiskajām iekārtām, kas veic noteiktas piesārṇojošās darbības.

Latvijas kopējās SEG emisijas 2013. gadā bija par vairāk nekā 58\% mazākas nekā 1990. gadā, taču tikai par apmēram 1\% mazākas nekā 2005. gadā. Lielākā dalı no Latvijas kopējām SEG emisijām rodas no kurināmā izmantošanas stacionārajās sadedzināšanas iekārtās (38\%), no transporta (25\%) un no lauksaimniecības (21\%).

2013. gadā 24\% no Latvijas kopējām SEG emisijām bija ietvertas ES ETS, bet 2014. gadā ES ETS bija ietvertas vairs tikai 21\%. N,emot vērā vāji attīstīto ražošanu, kā arī Latvijas ES ETS operatoru jau veiktos SEG emisiju samazināšanas pasākumus, piemēram, biomasas izmantošanas apjoma palielināšana, Latvijā ES ETS aptvertā kopējo SEG emisiju dalı ir būtiski mazāka nekā vidēji ES.

ES ETS 1. periodā (2005.-2007.) un 2. periodā (2008.-2012.) vienlaikus bija līdz pat attiecīgi 97 un 82 iekārtām, taču liela dalı no tām bija ES ETS brīvprātīgi dalībnieki un pakāpeniski no dalības ES ETS izstājās. 2015. gadā ES ETS no Latvijas bija ieklıutas vairs tikai 66 iekārtas, un tās piederēja 47 lielākajiem Latvijas

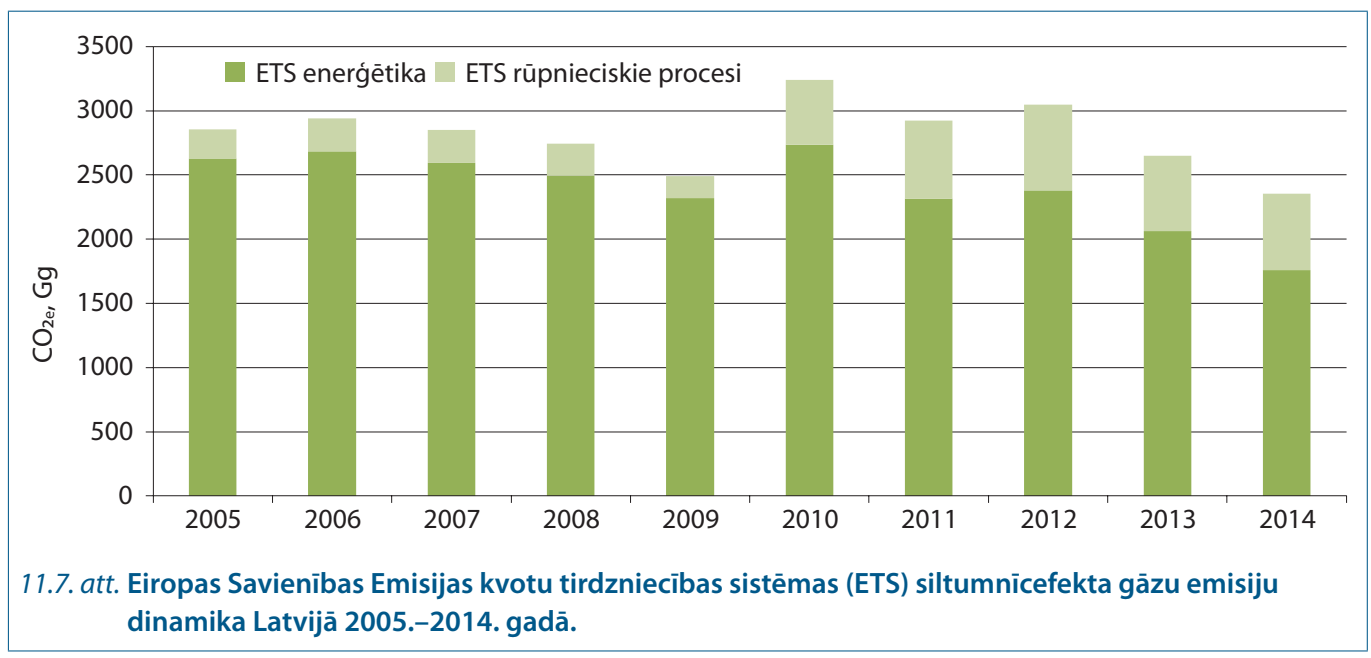


energétikas un rūpniecības komersantiem, t.sk. gan siltumenerǵijas un elektroenerǵijas ražotājiem (privātiem, kā arī valsts un pašvaldību komersantiem), gan dažāda veida rūpnieciskajiem ražotājiem, piemēram, kokapstrādes komersantiem, cementa ražotājiem, metalurǵiskajai rūpniecībai. Papildus, ES ETS ietvaros Latvijas administrācijā 2015. gadā bija arī 14 gaisa kuǵu operatori, taču tikai 2 no tiem nebija piemērots izṇēmums līdz 2016. gadam, t.i. pienākums nodot emisijas vienības par savu lidojumu emisijām bija 2 komersantiem.

Latvijas ES ETS dalībnieki investē jaunās un modernizē esošās tehnologijas (piemēram, uzstādot tvaika kondensatorus otrreizējai siltuma izmantošanai). ES ETS operatori arī aktīvi veic pāreju no fosilo kurināmo izmantošanas uz biomasas izmantošanu, un jau aptuveni 22\% no ES ETS operatoru iekārtās saražotās energijas daudzuma iegūti, izmantojot biomasu. Biomasas izmantošana ES ETS Latvijā ir pieaugusi no 2191 TJ (teradžouls) 2005. gadā līdz 8655 TJ 2014. gadā. Latvijas ES ETS dalībnieki 2013.-2014. gadā samazināja savas SEG emisijas par vairāk nekā 11\%.

Ne-ETS SEG emisijas kopš 2005. gada pakāpeniski palielinās. Kopējais palielinājums 2005.-2014. gadā bija gandrīz 5\%, taču lielākā dal̦a no šì palielinājuma (vairāk nekā 4\%) bija 2013.-2014. gadā, un tas liecina par SEG emisiju palielināšanās tempa pieaugumu.

2015. gadā sagatavotās SEG emisiju prognozes liecina, ka, n,emot vērā esošos un ieplānotos politikas pasākumus, kopējās neETS SEG emisijas laika periodā no 2005. līdz 2020. gadam pieaugs par nedaudz vairāk nekā 8\%. Tādējādi sagaidāms, ka Latvija izpildīs tās SEG emisiju ierobežošanas mērḳi periodā līdz 2020. gadam. 2030. gadam Latvijas mērḳis neETS SEG emisiju samazināšanai visticamāk būs robežās no $0 \%$ līdz 10\% samazinājums salīdzinājumā ar 2005. gadu. N̦emot vērā 2015. gada prognozes par turpmāko SEG emisiju palielinājumu, 2030. gada mērksa sasniegšanai būs nepieciešama papildu pasākumu īstenošana.

Nodokl̦us un nodevas kā instrumentu SEG ierobežošanai Latvijā pagaidām izmanto samērā maz. SEG komponente tiešā veidā ietverta vienīgi dabas resursu nodoklī (DRN), kuru komersanti maksā par $\mathrm{CO}_{2}$ emisijām no stacionārajām tehnologiiskajām iekārtām, kas veic noteiktas piesārn,ojošās darbības. DRN piemēro par katru emitēto $\mathrm{CO}_{2}$ tonnu, iznnemot par ES ETS iekḷautajām emisijām. Taču nodokḷu un nodevu instrumentu saistībā ar klimata politiku daudz izmanto citu nozaru politikās. Piemēram,

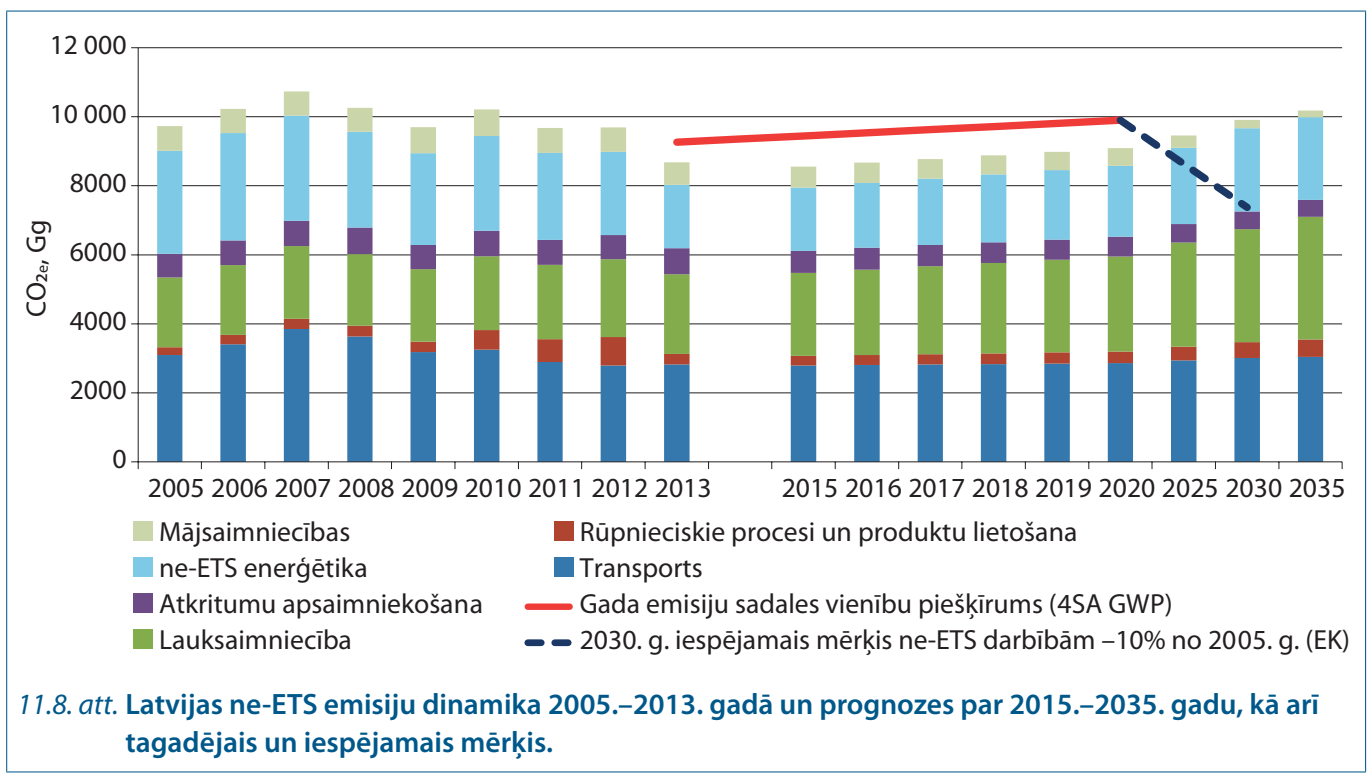


viens no transporta emisiju samazināšanas veidiem ir elektrotransportlīdzekḷu izmantošana, un Latvijā elektrotransportlīdzekḷi ir atbrīvoti no transportlīdzekḷu ekspluatācijas nodokḷa, kā arī tiem nav jāmaksā vieglo automobilı un motociklu nodoklis. Rapšu sēklu el̦lai, kuru realizē vai izmanto par kurināmo vai degvielu, un biodīzel̦degvielai, kas pilnībā iegūta no rapšu sēklu ellıas, noteikts atbrīvojums no akcīzes nodokḷa, bet fosilās degvielas maisijumiem ar biodegvielām noteikta samazināta akcīzes nodokḷa likme.

Subsidēšanas mehānismu Latvijā izmanto atjaunojamo energoresursu atbalstam - no atjaunojamajiem energoresursiem un koǵenerācijā saražotās elektroenerǵijas valsts iepirkumiem piemēro obligātā iepirkuma komponenti (OIK). OIK kompensē šādi ražotas elektroenerǵijas dārgumu salīdzinājumā ar tirgus cenu.

SEG ierobežošanai pieejami dažādi fondi, t.sk. Eiropas Ekonomikas zonas finanšu instruments un ES fondi, kuru ietvaros 2014.-2020. gadā ES dalībvalstīm ieteikts vismaz $20 \%$ no visa finansējuma izmantot ar

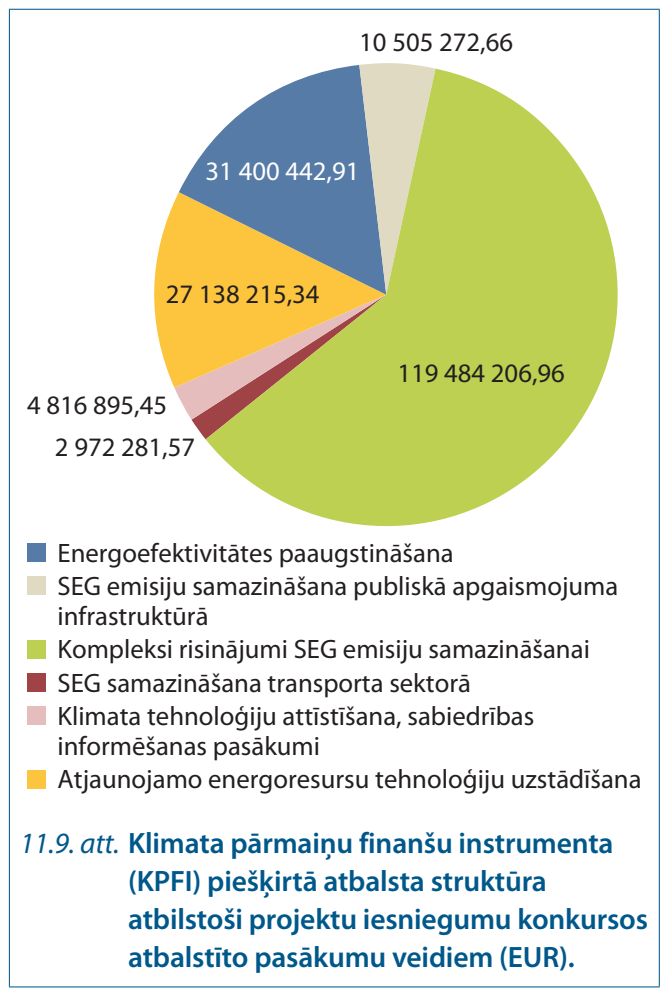

klimata politikas ieviešanu saistītu pasākumu finansēšanai. Taču vienīgais specializētais fonds klimata pasākumu atbalstam Latvijā līdz 2015. gadam bija Klimata pārmaiṇu finanšu instruments (KPFI), ko nākotnē visticamāk aizstās Emisijas kvotu izsolīšanas instruments (EKII). KPFI ir valsts budžeta programma, kuras mērḳis ir veicināt globālo klimata pārmaiṇu novēršanu, pielāgošanos klimata pārmainu radītajām sekām un sekmēt SEG emisiju samazināšanu. KPFI finansējuma avots ir ien,ēmumi no Latvijas dalības Starptautiskajā emisiju tirdzniecībā (nevis ES fondi). KPFI savu darbību uzsāka 2008. gadā.

KPFI ietvaros līdz 2014. gadam tika izveidoti 16 dažādi konkursi projektu atbalstam, un šo konkursu ietvaros noorganizētas pavisam 23 kārtas (dažu konkursu ietvaros notika vairākas kārtas). Līdz 2015. gada beigām KPFI ietvaros veiksmīgi tika pabeigti 2614 projekti. To kopējās attiecināmās izmaksas bija 433 miljoni eiro, un no KPFI tie saṇēma vairāk nekā 45\% no kopējām attiecināmām izmaksām.

KPFI ietvaros tika finansēti visa veida pasākumi SEG emisiju samazināšanai un atbalsts bija pieejams visplašākajam pretendentu lokam, t.sk. komersantiem, pašvaldībām, valsts iestādēm, sabiedriskajām organizācijām un pat mājsaimniecībām.

\subsubsection{Pielāgošanās klimata pārmaiṇām}

Par pielāgošanās klimata pārmaiṇām nozīmīgumu Latvijā sāka domāt līdz ar Kioto protokola darbības sākumu. 2008. gadā Ministru kabinets pieñēma informatīvo ziṇojumu "Par piemērošanos (adaptāciju) klimata pārmaiñām", un Vides aizsardzības un regionālās attīstības ministrija izveidoja starpministriju un ekspertu darba grupas pielāgošanās klimata pārmaiṇām jautājumu risināšanai. 2012. gadā tika veikts klimata pārmaiṇu risku novērtējums, kas kḷuva par pamatu mērḳa "veicināt Latvijas gatavību pielāgoties klimata pārmaiņām un to izraisītajai ietekmei" iekḷaušanai Vides politikas pamatnostādnēs 2014.-2020. gadam 
(VPP2020). Saistībā ar pielāgošanos klimata pārmaiṇām VPP2020 noteiktie rīcības virzieni:

- klimata pārmaiṇu Latvijā modelēšana un integrētas datu sistēmas izveide,

- risku un jutīguma analizēšana un pasākumu identificēšana, lai nodrošinātu pielāgošanos klimata pārmaiṇām,

- klimata pārmaiṇu monitoringa sistēmas attīstīšana,

- nacionālās sistēmas pilnveidošana gatavībai un reaǵěšanai uz klimata pārmainuu radītajām sekām,

- infrastruktūras nodrošināšana klimata pārmainu izraisīto plūdu risku novēršanai,

- krasta erozijas riska mazināšanas pasākumu ieviešana sabiedriski nozīmīgu infrastruktūras objektu aizsardzībai,

- jautājumu par pielāgošanos klimata pārmaiṇām integrēšana dažādu nozaru politikās un pašvaldību darbībā, t.sk. reǵionālu stratēgiju un plānu izstrāde.

Papildus šai specifiskajai politikai, kas vērsta uz to, lai koordinēti attīstītu pielāgošanos klimata pārmaiṇām, pielāgošanās klimata pārmain̄ām aspekti ir ņemti vērā arī daudzos esošos citu nozaru politikas plānošanas dokumentos, t.sk. Latvijas Ilgtspējīgas attīstības stratēǵijā līdz 2030. gadam (2010.), Nacionālajā attīstības plānā 2014.-2020. gadam (2012.), Latvijas nacionālā reformu programmā ES2020 stratēǵijas īstenošanai (2011.), kā arī Sabiedrības veselības pamatnostādnēs 2014.2020. gadam (2014.), Reǵionālās politikas pamatnostādnēs 2013.-2019. gadam (2013.), Piekrastes telpiskās attīstības pamatnostādnēs 2011.-2017. gadam (2011.). Klimata pārmaiṇu risku mazināšanu Latvijā veicina arī politika un pasākumi civilās drošības aizsardzībai.

Latvijā tiek veikta sistemātiska meteorologiskās informācijas ieguve un uzkrāšana. Latvijas Vides, ǵeoloǵijas un meteoroloǵijas centrs uzkrāj un analizē informāciju par ilggadīgiem novērojumiem. Balstoties uz šiem datiem, ir iespējams spriest par klimata pārmaiṇām Latvijā, kā arī plānot pielāgošanos klimata pārmaiṇām. 2016. gadā Vides aizsardzības un regionālās attīstības ministrija plāno izstrādāt Nacionālo pielāgošanās klimata pārmaiṇām stratēgiju.

\subsection{Nevalstiskā sektora loma klimata politikas veidošanā un ìstenošanā}

Kopš klimata politikas pirmsākumiem nozīmīga loma klimata politikas veidošanā un îstenošanā ir nevalstiskajam sektoram šī jēdziena visplašākajā nozīmē - pilsētu un reǵionu pašvaldībām, komersantiem, nacionālām un starptautiskām nevalstiskajām organizācijām. Kopš 2014. gada informācija par nevalstiskā sektora aktivitātēm klimata politikā apkopota NAZCA (Non-State Actor Zone for Climate Action) portālā. Arī 2015. gada Parīzes nolīgums apstiprina nevalstiskā sektora nozīmīgumu.

N̦emot vērā nu jau daudzas desmitgades valdošo urbanizācijas tendenci (2014. gadā pilsētās dzīvoja 54\% no pasaules iedzivotājiem, bet 2050. gadā šis skaitlis varētu sasniegt jau $66 \%$ ), pilsētas ir kḷuvušas par nozīmīgāko SEG emisiju avotu. Aprēksināts, ka šobrīd pilsētas ir atbildīgas par 71-76\% no pasaules kopējām emisijām. Specifiskās vides dēḷ pilsētas saskaras ar īpašiem izaicinājumiem (sevišksi pielāgošanās klimata pārmaiṇu jomā), taču tām arī ir daudz iespēju, īpaši saistībā ar infrastruktūras maiṇu un pielāgošanu oglekḷa mazietilpīgai attīstībai (OMA), piemēram, sabiedriskā transporta attīstīšana, elektrotransportlīdzekḷu tīkla attīstīšana, un noturībai pret klimata pārmaiñām. Pilsētu un reǵionu pašvaldības bieži vien veido savas individuālās klimata politikas, un nereti tās ir ambiciozākas par to valstu klimata politikām. Nozīmīgākie starptautiskie pašvaldību sadarbības tīkli:

- C40 - pasaules lielāko 75 pilsētu tīkls, kas vērsts uz pilsētu rīcību SEG emisiju un klimata pārmaiṇu risku samazināšanai, tajā 
pašā laikā uzlabojot pilsētu iedzīvotāju veselību, labklājību un ekonomiskās iespējas.

- Mēru līgums (Compact of Mayors) - vienošanās starp pilsētām, kas tiecas caurskatāmā veidā panākt pilsētu emisiju samazināšanu, jutīguma pret klimata pārmaiñām samazināšanu un noturīguma pret klimata pārmaiṇām nodrošināšanu. Līdz 2015. gada 21. decembrim Mēru līgumā bija iesaistījušās 436 pilsētas, kurās dzīvo vairāk nekā 5\% no pasaules iedzìvotājiem, t.sk. 1 pašvaldība no Latvijas.

- Mēru pakts (Covenant of Mayors) - Eiropas vietējo un regionālo pašvaldību kustība cīn,ai pret klimata pārmaiñām, kas balstīta uz dalībnieku brīvprātīgu apn,emšanos sasniegt un pat pārpildīt ES mērḳi SEG emisiju samazināšanai par 20\%, uzlabojot energoefektivitāti un attīstot atjaunojamo energoresursu izmantošanu. Dalība Mēru paktā prasa attīstīt SEG emisiju uzskaiti, kā arī izstrādāt un ieviest ilgtspējīgas enerǵētikas rīcības plānus. Līdz 2015. gada 21. decembrim Mēru paktam bija pievienojušās 6031 pašvaldības, t.sk. 19 pašvaldības no Latvijas.

- "Mēri pielāgojas" (Mayors Adapt) - Mēru Pakta ietvaros uzsākta iniciatīva, kas vērsta uz pielāgošanās pasākumu ieviešanu pašvaldību līmenī, veicinot pielāgošanās stratēgiju un pasākumu izstrādi un ieviešanu. Līdz 2015. gada 21. decembrim iniciatìvai "Mēri pielāgojas” bija pievienojušās 143 pašvaldības, t.sk. 1 pašvaldība no Latvijas.

Lai gan atsevišķas Latvijas pašvaldības ir pievienojušās Mēru līgumam, Mēru paktam un iniciatīvai "Mēri pielāgojas", un dažas Latvijas pašvaldību aktivitātes ir atspogulotas NAZCA portālā, pagaidām klimata politikas veidošana un ieviešana pašvaldībās Latvijā ir attīstības pirmsākumos. Vairums pašvaldību īstenojušas vien Klimata pārmaiṇu finanšu instrumenta (KPFI) vai citu finansējuma avotu atbalstītus atsevišksus projektus, taču nav formulējušas klimata politiku un nepievērš šiem jautājumiem regulāru uzmanību. Klimata politikas veidošana un ieviešana pašvaldībām varētu palīdzēt nodrošināt ilgtspējīgu attīstību un gūt visus tos pašus labumus, ko no OMA un pielāgošanās klimata pārmaiṇām var gūt valsts kopumā.

Otra nozīmīgākā nevalstiskā sektora grupa ir privātais sektors. 1000 korporācijas ar vislielākajām SEG emisijām kopā rada ap 20\% no kopējām pasaules emisijām, tāpēc klimata politikas veidošanā un īstenošanā korporācijām mūsdienās nereti var būt pat tikpat liela vai pat vēl lielāka nozīme kā valstu valdībām. Pēdējos gados strauji pieaug to korporāciju skaits, kas ievieš pasākumus klimata pārmainuu ierobežošanai neatkarīgi no valstu politikām. Klimata politika kḷūst par dalı no to korporatīvās sociālās atbildības (corporate social responsibility) pasākumiem, un palīdz ne vien ierobežot klimata pārmaiṇas, bet arī uzlabot komersantu konkurētspēju. Daudzi komersanti pat gūst tiešu peḷnu no klimata politikas ieviešanas, proti, tie attīsta Kioto protokola elastīgo mehānismu projektus. Tomēr pēdējos gados aizvien biežāk komersanti izcel̦as ar nopietnas klimata politikas veidošanu un īstenošanu, klimata finansējuma sniegšanu (ar OMA saderīgu investīciju rezultātā) attīstības valstīm. Dažas no pasaulē pazīstamākajām privātā sektora iniciatīvām klimata politikas jomā ir 2014. gada globālais investoru pazingojums par klimata pārmaiñām (2014 Global Investor Statement on Climate Change), RE100, Rūpes par klimatu (Care for Climate) u.c.

Latvijā, neskaitot ES Emisijas kvotu tirdzniecības sistēmā (ETS) iesaistītos komersantus, samērā maz dzirdēts par komersantu aktivitātēm klimata pārmaiṇu ierobežošanas un pielāgošanās klimata pārmaiṇām jomā. Klimata pārmaiṇu jautājumiem Latvijā iegūstot aizvien lielāku atpazīstamību un stājoties spēkā Parīzes nolīgumam, tā varētu klūu par labu iespēju komersantu darbības pilnveidošanai un tālākai attīstībai gan nacionālā, gan starptautiskā mērogā.

Nacionālo un starptautisko organizāciju lomas klimata politikas veidošanā un īstenošanā ir ḷoti dažāda - sākot no pētniekiem un padomdevējiem un beidzot ar investoriem. Dalı organizāciju ir specializējušās noteiktu nozaru vai ar klimata politikas īstenošanu saistītu tehnologiju jautājumos, daḷa seko līdzi un cenšas 
ietekmēt politiskos procesus, t.sk. starptautiskās klimata sarunas, dal̦a koncentrējas uz sabiedrības vispārīgu informēšanu un izglītošanu u.tml. Latvijā līdz 2015. gada beigām nebija izveidota neviena organizācija, kas darbotos tikai ar klimata politikas jautājumiem, taču atsevišksas organizācijas, piemēram, "Zaḷā brīvība" un "Homo Ecos", klimata politikas jautājumiem tradicionāli pievērsušas diezgan lielu uzmanību.

\section{Literatūra}

Apvienoto Nāciju Organizācijas Vispārējā konvencija par klimata pārmaiṇām: ratificēta ar Latvijas Republikas 23.02.1995. likumu "Par Apvienoto Nāciju Organizācijas Vispārējo konvenciju par klimata pārmaiṇām". Latvijas Vëstnesis, Nr. 37 (320), 09.03.1995.

Apvienoto Nāciju Organizācijas Vispārējās konvencijas par klimata pārmainām Kioto protokols: ratificēts ar Latvijas Republikas 30.05.2002. likumu "Par Apvienoto Nāciju Organizācijas Vispārējās konvencijas par klimata pārmain,ām Kioto protokolu". Latvijas Vēstnesis, Nr. 89 (2664), 13.06.2002.

Climate Action Now: Summary for Policymakers 2015. Bonn: UNFCCC Secretariat, 2015, 66 p.

Climate Change Secretariat. United Nations Framework Convention on Climate Change: Handbook. Bonn: Climate Change Secretariat. 2006, $216 \mathrm{p}$

Compact of Mayors (pieejams: $h$ ttp://www.compactofmayors.org/)

Covenant of Mayors (pieejams: $\left.h t t p: / / w w w . p i l s e t u m e r u p a k t s . e u / i n d e x \_n . h t m l\right)$

Dales J. H. (1968) Pollution, Property and Prices: an Essay in Policy-making and Economics, Toronto: University of Toronto Press, pp. 109-111.

Eiropadome. Secinäjumi par klimata un enerǵétikas politikas satvaru laikposmam lìdz 2030. gadam. Brisele, 23.10.2014. Eiropas Komisija. Baltā grāmata "Adaptācija klimata pārmainām - iedibinot Eiropas rīcības pamatprincipus". Brisele, 01.04.2009. COM(2009) 147.

Eiropas Komisija. Celvedis virzïbai uz konkurētspējigu ekonomiku ar zemu oglekḷa dioksïda emisiju lïmeni 2050. g. Komisijas paziṇojums Eiropas Parlamentam, Padomei, Ekonomikas un sociālo lietu komitejai un Reǵionu komitejai, Brisele, 08.03.2011. COM(2011) 112.

Eiropas Komisija. Pielāgošanās klimata pārmaiñām: ES stratēgija. Komisijas paziñojums Eiropas Parlamentam, Padomei, Ekonomikas un sociālo lietu komitejai un Reǵionu komitejai, Brisele, 16.4.2013. COM(2013) 216.

Eiropas Komisijas 2010. gada 12. novembra regula Nr. 1031/2010 par siltumnīcas efektu izraisošo gāzu emisiju kvotu izsoḷu laika grafiku, administrēšanu un citiem aspektiem saskaņā ar Eiropas Parlamenta un Padomes Direktīvu 2003/87/EK, ar kuru nosaka sistēmu siltumnīcas efektu izraisošo gāzu emisijas kvotu tirdzniecībai Kopienā. Eiropas Savienïbas Oficiälais Vēstnesis, L302, 18.11.2010.

Eiropas Komisijas 2010. gada 7. oktobra Regulas Nr. 920/2010 par standartizētu un drošu reǵistru sistēmu saskaṇā ar Eiropas Parlamenta un Padomes Direktīvu 2003/87/EK un Eiropas Parlamenta un Padomes Lēmumu Nr. 280/2004/ EK. Eiropas Savienïbas Oficiālais Vēstnesis, L270, 14.10.2010.

Eiropas Komisijas 2011. gada 27. aprịla lēmums, ar kuru visā Eiropas Savienībā nosaka pagaidu noteikumus saskanotai bezmaksas emisiju kvotu sadalei atbilstoši 10a pantam Eiropas Parlamenta un Padomes Direktīvā 2003/87/EK. Eiropas Savienïbas Oficiälais Vēstnesis, L130, 17.05.2011.

Eiropas Parlamenta un Padomes 2003. gada 13. oktobra Direktīva 2003/87/EK, ar kuru nosaka siltumnīcefekta gāzu emisijas kvotu tirdzniecības sistēmas izveidi Kopienā un groza Padomes Direktīvu 96/61/EK. Eiropas Savienības Oficiālais Vēstnesis, L 275, 25.10.2003.

Eiropas Parlamenta un Padomes 2004. gada 27. oktobra Direktīva 2004/101/EK, ar ko groza Direktīvu 2003/87/ EK, ar kuru izveido siltumnīcefekta gāzu emisijas kvotu tirdzniecības sistēmu Kopienā, ņemot vērā Kioto protokola projekta mehānismus. Eiropas Savienības Oficiälais Vēstnesis, L 338, 13.11.2004.

Eiropas Parlamenta un Padomes 2008. gada 19. novembra Direktīva 2008/101/EK, ar ko groza Direktīvu 2003/87/ EK, lai aviācijas darbības iekḷautu Kopienas siltumnīcas efektu izraisošo gāzu emisijas kvotu tirdzniecības sistēmā. Eiropas Savienïbas Oficiälais Vēstnesis, L 008, 13.01.2009.

Eiropas Parlamenta un Padomes 2009. gada 23. aprị̄a Direktīva 2009/29/EK, ar ko groza Direktīvu 2003/87/EK, lai uzlabotu un paplašinātu Kopienas siltumnīcas efektu izraisošo gāzu emisiju kvotu tirdzniecības sistēmu. Eiropas Savienības Oficiälais Vēstnesis, L 140, 05.06.2009. 
Ellerman A. D. A Note on Tradable Permits. Environmental \& Resources Economics, Vol 31, 2005. pp. 123-131.

Enerǵētikas attīstības pamatnostādnes 2007.-2016. gadam (informatīvā dala): apstiprināts ar Ministru kabineta 01.08.2006. rīkojumu Nr. 571. Latvijas Vēstnesis, Nr. 122 (3490), 03.08.2006.

Hanley N. D., Shogren J. F. White B. (1997) Environmental Economics in Theory and Practice. UK: Macmillian Press, 464 p. Informatīvais ziṇojums "Par Klimata pārmainu finanšu instrumenta darbību 2014. gadā” (pieejams: http://www. varam.gov.Iv/in_site/tools/download.php?file=files/text/KPFI/lik//KPFI_darbiba_2014_gada.pdf)

Klimata pārmaiṇu samazināšanas programma 2005.-2010. gadam (informatīvā daḷa): apstiprināts ar Ministru kabineta 06.04.2005. rīkojumu Nr. 220. Latvijas Vēstnesis, Nr. 56 (3214), 08.04.2005.

Kossoy A., Peszko G., Oppermann K., Prytz N., Klein N., Blok K., Lam L., Wong L., Borkent B. (2015) State and trends of carbon pricing 2015. Washington, D.C. : World Bank Group, 85 p.

Latvia's National Inventory Report: submission under UNFCCC 1990-2013. (2015) (pieejams: http://www.meteo.IV/ fs/CKFinderJava/userfiles/files/Vide/Klimats/Zin_starpt_org/LV_NIR_2015.pdf).

Latvijas ilgtspējīgas attīstības stratēǵija līdz 2030. gadam: apstiprināta Saeimā 10.06.2010. (pieejams: http://www. latvija2030.Iv/upload/latvija2030_Iv.pdf).

Latvijas Republikas likums "Par Latvijas Republikas dalību Kioto protokola elastīgajos mehānismos": Saeimā pieñemts 08.11.2007. Latvijas Vēstnesis, Nr. 192 (3768), 29.11.2007. (ar grozijumiem līdz 01.01.2011. pieejams: http:// likumi.lv/doc.php?id=167091).

Latvijas Republikas likums "Dabas resursu nodoḳ̣a likums": Saeimā pieṇemts 15.12.2005. Latvijas Vēstnesis, Nr. 209 (3367), 29.12.2005. (ar grozijumiem līdz 22.10.2014. pieejams: http://likumi.lv/doc.php?id=124707).

Latvijas Republikas likums “Latvijas Administratīvo pārkāpumu kodekss": Saeimā pieṇemts 07.12.1984. Ziṇotājs, Nr. 51, 20.12.1984. (ar grozijumiem līdz 06.07.2015. pieejams http://likumi.Iv/doc.php?id=89648).

Latvijas Republikas likums "Par piesārṇojumu": Saeimā pieṇemts 15.03.2001. Latvijas Vēstnesis, Nr. 51 (2438), 29.03.2001. (ar grozijumiem līdz 22.02.2014. pieejams: http://likumi./v/doc.php?id=6075).

Latvijas SEG emisiju 2015. gada prognozes (pieejams: http://cdr.eionet.europa.eu/lv/eu/mmr/art04-13-14_Icds_ pams_projections/envvyqbag/).

Markandya A., Harou P., Bellú L. G., Cistulli V. (2002) Environmental Economics for Sustainable Growth. UK: Edward Elgar \& The World Bank, $568 \mathrm{p}$.

Mayors Adapt (pieejams: http://mayors-adapt.eu/)

Plūdu riska novērtēšanas un pārvaldības nacionālajā programmā 2008.-2015. gadam: apstiprināta ar Ministru kabineta 20.12.2007. rïkojumu Nr. 830. Latvijas Vēstnesis, Nr. 206 (3782), 22.12.2007.

Tietenberg T. H. (2003) The Tradable-Permits Approach to Protecting the Commons: Lessons for Climate Change, Oxford Review of Economic Policy, Vol. 19, No. 3, pp. 400-419.

Vides politikas pamatnostādnes 2004.-2020. gadam (informatīvā daḷa): apstiprinātas ar Ministru kabineta 26.03.2014. rīkojumu Nr. 130. Latvijas Vēstnesis, Nr. 62 (5122), 27.03.2014.

Vides politikas pamatnostādnes 2009.-2015. gadam (informatīvā daḷa): apstiprinātas ar Ministru kabineta 31.07.2009. rīkojumu Nr. 517. Latvijas Vēstnesis, Nr. 122 (4108), 04.08.2009.

Izmantotie attēli un tabulas

11.1. I. Prūse

11.2. Vides aizsardzības un reǵionālās attīstības ministrija

11.3. I. Prūse

11.4. I. Prūse

11.5. I. Prūse

11.6. I. Prūse

11.7. Vides aizsardzības un reǵionālās attīstības ministrija

11.8. Vides aizsardzības un reǵionālās attīstības ministrija

11.9. Vides aizsardzības un reǵionālās attīstības ministrija

11.1. tabula. Ceḷvedis virzībai uz konkurētspējīgu ekonomiku ar zemu oglekḷa dioksīda emisiju līmeni 2050. gadā

11.2. tabula. Vides politikas pamatnostādnes 2014.-2020. gadam 


\section{Ilgtspējīgas attīstības pamati}


Ilgtspējīgas attīstības koncepcija ir ne tikai viedoklis, kā cilvēcei kopumā un arī konkrētai kopienai un sabiedrībai attīstīties, bet galvenokārt uzskatu kopums par to, kāds sabiedrības modelis var nodrošināt tās pastāvēšanu.

Jau no senseniem laikiem cilvēki ir tiekušies veidot sabiedrību ne tikai tā, lai nodrošinātu labumu sev, t.i., konkrētam indivīdam, bet arī tā, lai visa kopiena spētu pastāvēt ilgtermiṇā. Taču no vēstures liecībām ir zināms, ka nereti valstis, kuras pretendējušas uz pastāvēšanu tūkstošiem gadu, ir sabrukušas dažu gadu desmitu laikā.

\subsection{Sociālās pārmaiṇas pasaulē}

Cilvēces attīstība saistībā ar lauksaimniecības un rūpniecības revolūcijas norisēm nav spējusi mainīt ne cilvēku attieksmi pret vidi, ne arī attiecības pašu cilvēku starpā. Tomēr attiecības cilvēks-vide un cilvēks-cilvēks ir l̦oti svarīgas pašreiz un tādas tās būs arī nākotnē. Šīs divas revolūcijas cilvēces vēsturi sadalīja trijās daḷās:

- mednieku-augu vācēju sabiedrības vēsture,

- agrārās sabiedrības vēsture,

- industriālās sabiedrības vēsture.

Šie trīs sabiedrību veidi būtiski atškiras, jo tām bija krasi atškirīga attieksme pret apkārtējo vidi. Tomēr tie nebija secīgi attīstības soḷi, visiem atsakoties no agrāk ierastā un nepieciešamā. Vēl pašlaik pastāv nelielas mednieku-augu

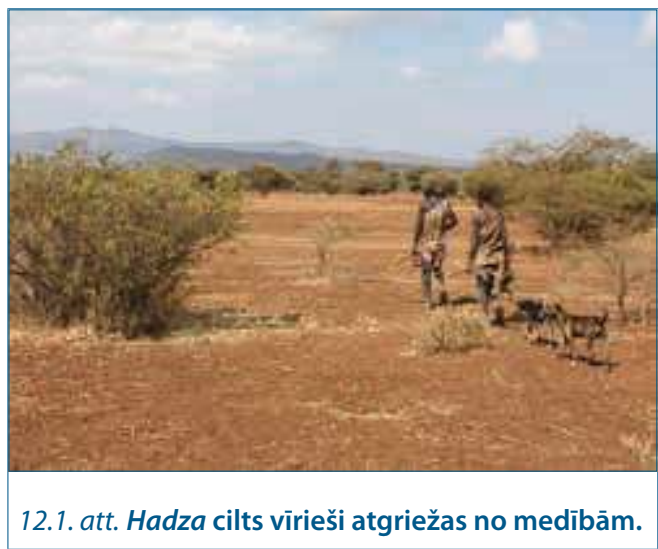

Mums jāapzinās, kādi ir sociāli taisnīgas, vides kvalitāti saglabājošas sabiedrības ilgtspējīgas attīstības pastāvēšanas principi. Jānem vērā, ka sabiedrības attīstības model̦iem pastāv arī ierobežojumi. Ilgtspējīgas attīstības koncepcijas virzība un tās iedzīvināšana ir atkarīga no patēriña un ražošanas model̦iem, planētas spējas nodrošināt telpu, pārtiku, dzeramo ūdeni strauji augošajam iedzīvotāju skaitam, cilvēku darbības ekoefektivitātes un produktivitātes, kā arī no paṇēmieniem un līdzekḷiem nākotnes veidošanai. vācēju kopienas, piemēram, Ju/Hoansi Dienvidāfrikā ( $\approx 34000)$; ache Paragvajā ( $\approx 1500)$; hadza Tanzānijā ( $\approx$ 800); meriami Austrālijā $(\approx 300)$. Meriami jeb Torresa šauruma salinieki joprojām ir mednieki-zvejnieki-augu vācēji, kuri cauri tūkstošgadēm ir izdzīvojuši ǵimeṇu kopienās.

Nebūt nepastāv secīga pāreja no viena veida sabiedrības uz citu, taču pastāv iespēja atgriezties iepriekšējā sabiedrībā. Tomēr tas notiek l̦oti reti, bet tieša pāreja no mednieku-augu vācēju sabiedrības uz industriālo sabiedrību ir neiespējama.

Nav informācijas par agrīnās agrārās sabiedrības dzīvesveidu. Tomēr varētu teikt, ka mednieku-augu vācēju sabiedrība bija pilnībā atkarīga no tā, kas tika nomedīts vai atrasts.

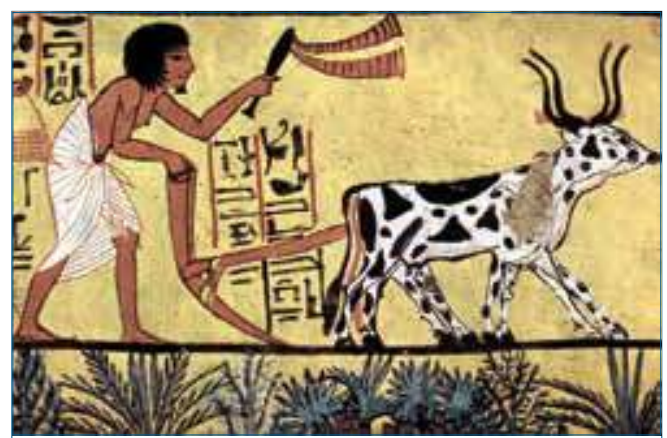

12.2. att. Daudzviet, arī auglīgajās Ėǵiptes zemēs, sāka veidoties agrīnās agrārās kopienas. 
Viņiem nebija iespēju uzkrāt bagātību vai vairot labklājību. Šo sabiedrību var raksturot kā egalitāru - pilnīgi vienlīdzīgu visiem tās locekliem ar kopēju īpašumu (dzīves vidi), kopēju pārtiku un līdzīgu sociālo statusu.

Savulaik marksisti šādu sabiedrību nosauca par "primitīvo komunismu". Kopienas bija nelielas, un tās saistīja radniecība, tomēr darba dalī̌sana nebija izteikta. Apmaiṇa starp indivīdiem balstījās uz savstarpēju izdevīgumu, uzsverot neformālu vadību, personu autonomiju, sadarbību, augstsirdību un līdztiesību. N,emot vērā šìs iezīmes, ir grūti saprast, kāpēc vēlāk kādam iegribējās to visu mainīt.

Agrārās sabiedrības sēja graudus un novāca ražu, t.i., ražoja un uzkrāja pārtiku, kā arī varēja sakrāt citas bagātības - darba rīkus, ieročus, greznumlietas, kas liecināja par labklājības paaugstināšanos. Radās iespēja palielināt kopienas iedzīvotāju skaitu, bet līdz ar to arī sākās darba dalīšana un mainījās sociālā struktūra.

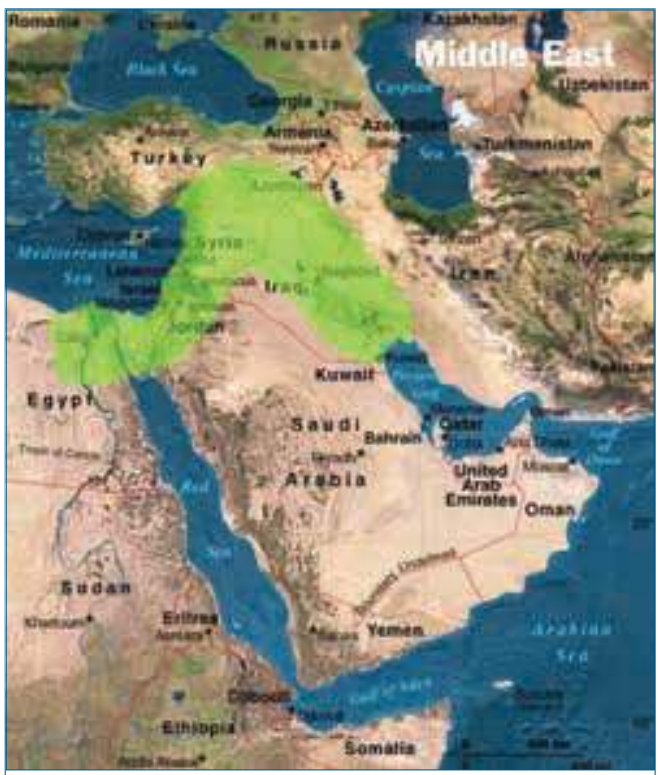

12.3. att. "Auglīgais pusmēness" ir viens no senākajiem centriem, kurā notika pāreja uz jauno saimniecibas veidu. Tas aptver plašas teritorijas Tuvajos Austrumos - mūsdienu Turciju, Izraēlu, Irāku, Irānu, Sīriju un dal̦ēji Éǵipti. Šiss teritorijas ir izvietotas it kā puslokā, tāpēc to dēvē par "auglīgo pusmēnesi".
Tomēr pēc kāda laika izveidojās stāvoklis, kad izteikti lielākā daḷa sabiedrības locekḷu bija spiesti nodrošināt ar produktiem un pakalpojumiem nelielu, elitāru kopienas grupu. Vēlāk sāka veidoties arī valdošā šksira un vairāk zinošo slānis. Tas kopumā radīja pamatus jaunai sociālai kārtībai.

Lai saṇemtu drošību un aizsardzību, zemākajai šķirai nācās par to maksāt ar savu darbu, saražotiem produktiem un pakalpojumiem. Kopumā agrārā sabiedrība bija zināmā mērā stagnanta, nomākta, kurā dominēja zobens un māṇticība.

Atšķirībā no agrārās sabiedrības industriālās sabiedrības balsts ir nevis atsevišksas inovācijas, bet gan būtiski zinātniski atklājumi, kas l̦auj risināt jaunā laikmeta problēmas.

Atklājumi lauksaimniecības nozarē bija samazinājuši roku darba nepieciešamību, paverot iespējas citām jomām. Darba ražìgums strauji auga, pastāvīgi mainījās profesiju struktūra. Tas nodrošināja aizvien augošā tirgus vajadzības. Vara bija pārgājusi lielražotāju rokās. Prasības indivīdiem sāka diktēt tirgus principi.

Agrāko īpašnieka-padotā sistēmu ir nomainījusi centralizēta un hierarhiska birokrātija, bet valsts ir monopolizējusi likumīgas varas tiesības. Savukārt iedzīvotājiem relatīvi reti ir kaut kas jādara piespiedu veidā. Tomēr būtisks izṇēmums ir starptautiski brun,oti konflikti, kā arī disidentiska, alternatīva rīcība, vienpusēja politiska vardarbība, organizēti noziegumi. Legitimitāti vairs nenosaka reliǵiskie uzstādījumi vai rituāli, bet gan ritualizēta sacensība. Tās

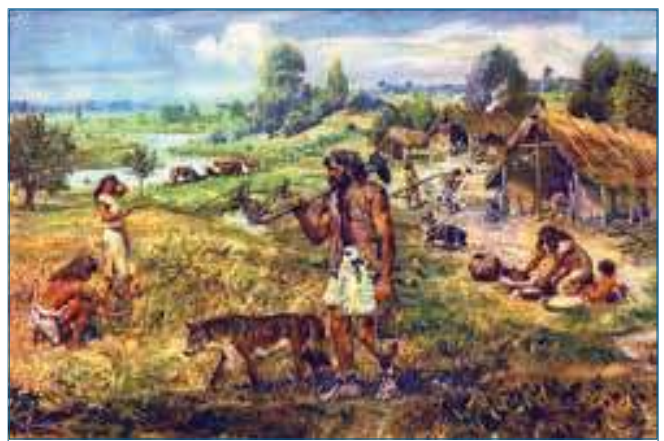

12.4. att. Mednieku-augu vācēju sabiedrības transformācija par agrāro sabiedrību. 


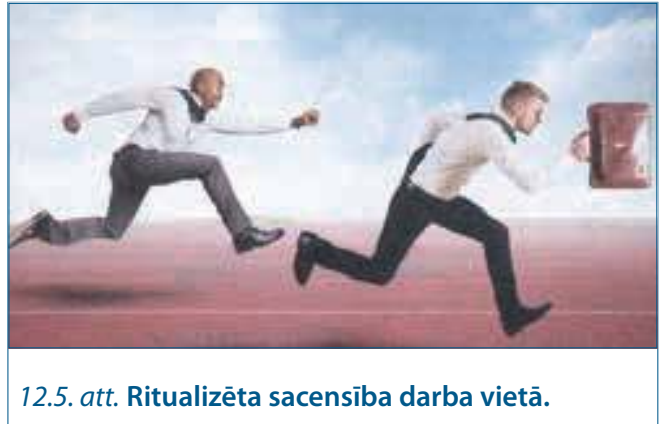

piemēri ir vispārējās vēlēšanas, īpašuma izsole vai darba piedāvājumu konkursi.

No šo lielo transformāciju norisēm kḷūst skaidrs, ka ir notikušas būtiskas sociālas pārmaiṇas, tāpēc arī nākamās pārejas sabiedrība būs principiāli atšksirīga no tagadējās.

Iepriekšējās pārejas nenotika vienlaikus visā pasaulē. Arī nākamā pāreja droši vien sāksies kādā vienā vietā, kur būs savijušies visi nepieciešamie priekšnoteikumi un radusies pārliecība, ka pārmaiṇas sniegs ilgtermiṇa priekšrocības. Maz ticams, ka šādu pārejas sākumu varētu izplānot un īstenot mākslīgi. Neviens arī priekšlaikus nevar saskatīt visu nākotnes ainu kopumā.

Jārēksinās arī ar stāvokli, kad par iedzīvotājiem un kopienām atbildīgās institūcijas un organizācijas piedāvā viedokli, kas tiek pasniegts kā absolūts un pašsaprotams, bet neatspogulo patieso stāvokli un ir pat maldīgs attiecībā uz nākotnes perspektīvām. Reizēm tiek veidota aizsardzības sistēma, lai šāds viedoklis netiktu apšaubìts. Tas lielā mērā attiecas arī uz pašreizējām sarunām pasaules mērogā.
Lai samazinātu klimata pārmaiṇas, notiek vienošanās par SEG emisiju tirdzniecību, piemērojot vispārīgos tirgus principus. Taču kapitālisma tirgus dominējošie principi tiek reti pārbaudīti reālā procesu norisē un nav pārliecības, ka vēlamais efekts tiks panākts nākotnē.

Mūsu atrašanās vieta pārejas perioda skalā nav precīzi nosakāma. Paliekot pašreizējās domāšanas veida un pazīstamo modelı ietvaros, mēs varētu būt zaudētāji pat ne tik tālā nākotnē. Ir svarīgi izprast iepriekšējo lielo pāreju sociālās izmaiṇas, lai nākotnē mēs šajās pārejās nepiedzīvotu neveiksmes.

Mēs esam "iekarojuši" paši savu planētu. Ne tikai tāpēc, ka esam iekārtojušies visos tās stūrīšos, bet arī tādā ziṇā, ka arvien pastiprinām ietekmi uz visām planētas dzīvību nodrošinošām sistēmām. Mēs esam nonākuši jaunā ǵeoloǵiskā periodā - antropocēnā (laikmetā, kam raksturīga pastiprināta cilvēka darbības ietekme uz ekosistēmām, kuras rezultātā izmirst un ir izmirušas daudzas augu un dzīvnieku sugas, mainās reljefs un ainavas), tādējādi apliecinot, ka cilvēces iedarbība uz vidi jau kluvusi līdzvērtīga ǵeoloǵiskajiem dabas spēkiem. Pašlaik cilvēce destruktīvi iedarbojas uz apkārtējo vidi. Cilvēki tūkstošgadu vēsturē kopumā ir bijuši veiksminieki, neraugoties pat uz impēriju bojā eju. Tomēr mēs vēl neesam apzinājušies un izpratuši, kā atrisināt pašreizējās un arī nākotnes problēmas, lai saglabātu dzīves vidi.

Vienīgais, ko mēs varam izdarīt, ir skaidri apjaust, kas varētu notikt un ar kādu varbūtību, un kādas sekas tam varētu būt. Mums vajadzētu apkopot visas zināšanas un pieredzi, lai pien,emtu optimālus lēmumus ilgtspējīgai nākotnei.

\subsection{Pasaules ekonomiskā attīstība}

\subsubsection{Ekonomiskā izaugsme}

Iedzīvotāju skaita pieaugums ir tikai viens no faktoriem, kas ietekmē ekonomisko izaugsmi, bet tas ir l̦oti būtisks faktors.

Cilvēki pārvietojās uz katru apdzīvojamu planētas nostūri. Meži un purvi tika pārvērsti par lauksaimniecības zemēm. Apdzīvotu vietu, vēlāk, pilsētu skaits sāka strauji augt. Pašlaik nelielu cilvēku grupu bāzes ir pat polos un kosmosa stacijās.

Tā kā cilvēku skaits pastāvīgi palielinās, pieaug arī patērēto dabas resursu apjoms, jo jānodrošina patēriņš, jāizgatavo ražošanas rīki, 
mašīnas utt. Nepārtraukti jāievieš jauni izgudrojumi, taču tas prasa lielus vides resursus un galu galā uz vidi iedarbojas destruktīvi.

Cilvēki vienmēr ir centušies uzlabot materiālās dzīves līmeni. Tāpēc pieaug arī enerǵijas patērinšs. Mēs esam liecinieki tam, ka strauji izplatās informācijas un komunikāciju tehnologijas, notiek tirdzniecības tīklu konsolidācija (sablīvēšanās) un ir sācies patiesi fenomenāls naudas vairošanas pieaugums, un naudas plūsma kḷūst aizvien intensīvāka.

Šie procesi rada priekšnoteikumus straujām izmaiṇām apkārtējā vidē.

\subsubsection{Ekonomikas izaugsmes pirmsākumi}

Vēsturiski pastāv daudz izškirošu pagrieziena punktu, kas ir ietekmējuši ekonomikas izaugsmi. Tādi, piemēram, bija eiropiešu jūras braucēju atklājumi un kolonizācija Ziemel̦amerikā un Dienvidamerikā, feodālisma sabrukums Eiropā, komerctirdzniecības veidošanās, jauno tehnoloǵiju izplatī̌̌anās.

Lai izprastu lielā paātrinājuma parādību, ir lietderīgi to sasaistīt ar reāliem notikumiem vēsturē. Par paātrinātas ekonomiskās izaugsmes pirmo pagrieziena punktu un simbolisku "starta šāvienu" uzskata Kalifornijas "zelta drudzi”, sākot no 1849. gada.

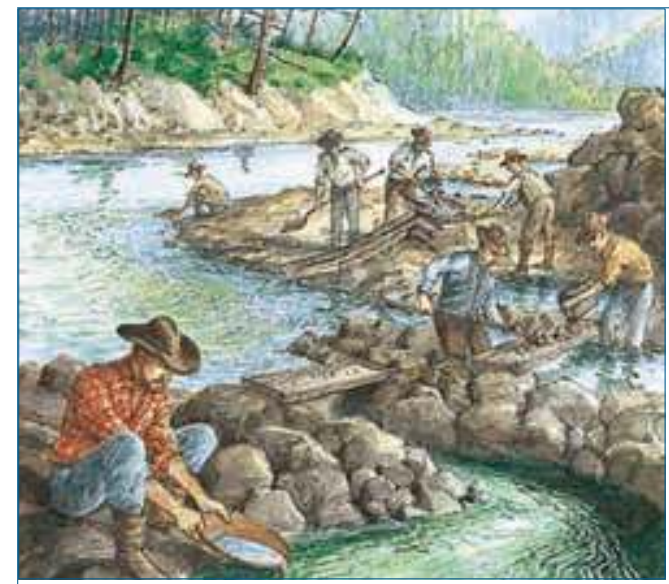

Kalifornijas zelta drudzim ir simboliski svarīga un vēsturiska nozīme izaugsmes procesā, jo tas notika eiropiešu Amerikas ekspansijas beigās, ko daudzi vēsturnieki atzīst par Eiropas kolonizācijas kustības beigām kopumā. Pēc tam bija palikusi vairs visai maza planētas daḷa ar samērā mērenu un patīkamu klimatu, uz kurieni cilvēki, neatkarīgi no to izcelsmes, varētu migrēt. Gandrīz visas labākās vietas jau bija aiznemtas.

Kalifornijas zelta drudzis iezīmēja pēdējo vēsturisko brīdi, kad cilvēki brīvi varēja doties uz vietu, kur viṇi varēja iegūt zeltu. Zelts jau izsenis ir vēlamā valūta (maksāšanas līdzeklis) daudzās ekonomikas sistēmās neatkarīgi no tā, vai pastāv citas valūtas sistēmas.

Pārējos resursus, piemēram, naftu, kokmateriālus, zivis, labību, bija jāpērk vai jāpārdod, t.i.., jātransformē naudā, kas tika lietota konkrētā sabiedrībā, lai šie resursi dotu iespēju gūt ekonomisku labumu. Plaša mēroga bartera darījumi bija pārāk sarežǵîti, lai pārvērstu mantu naudā, tāpēc bija nepieciešama monetāra ekonomiskā sistēma.

Šādu iespēju varēja izmantot, arī pārdodot zeltu, bet praktiski tas bija nevajadzīgi, jo zelts arī bija nauda. Tā, piemēram, Indijā cilvēki joprojām izvairās no bankām un "valkā savu naudu" - zelta aproces, kaklarotas un citas rotaslietas. Centieni pārliecināt šos cilvēkus pārdot savu zeltu un pārvērst to par monetāru bankas

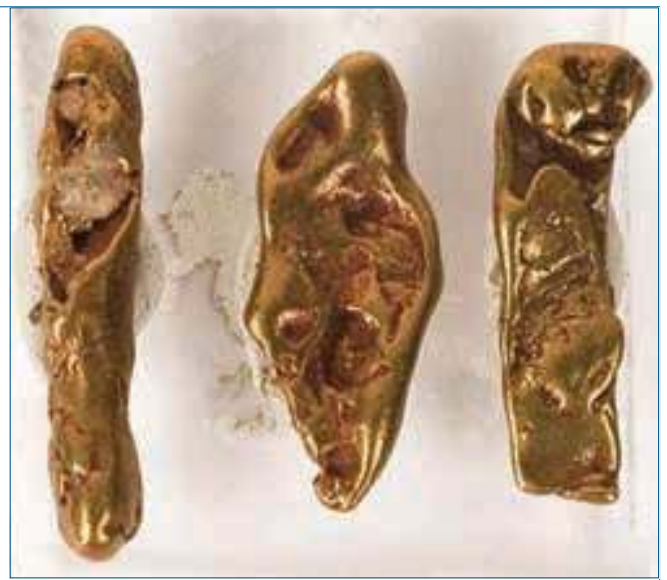

12.6. att. Zelta skalošana un zelta tīrradņi. 
kontu sastop spītīgu pretestību pat ne tik bagātu cilvēku vidū.

Dažās valstīs valdības joprojām aktīvi aicina cilvēkus "likt zeltu bankā" - pārvērst par naudu, lai uzlabotu nācijas bilanci.

Pasaules finanšu tirgos zelts joprojām tiek izmantots īpaši. Kad akciju un obligāciju tirgos rodas problēmas, cilvēki raugās uz zeltu kā stabilāku uzkrājumu līdzekli.

Kaut gan zelta kā naudas izmantošana joprojām pastāv, Kalifornijas zelta drudzis iezīmēja galu vēsturiskajam periodam, kam bija raksturīga impēriska paplašināšanās, balstoties uz zeltu.

19. gs. beigās, kad būtībā visas zemes jau bija aizn,emtas, bet zelta un citi resursi jau bija sadalīti starp valstīm, uzmanība tika pievērsta procesiem, lai resursus izmantotu monetārās ekonomiskās aktivitātes celšanai. Cilvēki lielu uzmanību sāka pievērst ekonomiskai izaugsmei, kad no uzkrātiem izejvielu resursiem (zeme, metāli, koksne), izmantojot dažādus procesus, tika iegūtas lietas, kam bija jauna vērtība, ko varēja pārvērst naudā. Taču šĩ izaugsme vienmēr ir saistīta ar vides un morāles degradāciju.

\subsubsection{Energ̉ētikas un tehnoloǵiju revolūcija un tās sekas}

Energeētikas un tehnoloǵiju revolūcija sākās 19. gadsimta beigās. Tika iegūta nafta, deggāze un ogles, kuras sāka izmantot arī elektroenerǵijas ražošanā. Tādējādi pasaules ekonomika lielos apmēros varēja kāpināt ražošanu - tas attiecas gan uz papīra ražošanu, kokvilnas un vilnas apgērbu aušanu, gan metālu iegūšanu no rūdām utt.

20. gs. sākumā strauji attīstījās mašīnbūve. Piemēram, Ford automobilis tapa, iespējams, pateicoties arī Henrija Forda jaunievedumiem, konveijera līnijas ieviešanai un jaunai darbinieku atalgošanas sistēmai, kas pamatojās uz automobilı vērtībai proporcionālu atalgojumu.

No 1916. līdz 1917. gadam vairāk nekā 780000 automobilı tika pārdoti par pazeminātu cenu - 350 dolāriem, jo Henrijs Fords strukturēja savu uzñēmumu tā, lai viṇa autorūpnīcu darbiniekiem būtu tik daudz naudas, lai tie varētu ațauties nopirkt auto un, turpinot darbu, spēt atmaksāt aizdevumus.

Radās arī daudz problēmu un konfliktu. Strādnieku neapmierinātības dēl tika nodibinātas arodbiedrības. Notika arī briesmīgi un groteski gadījumi rūpnieciskajās pārtikas apgādes sistēmās. Šai sakarā īpaši ietekmīgs 20. gs. pirmajā pusē kḷuva amerikānu rakstnieks Aptons Sinklers. Viņš tika uzskatīts par vienu no labākajiem pētnieciskās žurnālistikas pārstāvjiem ASV. Kḷuva slavens, 1906. gadā publicējot romānu "Džunglil", kura ietekmē pat tika mainīta ASV pārtikas rūpniecības likumdošana.

Jāpiemin arī bēdīgi slavenās Čikāgas lopkautuves, kurās 19. gadsimta beigās strādāja vairāk nekā 25000 darbinieku (sievietes un bērnus ieskaitot), kuri apgādāja aptuveni 80\% ASV iedzīvotājus ar galı.u.

Cīña par varu, precēm un resursiem izraisīja asus politiskus strīdus. Tas zināmā mērā bija priekšvēstnesis 1. pasaules karam, kas prasīja šausminošus zaudējumus gan attiecībā uz cilvēkiem, gan arī uz vidi.

Taču, raugoties no ekonomiskās izaugsmes perspektīvām, karš, diemžēl, tās ietekmē pozitīvi.

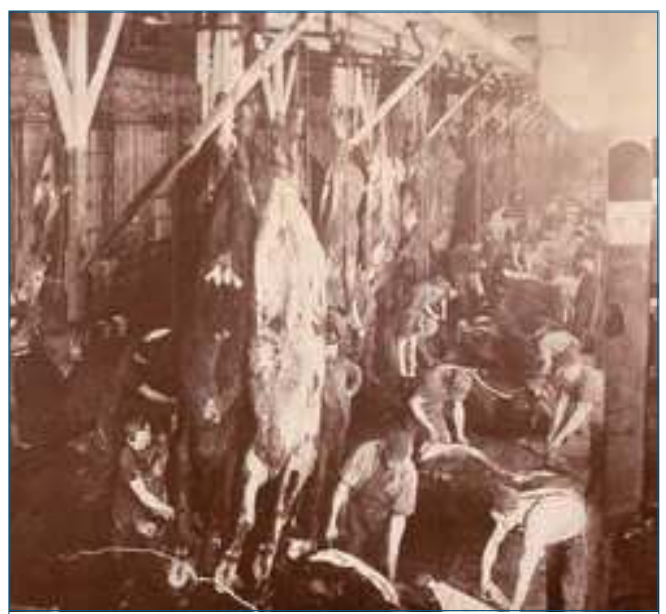

12.7. att. Čikāgas lopkautuves. 


\subsubsection{Izaugsme un kari}

Lai arī pastāv daudzas interpretācijas gan par 1. pasaules kara, gan 2. pasaules kara cēloniem un virzības faktoriem, tomēr ir skaidrs, ka šīs 20. gadsimta pasaules mēroga katastrofas vismaz dậeji virzīja tā laika vērienīgā impēriju un nacionālo valstu nepārvarama vēlme pēc ātras ekonomiskās izaugsmes. Tas nozīmē, ka ekonomiskai izaugsmei ir nepieciešama energija, zeme, izejvielas, tehnologijas, tirdzniecības un investīciju sistēma.

Impēriju veidošanās procesu, kas ierakstīts cilvēces vēsturē, vienmēr ir vadījusi politiskā vīzija par nepārtrauktu un ātru ekonomikas paplašināšanos. 20. gadsimta pasaules karu iespējamību virzīja modernās tehnoloǵijas un destruktīvie impērijas veidotāji. Tehnologijas bija atkarīgas no piekḷuves milzīgam daudzumam enerǵijas resursu. Tāpēc daži mūsdienu komentētāji interpretē, ka galvenās kaujas darbības 2. pasaules karā (Japānas ekspansija Dienvidaustrumāzijas virzienā, Vācijas iebrukums Krievijā un ASV pozīcijas nostiprināšana Atlantijas un Klusajā okeānā) bija saistītas ar nepieciešamību kontrolēt galvenos resursus, piemēram, naftu.

Daudzi vēsturnieki atzīmē, ka dziḷā ekonomikas depresija, ko piedzīvoja industrializētā pasaule 20. gs. 30. gados, beidzās tikai ar industriālo valstu iesaistīšanos karos. Kad kara vajadzībām valsts investē milzīgas summas, lai izstrādātu jaunas tehnologijas un attīstītu rūpniecisko ražošanu, ikviens tiek iesaistīts darbā. Daži pat atzīmē, ka pasaules ekonomika turpina attīstīties kara laika režīmā līdz pat mūsdienām. To apliecina gan aukstais karš, gan pašreizējie kari pret teroristiem.

Karš ir izrādījies par vienu no veidiem, lai pasaulē nodrošinātu būtisku ekonomikas izaugsmi un iekšzemes kopprodukta (IKP) palielināšanos. Ja IKP skaitliskā vērtība kḷūst lielāka, var teikt, ka notiek ekonomiskā izaugsme, ja kḷūst mazāka, runā par lejupslīdi, bet, ja lejupslīde turpinās ilgāku laiku, ir iestājusies "depresija”.

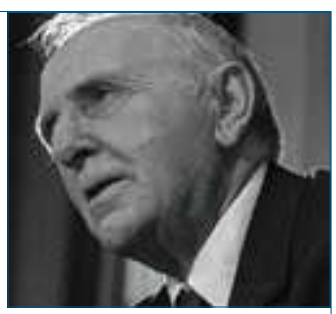

12.8. att. Saimons Kuznecs, 1971. gada Nobela prēmijas ieguvējs (Zviedrijas Centrālās bankas Alfrēda Nobela balva ekonomikas zinātnēs).

IKP kā indikatoru sākotnēji radīja amerikāṇu ekonomisti, lai palīdzētu ASV valdībai tikt galā ar 20. gs. 30. gadu ekonomisko depresiju. Taču IKP izgudrotājs Saimons Kuznecs bija noraizējies, ka viṇa izgudrojums varētu tikt izmantots l̦aunprātīgi. Par to viṇš ziṇoja ASV Kongresam jau 1934. gadā, brīdinot, ka jauno valsts ekonomikas statistiku nedrīkst izmantot, lai novērtētu kopējo tautas labklājību. 1960. gadā viṇš brīdināja, ka jāpatur prātā atšksirība iedalījumam starp izaugsmes kvantitāti un kvalitāti, starp tās izmaksām un atdevi, kā arī starp izaugsmi īstermiṇā un ilgtermiṇā (..); izvirzot mērḳi lielākai izaugsmei, ir jāapsver "tieši kādai izaugsmei" un "kāpēc".

Taču IKP izgudrotāja brīdinājumi tika pilnībā ignorēti. Pasaules finanšu un ekonomikas sistēmas auga, IKP kḷuva par arvien nozīmīgāku esošās ekonomiskās sistēmas panākumu rādītāju. Starptautiskie finanšu līgumi un politiskās kampaṇas koncentrējas uz izaugsmi. ANO rādītāji, kas atspoguḷo valstu sociālekonomisko statusu, regulārie ziņojumi par IKP pieaugumu, valstu plašsaziṇas līdzekḷi, kas slavina ekonomisko izaugsmi, nostiprina IKP dominanti un aizvien dziḷāku lēmumu pieṇēmēju atkarību no šī indikatora gandrīz visur.

Ja kāds izmanto tikai IKP datus kā "uzvaras karogu", civilizācija droši virzās uz sabrukumu. Tikai meklējot un izmantojot vēl arī citus indikatorus, mēs varam saprast, ka ekonomiskā izaugsme nes sev līdz arī augošas negatìvas sekas. 


\subsection{5. "Izaugsme kā parasti"}

Sākot ar 20. gs. 50. gadiem izaugsmes līknes daudziem ekonomiskiem rādītājiem strauji pieauga. Tas attiecās ne tikai uz IKP, bet arī uz cilvēku skaita, dabas resursu izmantošanas straujo pieaugumu. Iestājās raksešu un kosmosa izpētes laikmets, kam par cēloni varēja būt arī aukstais karš starp kapitālistiskajiem Rietumiem un komunistiskajiem Austrumiem. Konkurējošās pasaules ekonomiskās un politiskās sistēmas, ko vadīja ASV un PSRS, ieguldīja milzīgus līdzekḷus zinātnē, ražošanā, kā arī izglītībā, kas bija nepieciešama tehnologiskajam progresam un sacensībai starp divām lielvarām.

Rietumu valstis veicināja aizvien komercializētāku dzīvesveidu, lai pierādītu, ka Rietumu modelis ir labāks nekā valsts kontrolēta vardarbīgā "vienlīdzība". Rezultātā bija iespaidīgs pieaugums visās jomās: vairāk cilvēku, vairāk ražošanas un patērin, vairāk naudas un strauja tehnoloǵiju izstrāde. Izaugsme nebija apšaubāma. Atskanēja arī brīdinājumi no zinātniekiem un rakstniekiem. Vairākums no tiem bija amerikāṇi. Tā, piemēram, Reičela Kārsone (Rachel Carson) 1962. gadā izdotajā grāmatā "Klusais pavasaris" izvirzijja iebildumus par pesticīdu pārmērīgo izmantošanu un uzsvēra pesticīdu negatīvo ietekmi uz cilvēka veselību

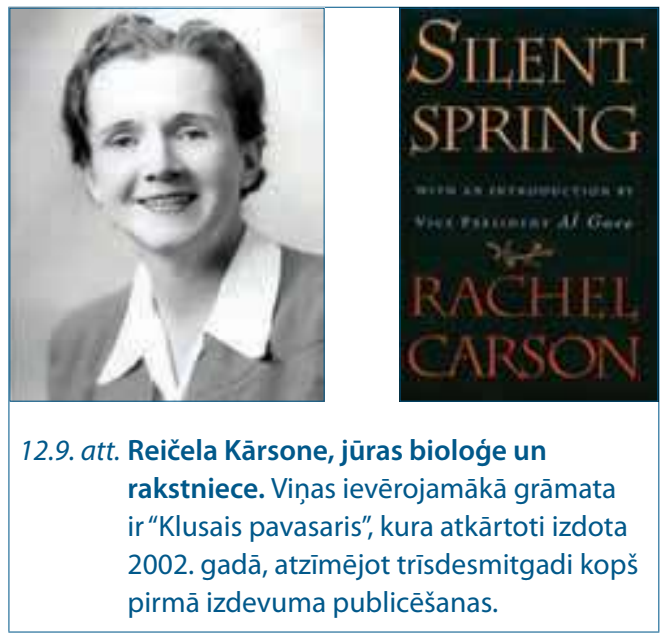

un ekosistēmām. Kaut gan zinātnieku aprindās R. Kārsones darbs tika kritizēts kā pārāk emocionāls, šobrīd gandrīz visi viṇas grāmatā minētie pesticīdi ir aizliegti.

\subsubsection{Globālās diskusijas par izaugsmi}

Vēsturiski 1972. gads iezīmējās kā pavērsiena punkts. Tas bija gads, kad kosmosā pacēlās pēdējais kosmosa kuǵis "Apollo". Pēc tam ASV Mēness izpētes programma tika apturēta valsts budžeta spiedīgo problēmu dēḷ.

Cilvēki sāka saprast, ka Zeme ir mūsu vienīgās mājas. Mēs nevaram izglābties aiz tās robežām un atrast jaunas planētas vai to pavadoņus, kas būtu apdzīvojami tuvākajā laikā.

1972. gads iezīmējās arī ar ANO pirmo globālo cilvēkvides konferenci Stokholmā, kurā tika izteikti daudzi brīdinājumi par planētas nākotni. Stokholmas konference šobrīd tiek uzskatīta par sākuma punktu pasaules augstākā līmen,a sanāksmēm par vides un attīstības jautājumiem.

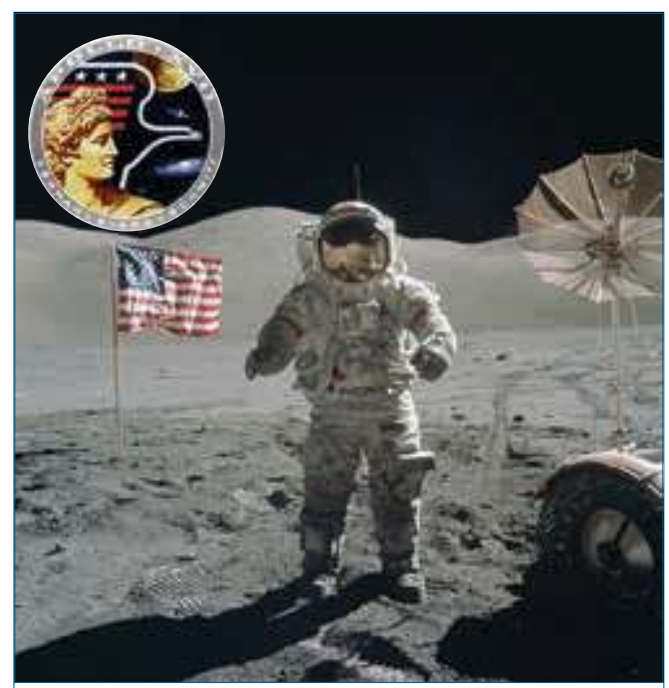

12.10. att. Eižens Kernans (Eugene Cernan) uz Mēness virsmas 1972. gada 13. decembrī. 
1972. gadā tika izveidotas pirmās vides ministrijas un pieñemti pirmie visaptverošie vides likumi ASV un vairākās Eiropas valstīs.

Taču neviens cits notikums tik īpaši neatspoguḷo 1972. gada nozīmi vēsturē, kā Romas kluba un Masačūsetas Tehnologiskā institūta pētijjums "Izaugsmes robežas" (The limits to growth). Šī revolucionārā grāmata ziṇoja par pētījumu, kas izmantoja datormodelēšanu, lai atrastu kopsakarības starp pasaules iedzīvotāju skaita pieaugumu, rūpniecisko ražošanu, resursu izmantošanu un piesārņojumu. Tās autori brīdināja par nopietnām resursu un vides problēmām nākotnē, ja cilvēki turpinās savu pašreizējo kursu.

Grāmata "Izaugsmes robežas" tika pārdota miljonos eksemplāru, bija publikācijas simtiem laikrakstos un žurnālos. Pasaulē sākās debates par ilgtermiña perspektivvas ekonomikas izaugsmes iespējām, un šīs debates turpinās līdz pat šai dienai.
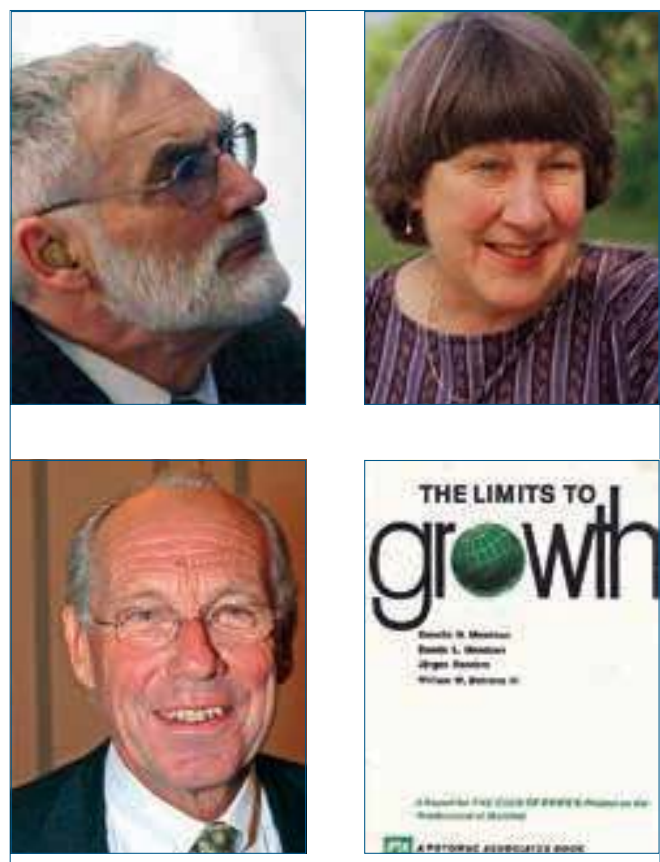

12.11. att. Grāmatas "Izaugsmes ierobežojumi" autori - Deniss Medouzs un Donella Medouza (augšējā rindā), un Jorgens Randers.

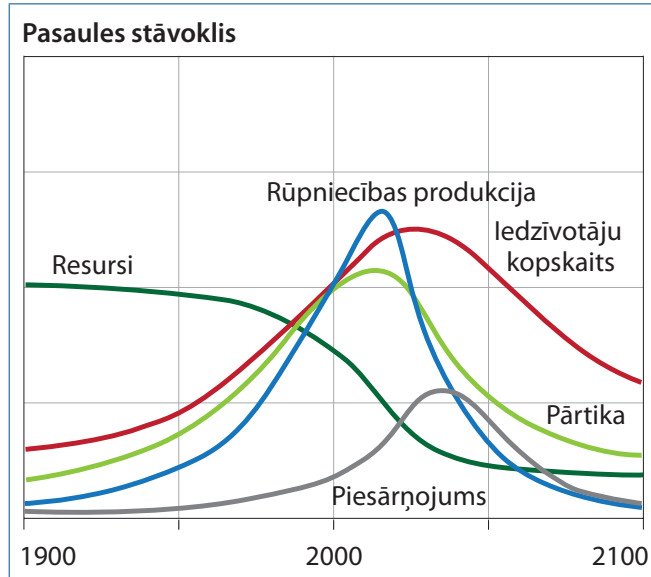

Materiālā labklājība

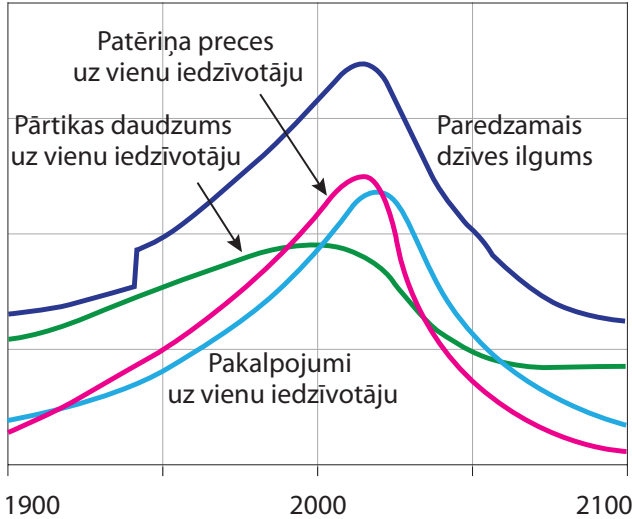

Cilvēces labklājība un "ekoloǵiskā pēda"

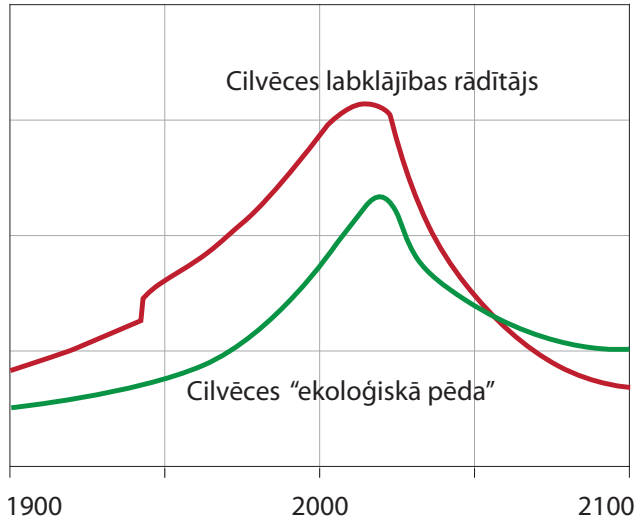

12.12. att. Cilvēces attīstībai raksturīgo rādītāju mainība simtgadēs. 


\subsection{Izaugsmes robežas}

\subsubsection{Izaugsme un sabiedrības attīstība}

Cilvēces attīstību 20. gadsimta laikā raksturo iedzivvotāju skaita, ražošanas un patēriņa eksponenciāls pieaugums un daudzu procesu globalizācija. Protams, ne viss pieaug ar vienādu ātrumu, piemēram, pasaules naftas patēriňš nedaudz samazinās, bet dabasgāzes patērinšs palielinās.

Pārmaiṇu ātrumi ir atšksirīgi, bet kopējā tendence - izaugsme - turpinās. Pasaules iedzīvotāju skaits ir sācis palielināties eksponenciāli kopš industriālās revolūcijas sākuma. Pasaules rūpniecības produkcijas daudzums parāda eksponenciālas izaugsmes tendences, pat neñemot vērā izmaiṇas, ko radīja pasaules naftas cenas svārstības un ekonomiskā krīze. Arī piesārṇojošo vielu emisijas apjomi palielinās un globālās klimata izmaiṇas ir sekas og̣̣skābās gāzes koncentrācijas pieaugumam atmosfērā.

Sabiedrība izaugsmi nereti vērtē kā sasniegumu. Daudzas kopienas un tautas, bagātas vai nabadzīgas, meklē iespēju paplašināt savu darbību, lai varētu atrisināt svarīgākās problēmas. Bagātajā pasaulē ekonomiskās izaugsmes nepieciešamību pamato ar vajadzību radīt darbavietas, nodrošināt sociālo aizsardzību. Nabadzīgās valstīs ekonomikas attīstība ir vienīgais celšs, lai izrautos no trūkuma. Kamēr nav atrasts cits risinājums pasaules problēmām, cilvēki uzskatīs ekonomikas attīstību par galveno cel̦u uz laimīgu nākotni un darīs visu, lai veicinātu izaugsmi.

Diemžēl izaugsme ne tikai spēj atrisināt vairākas problēmas, bet diemžēl rada arī jaunas. Zeme nav bezgalīga ne telpas ne resursu zin̄ā. Taču iedzīvotāju skaits, arī saražoto preču apjoms un reizē ar to piesārn,ojuma līmenis joprojām turpina palielināties.

Sabiedrība un ekonomika ir atkarīga no gaisa, ūdens, pārtikas, izejvielām un kurināmā. Izaugsmes ierobežojumi faktiski ir globālo resursu ierobežojumi un planētas ierobežotā spēja tikt galā ar lielo atkritumu masu un piesārn,ojumu.
Daudzas cilvēku darbības, sākot no minerālmēslu izmantošanas līdz pilsētu attīstǐšanai, ir eksponenciāli augošas, un tās var aprakstīt ar konkrētām līknēm. Eksponenciālā augsme ir virzošais spēks, kas izraisa sabiedrības ekonomikas tuvošanos planētas fiziskajām robežām. Eksponenciālais pieaugums, kas škietami ir tik vienkāršs, var sniegt pārsteidzošas atklāsmes.

Iedzīvotāju skaits un kapitāls ir tie dzinēji, kas nodrošina industrializētās pasaules izaugsmi. Citi lielumi - pārtikas ražošana, resursu izmantošana un piesārn,ojums arī tiecas augt eksponenciāli. Tādējādi pārtikas ražošana, resursu un enerǵijas izmantošana palielinās nevis to struktūras ietilpības dēl, bet tāpēc, ka eksponenciāli augošais iedzīvotāju skaits pieprasa arvien vairāk pārtikas, materiālu un enerǵijas.

Ražošanas kapitāls ietver iekārtas, aparatūru, mašīnas un rūpnīcas, kas ir nepieciešamas, lai iegūtu produkciju, izmantojot darbaspēku, enerǵiju, izejvielas, zemi, ūdeni, tehnologijas un mūsu planētas dabiskās ekosistēmas.

Kapitāla mainību var raksturot eksponenciālā izaugsme, eksponenciālā samazināšanās vai dinamisks līdzsvars. Tāpat kā iedzīvotāju skaits ir pakḷauts demogrāfiskām izmaiṇām, arī ekonomika ir pakārtota ilgtermiṇa pārmain,u procesam. Ražošanas kapitāls aug eksponenciāli, taču ātrāk par iedzīvotāju skaitu.

Laika posmā starp 1970. un 2010. gadu ražošanas apjoms ir palielinājies gandrīz par $100 \%$. Tādai izaugsmei pasaulē būtu vajadzējis radīt divas reizes lielāku rūpniecības preču daudzumu uz vienu iedzīvotāju, ja vien iedzīvotāju skaits būtu palicis nemainīgs. Tomēr, augot arī iedzīvotāju skaitam, vidējais rūpniecības preču daudzums uz vienu iedzīvotāju ir palielinājies tikai par trešdalıu.

Ja kapitāla daudzums aug ātrāk par iedzīvotāju skaitu, tad atbilstoši demogrāfiskās pārejas teorijai tam vajadzētu nozīmēt, ka materiālā dzīves līmeña celšanās samazinātu iedzīvotāju skaita palielināšanās ātrumu. Zināmā mērā un dažās vietās tā patiešām notiek. Bet ne ekonomiskā izaugsme, ne tās demogrāfiskā pretdarbība nenotiek pietiekami ātri. Dažos gadījumos 
šîs ietekmes pat veicina viena otru. Tāpēc ekonomiskā labklājība samazinās, bet iedzīvotāju skaits ir pastāvīgs vai augošs. To nosaka ražošanas produkcijas sadales veids.

Lai arī kopumā pasaulē visos cilvēka darbības sektoros ir notikusi milzīga attīstība, tomēr sociālo problēmu klāsts gadu no gada kḷūst satraucošāks:

- katru gadu pasaulē no viegli novēršamām slimībām mirst vairāk nekā 2 miljoni bērnu, kas jaunāki par 5 gadiem;

- katru dienu pasaulē 6000 bērnu mirst no slimībām, kas saistītas ar tīra dzeramā ūdens trūkumu vai sliktiem sadzīves apstāklıiem;

- ap 2 miljardiem cilvēku dzīvo bez elektrības, vēl 2 miljardiem tā ir nepietiekamā daudzumā;

- kopš 1985. gada no AIDS 25 valstīs ir miruši vairāk nekā 7 miljoni cilvēku;

- no 1,2 miljardiem cilvēku, kuri dzīvo ārkārtējā nabadzībā, apmēram 900 miljoni mitinās lauku rajonos, bet vinu izdzīvošana ir tieši atkarīga no biologiskās daudzveidības, ūdens piesārṇojuma un augsnes degradācijas.

Seviški izteikta ir pasaules sabiedrības ekonomiskā noslān,ošanās. Dabas resursu un cilvēku saražoto materiālo un nemateriālo labumu sadales veids ir padarījis cilvēkus gan l̦oti turīgus, gan galēji nabadzīgus. Pēc Pasaules Bankas aprēksiniem, vienai piektdal̦ai pasaules iedzīvotāju jeb vairāk nekā miljardam cilvēku vidējie ienākumi ir mazāki par 0,75 eiro dienā. 70\% no šiem cilvēkiem ir sievietes.

Pasaules 20 bagātākās valstis pārsvarā ir Ziemel̦amerikā un Rietumeiropā. Šajā grupā ietilpst arī Japāna, Singapūra, Austrālija, Jaunzēlande, Apvienotie Arābu Emirāti un Izraēla, un tajās dzīvo apmēram viena piektdalı pasaules iedzīvotāju. Vairāk nekā trīs miljardi iedzìvotāju dzīvo nabadzīgākajās valstīs Âfrikā un Āzijā. Plaisa starp šīm divām pasaulēm arvien palielinās. Gada ienākumu līmenis vienam iedzìvotājam no pasaules bagātākajām valstīm vidēji ir vairāk nekā 100 reizes lielāks nekā vidēji iedzīvotājam valstī ar zemu ienākumu līmeni. Nevienlīdzības plaisa ir vēl lielāka indivīdu līmenī.
Pasaules gandrīz divu tūkstošu miljardieru kopējā bagātība ir vairāk nekā 7 triljoni eiro, kas ir vairāk, nekā pieder trim miljardiem pasaules nabadzīgāko iedzīvotāju kopā. 2015. gada Davosas ekonomikas forumā izskanēja ziṇa, ka 2016. gadā vienam procentam pasaules bagātāko cilvēku piederēs vairāk par pusi pasaules bagātību.

Pārtikušo iedzivotāju dzivesveids būtiski ietekmē pasaules resursu patēriṇu. Piemēram, ASV, kur dzīvo 5\% pasaules iedzīvotāju, tiek patērēta apmēram viena ceturtā dậa pasaulē saražoto preču un veidojas gandrīz puse rūpniecisko atkritumu. Viena vidusmēra amerikāna dienas patēriṇam vajadzīgi apmēram 450 kilogrami izejmateriālu, to skaitā 18 kilogrami fosilā kurināmā, 12 kilogrami lauksaimniecības produktu, 10 kilogrami koksnes un papīra un 450 litri ūdens. Vienā gadā amerikān,i izsviež atkritumos 50 miljonu tonnu papīra, 67 miljardus pudel̦u, 18 miljardus autiņbiksīšu, 2 miljardus žilešu u.c.

Ekonomists Džefrijs Sahs, ANO Tūkstošgades attīstības projekta direktors, norāda, ka pasaulē būtu iespējams likvidēt galēju nabadzību līdz 2025. gadam, ja bagātākās valstis ziedotu tikai $0,7 \%$ nacionālā ienākuma palīdzībai nabadzīgajām valstīm. Šie fondi būtu jāizlieto bērnu vakcinācijai pret infekcijas slimībām, sākumskolu vispārējas pieejamības nodrošināšanai, gimenes plānošanas pakalpojumiem tiem, kas to vēlas, dzeramā ūdens un sanitāro apstākḷu nodrošināšanai, pārtikas izsniegšanai bada cietējiem, kā arī stratēǵiskiem mikrokredīta aizdevumiem pašnodarbinātajiem.

Šì summa - 100 miljardu eiro gadā - ir daudz lielāka, nekā tiek ziedots pašlaik, taču jautājums ir par prioritātēm. Pašlaik tēriṇi militārajām vajadzībām svārstās ap triljonu eiro gadā, kas ir līdzvērtīgi puses pasaules iedzīvotāju ienākumiem gada laikā. Viens aviobāzes kuǵis maksā tikpat, cik desmit gados visas rūpnieciski attīstītās valstis ziedo palīdzībai attīstības valstīm.

Ekonomika straujāk attīstās industrializētās valstīs, un ekonomiskā izaugsme sistemātiski turpinās pārsvarā bagātajās valstīs. Ekonomisko stagnāciju nabadzīgās valstīs nosaka 
vairāki iemesli, to skaitā sistemātiska netaisnība un apspiestība, īpaši attiecībā uz nabadzīgajiem slāniem.

Bagātām valstīm ir daudz vieglāk taupīt, investēt un pavairot kapitālu nekā nabadzīgām valstīm, un ne tikai tāpēc, ka bagātajiem ir lielākas iespējas kontrolēt tirgus apstākḷus, izstrādāt un nopirkt jaunas tehnologijas un pārvaldīt resursus. Bagātajās valstīs iepriekšējās izaugsmes gadsimtos ir uzkrājies vairāk kapitāla, kas tagad var palielināties daudz efektīvāk.

Tomēr pamatvajadzību nodrošināšana nākotnē būs iespējama tikai bez pašreizējo krājumu noplicināšanas, nodrošinot resursu taupīšanu un saglabājot investīciju apjomus. Mazāks iedzivotāju skaita pieaugums bagātākās valstīs l̦auj tām rūpniecības kapitāla lielāko daḷu novirzìt ražošanas investīcijām un samazināt investīciju dalıu pakalpojumu sfērā, kas paredzēta veselības aprūpei un izglìtībai. Taču to nevar ațlauties ātri augošas valstis un ekonomikas.

Nabadzīgās valstīs kapitāla izaugsmei ir lieli ierobežojumi iedzīvotāju skaita palielināšanās un citu iemeslu dēḷ. Virsvērtība, ko varētu izmantot investīcijām, tiek atvēlēta ārzemju investoriem, vietējās elites luksusa apstākḷu radīšanai, ārējo parādu nomaksai vai arī pārmērīgai militarizācijai. Nabadzību sekmē korupcija, zems izglītības līmenis un slikta vadība, bet iedzīvotāji tiek pakḷauti izaugsmes modelim, kas palielina iedzīvotāju skaitu, bet neḷauj kḷūt pārtikušākiem. Struktūra, kas saista iedzīvotāju skaitu ar kapitālu, ir tāda, ka globālās ekonomikas attīstības modelī realizējas
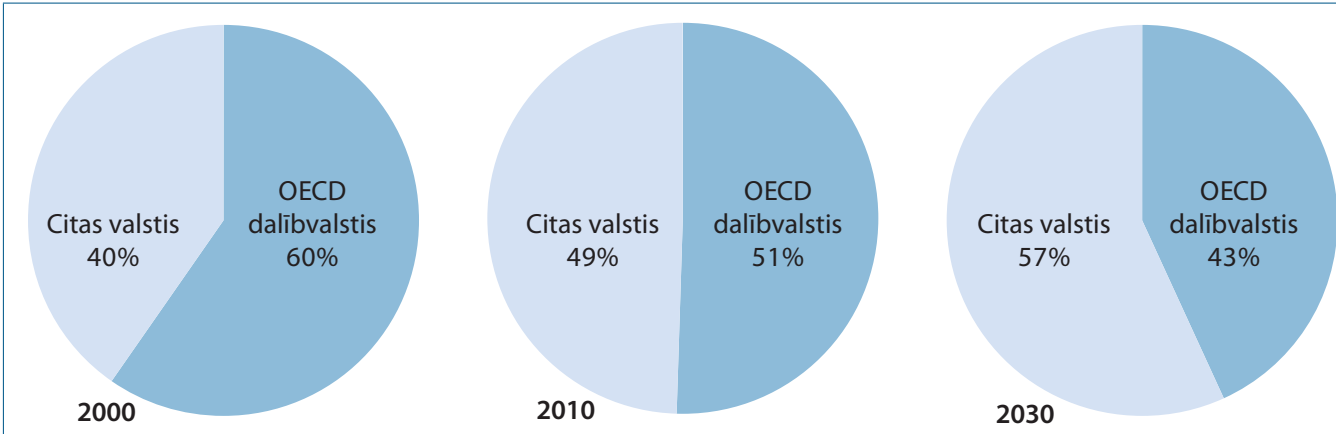

12.13. att. Pasaules ekonomikas dalïjuma izmaiṇas atbilstoši pirktspējas paritātei.

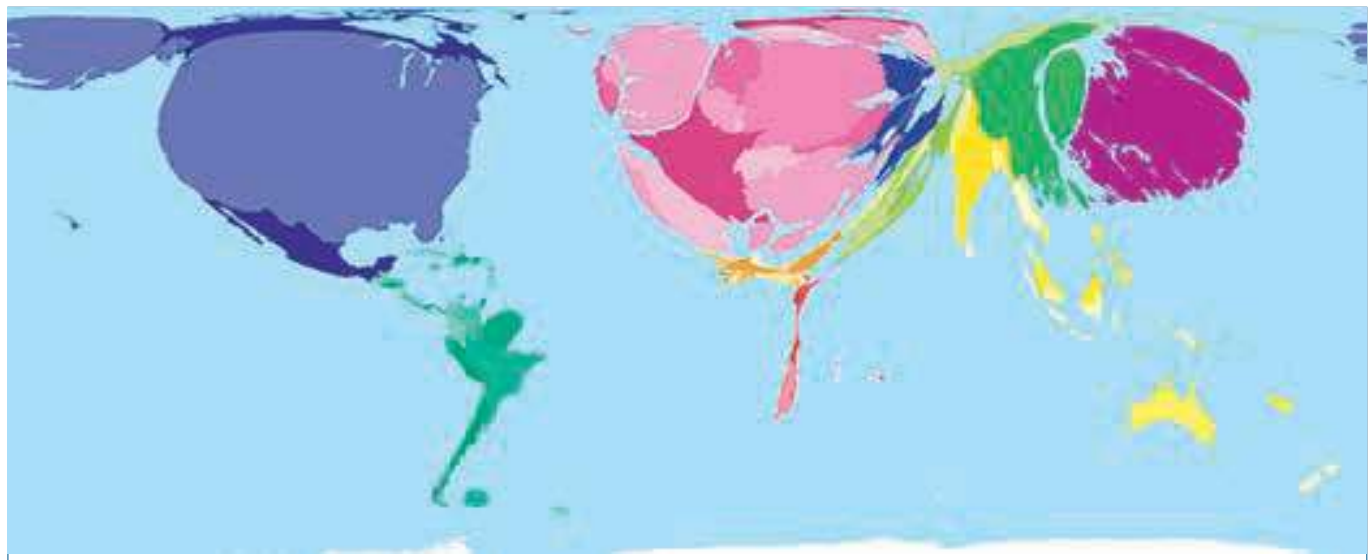

12.14. att. Pasaules valstu sadalījums pēc labklājības līmeṇa. Kartē attēloto valstu platība ir proporcionāla nacionālajam kopproduktam uz vienu iedzīvotāju. 
princips, ko labi raksturo sens sakāmvārds bagātais kḷūst bagātāks, bet nabagam dzimst bērni. Tomēr tā nav nejaušỉba, ka sistēmai piemīt šādas īpašības.

Tā ir veidota, lai radītu tieši tādu rezultātu, un tas turpināsies, ja vien struktūra netiks pārdomāti mainīta. Iedzìvotāju skaita pieaugums palēnina ražošanas kapitāla augsmi, radot augošas prasības pēc skolām, slimnīcām, resursiem un pamatprecēm, tādējādi samazinot rūpniecības produkcijas dal̦u investīcijām ražošanā.

Nabadzība padara cilvēku skaita palielināšanos nenovēršamu, liekot cilvēkiem dzīvot apstākḷos, kur nav iespējams saṇemt kvalitatìvu izglītību, veselības aprūpi, nodrošināt ǵimenes plānošanu. Nav citas izvēles vai ceḷa virzībai uz priekšu kā vien liela gimene un cerības, ka bērni palīdzēs vairot ienākumus vai kalpos ǵimenei kā darbaspēks.

Nabadzīgiem cilvēkiem ir nepieciešama pārtika, pajumte un materiālās vērtības. Pārtikušie l̦audis mēǵina izmantot materiālo izaugsmi, lai apmierinātu citas tieksmes, kas nav materiālas, - atzī̌̌anu, pašapziṇu, personības attīstīšanu.

\subsubsection{Attīstības ierobežojumi}

N̦emot vērā iedzīvotāju un rūpniecības kapitāla pašatjaunošanās potenciālu, tos var uzskatīt par pasaules sistēmas eksponenciālās izaugsmes virzošajiem spēkiem. Iedzīvotāju skaitam un kapitālam piemìt potenciāls, kas nodrošina ražošanu un atražošanu. Šis potenciāls nevar tikt īstenots bez nepārtrauktas enerǵijas un materiālu pievadīšanas, kā arī bez nepārtrauktas piesārn,ojuma aizvadīšanas.

Cilvēkiem vajag pārtiku, ūdeni un gaisu, lai nodrošinātu dzīvības procesus organismā un radītu pēcnācējus. Savukārt ražošanai vajag enerǵiju, ūdeni un gaisu, kā arī milzīgu daudzumu minerālu, kimikāliju un biologisko materiālu, lai ražotu preces, atvieglotu cilvēku dzīvi, kā arī lai uzturētu ražošanas sistēmu un palielinātu ražošanu. Saskaṇā ar fundamentāliem likumiem enerǵija nezūd, bet planētu piesārṇojošās vielas uzkrājas arvien lielākos daudzumos.
Materiālus var izmantot atkārtoti vai arī tie kḷūst par atkritumiem un piesārņojumu. Enerǵija tiek izkliedēta siltuma veidā vai akumulēta jaunās vielās un materiālos. Taču pastāv ierobežojumi, cik lielā apmērā un kādos tempos cilvēki drīkst izmantot dabas resursus un enerǵiju, kā arī radīt atkritumus, lai tie nenodarītu ļaunumu cilvēkiem, ekonomikai vai Zemes procesiem, reǵenerācijai, pašregulācijai.

Viss, ko izmanto cilvēki, - pārtika, ūdens, dzelzs, fosfors, nafta u.c. - ir ierobežots gan resursu, gan to ieguves, izmantošanas radītā piesārṇojuma dēḷ. Pastāv arī îslaicīgi ierobežojumi, piemēram, uzkrātās naftas daudzums rezervuārā kādai vajadzībai, un ilgtermiṇa ierobežojumi, piemēram, naftas daudzums Zemes dzīlēs.

Resursi un piesārn,ojums var savstarpēji mijiedarboties. Augsne, piemēram, var būt gan avots pārtikas ražošanai, gan noplūdes vieta skābajiem lietiem, kurus izraisa gaisa piesārṇojums. Tās spēja veikt kādu funkciju ir lielā mērā atkarīga no citu funkciju īstenošanas.

Pasaules Bankas ekonomists Hermans Deilijs (Herman Daly) ir piedāvājis trīs vienkāršas likumsakarības, lai ieviestu skaidrību šajā sarežgìitībā un definētu ilgtermiṇa līdzsvarotus ierobežojumus attīstībai:

1) atjaunojamiem resursiem - augsnei, ūdenim, mežiem, zivīm - ilgtspējīgas izmantošanas apjoms nedrīkst būt lielāks par reǵenerācijas apjomu. Piemēram, zivis var sabalansēti iegūt, ja tās tiek nozvejotas tādā daudzumā, ko līdzsvaro palikušās populācijas reprodukcija;

2) neatjaunojamiem resursiem - fosilajam kurināmam, augstas koncentrācijas minerālu rūdām, dabiskajam pazemes ūdenim - līdzsvarotas izmantošanas ātrums nedrīkst būt lielāks par to, ar kādu izmanto atjaunojamos resursus, lai aizvietotu neatjaunojamos resursus. Piemēram, naftas atradṇu izmantošanu varētu samazināt, ja dalı ienākumu, ko ienes nafta, sistemātiski investētu Saules panel̦u ražošanai vai koku stādīšanai, jo tad, kad nafta būs izbeigusies, būs pieejama atjaunojamā enerǵija;

3) piesārṇojuma noplūdes ātrums nedrīkst būt lielāks par ātrumu, ar kādu piesārņojums var tikt utilizēts, absorbēts vai padarīts 
nekaitīgs videi. Piemēram, notekūdeņi var tikt ievadīti upē vai ezerā tikai tad, ja ievadīšanas ātrums atbilst dabisko ekosistēmu pašattīrǐšanās spējai.

Ir daudzi pierādījumi tam, ka attīstība un izaugsme notiek uz esošo resursu neatgriezeniskas izsmelšanas vai degradācijas rēksina. Cilvēces attīstības raksturs diemžēl parāda, ka Zemes resursi un attīstības iespējas netiek izmantotas līdzsvaroti.

Augsne, virszemes un pazemes ūden,i, pārmitrās teritorijas, daba un vide ir sākusi degradēties. Pat vietās, kur atjaunojamie resursi šķiet stabili (piemēram, Ziemel̦amerikas meži vai Eiropas augsnes), resursu kvalitāte, daudzveidība un izdzīvošanas spējas var tikt apšaubītas.

Minerālu un fosilā kurināmā krājumi sāk izsīkt. Nav pat plāna un apmierinošas kapitāla investīciju programmas, lai uzturētu rūpniecību tad, kad fosilā kurināmā krājumi būs beigušies. Piesārṇojums uzkrājas un mainās atmosfēras k̦īmiskais sastāvs.

Ja tikai viens vai daži resursi izbeidzas, bet citi ir pietiekamā daudzumā, varētu domāt, ka izaugsme turpināsies, aizvietojot vienu resursu ar citu (kaut gan arī tādai aizvietošanai ir ierobežojumi). Taču, ja daudzi avoti tiek iztukšoti un piesārn,ojuma plūsma palielinās, vairs nav šaubu, ka cilvēces materiālu un enerǵijas patērinsš ir pārkāpis robežas.

Pasaules zinātnieki mēgina izprast un aprakstīt ilgtspējīgas attīstības būtību, kā arī meklē cel̦us, lai atrisinātu ilgtspèjīgas attīstības problēmas jau kopš renesanses laikmeta. Piemēram, Tomass Maltuss ir risinājis iedzīvotāju skaita straujās palielināšanās problēmu, bet Svante Areniuss apmēram gadsimtu vēlāk (1896. gadā) izvirzīja siltumnīcefekta teoriju un pirmais aprēksināja cilvēka izraisīto klimata pārmaiṇu iespējamās sekas.

Cilvēces pastāvēšanai īpaši svarīgs ir pieejamais saldūdens daudzums. Diemžēel, pašreizējās cilvēku darbības veicina globālā ūdens aprites cikla sarukšanu. Apmēram 25\% no pasaules upēm nesasniedz izteku pārmērīgā ūdens patēriṇa dēḷ. Pasaules saldūdens resursus apdraud apjomīgā mežu izciršana un augsnes degradācija. Rezultātā zūd augsnes mitrums. Tas savukārt izraisa biomasas produktivitātes samazināšanos un atbilstoši arī $\mathrm{CO}_{2}$ piesaistīšanas apjomu no atmosfēras. Pārmērīgs pašreizējais ūdens patērinšs rada draudus nākotnē nesaṇemt to pietiekamā apjomā cilvēku un ekosistēmu vajadzībām. Saistībā ar ūdens resursu izmantošanu sausajās klimatiskajās zonās tiek izraisīti pat brun,oti konflikti.

Jān,em vērā, ka daudzos gadījumos planētas robežas tiek vērtētas globālā mērogā, tomēr ilgtspējīgas attīstības sasniegšanai ir nepieciešams rēḳināties arī ar reǵionālām un vietējām problēmām. Piemēram, ķīmisko savienojumu un aerosolu piesārṇojums ir vairāk raksturīgs pilsētām un industriālām zonām, savukārt korālu rifus graujoši ietekmē okeāna ūdens paskābināšanās.

Baltijas jūrā no sateces baseina pēdējos 50 gados ir ieplūduši apmēram 20 miljoni tonnu slāpekla savienojumu un 2 miljoni tonnu fosfora savienojumu. Tas ir izraisījis skābekḷa deficìtu un radījis mirušās zonas Baltijas jūras dienvidos (apmēram Latvijas lieluma platībā).

Planētas spēju pārsniegšana l̦oti nopietni ietekmē arī cilvēku dzīves apstākḷus un apdraud izdzìvošanu nākotnē. Tāpēc zinātnieki ir mēginājuši savietot planētas robežas ar cilvēces sociālajām robežām, pamatojoties uz vispārējām cilvēku tiesībām.

Šādā skatījumā pasaule sociālā ziṇā nevar būt ilgtspējīga, ja pašlaik apmēram viens miljards cilvēku pastāvīgi nav paēduši. Pat, ja bērnu stāvoklis ar pārtikas nodrošinājumu ir uzlabojies, tomēr nav pien,emams, ka 16\% bērnu vecumā līdz 5 gadiem ir ar neatbilstoši mazu masu, bet $26 \%$ ir panīkuši augumā. Īpaši jāuzsver, ka tad, ja bērniem nepietiek pārtikas, palielinās vinuu saslimšanas risks un nāves gadījumu skaits, viṇiem ir kavēta izziṇas spēju attīstība, kas izpaužas kā pazemināta spēja mācīties un apgūt iemaņas. Cilvēce nevar samierināties ar tādu pasaules kārtību, kurā apmēram $11 \%$ iedzīvotāju nav pieejams kvalitatīvs dzeramais ūdens, bet gandrīz pusei iedzīvotāju nav nodrošināti elementāri sanitārie apstākḷi.

Iepriekšējos vēsturiskajos posmos cilvēcei ir izdevies pārvarēt kritiskus apstākḷus, bet nekad agrāk šādu atsevišksu apstākḷu nav bijis tik 
daudz un tie nav savstarpēji ietekmējuši cits citu tik izteikti negatīvo ietekmju pastiprināšanās virzienā. Tāpēc tagad šajā jomā īpaši svarīgas kḷūst inovācijas, kā arī jaunu zināšanu izmantošana un izplatǐšana.

\subsection{3. lerobežojumu pārsniegšanas sekas}

Cilvēces attīstības raksturu un ierobežojumus tās attīstībai, kā arī to, kādas var būt šo ierobežojumu pārsniegšanas sekas, 20. gs. 70. gados mēǵināja interpretēt, bet, galvenais, modelēt un izstrādāt ieteikumus rīcībai grāmatas "Izaugsmes robežas" autori Donella Medouza, Jorgens Randers un Deniss Medouzs.

Cilvēces ekonomiskās attīstības raksturs, kā arī pieeja vides un sociālo problēmu risinājumiem apliecina izteikto prognožu un model̦u pareizību un to, ka nepieciešams mainìt attīstības raksturu.

Cilvēces attīstības rakstura modelēšanas pamatā ir esošo un pieejamo resursu apjoma novērtējums, to mainību skatot kopā ar iedzīvotāju skaitu un kapitālu. Lai to izdarītu, nepieciešams

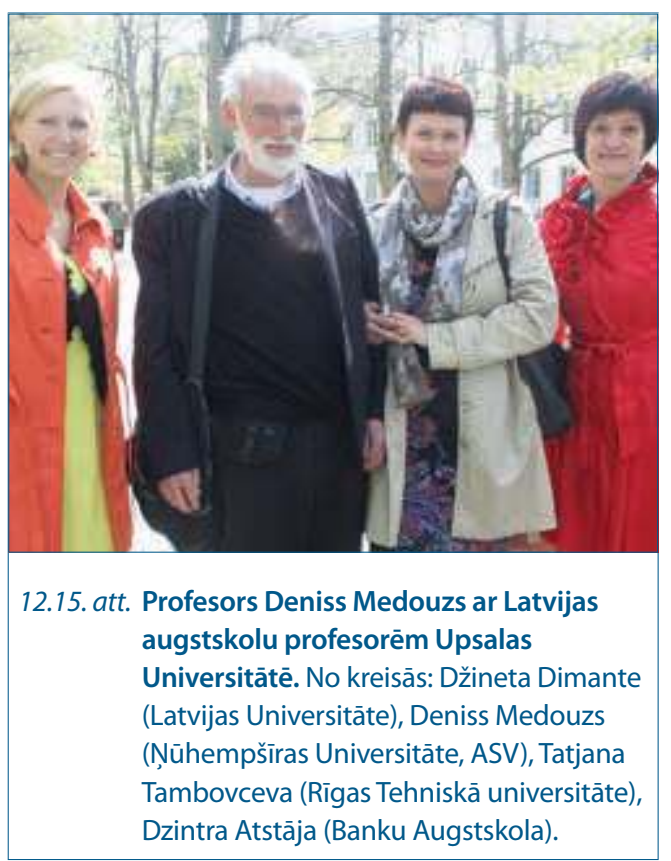

pāriet no statiskās, viena faktora analīzes laikā uz dinamisku visas sistēmas analīzi.

Vairumā pasaules valstu kapitāls aug straujāk nekā iedzīvotāju skaits, bet dažās pasaules valstīs ir pretēji. Dažās valstīs augošā ekonomika lauj samazināt dzimstību, bet citās valstīs nabadzība un sociālā nevienlīdzība palielina mirstību. Cilvēki, kuri ir kḷuvuši bagātāki, pieprasa vairāk preču, vairāk enerǵijas, tīrāku gaisu.

Nabadzīgie l̦audis cīnās par tīru ūdeni, zemi lauksaimniecībai un malku kurināšanai. Dažas tehnologijas palielina piesārṇojumu apjomu, citas to samazina. Neatjaunojamo un dažu atjaunojamo resursu krājumi sāk izsīkt, bet atlikušie krājumi tiek izmantoti daudz intensīvāk un efektīvāk.

Cilvēces attīstības rakstura modelēšana parāda, ka, turpinoties līdzšinējam attīstības raksturam, pat pastāvot tehnologiskajam progresam un paplašinoties izejvielu un resursu pieejamībai, jau šī gadsimta laikā iespējama izaugsmes robežu pārsniegšana un labklājības rādītāju katastrofāla samazināšanās. Tā sekas var būt rūpnieciskās ražošanas un pārtikas pieejamības samazināšanās, kā arī iedzīvotāju skaita samazināšanās.

Mūsdienu sabiedrība ir piedzivojusi ātru iedzīvotāju skaita pieaugumu pēdējos trīssimt gados, un pēdējo gadsimtu laikā ir gūti ievērojami sasniegumi tehniskā un sabiedriskā jomā: no tvaika mašīnas līdz datoram, demokrātijai. Tas ir l̦āvis ekonomikai pārsniegt redzamās fiziskās un materiālās robežas un nepārtraukti uzturēt pieaugumu.

İpaši pēdējo gadu desmitu laikā izvērstā rūpniecības kultūra tika saistīta ar patērētāju sabiedrības attīstību un ieviesta cilvēku apziṇā saistībā ar ideju par izaugsmi, kas vienmēr turpināsies. Tāpēc ideju, ka varētu būt kādi izaugsmes ierobežojumi, vairums cilvēku nevar pat iedomāties vai pien,emt. Ierobežojumi nav politiski pieminami un ekonomiski iedomājami.

Iedzīvotāju skaita pieaugums, resursu izmantošanas apjomi un attīstīto valstu patēriṇa apjomi turpina pieaugt, kā tas noticis 20. gadsimta laikā, līdz izaugsmes ātrumu samazina neatjaunojamo resursu pieejamības un to vērtības pieaugums. Tas, savukārt, 
izraisa ražošanas apjomu samazināšanos un investīciju novirzīšanu resursu plūsmu uzturēšanai, bet investīciju pieejamības samazināšanās citos ekonomikas sektoros izraisa rūpnieciskās ražošanas un pakalpojumu apjoma samazināšanos.

Samazinoties rūpnieciskās un pārtikas ražošanas apjomam, sarūk veselības pakalpojumu pieejamība, un, vienlaikus, palielinoties vides piesārn,ojumam, samazinās mūža ilgums.

Sabiedrība tiecas noraidīt ierobežojumu iespēju un cenšas to aizvietot ar iespējamo cīṇu par tehnoloǵiju uzlabošanu un brīvā tirgus attīstību. Tomēr sabiedrības izaugsmes modelēšanas rezultāti parāda, ka līdzšinējais cilvēces attīstības cel̦š ir izsmelts.

- Ja pasaules iedzīvotāju skaita, rūpniecības, piesārn,ojuma, pārtikas ražošanas un resursu patēriṇa augšanas tendences turpināsies, mūsu planētas iespēju robežas tiks sasniegtas aptuveni nākamo piecdesmit gadu laikā. Daudzu ierastāko resursu izmantošana un daudzie piesārnojuma veidi jau pārsniedz līdzsvarotus apjomus. Bez ievērojamas materiālu un enerǵijas plūsmu samazināšanas nākamajās desmitgadēs notiks nekontrolējama pārtikas, enerǵijas un rūpniecības produkcijas daudzuma samazināšanās uz vienu iedzīvotāju. Iespējamākais rezultāts varētu būt pēkšn,na iedzīvotāju skaita un ražošanas apjoma samazināšanās.

- Šĩ samazināšanās nav neizbēgama. Ir iespējams mazināt izaugsmes tendences un veidot apstākḷus vides un ekonomikas stabilitātei, kas varētu būt līdzsvarota arī tālākā nākotnē. Globālā līdzsvara stāvokli vajadzētu veidot tā, lai tiktu apmierinātas katras personas materiālās pamatvajadzības un katram būtu vienlīdzīgas iespējas īstenot savas ieceres.

- Līdzsvarotas un ilgtspējīgas sabiedrības pastāvēšana ir tehniski un ekonomiski iespējama. Tā ir vairāk vēlama nekā sabiedrība, kas tiecas atrisināt savas problēmas ar pastāvīgu ekspansiju. Pāreja uz līdzsvarotu un ilgtspējīgu sabiedrību prasa rūpīgi sabalansēt ilgtermiña un īstermiṇa mērksus, dot priekšroku dzīves pietiekamam nodrošinājumam, vienlīdzībai un kvalitātei, nevis kopprodukta daudzumam. Tas prasa vairāk nekā tikai darba ražīgumu un vairāk nekā tikai tehnoloǵiju attīstību - tas prasa arī briedumu, līdzjūtību un gudrību. Ja l̦audis izlems īstenot otro iespēju pirmās vietā un jo ātrāk tas notiks, jo lielākas būs izredzes ilgtspējīgai attīstībai.

\section{4. llgtspējiga attīstība}

\subsubsection{Ilgtspējīgas attīstības koncepcija}

Ilgtspējīgas attīstības koncepcija ietver fiziskos apstākḷus, politiskas koncepcijas, jēdzienu par dzīves kvalitāti vai labklājību un optimizētu ietekmi uz vidi, lai nodrošinātu, ka tās resursi ir vienlīdz pieejami visām paaudzēm.

Ilgtspējīgas attīstības koncepcijas pamatā ir izpratne par trim jēdzieniem: attīstību, sabiedrības vajadzībām un nākamo paaudžu vajadzībām. Ilgtspējīgas attīstības koncepcijā ar jēdzienu "attīstība" tiek saprasts ne tikai pieaugums (ražošanas, nacionālā kopprodukta, labklājības), bet arī sociālās un ekonomiskās sfēras

attīstība, vienlaikus nodrošinot dabisko ekosistēmu un cilvēka dzīves vides saglabāšanu.

Ilgtspèjīgas attīstības koncepcija līdz ar to ne tikai aplūko īstermiṇa procesus (nodrošināt tagadnes vajadzības), bet arī pretendē uz vienlīdzīgu iespēju nodrošināšanu starp paaudzēm. Ilgtspējīga būtu tāda sabiedrība, kas varētu pastāvēt mūžīgi. Līdz ar to ilgtspējīgas attīstības koncepcijas mērḳis ir ietekmēt cilvēces nākotni un sabiedrības pastāvēšanu.

Var uzskatīt, ka līdzšinējie sabiedrības attīstības model̦i ir bijuši neveiksmīgi ilgtermiṇā un pierādījuši vai nu savu acīmredzamo nespēju nodrošināt sabiedrības attīstību, vai arī nav spējuši ietvert būtiskās atšksirības 
starp dažādiem pasaules regioniem. Sabiedrības attīstības koncepciju pārvērtēšanā liela loma ir izpratnei par sabiedrības attīstības ietekmi uz vidi un tās aizsardzības nepieciešamību. Tāpēc ir vairāki argumenti, kādēl nepieciešams pārvērtēt līdzšinējos sabiedrības attīstības modelus.

- Attīstība, īpaši rietumu sabiedrībā, tiek saprasta kā cilvēka dominēšana pār dabu (šo attieksmi raksturo frāze "cilvēks - radības kronis") un tās resursu izmantošana ražošanas attīstībai. Līdz ar to tiek ignorēts dabas un ekosistēmu sniegtais nodrošinājums cilvēcei un tas, ka dabai ir vērtība pašai par sevi, bet citām dzīvības formām un dzīvajiem organismiem var būt savas vajadzības, un, galvenais, tiesības pastāvēt.

- Rietumu sabiedrības dominējošā attīstības modelī galvenā prioritāte ir ekonomiskā izaugsme un tas, ka patērinš̌ ir galvenais rādītājs, kas raksturo cilvēka un cilvēces labklājību. Saskaṇā ar šo koncepciju sabiedrības labklājība ir pien,emtu dzives standartu pastāvēšana. Ieñēmumu dalı tiek izmantota, lai iegādātos lietas un pakalpojumus. Šāds attīstības modelis, kas pamatojas uz individuālo patēriṇu, neizbēgami noved pie milzīgas ieṇēmumu un labklājības nevienlīdzības pat vienā valstī (īpaši n,emot vērā brīvā tirgus ekonomikas ciklisko raksturu), nemaz nerunājot par atšksirību veidošanos starp dažādiem pasaules reǵioniem. Šādi definētās labklājības atšķirības izraisa sociālu spriedzi, militārus konfliktus un sabiedrības nestabilitāti.

- Sabiedrības attīstība, kas balstās uz pieaugošu resursu izmantošanu, noved pie patēriṇa un ražošanas atkritumu (piesārṇojuma) palielināšanās un resursu izsīkšanas. Ražošanas un patēriṇa attīstības dēl pēdējās desmitgadēs ir mainījies arī vides problēmu raksturs.

Vides piesārṇojuma avoti - punktveida vai difūzi.

Agrāk piesārṇojuma avoti bija punktveida, piemēram, gaisa vai ūdens piesārṇojums no rūpnīcas, kaitīgo vielu izplūde kādā katastrofā vai kaitīgo vielu noplūde no atkritumu izgāztuves. Pamazām kaitīgā ietekme uz vidi kḷuva mazāk koncentrēta un sāka dominēt difūzie piesārn,ojuma avoti, kas ietver augu barības vielu noplūdi no lauksaimniecības zemēm, ķimikāliju lietošanu mājsaimniecībās, automašīnu radīto gaisa piesārṇojumu. Punktveida piesārṇojuma avotu radītās problēmas var risināt ar skaidri saskatāmu un ierobežojošu darbību, bet difūzo avotu izraisīto problēmu risināšana ir daudz sarežǵītāka, bet uzlabojumi ir sasniedzami daudz lēnāk.

Vides problēmu mērogs - vietējs, reǵionāls vai globāls.

Vēl nesen daudzi piesārṇojuma veidi bija vietēja rakstura, parasti ap punktveida piesārṇojuma avotu. Vēlāk atklājās, ka piesārṇojums var ietekmēt pat reǵionus, škēērsojot valstu robežas, piemēram, skābie nokrišņi un eitrofikācija. Pašlaik aktuālākās vides problēmas ir globālas. Jo plašāks problēmas mērogs, jo grūtāk to risināt. Tāpēc nepieciešama starptautiska sadarbība.

Vides problēmu turpināšanās - neilga vai ilga.

Kaitīgā ietekme uz vidi daudzos gadījumos ir îslaicīga, ja avota pastāvēšana ir ierobežota laikā. Tā tas bija ar gaisa piesārṇojumu no centralizētās apkures uzṇēmumiem vai ar ūdens piesārṇojumu no nelielām apdzīvotām vietām. Pašlaik vairums vides problēmu ir ilglaicīgas, tās nepazūd īsā laika posmā arī tad, ja cēlonis ir likvidēts. Noturīgie organiskie savienojumi, smago metālu savienojumi vai radioaktīvais piesārn,ojums var ietekmēt vidi ilgu laiku pēc tiešas piesārn,ošanas beigām. Tā tas ir arī ar Baltijas jūras eitrofikāciju, kuras samazināšana prasīs vairākas desmitgades pat tad, ja papildu augu barības vielu ieplūde tiks pilnīgi apturēta.

Vides piesārṇojuma problēmu pakāpe vienkārša vai sarežgíta.

Daudzas vides problēmas kḷūst arvien kompleksākas. Vienā rūpnīcā var izmantot simtiem dažādu kūmisko vielu un daudzas no tām var būt vidē noturīgas. Tāpat arī dažādas patēriṇa preces var dažādi ietekmēt vidi. Daudzas vielas, kā arī tautsaimniecības nozares iedarbojas uz vidi savstarpēji saistīti, piemēram, organiskie atkritumi no celulozes ražošanas rūpnīcas 
vai pilsētas notekūdeṇi piesaista aromātiskās vielas vai smago metālu savienojumus, kuri atbrīvojas, ja organiskās vielas sadalās. Jo kompleksāka ir vides problēma, jo sarežgiītāk ir to izprast un atrisināt.

- Patēriña sabiedrības attīstības modelis ignorē faktu, ka tāda ražošana, kas pārtērē resursus un degradē vidi, bet nodrošina augsta līmen,a dzīvesveidu bagātākajās pasaules valstīs, uz visas planētas nav iespējama. Jau pašlaik, kad vēlamais patērin, līmenis sasniegts tikai relatīvi nedaudzās pasaules valstīs, visas planētas ekosistēmas nespēj absorbēt radīto piesārṇojumu, kā tas ir siltumnīcefekta gāzu emisijas radīto klimata pārmainu piemērā. Planētai nepietiek resursu, lai ilgtermiṇā nodrošinātu esošā patēriña līmeni Rietumeiropas un Ziemel̦amerikas valstīs, bet šāds patēriṇa apjoms nav nodrošināms visiem pasaules iedzīvotājiem. Bez tam šādu patēriṇa līmeña pieaugumu nebūs iespējams nodrošināt arī nākotnē, pat strauja tehnologiskā progresa ietekmē.

- Līdzšinējās rietumu sabiedrības attīstības pamatā bija izpratne, ka attīstība un izaugsme nav ierobežota. Tomēr jāatzīst, ka ekonomiskajai izaugsmei tomē pastāv ierobežojumi. Izaugsmes robežas nosaka planētas nestspēja, resursu pieejamība un planētas ekosistēmu spēja absorbēt piesārṇojumu. Kaut arī tehnologiskais progress var paaugstināt resursu izmantošanas efektivitāti, tomēr šos attīstības ierobežojumus pārvarēt nav iespējams.

Nākotnes attīstībai jānodrošina līdzsvars starp planētas spēju uzturēt cilvēci un cilvēkiem vēlamo dzīvesveidu.

\subsubsection{Ilgtspèjīgas attīstības ietvars}

Pasaules diskusiju process par nākotnes perspektīvām sākās 1972. gadā Stokholmā, ANO konferencē par cilvēkvidi. Kaut gan aukstā kara attiecību dēl PSRS un sociālistisko valstu bloks atteicās piedalīties konferencē, tomēr ieradās 113 valstu delegācijas gan no ekonomiski attīstītām, gan mazāk attīstītām valstīm, kā arī no daudzām starptautiski atzītām organizācijām.

Konferences deklarācijā tika iekḷauti 26 principi, kas cilvēkvidi definēja daudz plašāk, nekā tas bija pien,emts vides aizsardzības jomā, jo tika iekḷautas arī cilvēktiesību, vienlīdzības un adekvātu dzīves apstākḷu prasības.

Deklarācija prasīja samazināt vides piesārn,ojumu, aizsargāt atjaunojamos un neatjaunojamos resursus nākotnes attīstības vajadzībām, ierobežot cilvēku skaita palielināšanos. ANO dalībvalstīm tika ieteikts veidot vides aizsardzības politiku, kas uzlabotu dzīves apstākḷus visiem un izveidot atbilstošas vides pārvaldes institūcijas, uzsverot pētniecības, izglītības un inovāciju svarīgumu.

Mūsdienu izpratne par ilgtspējīgu attīstību pamatojas uz 1987. gadā ANO Vides un attīstības komisijas ziṇojumā "Mūsu kopīgā nākotne" izteikto ideju:

"Ilgtspējīga attīstība ir attīstība, kas apmierina pašreizējās paaudzes vajadzības, neradot draudus nākamajām paaudzēm to vajadzību apmierināšanā".

Divdesmit gadus pēc Stokholmas konferences 1992. gadā Riodežaneiro, Brazīlijā notika ANO konference par vidi un attīstību, kurā piedalījās 172 valstu delegācijas, ieskaitot 108 valstu vai valdību vadītājus.

Tika pieñemta Riodežaneiro Deklarācija par vidi un attīstību un Rīcības programma 21. gadsimtam (Agenda 21).

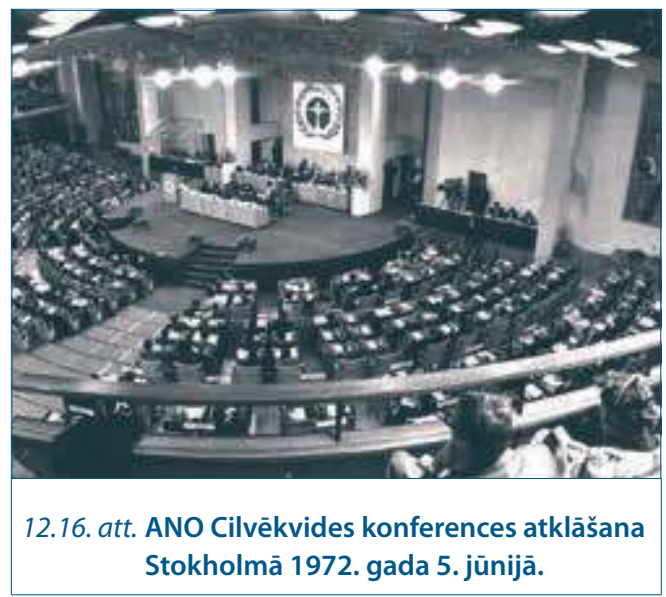



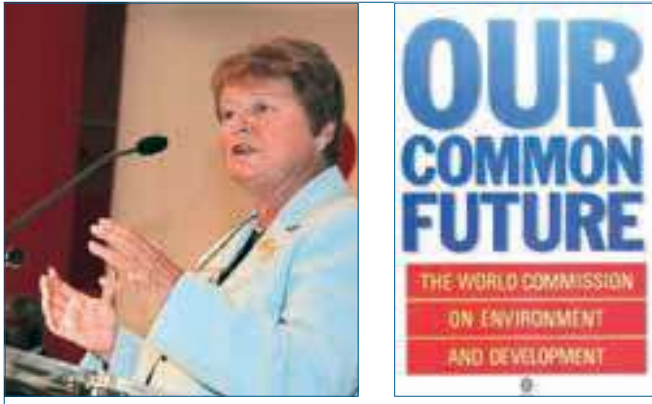

12.17. att. Grū Hārlema Bruntlande, bijusī Norvēǵijas Karalistes premjerministre un ANO Vides un attīstības komisijas vadītāja.

Latvijas Republikas Saeima ratificēja Riodežaneiro pien,emtos dokumentus, arī Rīcības programmu 21. gadsimtam, kurā ietverti nepieciešamo darbību apraksti pasaules vides problēmu risināšanā. "Domā globāli, rīkojies konkrētajā vietā" - šajā stratēǵijā pausta atziña, ka neviena globāla darbība nav iedomājama bez apzinātas vietējā līmeṇa rīcības.

Daudzās pasaules valstīs tika atzīts, ka jāveido sava attīstības stratēǵija tā, lai tiktu saglabāti ne tikai ekonomiskās attīstības tempi un iespējas, saglabāta dzīves kvalitāte, bet arī novērsta vides degradācija un resursu pārtēriņš̌.

Lai ilgtspējīga attīstība tiktu īstenota, vides aizsardzībai jākḷūst par attīstības integrētu daḷu, bet tās abas kopā satur sociālā joma. Tai ir būtiska nozìme nabadzības izskaušanā pasaulē un pasaules iedzīvotāju vairākuma vajadzību nodrošināšanā. Tā kā lielu dal̦u nepieciešamā cilvēki saṇem no dabas, ir jārūpējas par Zemes ekosistēmu integritāti un dzīvotspēju.

Ilgtspējīga attīstība ir viens no būtiskiem mērksiem Eiropas Savienības līgumā, kas nosaka ES politiku un rīcību. Ilgtspējīgai attīstībai, kas nodrošina Zemes spēju uzturēt dzìvību visā daudzveidībā, jābalstās uz demokrātijas, dzimumu līdztiesības, solidaritātes un likumu varas principiem, kā arī uz pamattiesību, brīvības un vienādu iespēju ievērošanu. Tā ir orientēta uz šìs un visu turpmāko paaudžu pastāvīgas dzīves kvalitātes uzlabošanu un labklājības veicināšanu. Ilgtspējīga attīstība veicina

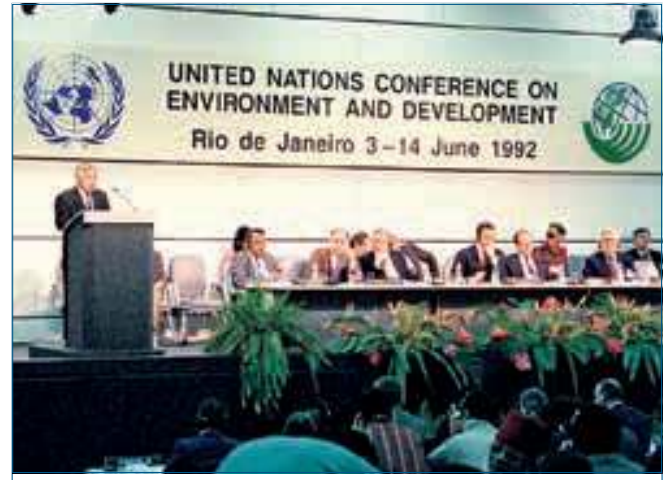

12.18. att. ANO konference par vidi un attīstību, Riodežaneiro, Brazïlija, 1992. gads.

dinamisku ekonomiku, pilnīgu nodarbinātību, augstu izglītības līmeni, labu medicīnisko aprūpi, sociālu un teritoriālu kohēziju un vides aizsardzību mierīgā un drošā pasaulē, respektējot kultūras daudzveidību.

Ilgtspējīgas attīstības koncepcija balstās uz nepieciešamību optimizēt ekonomisko attīstību un sociālo sistēmu, kā arī ietekmi uz vidi un resursu izmantošanu. Šim attīstības modelim jānodrošina ekonomikas, vides un sociālās sfēras ilgtspēja laikā un telpā.

Trīs pamatsfēras, bez kurām mūsdienās nav iespējama cilvēces pastāvēšana, ir ekonomika, harmoniska sabiedrība un veselīga vide,

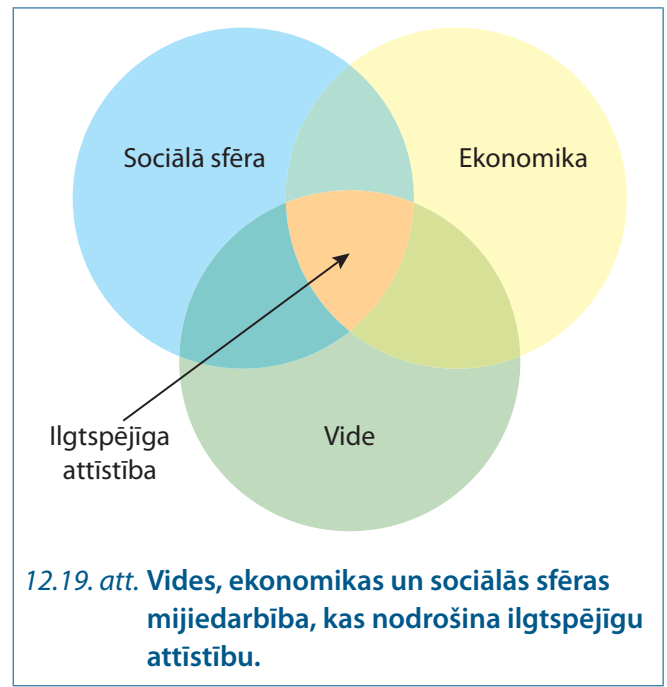


kas vienlaikus ir vēlamie ārējie priekšnosacījumi indivīda attīstībai.

Ilgtspējīga attīstība nozīmē to, ka jebkurš ekonomikas, sabiedrības vai vides jautājums jārisina tā, lai pien,emtais lēmums būtu labvēlīgs vai pēc iespējas mazāk nelabvēlīgs pārējo sfēru attīstībai.

Ilgtspējīgas attīstības mērķi un principi ir kḷuvuši par vadlīnijām, lai pien,emtu atbilstošus ekonomiskus un politiskus, kā arī vides aizsardzības lēmumus, kuru mērksis ir

- ierobežot cilvēces ietekmi uz apkārtējo vidi un nepiel̦aut tālāku vides pašatjaunošanās spēju pārsniegšanu;

- samazināt līdz minimumam neatjaunojamo resursu patēriṇu un nodrošināt atjaunojamo resursu izmantošanas paplašināšanu;

- saudzēt un aizsargāt dabu, nodrošinot bioloǵiskās daudzveidības saglabāšanu;

- veicināt ekonomisko attīstību, lai nodrošinātu cilvēka vajadzības, l̦autu paaugstināt dzīves kvalitāti un nodrošinātu taisnīgu pasaules bagātību sadali;

- izveidot tādu lēmumu pieñemšanas un pārvaldes sistēmu, kas sekmē sabiedrības līdzdalību lēmumu piennemšanas procesā. Lai nodrošinātu ilgtspējīgu attīstību, sabiedrībai jāizpilda vairāki galvenie uzdevumi.

1. Resursu saglabāšana, respektīvi, cilvēces attīstībai nepieciešamo resursu pieejamības nodrošināšana ne tikai esošajām, bet arī nākamajām paaudzēm. Līdz ar to nepieciešams realizēt rīcības programmu un politiku, kuras mērksis ir paaugstināt neatjaunojamo resursu izmantošanas efektivitāti, to aizvietošanu ar atjaunojamiem resursiem, vienlaikus saglabājot biologisko daudzveidību un aizsargājot sugu genētisko potenciālu. Šĩ uzdevuma risināšanas pieejas ir alternatīvo energíjas avotu attīstība, ražošanas un cita veida atkritumu atkārtota izmantošana, videi draudzīgu tehnoloǵiju attīstība.

2. Cilvēka ietekmētās un neskartās vides sabalansēta attīstība, kas saistās, piemēram, ar nepieciešamību saglabāt lauksaimnieciski izmantojamo zemju produktivitāti, optimizēt pilsētu teritoriju lietošanu un transporta plūsmas.

3. Sabiedrības attīstībai piennemamas vides kvalitātes nodrošināšana, pārtraucot vai ierobežojot procesus, kas degradē vidi, negatīvi ietekmē ekosistēmu pašatjaunošanās spējas un, nepiel̦aujot procesus, kas var nelabvēlīgi ietekmēt cilvēku veselību un samazina dzīves kvalitāti. Vienlaikus jāpatur prātā nepieciešamība atjaunot degradēto vidi.

4. Ilgtspējīga attīstība nav iedomājama bez sociālās vienlīdzības nodrošināšanas gan valstī, gan starp valstīm, nepiel̦aujot ienākumu nevienlīdzības pieaugumu un nodrošinot tādu attīstību, kas samazina sociālo plaisu starp bagātajiem un trūcīgajiem.

5. Sabiedrības līdzdalība valsts un vides pārvaldē, lai ilgtspèjīga attīstība tiktu atbalstīta un uzturēta visas tautas mērogā, jo tā nav sasniedzama bez sabiedrības attieksmes maiñas par patērinu un resursu izmantošanu. Sabiedrībai ir svarīga politiskā apn,emšanās veidot tādu sistēmu, kas balstās uz esošo un iegūto labumu vienlīdzīgu sadali, uz sociālo vienlīdzību, resursu saudzīgu izmantošanu un efektīvu pārvaldi.

6. Ilgtspējīgas attīstības îstenošanas procesā ir jāpanāk izmainuas attieksmē pret vērtībām un tām ir jābūt ierosinātām un atbalstītām no apakšas, iesaistot aizvien lielāku sabiedrības dạ̦u politisku lēmumu pieṇemšanā un pārvaldē. Vienlaikus ir skaidrs, ka šādas izmaiṇas sabiedrībā nav sasniedzamas ar administratīvām reformām.

Ilgtspèjīga attīstība sasniedzama, rodot risinājumus visiem šiem uzdevumiem, - īstenojot sabiedrības plānošanu tirgus ekonomikā atbilstoši optimālai politiskai sistēmai. Ilgtspējīga attīstība pastāv tad, ja kopīgie Zemes kapitāla krājumi paliek nemainīgi vai turpina augt. Ar to saprot trīs galvenās kapitāla formas:

- ekonomiskais (cilvēku radītais) kapitāls, kas tradicionāli ietver iekārtas, tehni$\mathrm{ku}$, celtnes un infrastruktūru un tiek izmantots preču ražošanā un pakalpojumu sniegšanā; 
- sociālais kapitāls, kas saistīts ar cilvēku labklājību gan sabiedriskā, gan individuālā veidā. Tas sastāv no sociālajām normām, no formālām un neformālām struktūrām, kas nodrošina pieeju resursiem, palīdz risināt kopīgas problēmas un veicina sociālo vienotību, bet balstās uz cilvēku garīgo un fizisko veselību, izglīiību, motivāciju, talantu, prasmēm un iemañām;

- dabas kapitāls - visas ekosistēmas un dabas resursi (atjaunojamie un neatjaunojamie). Papildus tradicionālajiem dabas resursiem (koksne, ūdens, enerǵija, minerāli) dabas kapitāls ietver arī dabas vērtības, ko grūti izteikt monetārās vienībās, - bioloǵisko daudzveidību, sugas un ekosistēmas, kas nodrošina ekosistēmu pakalpojumus (piemēram, gaisa un ūdens sagatavošanu un attīrǐšanu).

Ilgtspējīga attīstība paredz pastāvīgu visu kapitāla formu attīstību un saglabāšanu, jo no tām ir atkarīga cilvēces eksistence un labklājība gan tagad, gan nākotnē. Tā kā Zemes kopējais kapitāls sastāv no šo kapitālu kopsummas, tad pastāv iespēja, ka kopējie kapitāla krājumi var palielināties arī tad, ja viena kapitāla forma samazinās un cita aug. Piemēram, tiek samazināts dabas kapitāls, bet ekonomiskā izaugsme ir pietiekami liela, lai nodrošinātu kopējā kapitāla pieaugumu.

Tāpēc kapitāla formu savstarpējo aizstājamību var izteikt kā ilgtspējīgas attīstības divas pieejas:

- paliekoša ilgtspēja tiek nodrošināta, ja neviena no ilgtspējīgas attīstības kapitāla formām nesamazinās. Tā nebalstās uz aizstāšanas principu un nepiel̦auj dabas kapitāla aizstāšanu ar cilvēka radīto kapitālu. Izmantojot šo pieeju, rodas problēmas, nosakot dabas kapitāla kritiskās robežas. Savukārt, nepiel̦aujot kapitālu aizstājamību, rodas situācija, kad dažiem kapitāla veidiem tiek piešksirta absolūtā vērtība, kas ir lielāka nekā citiem;

- vāja ilgtspēja balstās uz pieñēmumu, ka labklājība un ilgtspēja nav atkarīga no kādas īpašas kapitāla formas, bet tiek nodrošināta, ja kopējie Zemes kapitāla krājumi pieaug. Šāda pieeja piel̦auj dažādu kapitāla formu savstarpējo aizstājamību. Izmantojot šo pieeju, būtu, piemēram, iespējams izcirst Brazīlijas mūžamežus, lai šajā teritorijā nodrošinātu biologiiskās pārtikas ražošanu vai arī, lai iegūtos finanšu līdzekḷus ieguldītu cilvēku kapitāla attīstībā. Šajā gadījumā problēma rodas, salīdzinot dažādas nesalīdzināmas kategorijas - mežus ar cilvēkiem, kā arī nosakot to vērtību un aizstājamības pakāpi. Vājā ilgtspēja balstās arī uz ieguvumu un izdevumu analīzi, kurā savstarpēja aizstājamība ir pienemama.

\subsubsection{Ilgtspējīgas attīstības pamatprincipi}

Plānojot, īstenojot un vērtējot attīstības ilgtspēju, ir izstrādāti vairāki pamatprincipi. Vieni no tiem ir sociāli ekologiskie principi, kas skaidri parāda attīstības procesa likumsakarības, tādējādi l̦aujot precīzi definēt attīstības mērksus.

Pārejas ceḷi uz ilgtspējīgu attīstību var būt dažādi, un tajos iespējams kḷūdīties, taču skaidra mērksa definēšana ir uzskatāma par attīstības priekšnoteikumu. Sociāli ekologisko principu priekšrocības ir tās, ka tie ilgtspējīgu attīstību vērtē no sistēmu viedokḷa un darbības aplūko virknē kopš paša sākuma.

Ilgtspèjīgas attīstības pamatprincipos par nozīmīgākajiem jāuzskata četri ilgtspējas veidi, kas sniedz atbildi uz jautājumu "Kā to izdarīt?", lai nodrošinātu sabiedrības attīstību.

1. Daudzveidība ir uzskatāma par nepieciešamu priekšnoteikumu jebkuras sistēmas (arī sabiedrības) tālākai attīstībai. Biologiskā daudzveidība, ekonomiskā daudzveidība, kultūru daudzveidība ir pamatā biosfēras un sabiedrības spējai uzturēt to dinamisko stabilitāti. Inovācija un pielāgošanās jauniem apstākḷiem ir iespējama tad, 
ja pastāv dažādas pieejas un attīstības alternatīvas, no kurām var veidot jaunas, stabilas sabiedriskas sistēmas. Lai palielinātu ilglaicīgu stabilitāti, bieži vien piemērotākā stratēgóija ir attīstības dažādošana.

2. Subsidiaritāte nozīmē visa veida funkcijas zemākajā iespējamā pārvaldes līmenī. Palīdzība vai norādījumi no ārpuses ir vēlami tikai gadījumā, ja tie veicina attiecīgās deleǵētās funkcijas izpildi, bet tajā pašā laikā bīstami nesamazina apakšsistēmas autonomiju. Pašpārvalde ir cieši saistìta ar sociālo atbildību un sociālo drošību un var tikt lietota visās jomās - politikā, administrācijā, uzṇēmējdarbībā, tehniskajās sistēmās, ekonomikas materiālo plūsmu nodrošināšanā. Šis princips nesniedz skaidrus norādījumus, bet liek meklēt optimālo risinājumu starp autonomiju un integrāciju plašākās sistēmās. Pašnoteikšanās principa ieviešana veicina indivīdu iesaistǐšanos un pašvaldību aktivitāti veidot un pārvaldīt savu dzīvi, tādējādi veicinot demokrātiju.

3. Sadarbības princips akcentē horizontālo, nehierarhisko mijiedarbību nozīmi. Tāds sadarbības modelis balstās uz savstarpēji vienotiem mērkiem un likumiem un parasti ir atvērts: dalībnieki var pievienoties vai izstāties. Sadarbības tīkli nodrošina pieredzes un informācijas apmaiṇu, rada savstarpējo atbalstu, stabilizē sistēmas, kā arī veicina konkurenci - dalībnieki var izvēlēties citu, pievilcīgāku sadarbības tīklu. Tādēl sadarbības tîklu pastāvēšanai vitāli svarīga ir spēja piemēroties jaunajam un orientēties uz dalībnieku vajadzībām.

4. Piedalīšanās jeb līdzdalības princips atbilst demokrātijas idejām un ir pamats pieeju daudzveidībai. Tas var būt svarīgs, lai izvairītos no konfliktiem. Īpaši būtiska ir visu jautājuma risināšanā iesaistīto pušu piedalīšanās problēmas formulēšanas sākuma stadijā un iespējamo alternatīvu apzināšanā. Piedalīšanās veicina atbildību un motivē cilvēkus dot savu ieguldījumu pieñemtā lēmuma izpildē. Turklāt piedalīšanās prasa dalībnieku laiku un ieinteresētību, iesaistītās institūcijas atvērtību un bieži arī vairāk laika un līdzekḷu nekā labi izstrādāta hierarhiskā tipa lēmumu pien,emšana. No izvēlētās procedūras ir atkarīgs risks, ka lēmums var neatbilst ekspertu viedoklim, bet piedalīšanās princips liek respektēt atšķirīgas intereses un viedoklus.

Kaut arī ilgtspējīgas attīstības pamatprincipi ir daudzveidīgi, tomēr konkrētu pamatprincipu izmantošana atbildīgu ekonomisku, politisku un vides aizsardzības lēmumu pien,emšanu padara praktiskāku. Vērtējot ilgtspējīgas attīstības īstenošanu, ìpaši būtisks ir jautājums par ilgtspējīgas attīstības koncepcijas izmantošanas iespējām atšksirīga ekonomiskā un sociālā režīma valstīm.

Līdz šim visplašāk ir pētītas industriāli attīstīto valstu ilgtspējīgas attīstības iespējas. Lai arī šo valstu skaits ir relatīvi mazs, tomēr ilgtspējīgas attīstības pamatprincipu ievērošana tajās ir īpaši aktuāla saistībā ar augsto patērin,a līmeni, kas mijiedarbībā ar brīvā tirgus ekonomikas un globalizācijas procesiem būtībā ir viens no galvenajiem problēmu cēloṇiem.

No otras puses, tieši industriāli attīstīto valstu grupā vērojama izpratne par ilgtspējīgas attīstības nepieciešamību. Industriāli attīstītajās valstīs par ilgtspējīgas attīstības stratēgiski nozīmīgu virzienu priekšplānā ir dematerializācijas koncepcija - ekonomiskās attīstības un materiālu patēriṇa atsaistīšana jeb labklājības pieauguma nodrošināšana, vienlaikus samazinot materiālu un resursu patēriṇu.

Situācija industriāli attīstītajās valstīs visai ievērojami atšksiras no situācijas, piemēram, Āfrikā, lielākajā daḷā Āzijas un Dienvidamerikas valstu, arī daudzās Eiropas valstīs. Šo valstu iedzīvotāju vēlme pēc iespējas straujāk sasniegt industriāli attīstīto valstu labklājības līmeni vēl vairāk aktualizē nepieciešamību panākt ekonomiskās attīstības un materiālu patēriña atsaistī̌sanu.

Savukārt pasaules nabadzīgākajās valstīs ilgtspējīgas attīstības jautājumi ir saistīti ar brīvā tirgus ekonomikas un globalizācijas negatīvo seku radīto problēmu risināšanu, kas būtībā nav iespējams vietējā mērogā. 


\section{Literatūra}

AtKisson A. (2012) Annual Survey Report of the Institute for Studies in Happiness, Economy, and Society, Tokyo, Japan.

AtKisson A. (1999) Believing Cassandra. Vermont, ChelseaPublishing company.

Baker S. (2006) Sustainable Development. London: Routledge.

Becker P. (2014) Sustainability Science. Elsevier, London, New York, Sydney, Tokyo.

Degnbol-Martinussen J, Engberg-Pedersen P. (1999) Understanding International Development Cooperation. ZED Books, London, New York, Copenhagen.

Epstein M. (2008) Making Sustainability Work. Greenleaf Publishing, Sheffield.

Foundations of environmental sustainability. Eds. Rockwood L., Stewart R., Dietz T. (2008) Oxford University Press.

Gore A. (2006) An Inconvenient Truth. London, Bloomsbury Publishing.

Gors A. (2009) Neērtā patiesība. Rīga, apgāds Zvaigzne ABC.

Latvijas ilgtspējīgas attīstības pamatnostādnes (2002) Latvijas Republikas Ministru kabinetā apstiprinātas 2002. gada 13. augustā.

Lauder H., Brown P., Dillabough J., Halsey A. (2006) Education, Globalozation and Social Change. Oxford University Press, Oxford, New York.

Leichenko R., O'Brien K. (2008) Environmental Change and Globalization. Oxford University Press, New York, Oxford, Nairobi, Toronto.

Meadows D. H., Meadows D. L., Randers J. (1992) Beyond the Limits: Confronting Global Collapse, Envisioning a Sustainable Future. UK: Earthscan.

Meadows D., Randers J., Meadows D. (2008) Limits to Growth: The 30-year Update. London: Earthscan.

Muler H. (2009). Building a New World Order. Haus Publishing, London.

O'Neil K. (2009) The Environment and International Relations. Cambridge University Press, Cambridge, Cambridge, New York, Melbourne, Dehli.

Our Common Future. The World Commission on Environment and Development. Chair. Bruntland G.H. Oxford, New York, Oxford University Press, 1987.

Randers J. (2012) 2052: A Global Forecast for the Next Forty Years. Chelsea Green publishing, Vermont.

Revesz R., Sands P., Stewart R. (2008) Environmental Law, the Economy and Sustainable Development. Cambridge University Press, Cambridge, New York, Melbourne, Madrid, Cape Town.

Römpczyk E. (2007) Gribam ilgtspējigu attīstību. Rīga: Friedrich-Ebert-Stiftung.

Sorensen S. (2010) The Sustainable Network. Beijing, Cambridge, Taipei, Tokyo, O'Reilly Media.

Strategies Toward Sustainable Development: Implementing Agenda 21. Oceana publications, New York, 2004.

Success Factors for Local Agenda 21 in the Baltic Sea Region. Eds. Gronholm B., Joas M., Nordstrom M. Abo, Finland, 2001.

Sustainability Measures. Eds. Bennet M., James P. Greenleaf Publishing. Sheffield, 1999.

The Baltic Sea Region - Cultures, Politics, Societies. Ed. Maciejewski W., Uppsala, A Baltic University Publication, 2002.

The Sustainability Curriculum. Eds. Blewitt J., Cullingford. Earthscan, London, 2004.

Towards Sustainable Household Consumption. Paris, OECD, 2002.

UNDP Latvia (2004) Kā dzīvosim Latvijā 2015. gadā? Ziṇojums par ANO Tūkstošgades attīstības mērkiem Latvijā. Rìga: UNDP Latvia.

Vide un ilgtspējīga attīstība (2010) Red. M. Kḷaviņšs, J. Zaḷoksnis. Rīga, LU Akadēmiskais apgāds.

Vides zinātne (2008) Red. M. Kḷaviņš. Rīga, LU Akadēmiskais apgāds.

Vries B. (2013) Sustainability Science. Cambridge, Cambridge University Press.

Interneta resursi

WWF - World Wildlife Fund (2002) Living Planet Report 2002. WWF. [23.01.2005.]

Pieejams: $h t t p: / / g l o b a l i s . g v u . u n u . e d u / i n d i c a t o r . c f m ? C o u n t r y=L V \& I n d i c a t o r l D=99$

Baltic 21 (1998) An Agenda 21 for the Baltic Sea Region - Baltic 21. Pieejams: www.baltic21.org/?a,166 
ICLEI - International Council for Local Environmental Initiatives (2004) Aalborg Commitments. ICLEl. Pieejams: www.aalborgplus 10.dk/

Sustainable Development Strategy. Pieejams: $h$ ttp://ec.europa.eu/comm/sustainable/

Ekonomisko instrumentu datubāze. Pieejams: www.economicinstruments.com/

\section{Izmantotie attēli}

12.1. https://en.wikipedia.org/wiki/Hadza_people

12.2. https://en.wikipedia.org/wiki/File:Maler_der_Grabkammer_des_Sennudem_001.jpg

12.3. http://www.uzdevumi.Iv/p/vesture/10-klase/cilveces-attistiba-akmens-laikmets-4294/re-d7b62406-6f13-41ac80b7-8180c8d462b7

12.4. https://libcom.org/blog/climate-class-neolithic-revolution-09062014

12.5. Alphaspirit/Shutterstock.com

12.6. http://en.wikipedia.org/wiki/California_Gold_Rush

12.7. http://en.wikipedia.org/wiki/The_Jungle

12.9. https://en.wikipedia.org/wiki/Silent_Spring

12.10. http://en.wikipedia.org/wiki/File:Apollo_17_Cernan_on_moon.jpg

12.12. Donella Meadows, Jorgen Randers, Dennis Meadows. Limits to Growth: the 30-year update. Earthscan, London, Sterling VA, (2008), $169 \mathrm{p}$.

12.13. $h$ ttp://www.oecd.org/dev/pgd/economydevelopingcountriessettoaccountfornearly60ofworldgdpby2030 accordingtonewestimates.htm 
13.

Adaptācija

klimata pārmaiṇām 


\subsection{Adaptācijas koncepcija}

Klimata pārmaiṇas patiešām notiek! Taču laika apstākḷi var būt risku cēlonis, kurus nosaka klimata dabiskā mainība. Mūs apdraud ne tikai klimata pārmain, as, bet arī cilvēka neietekmēta dabiska klimata ekstremālas parādības. Sausums vai intensīvi nokrišni, karstuma viḷni vai neparasts aukstums, vētras, plūdi, virpulviesuḷi, krusa utt. ir klimatiskas parādības, kuru cēlonis var būt dabiski norisoši procesi. Šādas parādības ir pastāvējušas un būs arī nākotnē. Piemēram, 2012. gadā novērotas 905 dabas katastrofas, no kurām 93\% saistāmas ar klimatiskām parādībām: 45\% meteorologiskas (vētras), 36\% hidrologiskas (plūdi), 12\% klimatoloǵiskas (karstuma vilṇi, mežu ugunsgrēki un citi), bet 7\% bija geofizikālas izcelsmes dabas katastrofas (zemestrīces, vulkānu izvirdumi). No 1980. līdz 2011. gadam geofizikālas dabas katastrofas veidoja 14\% no visām dabas katastrofām.

Lai nodrošinātu kvalitatīvu dzīves vidi un mazinātu bīstamu klimatisko parādību radītās ietekmes, ir svarīgi tām piemēroties, t.i., adaptēties klimata pārmaiṇām un klimata dabiskajai mainībai.

Adaptācijas pirmais solis ir politisku lēmumu pieñemšana (Latvijā, Eiropas Savienībā, starptautiskā līmenī). Tā ir jauna politika, kas atrodas izstrādes stadijā. Adaptācijas mērkis ir konkrētas darbības, rīcības, lai nodrošinātu cilvēku, tautsaimniecības un dabas vides aizsardzību no klimata izraisītiem riskiem. Adaptācijas politika un rīcības programmas ir ilgtspējīgas attīstības politikas elementi. Adaptāciju var definēt kā dabas vai cilvēka radītu sistēmu pielāgošanu tā, lai mazinātu potenciālu kaitējumu vai izmantotu iespējamus ieguvumus, kurus rada klimata pārmaiņas vai klimata dabiskā mainība.

Kaut arī adaptācijas koncepcija ir jauna, piemērošanās klimata riskiem ir sākusies, cilvēcei mazinot atkarību no dabas vides, piemēram, cilvēks kḷuva aizvien mazāk atkarīgs no aukstuma, kad iemācījās izmantot uguni, izveidot apmetnes. Nepieciešamība aizsargāties no plūdu riskiem sekmēja pilsētu attīstību un rūpniecību. Ja pašlaik viena no vides politikas prioritātēm ir ES Plūdu direktīvas ieviešana, tad pretplūdu aizsardzība, dzīves vietu izveide, lai plūdi neapdraudētu mìtnes un cilvēkus, ir bijusi viens no cilvēku kopienu sekmīgas attīstības priekšnosacījumiem. Vienkāršā atziṇa, ka māju nedrīkst celt plūdu apdraudētās upju palienās, ir bijusi pašsaprotama gadsimtiem ilgi, bet mūsdienās tas dažkārt ir jāatklāj no jauna! Var apgalvot, ka mūsdienu klimata adaptācijas koncepcijas viens no būtiskiem avotiem ir tās zināšanas un mutvārdu tradīcijas, kuras ir pastāvējušas gadsimtiem ilgi. Taču mūsdienu tehnologiskais progress, sabiedrības pārvaldības sistēma un strukturētās pieejas problēmu risināšanai prasa izstrādāt jaunas metodes, lai mazinātu klimata pārmaiṇu vai mainības radītos riskus.

Adaptācijas jēdziens ir cieši saistīts ar ilgtspējīgas attīstības politikas izstrādi un ir pieminēts ANO Vispārējā konvencijā par klimata pārmain̄ām, tās Kioto protokolā un citos starptautiskās likumdošanas aktos. Tomēr saikne ar ilgtspējīgas attīstības politiku ir dzilāka, jo adaptācijas nepieciešamība ietver nepieciešamību veikt darbības, kuras sniedzas pāri tai robežai, kas parasti ir kritiska ikviena politiksa vēlēšanu periodam. Adaptācijas mērksis ir mazināt riskus, kurus var radīt, piemēram, plūdi, kuru notikšanas varbūtība ir reizi 100 gados. Tātad adaptācijas koncepcija ietver sevī rūpes par sabiedrību kopumā, nevis tikai noteiktu elektorāta grupu, turklāt jārēksinās ar iespējamām ietekmēm un riskiem. Adaptācijas mērkis ir novērst riskus, nevis rīkoties pēc tam, kad nelaime jau ir notikusi.

Klimata pārmaiṇu radītie riski ir tik būtiski, ka to risināšanai ir mobilizēta starptautiskā sabiedrība. Ja klimata pārmaiṇu mazināšana lielā mērā ir atkarīga no valstu sadarbības saskañā ar savstarpējas vienošanās principiem, tad adaptācija lielā mērā ir katras valsts risināms politikas uzdevumu un rīcību kopums. Adaptācijai ir jāatbalsta arī reǵionālas darbības un jāveic nepieciešamie vietējie uzdevumi atbilstoši katras pašvaldības pastāvošām aktualitātēm. 
Protams, risināmās problēmas un jautājumi starptautiskā, reǵionālā, nacionālā un vietējā līmenī ir būtiski atšksirīgi.

Adaptācijas politika ir viens no pasaules vides politikas elementiem un saistīts ar klimata pārmaiṇu mazināšanas politiku. Respektīvi, klimata pārmaiṇu mazināšana un piemērošanās tām ir integrāli saistītas. Mūsdienu vides problēmu aktualitātes pieaugums klimata politiku izvirza par vienu no politiskā procesa būtiskiem elementiem, un tā ir nozīmìga aktualitāte ES dalībvalstīs, arī Latvijā. Pašvaldību līmenī adaptācijas jautājumi kḷūst aizvien nozīmīgāki. Lai sekmētu adaptācijas plānošanu un ieviešanu, ir svarīga sadarbība visos politikas veidošanas un ieviešanas līmenos.

Vienlaikus adaptācija saistīta ar ieguldījumiem, lai mazinātu riskus, kas ir tikai iespējami. Lai pamatotu rīcību nepieciešamību un pieñemtu lēmumu, svarīgi ir izvērtēt klimata radītos riskus ekonomikas kategorijās. Tieši klimata pārmaiṇu ekonomiskā novērtējuma komplicētība ir galvenais faktors, kas ir svarīgs gan diskusijās ar sabiedrību par klimata politikas mērksu sasniegšanu, gan arī konkrētu investīciju projektu pamatošanai. Jautājumu sarežgi tas, ka ir ietekmes, kuras monetārās kategorijās vērtēt ir grūti, piemēram, biologiiskās daudzveidības samazināšanās. Tomēr ir pietiekami daudz klimata risku veidu, kuru ietekmes un potenciālās izmaksas novērtēt var visai precīzi, piemēram, zemes platību zaudējumus piekrastes noskalošanas rezultātā.

Ir iespējams izdalīt vairākus adaptācijas veidus gan atkarībā no tā, kā notiek reakcija uz klimata pārmaiṇu riskiem, gan atkarībā no rīcībām, kas nodrošina piemērošanos. Izškịir

1) autonomo adaptāciju,

2) preventīvo adaptāciju,

3) post factum adaptāciju,

4) plānoto adaptāciju.

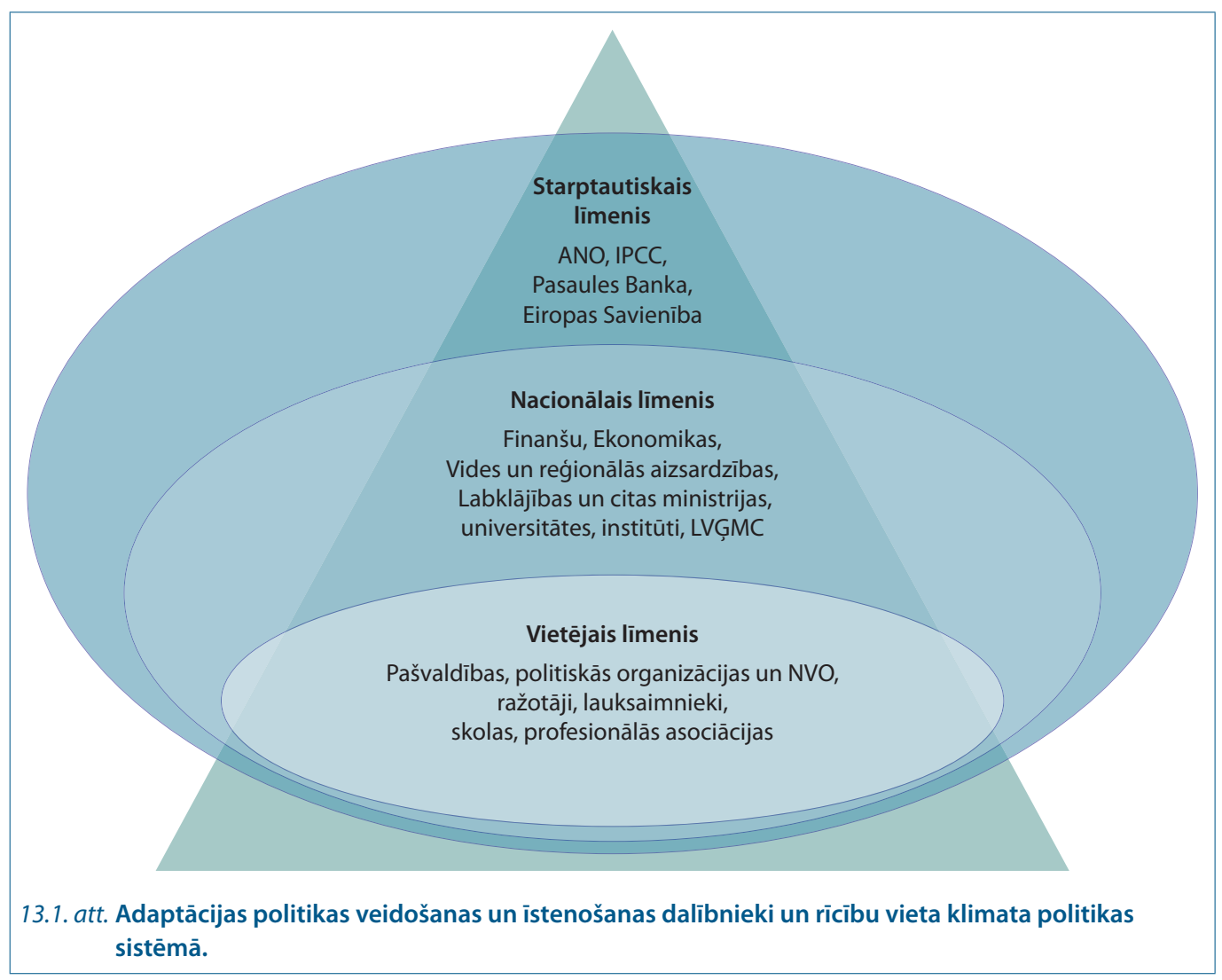


Adaptācijas uzdevumu sasniegšanai var izmantot dažāda veida kombinācijas, kuru mērķis ir samazināt jutīgumu, nodrošināt klimata risku pārvaldību vai veikt proaktīvu risku mazināšanu.

1. Sociālās vides aizsardzības pasākumi.

2. Infrastruktūras pilnveidošana.
3. Tehnologiskie risinājumi.

4. Integrēta dabas resursu pārvaldība.

5. Institucionālās sistēmas, izglītošana vai izturēšanās veida izmaiñas.

6. Finansiālie pakalpojumi.

7. Informācijas sistēmu izveide, lai nodrošinātu agrīnu brīdināšanu.

\section{1. tabula. Pieejas adaptācijai, lai mazinātu klimata pārmaiṇu risku:} jutīguma un atkarības ierobežošana no laika apstākḷiem

\begin{tabular}{|l|l|}
\hline \multicolumn{1}{|c|}{ Adaptācijas aktivitāte } & \multicolumn{1}{c|}{ Piemērs } \\
\hline Cilvēkresursu attīstība & $\begin{array}{l}\text { Uzlabotas pieejas izglītībai, veselības aprūpei, drošai mītnei, sociālā atbalsta sistēmai. } \\
\text { lenākumu nevienlīdzības mazināšana. }\end{array}$ \\
\hline Nabadzības mazināšana & Uzlabota pieejamība vietējiem resursiem. Katastrofu risku pārvaldība. Sociālās palīdzības tīkli. \\
\hline Dzīves vides drošība & $\begin{array}{l}\text { Uzlabota infrastruktūra. Līdzdalība lēmumu pien,emšanā. Pieeja jaunākajiem tehnoloǵiskajiem } \\
\text { risinājumiem. }\end{array}$ \\
\hline $\begin{array}{l}\text { Katastrofu riska } \\
\text { mazināšana }\end{array}$ & $\begin{array}{l}\text { Informācija par riskiem. Agrīnās brīdināšanas sistēmas. Ūdens un enerǵijas resursu } \\
\text { pieejamības nodrošinājums. Būvju drošība. Vētru riska mazināšana. Transporta } \\
\text { infrastruktūras pilnveidošana. }\end{array}$ \\
\hline Ekosistēmu pārvaldība & $\begin{array}{l}\text { Mitrāju un pilsētu zaḷo platību aizsardzība. Piekrastes teritoriju apmežošana. Ūdens resursu } \\
\text { pārvaldība. }\end{array}$ \\
\hline $\begin{array}{l}\text { Telpiskā un zemes } \\
\text { izmantošanas plānošana }\end{array}$ & $\begin{array}{l}\text { Dzīves vietu kvalitātes nodrošināšana. Plānošana plūdu un citu risku teritorijās. Attīstība } \\
\text { aizsargājamās teritorijās. Pilsētas plānošanas risinājumi. }\end{array}$ \\
\hline
\end{tabular}

\section{2. tabula. Pieejas adaptācijai, lai mazinātu klimata pārmaiṇu risku:} tehnoloǵiskie risinājumi un adaptācijas sistēmas izveidošana

\section{\begin{tabular}{l|l} 
Adaptācijas aktivitāte & Piemērs \\
\hline
\end{tabular}}

Nacionāla līmeṇa $\quad$ Nacionāla un vietēja līmeṇa adaptācijas stratēǵijas un rīcības programmas. Ekonomikas politika un adaptācijas diversifikācija. Pilsētvides pielāgošana. Katastrofu risku mazināšanas programmas un rīcību pārvaldība plānojums. Ūdens resursu un piekrastes pārvaldības plāni.

Likumdošanas sistēmas pilnveidošana

Zemes lietojuma zonēšana. Celtniecības kvalitātes kontrole. Likumdošana, lai sekmētu katastrofu risku mazināšanu. Likumdošana, kas sekmē risku apdrošināšanu. Likumdošana, kas sekmē tehnoloǵisko progresu.

Ekonomikas sektora iniciatīvas

Klimatisko risku apdrošināšanas sistēma (valsts garantijas). Ekosistēmu pakalpojumu novērtējums. Resursu taupīšanas sekmēšana. Adaptācijas tehnoloǵisko
risinājumu attīstība

Adaptācija lauksaimniecībā, mežsaimniecībā

Ekosistēmu resursu izmantošana

Izglītība un pētniecība
Bīstamības un risku kartēšana. Agrīnas brīdināšanas un prognozēěanas sistēmas. Krasta aizsardzības struktūras. Pretplūdu risinājumi. Celtniecības prakses pilnveidošana. Transporta un ceḷu infrastruktūras uzlabošana. Energopārvades un informāciju tehnoloǵiju drošība.

Jaunas augu kultūras un to izmantošanas risinājumi. Tradicionālo zināšanu izmantošana. Irigācija un ūdens taupī̌̌ana. Siltumizolācijas un dzesēšanas risinājumi.

Vides rekultivācija. Apmežošana. Zaḷās infrastruktūras izveide (parki, zaḷie jumti utt.). Ekoloǵiskie koridori un tīklojums.

Risku kartējums. Brīdināšanas un prognozēšanas sistēma. Klimata izglītības sistēmas izveide. Tālākizglīīiba. Klimata risku izpēte. 


\subsection{Adaptācijas politika}

Adaptācijas politikā iniciatìva pieder starptautiska līmeña dalībniekiem, un to nosaka klimata pārmainu globālie draudi, kas izpaužas gan kā pasaules gada vidējās temperatūras paaugstinājums, gan arī kā dažādas ietekmes uz ekosistēmām visos kontinentos, Pasaules okeāna ūdens līmeña celšanās, arvien pieaugošie dabas katastrofu seku apmēri:

- ekstremālo dabas parādību biežuma pieaugums,

- jūras līmeña celšanās un piekrastes teritoriju apdraudējums,

- ietekme uz cilvēku veselību un labklājību,

- ietekme uz lauksaimniecību un mežsaimniecību,

- ietekme uz biologisko daudzveidību un ekosistēmu pakalpojumiem,

- ietekme uz reǵionālo attīstību,

- ietekme uz pilsētvides attīstību, plānošanu un būvniecību,

- ietekme uz iedzīvotāju migrāciju.

Globālās adaptācijas politikas nozīmīgs elements ir tādu procesu negatīvo ietekmju mazināšana, kas sniedzas pāri nacionālo valstu iespēju un interešu spējām. Izteikta problēma ir, piemēram, okeānu salu applūšanas draudi, jo šajā gadỉjumā kombinējas gan jūras līmeña celšanās draudi, gan ekstremālo parādību ietekmju draudi.

Cita globālās adaptācijas politikas aktivitāšu joma ir rīcība, lai mazinātu klimata pārmain,u ietekmi uz iedzìvotāju migrāciju. Tas parāda klimata pārmaiṇu milzīgo ietekmi un nepieciešamību sākt darbības, lai mazinātu negatīvo ietekmi. Visi klimata pārmain,u rakstura novērojumi un modeḷi rāda ievērojamu nokrišṇu daudzuma samazināšanās risku, piemēram, Ziemel̦āfrikā, kas, apvienojoties ar iedzīvotāju skaita pieaugumu un politisko nestabilitāti, ir nozīmīgs drauds ne tikai regiona, Eiropas, bet visas cilvēces attīstībai.

Gan klimata, gan adaptācijas politikas specifika ir tāda, ka tās pirmsākumi meklējami starptautiskā līmenī. Tiek uzskatīts, ka ir svarīgi adaptācijas politiku risināt valdības līmenī:
- piemērošanās (preventīvie) pasākumi lauj samazināt izmaksas un dod tūlītējus rezultātus (jo īpaši tas attiecas uz lauksaimniecību);

- neskaidrības, riski un ieguvumi apgrūtina indivīda izpratni par ieguvumiem no pielāgošanās politikas, tāpēc tie risināmi valdības līmenī;

- informēšana, zināšanas, apmācība vissekmīgāk nodrošināma, ja tā ir integrēta visas valsts politikā;

- palīdzība nelaimē sniedzas pāri indivīda vai reǵiona spējām un risināma vismaz nacionālā līmenī;

- risinājumu, vadlīniju izstrāde prasa kompetenci;

- atbilstošu rīcības spēju (finanšu un cilvēkresursu) nodrošināšana;

- infrastruktūras plānošana un attīstība.

Mūsdienās risku identifikācija vairāk vai mazāk ir notikusi atsevišku nozaru politikas plānošanas dokumentos, detalizētāk - civilās aizsardzības sistēmā. Taču risku apzināšana un pārvaldības mehānisms ir jāparedz arī visaptverošā nacionālās drošības sistēmā. Klimata mainības risku ietveršana nacionālajā valsts drošîbas sistēmā, izstrādājot monitoringa sistēmu un sastādot riska objektu kartes (tās regulāri

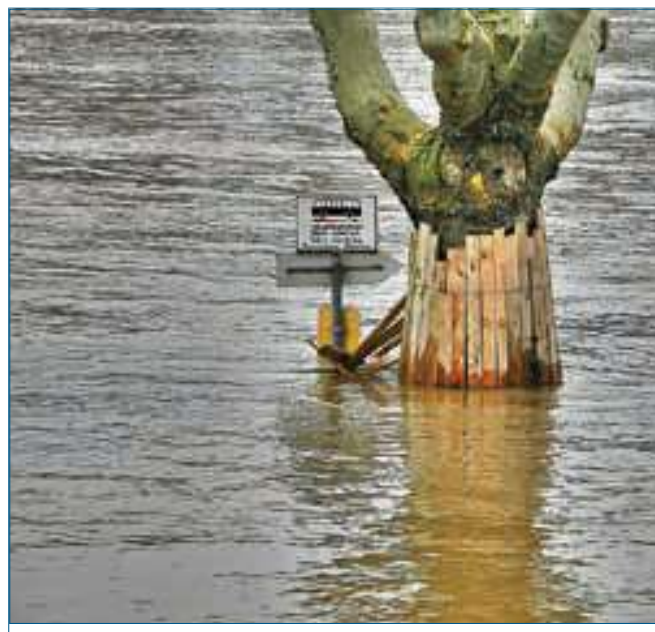

13.2. att. Plūdi Koblencā 2011. gadā (Vācija). 
atjaunojot), atvieglotu risku identificēšanas un novērtēšanas (ieskaitot finansiālo) procesu, pilnveidotu dažādu prognožu un attīstības modeḷu sistēmas veidošanu, arī tās sistēmas, kas saistītas ar klimata mainības ietekmju izvērtējumu uz dažādām dabas ekosistēmām un bioloǵisko daudzveidību, cilvēku veselību un labklājību kopumā.

Kāpēc ir jāveido vienota stratēǵija ar klimata riskiem saistītas visaptverošas sistēmas izveidei? Vai nevar iztikt kā līdz šim, jo tik l,oti postošas kataklizmas Latviju vēl neapdraud?

Diemžēl tā ir tikai ilūzija, jo iespējamas negatīvas sekas, ja klimata mainības radītie riski netiks laikus identificēti un radītas alternatīvas šo risku novēršanai vai efektīvai piemērošanās procesu veikšanai:

- katru gadu valsts būs spiesta maksāt milzīgas kompensācijas gan atsevišksiem sektoriem (jo īpaši lauksaimniecībā un mežsaimniecībā), gan iedzīvotājiem par dabas nodarītajiem postījumiem viṇu īpašumiem, veselībai vai pat dzīvībai,

- šie riski kroplos dabisko konkurenci tirgus ekonomikā, iznīcinot pat atsevišksas apakšnozares,

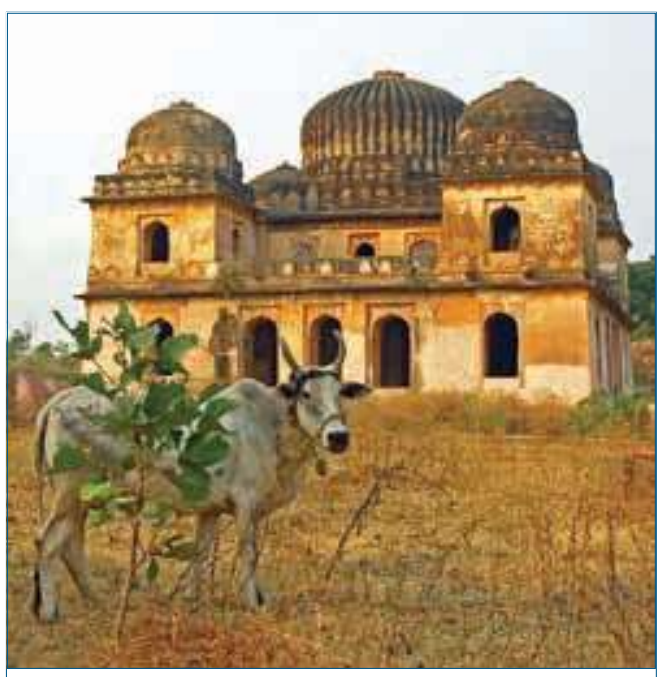

13.3. att. Karstuma vilnis Indijā - gaisa temperatūra 2015. gada pavasarī pārsniedza $43^{\circ} \mathrm{C}$, tika radīti milzīgi zaudējumi lauksaimniecībā, gāja bojā cilvēki.
- netiks pildītas ES tiesību aktos un politikas plānošanas dokumentos, kā arī ANO Vispārējās konvencijas par klimata mainību un tās Kioto protokolā noteiktās saistības, tādējādi valsts var nonākt nepatīkamā stāvoklī, raugoties no starptautiskā viedokḷa.

Par galvenajiem adaptācijas politikas īstenošanas veidiem noteikta pārvaldība (ieskaitot riska pārvaldību kā galveno), būtiskāko darbības virzienu noteikšana (ieskaitot valstu valdību, pašvaldību, privātā sektora utt. lomu) un adekvātas apdrošināšanas sistēmas radīšana. Neskaidrības vēl rada Kioto protokola funkcijas adaptācijas pasākumu finansēšanas mehānismu (piemēram, pielāgošanās fonda) radīšanā un pilnveidošanā.

Piemērošanās politikai jākḷūst par ekonomiski pamatotu papildinājumu nepieciešamajiem klimata mainības mazināšanas pasākumiem, turklāt tā būtu jāuztver par ilgtspējīgas attīstības nepieciešamāko sastāvdalıu, integrējot to sektoru politikās kopā ar pētījumiem, tehnologiju pārnesi, sabiedrības informēšanu un informētības līmen,a paaugstināšanu, kā arī strauju un pamatotu rīcībspējas celšanu.

Pirmais nozīmīgais starptautiskais dokuments, kas attiecas tieši uz klimata pārmain,u radītajiem riskiem un ar tiem saistītajiem jautājumiem, bija ANO Lēmums 1/CP.10 Buenosairesas darba programma par adaptāciju$^{1}$. Tajā pausts, ka līdztekus jau aprobētiem adaptācijas pasākumiem (piemēram, aizsargdambji pret plūdiem, hidromezglu ierīkošana, upju gultṇu tīrīšana, stāvkrastu nostiprināšana u.c.) jāstimulē inovatīvi pasākumi un tehnologiju attīstība. To varētu veikt, attīstoties un veiksmīgi funkcionējot starptautiskajam $\mathrm{CO}_{2}$ emisiju tirgum, dažādiem fondiem, daudzpusējām finansiālām institūcijām u.c.

ANO Vispārējās konvencijas par klimata pārmaiṇām dalībvalstu 12. sesijā un Kioto protokola dalībvalstu otrajā sesijā, kas 2006. gadā notika Nairobi (Kenijā), tika pien,emta Nairobi

\footnotetext{
${ }^{1}$ Decision 1/CP.10 Buenos Aires programme of work on adaptation and response measures, FCCC/CP/2004/ 10/Add.1,19.04.2005.
} 
Piecu gadu darba programma par klimata pārmaiñu ietekmi, to radītajiem apdraudējumiem un pielāgošanos tām. Tika panākta vienošanās par principiem un nosacījumiem Pielāgošanās fonda (kā galvenā starptautiskā finanšu mehānisma) darbībai un pārvaldībai.

2013. gadā tika izveidots Varšavas Starptautiskais mehānisms, lai sekmētu iniciatīvas klimata pārmaiṇu radīto zaudējumu mazināšanai, bet 2015. gadā notika ANO konference par Klimata katastrofu risku mazināšanu. Nozīmīgs pagrieziena punkts ir 2015. gada Parīzes ANO konference par klimata politiku.

Eiropas Kopienas ietvaros izstrādāti pamatdokumenti, lai nodrošinātu ES dalībvalstu, visas ES un reǵionu (piemēram, Vidusjūras reǵiona) politikas izveidi klimata pārmainu adaptācijai. Eiropas Komisijas "Zalıajā grāmatā" par adaptāciju klimata mainībai ${ }^{2}$ pausts viedoklis, ka nepieciešams izstrādāt adaptācijas politiku visos līmeños (nacionālajā, regionālajā, vietējā), integrējot politikas un to realizāciju galvenajos tautsaimniecības sektoros, īpašu uzmanību veltot ūdenssaimniecībai un ūdensapgādei, veselībai, lauksaimniecībai, regionālajai plānošanai, enerǵêtikai, transportam, ekosistēmām, vides ietekmes izvērtējuma un stratēgiskā vides izvērtējuma nozīmībai, kā arī civilās sistēmas un agrās brīdināšanas sistēmas pastiprināšanai preventīvu pasākumu nodrošināšanā.

"Zalıajā grāmatā" uzsvērts, ka piemērošanās klimata mainībai politikas mērkis ir izmaksu zinnā efektīvi samazināt riskus un zaudējumus, ko rada dabas katastrofas un cita veida klimata mainība, kā arī izpētīt potenciālos labumus, kādus iegūtu sabiedrība un ekosistēmas, laikus novēršot riskus. "Zalıjajā grāmatā" izvirzītas šādas prioritātes:

- savlaicīga rīcība, lai izstrādātu piemērošanās stratēǵijas nozarēs un jomās, kur pašreizējās zināšanas ir visvājākās,

\footnotetext{
${ }^{2}$ Komisijas "Zaḷā grāmata" Padomei, Eiropas Parlamentam, Eiropas Ekonomikas un Sociālo lietu komitejai un Reǵionu komitejai "Adaptācija klimata mainībai Eiropā. ES rīcības varianti”, COM (2007) 354, Briselē, 29.06.2007.
}

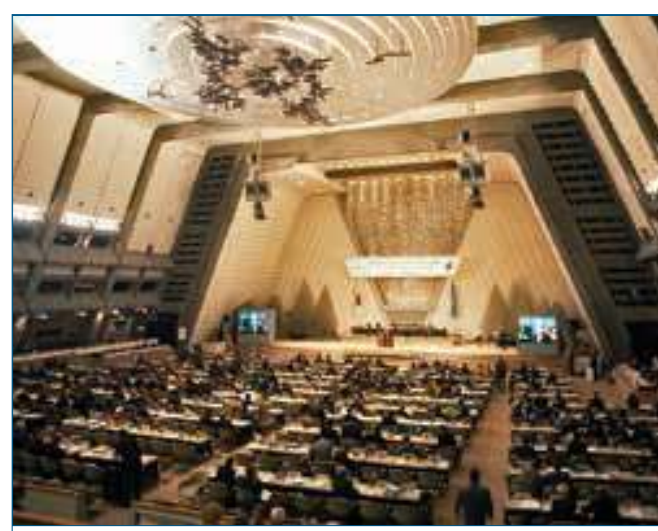

13.4. att. Apvienoto Nāciju organizācijas konference par klimata pārmaiñām Kioto (Japāna), 1997. gads.

- globālo piemērošanos vajadzību integrēšana ES ārējās attiecībās un jaunas starptautiskas partnerības dibināšana,

- zināšanu trūkuma vai nepilnību novēršana par piemērošanās jautājumiem, veicot pētījumus un informācijas apmaingu ES līmenī,

- Eiropas pārraudzības grupas izveide, lai analizētu koordinēto stratēǵiju un rīcību īstenošanu.

Kā nākamais ES klimata politiskais dokuments tika izstrādāta "Baltā grāmata" ${ }^{3}$. ES "Baltajā grāmatā” sniegts izvērtējums adaptācijai klimata pārmaiṇām, uzsvērta nepieciešamība adaptācijas stratēǵijas un rīcības programmu izstrādi pamatot, izmantojot plānoto rīcību ekonomisko analīzi. Tomēr par galveno sasniegumu var uzskatīt prasību izstrādāt ES stratēgiju adaptācijai klimata pārmaiṇām un dalībvalstu adaptācijas stratēǵijas.

ES adaptācijas stratēgijas mērḳis ir nodrošināt dalībvalstu noturību pret klimata pārmaiñām, uzlabot gatavību un spēju reagēêt uz klimata pārmaiṇu ietekmi pašvaldību, reǵionālā,

\footnotetext{
${ }^{3}$ Komisijas "Baltā grāmata" Padomei, Eiropas Parlamentam, Eiropas Ekonomikas un Sociālo lietu komitejai un Reǵionu komitejai "Adaptācija klimata pārmaiṇām Eiropā: Virzībā uz Eiropas ietvaru darbībai", COM (2009) 147, galīgā redakcija, Briselē, 1.04.2009.
} 
valsts un ES līmenī, izstrādājot saskaņotu pieeju un koordinējot pasākumus.

Galvenais veids adaptācijas mērḳu sasniegšanai ir valstu līmeṇa pielāgošanās stratēǵijas, kas var nodrošināt piemērošanos un prioritāšu noteikšanu attiecībā uz darbībām un ieguldījumiem, kā arī kopīgu pieeju izstrādi un saskaṇošanu starp valstu pielāgošanās stratēgijām un valstu risku pārvaldības plāniem. ES atbalsta labas prakses apmainu starp dalībvalstīm, reǵioniem, pilsētām un citām ieinteresētajām organizācijām un personām.

Adaptācijas stratēgijā īpašu uzmanību paredzēts pievērst darbībām pilsētās, kā arī pielāgošanās pasākumu integrēšanai ES rīcībpolitikās un programmās, lai nodrošinātu ES darbības "klimatgatavību". Tās jomas, kurās pielāgošanās plānojuma integrācija ir īpaši nozīmīga, ir jūras ūden,i, mežsaimniecība, transports, iekšzemes ūdeṇi, biologiskā daudzveidība, migrācija un mobilitāte. Šĩs iniciatīvas, lai pielāgošanos klimata pārmaināām integrētu ES rīcībpolitikās, tiks turpinātās tādās prioritārās jomās kā energétika un transports. Veselības politikas jomā vairums cilvēku, dzīvnieku un augu aizsardzības veselības pasākumu un sistēmu jau ir ieviestas, taču tās būs jāpielāgo jaunajiem klimata pārmainu radītajiem sarežǵijumiem.

Par būtisku jutīguma samazināšanai uzskatāma katastrofu riska apdrošināšana, kas gan dalībvalstīs pašlaik ir maz pieejama.

Adaptācijas stratēǵijas uzmanības centrā ir zināšanas par pielāgošanos un pētniecības programmas valstu un reǵionālo pielāgošanās stratēgiju izstrādei. Lai stimulētu inovācijuas un atbalstītu tādu inovatīvu tehnologiju ieviešanu tirgū, kuras palīdz pielāgoties klimata pārmaiṇām, ir vajadzīgas zināšanas.

Plānotās darbības ir šādas.

1. Mudināt dalībvalstis pieñemt visaptverošas pielāgošanās stratēǵijas.

2. Ar LIFE finansējumu atbalstīt spēju veidošanu un palielināt Eiropā veikto pielāgošanās darbību intensitāti (2013.-2020.). Îpaši paredzēts atbalstīt pielāgošanos šādās jomās:

- plūdu pārvaldība pārrobežu līmenī, sadarbības līgumu atbalstǐšana, pamatojoties uz Eiropas parlamenta un padomes direktīvu 2007/60/EK (2007. gada 23. oktobris) par plūdu riska novērtējumu un pārvaldību,

- piekrastes pārvaldība pārrobežu līmenī, jo sevišķi blīvi apdzīvotu deltu un piekrastes pilsētu pārvaldība,

- pielāgošanās integrēšana pilsētu zemes izmantojuma plānošanā, ēku plānošanā un dabas resursu pārvaldībā,

- lauksaimniecības, mežsaimniecības un tūrisma nozaru ilgtspēja un noturība pret klimata pārmaiṇām,

- ūdens resursu ilgtspējīga pārvaldība; cīnna ar pārtuksnešošanos un meža ugunsgrēkiem teritorijās, kam raksturīgs sausums,

- pasākumi, kuru mērksis ir palielināt informētību par pielāgošanos.

3. Atbalstīt pielāgošanos pilsētās, galvenokārt aicinot brīvprātīgi pieñemt pašvaldību pielāgošanās stratēǵijas un veikt informētības veicināšanas darbības.

4. Nodrošināt zinātniski pamatotu informāciju par klimata pārmaiṇām un to ietekmēm:

- informācija par zaudējumiem, pielāgošanās izmaksām un sniegtajiem ieguvumiem,

- regionu un pašvaldību līmeña analīze un risku novērtējumi,

- sistēmas, modeli un uzdevumi lēmumu pieñemšanas atbalstam un dažādo pielāgošanās pasākumu efektivitātes novērtēšanai,

- līdzšinējo pielāgošanās pasākumu monitoringa un novērtēšanas rezultāti.

5. Turpināt Interneta vietnes Climate-ADAPT pilnveidošanu, lai tā Eiropas mērogā kḷūtu par "vienas pieturas aǵentūru" attiecībā uz informāciju par pielāgošanos.

6. Sekmēt kopējās lauksaimniecības politikas, kohēzijas politikas un kopējās zivsaimniecības politikas gatavību klimata pārmaiṇu uzdevumiem.

7. Izveidot noturīgāku infrastruktūru.

8. Atbalstīt apdrošināšanu un citas finanšu metodes, kas uzlabo ieguldījumu un uzñēmējdarbības lēmumu noturību pret klimata pārmaiṇām. 
Pien,emta ES direktīva par plūdu riska izvērtēšanu un pārvaldībư ${ }^{4}$, lai izveidotu plūdu radīto apdraudējumu izvērtēšanas un pārvaldības sistēmu, tādējādi mazinot nelabvēlīgo ietekmi uz cilvēku veselību, vidi, kultūras mantojumu un saimniecisko darbību.

Eiropas Parlaments šajā sakarā norādījis, ka "plūdi ir dabas parādība, kas nav novēršama. Tomēr cilvēka nesaprātīga rīcība (piemēram, apdzīvoto vietu veidošana un investīciju ieguldīšana regulāri applūstošās teritorijās, erozija un zemes dabisko ūdens aiztures spēju samazināšana, izcērtot mežus un nodarbojoties ar lauksaimniecību upju baseinos), kā arī klimata mainība palielinās plūdu rašanās varbūtību un plūdu negatīvās sekas".

Direktīvā minēts: "lai konkrētajā teritorijā izvairītos no plūdiem un lai samazinātu to negatīvās sekas, ir lietderīgi izstrādāt plūdu riska pārvaldības plānus. Plūdu cēloṇi un sekas dažādos Kopienas vai ES reǵionos un valstīs ir dažādi. Tādēḷ plūdu riska pārvaldības plānos būtu jān,em vērā konkrēto apgabalu raksturojums, kurus tie aptver, kā arī rūpniecības un lauksaimniecības iekārtas un citi iespējamie piesārṇojuma avoti attiecīgajā apgabalā, lai novērstu šādu piesārṇojumu, un jānodrošina piemēroti risinājumi saistībā ar šo apgabalu vajadzībām un prioritātēm, tajā pašā laikā nodrošinot piemērotu koordināciju

${ }^{4}$ Eiropas Parlamenta un Padomes direktīva 2007/60/EC par plūdu riska novērtējumu un pārvaldību, publiskots 2007. gada 26. novembrī.

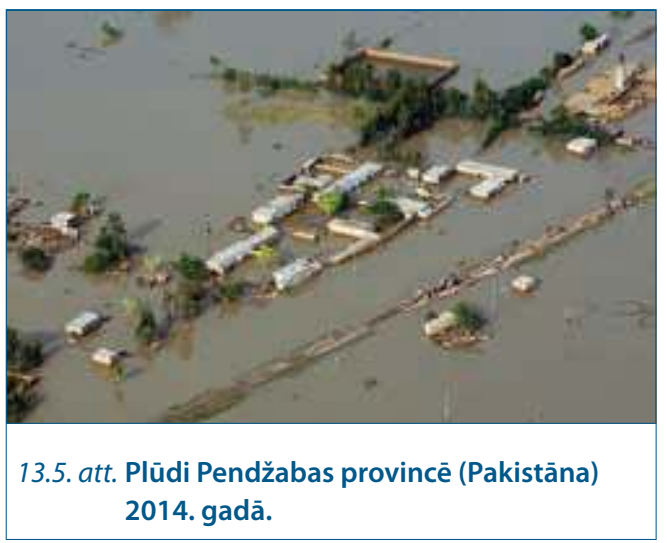

ar upju baseinu rajoniem". Turklāt "plūdu riska pārvaldības plānos uzmanība būtu jāvelta plūdu novēršanai, aizsardzībai un gatavībai tos novērst. Plūdu riska pārvaldības plānu elementi periodiski būtu jāpārskata un vajadzības gadījumā jāatjaunina, n,emot vērā iespējamo klimata pārmaiṇu ietekmi uz plūdu iespējamību".

Plūdu riska pārvaldības plānos jāieklıauj pasākumi, kas ir saistīti ar dabiskiem procesiem, piemēram, palieṇu saglabāšana un/vai atjaunošana, lai atdotu upēm teritoriju, kur vien tas ir iespējams, un veicinātu piemērotu zemes izmantošanu, lauksaimniecisko un mežsaimniecisko darbību visā upes baseinā.

Eiropas Komisijas paziņojumā "Meklējot risinājumu sausuma un ūdens trūkuma problēmai Eiropas Savienībā" teikts, ka līdztekus plūdiem arvien biežāki kḷūst karstie un sausie periodi. Laika posmā no 1976. līdz 2006. gadam sausuma skarto teritoriju un cilvēku skaits ir pieaudzis par gandrīz 20\%. Piemēram, sausums 2003. gadā skāra vairāk nekā 100 miljonus cilvēku un vienu trešdalı no ES teritorijas. Tika aplēsts, ka Eiropas ekonomikai radīto zaudējumu apmērs bija 8,7 miljardi eiro. Pēdējos trīsdesmit gados piedzīvotā sausuma radīto izdevumu apjoms savukārt mērāms simtos miljardu eiro. Ikgadējās vidējās izmaksas šajā periodā palielinājušās četrkārt.

Arī Ūdens struktūrdirektīva, kas ir ES t.s. ietvardirektīva ūdens politikā, akcentē nepieciešamību nodrošināt piemērošanos klimata pārmaiṇām.

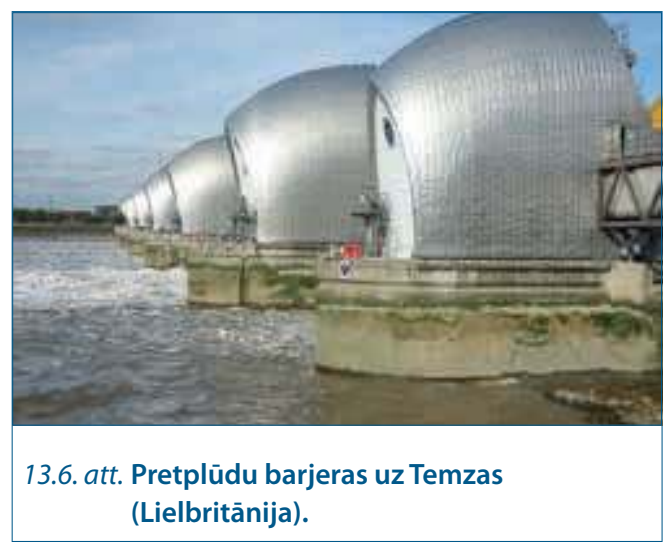


Plūdu jautājumu ES pašlaik risina gan 2001. gadā izveidotais ES civilās aizsardzības mehānisms, gan ES padomes direktīva 2008/114/EK par to, lai apzinātu un noteiktu Eiropas kritiskās infrastruktūras un novērtētu vajadzību uzlabot to aizsardzību (2008. gada 8. decembris), gan vadlīnijas plūdu riska pārvaldības plānu un plūdu riska zonu karšu izstrādei un ieviešanai. Tālākā politikas un pasākumu ieviešana jau būs atkarīga no tā, cik efektīvi nacionālās valstis realizēs izstrādātos plūdu pārvaldības plānus, saistot tos vienotā sistēmā ar valsts nacionālās drošības un civilās aizsardzības mehānismiem, pēdējo ietverot kā būtisku sastāvdaḷu no nacionālās drošības politikas un izvirzot tēzi, ka vides riski ir līdzvērtīgi citiem apdraudējumiem.

\section{3. leteikumi adaptācijas risinājumiem}

Adaptācijas plānojuma un rīcības programmas tiek izstrādātas gan starptautiskā, gan valsts līmenī, tomēr svarīgākās ir tās darbības, kuras ietekmē ne tikai politisku lēmumu pieñemšanu, bet rīcību konkrētā vietā: pašvaldībā, uzṇēmumā, saimniecībā. Taču bez valsts politiskajām nostādnēm un uzdevumiem, kā arī finanšu nodrošinājuma rezultātus sasniegt neizdosies. Svarīga ir arī sabiedrības izpratne par to, kāpēc adaptācija ir nepieciešama un nepieciešamas arī rīcības ikdienas darba plānošanā.

Nozīmīgs resurss adaptācijas risinājumu izstrādāšanā ir platforma ES adaptācijām klimata pārmaiṇām, kurā pieejama informācija gan par teorētiskām koncepcijām adaptācijas uzdevumu risināšanai dažādos līmen,os, gan arī piemēri, kā adaptācijas jautājumi jau

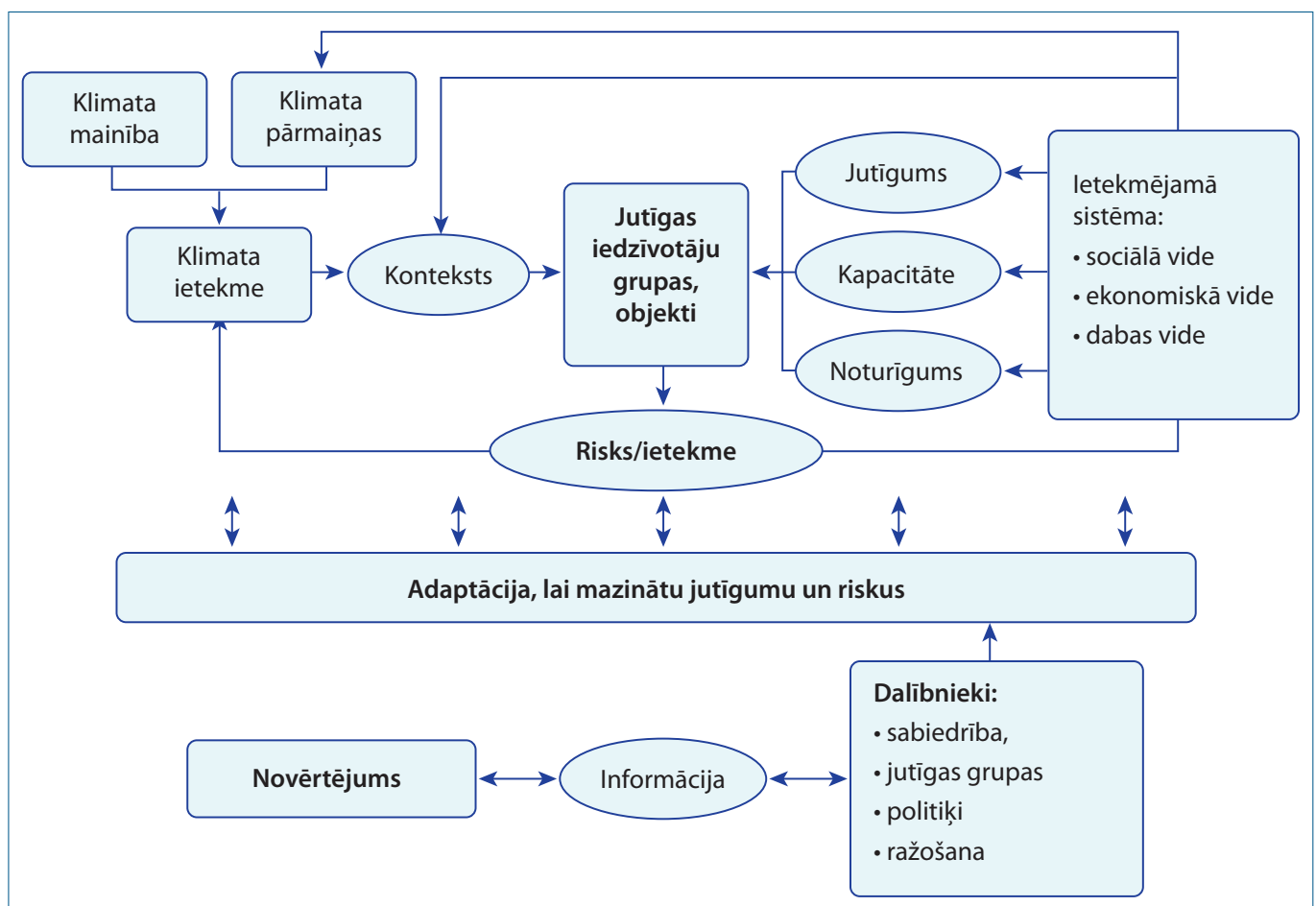

13.7. att. Adaptācijas risinājumu izstrādes koncepcija. 
tiek risināti ${ }^{5}$. Likumdošanas ietvarus adaptācijas risinājumiem konkrētās darbības jomās (ūdenssaimniecība, mežsaimniecība, aizsardzība pret plūdiem un citiem klimata riskiem) sniedz un regulāri atjauno Eiropas Komisija ${ }^{6}$. Domājot par adaptācijas risinājumiem, svarīgi atcerēties, ka neviena problēma nav absolūti unikāla un esošās informācijas un sadarbības tīklu platformas piedāvā apjomīgu informāciju par līdzīgām problēmām un to risinājumiem, kuri ir aktuāli Latvijā.

Par pirmo nozīmīgo soli adaptācijas risinājumu izstrādē var uzskatīt galveno riska objektu vai ietekmējamo iedzīvotāju grupu identifikāciju - ko klimata pārmaiṇas vai dabiskā mainība konkrētajā vietā var ietekmēt, kas vispirms ir apdraudēts. Riska objekts vai iedzīvotāju grupa var būt piemēram, palien,u pḷavās uzceltas mājas, skola, kuru var apdraudēt mazās HES ūdeṇi, ja sabrūk uzpludinājuma dambji. Sociālās aprūpes nama iemītniekus var apdraudēt karstums. Nepieciešams veikt apdraudējuma riska novērtējumu, kuru iespējams izteikt arī nepieciešamo līdzekḷu apmērā un novērtēt iespējamos ekonomiskos zaudējumus vai ietekmes uz cilvēku veselību un labklājību. Izstrādājot priekšlikumus par adaptācijas pasākumiem, svarīgs posms ir sabiedrības informēšana un vienotas izpratnes izveide par plānoto pasākumu nepieciešamību.

\subsubsection{Klimata pārmaiṇu adaptācijas risinājumi valsts līmenī}

Kaut arī dažādu klimata risku ir daudz, tieši tāpat kā situācijas, kurās var būt nepieciešamība mazināt to ietekmes, tomēr ir iespējams ieteikt priekšlikumus par jautājumiem, kuriem jāpievērš īpaša uzmanība, izstrādājot risinājumus piemērošanās pasākumiem. Latvijas klimata pārmaiṇu adaptācijas politikas nepieciešamību reglamentē ES adaptācijas stratēǵijas

\footnotetext{
${ }^{5}$ European climate adaptation platform http://climate-adapt.eea.europa.eu/adaptation-support-tool

${ }^{6}$ Climate action http://ec.europa.eu/clima/policies/ adaptation/what/documentation_en.htm
}

prasības, ES plūdu direktīvas, Ūdeṇu ietvardirektīvas un citu ES līmeña politisko dokumentu prasības, nosakot valsts atbildību ne tikai stratēgiju izstrādē, bet arī rīcības programmu izstrādē un ieviešanā. Šo uzdevumu sasniegšanā ievērojamu palīdzību sniedz citas Baltijas jūras reǵiona valstis, bet īpaši Vācija un Norvēǵija, kā arī Latvijas zinātnieku aktìva iesaiste starptautiskās sadarbības tīklos.

Adaptācijas politika valstī nepieciešama tās ilgtspējīgas attīstības nodrošināšanai, un klimata pārmaiṇu jautājumiem jābūt integrētiem tālākās attīstības plānošanā Latvijā gan valsts līmenī (Nacionālās attīstības plāns), gan sektoru attīstības plānojumos. Klimata pārmaiņu adaptācijas jautājumus nepieciešams ṇemt vērā, veicot novērtējumu par attīstības ietekmi uz vidi gan teritoriju plānojumos, gan upju baseinu apsaimniekošanas plānos, gan attīstības stratēgoiju un sektoru plānu izstrādē. Valsts adaptācijas politikas nozīmīgs elements ir klimata adaptācijas finansēšanas mehānismu izstrāde, nepaļaujoties tikai uz ES finansējumu, turklāt ir svarīgi lēmumu pieṇemšanā finansējumu pieškirt prioritārajiem pasākumiem, kuri dod lielāko atdevi problēmas risināšanā. Nozīmīgs adaptācijas politikas elements ir klimata risku apdrošināšana, bet privāta kapitāla kompānijas, n,emot vērā augsto riska pakāpi, ir maz ieinteresētas risku apdrošināšanas programmu izstrādē un piedāvājuma radīšanā. Līdz ar to valsts ieguldījums klimata risku apdrošināšanā īpaši būtiskās riska zonās (piemēram, plūdu risks, ražas apdrošināšana utt.) ir nozīmīgs valsts adaptācijas sistēmas elements. Nacionālās politikas līmenī, ievērojot visus riska vadības principus, ir svarīgi sistēmā iekḷaut ar klimata pārmaiņām saistītos vides riskus un to iespējamo ietekmi gan uz ekosistēmām, gan uz cilvēku radīto vidi, gan uz pašiem cilvēkiem (viṇu veselību un labklājību). Īpaši atzīmējami klimata pārmaiṇu riski un ietekme uz cilvēka veselību.

Valstiskā līmenī nepieciešams risināt jautājumus par plūdu risku mazināšanu, to skaitā hidrotehnisko būvju izveidi un apsaimniekošanu, ja pastāv draudi iedzīvotājiem vai var tikt apdraudēti valstiski nozīmīgi resursi, turklāt 
svarīgi n,emt vērā tādus faktorus kā ūdens pieejamība cilvēkiem, dabisko ūdenu ǵeomorfologiskā un ǵeologiiskā struktūra (cieša saistība ar piesārṇojumu un infekcijas izplatīšanās draudiem). Valsts tieša atbildība ir izstrādāt normatīvos aktus, kas regulē valsts, pašvaldību un privātīpašnieku rīcību katastrofu situācijās, nosakot institucionālās atbildības. Valstiskā līmenī nepieciešams risināt jautājumus par prognozēšanas un agrīnās brīdināšanas sistēmas izveidi.

Kaut arī ne prioritāri, tomēr nozīmīgi ir jautājumi par erozijas un jūras krastu noskalošanas risku pārvaldību, kad nepieciešama nenovēršamā riska joslā esošu objektu vai īpašumu aizsardzība vai pārcelšana tālāk no krasta. Nepieciešams izstrādāt priekšlikumus, normatīvos aktus, kas regulētu valsts, pašvaldības un privātīpašnieku rīcību jūras krastu katastrofālas noskalošanas gadījumos.

Lai sasniegtu izvirzītos uzdevumus, svarīga ir ekonomiskās pārvaldības veidu izstrāde, t.i.., jāizstrādā metodika vētru laikā noskaloto mežu, lauksaimniecības zemju, īpaši aizsargājamo dabas teritoriju un apdzivvoto vietu apbūves platību zaudējumu aprēḳināšanai.

\subsubsection{Izglìtība un zinātne adaptācijas izstrādei un ieviešanai}

Adaptācijas stratēgijas, rīcības plānojumu un ieviešanas izstrādes priekšnosacījumi veido izpratni par to, ko nepieciešams darīt, kā tas darāms, un sabiedrības atbalsts, respektīvi, sabiedrības (ieskaitot politiķus un lēmumu pieṇēmējus) izpratne par klimata pārmaiṇām. Adaptācijas (tāpat kā vides politikas) ieviešanas priekšnosacījums ir sabiedrības izpratnes izveidošana, kas jāpasniedz zinātniski korekti, bez neadekvātiem pārspīlējumiem, izprotot klimata pārmainu riskus, to iespējamās ietekmes un atbalsta rīcības, lai novērstu vai mazinātu zaudējumus nākotnē. Tas sasniedzams, iekḷaujot izglītību par klimata pārmaiṇām visos izglītības sistēmas līmeños.

Zinātniskās pētniecības mērksis ir radīt priekšnoteikumus pamatotu lēmumu pien,emšanai, bet pētniecība nepieciešama gan fundamentāli nozīmīgu zināšanu iegūšanai, gan ieteikumu saṇemšanai par aktuāliem jautājumiem:

- vides (arī mūsdienu geoloǵisko procesu) un ekoloǵisko novērojumu ilgtermiņa monitorings un klimata pārmaiņu ietekmju izpēte, prognožu model̦u izstrādei,

- klimata pārmaiṇu ietekme uz virszemes un pazemes ūdens resursiem, to kvalitāte mainīga klimata apstāklı os,

- klimata pārmaiṇu novērtēšana un to ietekmju ekonomiskais izvērtējums, ietverot adaptācijas risinājumu izmaksu ekonomisko un sociālo izvērtējumu,

- klimata risku pārvaldības pilns cikls, ievērojot risku vai ieguvumu nozīmi un ietekmi uz atsevišķiem saimniecības sektoriem, biologisko daudzveidību, aizsargājamajām teritorijām, ekosistēmu pakalpojumiem un produktiem, sabiedrības veselību,

- klimata pārmainu nacionālas nozīmes informatīvā mehānisma izveide,

- klimata pārmaiṇu ietekme uz mežiem, lauksaimniecības kultūrām, dabiskajām zivju populācijām, zivsaimniecību,

- risinājumi lauksaimniecības, mežsaimniecības un citu tautsaimniecības nozaru attīstībai saistībā ar klimata pārmaiñām,

- enerǵētikas, būvniecības un citu sektoru attīstības risinājumi mainīga klimata apstākḷıs, ietverot izmaiṇas būvnormatīvos un hidrotehnisko būvju drošības risinājumos,

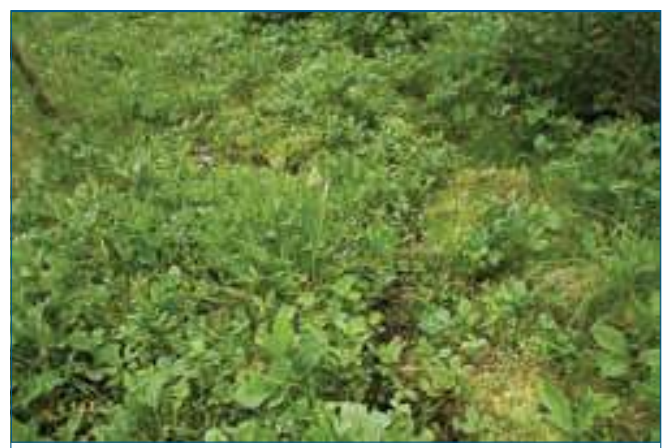

13.8. att. Avotains zālu purvs - nozìmīga aizsargājamā teritorija. 
- klimata politikas indikatoru sistēmas izveide, kā arī adaptācijas politikas un pasākumu efektivitātes vērtēšanas un izpētes sistēmas izveide.

\subsubsection{Adaptācija klimata pārmainām pilsētvidē un telpiskās attīstības plānošanā}

Lielākā dal̦a Latvijas un citu attīstīto valstu iedzīvotāju dzīvo pilsētās. Neraugoties uz pastāvošo komforta līmeni, klimata mainības ietekmes pilsētvidē var būt īpaši katastrofālas, piemēram, plūdi. Pilsētās koncentrējas ne tikai iedzìvotāji, bet pastāv arī lielas kultūras un materiālās vērtības, kā arī notiek liela dal̦a no rūpnieciskās ražošanas un tirdzniecības. Līdz ar to adaptācijas risinājumiem pilsētvidē nepieciešams pievērst īpašu uzmanību. Adaptācija pilsētvidē ir cieši saistīta ar pilsētu attīstību. Plānošanā un projektēšanā ir svarīgi orientēties uz nākotnes, nevis pašreizējo situāciju, tādējādi veidojot teritorijas un ēkas, kurās iedzīvotājiem tiek piedāvāts lielāks komforts un mazāks risks, ko var radīt klimata mainība. Ėkām paredzētais mūžs parasti ir 40-100 gadi, bet apdzīvotas vietas veidols pastāv vēl ilgāk. Tādēl plānošanā un būvniecībā klimata pārmaiṇas ir aktuāls nevis nākotnes jautājums. Pielāgojot ne tikai ēkas, bet arī ārtelpu un infrastruktūru paredzamajām izmaiñām, un n,emot vērā iedzīvotāju potenciālās vajadzības, tiks veidoti vērtīgi îpašumi, samazināts risks veselībai un apdrošināšanas izmaksas.

Pilsētās īpaši bīstama ir plūdu ietekme un līdz ar to ir svarīgi veikt plūdu kartēšanu - apzināt teritorijas, kuras var apdraudēt gan lietusūdeņu plūdi, vēja sadzinuma plūdi, upju pārplūšana vai kombinētas veidošanās avotu plūdi, izmantojot informāciju par ūdens līmeña celšanās tendencēm, vējuzplūdiem un plūdu riskiem dažādos gada periodos. Rīgai šāds plūdu kartējums ir veikts ${ }^{7}$, un tas l̦auj izvērtēt paaugstināta riska teritorijas Rīgā un līdz ar to

\footnotetext{
${ }^{7}$ Rīga pret plūdiem http://www.rigapretpludiem.lv/
}

sekmēt pretplūdu risinājumu izstrādi un adaptāciju plūdu risku mazināšanai. Vienlaikus plūdu kartējuma izstrāde ir tikai pirmais solis, lai piemērotos plūdu radītajiem riskiem. Svarīgi ir nodrošināt kvalitatīvas zal̦ās zonas gan pie ēkām, gan apkaimē, nebūvēt ēkas un infrastruktūras objektus applūstošajās teritorijās un upju palienēs. Teritoriju aizsardzībai svarīgi izmantot pretplūdu inženierbūves. Jāievēro nelabvēlīgu apstākḷlu kombinācijas (vējuzplūdi vienlaikus ar ekstrēmu nokrišn,u daudzumu) teritoriju applūduma zonējuma izveidē. Erozijas un plūdu apdraudētajos krasta posmos apdzīvotās vietās nevajadzētu piel̦aut jaunas, valstij vai pašvaldībām svarīgas infrastruktūras attīstību.

Plūdu risku mazināšanai jāveido ūdenscaurlaidīgi zemes segumi. Plūdu risku var ievērojami samazināt, plānojot dabisku ūdenstilpju piemērošanu vai mākslīgu ūdenstilpju izveidi parkos un zal̦ajās zonās lietusūdens uztveršanai un infiltrēšanai, kā arī nodrošināt plūdu ūdens uzkrāšanās vietas, lai samazinātu maksimālo ūdens līmeña augstumu. Tas ietver plūdu aiztures baseinu un "ziedojamo" teritoriju (sporta laukumi, autostāvvietas) izveidi, kurās plūdu laikā uzkrājas ūdens. Nozīmīgi izveidot lietus notekūdenu sistēmu, atdalot to no komunālās notekūdenu sistēmas. Ir iespējams izmantot zalıos jumtus un teritorijas ūdens aizturei un infiltrācijai spēcīgu lietusgāžu laikā, lai mazinātu slodzi notekūdeṇu novadīšanas sistēmai. Nozīmīgs adaptācijas uzdevumu kopums saistās ar ekstremālu nokrišn,u apjoma izmantošanu ūdens resursu taupīgas izmantošanas sekmēšanai garākos sausuma periodos vasarā, ko var panākt, savācot un izmantojot lietusūdeni, piemēram, apstādījumu laistī̌anai. Sausuma seku mazināšanai ieteicams izstrādāt risinājumus, kas l̦auj attīrīt mājsaimniecībās mazgāšanai izlietoto ūdeni un izmantot to saimnieciskām vajadzībām, arī zalıo zonu laistǐšanai vai tualetēs. Pilsētu zaḷās zonas plānošanā apstādījumiem ieteicams izvēlēties sausumizturīgus augus.

Tieši pilsētvidē vispirms ir aktuāls jautājums par cilvēku aizsardzību ekstremāla aukstuma vai karstuma gadījumā, īpaši pret "karstuma viḷnniem". Lauku teritorijās šāda ietekme 
ir mazāk jūtama. Pilsētvidē pret klimatiskiem ekstrēmiem cilvēka veselības aizsardzībā uzmanības centrā ir iedzīvotāju riska grupu aizsardzība. Klimatiskām ekstremālām ietekmēm vispirms ir pakḷauti veci cilvēki, sociāli nelabvēlīgā vidē dzīvojoši, sociāli izolēti iedzīvotāji, smaga darba strādnieki. Adaptācijas programmām ir jābūt orientētām vispirms uz augsta riska iedzīvotāju aizsardzību, paredzot to izolētības samazināšanu, informācijas un palīdzības nodrošināšanu utt.
Pilsētvidē ir svarīgi izstrādāt risinājumus augstākas vasaras temperatūras negatīvo seku mazināšanai. Veiktie pētījumi pierāda, ka zaḷās zonas samazināšana par $10 \%$ var izraisīt maksimālās temperatūras paaugstināšanos pie zemes virsmas par $8,2^{\circ} \mathrm{C}$ piecdesmit gadu laikā, taču zaḷās zonas palielināšana pilsētā par 10\% nodrošinātu maksimālās temperatūras palikšanu līdzšinējās robežās līdz pat 2080. gadam. Līdz ar to adaptācijas uzdevumi prasa nodrošināt kvalitatīvas zaḷās zonas gan pie ēkām, gan

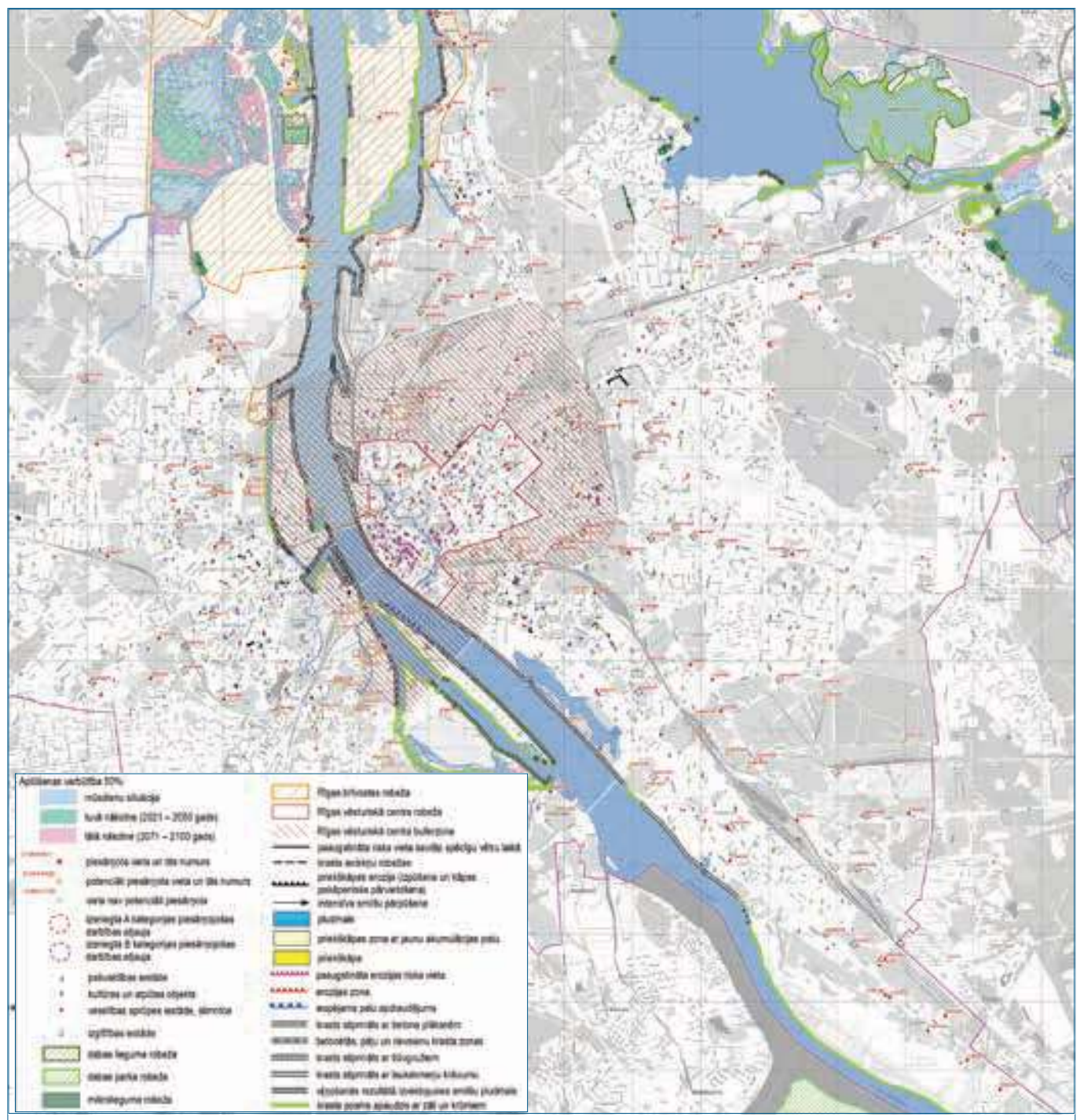

13.9. att. Rīgas plūdu riska kartes fragments. 
arī apkaimēs. Apstādījumos un zaḷajās zonās ieteicams izveidot ūdens objektus - strūklakas, baseinus, grāvjus, dīksus un ūdensteces. Vēlams izmantot zālienu mākslīgā virsmas seguma vietā, bet stādīt kokus ne tikai estētiskajām, bet arī noēnojuma vajadzībām. Apstādījumos jāizmanto siltumizturīgus un vietējiem apstākliem piemērotus augus. Zālienos jāizmanto vietējo sugu daudzveidība. Ēkām ieteicams veidot zalıos jumtus. Savukārt "zalıie koridori”, nelielas atklātas teritorijas, koki ielās, kā arī zalıie jumti un sienas var būtiski nodrošināt iztvaikošanas atvēsinošo ietekmi.

Plānotājiem, arhitektiem un attīstītājiem ir pavērtas lielas iespējas veidot vai pārveidot pilsētu ēkas un ārtelpu atbilstoši kvalitatīvai dzīves videi saskaṇā ar notiekošajām un paredzamajām klimata pārmainām. Telpiskās plānošanas mērksis klimata jomā ir ūdens, atklāto teritoriju un apbūvētās vides integrācija, izmantojot zalo un ūdens teritoriju attīstības stratēǵiju. Šie uzdevumi sasniedzami, plānojot un veidojot:

- augstas kvalitātes un plašam cilvēku lokam lietojamas zal̦ās zonas, kuras ir savstarpēji savienotas, labi apūden,otas un kurām ir ekoloǵiskā, atpūtas un plūdu ūdeṇu uzglabāšanas funkcija. Pilsētu zal̦ā infrastruktūra ietver atklātās teritorijas, mežus, kokus pagalmos un ielu malās, laukus, parkus, sporta laukumus, gimenes dārziṇus, atmatas, privātos dārzus, arī jumta dārzus un vīteñaugiem noaugušas sienas. Apstādījumos un zaḷajās zonās izmanto ūdens objektus - strūklakas, baseinus, grāvjus, dīksus un ūdensteces;

- attīstot pilsētvidē ūdens jeb "zilās" teritorijas - upes, ezerus, grāvjus, kanālus. Ievērojot mozaīkveida principu ūdensteču $10 \mathrm{~m}$ aizsargjoslas plānošanā upes noēnojumam; izvērtējot vietas, kur nepieciešams noēnojums, un vietas, kur kokus un krūmus būtu vēlams izcirst un nodrošināt gaismas pieplūdi;

- plānojot noēnojumu un objektu izvietojumu, lai samazinātu pārlieku Saules starojumu vasarā, vienlaikus ņemot vērā vajadzību pēc gaismas un siltuma ziemā;
- attīstot pilsētas pasīvo ventilāciju, kuru veido ēku un ielu izvietojums un morfoloǵija un kurā jāsaskaṇo vēlme pēc vēsākām gaisa plūsmām vasarā un pēc aizvēja ziemā.

Vienlaikus, attīstot būvniecības standartus, iespējams plānot patīkamu mikroklimatu ēkās karstākiem vasaras mēnešiem, minimizējot enerǵijas patērinu dzesēšanai.

Telpiskās plānošanas gaitā nepieciešams ievērot Baltijas jūras krasta noskalošanas un upju krastu erozijas iespēju:

- erozijas apdraudētajos krasta posmos, to skaitā apdzīvotās vietās, nepiel̦aut jaunas, valstij vai pašvaldībām svarīgas infrastruktūras attīstību,

- erozijas apdraudētajos krasta posmos nepiel̦aut jaunu nekustamo īpašumu celšanu,

- krasta posmu aizsardzībai izmantot preterozijas pasākumus,

- plašāk izmantot geogrāfiskās informācijas sistēmas riska karšu izveidē, vides risku pārvaldībā un teritoriālajā plānošanā un attīstībā,

- izmantot vēsturisko pieredzi,

- izvērtēt polderu apbūves lietderību.

Pašvaldību darba un plānošanas specifika rada problēmas, kuras jāpārvar, lai nodrošinātu

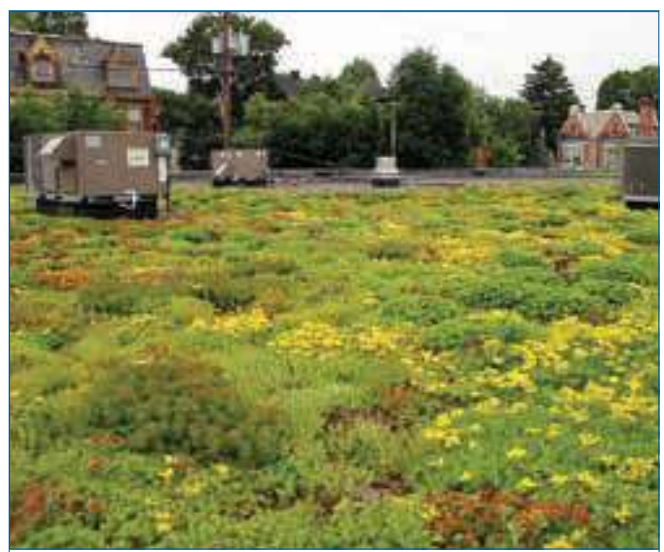

13.10. att. Zaḷie jumti ir ne tikai estētiski pievilcīgi un atdzīvina pilsētvidi, bet arī palīdz saistīt piesārṇojumu pilsētās un paaugstināt ēku energoefektivitāti. 
piemērošanos klimata pārmaiṇām pašvaldību līmenī un plānojot teritoriju un reǵionu attīstību:

- izglītot pašvaldību politiķus un darbiniekus, lai veidotu izpratni un attīstītu spējas pamatot iedzìvotājiem veicamo darbību nepieciešamību,

- veidot pašvaldību partnerību, sadarbojoties ar mājsaimniecībām un privāto sektoru projektu realizēšanā,

- noteikt visvairāk jutīgās teritorijas un jomas pret klimata pārmaiñām un kritiskās robežas, kuru pārsniegšana ir bīstama infrastruktūrai vai sabiedrībai,

- noteikt klimata mainības riskus, izmantojot jaunākos model̦us un scenārijus,

- lēmumu pieñemšanā par attīstību izmantot informāciju par klimata riskam pakḷautajām teritorijām un procesiem,

- izvairīties no darbībām, kas piemērošanos klimata pārmaiṇām nākotnē padarītu vēl grūtāku,

- regulāri pārskatīt piemērošanās stratēǵiju un pasākumus.

\subsubsection{Adaptācija klimata pārmainām lauksaimniecībā, mežsaimniecībā}

Lauksaimniecība, mežsaimniecība, zivkopība, medību saimniecība un citas jomas ir l̦oti atkarīgas no klimatiskajiem apstākḷiem, un adaptācijas plānojuma izstrādi ietekmē klimata pārmaiṇas tieši Latvijā. Tās nepieciešams apzināt un izprast. Vairāki ieteikumi, kā rīkoties, ir izstrādāti un ir tieši piemērojami klimata adaptācijas risinājumu izstrādei Latvijā. Lauksaimniecisko ražošanu vispirms var ietekmēt nokrišnuu režīma mainība, īpaši sausuma periodi, un risinājumi šādu ietekmju mazināšanai var būt gan pret sausumu mazāk jutīgu kultūraugu izvēle, gan augu audzēšana apūden,ojamās platībās. Lauksaimniecības kultūraugu izslīkšanu siltās, slapjās ziemās var novērst, lauksaimniecības zemēs uzturot un atjaunojot meliorācijas sistēmas, tās papildinot ar mitrājiem vai sedimentācijas dīḳiem, niedrājiem. Nav šaubu, ka audzējamo kultūru un lauksaimnieciskās prakses izpēte un priekšlikumu izstrāde ir viens no aktuālākajiem uzdevumiem pētniekiem. Vienlaikus ar lauksaimniecības tehnologisko risinājumu pilnveidošanu nepieciešams rūpēties par to, lai samazinātu augsnes eroziju, augu aizsardzības līdzekḷu un augu barības vielu noplūdi virszemes ūdeņos. Piesārṇojuma noplūdes samazināšanai iespējams veidot zal̦ās platības ziemā, piemēram, ziemājus vai rudenī iesētas starpkultūras - zal̦mēslojuma augus vai tauriṇziežus, kā arī ievērot labu lauksaimniecības praksi.

Mežsaimniecībā galvenais ir jautājums par koku sekas, mežu kopšanas tehnologisko risinājumu izvēli, tomēr arī mežu kopšanai un adaptācijai ir liela nozīme. Ieteikums izvairīties no kailcirtēm, kā arī aizvākt koku atliekas no cirsmām, lai samazinātu mineralizācijai pakḷauto biomasas apjomu. Svarīgi ir ievērot mitruma un nesasalušas augsnes apstākḷiem piemērotas mežizstrādes tehnoloğijas, labas ciršanas praksi ūdensteču tuvumā attiecīgos reljefa apstākḷıs, n,emot vērā sezonalitāti. Ciršana būtu jāveic, kad ir mazāka notece. Svarīgi ir izbūvēt un pareizi izmantot meža cel̦us, ievērot mitruma un nesasalušas augsnes apstākliem piemērotas mežizstrādes tehnoloǵijas.

Būtiska kḷūs enerǵētiskās koksnes resursu izmantošanas palielināšana siltumenerǵijas ražošanā. Ne tikai koksne, bet visa pārējā biomasa, kas iegūstama no lauksaimnieciskās

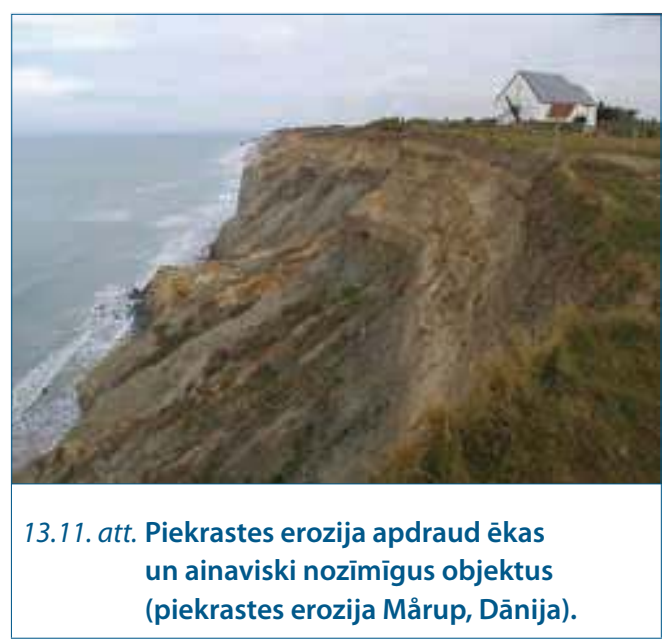


darbības, ir izmantojama gan siltumenerǵijas un elektroenerǵijas ražošanai, gan biodegvielas iegūšanai autotransportam.

Zivsaimniecībā nepieciešams samazināt upju aizaugumu, ierobežojot augu barības vielu noplūdi, kā arī atjaunot lašveidīgajām zivīm nozīmīgās upes. Dabisko populāciju attīstībai svarīgi ir samazināt augu barības vielu noplūdi un punktveida piesārņojumu. Dīkssaimniecībā ieteicams orientēties uz siltumu mīlošām sugām, jo sagaidāms, ka vairumam Latvijas zivju sugu palielināsies produktivitāte.

\subsubsection{Adaptācija klimata pārmaiṇām un ūdens resursu apsaimniekošana}

Klimata pārmaingas var ietekmēt gan ūdens resursu apjomu, gan to kvalitāti. Līdz ar to risinājumi ūdens resursu apsaimniekošanā ietver gan konkrētus risinājumus, gan konceptuālus ūdens resursu saudzēšanas plānus. Piemēram, nepieciešams izveidot kanalizācijas tīklu un būves ekstremālu lietusgāžu ūdens novadīšanai, lietus notekūdeñu sistēmu veidot atsevišksi no komunālo notekūdeṇu sistēmas. Nepieciešams nodrošināt notekūdeṇu attīrīšanas iekārtu augstu efektivitāti mainīga klimata apstāklı̆, īpašu uzmanību pievēršot notekūden,u izplūdēm atkarībā no sezonas (mazūdens periodā vai daudzūdens periodā). Pilsētās ieteicams veidot dabisko drenāžu piejamās vietās. Pilsētvidē ieteicams izmantot zalıs jumtus un teritorijas ūdens aizturei un infiltrācijai spēcīgu lietusgāžu laikā, lai mazinātu slodzi notekūdeñu novadīšanas sistēmai, kā arī paredzēt lietusūdens dabisku infiltrāciju un virszemes noteci teritoriju plānojumos.
Adaptācijai nepieciešams izveidot ūdens apgādes sistēmas, kas spēj darboties mazūdens periodos, kā arī regulēt pazemes ūdens resursu izmantošanu sausuma apstākḷıos. Būtiski ieviest ekstremālu lietusgāžu izraisītu plūdu ūdens pārvaldi.

Ūdens resursu taupī̌sanas nodrošināšanai nepieciešams pārskatīt pilnās ūdens lietošanas izmaksas atbilstoši visiem kritērijiem, jo ūdens izmaksās netiek iekḷauti paredzamie riski (neierēksinātās izmaksas), tajā pašā laikā tajās ñemts vērā pilns ūdens aprites cikls (ieguve, ražošana, padeve, savākšana utt.). Mazūdens periodos noteikt piesārn,ojošo vielu zemāku koncentrāciju vai apjomu. Nodrošināt ūdeṇu kvalitātes monitoringa programmas izpildi un nosakāmo rādītāju skaitā iekḷaut arī klimata pārmaiṇu ietekmju monitoringu. Nacionālajā vides monitoringa programmā iekḷaut klimata pārmaiṇu ietekmju monitoringu, pievēršoties arī ietekmju un atbilstošo indikatoru savstarpējam izvērtējumam un iekḷaujot analīzē ne tikai vides, bet arī sociālekonomiskos rādītājus.

Izstrādāt koncepcijas un stratēǵijas slodzes samazināšanai, ko rada iedzīvotāji, kuru mājokḷi nav iekḷauti centralizētajā kanalizācijas sistēmā.

Stingri kontrolēt ūdenu monitoringa programmas izpildi, kontrolē iesaistoties nevalstisko organizāciju sektoram.

Lai plānotu ūdens resursu pārvaldību, modelēt ūdens kvalitāti, izmantojot starptautiskā praksē atzìtas metodes un model̦us.

Ievērot, ka enerǵijas ražošanai hidroelektrostacijās ūdens mazāk ir pieejams vasarā sausuma dēl, bet vairāk pieejams siltās ziemās, kad ir palielināts nokrišn,u daudzums.

Stingri ievērot minimālā caurplūduma normas mazajos HES, lai samazinātu to negatīvo ietekmi uz zivju populāciju.

\section{Avoti tālākām studijām}

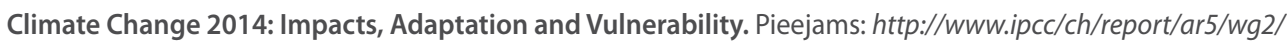

European Commission. Pieejams: $h$ ttp://ec.europa.eu/clima/policies/adaptation/index_en.htm

Center for Climate Adaptation. Pieejams: http://www.climateadaptation.eu/

European Climate Adaptation Platform. Pieejams: http://climate-adapt.eea.europa.eu/ 
Adaptation in Germany. Kompetenzcentrum Klimafolgen und Anpassung.

Pieejams: http://www.umweltbundesamt.de/en/topics/climate-energy/climate-change-adaptation/kompass

Climate Change Impacts and Adapting. Pieejams: http://www.epa.gov/climatechange/impacts-adaptation/

Adaptation and Mitigation Strategies. Pieejams: http://adam-digital-compendium.pik-potsdam.de/adaptationcataloguel

\section{Literatūra}

Klimata mainība Latvijā: aktualitātes un piemērošanās pasākumi (K. Āboliṇas red.) (2009) Rīga, LU Akadēmiskais apgāds.

Lim B., Spanger-Siegfried E. (2005) Adaptation Policy Frameworks for Climate Change. Developing Strategies, Policies and Measures. Cambridge, Cambridge University Press.

Hilpert K., Mannke F., Schmidt Thome P. (2007) Towards Climate Change Adaptation in the Baltic Sea Region. Espoo, Geological Survey of Finland.

Atlas of Mortality and Economic Losses from Weather, Climate and Water Extremes (1970-2012) Geneva, WMO No.1123.

Indriksone D., Aḷeksejeva I. (2013) Sekmējot klimata pārmainu pielāgošanās stratēǵijas izstrādi Latvijā. Rīga, BEF.

Projekts "Rīga pret plūdiem" - "Rīgas pilsētas virszemes ūdeṇu ietekmju novērtēšana, novēršana un ekoloǵiskā stāvok!̣a uzlabošana" (2010-2012), www.rigapretpludiem.lv

Salacgrīvas novada klimata pārmaiṇu adaptācijas stratēǵija (2011), www.salacgriva.Iv/lat/salacgrivas_novads/ zalais_novads/?text_id=6401

Projekts “Atbildīga klimata politika" (2010-2011), www.zb-zeme.Iv/klimats-un-energija/jauna-politika

Buklets "Meža apsaimniekošana klimata izmainu kontekstā", www.zm.gov.Iv/doc_upl/Buklets_Meza_ apsaimniekosana_klimata_izmainu_konteksta.pdf

Report Climate Change, Impacts and Vulnerability in Europe 2012 (2012), www.eea. europa.eu/publications/ climate-impacts-and-vulnerability-2012

German Strategy for Adaptation to Climate Change (2008), www.bmu.de/fileadmin/bmu-import/files/english/pdf/ application/pdf/das_gesamt_en_bf.pdf

Adaptation Action Plan of the German Strategy for Adaptation to Climate Change (2011), www.bmu.de/ fileadmin/bmu-import/files/pdfs/allgemein/application/pdf/aktionsplan_anpassung_klimawandel_en_bf.pdf

Project "BaltCICA" - "Climate Change: Impacts, Costs and Adaptation in the Baltic Sea Region" (2009-2012), www.baltcica.org

Project "Baltadapt" - "Baltic Sea Region Climate Change Adaptation Strategy" (2010-2013), www.baltadapt.eu

Izmantotie attēli

13.1. Pēc Lim un Spanger-Siegfried, 2005 un IPCC, 2001.

13.2. Autors Robert Muller. Creative commons licence.

13.3. Dennis Jarvis. Creative commons licence.

13.4. ANO fotoarhīvs, ar aț̣uju.

13.5. Avots ANO fotoarhìvs, ar ațauju

13.6. Avots Chris Wheal. Creative commons licence

13.8. Foto: Liene Aunina

13.9. Rīgas dome http://www.rigapretpludiem.lv/data/doc/13056369114513.jpg

13.10. Chesapeake Bay Program. Creative commons licence.

13.11. John Nuttall. Creative commons licence. 
14.

Klimata pārmaiṇas,

dzivesveids un patēriṇš,

ogleḳla mazietilpīga attīstība 
Pasaules iedzīvotāju skaits pēdējo 50 gadu laikā ir vairāk nekā dubultojies, bet patēriṇa apjoms, mērot to pēc iekšzemes kopprodukta (IKP), šajā laika periodā ir gandrīz pieckāršojies. Tiek prognozēts, ka 2050. gadā pasaules iedzīvotāju skaits sasniegs 9 miljardus, bet pasaules IKP varētu palielināties 3,5 reizes salīdzinājumā ar mūsdienām. Augošais iedzīvotāju skaits un dzīvesveida izmain,as, kā arī strukturālas pārmaiṇas nozīmē arvien pieaugošu globālo resursu patēriṇu un piesārṇojumu, kā arī klimata pārmain,as. Mājsaimniecību patērinš̌ Eiropā un arī Latvijā rada $60-80 \%$ no visām antropogēnajām ietekmēm uz klimata pārmaiṇām, bet patēriṇa apjoma pieaugums lielā dal̦ā valstu nav spējis nodrošināt labklājības celšanos. Klimata pārmaiṇu samazināšanai un cilvēku vajadzību apmierināšanai ir nepieciešams noteikt ilgtspējīgu patēriṇu, kas nodrošina izmainnas pašreizējos patēriṇa paradumos, kā arī tā apjomu un struktūru ietekmējošos faktorus.

Klimata politika Latvijā pamatā ir veidota un īstenota nacionālā līmenī. Arī siltumnīcefekta gāzu (SEG) emisiju aprēḳini ir pieejami par valsti kopumā, bet trūkst informācijas, aprobētas metodikas un prakses vietējā, pašvaldību līmeṇa SEG emisiju aprēksiniem un vietējā līmeṇa klimata un attīstības politikas izstrādē un īstenošanā. Taču tieši pašvaldības ir tās, kuras lielā mērā var ietekmēt izmain,as patēriṇa un ražošanas paradumos, kas nosaka kopējo SEG emisiju apjomu. Pašvaldības var stimulēt tādu infrastruktūras, tehnoloǵiju izmantošanas, piegādes sistēmu attīstību savā teritorijā, kas patērē mazāk oglekḷa savienojumu un tādējādi veicina ilgtspējīgu dzìvesveidu, kā arī integrēt klimata jautājumus publiskā iepirkuma nosacījumos.

Priekšnosacījums efektīvai emisiju samazināšanai ir labi organizētas struktūras izveide un skaidrs process. Pirmais ir apṇemšanās virzīties uz oglekḷa dioksīda zemu emisiju sabiedrību. Pēc tam ir jāapzinās patēriṇa un ražošanas darbības, kas saistītas ar mūsu radītajām $\mathrm{CO}_{2}$ emisijām, un jāmāk tās uzskaitīt un analizēt, lai saprastu, kā mēs spējam tās mazināt, kādas ir mūsu izvēles un iespējas un kā tas ietekmē citus sociālekonomiskos, kā arī vides procesus, lai izvairītos no nevēlamām parādībām. Savukārt pēc tam mums ir jānovērtē veikto rīcību efektivitāte gan vides, gan sociālajā un ekonomiskajā sfērā un jāsāk viss process no gala, ņemot vērā izdarītos secinājumus. Šis vides pārvaldības procesa cikls ir līdzīgs visām vides jomām, bet īpaši būtisks klimata sfērā, jo bieži vien ietekmes ir izkliedētās telpā un laikā, līdz ar to grūti apzināmas un kontrolējamas.

\subsection{Siltumnīcefekta gāzu emisiju novērtēšanas metodes - "oglekḷa pēda"}

Emisiju uzskaite un analīze ir viens no būtiskākajiem soliem, lai saprastu rīcības, kas jāveic, lai samazinātu radītās ietekmes uz klimatu. Slodžu apzināšana l̦auj identificēt būtiskākās ietekmes jomas, noteikt prioritātes un identificēt rādītājus, lai novērtētu progresu. Jautājumi, uz kuriem jāatbild, veidojot emisiju novērtējumu, ir vairāki.

- Kādas SEG emisijas iekḷaut uzskaitē?

- Kuri emisiju avoti tiek ieklauti uzskaitē? Šeit var identificēt dažādus rūpnieciskos procesus, piemēram, energeētika, transports, lauksaimniecība, atkritumi.

- Kuras preces un pakalpojumus ieklaut uzskaitē?

- Kas ir atbildīgs par šīm emisijām, un kur tās rodas?

Atbildot uz šiem jautājumiem, SEG emisijas var aprēḳināt gan atsevišksam produktam vai organizācijai, gan pašvaldībai, reǵionam vai valstij. Lai nodrošinātu savstarpēju rezultātu salīdzināšanu, ir izstrādāti vairāki standarti, 


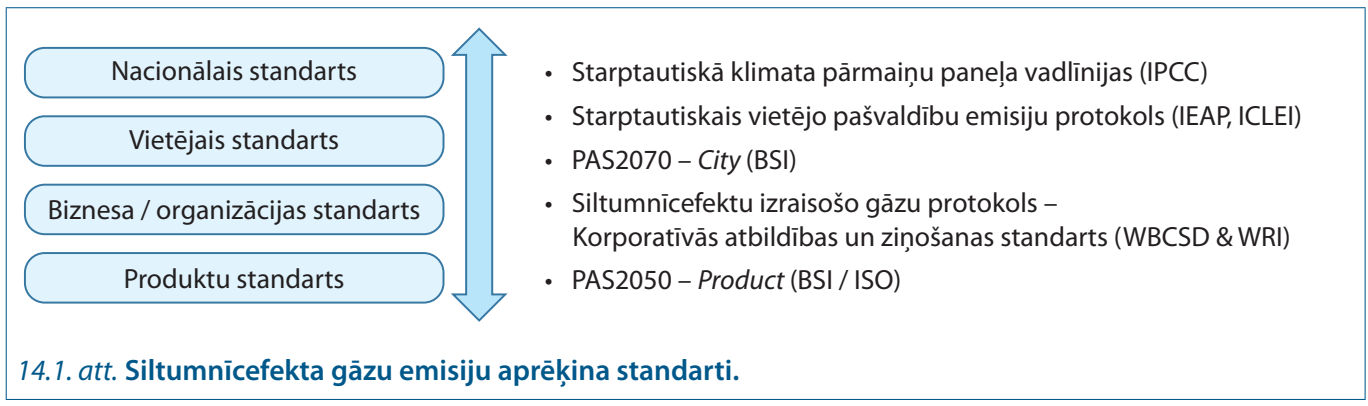

kas nosaka vienotu kārtību SEG emisiju aprēḳiniem dažādos līmeños.

Nacionālās SEG emisijas ir daudz pētìtas un zināmas gandrīz visām pasaules valstīm. Taču arī šeit ir iespējamas dažādas pieejas. Vispirms tiek aprēķinātas teritoriālās emisijas - tās ir emisijas, kas radušās attiecīgajā teritorijā energētikas, rūpniecības, transporta, lauksaimniecības un citu darbību rezultātā. Šĩs ir emisijas, par kurām jāatskaitās ANO un kuras tirgojam ES un pasaules līmenī. Latvijā tās salīdzinājumā ar 1990. gadu ir samazinājušās par vairāk nekā $40 \%$.

Taču Latvijas ekonomika nav izolēta, bet aktīvi iesaistīta starptautiskajā tirdzniecībā. Lìdz ar to liela dạla emisiju ir ieguldìtas Latvijā ražotajos produktos, kurus eksportējam uz citām valstīm, piemēram, starptautiskajā tirgū pārdodot kokmateriālus. Tai pašā laikā Latvija importē preces no citām valstīm. Šim importam savukārt seko emisijas, kas ieguldìtas šajos importētajos produktos. Līdz ar to bez teritoriālajām emisijām ir iespējams aprēksināt arī patēriņa emisijas - visas attiecīgajā teritorijā patērēto preču un pakalpojumu (gan nacionālās, kas tiek patērētas iekšējā tirgū, gan importētās) dzìves ciklā radītās tiešãs un netiešās SEG emisijas.

- Tiešãs emisijas - attiecīgã produkta, procesa vai darbības lietošanas laikā radītās emisijas, kas parasti ir saistītas ar fosilā kurināmā sadedzināšanu, piemēram, automašīnai patērējot dīzeḷdegvielu, rodas tiešās $\mathrm{CO}_{2}$ emisijas.

- Netiešās emisijas - attiecīgā produkta, procesa vai darbības piegādes kjēdē radušās
SEG emisijas, piemēram, emisijas, kas saistītas ar dīzel̦degvielas ieguvi, transportēšanu un realizāciju, līdz tā nonāk transporta līdzeklī.

- Iegultās emisijas - visu tiešo un netiešo SEG emisiju summa, kas radusies attiecīgā produkta, procesa vai darbības pilnā dzīves ciklā.

Latvijā liela dal̦a mūsu patērēto produktu tiek radīti citur pasaulē, tāpēc ar šo preču ražošanu saistîtās emisijas ir izkaisītas pa visu pasauli. Lielākā dạ̣a mūsu importēto emisiju rodas Krievijā, Ķīnā, Igaunijā, Lietuvā un Polijā, jo šiss valstis ir mūsu tirdzniecības partneri. Arī daḷa Latvijā saražoto preču netiek patērētas uz vietas, bet eksportētas uz citām valstīm, tāpēc tās netiek pieskaitītas pie patēriṇa emisijām.

N̦emot vērā Latvijas ražošanas procesu, patēriṇa paradumu un starptautiskā tirdzniecībā

\begin{tabular}{|c|c|c|c|}
\hline \multirow{4}{*}{ 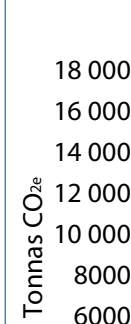 } & $\begin{array}{l}\text { Piedāvājuma } \\
\text { emisijas }\end{array}$ & & \multirow{2}{*}{$\begin{array}{l}\text { Pieprasijuma } \\
\text { emisijas } \\
\text { Eksports }\end{array}$} \\
\hline & \multirow{2}{*}{ Imports } & & \\
\hline & & $\begin{array}{l}\text { Neto } \\
\text { tirdznieciiba }\end{array}$ & \multirow{4}{*}{ Patēriņš } \\
\hline & \multirow{3}{*}{ Ražošana } & & \\
\hline 4000 & & & \\
\hline $\begin{array}{r}2000 \\
0\end{array}$ & & & \\
\hline & \multicolumn{3}{|c|}{$\begin{array}{l}\square \text { Ar patēriṇu un ražošanu saistītās emisijas } \\
\square \text { Tirdzniecībā iegultās emisijas }\end{array}$} \\
\hline 14.2. att. S & $\begin{array}{l}\text { Itumnīcefek } \\
\text { atvijā. }\end{array}$ & a gāzu emisij & iju bilance \\
\hline
\end{tabular}


(eksportā un importā) iegultās SEG emisijas, var gūt pilnīgu priekšstatu par Latvijas ekonomikas ietekmēm uz klimatu (sk. 14.2. att.).

Iegultās emisijas l̦auj labāk saprast vietējā patēriņa un globālās ražošanas vides ietekmju atšksirības un parāda emisiju noplūdi no attīstītajām uz jaunattīstības valstīm. Ar starptautiskās tirdzniecības palīdzību attīstītās valstis, kurām attiecībā pret vidi ir augstākas prasības, pārcel piesārn,ojošo rūpniecību uz citiem reǵioniem, tādējādi nevis samazinot savas emisijas, bet pārnesot tās uz citām valstīm.

Atbilstoši PAS2070, vietējo emisiju aprēkina standartam pašvaldības emisiju aprēkinā tiek iekḷautas trīs līmeṇu emisijas (sk. 14.3. att.):

- 1. līmeña emisijas (visas pašvaldības, vietējo uzñēmumu un iedzīvotāju tiešās emisijas) - fosilās enerǵijas sadedzināšana; vietējais transports, noplūdes u.tml.,

- 2. līmeña emisijas - netiešās emisijas, kas saistītas ar pašvaldības elektroapgādi un siltumapgādi,
- 3. līmeña emisijas - visas pārējās iegultās piegādes k̦ēdes emisijas, kas radušās saistībā ar aktivitātēm attiecīgajā teritorijā (pārtikas, celtniecības, transporta un citu preču un pakalpojumu aprites ciklā radītās emisijas).

Šis dalījums norāda uz SEG emisiju rašanās vietu, kas ir būtiski, lai nodalītu emisijas, kas rodas attiecīgās pašvaldības teritorijā, un tās, kas rodas ārpus teritorijas, bet par kuru rašanos ir atbildīgi pašvaldības iedzīvotāji, uzṇēmumi un/vai administrācija, kas ir to gala patērētāji.

Patēriña emisiju aprēksina metodika aptver visas pašvaldības iedzīvotāju radītās tiešās un netiešās (aprites cikla) SEG emisijas, t.i., SEG emisijas tiek pieškjirtas preču un pakalpojumu gala patērētājiem, nevis to ražotājiem. Patēriṇa emisiju metodika nevērtē pašvaldības teritorijā radītās emisijas precēm un pakalpojumiem, kuras tiek eksportētas (netiek patērētas attiecīgajā pašvaldībā) vai kuru gala patērētāji ir pašvaldības.

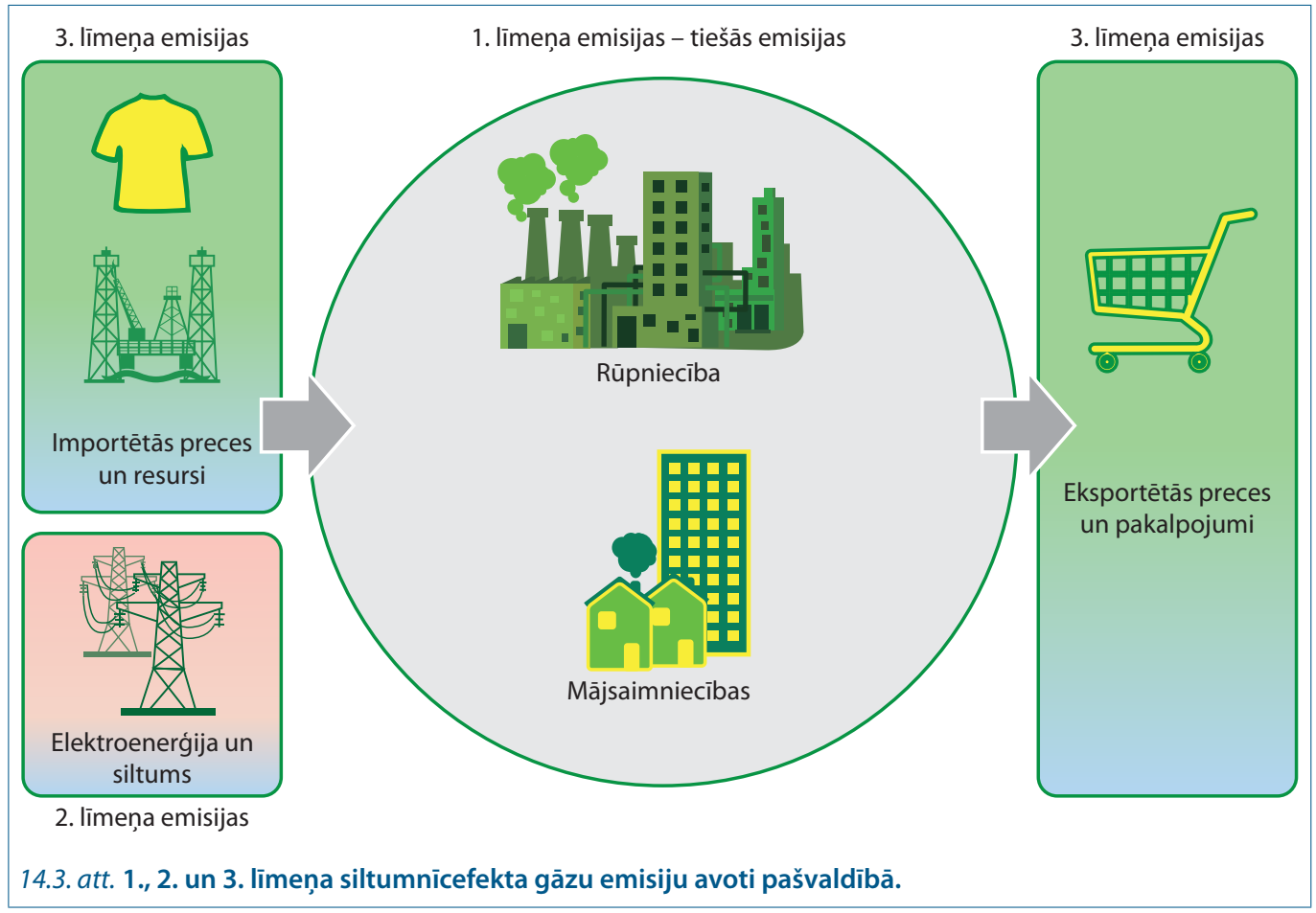


Tā kā preces un pakalpojumi, ko ikdienā patērējam, un to ieguvei nepieciešamie resursi ir izkliedēti Latvijā un pasaulē, arī patēriña emisijas nerodas tikai vienā pašvaldībā, bet ir izkliedētas pa visu piegādes k̦ēdi. Šo emisiju kopsumma veido attiecīgā produkta "ogleklı pēdu", ar ko šajā gadījumā saprot attiecīgajā pašvaldības teritorijā patērēto preču un pakalpojumu pilnā aprites ciklā radīto tiešo un netiešo SEG emisiju apjomu, kas izteikts $\mathrm{CO}_{2}$ ekvivalentu $\left(\mathrm{CO}_{2 \mathrm{e}}\right)$ tonnās.

"Oglekḷa pēdas" popularitāte visā pasaulē strauji aug. To plaši izmanto pētniecībā, uzṇēmējdarbībā (piemēram, dažādu preču un pakalpojumu klimata slodžu novērtēšanai) un politikas veidošanā. Tā kḷuvusi par daudzu pilsētu un pašvaldību vides ilgtspējības indikatoru, un to izmanto, piemēram, Berlīne, Helsinki, Liverpūle, Londona, Manila, Sandjego, Tokija, Toronto. Tā ir labs līdzeklis, lai identificētu būtiskākās slodzes, noteiktu to attīstības tendences, izdarītu savstarpējos salīdzinājumus un plānotu oglekḷa savienojumu zemu izmantošanas attīstību nākotnē. "Oglekḷa pēdas" aprēḳina rezultāti pašvaldībām l̦auj izvirzīt pareizās prioritātes SEG emisiju samazināšanā, veiksmìgi komunicēt un pamatot pieñemtos lēmumus un attīstības scenārijus un stratēǵiju zemu $\mathrm{CO}_{2}$ emisiju virzienā.

Patēriṇa emisiju rezultāti tiek atspoguloti pa patēringa izdevumu kategorijām. Līdz ar to "oglekḷa pēdas" aprēksinā tiek iekḷautas ar transportu, mājokli, pārtiku, patēriña preču un pakalpojumu radīšanu, lietošanu un utilizāciju saistītās tiešās un netiešās SEG emisijas. "Oglekḷa pēdas” aprēķināšanai bieži vien tiek izmantota multireǵionālās ielaidesizlaides analīzes metode (anglu val. Environmentally extended Multi Regional Input-Output Model - EE-MRIO), kas papildināts ar vidi ietekmējošiem faktoriem (šajā gadījumā ar $\mathrm{CO}_{2 \mathrm{e}}$ emisijām).

EE-MRIO modelis nodrošina iespēju noteikt naudas plūsmu starp valstīm, nozarēm, apakšnozarēm, organizācijām un patērētājiem, kā arī l̦auj izsekot dažādiem multiplikatora efektiem ekonomikā. Šo metodi bieži izmanto, lai analizètu makroekonomikas izmainu ietekmi uz vietējo, nacionālo vai starptautisko ekonomiku vai lai noteiktu konkrētas nozares vai iestādes pienesumu vietējai ekonomikai. Šis modelis balstās uz savstarpēji saistītām valstu ielaides-izlaides vai piedāvājuma-pieprasījuma tabulām, kas attēlo preču un pakalpojumu plūsmu starp valstīm un ekonomikas nozarēm viena gada griezumā un sniedz informāciju par visu ielaidi, ko izmanto ražošanā, proti, starpproduktiem, darbaspēku, kapitālu un zemi.

Ielaides-izlaides analīze ir pētniecības metode, kas izmanto MRIO modeli, lai noteiktu, cik daudz ir savstarpējo saistību starp dažādām ekonomikas nozarēm un modelētu ekonomisko attīstību.

Lai novērtētu ietekmi uz vidi, MRIO modeli tiek papildināti ar vides faktoriem. SEG emisiju novērtēšanā tiek noteikti $\mathrm{CO}_{2 \mathrm{e}}$ emisiju apjomi katrai tautsaimniecības nozarei. Tādējādi, izmantojot ekonomisko procesu analīzi,
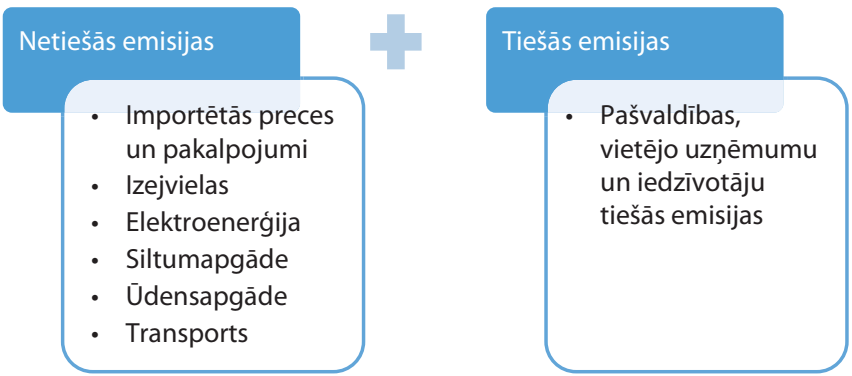

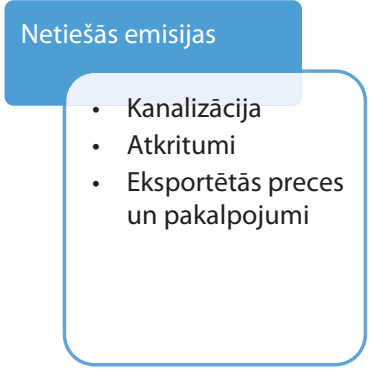

14.4. att. "Oglekḷa pēdas" aprēḳina ietvars. 
iespējams aprēksināt dažādu tautsaimniecības nozaru pilnas piegādes kēēes SEG emisijas. Dalot tās ar attiecīgās nozares izlaides vērtību, iespējams iegūt nozaru oglekḷa ietilpības rādītājus $\left(\mathrm{CO}_{2 \mathrm{e}} / \mathrm{EUR}\right)$.

Ielaides-izlaides metodes precizitāte atkarīga no koeficientu precizitātes, vecuma, ekonomikas izmainu ātruma, perioda, par kuru tāme sastādīta, plānoto gala pieprasījumu precizitātes un pieñēmumu piemērotības. Latvijā šobrīd ir pieejamas ielaides-izlaides tabulas no dažādiem avotiem, un tās atškiriras pēc savas precizitātes, detalizētības pakāpes un aktualitātes. Ielaides-izlaides tabulas izstrādā vairākas institūcijas:

- Latvijas Centrālā statistikas biroja izstrādātās tabulas ir pieejamas Eurostat mājaslapā;

- Pasaules ielaides-izlaides datubāze ir vēl viens labs datu avots, kur pieejama arī informācija par Latviju;

Lai noteiktu patēriṇa emisijas, mājsaimniecību izdevumu apjoms tiek reizināts ar attiecīgās nozares oglekḷa ietilpības koeficientiem, tādējādi iegūstot datus par mājsaimniecību SEG emisijām. Diemžēl ielaides-izlaides tabulas Latvijā ir pieejamas tikai nacionālā griezumā, līdz ar to pašvaldību emisiju aprēksinam tiek izmantoti Centrālās statistikas pārvaldes dati par mājsaimniecību budžetu, bet arī tās Latvijā ir tikai regionālā nevis novadu un pilsētu griezumā.

Tāpēc aktuālākas informācijas iegūšanai var izmantot iedzīvotāju aptauju, ar kuras palīdzību var iegūt datus par mājsaimniecību patēriṇa struktūru un apjomu. Aptauju arī ieteicams izmantot, lai iegūtu papildu informāciju tiešo un piegādes kēèdes emisiju aprēksinam.

SEG emisiju aprēksiniem nepieciešams ievērojams datu apjoms. Šie dati var atšksirties pēc to kvalitātes, formāta un pilnīguma un daudzos gadījumos tie ir jāprecizē, lai varētu tos pilnvērtīgi izmantot aprēksinos. Būtiskas problēmas ir saistītas ar Latvijas Vides, ǵeologijas un meteorologijas centra uzskaites formas Gaiss 2 pieejamo energoresursu patērina un SEG emisiju datu kvalitāti, kā arī ar sociālekonomisko datu pieejamību pilsētās un novados.
Taču standarti piel̦auj iespēju izmantot dažādus datu avotus darbības datu un emisijas faktoru iegūšanai. Priekšroka būtu jādod Centrālās statiskas pārvaldes datiem un pašvaldībā pieejamiem primāriem datiem par siltumapgādi, ēku energoefektivitāti, atkritumu apsaimniekošanu un sabiedrisko transportu.

Jomās, kur šādi dati nav pieejami, izmantojami aktuālākie nacionālie dati, kurus pielāgo pašvaldības specifikai, tos koriǵējot ar mēroga koeficientu, piemēram, iedzīvotāju skaitu vai ekonomisko aktivitāti. Pēc iespējas jāizmanto attiecīgā gada dati, taču, ja tādi nav pieejami, var izmantot tuvāko gadu datus. Diemžēl vairākām darbības jomām datu pieejamība var būt loti ierobežota, piemēram, par pārrobežu kravu pārvadājumiem pa autocel̦iem vai ūdeni. Tādā gadījumā jāparedz atsauce, ka šie dati kopējā aprēķinā nav iekḷauti. Papildus tam datus var iegūt aptauju veidā, piemēram, par mājsaimniecībās patērēto energoresursu veidiem un apjomu.

Oglekḷa emisijas pasaulē 2014. gadā bija 4,4 tonnas $\mathrm{CO}_{2 \mathrm{e}}$ uz cilvēku. Taču šìs emisijas nav vienmērīgi sadalītas visā pasaulē. ASV "oglekḷa pēda" ir aptuveni 28,6 tonnas $\mathrm{CO}_{2 \mathrm{e}}$ uz cilvēku gadā, Krievijā - 10 tonnas $\mathrm{CO}_{2 \mathrm{e}}$, Kīnā $-3,1$ tonna $\mathrm{CO}_{2 \mathrm{e}}$, bet Indijā - tikai 1,8 tonnas $\mathrm{CO}_{2 \mathrm{e}} \mathrm{uz}$ cilvēku gadā. Eiropas Savienībā vidējā "oglekḷa pēda" ir 13,3 tonnas $\mathrm{CO}_{2 \mathrm{e}}$ uz cilvēku gadā; lielākā "oglekḷa pēda" Eiropas Savienībā ir Lihtenšteinas iedzìvotājiem (41 tonna $\mathrm{CO}_{2 \mathrm{e}}$ uz cilvēku gadā) un Beḷgijas iedzīvotajiem (20 tonnu $\mathrm{CO}_{2 \mathrm{e}}$ uz cilvēku gadā). Savukārt mazākā tā ir Rumānijā un Bulgārijā - nedaudz mazāka par 5 tonnām $\mathrm{CO}_{2 \mathrm{e}}$ uz cilvēku gadā.

Latvijas iedzìvotāju ekologiskā pēda būtiski pārsniedz pasaules vidējo rādītāju. Ja 2000. gadā tā bija 4,2 tonnas, tad 2013. gadā jau sasniedza 7,5 tonnas $\mathrm{CO}_{2 \mathrm{e}}$ uz cilvēku gadā. Tas ir lielā mērā noticis sakarā ar straujo ekonomikas attīstību, kas veicinājusi iedzìvotāju pirktspējas pieaugumu. Savukārt tehnologiskie uzlabojumi emisiju samazināšanā nav bijuši pietiekami, lai nepiel̦autu "oglekḷa pēdas” pieaugumu.

Taču emisijas nav arī vienmērīgi sadalītas visā valstī. Pētījums, kurā salīdzinātas patēriṇa emisijas Rīgā, Ventspilī un Salacgrīvā, parāda, ka lielākās emisijas Latvijā ir tieši galvaspilsētā 
Rīgā - 9 tonnas $\mathrm{CO}_{2 \mathrm{e}}$ uz vienu cilvēku gadā. Savukārt patēriṇa emisijas Salacgrīvas novadā un Ventspils pilsētā ir zemākas nekā vidēji Latvijā, attiecīgi 5,75 un 7,2 tonnas $\mathrm{CO}_{2 \mathrm{e}}$ uz vienu iedzīvotāju gadā (sk. 14.4. att.). Līdzīgi kā citur pasaulē, arī Latvijā lielākās emisijas saistītas ar pārtikas produktu patēriṇu (36\% Salacgrīvā, 31\% Ventspilī), transportu (27\% Salacgrīvā, 19\% Ventspilī) un komunālajiem pakalpojumiem (20\% Salacgrīvā, 30\% Ventspilī).

Patēriña emisijas ir loti cieši saistìtas ar iedzīvotāju ienākumiem, līdz ar to pēdējos gados, ekonomikai atgūstoties un pieaugot mājsaimniecību ienākumiem, visā Latvijā vērojams straujš patēriņa emisiju pieaugums. Kopš 2010. gada salacgrīviešu patēriṇa emisijas ir pieaugušas par 39\%, bet ventspilnieku emisijas augušas par $19 \%$.

Pašvaldību līmenī iespējams aprēksināt ne tikai patēriṇa emisijas, bet arī tiešās SEG emisijas. Teritoriālās emisijas Salacgrīvas novadā 2013. gadā bija 49387 tonnas $\mathrm{CO}_{2 \mathrm{e}}$ (par 5\% mazāk nekā Salacgrīvas iedzìvotāju patēriṇa rezultātā radītās emisijas), bet Ventspils pilsētā - 357634 tonnas $\mathrm{CO}_{2 \mathrm{e}}$ (par 17\% vairāk nekā Ventspils iedzīvotāju patēriṇa rezultātā radītās emisijas).
Enerǵētika (apkure un rūpniecība), autotransports un pārtika veido lielākās emisijas gan Salacgrīvas novadā, gan Ventspils pilsētā. Laika posmā no 2010. gada līdz 2013. gadam SEG emisijas Salacgrīvas novadā nav būtiski mainījušās. Taču Ventspils pilsētas SEG emisijām ir tendence samazināties - no 2010. gada līdz 2013. gadam tās ir samazinājušās par 9\%. Îpaši pozitīvi vērtējams emisiju samazinājums no pasažieru pārvadājumiem, centralizētās pilsētas siltumapgādes un privātā autotransporta (-7\%). Arī ēku siltināšanai ir pozitīva ietekme uz mājokḷu radītajām emisijām. Lielākā dalı emisiju - gan pārtikas, gan citu preču un energoresursu ražošanas emisijas - rodas ārpus pašvaldību robežām, līdz ar to pašvaldībai ir ierobežotas iespējas tās ietekmēt. Labākais līdzeklis ārējo emisiju samazināšanai ir "zaḷā" iepirkuma kritēriju integrēšana pašvaldību iepirkumos. Viens no sektoriem ar lielām ārējām izmaksām ir pārtika. Šì sektora emisiju samazināšanu varētu veicināt ar sezonālās, vietējās un biologiskajā lauksaimniecībā audzētās pārtikas patēriña veicināšanu mājsaimniecībās un pašvaldības pakḷautības iestādēs, piemēram, skolās un medicīnas iestādēs.

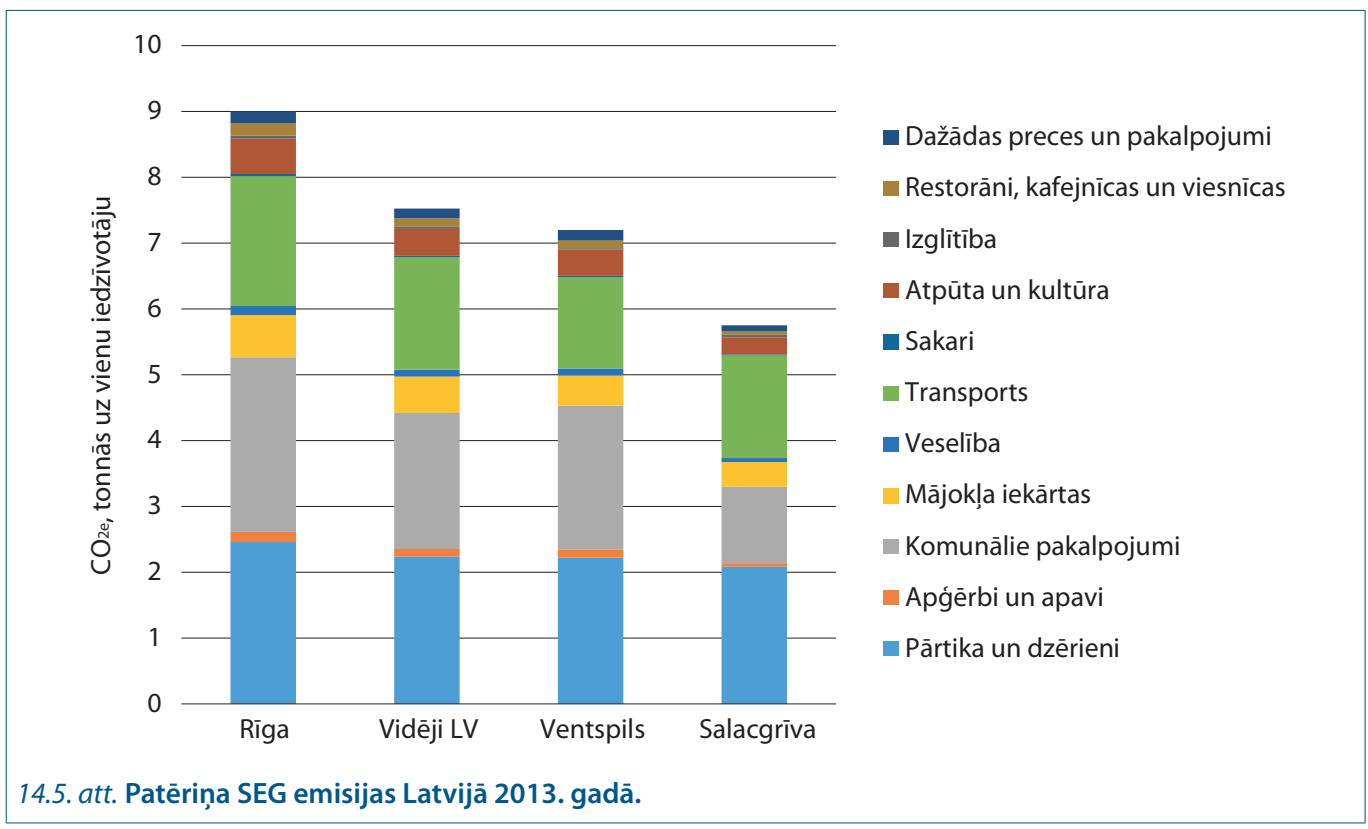




\subsection{Oglekḷa mazietilpīga attīstība}

Oglekḷa mazietilpīgas attīstības (OMA) (anglu val. - low carbon development) koncepcijas pirmsākumi rodami ANO Vispārējā konvencijā par klimata pārmaiñām. 2008. gada līgumslēdzēju pušu konferencē tika ierosināts sākotnējais priekšlikums šādu attīstību ieviest visās valstīs, kas ratificējušas konvenciju.

OMA ir kompleksa attīstības pieeja, kurā atsevišķi tiek izdalīta arī oglekḷa mazietilpīga ekonomika, ko lieto kontekstā ar ekonomikas plānošanas stratēgoijām attiecībā uz SEG emisiju samazināšanu, bet kopumā OMA var ietvert arī citas jomas, piemēram, vides ilgtspēju un sociālo vienlīdzību. Diemžēl līdz šim brīdim nav ieviesta starptautiski vienota OMA definīcija. Līdz ar to katra valsts ogleklı mazietilpīgu attīstību interpretē citādi, kas pēc būtības nav slikti, ja vien izvirzītie starptautiskie mērksi tiek sasniegti.

Uz ANO pien,emto stratēǵiju pamata arī ES sākusi īstenot pāreju uz zemu SEG emisiju ekonomiku. Priekšnosacījumi šim attīstības virzienam ir noteikti dokumentā "Eiropa 2020 - ES stratēgijā gudrai, ilgtspējīgai un integrējošai izaugsmei", kas izvirza trīs prioritātes:

- uz zināšanām un inovāciju balstītu ekonomikas attīstību,

- tādas ekonomikas veicināšanu, kas rada zemu oglekḷa dioksīda emisiju līmeni, taupīgi izmanto resursus un ir konkurētspējīga,

- tādas ekonomikas sekmēšanu, kurā ir augsts nodarbinātības līmenis un kura nodrošina sociālo un teritoriālo kohēziju.

OMA ir kompleksa un starpdisciplināra sistēma, kurā ir gan politikas izstrāde un instrumenti, gan ilgtspējīga zinātne un pētījumi, organizatoriskas pārmaiṇas, pārvaldības vadība, finanšu instrumenti un citas sfēras, kurās nepieciešama uz OMA ieviešanu vērsta rīcība. Šādi emisiju samazināšanas pasākumi ir domāti, lai panāktu noturīgas izmaiṇas mājsaimniecību, iestāžu un uzṇēmumu uzvedībā. Taču indivīdiem un grupām, kam jāievieš šīs izmain,as, joprojām nav brīvi pieejami instrumenti un tehnologijas, kas atvieglotu šādu rīcību. Lai panāktu SEG emisiju samazinājumu globālā un nacionālā līmenī, būtiski ir saprast faktorus, kas ietekmē izmain,as patēriṇa un ražošanas paradumos. Emisiju samazināšanas nolūkā ir jācenšas panākt attieksmes maiṇa un jārada motivācija videi draudzīgai rīcībai, kā arī jāmeklē jaunas partnerības un jārada rīki, lai izvērtētu un nodrošinātu nepieciešamās izmaiñas. Tieši pašvaldībām šajā ziṇā ir lielas priekšrocības, jo tām ir tieša saikne ar mājsaimniecībām un vietējiem uzṇēmumiem. Tāpat vietējās pašvaldības var identificēt un atbalstīt pārmain,u agentus, kas veicina zemu SEG emisiju līmeni, tādejādi nostiprinot motivāciju. Tas, savukārt, stiprina vietējo identitāti un lepnumu par sasniegto labklājības veicināšanā un emisiju samazināšanā.

Daudzas no jomām, kam ir būtiska ietekme uz SEG emisijām, ir pašvaldības tiešās funkcijas vai arī iekḷaujas to plašākā atbildības lokā. Mājoklu sektors ir viena no šìm jomām, kur pašvaldība var panākt būtisku SEG emisiju samazinājumu, siltinot savā īpašumā esošās ēkas, veicinot privātmāju energoefektivitātes uzlabojumus un nodrošinot labāku būvniecības praksi. Tāpat ir būtiski SEG emisiju samazināšanas pasākumus integrēt vietējā attīstības telpiskajā plānošanā, kas nodrošinātu ilgtermiṇa stratēgisku pieeju zemu SEG emisiju panākšanai un dotu attiecīgus signālus investoriem, kā arī iepirkumu procedūrās aktīvāk izmantot vides kritērijus.

Patēriņa emisijas bieži vien ir grūti kontrolēt, jo, piemēram, nevaram likt Ķinai izvēlēties vienu vai citu energoresursu vai izmantot videi draudzīgas tehnologijas. Globālajai tirdzniecībai liberalizējoties, arī valstu valdībām ir aizvien mazāk iespēju aizliegt ievest produktus, kuriem ir būtiska ietekme uz vidi. Vienīgi mēs, kā patērētāji, varam boikotēt preces ar lielu "oglekḷa pēdu" vai preces no valstīm, kas necenšas samazināt SEG emisijas. Tomēr arī tas ne vienmēr izdodas, jo pārsvarā mūsu izvēli nosaka preces vai pakalpojuma cena nevis doma par klimata pārmaiṇu ierobežošanu. 
Mūsu ikdienas patēriṇa un ražošanas paradumi nosaka lielāko dal̦u SEG emisiju un līdz ar to arī klimata pārmaiņas. Taču pašus patēriṇa paradumus veido komplekss savstarpēji saistītu faktoru kopums (vajadzības, iekšējie un ārējie faktori), kuri ir atkarīgi no dabas vides un plašākas sociālekonomiskās vides - makrovides faktoriem: pieejamajām tehnologijām un infrastruktūras, ekonomiskās, demogrāfiskās, institucionālās un sociālās vides (sk. 14.6. att.).

Mājsaimniecību radīto vides slodžu novērtējumi viennozīmīgi atzīst pārtikas, transporta un mājokḷa patērina sektorus par jomām ar lielāko ietekmi uz klimatu. Šîs slodzes var izteikt, izmantojot IPAT vienādojumu, kas tiek lietots arī SEG emisiju novērtēšanā un modelēšanā:

$$
I=P \times A \times T
$$

kur $I$ - kopējās radītās SEG emisijas,

$P$ - iedzīvotāju skaits,

$A$ - ienākumi uz vienu mājsaimniecības locekli gadā,

$T$ - ekoefektivitātes rādītājs (SEG emisijas uz vienu EUR).

IPAT vienādojumu var raksturot ar šādu piemēru. 1990. gadā, kas ir pieñemts par atskaites punktu SEG emisiju samazināšanai, kopējās pasaules radītās SEG emisijas bija 21,7 milj. t $\mathrm{CO}_{2}$, iedzīvotāju skaits bija 5,3 miljardi, ienākumi - vidēji 5,69 tūkstoši USD uz cilvēku gadā, bet ekoefektivitāte $-0,72 \mathrm{~g} \mathrm{CO}_{2}$ uz vienu radìto USD $(5,3 \times 5,69 \mathrm{USD} /$ cilv. $\times 0,72 \mathrm{~g}$ $\mathrm{CO}_{2} / \mathrm{USD}=21,7$ milj. $\mathrm{t} \mathrm{CO}_{2}$ ).

Savukārt divdesmit gadus vēlāk SEG emisijas bija pieaugušas līdz 31,1 miljardam tonnu, iedzīvotāju skaits 2010. gadā bija palielinājies līdz 6,8 miljardiem, ienākumi - līdz 7,5 tūkstošiem ASV dolāru uz cilvēku gadā, bet tehnologiskais progress emisiju intensitāti bija samazinājis līdz 0,61 $\mathrm{g} \mathrm{CO}_{2} / \mathrm{USD}$ (6,8 × 7,5 USD/cilv. × 0,61 $\mathrm{g} \mathrm{CO}_{2} / \mathrm{USD}=31,1$ milj. $\mathrm{t} \mathrm{CO}_{2}$ ). Lìdz ar to, neskatoties uz tehnoloǵisko progresu šajā laika periodā, emisijas bija pieaugušas par $43 \%$. Tas bija noticis iedzīvotāju skaita pieauguma un ekonomiskās attīstības ietekmē.

Izmantojot IPAT vienādojumu, iespējams modelēt SEG emisiju nākotnes scenārijus. Lai nodrošinātu SEG emisiju samazinājumu, nepieciešams nodrošināt izmaiṇas labklājībā un tehnologijās. Šĩs izmainas ietekmē apjoma, strukturālais un intensitātes efekts, kas saistìts ar dažādām pieejām ilgtspējīga patēriṇa vides slodžu pārvaldībā:

- ekoefektivitātes pieeja, kas ir vērsta uz ekoefektivitātes uzlabošanu visos produkta aprites cikla posmos,

- pārslēgšanās pieeja, kas ir vērsta uz izmaiñām patērina struktūrā, mainot

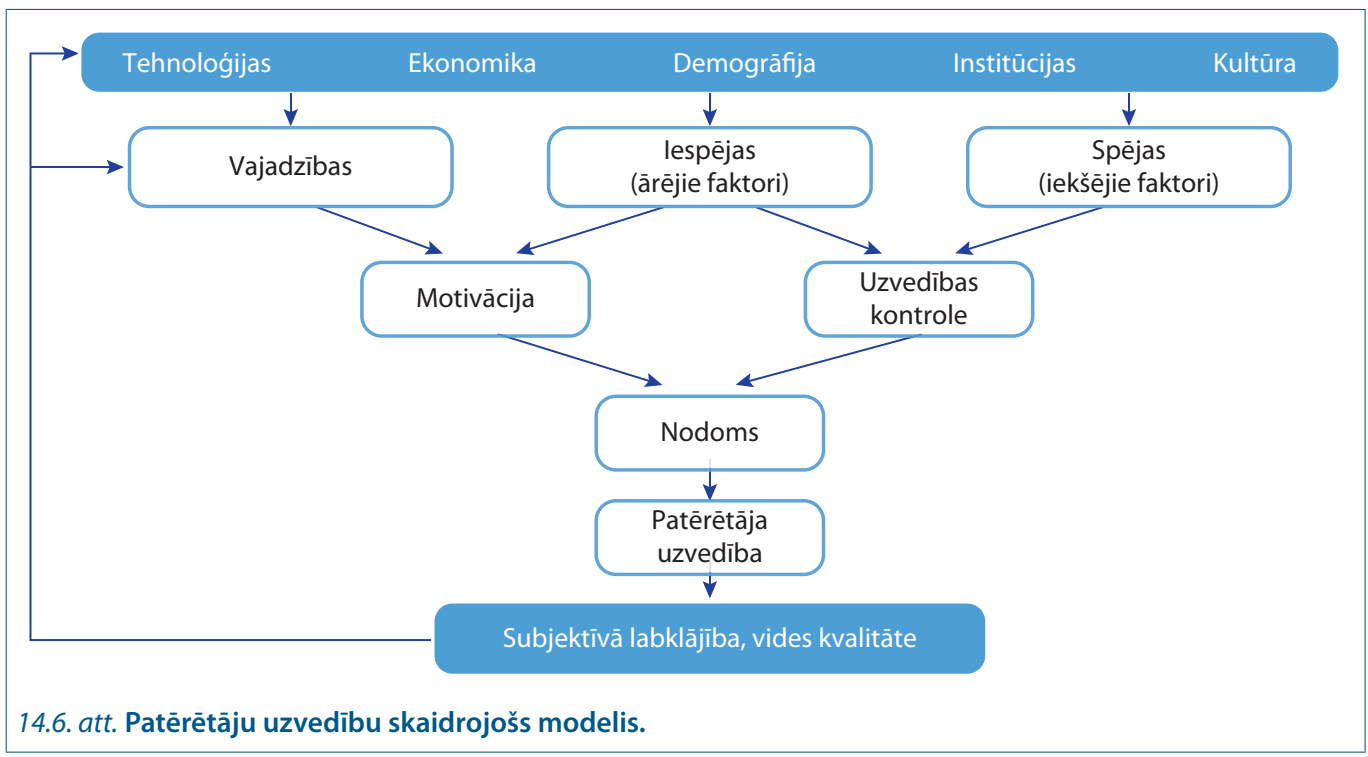


kolektīvo rīcību un koncentrējoties uz izmaiṇām piegādes sistēmās,

- pietiekamības pieeja, kas ir vērsta uz patēriṇa apjoma samazināšanu un atbalsta ekonomiku bez izaugsmes un attīstītajās valstīs pat ekonomiskās izaugsmes samazināšanu. Labklājību un apmierinātību ar dzīvi var nodrošināt, attīstot sociālo kapitālu un dzīvesveidu, kas vairāk tendēts uz garīgām nevis materiālām vērtībām.

Mūsdienu sabiedrība ir pārlieku koncentrējusies uz ekoefektivitātes pieeju - tehnologiskajām inovācijām un brīvā tirgus risinājumiem, lai sabiedrību ievirzītu videi draudzīgākā gultnē. Taču "atsitiena" efektu ietekmē šì pieeja nespēj nodrošināt absolūtu resursu patēriņa un piesārṇojuma samazinājumu. Tā tiek kritizēta no pietiekamības pieejas atbalstītāju puses, kas uzsver, ka ikdienas dzīvē cilvēkiem ir grūti mainìt savus ieradumus pat tad, ja vini ir labi informēti un motivēti. Līdz ar to nepieciešams ar sistēmiskām sociālām inovācijām un pieprasījuma puses pārvaldību mainīt ne tikai individuālu, bet arī kolektīvu rīcību, mainot patēriṇa struktūru un apjomu.

Ilgtspējīga patēriṇa pārvaldībā nevar koncentrēties tikai uz vienu no minētajām pieejām. Tā ir atkarīga no patēriṇa sektora, mērkgrupas un sociālekonomiskā konteksta. Līdz ar to jālieto šo pieeju dažādas kombinācijas, kas vērstas uz pārmaināām makrovides faktoros:

- ekonomiskajā sistēmā - jāattīsta tirgus mehānismi, kas veicina videi draudzīgu ražošanu un patēriṇu un ierobežo neilgtspējīgus patēringa paradumus,

- tehnologijās - produktiem un pakalpojumiem ar mazāku ekoloǵisko pēdu ir jākḷūst pieejamākiem un dominējošiem tirgū,

- infrastruktūrā - vides attīstība, kas atvieglo ilgtspējīgu patēriņu un izskauž neilgtspējīgus patēriṇa paradumus,

- institucionālajā vidē - jāveicina cilvēku vajadzību apmierināšana ārpus tirgus (piem., sociālā kapitāla stiprināšana),

- sociālpsiholoǵiskajā vidē - palielinot patērētāju zināšanas par patēriṇa vides slodzēm un mainot patēriṇa simbolisko nozīmi un attīstot mazāk materiālistisku, altruistiskāku dzīves stilu un vērtības.

Šo spēku ietekmē patēriṇa paradumi Latvijā pēdējos 20 gados ir būtiski mainījušies. Ir notikušas izmaiṇas iedzīvotāju dzīves stilā, piegādes sistēmās, ekonomiskajos procesos u.c. Daudzos gadījumos šìs izmainnas ir bijušas neilgtspējīgas. Izmaiṇas piegādes sistēmās ir pārlikušas vides slodzes no ražošanas uz patēriņu. Piemēram, pieaugošā mobilitāte, piepilsētas lielveikalu attīstība un "pilsētu atlūzas" ir palielinājušas nobraukto pasažierkilometru skaitu un tādējādi palielinājušas ietekmi uz klimatu. Arī izmaiñas dzīves stilā, piemēram, aizvien pieaugošais pieprasījums pēc sadzīves elektronikas un dzīvnieku izcelsmes pārtikas produktiem, ir veicinājušas vides slodžu pieaugumu.

Daudziem no patēriņu ietekmējošajiem faktoriem ir dubulta daba. Ienākumi, tehnologiju attīstība un informācijas pieejamība var veicināt patēringa apjoma pieaugumu un jaunu iekārtu izmantošanu, gan arī, tieši pretēji, videi draudzīgu rīcību, energoefektivitāti un resursu taupību. Ekonomiskā izaugsme veicina elektroierīču skaita palielināšanos un elektroenerǵijas patēriṇu mājsaimniecībās, bet ekonomiskās krīzes ietekmē 2008. un 2009. gadā samazinājās energoresursu un pārtikas produktu patēriṇš, veicinot SEG emisiju samazināšanos. Tāpat ekonomiskās problēmas veicināja aktīvāku iedzīvotāju sadarbību resursu taupīšanā.

Pētījumi atklāj būtiskākos patēriṇa virzošos spēkus, kas vecina gan ilgtspējīgu, gan neilgtspējīgu patēriṇu. Tie ir saistīti ar tirgus nepilnībām, kas valdības līmenī netiek risināti, un "labas dzīves" un labklājības izpratni sabiedrībā:

- zemās videi kaitīgo produktu cenas, kas neatspoguḷo ārējās vides izmaksas,

- infrastruktūra un piegādes sistēmas, kas patērētāju ieslēdz neilgtspējīgās izvēlēs,

- tirgus ekonomikā iebūvētais konkurences un izaugsmes modelis, kas veicina visu dzīves sfēru komercializāciju un produktu ražošanas inovācijas,

- mārketings, kas izmanto produktu statusa nozīmi un veicina materiālistisku vērtību nostiprināšanos sabiedrībā ar masu 
mediju (īpaši televīzijas), publiskās telpas komercializācijas un atlikto maksājumu palīdzību,

- sabiedrības materiālistiskās vērtības un vēlme pēc augstāka komforta.

Šo virzošo spēku kompleksās mijsakarības un daudzveidīgās ietekmes liedz skaidri prognozēt mājokḷa, transporta un pārtikas sektoru vides slodžu dinamiku. Piemēram, mājokḷu sektorā cilvēkiem būs vēlme pēc lielākas dzīvojamās telpas un daudzām elektroierīcēm, kas veicinās vides slodžu pieaugumu, taču ēku siltināšana, elektroierīču efektivitātes palielināšana un pāreja uz atjaunojamiem energoresursiem veicinās SEG emisiju samazināšanos.

Sociologiskās aptaujas atklāj, ka iedzīvotājiem Latvijā rūp vides jautājumi (pārsvarā vides piesārn,ojums un atkritumu problemātika) un klimata pārmaiñas tie uzskata par būtisku vides problēmu, taču aptaujātie nav ieinteresēti ilgtspējīgā patēriṇā un neuzskata, ka viṇu ikdienas patēriṇa paradumi atstāj būtisku ietekmi uz vidi. Tajā pašā laikā veidojas nišas dzīves stili un tirgi, piemēram, biologiiskās pārtikas, ekokosmētikas un dažādu energoefektīvu iekārtu jomā. Tas saistās ar ilgtspējīga patēriṇa dzīves stila nostabilizēšanos noteiktās sociālās grupās, taču šie dzīves stili ir margināli un nespēj atsvērt apjoma efektu un ar to saistītās augošās patērin,a ietekmes uz klimatu.

Sabiedrība nav homogēna un, vērtējot iedzīvotāju rūpes par vidi un ilgtspējīgu patēriñu, visus iedzīvotājus var iedalīt četrās apjoma ziṇā līdzīgās grupās (sk. 14.1. tabulu). Pirmā grupa, kurai rūp vides aizsardzība un kura rīkojas videi draudzīgi, iekšēji var būt l̦oti atšķirīga. Dalı šīs grupas pārstāvju var būt gatavi aktīvi rīkoties paši un piedalīties ilgtspējīgas kopienas veidošanā, preču koplietošanā un dekomercializācijā. Savukārt citi (trešā grupa) paļaujas uz ekomarķejumiem un, nemainot savas vajadzības un sociālekonomiskos nosacījumus, izvēlas videi draudzīgus produktus un pakalpojumus. Arī ceturtajā grupā var izdalīt apakšgrupas ar indivīdiem, kuri neinteresējas par videi draudzīgu rīcību, bet pasīvi labprāt izvēlētos videi draudzīgus produktus un pakalpojumus, kā arī ar indivīdiem, kuri uzskata videi draudzīgu dzīvesveidu par aplamu un nevajadzīgu. Līdz ar to, analizējot patērētāju vides rīcību, bez attieksmēm un rīcības būtiski ir saprast arī patērētāju gatavību mainīt savas vajadzības un apmierināt tās ārpus tirgus vai esošo sistēmu ietvaros pārslēgties uz videi draudzīgākām izvēlēm.

Šis dalījums atklāj arī vērtību un rīcības atš̌kirības starp cilvēku zināšanām par to, kas būtu jādara, un patieso rīcību. Piemēram, 3. grupa, kurai vides jautājumi nerūp, rīkojas videi draudzīgi, jo ierobežoto ienākumu dēḷ ir spiesti dzīvot mazākos dzīvokḷos, apkurē izmantot koksni, braukt ar sabiedrisko transportu, bet labprāt šīs izvēles aizstātu ar neilgtspējīgākām. 2. grupa apzinās vides jautājumu aktualitāti, bet ierobežoto iespēju dēḷ ilgtspējīgu dzīvesveidu nespēj îstenot. Sabiedrības grupās, kurām nerūp vides jautājumi, videi draudzīgu rīcību ir iespējams veicināt, veidojot ilgtspējīgu produktu piegādes sistēmas, tirgū nodrošinot videi draudzīgu produktu piedāvājumu un produktu cenās integrējot ārējās vides un sociālās izmaksas. Taču patērētāji, kuriem rūp vides jautājumi un kuri interesējas par patēriṇa ietekmēm uz vidi un veselību, ir vai nu gatavi maksāt vairāk, vai arī mainīt savus uzvedības paradumus par labu videi draudzīgākām izvēlēm, kuras lielā mērā ir atkarīgas no iedzīvotāju ienākumu līmeṇa un citiem iekšējiem

\section{1. tabula. Ilgtspējīga patēriṇa mērḳgrupu dalījums}

\begin{tabular}{|l|l|l|}
\hline & \multicolumn{1}{|c|}{ Attieksme - rūp vides jautājumi } & \multicolumn{1}{c|}{ Attieksme - nerūp vides jautājumi } \\
\hline Ilgtspējīgs patēriņš & $\begin{array}{l}\text { 1.grupa - rūp vides jautājumi, praktizē } \\
\text { ilgtspējīgu patēriṇu }\end{array}$ & $\begin{array}{l}\text { 3. grupa - nerūp vides jautājumi, } \\
\text { bet praktizē ilgtspējīgu patēriṇu }\end{array}$ \\
\hline Neilgtspējīgs patēriņš & $\begin{array}{l}\text { 2. grupa - rūp vides jautājumi, bet } \\
\text { nepraktizē ilgtspējīgu patēriṇu }\end{array}$ & $\begin{array}{l}\text { 4. grupa - nerūp vides jautājumi, } \\
\text { nepraktizē ilgtspējīgu patēriṇu }\end{array}$ \\
\hline
\end{tabular}


faktoriem, piemēram, prasmēm vai zināšanām par videi draudzīgas rīcības iespējām.

Veidojot oglekḷa mazietilpīgu attīstību, jāñem vērā patērētāju rīcības atkarība no vajadzībām, spējām un iespējām. Šie spēki darbojas atšķirīgi dažādos patēriṇa sektoros un dažādās mērkgrupās un ir atkarīgi no aktuālā vides aspekta un pieliekamajām pūlēm. Tā, piemēram, socioloǵiskajās aptaujās lielākā dalı respondentu atzīst, ka cena un produktu kvalitāte nevis produktu ietekme uz vidi vai veselību, ir būtiskākie patēriṇa izvēli noteicošie faktori. Taču patērētājs var būt vairāk norūpējies, piemēram, par dzīnnieku izcelsmes produktu patērinu, bet tajā pašā laikā būt vienaldzīgs par transporta līdzekḷu radīto gaisa piesārṇojumu un klimata pārmaiṇām.

Viens no pirmajiem soḷiem OMA īstenošanai ir izstrādāt un ieviest zemu $\mathrm{CO}_{2}$ emisiju attīstības stratēgiju, kas arī paredzētu galvenās vadlīnijas dažādiem tautsaimniecības sektoriem. Lai nodrošinātu mērķtiecīgu pāreju uz SEG mazietilpīgu attīstību un samazinātu valsts vai pašvaldības ietekmi uz klimatu, būtu jāseko vienkāršam priekšrakstam:

- jāsāk ar SEG emisiju samazināšanu tajos sektoros, kas rada lielāko ietekmi uz klimatu (noderēs "oglekḷa pēdas" aprēkins),

- pēc iespējas jāizvairās no rīcībām, kas îstermiṇā vai ilgtermiṇā veicinās tiešo un netiešo SEG emisiju pieaugumu,

- jāizvēlas iespējas, kas l̦auj samazināt SEG emisijas, piemēram, uzlabojot darbības efektivitāti un izmantojot labākos pieejamos tehniskos risinājumus.

Veicamie uzdevumi šajā ziṇā būtu, piemēram, pēc iespējas ātrāk samazināt SEG emisiju apjomu un palielināt atjaunojamās enerǵijas īpatsvaru kopējā energobilancē, veicināt energoefektivitāti un nostiprināt Latvijas ekonomikas noturību pret klimata pārmain,u radītajiem riskiem, attīstīt spēju novērst katastrofas un reagèt uz tām.

Līdz ar to OMA potenciālie rīcību virzieni skar tādas jomas kā $\mathrm{CO}_{2}$ emisiju mazietilpīgu tehnoloǵiju attīstība, resursu efektivitātes uzlabošana uzṇēmējdarbībā, ekodizaina un ekoinovāciju attīstība, ēku energoefektivitāte, vides nodokḷi, videi kaitīgu subsīdiju izskaušana, "zalıais" publiskais iepirkums un ES fondu ieguldīšana SEG emisijas mazietilpīgos pasākumos.

Daudz no iepriekš minētā SEG emisiju samazināšanā uzlabotu arī citas rīcības jomas. Tā, piemēram, ieviešot energoefektivitātes pasākumus, ir iespējams ietaupīt līdzekḷus, nodrošināt augstāku energoneatkarību un panākt būtiskus labklājības uzlabojumus. Daudzas no klimatam draudzīgām rīcībām ir arī ekonomiski izdevīgas ilgtermiṇā. Aprites cikla izmaksu aprēḳins var atvieglot šādu izvēli.

Jau pašlaik ilgtspèjīgas un oglekḷa mazietilpīgas attīstības nodrošināšanai Latvijā tiek izmantots plašs pārvaldības instrumentu klāsts: regulējošie, brīvprātīgie, komunikācijas un ekonomiskie instrumenti, piemēram, fiskālie stimuli un ekomarķējumi (izmantoto pārvaldības instrumentu kopums katrā sektorā ir atšksirīgs). Pārvaldības instrumentu lokam ir jābūt pietiekami plašam, un brīvā tirgus un ekoefektivitātes pieeja ir jāpapildina ar sociālajām (sistēmiskajām) inovācijām, jāattīsta ilgtspējīga infrastruktūra un jāmaina sabiedrības vērtības.

Mājokḷa sektorā OMA nodrošināšanai būtiski ir ne tikai veicināt pārslēgšanos uz atjaunojamiem energoresursiem, energoefektīvu ierīču (elektroierīču un apkures katlu) izmantošanu un èku sienu, logu un griestu termisko izolāciju, bet arī veicināt ilgtspējīgu pilsētplānošanu un ēku dizainu, lai maksimāli izmantotu dabisko siltumu un apgaismojumu, kā arī attīstītu videi draudzīgu uzvedību un sabiedrības diskusiju par "labu dzivi". Tādējādi jāizmanto ne tikai ekonomiskie, bet arī interešu grupas iesaistoši teritorijas plānošanas un komunikācijas paṇēmieni, lai veicinātu iedzīvotāju interesi un iesaistīšanos energoefektivitātes pasākumos, veicinātu vajadzību nevis par labu materiālām, bet garīgām vērtībām.

Transporta sektorā dominē regulējoši un ekonomiski risinājumi, cenšoties problēmas atrisināt, būvējot jaunu un atjaunojot esošo satiksmes infrastruktūru, ieviešot ekonomiskos stimulus autovadītājiem. Taču, neskatoties uz to, transporta radītās SEG emisijas palielinās, 
jo cilvēki aizvien vairāk pārslēdzas no sabiedriskā uz privāto autotransportu. Tam par iemeslu ir vides un transporta jomās nesaskaņotie pārvaldības mērksi un lietoto instrumentu fragmentētais raksturs. Taču nedrīkst aizmirst par autotransporta simbolisko, sociālpsiholoǵisko nozīmi. Līdz ar to ilgtspējīgas mobilitātes nodrošināšanai ne tikai jāattīsta sabiedriskais un nemotorizētais transports, bet, izmantojot plānošanas un komunikācijas līdzekḷus, jāveido ilgtspējīga infrastruktūra, piegādes sistēmas un jāierobežo privātā autotransporta izmantošanas nepieciešamība.

Pārtikas sektorā tāpat kā mājokḷa sektorā klimata ietekmes pēdējo gadu laikā nav būtiski palielinājušās, neraugoties uz rīcībpolitiku vājo savstarpējo integrāciju. Pārtikas produktu patērinšs ir viena no sabiedrības pamatvajadzībām, un pārtikas pieejamības nodrošināšana tiek uztverta kā valdības pienākums. Tāpēc pārtikas sektorā minimāli tiek izmantoti instrumenti, kas celtu produktu cenas. Tieši pretēji, ekonomiskās metodes aprobežojas ar tiešām un netiešām subsīdijām lauksaimniecības produkcijas ražotājiem. Pārtikas sektorā, iesaistoties dažādām interešu grupām, plaši izmanto arī komunikācijas instrumentus, lai veicinātu patēriṇu produktu kategorijās ar lielām vides slodzēm (piemēram, piena un zivju produktu patērinu). Ilgtspējīga pārtikas produktu patēriṇa nodrošināšanai jāveicina biologiskās lauksaimniecības attīstība un pieejamība, pārtikas produktu cenās jāintegrē vides izmaksas un jāizvērš sabiedrības diskusija un informatīvās kampaṇas par videi draudzīgu pārtiku.

Labākie sasniegumi, piemēram, mājoklıu vides slodžu ierobežošanā - pārslēgšanās uz koksni apkurē un ūdens patēriña samazinājums mājsaimniecībās, kā arī tehnologiskie risinājumi, ekonomiskie stimuli (cenas un nodokḷi) un komunikācijas pasākumi ir bijuši savstarpēji saskanīgi un papildinoši. Valsts pārvaldes iestāžu lietotās metodes ir izrādījušās neefektīvas jomās, kur patēriṇam ir būtiska simboliskā nozīme saistībā ar dzīves kvalitātes pieaugumu un izpratni par labu dzīvi. Piemēram, autotransporta un elektroenergíjas patēriṇa pieaugums ir lielā mērā skaidrojams ar automašīnu un elektropreču aizvien pieaugošo lomu cilvēku ikdienas dzīvē. Līdz ar to cilvēkiem, kuri atteiktos no automašīnas, papildu elektroierǐču izmantošanas, dzīvnieku izcelsmes produktu liela patēriṇa uzturā un lielas dzīvojamās platības, būtu jāatsakās no lietām, kuras tiek uzskatītas par labas dzìves standartu.

\section{Literatūra}

Brizga J. (2012) Ilgtspējīga patēriṇa pārvaldība Latvijā: politikas instrumenti, tīkli un indikatori. Disertācija, Latvijas Universitāte, Rīga.

Brizga J. (2015) Patēriṇa emisijas Latvijā aug. Vides Vēstis, 2(153), 12-13. Ipp. http://www.videsvestis.Iv/view. asp? ID $=153 \&$ what $=12$

Brizga J. (2014) Klimats un mēs - kurš kuru? Vides Vēstis, 2(147), 28-29. Ipp. http://www.videsvestis.Iv/view. asp?ID=147\&what $=28$

Brizga J., Kudreṇickis I. (2010) Mājsaimniecību ietekme uz klimatu Latvijā: oglekḷa pēdas rādītājs. Scientific Journal of Riga Technical University. Environmental and Climate Technologies, 3(3), 34-40. doi: 10.2478/v10145-009-0004-9

Davis S. J., Caldeira K. (2010) Consumption-based accounting of $\mathrm{CO}_{2}$ emissions. Proceedings of the National Academy of Sciences, 107(12), 5687-5692. doi: 10.1073/pnas.0906974107

EEA (2013) Environmental Pressures from European Consumption and Production. A Study in Integrated Environmental and Economic Analysis. EEA Technical report 2/2013. Copenhagen: European Topic Centre on Sustainable Consumption and Production.

IPCC (2014) IPCC Fifth Assessment Synthesis Report (p. 110): IPCC.

Fuchs D. A., Lorek S. (2005) Sustainable Consumption Governance: A History of Promises and Failures. Journal of Consumer Policy, 28(3), pp. 261-288. 
Steen-Olsen K., Weinzettel J., Cranston G., Ercin A. E., \& Hertwich E. G. (2012) Carbon, Land, and Water Footprint Accounts for the European Union: Consumption, Production, and Displacements Through International Trade. Environmental Science \& Technology, 46(20), 10883-10891.

Stern N. (2007) The Economics of Climate Change: the Stern Review: Cambridge University Press.

Tukker A., Bulavskaya T., Giljum S., de Koning A., Lutter S., Simas M., Stadler K., Wood R. (2014) The Global Resource Footprint of Nations. Carbon, Water, Land and Materials Embodied in Trade and Final Consumption Calculated with EXIOBASE 2.1. (p. 74). Leiden/Delft/Vienna/Trondheim.

Tukker A., Dietzenbacher E. (2013) Global Multiregional Input-Output Frameworks: An Introduction and Outlook. Economic Systems Research, 25(1), 1-19. doi: 10.1080/09535319100000001

Tukker A., Huppes G., Guinée J., Heijungs R., Koning A. D., Oers L. V., Jansen B. (2006) Environmental Impact of Products (EIPRO) Analysis of the Life Cycle Environmental Impacts Related to the Final Consumption of the EU-25.

Victor P. A. (2012) Growth, Degrowth and Climate Change: A Scenario Analysis. Ecological Economics, 84, pp. $206-212$. Zaḷā brīvība, Oglekḷa pēda Latvijas pašvaldībās. http://www.zalabriviba.lv/dzivesveids/pasvaldibu-oglekla-peda/

Izmantotie attēli

14.6. Gatersleben \& Vlek, 1998. 


\section{5. \\ Ilgtspèjigas attīstibas istenošana}




\subsection{Starptautiskā sadarbība ilgtspējīgas attīstības īstenošanai}

2012. gada sākumā ANO Augsta līmeña Globālās ilgtspējas grupa, ko vadīja Dienvidāfrikas Republikas prezidents Džeikobs Zuma (Jacob Zuma) un Somijas prezidente Tarja Halonena (Tarja Halonen), uzsvēra nepieciešamību "starptautiskajai sabiedrībai izvērtēt iekšzemes kopprodukta nozīmi un izstrādāt jaunu ilgtspējīgas attīstības rādītāju kopumu".

Daudzpusējie starptautiskie vides līgumi (konvencijas) ir viena no senākajām sadarbības formām, lai risinātu klimata, dabas, vides un ilgtspējīgas attīstības problēmas. Pēc 1972. gada ANO Cilvēkvides konferences starptautiskie vides līgumi ir kḷuvuši par galveno globālās vides pārvaldes veidu, tomēr vairāk uzsverot starptautisko diplomātiju nevis vienkārši tehnisko izpratni un izpildījumu. Kopš 1920. gada ir parakstīti, ratificēti un stājušies spēkā ap 140 starptautiskie līgumi, bet tos papildinošo dokumentu, piemēram, protokolu un grozījumu, skaits ir daudzkārt lielāks. Starp tiem vairākas konvencijas un protokoli īpaši izcel̦as ar savu nozīmīgumu saistībā ar ozona slāña degradāciju, bioloǵiskās daudzveidības samazināšanos un klimata pārmaiṇām.
Kaut gan konvencijas un to protokoli ir atšksirīgi pēc būtības un izvirzītajiem mērksiem, tomēr ir arī līdzības. Konvencijas faktiski ir starptautiski likumi, par kuriem ir vienojušās neatkarīgas valstis vai to pilnvarotas institūcijas. Tā kā konvencijas nosaka valstu tiesības un pienākumus noteiktā jomā, pirms to pien,emšanas parasti notiek samērā ilga saskaṇošana, ko veic valstu oficiāli pārstāvji. Pēc tam tehniskie eksperti sagatavo konvencijas projektu un nodod izvērtēšanai dalībvalstīm. Dalībvalstu augstākās amatpersonas starptautiskas konferences laikā, kas veltīta ar konvenciju saistīto jautājumu izskatǐšanai, paraksta konvenciju un pēc tam veic ratifikācijas procedūru, kas ietver valsts likumdevēja (parlamenta) oficiālu lēmumu par konvencijas atbilstību nacionālajai likumdošanai un vēlmei to pildīt, uzṇemoties starptautiskas saistības, kas izriet no konvencijas. Ja noteikts skaits dalībvalstu ir ratificējušas konvenciju (minimālo dalībvalstu skaitu, kas nepieciešams, lai konvencija efektīvi darbotos, izlemj pašas dalībvalstis), tās sasauc pirmo konvencijas dalībvalstu konferenci, kurā vienojas par konvencijas īstenošanas pasākumiem,

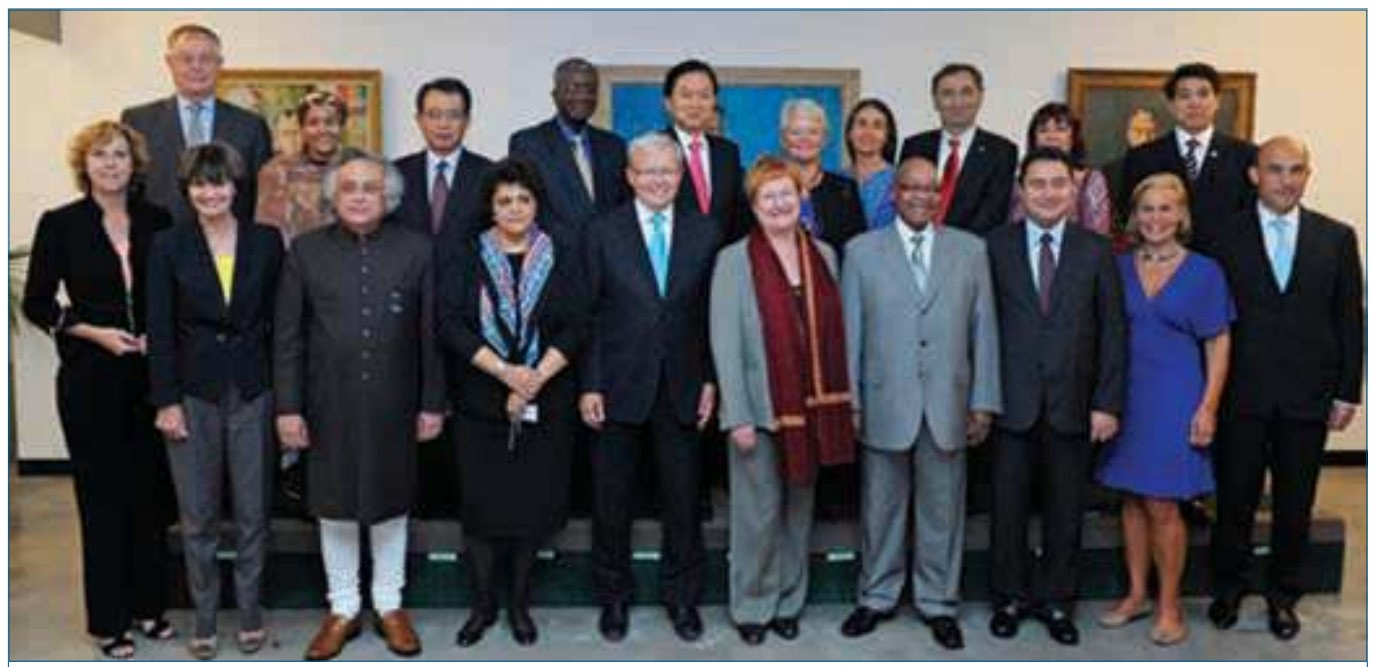

15.1. att. ANO Augsta līmeṇa Globālās ilgtspējas Padomes 5. sanāksme. ANO Galvenā mītne, N̦ujorka, 2011. gada septembris. Līdzpriekšsēdētāji: Somijas Republikas prezidente Tarja Halonena un Dienvidāfrikas Republikas prezidents Džeikobs Zuma. 
ieskaitot konvencijas sekretariāta izveidošanu, finansējuma nodrošināšanu, budžeta līdzekḷu izmantošanu, dalībvalstu atskaitīšanās kārtību un nepieciešamības gadījumā arī dalībvalstu atbilstības izvērtējumu. Dažkārt tiek izveidotas ekspertu komisijas vai darba grupas aktuālu jautājumu risināšanai.

Globālās vides politikas veidošanā, kā arī konvenciju un to protokolu tapšanā nenovērtējama ir zinātnieku un ekspertu loma. Kā labu piemēru var minēt Starpvaldību klimata pārmaiṇu speciālistu grupu, kurā ietilpst apmēram trīs tūkstoši zinātnieku. Viṇu pētījumu rezultāti, to savstarpēja apmaina un kolektīva interpretācija ir veicinājusi pasaules sabiedrības izpratni par pašlaik aktuālāko vides problēmu,
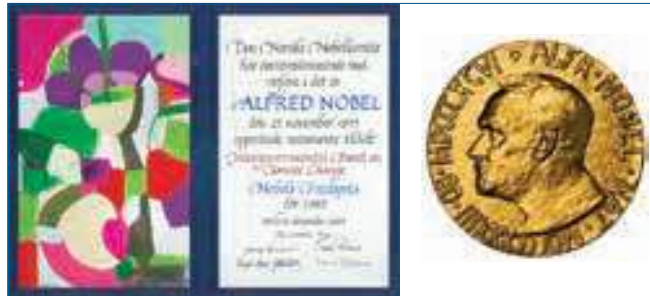

15.2. att. Starpvaldību klimata pārmainu speciālistu grupas apbalvojums 2007. gada Nobela Miera prēmija.

kā arī palīdzējusi veidot vienotu klimata pārmaiṇu negatīvo seku mazināšanas politiku. Šîs starptautiskās organizācijas ieguldījums ir novērtēts ar 2007. gada Nobela Miera prēmiju.

\subsection{Vienkāršākas dzīves iespējas}

1981. gadā amerikāṇu rakstnieks Daiens Elgins (Duane Elgin) publicēja grāmatu "Brīvprātīgā vienkāršība” un pats atzina, ka šis darbs ir radies, iedvesmojoties no Ernesta Šumahera (Ernst Friedrich Schumacher) idejām, īpaši saistībā ar Šumahera 1973. gadā izdoto grāmatu "Mazais ir skaists" ("Small is Beautiful”). Viṇš redzēja "brīvprātīgās vienkāršības" sūtību kā savā ziṇā aicinošu dzives virzienu.

Ideja par izvēli dzīvot vienkārši nozīmē nepalielināt savus izdevumus, lai mazinātu ietekmi uz vidi, bet vienlaikus tiekties paplašināt savu brīvību un iekšējā miera sajūtu. Šì ideja izplatījās, līdz tā kḷuva par sociālo kustību arī OECD (Ekonomiskās sadarbības un attīstības organizācija - Organisation for Economic Cooperation and Development) valstu ietvaros, aptverot dažādas sociālās grupas.

Izvēle par labu vienkāršîbai un pretošanās "žurkas skrējienam" ("vāveres ratam”) izraisīja pat žurnālu un televīzijas interesi un iesaistīšanos, jo īpaši 1990. gadā, kad aktualizējās jautājums par dzìvesveidu.

Tas vienlaikus radīja paralēlas kustības. "Lēnā ēšana" ("Slow Food") un "rāmā pilsēta" ("Slow City") saistīta ar ideju par vienkāršîbu un nekomercializētu darbību, kas veicina augstāku dzīves kvalitāti. "Lēnā ēšana" ir starptautiska kustība, ko iedibināja Karlo Petrīni (Carlo Petrini) 1986. gadā kā alternatīvu "ātrai ēšanai" ("Fast food"), tā cenšoties saglabāt tradicionālo virtuvi. Viṇš mudināja lauksaimniekus audzēt augus, sēklas un mājlopus, kas raksturīgi vietējām ekosistēmām. Kustība ir aptvērusi pasauli un iekl̦auj vairāk nekā 100000 biedru 150 valstīs. Tās mērksi ir ilgtspējīgas pārtikas un vietējo mazo uzṇēmumu attīstības veicināšana, kā arī politiska prasība, kas vērsta pret lauksaimniecības produktu aprites globalizāciju.

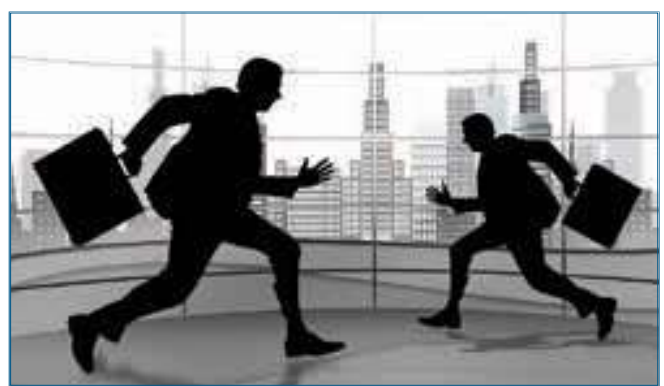

15.3. att. "Žurkas skrējiens" tiek veikts paša skrējiena dẹl un ir bezjēdzīgs - tã ir paka!̣dzī̌̌anās pēc kaut kā nezināma. 


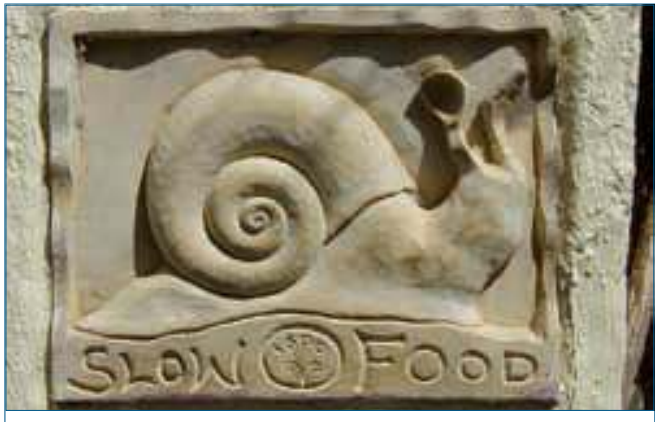

15.4. att. Restorāna izkārtne Santorīni, Grieḳijā.

Populārais šefpavārs Mārtiņš Rītinš ir šīs starptautiskās kustības aizsācējs Latvijā. Viṇš 1996. gadā nodibināja biedrību "Slow Food Riga".

Tomēr "brīvprātīgās vienkāršības" kustība nav sasniegusi vairākumu - kritisko masu, kas ir svarīgs parametrs, lai veicinātu domu apmaiñu sociālo tīklu plūsmā, tādējādi palīdzot sagatavot augsni jaunai ekonomiskai domāšanai par laimi un labklājību.

Individuālā apn,emšanās par labu "brīvprātīgajai vienkāršî̉bai" paver ceḷu tāda paša veida kolektīvām saistībām, ko pieṇem mazās kopienas, ciemati un pilsētas.

Rūpes par planētas lielajām vides problēmas pastiprinājās 20. gs. 90. gados un 21. gs. sākumā. Tās vienoja cilvēku kustības, mēǵinot parādīt alternatīva dzīvesveida iespējas, par kurām nevajadzēs "samaksāt ar planētu Zeme". Tās būs elastīgākas, saskaroties ar iespējamām vides, sociālajām un ekonomikas problēmām. Daži cilvēki pārvietojās, lai veidotu jaunas kopienas un īstenotu alternatīvās ekonomikas un vides principus.

Ekociemati (Ecovillages) parasti bija maza mēroga apmetnes, kas tika izveidotas industriālās sabiedrības robežteritorijās - pamestās rūpnieciskās zonās, ārpilsētās vai lauku rajonos. Projekti tika izstrādāti, lai būtu vairāk videi draudzīgi, kā arī lai nodrošinātu iztikas pietiekamību ekonomiskā skatījumā, bet nevis pieaugumu.

Citi projekti bija vairāk tendēti reformēt pastāvošās kopienas. Tika ieteikti arī principi, lai izmantotu vairāk amatnieku darbībai līdzīgu un ekologisku pieeju. Šāda pieeja iemiesojās arī

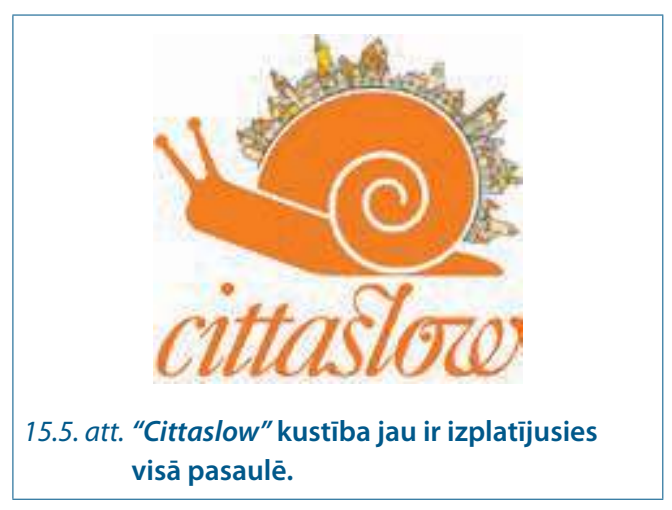

apdzīvotās vietās un kopienās, piemēram "Slow Society" koncepcija, kas guva atzinību no biznesa līderiem Japānā 21. gs. sākumā.

Šīs kustības mērksi ir

- padarīt dzīvi labāku ikvienam, kas dzīvo pilsētvidē,

- uzlabot dzīves kvalitāti pilsētās,

- pretoties pilsētu homogenizācijai un globalizācijai visā pasaulē,

- aizsargāt vidi,

- veicināt kultūras daudzveidību un unikalitāti atsevišksās pilsētās,

- iedvesmot veselīgākam dzīvesveidam.

Ekociemati tiek plānoti 50-150 personām. Lielāki ekociemati līdz pat 2000 personām pastāv kā veidojumi no daudzām mazākām vienībām, lai saṇemtu lielāku sociālo fondu atbalstu. Daži ekociemati pieaug uz tuvējo iedzīvotāju rēksina, kas ne vienmēr ir to îstenie locekḷ,i, bet

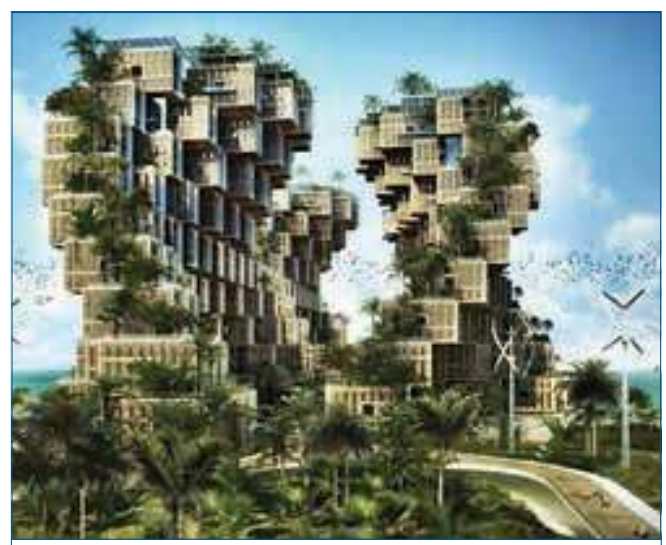

15.6. att. Moderna ekociemata vīzija. 
dzīvo perifērijā un efektīvi piedalās ekociemata dzīves norisēs.

Ekociematos locekḷus vieno kopīgas ekologiskās, sociālās, ekonomiskās, kultūras un garīgās vērtības. Tur bieži dzīvo cilvēki, kuri izvēlējušies alternatīvu elektroapgādes, ūdens un kanalizācijas sistēmu. Daudzi uzskata, ka pašreizējais patērētāja dzīvesveids ir izškēērdīgs, kas iznīcina dabiskos biotopus, veicina pilsētu, rūpnīcu un fermu pārlieku izvēršanos, pal̦aušanos uz fosilo kurināmo, un tās ir tendences, kas jāmaina, lai nepiel̦autu ekologisko katastrofu.

\subsection{Alternatīvās attīstības iespējas}

\subsubsection{Ekonomiskās izaugsmes vēsturiskais pamats}

Ekonomiskā augsme ir saistīts jēdziens, taču tā nav tā pati vienkāršā "izaugsme". Pauls Romers (Paul Romer), Stenfordas universitātes ekonomists, to definē šādi: "Ekonomiskā izaugsme notiek, ja cilvēki ņem resursus un pārkārto tos vērtīgākā veidā".

Tas ir līdzīgi èdiena gatavošanai - izejvielas nonāk virtuvē, tiek pielikts darbs, zināšanas, energija un tehnologijas. Pagatavotais garšīgais ēdiens ir daudz vērtīgāks nekā izejvielas, tādējādi ir radīta pievienotā vērtība, t.i., ekonomiskais pieaugums.

Bet kā izmērīt šo pievienoto vērtību? Mūsdienu pasaulē to mēra ar naudu. Pievilcīgas maltìtes vērtība nav atkarīga no tā, vai kāds ir gatavs maksāt par to. Tomēr šāda vērtības mērīšana rada zināmas grūtības. Ja maltīti ir sagatavojusi mana māte, tā varētu būt liela vērtība man. Taču šāda vērtība netiek reǵistrēta ekonomikas statistikā, jo mēs jau nemaksājam par èdiena gatavošanu savai mātei.

Teorētiski, mātes darbība ēdiena gatavošanā un pasniegšanā veicina tautas ekonomisko

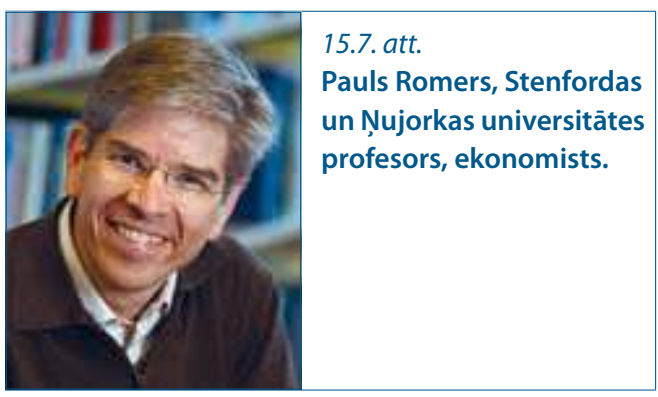

izaugsmi. Taču tā kā nav veikts maksājums, un par šo darbību netiek ziṇots oficiālajai uzskaites sistēmai, jaukā ēdienreize paliek ekonomiski neredzama.

Varētu piel̦aut, ka māte tomēr iesniedz rēksinu par maltīti. Dēls vai meita varētu apmaksāt šo rēksinu skaidrā naudā. Māte ieraksta to ienākumu deklarācijā un nomaksā atbilstošu nodokli. Tad un tikai tad, sniedzot ziñas par maltìtes sagatavošanu un pasniegšanu, kā arī saṇemto samaksu, viṇa un viṇas bērni būs veicinājuši savas tautas mērāmo ekonomisko izaugsmi.

Modernā pasaule ir apsēsta ar augošu mērīšanas māniju, vai "monetāru" ekonomisko izaugsmi. Tika izgudrots un ieviests pasākums apkopot stāvokli par monetārās ekonomikas pieauguma līmenī valstīs jeb iekšzemes kopproduktu (IKP). Par šo skaitli visbiežāk ziṇo saistībā ar panākumiem vai panīkumu pasaules valstīs. Tas atspoguḷo arī darba efektivitāti un ekonomikas aktivitāti.

Tomēr ir bīstami saistīt panākumus vai panīkumu ar IKP vērtību. Katastrofas, nelaimes gadījumi un pat kari palielina IKP, jo nācija mobilizē savu ekonomiku, lai atgūtos pēc stihijas, veiktu atjaunošanas darbus vai dotos uzbrukumā citai valstij. Turklāt vides degradācija vai dzila sociālā nevienlīdzība biežāk izraisa IKP pieaugumu, bet šo nedienu mazināšana vairāk saistās ar IKP kritumu.

"Augsme kā parasti" (bussines as usual) atsaucas uz fiziskās paplašināšanas saplūšanu ar monetārās ekonomikas izaugsmi, atstājot malā kvalitativva, laba vai slikta veida izaugsmi un ignorē sistēmiskos izaugsmes ierobežojumus. "Augsme kā parasti" tik labi korelē ar IKP, ka šie divi termini kḷūst gandrīz sinonīmi. Gada IKP 


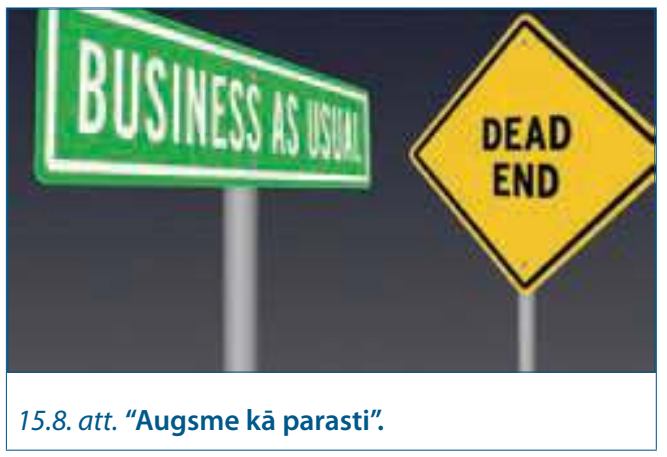

pieaugums liecina par "augsmes kā parasti” uzvaras gājiena turpināšanos.

Tomēr pēdējos gados vairāku valstu valdībās kritika par IKP izmantošanu kā galveno parametru valstu attīstības vērtēšanai ir ievērojami pastiprinājusies. Pat Kīnas valdība, kas spēja nodrošināt strauju ekonomikas attīstību pēdējās desmitgadēs, publiski ir norādījusi par savu nodomu mazināt ar IKP saistīto attīstības vērtējuma īpatsvaru un izaugsmē uzsvērt cilvēku laimes līmeni un lielākas rūpes par dabu.

Ekonomiskās domāšanas globālas izmain,as un pat valstu ekonomikas politikas izmaiñas ir sākušās. Kvantitatīvi šĩs izmainnas vēl nav noteiktas, taču jau pastāv daudzi virzieni, kas pētījumos izmanto sasniegumus psihologijā un neirologiijā, bažas par klimata pārmaiṇām, demogrāfisko tendenču izmaiņas.

\subsection{2. "Jaunā ekonomika"}

"Jaunā ekonomika" ir ekonomiskā filozofija un teorija, kas vairāk balstās uz idejām par pietiekamību nekā izaugsmi, arī uz Zemes sistēmu ierobežojumu ievērošanu, bet mazāk nodarbojas ar pašu ierobežojumu vērtēšanu un iespēju meklēšanu, lai mazinātu pašus ierobežojumus. "Jaunā ekonomika” varētu sākt alternatīvu, kultūras ziṇā atšksirīgu, bet mazāk staigātu cel̦u.

Celmlaužu - Hermana Deilī un Ernesta Šumahera centieniem ir pievienojušās neskaitāmas citu zinātnieku idejas ekonomikā, kā arī sociālajās un dabaszinātnēs. Kopā ar jaunām ekonomikas idejām ir radušās jaunas metodes un pan̄ēmieni, iesaistot pilnveidotas matemātikas un datoru modelēšanas metodes, lai palīdzētu leǵitimēt "jauno ekonomiku" tradicionālās augsmes ekonomikas pārāk skeptisko politiķu acīs.

Pašlaik domāšana "jaunās ekonomikas" virzienā aptver aizvien vairāk cilvēku, kuru līderi ir gan Nobela prēmijas laureāti ekonomikā, gan arī valstu vadītāji. Atš̌kirību starp "jauno ekonomiku” un pašreizējo augsmes modeli îsumā var formulēt šādi.

- Plašāki un daudz humānāki mērki. "Augsme kā parasti" ir vērsta uz ekonomikas izaugsmi, kas balstīta pārliecībā, ka šī izaugsme vienmēr garantē cilvēces progresu. "Jaunā ekonomika" koncentrējas uz reāliem rezultātiem, kurus tradicionālā ekonomika tikai šksietami cenšas panākt - uz labklājību iedzīvotājiem.

- Étiska orientācija. "Augsme kā parasti" nepietiekami novērtē ētiskos jautājumus par bagātības vairošanu šodien, neraugoties uz tās negatīvo ietekmi nākotnē. Turklāt tai ir tendence vērtības koncentrēt, nevis bagātību taisnīgāk sadalīt. "Jaunā ekonomika" uzskata, ka nevienlīdzības problēmas jārisina ne vien šodien, bet arī rīt. Tā īpaši uzsver godīgumu arī attiecībā uz nākotnes paaudzēm, balstoties uz koncepciju par starppaaudžu taisnīgumu.

- Skaidras ekoloǵiskās robežas. "Augsme kā parasti" bieži ignorē realitāti, ka ekosistēmu pakalpojumi un dabas resursi ir ierobežoti. "Jaunā ekonomika" izmanto šos ierobežojumus kā sākuma punktu, ap kuru veidot jaunu, funkcionējošu sistēmu vērtēšanai, attīstībai, nodarbinātības politikai utt.

- Vairāk sistēmisko rādītāju. "Augsme kā parasti” izmanto vienkāršotus indikatorus, kā galveno izcel̦ot IKP un tam analogus rādītājus. "Jaunā ekonomika" izmanto virkni mūsdienīgu mērījumu, lai varētu iegūt korektas atbildes uz jautājumiem, kas ir patiesi nozīmīgi iedzìvotājiem, to skaitā, vērtējumu par personīgo laimi un dzīves kvalitāti.

"Jaunās ekonomikas" idejas jāieklıauj ekonomikā, kas pašlaik dominē vairākumā gadījumu. Tas nozīmē, ka jaunās ekonomiskās koncepcijas, politika un pasākumi kḷūs aizvien 
nozīmīgāki valsts vai valdības lēmumu pieñēmējiem. Turklāt "Jaunā ekonomika" saglabā arī noteiktu specifiku - tā ir alternatīva, bet pagaidām vēl nav līdz galam sakārtota, jo tās dažādie piekritēji vēl nav vienojušies par kopīgu ietvaru. Tas veicina atšksirīgus formulējumus, aprakstus un redzējumus samērā līdzīgām koncepcijām.

Pēdējos gados ir parādījušās dažas norādes, ka augsmes modeḷa dominance sāk vājināties, kaut gan tikai nedaudz. Pierādījumi ir ḷoti pārliecinoši, ja pieminām, piemēram, pasaules vadošo ekonomistu viedokḷus, kādi tiek izteikti, tiem runājot ar ietekmīgāko valstu vadītājiem. Spilgtākais piemērs tam bija Ekonomiskās darbības un sociālā progresa novērtēšanas komisijas izveidošana, kas pazīstama arī kā "Štiglica komisija" pēc tās priekšsēdētāja, Nobela prēmijas laureāta, ekonomista Džozefa Štiglica (Joseph Stiglitz) vārda.

Štiglica komisija tika izveidota 2008. gadā pēc Francijas prezidenta Nikolā Sarkozī (Nicolas Sarkozy) lūguma. Tā sniedza oficiālu paskaidrojumu: "Jau ilgāku laiku rodas aizvien lielākas bažas par pašreizējo ekonomisko rādītāju pietiekamību, īpaši, ja izaugsmi pamato galvenokārt tikai ar IKP datiem. Tomēr attiecībā uz šiem skaițiem jāraugās plašāk un dziḷāk - kā tie atspogulo pasākumu efektivitāti un vai tie ir izmantojami ekonomikas, vides un sociālās ilgtspējas raksturošanai".

Darba noslēgumā komisija iesniedza ziṇojumu un uzsvēra, ka "ir pienācis laiks mūsu vērtēšanas sistēmā pārvirzīt uzsvaru no ekonomiskās ražošanas mērīšanas uz cilvēku labklājības novērtēšanu". Turklāt komisija sniedza arī detalizētas rekomendācijas par sociālekonomisko procesu norisi un to analīzes iespējām.

Štiglica komisijas darbību var uzskatīt par galveno pavērsienu ceḷā uz "jauno ekonomiku", kā arī par potenciālu pagrieziena punktu valstu attīstības procesu vēsturē. Īpaši nozīmīgas ir rekomendācijas, kā novērtēt tautas progresu un kādus mērksus izvirzīt nācijas attīstībai.

Darbu ar Štiglica komisijas secinājumiem turpina Francijas valdības aǵentūra, sanemot Ekonomiskās sadarbības un attīstības organizācijas (Organisation for Economic Co-operation and Development, OECD) finansiālu atbalstu programmas "Sabiedrības attīstības progress" ietvaros.

Tagad par jaunumiem šajā programmā iespējams uzzināt, izmantojot l̦oti noderīgu un visaptverošu tīmekḷa vietni "Wikiprogress.org", ko pārvalda OECD. "Wikiprogress" sniedz ne vien informāciju par pašlaik notiekošo, bet arī datus, zinnas un saites ar citiem, kas ir profesionāli iesaistīti jaunu pieeju meklējumos, lai pārietu uz labāku uzskaiti saistībā ar labklājības pētniecības un sociālo progresu kopumā. Tas ir būtisks resurss ikvienam, kas vēlas sekot alternatīvam domāšanas veidam par progresu.

\subsection{3. "Zal̦ā ekonomika"}

"Zal̦ā ekonomika" ir ANO iniciatīva, kas tika ieviesta un atbalstīta galvenokārt ANO Vides programmas ANO-VP (United Nations Environment Programme - UNEP) ietvaros.

ANO-VP izpilddirektors Ahims Steiners (Achim Steiner) vērtē "zaḷās ekonomikas" iniciatīvu kā neitralizējošu attiecībā uz to, ka ilgtspēju var sasniegt tikai uz ekonomiskās attīstības rēkina.

ANO-VP atbalstītā "Zaḷās stimulēšanas pakete" 2008. gada finanšu krīzes laikā identificēja konkrētās jomas, kurās plaša mēroga publiskā sektora ieguldījumi varētu iedarbināt "Zalı o ekonomiku”. Rūpniecībai, kas pārmērīgi izmanto resursus, ik gadu globālā mērogā vajadzētu novirzìt 1,3 triljonus EUR uz desmit "zal̦ākām" jomām, sākot no ilgtspējīgas mežsaimniecības līdz ēku modernizēšanai. Investīcijas - aptuveni 2\% no pasaules ekonomikas kopprodukta palīdzētu mazināt siltumnīcefekta gāzu emisijas un ļautu izvairīties no cenu šoka saistībā ar atkarību no fosilā kurināmā un citām precēm.

\section{GREEN CCONOMY}

Sākot ar 2011. gadu ANO-VP piedāvā dažādus pakalpojumus, kas saistīti ar videi draudzīgo "zalı ekonomiku" un būtiski svarīgas konsultācijas par zinātnes un pētniecības attīstību. Tādējādi tiek palīdzēts valstīm veidot stratēgiju 
un politiku, kā arī tiek piedāvātas uz model̦iem bāzētas analīzes metodes par "zaḷās ekonomikas" investīciju ietekmi.

"Zaḷā ekonomika" bija arī viena no divām galvenajām tēmām "Rio+20" konferencē 2012. gadā, kad tā tika minēta kā centrālā stratēǵija daudzu valstu valdību uzstādījumā, bet daudzas nevalstiskās organizācijas to uzskatīja par galveno, lai tiektos uz ilgtspējīgu attīstību. Tas būtiski ir ietekmējis globālo politiku par ilgtspējīgu attīstību. Pašlaik tiek strādāts pie tā, lai panāktu saistošu vai brīvprātīgu vienošanos par "zal̦ās ekonomikas" plašāku ieviešanu.

"Zaḷās ekonomikas" koncepcijas veicināšanā ANO-VP sadarbojas ar ideju ǵeneratoriem (domnīcām - think tank) un komerciāliem partneriem (piemēram, Deutsche Bank) par uzticēšanos starptautiskiem aizdevumiem un ekonomiskās analīzes pilnveidošanu.

\subsection{4. "Zalıāa augsme"}

"Zaḷā augsme" ir jēdziens, ko bija iecerējusi McKinsey konsultāciju firma saistībā ar praktiskajām darbībām klimata pārmaiṇu ietekmes mazināšanai. Šo jēdzienu kā labu atzina arī ANO, saistībā ar Ilgtspējīgas attīstības konferences (Johannesburga, 2002) Īstenošanas plānu.

"Zaḷās augsmes" intelektuālais centrs saistās ar Koreju, kur darbojas Globālās zal̦ās augsmes institūts (Global Green Growth Institute - GGGI).
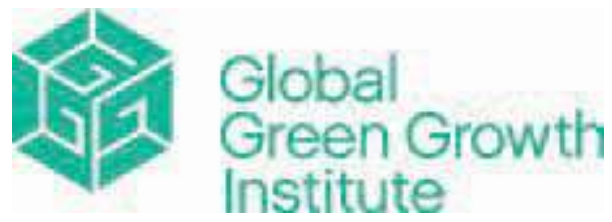

"Zaḷā augsme" atspoguḷo ekonomisko domātāju - Nikolasa Šterna, Džefrija Saha (Nicholas Stern, Jeffrey Sachs) uzskatus. GGGI atrašanās vieta Dienvidkorejā atspoguḷo šīs valsts īstenotos politikas pasākumus, jo īpaši pēc 2008. gada finanšu krīzes, lai stimulētu tradicionālo ekonomikas izaugsmi "zaḷākā" veidā (galvenokārt ar zemām $\mathrm{CO}_{2}$ emisijām). GGGI izvietošana Korejā ietvēra arī plašāku starptautisku interesi, ko virzīja ANO, palīdzot Āzijas-Klusā okeāna reǵionam, veicot pārlēcienu pāri Rietumu industrializācijas model̦iem un izvairoties no slazda "vispirms augsme, bet sakopšana vēlāk".

Klusā okeāna un Āzijas reǵiona valstis jūt neatliekamu vēlmi turpināt savas ekonomikas izaugsmi, lai mazinātu nabadzību un panāktu sociālo progresu. Tomēr tās arī jau ir piedzìvojušas ievērojami pieaugošu vides degradāciju, dabas resursu izsīkšanu, veselības problēmas un klimata pārmaiṇu ietekmi. Šīs valstis aizvien ir atzinušas atšksirīgas pieejas nepieciešamību, lai atbalstītu uz eksportu orientētu saimniecisko darbību reǵionā, bet "zaḷā augsme" ir kḷuvusi par vēlamo pieeju augstākā valdības līmeṇa vadībā. Dažādas ANO sponsorētas programmas tiek izmantotas, lai īstenotu "zalıo augsmi", kas ir "zaḷās ekonomikas" atzars - vadošā ekonomikas attīstības stratēǵija visā Āzijas-Klusā okeāna regionā un daḷeji arī pasaulē.

OECD arī veicina videi draudzīgu izaugsmi, un tai ir sava "zaḷās augsmes" stratēgija. "Zaḷā augsme" ir galvenokārt pieeja "no augšas uz leju", ko virza valdības iniciatīvas, bet tā vēl nav tik nozīmīga kopienām un investoriem kā klasiskā ilgtspējīgā attīstība. "Zaḷā augsme" tiek kritizēta par "zalı,o" attieksmi samērā ierobežotā veidā, un to bieži kritizē ekologi un arī ne-augsmes aktīvisti, kuriem "ne-augsme" ir vēlamais veids. "Zaḷās augsmes" galīgais mērkjis joprojām paliek augsme, bet dažkārt pat uz esošo ekosistēmu rēksina. Tomēr "zaḷā augsme" ir kḷuvusi par nopietnu alternatīvu "augsmei kā parasti" abos - gan vides, gan arī sociālajā virzienā.

ANO “zaḷās augsmes" programmas uzsver ilgtspējīga patēriṇa pieeju, t.i., koncepciju, kas liecina, ka galvenie ieinteresētie attīstības procesā ir nabadzīgie. "Zaḷā augsme" mudina izmantot līdzdalības novērtējumu, kas palīdz noteikt galvenos ierobežojumus, iespējas un problēmas, ar ko saskaras trūcīgie cilvēki, un iekḷaut tos politikas plānošanas un īstenošanas ciklos. Tas atbalsta neaizsargātās kopienas, nodrošinot nabadzīgajiem sociālos pakalpojumus un radot labvēlīgu vidi ilgtspējīgai attīstībai. 


\subsection{5. "Ilgtspējīga attīstība"}

Ilgtspējīga attīstība ir definēta ar ANO mandātu 1987. gadā izveidotās Komisijas par vidi un attīstību ietvaros un tika akceptēta ANO Vides un attīstības konferences laikā (Riodežaneiro, 1992).

Ilgtspējīga attīstība ir attīstība, kas nodrošina pašreizējās paaudzes vajadzības, respektējot nākamo paaudžu iespējas apmierināt savas vajadzības.

Jau gadsimta ceturksni kopš tās definēšanas, šis jēdziens bija kluvis par starptautisko sarunu stūrakmeni un vienošanās pamatu par dažādiem sociāliem, vides un ekonomikas jautājumiem, sākot no klimata pārmaiṇām (Vispārējā konvenciju par klimata izmain,ām), biologisko daudzveidību (Vispārējā konvencija par bioloǵisko daudzveidību) un sociālajiem mērķiem (Tūkstošgades attīstības mērksi).

"Ilgtspējīgai attīstībai" nav skaidri noteikta ekonomiskā filosofija vai stratēǵija. Ilgtspējīgas attīstības kritiḳi mēdz teikt, ka tā cenšas aptvert visas lietas saistībā ar visiem cilvēkiem un atrisināt visas problēmas.

Vairākums gan ir gatavi atbalstīt "ilgtspējīgu attīstību" kā galveno virzienu un alternatīvu "augsmei kā parasti", un to veicina ANO Ilgtspējīgas attīstības birojs (United Nations Office for Sustainable Development - UN OSD), kas tika atklāts 2011. gada beigās. Šì biroja darbība tiek atbalstīta visā pasaulē, padarot to par ārkārtas situācijas "smaguma centru" attiecībā uz "zalı

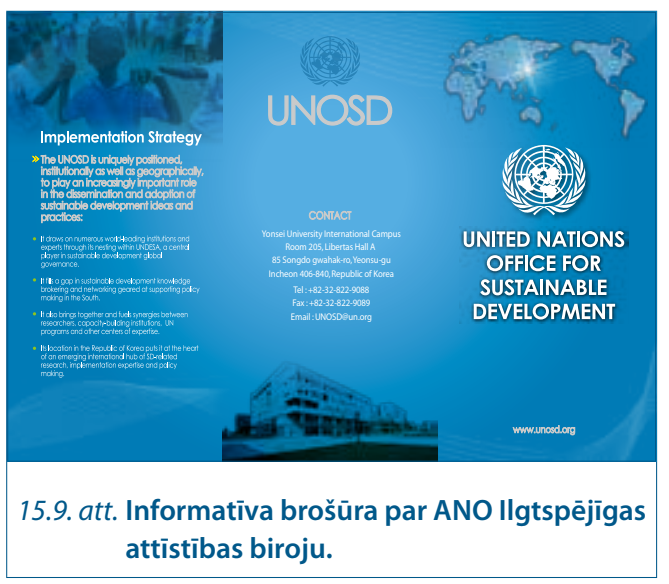

augsmi", "zalı ekonomiku” un "ilgtspējīgu attīstību” vismaz ANO kompetences ziṇā.

Šāda ANO ievirze atspoguḷo augsto nozīmības pakāpi attiecībā uz "ilgtspējīgu attīstību”, kas ir kḷuvusi par vispārējās plānošanas koncepciju un ko atbalsta plašas zināšanas par konkrētām tēmām (piemēram, enerǵētika, mājoklis, pārtika) un procesu virzību (piemēram, ieinteresēto pušu konsultācijas, integrētā plānošana, atbilstošu indikatoru lietošana). Loti daudzas valstis gatavo Ilgtspējīgas attīstības stratēǵiju, programmas vai plānus. Tomēr šiem dokumentiem parasti ir vāja pozīcija attiecībā pret valsts ekonomisko lēmumu pieñemšanu.

Kā integrējoša plānošanas un vīzijas koncepcija, ilgtspējīgas attīstības pozīcija ir krasi atšķirīga salīdzinājumā ar tradicionālo ekonomikas izaugsmes politiku, kas uznemas neierobežotu brīvību kapitāla, infrastruktūras, tehnologiju un patēriṇa paplašināšanā, lai nodrošinātu brīvā tirgus virzītu līdzekḷu izmantošanu vēlamās nākotnes sasniegšanai.

Ilgtspējīgā attīstība, kā to mūsdienās saprot un praktizē vairums speciālistu, netieši atzīst, ka izaugsmei jābūt vismaz virzìtai un orientētai, bet dažos gadījumos pat ierobežotai, lai spēja "nākamajām paaudzēm apmierināt savas vajadzības" netiktu apdraudēta. Tomēr lielākā dal̦a valstu ilgtspējīgas attīstības plānošanas procesos neidentificē konkrētus ierobežojumus vai robežas augsmei pašai par sevi, kas liecina, ka nav skaidras izpratnes par vārda "ilgtspēja" būtību.

Kaut gan ir izvērsts pamatīgs darbs ilgtspējīgas attīstības rādītāju sasniegšanas jomā vairāk nekā divdesmit gadu periodā, joprojām nav vienota, galīga un saskan,ota veida, kā mērīt sociālo progresu attiecībā uz ilgtspējīgu attīstību. Pārliecinošu priekšlikumu par to, kā nomainīt IKP, ir viens no iemesliem, kāpēc vienkāršāk ir izmantot alternatīvas - piemēram, Butānas nacionālās laimes indikators ir izrādījies itin pievilcīgs.

ANO Ekonomikas un sociālo lietu padome ir publicējusi dokumentu kopu par pamatnostādñu lietošanu valsts līmenī. No mērīšanai domātiem 96 indikatoriem 50 ir identificējami kā pamatindikatori. Tiek piedāvāta arī metodoloǵija, 


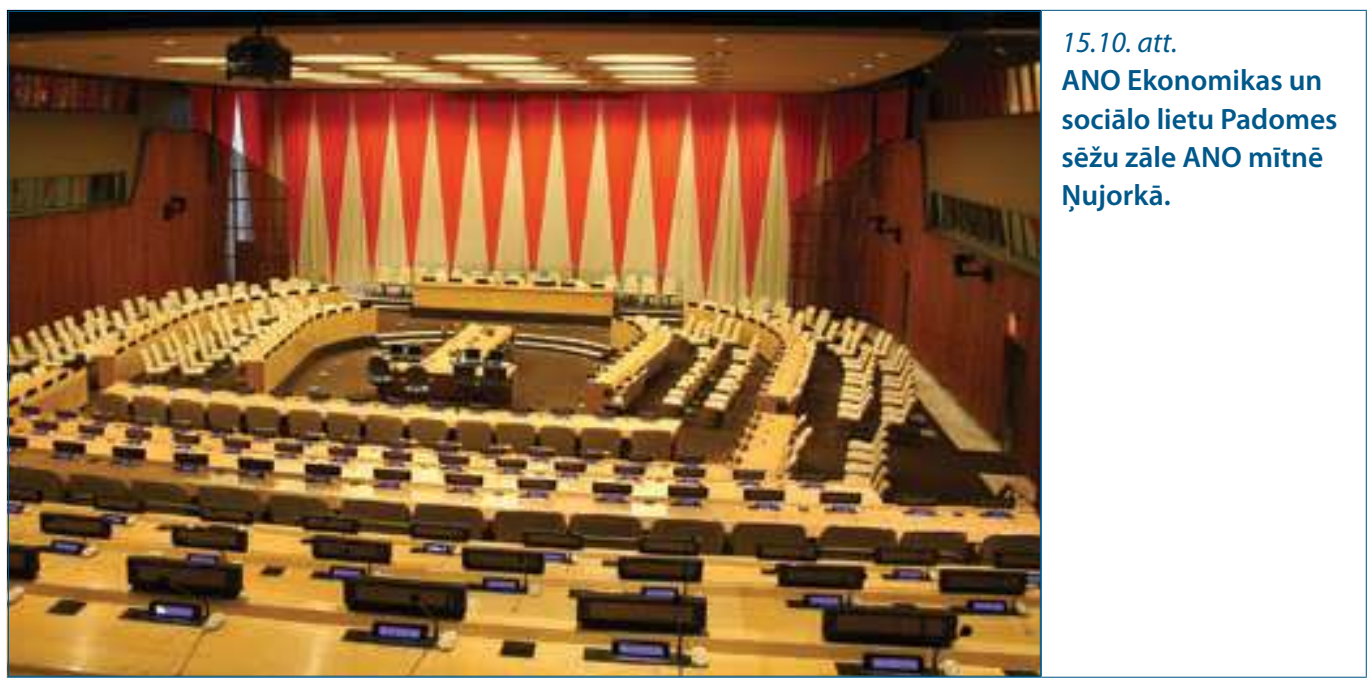

lai pareizi veiktu mērījumus. Valstis pēc tam var augšuplādēt to gatavos nacionālos ziṇojumus par ilgtspējīgu attīstību ANO mājas lapā.

Daudz ir bijis centienu pārveidot indikatoru sistēmu, kura būtu vairāk atbilstoša reālajam stāvoklim pasaulē un kura l̦autu panākt ekonomiskās izaugsmes mērksa maiṇu. Vairāki no šiem centieniem ir pietuvojušies oficiālas atzišanas līmenim valsts iestādēs. Ieteicamie indikatori varētu būt "Patiesais progress", "Patiesais ietaupijums" vai "Zalıais IKP"

Patiesā progresa indikators. Kā jēdziens ekonomikā tas radās saistībā ar ekonomista Hermana Deilī (Herman Daly) un viṇa kolēga Džona Koba (John Cobb) darbiem, lai ekonomikas mērījumus izteiktu jaunā, vairāk integrētā veidā. Viṇi arī ieviesa Sociālās un ekonomiskās labklājības indeksu, lai koriǵētu iekšzemes kopproduktu.

Sociālās un ekonomiskās labklājības indekss bieži tika aizstāts ar jēdzienu "Patiesais progresa indikators" (PPI). Savukārt PPI aprēķini bija mēginājums būtiski uzlabot IKP, ñemot vērā arī sociālās un vides izmaksas, kas faktiski izraisītu IKP palielināšanos, kā arī pievienojot ne-ekonomisko aktivitāšu vērtību (piemēram, brīvprātīgo darbu). Kanādas ideju generatori nesen ieviesuši jaunu, nedaudz uzlabotu variantu, kas neṇem vērā tīri izteiktus vides faktorus un tiek saukts par "Ekonomiskās labklājības indeksu - ELI" (Index of Economic Well-Being - IEWB). Šì metodoloǵija koncentrējas uz atškkirību starp patēriṇu un kapitālu un ñem vērā tādus jautājumus kā taisnīgi ienākumi un ekonomiskā drošība vecumdienās.

Ķīnas ekonomists Niu Venjuans (Niu Wenyuan) nesen ieteica jaunu "IKP kvalitātes indikatoru". Viņš jau agrāk bija mēginājis ieviest Ķīnas "Zalıo IKP”, bet sastapa sīvu pretestību. Jaunais indikators ir kas vairāk nekā "Patiesais progresa indikators" un ietver vairākus elementus: energijas intensitāte uz vienu IKP vienību, ienākumu atšķirības starp bagātajiem un nabagajiem, atkritumu daudzums uz vienu IKP vienību, dzives kvalitāte (mūža ilgums un citi cilvēkiem svarīgi attīstības indikatori). Tas tika saistīts arī ar pārvaldības kvalitāti (komunālā infrastruktūra; valsts ierēdniecības apmērs).

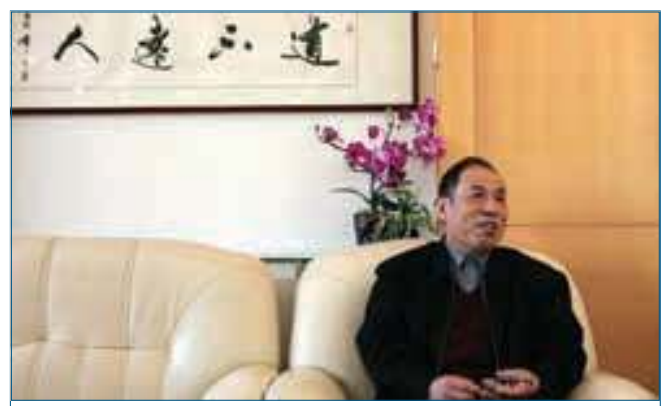

15.11. att. Ķinas valdības padomnieks Niu Venjuans. 
Tomēr neviens no šiem centieniem nav radījis kaut kādas būtiskas izmaiṇas attiecībā uz tradicionālajiem IKP mērījumiem, bet nopietna diskusija par jaunajiem indikatoriem ir palīdzējusi radīt vienprātība par IKP kā indikatora vājumu attiecībā uz sociālo un ekonomisko labklājību.

Darbība ap PPI dod iespēju izvēlēties, kuras jomas būtu jāuzskata par "izmaksām” un kuras par "labuma gūšanu", lai aplēstu naudas vērtību saistībā ar "izmaksām" un "ieguvumu”, kas nav monetārs. Piemēram, vai meža izciršana ir "izmaksas" vai "pabalsts" sabiedrībai? To var uzskatīt par izmaksām no apkārtējās vides aizsargātāja viedokḷa, bet to uzskata par labumu tie, kas izmanto zāǵmateriālus un papīru.

Tradicionālais IKP, gluži pretēji, neredz šādas atškirīības - tas vienkārši pārvērš nocirsto mežu naudā, atbilstoši esošajai cenai kokmateriālu tirgū. Tādējādi IKP neprasa nekādus papildu ētikas vai ar vērtībām saistītus lēmumus par to, kā vērtēt mežus grāmatvedībā.

"Zaḷais IKP" faktiski ir parastais IKP, kas koriǵēts ar vides izmaksām ekonomiskajās kategorijās. "Zaḷo IKP” ir pieñēmušas dažas valdības, piemēram, Indija, kas plānoja sākt "Zaḷā IKP" datu publicēšanu no 2015. gada.

"Zaḷā IKP" ideja nav jauna - jau 1993. gadā ASV regulējošās institūcijas, kas pārrauga finanšu iestādes, sāka veidot "zalı grāmatvedību", jo radās bažas, ka IKP indikatoram būs vajadzīga reforma. Jaunā sistēma tika nosaukta par "Integrētiem vides un ekonomikas kontiem".

Sākotnējie rezultāti liecināja, ka IKP skaitliem ir pārspīlēta ietekme attiecībā uz kalnrūpniecības un citiem uzṇēmumiem, vērtējot kopējo tautas ekonomisko bagātību. Ieguves kompānijām nepatika šie rezultāti, un ASV Kongress būtībā "iesaldēja” šo virzību.

"Zaḷā IKP" kritiḳi vērtē, ka ieteiktos indikatorus ir grūti precīzi aprēksināt, jo daudzi dabas resursi bieži tiek izmantoti bez maksas (ieskaitot ūdeni, ekosistēmu pakalpojumus), tiem nav cenas vai monetārās vērtības. Tāpēc nav iespējams tos iekḷaut monetārā ekonomiskajā apritē, kas balstās uz "klasisko" IKP aprēķinu metodiku.

"Patiesā ietaupijuma indikators" ir daudz tradicionālāks ekonomikas rādītājs - faktiski, tas atspogul,o valsts "neto ietaupījumu likmi", kas ir nedaudz pārveidota, lai integrētu dabas un cilvēka kapitāla vērtības. Datus par "patieso ietaupījumu" tarifiem ir aprēķinājusi un publicējusi Pasaules Banka. Tie tiek izmantoti, lai parādītu, cik lielā mērā tradicionālais ekonomikas izaugsmes cel̦š, kas izraisa vides degradāciju un resursu izsmelšanu, var novest līdz izmisumam nabadzīgākās tautas.

\subsection{6. "Nacionālā kopīgā laime"}

Jēdzienu "nacionālā kopīgā laime" pirmoreiz ieviesa Butānas karalis Džigme Singje Vangčuks (Jigme Singye Wangchuck) 1972. gadā. Daudz vēlāk jēdziens pārtapa par apsekojuma metodi, ko lietoja Butānas pētījumu centra darbinieki, lai novērtētu Butānas iedzīvotāju labklājības līmeni. Pēdējos gados Butānas arvien sarežǵitākos aptaujas paṇēmienus sāka pētīt un pielāgot arī citas valdības daudzās pasaules valstīs.

Kaut gan ideja par "laimes noteikšanu" daudziem cilvēkiem izklausās dīvaini, pieredze, apsekojot cilvēkus, lai noteiktu, kā tie uztver savu labklājību, apmierinātību ar dzìvi un vērtē pašu laimes līmeni, ir ar ilgu vēsturi. Tomēr jau tagad pamati ir pietiekami labi izstrādāti, lai būtu iespējams novērtēt valsts attīstības virzību un politikas veidošanas atbilstību valstīs, kas būtiski atšksiras, piemēram, Butānā, Kīnā, Francijā un Lielbritānijā.

Butānas pētijumu centrs ir pilnveidojis apsekošanas metodes, kas aptver visu iespējamo informāciju, sākot ar subjektīviem ziņojumiem par emocionālo stāvokli, un beidzot ar personīgā laika izmantošanu vai attieksmi pret vietējām ekosistēmām.

Indikatoru izvēle sakṇojas Butānas nacionālajā kultūrā, bet laimes definīcija tika ieteikta Butānas kontekstā.

Svarīgākie indikatori ir šādi:

- savtības sajūtas biežums,

- cēlsirdības sajūtas biežums,

- domas par pašnāvību,

- zināšanas par augu un dzīvnieku sugu nosaukumiem,

- izglītības līmenis, 
- lasītprasmes un rakstītprasmes līmenis,

- tradicionālo spēḷ spēlēšanas biežums,

- dienu skaits gadā, kad tiek apmeklēti kopienas pasākumi,

- mājsaimniecības ienākumi,

- ienākumu pietiekamība ikdienas vajadzībām,

- telpu skaits (personu skaits vienā telpā),

- lietotu apǵērbu iegāde,

- miega stundu skaits,

- uzticība kaimiñiem,

- palīdzība darbā kopienas locekliem,

- attiecības ǵimenē,

- uzticēšanās plašsaziñas līdzekḷiem.

Tradīcijas, psiholoǵija, veselība, ekoloǵiskās problēmas, svarīgākās attiecības un mūsdienu tehnologijas - tam visam ir sava vieta Butānas jēdzienā par nacionālo laimi, tomēr to izmantošana nav tikai teorētiska. Atšķirībā no citām sistēmām un rādītājiem, Butānas "nacionālā kopīgā laime” ir politiski saistoša. Butānas apmeklētāji stāsta par plašām un ilgām kopienas apspriedēm saistībā ar būtiskiem attīstības lēmumiem, piemēram, par jaunas šosejas būvniecību. Kopienas locekḷiem tiek lūgts apsvērt, kā jaunā attīstība varētu ietekmēt "nacionālās kopīgās laimes" rādītājus, un atsevišksu cilvēku pārdomas tiek ievērotas, pien,emot gala lēmumus par politiku un ieguldījumiem.

Pašreizējā ekonomiskajā situācijā, kad pastāv nopietni Rietumu ekonomikas un valūtas sistēmas traucējumi, kad politiskie līderi cenšas "atkal atjaunot augsmi", ir grūti iedomāties reālu pāreju no IKP uz "nacionālo kopīgo laimi". Tomēr izmaiṇas, kas notiek jau tagad, norāda, ka ne pārāk tālā nākotnē, "valsts laimes" rādītāji var sākt nopietni konkurēt ar ekonomiskās izaugsmes klasiskajiem indikatoriem, ja tie ir parasto pilsoṇu uzmanības lokā.

To apliecina Apvienotās Karalistes valdības publicētais pirmais "Nacionālās laimes indekss" 2012. gadā un Vācijas parlamenta izveidotā oficiālā komiteja, lai izpētītu "Nacionālo laimes indeksu" un to ieviestu tuvākajā laikā. Savukārt, Austrija jau publicē oficiālo statistiku par valsts laimi un labklājību ilgtspējīgas attīstības programmu ietvaros, bet Francijas valdība ir izstrādājusi oficiālas vadlīnijas par "valsts laimes indeksu", kas ir līdzīgas Butānas modelim.

OECD ziṇojumā par labklājību ("How's Life? Measuring Well-Being”, 2015) teikts, ka līdzīgi centieni, kas variē no valsts mēroga apspriešanas procesiem līdz statistiskās informācijas savākšanai, jau notiek Norvēgijā, Austrālijā, Itālijā, Spānijā, Slovēnijā, Japānā un vairākas citās valstīs.

Katra no šìm iniciatīvām ir pielāgota savas valsts specifikai un īpašā veidā katras tautas kultūras skatījumam attiecībā uz laimi un labklājību. Tomēr uzdotie jautājumi Latvijā varētu loti atšksirties no tiem, ko uzdod Butānā, piemēram: "Vai jums pieder vismaz divi pāri apavu? Vai varat ațauties ēst gal̦u katru otro dienu? Vai māja ir pietiekama ērta, lai jūs varētu apmeklēt draugi? Vai jūs traucē skalıi kaimiṇi?".
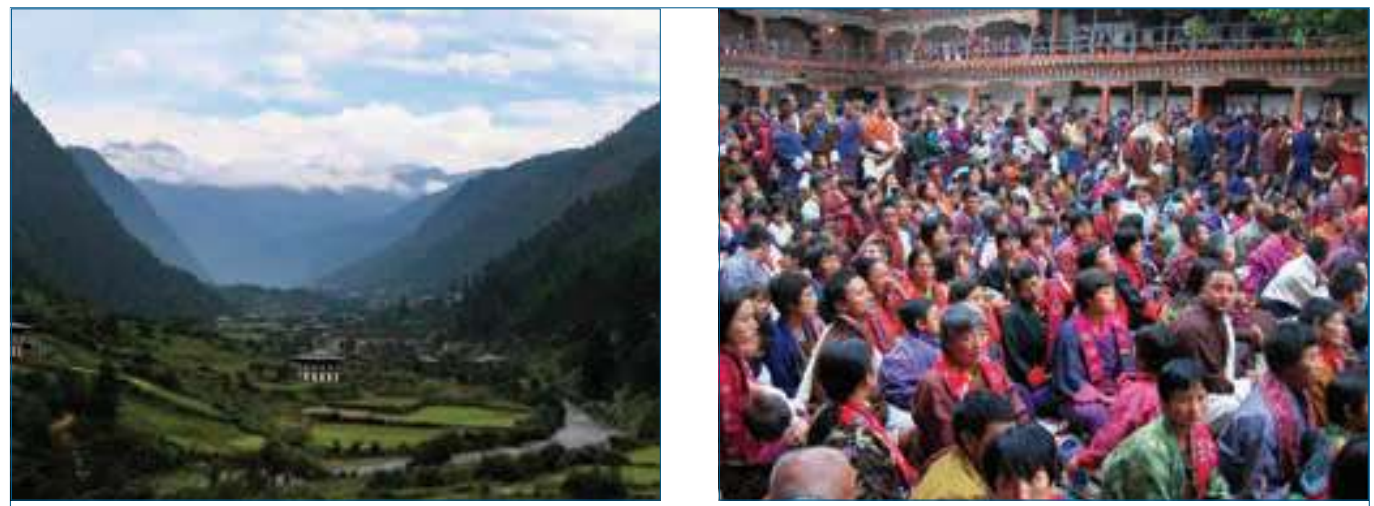

15.12. att. Butāna un tās ḷaudis. 
Lai gan tas šķiet pretēji intuīcijai, valdību rīcībā, kas koncentrējas uz laimes izvērtēšanu grūtajos ekonomikas depresijas gados, ir uztverama politiskā logiika. Virzība uz "laimi” un prom no "augsmes" iezīmē "izmaiñas rezultātu tabulā", kas potenciāli var kalpot valdošās politikas interesēm. Piedāvāt tradicionālo ekonomisko augsmi kḷūst arvien grūtāk attīstītās valstīs, piemēram, Francijā, Vācijā vai Japānā, jo tur pastāv demogrāfiskās problēmas sabiedrības novecošanās dēḷ un samazinās ekonomiskā izaugsme atšksirībā no ekonomiskajiem sasniegumiem Ķīnā un Indijā.

Laime, labklājība un dzīves kvalitāte nav cieši saistīta ar ekonomisko izaugsmi un ienākumiem, ja reiz valsts ir sasniegusi minimālo materiālā ekonomikas komforta līmeni.

Ir skaidrs, ka par naudu, kas ir ekonomiskās izaugsmes mērīšanas pamatā, nevar nopirkt laimi. Tomēr daudzi pētījumi liecina, ka patiesībā par naudu var nopirkt cel̦u uz laimi, bet tikai līdz noteiktam līmenim. Pētījumi par cilvēku laimi un vispārējo apmierinātību ar dzīvi liecina, ka, pieaugot naudas ienākumiem, apmierinātībai ar dzìvi ir tendence pieaugt visās kultūrās. Pēc tam, kad tiek sasniegts noteikts ienākumu līmenis (aptuveni 15000-75000 EUR uz vienu iedzīvotāju gadā), laime pārstāj augt. Palielinoties IKP uz vienu iedzīvotāju virs šì līmeña, tiek pirktas neskaitāmi daudz lietu, taču tās vairs laimes sajūtu nepastiprina. To bieži sauc par "Īsterlina paradoksu", jo ekonomists Ričards Īsterlins (Richard Easterlin) pētīja šo parādību pagājušā gadsimta 70 . gados. Paradokss ir tas, ka mēs turpinām strādāt monetārās ekonomiskās izaugsmes virzienā, uzskatot, ka tas pastiprinās mūsu laimes izjūtu, tomēr pētniecība liecina, ka tā tas nav.

Cilvēki, kas dzīvo valstīs, kurās IKP uz vienu iedzīvotāju ir mazāks par 15000 EUR gadā, ir pelnījuši lielāku izaugsmi. Tomēr ir apmēram 100 pasaules valstis, kurās ienākumi uz vienu personu ir pat mazāki par 10\% no ši skaiț̣a (1500 EUR/iedz. gadā).

2014. gadā ES-28 IKP uz vienu iedzīvotāju bija 27300 EUR, Latvijā 12100 EUR, un tas bija sestais zemākais rādītājs no visām Eiropas Savienības dalībvalstīm. Vislielākais IKP uz vienu iedzivotāju bija Dānijā - 45500 EUR/iedz. gadā, Zviedrijā - 44300 un Îrijā - 40 200, Horvātijā - 10 200, Rumānijā - 7600, bet vismazākais tas bija Bulgārijā - 5000 EUR/iedz. gadā.

Kā būt ar tām valstīm, kuru ienākumi ir daudz lielāki un ekonomikas "augsme kā parasti" uzskatāmi grauj planētu, pat nenodrošinot laimīgāku dzīvi? Būtu politiski muḷ̣̂īgi ieteikt, lai cilvēki šajās valstīs samazinātu savus ienākumus pat tad, ja tas būtu motivēts ar ētiskiem apsvērumiem. Cilvēki, kuri pēkšñi jūtas nabadzīgāki naudas izteiksmē, neapšaubāmi jutīsies mazāk laimīgi, ja viṇu ienākumi pat saglabāsies krietni virs 15000 EUR gadā. Protesti Grieksijas ielās klaji demonstrē šo faktu (Griekijā 2014. gadā IKP bija 72\% no ES-28 vidējā līmeņa, t.i., aptuveni 19700 EUR/iedz. gadā). Tāpēc 15000 EUR ienākumus vienai personai varētu pien,emt kā minimālo universālo viena iedzīvotāja ienākumu gadā, uz ko valstīm vajadzētu tiekties. Tomēr tas ir lıti maz ticams, ka šāds mērksis varētu tikt sasniegts visā pasaulē.

\subsection{7. "Ne-augsme"}

"Ne-augsme" ir visradikālākais jēdziens attiecībā uz alternatīvām, lai aizvietotu ekonomiskās augsmes modeli. "Ne-augsmes" kustībā lielākoties iesaistās pārstāvji no akadēmisko pētnieku un ekonomikas aktīvistu tīkla, kuri veicina domu, ka mērḳis ir mazāka mēroga ekonomika, kas radīs lielāku cilvēka labklājību, vienlaikus samazinot dabas resursu pārmērīgu izlietošanu un saudzējot ekosistēmas.

Jēdziens "ne-augsme" pievērsa uzmanību starptautiski līdz ar ekonomista Tima Džeksona (Tim Jackson) gada ziṇojuma publikāciju, ko 2009. gadā izdeva Apvienotās Karalistes valdības oficiālā Ilgtspējīgas attīstības komisija. Profesora Džeksona zinojums ar nosaukumu "Labklājība bez izaugsmes?" ("Prosperity without Growth?") bija pirmais, kas pauda šādu oficiālu valdības attieksmi. Tas vēlāk tika pārpublicēts šāda paša nosaukuma grāmatā.

Šì grāmata ir kḷuvusi par visvairāk lasīto saistībā ar "ne-augsmi" un var kalpot kā būtisks atskaites punkts par izaugsmes tēmu. 

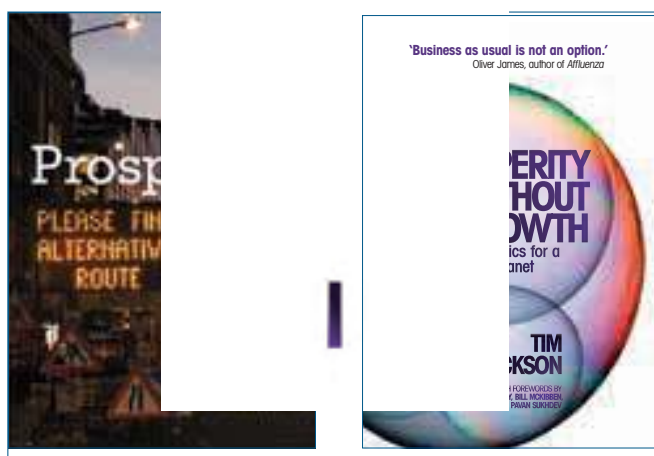

15.13. att. Džeksona zinojums “Labklājība bez izaugsmes?" un grāmata.

Džeksona argumentus var apkopot vairākos kopsavilkumos.

Augsme nav ilgtspējīga. Jāpiekrît desmitgades veiktajiem zinātniskiem pētījumiem, kas ir radījuši publikācijas "Izaugsmes robežas" ("Limits to Growth") un "Planētas robežas" ("Planetary Boundaries"). Uz mūsu planētas, kur jādzīvo cilvēkiem, nepārtraukta ekonomiska izaugsme, lai iegūtu resursus, ražotu, patērētu un tiktu galā ar atkritumiem, acīmredzami nav iespējama.

Augsme nav stabila. Jāmēgina būvēt tiltu starp tradicionālo ekonomisko domāšanu un alternatīvu atbalstītājiem, jo pastāv valstu ekonomisko sistēmu pilnīga atkarība no planētas spējām, tās stabilitātes pamatnosacījumiem un nepārtrauktas izaugsmes neiespējamības. "Lejupslīdes" un "depresijas" nes sev līdz nopietnu sociālu neapmierinātību un politisku nestabilitāti, kas ir jānovērš valdībām.

Tas palīdz izskaidrot intensitāti, ar kādu valdības cenšas par katru cenu panākt, lai saglabātos augsme, neskatoties uz visiem uzkrātiem negatīviem pierādījumiem par izaugsmi, negatīvām sekām apkārtējā vidē un izaugsmes nespēju piegādāt aizvien pieaugošu labklājību.

Atsaiste nedarbojas. Atsaiste nozīmē uzturēt nepārtrauktu monetāro ekonomikas pieaugumu (IKP pieaugumu), vienlaikus samazinot resursu izmantošanu, atkritumu daudzumu un piesārn,ojumu (kas gan pieaug līdz ar augsmi "atsaistes" modelī). Pirmo reizi uzstādījums "atsaiste" tika ieviesta kā mērksis Nīderlandes valdības politikā 20. gs. 90. gadu gadu sākumā. Tika paredzēts, ka atsaiste palielinās efektivitāti, ar kuru ekonomika labāk iesaistīs resursus jaunās lietas vērtībā, ko varētu izmērīt ar kādu indikatoru, piemēram, ar "oglekḷa savienojumu izmantošanas intensitāti" (cik daudz $\mathrm{CO}_{2}$ tiek emitēts, iegūstot vienu IKP naudas vienību).

Džeksons ir parādījis, ka līdz šim atsaistes ieguvumi ir bijuši minimāli salīdzinājumā ar absolūto $\mathrm{CO}_{2}$ emisiju pieaugumu. Šĩs uz efektivitāti bāzētās pieejas, samazinot kopējo ietekmi uz planētas ekosistēmām, nav reālas. Nav nekādu iespēju, lai augoša ekonomika tiktu atsaistīta, izaugsmes process tiktu atdalīts no ekosistēmu degradācijas procesa pietiekami ātri, lai netiktu radītas problēmas, kā tas ir noticis, mainoties klimatam un pastāvot globālai sasilšanai.

Koncepcijas rosinātāji ir izstrādājuši arī politikas priekšlikumus un pat alternatīvus ekonomiskos modeḷus, kas mēǵina pierādīt, ka patiešām pastāv citi atškirīgi ekonomikas attīstības cel̦i. Aptuvens nepieciešamo izmainu redzējums ietver

- radikālu kapitāla investīciju tirgu revīziju ar mērksi būtiski samazināt spekulācijas ar precēm vai pakalpojumiem, piemēram, pārtiku vai finansēm (riska ieguldījumu fondi), bet palielinot ieguldijumus zemu SEG emisiju tehnologijām, transporta sistēmām, veselības aprūpei, izglītībai un energoefektīvu mājokḷu radīšanai;

- neierobežotas spekulācijas izbeigšanu uz klientu un nodoḳ̣u maksātāju rēķina, iespējams, izmantojot stingrāku uzṇēmējdarbības regulēšanu un pamudinājumus jaunu korporatīvo formu veidošanai, kas ietvertu stingrākus pārvaldības noteikumus, prasību, lai kapitālsabiedrības darbojas sabiedrības labā, nodrošinot korektu sociālo, vides un ekonomisko nosacījumu izpildi;

- būtiskas apziñas kultūras izmainas, lai pārvirzītu līdzsvaru domāšanā no patēriṇa un materiāliem labumiem uz "labu uzturu, atbilstošu mājokli, augstas kvalitātes pakalpojumiem, stabilām kopienām, cienīgu un drošu nodarbinātību un veselīgu vidi". 


\subsubsection{Alternativu spektrs}

Pastāv dažādi veidi, kā modelis "augsme kā parasti" varētu tikt pārveidots vai "ne-augsmes" gadījumā pilnīgi noraidìts par labu radikālākam, bet mazāka mēroga alternatīvam redzējumam par globālo ekonomiku. Tomēr būtu jāiekḷauj vairāki inovatīvi rādītāji, piemēram, OECD jaunais "Tavas labākas dzīves indekss", kas l,auj lietotājam apskatīt OECD valstu datus, kas ir saistīti ar vispārējo progresu un labklājību vai arī "Jaunās ekonomikas" fonda projektu "Laimīgās planētas indekss", kas apvieno apmierinātību ar dzīvi, dzīves ilgumu un "ekoloǵisko pēdu" (kopējo cilvēka spiedienu uz ekosistēmām). Šie indikatori var uzrādīt tās valstis, kuras spēj nodrošināt lielāku laimi cilvēkiem, bet rada mazāko ekologisko ietekmi.

Politikai svarīgi ir konkrēti priekšlikumi par alternatīvu spektru, jo praksē robežas starp šīm alternatīvām bieži vien ir diezgan izplūdušas.

Vajadzētu panākt plašu vienošanos daudzveidīgajā alternatìvo modelı sistēmā vismaz četros galvenajos punktos.

1. "Augsme kā parasti" nav iespējama ilgtermiñā. Augsme var radìt daudz labumu cilvēcei, bet tā ir arī radījusi bīstamās klimata pārmaiṇas, degradē ekosistēmas, radījusi dziḷas atšksirības starp bagātajiem un nabadzīgajiem un citas nopietnas problēmas. Planēta nav pietiekami liela, lai nodrošinātu "augsmi kā parasti” ilgu laiku.

2. IKP ir neatbilstošs vai pat maldinošs progresa rādītājs. To nepieciešams vismaz reformēt, un tas nav jāuzskata par galveno rādītāju, pēc kura tiek vērtēti politisko un sociālo sistēmu panākumi.

3. Alternatīvas ir vajadzīgas un ir iespējamas. Pasaule pašlaik atrodas "meklējumu režīmā", lai atrastu labāko kombināciju no tradicionālās ekonomiskās domāšanas un no jaunās ekonomiskās domāšanas. Pastāv zināma vienprātība, ka šādu kombināciju var atrast, bet nav vienprātības, ka tas varētu izdoties galīgajā formulējumā.

4. Laime un cilvēku labklājība ir būtiski jebkāda ekonomiska uzstādījuma mērksi. Iespējams, ka tā ir visradikālākā jaunā ideja, lai izkḷūtu no dažādajiem strāvojumiem un panāktu vienprātību par laimes un labklājības milzīgo nozīmi. Ja šì perspektīva iesakn,osies dziḷāk un kḷūs par organizējošo principu valsts ekonomiskās politikas veidošanā, to varēs uzskatīt par revolucionāru.

\subsubsection{Dzive bez augsmes?}

Pasaules izvēles iespējas par ekonomiskās labklājības sasniegšanu lielā mērā ir ētikas jautājums. Vai esam radīti, lai vienmēr vēlētos izaugsmi, tādējādi padarot "jauno ekonomiku" par sava veida starpspēli attīstības procesā, vai arī izvēlēsimies tikai tādas darbības, lai spētu izdzīvot uz mūsu mazās planētas, kas tomēr dod iespēju pastāvēt, ja savstarpēji dalāmies ar nepieciešamo.

Optimistiskā pieeja piedāvā cerību, ka spēsim nodrošināt apmierinošu dzīvi visiem uz mūsu daudzveidīgās planētas un varēsim

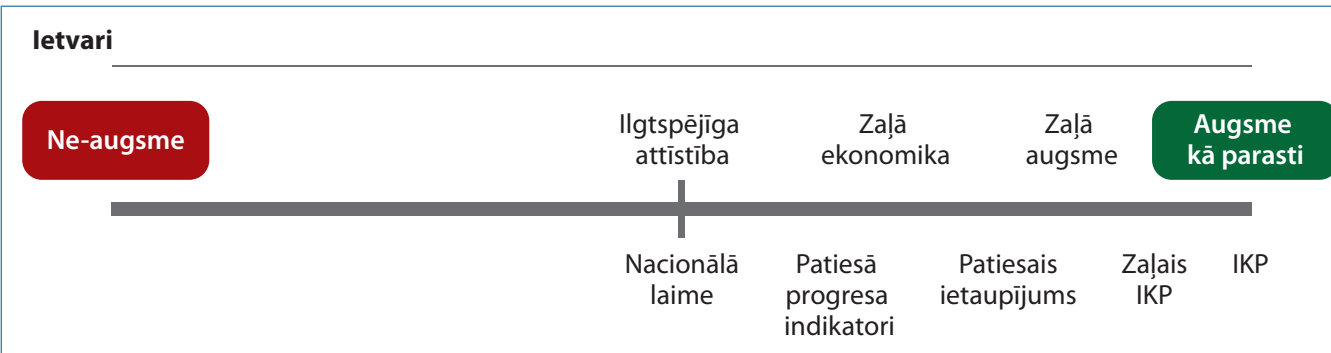

Indikatori

15.14. att. Attīstības alternatīvu spektrs dažādām ekonomikas sistēmām un indikatoriem. 

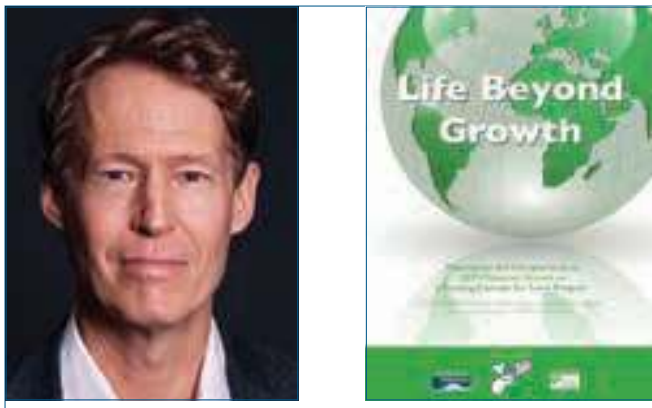

15.15. att. Alans AtKissons (Alan AtKisson) un viņa pārskats "Dzīve pēc augsmes".

izvairīties no kḷūdām, kas var gadīties ceḷā uz ilgtspējīgu nākotni.

Par ilgtspējīgas attīstības jautājumiem stāsta AtKissona grāmatas, publikācijas un nesenais pētījums, kas apkopots ziṇojumā "Dzive pēc augsmes".

Vai cilvēce kopumā var būt laimīga un apmierināta, neiznīcinot pasaules dabas sistēmas, no kurām mēs esam atkarīgi? Tas ir kluvis par mūslaiku aktuālāko jautājumu. Atsevišksi zinātnieki izdala vēl īpašu epohu - antropocēnu, kam raksturīga pastiprināta cilvēka darbības ietekme uz ekosistēmu, ietekmēts klimats, bioloǵiskās un ǵeoloǵiskās sistēmas. kā rezultātā izmirušas vairākas augu un dzīvnieku sugas, mainīts reljefs utt.

Pašlaik visām pasaules lielākajām ekonomikas sistēmām ir kopīga atkarība no izaugsmes. Katras valsts ekonomiskā veiksme pasaulē tiek mērīta ar to, cik ātri katra valsts patērē resursus, nodrošina preču ražošanu un pakalpojumus un rezultātā paplašina naudas plūsmu. Straujš pieaugums ir labāks nekā lēna izaugsme, ne-augsme ir slikta, bet lejupslīde jau tiek uzskatīta par katastrofālu, ja tā turpinās ilgāk nekā dažus mēnešus.

Mēs dzīvojam uz nelielas planētas ar ierobežotām iespējām. Zeme mums reiz šķita neizmērojami liela, bet tagad ar reaktīvo lidmašīnu zemeslode aplidojama dienas laikā.

Pētnieki spriež, cik desmitgades (ne gadsimtus) vēl būs pieejami naftas produkti. Metālu, zivju, pat svaiga ūdens nodrošinājuma līmenis kḷūst aizvien zemāks. Vēl vairāk satrauc tas, ka mājsaimniecību un ražošanas atkritumu daudzums, kas rodas mūsu darbības rezultātā, turpina palielināties. Dažreiz atkritumi satur vielas, kas ir bīstamas, bet ir arī neredzamas (piemēram, siltumnīcefektu izraisošās gāzes).

Šādos apstākḷos uzskats, ka augsme var turpināties bezgalīgi, ir maldīgs. Ekonomika laika gaitā kḷūst efektīvāka, bet inovācijas sniedz aizstājējus dažiem resursiem, kad tie beidzas vai kḷūst pārāk reti un dārgi. Var pienākt brīdis, kad tos nav ar ko aizstāt, nav arī iespējams panākt vēl augstāku efektivitāti, un ir pat palicis pārāk maz resursu, lai apmierinātu pamatvajadzības.

Ja izaugsme vēl nav pārtraukta pirms šĩ brīža un, ja ekonomika nav mainïjusies un pietuvinājusies dabas sistēmu iespējām, kas nepiel̦auj nepārtrauktu ražošanas paplašināšanu fiziskā patēriṇa nodrošināšanai, tad sabrukums ir neizbēgams.

Lai panāktu ilgtspējīgu un drošu attīstību nākotnē, ir nepietiekami tikai runāt par nepieciešamām izmaiṇām globālajā ekonomikā, mums pašiem ir jāsāk mainīt pasaule.

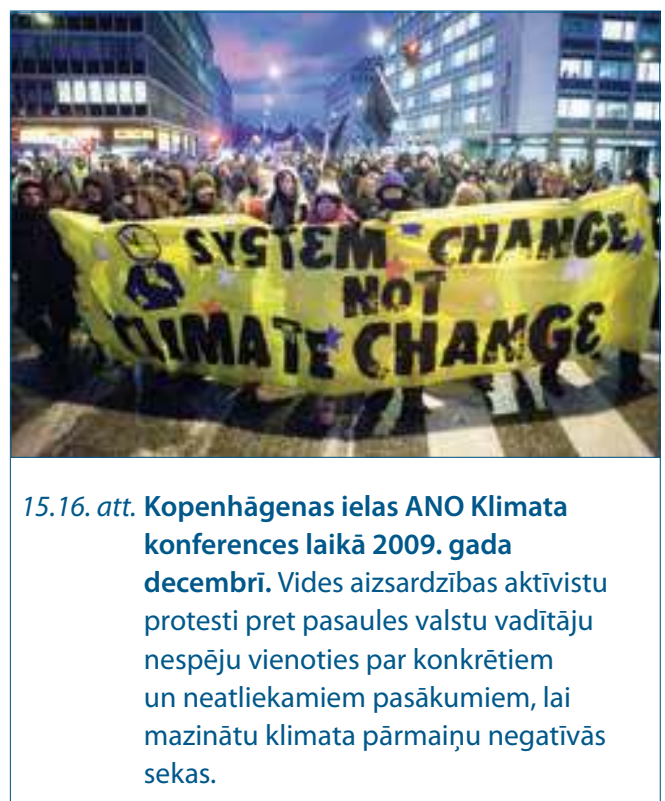




\subsection{Ilgtspējīgas attīstības īstenošana}

\subsection{1. "Rio+20"}

ANO konference par ilgtspējīgu attīstību ("Rio+20"), kas notika 2012. gadā Riodežaneiro, noteikti kalpos kā liels vēstures pagrieziena punkts ilgtspējas veicināšanā.

"Rio+20" bija grandiozs notikums, pat lielākais ANO konferenču organizēšanas pieredzē, jo tajā piedalījās 192 valstu delegācijas, to skaitā 105 delegācijas vadīja valstu vai valdību vadītāji. Kopumā šajā pasākumā bija iesaistīti apmēram 50000 cilvēku. Konferences divi galvenie temati bija "Zaḷā ekonomika" un "Ilgtspējīgas attīstības institucionālais ietvars". Balstoties uz iepriekšējās konferencēs nolemto, atkal priekšplānā bija izvirzītas septiṇas svarīgākās jomas - bezdarbs, enerǵētika, pilsētu attīstība, nodrošinājums ar pārtiku, ūdens, okeānu aizsardzība un dabas katastrofas. Konferences svarīgākajam dokumentam "Nākotne, ko vēlamies" (The Future We Want) ir 53 lappuses, 283 paragrāfi un sešas galvenās nodal̦as.

I. Mūsu kopējais redzējums apliecina vienošanos par nepieciešamību veidot ekonomisku, sociālu un videi draudzīgu planētas ilgtspēju mūsdienu paaudzei un nākotnes paaudzēm, kā arī paātrināt agrāk pien,emto mērksu sasniegšanu atbilstoši ANO Hartai, Cilvēktiesību deklarācijai un citiem saistošiem dokumentiem.

Tiek uzsvērts, ka cilvēks ir ilgtspèjīgas attīstības centrā un tāpēc līdztiesīgai un visus ietverošai pasaulei jāizskauž nabadzība, neilgtspējīga ražošana un patēriņš, resursu izsīkšana.

II. Politisko saistību atjaunošana norāda uz nepieciešamību pārapstiprināt "Riodežaneiro-1992" konferencē noteiktos pamatprincipus

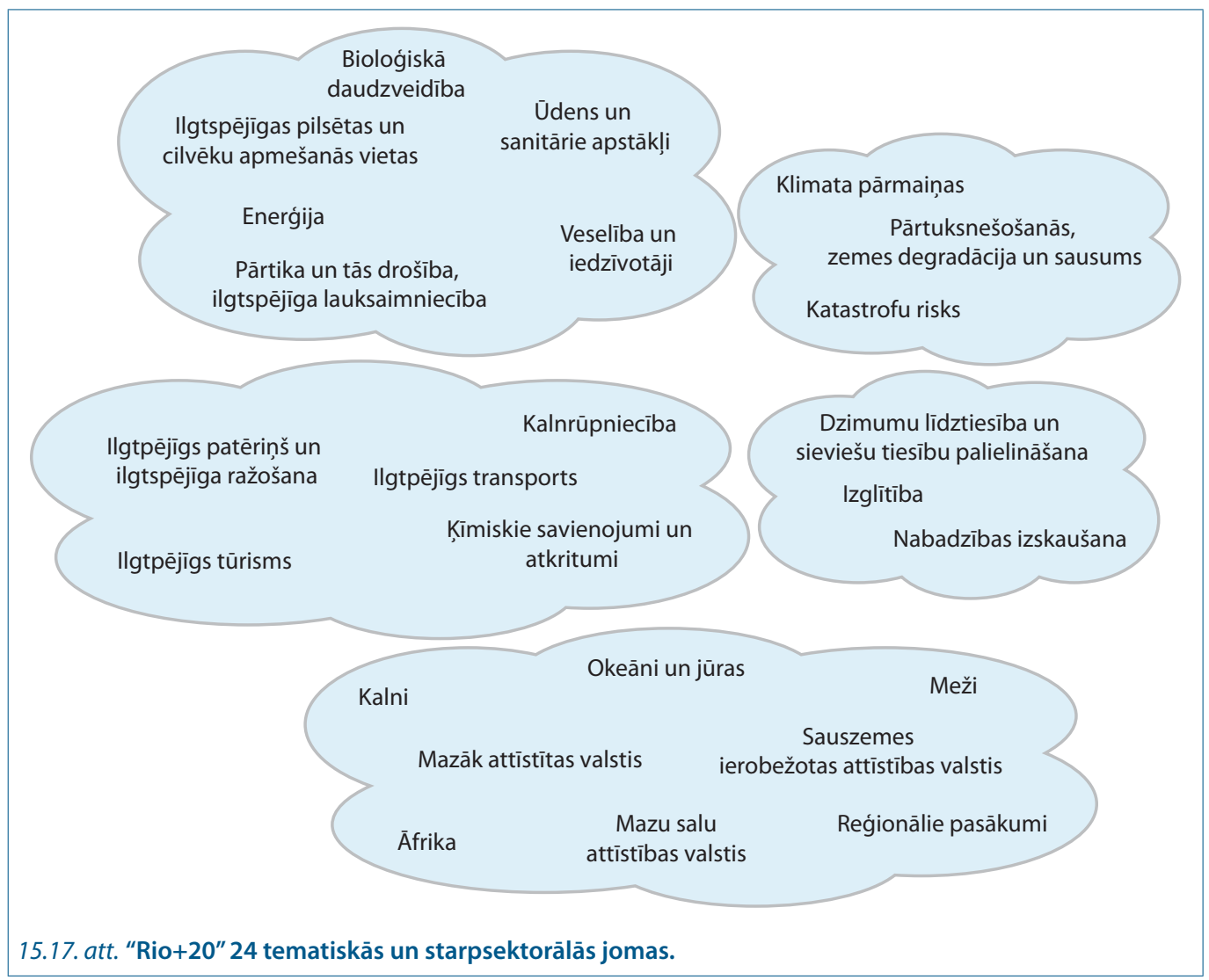


un agrāk pieṇemtos darbības plānus, kā arī pielikt papildu pūles saistībā ar ilgtspējīgas attīstības īstenošanu, sektoru integrēšanu un saskan,ošanu. Uzsvars tiek likts uz ANO Tūkstošgades mērķu izpildi, Dohas Deklarāciju par finansējumu ilgtspējīgai attīstībai un ANO Vispārējo konvenciju par klimata pārmaiṇām un ANO Konvenciju par biologisko daudzveidību.

Tiek uzsvērts, ka jāpalielina atbalsts attīstības valstīm, lai panāktu arī to nostāšanos uz ilgtspējīgas attīstības cel̦a. Îpaša uzmanība jāpievērš to cilvēku atbalstam, kuri dzīvo okupētās vai bijušajās okupētajās teritorijās un teritorijās, kuras apdraud teroristi.

Jānem vērā, ka ilgtspējīgas attīstības īstenošanā jāpiedalās visiem, jo tikai tad arī visi gūs labumu. Procesā ir jāiesaistās ne vien valstīm, bet arī privātajam sektoram, augstskolām un vietējām kopienām.

III. "Zaḷā ekonomika" ilgtspējīgas attīstības un nabadzības izskaušanas kontekstā ir ekonomika, kas uzlabo cilvēku labklājību un sociālo līdztiesību, būtiski samazina vides riskus un ekologiisko nepietiekamību. Šo ekonomiku raksturo zemu SEG emisiju izejvielu izmantošana, tā ir resursu ziṇā efektīva un sociāli ieklaujoša.

IV. Ilgtspējīgas attīstības institucionālais ietvars ir jāuzlabo visos līmeños - vietējā, nacionālā, reǵionālā, kā arī globālā. ANO G̣enerālajai Asamblejai tiek ieteikts pastiprināt Ekonomikas un sociālās padomes darbu, izveidot Augsta līmeña politisko forumu, būtiski uzlabot ANO Vides programmas darbu.

Starptautiskās finanšu organizācijas tiek aicinātas uzṇemties lielākas saistības, lai atbalstītu ilgtspējīgas attīstības programmas, stratēgijas un pozitīvi ietekmētu lēmumu pien,emšanas procesu.

V. Svarīgākie pasākumi un mērḳu sasniegšana. Ir noteiktas 24 tematiskās un starpsektoru jomas, atkārtoti izcelıtot nabadzības izskaušanu, kā arī veltot lielāku uzmanību dzeramā ūdens apgādei un sanitārajam stāvoklim, enerǵētikai, iedzīvotāju veselībai un demogrāfiskajam stāvoklim, nodrošinājumam ar pārtiku, ilgtspējīgai lauksaimniecībai un biologiskajai daudzveidībai.
Ilgtspējīgas pilsētas, cilvēku dzīves vietu kvalitāte, ilgtspējīgs transports un tūrisms, sabalansēta ražošana un patēriņš, vides k̦īmiskais piesārn,ojums un atkritumi arī ir būtiski un steidzami risināmi jautājumi.

Saistībā ar klimata pārmaiṇām jāpievērš uzmanība zemes degradācijai, sausuma sekām un pārtuksnešošanās problēmai.

VI. İstenošanas veidi. Tiek izdalīti pieci svarīgi ilgtspējīgas attīstības īstenošanas elementi - finanses, tehnologijas, spēju paaugstināšana, tirdzniecība un atbilstības reǵistrs.

\subsubsection{ANO Tūkstošgades attīstības mērki}

ANO Tūkstošgades Deklarācija un attīstības mērksi tika apstiprināti 2000. gadā un ietvēra bezprecedenta uzdevumus padarìt pasauli pieñemamāku un labāku visām tautām. 2015. gadā ANO publicēja Ziṇojumu par Tūkstošgades mērksu izpildes rezultātiem.

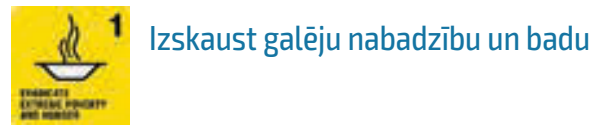

Galēja nabadzība ir ievērojami samazinājusies pēdējo desmitgažu laikā. 1990. gadā gandrīz puse iedzīvotāju jaunattīstības valstīs dzīvoja ar mazāk nekā 1,25 ASV dolāriem dienā; šī daḷa ir samazinājusies līdz 14\% 2015. gadā.

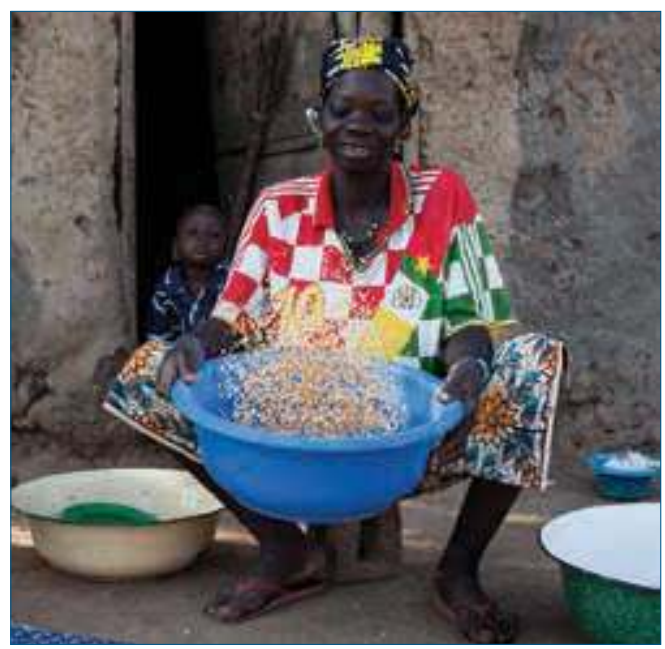


Cilvēku skaits, kas dzīvo galējā nabadzībā, pasaulē ir samazinājies no 1,9 miljardiem 1990. gadā līdz 836 miljoniem 2015. gadā.

Strādājošo cilvēku skaits, kas iztika ar vairāk nekā 4 ASV dolāriem dienā ir gandrīz trīskāršojies no 1991. līdz 2015. gadam.

Nepietiekami paēdušu cilvēku īpatsvars jaunattīstības reǵionos ir samazinājies no 23\% 1990.-1992. gadā līdz 13\% 2015. gadā.

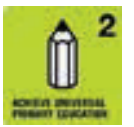

Nodrošināt visiem iedzīvotāiem pamatizglīīibu

Pamatskolās kopējais uzn,emto līmenis jaunattīstības regionos ir sasniedzis 91\% 2015. gadā salīdzinājumā ar 83\% 2000. gadā.

Ārpus skolas palikušo bērnu skaits pamatskolas vecumā visā pasaulē ir samazinājies gandrīz uz pusi - līdz aptuveni 57 miljoniem 2015. gadā salīdzinājumā ar 100 miljoniem 2000. gadā.

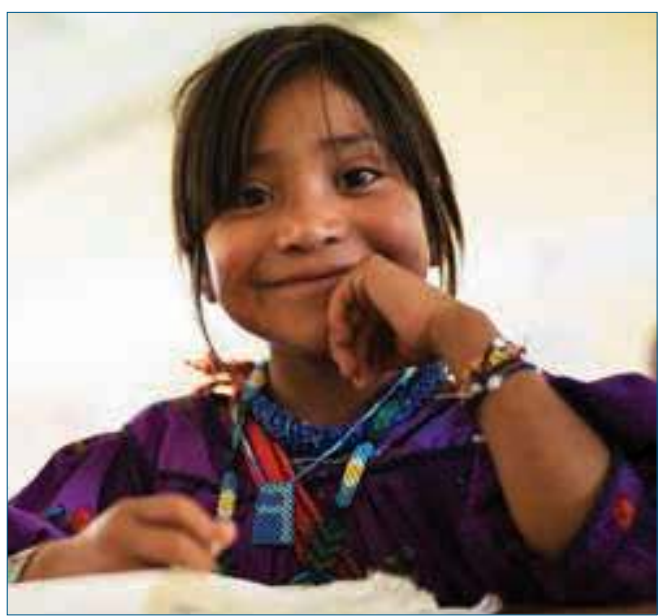

Lasītprasmes līmenis jauniešu vidū vecumā no 15 līdz 24 gadiem visā pasaulē ir palielinājies no 83\% līdz 91\% laika posmā no 1990. līdz 2015. gadam. Turklāt šai ziṇā plaisa starp sievietēm un vīriešiem ir samazinājusies.

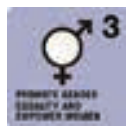

Nodrošināt dzimumu līdztiesību un palielināt sieviešu iespējas

Daudz vairāk meiteṇu tagad iet skolā salīdzinājumā ar laika posmu pirms 15 gadiem.
Jaunattīstības reǵioni kopumā ir sasnieguši mērksi, lai novērstu dzimumu nevienlīdzību pamatizglìtībā, vidējā un augstākā izglìtībā.

Sievietes tagad veido 41\% no apmaksātām darba n,ēmējām, neskaitot lauksaimniecības nozares. Tas ir 35\% palielinājums salīdzinājumā ar 1990. gadu.

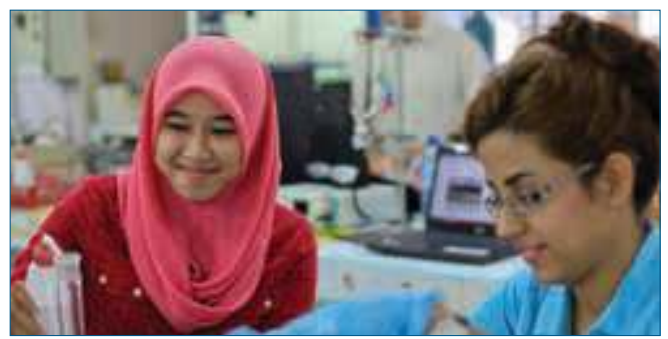

Sievietēm ir nostabilizējusies parlamentārā pārstāvniecība gandrīz 90\% apmērā 174 valstīs pēdējo 20 gadu laikā. Tomēr no pieciem parlamenta locekḷiem tikai viena ir sieviete.

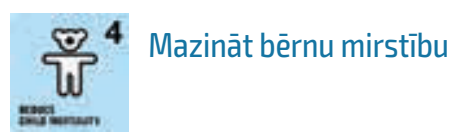

Pasaules bērnu mirstības līmenis līdz piecu gadu vecumam ir samazinājies no 90 līdz 43 mirušajiem uz 1000 dzīvi dzimušiem bērniem laika posmā no 1990. gada līdz 2015. gadam.

Neskatoties uz iedzīvotāju skaita pieaugumu jaunattīstības regionos, bērniem līdz piecu gadu vecumam nāves gadījumu skaits ir samazinājies no 12,7 miljoniem 1990. gadā līdz gandrīz 6 miljoniem 2015. gadā.

Masalu vakcinācija ir palīdzējusi novērst miljonu nāves gadījumu, un laikā starp 2000. un 2013. gadu pasaules mērogā masalu gadījumu skaits samazinājies par $67 \%$.

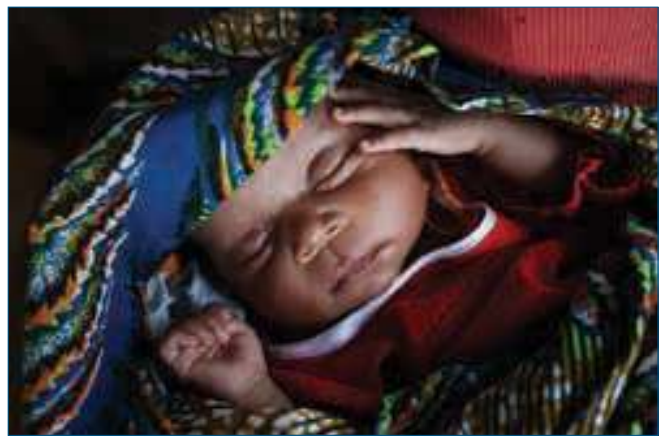




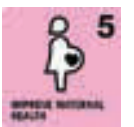

Uzlabot mātes veselību

Kopš 1990. gada dzemdētāju mirstība ir samazinājusies par 45\% visā pasaulē.

2014. gadā vairāk nekā $71 \%$ no dzemdībām pasaulē ir palīdzējis kvalificēts veselības aprūpes personāls salīdzinājumā ar 59\% 1990. gadā.

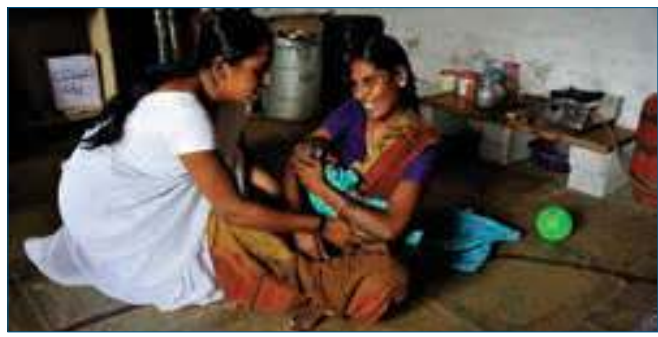

Kontracepcijas līdzekḷu izmantošana pasaulē precētām vai nopietnās attiecībās esošām sievietēm vecumā no 15 līdz 49 gadiem ir pieaugusi no 55\% 1990. gadā līdz 64\% 2015. gadā.

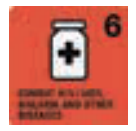

Apkarot HIV/AIDS, malārijas un citu slimību izplatību

Jauni HIV infekciju gadījumi laikā no 2000. līdz 2013. gadam ir samazinājušies par aptuveni $40 \%$, t.i., no aptuveni 3,5 miljoniem gadījumu līdz 2,1 miljonam gadījumu.

Līdz 2014. gadam 13,6 miljoni cilvēku pasaulē, kas inficēti ar HIV, saṇēma antiretrovirālo terapiju, bet 2003. gadā tādu bija tikai 0,8 miljoni.

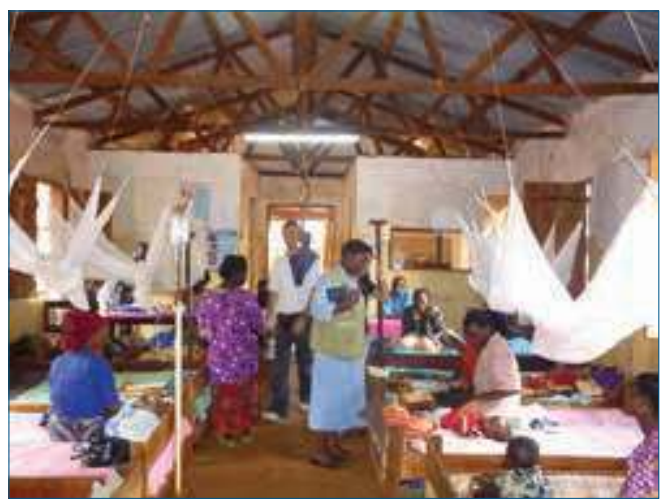

Vairāk nekā 6,2 miljoni malārijas nāves gadỉjumu tika novērsti pasaulē no 2000. līdz 2015. gadam. Pasaules mērogā saslimstība ar malāriju ir samazinājies par aptuveni $37 \%$, bet mirstība - par 58\%.

No 2000. līdz 2013. gadam tuberkulozes profilakse, diagnostika un ārstēšana ir izglābusi aptuveni 37 miljonus dzīvību. Mirstība no tuberkulozes ir samazinājusies par 45\%, bet tās izplatība - par 41\% kopš 1990. gada.

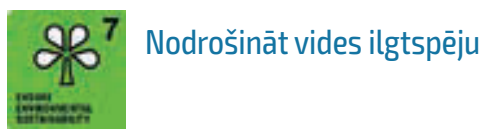

Ozona slāni noārdošo vielu izmantošana ir faktiski likvidēta kopš 1990. gada, un ozona slānis varētu atjaunoties līdz mūsu gadsimta vidum.

Sauszemes un jūras aizsargājamās teritorijas daudzos reǵionos ir ievērojami palielinājušās kopš 1990. gada.

2015. gadā 91\% no pasaules iedzīvotājiem izmanto uzlabotus dzeramā ūdens avotus salīdzinājumā ar 76\% 1990. gadā.

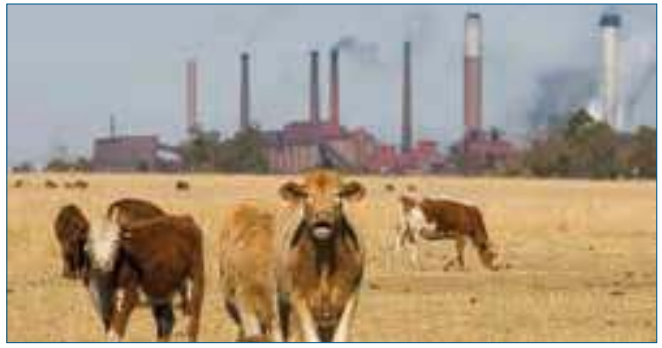

No 2,6 miljardiem cilvēku, kuriem kopš 1990. gada ir piekluve uzlabotiem dzeramā ūdens avotiem, 1,9 miljardi var san,emt dzeramo ūdeni savās telpās no centralizētās ūdens apgādes sistēmas.

147 valstis ir izpildījušas dzeramā ūdens apgādes mērḳi, 95 valstis ir izpildījušas sanitārā nodrošinājuma mērksi un 77 valstis ir izpildījušas abus šos mērksus.

2,1 miljardam pasaules iedzīvotāju ir pieeja uzlabotiem sanitāriem apstākḷiem, bet cilvēku īpatsvars, kuri praktizē atklātu defekāciju, ir samazinājies gandrīz uz pusi.

Pilsētu iedzīvotāju īpatsvars, kuri dzīvo graustos, jaunattīstības reǵionos ir samazinājās no aptuveni 39,4\% 2000. gadā līdz 29,7\% 2014. gadā. 


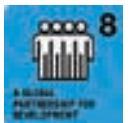

Paplašināt attīstības sadarbību

Attīstības palīdzība no attīstītajām valstīm ir pieaugusi par $66 \%$ reālā naudas izteiksmē no 2000. gada līdz 2014. gadam, sasniedzot 135,2 miljardus ASV dolāru.

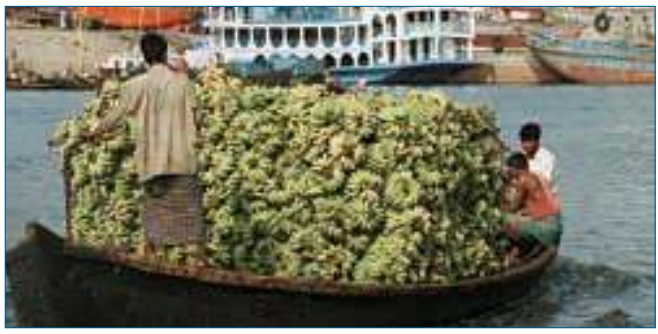

Ārējā parāda apkalpošanas daḷa eksporta ieñēmumos jaunattīstības valstīs samazinājusies no 12\% 2000. gadā līdz 3\% 2013. gadā.

2015. gadā 95\% pasaules iedzīvotāju izmanto mobilo telefonu sakarus.

Pasaules iedzīvotāju interneta izmantošana ir pieaugusi no 6\% 2000. gadā līdz 43\%
2015. gadā. Rezultātā 3,2 miljardi cilvēku ir saistīti ar pasaules mēroga tīklu un lietojumprogrammām.

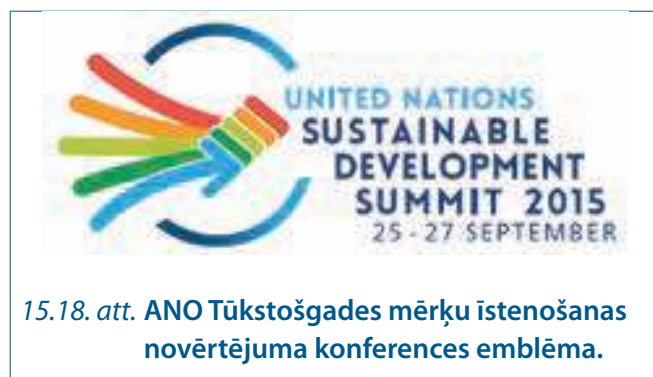

2015. gada septembrī N,ujorkā notika ANO G̣enerālā Asambleja, kura lēma par Tūkstošgades mērksu īstenošanas rezultātiem un izvirzīja jaunus, mūsdienu pasaulei aktuālus mērķus līdz 2030. gadam "Mūsu pasaules pārveidošana: ilgtspējīgas attīstības īstenošana līdz 2030. gadam". Tā ietver 17 ilgtspējīgas attīstības mērksus.

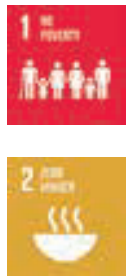

1. Nabadzības
izbeigšanās.

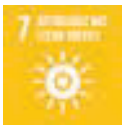

\section{Bada izbeigšanās.}
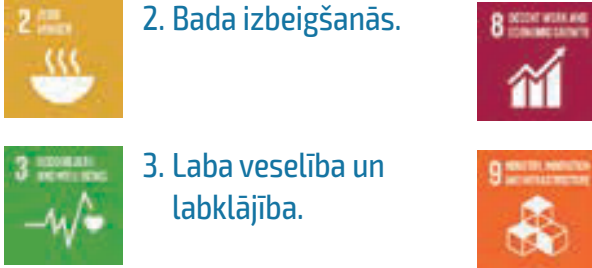

3. Laba veselība un labklājỉba.

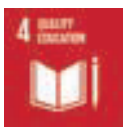

4. Kvalitativa

izglìtība.

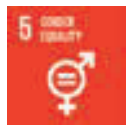

\section{Dzimumu līdztiesība.}

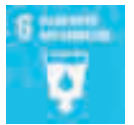

6. Tìrs ūdens un sanitārie apstākli.
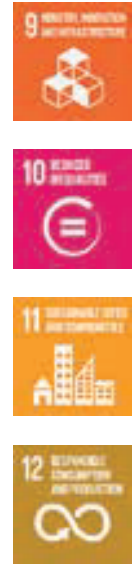

7. Pieejama un tīra enerğija.

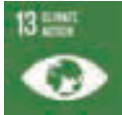

13. Klimata pārmainu rīcíbas.

8. Atbilstošs darbs un ekonomiskā augsme.

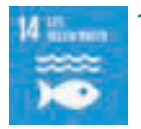

14. Ūdens dzīvības saglabāšana.

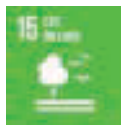

15. Sauszemes dzivīibas saglabāšana. infrastruktūra.

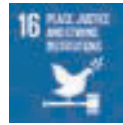

16. Miers, taisnīgums un spēcīgas institūcijas.

11. Ilgtspējīgas pilsētas un kopienas.

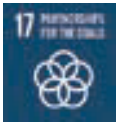

12. Atbildīgs patēriṇš un ražošana. 


\subsubsection{Latvijas ilgtspējīga attīstība}

Latvijā koordinētā un sistemātiskā veidā ilgtspējīgas attīstības īstenošana ir pašos pirmsākumos. Nav izveidota atsevišşa institūcija tās īstenošanai, tāpēc lielais funkciju apjoms un to izpildei pieejamo resursu neatbilstība ir skaidrojums lēnajam ilgtspējīgas attīstības procesam Latvijā.

Ilgtspējīgas attīstības jautājumu iekḷaušanu politiskajā diskusijā galvenokārt motivēja ārējie faktori - šo jautājumu augstā prioritāte Eiropas Savienības un ANO līmenī. Diemžēl Latvijas valsts pārvaldes institūciju, politisko spēku un sabiedrības iesaistīšanās ir bijusi nenozìmīga.

Valsts ilgtspèjīgas attīstības virzieni galveno problēmu risināšanai, kā arī politikas mērḳi atsevišķu nozaru politikā sākotnēji tika noteikti Latvijas ilgtspējīgas attīstības pamatnostādnēs jau 2002. gadā atbilstoši ANO Vides un attīstības konferences (Riodežaneiro, 1992) deklarācijā iekḷautajiem ilgtspējīgas attīstības 27 politiskajiem principiem. Tomēr pamatnostādnes neietvēra noteikto mērksu un darbību konkrētus izpildes terminus. Kaut gan tika norādīti mērḳu sasniegšanas rādītāji, tomēr kopumā šis dokuments praktiski nebija īsti saistošs. N̦emot vērā Latvijas ǵeopolitisko vietu pasaulē, dabas īpatnības, sociālās un ekonomiskās attīstības iespējas un sasniegto stāvokli, tika izvirzīti nākotnes uzstādījumi:

- jāveido labklājības sabiedrība, kura augstu vērtē un attīsta demokrātiju, līdztiesību, godīgumu un gādā par kultūras mantojuma saglabāšanu,

- jāveido stabila tautsaimniecība, kas nodrošina sabiedrības vajadzības, vienlaikus panākot, lai ekonomiskās izaugsmes tempi pārsniegtu vides piesārņojuma un resursu patērina tempus,

- jāveicina droša un veselību neapdraudoša vide pašreizējai un nākamajām paaudzēm,

- jāveic pasākumi biologiskās daudzveidības saglabāšanai un ekosistēmu aizsardzībai,
- jāattīsta sabiedrības atbildīga attieksme pret dabas resursiem un nepārtraukti jāpaaugstina resursu izmantošanas efektivitāte,

- no starptautiskas palīdzības sañēmējas valsts pakāpeniski jākḷūst par valsti, kas spēj pati nodrošināt savas vajadzības un nepieciešamības gadījumā sniegt palīdzību citām valstīm,

- jānodrošina vides jautājumu integrācija un jāattīsta plašs vides politikas līdzekḷu izmantojums citu nozaru politikā,

- jānodrošina, lai tirgus ekonomikas mehānismi kalpotu ilgtspējīgai attīstībai,

- jānodrošina sabiedrības līdzdalība ilgtspējīgas attīstības procesos,

- nepārtraukti jānovērtē valsts progress noteikto ilgtspējīgas attīstības mērḳu sasniegšanā.

Apliecinājums līdzšinējās politikas daḷējai neefektivitātei ilgtspējīgas attīstības jomā ir tas, ka, attīstoties valsts ekonomikai un palielinoties iedzīvotāju ienākumiem, Latvijā ir strauji pieaudzis privātais patēriņš, kā arī plaisa starp bagātajiem un nabadzīgajiem iedzīvotājiem, kas būtībā ir pretēja tendence ilgtspējīgas attīstības izvirzītajiem mērķiem.

Pēc neatkarības atgūšanas un iestāšanās Eiropas Savienībā Latvijai nav tālejoša stratēgiska mērksa, bet, n,emot vērā ilgtspējīgas attīstības koncepcijas nozīmīgo lomu mūsdienu pasaules un ES attīstībā, tas ir nepieciešams.

Perspektivs politisks un praktisks stratēgiskais mērksis ir vajadzīgs arī Latvijas vietēja mēroga attīstībā. Izšķirošais apstāklis Latvijas ilgtspējīgai attīstībai ir pārvaldes sistēmas spēja dažādu līmeṇu un teritoriju plānus un stratēgijas pakārtot vienotam ilgtermiña un ilgtspējīgam skatījumam. Ilgtspējīgas attīstības model̦a izmantošanu Latvijas apstākḷlos ietekmē vairāki specifiski faktori:

- relatīvi zemais vides piesārn,ojuma līmenis un zemā vides degradācijas pakāpe (salīdzinājumā ar situāciju Rietumeiropas valstīs, kā arī daudzās attīstības valstīs),

- ierobežotā resursu pieejamība un relatīvi vāji attīstītā rūpnieciskā ražošana, 
- atkarība no ievestiem resursiem,

- nepieciešamība restrukturēt ekonomisko sistēmu,

- sociālās vides problēmu pieaugums.

Tomēr kopumā Latvijai ir labas iespējas izmantot Rietumvalstu pieredzi vides aizsardzības sistēmas pilnveidošanā un sabiedrības attīstības plānošanā, n,emot vērā risinājumus par ietekmes uz vidi samazināšanu.

Tomēr pastāv rinda šḳēršlı ilgtspējīgas attīstības īstenošanai Latvijā:

- orientācija uz Rietumvalstīs pastāvošo patēriña modeli, ja vienlaikus trūkst nepieciešamo resursu tā realizācijai,

- demokrātisku tradīciju trūkums sabiedrībā, nesakārtota likumdošana, ierobežoti finanšu resursi,

- zems vides un sabiedrības problēmu izpratnes līmenis, zināšanu trūkums par ilgtspējīgu attīstību.

Pēc attīstības rādītājiem Latvijā nenoliedzami būtu iespējas sekot ilgtspējīgas attīstības modelim, tomēr minētie un citi traucēkḷi šì modeḷa ieviešanai uzskatāmi par būtisku šksērsli. Nereti jēdziens "ilgtspējīgs" tiek izmantots kā metafora cerību un vīziju apzīmēšanai. Vienlaikus šì jēdziena saturs ietver nepieciešamību vadīt un plānot sabiedrības attīstību.

Diemžēl jāatzīst, ka pašreizējā Latvijas pārvaldes politiskā un administratīvā sistēma ir izrādījusies nespējīga risināt Latvijai būtiskus jautājumus gan īstermiṇā, gan ilgtermiṇā. Kaut arī san,emta ievērojama ārvalstu finansiālā palīdzība, kopš neatkarības atgūšanas nav izdevies nodrošināt stabilu tautsaimniecības augsmi un Latvijas iedzīvotāju primāro vajadzību nodrošināšanu. Izrādās, ka pēdējo 20 gadu laikā izveidotais valsts pārvaldes aparāts ir nespējīgs nodrošināt valsts attīstību un iedzìvotāju drošību, bet tā uzturēšanas izmaksas ievērojami pārsniedz valsts budžeta iespējas. Lai gan jaunās tūkstošgades pirmajā desmitgadē bija vērojams šķietams ekonomikas pieaugums, ieguldījumi valsts attīstības un izaugsmes nodrošināšanai nākotnē (ieguldījumi zinātnē un pētniecībā inovāciju attīstībai), kā arī uzkrājumi netika veikti.
N̦emot vērā galvenokārt valstī notiekošo politisko procesu raksturu un no PSRS laikiem mantoto mentalitāti, lielākā daḷa valsts iedzīvotāju ir inerti attiecībā pret politiskajiem procesiem un nepiedalās būtisku valsts pārvaldes jautājumu risināšanā.

Valsts pastāvēšanas pamats, Satversme, kas izveidota pēc pagājušā gadsimta 20. gadu parauga, faktiski ir izrādījusies nespējīga nodrošināt valsts politiskās sistēmas izveidi, kas baudītu iedzīvotāju vairākuma uzticību. Augstākais valsts pārvaldes orgāns - Saeima, kā to rāda sabiedriskās domas aptaujas, nav sevi pilnībā attaisnojis, bet izpildvara un politiskās partijas nemitīgi iestieg korupcijas, krāpšanas un citos skandālos.

Ekonomiskā krīze, kas sākās 2008. gadā, pierādīja, ka īslaicīgais labklājības pieaugums bija sasniegts, izmantojot ārvalstu kredītresursus un ES finansiālo atbalstu (tā mērḳis bija sekmēt tautsaimniecības attīstību).

Sākoties globālajai ekonomiskajai krīzei, šie apstāklıli izraisīja valsts ekonomikas faktisku sabrukumu un dramatisku nacionālā kopprodukta kritumu. Neapdomīgu politisku lēmumu dēl ir izveidojies milzīgs valsts parāds, kura atdošanu vajadzēs nodrošināt vēl arī nākamajām paaudzēm.

Lìdz ar to ievērojama dal̦a nacionālā kopprodukta dažu nākamo paaudžu laikā būs izmantojama nevis tautas labklājības paaugstināšanai un investīcijām attīstībai, bet gan parāda maksājumu segšanai. Diemžēl šī paaudze dzīvo uz nākamo paaudžu rēksina!

Būtiskās dzìves līmeṇa atšksirības Latvijā un lielākajā daḷā ES dalībvalstu, no vienas puses, un izdzīvošanas perspektīvu trūkums, no otras puses, nosaka aizvien lielāku emigrāciju ekonomisko bēgḷ plūsmu. Saprotams, ka no šìs situācijas ir izeja. Un tā ir ilgtspējīgas attīstības nepieciešamības apzināšanās gan valstiskā, gan arī indivīda, t.i., katra Latvijas iedzīvotāja līmenī.

20. gadsimtā Latvijai bija vairākas lielas ieceres - neatkarīgas valsts atjaunošana, iestāšanās Eiropas Savienībā un NATO. Šīs ieceres ir piepildījušās, un pienācis laiks lemt, kādā Latvijā dzīvos mūsu bērni un nākamās paaudzes. 


\subsubsection{Latvijas ilgtspējīgas attīstības stratēgiija}

Latvijā ir izstrādāta un 2010. gada 3. jūnijā Saeimā apstiprināta Latvijas ilgtspējīgas attīstības stratēgija. Stratēǵijas pamatmērḳi laimīgs cilvēks labklājības valstī, ilgtspējīgs un veselīgs dzìvesveids, radoša, iecietīga un toleranta sabiedrība, sadarbībā radīta konkurētspēja un valsts kā uzticams partneris.

2030. gadā Latvija būs plaukstoša aktīvu un atbildīgu pilsoṇu valsts.

Ikviens varēs justies drošs un piederīgs Latvijai, šeit katrs varēs īstenot savus mērķus.

Nācijas stiprums sakṇosies mantotajās, iepazītajās un jaunradītajās kultūras un garīgajās vērtībās, latviešu valodas bagātībā un citu

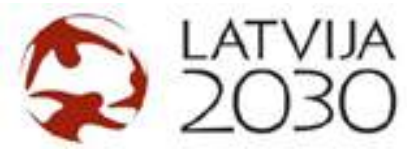

valodu zināšanās. Tas vienos sabiedrību jaunu, daudzveidīgu un neatkārtojamu vērtību radīšanai ekonomikā, zinātnē un kultūrā, kuras novērtēs, pazīs un cienīs arī ārpus Latvijas.

Rīga būs nozīmīgs kultūras, tūrisma un biznesa centrs Eiropā.

Pilsētu un lauku partnerība nodrošinās augstu dzīves kvalitāti visā Latvijas teritorijā.

Latvija - mūsu mājas - zaḷa un sakopta, radoša un ērti sasniedzama vieta pasaules telpā, par kuras ilgtspējīgu attīstību mēs esam atbildīgi nākamo paaudžu priekšā.

\subsection{Pašvaldības un ilgtspējīga attīstība}

Latvijā darbojas 119 pašvaldības - 110 novadi $(\approx 520$ pagasti) un devinas republikas pilsētas: Rīga, Jūrmala, Valmiera, Liepāja, Ventspils, Rēzekne, Daugavpils, Jēkabpils un Jelgava. 2013. gada 1. jūnijā 119 Latvijas pašvaldībās tika ievēlēti 1618 deputāti.

Latvija uzṇēmusies pildīt starptautiskās saistības globālo klimata pārmaiṇu novēršanai, parakstot ANO Vides un attīstības konferences (Riodežaneiro, 1992) Deklarāciju, Vietējās rīcības programmu 21. gadsimtam, Vispārējo konvenciju par klimata pārmaiñām un citus dokumentus, kas tika ratificēti Latvijas Republikas Saeimā 1995. gadā. Šie dokumenti iezīmēja pagrieziena punktu pasaules vēsturē, izvirzot kopīgus mērksus ilgtspējīgas attīstības īstenošanai visām valstīm.

ANO dokumenta nosaukumam - "Vietējā darba kārtība 21. gadsimtam” ir dzili simboliska jēga, jo tas atspoguḷo sabiedrības nākotnes attīstības virzienus jaunajā tūkstošgadē. Daudzu "Agenda 21" minēto problēmu un risinājumu saknes ir meklējamas pašvaldību līmenī, tieši tāpēc pašvaldībām savi attīstības plāni ir jāizstrādā, balstoties uz ilgtspējīgas attīstības principiem.
Vietējā pašvaldība veido un uztur ekonomisko, sociālo un vides infrastruktūru, pārrauga plānošanas procesu, nosaka vides politiku pašvaldībā, kā arī atbalsta nacionālās vides politikas īstenošanu. Vietējai pašvaldībai, kas ir iedzīvotājiem vistuvāk esošā pārvalde, ir liela nozīme sabiedrības izglītošanā un mobilizēšanā ilgtspējīgas attīstības jautājumu veicināšanā.

"Agenda 21" mērķis ir iesaistīt gan pašvaldības iedzivotājus, gan dažādas intereses pārstāvošas sabiedrības grupas, kā arī komercuzñēmējus kopējā attīstības procesā. Tās uzdevums ir aicināt uz sadarbību gan ražotājus, gan nevalstiskās organizācijas, gan skolas un arodbiedrības, gan etniskās minoritātes, gan arī kaimiṇu pašvaldības un valstiskās institūcijas.

"Agenda 21" nebeidzas un nesākas ar dokumenta sagatavošanu. Tas ir ilglaicīgs process un demokrātijas skola vietējā līmenī. "Agenda 21" ietver izteiktu orientāciju uz demokrātiskām rīcībām, piedaloties visiem iedzīvotājiem un interešu grupām, tādējādi veicinot vides, ekoloǵisko, sociālo un ekonomisko mērḳu integrāciju. 
"Agenda 21" mērḳi sakrīt ar ilgtspējīgas attīstības mērksiem:

- ekonomisko, ekologisko un sociālo sistēmu saskan,a,

- dabas resursu saglabāšana un saprātīga izmantošana,

- garantēta drošība cilvēkiem un to veselībai.

Eiropas līmenī ilgtspējīgas attīstības îstenošanas process iezīmējās ar Eiropas Ilgtspējīgu pilsētu konferenci (Olborga, Dānija, 1994), kur 80 Eiropas vietējās pašvaldības ierosināja, apsprieda un parakstija Olborgas Hartu "Eiropas pilsētas cel̦ā uz ilgtspējīgu sabiedrību". Kopumā vairāk nekā 410 pašvaldības no 32 valstīm pievienojās kampaņai, kuras mērķis ir veicināt ilgtspējīgu attīstību vietējā līmenī un atbalstīt Eiropas pašvaldībām atbilstošas politikas un darbības. Pašlaik jau ir iesaistījušās vairāk nekā 2700 pašvaldību no 40 valstīm.

Tās ir apñēmušās ievērot labas un ilgtspējīgas pārvaldības principus gan pilsētu, ciematu un lauku teritorijās. Tas ir nopietns pamats stratēǵiskai plānošanai un ilgtspējīgai vietējai ekonomikai, orientējoties uz efektīvu, bet vienlaikus atbildīgu vietējo resursu izmantošanu.

"Agenda 21" nosaka, ka ilgtspējīgā attīstība ir veids, kā samazināt gan nabadzību, gan vides degradāciju. Nozīmīgākās ar resursu izmantošanu saistītas problēmas ir

- atmosfēras piesārn,ojums,

- zemes neilgtspējīga izmantošana,

- mežu pārmērīga izciršana,

- augsnes noplicināšana un ilgstoša sausuma ietekme,

- bioloǵiskās daudzveidības mazināšanās,

- jūru un saldūdeñu piesārṇojums,

- nedroša toksisko ksimikāliju izmantošana,

- radioaktīvo atkritumu izplatīšanās.

Pašvaldību organizatoriskie priekšnoteikumi "Agenda 21" procesa veidošanā ietver

- atbalsta nodrošināšanu nacionālā līmenī (likumdošanas prasību īstenošana, informācijas izplatīšana).

- vides prasību iekḷaušanu visās pašvaldības attīstības stratēgijās un lēmumos

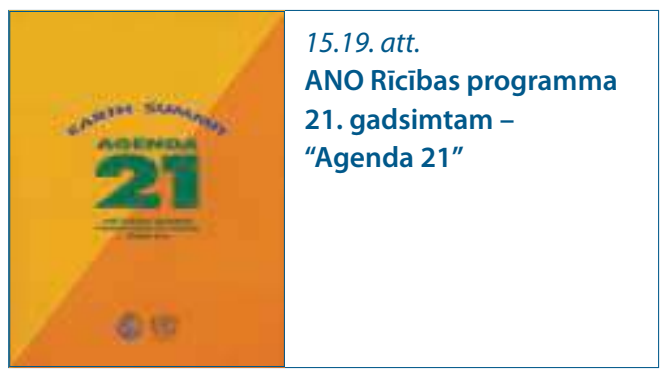

(saistībā ar transporta politiku, nodarbinātību, tūrismu utt.),

- galveno sadarbības partneru izvēli dažādās organizācijas un iestādēs pašvaldības ietvaros un ārpus tās, arī valsts līmenī,

- iekšējās saziṇas uzlabošanu, darbinieku informēšanu un apmācības, vides izglītības ilgtspējīgai attīstībai veicināšanu, apziņas pilnveidošanu un attieksmes mainu,

- pastāvīgu ilgtspējīgas attīstības profila komisiju izveidošanu, kurās ir pārstāvēti dažādu jomu speciālisti un politiķi (transports, veselība, atkritumu apsaimniekošana utt.),

- reālas varas un plašāku lēmumu pien,emšanas pilnvaru nodrošināšanu vides un ilgtspējīgas attīstības struktūrvienību vadītājiem,

- labu attiecību uzturēšanu starp deputātiem, izpildvaras amatpersonām un speciālistiem, kuri ir ieinteresēti vai kuru pārziṇā ir jautājumi, kas saistīti ar apkārtējo vidi un ilgtspējīgu attīstību (ieskaitot tādas sfēras, kā mājoklis, sociālās aktivitātes, komunikācija utt.).

Lai padarītu ilgtspējīgas attīstības îstenošanu vieglāku visām mērksgrupām, valstu valdības 1996. gadā nolēma veicināt kopīgu sapratni par ilgtspējīgu attīstību Baltijas jūras reǵionā. 1998. gadā tika apstiprināts dokuments "Baltija 21 - Darba kārtība Baltijas jūras reǵionam". Tās ir vadlīnijas ilgtspējīgai attīstībai reǵionā. Pèc būtības šis dokuments ir valdības līmeña rīcības programma, kas ietver daudzus pasākumus, kuri ir saistoši arī pašvaldībām. 
"Baltija 21" sastāv no 37 praktiski orientētiem priekšlikumiem, aptverot tādus sektorus kā lauksaimniecība, enerǵētikas saimniecība, zvejniecība, mežsaimniecība, tūrisms, ražošana un transports, kā arī telpisko plānošanu un attiecības starp pašvaldībām.

Pirmās pašvaldības, kuras Latvijā izrādīja iniciatīvu saistībā ar "Baltija 21", bija Jūrmala, Jelgava, vēlākā posmā tām pievienojās Talsi, Cēsis, Rēzekne, Rūjiena, Rīga, Ventspils, Kuldīga, kā arī daži pagasti. Šobrīd var jau runāt par Latvijas pieredzi šajā procesā, kurš ar starptautisko projektu palīdzību iekḷaujas Eiropas apritē.

Jau kopš 20. gs. 60. gadiem dabas pētnieki centās saistìt globālās vides izmaiñas ar antropogēno darbību. Sākotnējā iniciatīva nāca no zinātniekiem, kuri pētīja atmosfēru un mēgināja atrast kopsakarības starp cilvēces kolektīvās darbības ietekmi un visu atmosfēras sistēmu, kā arī tās iespējamām izmaiṇām. Šāda interdisciplināra pieeja tika izmantota plašā zinātniskā programmā "Cilvēks un biosfēra", kas ar ANO Izglītības, zinātnes un kultūras organizācijas atbalstu tika îstenota kopš 1971. gada.

Tas zināmā mērā lika pamatus vides zinātnes un vides politikas mijiedarbībai, kā arī l̦āva veiksmīgāk risināt globālās problēmas, kas joprojām ir l̦oti aktuālas. Šajā procesā iezīmējās būtiska pašvaldību joma, jo darbības tika īstenotas pašvaldību teritorijās. Labs piemērs ir Ziemelvidzemes biosfēras rezervāts, kas ir vienīgā šāda veida īpaši aizsargājamā dabas teritorija Latvijā un aizñem $4576 \mathrm{~km}^{2}$ lielu platību.

Rezultātā ir uzlabojusies ekologiskā situācija Salacas upes baseinā un Rīgas līča Ziemel̦vidzemes piekrastē, kā arī tiek gūta pieredze nākotnei, lai ne vien radītu priekšnoteikumus jaunu biosfēras rezervātu organizēšanai Latvijā, bet arī orientētos uz pašvaldību teritoriju ilgtspējīgu sociālo un ekonomisko attīstību.

Kopš 1992. gada lielākā daḷa demokrātisko valstu ir izstrādājušas savu "Agenda 21". Latvija to vēl nav paveikusi. Arī 2000. gadā izstrādātā "Ilgtspējīgās attīstības koncepcija Latvijā: no vīzijas uz darbību" nav uzskatāma par alternatīvu risinājumu, jo tajā tikai nedaudz apskatītas vides prasības, turklāt ne tādā kontekstā, kā tas pien,emts starptautiskajā "Agenda 21". Šajā koncepcijā gandrīz nemaz nav minēti sociālie jautājumi un problēmas. Šo dokumentu drīzāk var uzskatīt par plānu tautsaimniecības attīstībai ar nepietiekamu vides aizsardzības prasību integrāciju.

Latvijas pārskats par tautas attīstību (2012./2013. gads) - "Ilgtspējīga nācija", ko veicis Latvijas Universitātes Sociālo un politisko pētījumu institūts valsts pētījumu programmas "Nacionālā identitāte" ietvaros, uzsver, ka no tautas attīstības perspektīvas dzīvesvieta ir nozīmīgs nosacījums cilvēka un vietējās kopienas darbības iespēju īstenošanai. Lai arī teritoriju ilgtspējas sociālā dimensija ir grūti nosakāma, tā ir l,oti svarīga vietējās teritorijas un cilvēku kopienas dzīvotspējai.

Diemžēl veiktās iedzīvotāju aptaujas liecina, ka tikai 7,6\% respondentu varēja droši apgalvot, ka vinu mazbērni turpinās dzīvot tajā pašā apdzīvotajā vietā. Ja Latvijas iedzīvotāji neuzskata savu dzìvesvietu par pievilcīgu mazbērniem, vai varam domāt, ka šīs teritorijas būs ilgtspējīgas?

Labi iecerēti atsevišksu nozaru politiku pasākumi to realizācijas gaitā var radīt iepriekš neparedzētas sekas - atbalsts intensīvai lauksaimnieciskai darbībai var apdraudēt ainavas biologiisko daudzveidību, bet ārējo investoru plānu realizācija - vietējo iedzīvotāju intereses. Tā kā ilgtspējīgas attīstības koncepcijas pamatā ir nepieciešamība nodrošināt dažādu sistēmu līdzsvaru, relatīvi īslaicīgas ekonomiskās intereses jāsamēro ar sociālās sistēmas un ekosistēmas ilgtermiṇa attīstības vajadzībām. Ilgtspēja nozīmē nevis īslaicīgu izrāvienu, bet gan virzību uz stabilu, ilglaicīgu līdzsvaru dabas, sabiedrības un katra indivīda dzìvē.

Latvijas Nacionālais attīstības plāns 2014.2020. gadam kā galvenais vidēja termiṇa attīstības plānošanas dokuments valstī var tikt

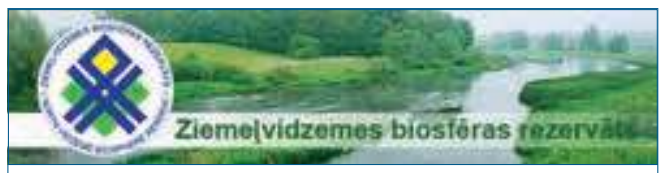

15.20. att. VIDZEME. Ziemel̦vidzemes biosfēras rezervāta logo. 
uzskatīts arī kā "sabiedriskais līgums". Šis valsts plānošanas dokuments gan iezīmē attīstības vadlīnijas, tomēr nesniedz skaidru redzējumu pašvaldībām teritoriju attīstības plānošanā vidējā termiṇā. Latvija kā maza valsts ar ierobežotiem resursiem un lıti nevienmērīgi attīstītām teritorijām noteikti iegūtu, ja ilgtspējīgas attīstības uzstādījumi tiktu lietoti mazāk deklaratīvā formā, bet vairāk praktiskā nozīmē, savstarpēji saskan,oti izstrādājot teritoriju un nozaru attīstības dokumentus.

Dažāda mēroga (valsts, reǵiona, novada, pagasta, konkrētas apdzīvotas vietas) ilgtspējīga attīstība ir jāvērtē arī no sociālās attīstības iespējām. Tomēr ilgtspēja parasti tiek vairāk saistīta ar ekonomikas attīstību un vides kvalitātes saglabāšanu. Arī tāpēc, ka salīdzinoši vienkāršāk ir mērīt vides procesus, ko raksturo sugu daudzveidība, vides piesārņojuma līmenis, $\mathrm{CO}_{2}$ emisijas vai ekonomiskā attīstība (radīto darba vietu skaits, piesaistīto investīciju apjoms).

Sociālo procesu analīze ir sarežgitāka, jo sociālo ilgtspēju raksturo gan objektīvas (kvantitatīvi izmērāmas), gan subjektīvas (kvalitatīvi nosakāmas) norises. Līdztekus iedzīvotāju labklājību raksturojošiem kvantitatīvajiem indikatoriem (ienākumu līmenis, mājokḷa labiekārtotības pakāpe) l̦oti svarīgi ir subjektīvie rādītāji, kas raksturo individuālo apmierinātību ar dzīves kvalitāti.

Tomēr vietas un kopienas dzīvotspēja spēja pārdzīvot krīzes, adaptēties, elastīgi transformēties mainīgajos apstākḷ os - ir nozīmīgs ilgtspējīgas attīstības elements, jo uzrāda tās vietas, kas dažādos apstākḷos spēj saglabāt pievilcību.

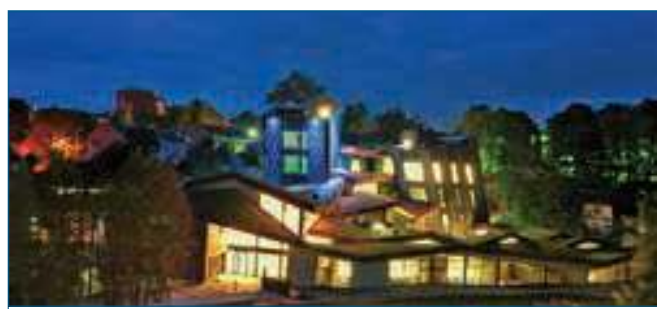

15.21. att. LATGALE. Austrumlatvijas radošo pakalpojumu centrs "Zeimuḷs" Rēzeknē.
Vietas sociālais kapitāls un cilvēkkapitāls (prasmes, iemañas, zināšanas, veselība, drošība, institūcijas, pārvaldība, iesaiste kopienā), dabas kapitāls (klimats, atmosfēra, zeme, ekosistēmas un bioloǵiskā daudzveidība, dabas resursi, ūdens) un ekonomiskais kapitāls (bagātība, ienākumi, mājokḷi, transports un infrastruktūra, produktivitāte, inovācijas) veido vienotu veselumu, kurā izškirošā loma ir sociālajai rīcībspējai - prasmei izmantot iespējas, ko piedāvā vieta. Tas rada konkrētas vietas pievienoto vērtību, bet kopienas un atsevišku indivīdu darbība, vērtības un tradīcijas, savstarpējās attiecības veido vietas sociālo dimensiju.

Tomēr sociālais kapitāls veidojas lēni, bet ātri zūd, piemēram, emigrācijas dēḷ. Tādējādi nozīmi zaudē vietējā prakse un zināšanas, pamazām sairst sociālie tīkli - kontakti ar bijušajiem kaimiṇiem, radiniekiem maina kvalitāti, savukārt jaunajā vietā sociālie tīkli veidojas lēni (imigranti zaudē iepriekšējo sociālo kapitālu, jaunajās vietās to veido no jauna).

Vietai zaudējot cilvēkkapitālu (iedzīvotāju novecošanās, dzimstības kritums, emigrācija), tā zaudē arī sociālo kapitālu un līdz ar to arī attīstības iespējas, lai gan mūsdienu tehnoloǵijas l̦auj emocionālās un gimeniskās saites uzturēt regulārāk un intensīvāk. Sociālās saites virtuālajā vidē, lēti un ērti mobilie sakari nav salīdzināmi ar mēnešiem ilgu vēstuḷu apmaiṇu pirmsinterneta laikmetā, tomēr pastarpināta sazinna tik un tā ir tikai vājš aizstājējs tiešai ikdienas saskarsmei ar līdzcilvēkiem. Emigrācijas dēḷ sairušas ǵimenes un novārtā pamesti bērni tam ir skarba liecība. Pēdējā laikā ǵimenes pamet Latviju ar visiem bērniem, un skolas gaitu sākšana ārpus Latvijas ievērojami samazina iespēju atgriezties.

Sociālais kapitāls neviennozīmīgi ietekmē vietas attīstību - tas var gan sekmēt resursu mobilizāciju un inovatīvu skatījumu uz vietu, gan arī kavēt ar inerci, aizspriedumiem utt. Jaunu ideju attīstību var bremzēt kopienas saliedēta pretestība, kuras pamatā ir tradicionālas vērtības un aizspriedumi pret jebkādām pārmaiṇām. Taču ne jau jebkura jauna ideja ir apsveicama pati par sevi. 


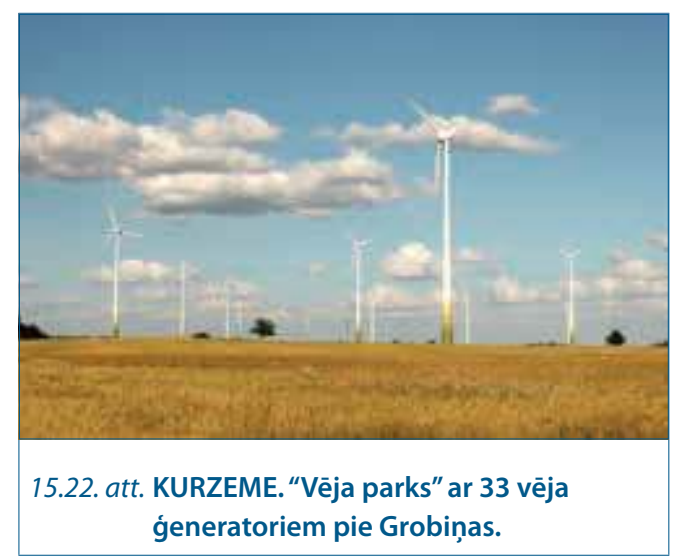

Vietējā kopiena bieži vien nenovērtē tās sociālā un kultūras kapitāla bagātības, kas konkrētajā vietā paaudžu paaudzēs radušās. Arī indivīdi savu piederību nelielai vietējai kopienai kā unikālu vērtību bieži vien neapzinās. Reizēm, tikai attālinoties no dzimtās puses, ir iespējams svaigs skats no malas, kas l̦auj atrast inovatīvu lietojumu senču krātajām vērtībām. Iespējams, ka Latvijas lauku kopienās ir saglabājušās specifiskas tradīcijas, receptes un dzīves gudrība, kas var pārvērst perifēriju par starptautiski pazīstamu tūrisma galamērksi, dodot darbu un ienākumus cilvēkiem, kas ir uzticīgi savai dzimtajai vietai.

Ņemot vērā cilvēkkapitāla izšksirošo lomu vietas attīstībā, īpaša uzmanība pievēršama demogrāfisko procesu tendencēm novadu griezumā. Līdz ar visas valsts iedzīvotāju skaita strauju samazināšanos jau ilgāku laiku turpinās Latvijas novadu un pagastu depopulācija - iedzīvotāju skaits gandrīz visos novados un pilsētās gadu no gada samazinās. Pēdējos 20 gados no tagadējiem 119 novadiem iedzīvotāju skaits ir samazinājies 107 novados (samazinājums pārsniedz pat 40\%).

Latvijā strauji pieaugošais to pagastu daudzums, kuros ir mazs iedzìvotāju skaits, aktualizē jautājumu par plašu valsts teritoriju iztukšošanos, kā arī par administratīvajām izmaksām uz vienu iedzīvotāju. Administratīvo

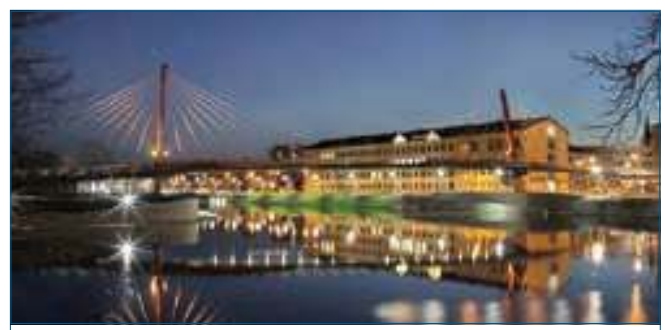

15.23. att. ZEMGALE. Gājēju tilts "Mītava” Jelgavā. Latvijā garākais gājēju un velobraucēju tilts. Tas savieno pilsētas centru ar Pasta salu. Tehniskā risinājuma dēl uzskatāms par unikālu visā Baltijā.

teritoriju un apdzīvoto vietu likums nosaka, ka minimālais novada iedzīvotāju skaits ir vismaz 4000, lai tajā varētu efektīvi uzturēt infrastruktūru, ieskaitot administratīvo pārvaldi. Diemžēl jau tagad 36 novados iedzīvotāju skaits ir mazāks nekā 4000, bet piecos no tiem iedzīvotāju skaits ir zem 2000, turklāt visos šajos novados iedzīvotāju skaits turpina samazināties.

Sabiedriskajās diskusijās par mazo pašvaldību nākotni izkristalizējušies divi galvenie viedokḷi. Pirmais aizstāv vēsturiski izveidojušos administratīvo iedalījumu, neraugoties uz to, cik mazs iedzīvotāju skaits tur arī ir palicis, un nen,emot vērā administratīvās un infrastruktūras izmaksas, kas nepieciešamas, lai nodrošinātu vietas dzīvotspēju un to, ka šis vietas uzturēšanai valstij būs jāatrod budžetā papildu līdzekḷi.

Otrs viedoklis ir par to, ka procesam jālauj ritēt savu gaitu, līdzekḷi attīstībā jāiegulda galvenokārt Rīgā un citās lielākajās pilsētās un attīstības centros, bet cilvēkiem vajadzētu pārcelties uz tām vietām, kurās ir rodamas darbavietas.

Vairumā sarūkošo novadu ir l̦oti maz darbavietu, zemā dzimstība un apjomīgā emigrācija ir radījusi nelabvēlīgas pārmaiṇas daudzu novadu iedzīvotāju vecuma sastāvā.

Katra novada un pat pagasta ietvaros iedzīvotāju izvietojums un to skaita izmainnas nav viendabīgas. Parasti pagastam vai novadam ir 


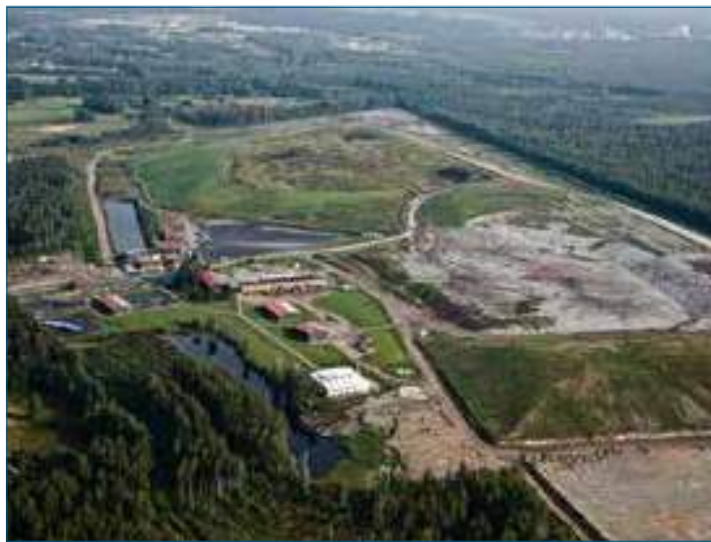

15.24. att.

RĪGA. Getliṇu sadzīves cieto atkritumu ekoloǵiskais poligons ir viens no lielākajiem un modernākajiem zaḷās enerǵijas ražotājiem Latvijā. Enerǵijas avots ir poligona biogāze, kas veidojas slēgtajos atkritumu noguldījumos. legūto enerǵiju izmanto elektrības ražošanai, arī tomātu un ziedu audzēšanai. Pēdējos gados ir iegūti apmēram 8 miljoni $\mathrm{m}^{3}$ biogāzes (pārrēḳinot uz tīru metānu), kas atbilst apmēram 80 miljoniem kWh. Gada ienākumi no elektroenerǵijas ražošanas sasniedz ap 4 miljoniem EUR, bet no dārzeṇu un ziedu audzēšanas - gandrīz 1 miljonu EUR.

sava "galvaspilsēta", kurā koncentrējas pat lielākā daļa iedzīvotāju. Šāda iedzīvotāju koncentrēšanās pagasta centrā vērojama daudzviet Latvijā, īpaši Latgalē. Savukārt ārpus pagasta centra mājas paliek tukšas - samazinās ciemu skaits un arī iedzīvotāju skaits tajos, daudzviet palicis pavisam maz cilvēku, lielākoties pensionāri.

Iedzīvotāju skaita samazināšanos noteikušas saimniekošanas veida izmaiṇas - agrāk uz katriem 10-30 hektāriem lauksaimniecībā izmantojamās zemes bija savi strādājošie, kuri zemi apstrādāja ar zirgiem, savukārt tagad daudzu desmitu cilvēku darbarokas ir aizstājušas dažas lauksaimniecības tehnikas vienības. Agrāk visi Latvijas pagasti bija samērā vienmērīgi apdzīvoti, šobrīd aizvien plašākas teritorijas paliekušas bez iedzīvotājiem.

Mūsdienās strauji mainās cilvēku un vietu funkcionālās attiecības, tādēl jautājums par lauku tukšošanos kā tendenci, kuras rezultātā tuvākā nākotnē iedzīvotāji vairāk koncentrēsies pilsētās, bet lauki kā vietas ar mazākām iespējām paliks gandrīz tukši, ir strīdīgs. Vēl samērā nesen cilvēki (īpaši laukos) bija l̦oti atkarīgi no vietas piedāvātajām iespējām. Tagad dzīves, darba un pakalpojumu san,emšanas, kā arī brīvā laika pavadīšanas vietas bieži vien nesakrīt, jo iedzìvotāji kḷūst mobilāki.

Ikdienas pārvietošanās ērtības ir samērā jauna parādība, kas maina cilvēku un vietas attiecības. To apliecina pētijumi par lauku iedzīvotāju pakalpojumu (iepirkšanās, bankas pakalpojumi, veselības aprūpe) izmantošanas praksi.

Latvijā kopumā notiek būtiskas demogrāfiskās un administratīvās pārmaiṇas, kas atstāj dziḷu ietekmi uz pašvaldību attīstības procesiem. Nākotnes veidošanā vairāk jābalstās uz plašu un dziḷu procesu izpratni, efektīvu rīcības politiku, lai pašvaldību teritorijās varētu nodrošināt ilgtspējīgu attīstību.

Kaut gan Latvijā darbojas relatīvi stabila, uz likumiem un normatīvajiem aktiem balstīta sociālās drošības sistēma, kā arī valdība krīzes un pēckrīzes apstākḷıs ir spērusi dažus soḷus, lai bezdarbnieku un maznodrošināto cilvēku situācija nepasliktinātos pārāk dramatiski, tomēr pastāv augsta ienākumu nevienlīdzība, kura tiek atražota kā darba tirgū, tā sociālās drošîbas sistēmā.

Tāpēc Latvijā viens no galvenajiem uzdevumiem būtu mazināt sociālās drošības sistēmas nevienlīdzību atražojošās darbības un pavērst tās nevienlīdzību kompensējošā virzienā. Lai samazinātu ienākumu nevienlīdzību, ievērojami jāsamazina nodokḷu slogs zemo algu saṇēmējiem vai arī jāratificē Eiropas Sociālās hartas punkts par taisnīgu darba samaksu.

Tas izriet no Latvijas iedzīvotāju vēlmēm, un to apliecina aptaujās izteiktais viedoklis. 


\subsection{Nākotnes iespējas}

Mainās gan pasaule, gan arī mēs tai līdzi, bet katrā periodā kaut kas ir ir īpaši nozīmīgs. Par to mēs vairāk domājam un runājam. Tas parādās arī attiecībā uz attīstību un iezīmējas desmitgažu laikā.

Izskatot attīstības iespējas, jāṇem vērā, ka geopolitikai ir milzīga nozīme. Lai līdzsvarotu stāvokli, uzdevumi būs pretrunā ar lielāko dal̦u no idejām, pamatprincipiem un jaunajiem rādītājiem, kurus var sagrupēt zem kopēja "jaunās ekonomikas" jumta.

Dažiem geopolitiskajiem faktoriem ir jaukta ietekme. Daži finanšu krīzes aspekti jau ir ievērojami veicinājuši "zaḷās augsmes" un "zal’ās ekonomikas” koncepcijas plašāku atzīšanu. To apliecina vairāku valstu daudzu miljardu ieguldījumi videi draudzīgās tehnologiijās, kas ir ekonomisko stimulu paketes pamatā. "Zaḷā augsme" ir kḷuvusi par mērksi pasaules mēroga uzṇēmumiem, kas savukārt palīdz "vilkt" visu privāto sektoru "zal̦ākā" virzienā.

Demokrātiskas protesta kustības parāda arvien radikālākas tendences, kas vērstas pret augsmes modeli. Tomēr šāda tendence ir tikai protestētājiem attīstītajās valstīs, piemēram, "Occupy Wall Street" kustība N,ujorkā vai studentu protesti Spānijā.

Jaunattīstības valstīs, kur protesta kustības parasti notiek pret diktatoriskiem režīmiem, tās arī ir populāras, bet izsaka ilgas pēc lielākas materiālā labklājības, tāpēc tur valda cerības, ka "augsme kā parasti" radīs papildu darbavietas, piekḷuvi izglītībai, labākus veselības aprūpes pakalpojumus un citus labumus.

Vērtējot šo atšķirīgo protestu motivācijas līdzsvaru no globālā viedokḷa, demokrātijas kustības ir virzījušās abos virzienos: dal̦ēji uz "jauno ekonomiku" un dalıēji uz "augsmi kā parasti".

Apsvērumi par nākotnes iespējām:

- finanšu krīze valdībām visvairāk liek stingri iestāties par "augsmi kā parasti”, bet dažas valdības, izmantojot krīzi, ir daudz darījušas, lai veicinātu pāreju uz "zaḷo augsmi";

- pasaules varas maiña, tostarp, Kīnas, Indijas, Brazīlijas un citu jauno ekonomiku izaugsme, ir l,oti nozīmīgs faktors, kas virza valstu nākotnes politiku visā pasaulē galvenokārt "augsmes kā parasti” virzienā. Kaut gan dažas valstis publiski ir pien,ēmušas "zal̦ās augsmes" stratēgiju, lielākais smaguma centrs pasaulē, reaǵējot uz globālo spēku izmaināam, joprojām ir "augsme kā parasti";

- bruṇoti konflikti pasaulē turpinās, jo, vērtējot dzilıāk, tiek uztverta to pozitīvā ietekme uz ekonomiskajiem rādītājiem, piemēram, IKP, kas darbojas tradicionālās augsmes ("augsme kā parasti") atbalstam. Patiesās kara izmaksas, kuras atspogulo piemēram, "īstā progresa" indekss vai "patieso uzkrājumu" rādītājs, nav nonākušas cilvēku vairākuma apziṇā un netiek izmantotas ekonomikas politikas veidošanā nozīmīgā veidā;

- privātais sektors joprojām ir apñēmības pilns par "augsmi kā parasti" un saglabā stingras pozīcijas pasaulē. Bet tālredzīgi uzñēmumi ir pieñēmuši sevis modificētu "zal̦o augsmi", radot sava veida pretēju virzību privātajā sfērā, kas var mainīt līdzsvaru;

- dabas katastrofu seku novēršana palielina IKP, taču tas ir maldinošs signāls "augsmes kā parasti” virzienā. Diemžēl darbība šajā gadījumā sākas no pozīcijām, kad jāizmanto faktiskie ietaupijumi, bet progress nav reāls, jo katastrofa ir ietekmējusi vispārējo sociālo, ekonomisko un vides bilanci, bet faktiskie sasniegumi ir tikai tuvošanās pirmskatastrofas stāvoklim;

- nabadzības mazināšana ir viens no īpaši svarīgiem ilgtspējīgas attīstības mērḳiem;

- "Rio+20" konference bija par ilgtspējīgu attīstību, kā arī par sociālā taisnīguma un vides saglabāšanas principiem, kas izriet no ilgtspējīgas attīstības būtības. Lai arī bija jūtams stiprs atbalsts "zalıajai ekonomikai" un "zalıajai augsmei”, tomēr galvenais uzstādījums noteica, ka nedrīkst virzīties uz "ne-augsmes" pusi.

G̣eopolitiskā realitāte pasaulē pašlaik liecina, ka tuvākajā laikā laime un labklājība visticamāk tiks uzskatīti par paralēliem vai papildu mērksiem, bet nevis par augsmes model̦a aizstājējiem. 
Prognozes rāda, ka drīz "zaḷās augsmes" koncepcija kḷūs par jauno "smaguma centru" ekonomikas politikai. Vienprātība par jaunajiem valstu attīstības rādītājiem ("Zaḷais IKP", "IKP kvalitātes indekss"), kas pārstāv reformas tradicionālās ekonomiskās izaugsmes mērījumos, arī pakāpeniski ieviesīsies. Ja izrādīsies, ka šāda prognoze ir pareiza, tas patiešām nozīmēs ekonomiskās politikas maiṇu valstu praksē.

Pāreja uz "zaḷo augsmi", kas papildināta ar "nacionālās laimes" sasniegšanas pasākumiem, liecinās par nozīmīgu sabiedrības vispārējo ekonomisko programmu paplašināšanu. Tā būs "zaḷā gaisma" sociālām un ekonomiskām inovācijām. Šì pāreja pavērs durvis arī uz jaunu ètikas ietvaru saistībā ar izaugsmi un labklājību globālā mērogā.

Pastāv vairāki ētikas jautājumi, kas jāṇem vērā. Piemēram, ja laime (vai vismaz iespējas uz laimi) tiek pausta kā mērḳis, vai tā būtu uzskatāma par cilvēka tiesībām? Diemžēl neviens no 30 pantiem Vispārējā cilvēktiesību deklarācijā, ko pieñēma ANO 1948. gadā, laimi nepiemin. Par tuvu laimes sasniegšanas sajūtai varam uzskatìt 25. pantu, kas nosaka: "Ikvienam ir tiesības uz dzìves līmeni, kas ir adekvāts veselības un labklājības nodrošināšanai pašam un savai ǵimenei ... ".

Tas arī norāda uz daudziem faktoriem, ko pētnieki ir noteikuši kā priekšnosacījumus subjektīvai laimei. Pamatvajadzības ietver pārtiku, pajumti, apǵērbu, medicīnisko aprūpi un citus sociālos pakalpojumus, tostarp atbalstu tiem, kuri ir bezdarbnieki. Daudzas citas tiesības, ko garantē deklarācija, ir saistītas vien ar to, ko pētnieki uzskata par svarīgām laimīgai dzīvei, - darbu, atpūtu un iespēju piedalīties lēmumu pien,emšanā, kas ietekmē mūsu dzivi.

Ja "nacionālā laime" un "valsts labklājība" ir tuvi jēdzieni, tad var uzskatīt, ka koncepcijas politiska pieñemšana ir nokavēta par kādiem sešdesmit gadiem, kad šie ideāli jau tika pausti pasaulē.

Tagad l̦oti svarīgi būtu noteikt, ka iespēja būt laimīgam tomēr ietilpst vispārējās tiesībās, ko visas tautas apṇemtos panākt saviem pilsoñiem. Tomēr laimes un labklājības nodrošināšanas priekšnoteikumi bieži ir atkarīgi no noteiktu minimālo standartu prasībām attiecībā uz materiālo labklājību. Tāpēc vajadzētu atzìt, ka nepieciešams sasniegt konkrētu ekonomiskās izaugsmes līmeni kā obligātu visām valstīm.

Zinātne apliecina, ka dažas "ne-augsmes" formas pasaules valstu ekonomiskajās struktūrās pastāv. Mums vajag "ne-augsmi" oglekl̦a savienojumu emisijām, ja vēlamies saglabāt planētas klimatu. Mums nepieciešama "neaugsme" ekosistēmu izmantošanā, ja vēlamies saglabāt planētas biologisko daudzveidību. "Ne-augsme" ir nepieciešama neatjaunojamo resursu patēriñam, lai būtu cerības uz labu dzīves kvalitāti arī nākamajām paaudzēm.

Pasaulei ir vajadzīgs jauns redzējums, kas sniegtu jaunu kopības izjūtu visās pasaules zemēs. Tas varētu būt arī šāds:

\section{"Zaḷā ekonomika" + "Nacionālā laime" = "Ilgtspējīga pasaule"}

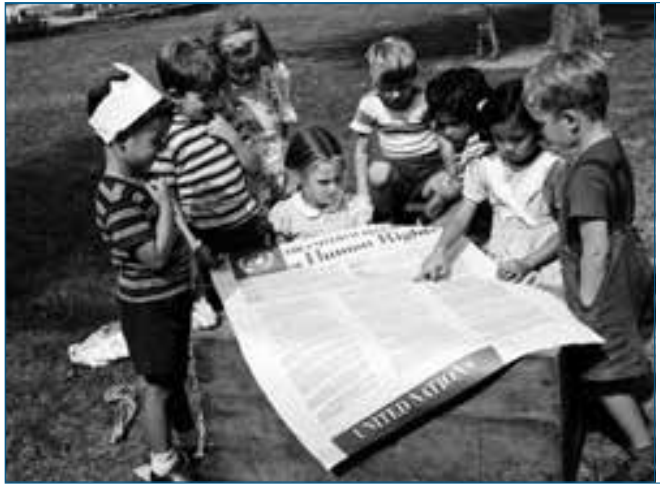

15.25. att.

Vispārējās cilvēktiesību deklarācijas pieṇemšanas otrajā gadadienā (1950. gadā). N̦ujorkas bērnudārza bērni apskata plakātu, kurā vēstīts par vēsturisko dokumentu.

Pēc Vispārējās cilvēktiesību deklarācijas pien,emšanas 1948. gada 10. decembrī, ANO Ģenerālā asambleja ir aicinājusi visas dalībvalstis popularizēt deklarācijas tekstu un "nodrošināt tā izplatǐšanu, lai visi to varētu redzēt, izlasīt un lai tas tiktu izskaidrots galvenokārt skolās un citās izglītības iestādēs neatkarīgi no valstu politiskā statusa vai atrašanās vietas. 
Literatūra

AtKisson A. (2012) Annual Survey Report of the Institute for Studies in Happiness, Economy, and Society. Tokyo, Japan.

AtKisson A. (2008) The ISIS Agreement. London, Sterling, Earthscsn.

AtKisson A. (1999) Believing Cassandra. Vermont, Chelsea Publishing company.

Baker S. (2006) Sustainable Development. London, Routledge.

Becker P. (2014) Sustainability Science. Elsevier, London, New York, Sydney, Tokyo.

Blewitt J. (2008) Understanding Sustainable Development. London, Earthscan.

Dresner S. (2008) The Principles of Sustainability. London, Earthscan.

Earth Summit. Agenda 21. UN Publication, New York, 1993.

Foundations of Environmental Sustainability. Eds. Rockwood L., Stewar, R., Diet, T. Oxford University Press, 2008.

Kolstad C. (2000) Environmental Economics. New York, Oxford, Oxford University Press.

Latvijas ilgtspējīgas attīstības pamatnostādnes (2002) LR Ministru kabinetā apstiprinātas 2002. gada 13. augustā.

Lauder H., Brown, P., Dillabough, J., Halsey, A. (2006) Education, Globalization and Social Change. Oxford, New York, Melbourne, Nairobi, Oxford University Press.

Meadows D. H., Meadows D. L., Randers J. (1992) Beyond the Limits: Confronting Global Collapse, Envisioning a Sustainable Future. UK, Earthscan.

Meadows D., Randers J., Meadows D. (2008) Limits to Growth: The 30-year Update. London, Earthscan.

Our Common Future. The World Commission on Environment and Development. Chair. Bruntland G. H. Oxford, New York, Oxford University Press, 1987.

Randers J. (2012) 2052: A Global Forecast for the Next Forty Years. Chelsea Green publishing, Vermont.

Strategies Toward Sustainable Developmwent; Implementing Agenda 21. Ed. Robinson N. Oceana Publications, Inc., New York, 2004.

Sorensen S. (2010) The Sustainable Network. Beijing, Cambridge, Taipei, Tokyo, O'Reilly Media.

Success Factors for Local Agenda 21 in the Baltic Sea Region. Eds. Gronholm B., Joas M., Nordstrom M., Abo, Finland, 2001.

The Baltic Sea Region - Cultures, Politics, Societies. Ed. Maciejewski W., Uppsala, A Baltic University Publication, 2002.

The Sustainability Curriculum. Eds. Blewitt J., Cullingford. Earthscan, London, 2004.

Towards Sustainable Household Consumption. Paris, OECD, 2002.

UNDP Latvia (2004) Kā dzīvosim Latvijā 2015. gadā? Ziṇojums par ANO Tūkstošgades attīstības mērkiem Latvijā. Rīga, UNDP Latvia.

United Nations (2002) Report of the World Summit on Sustainable Development. Johannesburg, South Africa, 26 August -4 September 2002, New York.

Vide un ilgtspējīga attīstība. Red. Kḷaviņš M., Zaḷoksnis J. LU Akadēmiskais apgāds. Rīga, 2010.

Vides zinātne. Red. Kḷavinšs M. Rīga, LU Akadēmiskais apgāds, 2008.

Vries B. Sustainability Science. Cambridge, Cambridge University Press, 2013.

Walker B., Salt D. Resilience Thinking. Washington, London, Island Press, 2006.

WCED - World Comission on Environment and Development (1987) Our Common Future (The Bruntland Report). Oxford, World Commission on Environment and Development, Oxford University Press.

\section{Interneta resursi}

WWF - World Wildlife Fund (2002) Living Planet Report 2002. WWF. [23.01.2005.]

Pieejams: $h t t p: / / g l o b a l i s . g v u . u n u . e d u / i n d i c a t o r . c f m ? C o u n t r y=L V \& I n d i c a t o r I D=99$

Baltic 21 (1998) An Agenda 21 for the Baltic Sea Region - Baltic 21. Pieejams: www.baltic21.org/?a, 166

ICLEI - International Council for Local Environmental Initiatives (2004) Aalborg Commitments. ICLEI.

Pieejams: www.aalborgplus10.dk/

Sustainable Development Strategy. Pieejams: $h$ ttp://ec.europa.eu/comm/sustainable/

Ekonomisko instrumentu datubāze. Pieejams: www.economicinstruments.com/ 
Latvijas tūkstošgades mērḳi

http://www.mfa.gov.Iv/newyork/informacija-par-ano/latvija-ano/tukstosgades-attistibas-merki

ANO Tūkstošgades Deklarācija http://www.un.org/millenniumgoals/

ANO Ziṇojums par Tūkstošgades mērḳu izpildes rezultātiem 2015. gadā

http://www.un.org/millenniumgoals/2015_MDG_Report/pdf/MDG\%202015\%20rev\%20(July\%201)

ANO portāls www.greengrowth.org

Globālās zaḷās augsmes institūts $h$ ttp://gggi.org

"Zaḷā ekonomika" http://www.unep.org/greeneconomy

http://sustainabledevelopment.un.org/

Zinojums par ELI indeksu www.cs/s.ca/iwb/oecd.asp

http://alanatkisson.com/2012/02/29/life-beyond-growth/

http://www.unep.org/greeneconomy

http://www.dummies.com/how-to/content/us-regulatory-bodies-that-oversee-corporate-financ.html

www.bhutanstudies.org.bt

http://DeGrowth.net

https://sustainabledevelopment.un.org/post2015/transformingourworld

http://www.varam.gov./v/lat/darbibas_veidi/ilgtspejiga_attistiba/

http://www.bla21f.net/projects/sail/latvia/bs1.pdf

http://www.bla21f.net/projects/sail/latvia/bs2.pdf

http://www.szf.lu.Iv/fileadmin/user_upload/szf_faili/Petnieciba/sppi/tautas/TAP-makets2013_ar_vaaku.pdf

http://www.unep.org/greeneconomy

http://www.csb.gov.Iv/sites/default/files/skoleniem/LV_ES/ekonomikas_apjomi_es_kr.pdf

\section{Izmantotie attēli}

15.1. http://www.un.org/wcm/content/site/climatechange/pages/gsp

15.4. http://en.wikipedia.org/wiki/Slow_Food

15.5. http://www.cittaslow.org/

15.6. http://www.google.com/imgres?q=eco-villages

15.7 https://en.wikipedia.org/wiki/Paul_Romer

15.8. http://inspiredeconomist.com/2011/02/22/defining-the-qualities-of-business-sustainability-leaders/

15.9. http://www.unosd.org/ http://www.gggi.org

15.10. https://en.wikipedia.org/wiki/United_Nations_Economic_and_Social_Council

15.11. http://www.guardian.co.uk/environment/2011/sep/16/china-green-economist-gdp

15.13. http://en.wikipedia.org/wiki/File:Prosperity-without-growth-Report_cover.gif

Prosperity Without Growth. Economics for a Finite Planet. Earthscan/Routledge, 2009

15.17. P. Becker. Sustainability Science. Elsevier. 2014., 43 p.

15.21. http://zeimuls.lv/

15.22. http://www.grobinasturisms./v/lv/apskates-objekti-2/veja-parks/

15.23. http://www.visit.jelgava.Iv/sakums/jaunumi/item/2435-gajeju-tilts-mitava

15.25. http://www.un.org/en/documents/udhr/history.shtml 

16.

Piemērošanās

klimata pārmaiṇām Eiropā 


\subsection{Norvēgijas Klimata līgums}

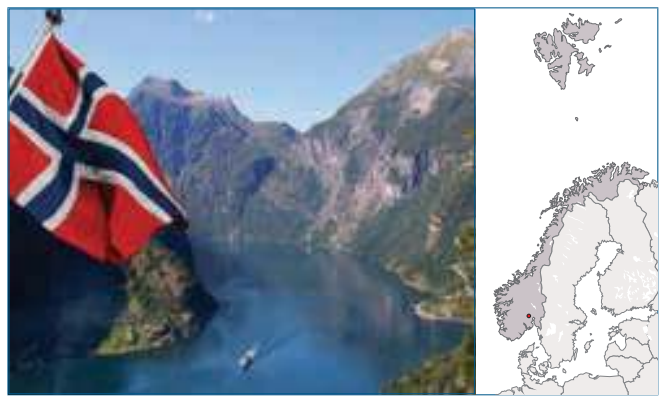

Klimata politikas veidošana ir īpaši grūta, jo daudzu pasākumu īstenošana īstermiṇā ir dārga, bet ieguvumi būs jūtami tikai vēlāk un varbūt pat citur pasaulē. Politiksiem ir grūti iestāties par budžeta samazinājumu veselības aprūpei vai izglìtībai, lai līdzekḷus varētu novirzīt emisiju samazināšanas pasākumiem, kas vēlētajiem nedos redzamus rezultātus deputātu pilnvaru periodā.

Norvēǵijā šì problēma ir dal̦ēji atrisināta ar plaša kompromisa panākšanu starp vairumu politisko partiju, kas ievēlētas parlamentā. Norvēgijas Klimata līgums tika saskaņots, vienojoties sešām partijām - gan pozīcijas, gan opozīcijas partijām. Tas ir nodrošinājis jaunas politikas pamatnostādṇu pien,emšanu neatkarīgi no iespējamām izmaiñām valdībā, jo šīs sešas partijas vienmēr ir bijušas ievēlētas parlamentā. Tādējādi Klimata līgums nodrošina ilgtermiṇa perspektīvu klimata politikas īstenošanai, pat n,emot vērā, ka jaunas vēlēšanas notiek ik pēc četriem gadiem.

Pirmais kompromiss tika pienemts 2008. gadā un ietvēra Norvēǵijas klimata politiku un pasākumus, lai sasniegtu izvirzītos mērķus. Kompromiss tika panākts starp toreizējo opozīcijas partiju konservatīvajiem, liberāliem un kristīgo demokrātu deputātiem, kā arī trīspusējo koalīciju, kas ietvēra Sociālistu, Darba un Centra partijas. Kaut arī vairākām no šīm partijām bija vērienīgāka klimata politika, un tās turpinās cīnīties par plašākiem klimata politikas mērķiem un pasākumiem, kompromiss noteica kopējus mērksus, kam piekrita visas sešas partijas.
Vienošanās tika atjaunināta 2012. gadā, vienlaikus publicējot Balto grāmatu par Norvēgijas klimata politiku.

Atjauninātais Klimata līgums ietver šādus galvenos mērksus:

- Norvēǵija būs klimata ziṇā neitrāla valsts 2050. gadā;

- Norvēgija būs oglekḷa dioksīda emisiju neitrāla pirms 2030. gada, ja arī citām valstīm būs līdzīga apn,emšanās;

- Norvēgoija līdz 2020. gadam samazinās SEG emisijas 30\% apmērā salīdzinājumā ar 1990. gadu;

- Norvēgijas klimata mērksos būs uzstādījums samazināt SEG emisijas par 40\% 2020. gadā salīdzinājumā ar 1990. gada līmeni, ja valstis, kurās ir lielākās SEG emisijas, uzṇemsies līdzīgas emisiju samazināšanas saistības.

SEG emisijas Norvēǵijā tiks samazinātas apmēram par trešdalıu vai pat pusi, bet pārējo samazinājumu segs, iegādājoties oglekḷa kvotas starptautiskā tirdzniecībā.

Daži konkrēti veicamie pasākumi ir šādi:

- nodrošināt papildu finanšu līdzekl̦us Klimata un tehnologiju fondam nākamajiem četriem gadiem, lai veicinātu SEG emisiju samazināšanas tehnologiju attīstību, paredzot līdzekḷu palielinājumu līdz 50 miljardiem Norvēǵijas kronu (5,3 miljardi EUR) 2020. gadā;

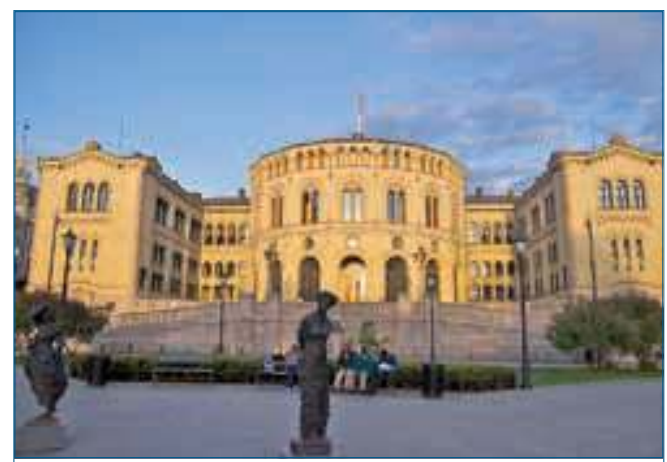

16.1. att. Norvēǵijas parlamenta (Storting) èka galvaspilsētā Oslo. 
- panākt aizliegumu naftas produktu izmantošanai dzīvojamo un sabiedrisko èku apkurei nākamo astoṇu gadu laikā ar nosacījumu, ka mājsaimniecībām tiks nodrošinātas labas atbalsta shēmas;

- pašreizējie nodokḷu atvieglojumi "nulles emisiju" automašīnu iegādei un izmantošanai tiks pagarināti vēl uz pieciem gadiem, līdz "nulles emisiju" automašīnu skaits pārsniegs 50 000;

- strauji palielināt atlīdzības apjomu sabiedriskajam transportam nākamajiem diviem gadiem, bet finansiālo atbalstu izmaksāt tikai saskaṇā ar dokumentētiem rezultātiem;

- valdībai nākamajā valsts budžetā palielināt finansējumu videi draudzīgas energiijas pētniecības centriem, to skaitā jaunam pētniecības centram par ǵeotermālās enerǵijas plašāku izmantošanu;

- valdībi palielināt iemaksas lielākiem sabiedriskā transporta projektiem lielākajās pilsētās un ap tām - lai tas nebūtu jāfinansē no pašvaldību puses;

- àtrāk attīstīt starppilsētu vilcienu satiksmi starp lielākajām pilsētām, kas saistītas ar galvaspilsētu Oslo;
- izveidot vismaz vienu pilna apjoma oglekla savienojumu uztveršanas un uzglabāšanas demonstrācijas iekārtu astoñu gadu laikā;

- izstrādāt stratēǵiju biogāzes izmantošanai;

- palielināt $\mathrm{CO}_{2}$ nodokli naftas nozarē līdz 400 NOK (42 EUR) par vienu tonnu $\mathrm{CO}_{2}$ ekvivalenta.

Baltajā grāmatā par klimata politiku ir konstatēts, ka Norvēgijas valdības veiktie pasākumi 2011.-2012. gadā ir samazinājuši SEG emisijas par aptuveni 20\% salīdzinājumā ar "neiejaukšanās" scenāriju. Oglekḷa savienojumu izmantošanas intensitāte (emisiju apjoms uz saražotā produkta vienību) Norvēgijas ekonomikā laika posmā no 1990. līdz 2010. gadam ir samazinājies par aptuveni 36\%. Tomēr sakarā ar ekonomisko izaugsmi emisiju apjoms Norvēgijā joprojām palielinās, lai gan lēnāk, nekā tas būtu, ja pasākumi netiktu veikti.

1990. gadā Norvēǵijas emisiju apjoms bija 49,8 miljoni tonnu $\mathrm{CO}_{2}$ ekvivalenta, bet tās ir pieaugušas līdz 53,9 miljoniem tonnu 2010. gadā.

Norvēgijas Klimata līgums ir arī ievērojami palielinājis ar enerǵētiku saistīto pētniecību, veicinājis valsts attīstību un praktiski parādījis jaunās klimata politikas devumu nākotnei.

\subsection{Maksa par oglekḷa savienojumu emisijām Norvēgeijā}

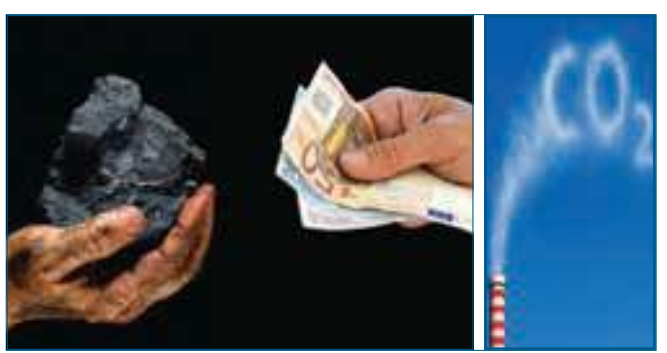

Princips, ka piesārṇotājiem ir jāmaksā par radītām kaitīgām emisijām, ir svarīgs faktors Ziemelvvalstu valdību klimata politikas veidošanā. Apgalvojums, ka lielās SEG emisijas ir tirgus nepilnību rezultāts, ir pamatots patiesās izmaksas par oglekḷa savienojumu emisijām netiek uzskaitītas un neparādās ekonomikas pārskatos.

Ja piesārn,otājs maksātu pilnu cenu par visām darbībām un produktiem, arī segtu izmaksas par sabiedrībai nodarīto vides kaitējumu, tas stimulētu ražotājus samazināt emisijas un izstrādāt un īstenot jaunas un videi draudzīgas tehnologijas.

Taču tirgus vajadzībām ir nepieciešama telpa un laiks, lai varētu pielāgoties jaunajiem izaicinājumiem. Ir svarīgi nenomākt ekonomiku, palielinot izmaksas dažām nozarēm pārāk ātri. Labāk ir atvieglot pāreju uz zemu emisiju risinājumiem, gan pakāpeniski palielinot izmaksas par piesārṇojumu, gan arī sniedzot mērḳtiecīgas subsīdijas. 
Aptuveni uz 80\% Norvēǵijas SEG emisiju attiecas vai nu nodokli, vai emisiju kvotu tirdzniecības sistēma, vai arī abi veidi kopā.

\section{$\mathrm{CO}_{2}$ nodoklis}

Visās Ziemelvalstīs nodokḷ tiek piemēroti par enerǵijas izmantošanu un par $\mathrm{CO}_{2}$ emisijām. Kopš 1991. gada Norvēgijā šis nodoklis tiek piemērots

- benzīnam,

- vieglajām un smagajām naftas frakcijām,

- Ziemeḷjūrā iegūtai naftai,

- celulozes un papīra ražošanai,

- zivju produkcijas ražošanai,

- iekšzemes aviācijai un kuǵniecībai.

Dažas nozares, piemēram, zvejniecība tālajos un piekrastes ūden,os, rūpnieciskie procesi, starptautiskā kuǵniecība un aviācija, ir atbrīvotas no šĩ nodokḷa. Minētās nozarēs rit intensīva tirdzniecība, kas ir paklıuta starptautiskai konkurencei, tāpēc tās ir jāaizsargā.

Emisijas, ko rada starptautiskā kuǵošana un aviācija, netiek uzskaitītas Norvēǵijas emisiju reǵistrā, jo nerada piesārṇojumu Norvēǵijas robežās.

Koksnes pārstrādes rūpniecībai, siḷçu pārstrādei un zivju miltu ražošanai $\mathrm{CO}_{2}$ emisiju nodoklis ir samazināts par $50 \%$.

Norvēgijas $\mathrm{CO}_{2}$ emisiju nodokḷi ievērojami atšksiras starp nozarēm, kā arī atkarībā no degvielas avotiem un degvielas izmantojuma. Zināmā mērā nodokḷi atšksiras arī dažādās

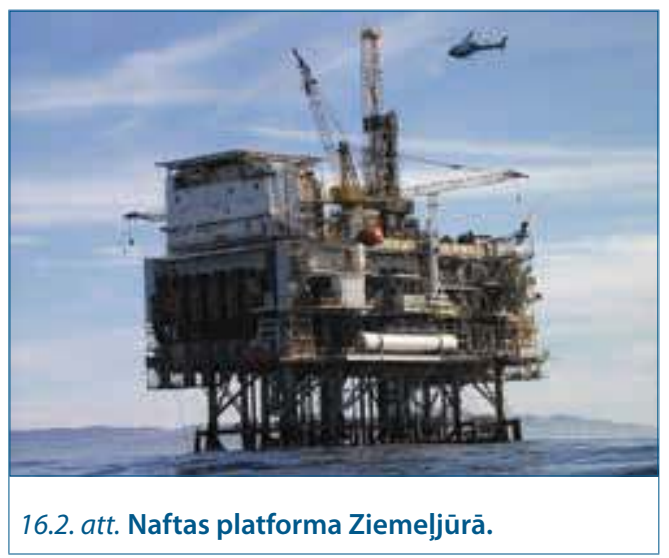

tautsaimniecības nozarēs. Iekšzemē nodokḷu līmenis galvenokārt ir atkarīgs no minerālelllu un benzīna izmantošanas, to atškirīgi apliekot ar nodokli iegādei vai importam. No Norvēgijas naftas platformām nodokḷ tiek iekasēti par naftas un dabasgāzes dedzināšanu. $\mathrm{CO}_{2}$ emisiju nodoklis tiek piemērots arī par emisijām no atkritumu sadedzināšanas.

2014. gadā cena par vienu tonnu $\mathrm{CO}_{2}$ ekvivalenta svārstījās no 4 līdz 65 eiro atkarībā no fosilā kurināmā un lietošanas veida. Vidējā cena ir 250 NOK (26 EUR) par vienu $\mathrm{CO}_{2}$ tonnu. Lielās atškirīības nodokḷu līmeṇa ziṇā nosaka tas, ka robežizmaksas emisiju samazināšanā ievērojami atšksiras starp dažādām nozarēm. Naftas nozarei ir visaugstākie nodokḷi, bet ražošanas procesi ir lielā mērā atbrīvoti no tiem (18\% no emisijas 2006. gadā).

Norvēgijas $\mathrm{CO}_{2}$ emisijas nodoklu nosaka divi dažādi likumi - Likums par tirdzniecības nodokli un Likums par $\mathrm{CO}_{2}$ nodokli darbībām ar naftu kontinentālajā šelfā. Ir arī nodokḷi par metāna emisijām, kas rodas atkritumu apglabāšanā, un par freonu emisijām.

Svarīga ir attieksme par $\mathrm{CO}_{2}$ maksājumiem. Tiem jābūt tādiem, lai nevis tikai subsidētu emisiju samazināšanu, bet arī rūpētos, lai valdības izdevumi veicinātu ieñēmumu palielināšanos. 2004. gadā nodokḷi radīja Norvēǵijas valdībai ieṇēmumus 3 miljardus NOK

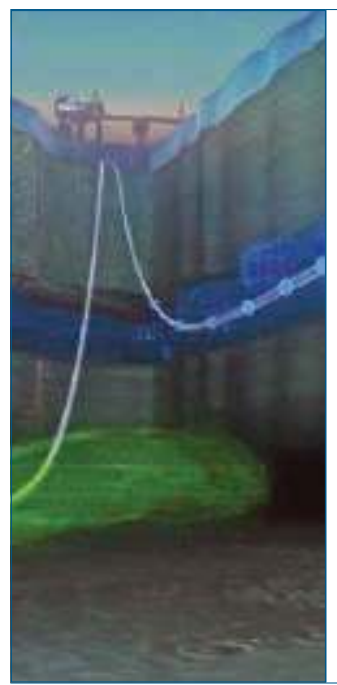

16.3. att.

Shēma par

$\mathrm{CO}_{2}$ noglabāšanu

Ziemeljūrā. Jau vairāk nekā 13 miljoni tonnu $\mathrm{CO}_{2}$ ir noglabāts iežu formācijās zem Ziemeljjūras. Katru gadu kopš 1996. gada 1 miljonu tonnu $\mathrm{CO}_{2}$, kas tika atdalīts dabasgāzes ieguvē, ievadīja atbilstošas struktūras porainos smilšakmens iežos vairāk nekā 800 metru dziḷumā zem jūras dibena. 
(330 miljonus EUR). Šos līdzekḷus varēja izmantot, lai subsidētu zema emisiju līmen,a risinājumus vai citu nodokḷu samazināšanai, tādējādi veicinot visas ekonomikas attīstību.

Vēl viens svarīgs iemesls, lai izmantotu $\mathrm{CO}_{2}$ emisiju nodokli, nevis tikai dotu subsīdijas, ir tas, ka pats tirgus mehānisms sakārto, kur emisiju samazinājums ir lētākais. Rezultātam, vismaz teorētiski, ir jābūt tādam, lai $\mathrm{CO}_{2}$ emisiju samazinājums notiktu par vismazāko iespējamo cenu. Priekšnoteikums, lai tas notiktu, ir vienāda maksa par emisijām visos sabiedrības sektoros. Tas pagaidām Norvēgijā vēl nav stājies spēkā, jo daži sektori ir mazāk aizsargāti pret paaugstinātu nodokḷa likmi nekā citi.

\section{Norvēǵijas emisijas kvotu tirdzniecības sistēma}

Norvēgijā 2005. gadā sistēma tirdzniecībai ar $\mathrm{CO}_{2}$ emisijas ațlaujām tika ieviesta tikai 42 uzṇēmumiem. Šo uzṇēmumu pārstāvētās nozares:

- centralizētā siltumapgāde,

- kokapstrāde,

- zivju pārstrāde,

- naftas kuimiskā pārstrāde,

- gāzes pārstrādes tehnoloǵijas,

- tērauda un minerālvielu ražošana.

Vēl to skaitā bija naftas rektifikācijas uzñēmumi, gāzes termināḷi, gāzes fabrikas un energeētiskās iekārtas. Šie uzṇēmumi radīja 17,8 miljonus tonnu $\mathrm{CO}_{2}$ emisiju. Sešpadsmit no uzñēmumiem bija augstākas emisijas šajā laika posmā, nekā to piel̦āva kvotas, tāpēc tiem nācās pirkt aț̣aujas ES tirgū. Tomēr nebija iespējams pārdot atlaujas tajā pašā sistēmā.

2008. gadā šì sistēma tika paplašināta, lai kḷūtu par dalı no ES emisijas kvotu tirdzniecības sistēmas (ETS). Iekšzemes nozares var izmantot ETS un daudzos gadījumos ir atbrīvotas vai dal̦ejji atbrīvotas no $\mathrm{CO}_{2}$ emisiju nodokḷa. Ārzonas naftas industrijai tika piemēroti ETS un $\mathrm{CO}_{2}$ emisiju nodokḷi, taču tie tika pazemināti, kad ETS stājās spēkā no 2007. līdz 2008. gadam. 2013. gadā $\mathrm{CO}_{2}$ emisiju nodoklis attiecībā uz jūras naftas ieguvi tika atkal pielietots, lai starptautiski līdzsvarotu $\mathrm{CO}_{2}$ emisiju nodoklus ar emisiju kvotu cenu, kā arī lai padarītu sistēmu relatīvi stabilāku.

\section{Transporta nodokli}

Norvēgiijā ir samērā augstas automašīnu nodevas, un tā ierindojas starp pasaules valstīm ar augstākajām šāda veida nodevām. Tās gan ir diferencētas, dodot priekšrocības automašīnām ar mazu izmešu daudzumu. Elektriskie transporta līdzekḷi ir atbrīvoti no nodevas, bet dažiem jāmaksā PVN. Turklāt Norvēǵijā ir augsta cena par benzīnu.

\subsection{Ilgtspējīgs ekociemats Norvēǵijā}

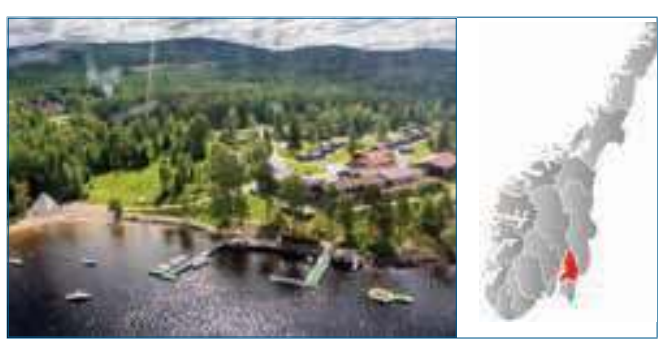

Vìzija visiem ekociematiem ir līdzīga piekopt vienkāršotu dzīvesveidu indivīdiem un kopienai, lai krasi samazinātu savu "oglekḷa pēdu". Pētījumi Norvēgiijā parāda, ka ekokopienas ir sabiedrības konkrēta un izvērtējama atbildes reakcija saistībā ar klimata problēmām, ar kurām nākas saskarties jau šodien. Tas nav pietiekami, lai būvētu un pārbūvētu mājas, kas tiek uzturētas tikai ar "tīru enerǵiju". Jānem vērā arī pats būvniecības process, materiālu transportēšanas veids un kopējais aprites cikls. Tikai rūpīgi visu apsverot, izstrādājot struktūru un arhitektūras risinājumus, ir iespējams izveidot patiešām "tīras" enerǵijas mājas - no brīža, kad sākas celtniecība un turpmāk vietās, kur visu mūžu dzīvos cilvēki. 
Ēku nozare Norvēgijā veido aptuveni 40\% no valsts enerǵijas patēriņa. Daudzi projekti nodrošina "zalı sakopšanu". Tas nozīmē, ka tiek īstenoti nelieli, videi draudzīgi pasākumi, nodrošināta laba reputācija, jo lielākā daḷa no pasākumiem nemaz nav ne mazi un nepavisam nav nenozīmīgi.

Hurdāle ir pašvaldības komūna (administratīva vienība), kas atrodas Akershusas regionā Norvēgijas austrumos. "Filago" ir uzñēmums, kas jau desmit gadus izstrādājis ekociematu projektus ar vidēji 200 dzīvojamām ēkām, arī Hurdālei. Šie projekti ir efektīvs veids kā konkrēti sasniegt izvirzītos vides aizsardzības mērḳus, ko noteikusi Norvēǵijas valdība.

Hurdāles modeḷa metode atšksiras no citām "zal̦as" mājokḷu attīstības metodēm, jo aprēḳinos ietver emisijas un izmantotos resursus gan ražošanas un transportēšanas posmā, gan arī ietekmi uz vidi ēku izmantošanas laikā, ieskaitot nepieciešamās kvalitātes kontroli. Turklāt tiek uzsvērts iekštelpu gaisa kvalitātes līmenis un minimāla mākslīgo materiālu izmantošana. Savukārt atbilstoši izvēlēta infrastruktūra veicina kopienas un iedzīvotāju ilgtspējīgu dzīvesveidu un resursus taupošu attieksmi. Mājas ir enerǵētiski pašpietiekamas un tām nav nepieciešama ārsienu apkope.

Tas sākās 1990. gadā, kad grupa norvēǵu sanāca kopā, lai apspriestu savu redzējumu par jaunu un ilgtspējīgāku dzīvesveidu. Tie bija dažāda vecuma cilvēki ar kopīgām interesēm par ilgtspējīgu dzīvi. Ar lielu entuziasmu viņiem izdevās 1998. gadā nodibināt fondu un viṇi sāka meklēt vietu, kur izveidot Norvēgijas pirmo ekociematu.

Hurdāles pašvaldība tai laikā bija iegādājusies zemes gabalu, lai sāktu veidot ilgtspējīgas attīstības ciematu, un tai škita pievilcīgas fonda idejas. Fonds mainīja savu nosaukumu uz Hurdal Ecovillage Co (HECO), un no 2002. līdz 2003. gadam Hurdālē tika uzceltas astoṇas nelielas mājas. Tālākā attīstība bija grūta, jo nevienam no HECO locekḷiem nebija pietiekamas pieredzes par likumdošanu un finansēm. Tomēr galu galā komandai pievienojās vairāk cilvēku un sākās pārmaiṇas uz labo pusi.

Hurdāle ir Norvēgijas pirmais ekociemats, un tajā jau ir uzbūvētas 200 mājas. Vietējā pašvaldība ir izvirzījusi mērksi līdz 2025. gadam padarīt ciematu par neitrālu attiecībā uz $\mathrm{CO}_{2}$ izmešiem. Tas tiek veidots kā "Ilgtspējīga ieleja”. Ik gadu tiek paplašināta Saules paneḷu izmantošana, līdz tiks sasniegts nepieciešamās energijas nodrošinājums visam ciematam.

Papildus $\mathrm{CO}_{2}$ emisiju neitrālam būvniecības procesam, ciematā ir uzsākti vairāki citi projekti, lai līdz 2025. gadam sasniegtu izvirzìtos mērķus. Emisijas, kas saistītas ar pārtikas ražošanu, iepakošanu un transportēšanu, prasa lielu mākslu, lai nepalielinātos individuālā "oglekl’a pēda". Vietējā un ekoloǵiskā pārtika varētu to samazināt, tāpēc pārtikas ražotāji Hurdālē kopā strādāja, lai izveidotu uzṇēmumu "Hurdāles pārtika", kas cenšas visu nepieciešamo pārtiku audzēt un iegūt vietējās saimniecībās un pārdod savā kopienā.
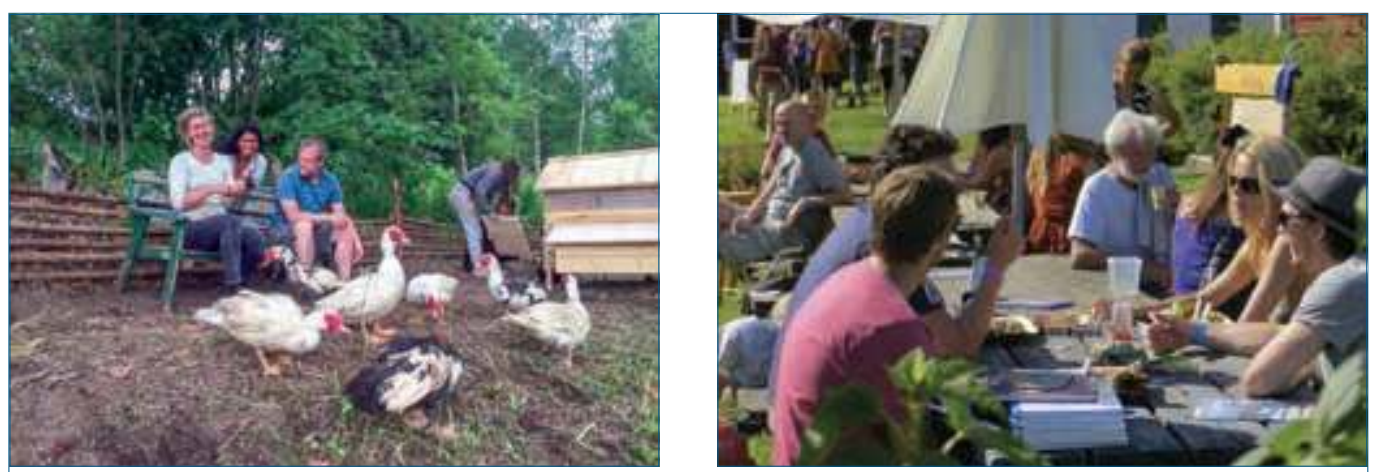

16.4. att. Hurdāles ekociemata ikdiena. 
Būvniecība "Ilgtspējīgā ielejā" prasa daudz koksnes, jo tas ir videi draudzīgākais materiāls, kas pieejams Norvēgijā.

Hurdāles pašvaldība ir uzsākusi "Koksnes projektu". Tas nozīmē, ka visiem izmantotajiem kokmateriāliem jābūt no vietējiem mežiem un tie jāapstrādā uz vietas.

Hurdālē ir izveidots oficiāls kontaktpunkts starp iedzīvotājiem, zemes īpašniekiem un pārdevējiem. Visiem iedzīvotājiem jāiesaistās ekociemata mērksu îstenošanā un ir jāstrādā drošas, laimīgas un ilgtspējīgas sabiedrības dzīves veicināšanai. Iedzīvotāji strādā, lai uzlabotu un saglabātu kopējās platības un sociālo vidi ciematā. Kopienas gars kalpo par pamatu, lai saglabātu ilgtspēju un zemas $\mathrm{CO}_{2}$ emisijas.

Atšķirīgās ciemata sociālās grupas regulāri organizē kursus, seminārus un citus pasākumus, kur ikviens ir laipni aicināts mācīties un attīstīt jaunas prasmes, kas ir svarīgas, lai dzīvotu ekociematā.

\subsection{Samso - Dānijas atjaunojamās enerğijas sala}

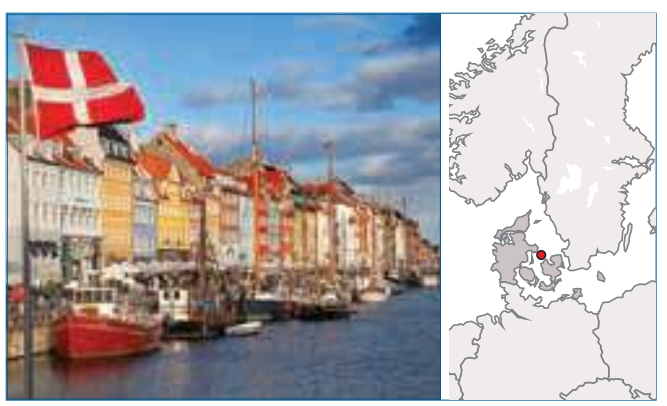

Dānijas sala Samso atrodas Kategata līcī Ziemeljjūrā aptuveni $120 \mathrm{~km}$ uz rietumiem no Kopenhāgenas. Sala ir tikai $114 \mathrm{~km}^{2}$ liela un tur mājvietu rod 3800 cilvēki. Tie dzīvo kā paraugs dāṇu sabiedrības pašpietiekamībai.

1997. gadā Samso sala uzvarēja konkursā "Dānijas atjaunojamās enerǵijas sala". Tas nozīmēja, ka bija gaidāms, ka sala kḷūs 100\% energijas pašpietiekama desmitgades ietvaros.

Plāns mainīt visu enerǵijas ražošanu un patēriṇu desmit gadu laikā bija pārsteidzošs, jo salā līdz tam nebija nekādu parasto enerǵijas avotu un tā bija pilnīgi atkarīga no fosilā kurināmā enerǵijas, ko uz salu nogādāja ar tankkugiem, kā arī no elektroenerǵijas, ko ieguva caur savienojumu ar cietzemes tīkliem. Lai sasniegtu šo mērksi, bija jāpanāk dažādo dalībnieku iesaistīšanās atbalsta projektā. Tas ietvēra salas atjaunojamās enerǵijas projekta personālu, Samso iedzīvotājus un pašvaldību, Dānijas valdību, kā arī vietējos un ārējos uzṇēmumus.
1997. gada iniciatīvas pamats bija valdības ziņojums, kas ieteica palielināt atjaunojamās enerǵijas dalı 35\% apjomā no Dānijas kopējā enerǵijas patēriṇa līdz 2030. gadam. Konkursa uzdevums bija veicināt atjaunojamās enerǵijas izmantošanu, izpētīt iespējamo procentuālo atjaunojamās enerǵijas daḷu, kas varētu tikt sasniegta noteiktā jomā un laikā, izmantojot modernās tehnologijas. Lai uzvarētu konkursā, projekta pieteikuma plāns bija jāizveido, n,emot vērā, kādi resursi būs pieejami enerǵētikas jomā un kā varētu veikt pāreju, izmantojot tehniskos un organizatoriskos risinājumus.

Enerǵijas patēriṇa samazināšana visās nozarēs bija prioritāte. To veicināja arī vietējo iedzīvotāju līdzdalības pakāpe. Samso iesniegtais pieteikums tika novērtēts kā labākais un atbilstošākais Dānijas Enerǵētikas ministrijas prasībām.

Lai sāktu projekta īstenošanu, firma "PlanEnergi" izstrādāja salas energètikas attīstības plānu, n,emot vērā uz salas pieejamos resursus, kā arī iezīmēja aptuvenu laika grafiku. Tas tika izmantots projekta "Dānijas atjaunojamās energijas sala” īstenošanas vadlīniju sagatavošanai.

Visi salas iedzīvotāji tika aicināti uz tikšanos, kur tiem tika sniegta informācija par izmaksām, atmaksāšanās laiku, iespējamajiem tehnologiskiem risinājumiem utt. Iedzìvotāji tika uzaicināti piedalīties darba grupās. Daudzi iesaistījās izmantojamo tehnoloǵiju izvēles procesā, un vēlāk tiem tika dota iespēja veikt 
arī finanšu ieguldījumus tehnoloǵijās, ko viṇi bija izvēlējušies. Tas atbilda arī projekta filosofiskajam uzstādījumam - "domā kā vietējais un rīkojies atbilstoši vietējai videi”.

\section{Siltums}

Atjaunojamās enerǵijas procentuālā daḷa siltuma nodrošināšanai pieauga no aptuveni 25\% 1995. gadā līdz 65\% 2005. gadā. Tajā pašā periodā kopējais siltumenergíjas patērinš̌ samazinājās par aptuveni 10\%. Jau projekta sākumā pašvaldība nolēma, ka visām esošām mājsaimniecībām vai nu jāpieṇem vai jānoraida iespēja pieslēgties centralizētās siltumapgādes sistēmai. Visas jaunuzceltās ēkas bija jāpievieno centralizētās siltumapgādes sistēmai.

Dānijā maksa par pieslēgšanos centralizētai siltumapgādei ir l,oti augsta, bet, san,emot dotāciju projektam no Valsts enerǵijas taupīšanas asociācijas, tas bija l̦oti lēti. Tas bija viens no iemesliem, kāpēc Samso salā pāreja uz jauno enerǵētisko sistēmu bija veiksmīga.

\section{Elektrība}

Pētījumi apliecināja, ka Samso salas kopējam saražotajam elektroenerǵijas apjomam jābūt $11 \mathrm{MW}$, lai to padarītu par enerǵētiski pašpietiekamu. Lauksaimnieki, kuru īpašumā bija potenciālās vēja turbīnu uzstādīšanas vietas (zeme) l̦oti labprāt ieguldīja līdzekḷus savu vēja turbīnu uzstādīšanā. Tādējādi netrūka potenciālu investoru. Trijās grupās uz salas tika uzstādītas vienpadsmit 77 metrus augstas $1 \mathrm{MW}$ vēja turbīnas. Tā kā tolaik tirgū nebija pieejamas tehnoloǵijas, kas var nodrošināt transporta nozares vajadzības ar atjaunojamo energoresursu enerǵiju, Samso salā tika ieteikts ražot līdzvērtīgu apjomu "tīrās" enerǵijas, izmantojot vēja turbīnas, kas uzstādītas jūrā. Tika aprēkināts, ka šai nolūkā ir vajadzīgas piecpadsmit 1,5 MW vēja turbīnas.

Lai nodrošinātu, ka Samso salai pieder projekta koncesija, tika iesaistīti vietējie partneri un dibināts uzñēmums "Samso Offshore Wind Co". Turklāt kompāniju "Energi midt", ar kuru jau vairākus gadus sadarbojas Dānijas Energèētikas ministrija par Saules panel̦u uzstādīšanu, subsidēja Saules paneḷu uzstādīšanu trim Samso salas mājām (katrai $20 \mathrm{~m}^{2}$ Saules paneḷu).

Jau 2005. gadā salā tika saražots vairāk enerǵijas nekā bija nepieciešams, lai apmierinātu salas vajadzības, tāpēc enerǵijas pārpalikumu sāka eksportēt uz Dānijas cietzemi.

\section{Transports}

Samso salā 10 gadu periodā tika īstenotas šādas iniciatīvas:

- lielie autobusi nomainīti ar mazajiem ārpus maksimālās slodzes stundām,

- padarīts elastīgāks autobusu saraksts,

- paplašināts bezmaksas sabiedriskais transports, ietaupījumi 10-25\% apmērā,

- samazinājies enerğijas patērinšs traktoriem, ietaupïjumi lauksaimniecības nozarē 30\% apmērā,

- sākusies pakāpeniska pāreja uz elektroautomobiliem.
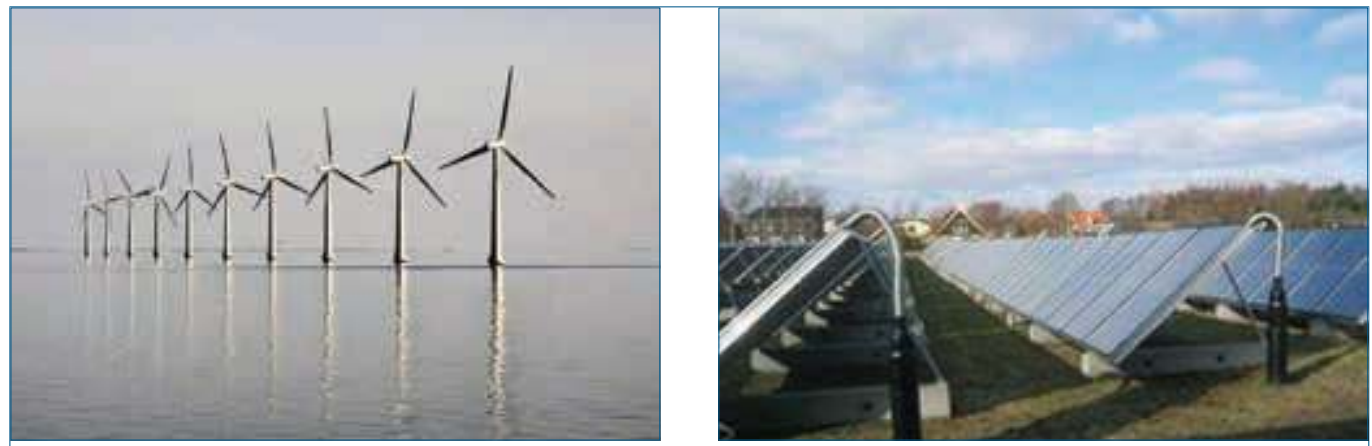

16.5. att. Samso salas vēja turbīnas jūrā un termiskie Saules paneḷi siltumapgādes iekārtām. 
Vide

Tas bija l,oti veiksmīgs projekts ar 100\% ilgtspējīgu rezultātu, jo samazinājās SEG emisijas enerǵijas patēriṇā, palielinājās nodarbinātības iespējas un uzlabojās vispārējā sociāli ekonomiskā sabiedrības ieklautība.

Naftas produktu patēriņš samazinājās par 15\% laika periodā no 1997. gada līdz 2005. gadam. Tas bija galvenokārt saistīts ar naftas produktu patēriṇa samazinājumu apkurei, jo siltumapgādes sistēmas sāka vairāk izmantot biomasu (salmi, koka skaidas) un Saules kolektorus.

Fosilās degvielas (benzīns, dīzel,degviela) izmantošana transportā (prāmji, automašīnas) patērinšs palika gandrīz nemainīgs.

Elektroenerǵētikas jomā sauszemes un jūras vēja turbīnas aizstāja elektrības importu no kontinenta. 11 vēja turbīnu uz sauszemes un vēlāk 10 vēja turbīnu jūrā uzstādīšana palielināja vēja enerǵijas ražošanu par 100\%. Neskatoties uz to, ka Saules panel̦i un to uzstādīšana ir samērā dārga, salinieki sāka ar niecīgu ieguldījumu, līdz sasniedza vērā n,emamu enerǵijas ražošanas līmeni, galvenokārt, sakarā

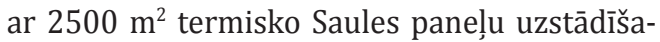
nu siltumapgādes iekārtām.

\section{Darba nodrošinājums}

Projekts "Dānijas atjaunojamās enerǵijas sala" radijja daudz darba vietu, gan plānojot un uzstādot vēja turbīnas, gan centralizētās siltumapgādes iekārtas.

Siltumapgādes projektus un vēja turbīnu uzstādīšanu veica vietējie uzṇēmēji par projekta līdzekḷiem. Tas, savukārt, deva darbu vietējiem iedzīvotājiem mehāniskajās un elektroiekārtu darbnīcās, kā arī vēja turbīnu apkalpošanā.

Vietējie tehniḳi tika apmācīti un sertificēti, lai varētu uzstādīt Saules termiskos paneḷus, kā arī nodrošināt jauno iekārtu darbību.

Vietējiem lauksaimniekiem tiek maksātas izdevīgas cenas par lauksaimniecības atkritumiem, tāpēc tie labprāt tos piegādā vietējām siltumcentrālēm.

\subsection{Dānijas "zal̦āa" sala Bornholma}

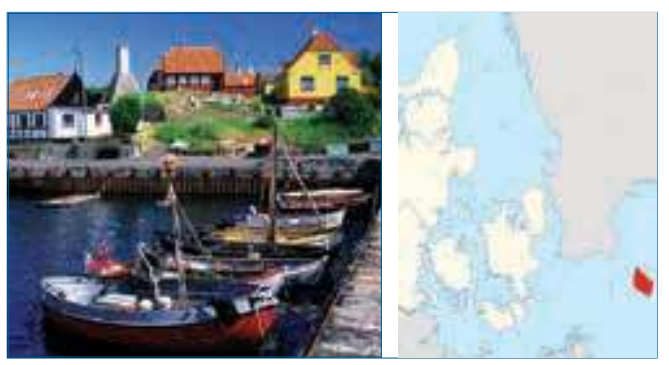

Bornholma ir neliela sala Baltijas jūrā, kas atrodas uz austrumiem no Dānijas cietzemes. Salas iedzīvotāju skaits - 41000.

Salā ir bijušas vairākas uzṇēmējdarbības krīzes un finanšu lejupslīde, bet ir izdevies tās pārvarēt. Sala ir uzsākusi projektu "Bright Green Island", un tā mērḳis ir līdz 2025. gadam izveidot ilgtspējīgu, $\mathrm{CO}_{2}$ emisiju neitrālu sabiedrību, kas būtu pašpietiekama atjaunojamās enerǵijas ziṇā. Stingra politiskā apṇemšanās un vietējais atbalsts "zal̦ām" iniciatīvām padara Bornholmu par ideālu reālās dzīves laboratoriju jauno enerǵijas tehnoloǵiju pārbaudei.

Bornholmieši uzskatīja, ka risinājumiem nevajadzētu būt pārāk apjomīgiem vai veiktiem ar lielu uzñēmumu resursiem. Tas veicinātu vietējus, integrētus risinājumus ar vispārēju atbalstu vietējā sabiedrībā, kā arī dotu iespēju pārbaudīt vairākus dažādus projektus salas apstākḷos. Tā būtu laba iespēja mācīties citam no cita.

Projekts paredz konsultācijas par ilgtspējīgu attīstību, sazin,as tīklu veidošanu un kontaktu iespēju uzlabošanu. Tas veicināja semināru, lekciju, darba grupu sanāksmju organizēšanu, zināšanu izplatīšanu un uznēemējdarbības izvēršanu. "Zalılie" risinājumi tika meklēti visās nozarēs, lai salu pārveidotu pēc iespējas ātrāk.

Tiek attīstītas gan "tīrās" tehnologijas enerǵijas ražošanā un sadalē, gan veicināta 
biologiskā lauksaimniecība, dabas aizsardzība un vides izglītība (arī bērnudārzos).

Bornholmas projekts ir piesaistījis interesi pasaulē. Uzñēmumu vadītāji, zinātnieki, tūristi un politiki apmeklē salu, lai uzzinātu par tehnologiskajiem eksperimentiem un projekta īstenošanas ietekmi uz salu. Bornholmas Biznesa centrs organizē ekskursijas pa salas "enerǵētikas" maršrutiem. Enerǵiju Bornholmā nodrošina vējš (64\%), Saule (1\%) un biomasa (10\%), kas kopā veido 85\%. Atlikušo dalu nodrošina akmen,ogles (8\%) un naftas produkti (7\%).

Ar "labas dzīves" mērksi projekts panāk daudz vairāk nekā varētu gūt no jauno tehnoloǵiju izmantošanas. Piemēram, Bornholmas jaunpienācējiem un jauniem biznesa projektiem tiek piedāvāts kontaktpunkts, bet visa Bornholmas kopiena ir iesaistīta salas nākotnes veidošanā, izmantojot 900 vietējo iedzīvotāju konsultantu grupu, ar kuru tiek apspriesti visi jautājumi saistībā ar dažādu virzienu attīstības iespējām.

\section{Līdzdalība ES Ekotīklā}

Elektroenerǵijai piemīt savdabīga īpatnība - tajā pašā brīdī, kad tā ir saražota, nepieciešams to nekavējoties izmantot. Vienmēr ir jābūt acumirkḷa līdzsvaram starp elektroenerǵijas ražošanu un patēriṇu. Tāpēc parasti samazina ražošanas apjomu periodos ar nelielu patēriṇu, piemēram, naktīs, bet palielina ražošanu, kad visi ir mājās un sāk gatavot vakariṇas.

Atjaunojamā enerǵija balstās uz mainīgiem avotiem, piemēram, vēja un Saules enerǵiju. Ar

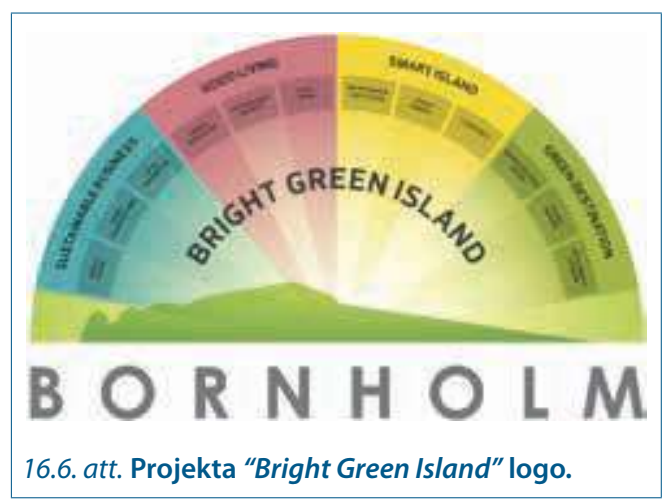

izmain̄ām piegādē apvienojumā ar pieaugošo pieprasījumu pēc elektroenerǵijas no, piemēram, siltumsūkṇa, lai uzlādētu elektrisko transportlīdzekli, energoapgādes tīklā jāsaglabā līdzsvars. Tas ir milzīgs izaicinājums visām valstīm, kas vēlas būt "zal̦as".

Atjaunojamās enerǵijas ieviešana nebūt nenozīmē mainīt enerǵijas avotus. Jāmaina arī enerǵijas ražotāju un patērētāju mijiedarbība, lai ražošana tiktu koriǵêta līdz ar patēriṇa pieprasījumu. Drošā sistēmā arī patērētājiem jāpielāgojas pieejamām elektroenerǵijas piegādēm.

Elektroenerǵijas tirgū cenas krītas katru reizi, kad elektrības padeve ir lielāka nekā pieprasījums. Dažām ierīcēm, piemēram, vel̦as mazgājamām mašīnām un, zināmā mērā, arī siltumsūkṇiem, ne vienmēr ir jābūt ieslēdzamiem un izslēdzamiem jebkurā laikā. Tā vietā iekārtu ieslēgšanu var atlikt uz piemērotāko laiku, kad cenas ir zemas.

Pārkārtojot pieslēgšanos kādam energoietilpīgam patēriṇam uz laiku, kad cena ir zema, var panākt efektivāku atjaunojamo energoresursu izmantošanu. Tā var ietaupīt patērētāja naudu, paaugstināt energoapgādes drošību un samazināt atkarību no fosilā kurināmā rezerves jaudām. Lai to panāktu, patērētājiem ir svarīgi saprast un pieñemt jaunu elektroenerǵijas patēriṇa veidu. Patērētāju elastīgums ir būtiska viedo elektroapgādes tīklu dalı.

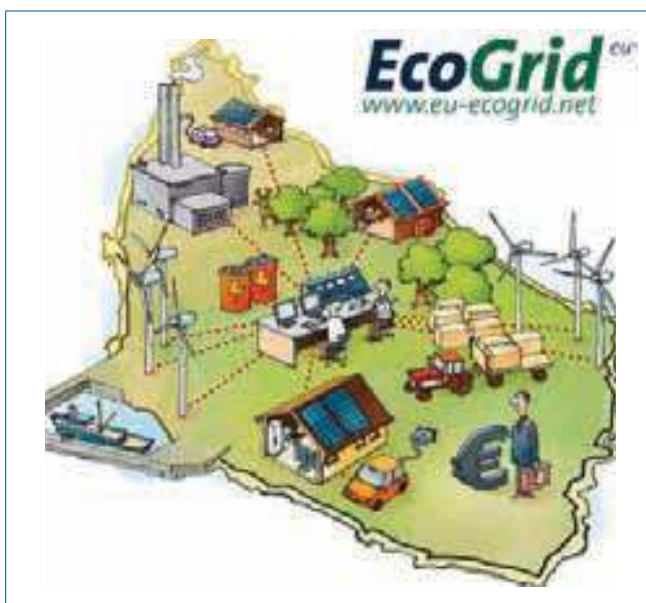

16.7. att. Bornholmas līdzdalība ES Ekotīklā. 
Bornholmas iedzīvotāji tiek labi sagatavoti jaunās enerǵētikas sistēmas izmantošanai un zina, ka elastīgs elektroenerǵijas patēriņš veicina līdzsvara saglabāšanu elektroenerǵijas tirgū.

ES Ekotīkla projekta dalībnieki ir saṇēmuši viedos elektrības skaitītājus, kas uzrāda esošo elektroenerǵijas cenu ik pēc piecām minūtēm. Tas ḷauj gala lietotājam tieši piedalīties elektroenerǵijas tirgū, pielāgojot patēriņa pieaugumu vai samazinājumu atkarībā no cenas. Tādā veidā elektroenerǵijas patēriṇa un ražošanas maksimumi var tikt samazināti, padarot sistēmu elastīgāku pret svārstībām.

Projekts veicina izpratni un uzvedības mainu, jo tiek izmantotas kampanas, kas saistītas ar brošūru izplatīšanu, reklāmu televīzijā un laikrakstos, kā arī ar enerǵijas izmantošanas konsultācijām dalībniekiem. Projekts dod jaunu ieskatu par to, kā patērētāju pieprasījums reaǵē uz cenu signāliem un kā reālā laika tirgū var darboties ar plašām kombināciju iespējām attiecībā uz izplatītākiem enerǵijas avotiem. Projekta dalībnieki pakāpeniski pieradīs pie domas par mainīgām elektroenerǵijas izmaksām un sapratīs, ka daži no viṇu paradumiem attiecībā uz elektroenerǵijas patērinu ir jāmaina.
Atbilstoši pētījumi ir devuši vērtīgu ieskatu par enerǵijas tirgus funkcijām un to, kā patērētāji reaǵē uz konkrētā laika cenu.

Jāpiemin arī citi tehniskie projekti:

- pilnībā īstenota testa iekārta par viedajiem tīkliem, izmantojot Bornholmu kā testa tīklu,

- Bornholmā izvietotas Saules panel̦u vienības, sākot ar $2 \mathrm{MW}$,

- 200 individuālās mājsaimniecības apgādātas ar automātiskām kontroles ierīcēm,

- 250 privātās mājsaimniecībās izveidota pilnīga automātiskā kontrole pār visām elektroierīcēm,

- 150 privātmājās nomainīti mazuta katli pret siltumsūkṇiem ar tālvadības pulti,

- notiek gatavošanās projektam ar piecām kurināmā elementu mikrokoǵenerācijas iekārtām privātmājās,

- elektrisko transportlīdzekḷu projekta īstenošana Dānijā ar demonstrācijām Bornholmā, kas paredzēja noskaidrot iespēju, vai elektriskais transportlīdzeklis, kas bijis pievienots elektrotīklam, var pārdot atpakal elektroenerǵiju energosistēmai, ja tīkla pieprasījums pēc elektroenergijas ir augsts.

\subsection{Biroju ēkas apsildǐšana ar k̦ermeṇa siltumu Zviedrijā}

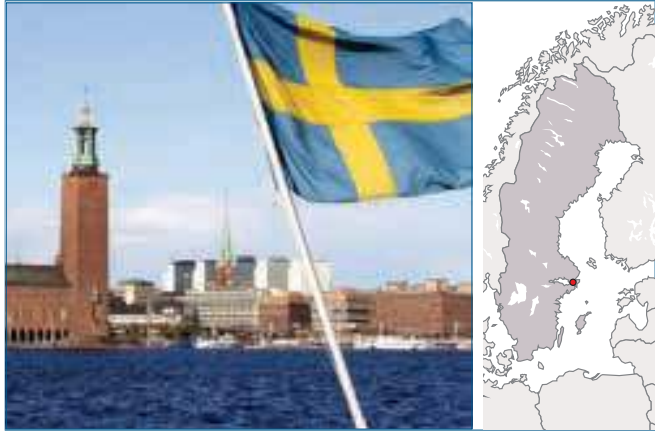

Grūti iedomāties, ka ķermeña siltums varētu būt arī enerǵijas avots. Tomēr kermen,a siltumu ir sākusi izmantot kāda Zviedrijas kompānija.
Cauri Stokholmas Centrālajai dzelzcel̦a stacijai katru dienu iziet vairāk nekā 250000 cilvēku, radot lielu siltuma daudzumu. Viṇi ne tikai paši rada siltumu, bet arī veic dažādas darbības, piemēram, iegādājas pārtiku, dzērienus un preses izdevumus. Tā vietā, lai k,ermeña siltums izkliedētos stacijas gaisā, šī enerǵija tiek izmantota, lai sildītu tuvējo biroju ēku, kas pieder valsts uzñēmumam.

Tāds risinājums konkrētai ēkai samazina apkures izmaksas pat par 25\% salīdzinājumā ar dabasgāzes izmantošanu, kas Zviedrijā ir dārga.

N̦emot vērā aukstās ziemas un augstās enerǵijas cenas, Zviedrija meklē alternatīvus veidus, kā apsildīt ēkas. Ziemel̦valstis - Zviedrija, Dānija, Norvēǵija un Islande plaši izmanto 


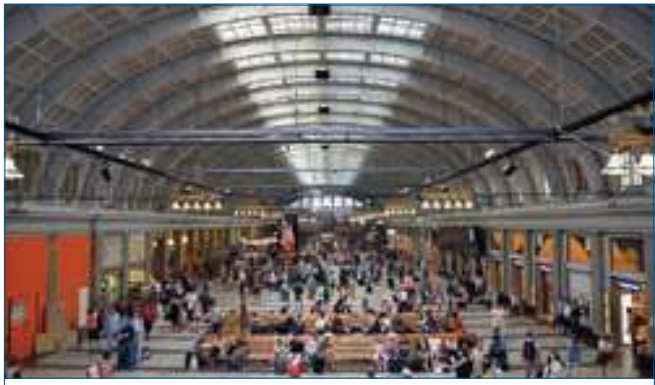

16.8. att. Stokholmas Centrālās dzelzceḷa stacijas uzgaidāmā zāle.

centralizēto siltumapgādi, izmantojot kombinēto siltuma un elektroenerǵijas ražošanu, parasti par kurināmo lietojot biomasu. Taču ir iespējams izmantot arī citus avotus ar zemāku temperatūru.

Stokholmas Centrālā dzelzceḷa stacija ir lielākā un aktīvākā dzelzcel̦a stacija Zviedrijā. Vilcieni, veikali un cilvēki stacijā rada milzīgu siltuma daudzumu, kas parasti tiek ventilēts uz āru. Kaut gan siltuma apmainītāji nav no jauna izgudrota tehnologija, tomēr uzdevums nodot siltumu no vienas ēkas uz otru prasa ilgtermiña sadarbību starp divu ēku īpašniekiem.

Biroju ēkas (Kungsbrohuset) platība ir $40000 \mathrm{~m}^{2}$, un tā atrodas Stokholmā netālu no stacijas ēkas. Tagad liekais siltums no Centrālās
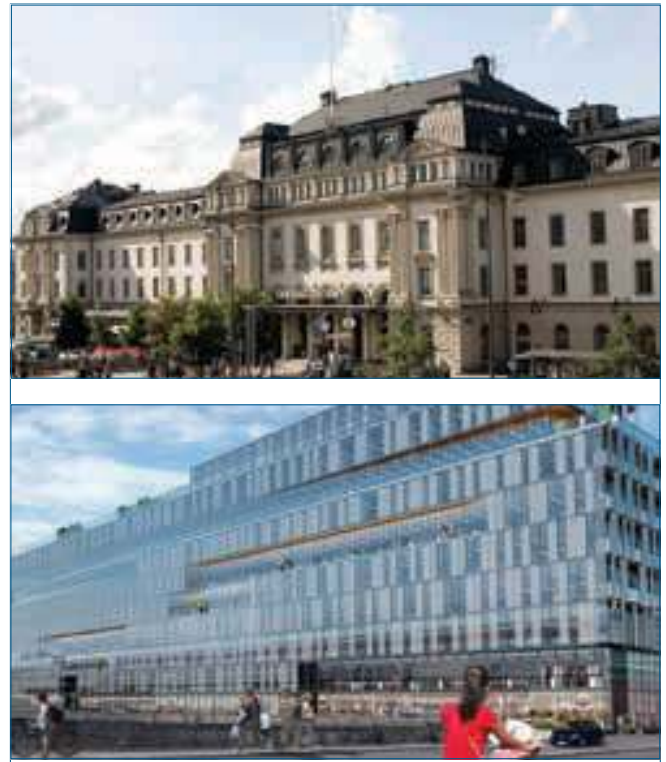

16.9. att. Stokholmas Centrālā dzelzceḷa stacija un biroju ēka (Kungsbrohuset).

stacijas tiek pārvadīts uz šo biroja ēku. Tas ir labāks risinājumus, nekā izmantot ezera ūdeni stacijas dzesēšanai.

Šis Stokholmas projekts ir iedvesmojis līdzīgai iniciatīvai Parīzē, kur siltums no metro stacijas tiek izmantots, lai apsildìtu dzìvokḷus tuvējā dzīvojamā kompleksā.

\subsection{Saragosas "Ūdens taupī̌̌anas programma" Spānijā}

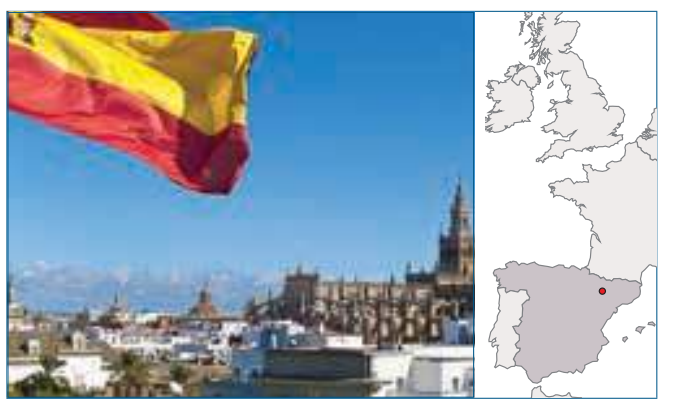

Saragosas pilsēta atrodas pussausajā klimata joslā Spānijas ziemel̦austrumos. Tajā vidējais nokrišnu daudzums ir tikai $314 \mathrm{~mm}$ gadā, un tāpēc lielāko daļu ūdens apgādei n,em no Spānijas lielākās upes Ebro. Sakarā ar to, ka upes līmenis svārstās atkarībā no sezonas, bet ūdens kvalitāte ir zema, kā arī ilgstošā sausuma dēl, kas sākās 20. gs. 90. gados, 1996. gadā tika uzsākta Saragosas pilsētas "Ūdens taupīšanas programma”, lai risinātu ūdens trūkuma problēmu.

Pilsētas pieaugošais iedzìvotāju skaits un ekonomikas straujā attīstība bija papildu faktori, kas vēl vairāk pastiprināja ūdens taupīšanas programmas nepieciešamību. Vajadzēja arī 
paaugstināt pilsētas noturību un elastību saistībā ar gaidāmām klimata pārmaināām 21. gadsimtā.

N̦emot vērā sabiedrības prasību samazināt ūdens patēriṇu, Saragosas pašvaldība ar vietējo vides aizsardzības organizāciju atbalstu uzsāka "Ūdens taupī̌sanas programmu". Galvenais programmas mērksis bija samazināt ūdens patēriṇu un piesārṇojumu no dažādām patērētāju grupām, arī pašvaldības, uzṇēmumiem un vietējiem iedzivvotājiem. Saragosas "Ūdens taupīšanas programma” paredzēja arī palielināt ieñēmumus no ūdens patērētājiem, lai pilnībā segtu izmaksas par ūdens apgādi un notekūdenuu attīrīšanu. Palielinātie ieñēmumi turklāt palīdzētu segt izmaksas, lai uzlabotu novecojošo pilsētas ūdens saimniecības infrastruktūru.

Lai samazinātu ūdens patēriṇu, tika izmantotas trīs atškirīgas pieejas. Pirmkārt, pamatojoties uz sociālām un kultūras iniciatīvām, tika veicināta "ūdens taupī̌sanas kultūra", kas kḷuva par dalı no pilsētas un iedzīvotāju identitātes. Otrkārt, izmantojot ekonomiskos līdzekḷus, ūdens patērētāji kḷuva jutīgāki pret ūdens trūkumu, vides piesārṇojumu un ūdens pārmērīgu lietošanu. Treškārt, tika veikti pasākumi, lai atjaunotu un uzlabotu ūdensapgādes infrastruktūru, izmantojot dažādas modernās tehnoloǵijas un atbilstošus materiālus.
"Ūdens taupīšanas kultūras" veicināšanai tika izveidotas izstādes un stendi sabiedriskās vietās, piemēram, parkos un dārzos, lai pārliecinātu iedzīvotājus par pievēršanos labai ūdens izmantošanas praksei. Tika sagatavotas un izplatītas brošūras un plakāti par ūdens taupīšanu dažādiem ūdens patērētājiem, galvenokārt, pilsētas iedzīvotājiem. Visbeidzot, n,emot vērā starptautisko izstādi "Ūdens un ilgtspējīga attīstība", ko rīkoja Saragosā 2008. gadā, vietējie iedzivotāji un uzñēmēji tika aicināti samazināt ūdens patērin,u, izmantojot plašsaziṇas līdzeklu iesaistīšanos un tiešsaistes platformas.

Izmain, tika veiktas arī attiecībā uz ūdens tarifiem, kurus paaugstināja, lai vēl vairāk samazinātu patēriņu. Pilsētas pašvaldība pat ieviesa "atlaidi par patērēto ūdeni tām mājsaimniecībām, kas bija samazinājušas savu ikgadējo ūdens patēriṇu par $10 \%$ vai vairāk". Pilsētas vadība arī izvērtēja, cik daudz par ūdeni būtu jāmaksā maznodrošinātām mājsaimniecībām (pensionāri, bezdarbnieki, daudzbērnu gimenes), lai tie varētu sañemt vismaz minimālo, bet absolūti nepieciešamo ūdens daudzumu un ar to saistītos pakalpojumus. Cenas tika stratēǵiski pārvērtētas, lai nodrošinātu, ka tās atspoguḷojas arī patērētājiem sniegtajos pabalstos. Savukārt pārmērīga ūdens lietošana tika sodīta ar augstu maksu par virsnormatīvo patēriṇu.

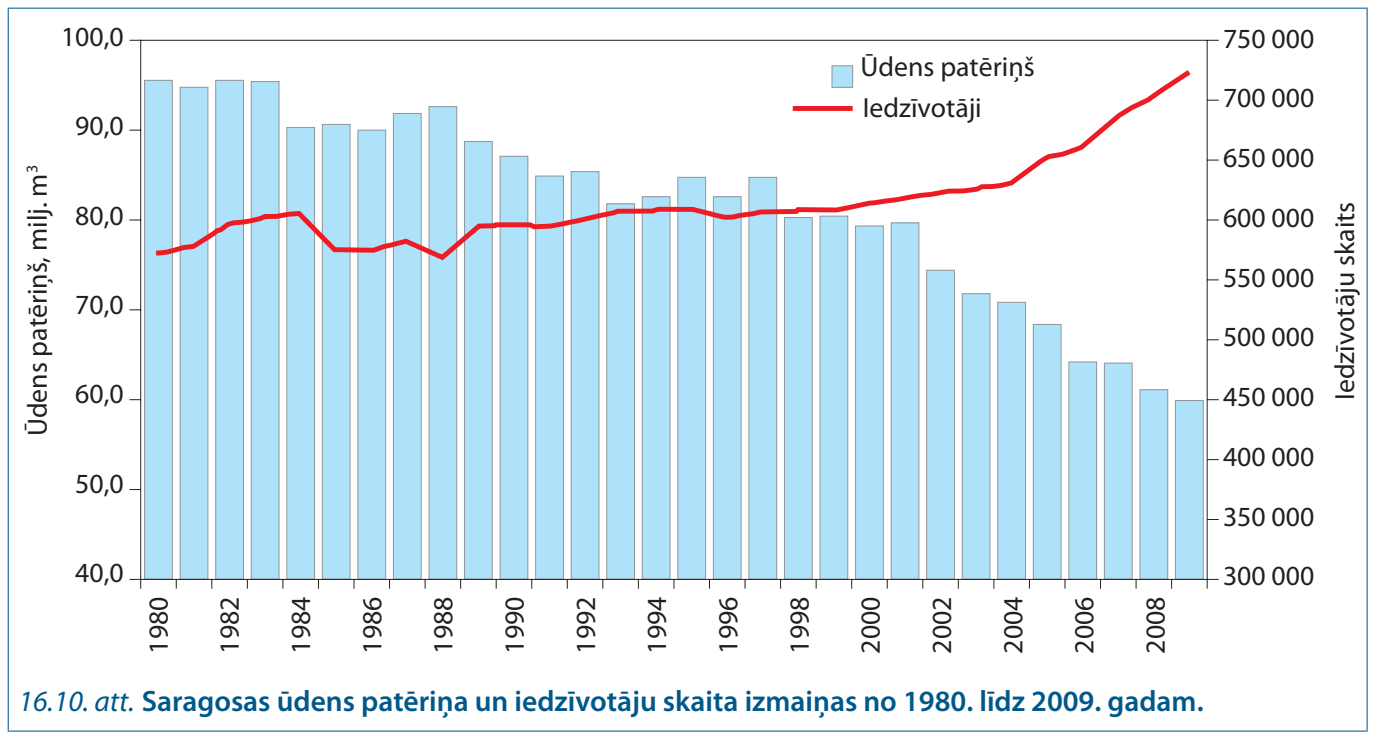


Izmantojot papildu ienākumus no izmaiṇām ūdens tarifos, kā arī pašvaldības ieguldījumus, tika veikts pilsētas ūdensapgādes cauruḷvadu remonts un likvidētas ūdens noplūdes, uzsākta ūdens spiediena kontrole un uzstādīta atbilstoša aparatūra, lai samazinātu ūdens zudumus, bet ūdens uzglabāšanas rezervuāru bojājumus salaboja vai pat aizstāja ar jauniem rezervuāriem.

Šāda daudzšksautnainā pieeja, kas apvienoja sociālos, finansiālos un tehniskos pasākumus, lai palielinātu pilsētas noturību pret ūdens trūkumu, izrādījās l̦oti veiksmīga. Diennakts ūdens patēriņš uz vienu iedzīvotāju samazinājās no 180 litriem 1980. gadā līdz 136 litriem 2000. gadā un nokritās zem 100 litriem 2010. gadā. Pilsētas mērogā, neskatoties uz pieaugošo iedzivotāju skaitu, ūdens patēriņš samazinājās par 27\% 15 gadu laikā: no 84,8 miljoniem $\mathrm{m}^{3}$ 1997. gadā līdz 61,5 miljoniem $\mathrm{m}^{3}$ 2008. gadā.

Tik ievērojams patēriṇa samazinājums bija īstenoto risinājumu rezultāts visos līmeṇos, mērkstiecīgi piedaloties visiem Saragosas ūdens patērētājiem. Kultūras un sociālās iniciatīvas, ko rosināja "Ūdens taupī̌sanas programma", veicināja arī izpratni par ūdens taupīšanas pasākumiem iedzīvotāju vidū. Turklāt investīcijas infrastruktūras uzlabošanai palīdzēja samazināt nopietnus cauruḷu pārrāvumus, plīsumus vai bojājumus no 750 gadījumiem 2000. gadā līdz 350 gadījumiem 2010. gadā.

Ūdens tarifu pārstrukturēšana palielināja ieñēmumus no ūdens patērētājiem. 2006. gadā ieñēmumi sedza $90 \%$ no ūdens piegādes un notekūdeṇu attīrīšanas izmaksām salīdzinājumā ar 70\% 1997. gadā.

Šìs iniciatīvas panākumi tika gūti, pateicoties tam, ka procesā piedalījās visas ieinteresētās puses, tostarp pašvaldības, attiecīgās komisijas, NVO, uzñēmumi, universitātes un vietējie iedzīvotāji. Tas arī nodrošināja reālu ūdens taupīšanas mērķa sasniegšanu, jo dažādās grupas spēja ātri novērtēt situāciju, un komunikācija ar dažādiem ūdens patērētājiem bija efektīva.

\subsection{Freiburga - Vācijas Saules energíijas galvaspilsēta}

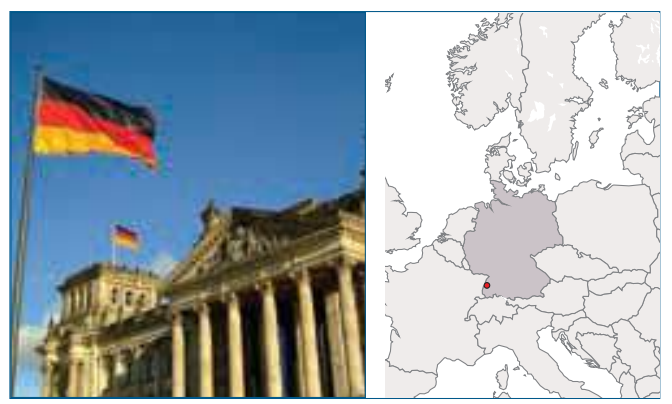

Freiburgas pilsēta, kas atrodas Vācijas dienvidrietumos, ir labs piemērs ilgtspējīgai pilsētas attīstībai. Freiburga ir ceturtā lielākā (220 000 iedzìvotāju) Vācijas pilsēta BādenesVirtembergas federālajā zemē.

Jau kopš 1970. gada sadarbībā ar dažādām sociālajām grupām pilsētai ir veiksmīgi izdevies paplašināt "zal̦o" ekonomiku, īstenojot vairākas iniciatīvas, piemēram, automašīnu ierobežotu izmantošanu, taču tai pašā laikā uzlabotu sabiedriskā transporta sistēmu. Freiburga ir augstu standartu pilsēta attiecībā uz mājokḷiem. Tas ir panākts, uzlabojot vides kvalitāti, enerǵijas un ūdens izmantošanu, kā arī rūpējoties par dabas saglabāšanu.

Freiburga ir zināmā mērā unikāla, jo veiksmīgi izmanto vietējos faktorus - pašvaldības politiku, pilson,u apn,emšanos un iesaistīšanos, apkārtējo dabu un klimatu, kā arī zināšanas un inovācijas.

1996. gadā pilsētas pašvaldība izvirzīja mērksi samazināt $\mathrm{CO}_{2}$ emisijas par $25 \%$ līdz 2010. gadam. Emisijas tika būtiski samazinātas, jo īpaši satiksmes un enerǵētikas nozarē, piemērojot virkni pasākumu - uzlabojot sabiedriskā transporta sistēmu, uzlabojot velosipēdistu iespējas, paaugstinot energoefektivitāti ēkās, izmantojot ilgtspējīgus būvmateriālus un Saules panel̦us, kā arī pārejot uz atjaunojamās enerǵijas izmantošanu pilsētā kopumā. 
Pilsētas kodolenerǵijas izmantošanas īpatsvars tika samazināts no $60 \%$ līdz $30 \%$, un pašlaik kombinētās apkures sistēmas un elektrostacijas nodrošina gandrīz pusi no pilsētai nepieciešamās elektroenerǵijas.

\section{Saules enerǵija}

Kopš 1986. gada pilsēta ir atbalstījusi Saules enerǵijas izmantošanu ar saviem projektiem, finansēšanas programmām un izvietošanas vietām. Saules panel̦i tagad atrodas daudzās vietās gan uz privātām, gan sabiedriskām ēkām, un tos var izmantot vairāk nekā 1800 stundu saulainā laika gadā, jo Freiburga ir viena no saulainākajām pilsētām Vācijā.

Rezultātā, n,emot vērā Freiburgas labvēlīgos klimatiskos apstākḷus, kā arī vietējo iedzīvotāju un uzñēmēju iesaistīšanos un entuziasmu, pilsēta ir kḷuvusi pazīstama kā Vācijas "Saules galvaspilsēta”. Lai gan klimata pārmainu problēmas parasti risina starptautiskie un nacionālie līgumi un izvirzītie mērksi, pilsētas un reǵioni arī var daudz darīt, kā tas jau notiek Freiburgā.

Pašlaik Freiburgu var uzskatīt par paraugu visai pasaulei.

\section{Atkritumu apsaimniekošanas koncepcija}

Atkritumu daudzums uz vienu iedzīvotāju Freiburgā ir zemāks nekā vidēji Vācijā. 2003. gadā pilsētas atkritumu pārstrādes līmenis bija 62\% salīdzinājumā ar 42\% valstī kopumā, bet 2011. gadā kopējais pārstrādes apjoms Freiburgā bija pieaudzis līdz 69\%.

1991. gadā tika ieviesta atkritumu apsaimniekošanas koncepcija, kas bija saistoša visām nozarēm. Tā tika plaši atbalstīta un radỉja sistēmu, kurā atbilstoša atkritumu apsaimniekošana tika atalgota ar stimuliem, ieskaitot atvieglojumus, ja tika izmantoti bērnu audumu autini, atlaides par kolektīvo atkritumu apglabāšanu un atlaides cilvēkiem, kuri kompostē "zalıos" atkritumus, piemēram, pārtikas un dārza atkritumus. Pilsētas nepārstrādājamie atkritumi tiek sadedzināti uzṇēmumā, aptuveni 20 km uz dienvidiem no Freiburgas. Sadedzināšanas iekārtu darbībai tiek uzturēti augsti vides standarti, un uzñēmums apgādā ar elektroenerǵiju 25000 mājsaimniecības. Uzṇēmuma vadības stratēgija - "samazināt atkritumu daudzumu jau pirms pārstrādes un, jo īpaši, pirms atkritumu apglabāšanas".

\section{Transporta sistēma}

Neraugoties uz ekonomikas izaugsmi, transporta $\mathrm{CO}_{2}$ emisijas uz vienu iedzīvotāju Freiburgā ir samazinājušās kopš 1990. gada. Velosipēdu braucēju skaits ir trīskāršojies, sabiedriskā transporta izmantošana ir dubultojies, bet automašīnu izmantošanas īpatsvars ir samazinājies no 38\% līdz 32\%. Lai samazinātu privāto automašīnu skaitu un to izmantošanu,
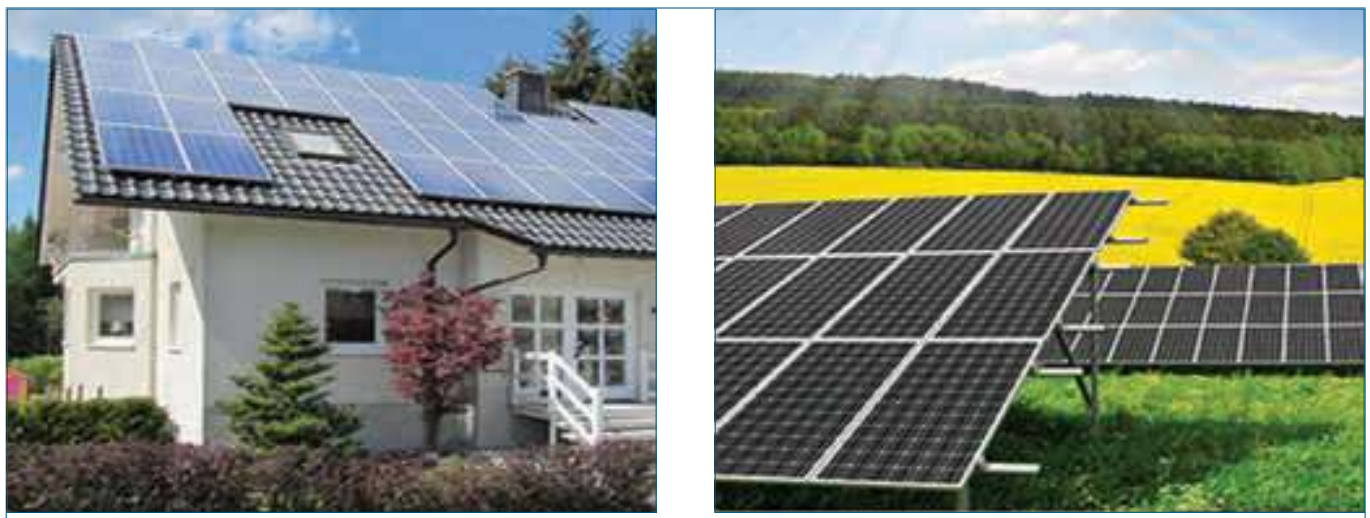

16.11. att. Freiburgas Saules paneḷi - uz privātmājām un ārpilsētas laukos. 

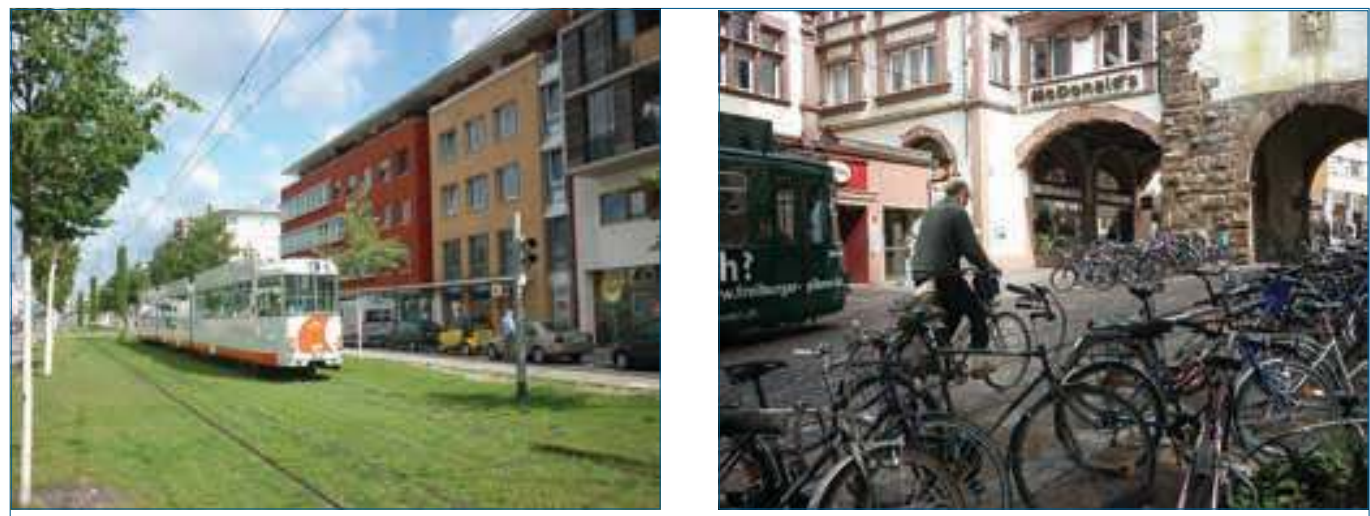

16.12. att. Freiburgas transporta sistēma - jaunas tramvaja līnijas un velosipēdi.

Freiburga ir izstrādājusi Satiksmes un transporta politiku, kurā viens no galvenajiem mērkjiem ir transporta intensitātes mazināšana.

Ar projektēšanas palīdzību pilsēta tika padarīta kompaktāka, ko var ātri škēērsot, bet, izveidojot spēcīgus pakalpojumu centrus nomalēs, nepieciešamība pēc transporta krasi mazinājās. Tagad automobiḷu blīvums Freiburgā ir l̦oti zems - 428 automobiḷi uz 1000 iedzīvotājiem. Lai palielinātu sabiedriskā transporta apjomu, tika iepirkti jauni tramvaji un izveidotas jaunas tramvaju līnijas. Biḷešu sistēmas maiṇa arī veicināja plašāku sabiedriskā transporta izmantošanu. Transporta kompānija ieviesa arī citiem nododamas mēnešbiḷetes, noteica vienotu transporta līdzekḷu tarifu un piedāvāja iegādāties arī biḷetes vienreizējiem braucieniem, braucienu kartes un 24 stundu biḷetes.

Lai veicinātu riteņbraukšanu, pilsētā tagad ir 500 km velosipēdistu joslu, kas veido pārdomātu satiksmes tīklu un paver labas transporta iespējas. Bez tam pilsētā ir iekārtotas 9000 velosipēdu stāvvietas.

Tas viss pilsētā veido labu vietējo sabiedriskā transporta tīklu un paver arī cerīgas nākotnes attīstības iespējas.

\section{9. letekmes uz klimatu novērtēšana Londonā un pielāgošanās paaugstinātam plūdu riskam pie Temzas}

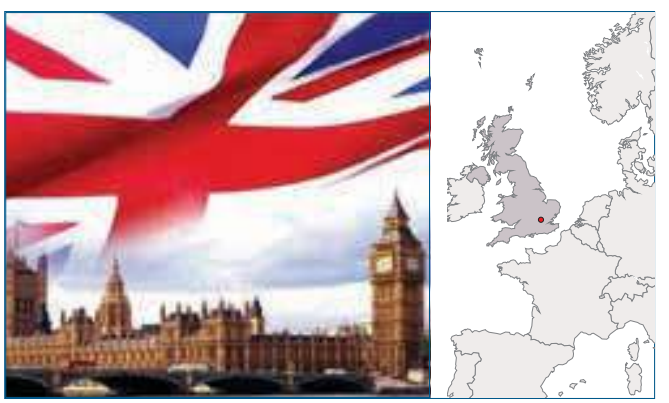

Londona ir viena no pirmajām pilsētām pasaulē, kas jau 2004. gadā uzsāka klimata ietekmju novērtēšanu. SEG emisijas Londonā tiek mērītas, izmantojot Londonas energètikas un siltumnīcefekta gāzu emisiju inventarizāciju, kas kalpo par pamatu formālajiem emisiju aprēksiniem pilsētā un parāda pilsētas enerǵijas patēriṇu, kā arī tiešās oglekḷa dioksīda $\mathrm{CO}_{2}$ emisijas no mājsaimniecībām, uzñēmumiem un transporta. Šis aprēksins tiek veikts katru gadu, lai izvērtētu progresu attiecībā uz "Klimata pārmaiṇu mazināšanu un energétikas stratēgijas mērḳu izpildi”. Aprēḳinos tiek izmantoti reǵionālie enerǵijas (elektrība, gāze un citi kurināmie) patēriṇa un 
$\mathrm{CO}_{2}$ emisiju dati. Taču šī pieeja neaptver netiešās SEG emisijas, kas rodas preču un pakalpojumu aprites ciklā.

Tāpēc netiešu emisiju aprēksinam tika izmantots Lielbritānijas standarts SEG emisiju novērtēšanai pilsētās. Šis standarts tika aprobēts, izmantojot Londonas piemēru, lai novērtētu pilsētas tiešās un netiešās piegādes kēēdes $\mathrm{CO}_{2}$ emisijas, kā arī aprēksinot Londonas patēriña emisijas katru gadu.

SEG emisiju apjoms Londonā 2010. gadā bija 44 miljoni tonnu $\mathrm{CO}_{2}$. Saskaṇā ar tiešo un piegādes k,ēdes emisiju aprēksina metodi emisijas Londonā bija 81 miljons tonnu $\mathrm{CO}_{2 \mathrm{e}}$. Savukārt saskaṇā ar patēriṇa emisiju aprēksina metodi emisijas bija 114 miljoni tonnu $\mathrm{CO}_{2 \mathrm{e}}$.

Emisiju mazināšanai Londonas pilsētas mērs ir apstiprinājis vairākus plānošanas dokumentus. Galvenie no tiem ir "Klimata pārmaiṇu mazināšanas stratēgoija”, "Enerǵētikas stratēgoija" un "Pārtikas stratēǵija". SEG emisiju samazināšanai Londonas pilsētā ir izvirzītas 4 prioritārās jomas.

- Ēkas energoefektivitāte - Londonas privātmāju un publiskā sektora ēku emisiju mazināšanai tiek īstenotas kampaņas, kas paredz pakāpenisku pašvaldības èku renovāciju, palielinot to energoefektivitāti (paredzamais SEG emisiju samazinājums ir 2,5 miljoni tonnu $\mathrm{CO}_{2}$ gadā).

- Ēku energoapgāde - politikas mērksis ir nodrošināt, lai līdz 2025. gadam 25\% enerǵijas Londonā tiktu saražots decentralizēti. Decentralizētās enerǵijas projekti sniedz atbalstu jauniem decentralizētās enerǵijas ražotājiem, laujot tiem pārdot saražoto enerǵiju tieši pašvaldības uzṇēmumiem. Paredzams, ka šì iniciatīva Londonas pilsētai līdz 2025. gadam piesaistīs 8 miljardus mārciṇu investīcijās un nodrošinās 850 jaunas darba vietas.

- Ilgtspējīga pārtikas apgāde Londonā, kur darbojas Londonas Pārtikas padome. Tās uzdevums ir panākt, lai Londonas pārtika kḷūtu veselīgāka - tiek veicinātas īsās pārtikas piegādes kjēdes, publiskajā iepirkumā priekšroku dodot vietējiem, sezonāliem produktiem.
- Ilgtspējīgs transports - viens no mērķiem ir elektrisko autobusu un automašĩnu skaita palielināšana Londonā, kā arī sabiedriskā transporta pakalpojumu uzlabošana.

Citas patēriṇa jomas, piemēram, aviācija, mājsaimniecības preču patēriņš, kas arī rada būtiskas emisijas, tomēr pamatā saistās ar netiešām emisijām un līdz ar to neiekḷaujas Londonas pilsētas atbildību jomā. Līdz ar to tās nav arī iekḷautas Londonas pilsētas emisiju samazināšanas plānos. Tomēr šo emisiju novērtējums sniedz lietderīgu informāciju par patēriṇa emisiju plašo izkliedi un ietekmes jomām.

\section{Pielāgošanās paaugstinātam plūdu riskam pie Temzas}

Londona ir pakḷauta pieciem dažādiem plūdu avotiem. Tāpēc nepieciešamas atšksirīgas metodes datu apstrādei, iekḷaujot upes un paisuma plūdus, plūdmainu līmeña pārsniegumu, kā arī palielināt mērījumu atkārtojumus zema atmosfēras spiediena sistēmās. Jārēksinās arī ar virszemes plūdiem, ko izraisa lietusgāzes, ar kanalizācijas ūdeṇu plūdiem, ja notekas ir aizsērējušas, un gruntsūdeṇu plūdiem, ja cel̦as gruntsūdens līmenis.

Teritorijas ap Temzu ir īpaši jutīgas pret plūdiem, lai gan trīs galvenie plūdu veidi upju, paisuma un virsmas - ietekmē visu Londonas apgabalu. Paisuma plūdi no Ziemeḷjūras ir ar zemu risku, Temzas un tās pieteku plūdi ir ar vidēju risku, bet pastāv liels risks, ja plūdi veidojas no virszemes ūdens noteces. Pašlaik Londonu aizsargā pretplūdu aizsardzības sistēma, kas ietver aizsargsienas, uzbērumu valınus, vārtu caurteces un Temzas barjeru, kā arī kanalizācijas tīklus.

Temzas barjera ir ūdens šķērslis, kas uzbūvēts pāri Temzai pie Vūlvičas. Barjera sastāv no izliektiem plūdu vārtiem, kas var rotēt 90 grādu leṇkī no zemūdens stāvokḷa. Ja ir sagaidāms, ka būs ekstremāli augsta plūdmaiṇa, tiek nodrošināta barjeras darbība.

Tomēr riska faktors visiem iespējamiem Londonas plūdu veidiem var palielināties ilgtermiṇā līdz ar prognozēto jūras līmeṇa 
celšanos, tādējādi palielinot plūdmaiṇu līmeña pārsniegumu (uzbangojumu). Jārēḳinās arī ar ierobežoto drenāžas spēju un straujo ūdens noplūdes pieaugumu zema spiediena sistēmās.

$15 \%$ no Londonas atrodas upes palienēs un aptuveni 1,25 miljoni cilvēku tādējādi tiek pakḷauti riskam. Tāpēc arī nākotnē būs nepieciešams izmantot aizvien modernākas aizsardzības metodes.

\section{Risinājumi}

Lielās Londonas pašvaldības uzdevumi ir samazināt Londonas SEG emisijas par $60 \%$ līdz 2025. gadam un sagatavot Londonu gaidāmajām klimata pārmaiṇām un ekstremāliem laika apstākḷiem, uzlabot pilsētas dzīves kvalitāti un nodrošināt pieejamu, kvalitatīvu mājokli. Lai to izdarītu, pašvaldībai jāizstrādā adaptācijas stratēgijas, jo klimata pārmaingas jau ir jūtamas un, iespējams, kḷūs pat draudīgākas, tāpēc ir vajadzīga rīcība.

Mainīgais klimats nozīmē aizvien lielāku risku ietekmi uz Londonu, tajā skaitā arī sausuma risku, biežākiem karstuma viḷniem un plūdiem. Gaidīšana nav risinājums, jo profilaktiski pasākumi ir lētāki un efektīvāki.

Temza rada lielu plūdu risku, un, lai samazinātu tās ietekmi un mazinātu iespējamo kaitējumu, Londonas Klimata pārmaiṇu pielāgošanās stratēgijā ir uzsvērtas trīs prioritātes.

1. Izstrādāt efektīvākus plūdu pārvaldības pañēmienus, uzlabojot izpratni par plūdu riskiem Londonā.

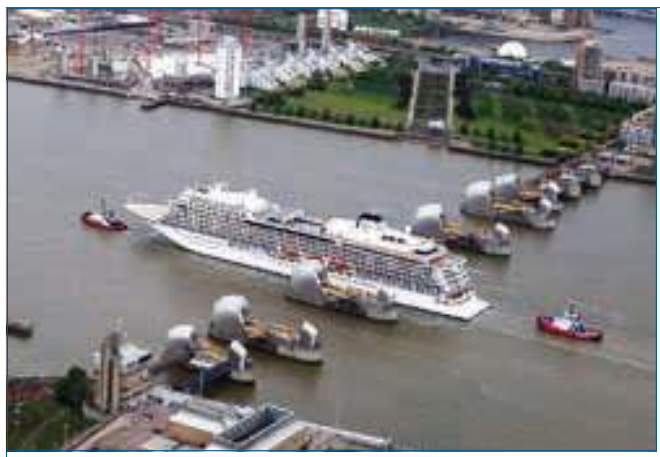

2. Identificēt un aizsargāt mazāk aizsargātās kopienas, jo tām trūkst zināšanu sakarā ar ierobežoto valsts atbalstu, kā arī novērst saziṇas nepilnības starp aǵentūrām, kas ir atbildīgas par šo jautājumu risināšanu.

3. Palielināt sabiedrības informētību un izpratni, lai uzlabotu noturību un elastību gan indivīdiem, gan kopienām, ko var izdarìt, tikai izprotot sabiedrības attieksmi un vērtējumu par iespējamiem plūdu riskiem un apdraudējumiem.

Plūdu aizsardzības sistēma Temzas iztekā ir veidota simtiem gadu un ir veiksmīgi pārvarējusi plūdu briesmas, kas notikušas gadiem ejot. Ir paaugstināts pretplūdu aizsardzības sienu un uzbērumu augstums. Mūsdienu pasākumi tika veikti no 20. gs. 70. un 80. gadiem, reaǵējot uz lielajiem plūdiem, kas notika 1953. gadā. Kopš tā laika ir uzbūvēta Temzas barjera, kā arī vairākas citas inženiertehniskas, arī pārvietojamās struktūras.

Šìs sistēmas izstrādātas, n̦emot vērā zināšanas par paredzamo jūras līmeña paaugstināšanos. Tiek lēsts, ka tā efektīvi nodrošinās paredzētās funkcijas līdz 2030. gadam. Pēc tam gan aizsardzības līmenis samazināsies, ja vien netiks veikti citi pasākumi.

Londonas Vides aǵentūra ir izstrādājusi Temzas iztekas pilnveidošanas projektu līdz 2100. gadam, paredzot plūdu pārvaldību, kas nepieciešama, palielinoties plūdu radītai ietekmei tuvākajā nākotnē.

Lai attīstìtu šo plānu, tiek veikti plaši pētījumi, lai labāk izprastu Temzas grīvas plūdu

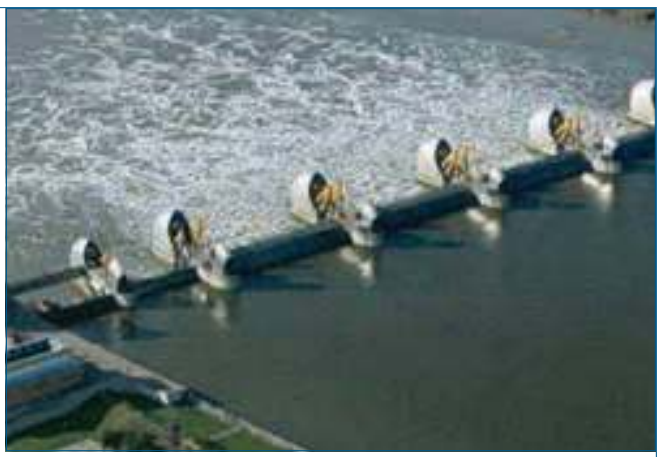

16.13. att. Temzas barjera atvērtā un slēgtā (aizsprosta) stāvoklī. 
risku tagad un to, kā tas varētu mainīties nākotnē. Jāapzinās arī dažādie risku veidi un pielāgošanās iespējas izmaiṇām.

Projekta darbības plāns ir sadalīts dažādām darbības zonām, un ir identificēti četri iespējamie varianti.

1. variants. Uzlabot esošo aizsargsistēmu:

- uzlabot aizsargspējas turpmākajam pielāgošanās procesam,

- optimizēt līdzsvaru starp aizsardzības sistēmas uzlabošanu un nomainu,

- optimizēt aizsardzības sistēmas uzlabošanu, bet uzsākt jaunas sistēmas veidošanu, kas būtu vairāk pielāgota nākotnes klimata pārmaiṇām.
2. variants. Mazināt plūdmain, plūdu risku:

- identificēt četras vietas labajā krastā, kuras varētu izmantot, lai uztvertu un uzglabātu paisuma-bēguma ūdeñus un līdz ar to varētu samazināt vētras bangu līmeni.

3. variants. Būvēt jaunu barjeru:

- "Tilbury" vietā vai "Long Reach" vietā,

- barjera būtu jāveido tā, lai tā izturētu augstākās plūdmaiṇu bangas, kas tiek prognozētas valdības pašreizējās klimata pārmainu vadlīnijās.

4. variants. Būvēt barjeru ar aizvariem:

- "Tilbury" vietā vai "Long Reach" vietā,

- pie jau esošās Temzas barjeras (tās ekspluatācijas laika beigās).

\subsection{Pielāgošanās klimata pārmaiṇām Nĩderlandes lauksaimniecïbas nozarē}

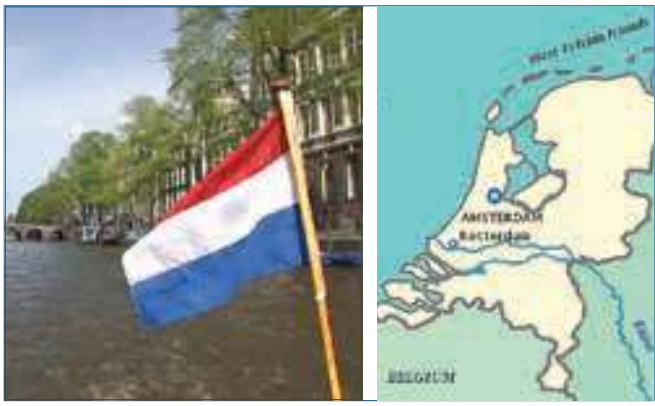

Nīderlande atrodas Atlantijas ekoregionā un tās lielākā zemes daḷa ir pārvērsta par lauksaimniecībā izmantojamu zemi, kas satur barības vielām bagātu augsni un atrodas labvēlīga klimata zonā. Kaut arī augsnei ir laba kvalitāte, klimata pārmaiṇas rada bažas lauksaimniecības nozarei. Mitrāko ziemu dēl augsne valsts dienvidu dal̦ā ir pārāk mitra pavasarī un stipro nokrišņu dēl rudenī, lai varētu veikt tās labu apsaimniekošanu (apmēslošanu, sēšanu, stādīšanu, audzēšanu, novākšanu), jo nebūs iespējams izmantot esošo aprīkojumu un tehniku. Savukārt sausākās vasarās paaugstinātās virsmas dal̦ās var samazināties kultūraugu ražība sakarā ar vasaras nokrišn,u samazināšanos un biežākiem augstas intensitātes lietiem. Pie kultūraugiem, kas ir visvairāk jutīgi pret sausumu, pieskaitāmi lapu dārzeñi, sīpolaugi, auglu un ogu kultūras, ziedaugi.

Tāpat sausākajos vasaras mēnešos purvainās plavās, kas atrodas valsts rietumu daḷā, varētu rasties vairākas savstarpēji saistītas problēmas - zemes nosēšanās, ūdens trūkums sausā vasaras periodā, liekais ūdens mitrajos periodos, kā arī sālsūdens ieplūšana saistībā ar jūras līmeña celšanos.

Tā kā Nīderlandes lauksaimniecības zemēs tiek uzturēts zems gruntsūdens līmenis, paātrināti oksidējas kūdra un nosēžas augsne. Tas pastiprina gruntsūdeñu līmeñu izmaiñas starp lauksaimniecības zemēm un dabas teritorijām.

Pašreizējā gada vidējā temperatūra Nīderlandē ir aptuveni par $1{ }^{\circ} \mathrm{C}$ augstāka nekā 20. gadsimta sākumā. Tā rezultātā augu veǵetācijas sezona ir pieaugusi vidēji par vairāk nekā trim nedēḷām.

Kaitēkḷu invāzija un augu slimību riska iespējas nākotnē palielināsies, jo Nīderlande šai ziṇā ir îpaši neaizsargāta sakarā ar augsto dzīvnieku blīvumu un plašajiem sakariem ar ārzemēm. Šiem apstākḷiem būs vērā n,emama 
ietekme uz vietējo lauksaimniecības ražošanas līmeni, tomēr nav īsti skaidrs, kā šī ietekme attīstīsies.

Jūras līmeṇa celšanās radīs virszemes ūdeñu sāḷu koncentrācijas pieaugumu, kas var kaitēt pret sāliem jutīgām kultūrām. Tomēr nesenie pētījumi liecina, ka kaitējums kultūraugiem saistībā ar pārsāḷošanos var būt neliels, ja pastāv izolētas saldūdens "saliṇas" un nav daudz labi drenētu teritoriju.

Klimata pārmaiñām varētu būt gan pozitīva, gan arī negatīva ietekme uz lauksaimniecisko ražošanu un lauksaimniecības ekonomisko stāvokli Nīderlandē. Faktori, kas var radīt pozitīvu ietekmi, ir vidēji augstākas $\mathrm{CO}_{2}$ koncentrācijas, augstāka temperatūra un augu augšanas sezonas pagarinājums. Lauksaimnieciskās situācijas pasliktināšanās Dienvideiropas valstīs var radīt priekšrocības holandiešu lauksaimniekiem Eiropas un pasaules tirgos.

Tomēr pozitīvā ietekme kādā brīdī var apstāties noteiktā līmenī, un pēc tam labības raža sāks ievērojami samazināties - tātad pastiprināsies negatīvā ietekme, jo arvien vairāk teritoriju var pārsteigt ārkārtēji, postoši klimatiskie apstākḷi.

Lai sagatavotos gaidāmajām pārmaiṇām, 2007. gadā Nīderlandes valdība izstrādāja Nacionālo programmu par pielāgošanos klimata pārmaiñām. Papildus tam valdības iestādes, uzñēmējdarbības aprindas, zinātnieki un pilsoniskās sabiedrības organizācijas uzṇēmās dalīto atbildību Nacionālās programmas īstenošanai.
Tādējādi piemērošanās klimata pārmaiṇām Nīderlandē tiks risināta solidāri un kolektīvi.

Stratēgiskie lēmumi saimniecību līmenī tiks orientēti laika periodam līdz 5 gadiem, bet adaptācijas stratēgijas, kas ietver izmaiṇas kultūraugu audzēšanā, finanšu risinājumus vai nozaru politikas veidošanu, paredzēs darbības līdz 10 gadiem. N̦emot vērā nenoteiktību, tendences un iespējamās klimata pārmaiṇu ietekmes, tiks piemērots piesardzības princips, kas l̦aus labāk izvērtēt un piemērot nepieciešamās stratēgijas.

Piemērošanās stratēgijas klimata pārmaiñām ietver gan maza, gan arī plaša mēroga metodes, un to mērksis ir samazināt vispārējo klimata ietekmi uz lauksaimniecību Nīderlandē:

- sakarā ar temperatūras izmaiñām augu veǵetācijas periods palielinās, tāpēc lauksaimniekiem jāpielāgo tam augu sekas shēmas, sēšanas vai stādīšanas, kā arī ražas novākšanas laiks,

- lai risinātu ūdens pārsāḷošanos, mitruma, sausuma, kaitēkḷu, slimību, salnu, augu augšanas sezonas izmaiṇas jautājumus, nepieciešams veikt kultūraugu šķirņu un genotipu atbilstošu atlasi (to varētu uzskatīt par svarīgāko adaptācijas stratēǵiju). Lai to sekmīgi realizētu, jāveic vairāk pētījumu par dažādu šķirṇu un metožu pieejamību, kā arī jānosaka to praktiskās izmantošanas robežas,

- lai samazinātu sauso vasaras periodu ietekmi, jāizmato augsnes mitruma
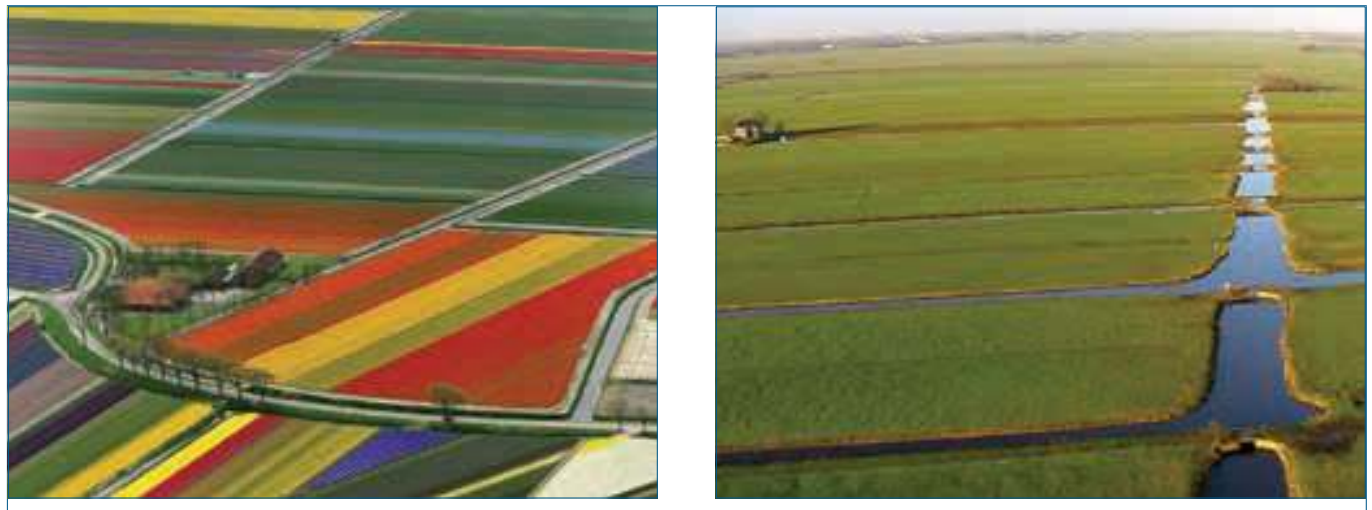

16.14. att. Nīderlandes lauksaimniecības atkarība no ūdens līmeṇa. 
saglabāšanas labākā pieredze, piemēram, saudzējošā augsnes apstrāde, atstājot dalı iepriekšējās sezonas kultūraugu atlieku uz augsnes virskārtas, kas var kalpot augsnes aizsardzībai pret vēja un ūdens eroziju, kā arī palīdz saglabāt mitrumu, samazinot iztvaikošanu un palielinot infiltrācija, bet kopumā arī uzlabojot augsnes struktūru,

- regulēt apūdeñošanu visā gada garumā, lai samazinātu sauso vasaru ietekmi un optimizētu ūdens izmantošanu.

\subsection{Piekrastes plānošana Horvātijā}

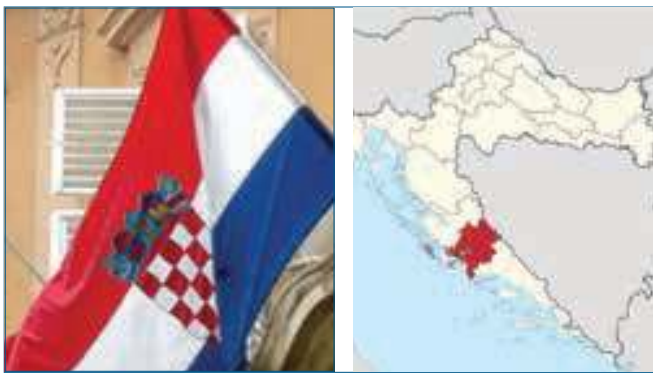

Horvātijas piekrastes garums gar Adrijas jūru ir apmēram $5800 \mathrm{~km}$ un ietver vairāk nekā tūkstoš salas un salinas. No tām 47 ir apdzīvotas. Šì piekraste nodrošina dinamisku telpu, kurā attīstītās dažādas tautsaimniecības nozares - lauksaimniecība, tūrisms, gāzes ieguve jūrā, zivsaimniecība, kuǵu būvniecība utt.

Globālā sasilšana un jūras līmeṇa celšanās rada tiešus draudus Horvātijas piekrastei un ekonomikai. Jūras līmeña celšanās varētu padarīt ostas mazāk drošas, īpaši vētru laikā, piesārṇot ar sālsūdeni saldūdens ieguves vietas

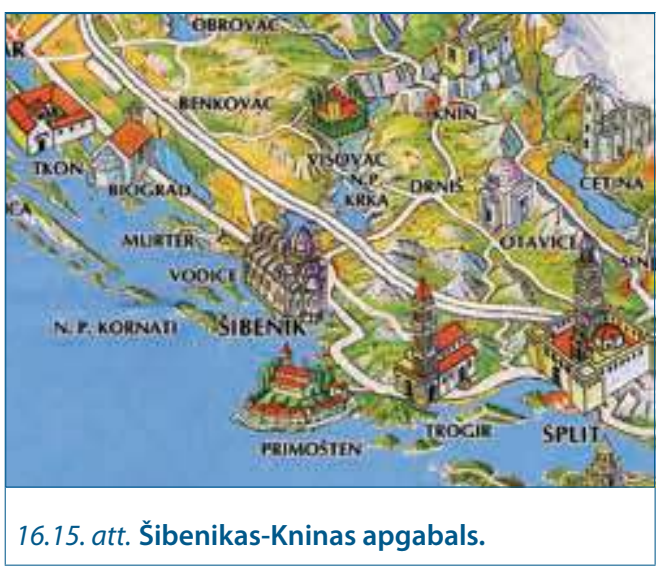

piekrastē, kaitēt ekosistēmām, piemēram, mitrājiem un purviem, tādējādi apdraudot vietējo biologisko daudzveidību, kā arī radīt kaitējumu vēsturiskām un tūristu atpūtas vietām, kas ir svarīgas kultūras un ekonomiskās vērtības.

Šibenikas-Kninas apgabals atrodas starp Adrijas jūru un Bosniju-Hercegovinu. Šibenikas-Kninas pašvaldība sadarbībā ar Pasaules Vides fondu, ANO Vides programmu un Horvātijas piekrastes zonas apsaimniekošanas programmu ir izstrādājusi savu "Piekrastes plānu", lai pētìtu un mazinātu klimata pārmaiṇu ietekmi piekrastes teritorijās.

Šis projekts lielā mērā iekḷaujas Vidusjūras reǵiona integrācijas programmā par nacionālo klimata pārmaiṇu adaptācijas stratēgiju izstrādāšanu un koordinēšanu. "Piekrastes plāna" mērksis ir panākt ilgtspējīgu attīstību Šibenikas-Kninas apgabalā septinās plašās jomās: iedzīvotāji, teritorija, piekraste, jūra, ūdens, daba un tautsaimniecība, izstrādājot vadlīnijas un rekomendācijas politikas veidotājiem, kā arī

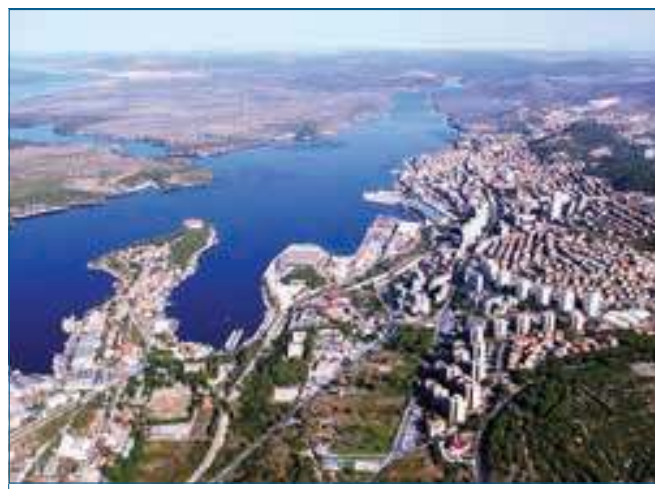

16.16. att. Šibenikas pilsēta. 
paplašinot irdzīvotāju līdzdalību un izglītības līmeña paaugstināšanu, īpaši par vietējās piekrastes kopienu pārvaldību.

Šibenikas-Kninas apgabala "Piekrastes plānā" tika izmantotas divas novatoriskas pieejas:

- izvēlētajai metodikai nepieciešamie īpaši sagatavotie dati (vietējie dabas un sociālie dati, kas modificēti interpolācijas variāciju analīzes veikšanai) integrētu datora model̦u izstrādei, lai prognozētu dažādas adaptācijas stratēgijas,

- līdzdalības metodologija, lai apvienotu ieinteresētās personas ilgtspējas līmeṇa

\subsection{2. "Klimata bēglị"}

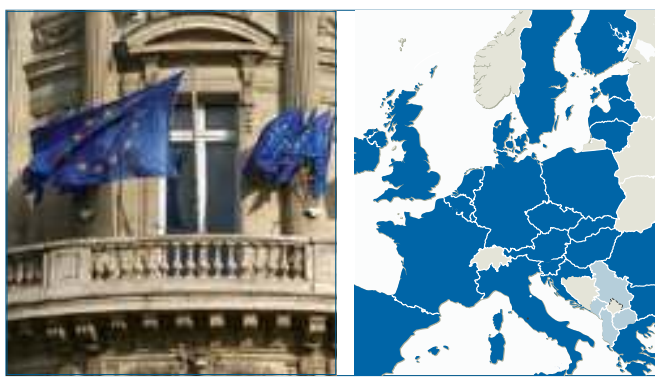

Zemes klimats mainās. Daudzas ǵimenes un kopienas pasaulē cieš no negatīvām klimata pārmaiṇām un ir spiestas pamest savas mājas.

Klimata pārmainu ietekmē sarūk dabas resursi, piemēram, pieeja dzeramajam ūdenim kḷūst arvien ierobežotāka. Daudzi kultūraugi un mājlopi atsevišksās vietās, iespējams, neizdzīvos, ja kḷūs pārāk karsts un sauss vai arī pārāk auksts un mitrs. Pārtikas nodrošinājums, kas jau tagad rada būtiskas problēmas, izsīks vēl vairāk.

Klimata pārmaiñas nav tikai vērtējums par vidi - tās ietekmē arī valdību un ekonomiku stabilitāti, bet jo īpaši - cilvēku veselību, labklājību un laimi.

Konflikti par piekḷuvi ūdenim un auglīgām zemēm palielinās līdz ar iedzīvotāju skaita pieaugumu. Bruņoto konfliktu saknes Sīrijā daudzos gadījumos saistās ar ūdens trūkumu lauksaimniecībai, izsīkstot ūdenim Eifratas un novērtēšanā konkrētā teritoriālā vienībā un izstrādātu risinājumus paaugstinātai noturībai pret klimata pārmainām.

Attiecībā uz Šibenikas-Kninas apgabala "Piekrastes plānu" tika organizēti četri semināri - katru gadu divi, kuros bija iesaistīti aptuveni 50 dalībnieki.

Izmantojot šādu integrētu pieeju "Piekrastes plāns" sniedza iespējamos risinājumus, piemēram, par ūdens apsaimniekošanas veidiem, infrastruktūru, meža ugunsgrēkiem, kopējo regionālo attīstību, teritorijas plānošanu, procesa pārvaldību.

Tigras upju baseinos, un ar ilgiem sausuma periodiem. Irākas un Sīrijas konflikta rezultātā iezīmēsies vara, kas kontrolēs reǵiona sarūkošos ūdens krājumus.

Cilvēkiem jāpielāgojas jaunai situācijai, bet tas daudziem nozīmē arī pārcelšanos uz citu vietu, lai izdzīvotu. Šāda piespiedu darbība, kas saistīta ar klimata pārmainu negatīvo ietekmi, ìstenojas attiecībā uz dabas resursiem. Uzliesmo arī konflikti kopienu starpā, jo aizvien vairāk cilvēku sāk sacensties par atlikušajiem resursiem.

Bēgḷ plūsmas rodas ekstremālās situācijās, un tās, visticamāk, jau tuvākajā nākotnē būs daudz apjomīgākas. Lielākā daļa "klimata bēglıu" vēlas iegūt "iekšzemē pārvietotas personas" statusu, lai gan tas nozīmē iekḷūt sociālajā grupā, kas ietver pasaules neaizsargātākos iedzīvotājus. Pat tad, ja viṇi ir bēguši līdzīgu iemeslu dēḷ kā bēgli no valsts (bruṇoti konflikti, vispārēja vardarbība, cilvēktiesību pārkāpumi), tomēr šie cilvēki juridiski paliek savas valdības aizsardzībā, jo tā ir atbildīga par šāda stāvokḷa rašanos.

"Klimata bēglis" ir persona, kura ir spiesta pamest savas mājas klimata pārmaiṇu un globālās sasilšanas ietekmē. Līdz ar temperatūras paaugstināšanos palielinās ekstremālo laika apstākḷu biežums, kultūraugi izkalst, iet bojā dzīvnieki, tāpēc pieaug globālā masu migrācija un robežu konflikti. Izcirsto mežu vietā uz 


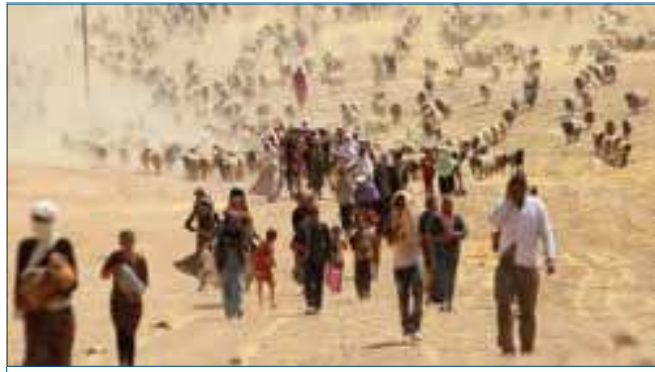

16.17. att. Cilvēku pārvietošanās klimata pārmainu izraisīto dabas katastrofu dēḷ.

kalnu nogāzēm ir izveidoti tīrumi, kurus tagad noskalo aizvien intensīvākas lietusgāzes, kas appludina ar dublıiem zemāk esošos ciematus.

Postošais pilsoṇu karš, kas sākās Sīrijā 2011. gadā, ir sarežǵìtu savstarpēji saistītu faktoru rezultāts. Kaut gan konflikta uzmanības centrā ir režìma maiṇa, tomēr cēloṇi ietver plašu reliǵisko un sociālās politikas faktoru kopumu, ekonomiskā stāvokḷa pasliktināšanos, politisko reformu vilni Tuvajos Austrumos un Ziemel̦āfrikā, kā arī problēmas, kas saistītas ar klimata pārmaiṇām un, jo īpaši, saldūdens pieejamību un izmantošanas iespējām. Sīrijas vēsture ietver daudzus konfliktus par dzeramo ūdeni, jo reǵionā pastāv ūdens nepietiekamība, kas ir nepieciešams lauksaimniecībā un pārtikas apgādē.

Kūst ledāji un paaugstinās jūras līmenis, kas nogremdē salas un zemākās piejūras teritorijas daudzās valstīs, rīsu laukus applūdina sālsūdens. Paaugstinātais toksisko k,imikāliju piesārn,ojums upēs un okeānos nogalina zivis un apdraud iztikas pieejamību. Tāpēc cilvēki bēg. Diemžēl daudzi no bēgliem atklāj, ka viṇu prasmes, piemēram, labības vai dārzeṇu audzēšana un tradicionālā saimniekošana vairs nav izmantojama jaunajā dzīves vietā, tādēl bēgliem ir grūti atrast darbu.

ANO aprēksini parāda, ka 2009. gadā (kopš šì gada pasaulē ir pieejami korekti statistikas dati par bēgliem) dabas katastrofu un neražas dēḷ pārvietojušies apmēram 36 miljoni cilvēku. Zinātnieki prognozē, ka šis skaits varētu pieaugt līdz 200 miljoniem 2050. gadā - tas nozīmē, ka 34 gadu laikā, viens no katriem 45 cilvēkiem pasaulē būs spiests pārvietoties klimata pārmaiṇu dēḷ.

"Klimata bēglil" saskaras ar daudzām problēmām - tos ne vienmēr aizsargā starptautiskās tiesības. Neraugoties uz lielo bēglu skaitu, daudzas valstis neatzīst bēgḷ statusu. ANO Konvencija par bēglu statusu (1951) definē

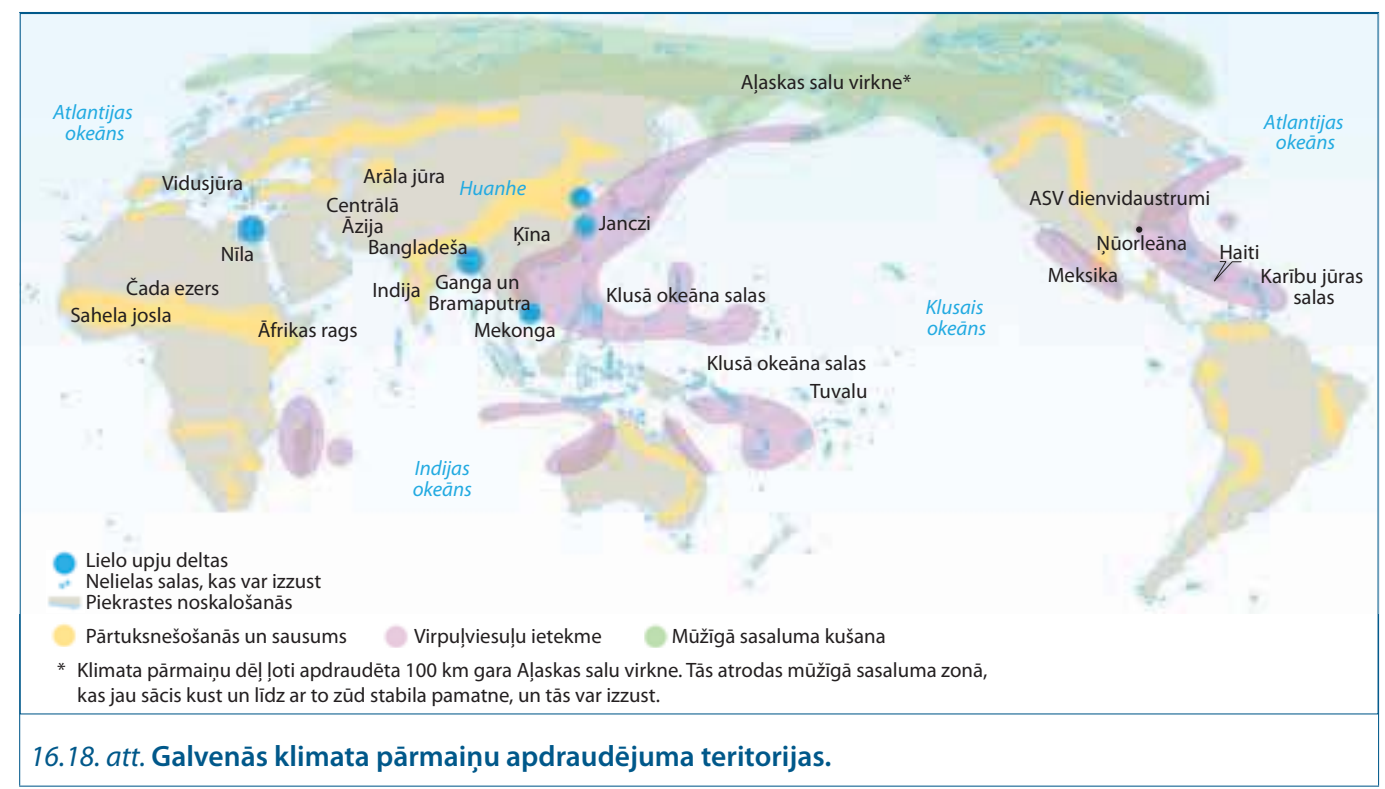


bēgli kā personu, kuram ir patiesas bailes no vajāšanas saistībā ar piederību kādai konkrētai sociālajai grupai, kategorijai vai šķirai. "Klimata bēgli" ne vienmēr tiek vajāti, tomēr ir spiesti bēgt, tāpēc faktiski pēc Konvencijas definīcijas neatbilst bēgla statusam.

Tā kā "klimata bēglis" vēl nav oficiāli atzīts saskaṇā ar starptautiskajām tiesībām, joprojām nav atbilstošas konvencijas, protokolu un īpašu vadlīniju, kas varētu sniegt aizsardzību un palīdzību cilvēkiem, kas šksērso starptautiskās robežas nelabvēlīgo klimata pārmainu dēḷ.

Pēdējā laikā palielinās tieši "klimata bēglı" skaits visā pasaulē kopumā, un to ir apmēram trīs reizes vairāk nekā to bēgḷu, kas dodas svešumā konfliktu un karu dēḷ. Maldīvu salas un Tuvalu lēnām izzūd, jo jūras līmenis turpina paaugstināties.

Pasaules Banka lēš, ka ar 1 metra jūras līmeña kāpumu Bangladeša zaudētu gandrīz $20 \%$ no savas valsts teritorijas. Tā rezultātā būtu neskaitāmi nāves gadījumi un desmitiem miljonu "klimata bēglu".

N,emot vērā pašreizējās neražas, zvejniecības, bioloǵiskās daudzveidības un plūdu problēmas, daudzi apdraudēto teritoriju iedzīvotāji jau ir aizceḷojuši uz citām valstīm, kur viṇi cer pārdzīvot posta periodu un pēc tam atgriezties atpakal.

Arī Kīna ir kḷuvusi par vides katastrofu vietu saistībā ar neilgtspējīgu attīstību, milzīgo gaisa piesārṇojumu un saindētām upēm. Līdz ar plašu teritoriju pārtuksnešošanos un antropogēno katastrofu un avāriju pieaugumu, Kīnu jau atstājuši desmitiem miljonu cilvēku.

Par klimata pārmaiṇām un migrāciju nav un nevar būt precīza nākotnes scenārija, jo nav atbilstošu datu un tieša cēloṇu-seku redzējuma. Ja kḷūst karstāks vai lietusgāzes kḷūst intensīvākas, tas uzreiz neizraisa lielāku migrāciju. Vairumā gadījumu migrāciju izraisa mijiedarbība starp ekonomiskiem, politiskiem, sociāliem, kultūras un vides faktoriem. Tas pats attiecas uz vardarbīgu konfliktu uzliesmojumiem, kas ir galvenais iemesls pēdējā laika bēglu plūsmai. Tomēr klimata pārmaiņas var radīt pamatu vardarbīgu konfliktu attīstībai. Tāpēc politiskā stabilitāte un spēja sniegt neatliekamu palīdzību problēmu skartajās valstīs ir būtiska, lai nepiel̦autu konfliktu izplatǐšanos.

Klimata pārmaingas nav vienādu draudu iespēja visiem, jo pārtikas pieejamība, spēcīgas vētras un nežēlīgs sausums visvairāk liek ciest tieši pasaules nabadzīgākajām valstīm.
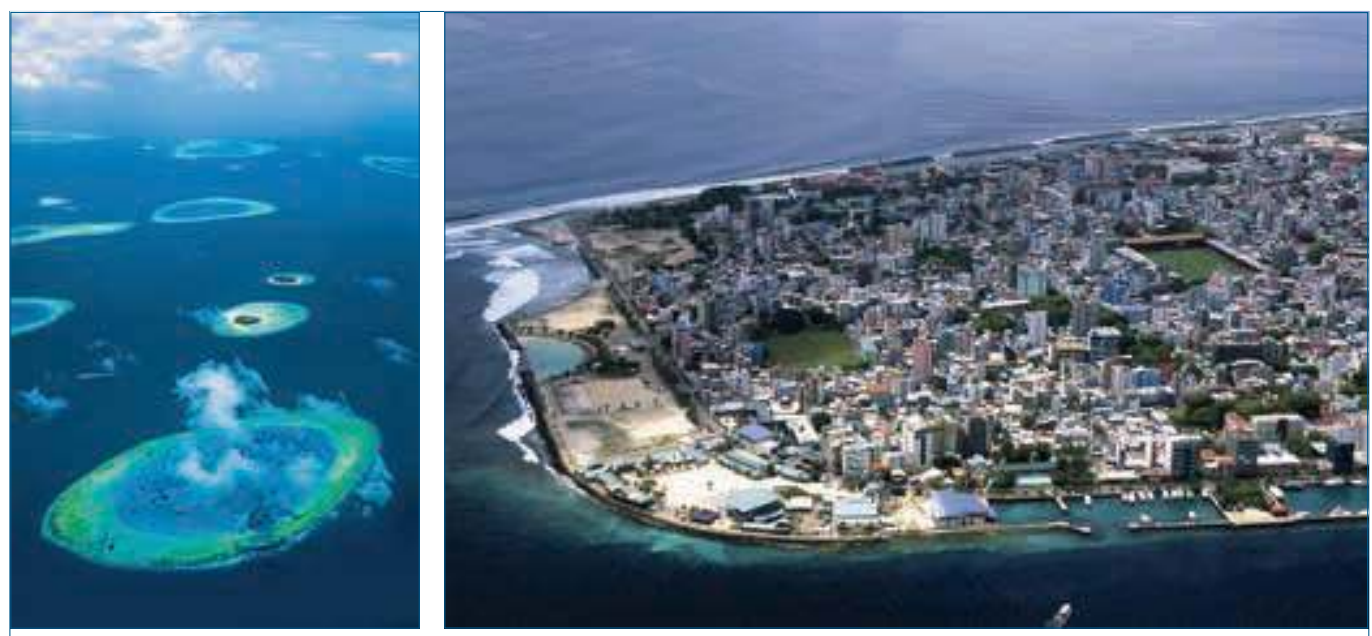

16.19. att. Maldīvijas Republikas salas un galvaspilsēta Male. Valsts teritorija aizñem apmēram 90000 km², bet pamatā ir Indijas okeāna neliela daḷa ar l̦oti daudzām, izkaisītām salām (1190), kuru augstākais

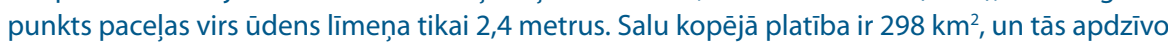
apmēram 340000 iedzīvotāju. (Rīgas platība ir 304 km².) 
Sievietes ir īpaši neaizsargātas pret klimata pārmainu sekām, un tās veido $80 \%$ no klimata bēgliem. Sieviešu dzimuma "klimata bēglēm" nākas saskarties ar papildu briesmām (seksuālu vardarbību, kā arī ar grūtniecību saistītiem sarežgijijumiem - slimībām un pat mirstību).

Bēglu pārvietošanās laikā ḷoti cieš bērni, kas tiek l̦aunprātīgu izmantoti un pat ierauti cilvēku tirdzniecības apritē. Pasaules pieredze liecina, ka pēc Pinatubo vulkāna izvirduma Filipīnās (1991), spēcīgas viesulveētras Nikaragvā (1998) un Ziemel̦kalifornijas zemestrīces ASV (1989), vardarbība bija ievērojami palielinājusies. Tāpat ziṇojumi no Šrilankas un Indonēzijas pēc Indijas okeāna cunami (2004) pastiprina bažas par seksuālu vardarbību.

Globālās sasilšanas kontekstā migrācija izpaužas daudz biežāk kā pagaidu process vai reǵionālā kustība nekā masveida emigrācija uz citiem kontinentiem, piemēram, no Subsahāras Āfrikas uz Eiropu. Tas ir tāpēc, ka daudzas klimata pārmainu izpausmes visvairāk ietekmē tiešu dabas resursu izmantošanu, kas nodrošina iztiku sīkzemniekiem, lopkopjiem un zvejniekiem.

Visbiežāk šie cilvēki pieskaitāmi nabadzīgāko iedzīvotāju grupām un tiem nav pietiekami daudz līdzekḷu, lai vispār varētu aizcel̦ot. Šĩ iemesla dēl uz tiem varētu attiecināt raksturojumu "iesprostotā populācija". Šos cilvēkus nelaimes skar īpaši smagi, jo klimata pārmainu rezultātā samazinās pārtikas pieejamība. Tādā gadījumā "ne-migrācija" var radīt daudz vairāk problēmu nekā migrācija.

Kad cilvēki atstāj savas mājas sakarā ar klimata pārmaiṇām, viṇi parasti pārvietojas savās valstīs vai uz kaimiṇvalstīm. Un tie biežāk ir atsevišksi gimenes vai mājsaimniecības locekḷi, kuri pamet savas mājas, nevis visa ǵimene. Viṇi izmanto nopelnīto naudu, lai atbalstītu ǵimeni, kas pakḷauta nelabvēlīgiem apstākḷiem.

Klimata pārmaiṇu starpvaldību padomes 5. novērtējuma ziṇojums (2014) norāda, ka "klimata pārmaiṇas var netieši palielināt vardarbīgu konfliktu riskus, ko apstiprina dokumentētas tendences un gadījumi saistībā ar nabadzību un ekonomiskiem satricinājumiem". Îpaši tiek uzsvērta klimata pārmaiṇu ietekme

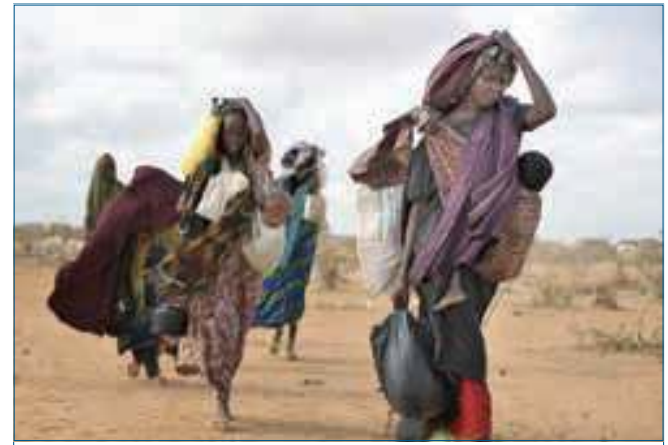

16.20. att. Sausuma pārṇemtās Somālijas “klimata bēgḷi" ierodas Dadaabas nometnē Kenijā.

uz daudzu mazo salu jaunattīstības valstīm, kuras jau pašlaik apdraud jūras līmeña paaugstināšanās. Tas attiecas arī uz nepieciešamību veikt ilgtspējīgu zemes apsaimniekošanu, lai varētu mazināt klimata pārmainu kaitīgo ietekmi - pārtuksnešošanos, sausumu un zemes degradāciju - parādības, kas var izraisīt piespiedu migrācijas plūsmas un konfliktus par izzūdošiem resursiem.

Šāda jautājuma nostādne ir izraisījusi bažas arī ANO Drošības padomē, kura ir aicinājusi apspriest, kā ANO varētu visaptverošā un koordinējošā veidā risināt drošības jautājumus saistībā ar klimata pārmaiṇām. ANO Drošîbas padome ir pieprasījusi arī atbilstošu papildu informāciju par tām situācijām, kādas klimata pārmaiṇas varētu izraisīt konfliktus, kur un kāpēc tas varētu notikt un vai tas nevarētu apdraudēt miera nodrošināšanas procesus pasaulē.

ANO Drošības padomes pastāvīgie locekḷi ir atbalstījuši viedokli, ka Vispārējā konvencija par klimata pārmaiṇām un tās îstenošana ir svarīga ANO sistēmā, jo ietver miera un drošības jautājumus pasaulē, to skaitā arī mazo salu jaunattīstības valstu likteni.

Savukārt NATO Parlamentārā asambleja (rezolūcija Nr. 427 "Par klimata pārmaiṇām un starptautisko drošību”; 12.10.2015., Stavangera, Norvēǵija) ir pārliecināta, ka ar klimata pārmaiṇām saistītie riski ietekmēs starptautisko drošību. Tas attiecas uz biežākām dabas 


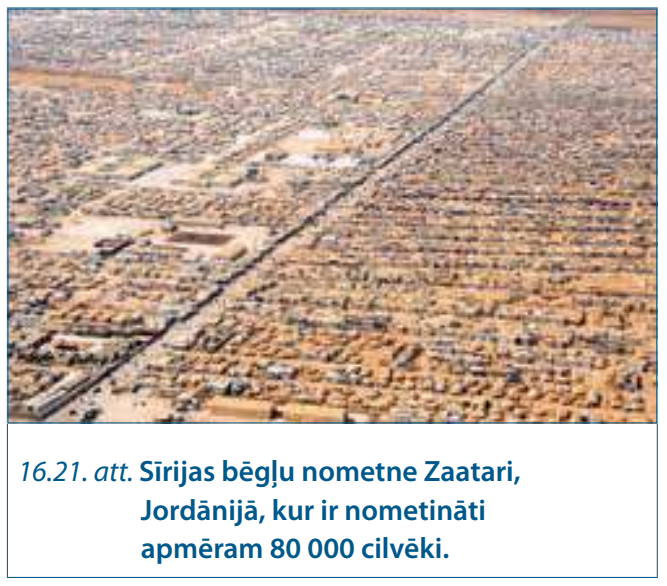

katastrofām, ekonomikas grūtībām, pārtikas un ūdens nepietiekamību, sabiedrības veselības aizsardzības sistēmas vājināšanos, iekšējo un ārējo migrāciju, konkurenci par resursiem.

Ar klimata pārmain̄ām saistītie riski ir nopietns apdraudējums daudzās drošības jomās, tie skar NATO, kā arī var potenciāli un pat būtiski ietekmēt NATO plānus un operācijas. Tāpēc tiek atzìts par nepieciešamību papildināt negatīvo klimata pārmaiṇu mazināšanas rīcības arī ar centieniem stiprināt valstu un sabiedrības noturību, humānās palīdzības paplašināšanu, miera uzturēšanu un konfliktu novēršanas programmu îstenošanu.
NATO kopumā un tās dalībvalstis tiek mudinātas izvērtēt, kā NATO kolektīvās drošības centieni ṇem vērā ar klimata pārmaiṇām saistītos apdraudējumus, jo īpaši sadarbībā ar NATO partneriem, kas ir īpaši neaizsargāti un pakḷauti klimata pārmaināām.

Kankunas "Vadlīnijas par pielāgošanos klimata pārmaiṇām" izriet no Kankunas nolīgumiem, kas tika pien,emti Klimata pārmaiṇu konferencē Kankunā, Meksikā (2010). To mērksis ir uzlabot pielāgošanās pasākumus starptautiskās sadarbības un saskan,otas rīcības jomā, uzsverot jautājumus, kas saistīti ar uzturēšanās spēju veicināšanu jaunattīstības valstīs, kas ir īpaši neaizsargātas. Kankunas Vadlīnijas bija pirmais starptautiskais dokuments par cilvēku migrāciju saistībā ar klimata pārmaināām un turpmāk veidoja starptautisku diskusiju par lēmumu pien,emšanu, lai veidotu nākotnes vīziju saistībā ar cilvēku migrāciju.

ANO Klimata pārmaiṇu konferencē Varšavā, Polijā (2013) tika izveidots Varšavas "Starptautiskais mehānisms par zaudējumiem un kaitējumiem, kas saistīti ar klimata pārmaiṇu negatīvo ietekmi", ieskaitot dabas katastrofas un negaidītus ārkārtējus notikumus, kā arī lēni progresējošus, bet draudīgus notikumus. Pārsvarā šis dokuments ir orientēts uz jaunattīstības valstīm, kuras ir vāji aizsargātas pret nelabvēlīgu klimata pārmaiṇu ietekmēm.

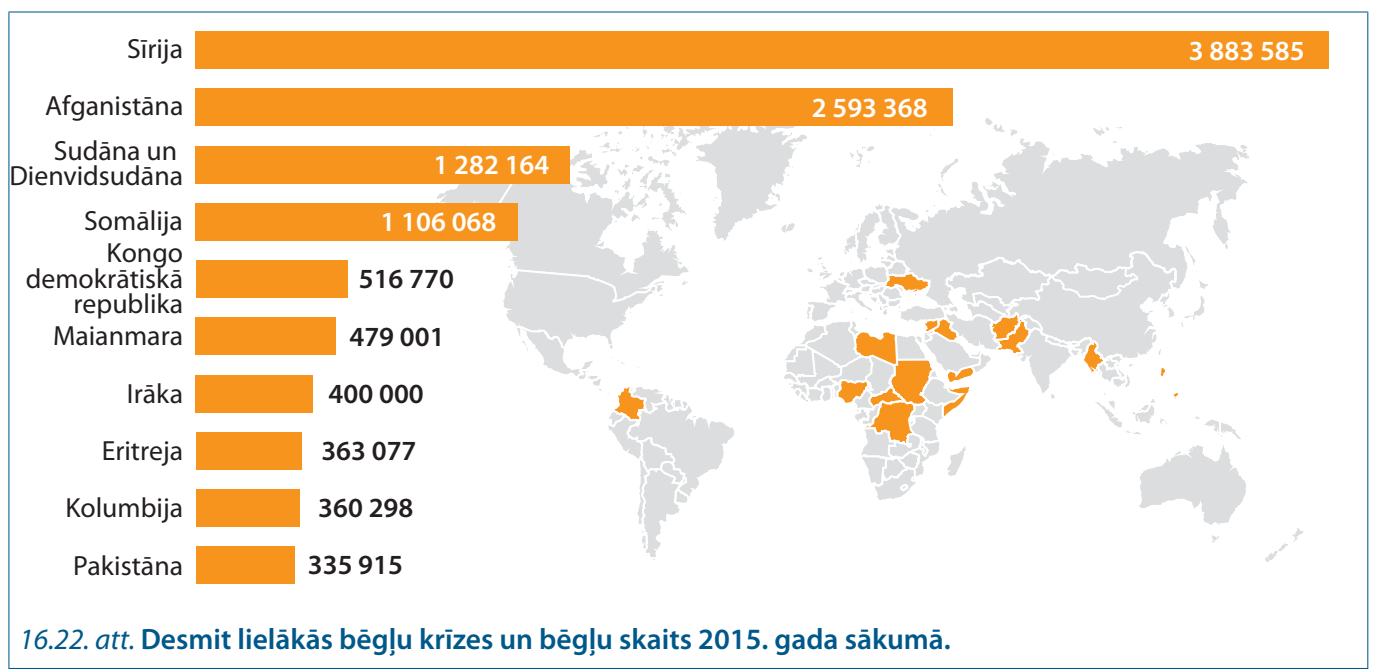


Šis mehānisms izriet no ANO Klimata pārmainu konvencijas un paredz:

- paaugstināt zināšanas un izpratni par visaptverošas riska pārvaldības uzlabošanas pieejām,

- veicināt dialogu, koordināciju un saskaņotību starp ieinteresētām valstīm, valdībām un institūcijām,

- uzlabot rīcības un praktisku atbalstu, arī finanšu, tehnoloǵiju un resursu palielināšanu.

ANO Augstais komisārs bēg̣̣u jautājumos ir Filipo Grandi (ir ieñēmis šo amatu no 1.01.2016. un pildīs pienākumus līdz 31.12.2020.). Vinsš piel̦auj, ka klimata pārmainas kḹūs par galveno faktoru saistībā ar iedzīvotāju pārvietošanos gan iekšzemē, gan arī pāri valstu robežām ne pārāk tālā nākotnē. Viṇš vada vienu no pasaules lielākajām humānās palīdzības organizācijām. Tās gandrīz 10000 darbinieki strādā 126 valstīs, nodrošinot aizsardzību un palīdzību gandrīz 60 miljoniem bēglu, valsts iekšienē pārvietotajām personām, bezvalstniekiem un personām, kas atgriežas dzimtenē. Gandrīz $88 \%$ no personāla darbu veic sarežǵìtos, bieži vien bīstamos apstākḷos. ANO Bēg̣̦u aǵentūras 2016. gada budžets ir 6,5 miljardi ASV dolāru.

Pasaulē ir sācies "bēglu laikmets", tāpēc jārēksinās ar gaidāmo krīzi. Viena no draudīgākajām prognozēm saistībā ar klimata pārmaiṇām ir tā, ka miljoniem, varbūt pat desmitiem vai simtiem miljonu cilvēku nāksies pamest savas dzimtās vietas un meklēt jaunas mājas. Vēl sarežgìtāku situāciju var padarìt tas, ka savstarpēji cieši saistītā pasaule var būt nespējīga tikt galā ar šo problēmu.

Mēs jau saṇemam brīdinājumus, ka pašreizējā bēgl̦u krīze ir tikai nieks salīdzinājumā ar daudz lielāku "klimata bēglulu" plūsmu, kas varētu sasniegt Eiropu nākotnē, jo klimata pārmaiṇas pasaulē turpinās. Bēgḷus uzṇemošās Eiropas valstis Parīzes ANO Klimata konferences laikā (2015) jau ir ieteikušas sniegt pienācīgu atbalstu nabadzīgajām valstīm, kuras ir skārušas klimata pārmaiñas.

Klimata pārmaingas nav tikai iespēja politikiem, administratoriem, zinātniekiem un pētniekiem strādāt, pirms problēmas kḷūst pārāk dramatiskas. Tā ir pasaules mēroga problēma, kas notiek tieši tagad, un "klimata bēglu" skaits

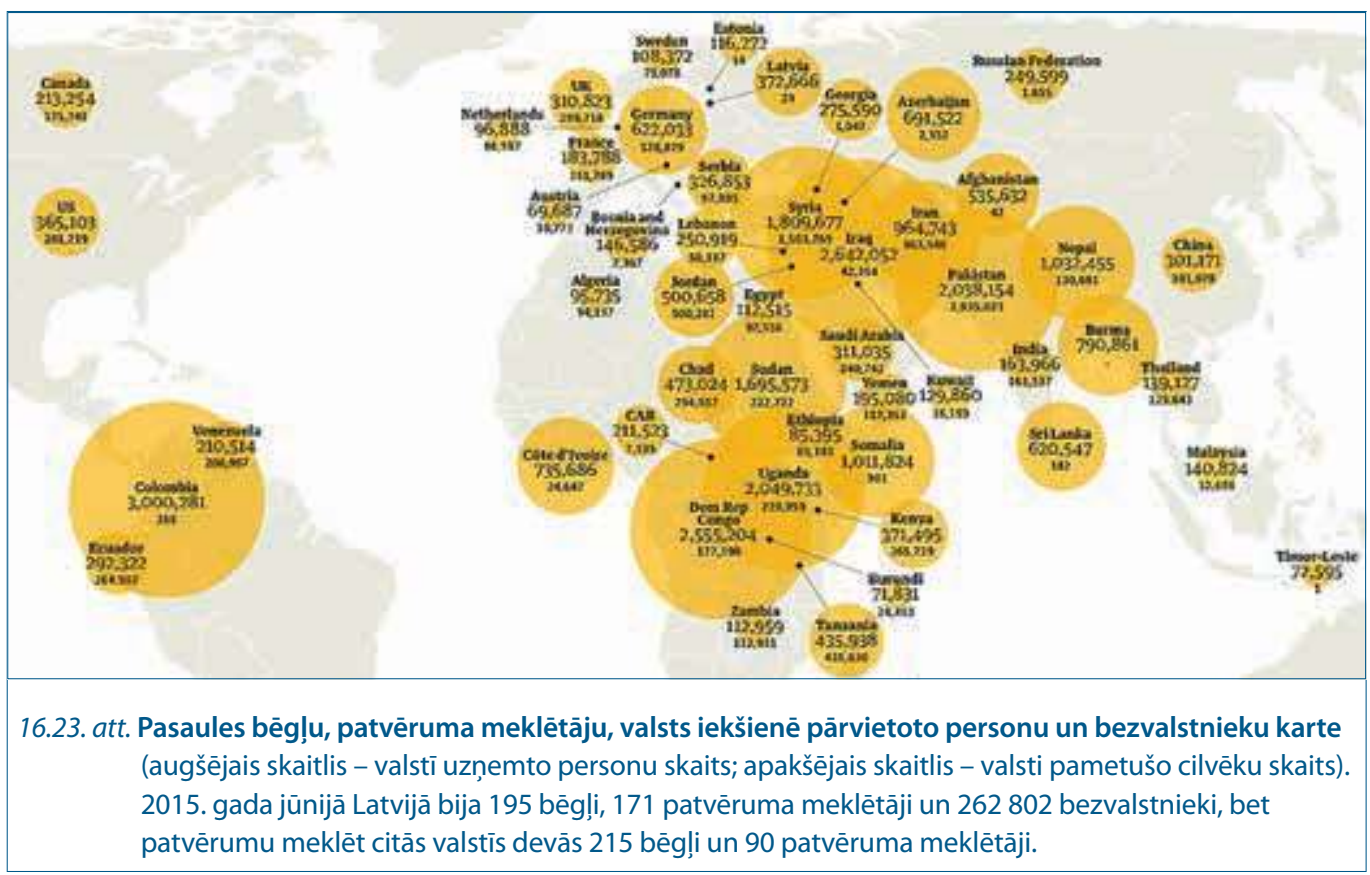




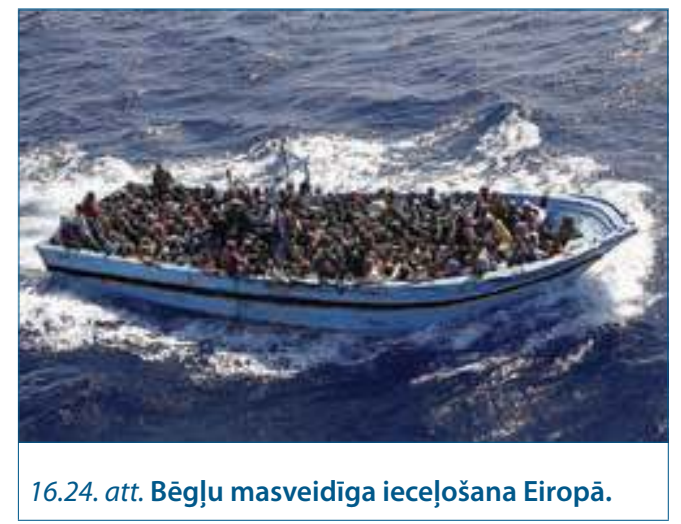

turpina pieaugt. Tas apdraudēs ne tikai atsevišķus cietušos indivīdus, bet varētu izraisìt arī masveida negatīvas sekas cilvēcei kopumā. Piespiedu cilvēku pārvietošanās klimata pārmaiṇu dēḷ jau ir palielinājušas robežkonfliktus un politisko nestabilitāti. Pat Pentagons tagad uzskata, ka klimata pārmain,as rada nopietnus riskus ASV valsts drošībai.

Rietumu civilizācijai jāuzṇemas vēsturiska atbildība par izraisītajām klimata pārmaiṇām. Tas prasīs finansiāla atbalsta sniegšanu pielāgošanās pasākumiem smagi skartajās valstīs un tiešu palīdzību valstīm, kas cieš no klimata pārmaiṇu radītajiem kaitējumiem un zaudējumiem. Tas jādara, lai nepadarītu cilvēkus kḷūt par "klimata bēgliem".

2012.-2013. gada publiskais finansējums klimata pārmaiṇu mazināšanai pasaulē bija apmēram 23 miljardi eiro. Tomēr jaunattīstības valstīm vēl būtu nepieciešami papildu vismaz 70 miljardi gadā, jo tikai 16\% no sabiedriskā finansējuma izmanto pielāgošanās pasākumiem (tas ir liels finansējuma iztrūkums).

Apsveicami, ka Parīzes Vienošanās paredz jaunu kolektīvo kvantitatīvo mērksu sasniegšanas finansējumu - 100 miljardus ASV dolāru $(\approx 88$ miljardi eiro) gadā, n,emot vērā jaunattīstības valstu vajadzības un prioritātes.

Ir svarīgi, lai visu valstu valdības sagatavotu nacionālos klimata pārmainu pielāgošanās plānus un tos īstenotu, mazinot nelabvēlīgo ietekmi. Pielāgošanās ietver visu, sākot ar plūdu aizsargbarjeru būvniecību un beidzot ar skolēnu mācīšanu par mainīgajiem klimatiskajiem apstākḷiem. Turklāt turīgākām valstīm vajadzētu palielināt finansējumu pielāgošanās vajadzībām neaizsargātākām jaunattīstības valstīm.

ASV prezidents Baraks Obama savā 2015. gada "Ziṇojumā par stāvokli valstī" (State of the Union) norādīja, ka "Neiesaistīšanās globālo problēmu risināšanā radīs lielākus draudus nākamajām paaudzēm nekā pašas klimata pārmaiñas. Ja mēs nerīkosimies stingri un mērkstiecīgi, mēs piedzīvosim bīstamus sausuma un plūdu periodus, masveida nelaimes, kas var izraisīt migrāciju, konfliktus un badu visā pasaulē".

Daudzsološa iezīme ANO Klimata pārmainu konferences laikā Parīzē bija ASV valsts sekretāra Džona Kerija paziṇojums, ka ASV dubultos valsts finansējumu, lai pielāgotos klimata pārmaiṇām, līdz vairāk nekā 800 miljoniem dolāru gadā.

\subsection{Klimata pārmaiṇu radītie riski Latvijai un ieteikumi to novēršanai}

Latvijas galvaspilsēta Rīga atrodas Daugavas krastos pie Rīgas līča. Galvenie plūdu riski galvaspilsētā ir vētras ziemā, ledus kušanas laiks pavasarī un ūdens līmeña paaugstināšanās, ko izraisa ūdens nopludināšana pa Daugavu.

2010. gadā Rīgas domes Pilsētas attīstības departaments sāka īstenot "integrētu stratēgiju, lai Rīgas pilsēta pielāgotos hidrologisko procesu izmaiñām saistībā ar klimata pārmaiṇām". Ievērojamais ekonomiskais kaitējums, ko ir radījuši plūdi, visticamāk palielināsies klimata pārmaiṇu dēḷ. Jāveic detalizēti pētījumi par klimata pārmaiṇu ietekmi uz plūdu norises procesiem, lai izstrādātu atbilstošu adaptācijas 
stratēǵiju. Lai gan stratēǵijas izstrādāšanai varētu būt labs sākums, Rīgas dome varētu iepazīties arī ar citu pilsētu līdzīgām situācijām un izstrādāt pilnīgāku adaptācijas stratēǵiju, kas ierobežotu plūdu negatìvo ietekmi.

Lauksaimniecības nozares IKP īpatsvars Latvijā nav augsts, bet tā nozīme tautsaimniecībā ir liela - tā ir svarīga nozare, ar kuru jārēḳinās, lai pielāgotos klimata pārmaiṇām.
Nīderlande un Latvija ir no tā paša Atlantijas un boreālā ekoreǵiona. Reāli tie nav identiski, bet ar daudzām līdzībām. Tas nozīmē, ka arī klimata pārmaiṇu sekas varētu būt līdzīgas.

Tāpēc būtu lietderīgi izmantot Nīderlandes klimata pārmaiṇu adaptācijas stratēgiju, pilnveidojot un attīstot ar Latvijas klimata pārmain̄ām saistītos politikas plānošanas dokumentus.

\section{Literatūra}

\subsection{Norvēǵgijas Klimata līgums}

Berglund N., Goll S. (2010, 12 13) Solheim happy with climate compromise. Hentet 11 14, 2015 fra newsinenglish.no: http://www.newsinenglish.no/2010/12/13/solheim-happy-with-climate-compromise/

Borge L.-E. (2015, December 09). Norsk Offentlig Utredning 2015:15 Sett pris på miljøet - Rapport fra grønn skattekommisjon. Hentet December 13, 2015 fra regjeringen.no: https://www.regjeringen.no/no/dokumenter/nou2015-15/id2465882/?q=\&ch=1

\section{Bright Green Island Catalogue.}

Bright Green Island web page (u.d.). Hentet fra http://brightgreenisland.com/

Bruvoll A., Dalen H. M. (2009). Pricing of $\mathrm{CO}_{2}$ emissions in Norway - Documentation of data and methods used in estimations of average $\mathrm{CO}_{2}$ tax rates in Norwegian sectors in 2006. Oslo: Statistics Norway.

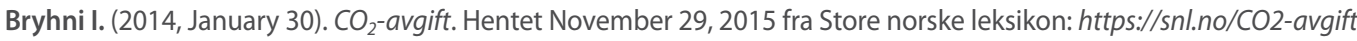
Danielsen M. A. (2014, November 17). Regjeringen.no. Hentet November 29, 2015 fra Grønn skatteomlegging i Europa: https://www.regjeringen.no/no/aktuelt/Gronn-skatteomlegging-i-Europa/id2340842/

EcoGrid EU: From Design to Implementation - summary (u.d.). Hentet fra http://www.eu-ecogrid.net/images/ Documents/131120_ecogrid_popular_summary.pdf

Environment, N. D. (2012, 06 11) Klimaforliket vedtatt i Stortinget. Hentet 11 14, 2015 fra Regjeringen.no: https:// www.regjeringen.no/no/aktuelt/klimaforliket-vedtatt-i-stortinget/id684927/

Europaportalen (2009, December 04) Regjeringen.no. Hentet November 29, 2015 fra CO2-skatt: Fordeler og ulemper: https://www.regjeringen.no/no/aktuelt/co2-skatt-fordeler-og-ulemper/id694307/

Furdal T. (2012, 06 08) New cross-Party climate compromise agreed. Hentet 11 14, 2015 fra aftenbladet.no: http:// www.aftenbladet.no/energi/aenergy/New-cross-Party-climate-compromise-agreed-2985720.html

IEA, I. E. (2012) Nordic Energy Technology Perspectives. Oslo: IEA/Nordic Energy Research.

IETA, I. E. (2013, May) ieta.org. Hentet November 29, 2015 fra Norway - The World's Carbon Markets: A Case Study

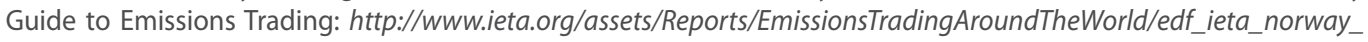
case_study_may_2013.pdf

Norwegian Government (2011-2012) White paper on Norwegian climate politics. Meld. St. 21 (2011-2012) Norsk klimapolitikk.

Rolf Golombek M. G. (2015) Virkemidler som kan fremme utvikling og bruk av miljøteknologi. CREE/Frischsenteret.

Rosvold K. A. (2015, 06 19) Klimameldingen. Hentet 11 14, 2015 fra snl.no - Store norske leksikon: https://snl.no/ Klimameldingen

Rosvold K. A., Olerud K. (2015, 01 06) Klimaforliket. Hentet 11 14, 2015 fra snl.no - Store norske leksikon: https://snl. no/Klimaforliket

Schlaupitz H. (2012) Alt om klimameldingen. Hentet 11 16, 2015 fra naturvernforbundet.no: http://naturvernforbundet. no/klima/norsk_klimapolitikk/alt-om-klimameldingen-og-klimaforliket-article26633-131.html

World Bank (u.d.) worldbank.org. Hentet November 29, 2015 fra Putting a Price on Carbon with a Tax: http://www. worldbank.org/content/dam/Worldbank/document/Climate/background-note_carbon-tax.pdf 
16.2. Maksa par oglekl̦a savienojumu emisijām Norvēǵijā

Borge L.-E. (2015, December 09) Norsk Offentlig Utredning 2015:15 Sett pris på miljøet - Rapport fra grønn skattekommisjon. Hentet December 13, 2015 fra regjeringen.no: https://www.regjeringen.no/no/dokumenter/nou2015-15/id2465882/?q=\&ch=1

Bright Green Island Catalogue.

Bright Green Island web page (u.d.). Hentet fra http://brightgreenisland.com/

Bruvoll A., Dalen H. M. (2009) Pricing of $\mathrm{CO}_{2}$ emissions in Norway - Documentation of data and methods used in estimations of average $\mathrm{CO}_{2}$ tax rates in Norwegian sectors in 2006. Oslo: Statistics Norway.

Bryhni I. (2014, January 30) $\mathrm{CO}_{2}$-avgift. Hentet November 29, 2015 fra Store norske leksikon: https://snl.no/CO2-avgift

Danielsen M. A. (2014, November 17) Regjeringen.no. Hentet November 29, 2015 fra Grønn skatteomlegging i Europa: https://www.regjeringen.no/no/aktuelt/Gronn-skatteomlegging-i-Europa/id2340842/

EcoGrid EU: From Design to Implementation - summary. (u.d.). Hentet fra http://www.eu-ecogrid.net/images/ Documents/131120_ecogrid_popular_summary.pdf

Europaportalen (2009, December 04) Regjeringen.no. Hentet November 29, 2015 fra CO2-skatt: Fordeler og ulemper: https://www.regjeringen.no/no/aktuelt/co2-skatt-fordeler-og-ulemper/id694307/

IEA, I. E. (2012) Nordic Energy Technology Perspectives. Oslo: IEA/Nordic Energy Research.

IETA, I. E. (2013, May) ieta.org. Hentet November 29, 2015 fra Norway - The World's Carbon Markets: A Case Study Guide to Emissions Trading: http://www.ieta.org/assets/Reports/EmissionsTradingAroundTheWorld/edf_ieta_norway_ case_study_may_2013.pdf

Norwegian Government (2011-2012) White paper on Norwegian climate politics. Meld. St. 21 (2011-2012) Norsk klimapolitikk.

Rolf Golombek M. G. (2015) Virkemidler som kan fremme utvikling og bruk av miljøteknologi. CREE/Frischsenteret. World Bank (u.d.) worldbank.org. Hentet November 29, 2015 fra Putting a Price on Carbon with a Tax: http://www. worldbank.org/content/dam/Worldbank/document/Climate/background-note_carbon-tax.pdf

\subsection{Ilgtspējīgs ekociemats Norvēgiijā}

Hurdal Økolandsby (2014) Historikk, Bærekraftsdale Hurdal. $1^{\text {st }}$ ed. Hurdal: Hurdal Økolandsby, 2014. Web. 4 Dec. 2015. Hurdalsmodellen: $10 \varnothing$ øolandsbyer På 10 År. $1^{\text {st }}$ ed. Hurdal: Filago, 2015. Print.

16.4. Samso - Dānijas atjaunojamās enerǵijas sala

Denmark, Samsø. "Samsø - Denmark | Profile | State Of Green". Stateofgreen.com. N.p., 2015.

Godoy J. "ENERGY-DENMARK: SAMSO ISLAND - LIVING IN HARMONY WITH NATURE". Global Information Network 2009. Web. 4 Dec. 2015.

Jørgensen P. J. Samsø - A Renewable Energy Island: 10 Years of Development and Evaluation. $2^{\text {nd }}$ ed. Samsø Energy Academy, 2007. Web. 4 Dec. 2015.

Nevin J. "The Power of Cooperation". The Behavior Analyst 33.2 (2010): 189. Web. 2015.

Saastamoinen M. "Contextualising Behavioural Change in Energy Programmes Involving Intermediaries and Policymaking Organizations Working Towards Changing Behaviour: Samsö - Renewable Energy Island Programme". Energychange.info. N.p., 2009. Web. 4 Dec. 2015.

Spear S. et al. "Samso: World'S First 100\% Renewable Energy-Powered Island Is A Beacon For Sustainable Communities". EcoWatch. N.p., 2014. Web. 18 Dec. 2015.

\subsection{Dānijas "zal̦ā" sala Bornholma}

\section{Bright Green Island Catalogue.}

Bright Green Island web page. (u.d.). Hentet fra http://brightgreenisland.com/

EcoGrid EU: From Design to Implementation - summary. (u.d.). Hentet fra http://www.eu-cogrid.net/images/ Documents/131120_ecogrid_popular_summary.pdf 
16.6. Biroju ēkas apsildǐšana ar k̦ermeṇa siltumu Zviedrijā

http://www.greenoptimistic.com/2011/01/12/stockholm-central-body-heat/

http://www.bbc.co.uk/news/business-12137680

http://www.icenews.is/index.php/2011/01/18/body-heat-harnessed-for-heating-at-stockholm-central-station/\#ixzz1CzkwEVlg http://cleantechnica.com/2011/01/20/250000-swedes-heat-a-building-with-their-bodies/

http://www.eurocities.eu/eurocities/news/Body-heat-new-green-energy-source-WSPO-9HLBUY

\subsection{Saragosas "Ūdens taupīšanas programma" Spānijā}

Arbués F., Villanúa I. (2006) Potential for Pricing Policies in Water Resource Management: Estimation of Urban Residential Water Demand in Zaragoza, Spain, Urban Studies, 43(13), 2421-2442.

Barberán R., ed. (2006) Consumo y gravamen del agua para usos residenciales en la ciudad de Zaragoza. Evaluación y propuesta de reforma. Ayuntamiento de Zaragoza, Zaragoza. Accessed at: $h$ ttps://www.zaragoza.es/ on 12.07.2015.

European Climate Adaptation Platform (ECAP) 2014. Zaragoza: combining awareness raising and financial measures to enhance water efficiency. Accessed at: $h$ ttp://climate-adapt.eea.europa.eu/ on 12.07.2015

Expo Zaragoza (2008) Exposición Internacional "Agua y Desarrollo Sostenible". Accessed at: http://www.expozaragoza2008.es/on 12.07.2015.

Ralf P. (2011) Reducing Water Demand and Establishing a Water Saving Culture in the City of Zaragoza. Accessed at: http://www.switchtraining.eu/

Smits S. et al. (2010) Zaragoza: Taking Pride in Integrated Water Management in the City. Accessed at: http://www. switchurbanwater.eu/

Zaragoza City (2015) Publicly available data from the Zaragoza City Website. Accessed at: https://www.zaragoza.es/ ciudad/risp/

\subsection{Freiburga - Vācijas Saules enerğijas galvaspilsēta}

Buehler R., Pucher J. "Sustainable Transport in Freiburg: Lessons From Germany's Environmental Capital". International Journal of Sustainable Transportation 5.1 (2011).

Anon. "Freiburg, Germany Pioneers Solar Energy Use". Business and the Environment 19.3 (2008): 9-10. Web. 15 Dec. 2015.

Dresel T., Bertram K. Solarregion Freiburg. $1^{\text {st }}$ ed. Freiburg: City of Freiburg Environmental Protection Agency, 2007. Web. 21 Dec. 2015.

Freiburg Greencity - Approaches to Sustainability. $1^{\text {st }}$ ed. Freiburg: Freiburg Wirtschaft Touristik und Messe GmbH \& Co. KG, 2011. Web. 14 Dec. 2015.

Freytag T., Gössling S., Mössner S. “Living the Green City: Freiburg's Solarsiedlung Between Narratives and Practices of Sustainable Urban Development". Local Environment 19.6 (2014): 644-659. Web. 16 Dec. 2015.

Gordon D. "Lessons From the Green Capital of Europe ; David Gordon Joined a Recent Waste Management Study Tour Of Freiburg, Germany. He Reflects on the Lessons the Green Capital of Europe Can Teach Northern Ireland". Belfast Telegraph 2003: 1. Web. 15 Dec. 2015.

Hamiduddin I. "Social Sustainability, Residential Design and Demographic Balance: Neighbourhood Planning Strategies in Freiburg, Germany". Town Planning Review 86.1 (2015): 29-52. Web. 15 Dec. 2015.

IPCC. "Climate Change 2007: Working Group II: Impacts, Adaptation And Vulnerability". N.p., 2007. Web. 16 Dec. 2015. Ryan S., Throgmorton J. A. "Sustainable Transportation and Land Development on the Periphery: a Case Study of Freiburg, Germany and Chula Vista, California". Transportation Research Part D: Transport and Environment 8.1 (2003): 37-52. Web. 14 Dec. 2015.

wwf.panda.org, "Freiburg Green City". N.p., 2012. Web. 14 Dec. 2015.

\subsection{Pielāgošanās paaugstinātam plūdu riskam pie Temzas}

Davoudi S., Mehmood A., Brooks L. The London Climate Change Adaptation Strategy: Gap Analysis. $1^{\text {st }}$ ed. London: Engineering and Physical Sciences Research Council, 2015. Web. 18 Dec. 2015. 
Gov.uk. "The Thames Barrier - Detailed Guidance - GOV.UK". N.p., 2014. Web. 18 Dec. 2015.

London Regional Flood Risk Appraisal. $1^{\text {st }}$ ed. London: Greater London Authority, 2009. Web. 18 Dec. 2015.

London.gov.uk. "Policy 5.12 Flood Risk Management | London City Hall”. N.p., 2015. Web. 18 Dec. 2015.

Managing Flood Risk Through London And The Thames Estuary: TE2100 Plan. $1^{\text {st }}$ ed. London: Thames Estuary 2100 Environment Agency, 2012. Web. 18 Dec. 2015.

Nickson A. et al. FLOOD RISKS IN LONDON. ${ }^{\text {st }}$ ed. London: The Environment Committee London, 2014. Web. 18 Dec. 2015.

Piliksere A., Valainis A., Sennikovs J. "A Flood Risk Assessment For Riga City Taking Account Climate Changes". Geophysical Research Abstracts 13 (2011) Rigapretpludiem.lv, "Riga Against Flood - About The Project". N.p., 2012. Web. 2015.

Rodrigues S. The London Climate Change Adaptation Strategy. $1^{\text {st }}$ ed. Tokyo: Greater London Authority, 2008. Web. 17 Dec. 2015.

"Thames Barrier." The Hutchinson Unabridged Encyclopedia with Atlas and Weather Guide. Abington: Helicon, 2015. Credo Reference. Web. 21 Dec. 2015.

The Draft Climate Change Adaptation Strategy for London. $1^{\text {st }}$ ed. London: Greater London Authority, 2010. Web. 18 Dec. 2015.

16.10. Pielāgošanās klimata pārmaiṇām Nīderlandes lauksaimniecības nozarē

EEA. "Agriculture and Horticulture - Netherlands - Climate Adaptation". N.p., 2014. Web. 7 Dec. 2015.

De Bruin K. et al. "Adapting to Climate Change in the Netherlands: An Inventory of Climate Adaptation Options and Ranking of Alternatives". Climatic Change 95.1-2 (2009): 23-45. Web. 10 Dec. 2015.

National Programme For National Programme For Spatial Adaptation To Climate Change. $1^{\text {st }}$ ed. The Netherlands: European Climate Adaptation Platform (ECAP), 2007. Web. 7 Dec. 2015.

Rozema J. et al. Saving Fresh Water By Crop Cultivation on Salinizing Soils, A Survey. $1^{\text {st }}$ ed. Amsterdam: Knowledge for Climate, 2014. Web. 10 Dec. 2015.

\subsection{Piekrastes plānošana Horvātijā}

Trumbić I. (N/A). "Coastal Plan for the Šibenik-Knin County” ppt presentation. Available from: http://meetings.papthecoastcentre.org/pptx/MedPartnership_Sibenik_Trumbic.pdf

EEA (N/A). Euroepan Climate Adaptation Platform. Available from: http://climate-adapt.eea.europa.eu/ viewmeasure?ace_measure_id $=5201$

PAP/RAC http://www.pap-thecoastcentre.org/

UNDP (2008). A Climate for Change. Available from: http://hdr.undp.org/sites/default/files/nhdr_2008_en_croatia.pdf

\subsection{2. "Klimata bēgḷi"}

Environmental Change, Adaptation and Migration: Bringing in the Region (2015) Eds. Felicitas Hillmann F., Rafflenbeul M., Sterly H., Springer

Becker P. (2014) Sustainability science. Elsevier, London, New York, Sydney, Tokyo.

Kolbert E. Unsafe Climates. http://www.newyorker.com/magazine/2015/12/07/unsafe-climates

"Climate refugees" in Europe? Climate-related migration affects developing countries in particular - https:// www.die-gdi.de/en/the-current-column/article/climate-refugees-in-europe-climate-related-migration-affectsdeveloping-countries-in-particular-1/

How Climate Change is Behind the Surge of Migrants to Europe - $h$ ttp://time.com/4024210/climate-change-migrants/ Climate change and refugees: Adaptation is the key to preventing displacement - $h t t p: / / w w w . v o x e u r o p . e u / e n /$ content/article/5038069-adaptation-key-preventing-displacement

Climate Change Could Wreck the Global Economy - http://time.com/4082328/climate-change-economic-impact/

Environmental change and migration: issues for european governance and migration management - $h t t p: / /$ www.migrationeducation.org/56.1.html?\&rid=208\&cHash=6cf222c08c5309a7e2288d393f5ba88

Environmental Migrations from Conflict-Affected Countries: Focus on EU Policy Response - http://www. thehagueinstituteforglobaljustice.org/wp-content/uploads/2015/10/ 
Will Pacific Island Nations Disappear as Seas Rise? Maybe Not - http://news.nationalgeographic.com/2015/02/ 150213-tuvalu-sopoaga-kench-kiribati-maldives-cyclone-marshall-islands/

Water, Drought, Climate Change, and Conflict in Syria - http://www.environmentalmigration.iom.int/waterdrought-climate-change-and-conflict-syria

Water supply key to outcome of conflicts in Iraq and Syria, experts warn - http://www.theguardian.com/ environment/2014/jul/02/water-key-conflict-iraq-syria-isis

What happens when the sea swallows a country? - http://www.bbc.com/future/story/20150616-what-happenswhen-the-sea-swallows-a-country

\section{Izmantotie attēli}

16.2. https://en.wikipedia.org/wiki/North_Sea_oil

16.3. http://www.npd.no/Global/Norsk/3-Publikasjoner/Rapporter/CO2-ATLAS-Norwegian-sea-2012.pdf

16.4. http://www.hurdalecovillage.no/

16.7. http://www.eu-ecogrid.net/

16.10. http://www.switchtraining.eu/fileadmin/template/projects/switch_training/files/Case_studies/Zaragoza/

16.11. http://www.solaranlage.de/

16.12. https://www.google.Iv/search?q=Freiburg;+Germany;+transport

16.13. https://www.google.Iv/search?q=The+Thames+Barrier\&espv

16.14. https://www.google.Iv/search?q=The+Netherlands;+agriculture

16.15. https://www.google./v/search?q=Šibenik-Knin

16.16. https://www.google.Iv/search?q=Šibenik

16.17. https://publichealthwatch.wordpress.com/2015/09/29/5-things-you-should-know-about-climate-refugees/

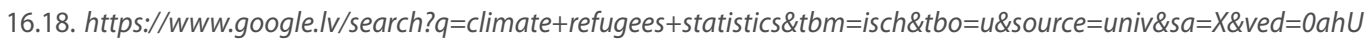
KEwiF7YOv5PzLAhVCFSwKHUrUDJEQsAQINw\&biw=1680\&bih=959\#imgrc=INheTiu4VFO0fM\%3A

16.19. http://news.nationalgeographic.com/2015/02/150213-tuvalu-sopoaga-kench-kiribati-maldives-cyclonemarshall-islands/

16.20. http://www.voxeurop.eu/en/content/article/5038069-adaptation-key-preventing-displacement

16.21. https://en.wikipedia.org/wiki/Refugees_of_the_Syrian_Civil_War\#/media/File:An_Aerial_View_of_the_ Za\%27atri_Refugee_Camp.jpg

16.22. http://www.worldvision.org/news-stories-videos/top-humanitarian-crises-2015

16.23. http://www.forestecologynetwork.org/climate_change/conflicts_fueled.html

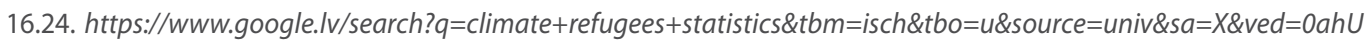
KEwiF7YOv5PZLAhVCFSwKHUrUDJEQsAQINw\&biw=1680\&bih=959\#imgrc $=x H R W o z N Q 00 x z y M \% 3 \mathrm{~A}$ 



\section{Climate and}

\section{Sustainable Development}

The climate is not only essential for the daily well-being, it also directly affects industry, agriculture, power sector, tourism and other fields.

The climate system is complicated, therefore the studies dedicated to formation of climate and climate changes are of an increased interest. The Earth's climate elements atmosphere, hydrosphere, lithosphere and biosphere - are closely linked and in constant interaction.

Taking into account the transformations in physical and biological systems that have occurred without human intervention at various stages of development of the Earth, it is possible to describe the impact of the climate on the natural changes in the environment. A particular interest has been aroused by the obvious and rapid climate changes, which have occurred during the century or even within a shorter period of time, because this analogy can be used for the future climate change forecasts.

Human activities are resulting in huge amounts of greenhouse gases and their emissions continue to increase since the beginning of the Industrial revolution.

The global warming of the planet can significantly affect a wide range of human life activities. The climate change has become one of the most important global environmental problems that affect human health and contribute to spreading of various diseases on Earth.

Consequently, practical and urgent solutions are needed for adaptation to climate change.

Until now, no academic books dedicated to the climate have been issued in Latvia to cover a wide range of issues, from climate formative factors to the application of scientific knowledge in practical life.

In view of the global concern about the impact of climate change, it was necessary to review scientific materials and prepare a book intended for a wide range of users, mainly university staff, school teachers, public and local government employees, as well as other stakeholders.

The 16 chapters of the book in 384 pages contain a wealth of images, tables, diagrams and graphics to illustrate the text. The main chapters are:

- Earth's climate and its constituent elements;

- Climate in Latvia;

- Climate change impacts on human health and on other living organisms;

- Adapting to climate change;

- Climate, energy and economy;

- Climate policy of Latvia;

- Sustainable development and climate;

- Practical adapting to climate change in the world and in Europe. 
Klimats un ilgtspējīga attīstība. Māra Kḷavina un Jāṇa Zaḷokšṇa redakcijā, 2016

Iespiests SIA “Latgales druka"

Baznīcas iela 28, Rēzekne, LV-4601 